UNITED STATES DEPARTMENT OF THE INTERIOR

Harold L. Ickes, Secretary

GEOLOGICAL SURVEY

W. C. Mendenhall, Director

\title{
Bulletin 892
}

\section{BIBLIOGRAPHY}

OF

\section{NORTH AMERICAN GEOLOGY}

FOR

\section{AND 1936}

BY

EMMA MERTINS THOM

।I
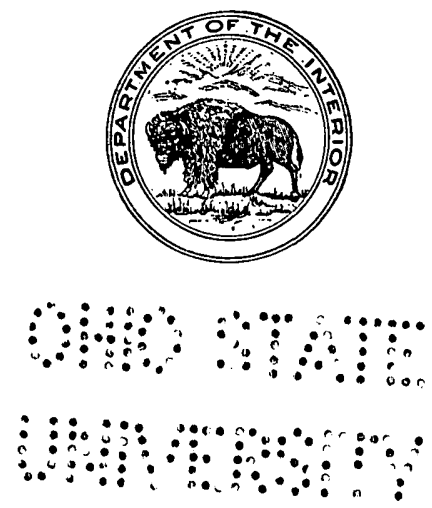

UNITED STATES

GOVERNMENT PRINTING OFFICE

WASHINGTON : 1937

Ifor sale by the Superintendent of Documents, Washington, D. C. - - - - - Price 50 cents 


$$
\begin{aligned}
& \text { 2E } 75 \\
& 89
\end{aligned}
$$

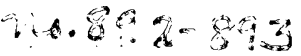

$$
\begin{aligned}
& \text { copy } 2
\end{aligned}
$$

\section{CONTENTS}

Page.

Intruduction._-

Serials examined___n 3

Bibliography _. 13

Index

I

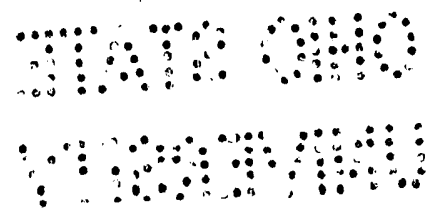




\title{
BIBLIOGRAPHY OF NORTH AMERICAN GEOLOGY 1935 and 1936
}

\author{
By Emma Mertins Thom
}

\section{INTRODUCTION}

The bibliography of North American geology, including paleontology, petrology, and mineralogy, for the years 1935 and 1936 lists publications on the geology of the continent of North America and adjacent islands and on Panama and the Hawaiian Islands. It includes textbooks and papers of general character by American authors, but not those by foreign authors, except papers that appear in American publications. The volume was closed January 31, 1937.

The papers, with full title and medium of publication, are listed under the names of their authors, which are arranged in alphabetic order. The author list is followed by an index to the literature cited.

The bibliography of North American geology to the end of the year 1934 is contained in Bulletins 746 (Bibliography) and 747 (Index), covering the period 1785-1918; Bulletin 823, covering the period 191928 , in which previous bibliographies and cumulations of the United States Geological Survey have been combined; Bulletin 834, 1929-30; Bulletin 858, 1931-32; Bulletin 869, 1933-34. All these Bulletins except 869 , by the present author, were compiled by John M. Nickles. 



\section{SERIALS EXAMINED}

Academia de ciencias médicas, físicas y naturales de la Habana [Cuba] : Anales, vols. 71, 72 (pt. 2), 73 (pt. 1). Habana, Cuba.

Academy. of Natural Sciences of Philadelphia: Proceedings, vols. 86, 87, 88 (part). Philadelphia, Pa.

Academy of Science of St. Louis: Bulletin, vols. 1, 2 (nos. 1-5) ; Transactions, vol. 29 (no. 1). St. Louis, Mo.

Alabama Geological Survey: Bulletin 42; Museum Paper 12. University, Ala.

Alberta, University of, Research Council: Reports 28, 29, 32, 33. Edmonton, Alberta.

American Academy of Arts and Sciences: Memoirs; vol. 18 (pts. 1, 2) ; Proceedings, vols. 69 (nos. 11-13), 70, 71, (nos. 1-5). Boston, Mass.

American Association of Petroleum Geologists: Bulletin, vols. 19, 20. Tulsa, Okla.

American Ceramic Society: Bulletin, vols. 14, 15; Journal, vols. 18, 19. Easton, Pa.

American Geophysical Union: Transactions, 16th and 17th Annual. Meetings. Washington, D. C.

American Institute of Mining and Metallurgical Engineers: Contributions, nos. 75-104; Technical Publications 587, 588, 598-761; Transactions, vols. 112, 114-120, 122; Year Book Section of Bulletin, 1935, 1936. New York. See also Mining and Metallurgy.

American Journal of Botany, vols. 22, 23 (nos. 1-9). Lancaster, Pa.

American Journal of Science, 5th ser., vols. $29-32$, New Haven, Conṇ.

American Midland Naturalist, vols. 16, 17. Notre Dame, Ind.

American Mineralogist, vols. 20, 21. Menasha, Wisc.

American Museum of Natural History: Bulletin, vols. 67 (part), 68 (part), 70, 71, 72 (part) ; Guide Leaflet 84; American Museum Novitates, nos. 764898. New York. See also Natural History.

American Naturalist, vols. 69, 70. New York.

American Petroleum Institute, section 4: Bulletins 206-217; Drilling and Production Practice, 1934, 1935. New York.

American Philosophical Society: Proceedings, vols. 75, 76; Transactions, new ser., vols. 24 (pt. 2), 25-27, 28 (pt. 1), 29. Philadelphia, Pa.

American Society of Civil Engineers: Proceedings, vols. 61, 62. New York.

American Water Works Association: Journal, vols. 27, 28; Southeastern Sec. Journal, Proceedings no., vols. 5, 6. Baltimore, Maryland.

American Year Book; Record of the Year 1934, 1935. New York.

$\Lambda$ nnals and Magazine of Natural History, 10th ser., vols. 15-18. London.

Annals of Botany, vols. 49, 50. London.

Appalachia, nos. 79-82. Boston, Mass.

Arizona Bureau of Mines: Bulletins 138-140. Tucson, Ariz.

Arkansas Geological Survey: Annual Report for 1935-36; Bulletin 2; Information Circulars 6, 7, 9. Little Rock, Ark.

Association of American Geographers: Annals, vols. 25, 26. Lancaster, Pa. 
Association of American State Geologists: Journal, vols. 6, 7. Charlottesville, Va.

Auk, vols. 52, 53. Lancaster, Pa.

Barbados Museum and Historical Societ: : Journal, vols. 2 (nos. 2-4), 3, 4 (no.

1). Bridgetown,'Barbados, British West Indies.

Bermuda Biological Station for Research, Inc. : Contributions, vol. 1, (nos. 2033). St. George's West, Bermuda.

Bernice Pauahi Bishop Museum : Bulletins.131, 133, 140 ; Occasional Papers, vols. 11 (nos. 15-23), 12 (nos. 1-3). Honolulu, Hawaii.

Bibliographie des sciences géologiques, $2^{\mathrm{e}}$ sér., Annual, vol. 5. Paris.

Biological Abstracts, vols. 9, 10. Baltimore, Md.

Biological Society of Washington: Proceedings, vols. 48, 49. Washington, D. C.

Black Hills Engineer, vols. 22 (no. 4), 23 (nos. 1, 2). Rapid City, S. Dak.

Boletín de petróleo y minas, vols. 3 (nos. 3-6), 4. Mexico City.

Boston Society of Natural History: Bulletins 74-79, [With no. 80, of July 1986, the name is changed to New England Museum of Natural History Bulletin, q. v.] ; Memoirs, vol. 9, no. 1; Occasional Papers, vol. 8, pp. 199-292; Proceedings, vols, 40 (nos. 4-8), 41 (nos. 1-4). Boston, Mass.

Botanical Gazette, vols. 96 (nos. 3, 4), 97, 98 (nos. 1, 2). Chicago. Illinois.

British Columbia, Department of Mines: Annual Reports of Minister of Mines, 1934, 1935. Victoria, B. C.

Bryologist, vol. 38 (nos. 1-4). Brooklyn, N. Y.

Buffalo Society of Natural Sciences : Bulletin, vol. 17 (nos. 1, 2). Buffalo, N. Y.

Bulletins of American Paleontology, vols. 22 (nos. 73-76), 23 (nos. 77, 78). Ithaca, $\mathbf{N}$. $\mathbf{Y}$.

California Academy of Sciences: Proceedings, 4th ser., vols. 21 (nos. 19-27, 29), 22 (no. 1), 23 (nos. 1-6). San Francisco.

California, Department of Natural Resources, Division of Mines: Bulletins 108, 110, 111; California Journal of Mines and Geology, vols. 30 (no. 4), 31, 32 (nos. 1-3) ; California Oil Fields, vols. 19 (nos. 2-4), 20. San Francisco.

California, Department of Public Works, Division of Water Resources: Bulletins 45, 46, 46a, 47. Sacramento, Calif.

California Institute of Technology, Balch Graduate School of Geological Sciences : Contributions, 181, 193, 196, 200, 213. Pasadena, Calif.

Cailifornia, University of, Department of Geological Sciences: Bulletin, vols. 23 (nos. 9-15), 24 (no. 1) ; Publications in Geography, vol. 7 ; Publications in Biological Sciences, vol. 1 (no. 5) ; Scripps Institution of Oceanography, Bulletin, Technical ser., vols. 3 (nos. 15, 16), 4 (nos. 1, 2) ; Seismographic Stations, Bulletins, vols. 3 (no. 4), 4, 5 (nos. 1-3), 6 (nos. 1, 2), Bèrkeley, Calif.

Canada, Department of Mines, Geological Survey: Memoirs 175-193, 195; Papers, 1935, nos. $1-4 ; 1936$, nos. 1-16, 22. Ottawa, Ontario.

Canada, Department of Mines, Mines Branch: Annual Reports, 1935, 1936; Investigations in Ore Dressing and Metallurgy, nos. 738, 747, 748, 754, 755, $759,760,763,765,767,769,772,773$. Ottawa, Ontario.

Canada, Department of Mines, National Museum: Bulletins 74, 76-80. Ottawa, Ontario.

Canada, Dominion Observatory : Bibliography of Seismology, vol. 12 (nos. 4-11). Ottawa, Ontario.

Canadian Alpine Journal, vol. 23. Banff, Alberta.

Canadian Field Naturalist, vols. 49, 50. Ottawa, Ontario. 
Canadian Institute of Mining and Metallurgy : Transactions, vols. 37, 38; Canadian Mining and Metallurgical Bulletins 273-296. Montreal, Quebec.

Canadian Journal of Research, vols. 12-14. Ottawa, Ontario.

Canadian Mining Journal, vols. 56, 57. Gardenvale, Quebec.

Carnegie Institute of Washington: Year Book 34; Contributions to Paleontology, nos. 449, 452, 453, 458, 466; 470, 476 (pp. 47-72) ; Papers from the Tortugas Laboratories, vol. 29, Pub. 452; News Service Bulletin, School edition, vol. 3 , nos. $17,23,28,29$; vol. 4 , nos. 2, 9 ; Supplementary Publications 10 , 12-14, 20, 26. Washington, D. C.

Carnegie Museum: Annals, vol. 24; Annual Report for 1934; Memoirs, vols. 11 (no. 4) ; 12, Preface and contents, pts. 2, 3. Pittsburgh, Pa.

Cleveland Museum of Natural History: Scientific Publications, vols. 5, (no. 1): 6. Cleveland, Ohio.

Colorado Museum of Natural History: Proceedings, vols. 14 (nos. 1, 2), 15 (no. 1). Denver, Colorado.

Colorado Scientific Society: Proceedings, vol. 13 (nos. 6-10). Denver, Colo.

Colorado School of Mines: Quarterly, vols. 29 (nos. 3-4), 30. Golden, Colo.

Colorado, University of: Bulletin, vol. 36, no. 13 ; Studies, vols. 22 (no. 4), 23, 24 (no. 1). Boulder, Colo.

Condor, vols. 37, 38. Berkeley, Calif.

Connecticut Academy of Arts and Sciences: Transactions, vols. 32, pp. 111-379 ; 32, pp. 381-434. New Haven, Conn.

Connecticut State Geological and Natural History Survey: Bulletins 53-56. Hartford, Conn.

Copenhage, Museum de minéralogie et de géologie, de l'Université de Copenhague: Communications paléontologiques, nos. 51-53. København, Denmark.

Cranbrook Institute of Science: Bulletins 4-6. Bloomfield Hills, Mich.

Cushman Laboratory for Foraminiferal Research, Contributions, vols. 11, 12. Sharon, Mass.

Denison University, Scientific Laboratories: Journal, vols. 30, 31 (arts. 1-3). Granville, Ohio.

Earthquake Notes, vols. 6 (no. 4), 7, 8 (nos. 1-2). Washington, D. C.

Eastern Geologist, College of the City of New York, no. 1. New York.

Ecology, vols. 1-17. Brooklyn, N. Y.

Economic Geology, vols. 30, 31. Lancaster, Pa.

Elisha Mitchell Scientific Society: Journal, vols. 51, 52. Chapel Hill, N. C.

Engineering and Mining Journal, vols. 136, 137. New York.

Engineering News Record, vols. 110-117. New York.

Engineers' Bulletin (Colorado Society of Engineers), vols. 19, 20. Denver, Colo.

Explosives Engineer, vols. 13, 14. Wilmington, Del.

Field and Laboratory (Southern Methodist University), vols. 3 (no. 2), 4, 5 (no. 1). Dallas, Tex.

Field Museum of Natural History: Botanical Series, vols. 11 (nos. 5, 6), 12, 13, (pts. 1-3, 6), 14, 15; Geological Leaflets, vol. 6 (no. 16); Geological Series, vol. 6 (nos. 9-15) ; Zoological Series, vols. 13 (nos. 8, 9), 18 (no. 12 and index). Chicago, Ill.

Florida, Board of Conservation, Geological Department: Report of Investigations, no. 1.

Florida Geological Survey: First Biennial Report, pt. 4, ending Dec. 31, 1934 ; Bulletins 12-14. Tallahassee, Fla. •

Forestry-Geological Review, vols. 5, 6 (nos. 1-7, 9-12). Atlanta, Ga. 
Frankin Institute: Journal, vols. 219-222. Philadelphia, Pa.

Geographical Journal, vols. 85-88. London.

Geographical Review, vols. 25, 26, New York.

Géographie universelle, vols. 13, 14. Paris.

Geographical Society of Philadelphia: Bulletin, vols. 33, 34. Philadelphia, Pa. Geological Magazine, 10th ser., vols. 72, 73. London.

Geological Society of America: Bulletin, vols. 46, 47; Information Cireular 13; Memoir 3 (foreign); Proceedings, 1934, 1935; Special Papers 2, 3. Washington, D. C.

Geological Society of the Oregon Country: Geological News Letter [mimeographed], vols. 1, 2. ; Portland, Oreg.

Geologisches Zentralblatt, Abt. A.; Bände 53 (nos. 6-9), 54, 56, 57, 58 (nos. 1-4). Leipzig.

Geophysics, Society of Petroleum Geologists, vol. 1, nos. 1, 2. Houston, Tex. [This is a continuation of The Journal of the Society of Petroleum Geophysicists, which ends with vol. 6, no. 1, July 1935.]

Georgia Geological Survey, Department of Forestry and Geological Development: Bulletin 46; Information Circulars, nos. 4-8. Atlanta, Ga.

Glück Auf, Montana School of Mines, vols. 1, 2 (nos. 1, 2). Butte, Mont.

Grand Canyon Nature Notes, vol. 9 (nos. 10-12). [Last number issued.] Grand Canyon National Park, Ariz.

Grand Canyon Natural History Association: Bulletins 1-7. Grand Canyon, Ariz. [Takes the place of above; not a continuation, however.]

Harvard College Museum of Comparative Zoology: Annual Reports, 1934-35, 193̄-36; Bulletin, vols. 76 (nos. 2-6), 78 (nos. 1-4), 79 (nos. 1-7), 80 (nos. 1, 2) ; Memoirs, vols. 53, 54 (no. 3). Cambridge, Mass.

Hawaii (Territory), Department of Public Lands, Division of Hydrography: Bulletins 1, 3. Honolulu.

Hawaii, University of: Research Publications 9-11; Occasional Papers 23, 29. Honolulu.

Hobbies, vols. 15, (nos. 3-5), 16, 17 (nos. 1, 2). Buffalo, N. Y.

Idaho, 36th Annual Report of the Mining Industry: Boise, Idaho.

Idaho, Bureau of Mines and Geology: Pamphlets 42-44. Moscow, Idaho.

Illinois Academy of Science: Transactions, vols. 27 (nos. 3, 4), 28, 29 (no. 1). Springfield, Ill.

Illinois Geological Survey : Bulletins 62, 63; Press Bulletins 26-28; Information Circulars 9, 13-18; Reports of Investigation 33, 35, 37-43. Springfield, Ill.

Illinois, Department of Registration and Education, State Water Survey Division: Circulars 13-18. Urbana, Ill.

Indiana Academy of Science: Proceedings, vols. 44, 45. Indianapolis, Ind.

Indiana, Department of Conservation: Publication 133. Indianapolis, Ind.

Iowa Academy of Sciences: Proceedings, vols. 41, 42. Des Moines, Iowa.

Iowa Geological Survey : Annual Report, vol. 36, nos. 39-42; Technical Paper 3. Des Moines, Iowa.

Iowa State College, Engineering Experiment Station: Bulletin 128. Ames, Iowa.

Iowa, University, Studies in Natural History, new series, vols. 16 (nos. 5, 6), 17 (nos. 1-4). Iowa City, Iowa.

Irrigación en México, Revista mensual, vols. 10, 11, 12, 13 (nos. 1-2). Mexico City.

Journal of Geography, vols. 34 , 35. Menasha, Wis.

Journal of Geology, vols. 43, 44. Chicago, Ill. 
Journal of Mammalogy, vols. 16, 17. Baltimore, Md.

Journal of Paleontology, vols. 9, 10. Fort Worth, Tex.

Journal of Sedimentary Petrology, vols 5, 6. Menesha, Wis.

Kansas Academy of Sciences: Transactions, vol. 38. Topeka, Kans.

Kansas Geological Society: Annual Field Conference Guidebooks, 9th-10th, 1935-36. Wichita, Kans.

Kansas Geological Survey: Bulletins 20-22; Contribution to Paleontology no. 4. Lawrence, Kans.

Kansas University, Science Bulletin, vols. 22, 23; Engineering Bulletin 17 (1928). Lawrence, Kans.

Kentucky Academy of Science: Transactions, vol. 6. - Lexington, Ky.

Kentucky State Historical Society: Register, vols. 30 (no. 93) ; 33 (nos. 103, 104). Louisville, Ky.

Kentucky Department of Mines and Minerals: Geological Division, Ser. 8; Pamphlet 1; Bulletin 1. Lexington, Ky.

Louisiana, Department of Conservation: Geological Bulletins 5-7; Biennial Report, 12th. New Orleans, La.

Louisiana Conservation Review, vols. 4, 5. New Orleans, La.

Louisiana Engineering Society: Proceedings, vols. 21 (nos. 4, 6), 22 . New Orleans, La.

Maine Technology Experiment Station: Bulletins 30, 32 ; Papers 5, 9, 11. University of Maine, Orono, Maine.

Maryland Bureau of Mines: Annuạl Reports, 12th, 13th. Baltimore, Md.

Mazama, vols. 17, 18 (annual numbers). Portland, Oreg.

Meddelelser om Grönland, Bände 78-80, 84, 88, 93, 95-105, 109, 112, 117, 118 (part). Kфbenhavn, Denmark.

Michigan Academy of Science, Arts, and Letters: Papers, vols. 20, 21. Ann Arbor, Mich.

Michigan College of Mining and Technology : Bulletin, new ser., vols. 8 (no. 4), 9 (no. 3). Houghton, Mich.

Michigan Geological and Biological Survey, Department of Conservation, Geological Survey Division: Summary Report, 1930-34. Lansing, Mich.

Michigan, University of, Museum of Paleontology : Contributions, vols. 4 (nos. 13-18), 5 (nos. 1-6). Ann Arbor, Mich.

Military Engineer, vols. 27, 28. Washington, D. C.

Mineralogist, vols. 3, 4. [Formerly Oregon Mineralogist.] Portland, Oreg.

Mines Magazine, Colorado School of Mines, vols. 25, 26. Denrer, Colo.

Mining and Metallurgy (American Institute of Mining and Metallurgical Engineers), vols. 16, 17. New York.

Mining and Metallurgical Society of America: Bulletin, vols. 28, 29. New York City.

Mining Congress Journal, vols. 21, 22. Washington, D. C.

Mining Journal, vols. 18 (nos. 16-24), 19, 20 (nos. 1-15). Phoenix, Ariz.

Minnesota Geological Survey : Bulletins 25-27. Minneapolis, Minn.

Minnesota, University, Minnesota School of Mines Experiment Station: Bulletin, rol. 39 (nos. 6, 11). Minneapolis, Minn.

Minnesota, University, Mining Directory Bulletin, vols. 38 (no. 25), 39 (nos, 6, 23). Minneapolis, Minn.

Mississippi Geological Survey: Bulletins 22-A, 26-31; Biennial Reports, 14th, 15th. University, Miss.

Missouri Botanical Garden: Annals, vols. 22, 23. Fulton, Mo.

Missouri Bureau of Geology and Mines: Biennial Report, 58th. Jefferson City, Mo. 
Missouri, University, School of Mines and Metallurgy : Bulletin, vol. 12 (nos. 1, 2). Columbia, Mo.

Montana State Bureau of Mines and Geology : Memoirs 11, 13-17; Miscellaneous Contribution no. 7. Butte, Mont.

Monthly Weather Review, vols. 63, 64. Washington; D. C.

Museum of Northern Arizona: Museum Notes, vols. 1, 2, 7, 8, 9, in part. Flag$\therefore \quad$ staff, Ariz.

National Academy of Sciences: Biographical Memoirs, vols. 16, 17 (no. 2); Proceedings, vols: 21., 22. Washington, D. C.

National Geographic Magazine, vols. 67-70. Washington, D. C.

National Research Council : Bulletin 98; Reprint and Circular Series, no. 107. Washington, D. C.

National Research Council, Division of Geology and Geography: Annual Reports, 1930-31, 1934-35.

Natural History; the journal of the American Museum of Natural History, vols. 35-38. New York.

Nautilus, vols. 48 (nos. 3, 4), 49, 50 (nos. 1, 2). Philadelphia, Pa.

Nebraska Geological Survey: Bulletins, 2d ser., 10; Papers 7-11. Lincoln, Nebr.

Nebraska State Museum: Bulletin, vol. 1 (nos. 42-44). Lincoln, Nebr.

Nebraska University, Department of Conservation: Bulletins 8-14. Lincoln, Nebr.

Nevada State Bureau of Mines and Mackay School of Mines: Bulletin, vols. 29 (nos. 5, 6), 30 (nos. 1, 2, 4, 5). Reno, Nev.

New England Museum of Natural History (continuation of Boston Society of Natural History) : Bulletins 80, 81. Boston.

Newfoundland, Department of Natural Resources; Geological Section: Bulletins 2-5 (Contribution 14); Information Circular 2. St. Johns, Newfoundland.

New Jersey, Department of Conservation and Derelopment: Geological ser., Bulletins 42-44. Trenton, N. J.

New Mexico, School of Mines: Bulletin 11. Socorro, .N. Mex.

New Mexico, University: Bulletin, Geological ser., vol. 5 (no. 1) ; Monograph ser., vol. 1 (no. 2). Albuquerque, N. Mex.

New Phytologist, vols. 34, 35. London.

New York Academy of Sciences: Annals, vols. 35, 36 (part); Scientific Survey of Puerto Rico and the Virgin Islands, vol. 2, pt. 3. New York.

New York State Museum: Bulletins 296, 297, 299, 300, 302-307; Circulars 11, 15. Albany, N.Y.

North Carolîna, Department of Conservation and Development: Bulletin 38. Raleigh, N. C.

North Dakota Geological Survey, State Planning Board: Circular Reports 7-9. Grand Forks, N. Dak.

Northwest Science, vols. 9, 10. Cheney, Wash.

Northwestern University: Summaries of Doctoral Dissertations, vols. 1-3. Evanston, Ill.

Nova Scotia, Department of Public Works and Mines: Annual Reports, 1934, 1935. Halifax, Nova Scotia.

Nova Scotia Institute of Science: Proceedings and Transactions, vols. 18 (pt. 4), 19 (pt. 1). Halifax, Nova Scotia.

Ohio Journal of Science, vols. 35, 36. Columbus, Ohio.

Ohio State University: Abstracts of Doctors Dissertations, nos. 10, 11, 14; Bulletin, vol. 40 (no. 20) ; Engineering Experiment-Station Bulletin 92 ; Engineering Experiment Station News, vols. 7, 8. Columbus, Ohio. 
Oil and Gas Journal, vols. 33 (nos. 33-52), 34, 35 (nos. 1-33), Tulsa, Okla.

Oil Weekly, vols. 76-83, 84 (nos. 1-3). Houston, Tex.

Ontario Department of Mines: Annual Reports, vol. 43 (pts. 1-5). Toronto, Ontario.

Pacific Northwest Quarterly [Continuing the Washington Historical Quarterly], vol. 27. Seattle, Wash.

Pacific Mineralogist, vols. 2 (no. 1), 3 (nos. 1, 2). Los Angeles, Calif.

Palaeontologisches Zentralblatt (Geologische Zentralblatt, Abt. B), Bände 5 (nos. 6-8), 6 (no. 1) , 7, 8, 9 (no. 1). Leipzig, Germany.

Pan-American Geologist, vols. 63-66. Des Moines, Iowa.

Peabody Museum of Natural History: Bulletin 4. New Haven, Conn.

Pennsylvania Geological Survey: Fourth Series; Bulletin M18-A. Harrisburg; Pa.

Pennsylvania, Department of Internal Affairs: Monthly Bulletin, vols. 1, 2, 3 (no. 1). Harrisburg, Pa.

Pennsylvania State College, Mineral Industries Experiment Station: Bulletins 17-20; Circulars 2-9, 19; Technical Papers 14-27, 30, 31; State College, Pa.

Pennsylvania Topographic and Geologic Survey: Bulletins 113, 114. Harrisburg, Pa.

Physical Review, vols. 47-50: Lancaster, Pa.

Popular Astronomy, vols. 43, 44. . Northfield, Minn.

Puerto Rico, Report of Committee on Mineral Resources: 1934. San Juan, P. R:

Quebec (Province), Bureau of Mines: Annual Reports, 1933, Parts C-E; 1934, pts. A-E; French edition, 1934, Parts C-E. Quebec, Canada.

Revista de obras públicas de Puerto Rico: Años 12, 13. San Juan, P. R.

Revista industrial, Secretaría de la economía nacional, vols. 3, 4, 5 (no. 1). Mexico City.

Revue de géologie, vols. 15, 16 (fasc. 1-10). Liege, Belgium.

Rhodora, vols. 37, 38. Boston; Mass.

Rochester Academy of Science: Proceedings, vol. 7 (nos. 5-7). Rochester, N. Y.

Rocks and Minerals, vols. 10, 11 ; Bulletin 2. Peekskill, N. Y.

Royal Canadian. Institute: Proceedings, 3d ser., vol. 1; Transactions, vols. 20 (pt. 2), 21 (pt. 1). Toronto, Ontario.

Royal Society of Canada: Proceedings, 3d ser., vols. 29, 30 ; Transactions, 3d ser., vols. 29 (secs. I-IV), 30 (secs. III-V). Ottawa, Ontario.

Saint Paul Institute, Science Museum: Science Bulletin 1. St. Paul, Minn.

San Diego Society of Natural History: Transactions, vol. 8 (nos. 5-22). San Diego, Calif.

Santa Barbara Museum of Natural History: Occasional Paper 4. Santa Barbar'a, Calif.

Science, new ser., vols. 81-84. New York.

Scientific Monthly, vols. 40-43. New. York.

Seismological Society of America: Bulletin, vols. 25, 26. Stanford University, Calif.

Shore and Beach, vols. 3, 4. New Orleans, La.

Smithsonian Institution: Annual Reports, 1933, 1934, 1935; Exploration and Field Work, 1934, 1935; Miscellaneous Collections, vols. 91 (nos. 19-24), 92 (no. 14), 93 (nos. 2-10), 94 (1, 3-13, 15-17), 95, 73 (no. 8, October 28, 1936). Washington D. C.

Sociedad científica "Antonio Alzate": Memorias y revista vol. 53. Mexico City. Sociedad cubana de historia natural : Memorias de la Museo Poey, vols. 6, 8, 9 (in part). Habana, Cuba. 
Sociedad cubana de ingenieros: Revista, vols. 27-29. Habana, Cuba.

Sociedad geológica mexicana, Boletín, tomo 9 (no. 1, 2). Mexico City.

Society for Research on Meteorites: Contributions, no. 1. Los Angeles, Calif.

South Carolina Academy of Science: Bulletin, vols. 1, 2. Colombia, S. C.

South Dakota Geological Survey: Biennial Reports, 1932-34, 1934-36; Reports of Investigations 24-26. Vermillion, S. Dak.

Southern California Academy of Sciences: Bulletin, vols. 34 (pts. 1-3), 35 (pts. 1, 2). Los Angeles, Calif.

Southwest Museum Papers, nos. 8, 9. Los Angeles, Calif.

Staten Island Institute of Arts and Sciences: Proceedings, vol. 7 (pts. 3, 4). Staten Island, N. Y.

Tennessee Academy of Science: Journal, vols. 10, 11. Nashville, Tenn.

Tennessee Valley Authority, General Engineering and Geology Division: Geologic Bulletins 3, 4 (pt. 1). Knoxville, Tenn.

Texas, University, Bureau of Economic Geology : Bulletins 3301, 3401, 3501, 3502, 3534, 3619; Mineral Resources Circulars 8; News Letter, September 1935. Austin, Tex.

Toronto University: Studies, Geological series, 36-39. Toronto, Ontario.

Torreya, vols. 35, 36. Lancaster, Pa.

Torrey Botanical Club: Bulletin, vols. 62, 63. Menasha, Wis.

Tufts College Studies, vol. 6 (no. 1). Tufts College, Mass.

Tulsa Geological Society: Digest, 1934. Tulsa, Okla.

United States Bureau of Mines: Bulletins 381, 383-394, 397-399; Economic Paper 18; Monographs 6, 7; Technical Papers 558, 562-571. Washington, D. C.

United States Coast and Geodetic Survey: Special Publications 71, 111, 129, revised editions ; 140, 189, 190, 192-204, 206-208; Serial 564, 579, 581, 584, 587, 593. Washington, D. C.

United States Department of Agriculture: Miscellaneous Publications 200, 204, 205, 214, 217, 221, 229, 238, 240, 248, 252, 253; Techmical Bulletins 344, $451-475,482,484,502,524,526,528,530,533,541,542$. Washington, D. C.

United States Department of the Interior, Press Memoranda, nos. 79318, 1934; 29021, 97078, 98079, 99554, 101944, 102557, 103188, 103189, 105368, 106377, 108270, 108556, 109045, 109266, 109267, 1935; 110985, 113781, 115010, 115346, 1936. Washington, D. C.

United States Geological Survey: Annual Report, 56th, 57th ; Bulletins 843, 847, 851-856, 859, 860 (A-B) , 862, 863, 864 (B-C), 865-867, 868 (A-C), 869871, 873, 881, 886 (A) ; Professional Papers 177-184, 185 (B, H, I), 186 (A) ; Water-Supply Papers 494 (reprint), 657, 676-678, 679A, 680, 741772, 773 (A-E), 775, 777, 784, 785, 787, 791, 798, 794. Washington, D. C.

United States National Museum: Annual Reports, 1934, 1935; Proceedings, vols. 83, 84 (part). Washington, D. C.

United States Soil Conservation Service: Sedimentation Surveys, nos. 1-9. Washington, D. C.

Utah Academy of Sciences, Arts, and Letters: Proceedings, vols. 12, 13. Provo, Utah.

Utah State Agricultural College, Agricultural Experiment Station: Technical Bulletins 255, 256, 259. Logan, Utah.

Virginia Academy of Science: Proceedings, 1934-35, 1935-36. Charlottesville, Va.

Virginia Geological Survey: Bulletins 39, 43-45, 47. Charlottesville, Va.

Wagner Free Institute of Science: Bulletin, vols. 10, 11. Philadelphia, Pa.

Washington Academy of Sciences: Journal, vols. 25, 26. Washington, D. C. 
Washington Geological Survey, Division of Geology: Biennial Report, 1925-26, 1926-28, 1933-34; Information Circulars 1, 2 ; Reports of Investigations 2, 3. Olympia, Wash.

Washington, University : Engineering Experiment Station series, Bulletins 7881, 85, 88, 90, 91; Report, 1934; Publications in Geology, vol. 3 (no. 2). Seattle, Wash.

Washington University, St. Louis: Studies, new ser., in Science and Technology, no. 9. St. Louis, Mo.

West Virginia Geological Survey: Mimeographed series I, Bulletin 6. Morgantown, W. Va.

West Virginia, University : Bulletins 9, 1933 ; ser. 35, no. 1 (Res. Bull. 11), 1934 ; Deep-Well Records, 1936. Morgantown, W. Va.

Western Society of Engineers: Bulletin, vol. 6 (nos. 1-12). Evanston, Ill.

Wisconsin Academy of Science, Arts, and Letters: Transactions, vol. 29. Madison, Wis.

World Petroleum, vols. 6, 7. New York.

Wyoming Geological Survey: Bulletin 26. Laramie, Wyo.

Wyoming, State Geologist: Biennial Report, 16th, 1930-32. Cheyenne, Wyo. 



\section{.BIBLIOGRAPHY}

iA double dagger ( $\ddagger$ ) indicates matter reproduced by otber means than ordinary printing)

Abbott, L. V.

1. A study of the South Pass and Atlantic City mining district of Fremont County, Wyoming: Rocks and Minerals, vol. 11, no. 10, pp. 218-219, November 1936.

Aberdeen, Esther Jane. See Boos, 372.

Ackoff, Albert.

2. The fluorescence analysis 'of gems and minerals : Mineralogist, vol. 3, no. 1, pp. 7-8, 40-43, January 1935.

Adams, Bradford C. See Cushman, 942.

Adams, John Emery.

3. Upper Permian stratigraphy of west Texas Permian basin : Am. Assoc. Petroleum Geologists Bull., vol. 19, no. 7, pp. 1010-1022, 2 figs., July 1935.

4. Oil pool of open reservoir type [with discussion by W. B. Wilson]: Am. Assoc. Petroleum Geologists Bull., vol. 20, no. 6, pp. 780-796, 5 figs. (incl. index map), .June 1936; abstract, World Petroleum, vol. 7, no. S, p. 404, August 1936.

Addison, C. C. See Hake, 1600.

Adkins, Walter Scott.

5. Upper Cretaceous unconformities in Texas: Texas Univ. Bull. 3501, Jaṇuary 1, 1935, pp. 141-149, February 1936.

Adler, Joseph Leopold..

6. Stratigraphic zones in the Negaunee iron formation of Marquette County, Mich.: Jour. Geology, vol. 43, no. 2, pp. 113-132, 4 figs., 3 pls., February-March 1935.

Agar, William Macdonough. See also Fowler, 1317.

7. Value of a state geological survey to a nonmining community [with discussion] : Am. Inst. Min. Met. Eng. Trans., vol. 115 (Mining geology); pp. 448-451; discussion, pp. 452-459; 1935.

8. Pegmatite minerals in the marble at Falls Village, Conn.: Am. Jour. Sci., 5th ser., vol. 29, no. 169 , pp. 56-57, January 1935.

Ageton, Richard Valentine.

9. Salt occurrences in the potash mines of New Mexico: Am. Inst. Min. Met: Eng. Tech: Pub. 686, 11 pp., 4 figs., 1936.

Aguayo, C. G. See Clench, 778 .

Albritton, Claude C., Jr. See Boon, : 370 . 
Alcock, Frederick James. See also Canada G. S., 651, 652, 653, 654, 662, 663, $664,672,673$.

10. Lead and zinc deposits of the Cordilleran region, Canada: Fifth Pacific Sci. Cong., Canada, 1933, Proc., vol. 2, pp. 1425-1430, 1934.

11. Copper in Canada: Copper resources of the world, pp. 65-136, 2 pls. (geol. and sketch maps), 6 figs. (incl. geol. maps), Washington, 16th Internat. Geol. Cong., 1935.

12. Geology of Chaleur Bay region: Canada Dept. Mines Geol. Survey Mem. 1.33, Pub. 2398, 146 pp., 22 pls. (incl. geol. and index maps), 9 figs. (incl. index map), 1935.

13. Mudjatik-Haultain area, Saskatchewan: Canada Dept. Mines Geol. Survey Mem. 180, Pub. 2393, 16 pp., 8 pls. (incl. geol. maps), 1935.

14. Airplanes an aid in geologic studies: Eng. and Min. Jour., vol. 136, no. 11, pp. 546-547, 1 fig., November 1935.

15. The gold deposits of Lake Athakaska [Saskatchewan]: Canadian Min. Met. Bull. 292, pp. 531-546, 18 figs. (incl. index maps), August 1936.

Alden, William Clinton.

16. Memorial of Joseph Hartshorn Perry [1858-1934] : Geol. Soc. America Proc., 1935, pp. 297-300, 1 pl. (port.), June 1936.

Aldinger, Hermann.

17. Das Alter der jungpalaeozoischen Posidonomyaschiefer von Ostgrönland: Meddelelser om Grönland, Band 98, Nr. 4, 24 pp., 1934.

18. Geologische Beobachtungen im oberen Jura des Scoresbysundes (Ostgrönland) : Meddelelser om Grönland, Band 99, Nr. 1, 128 pp., 3 pls. (incl. geol. maps), 35 figs., 1935.

Aldrich, Truman Heminway, 1848-1932.

19. Description of a few Alabama Eocene species and remarks on varieties, with plates: Alabama Geol. Survey Mus. Paper 12, 21 pp., 6 pls., 1931.

Alessi, A. Joseph.

20. Serpentine at Ishpeming, Mich.: Rocks and Minerals, vol. 11, no. 1, p. 11, January 1936.

21. Hunting agates around Lake Superior: Rocks and Minerals, vol. 11, no. 9, p. 139, September-October 1936.

Alexander, Alexandre Emil.

22. The probable sedimentation of the slates and flintlike slates of North Carolina [abstract] : Elisha Mitchell Sci. Soc. Jour., vol. 47, no. 1, pp. 18-21, January 1932.

23. Differentiation of the Onondaga formation by means of heavy minerals [abstract] : Am. Mineralogits, vol. 20, no. 3, p. 208, March 1935; Geol. Soc. America Proc., 1934, pp. 429-430, June 1935.

24. Opalized spherules from Utah?: Am. Mineralogist, vol. 20, no. 8, pp. 602 603, 1 fig., August 1935.

Alexander, Charles Ivan.

25. Stratigraphy of Midway group (Eocene) of southwest Arkansas and northwest Louisiana: Am. Assoc. Petroleum Geologists Bull., vol. 19, no. 5, pp. 696-699, 1 fig., May 1935.

26. Ostracoda of the genus Argilloecia from the Cretaceous of Texas: Jour. Paleontology, vol. 9, no. 4, pjs. 35̌6-357, 2 figs., June-1985.

27. Ostracoda of the genera Eucythere, Cytherura, Eucytherura, and Loxoconcha from the Cretaceous of Texas: Jour. Paleontology, vol. 10, no. 8, pp. 689-694, 1 pl., December 1936. 
Alexander, John Andrew. See also MacCarthy, 2486, 2487.

28. Some geophysical experiments [abstract] : Elisha Mitchell Sci. Soc. Jour., vol. 49 , no. 1, pp. 21-22, September 1933.

29. Geomagnetic surveying [abstract]: Elisha Mitchell Sci. Soc. Jour., vol. 49, no. 1, p. 38, September 1.933 .

Allan, John Andrew.

30. Milestones in the mining industry in Canada: Canadian Inst. Min. Metallurgy Trans., vol. 36 [also appeared in Bull, 253], pp. 155-168, May 1933.

31. (and Rutherford, Ralph Leslie). [Report of the] Geological Survey Division: Alberta Research Council 13th Ann. Rept. (no. 28), 1932, pp. 19-38, 4 pls., 1935.

32. [Report of the] Geological Survey Division: Alberta Research Council 14th Ann. Rept. (no. 29), 1933, pp. 53-54, 1935.

33. [Report of the] Geological Survey Division: Alberta Research Council 15th Ann. Rept. (no. 32), 1934, pp. 74-76, 1935.

34. [Report of the] Geological Survey Division: Alberta Research Council 16th Ann. Rept. (no. 33), 1935, pp. 27-37, 5 pls. (incl. geol. map), 1936.

35. The trend of geology: Roy Soc. Canada Trans., ser. 3, sec. 4, vol. 30, pp. 1-8, May 1936.

Allen, Eugene Thomas. See also Behre, 261; Ross, 3367.

36. (and Day, Arthur Louis). Hot springs of the Yellowstone National Park: Fifth Pacific Sci. Cong., Canada, 1933, Proc., vol. 3, pp. 2275-2284, 1934.

37. (and Day, Arthur Louis). Hot springs of the Yellowstone National Park. Microscopic examinations by Herbert Eugene Merwin. Carnegie Inst. Washington Pub. 466, xviii, 525 pp., 1 pl. (front.), 215 figs., 1935.

38. Geyser basins and igneous emanations: Econ. Geology, vol. 30, no. 1, pp. 1-13, January-February 1935.

Allen, Francis Henry.

39. On the formation of lake balls: Science, new ser., vol. 82 , no. 2130 , pp. 389-390, October 25, 1935.

Allen, John Eliot.

40. Structures in the dacitic flows at Crater Lake, Oreg.: Jour. Geology, vol. 44, no. 6, pp. 737-744, 4 figs. (incl. index map), August-September 1936.

Allen, Maxwell Wilford.

41. The lunar triggering effect on earthquakes in southern California: Seismol. Soc. America Bull., vol. 26, no. 2, pp. 147-157, 2 figs., April 1936.

Allen, Victor Thomas. See also Farrar, 1215 ; Crim, 1549.

42. Mineral composition and origin of Missouri flint and diaspore clays: Missouri Geol. Survey 58th Bienn. Rept., Appendix 4, 24 pp., 2 figs. (incl. map), 4 pls., 1935.

43. Memorial of Stephen Richarz [1874-1934] : Am. Mineralogist, vol. 20, no. 3, pp. 184-187, port., March 1935.

44. Aluminum hydrates in Missouri diaspore deposits [abstract] : Geol. Soc. America Proc., 1934, p. 63, June 1935.

45. A mineralized spherulitic limestone in the Cheltenham [Missouri] fireclay: Am. Mineralogist, vol. 21, no. 6, pp. 369-373, 2 figs., June 1936 ; abstracts, Jan-Am. Geologist, vol. 65, no. 2, p. 159, March 1936 ; Geol. Soc. America Proc., 1935, p. 435, June 1936.

$311-37-2$ 
Allen, Victor Thomas-Continued.

.. 46. Dickite from St. Louis County, Mo.: Am. Mineralogist; vol. 21, no. 7, pp. 457-459, 2 figs., July 1936.

47. Terminology of medium-grained sediments (witl. notes by P. G. H. Boswell) : Nat. Research Council Ann. Rept., App. I, Report of committee on sedimentation, pp. 18-47 (\$), September 1936.

Allende, Roque.

48. Breves noticias del cobre en Cuba: Copper resources of the world, pp. 425-433, 1 pl. (index map) Washington, 16th Internat. Geol. Cong., 1935.

Alling, Harold Lattimore: See also Bowen, 390.

49. Interpretative petrology of the igneous rocks, 1st ed. $x v, 353 \mathrm{pp}$., 59 figs. New York, McGraw-Hill Book Co., Inc., 1936.

50. Petrology of the Niagara Gorge sediments: Rochester Acad. Sci.. Proc., vol. 7, no. 7, pp. 189-203, 1 pl., 3 figs., December 1936.

Allison, Ira Shimmin.

51. Glacial erratics in Willamette Valley: Geol. Soc. America Bull., vol. 46, no. 4, pp. 615-632, 1 fig. (map), 3 pls., April 30, 1935; abstract, Proc., 1934, p. 335, June 1935.

52. Correlation of glacial terraces by means of soils [abstract]: Geol. Soc. America Proc., 1934, p. 63, June 1935.

53. Pleistocene alluvial stages in northwestern Oregon: Science, new ser., vol. 83, no. 2158, pp. 441-443, May 8, 1936 ; abstract, Geol. Soc. Oregon Country News Letter, vol. 2, no. 11, p. $6 .(\ddagger), j$ une 10 , 1936.

54. Late Pleistocene topographic correlations on the Pacific coast: Geol. Soc. Oregon Country News Letter, vol. 2, no. 13, p. 10. (\$), July.10, 1936 ; abstracts, Pan-Am. Geologist, vol. 63, no. 4, p. 310, May 1935 ; Geol. Soc. America Proc., 1935, p. 333, June 1936.

Aloisi, Piero.

55. On the application of determinants to crystallography; Am. Mineraiogist, vol. 20, no. 5, pp. 400_401, May 1935.

Alter, Chester M.

56. (and Kipp; Egbert M.). The effect of alteration on the lead-uranium ratio and the calculated age of Wilberforce, Ontario, uraninite: Science, new ser., vol. 82, no. 2133, pp. 464-465, November 15, 1935.

57. (and Kipp, Egbert M.) The variation of the lead-uranium-thorium ratio of a single crystal of Wilberfore, Ontario, uraninite : Am. Jour. S'ci., 5th ser., vol. 32, no. 188, pp. 120-128, August 1936.

Ambrose, John Willis. See also Gunning, 1573.

58: Structures in the Missi series near Flinflon, Manitoba: Royal Soc. Canada, 3d ser., sec. 4, vol. 30, pp. 81-98, 4 figs. (incl. geol. map), May 1936; abstract, Proc. p. xcix, 1936.

59. Progressive kinetic metamorphism in the Missi series near Flinflon, Manitoba: Am. Jour. Sci., 5th ser., vol: 32, no. 190, pp. 257-286, 5 figs. (incl. geol. sketch map), October 1936.

American Institute of Mining and Metallurgical Engineers. See Graton, 1502. Amick, Harold Clyde. See Hall, 1608.

Amsden, Charles Avery.: See also Campbell, 635.

60. America's earliest man: Sci. Monthly, vol. 42, no. 4, pp. 365-368, April 1936. 
Anderson, Alfred Leonard.

61. The valley of Grimes Creek in the Payette Canyon, Idaho: Jour. Geology, vol. 43 , no. 6 , pp. 61S-629, 1 pl. (topog. map), 4 figs. (incl. sketch map), August-September 1935.

62. Petrology of Pearl-Horseshoe Bend porphyry belt [abstract]: Pan-Am, Geologist, vol. 65, no. 1, p. 78, February 1936.

Anderson, Carl Bernard. See Knechtel, 2228; U. S. G. S., 4231.

Anderson, Charles Alfred.

63. Alteration of the lavas surrounding the hot springs in Lassen Volcanic National Park: Am. Mineralogist, vol. 20, no. 4, pp: 240-25:2, April 1935 : abstract, Geol. Soc. America Proc., 1934, pp. 330-331, June 1935.

64. Volcanic history of the Clear Lake area, California: Geol. Soc. America Bull., vol. 47, no. 5, pp. 629-664, 7 pls. (incl. geol. map), 8 figs. incl. geol. map), May 31, 1936; abstracts, Pan-Am. Geologist, vol. 64, no. 1, pp. 66-67, August 1935 ; Geol. Soc. America Proc., 1935, pp. 343-344, June 1936.

Anderson, Frank Marion.

65. (and Hanna, G. Dallas). Cretaceous geology of Lower! California : California Acad. Sci. Proc., 4th ser.; vol. 23, no. 1, pp. 1-34, 11, pl., 2 figs., December 23, 1935.

Anderson, George Harold. See also Maxson, 2619.

66. (and Maxson, John Haviland). Physiography, of the northern Inyo Range [abstract]: Geol. Soc. America Proc., 1934, p. 318, June 1935.

67. Granitization and albitization in Inyo Range [Calif.] [abstract]: PanAm. Geologist, vol. 64, no. 1, p. 66, August 1935 ; Geol. Soc. America Proc,, 1935, pp. 63, 343, June 1936.

Anderson, John August. See Day, 987, 989.

Anderson, John Carter.

68. Occurrence of ore in the western United States: Econ. Geology, vol. 30, no. 2, pp. 191-192, March-April 1935.

69. Essential criteria in examining gold, quartz mines: Eng. and Min. Jour., rol. 136, no. 8, pp. 445-449, 2 figs., August 1935.

Andrau, E. W. K. See Deussen, 1036.

Andreas, 'A. See Winchester, 4565.

Andrews, David Arthur. See also U. S. G. S., 4228; Waring, 4339.

70. (and Simpson, R. B., Waldron, F. R., and Holmgren, L. E.). Geology and coal resources of the Minot area, north-central North Dakota: U. S. Dept. Interior Press Mem. 103189, 7 pp. ( $\$$ ), 1 pl. (geol. map); August 5, 1935.

71. Early stages of glacial Lake Souris, N. Dak. [abstract]: Washington Acad. Sci. Jour., vol. 25, no. 12, pp. 568-569, December 15; 1935.

Andrews, Ernest Clayton.

72. The origin of modern mountain ranges: Fifth Pacific Sci. Cong., Canada, 1933, Próc., vol. 2, pp. 907-914, 1934.

Andrews, Henry N:

73. A new. Sequoioxylon from Florissant, Colo.: Missouri Bot. Garden Annals,' vol. 23, no. 3, pp. 439-443; 1 fig., September 1936. 
Andrews, Philip.

74. Geology of the Pinnacles National Monument: California Univ., Dept. Geol. Sci., Bull., vol. 24, no. 1, pp. 1-38, 3 pls. (incl. geol. map), 11 figs. (incl. index map), 1936.

Andrews, Roy Chapman.

75. (and others). Henry Fairfield Osborn, August 8, 1857-November 6, 1935 ; tributes paid at memorial meetings in New York City, November 7 , November 12 , and December 18, 1935 : Supplement to Nat. History, vol. 37, no. 2, 15 pp., 1 pl. (port.), February 2, 1936.

Annis, Wilbert. See Byerly, 614, 616; Wilson, 4540, 4541.

Anters, Ernst Valdemar.

76. Alpine zone of Mount Washington Range. 118 pp., 36 figs. (incl. topog. map); Auburn, Maine, 1932.

77. The spread of aboriginal man to North America: Geog. Rev., vol. 25, no. 2, pp. 302-309, April 1935 .

78. Geology in relation to the spread of man to North America [abstract]: Geol. Soc. America Proc., 1934, p. 64, June 1935.

79. The occurrence of flints and extinct animals in pluvial deposits near Clovis, N. Mex.; pt. 2, Age of the Clovis lake clays: Acad. Nat. Sci. Philadelphia Proc., 1935, pp. 304-312,.1 pl., October 10, 1935.

80. Correlations of late Quaternary chronologies: 16th Internat. Geol. Cong. (1933) Rept., vol. 1, pp. 213-216, 1936.

81. Dating records of early man in the Southwest: Am. Naturalist, vol. 70, no. 729, pp. 331-336, July-August 1936.

Applin, Esther Richards.

82. Correlation of the California Turritella andersoni zone with Gulf coast Eocene [abstract] : Geol. Soc. America Proc., 1934, pp. 392-393, June 1935.

Archibald, Raymond Clare.

83. (and Lindsay, Robert Bruce). Carl Barus, 1856-1935: Science, new ser., vol. 82 , no. 2134, pp. 481-483, November $22,1935$.

Arick, Millard Boston.

- 84. Early Paleozoic unconformities in trans-Pecos Texas (Cambrian to Devonian inclusive) : Texas Univ. Bull. 3501, January 1, 1935, pp. 117121, February 1936.

Armstrong, E. J.

85. Schroeckingerite from Bedford, N. Y.: Am. Mineralogist, vol. 20, no. 1, pp. 62-63, January 1935.

Armstrong, H. K. See Jakosky, 1930.

Arnold, Chester Arthur.

86. Some new forms and new occurrences of fossil plants from the Middle and Upper Devonian of New York State: Buffalo Soc. Nat. Sci. Bull., vol. 17, no. 1, pp. 1-12, 1 pl., 2 figs., 1935.

87. Notes on some American species of Lepidostrobus: Am. Jour. Botany, vol. 22, no. 1, pp. 23-25, January 1935.

88. Observations on Alethopteris grandifolia Newberry and its seeds: Michigan Univ. Mus. Paleontology Contr., vol. 4, no. 15, pp. 279-282, 1 pl., February 20, 1935.

89. On seedlike structures associated with Archaeopteris, from the Upper Devonian of northern Pennsylvania: Michigan Univ. Mus. Paleontology Contr., vol. 4, no. 16, pp. 283-286, 1 fig., February 20, 1935. 
Arnold, Chester Arthur-Continued.

90. A Douglas fir cone from the Miocene of southeastern Oregon: Washington Acad. Sci. Jour., vol. 25, no. 8, pp. 378-380, 1 fig., August 15, 1935.

91. Observations on fossil plants from the Devonian of eastern North America; 1, Plant remains from Scaumenac Bay, Quebec: Michigan Univ. Mus. Paleontology Contr., vol. 5, no. 2, pp. 37-48, 4 pls., July 31, 1936.

92. Observations on fossil plants from the Devonian of eastern North America; 2, Archaeopteris macilenta and A. sphenophyllifolia of Lesquereux; Michigan Univ. Mus. Paleontology Contr., vol. 5, no. 3, pp. 49-56, 1 pl., July 31, 1936.

93. Some fossil species of Mahonia from the Tertiary of eastern and southeastern Oregon: Michigan Univ. Mus. Paleontology Contr., vol. 5, no. 4, pp. 57-66, 3 pls., July 31, 1936.

94. Paleozoic plants and their environmental relations : Nat. Research Council Ann. Rept., 1935-36, App. J, Report of the committee on pleoecology, pp. 55-64; ( $\ddagger)$, October 1936.

95. The occurrence of Cedrela in the Miocene of western America: Am. Midland Naturalist, vol. 17, no. 6, pp. 1018-1021, 11 figs., November 1936.

Arnold, Ralph. See Day, 987, 989.

Arreola, Vincente. See Juarez, 2014.

Arsandaux, H. C. R.

96. L'éruption actuelle de la Montagne Pelée: Cong. S. savantes, Alger 1930, Comptes rendus, pp. 39-44, 1934.

Artist, Russell C.

97. Stratigraphy and preliminary pollen analysis of a Lake County, Ill., bog: Butler Univ. Bot. Studies, vol. 3, paper 13, pp. 191-198, May 1936.

Ashauer, Hans. See also Stille, 3904.

98. (and Hollister, Joseph Steffens, and Reed, Ralph Daniel). Sedimentation und Faltung im suidlichen Kalifornien: Festschrift zum 60 . Geburtstag von Hans Stille, pp. 232-258, 4 figs. (incl. geol. maps), Stuttgart, Ferdinand Enke, 1936.

Ashley, George Hall.

99. The Topographic and Geologic Survey [of Pennsylvania]; a brief summary of its work since 1919 : Pennsylvania Topog. and Geol. Survey Bull. 101, 6 pp. ( $\ddagger)$, September 1930.

100. (and Cathcart, Stanley Holman, and Willard, Bradford, and Fettke, Charles Reinhard). Gas in the Tioga region, Pa.: Pennsylvania Topog. and Geol. Survey Bull. 102, 22 pp. (†), 2 pls. (geol. maps), August 10, 1931.

101. The undeveloped mineral resources of Pennsylvania ; introduction: Pennsylvania Geol. Survey, 4th ser., Bull. M 18-A, 16 pp., 1933.

102. Function of State surveys [with discussion] : Am. Inst. Min. Met. Eng. Trans., vol. 115 (Mining geology), pp. 415-419; discussion, pp. 452459, 1935.

103. Unsolved problems in coal-measures stratigraphy [abstract, with discussion by William Henry Collins] : Geol. Soc. America Proc., 1934, pp. 64-65, June 1935.

104. Memorial of Edward Vincent d'Invilliers [1857-1928] : Geol. Soc. America Proc., 1934, pp. 221-224, port., June 1935. 
Ashley, George Hall-Continued.

105. Evolution and the moral order [abstract]: Geol. Soc. America Proc., 1934, p. 439, June 1935.

106. (and Willard, Bradford). The use of the term Pocono: Science, new ser., vol. 81, no. 2112, pp. 615-617, June 21, 1935.

107. Studies in Appalachian mountain sculpture: Geol. Soc. America Bull., vol. 46 , no. 9 , pp. $1395-1436,8$ pls. (incl. topog. map), 14 figs. (incl. maps) ; discussion by George Halcott Chadwick and author's reply, pp. 2055-2057, 1 fig., September 30; 1935.

108. Geological Survey founded in Commonwealth [of Pennsylvania] just 50 years after Hutton founded science: Pennsylvania Dept. Internal Affairs Monthly Bull., vol. 2, no. 1, pp. 3-13, June 1936.

109. Memorial of James Donaldson Sisler [1896-1935]: Geol. Soc. America Proc., 1935, pp. 319-322, 1 pl. (port.), June 1936.

110. Pattern of evolution [abstract]: Geol. Soc. America Proc., 1935, pp. 368-369, June 1936.

Atkinson, James C. See Rice, George S., Jr., 3260-A.

111. Aerial maps, greatly improved, simplify work of geologist and engineer: Mining and Metallurgy, vol. 17, no. 360, pp. 569-572, 4 figs., December 1936.

Atwater, Gordon I. See also Kansas Geol. Soc., 2020; Kay, 2030.

112. The Keweenawan-Upper Cambrian unconformity in the upper Mississippi Valley: Kansas Geol. Soc. Guidebook 9th Ann. Field Conf., pp. 316-319 ( $¥, 1$ pl. (geol. map), 1935.

113. A summary of the stratigraphy and structure of the Gogebic iron range; Michigan and Wisconsin: Kansas Geol. Soc. Guidebook 9th Ann. Field Conf., pp. 417-420 ( $¥), 4$ figs., 1935.

114. (and Clement, George M.) Pre-Cambrian and Cambrian relations in the upper Mississippi Valley: Geol. Soc. America Bull., vol. 46, no. 11, pp. 1659-1686, 3 figs. (incl. geol. map) ; discussion by George M. Schwartz and reply by Atwater, pp. 2060-2066, November 30, 1935.

115. Correlation of the Copps and the Tyler formations of the Gogebic iron district [abstract] : Geol. Soc. America Proc., 1935, p. 63, June 1936.

Atwill, E. R.

116. Oligocene Tumey formation of California: Am. Assoc. Petroleum Geologists Bull., vol. 19, no. 8, pp. 1192-1204, 3 figs. (incl. geol. map), August 1935.

Atwood, Wallace Walter, Jr.

117. The glacial history of an extinct volcano, Crater Lake National Park: Jour. Geology, vol. 43, no. 2, pp. 142-168, 24 figs. (incl. index map), February-March, 1935 ; with slight alterations reprinted in Smithsonian Inst. Ann. Rept., 1935, Pub. 3348, pp. 303-320, 6 pls., 13 figs., 1936 ; abstracts, Pan-Am. Geologist, vol. 65, no. 2, p. 159, March 1936 ; Geol. Soc. America Proc., 1935, p. 435, June 1936.

118. Erosional history of the Wind River Range, Wyoming [abstract]: Assoc. Am. Geographers Annals, vol. 25, no. 1, pp. 33-34, March 1935.

119. (and Kingman, Eugene). A new method in physiographic presentation [abstract] : Assoc. Am. Geographers Annals, vol. 26, no. 1, p. 40, March 1936.

120. (and Kingman, Eugene). Art as an aid in physiographic presentations [abstract]: Geol. Soc. America Proc., 1985, p. 64, June 1936. 
Aubert de la Rue, Edgar.

121. Sur la présence de l'Acadien a Langlade (Îles Saint-Pierre et Miquelon) : Soc. géol. France Compte rendu, fasc. 1-2, pp. 13-14, janvier 7-21, 1935.

122. Recherches géologiques et minières effectuées aux Îles Saint-Pierre et Miquelon en 1935: Chronique mines coloniales, $5^{\circ}$ année, no. 46, pp. 2-8, January 1, 1936.

Averill, Charles Volney.

123. The Shasta County copper belt, Calif.: Copper resources of the world, pp. 237-240, 2 figs. (incl. index map), Washington, 16th Internat. Geol. Cong., 1935.

124. Mines and mineral resources of Siskiyou County: California Jour. Mines and Geology, vol. 31, no. 3, pp. 255-338, 1 pl. (index map), 13 figs., July 1935.

Ayer, Mary Youngman.

125. The archeological and faunal material from Williams Cave, Guadalupe Mountains, Tex. : Acad. Nat. Sci. Philadelphia Proc., 1936, vol. 88, pp. 599-619, 1 pl., December 23, 1936.

Backlund, Helge Götrik.

126. (and Malmquist, David). Zur Geologie und Petrographie der Nordostgrönlandischen Basaltformation; 2, Die sauren Ergussgesteine von Kap Franklin: Meddelelser om Grönland, Band 95, Nr. 3, 84 pp., 11 pls. (incl. geol. map), 12 figs., 1935.

127. [Revieiw of] Geologie von Grönland by Lauge Koch, 1935: Geog. Jour., vol. 87, no. 4, pp. 359-360, April 1936.

Backman, O. L.

128. The geology of the Siscoe gold mine: Canadian Min. Jour., rol. 57, no. 10, pp. 467-475, 6 figs. (incl. geol. maps), October 1936.

Badenoch, Byrne M. See Case, 691.

Bagley, James W. See Talley, 4010.

Bailey, Irving Widemar.

129. (and Faull, Anna F.) The cambium and its derivative tissues; no. 9, Structural variability in the redwood, Sequoia sempervirens, and its significance in the identification of fossil woods : Harvard Univ., Arnold Arboretum Jour., vol. 15, no. 3, pp. 233-254, 8 pls., 1 fig., 1934.

Bailey, Reed W.

130. Epicycles of erosion in the valleys of the Colorado Plateau province: Jour. Geology, vol. 43, no. 4, pp. 337-355, May-June 1935; abstract, Geol. Soc. America Proc. 1934, p. 440, June 1935.

Bailey, Thomas Laval. See also Morse, 2806.

131. Lateral change of fauna in the lower Pleistocene: Geol. Soc. America Bull., vol. 46, no. 3, pp. 489-502, 1 fig. (map), 1 pl. (relief map), March 31, 1935; abstract, Proc., 1934, p. 312, June 1935; PanAm. Geologist, vol. 61, no. 4, p. 309, May 1934.

Bailey, Willard Francis.

132. Natural gas from Paleozoic horizons in southern Cincinnati arch region: Geology of natural gas, pp. 853-880, 9 figs. (incl. geol. maps), Am. Assoc. Petroleum Geologists [June] 1935. 
Bailey, Willard Francis-Continued.

133. Micropaleontology and stratigraphy of the lower Pennsylvanian of central Missouri : Jour. Paleontology, vol. no. 6, pp. 483-502, 1 pl., 3 figs., September 1935.

Bain, George William.

134. Service of the surveys [with discussion]: Am. Inst. Min. Met. Eng. Trans., vol. 115 (Mining geology), pp. 420-435, 5 figs., discussion, pp. 452-459, 1935.

135. Pyrite oxidation: Econ. Geology, vol. 30, no. 2, pp. 166-169, 3 figs., March-April 1935.

136. Petrology of marble: Mineralogist, vol. 4, no. 2, pp. 3-4, 30-31, February 1936 ; no. 3, pp. 5-6, 36-37, March 1936.

137. Spontaneous rock expansion [abstract] : Geol. Soc. America Proc., 1935, pp. 64-65, June 1936.

138. Mechanics of metasomatism: Econ. Geology, vol. 31, no. 5, pp. 505-526, 6 figs., August 1936.

139. Preliminary report on the marble deposits of Canada Bay and White Bay, northern Newfoundland: Newfoundland Dept. Nat. Res., Geol. sec., 7 pp. (\$), August 11, 1936.

140. Serpentinization of Vermont ultrabasics: Geol. Soc. America Bull., vol. 47, no. 12, pp. 1961-1979, 5 pls., 5 figs. (incl. geol. sketch maps), December 31, 1936; abstract, Proc., 1935, p. 64, June 1936.

Bain, Harry Foster.

141. [Review of] Economic geology of mineral deposits, by Ernest R. Lilley, 1936 : Mining and Metallurgy, vol. 17, no. 359, p. 533, November 1936.

Baker, Arthur Alan. See also Schuchert, 3588; U. S. G. S., 4226, 4227, 4228.

142. Geologic structure of southeastern Utah: Am. Assoc. Petroleum Geologist Bull., vol. 19, no. 10, pp. 1472-1507, 1 pl. (geol. structure map), 2 figs., October 1935; abstract, Washington Acad. Sci. Jour., vol. 25, no. 12, p. 569, December 15, 1935.

143. (and Dane, Carle Hamilton, and Reeside, John Bernard, Jr.). Correlation of the Jurassic formations of parts of Utah, Arizona, New Mexico, and Colorado: U. S. Geol. Survey Prof. Paper 1S3, v, 66 pp., 33 pls. (incl. index map), 16 figs. (incl. geol. maps), 1936.

144. Geology of Monument Valley-Navajo Mountain region, San Juan County, Utah: U. S. Geol. Survey Bull. 865, 106 pp., 17 pls. (incl. geol. map), 2 figs. (incl. index maps), 1936.

Baker, Charles Laurence. See also Sellards, 3637.

145. Geology of Texas, vol. 2, pt. 2, Major structural features of trans-Pecos Texas: Texas Univ. Bull. 3401, pp. 137-214, 2 pls. (incl. geol. map), 5 figs. (incl. geol. and sketch maps), December 1935.

146. Geology of Texas, vol. 2, pt. 3, Economic geology of Texas (exclusive of petroleum); Construction materials, mineral, stone, and clay products, coal, lignite, and water supplies: Texas Univ. Bull. 3401, pp. 223-402, 5 figs. (incl. maps), December 1935.

147. Geology of Texas, vol. 2, pt. 3 , Economic geology of Texas (exclusive of petroleum); Metallic and nonmetallic minerals and ores: Texas Univ. Bull. 3401, pp. 402-640, 8 figs. (incl. maps), December 1935.

148. Pre-Cambrian unconformities in the trans-Pecos region: Texas Univ. Bull. 3501, January 1, 1935, pp. 113-114, February 1936. 
Baker, Charles Laurence-Continued.

149. [Review of] Historical geology of the Antillean-Caribbean region, or the lands bordering the Gulf of Mexico and the Caribbean sea by Charles Schuchert: Am. Assoc. Petroleum Geologists Bull., vol. 20, no. 4, pp. 496-504, 1 fig. (geol. map), April 1936.

Baker, Frank Collins. See also Walker, 4304.

150. Stratigraphic sequence of molluscan fossils in loess deposits [abstract] : Geol. Soc. America, Proc. 1934, pp. 372-373, June 1935.

151. Quantitative examination of molluscan fossils in two sections of Pleistocene loess in Illinois: Jour. Paleontology, rol. 10, no. 1, pp. 72-76, January 1936.

Baker, Howard Bigelow.

152. Structural features crossing the North Atlantic, 6 pp. (\$), 3 figs. (maps). [Lansing?], Mich., March 20, 1936.

153. Structural features crossing the Atlantic Ocean: Pan-Am. Geologist, vol. 66, no. 1, pp. 1-11, 1 pl. (map), 2 figs. (maps), August 1936.

Baker, Moses Nelson.

154. (and Horton, Robert Elmer). Historical development of ideas regarding the origin of springs and ground water: Am. Geophys. Union Trans. 17th Ann. Meeting, pt. 2, pp. 395-400 (\$), Nat. Research Council, 1936.

Baker, W. F.

155. Geology of God's Lake Gold Mines, Ltd. LManitoba] : Canadian Inst. Min. Metallurgy Trans., vol. 38, pp. 155-162, 6 figs. (incl. index map), 1935.

Baker, Warren L.

156. (and others). Absolute gravity survey in Gulf Coast States would be of great value to petroleum industry: Oil Weekly, vol. 79, no. 9, pp. $38,40,42,44,46$, Norember 11, 1935 .

Bakx, L. A. J.

157. Making prints of Foraminifera: Jour. Paleontology, vol. 10, no. 2, pp. 1.45-146, 3 figs., March 1936.

Balcom, W. A.

158. Materials for construction in public works and buildings: Denver Soc. Civil Eng. Trans., vol. 1, pp. 9-14, January-June 1890; abstract, Eng. Bull.; vol. 20, no. 10, pp. 13, 20, October 1936.

Balk, Robert.

159. Structure of metamorphic rocks in southeastern New York [abstract, with discussion]: 16th Internat. Geol. Cong. (1933) Rept., vol. 2, pp. 995-996, 1936.

160. Structure elements of domes: Am. Assoc. Petroleum Geologists Bull., vol. 20 , no. 1, pp. 51-67, 11 figs., January 1936; abstracts, vol. 19, no. 1, p. 136, January 1935; World Petroleum, vol. 7, no. 3, p. 150, March 1936.

161. Recognition of overthrusts in metamorphic terranes: Am. Jour. Sci., 5th ser., vol. 31, no. 182, p. 149, February 1936.

162. Structural and petrologic studies in Dutchess County, New York: Geol. Soc. America Bull., vol. 47, no. 5, pp. 685-774, 21 pls. (incl. geol. maps), 38 figs. (incl. index and geol. maps), May 31, 1936.

163. Devitrified felsite dikes from Ascutney Mountain, Vt.: Am. Mineralogist, vol. 21, no. 8, pp. 516-522, 5 figs., August 1936. 
Ball, Clayton G.

164. (and Cady, Gilbert Haven). Evaluation of ash-correction formulae based on petrographic analysis of mineral matter in coal: Econ. Geology, vol. 30, no. 1, pp. 72-88, January-February 1935.

165. Possible relations of mineral matter in coal to the time of coalification: Illinois Acad. Sci. Trans., vol. 28, no. 2, pp. 181-182, December 1935.

Ball, John Rice. See also Grant, 1495 ; Kans. Geol. Soc., 2020.

166. Isopach map of the Galena, Decorah, and Platteville [formations, upper Mississippi River Valley]: Kansas Geol. Soc. Guidebook 9th Ann. Field Conf., pp. 346-347 ( $\$$ ), 1 pl. (isopach map), 1935.

167. The 9th annual field conference of the Kansas Geological Society: Science, new ser., vol. 82, no. 2130, pp. 392-394, October 25, 1935.

168. [Review of] Guidebook 9th Annual Field Conference, the Kansas Geological Society, 1935: Jour. Geology, vol. 44, no. 3, pp. 423-425, April-May 1936.

169. Dwarfed gastropods in the basal Guttenberg, southwestern Wisconsin [abstract] : Geol. Soc. America Proc., 1935, p. 384, June 1936.

170. (and Maxwell, Ross A.). Correlation notes on the Bainbridge formation of Missouri and the Henryhouse formation of Oklahoma [abstract] : Geol. Soc. America Proc., 1935, p. 391, June 1936.

Ball, Max Waite.

171. Athabaska oil sands; apparent example of local origin of oil [with discussion] : Am. Assoc. Petroleum Geologists Bull., vol. 19, no. 2, pp. 153-171, map, February 1935.

172. Memorial of Charles Thomas Lupton [1878-1935]: Geol. Soc. America Proc., 1935, pp. 273-281, 1 pl. (port.), June 1936.

Ball, Oscar Melville.

173. Fossil leaves of dicotyledonous flowering plants: Science, new ser., vol. 84, no. 2188, p. 508, December 4, 1936.

Ball, Sydney Hobart.

174. A historical study of precious-stone valuation and prices: Econ. Geology, vol. 30, no. 6, pp. 630-642, 2 figs., September-October 1935.

Banks, H. E.

175. Using aerial photographs for topographic mapping: Eng. News-Record, vol. 116, no. 1, pp. 16-17, January 2, 1936.

Bannerman, Harold MacColl. See Gill, 1424.

Barbour, Erwin Hinckley. See also MacClintock, 2505, 2506.

176. (and Sternberg, George Fryer). Gnathabelodon thorpei, gen. et sp. nov., a new mud-grubbing mastodon: Nebraska State Mus. Bull., vol. 1, no. 42, pp. 395-404, 5 figs., May 1935.

177. (and Schultz, Charles Bertrand). A new Miocene dog, Mesocyon geringensis, sp. nov.: Nebraska State Mus. Bull., vol. 1, no. 43, pp. 407418, 7 figs., May 1935.

Barbour, Percy E.

178. World copper-ore reserves: Eng. and Min. Jour., vol. 135, no. 10, pp. 448-449, October 1934.

Barclay, George C.

179. Occurrence of fluorescent and phosphorescent calcite crystal shell casts in the Yorktown formation, Virginia: Rocks and Minerals, vol. 11, no. 4, p. 53, April 1936. 
. Barden, William J.

180. (and others). Beach-erosion studies by Federal Board: Eng. NewsRecord, vol. 111, no. 10, pp. 281-283, 4 figs., September 7, 1933.

Barker, Reginald Wright.

181. Some notes on the genus Helicolepidina Tobler: Jour. Paleontology, rol. 8, no. 3, pp. 344-351, 1 fig., 1 pl., September 1934.

182. Micropaleontology in Mexico, with special reference to the Tampico embayment: Am. Assoc. Petroleum Geologists Bull., vol. 20, no. 4, pp. 433-456, 2 figs., April 1936; extracted, in part, and translated by E. Díaz Lozano and J. Rodríguez Cabo, Jr., in Soc. geol. mexicana Bol., tomo 9, no. 2, pp. 118-127, 1936.

183. (and Grimsdale, Thomas Francis). A contribution to the phylogeny of the orbitoidal Foraminifera, with descriptions of new forms from the Eocene of Mexico: Jour. Paleontology, vol. 10, no. 4, pp. 231247, 9 pls., 4 figs. (incl. index map), June 1936.

Barksdale, Henry Compton. See also Critchlow, 915.

184 (and Sundstrom, Raymond W., and Brunstein, Maurice S.). Supplementary report on the ground-water supplies of the Atlantic City region: New Jersey State Water Policy Com. Special Rept. 6, ix, 139 pp., 23 figs. (incl. index map), 1936.

Barlow, Wallace.

185. Contributions to the geology of the Salem area [abstract]: Virginia Acad. Sci. Proc., 1934-35, p. 71 [1935].

Barnes, Farrell Francis. See also Brown, 477; Stark, 3829, 3832.

186. The pre-Cambrian rocks of the Sawatch Range, Colorado [abstract]: Northwestern Univ. Summaries Doctoral Dissertations, vol. 3, pp. 185-190, 1935.

Barnes, .Kenneth Boyd. See also Fancher, 1214.

187. Porosity and saturation methods [abstract] : Oil and Gas Jour., vol. 35, no. 28 , p. 45 , November $26,1986$.

Barnes, William Howard.

188. (and Wendling, A. V.). An X-ray method for distinguishing between certain space groups in the hexagonal system: Roy. Soc. Canada Trans., ser. 3, vol. 27, sec. 3, pp. 133-140, 4 figs., May 1933.

189. (and Wendling, A. V.). The space group of tourmaline: Roy. Soc. Canada Trans., ser. 3, vol. 27, sec. 3, pp. 169-175, 3 flgs., May 1933.

190. (and Wendling, A. V.). Note on the Laue symmetry exhibited by orthogonal crystals: Am. Mineralogist, vol. 20, no. 4, pp. 253-259, 3 figs., April 1935.

Barrabé, Louis. See also Reed, 3229.

191. Les caractères hydrogéologiques de la Guadeloupe: Cong. internat. mines, mét. géol. appliquée, sec. Géol. appliquée, $7^{\circ}$ sess., tome 2 , pp. 763773, 1 fig. (geol. map), 1936.

192. La constitution géologique des Antilles: Chronique mines coloniales, $5^{\circ}$ Annèe, no. 52, pp. 214-227, 2 figs. (geol. maps), July 1, 1936.

Barrera, Tomás.

193. Los placeres auriferos: Rev. industrial, tomo 3 , nos. 1-3, pp. 53-64, 6 figs. (incl. index map), July; August, September, 1934. 
Barret, William M.

194. Relation of geophysics to salt-dome structure [with discussion by James Brian Eby and Robert P. Clark] : Am. Assoc. Petroleum Geologists Bull., vol. 19, no. 7, pp. 1069-1073, 2 flgs., July 1935.

Barth, Thomas Fredrik Weybye. See also Ksanda, 2278.

195. Henry Stephens Washington, born January 17, 1867, died January 7, 1934: Min. pet. Mitt., Band 47, Heft 4-5, pp. 371-372, 1936.

196. Crystallography of the vivianite group [abstract]: Am. Mineralogist, vol. 21, no. 3, p. 204, March 1936.

197. The crystallization process of basalt: Am. Jour. Sci., 5th ser., vol. 31, no. 185, pp. 321-351, 7 figs., May 1936.

198. Structural and petrologic studies in Dutchess County, N. Y.; Part 2, Petrology and metamorphism of the Paleozoic rocks: Geol. Soc. America Bull., vol. 47, no. 6, pp. 775-850, 4 pls. (incl. geol. map), 8 figs., June 30, 1936.

Bartlett, Katherine.

199. Early stone-age man on Little Colorado River terraces [abstract] : PanAm. Geologist, vol. 64, no. 2, pp. 156-157, September 1935.

Bartlett, Terrell.

200. Relation between geology and engineering in water conservation: Texas Univ. Bull. 3501, January 1, 1935, pp. 159ட162, February 1936.

Barton, Donald Clinton. See also Baker, 156; Howe, 1840.

201. Mechanics of formation of salt domes with special reference to Gulf coast salt domes of Texas and Louisiana: Am. Assoc. Petroleum Geologists Bull., rol. 17, no. 9, pp. 1025-1083, \& figs., September 1933 ; reprinted in Gulf coast oil fields (see Barton and Sawtelle), pp. 20-78, 1936.

202. Surface fracture system of south Texas: Am. Assoc. Petroleum Geologists Bull., vol. 17, no. 10, pp. 1194-1212, 6 figs., October 1933; reprinted in Gulf coast oil fields (see Barton and Sawtelle), pp. 251-269, 1936.

203. (and Ritz, C. H., and Hickey, Maude). Gulf coast geosyncline: Am. Assoc. Petroleum Geologists Bull., rol. 17, no. 12, pp. 1446-1458, 4 figs., December 1933 ; reprinted in Gulf coast oil fields (see Barton. and Sawtelle), pp. 192-204, 1936.

204. Transformation of petroleum in nature: Inst. Petroleum Technologists Jour., vol. 20, no. 125, pp. 206-213, 3 figs., March 1934.

205. Prediction of overhang at Barbers Hill, Chambers County, Tex.; a study in quantitative calculations from torsion-balance data: Am. Assoc. Petroleum Geologists Bull., vol. 19, no. 1, pp. 25-36, 2 figs., January 1935.

206. Variation and migration of crude oil at Spindletop, Jefferson County, Tex.: Am. Assoc. Petroleum Geologists Bull., vol. 19, no. 5, pp. 618-643, 3 figs., May 1935; reprinted in Gulf coast oil fields (see Barton and Sawtelle), pp. 309-334, 1936.

207. Belle Isle salt dome, St. Mary Parish, La. : Am. Assoc. Petroleum Geologists Bull., vol. 19, no. 5, pp. 644-650, 2 figs., May 1935; reprinted in Gulf coast oil fields (see Barton and Sawtelle), pp. 1033-1039, 1936.

208. Calculation of the cap from torsion-balance data, Hoskins Mound salt dome, Brazoria County, Tex. : Am. Inst. Min. Met. Eng. Tech. Pub. 719, 10 pp., 5 figs., 1936. 
Barton, Donald Clinton-Continued.

209. Foreword: Gulf coast oil fields (see Barton and Sawtelle), pp. ix-xv, 1936.

210. Reading the aerial photomosaic of the Barbers Hill area, Chambers County, Tex: : Gulf coast oil fields (see Barton and Sawtelle), pp. xvii-xxii, 1 pl. (front., aerial photomosaic map), 1936.

211. Late recent history of Côte Blanche salt dome, St. Mary Parish, La.: Am. Assoc. Petroleum Geologists Bull., vol. 20, no. 2, pp. 179-185, 3 figs., February 1936.; abstract, World Petroleum, vol. 7, no. 5, p. 278, May 1936; reprinted in Gulf coast oil fields (see Barton and Sawtelle), pp. 1026-1032, 1936.

212. (and others). Examples of migration of: petroleum; partial digest of round-table meeting of Research Committee, Wichita, Kans., March 20, 1935: Am. Assoc. Petroleum Geologists Bull., vol. 20, no. 5, pp. 612-619, May 1936.

213. [Review of] Fortschritte' der Ölgeologie, by Karl Krejci-Graf, 1935: Am. Assoc. Petroleum Geologists Bull., vol. 20, no. 6, p. 837, June 1936.

214. Current geophysical activity in Texas and Louisiana [abstract] : Am. Geophys. Union Trans. 17th Ann. Meeting, pt. 1, pp. 76-77 (\$), Nat. Research Council, July 1936; Earthquake Notes, vol. 8, nos. 1-2, p. 76 ( $\ddagger)$, June 1936.

Barton, Donald Clinton, and Sawtelle, George. (editors).

215. Gulf coast oil fields, a symposium on the Gulf coast Cenozoic by 52 authors: 44 papers reprinted from the Bulletin of the American Association of Petrologists, with a foreword by Donald C. Barton. 1070 pp., illus. (incl. maps), Tulsa, Am. Assoc. Petroleum Geologists, 1936.

Bartram; J. C. See Barton, 212.

Bartram, John Greer.

216. (and Erdmann, Charles Edgar). Natural gas in Montana: Geology of natural gas, pp. 245-276, 7. figs. (incl. maps), Am. Assoc. Petroleum Geologists, [June] 1935.

Bartsch, Paul.

217. The Hawaiian Island arc: Am. Geophys. Union Trans. 17th Aun. Meeting, pt. 1, pp. 45-46 ( $\$)$, Nat. Research Council, July 1936.

Bascom, Florence.

218. Igneous complex of Pennsylvania-Maryland Blue Ridge-Piedmont provinces [abstract]: Geol. Soc. America Proc., 1934, p. 440, June 1935.

219. The pre-Cambrian igneous rocks of eastern Pennsylvania and Maryland. Am. Geophys. Union Trans. 16th Ann. Meeting, pt. 1, pp. 328-350 (\$), 5 figs., Nat. Research Council, August 1935 .

Bass, Nathan Wood. See also Leatherock, 2363 ; U. S. G. S., 4235, 4236, 4237, 4238.

220. (and Kennedy, Luther E., Dillard, William Reese, and Leatherock, Constance). Subsurface geology of Osage County, Okla.: U. S. Dept. Interior Press Mem. 105368, 15 pp. ( $\$)$ [1935].

221. (and Dillard, William Reese, and Hengst, Jess H.). Possibility of new oil pools in the siliceous lime and Bartlesville sand in T. 23 N., R. 10 E., Osage County, Okla.: U. S. Geol. Survey Bull. S8G-A. pp. 1-4, 1 fig. (geol. map), 1936. 
Bass, Nathan Wood-Continued.

222: (and Dillard, William Reese). New Midcontinent shoestring fields indicated by survey: Oil and Gas Jour., vol. 35, no. 30, pp. 36, 38, 3 figs., December 10, 1936.

Bassett, Charles Fernando.

223. Stratigraphy and paleontology of the Dundee limestone of southeastern Michigan: Geol. Soc. America Bull., vol. 46, no. 3, pp. 425-462, 1 fig., 7 pls., March 31, 1935 ; abstract, Proc., 1933, p. 379, June 1934.

Bassler, Ray Smith.

224. A geologist's paradise: Smithsonian Inst. Ann. Rept., 1933, pp. 327-332, 4. pls., 1935.

225. [Report on the] Department of geology: U. S. Nat. Mus. Rept., 1934, pp. 40-50, 1935.

226. The classification of the Edrioasteroidea: Smithsonian Misc. Coll., vol. 93, no. 8, Pub. 3301, 11 pp., 1 pl., April 4, 1935; abstract, Geol. Soc. America Proc., 1934, p. 366, June 1935.

227. Descriptions of Paleozoic fossils from the Central Basin of Tennessee: Washington Acad. Sci. Jour., vol. 25, no. 9, pp. 403-409, September $15,1935$.

228. Concretions-freaks in stone: Smithsonian Inst. Ann. Rept., 1935, Pub. 3348, pp. 321-326, 3 pls., 1936.

229. [Report on the] department of geology: U. S. Nat. Mus. Rept., 1935, pp. $45-56,1936$.

230. Geology and paleontology of the Georges Bank canyons; pt. 3, Cretaceous bryozoan from Georges Bank: Geol. Soc. America Bull., vol. 47, no. 3, pp. 411-412, 1 fig., March 31, 1936.

231. Nomenclatorial notes on fossil and recent Bryozoa: Washington Acad. Sci. Jour., vol. 26, no. 4, pp. 156-162, 12 figs., April 15, 1936.

232. New species of American Edrioasteroidea: Smithsonian Misc. vol: 95, no. 6, Pub. 3385, 33 pp., 7 pls., May 4, 1936.

Bastin, Edson Sunderland.

233. The story of ore deposits: Sci. Monthly, vol. 41, no. 4, pp. 363-365, October 1935.

234. "Aplites" of hydrothermal origin associated with Canadian cobalt-silver ores: Econ. Geology, vol. 30, no. 7, pp. 715-734, 6 figs., November 1935 ; abstract, Geol. Soc. America Proc., 1934, p. 66, June 1935.

235. [Annual report of the] Division of Geology and Geography: Nat. Acad. Sci. Rept., 1934-35, Nat. Research Council Rept., 1934-1935, pp. 22-27, 1936.

Bateman, Alan Mara.

236. The copper deposits of Ely, Nev.: Copper resources of the world, pp. 307-321, 1 pl. (geol. map), 1 fig. (index map), Washington, 16th Internat. Geol. Cong., 1935.

Bates, Robert E. See also Johnson, 1961.

237. Peneplanation in the driftless area of Wisconsin [abstract]: Geol. Soc. America Proc., 1985, p. 65, June 1936.

\section{Bauer, Lawson $\mathbf{H}$.}

238: (and Berman, Harry). Xonotlite from Franklin Furnace (abstract) : Am. Mineralogist, rol. 20, no. 3, p. 197, March 1935; Geol. Soc. America Proc., 1934, pp. 420-421, June 1935. 
Baulig, Henri.

239. Amérique septentrionale; pt. 1, Généralités, Canada : Géographie universelle, tome 13, 315 pp., 60 pls. (incl. geol. maps), 65 figs. (inc. geol. maps), Paris, Librairie Armand Colin, 1935.

240. Amérique septentrionale; pt. 2, États-Unis: Géographie universelle, tome 13, pt. 2, pp. 318-639, 56 pls., 66 figs. (incl. geol. maps), Paris, Librairie Armand Colin, 1936.

Bay, Harry X. See also George, 1402.

241. (and Munyan, Arthur Claude). The bleaching clays of Georgia : Georgia Div. Geology Inf. Circ. 6, 4 pp., 2 figs. (incl. sketch map), 1935; Georgia Forestry-Geol. Rev., vol. 5, no. 10, pp. 7-8, no. 11, p. 8, no. 12, p. $7,1935$.

242. A preliminary investigation of the bleaching clays of Mississippi: Mississippi Geol. Survey Bull. 29, 62 pp., 1 pl., 4 figs. (incl. sketch maps), 1935.

Bay, James William.

243. Abandoned channels of the lower Huron River, Mich.: Michigan Acad. Sci. Papers, vol. 20, pp. 435-438, 1 pl. (geol. map), 1935.

Bayley, William Shirley.

244. [Review of] Erdöl-Muttersubstanz, by Franz E. Hecht and others, 1935: Econ. Geology, vol. 31, no. 3, pp. 321-322, May 1936.

245. [Review of] Copper resources of the world, 16th Internat. Geol. Cong., 1935 : Science, new ser., vol. 83, no. 2164 , p. 598, June 19, 1936.

246. [Review of] Down to earth, by C. Croneis and W. C. Krumbein, 1936: Econ. Geology, vol. 31, no. 6, pp. 644-645, September-October 1936.

Bays, Carl A. See also Kansas Geol. Soc., 2020.

247. (and Raasch, Gilbert O.). Mohawkian relations in Wisconsin: Kansas Geol. Soc. Guidebook 9th Ann. Field Conf., pp. 296-301 ( $\$), 193 \overline{5}$.

Beath, Orville Andrew.

248. (and Gilbert, C. S.). Selenium-bearing vegetation during late Cretaceous time: Science, new ser., vol. 84 , no. 2187 , pp. $484-485$, November 27 , 1936.

Beck, George F.

249. The quest of the sacred ginkgo: Washington Univ. [Seattle] Hist. Quart., vol. 26, no. 1, pp. 3-9, January 1935.

250. Fossil-bearing basalts, more particularly the Yakima basalts of central Washington: Northwest Sci., vol. 9, no. 4, pp. 4-7, 3 figs., November 1935.

251. Exotic ancient forests of Washington: Northwest Sci., vol. 10, no. 3, pp. 22-24, August 1936; Geol. Soc. Oregon Country News Letter, vol. 2 , no. 20 , pp. 9-10 ( $¥)$, October $25,1936$.

252. Limerock zone of Columbia Basin : Mineralogist, vol. 4, no. 11, pp. 12, 14, November 1936.

253. Spruce in the western Miocene: Northwest Sci., vol. 10, no. 4, pp. 18-20, November 1936.

254. Wood occurring in the Ginkgo and associated Petrified Forests; pt. 1 , The ginkgo: Mineralogist, vol. 4, no. 12, pp. 7-8, 4 figs., December 1936. 
Behre, Charles Henry, Jr. See also Grant, 1495; Kansas Geol. Soc., 2020; Loughlin 2462 ; Powers, 3120, 3123, 3124; Stark, 3833, 3834, 3836.

255. The geology and development of the Wisconsin-Illinois lead-zinc district: Kansas Geol. Soc. Guidebook 9th Ann. Field Conf., pp. 377-382 ( $\$$ ), 3 figs. (incl. index map), 1935.

256. (and Schwade, I. T., and Dreyer, R. M.). Bedrock geology of northern South Park [abstract]: Geol. Soc. America Proc. 1934, pp. 66-67, June 1935.

257. Mining on the Continental Divide: Eng. and Min. Jour., vol. 136, no. 8, pp. 398-401, 3 figs. (incl. geol. map), August 1935.

258. Some problems in the origin of the mineral vein: Illinois Acad. Sci. Trans., vol. 28, no. 1, pp. 5-18, 4 figs., September 1935 .

259. [Review of] Geology and ore deposits of the Breckenridge mining district, Colo., by T. S. Lovering, 1934: Econ. Geology, rol. 30, no. 7, pp. 834-835, November 1935.

260. [Review of] Geology and ore deposits of the Cripple Creek district, Colo., by G. F. Loughlin and A. H. Koschmann, 1935: Econ. Geology, vol. 31, no. 2, pp. 228-229, March-April 1936.

261. [Review of] Hot springs of the Yellowstone National Park, by E. T. Allen and A. L. Day, 1935 : Jour. Geology, vol. 44, no. 5, pp 650-651, July-August 1936.

262. (and Osborn, E. F., and Rainwater, E. H.). Contact ore deposition at the Calumet iron mine of Colorado: Econ. Geology, rol. 31, no. 8, pp. 781-804, 8 figs. (incl. index and geol. maps), December 1936.

Bell, Alfred Hannam. See also Weller, 4385.

263. Natural gas in Eastern Interior coal basin: Geology of natural gas, pp. 813-842, 5 figs. (incl. maps), Am. Assoc. Petroleum Geologists, [June] 1935.

264. Status of the carbon-ratio theory in Illinois: Illinois Acad. Sci. Trans., vol. 28 , no. 2, p. 183, December 1935.

Bell, A. M. See Bell, L. V., 268.

Bell, Gordon K., Jr:

265. Poundridge [New York] granite [abstract]: Geol. Soc. America Proc., 1985, pp. 65-66, June 1936.

Bell, James Forbes.

266. The investigation of the cleavage of granites: Econ. Geology, vol. 31, no. 3, pp. 272-277, May 1936.

Bell, Leslie victor.

267. Lamaque-Sigma mines and vicinity, western Bourlamaque Township, Abitibi County [Quebec]: Quebec Bur. Mines Ann. Rept., 1934, pt. B, pp. $3-60,8$ pls. (incl. geol. map), 2 figs., 1935 ; also in French as Rapport annuel du Service des mines de Québec pour l'année 1984, partie B, Mines Lamaque-Sigma et les environs, partie ouest du Canton de Bourlamaque, pp. 3-68, 8 pls. (incl. geol. maps), 2 figs., 1935.

268. (and Bell, A. M.). Structural features of gold deposits in certain intrusives of western Quebec: Econ. Geology, vol. 30, no. 4, pp. 347369, 6 figs., June-July 1935.

269. Géologie et gisements minéraux de la région de l'ouest de Québec, Canada: Cong. internat. mines, mét. géol. appliquée, sec. Géol. appliquée, $7^{\circ}$ sess., tome 1, pp. 67-78, 2 figs. (index and geol, maps), 1936. 
Bell, Leslie Victor-Continued.

270. Geology in prospecting; with special reference to western Quebec: Canadian Inst. Min. Metallurgy Bull. 289, pp. 235-256, 5 figs. (incl. geol. and index maps), May 1936.

Bell, Robert N., 1864-1955.

271. The gold resources of Idaho: Mining and Contracting Rev., vol. 37, no. 32 , pp. 7-8, August 13, 1935; no. 33, pp. 6-7, August 20, 1935 ; no. 34 , pp. $6-8$, August 27,1935 ; no. 35 , pp. 5-6, September 3 , 1935 ; no. 36 , pp. $6-7$, September 10,1935 ; no. 37 , pp. $5-6$, September 17, 1935 ; no. 38 , pp. 7-8, September $24,1935$.

272. Idaho rare metals: Mining and Contracting Rev., vol. 37, no. 47, pp. $5-6$, November 26, 1985 .

Belluigi, Arnaldo.

273. New applied geophysics: Oil Weekly, vol. 78, no. 9, p. 47, August 12, 1935.

Belyea, Helen $\mathbf{R}$.

274. (and Scott, A. Winifred). Conditions of sedimentation of the Halifax formation as observed in Point Pleasant Park: Nova Scotian Inst. Sci. Proc. and Trans., vol. 18, 1933-34, pt. 4, pp. 225-239, 4 figs., 2 pls., June 20, 1935.

275. Notes on the criteria for determining the tops of stratified beds [abstract] : Nova Scotian Inst. Sci. Proc., vol. 19, no. 1, p. 154, December 31,1935 .

Benioff, Hugo. See also Heck, 1678.

276. A new electromagnetic seismograph: Fifth Pacific Sci. Cong., Canada, 1933, Proc., vol. 3, pp. 2443-2450, 8 figs. 1934; abstract, Earthquake Notes, vol. 7, nos. 1-2, p. $24(\ddagger)$, September 1935.

277. Recent developments in seismologic instruments at the Seismological Laboratory, Pasadena [Calif.] [abstract] : Earthquake Notes, vol. 7, nos. 1-2, p. 24 ( $\ddagger$, September 1935.

278. A linear-strain seismograph: Seismol. Soc. America Bull., vol. 25, no. 4, pp. 283-309, 20 figs., October 1935.

Benn, James Harrison.

279. Note on the occurrence of vivianite in the District of Columbia: Am. Mineralogist, vol. 20, no. 4, pp. 311-312, April 1935.

Benson, Edmund $T$.

280. Local calorific variations in coal No. 6, and the geological implications: Illinois Acad. Sci. Trans., vol. 28, no. 2, pp. 186-187, 1 fig. (index map), December 1935.

Bentham, $\mathbf{R}$.

281. Oxford University Ellesmere Land expedition, appendix 1, Geology : Geog. Jour., vol. 87, no. 5, pp. 427-431, May 1936.

Bentz, Alfred.

282. Erdöllagerstätten im Perm von Westtexas und Newmexiko: Preuss. geol. Landesanstalt Jahrb., 1933, Band 54, Sitzungsber., p. 6,.1984.

Bequaert, Joseph Charles.

283. (and Carpenter, Frank Morton). The Nemestrinidae of the Miocene of Florissant, Colo., and their relations to the recent fauna: Jour. Paleontology, vol. 10, no. 5, pp. 395-409, 11 figs., July 1936.

$311-37-3$ 
Berg, Gilman A.

284. Notes on the dielectric separation of mineral grains: Jour. Sedimentary Petrology, vol. 6, no. 1, pp. 23-27, 1 fig., April 1936.

Bergman, Eugene E.

285. Magnetic surveying valuable to mining prospector: Min: Jour., vol. 19, no. 18, pp. 3-4, 3 figs.; Phoenix, Ariz., February 15, 1936.

Bergquist; Stanard Gustaf.

286. Laboratory manual for use in introductory geology, mineral, and rock studies. 61 pp. ( $\$), 30$ figs., Ann Arbor, Mich., Edwards Bros. Inc., 1935.

287. Valley-train deposits in the Northern Peninsula of Michigan: Michigan Acad. Sci. Papers, vol. 20, pp. 439-447, 4 pls. (incl. geol. map), 1935.

288. The Grand Sable dunes on Lake Superior, Alger County, Mich.: Michigan Acad. Sci. Papers, vol. 21, 1935, pp.:429-438, 6 pls., 3 figs: (incl. geol. map), 1936.

Berkey, Charles Peter.

289. Proceedings of the 46th annual meeting of the Geological Society of America, held at Chicago, Ill., Thursday, Friday, and Saturday, December 28, 29, and 30, 1933:: Geol. Soc. America Proc., 1933, pp. 1-128, 1 pl., June 1934.

290. Proceedings of the 47th annual meeting of the Geological Society of America, held at Rochester, N. Y.; Thursday, Friday, and Saturday, December 27, 28, and 29, 1934: Geol. Soc. America Proc., 1934, pp. 1-130, 1 pl., June 1935.

291. Proceedings of the 48th annual meeting of the Geological Society of America, held at New York, N. Y., Thursday, Friday, and Saturday, December 26,27 , and 28, 1935: Geol. Soc. America Proc., 1935, pp. 1-136, June 1936.

Berl, Ernest.

292. The origin of natural.oil : Science, new ser., vol. 81 , no. 2088 , p. 18, January 4,1935 .

Berman, Harry. See also Bauer, 238.

293. Outline of a classification of the silicates (abstract) : Am. Mineralogist, vol. 21, no: 3, p. 201, March 1936.

Bermudez, Pedro J. See Cushman, 942; Palmer, 2991.

Bernheimer, Alan W.

294. Fluorescence in Herkimer quartz crystals : Rocks and Minerals, vol. 11, no. 5, p. 67, May 1936 .

Berry, Charles Thompson.

295. A Pliocene ophiuran from Trinidad: Jour. Paleontology, vol. 9, no. 5, pp. 430-433, 3 figs., July 1935.

296. (and Lynn, William Gardner).' A new turtle, Peritresius virginianus, from the Miocene of Virginia: Am. Philos. Soc., vol. 76, no.:2, pp. 175-190, 4 pls., 2 figs., 1936.

297. A miocene pearl: Am. Midland Naturalist, vol. 17, no. 2, pp. 464-470, 3 figs., March 1936.

Berry, Edward Wilber. See also Miser, 2750.

298. Former land connection between Asia and North America as indicated by the distribution of fossil trees: Fifth Pacific Sci. Cong., Canada 1933, Proc. vol. 4, pp. 2093-3106, 1 fig. (map), 1934. 
Berry, Edward Wilber-Continued.

299. (and Hawkins, Alfred, Cary). Flora of the Pensauken formation in New Jersey: Geol. Soc. America Bull., vol. 46, no. 2, pp. 245-252, 3 pls., February 28, 1935; abstract, Proc., 1933, p. 65, June 1934.

300. A preliminary contribution to the floras of the Whitemud and Ravenscrag formations: Canada. Dept. Mines, Geol. Survey Mem. 182, Pub. 2397, 107 pp., 20 pls., 1935.

301. David White [1862-1935]: Am. Jour. Sci., 5th ser., vol. 29, no. 172, pp. 390-391, April 1935.

302. A fig from the Elocene of Virginia: Washington Acad. Sci. Jour., vol. 26, no. 3, pp. 108-111, 2 figs., March 15, 1936.

303. Pine and cherry from the Calvert Miocene: Torreya, vol. 36, no. 5, pp. 124-127, 2 figs., September-October 1936.

Berthiaume, Sheridạn A.

304. Middle Eocene Foraminifera in western Oregon (abstract): Geol. Soc. America Proc., 1934, p. 393, June 1935.

Bertrand, Paul. See also Darrah, 975.

305. Les flores houillères d'Amérique d'après les travaux de M. David White: Soc. géol. Nord Annales, tome 58, pp. 231-254, 1933.

Betts, Rachel M.

306. Bibliography of the geology of Newfoundland, 1818-1936; Newfoundland Dept. Nat. Res.; Geol. sec. Bull. 5, 35 pp. ( $\$), 1936$.

Bevan; Arthur Charles. See also Kansas Geol. Soc., 2020.

307. Cambrian inlier at Oregon, Ill.: Kansas Geol. Soc. Guidebook 9th Ann. Field Conf., pp. 383-385 ( $\$)$, 1935.

308. William Barton Rogers, first State geologist of Virginia (1835-1841) : Virginia Acad. Sci. Proc., 1934-35, pp. 63-67 [1935].

309. The geological making of the Richmond area [abstract] : Virginia Acad. Sci. Proc., 1934-35, pp. 69-70 [1935].

310. State Geological Surveys: Assoc. Am. State Geologists Jour., vol. 6, no. 1, pp. 5-12 (\$), January 1, 1935.

311. Geology and education [abstract] : Virginia Acad. Sci. Proc. 1935-36, p. 66, 1936.

312. Structural pattern of Virginia [abstract] : 16th Internat. Geol. Cong. (1933) Rept., vol. 2, pp. 993-994, 1936.

313. State geological surveys . . . : Assoc. Am. State Geologists Jour., vol. 17, no. 1, pp. 3-9 (†), January 1, 1936.

Bichan, James.

314. Ore deposits; they follow the synclines: Canadian Min. Jour., vol. 56, no. 11, pp. 522-525, 4 figs., November 1935.

Biddison, P. McDonald.

315. Estimation of natural-gas reserves: Geology of natural gas, pp. 10351052, Am. Assoc. Petroleum Geologists, [June] 1935.

Bignel, L. E. G.

316. Stratigraphic traps explored for future Utah oil supply: Oil and Gas Jour., vol. 35, no. 30, pp. 21-22, 4 figs. (incl. index map), December 10, 1936.

Billings, Marland Pratt.

317. (and Williams, Charles R.) Geology of the Franconia quadrange, N. H. 35 pp., 2 pls. (incl. geol. map), 1 fig., Concord, New Hampshire Planning and Development Comm., 1935. 
Billings, Marland Pratt-Continued.

318. Geology of the Littleton and Moosilauke quadrangles, N. H. 51 pp., 3 pls. (incl. geol. maps), 2 figs., Concord, New Hampshire Planning and Development Comm., 1935.

319. (and Cleaves, Arthur Bailey). Braichiopods from mica schist, Mount Clough, N. H. : Am. Jour. Sci., 5th ser., vol. 30, no. 180, pp. 530-536. 2 figs., December 1935.

320. Geology and regional metamorphism of the Littleton-Moosilauke area, N. H. [abstract] : Geol. Soc. America Proc., 1935, p. 66, June 1936.

Billings, Martin Hewitt.

321. The Nocona oil field, Montague County, Tex. [abstract of thesis], University of Illinois, 5 pp., 1934.

Billingsley, Paul.

322. (and Locke, Augustus). Tectonic position of ore districts in the Rocky Mountain region: Am. Inst. Min. Met. Eng. Trans., vol. 115 (Mining geology), pp. 59-68, 4 figs., 1935.

Birch, Francis.

323. (and Law, Russell L.). Measurement of compressibility at high pressures and at high temperatures: Geol. Soc. America Bull., vol. 46, no. 8, pp. 1219-1250, 8 figs., August 31, 1935.

324. (and Dow, Richard B.). Compressibility of rocks and glasses at high temperatures and pressures; Seismological application: Geol Soc. America Bull., vol. 47, no. 8, pp. 1235-1255, 4 figs., August 31, 1936.

Bïrdseye, Claude Hale.

325. Plotting maps from aerial photographs: Eng. and Min. Jour., rol. 136, no. 11, pp. 558-559, 2 figs., November 1935.

Bisat, William Sawney.

326. The faunal stratigraphy and goniatite phylogeny of the Carboniferous of western Europe, with notes on the connecting links with North America [with discussion]: 16th Internat. Geol. Cong. (1933) Rept., vol. 1, pp. 529-537, 2 pls. (correl. tables), 1936.

Bisschop, Philip R. R. See Stevens, 3894.

Bissell, Harold J.

327. (and Hansen, George Henry). The Mississippian-Pennsylvanian contact in the central Wasatch Mountains, Utah: Utah Acad. Sci. Proc., vol. 12 , p. 163,1935 .

328. Pennsylvanian stratigraphy in southern Wasatch Mountains [Utah] [abstract] : Pan-Am. Geologist, vol. 65, no. 4, p. 316, May 1936.

Blackburn, W. C.

329. Hilbig oil field, Bastrop County, Tex. : Am. Assoc. Petroleum Geologists Bull., vol. 19, no. 7, pp. 1023-1037, 10 figs., July 1935.

Blackwelder, Eliot.

330. Summary of the pre-Cambrian rocks of Utah and Wyoming: Utah Acad. Sci. Proc., vol. 12, pp. 153-157, 1935 .

331. Pleistocene terraces of upper Colorado River [abstract] : Pan-Am. Geologist, vol. 63, no. 4, pp. 310-311, May 1935; Geol. Soc. America Proc. 1935 , p. 334, June 1936.

332. Pleistocene Lake Tecopa [abstract] : Pan-Am. Geologist, vol. 63, no. 4, p. 311, May 1935; Geol. Soc. America Proc., 1935, p. 333, June 1936.

333. Rate of fault movement in the Great Basin province [abstract]: Geol. Soc. America Proc., 1934, p. 67, June 1935. 
Blackwelder, Eliot-Continued.

334. Talus slopes in the Basin Range province [abstract] : Geol. Soc. America Proc., 1934, p. 317, June 1935.

335. Sedimentation studies at Stanford University, 1932 to 1934 : Nat. Research Council Bull. 98, p. 81, July 1935.

336. The insolation hypothesis of rock weathering [abstract, with discussion] : 16th Internat. Geol. Cong. (1933) Rept., vol. 2, pp. 780-781, 1936 .

377. (and Ellsworth, Elmer William). Pleistocene lakes of the Afton Basin, Calif.: Am. Jour. Sci., 5th ser., vol. 31, no. 186, pp. 453-463, 4 figs. (incl. geol. and index maps), June 1936.

Blair, Charles Schofield.

338. Relation of the mining geologist to the mining industry in the Birmingham district, Ala.: Am. Inst. Min. Met. Eng. Trans., vol. 115 (Mining geology), pp. 290-306, 3 figs. (incl. sketch maps), 1935.

Blair, Johnathan McCollum.

339. Amber: Rocks and Minerals, vol. 10, no. 8, pp. 116-119, August 1935.

340. Agate: Rocks and Minerals, vol. 11, no. 9, pp. 160-164, SeptemberOctober 1936.

Blake, A.

341. The results of strong-motion measurements: Earthquake Notes, vol. 7, nos. 1-2, pp. 10-12 ( $¥), 1$ fig., September 1935.

342. The determination of ground motion from seismograms [abstracts]: Am. Geophys. Union Trans. 17th Ann. Meeting, pt. 1, p. $102(\ddagger)$, Nat. Research Council, July 1936; Earthquake Notes, vol. 8, nos. 1-2, p. 102 ( $\ddagger)$, June 1936.

Blakemore, Page B., Jr.

343. Minerals of the Ducktown Basin: Mineralogist, vol. 4, no. 8, pp. 5-6, 28, August 1936.

Blanchard, Francis B.

344. (and Byerly, Perry). A study of a well gage as a seismograph: Seismol. Soc. America Bull., vol. 25, no. 4, pp. 313-321, 3 figs., October 1935.

345. (and Byerly, Perry). The effect of distant earthquakes on water leveI in wells: Am. Geophys. Union Trans. 17th Ann. Meeting, pt. 2, pp. 405-406 ( $\$)$, Nat. Research Council, 1936.

Blanchard, Roland $\mathrm{F}$.

346. (and Boswell, P. F.). "Limonite" of molybdenite derivation: Econ. Geology, vol. 30, no. 3, pp. 313-319, 2 figs., May 1935.

Blaney, Harry F. See Stevens, 3894.

Blank, Eugene W.

347. Diamond finds in the United States: Rocks and Minerals, vol. 10, no. 1, pp. 7-10, 3 figs., January 1935; no. 2, pp. 23-26, 1 fig., February 1935 ; no. 3, pp. 39-40, 2 figs., March 1935.

Blank, Horace R. See Thompson, 4095.

Blau, Ludwig Wilhelm.

348. Black magic in geophysical prospecting: Geophysics, vol. 1, no. 1, pp. 1-8, January 1936.

Block, C. F.

349. (and Block, Lylyan H.). William Morris Davis [1850-1934]: Am. Meteorol. Soc. Bull., vol. 15, no. 3, pp. 56-61, March 1934. 
Block, Lylyan H. See Block, C. F., 349.

Bloesch, Edward. See also Barton, 212.

350. Observations on Oklahoma gravel deposits [abstract with discussion]: Tulsa Geol. Soc. Digest, 1934, pp. 37-38.

Blount, A. L. See Hoots, 1790, 1791.

Blüthen, J.

351. Die Bodenschätze der Arktis, ihr Abbau und ihre Bedeutung: Geog. Anzeiger, Jahrg. 37, Heft 9, pp. 205-210, Gotha, 1936.

Blum, Victor J.

352. The intermediate earthquake of June 24, 1935: Seismol. Soc. America Bull., vol. 26, no. 3, pp. 195-196, 1 fig., July 1936.

Boatright, Byron Blackburn.

353. Fluid phenomena in porous subsurface strata [abstract] : Colorado Univ. Studies, vol. 24, no. 1, p. 7, November 1936.

Bode, Francis D. See also Stock, 3924, 3931.

354. Tooth characters of protohippine horses with special reference to species from the Merychippus zone, California: Carnegie Inst. Washington Pub. 453, pp. 39-63, 2 pls., 6 figs., July 1935 [preprint, December 20, 1934].

355. The fauna of the Merychippus zone, north Coalinga district, Calif. : Carnegie Inst. Washington Pub. 453, pp. 65-96, 2 pls., 10 figs. (incl. index map), July 1935 [preprint, July 20, 1935]; abstract, Geol. Soc. America Proc., 1984, p. 383, June 1935.

356. The geology of the eastern half of the San Joaquin Hills, Orange County, Calif. [abstract] : Am. Assoc. Petroleum Geologists Bull., vol. 20, no. 11, p. 1519, November 1936.

Bodle, Ralph Robinson.

357. Notes on the [Panama] earthquake of November 30, 1935: Seismol. Soc. America Bull., vol. 26, no. 2, pp. 173-175, 1 fig., April 1936.

358. A discussion of some problems in epicenter work: Am. Geophys. Union Trans. 17th Ann. Meeting, pt. 1, pp. 104-108 ( $\$$ ), 5 figs., Nat. Research Council, July 1936; Earthquake Notes, vol. 8, nos. 1-2, pp. 104-108 (\$), 5 figs. June 1936; abstract, vol. 7, nos. 1-2, pp. 18-19 (¥), September 1935 .

Bøggild, Ove Balthasar. See also Koch, 2244.

359. Igalikite and naujakasite, two new minerals from South Greenland: Copenhage Univ., Mus. mineralog. and geol., Contr. Mineralogy, no. 25, 12 pp., 2 pls., 1933. [Reprint from Meddelelser om Grönland, Band 92, Nr. 9, 1983.]

360: (and others). Bemaerkninger til Lauge Koch, Geologie von Grönland, 1935 : Dansk geol. Fören. Medd., Bind 8, Hefte 5, pp. 483-512 (English transl., pp. 497-510), 1935.

B $\varnothing$ gvad, Richard. See also B $\varnothing$ ggild, 360.

361. (and Rosenkrantz, Alfred). Beiträge zur Kenntnis der untern Kreide Ostgrönlands: Meddelelser om Grönland, Band 93, Nr. 1, 28 pp., 5 pls., 3 figs. (incl. map), 1934; Copenhague Univ., Mus. minéralogie et géologie, Comm. paléont. 51, 1934. 
Boesch, Hans.

362. Das Problem der Bodenerosion in den Vereinigten Staaten: Matériaux pour l'etude des calamités (Soc. géog. Genève), no. 36 (nos. 3-4. année 1935), pp. 123-138, 1 fig. (map), 1936.

363. Zur Deutung des Querprofiles durch die südlichen Appalachen: Eclogae geol. Helvetiae, vol. 29, no. 1, pp. 261-281, 4 figs. (incl. geol: map), June 1936.

Boeshore, Irwin.

364. (and Gray, William D.). An Upper Cretaceous wood, Torreya antiqua: Am. Jour. Botany, vol. 23, no. 8, pp. 524-528, 14 figs., October, 1936.

Bohuslaw, Stočes. See Gilluly, 1432.

Boldyrev, A. $\mathbf{K}$.

365. Are there 47 or 48 simple forms possible on crystals?: Am. Mineralogist, vol. 21, no. 11, pp. 731-734, November 1936.

Bonillas, Ygnacio.

; 366. The dentition of Lambdotherium: Jour. Mammalogy, vol. 17, no. 2, pp. 139-142, 3 figs., May 1936; abstract, Pan-Am. Geologist, vol. 64, no. 1, p. 78, August 1935.

367. Lambdotherium from the Lost Cabin lower Eocene, of Wyoming [abstract] : Geol. Soc. America Proc., 1935, p. 418, June 1936.

Bonner, Frank E. See Stevens, 3894.

Boon, John Daniel.

368. Dust storms in the southwest: Field and Laboratory (Southern Methodist Univ.), vol. 3, no. 2, pp. 33-40, 3 figs., April 1935.

369. The impact of meteors: Field and Laboratory (Southern Methodist Univ.), vol. 4, no. 2, pp. 56-59, April 1936.

370. (and Albritton, Claude C., Jr.)... Meteorite craters and their possible relationship to "cryptovolcanic structures": Field and Laboratory (Southern Methodist Univ.); vol. 5, no. 1, pp. 1-9, November 1936.

Boos, Margaret Fuller.

371. Some heavy minerals of the Front Range granites: Jour. Geology, vol. 43, no. 8, pt. 2, pp. 1033-1048, 1 fig. (geol. sketch map), NovemberDecember 1935.

372. (and Aberdeen, Esther Jane). Indian Creek plutons of the Front Range, Colo. [abstract] : Geol. Soc. America Proc., 1935, pp. 66-67, June 1936.

373. Primary structure and mode of intrusion of some younger pre-Cambrian batholiths of the Front Range [abstract] : Geol. Soc. America Proc., 1935, p. 67, June 1936.

Bopp, Charles Robert. See Swarts, 3987.

Born, Axel, 1887-1985.

374. Periodizität epirogener Krustenbewegungen [with discussion by Alfred Church Lane] : 16th Internat. Geol. Cong. (1933) Rept., vol. 1, pp. 169-189, 8 figs., 1936.

Born, Kendall Eugene. See also Greger, 1519; Pohl, 3103; Wilson, 4536.

375. Outliers of the Tuscaloosa formation on the western highland rim of Tennessee: Washington Acad. Sci. Jour., vol. 25, no. 5, pp. 222-230, 2 figs. (incl. geol. sketch map), May 15, 1935. 
Born, Kendall Eugene-Continued.

376. Notes on the Upper Cretaceous and Tertiary subsurface stratigraphy of western Tennessee: Tennessee Acad. Sci. Jour., vol. 10, no. 4, pp. 248-264, 1 pl. (geol. map), 3 figs. (incl. map), October 1935.

Born, W. T.

377. (and Owen, J. E.). Effect of moisture upon velocity of elastic waves in Amherst sandstone: Am. Assoc. Petroleum Geologists Bull., vol. 19, no. 1, pp. 9-18, 6 figs., January 1935; abstract, Mines Mag., vol. 26, no. 12 , p. 26 , December 1936.

Bostock, Hugh Samuel. See also Canada G. S., 660, 665.

378. The mining industry of Yukon, 1934: Canada, Dept. Mines, Geol. Survey Mem. 178, Pub. 2387, 10 pp., 1 fig., 1935.

379. Carmacks district, Yukon: Canada Dept. Mines, Geol. Survey Mem. 189 Pub. 2413, 67 pp., 5 pls. (incl. geol. map), 1936.

380. Mining industry of Yukon, 1935: Canada Dept. Mines, Geol. Survey Mem. 193, Pub. 2417, 12 pp., 1936.

381. Prospecting possibilities of Teslin-Quiet Lake-Big Salmon area, Yukon: Canada Dept. Mines, Geol. Survey Paper 36-2, 6 pp. (\$), 1 pl. geol. map), January 13, 1936.

Boswell, P. F. See Blanchard, 346.

Boswell, P. G. H. See Allen, 47 ; Wentworth, 4405.

Botset, Holbrook Gorham.

382. (and Reed, D. W.). Experiment on compressibility of sand: Am. Assoc. petroleum Geologists Bull., vol. 19, no. 7, pp. 1053-1060, 3 figs., July 1935.

Boutwell, John Mason.

383. Copper deposits at Bingham, Utah: Copper resources of the world, pp. 347-359, 1 pl. (geol. map), 1 fig. (index map), Washington, 16th Internat. Geol. Cong., 1935.

Bowden, Aberdeen Orlando.

384. (and Lopatkin, Ivan A.). Pleistocene man in southern California: Science, new ser., vol. 84, no. 2188, pp. 507-508, December 4, 1936.

Bowen, Norman Levi. See also Schairer, 3528, 3529, 3530.

385. (and Schairer, John Frank). The system $\mathrm{MgO}-\mathrm{FeO}-\mathrm{SiO}_{2}$ : Am. Jour. Sci., 5th ser., vol. 29, no. 170, pp. 151-217, 28 figs., February 1985; abstracts, Am. Mineralogist, vol. 20, no. 3, pp. 208-209, March 1935; Geol. Soc. America Proc., 1934, pp. 67-68, June 1935.

386. The igneous rocks in the light of high-temperature research: Sci. Monthly, vol. 40 , no. 6 , pp. $487-503$, 7 figs., June 1935 ; also pub. as Carnegie Inst. Washington Suppl. Pub. 14, July 1, 1935.

387. (and Schairer, John Frank). Grünerite from Rockport, Mass., and a series of synthetic fluor-amphiboles: Am. Mineralogist, vol. 20, no. 8, pp. 543-551, 1 fig., August 1935.

388. (and Schairer, John Frank). The problem of the intrusion of dunite in the light of the olivine diagram [with discussion] : 16th Internat. Geol. Cong. (1933) Rept., vol. 1, pp. 391-396, 2 figs., 1936.

389. (and Schairer, John Frank). The system albite-fayalite: Nat. Acad. Sci. Proc., vol. 22, no. 6, pp. 345-350, 2 figs., June 1936; abstract, Science, new ser., vol. 83, no. 2160, p. 485, May 22, 1936.

390. [Review of] Interpretative petrology of the igneous rocks by Harold Lattimore Alling, 1936: Am. Mineralogist, vol. 21, no. 12, pt. 1, pp. 813-814, December 1936. 
Bowie, William. See also Baker, 156.

391. Triangulating the continent of North America: Eng. News-Record, vol. 110, no. 13, pp. 405-406, 2 figs. (maps), March 30, 1933.

392. Isostasy and its importance in geological and geophysical investigations and research: Fifth Pacific Sci. Cong., Canada, 1933, Proc., rol.' 2, pp. 1165-1168, 1934; abstract, Pan-Am. Geologist, vol. 66, no. 3 , pp. 232-233, October 1936.

393. The use in the United States of geodetic control surveys in testing the stability of the earth's crust: Fifth Pacific Sci. Cong., Canada, 1933, Proc., vol. 2, pp. 1279-1283, 1934.

394. Fundamental geodetic surveys in the United States nearing completion: Nat. Acad. Sci. Proc., vol. 21, no. 1, pp. 32-36, January 15, 1935.

395. Significance of gravity anomalies at stations in the West Indies: Geol. Soc. America Bull., vol. 46, no. 6, pp. 869-878, 1 fig. (map), June 30, 1935.

396. Mapping the country: Am. Geophys. Union Trans. 16th Ann. Meeting., pt. 1, pp. 61-62 (\$), Nat. Research Council, August 1935.

397. Isostasy : Sci. Monthly, vol. 41, no. 3, pp. 234-239, September 1935.

398. National mapping plan: Assoc. Am. State Geologists Jour., vol. 6, no. 4 , pp. 8-10 ( $\$)$, October $1,1935$.

399. The origin of continents and oceans: Sci. Monthly. vol. 41, no. 5, pp. 444-449, November 1935.

400. Science in the United States Coast and Geodetic Survey: Franklin Inst. Jour., vol. 220, no. 6, pp. 719-731, December 1935.

401. Geodetic operations in the United States, 1933-35: U. S. Coast and Geodetic Survey Special Pub. 207, 25 pp., 2 figs. (index maps), 1936.

402. The national mapping plan of the National Resources Board: Science, new ser., vol. 83, no. 2144, pp. 94-95, January 31, 1936.

403. Status of the work of the Coast and Geodetic Survey of importance to geologists: Assoc. Am. State Geologists Jour., vol. 7, no. 2, pp. 21-28 ( $\ddagger)$, April 1, 1936.

404. Vertical movements of earth's crust, as determined by leveling: Jour. Geology, vol. 44, no. 3, pp. 387-395, 1 fig. (index map), April-May 1936.

405. Local densities affect values of gravity: Jour. Geology, vol. 44, no. 4, pp. 510-514, May-June 1936.

406. Symposium on recent trends in geophysical research; The place of geodesy in geophysical research: Am. Geophys. Union Trans. 17th Ann. Meeting, pt. 1, pp. 15-20 (\$), Nat. Research Council, July 1936.

Bowling, Leslie.

407. (and Wendler, Arno P.). Detailed study of some beds, commonly known as Catahoula formation, in Fayette County, Tex., with particular reference to their age: Am. Assoc. Petroleum Geologists Bull., vol. 17, no. 5, pp. 526-547, 4 figs., May 1933 ; reprinted in Gulf coast oil fields (see Barton and Sawtelle), pp. 528-549, 1936.

Bowman, Paul William.

408. Study of peat bog near the Matamek River, Quebec, Canada, by the method of pollen analysis: Ecology, vol. 12, no. 4, pp. 694-708. 6 figs., October 1931.

Boyd, Louise Arner.

409. (and others). The fiord region of east Greenland: Am. Geog. Soc. Special Pub. 18, 369 pp., front., illus., pls., map, facsims tables (1 folded), and atlas of 14 folded pls. (incl. maps, diagrs.), 1935. 
Boyer, Will W.

410. Billy Creek gas field, Johnson County, Wyo.: Geology of natural gas, pp. 297-304, 1. fig., Am. Assoc. Petroleum Geologists [June] 1935.

Boyle, Rockwell s.

411. History of the mineral industry in Virginia [abstract]: Virginia Acad. Sci. Proc., 1934-35, p. 60, [1935].

412. Virginia's mineral contribution to the Confederacy [abstract] : Virginia Acad. Sci. Proc., 1935-36, pp. 65-66, 1936.

Brace, Orval Lester.

413. Hardin dome, Liberty County, Tex.: Am. Assoc. Petroleum Geologists Bull., vol. 20, no. 8, pp. 1122-1123, August 1936.

Bradfield, Herbert Henry.

414. Pennsylvanian Ostracoda of the Ardmore Basin, Okla.: Bull. Am. Paleontology, vol. 22, no. 73, 172 pp., 13 pls., January 11, 1935.

Bradford, Donald Comnick.

415. Seismic history of the Puget Sound Basin: Seismol. Soc. America Bull., vol. 25, no. 2, pp. 138-153, April 1935.

416. (and Dahm, Cornelius George). The Rodney, Mo., earthquake of August 20, 1934: Seismol. Soc. America Bull., vol. 25, no. 2, pp. 154-160, 2 figs. (incl. sketch map), April 1935.

417. The relation between changing meteorological conditions and microseisms recorded at St. Louis University [abstract]: Earthquake Notes, vol. 7, nos. 1-2, p. $9(\$)$, September 1935 .

418. (and Macelwane, James Bernard). A preliminary sketch of the seismic history of Missouri [abstract] : Earthquake Notes, vol. 7, nos 1-2, p. 17 ( $\ddagger)$, September 1935 .

419. On a study of microseisms recorded at Sitka, Alaska, during the period from January 1, 1929, to December 31, 1931, inclusive: Seismol. Soc. America Bull., vol. 25, no. 4, pp. 323-342, 2 figs., October 1935.

Bradley, John Hodgdon.

420. Autobiography of earth. 347 pp., illus., New York, Coward-McCann, Inc., 1935.

Bradley, Walter Wadsworth.

421. The nonmetallic minerals of California: Pit and Quarry, vol. 26, no. 11, pp. 35-40, 6 figs. (incl. index map), May 1934.

422. Biennial report of the State mineralogist: California Jour. Mines and Geology, vol. 30, no. 4, October 1934, pp. 431-439, 1 fig., 1935.

Bradley, Wilmot Hyde.

423. Geology of the Alcova Dam and reservoir sites, North Platte River, Natrona County, Wyo.: Econ. Geology, vol. 30, no. 2, pp. 147-165, 5 figs. (incl. geol. map), March-April 1935.

424. Anticlines between Hiawatha gas field and Baggs, Wyo.: Am. Assoc. Petroleum Geologists Bull., vol. 19, no. 4, pp. 537-543, 2 figs (incl. geol. map), April 1935.

425. Structure and gas possibilities of the Watkins quadrangle, N. I.: U. S. Dept. Interior, Press Mem. 101944, 14 pp. (\$), 2 figs. 2 .pls.. (incl. geol. map), June 14, 1935.

426. Geomorphology of the north flank of the Uinta Mountains [Utah] : U. S. Geol. Survey Prof. Paper 185-I, pp. iv, 163-199, 12 pls. (incl. geol. map), 14 figs. (incl. index and sketch maps), 1936.

427. The biography of an ancient American lake: Sci. Monthly, vol. 42, no. 5, pp. 421-430, 5 figs. (incl. index map), May 1936. 
Brady, Lionel Francis.

428. Notes on the geology of northern Arizona; 2, The Moencopi sandstone; Mus. Northern Arizona, Mus. Notes, vol. 8, no. 2, pp. 8-12, 3 figs., Flagstaff, August 1935.

429. Vertebrate and invertebrate tracks from Meonkopi sandstone [abstract]: Pan-Am. Geologist, vol. 65, no. 5, pp. 374-375, June 1935.

430. Preliminary note on the occurrence of a primitive theropod in the Navajo: Am. Jour. Sci., 5th ser., vol. 30, no. 177, pp. 210-215, 3 figs., September 1935.

431. New theropod remains from Navajo (La Plata) sandstone [Arizona] [abstract] : Pan-Am. Geologist, vol, 64, no. 2, p. 150, September 1935.

432. A note concerning the fragmentary remains of a small theropod recovered from the Navajo sandstone in northern Arizona: Am. Jour. Sci., 5th ser., vol. 31 , no. 182, p. 150, February 1936.

433. The arroyo of the Rio de Flag; a study of an erosion cycle: Mus. Northern Arizona, Museum Notes, vol. 9, no. 6, pp. 33-37, 3 figs., December 1936.

Briinerd, Arthur E.

434. (and Lavington, Charles S.). The Lance Creek oil and gas field, Niobrara County, Wyo. : Mines Mag., vol. 26, no. 2, pp. 15-19, 58, 2 figs., February 1936.

Bramkamp, Richard A.

435. Molluscan fauna of the Imperial formation of San Gorgonio Pass [abstract]:: Geol. Soc. America Proc., 1934, p. 385, June 1935.

Bramlette, Milton Nunn. See Woodring, 4603.

Brandenthaler, Rudolph Richard. See also Wardwell, 4338.

436. (and .Sclater, K. C., and Kent, H. M.). Engineering report on the Davenport oil field, Lincoln County, Okla., 48 pp. (\$), 12 pls. (incl. maps), U. S. Bur. Mines, in cooperation with the State of Oklahoma and the Bartlesville Chamber of Commerce, June 1936.

Branson, Carl Colton.

437. Tensleep formation (Pennsylvanian) of Wyoming [abstract] : Geol. Soc. America Proc., 1934, p. 367, June 1935.

438. Fresh-water invertebrates from the Morrison (Jurassic?) of Wyoming: Jour. Paleontology, vol. 9, no. 6, pp. 514-522, 2 pls., September 1935.

439. New name for a Morrison ostracode genus: Jour. Paleontology, vol. 10, no. 4, p. 323, June 1936.

440. Carboniferous stratigraphy of Wyoming [abstract]: Geol. Soc. America Proc., 1935, pp. 391-392, June 1936.

Branson, Edwin Bayer.

441. (and Tarr, William Arthur). Introduction to geology. 470 pp., 456 figs., New York, McGraw-Hill Book Co., Inc., 1935.

442. Long-distance geology [abstract] : Geol. Soc. America Proc., 1934, p. 68, June 1935.

443. (and Mehl, Maurice Goldsmith). Value of conodonts in stratigraphic determinations [abstract]: Geol. Soc. America Proc., 1934, p. 375, June 1935.

444. (and Mehl, Maurice Goldsmith). Methods; problems, and results of conodont studies [abstract] : Geol. Soc. America Proc., 1934, p. 441, June 1935. 
Branson, Edwin Bayer-Continued.

445. (and Mehl, Maurice Goldsmith). Geological affinities and taxonomy of conodonts [abstract] : Pan-Am. Geologist, vol. 65, no. 3, p. 233, April 1936; Geol. Soc. America Proc., 1935, p. 436, June 1936.

446. (and Mehl, Maurice Goldsmith). Stratigraphic and geographic range of conodont genus Icriodus [abstract] : Pan-Am. Geologist, vol. 65, no. 3, pp. 233-234, April 1936 ; Geol. Soc. America Proc., 1935, p. 436, June 1936.

Brant, Ralph Allen.

447. Problems of the Mayes-Boone [Oklahoma] [abstract] : Tulsa Geol. Soc. Digest, 1934 pp. $3-4$.

Brauchli, Rudolf Walter.

448. Migration of oil in Oklahoma City field: Am. Assoc. Petroleum Geologists Bull., vol. 19, no. 5, pp. 699-701, May 1935.

449. [Review of] Erdöl, by Karl Krejci-Graf, 1936: Am. Assoc. Petroleum Geologists Bull., vol. 20, no. 11, pp. 1504-1505, November 1936.

Braun, Emma Lucy.

450. Glacial and postglacial plant migrations indicated by relic colonies of southern Ohio: Ecology, vol. 9, no. 3, pp. 284-302, 4 figs. (incl. index map), July 1928.

Bray, Roger Hammond. See also Grim, 1550.

451. (and Grim, Ralph Early, and Kerr, Paul Francis). Application of clay mineral technique to Illinois clay and shale: Geol. Soc. America Bull., vol. 46, no. 12, pp. 1909-1926, December 31, 1935; abstracts, Proc., 1934, p. 426, June 1935; Am. Mineralogist, vol. 20, no. 3, pp. 202-203, March 1935.

Brennan, J. F.

452. The synchronism of Jamaica earthquakes with the periods of monthly recurrent rainfall, and with monthly barometric mean pressure [abstract] : Earthquake Notes, vol. 7, nos. 1-2, pp. 25-26 (\$), 1 fig., September 1935.

Bretz, J Harlan. See Boyd, 409.

Bretz, Rudolf.

453. How the earth is changing. 144 pp., illus., Chicago, Follett Pub. Co., 1936.

Bridge, Josiah. See also Williams, 4512.

454. Copper in Missouri : Copper resources of the world, pp. 285-286, Washington, 16th Internat. Geol. Cong., 1985.

455. Charles Laurence Dake [1883-1934]: Am. Assoc. Petroleum Geologists Bull., vol. 19, no. 1, pp. 143-147, port., January 1935.

456. Correlation of the Upper Cambrian sections of Missouri and Texas [abstract] : Geol. Soc. America Proc. 1935, p. 387, June 1936.

457. Position of Cambrian-Ordovician boundary in section of Arbuckle limestone exposed on Highway 77, Murray County, Okla.: Am. Assoc. Petroleum Geologists Bull., vol, 20, no. 7, pp. 980-984, 1 fig., July 1936.

Bridges, Thomas W. See Livingston, 2430.

Bridgman, Percy Williams.

458. Shearing phenomena at high pressure of possible importance for geology : Jour. Geology, vol. 44, no. 6, pp. 653-669, 3 figs., AugustSeptember 1936. 
Brill, Karl G., Jr.

459. Productella wayensis, a new brachiopod from the New Providence shale of Kentucky: Michigan Univ. Mus. Paleontology Contr., vol. 5, no. 5, pp. 67-68, 1 pl., July 31, 1936.

Brock, Clarence $\mathbf{L}$.

460. Titanium at Magnet Cove, Ark. : Rocks and Minerals, vol. 10, no. 11, p. 169, November 1935.

Brock, Reginald Walter, 1874-1935. See also Kindle, 2205.

461. Notes on the pre-Cambrian of the Canadian Shield with reference to pre-Cambrian nomenclature: Geol. Mag., no. 861 (vol. 73, no. 3), pp. 119-141, 1 pl., March 1936.

Broderick, Thomas Monteith.

462. (and Hohl, C. D.). The Michigan copper district: Copper resources of the world, pp. 271-284, 2 figs. (incl. geol. map), Washington, 16th Internat. Geol. Cong., 1935.

463. Application of geology to problems of iron ore concentration [with: discussion] : Am. Inst. Min. Met. Eng. Trans., vol. 115 (Mining geology), pp. 273-289, 7 figs., 1935.

464. Differentiation in lavas of the Michigan Keweenawan: Geol. Soc. America Bull., vol. 46, no. 4, pp. 503-558, 22 figs., April 30, 1935; Michigan College Min. Tech. Bull., new ser., vol. 8, no. 4, pp. 503558, 22 figs., July 1935.

465. (and Hohl, C. D.). Differentiation in traps and ore deposition: Econ. Geology, vol. 30, no. 3, pp. 301-312, 2 figs., May 1935; Michigan College Min. Tech. Bull., new ser., vol. 8, no. 4, pp. 301-312, 2 figs., July 1935.

Broggi, Jorge Alberto.

466. Preliminary note on a physical phenomena resembling mountain building: Jour. Geology, vol. 43, no. 8, pt. 2, pp. 1067-1070, 1 fig., November-December 1935.

467. Tectónica y acumulaciones petrolíferas [abstract]: 16th Internat. Geol. Cong. (1933) Rept., vol. 2, pp. 1005-1006, 1936.

Brooks, Benjamin Talbott. See also Snider, 3782.

468. Origin of petroleum: Science, new ser., vol. 81, no. 2094, p. 176, February $15,1935$.

469. Origins of petroleums; chemical and geochemical aspects: Am. Assoc. Petroleum Geologists Bull., vol. 20, no. 3, pp. 280-300, March 1936 ; abstract, World Petroleum, vol. 7, no. 6, p. 330, June 1936.

Brooks, Betty Watt.

470. Fossil plants from Sucker Creek, Idaho: Carnegie Mus. Annals, vol. 24, serial 164, December 1934-August 1935, art. 9, pp. 275-336, 21 pls., July 29, 1935.

Brooks, Stanley Truman.

471. Molluses from the Harmonsburg (Pa.) marl : Carnegie Mus. Annals. vol. 24, serial 164, December 1934-August 1935, art. 4, pp. 59-60, March 21, 1935.

Brouwer, Hendrik Albertus.

472. Steilstehende Laven in Yellowstone Park und ihre Bedeutung: Geol. Runschau, Band 27, Heft 1, p. 90, April 14, 1936.

473. On the structure of the rhyolites in Xellowstone Park: Jour. Geology, vol. 44, no. 8, pp. 940-949, 2 figs., November-December 1936. 
Brown, Barnum.

474. Sinclair dinosaur expedition, 1934: Nat. History, vol. 36 , no. 1, pp. 2-15, 22 figs. (incl. sketch map), June 1935.

475. The Folsom culture, an occurrence of prehistoric man with extinct animals near Folsom, New Mexico [abstract with discussion] : 16th Internat. Geol. Cong. (1933) Rept., vol. 2, p. 813, 1936.

476. A new dinosaur kingdom [Montana] [abstract] : Royal Canadian Inst. Proc., 3d ser., vol. 1, p. 51, 1936.

Brown, Carl B. See also Eakin, 1105.

477. (and Barnes, Farrell Francis). Advance report on the sediment investigations of reservoirs and navigation improvements on the New River, Va and W. Va., April 14-May 22, 1936: U. S. Soil Conservation Service S. S. 6,24 pp. ( $\ddagger), 28$ pls. (inc. maps), August 1936.

Brown, Charles Wilson.

478. A seaquake off the Island of Hawaii, T. H.: Earthquake Notes, vol. 7, nos. 1-2, p. 14 ( $\$)$, September 1935.

479. The Rhode Island earthquake of November 3, 1913 [abstract] : Earthquake Notes, vol. 7, nos. 1-2, pp. 17-18 (\$), September 1935.

480. The bay bar and its place in shore-line processes [abstract] : Geol. Soc. America Proc., 1935, p. 68, June 1936.

Brown, Edwin Jay, 1899-1935.

481. A determination of the relative values of gravity at Potsdam [Germany] and Washington: U. S. Coast and Geodetic Survey Special Pub. 204, 15 pp., 3 pls., 1936.

Brown, Howard E.

482. The earth. 449 pp., 1 pl. (front.), 195 figs. (incl. maps). Oklahoma City, Okla., Times-Journal' Pub. Co. [ $\left.{ }^{ } 1935\right]$ :

Brown, Ira Otho.

483. [Review of] Die Gebirgsumrahmung des Nordamerikanischen Kontinents, by Rudolf Schottenlohr, 1934: Am. Assoc. Petroleum Geologists Bull., vol. 20, no. 6, pp. 829-830, June 1936.

Brown, John Stafford.

484. Structure and primary mineralization of the zinc mine at Balmat, N. Y.: Econ. Geology, vol. 31, no. 3, pp. 233-258, 4 figs. (incl. geol. map), May 1936; abstract, Mines Mag., vol. 26, no. 12, p. 24, December 1936.

485. Memorial of Charles Laurence Dake [1883-1934]: Geol. Soc. America Proc., 1935, pp. 195-200, 1 pl. (port.), June 1936.

486. Supergene sphalerite, galena, and willemite at Balmat, N. Y.: Econ. Geology, vol. 31, no. 4, pp. 331-354, 2 figs., June-July 1936.

Brown, Levi Stanley. See Russell, 3445.

Brown, Ralph Hall.

487. A southwestern oasis; the Roswell region, New Mexico: Geog. Rev., vol. 26, no. 4, pp. 610-619, 9 figs. (incl. index map̀), October 1936; abstract, Assoc. Am. Geographers Annals, vol. 26, no. 1, pp. 43-44, March 1936.

Brown, Robert. See also Monnig, 2766, 2769; Sellards, 3639.

Brown Robert V.

488. Sait domes: Inst. Petroleum Technologists Jour., vol. 20, no. 123, pp. 73-93, January 1934. 
Brown, Roland Wilbur.

489. Miocene leaves, fruits, and seeds from Idaho, Oregon, and Washington:

Jour. Paleontology, vol. 9, no. 7, pp. 572-587, 3 pls., October 1935.

490. Some fossil conifers from Maryland and North Dakota: Washington

Acad. Sci. Jour., vol. 25, no. 10, pp. 441-450, 12 figs., October 15. 1935 .

491. Further notes on fossil larval chambers of mining bees: Washington Acad. Sci. Jour., vol. 25, no. 12, pp. 526-528, December 15, 1935.

492. Field identification of the fossil ferns called T'empslyya: Washington Acad. Sci. Jour., vol. 26, no. 2, pp. 45-52, 6 figs., February 15, 1936. 493. The genus Glyptostrobus in America: Washington Acad. Sci. Jour., vol. 26, no. 9, pp. 353-357, 7 figs., September 15, 1936.

494. A fossil shelf fungus from North Dakota: Washington Acad. Sci. Jour., vol. 26 , no. 11 , pp. $460-462$, 4 figs., November $15,1936$.

Brown, Samuel C.

495. Some minerals found in southwest Connecticut and southeastern New York: Mineralogist, vol. 3, no. 4, pp. 29-30, April 1935.

Brown, W. L.

496. Fluorescence of manganiferous calcites: Toronto Univ. Studies, Geol. ser. no. 36 , pp. $45-54,1934$.

Brown, Will L.

497. Chiastolite crystals, Madera, Calif.: Mineralogist, vol. 4, no. 7, p. 9, July 1936.

Brown, William Horatio.

498. Quantitative study of ore zoning, Austinville mine," Wythe County, Va.: Econ. Geology, vol. 30, no. 4, pp. 425-433, 4 figs.. June-July 1935; abstract with dișcussion, 16th Internạt. Geol. Cong. (1933) Rept., vol. 1, p. 459, 1936.

Brownell, George McLeod.

499. (and Kinkel, A. R., Jr.). The Flin Flon mine [Manitoba]; geology and paragenesis of the ore deposit: Canadian Inst. Min. Metallurgy. Trans., vol: 38, pp. 261-286, 16:figs., 1935.

Brownmiller, Lorrin Thomas.

500. A study of the system lime-potash-alumina :'Am. Jour. Sci., 5th ser., vol. 29, no. 171, pp. 260-277, 3 figs., March 1935.

Brubaker, Howard Winter.

501. Analyses of fragments from the tusks of four specimens of extinct elephants found in Kansas [abstract] : Kansas Acad. Sci. Trans., vol. 37, pp. 115-116, 1934.

Bruce, Everend Lester. See also Thomson, 4111.

502. (and Jewitt, W.). The heavy accessory minerals in certain granites of the Canadian Shield [abstract] : Royal Soc. Canada Trans., 3d ser., rol. 29, Proc., p. xcvii, 1935 .

503. Geological relations of some gold deposits of the Canadian Shield [abstract] : Royal Soc. Canada Trans. vol. 30; sec. 4,.Proc., p. c, 1936.

504. The localization of ore bodies : Canadian Min. Jour, vol 57., no 7, pp. 316-319, July 1936.

505. Area between Little Long Lac [Ontario] and Jellicoe; preliminary report on the geology.: Canadian Min. Jour., vol. 57; no: 12 , pp. 645-647, 1 fig., December 1936. 
Brucks, E. W.

506. Buckeye field, Matagorda County, Tex.: Am. Assoc. Petroleum Geologists Bull., vol. 19, no. 3, pp.378-400, 4 figs., March 1935: reprinted in Gulf coast oil fields (see Barton and Sawtelle), pp. 734-756, 1936.

Bruckshaw, J. McGarva.

507. An instrument for electrical prospecting by the inductive method: London Phys. Soc. Proc., vol. 46, pt. 3, no. 254, pp. 350-364, 6 figs., May 1, 1934

Brues, Charles Thomas.

508. Evidences of insect activity preserved in fossil wood : Jour. Paleontology, vol. 10, no. 7, pp. 637-643, 6 figs., ,October 1936.

Bruet, Edmond.

509. La théorie de Wegener, la derive des continents et la formation des chaînes de montagnes: Naturaliste Canadien, 3d ser., vol. 6, nos. 6-7, pp. 189-200, 4 figs., June-July 1935.

510. Le Bouclier Canadien et ses gisements aurifères (note pnéliminaire) : Soc. géol. France Compte rendu, fasc. 13, pp. 210-212, November 4, 1935.

Bruner, Frank $\mathbf{H}$.

511. Uraninite from Hottah Lake [Northwest Territories] : Am. Mineralogist, vol. 21, no. 4, pp. 265-266, April 1936.

Brunner, G. J.

512. (and Macelwane, James Bernard). The Brunner focal depth-time-distance chart. 12 pp., 3 figs., 1 pl. accompanying (chart), New York, John Wiley \& Sons, Inc., 1935.

513. Characteristics of deep-focus earthquakes: Am. Geophys. Union Trans. 16th Ann. Meeting, pt. 1, pp. 104-107 (\$), 3 figs., Nat. Research Council, August 1935.

Brunstein, Maurice S. See Barksdale, 184.

Bryan, Frank.

514. Evidence of recent. movements along faults of Balcones system in central Texas: Am. Assoc. Petroleum Geologists Bull., vol. 20, no. 10, pp. 1357-1371, 7 figs., October 1936.

Bryan, G. Gregory.

515. (and Crawford, Arthur Lorenzo). Mineragraphy and paragenesis of the ore of the Park City Consolidated mine, Park City, Utah [abstract]: Utah Acad. Sci. Proc., vol. 13, p. 93, 1936.

Bryan, Joseph J.

516. Barite deposits in the Redwall of Grand Canyon: Grand Canyon Nat. History Assoc. Bull. 5, pp. 23-26 (\$), 4 figs., May 1936.

Bryan, Kirk.

517. (and others). Reviews of papers on the geomorphology of the West Indies: Zeitschr. Geomorphologie, Band 8, Heft 3, pp. 143-144, January 1934.

518. (and others). Progress in the geomorphology of arid regions: Zeitschr. Geomorphologie, Band 8, Heft 3, pp. 144-146, January 1934.

519. (and Schoewe, Walter Henry). Selenite, a criterion of effective wind scour: Science, new ser., vol. 81, no. 2096; pp. 233-234, March 1, 1935. 
Bryan, Kirk-Continued.

520. William Morris Davis [1850-1934], leader in geomorphology and geography: Assoc. Am. Geographers Annals, vol. 25, no. 1, pp. 23-31, 1 pl. (port.), March 1935.

521. Minnesota man: Science, new ser., vol. 82, no. 2121, pp. 170-171, August 23, 1935.

522. Geological features in New England ground-water supply: New England Water Works Assoc. Jour., vol. 50, no. 2, pp. 222-228, 2 figs. (glacial maps), 1936.

523. The formation of pediments: 16th Internat. Geol. Cong. (1933) Rept., vol. 2 , pp. 765-775, 1936.

524. Processes of formation of pediments at Granite Gap, N. Mex.: Zeitschr. Geomorphologie, Band 9, Heft 4, pp. 125-135, 6 figs., January 1936.

525. (and McCann, Franklin T.). Successive pediments and terraces of the upper Rio Puerco in New Mexico: Jour. Geology, vol. 44, no. 2, pt. 1, pp. 145-172, 10 figs. (incl. index and geol. maps), FebruaryMarch 1936.

526. Late glacial history of southeastern New England [abstract] : Geol. Soc. America Proc., 1935, p. 68, June 1936.

Bryan, Lester L. See Stearns, 3847.

Bryant, William Letchworth.

527. New Upper Devonian fishes from western New York: Buffalo Soc. Nat. Sci. Bull., vol. 17, no. 1, pp. 18-22, 1 pl., 1935.

528. Cryptaspis and other Lower Devonian fossil fishes from Beartooth Butte, Wyo.: Am. Philos. Soc. Proc,, vol. 75, no. 2, pp. 111-128, 2 flgs., 18 pls., June 1935.

529. A study of the oldest known vertebrates, Astraspis and Eriptychius: Am. Philos. Soc. Proc., vol. 76, no. 4, pp. 409-428, 13 pls., 1936.

530. (and Johnson, Jesse Harlan). Upper Devonian fish from Colorado: Jour. Paleontology, vol. 10, no. 7, pp. 656-659, 5 figs., October 1936.

Bryson, Herman Jennings.

531. Relation of geology to ground-water resources of North Carolina [abstract]: Water Works and Sewerage, vol. 80 , no. 12, p. 444, December 1933.

532. Gold deposits in North Carolina: North Carolina Dept: Conservation and Development Bull. 38, 157 pp., 1 pl. (front.), 15 figs., 1936.

Buchanan, Charles. See Gesner, 1408.

Buchanan; George S.

533. Discovery of -Valentine (La Rose) dome, Louisiana, by reflection seismograph: Am. Assoc. Petroleum Geologists Bull., vol. 18, no. 4, p. 543, April 1934; reprinted in Gulf coast oil fields (see Barton and Sawtelle), p. 1040, 1936.

Bucher, Walter Hermann. See also Miller, 2718.

534. Cryptovolcanic structures in the United States [with discussion]: 16th Internat. Geol. Cong. (1933) Rept., vol. 2, pp. 1055-1084, 9 figs. (incl. geol. and index maps), 1936.

535. Remarkable local folding, possibly due to gravity, bearing on the Heart Mountain thrust problem [abstract]: Geol. Soc. America Proc., 1935, p. 69, June 1936.

536. The concept of natural law in geology: Science, new ser., vol. 84, no. 2188 , pp. 491-498, December 4, 1936 .

Buck, E. O. See Michaux, 2694.

$$
311-37-4
$$


Buddhue, Joḥn Davis.

537. Mexican amber: Rocks and Minerals, vol. 10, no. 11, pp. 170-171, November 1935 .

538. Native iron and its alloys: Mineralogist, vol. 4, no. 5, pp. 3-4, 29-35, May 1936.

539. Native metals widely distributed: Mineralogist, vol. 4 , no. 8, pp. 3-4, 28-31, August 1936.

540. Relationship between the structure and the composition of iron meteorites: Popular Astronomy, vol. 44, no. 9, pp. 511-514, November 1936.

541. Fossil ivory: Rocks and Minerals, vol. 11, no.' 10, pp. 207-210, 1 fig., November 1936.

542. Minerals of the platinum group: Mineralogist, vol. 4 , no. 11 , pp. $9-10$, 20, 22, November 1936.

Buddington, Arthur Francis. See also Gilluly, 1431; Grout, 1554.

543. Geology and mineral resources of the Hammond, Antwerp, and Lowville quadrangles, with a chapter on the Paleozoic rocks of the Lowville quadrangle by Rudolph Ruedmann: New York State Mus. Bull. 296, 251 pp., 4 pls. (geol. maps), 54 figs. (incl. maps), 1934.

544. High-temperature mineral associations at shallow to moderate depths: Econ. Geology, vol. 30, no. 3, pp. 205-222, May 1935.

545. [Review of] Life history of the Sudbury nickel irruptive, pt. 1, Petrogenesis, by W. H. Collins, 1934 : Econ. Geology, vol. 30 , no. 5, pp. 578-579, August 1935.

546. Gravity stratification as a criterion in the interpretation of the structure of certain inirusives of the northwestern Adirondacks: 16th Internat. Geol. Cong. (1933) Rept., vol. 1, pp. 347-352, 1 fig. (geol. map), 1936.

547. [Review of] Geology and ore deposits of the Montezuma quadrangle, Colo., by T. S. Lovering, 1935: Econ. Geology, vol. 31, no. 3, pp. 318-321, May 1936.

548. Dynamothermal metamorphism versus magmatic flowage in Adirondack rocks [abstract] : Geol. Soc. Ameriça Proc., 1935, pp. 69-70; June 1936.

549. (and Callaghan, Eugene). Dioritic intrusive rocks and contact metamorphism in the Cascade Range in Oregon: Am. Jour. Sci., 5th ser., vol. 31 , no. 186; pp. 421-449, 9 figs. (incl. geol. and index maps), June 1936.

550. Origin of anorthosite in the Adirondacks and in general : Am. Geophys. Union Trans. 17th Ann. Meeting, pt. 1, pp. 255-256 ( $¥)$, Nat. Research Council, July 1936.

Buhler, Henry Andrew.

551. Biennial report of the State geologist [58th, for 1933 and 1934], $56 \mathrm{pp}$., 1 pl., Missouri, State Geol. Survey and Water Resources, 1935.

552. Edwin Martin Shepard [1854-1934]: Am. Assoc. Petroleum Geologists Bull., vol. 19, no. 1, p. 142, January 1935.

553. Memorial of Edward Martin Sheppard [1854-1934] : Geol. Soc. America Proc., 1934, pp. 277-280, port., June 1935.

Buerger, Martin Julian.

554. Silica framework crystals and their stability fields [abstract]: Am. Mineralogist, vol. 20, no. 3, pp. 196-197, March 1935; Geol. Soc. America Proc., 1934; p. 420; June 1935. 
Buerger, Martin Julian-Continued.

555. Application of plane groups to the interpretation of Weissenberg photographs [abstract]: Am. Mineralogist, vol. 20, no. 3, pp. 212-213, March 1935; Geol. Soc. America Proc., 1934, p. 434, June 1935.

556. An X-ray powder camera: Am. Mineralogist, vol. 21, no. 1, pp. 11-17, 5 figs.; January 1936.

557. (and Butler, Robert D.). A technique for the construction of models illustrating the arrangement and packing of atoms in crystals: Am. Mineralogist, vol. 21, no. 3, pp. 150-172, 9 figs., March 1936.

558. The crystal structure of the arsenopyrite group [abstract]: Am. Mineralogist, vol. 21, no. 3, p. 203, March 1936.

559. The crystal structure of cubanite [abstract]: Am. Mineralogist, vol. 21, no. 3, p. 205, March 1936.

560. Crystals of the realgar type; The symmetry, unit cell, and space group of nitrogen sulfide: Am. Mineralogist, vol. 21, no. 9, pp. 575-583, 2 figs., September 1936.

561. (and Lukesh, J. $\mathrm{S}_{\text {: }}$ ). The preparation of oriented polished sections of small single crystals : Am. Mineralogist, vol. 21, no. 10, pp. 667-669, 4 figs., October 1936.

562. The law of complication: Am. Mineralogist, vol. 21, no. 11, pp. 702-714, 3 figśs., November 1936.

Iuerger, Newton. $\mathbf{W}$.

563. Optical properties of immersion liquids of the a-monochlornaphthalenemethylene iodide series [abstract] : Am. Mineralogist, vol. 20, no. 3, p. 199, March 1935: Geol. Soc. America Proc., 1934, pp. 423-424, June 1935.

564. The copper ores of Orange County, Vt.: Econ. Geology, vol. 30, no. 4, pp. 434-443; 1 fig., June-July 1935.

Buie, Bennett Frank. See also Larsen, 2339.

565. A peculiar form of differentiated igneous intrusion [Montana] [abstract] : Am. Mineralogist, vol. 21, no. 3, pp. 197-198, March 1936.

Bullard, Fred Mason.

566. (and Cuyler, Robert H.). The upper Pennsylvanian and lower Permian section of the Colorado River Valley, Tex. : Texas Univ. Bull. 3501, January 1, 1935; pp. 191-258, 1 pl. (geol. map), 2 figs. (incl. geol. sketch map), February 1936.

Bumgardner, Louis S. See U. S. G. S., 4228 .

Bunn, John R. See Rison, 3307.

I3uranek, Alfred.

567. Kunzite: Pacific Mineralogist, vol. 2, no. 1, pp. 8, 13, June 1935.

Burbank, Benjamin B.

568. Rare-element minerals; Ores of caesium: Mineralog. Soc. Southern California Bull., vol.. 2, no. 2, pp.' [1, 2], October 1932.

569. Night prospecting with the argon bulb: Mineralogist, vol. 3, no. 1, p. 21, January 1935.

Burbank, Wilbur Swett. See also Loughlin, 2462 ; U. S. G. S., 4229.

570. Copper-bearing ores of Colorado; San Juan Mountains: Copper resources of the world, pp. 253-257, 1 fig. (index map), Washington, 16th Internat. Geol. Cong., 1935.

571. Camps of San Juan [Colo.] : Eng. and Min. Jour., vol. 136, no. 8, pp. 386-389, 392, 4 figs. (incl. geol. map), August 1935. 
Burbank, Wilbur Swett-Continued.

572. (and Goddard, Edwin Newell). Fissure eruptions of the Independence Pass district, Sawatch Range, Colo.: Am. Geophys. Union Trans. 16th Ann. Meeting, pt. 1, pp. 321-325 (\$), Nat. Research Council, August 1935.

573. A source of heat energy in crystallization of granodiorite magma, and some related problems of volcanism: Am. Geophys. Union Trans. 17th Ann. Meeting, pt. 1, pp. 236-255 ( $\$), 3$ figs., Nat Research Council, July 1936.

Burch, Edward P. See Stauffer, 3839.

Burchfiel, B. M.

574. Ceramic materials other than clays abundant in California: Mining and Metallurgy, vol. 17, no. 537, pp. 441-443, September 1936.

Burdick, Edward $\mathrm{H}$.

575. Gold in the Juratrias of southwestern Colorado [abstract] : Mining and Metallurgy, Year Book section, p. 81, January 1935.

Burford, Selwyn O.

576. Structural features of Brenham salt dome, Washington and Austin Counties, Tex.: Am. Assoc. Petroleum Geologists Bull., vol. 19, no. 9 , pp. 1330-1338, 2 figs. (maps), September 1935 ; reprinted in Gulf coast oil fields (see Barton and Sawtelle), pp. 780-788, 1936.

Burger, William Henry.

577. Biographical memoir of John Fillmore Hayford, 1868-1925: Nat. Acad. Sci. Biog. Mem., vol. 16, no. 5, pp. 155-292, 1 pl. (port.), 1936.

Burgess, B. C.

578. Pyrophyllite, a new development; the Gerhardt deposit [N. C.] : Am. Ceramic Soc. Bull., vol. 15, no. 9, pp. 299-302, 5 figs., September 1936.

Burgess, C. Harry. See Larsen, 2339.

Burke, J. J.

579. Tetrapods in the Dunkard series: Science, new ser., vol. 82, no. 2120, p. 153, August 16, 1935.

580. Pseudocylindrodon, a new rodent genus from the Pipestone Springs Oligocene of Montana: Carnegie Mus. Annals, vol. 25, pp. 1-4, preprint October 21, 1935.

581. Fossil rodents from the Uinta Eocene series: Carnegie Mus. Annals, vol. 25, pp. 5-12, 4 figs., preprint October 21, 1935.

Burleigh, H. P. See Theis, 4062.

Burpee, George B.

582. Insoluble residues from Wisconsin sedimentary rocks; pt. 2, Studies of Wisconsin sedimentary rocks, no. 1 , Insoluble residues from Wisconsin Silurian dolomites: Wisconsin Acad. Sci. Trans., vol. 29, pp. 260-262, 1935.

Burpee, G. E.

583. (and Wilgus, Wallace La Fetra). Insoluble-residue methods and their application to oil-exploitation problems: Mining and Metallurgy, vol. 16, no. 346, pp. 418-420, 2 figs., October 1935; abstract, Year Book, sec., p. 52, January 1936.

Burr, Edith R. See Gregory, 1528. 
Burroughs, Wilbur Greeley.

584. New discoveries concerning the Devonian delta of the Appalachian geosyncline [abstract]: Kentucky Acad. Sci. Trans., vol. 6, 1933-34, pp. 55-56, 1935.

Burrows, Alfred Granville, 1878-1933.

585. (and Rickaby, Harold Colman). Sudbury nickel field restudied: Ontario Dept. Mines 43d Ann. Rept. (vol. 43, pt. 2), 1934, pp. iii, 49, 2 pls. (geol. maps), 16 figs. (incl. geol. sketch maps and port.), 1935.

Burwash, Edward Moore Jackson.

586. Metallogenetic relations of porphry and quartz diabase [abstract]: Am. Mineralogist, vol. 20, no. 3, p. 205, March 1935; Geol. Soc. America Proc., 1934, p. 68, June 1935.

587. Evidence of the older glaciations in northern Manitoba : Royal Canadian Inst. Trans., vol. 20, pt. 2 (no. 44), pp. 217-222, 2 figs., December 1935.

588. Structural bearings and time determinations [abstract]: 16th Internat. Geol. Cong. (1933) Repts., vol. 2, pp. 998-999, 1936.

Butcher, Cary Preston.

589. Wilson Keyes [1901-1936]: Am. Assoc. Petroleum Geologists Bull., vol. 20, no. 9, pp. 1272-1273, September 1936.

Butler, Bert Sylvenus. See also Loughlin, 2462 ; Singewald, 3731.

590. Public geological surveys and education [with discussion]: Am. Inst. Min. Met. Eng. Trans., vol. 115 (Mining geology), pp. 443-444; discussion, pp. 452-459, 1935.

591. High-temperature mineral associations at moderate to shallow depth: Econ. Geology, vol. 31, no. 1, pp. 115-118, January-February 1936.

Butler, Gurdon Montague.

592. Some facts about ore deposits: Arizona Bur. Mines Bull. 139 (Geol. ser., no. 8) (Arizona Univ. Bull., vol. 6, no. 6), 99 pp., August 15, 1935.

Butler, H.

593. Some new investigations of the Devonian stratigraphy and tectonics of east Greenland: Meddelelser om Grönland, Band 103, Nr. 2, 33 pp., 17 figs. (incl. geol. map), 1935.

Butler, John W., Jr.

594. Petrologic observations on the Palisades sill, New Jersey [abstract]: Geol. Soc. America Proc., 1935, p. 70, June 1936.

595. Origin of the emery deposits near Peekskill, N. Y.: Am. Mineralogist, vol. 21, no. 9, pp. 537-574, 18 figs. (incl. geol. and sketch maps), September 1936.

Butler, Robert D. See also Buerger, 557.

596. Mylonitic sphalerite from Friedensville, Pa. : Econ. Geology, vol. 30, no. 8, pp. 890-904, 12 figs., December 1935; abstracts, Am. Mineralogist, vol. 20, no. 3, pp. 203-204, March 1935; Geol. Soc. America Proc. 1934, p. 427, June 1935.

Butt, W. H. See Dickerson, 1043.

Butts, Charles. See also Miller, 2705.

597. The Brallier shale and Chemung formation of central Pennsylvania and Virginia and their bearing on the Portage-Chemung question [abstract] : Virginia Acad. Sci. Proc. 1935-36, pp. 67-68, 1936. 
Butts, Charles-Continued.

598. (and Moore, Elwood S.). Geology and mineral resources of the Bellefonte quadrangle, Pa.: U. S. Geol. Survey Bull. 855, vi, 111 pp., 12 pls. (incl. geol. maps), 2 figs. (index maps), 1936.

Buwalda, John Peter. See also Day, 987, 988; Gutenberg, 1580, 1581.

599. Postulated peneplanation in central Washington: Geól. Soc. Oregon Country News Letter, vol. 2, no. 13, p. 11 ( $\$$ ), July 10, 1933; abstracts, Pan-Am. Geologist, vol. 63, no. 4; p. 308, May 1935; Geol. Soc. America Proc., 1935, pp. 331-332, June 1936.

600. A tribute to William Morris Davis [1850-1934] : Science, new ser., vol. 80, no. 2064, p. 46, July 20, 1934.

601. (and Gutenberg, Beno). Investigation of overthrust faults by seismic methods: Science, new ser., vol. 81, no, 2103, pp. 384-386, April 19, 1935 ; abstract, Geol. Soc. America Proc., 1934, p. 69, June 1935.

602. Tertiary activity in the Tehachapi region [Calif.] [abstract] : Geol. Soc. America Proc., 1934, pp. 312-313, June 1935.

603. The geologic history of the California coast: Shore and Beach, vol. 4, no. 4, pp. 153-157, October 1936.

Byerly, Perry. See also Blanchard, 344, 345; Heck, 1678.

604. (and Sparks, Neil R.). Earthquakes in northern California and the registration of earthquakes at Berkeley, Mount Hamilton, Palo Alto, San Francisco, from October 1, 1932, to March 31, 1933 : California Univ. Seismog. Sta. Bull.; vol. 3, no. 4, pp. 151-241, January 30, 1935.

605. (and Wilson, James T.). Earthquakes in northern California and the registration of earthquakes at Berkeley, Mount Hamilton, Palo Alto, San Francisco, from April 1, 1933, to September 30, 1933: California Univ. Seismog. Sta. Bull., vol. 4, no. 1, pp. 1-73 ( $)$, March 26, 1935.

606. The first preliminary waves of the Nevada earthquake of December 20, 1932: Seismol. Soc. America Bull., vol. 25, no. 1, pp. 62-80, 6 pls., January 1935.

607. (and Blanchard, Francis B.). Well gages as seismographs: Nature, vol. 135, no. 3408, pp. 303-304, February 23, 1935.

608. (and Wilson, James T.) The central California earthquakes of May 16, 1933, and June 7, 1934: Seismol. Soc. America Bull., vol. 25, no. 3, pp. 223-246, 8 figs. (incl. sketch maps), July 1935.

609. (and Wilson, James T.). The Richmond [Calif.] quarry blast of August 16, 1934: Seismol. Soc: America Bull., vol. 25, no. 3, pp. 259-268, 3 figs. (incl. sketch map), July 1935.

610. (and Wilson, James T.). Northern California earthquakes, April 1, 1933, to March 31, 1934: Seismol. Soc. America Bull., vol. 25, no. 3, pp. 269-273, 1 fig. (index map), July.1935.

611. Seismology at the University of California [abstract]: Earthquake Notes, vol. 7, nos. 1-2, pp. 23-24 ( $\$$ ), September 1935 .

612. (and Wilson, James T.). Earthquakes in northern California and the registration of earthquakes at Berkeley, Mount Hamilton, Palo Alto, San Francisco, Ferndale, from October 1, 1933, to March 31, 1934: California Univ. Seismog. Sta. Bull., vol. 4, no. 2, pp. 75-165 (\$), October 12,1935 , 
Byerly, Perry-Continued.

: 613. (and Wilson, James T.). Earthquakes in northern California and the registration of éarthquakes at Berkeley, Mount Hamilton, Palo Alto, San Francisco, Ferndale, from April 1, 1934, to September 30, 1934: California Univ. Seismog. Sta. Bull., vol. 4, no. 3, pp. 167-243 ( $\ddagger)$, January 31, 1936.

614. (and Annis, Wilbert). Earthquakes in northern California and the registration of earthquakes at Berkeley, Mount Hamilton, Palo Alto, San Francisco, Ferndale, from July 1, 1935, to September 30, 1935: California Univ. Seismog. Sta. Bull., vol. 5, no. 2, pp. 39-78 ( $\ddagger)$, April 23, 1936.

615. (and Wilson, James T.). Northern California earthquakes, April 1, 1934, to December 31, 1935: Seismol. Soc. America Bull., vol. 26, no. 3, pp. 207-213, 1 fig. (index map), July 1936.

616. (and Annis, Wilbert). Earthquakes in northern California and the registration of earthquakes at Berkeley, Mount Hamilton, Palo Alto, San Francisco, Ferndale, from October 1, 1935, to December 31, 1935: California Univ. Seismog. Sta. Bull., vol. 5, no. 3, pp. 80-117 ( $\$$ ), 1 pl. (index map), July 7, 1936.

617. (and Hoskins, E. E.). Earthquakes in northern California and the registration of earthquakes at Berkeley; Mount Hamilton, Palo Alto, San Francisco, Ferndale, from January 1 to March 31, 1936: California Univ. Seismog. Sta. Bull., vol.. 6, no. 1, pp. 1-37, December 31, 1936.

618. (and Hoskins, E. E.). Earthquakes in northern California and the registration of earthquakes at Berkeley, Mount Hamilton, Palo Alto, San Francisco, Ferndale, Fresno, from April 1, 1936, to June 30, 1936: California Univ. Seismog. Sta. Bull., vol. 6. no. 2. pp. 38-85, December 31, 1936.

Cable, Emmett James.

619. The Hampton tusk: Iowa Acad. Sci. Proc., 1934 (vol. 41), pp. 191-198, 4 figs., 1934.

Cable, J. H. See Schwarzenbeck, 3600.

Cabo, J. Roderíguez, Jr. See Barker, 182.

Cadman, Wilson K.

620. Kansas natural gas: Kansas State Planning Board, 48 pp. ( $\ddagger), 4$ pls., Wichita, Kans., December 1934.

Cady, Gilbert Haven. See Ball, 164.

Cady, Richard Carlyle.' See also Leggette, 2376; Meinzer, 2639.

621. Ground-water resources of the Shenandoah Valley, Va.; with analyses by Edwin Wallace Lohr: Virginia Geol. Survey Bull. 45, 137 pp., 5 pls. (incl. geol. map), 1936.

Gahen, Edward.

622. Jelly chemistry [formation of agates] : Rocks and Minerals, vol. 3, no. 4, pp. 112-116, 4 figs., December 1928.

Cahn, Alvin Robert.

623. Further notes on the giant beaver: Jour. Mammalogy, vol. 17, no. 1, pp. 66-67, February.1936. 
Cairnes, Clive Elmore.

624. Descriptions of properties, Slocan mining camp, British Columbia: Canada Dept. Mines, Geol. Survey Mem. 184, Put. 2399, 274 pp., 8 pls. (incl. geol. sketch map), 9 figs. (incl. maps), 1935.

Calder, W.

625. (and Owen, R. M. S.). Alberta oil and gas development: Inst. Petroleum Technologists Jour., vol. 21, no. 143, pp. 753-773, 4 pls., 4 figs. (incl. geol. map), September 1935.

Calhoun, Fred Harvey Hall.

626. Origin of the pink granite in the Elberton, Ga., batholith [abstract]: Geol. Soc. America Proc., 1934, p. 441, June 1935.

Callaghan, Eugene. See also Buddington, 549; Hewett, 1735; Kerr, 2082.

627. (and Giannella, Vincent Paul). The earthquake of January 30, 1984, at Excelsior Mountains, Nev.: Seismol. Soc. America Bull., vol. 25, no. 2, pp. 161-168, 5 pls. (incl. topog. map), 1 fig., April 1935.

628. Pre-granodiorite dikes in granodiorite, Paradise Range, Nev.: Am. Geophys. Union Trans. 16th Aun. Meeting, pt. 1. pp. 302-307, (\$), 3 figs., Nat. Research Council, August 1935.

629. Geology of the Chief district, Lincoln County, Nev. : Nevada Univ. Bull., vol. 30, no. 2, $32 \mathrm{pp}, 1$ pl. (geol. map), 9 figs. (incl. index map), March 1, 1936.

Callisen, Karen. See Bøggild, 360.

Calohan, William Frank. See Owens, 2974.

Cameron, Alan Emerson.

630. Geology and mineral occurrences at Beaverlodge, Saskatchewan: Canadian Inst. Min. Metallurgy Bull. 282, pp. 520-523, October 1935.

Camp, Charles Lewis.

631. (and Vanderhoof, Vertres Lawrence). Small bipedal dinosaur from the Jurassic of northern Arizona [abstract]: Geol. Soc. America proc., 1934, pp. 384-385, June 1935.

632. Permian vertebrates from New Mexico [abstract]: Pan-Am. Geologist, vol. 63, no. 5, p. 379, June 1935; Geol. Soc. America Proc., 1935, p. 417, June 1936.

Campbell, Arthur Shackelton. S'ee Cushman, 942.

Campbell, Charles Duncan. See also Waters, 4357.

633. Kruger alkaline syenites of southern British Columbia [abstract]: Geol. Soc. America Proc., 1934, p. 327, June 1935.

634. Migmatites in the Kettle Range, Wash.: Northwest Sci., vol. 10, no. 1, pp. 15-19, 6 figs. (incl. sketch maps), February 1936; abstract, Pan-Am. Geologist, vol. 65, no. 1, p. 79, February 1936.

Campbell, Elizabeth W. Crozier.

635. (and Campbell, William H.). The Pinto Basin site, an ancient aboriginal camping ground in the California desert; with a geologic introduction by David Scharf and a description of the artifacts by Charles Avery Amsden: Southwest Mus. [Los Angeles] Papers, no. 9, 51 pp., 14 pls., March 1935.

Campbell, Ian. See also Gibson, 1417, 1418; Maxson, 2621.

636. (and Maxson, John Haviland). Geological studies of the Archean rocks at Grand Canyon [abstract]: Carnegie Inst. Washington Year Book 34, pp. 323-326, 1935. 
Campbell, Ian-Continued.

637. (and Maxson, John Haviland). Significance of concretions in Vishnu schist [Arizona] [abstract] : Pan-Am. Geologist, vol. 64, no. 1, p. 65, August 1935; Geol. Soc. America Proc., 1935, pp. 342-343, June 1936.

638. On the occurrence of sillimanite and staurolite in Grand Canyon: Grand Canyon Nat. History Ȧssoc. Bull. 5, pp. 17-22 ( $), 3$ figs., May 1936.

Campbell, Williabm H. See Campbell, E. W. C., 635.

Campbell, William Wallace. See also Day, 987, 989.

639. [National Academy of Sciences]: Science, new ser., vol. 81, no. 2105, pp. 409-414, May 3, 1935.

Camsell, Charles.

640. Report of the Department of Mines [of Canada] for the fiscal year ending March 31, 1935. Pub. 2402, 48 pp., Ottawa, 1935.

641. Report of the Department of Mines [of Canada] for the fiscal year ending March 31, 1936. Pub. 2423, 54 pp., 1936.

Canada Geological Survey.

642. Amisk Lake sheet, Saskatchewan. Geology by J. F. Wright and Clifford Howard Stockivell. Map 314A. Scale 1:126,720, or 1 inch to 2 miles. Pub. 2370, 1935.

643. Amos sheet, Abitibi County, Quebec. Geology by Ludlow J. Weeks, 193334. Map 327A. Scale 1:63,360, or 1 inch to 1 mile. Pub. 2403, 1935.

644. Cadwallader Creek area, Lillooet district, British Columbia. Map 324A. Scale 1:12,000, or 1 inch to 1,000 feet. Pub. 2386, 1935.

645. Canmore area, north portion, Alberta. Geology by B. R. McKay, 1934. Map 322A. Scale 1:9,600, or 1 inch to 800 feet. Pub. 2382, 1935. Sections supplementing Map 322A, geology by B. R. McKay, 1934. Pub. 2384, 1935.

646. Canmore area, south portion, Alberta. Geology by B. R. McKay, 1934. Map, 323A. Scale 1:9,600, or 1 inch to 800 feet. Pub. 2383, 1935. Sections supplementing Map 323A, geology by B. R. McKay, 1934. Pub. 2385, 1935.

647. Chibougamau sheet, Abitibi County, Quebec. Geology by J. B. Mawdsley, 1930, and G. W. H. Norman, 1934. Map 304A. Scale 1:63,360, or 1 inch to 1 mile. Pub. 2356, 1935.

648. Elbow-Morton area, Manitoba. Geology by C. H. Stockwell, 1934. Map 321A. Scale, 1:126,720, or 1 inch to 2 miles. Pub. 2381, 1935.

649. Kinojevis sheet, Temiscamingue and Abitibi Counties, Quebec. Geology by William Fleming James, James Buckland Mawdsley, and Arthur Hamilton Lang. Map 306A. Scale $1: 63,360$, or 1 inch to 1 mile. Pub. 2359, 1935.

650. Lake Nipigon sheet, Ontario. Map 308A, Scale 1:506,880, or 1 inch to 8 miles. Pub. 3264, 1935.

651. Mudjatik Haultain area, northeast quarter, Saskatchewan. Geology by F. J. Alcock, 1934. Map 318A. Scale 1:63,360, or 1 inch to 1 mile. Pub. 2378, 1935.

652. Mudjatik-Haultain area, northwest quarter, Saskatchewan. Geology by F. J. Alcock, 1934. Map 317A. Scale 1:63,360, or 1 inch to 1 mile. Pub. 2377, 1935. 
Canada Geological Survey-Continued.

653. Mudjatik-Haultain area, 'southeast quarter, Saskatchewan. Geology by F. J. Alcock; 1934. Map 320A. Scale 1: 63,360, or 1 inch to 1 mile. Pub. 2380, 1935 .

654. Mudjatik-Haultain area, southwest quarter, Saskatchewan. . Geology by F: J. Alcock, 1934. Map. 319A. Scale $1 \vdots 63,360$, or 1 inch to 1 mile. Pub. 2379, 1935:

655. Portland Canal area, Cassiar district, British Columbia. Geology by R. G. McConnell; J. J. O'Neill, S. J. Schofield and G. Hanson. Map 307A. Scale $1: 253,440$, or 1 inch to 4 miles. Pub. $2362,1935$.

656. Regina sheet, Saskatchewan:" Geology by F. H. McLearn, 1927-1931, and P. S. Warren, 1928-1930. Map 267A. Scale 1:506,880, or 1 inch to 8 miles. Pub. 2271, 1935. Sections supplementing Map 267A, Regina sheet, Saskatchewan, Pub. 2341, 1935.

657. Stikine River area, center sheet, Cassiar district, British Columbia. Geology by F. A. Kerr. 1926-29; topography by : F. A. Kerr and International Boundary Comm. Map 310A. Scale $1: 126,720$, or 1 inch to 2 miles. Pub..2366, 1935.

658. Stikine River area, north sheet. Cassiar district, British Columbia. Geology by F. A. Kerr. 1926-29; topography by F. A. Kerr and J. Davidson. Map 309A. Scale $1: 126,720$, or 1 inch to 2 miles. Pub. 2365, 1935.

659. Stikine River area, south sheet, Cassiar district, British Columbia. Geology by F. A. Kerr, 1926-29; topography by F. A. Kerr and International Boundary Comm. Map 311A. Scale, $1: 126,720$, or 1 inch to 2 miles. . Pub. 2367, 1935.

660. Carmacks sheet, Yukon Territory. Geology by H. S. Bostock, 1932-34. Map 340A. Scale 1:253,440, or 1 inch to 4 miles, 1936.

661. Chaleur Bay area, Quebec and New Brunswick. Map. 330A. Scale 1: 253,440, or 1 inch to 4 miles. 1936.

662. Escuminac sheet, Bonaventure County, Quebec. Geology by W. V. Howard, 1924-25; E. M. Kindle, 1925; F. J. Alcock, 1928-29. Map 266A. Scale 1:63,630, or 1 inch to 1 mile. 1936 .

663. Fond-Du-Lac sheet, northern Saskatchewan. Geology by Frederick James Alcock, 1985. Map 364A. Scale $1: 253,440$, or 1 inch to 4 miles. 1936.

664. Goldfields area, northern Saskatchewan. Geology by F. J. Alcock, ' 1935. Map 339A. Scale $1: 63,360$, or 1 inch to 1 mile. 1936.

665. Laberge sheet, Yukon Territory. Geology by William Egbert Cockfield (in charge), 1929-30; Everett John Lees, 1929-31; and Hugh Samuel Bostock, 1934. Map 372A. Scale 1:253,440, or 1 inch to 4 miles. 1936.

666. Mine Center area, Rainy River district, Ontario. Geology by Thomas Leslie Tanton. Map 334A. Scale $1: 31,680$, or 1 inch to $1 / 2$ mile. 1936.

667. Ogilvie sheet, Yukon Territory. Map 373A. Scale $1: 253,440$, or 1 inch to 4 miles. 1936 .

668. Rae-Great Bear Lake area, between Rae and Faber Lake, District of Mackenzie, Northwest Territories. Geology by D. F. Kidd, 1934. Map 331A, south sheet. Scale 1:253,440, or 1 inch to 4 miles. 1936. 
Canada Geological Survey-Continued.

. 669. Rae-Great Bear Lake area; between Faber Lake and Hottah Lake, District of Mackenzie, Northwest Territories. Geology by D. F. Kidd, 1934. Map 332A, center sheet. Scale $1: 253,440$, or 1 inch to $: 4$ miles. 1936 .

670. Rae-Great Bear Lake area, between Hottah Lake and Richardson Island, District of Mackenzie, Northwest Territories. Geology by D. F. Kidd, 1934. Map 333A, north sheet. Scale 1:253,440, or 1 inch to 4 miles. 1936.

671. Rouyn-Béll River area, Abitibi and Témiscamingue Counties, Quebec. Map 328A. Scale 1: 253,440, or 1 inch to 4 miles. Pub. 2404. 1936.

672. Stony Rapids sheet (west half), northern Saskatchewan. Geology by Frederick James Alcock, 1935. Map :365A. Scale 1:253,440, or 1 inch to 4 miles: 1936.

673. Tazin Lake sheet, northern .Saskatchewan. Geology by Frederick James Alcock, 1935. Map 363A. Scale 1:253,440, or 1 inch to 4 miles. 1936.

674. Teslin-Quiet Lake area, Yukon Territory. Geology by Everett John Lees. Map 350A. Scale 1:253,440, or 1 inch to 4 miles. 1936.

Caplan, Allan.

675. The Miocene lake of Creede, Colo.: Rocks and Minerals, vol. 10, no. 10, pp. 152-154, 2 figs., October 1.935.

676. The tellurides and associated minerals of Colorado: Mineralogist, vol. 3, no: :11, pp: 5-6, 24-25, November 1935.

Capps, Stephen Reid:

677. The southern Alaska Range: U. S. Geol. Survey Bull. 862,101 pp., 8 pls. (incl. geol. map); 1 fig. (index map), 1935.

.678. (and Tuck, Ralph). The Willow Creek-Kashwitna district, Alaska:

$\because$ U. S. Geol. Survey Bull. 864-B; pp. 95-113, 1 pl. (topog. map), 1 :'fig., 1935.

Card, R. H.

679. Earth resistivity and geological structure: Elec. Eng., vol. 54, no. 11, pp. 1153-1161, 8 figs., November 1935.

Carman, Joel. Ernest.

680. Sylvania sandstone of northwestern Ohio: Geol. Soc. America Bull., vol. : 47, no. 2, pp. 253-265, 1 pl., 5 figs. (incl. index maps), February 29, 1936 ; abstract, Proc. 1934 , p. 69, June 1935.

Carpenter, Frank Morton. See also Bequaert, 283.

681. Fossil insects in Canadian amber: Toronto Univ. Studies, Geol. ser. 38, p. $69,1935$.

682. Tertiary insects of the family Chrysopidae: Jour. Paleontology, vol. 9, no. 3, pp. 259-271, 9 figs., April 1935.

683. The lower Permian insects of Kansas; pt. 7, The order Protoperlaria: Am. Acad. Arts and Sci. Proc., vol. 70, no. 4, pp. 103-146, 11 flgs., 2 pls., May 1935.

684. Revision of the Neartic Raphidiodea (recent and fossil) : Am. Acad. Arts and Sci. Proc., vol. 71, no. 2, pp. 89-157, 2 pls., 13 figs., April 1936. 
Carpenter, Sir Harold.

685. Native iron from west Greenland: Nature, vol. 136, no. 3430, pp. 152-153,

6 figs., July 27, 1935.

Carpenter, John Tyler.

686. Idaho, the gem State: Mineralogist, vol. 4, no. 1, pp. 15-16, 54, January 1936.

Carsey, J. Ben. See also Rettger, 3254.

687. Unconformities in the Humble, White, and Baker deep test, Pecos County, Tex. : Texas Univ. Bull. 3501, January 1, 1935, pp. 127-129; February 1936.

Carter, Frank B.

688. The Edison oil field [abstract]: Am. Assoc. Petroleum Geologists Bull., vol. 19, no. 12, p. 1843, December 1935.

Carter, John Franklin. See U. S. Comm., 4224, 4225.

Carter, Neal Marshall.

689. The physiography and oceanography of some British Columbia fiords:

Fifth Pacific Sci. Cong., Canada, 1933, Proc., vol. 1, pp. 721-733, 4 figs. (incl. sketch map), 1933.

Cartwright, Weldon E. See Ross, 3375.

Casberg, Carl $\mathbf{H}$.

690. (and Schubert, Carl Edward). An investigation of the durability of molding sands: Illinois Univ. Bull., vol. 33, no. 24 (Eng. Exper. Sta. Bull. 281), 54 pp., 8 figs., April 21, 1936.

Case, Ermine Cowles.

691. (and Scott, Irving Day, Badenoch, Byrne M., and White, Theodore Elmer). Discovery of Elephas primigenius americanus in the bed of glacial Lake Mogodore, in Cass County, Mich.: Michigan Acad. Sci. Papers, vol. 20, pp. 449-454, 2 figs. (maps), 1935.

692. Description of a collection of associated skeletons of Trimerorhachis: Michigan Univ. Mus. Paleontology Contr., vol. 4, no. 13, pp. 227274, 29 figs., 11 pls., February 20, 1935.

693. A new paleoniscid fish, Eurylepidoides socialis, from the Permo-Carboniferous of Texas: Michigan Univ. Mus. Paleontology Contr., vol. 4, no. 14, pp. 275-277, 1 fig., February 20, 1935.

694. (and Stanley, George M.). The Bloomfield Hills mastodon: Cranbrook Inst. Sci. Bull. 4, 8 pp., 5 pls. 1 fig. (geol. index map), October 1935.

695. New reptile from the Triassic of Wyoming [abstract] : Geol. Soc. America Proc., 1935, p. 393, June 1936.

696. A nothosaur from the Triassic of Wyoming: Michigan Univ. Mus. Paleontology Contr., vol. 5, no. 1, pp. 1-36, 1 pl., 21 figs., July 31, 1936.

697. Paleoecology of the vertebrates: Nat. Research Council Ann. Rept., 1935-36, App. J, Report of the Committee on Paleoecology, pp. 10-21 ( $\vdots)$, October 1936 .

698. A specimen of Stylemys nebrascensis Leidy, showing the bones of the feet and limbs: Michigan Univ. Mus. Paleontology Contr., vol. 5, no. 6, pp. 69-73, 2 pls., December 31, 1936.

Casperson, William C.

699. An example of mineral coloring in nature: Rocks and Minerals, vol. 11, no. 6, p. 93, June 1936. 
Cassinet, Louis.

700. (and Fulton, H. K.). Fantastic concretions of Red Desert, Wyo.: Min-. eralogist, vol. 3, no. 4, pp. 20-21, 1 fig., April 1935.

Cassirer, F. W.

701. Theory of agate formation: Mineralogist, vol. 4, no. 9, pp. 11-12, September 1936. Translated by E. W. Lazell.

Caster, Kenneth E. See also Flower, 1291; Olsson, 2952; Willard, 4496.

702. Demise of "Bradfordian series" [with discussion by Paul Dwight Torrey and George Halcott Chadwick]: Am. Assoc. Petroleum Geologists Bull., vol. 19, no. 6, pp. 912-915, June 1935.

703. Upper Devonian marine faunas in the seaward phase of the Catskill magnafacies [abstract]: Geol. Soc. America Proc., 1934, p. 363, June 1935.

704. Boundary between Devonian and Mississippian systems in western Pennsylvania [abstract]: Geol. Soc. America Proc., 1934, pp. 441-442, June 1935.

Cathcart, Stanley Holman. See also Ashley, 100; Fettke, 1240, 1243.

705. Deep-sand development in the eastern area; Geology [with discussion] : Drilling and Production Practice, 1934, pp. 108-116, 5 figs. (incl. geol. maps), Am. Petroleum Inst., 1935.

Chadwick, George Halcott. See also Ashley, 107; Caster, 702 ; Cressey, 896 ; Reudemann, 3406 .

706. Faunal differentiation in the Upper Devonian: Geol. Soc. America Bull., vol. 46, no. 2, pp. 305-342, 1 fig.; discussion by Bradford Willard, p. 2017 ; reply, p. 2018, February 28, 1935 ; abstract, Proc., 1933, p. 349, June 1934 .

707. Chemung is Portage: Geol. Soc. America Bull., vol. 46, no. 2, pp. 343354, 2 figs., February 28, 1935; abstract, Proc., 1933, pp. 71-72, June 1934.

708. What is "Pocono"?: Am. Jour. Sci., 5th ser., vol. 29, no. 170, pp. 133-143, map, February 1935.

709. Thorold sandstone: Am. Assoc. Petroleum Geologists Bull., vol. 19, no. 5, p. 702, May 1935.

710. Rock stream in New York [abstract]: Geol. Soc. America Proc., 1934, p. 70, June 1935.

711. Map of New York Upper Devonian [abstract] : Geol. Soc. America Proc., 1934, pp. 70-71, June 1935.

712. Latest Devonian beds in New York [abstract]: Geol. Soc. America Proc., 1934, p. 71, June 1935.

713. Large coral in the New York Portage rocks [abstract]: Geol. Soc. America Proc., 1934, p. 373, June 1935.

714. Summary of Upper Devonian stratigraphy : Am. Midland Naturalist, vol. 16, no. 1, pp. 857-862, 1 flg. (correl. chart), November 1935.

715. History and value of the name "Catskill" in. geology: New York State Mus. Bull. 307, 116 pp., 3 pls., 10 figs. (incl. geol. and index maps), January 1936.

Chaffee, Robert G.

716. A new heteromyid skull of the genus Cupidinimus: Jour. Mammalogy, vol. 17, no. 4, pp. 419-420, November 1936.

Chamberlain, Allen.

717. The annals of the Grand Monadnock [N. H.]. 195 pp., illus. (incl. geol. man). Concord, N. H., Soc. Protection New Hampshire Forests, 1936. 
Chamberlin, Rollin Thomas. See also Grout, 1554; Thom, 4076.

718. Certain aspects of geologic classifications and correlations: Science, new ser., vol. 81 , no. 2095, pp. 183-190, February 22, 1935; no. 2096, pp. 216-218, March 1, 1935.

719. Geologic analysis of the gravity anomalies for the Black Hills-BighornBeartooth region: Geol. Soc. America Bull., vol. 46, no. 3, pp. 393-408, 2 figs., March 31, 1935; abstract, Proc., 1933, pp. 56-57, June 1934.

720. More than two pre-Cambrian granites in the Canadian Shield: Science, new ser., vol. 82, no. 2119, pp. 126-127, August 9, 1935.

721. Glacier movement as typical rock deformation: Jour. Geology, vol. 44, no. 1, pp. 93-104, January-February 1936.

722. [Review of] Historical geology of the Antillean Caribbean region, by Charles Schuchert, 1935: Jour. Geology, vol. 44, no. 7, pp. 870-874, October-November 1936.

723. [Review of] Geology and ground-water resources of the Island of Oahu, Hawaii, by Harold Thornton Stearns and Knute Nicholas Vaksvik, 1935: Jour. Geology, vol. 44, no. 7, pp. 874-875, October-November 1936.

Chamberlin, W. A. See Wright, 4624.

Chambers, G. H.

724. (and Enck, Ernest G.). Lithium salts and lithium ores: Chem. Industries, vol.. 34, no. 5, pp. 405-408, 5 figs., 1934.

Chambers, Jack. See Howe, 1838.

Champion, Oscar.

725. The stratigraphy and structure of the Pearsall field, Frio County, Tex. [abstract] ; Am. Assoc.. Petroleum Geologists Bull., vol. 20, no. 11, p. 1514, November 1936.

Chaney, Ralph Works.

726. Synopsis of lectures in paleontology ; 1 , Outline and general principles of the history of life: California Univ. Syllabus ser., no. 250, 79 pp., 1 map, 1934.

727. Age of the Clarno formation [Oregon] [abstract] : Pan-Am. Geologist, vol. 64, no. 1, p. 71, August 1935; Geol. Soc. Oregon Country News Letter, vol. 2 , no. 11, p. $7(\ddagger)$, June 10, 1936 ; Geol. Soc. America Proc., 1935, p. 348, June 1936.

728. The succession and distribution of Cenozoic floras around the northern Pacific basin: Essays in geobotany, pp. 55-85, Berkeley, Univ. California, 1936.

729. Factor of distribution in the interpretation of Tertiary floras [abstract] : Geol. Soc. America Proc., 1935, pp. 382-383, June 1936.

730. Plant distribution as a guide to age determination: Washington Acad. Sci. Jour., vol. 26, no. 8, pp. 313-324, 3 figs. (paleogeographic maps), August 15, 1936.

731. (and Mason, Herbert Louis). A Pleistocene flora from Fairbanks, Alaska: Am. Mus. Novitates, no. 887, 17 pp., 56 figs., October 15, 1936.

Chantler, Howard McDougall. See Rosewarne, 3361. 
Chapman, E. P.

732. The quartz monzonite batholithic intrusions of Twin Lakes and Clear Creek districts, Lane and Chaffee Counties, Colo.: Colorado Sci. Soc. Proc., vol. 13, no. 8, pp. 481-493, 1 pl. (geol. sketch map), 1935.

Chapman, Lucie. See Chapman, Wendell, 735.

Chapman, Oscar L. See U. S. Comm., 4224-4225.

Chapman, Randolph W.

733. (and Williams, Charles R.). Evolution of the White Mountain magma series: Am. Mineralogist, vol. 20, no. 7, pp. 502-530, 2 pls. (incl. geol. map), 1 fig., July 1935.

734. Percy ring-dike complex: Am. Jour. Sci., 5th ser., vol. 30, no. 179, pp. 401-431, 3 figs. (incl. geol. map), November 1935 .

Chapman, Wendell.

735. (and Chapman, Lucie). The petrified forest: Nat. History, vol. 35, no. 5, pp. 382-393, 15 figs. (incl. sketch map), May 1935.

Chapman, Winifred $\mathrm{M}$.

736. A study of feldspar twinning in a differentiated sill : Am. Mineralogist, vol. 21, no. 1, pp. 33-57, 4 figs., January 1936.

Chappars, Michael Stephen.

737. Catalogue of the type specimens of fossils in the University of Cincinnati Museum: Ohio Jour. Sci., vol. 36, no. 1, pp. 1-45, January 1936.

Chappell, Walter $\mathrm{M}$.

738. The effect of Miocene lavas on the course of Columbia River in central Washington: Jour. Geology, vol. 44, no. 3, pp. 379-386, 2 figs. (incl index map), April-May 1936.

Charlewood, G. H.

739. The nature and occurrence of carbonates in veins: Econ. Geology, vol. 30 , no. 5, pp. 502-517, August 1935 .

Chavan, A.

740. Șur les variations de Venericardia planicosta: Soc. géol. France Compte rendu, fasc. 7, pp. 116-118, March 30, 1936.

741. Les vénéricardes du groups Planicosta dans l'Éocene de l'Alabama: Soc. géol. France Compte rendu, fasc. 10, pp. 166-168, May 18, 1936.

Chawner, William Donald.

742. Alluvial-fan flooding; The Montrose, Calif.; flood of 1934: Geog. Rev., vol. 25, no. 2, pp. 255-263, 8 figs. (incl. aerial map), April 1935.

Chelikowsky, Joseph Rudolph. See Mayo, 2626.

743. Geologic distribution of fire clays in the United States: Am. Ceramic Soc. Jour., vol. 18, no. 12, pp. 367-390, December 1935.

Cheney, Monroe G.

744. The Concho arch [abstract] : Tulsa Geol. Soc. Digest, 1934, pp. 33-35.

745. Economic spacing of oil wells : Am. Assoc. Petroleum Geologists Bull., vol. 19, no. 6, pp. 876-899, June 1935.

746. Gilbert D. Harris : Am. Assoc. Petroleum Geologists Bull., vol. 19, no. 6. p. 922, June 1935. 
Cheney, Monroe G.-Continued.

747. Walter C. Mendenhall: Am. Assoc. Petroleum Geologists Bull., vol. 19, no. 6, pp. 922-924, port., June 1935.

748. Late Paleozoic unconformities in north-centrai Texas: Texas Univ. Bull 3501, January 1, 1935, pp. 123-126, February 1936.

749. Migration of oil [abstract] : Am. Assoc. Petroleum Geologists Bull., vol. 20, no. 11, p. 1514, November 1936 .

Choate, Bruce M. See U. S. G. S., 4232.

Choun, H. F.

750. Dust storms in the southwestern plains area: Monthly Weather Rev., vol. 64 , no. 6 , pp. 195-199, 2 pls., 3 figs. (incl. index maps), June 1936.

Christian, Walton. See Knechtel, 2228 ; U. S. G. S., 4231.

Chrysler, Mintin Asbury.

751. (and Haenseler, Conrad Martin). A Cretaceous fungus Xylomites cycadeoideae: Am. Jour. Botany, vol. 23, no. 1, pp. 33-36, 7 figs., January 1936.

Church, James Edward.

752. Evaporation at high altitudes and latitudes: Am. Geophys. Union Trans. 15th Ann. Meeting, pt. 2, pp. 326-351 ( $\$), 2$ figs. (maps), National Research Council, June 1934.

Clapp, Frederick Gardner.

753. Safety of water-flooding pressure at Bradford, Pa. : Am. Assoc. Petroleum Geologists Bull., vol. 19, no. 6, pp. 793-852, 8 pls., June 1935.

Clark, Alexander. See Clark, L. M., 762.

Clark, Austin Hobart.

754. (and Clark, Leila Forbes). The background and origin of the American Association for the Advancement of Science: Am. Assoc. Adv. Sci. Summarized Proc., 1929-34, pp. 15-30, 1934.

Clark, Bruce Laurence.

755. Tectonics of the Mount Diablo and Coalinga areas, middle Coast Ranges of California : Geol. Soc. America Bull., vol. 46, no. 7, pp. 1025-1078, 3 pls. (geol. maps), 9 figs. ; discussion by Bailey Willis and reply by Joseph A. Taff, pp. 2040-2045, 1 fig., July 31, 1935.

756. Folding by drag, and fault-trough deposition in Mount Diablo and Coa. linga areas of the Coast Ranges [abstract]: Geol. Soc. America Proc., 1934, p. 326, June 1935.

757. Santa Susana and lower Llajas fauna of Ventura County [Calif.] [abstract] : Geol. Soc. America Proc., 1934, p. 394, June 1935.

758. Status of correlation of marine Eocene of western North America [abstract] : Pan-Am. Geologist, vol. 63, no. 5, p. 373, June 1935; Geol. Soc. America Proc., 1935, p. 411, June 1936.

759. (and Vokes, Harold Ernest). Summary of marine Eocene sequence of western North America: Geol. Soc. America Bull., vol. 47, no. 6, pp. 851-878, 2 pls., 3 figs., June 30, 1936; abstract, Proc., 1935. p. 70. June 1936.

Clark, Frank Rinker.

760. Origin and accumulation of oil [abstract] : 16th Internat. Geol. Cong.

(1933) Rept., vol. 2, pp. 1008-1009, 1936. 
Clark, George Lindenberg.

761. (and Reynolds, Dexter H.). An X-ray diffraction method for the estimation of quartz in a mixture of silicate ores: Toronto Univ. Studies, Geol. ser. 38, pp. 13-22, 2 figs., 1935.

Clark, L. M.

762. (and Clark, Alexander). The Vaqueros in the Temblor Range [abstract] : Am. Assoc. Petroleum Geologists Bull., vol. 19, no. 1, p. 137, January 1935.

Clark, Lawrence Willis. See U. S. G. S., 4227.

Clark, Leila Forbes. See Clark, A. H., 754.

Clark, Robert P. See also Barret, 194; Eby, 1120.

763. Geophysical generalities: Oil and Gas Jour., vol. 34, no. 48, pp. 148, 150152, 3 figs., April 16, 1936.

Clark, Thomas Henry.

764. A new Ordovician graptolite locality in Utah: Jour. Paleontology, vol. 9, no. 3, pp. 239-246, 1 pl., April 1935.

765. Silurian rocks of Lake Memphremagog, Quebec: Canadian Field Naturalist, vol. 50, no. 3, pp. 31-33, 3 figs. (incl. geol. sketch map), March 1936.

766. '(and Fairbairn, Harold William). The Bolton igneous group of southern Quebec: Royal Soc. Canada Trans., 3d ser., sec. 4, vol. 30, pp. 13-18, 2 figs. (incl. geol. map), May 1936 ; abstract, Proc., 3d ser., vol. 29, sec. 4, p. xcviii, 1935.

767. (and McGerrigle, Harold William). Lacolle conglomerate; a new Ordovician formation in southern Quebec: Geol. Soc. America Bull., vol. 47, no. 5, pp. 665-674, 2 figs. (index and geol. maps), May 31, 1936 ; abstracts, Royal Soc. Canada Proc., 3d ser., vol. 29, sec. 4, p. xcviii, 1935; Geol. Soc. America Proc., 1935, p. 71, June 1936.

768. A Lower Cambrian series from southern Quebec: Royal Canadian Inst. Trans., vol. 21, pt. 1, pp. 135-151, 5 figs. (incl. index and geol. map), October 1936.

Clark, W. A.

769. Pressure phenomena in oil fields [abstract] : Am. Assoc. Petroleum Geologists Bull., vol. 19, no. 12, p. 1843, December 1935.

Clark, William Otterbein.

770. Geology of the Island of Kauai [abstract]: Geol. Soc. America Proc., 1934, p. 72, June 1935.

Cleaves, Arthur Bailey. See also Billings, 319.

771. Middle Devonian branchiopod from Perry County, Pa.: Jour. Paleontology, vol. 9, no. 1, p. 6, 3 figs., January 1935.

772. (and Fox, Ernest F.). Geology of the west end of Ymer Island, east Greenland: Geol. Soc. America Bull., vol. 46, no. 3, pp. 463-488, 1 fig. (geol. map), 4 pls.; discussion by Fox and reply by Cleaves, pp. 2018-2021, March 31; 1935.

Cleland, Ralph $\mathrm{H}$.

773. Rock temperatures and some ventilation conditions in the mines of northern Ontario: Canadian Inst. Min. Metallurgy Trans.; vol. 36, pp. 379-407, 14 figs., 1933.

$311-37-5$ 
Clement, George M. See also Atwater, 114.

774. Paleozoic stratigraphy and structure on St. Croix River: Iowa Univ. Studies in Nat. History, vol. 16, no. 6, pp. 473-496, 2 pls. (incl. geol. map), May 1, 1935.

Clements, Thomas.

775. (and Oakeshott, Gordon B.). Lower Eocene (Martinez) of the San Gabriel Mountains, southern California [abstract]: Geol. Soc. America Proc., 1934, p. 310, June 1935.

776. The geology. of gem stones: Pacific Mineralogist, vol. 2, no. 1, pp. 3-4, 17, June 1935.

777. Experiments on the fall of columns: Seismol. Soc. America Bull., vol. 26, no."3, pp. 229-234, 2 figs., July 1936.

Clench, William James.

778. (and Aguayo, C. G.). A new. Pleistocene Mecoliotia from Cuba : Nautilus, vol. 49, no. 3. pp. 91-93, 3 figs., January 1936 .

Cline, L. M. See also Miller, 2699.

779. Blastoids of the Osage group, Mississippian; part 1, The genus Schizoblastus: Jour. Paleontology, vol. 10, no. 4, pp. 260-281, 2 pls., June 1936.

Clinesmith, C. N.

780. Blue agate in Washington: Rocks and Minerals, vol. 11, no. 9, p. 136, September-October 1936.

Cloos, Ernest.

781. Mother Lode and Sierra Nevada batholiths: Jour. Geology, vol. 43, no. 3, pp. 225-249, 10 figs. (incl. geol. sketch map), April-May 1935.

782. [Review of] Geologic structures, by Bailey Willis and Robin Willis, 3d ed. rev., 1934: Econ. Geology, vol. 30, no. 8, pp. 936-939, December 1935.

783. (and Hershey, H. Garland). Structural age determination of Piedmont instrusives in Maryland : Nat. Acad. Sci. Proc., vol. 22, no. 1, pp. 7180, 10 figs. (incl. geol. sketch maps), January 15, 1936; abstract, Washington Acad. Sci. Jour., vol. 26, no. 9, p. 383, September 15, 1936.

784. Der Sierra-Nevada-Pluton in Californien: News Jahrb., Beilage-Band 76, Heft 3, Abt. B, pp. 355-450, 18 pls. (incl. geol. and sketch maps), 31 figs., November 20, 1936; abstract, Am. Geophys. Union Trans. 16th Ann. Meeting, p. 274, Nat. Research Council, August. 1935.

Clough, K. H.

785. A study of permeability measurements and their applicability to the oil industry: Oil Weekly, vol. 83, no. 3, pp. 33-34, September 28, 1936 ; no. 4, pp. 27-28, 30, 34, 4 figs., October 5, 1936; no. 5, pp. 54, 56, 58, 6 figs., October 12, 1936: no. 6, pp. 46, 48, 50, 52, 54, 5 figs.; October 19, 1936 ; no. 7, pp. 42, 44, 46, 48, 50, 4 figs., October 26, 1936 ; no. 8, pp. 39-40, 42, 44, 3 flgs., November 2, 1936.

Coats, Robert $\mathbf{R}$.

786. Intrusive domes of Washoe district [Nev.] [abstract] : Pan-Am. Geologist, vol. 64, 10. 1, p. 68, August 1935; Ge0l. Soc. America Proc, 1935, p. 345, June 1936. 
Coats, Robert R.-Continued.

787. Primary banding in basic plutonic rocks: Jour. Geology, vol. 44, no. 3, pp. 407-419, 1 fig., April-May 1936.

788. Aguilarite from the Comstock lode, Virginia City, Nev. : Am. Mineralogist. vol. 21, no. 8, pp. 532-534, August 1936.

Cobb, Collier, 1862-1934.

789. Dune sands and wind-blown soils of the Mississippi Basin [abstract] : Elisha Mitchell Sci. Soc. Jour., vol. 47, no. 1, p. 22, January 1932.

Cobb, William Battle.

790. Variations in soils developed from sands in eastern North Carolina [abstract] : Elisha Mitchell Sci. Soc. Jour., vol. 27, no. 1, pp. 17-18, January 1932.

Cockerell, Theodore Dru Alison.

791. A fossil camel from Nevada : Jour. Mammology, vol. 16, no. 1, pp. 64-65, $1 \mathrm{pl}$., February 1935.

792. The origin of the higher flowering plants: Science, new ser., vol. 81, no: 2106, pp. 458-459, May 10, 1935.

793. A fossil Berberis: Torreya, vol. 35, no. 5, p. 127, 1 fig., SeptemberOctober 1935.

794. Tertiary floras: Science, new ser., vol. 83, no. 2154, pp. 350-351, April $10,1936$.

Cockfield, William Egbert. See also Canada G. S., 665.

795. Lode gold deposits of Fairview Camp, Camp McKinney, and Vidette Lake area, and the Dividend-Lakeview property near Osoyoos, British Columbia: Canada Dept. Mines, Geol. Survey Mem. 179, Pub. 2392, 38 pp., 4 pls. (geol. maps), 1 fig. (map), 1935.

796. Lode gold deposits of Ymir-Nelson area, British Columbia : Canada Dept. Mines, Geol. Survey Mem. 191, Pub. 2415, 78 pp., 1 pl. (geol. map), 8 figs. (incl. index map), 1936.

Cogen, William M.

797. Some suggestions for heavy-mineral investigations of sediments: Jour.

Sedimentary Petrology, vol. 5, no. 1, pp. 3-8, 2 flgs., 2 tables, April 1935.

798. Heavy-mineral zones in the Modelo formation of the Santa Monica Mountains, Calif.: Jour. Sedimentary Petrology, vol. 6, no. 1, pp. 3-14, 11 figs., April 1936.

Cohee, George Vincent. See Shepard, 3675 .

Colbert, Edwin Harris.

799. Nebraska fffteen million years ago: Nat. History, vol. 35, no. 1, pp. 85-46, 7 flgs., January 1935.

800. A new fossil peccary, Prosthennops niobrarensis, from Brown County, Nebr.: Nebraska State Mus. Bull., vol. 1, no. 44, pp. 419-430, 2 figs., June 1935.

Colburn, Burnham S.

801. Stony Point hiddenite deposits: Mineralogist, vol. 3, no. 11, pp. 9-10, November 1935.

Colcord, R. M.

802. A condensed history of crystallography: Mineralogist, vol. 3, no. 7 , pp. 16-17, July 1935.

Cole, Lionel Heber.

803. Manitoba granite for monumental and building purposes: Canadian Min. Jour., vol. 56, no. 5, pp. 183-184, 3 figs., May 1935. 
Cole, Sandford Stoddard.

804. The conversion of quartz into cristobalite below $1,000^{\circ} \mathrm{C}$., and some properties of the cristobalite formed: Am. Ceramic Soc. Jour., vol. 18, no. 5, pp. 149-154, 3 figs., May 1935.

Cole, William Storrs. See also Vaughan, 4273.

805. Rock resistance and peneplain expression : Jour. Geology, vol. 43, no. 8, pt. 2, pp. 1049-1062, 4 figs. (incl. geol. map), November-December 1935.

Coleman, Arthur Philemon.

806. Correlation of glaciation in northern and southern hemispheres: Fifth Pacific Sci. Cong., Canada, 1933, Proc., vol. 2, pp. 897-900, discussion, pp. 1027-1029, 1934.

807. Mexico [abstract] : Royal Canadian Inst. Proc., 3d ser., vol. 1, pp. 78-79, 1936.

Collins, J. Russell. See Phillips, 3076.

Collins, Mary $\mathbf{P}$.

808. Local earthquakes in New England, 1934-35 [abstracts] : Am. Geophys. Union Trans. 17th Ann. Meeting, pt. 1, p. $103(\$)$, Nat. Research Council, July 1936; Earthquake Notes, vol. 8, nos. 1-2, p. 103 $(\ddagger)$, June 1936 .

Collins, R. Lee.

809. (and Lynn, William Gardner). Fossil turtles from Maryland: Am. Philos. Soc. Proc., vol. 76, no. 2, pp. 151-173, 3 pls., 1 fig., 1936.

Collins, Robert F. See Meyerhoff, 2686.

Collins, William Henry, 1878-1937. See also Ashley, 103; Buddington, 545; Fenner, 1221; Reynolds, 3258; Williams, 4518.

810: :[Report of: the] Geological Survey: Canada Dept. Mines Rept. Pub. 2402, pp. 10-21, 1935.

811. Geology and literature: Geol. Soc. America Bull., vol. 46, no. 3, pp. 355-374, March 31, 1935.

812. (and Kindle, Edward Darwin): The life history of the Sudbury nickel irruptive; pt. 2, Intrusion and deformation: Royal Soc. Canada Trans., 3ḍ ser., vol. 29 , sec. 4 , pp. $27-47,4$ figs. (incl. geol. map), May 1935 ; abstract, Proc., 3d ser., vol. 29, p. xcic, 1935.

813. Memorial of James Mackintosh Bell [1877-1934]: Geol. Soc. America Proc., 1934, pp. 187-192, port., June 1935.

814. Derivations of granitic rocks: 16th Internat. Geol. Cong. (1933) Rept., vol. 1, pp. 271-282, 2 figs. (incl. geol. map), 1936.

815. The life history of the Sudbury nickel irruptive; 3, Environment: Royal Soc. Canada Trans., 3d ser., vol. 30, sec. 4, pp. 29-53, 2 figs. (geol. maps), May 1936; abstract, Proc., p. xcriii, 1936.

816. Sudbury series: Geol. Soc. America Bull., vol. 47, no. 11, pp. 1675-1690, 2 pls. (incl. geol. map), November 30, 1936.

Colony, Roy Jed, 1870-1936.

817. (and Meyerhoff, Howard Augustus). The magnetite deposit near Humacao, Puerto Rico: Am. Inst. Min. and Met. Eng. Tech. Pub. 587, 28 pp., 14 figs., 1935; Trans., vol. 115 (Mining geology), pp. 247-272, 14 figs., 1935; extracts, Rev. de obras públicas de Puerto Rico, año 12, no. 4, pp. 903-906, April 1935; no. 6, pp. 966-969, June 1935; abstracts, Min. and Metallurgy, vol. 16, no. 338, p. 114, February 1935; Year Book sec., pp. 61-62, January 1936. 
Colony, Roy Jed, 1870-1936-Continued.

818. Mineralogy of silicosis [abstract]: Am. Mineralogist, vol. 20, no. 3, p. 196, March 1935; Geol. Soc. America Proc., 1934, p. 420, June 1935.

819. Schiller structures: Am. Mineralogist, vol. 20, no. 12, pp. 828-837, 8 figs., December 1935; abstracts, no. 3, pp. 201-202, March 1935; Geol. Soc. America Proc. 1934, p. 426, June 1935.

Colton, Earl G.

820. Natural gas in Arkansas basin of eastern Oklahoma: Geology of natural gas, pp. 511-532, 3 figs., Am. Assoc. Petroleum Geologists, [June] 1935.

Colvocoresses, George M.

821. Meteor Crater: Rocks and Minerals, vol. 11, no. 8, pp. 113-117, August 1936.

Combs, A. F.

822. Lake Superior thomsonite: Mineralogist, vol. 4, no. 1, p. 18, January 1936.

Compton, Lawrence Verlyn.

823. Fossil bird remains from the Pliocene and Pleistocene of Texas: Condor, col. 36, no. 1, pp. 40-41, 2 figs., January-February 1934.

824. Fossil bird remains from the Manix Lake deposits of California: Condor, vol. 36, no. 4, pp. 166-168, 2 figs., July-August 1934.

825. New bird records from the Pleistocene of Rancho La Brea: Condor, vol. 36, no. 5, pp. 221-222, September-October 1934.

826. An anserine fossil from the Pliocene of western Nebraska: Condor, vol. 37 , no. 1, pp. 43-44, January-February 1935.

827. Two avian fossils from the lower Pliocene of South Dakota: Am. Jour. Sci., 5th ser., vol. 30, no. 178, pp. 343-348, 1 fig., October 1935.

828. The cranium of the Miocene gannet Moris vagabundis Wetmore: California Acad. Sci. Proc., 4th ser., vol. 23, no. 5, pp. 83-84, 1 fig., Aug. 12, 1936.

Conant, Louis Cowles. See also Mayo, 2626.

829. Optically positive cordierite from New Hampshire: Am. Mineralogist, vol. 20, no. 4, pp. 310-311, April 1935.

830. The New Hampshire garnet deposits: Econ. Geology, vol. 30, no. 4, pp. 387-399, 1 fig., June-July 1935.

831. Protruding crest lines of waterfalls [abstract] ; Geol. Soc. America Proc., 1935, p. 71, June 1936.

Condit, Daniel Dale.

832. Age of the Kreyenhagen shale in Cantua Creek-Panoche Creek district, Calif.: Jơur. Paleontology, vol. 4, no. 3, pp. 259-262, September 1930.

Condra, George Evert.

833. Geologic cross section, Forest City, Mo., to Du Bois, Neb.: Nebraska Geol. Survey Paper 8, 23 pp., 1 fig., 1935.

834. (and Reed, Eugene Clifton). The Permo-Penñsylvanian section of the Hartville area of Wyoming: Nebraska Geol. Survey Paper 9, 46 pp., 16 figs. (incl. geol. map), 1 pl., 1935.

835. (and Reed, Eugene Clifton). Water-bearing formations of Nebraska: Nebraska Geol. Survey Paper 10, 24 pp., 3 pls. (geol. maps), 11 figs., 1936. 
Condra, George Evert-Continued.

836. Conservation of land and water resources of Nebraska: Nebraska Cons. and Soil Survey Bull. 14, 46 pp., 8 figs. (incl. geol. and index maps), December 1936.

Conklin, Harold.

837. (and others). Ventura County [Calif.] investigation: California Dept. Public Works, Div. Water Resources Bull. 46, 1933; 244 pp., 40 figs., 13 pls. (incl. geol. maps), 1934.

838. (and others). Ventura County [Calif.] investigation, basic data for the period 1927 to 1932, inclusive: California Dept. Public Works, Div. Water Resources Bull. 46-A, 574 pp. ( $\$$ ) 7 pls. (incl. maps), [1934].

839. (and others). Mojave River investigation: California Dept. Public Works, Div. Water Resources Bull. 47, xii, 249 pp., ( $) 9$ pls. (incl. index map), 1934.

Conley, J. N. See U. S. G. S., 4237, 4238.

Conolly, Harold James.

840. (and Hart, R. C.). Structural geology of the Osisko Lake area, Quebec: Canadian Inst. Min. Metallurgy Bull. 285, pp. 10-22, 5 figs. (incl. geol. and index maps), January 1936.

Conolly, Harold James Clube.

841. A contour method of revealing some ore structures: Econ. Geology, vol. 31, no. 3, pp. 259-271, 8 figs. (incl. maps), May 1936.

Connolly Joseph Peter.

842. Memorial of Cleophas C. O'Harra [1866-1935] : Geol. Soc. America Proc., 1935, pp. 289-296, 1 pl. (port.), June 1936.

Conway, Verona M. See Seward, 3643, 3644.

Cook, John $\mathrm{H}$.

843. The glacial geology of the Berne quadrangle: New York State Mus. Bul. 302, pp. 222-230, 1 pl. (geol. map), 1 fig. (drainage map), September 1935.

Cooke, Charles Wythe.

844. Argyrotheca gardnarae, new name: Washington Acad. Sci. Jour., vol. 25, no. 1, p. 34, January 15, 1935.

845. Tentative ages of Pleistocene shore lines: Washington Acad. Sci. Jour., vol. 25, no. 7, pp. 331-333, July 15, 1935.

846. Notes on the Vicksburg group: Am. Assoc, Petroleum Geologists Bull., vol. 19, no. 8, pp. 1162-1172, August 1935; reprinted in Gulf coast oil fields (see Barton and Sawtelle), pp. 358-368, 1936.

847. Geology of the Coastal Plain of South Carolina: U. S. Geol. Survey Bull. 867, 196 pp., 18 pls. (incl. geol. maps), 2 figs., 1936.

848. Suwannee limestone of Florida [abstract]: Geol. Soc. America Proc., 1935, pp. 71-72, June 1936.

849. Are the Maryland terraces warped? Am. Jour. Sci., 5th ser., vol. 32, no. 190 , pp. 306-309, October 1936.

Cooke, Harold Caswell.

850. The mode of emplacement of the peridotites and pyronexites of the eastern townshiys, Quebec: Royal Soc. Canada Trans., 3d ser., vol. 29, sec. 4, pp. 1-6, 2 figs. (geol. maps), May 1935. 
Cooke, Harold Caswell-Continued.

851. The composition of asbestos and other fibers of Thetford district, Quebec: Royal Soc. Canada Trans., 3d ser., vol. 29, sec. 4, pp. 7-19, May 1935.

852. Asbestos deposits of Thetford district, Quebec: Econ. Geology, vol. 31, no. 4, pp. 355-376, 9 figs. (incl. geol. map), June-July 1936.

Cooke, Strathmore Ridley Barnott.

853. (and Doan, Donald J.). The mineralogy and X-ray analysis of stainierite from the Swansea mine, Goodsprings, Nev.: Am. Mineralogist, vol. 20, no. 4, pp. 274-280, 5 figs., April 1935.

854. Microscopic structure and concentratability of the important iron ores of the United States: U. S. Bur. Mines Bull. 391, 121 pp., 46 figs., 1936.

Coombs, Howard A.

855. Extension of the Keechelus andesitic series [abstract] : Geol. Soc. America Proc., 1934, p. 336, June 1935.

856. The geology of Mount Rainier National Park: Washington Univ. Pub. in Geology, vol. 3 , no. 2, pp. 131-212, 2 pls. (incl. geol. map), 27 figs., July 1936.

Cooper, Chalmer Lewis.

857. Conodonts from the upper and middle Arkansas novaculite Mississippian, at Caddo Gap, Ark.: Jour. Paleontology, vol. 9, no. 4, pp. 307-315, $1 \mathrm{pl} .$, June 1935.

858. Ammonium chloride sublimate apparatus: Jour. Paleontology, vol. 9, no. 4, pp. 357-359, 2 figs., June 1935.

859. Actinopterygian jaws from the Mississippian black shales of the Mississippi Valley: Jour. Paleontology, vol. 10, no. 2, pp. 92-94, 1 pl. March 1936.

Cooper Gustav Arthur. See also Ulrich, 4214, 4216; Warthin, 4351, 4352.

860. Oligorhynchia, a new Ordovician (Chazy) brachiopod: Am. Jour. Sci., 5th ser., vol. 29, no. 169, pp. 48-53, 4 figs., 1 pl., January 1935.

861. Young stages of the Devonian trilobite Dipleura delcayi Green: Jour. Paleontology, vol. 9, no. 1, pp. 3-5, 1 pl., January 1935.

862. (and Williams, James Stuart). Tully formation of New York: Geol. Soc. America Bull., vol. 46, no. 5, pp. 781-868, 7 figs., 7 pls., May 31, 1935.

863. Facies relationships in the Hamilton group of New York [abstract] : 16th Internat. Geol. Cong. (1933) Rept., vol. 2, p. 1106, 1936.

864. Studies of Middle Devonian rocks in the midwest: Smithsonian Inst. Explorations and Field Work, 1935, Pub. 3382, pp. 9-12, 6 figs., 1936.

865. New Cambrian brachiopods from Alaska: Jour. Paleontology, vol. 10, no. 3, pp. 210-214, 1 pl., April 1936.

S66. (and Warthin, Aldred Scott, Jr.). New correlations of Hamilton rocks [abstract]: Geol. Soc. America Proc., 1935, pp. 376-377, June 1936.

867. (and Kindle, Cecil Haldane). New brachiopods and trilobites from the Upper Ordovician of Percé, Quebec: Jour. Paleontology, vol. 10, no. 5, pp. 348-372, 3 pls., 10 figs., July 1936 ; abstract, Geol. Soc. America Proc., 1934, p. 354, June 1935.

Cooper, Herschel $\mathbf{H}$.

868. Study of salient geological features of the Government Wells district [Tex.] : Oil and Gas Jour., vol. 34, no. 9, pp. 26-27, 29, 3 figs. (incl. sketch map), July 18, 1935. 
Cooper, John Roberts.

869. Geology of the southern half of the Bay of Islands igneous complex [Newfoundland] : Newfoundland Dept. Nat. Res., Geol. Sec., Bull. 4, 62 pp. (\$), 3 pls. (incl. geol. map), 18 figs. (incl. geol. maps), 1936.

Cooper, William Skinner. See also Flint, 1288.

870. The recent ecological history of Glacier Bay, Alaska; 1, The interglacial forests of Glacier Bay: Ecology, vol. 4, no. 2, pp. 93-128, 1 pl. (index map), 15 figs., April 1923.

871. Third expedition to Glacier Bay, Alaska: Ecology, vol. 12, no. 1, pp. 61-95, 14 figs. (incl. index and sketch maps), January 1931.

872. The history of the upper Mississippi River in late Wisconsin and postglacial time: Minnesota Geol. Survey Bull. 26, 116 pp., 4 pls. (incl. geol. map), 46 figs., 1935.

873. (and Field, William Osgood, Jr.). Glacial studies in southern Alaska, 1935 [abstract] : Assoc. Am. Geographers Annals, vol. 26, no. 1, pp. 44-45, March 1936.

Córdova, Ramón Gandía

874. Los temblores de tierra: Revista de obras publicas de Puerto Rico, año 12, no. 3, pp. 879-882, March 1935.

Corey, William Henry.

875. Age and correlation of schist-bearing clastics, Venice and Del Rey fields, California : Am. Assoc. Petroleum Geologists Bull., vol. 20, no. 2, pp. 150-154, February 1936: abstracts, vol. 19, no. 12, p. 1842, December 1935 ; World Petroleum, voi. 7, no. 5, p. 278, May 1936.

Cormie, J. M.

876. Geology and ore deposits of the Central Patricia gold mine, Ontario: Econ. Geology, vol. 31, no. 1, pp. 93-103, 3 figs., January-February 1936.

Corning, Leavitt, Jr.

877. Plymouth area reserves [Texas] : Oil Weekly, vol. 81 , no. 3, pp. 30, 3134, 1 fig. (contour map), March 30, 1936.

Cortes, Henry C.

878. Russell Fossler Ryan [1897-1935]: Am. Assoc. Petroleum Geologists Bull., vol. 20, no. 2, pp. 240-241, February 1936.

Coryell, Horace Noble.

879. Jonesites, a new name for the ostracode genus Placentala: Jour. Paleontology, vol. 4, no. 3, pp. 294-295, 1 fig., September 1930.

880. (and Williamson, Marjorie). A study of the Ostracoda fauna of the Waldron shale, Flat Rock Creek, St. Paul, Ind.: Am. Mus. Noritates, no. 870, 7 pp., 15 figs., July 6, 1936.

881. (and Malkin, Doris S.). Some Hamilton ostracodes from Arkona, Ontario: Am. Mus. Novitates, no. 891, 20 pp., 38 figs., November 3, 1936.

Cotner, Victor.

882. (and Crum, Harry Edwin). Geology and occurrance of natural gas in Amarillo district, Tex.: Geology of natural gas, pp. 385-416, 6 figs., Am. Assoc. Petroleum Geologists, [June] 1935.

Couch, Glen C. See Sears, 3625 . 
Coulter, Charles C.

883. Origin of molybdenite at Climax, Colo.: Min. Jour., vol. 19 , no. 20, p. 4, Phoenix, Ariz., March 15, 1936.

884. The platinum group discovery at Centennial, Wyo.: Min. Jour., vol. 20, no. 6, p. 5, Phoenix, Ariz., August 15, 1936.

Courtier, William Henry. See Anonymous, 4665; Pierce, 3081.

Couser, Chester Wendell.

885. Paleozoic stratigraphy and structure in the Minnesota River Valley: Iowa Univ. Studies in Nat. History, vol. 16, no. 6, pp. 451-472, 2 figs. (incl. sketch map), May 1, 1935.

Cox, Ian H. See also Foerste, 1301.

886. Revision of the genus Calapoecia Billings: Canada Nat. Mus. Bull. 80, Geol. ser. 53, 49 pp., 4 pls., 1 fig., 1936.

Crabtree, Edwin Heward.

887. (and Netzeband, W. F.). Quarry, and plant of Reliance Rock Asphalt Co.: Am. Inst. Min. Met. Eng. Contr. 77, 9 pp., 2 figs., February 1935; abstracts, Year Book sec., p. 59, January 1936; Mining and Metallurgy, vol. 16, no. 339, p. 159, March 1935.

Craft, Benjamin C.

888. Geology of Cameron and Vermilion Parishes; Mineral development: Louisiana Dept. Cons. Geol. Bull. 6, pp. 181-186, 1 fig., 1935.

Cram, Ira H. See also Gardner, 1380.

889. A study of subsurface faults in Oklahoma [abstract, with discussion] : Tulsa Geol. Soc. Digest, 1934, pp. 1-2.

890. William Armstrong Patterson Graham [1899-1934] : Am. Assoc. Petroleum Geologists Bull., vol. 19, no. 7, pp. 1082-1083, July 1935.

891. Geologic names and correlations: Am. Assoc. Petroleum Geologists Bull., vol. 20, no. 1, pp. 115-116, January 1936. .

Crampton, Frank A.

892. Locating rims of a buried gravel channel: Mining Jour; vol. 20, no. 15, pp. 7, 34, 1 fig., Phoenix, Ariz., December 30, 1936.

Crandall, Kenneth Hartley. See Whisenant, 4447.

Crandall, Lynn. See Stearns, 3847, 3852.

Crary, Albert Paddock. See Ewing 1195, 1196, 1197, 1198, 1200.

Crawford, Arthur Lorenzo. See also Bryan, 515; Redden, 3214.

893. Is gold isotropic? [abstract] : Utah Acad. Sci. Proc., vol. 12, p. 165, 1935.

894. Archean (?) metaquartzites east of Bountiful, Utah [abstract] : Utah Acad. Sci: Proc., vol. 12, p. 167, 1935.

895. Hunting sapphires in Utah [abstract]: Utah Acad. Sci. Proc., vol. 13, p. 95, 1936.

Cressey, George Babcock.

896. Kaaterskill piracy, 1934 [abstract, with discussion by G. H. Chadwick] : Geol. Soc. America Proc., 1934, p. 73, June 1935.

Crew, Henry.

897. Biographical memoir of Thomas Corwin Mendenhall, 1841-1924: Nat. Acad. Sci. Biog. Mem., vol. 16, no. 7, pp. 329-351, 1 pl. (port.), 1936. 
Cribbs, James Elias.

898. Cordaites missouriense from the Lower Carboniferous of Missouri : Am. J̦our. of Botany, vol. 22, no. 4, pp. 427-438, 3 pls., 1 fig., April 1935.

Crickmay, Colin Hayter.

899. The nature and origin of fusain: Am. Midland Naturalist, vol. 16, no. 1, pp. 94-98, January 1935.

900. Problem of Cascadia [abstract] : Geol. Soc. America Proc., 1934, p. 73, June 1935 .

901. Study in the Jurassic of Wyoming: Geol. Soc. America Bull., vol. 47, no. 4, pp. 541-564, 3 pls., April 30, 1936.

Crickmay, Geoffrey William. See also Prindle, 3137.

902. (and Mitchell, Lane). Earthquakes in Georgia: Forestry-Geol. Rev., vol. 5, no. 3, pp. 7-8, 1 fig., March 1935 .

903. Stone Mountain, Ga.: Forestry-Geol. Rev., vol. 5, no. 5, pp. 7-8, 1 fig., May 1935.

904. (and Mitchell, Lane). The southern Appalachian earthquake of January 1, 1935: Seismol. Soc. America Bull., vol. 25, no. 3, pp. 247-251, 1 fig. (sketch map), July 1935.

905. Origin of barite in the Appalachian Valley: Econ. Geology, vol. 30, no. 5, pp. 563-564, August 1935.

906. Soil erosion and land planning in Georgia: Forestry-Geol. Rev., vol. 5, no. 9, pp. 7-8, 1 fig., September 1935.

907. Granite pedestal rocks in the southern Appalachian Piedmont: Jour. Geology, vol. 43, no. 7, pp. 745-758, 8 figs., October-November 1935.

908. (and Mitchell, Lane). The Georgia State Museum: Georgia Dept. Forestry and Geol. Development, Div. Geology, Inf. Cir. 7, 4 pp., 1 fig., 1936.

909. Age of the Talladega series in Alabama, Georgia and North Carolina [abstract] : Geol. Soc. America Proc., 1935, p. 72, June 1936.

910. Status of the Talladega series in southern Appalachian stratigraphy: Geol. Soc. America Bull., vol. 37, no. 9, pp. 1371-1392, 3 figs. (incl. geol. sketch map), September 30, 1936.

911. The caves of Georgia: Forestry-Geol. Rev., vol. 6, no. 10, pp. 7-8, October 1936.

912. Talc deposits of Georgia: Forestry-Geol. Rev., vol. 6, no. 11, pp. 7-8, 1 fig., November 1936.

913. Ground water in the crystalline rocks of Georgia: Forestry-Geol. Rev., vol. 6 , no. 12 , pp. 7-8, 1 fig., December 1936.

Critchlow, Howard, Thompson.

914. New Jersey ground-water supply abundant: Civil Eng., vol. 2, no. 12, pp. 774-777, 3 figs. (incl. geol. map), December 1932.

915. (and Barksdale, Henry Compton). Symposium on fluctuations of ground water; A long-term record of water-level fluctuations at Plainfield, N. J.: Am. Geophys. Union Trans. 17th Ann. Meeting, pt. 2, pp. 361-363 (\$), 1 fig., Nat. Research Council, 1936.

Crockford, M. B. B. See also Miller, 2706.

916. (and Warren, Percival Sidney). The Cache Creek series of British columbia: Royal Soc. Canada Trans., 3d ser., vol. 29, sec. 4, pp. 149-161, 1 fig. (geol. map), May 1935. 
Croneis, Carey Gardiner. See also Bayley, 246; Mather, 2605; Snider, 3783. 917. (and Krumbein, William Christian). Down to earth; an introduction to geology. xviii, 501 pp., illus., Chicago, Univ. Chicago Press. [1935].

918. Natural gas in interior highlands of Arkansas: Geology of natural gas, pp. 533-574, 15 figs. (incl. maps), Am. Assoc. Petroleum Geologists, [June] 1935.

919. (and Geis, Harold Lorenz). Blastoid ontogeny [abstract] : Geol. Soc. America Proc., 1934, pp. 357-358, June 1935.

920. Talking motion pictures in geology [abstract]: Geol. Soc. America Proc., 1935, pp. 72-73, June 1936.

921. [Review of] Invertebrate plaeontology, by W. H. Twenhofel and Robert R. Shrock, 1935: Jour. Geology, vol. 44, no. 8, pp. 952-953, November-December 1936.

Crook, T. $\mathrm{H}$.

922. (and Kirby, J. M.). Capay formation [abstract]: Geol. Soc. America Proc., 1934, pp. 334-335, June 1935.

Crosby, Irving Ballard.

923. Report on the mineral resources of Massachusetts; a survey of the literature, 35 pp. ( $\$)$, Massachusetts Indus. and Devel. Comm., July 1932.

924. Geology of Fifteen Mile Falls development; design of dam on Con. necticut River required extensive study of the glaciated valley: Civ. Eng., vol. 4, no. 1, pp. 21-24, 3 figs. (incl. geol. maps), January 1934.

Cross, C. M. See Hanna, 1616.

Cross Charles Whitman.

925. (and Larsen, Esper Signius). A brief review of the geology of the San Juan region of southwestern Colorado: U. S. Geol. Survey Bull. 843, 138 pp., 16 pls. (incl. geol. map), 2 figs., 1935.

Crowley, Arthur J.

926. Critical observations of mineral behavior when associated with superheated water: Eng. and Min. Jour., vol. 137, no. 1, pp. 27-30, 4 figs., January 1936.

Crum, Harry Edwin. See Cotner, 882.

Cullings, Edwin Sandford.

927. Symposium on fluctuations of ground water; Fluctuations in ground water at Woodgate, N. Y.: Am. Geophys. Union Trans. 17th Ann. Meeting, pt. 2, pp. 357-360 ( $¥), 3$ figs., Nat. Research Council, 1936.

Cullison, James S.

928. Subterranean and surface stream piracy of Gap Creek and its tributary [abstract] : Geol. Soc. America Proc., 1985, p. 73, June 1936.

Culver, Harold Eugene.

929. Biennial report of the Supervisor of the Division of Geology: Washington Dept. Cons. and Devel. 3d Bienn. Rept., April 1, 1925, to September 30, 1926, pp. 84-92, 1927.

930. Biennial report of the Supervisor of the Division of Geology: Washington Dept Cons. and Devel. 4th Bienn. Rept., April 1, 1927, to September 30, 1928, pp. 67-74, 1928. 
Culver, Harold Eugene-Continued.

931. Biennial report of Division of Geology: Washington Dept. Cons. and Devel. Bienn. Rept., April 1, 1933, to November 30, 1934, 14 pp., 2 figs., 1935.

Cummings, Byron.

932. Pleistocene man in Arizona [abstract] : Pan. Am. Geologist, vol. 64, no. 2, pp. 155-156, September 1935.

Cummings, 'J. M. See Warren, 4346.

Cunningham, Charles H. See Talley, 4010.

Cunningham, William A.

933. Dolomite in Permian limestones of west Texas: Am. Assoc. Petroleum Geologists Bull., vol. 19, no. 11, pp. 1678-1692, 1 fig. (index map), November 1935.

934. Geology of Texas, vol. 2, pt. 3, Economic geology of Texas (exclusive of petroleum); The potassium sulfate mineral polyhalite in Texas: Texas Univ. Bull. 3401, pp. 833-867, 6 figs. (incl. geol. maps), December 1935.

Curfman, G. H.

935. Note on an unusually fine specimen of a trilobite [abstract]: Virginia Acad. Sci. Proc., 1934-35, p. 70 [1935].

Currier, Louis Wade.

936. Zinc and lead region of southwestern Virginia: Virginia Geol. Survey Bull. 43, xii, 122 pp., 26 pls. (incl. geol. maps), 3 figs. (incl. index map), 1935.

937. Structural relations of southern Appalachian zinc deposits: Econ. Geology, vol. 30, no. 3, pp. 260-286, 9 figs., May 1935.

938. A preliminary report on the geology and ore deposits of the eastern part of the Yellow Pine district, Idaho: Idaho Bur. Mines and Geology Pamph. 43, 27 pp. ( $\ddagger), 8$ pls. (incl. geol. maps), June 1935.

939. Structural features of the Illinois-Kentucky fluorspar field [abstract] : Washington Acad. Sci. Jour., vol. 25, no. 11, pp. 505-506, November $\mathbf{1 5}, 1935$.

940. Memorial of Charles Henry Richardson [1862-1935] : Am. Mineralogist, vol. 21, no. 3, pp. 178-182, 1 fig. (port.), March 1936.

Curry, H. Donald. See U. S. G. S., 4228.

Cushman, Joseph Augustine.

941. Upper Eocene Foraminifera of the southeastern United States: U. S. Geol. Survey Prof. Paper 181, 60 pp., 26 pls., 1935.

942. Contributions from the Cushman Laboratory for Foraminiferal Research, Sharon, Mass.

Vol. 11, pt. 1, March 1935.

152. (by Lalicker, Cecil Gordon). New Cretaceous Textulariidae, pp. 1-13, 2 pls.

153. (and Hedberg, Hollis Dow). A new genus of Foraminifera from the Miocene of Venezuela, pp. 13-16,1 pl. (in part).

154. (and Adams, Bradford C.). New late Tertiary Bolivinas from California, pp. $16-20,1$ pl. (in part).

155. Bitubulogenerina howei, a new species from the lower Oligocene, pp. 20-21, 1 pl. (in part).

Vol. 11, pt. 2, June 1935.

156. New species of Foraminifera from the lower Oligocene of Mississippi, pp. 25-39, 2 pis.

157. (by Lalicker, Cecil Gordon). New Tertiary Textularidae, pp. 39-51, 2 pls. 
Cushman, Joseph Augustine-Continued.

Vol. 11, pt. 3, September 1935.

158. (and Hobson, Henry David). A foraminiferal faunule from the type San Lorenzo formation, Santa Cruz County, Callf., pp. 53-64, 2 pls.

159. (and Campbell, Arthur Shackelton). Cretaceous, Foraminifera from the Moreno shale of California, pp. 65-73, 2 pls.

Vol. 11, pt. 4, December 1935.

160. Some new Foraminifera from the late Tertlary of Georges Bank, pp. 77-83, $1 \mathrm{pl}$.

161. Notes on some American Cretaceous Flabellinas, pp. 83-89, 1 pl.

162. (and Martin, Lois T.). A new genus of Foraminifera, Discorbinella, from Monterey Bay, Calif., pp. 89-90, 1 pl. (in part).

163. (and Siegfus, Stanley S.). New species of Foraminifera from the Kreyenhagen shale of Fresno County, Calif., pp. 90-95, 1 pl. (in part).

164. (and Parker, Frances L.) Some American Cretaceous Buliminas,, pp. 96-101. $1 \mathrm{pl}$.

Vol. 12, pt. 1, March 1936.

165. (and Bermidez, Pedro J.). The Foraminiferal genus Amphimorphina in theEocene of Cuba, pp. 1-3, 10 figs.

166. (and Jarvis, P. W.). Three new Foraminifera from the Miocene Bowden marl of Jamaica, pp. 3-5, 6 figs.

167. (and Parker, Frances L.). Notes on some Cretaceous species of Bultiminella and Neobulimina, pp. 5-10, 1 pl.

168. Notes on some American Cretaceous Frondicularias, pp. 11-22, 2 pls.

Vol. 12, pt. 2, June 1936.

169. (and Bermúdez, Pedro J.). New genera and species of Foraminifera from the Eocene of Cuba, pp. 27-38, 2 pls.

170. (and Parker, Frances L.). Some Amierican Eocene Buliminas, pp. 39-45, 2 pls.

171. (and Hanzawa, Shoshiro). New genera and species of Foraminifera of the late Tertiary of the Pacific, pp. 45-48.

Vol. 12, pt. 3, September 1936.

172. Some American Cretaceous species of Ellipsonodosaria and Chrysalogonium, pp. 51-55, 1 pl.

173. (and Bermúdez, Pedro J.). Additional new species of Foraminifera and a new genus from the Eocene of Cuba, pp. 55-63, 1 pl.

174. Some new species of Nonion, pp. 63-69, 2 pls.

Vol. 12, pt. 4, December 1936.

175. Cretaceous Foraminifera of the family Chilostomellidae, pp. 71-78, 1 pl. (figures drawn by Patricia G. Edwards and Ann Shepard).

176. Some new species of Elphidium and related genera, pp. 78-89, 1 pl. (Agures drawn by Ann Shepard).

177. (and White, Ella Marle). Pyrgoella, a new genus of the Millolldae, pp. 80-91, 1 pl. (Figures drawn by Ann Shepard).

178. (and Campbell, Arthur Shackelton). A new siphogenerinoides from Callfornia, pp. 91-92, 3 figs. (Figures drawn by Ann Shepard).

179. (and Parker, Frances L.). Some specles of Robertina, pp. 92-100, 1 pl. (Figures drawn by Ann Shepard).

943. Paleozoic Foraminifera, their relationships to modern faunas and to their environment: Jour. Paleontology, vol. 9, no. 3, pp. 284-287, April 1935.

944. Geology and paleontology of the Georges Bank canyons; pt. 4, Cretaceous and late Tertiary Foraminifera: Geol. Soc. America Bull., vol. 47, no. 3, pp. 413-440, 5 pls., March 31, 1936.

945. New zenera and species of the families Verneuilinidae and Valvulinidae and of the subfamily Virgulininae: Cushman Lab. Foram. Research Special Pub. 6, 71 pp., 8 pls., June 1936.

946. (and McMasters, John Herbert). Middle Eocene Foraminifera from the Llajas formation, Ventura County, Calif.: Jour. Paleontology, vol. 1.0, no. 6, pp. 497-517, 4 pls., 4 figs. (incl. index maps), September 1936. 
Dachnowski-Stokes, Alfred Paul.

947. The correlation of time units and climatic changes in peat deposits of the United States and Europe: Nat. Acad. Sci. Proc., vol. 8; no. 7, pp. 225-231, July 1922.

948. Peat land in the Pacific Coast States in relation to land and water resources: U. S. Dept. Agr. Misc. Pub. 248, 68 pp., 4 pls. (incl. maps), 2 figs. (maps), October 1936.

Dadson, A. S.

949. The influence of potential in ore deposition: Toronto Univ. Studies, Geol. ser. 38, pp. 51-60, 1935.

Dahm, Cornelius George. See also Bradford, 416.

.950. The southeastern Illinois earthquake of October 29, 1934 : Seismol. Soc. America Bull., vol. 25, no. 3, pp. 253-257, 1 fig. (sheteh map), July 1935.

951. Velocities of $P$ and $S$ waves calculated from the observed travel times of the Long Beach earthquake: Seismol. Soc. America Bull., vol. 26, no. 2, pp. 159-171, 6 figs., 6 tables, April 1936; abstract, Earthquake Notes, vol. 7, nos. 1-2, p. $14(\ddagger)$, September 1985 .

Dake, Charles Laurence, 1883-1934.

952. Basal Pennsylvanian transgression in the Ozarks: Geol. Soc. America Bull., vol. 46, no. 5, pp. 697-714, May 31, 1935.

Dake, Henry Carl. See also Randolph, 3172, 3174.

953. Fluorescent minerals of Oregon and Washington: Mineralogist, vol. 3, no. 1, p. 20, January 1935.

954. New iron meteorite found: Mineralogist, vol. 3, no. 2, p. 27, February 1935.

955. Fluorescence in opal: Mineralogist, vol. 4, no. 3, p. 20, March 1936.

956. Willamette meteorite, an erratic: Mineralogist, vol. 4, no. 7, pp. 10, 33-34, July 1936.

957. Curious stalagmites in western cave: Mineralogist, vol. 4, no. 9, pp. 5-6, 31, 1 fig., September 1936.

Dale, Nelson Clark.

958. Preliminary report on the geology of the Russell quadrangle: New York State Mus. Circ. 15, 16 pp., 1 pl. (geol. map), November 1934.

959. Grenville and post-Grenville structural relations in the western Adirondacks [abstract]: Geol. Soc. America Proc., 1934, pp. 73-74, June 1935.

960. Structural features of the Allegheny cuesta in New York [abstract]: Geol. Soc. America Proc., 1934, p. 442, June 1935.

961. Geology of Oswegatchie quadrangle: New York State Mus. Bull. 302, 101 pp., 9 pls. (incl. geol. map), 16 figs., September 1935.

Daly, John w. .

962. Paragenesis of the mineral assemblage at Crestmore, Riverside County, Calif.: Am. Mineralogist, vol. 20, no. 9, pp. 638-659, 1 pl. (geol. map), September 1935.

Daly, Reginald Aldworth.

963. John Horne (1848-1928) : Am. Acad. Arts and Sci. Proc., vol. 69, no. 13, pp. 515-516, February 1935.

964. Johan Herman Lie Vogt (1858-1932) : Am. Acad. Arts and Sci. Proc., vol. 69 , no. 13 , pp. 555-556, February 1935. 
Daly, Reginal Aldworth-Continued.

965. Testing a theory of the earth's interior: Washington Acad. Sci. Jour., vol. 25, no. 9, pp. 389-399, 3 figs., September 15, 1935.

966. Densities of rocks calculated from their chemical analyses: Nat. Acad. Sci. Proc., vol. 21, no. 12, pp. 657-663, December 15, 1935.

967. The strength of the earth [abstract]: Washington Acad. Sci. Jour., vol. 25 , no. 12 , p. 572 , December $15,1935$.

968. Origin of submarine canyons: Am. Jour. Sci., 5th ser., vol. 31, no. 186, pp. 401-420, June 1936; abstract, Geol. Soc. America Proc. 1935, pp. 73-74, June 1936.

Dane, Carle Hamilton. See also Baker, 143; Hendricks, 1709 ; Schuchert, 3588; U. S. G. S., 4226.

969. (and Rothrock, Howard Eugene, and Williams, James Steele). Preliminary map showing geologic structure of the Quinton-Scipio district, Pittsburg, Haskell, and Latimer Counties, Okla. Scale 1:62,500. Washington, U. S. Dept. Interior, U. S. Geol. Survey, 1935. (Contains sections.)

970. Geology of the Salt Valley anticline and adjacent areas, Grand County, Utah: U. S. Geol. Survey Bull. 863, v, 184 pp., 21 pls. (incl. geol. and structure maps), 4 figs. (incl. index map), 1935 [1936].

971. (and Hendricks, Thomas Andrews). Correlation of Bluejacket sandstone, Oklahoma: Am. Assoc. Petroleum Geologists Bull., vol. 20, no. 3, pp. 312-314, 1 fig. (index map), March 1936.

972. (and Pierce, William Gamewell). Dawson and Laramie formations in southeastern part of Denver Basin, Colo.: Am. Assoc. Petroleum Geologists Bull., vol. 20, no. 10, pp. 1308-1328, 1 pl. (geol. map), $\dot{2}$ figs. (incl. index map), October 1936.

Daniels, Joseph.

973. Coal in Washington; distribution, geology, mining, preparation, uses, and economic value of coal resources of Washington: Washington Univ. [Seattle], Eng. Exper. Sta. ser., Rept. 3, 17 pp., 2 pls. (incl. map), September 1934.

Danloux-Dumesnil, Maurice.

974. L'or du Canada: Rev, industrie minérale, no. 345, pp. 215-222, 2 figs. (incl. index map), May 1, 1935; no. 346, pp. 237-244, 3 figs. (incl. geol. map), May 15, 1935; no. 356, pp. 499-506, 5 figs. (incl. geol. maps), October 15, 1935 ; no. 357 , pp. 523-530, 1 fig., November 1 , 1935.

Darrah, William Culp.

975. (and Bertrand, Paul), Observations sur les flores houillères de Pennsylvanie: Soc. géol. Nord Annales, tome 58, pp. 211-224, 1933.

976. Permian elements in the fossil flora of the Appalachian province; 1 , Taeniopteris: Harvard Univ. Bot. Mus. Leaflets, vol. 3, nn. 9, pp. 137-148, 1935.

977. Some late Carboniferous correlations in the Appalachian province (abstract) : Geol. Soc. America Proc., 1934, pp. 442-443, June 1935.

978. Permian elements in the fossil flora of the Appalachian province; 2, Walchia: Harvard Univ. Bot. Mus. Leaflets, vol. 4, no. 2, pp. 9-19, March 1936. 
Darton, Nelson Horatio.

979. Overlap relations of the Cretaceous and the Tertiary of Maryland [abstract]: Geol. Soc. America Proc, 1934, p. 74, June 1935.

980. Structure and relations of the Tertiary and Cretaceous in the Washington [D. C.] region [abstract]: Geol. Soc. America Proc., 1935, p. 74, June 1936.

Daugherty, Lyman $\mathrm{H}$.

981. New fossil plants from the Petrified Forest (abstract) : Geol. Soc. America Proc., 1934, p. 389, June 1935.

David, Max W. See Howard, 1830.

Davidson, J. See Canada G. S., 658.

Davies, Arthur Morley. See also Dunbar, 1093 ; Ellisor, 1173.

982. [William Morris Davis, 1850-1934]: Geol. Assoc. Proc., vol. 47, pt. 1, pp. 95-96, March 27, 1936.

Davis, Charles McRea.

983. The high plains of Michigan: Michigan Acad. Sci. Papers, vol. 21, 1935, pp. 303-341, 3 pls., 9 figs. (maps), 1936.

Davis, Charles Wesley.

984. Geological significance of magnetic properties of minerals: Econ. Geology, vol. 30, no. 6, pp. 655-662, September-October 1935.

Davis, Harry Towles. See Henderson, 1698; Stuckey, 3942.

Davis, Joseph Dana. See Fieldner, 1255.

Davis, William Morris, 1850-1934.

985. (and Maxson, John Haviland). Valleys of the Panamint Mountains, Calif. [abstract] : Geol. Soc. America Proc. 1934, p. 339, June 1935.

986. Geomorphology of mountainous deserts: 16th Internat. Geol. Cong. (1933) Rept., vol. 2, pp. 703-714, 1936.

Day, Arthur Louis. See also Allen, 36, 37 ; Behre, 261 ; Ross, 3367.

987. (and others). Seismology report of the advisory committee: Carnegie Inst. Washington Year Book 33, pp. 349-359, 1934.

988. [Reports of investigations of the] Geophysical Laboratory : Carnegie Inst. Washington Year Book 34, pp. 93-112, 1935.

989. (and others). Seismology; report of the advisory committee: Carnegie Inst. Washington Year Book 34, pp. 360-370, 1935.

990. The mechanism of geysers [abstract] : Science, new ser., vol. 82, no. 2137, p. 573, December 13, 1935.

991. Hot Springs of Yellowstone Park [abstract] : Royal Canadian Inst. Proc., 3d ser., vol. 1, p. 31, 1936.

992. The hot-spring problem in Yellowstone Park [abstract]: Science, new ser., vol. 83, no. 2160, p. 486, May 22, 1936.

Dawson, Joseph M. See Tatum, 4022.

De Béthune, Pierre.

993. Thrusting of unfolded rocks [abstract] : Geol. Soc. America Proc., 1934, pp. 325-326, June 1935.

994. "Ripple marks", rhombiques fossiles đu Carbonifère de l'Oklahoma: Soc. belge géologie Bull., tome 46, fasc. 2, pp. 291-296, 1 flg., November 16, 1936. 
Debler, E. B.

995. (and Riter, J. R.). Report on upper Snake River storage investigations; Snake River above Idaho Falls: U. S. Bur. Reclamation Rept. on Snake River Invest., vol. 1, 236 pp. ( $\ddagger), 20$ pls. (incl. index and topographic maps), June 1935.

Decker, Charles Elijah. See also Ruedemann, 3402.

996. The graptolite of the Simpson group of Oklahoma: Nat. Acad. Sci. Proc., vol. 21, no. 5, pp. 239-243, 18 figs., May 15, 1935.

997. Graptolites from the Silurian of Oklahoma: Jour. Paleontology, vol. 9, no. 5, pp. 434-446, 43 figs., July 1935.

998. Graptolites of the Sylvan shale of Oklahoma and Polk Creek shale of Arkansas: Jour. Paleontology, vol. 9, no. 8, pp. 697-708, 2 pls., December 1935.

999. [Review of] Invertebrate paleontology, by William $H$. Twenhofel and Robert R. Shrock, 1935: Am. Assoc. Petroleum Geologists Bull., vol. 20, no. 2, pp. 228-229, February 1936.

1000. Some tentative correlations on the basis of graptolites of Oklahoma and Arkansas: Am. Assoc. Petroleum Geologists Bull., vol. 20, no. 3, pp. 301-311, March 1936.

1001. Table of tentative Lower Paleozoic correlations on basis of graptolites: Am. Assoc. Petroleum Geologists Bull., vol. 20, no. 9, pp. 1252-1257, 1. fig., September 1936.

Deflandre, Georges.

1002. Note sur les Archaeomonadacées: Soc. bot. France Bull., vol. 76, nos. 5/6, pp. 346-355, 38 figs., 1932.

De Geer, Ebba Hult.

1003. Teleconnection of geochronology and historic time: 16th Internat. Geol. Cong. (1933) Rept., vol. 1, pp. 203-211, 1 fig., 1936.

De Geer, Gerard Jakob.

1004. Gotiglacial broadmapping, Sweden-New York-Manitoba: 16th Internat. Geol. Cong. (1933) Rept., vol. 1, pp. 191-202, 1 pl., 2 figs. (incl. geol. map), 1936.

1005. International geochronology, its origin and scope [abstract] : 16th Internat. Geol. Cong. (1933) Rept., vol. 1, p. 234, 1936.

De Golyer, Everette Lee.

1006. Notes on the early history of applied geophysics in the petroleum industry: Soc. Petroleum Geophysicists Jour., vol. 6, no. 1, pp. 1-10, July 1935.

1007. [Review of] Geology of natural gas; a symposium, edited by Henry A. Ley, 1935: Econ. Geology, vol. 30, no. 7, pp. 831-833, November 1935.

1008. Geophysical prospecting for oil in 1935: Mining and Metallurgy, vol. 17 , no. 349, pp. 62-63, 1 fig., January 1936.

Deiss, Charles Frederick.

1009. Cambrian-Algonkian unconformity in western Montana: Geol. Soc. America Bull., vol. 46, no. 1, pp. 95-124, 2 pls., January 31, 1935; abstract, Proc., 1933, pp. 382-383, June 1934.

-1010. Memorial of Charles Horace Clapp [1883-1935] : Geol. Soc. America Proc., 1935, pp. 171-182, 1 pl. (port.), June 1936.

1011. Devonian rocks in the Big Snowy Mountains, Mont.: Jour. Geology, vol. 44, no. 5, pp. 639-644, 3 figs., July-August 1936; abstract, Geol. Soc. America Proc., 1935, pp. 387-388, June 1936. 
Deiss, Charles Frederick-Continued.

1012. Revision of type Cambrian formations and sections of Montana and Yellowstone National Park: Geol. Soc. America Bull., vol. 47, - no. 8, pp. 1257-1342, 2 pls. (incl. index map), 10 figs., August 31, 1936 ; abstract, Proc., 1935, p. 388, June 1936.

De Jong, W. F.

1013 (and De Lange, J. J.). X-ray study of pucherite: Am. Mineralogist, vol. 21 , no. 12 , pt. 1 , p. 809 , December 1936.

Delaney, John P.

1014. Seismographic sensitivity to tilt [abstract]: Geol. Soc. America Proc., 1934, p. 443, June 1935.

1015. Seismographic tilt measurements at Buffalo [abstract] : Am. Geophys. Union Trans. 17th Ann. Meeting, pt. 1, pp. 102-103 ( $\$)$, Nat. Research Council, July 1936 ; Earthquake Notes, vol. 7, nos. 1-2, p. 9, September 1935; vol 8, nos. 1-2, pp. 102-103, June 1936.

De Lange, J. J. See De Jong, 1013.

DeLaubenfels, Max Walker.

1016. The oecology of Porifera, and possibilities of deductions as to the pareoecology of sponges from their fossils: Nat. Research Council Ann. Rept., 1935-36, app. J, Report of the committee, on paleoecology, pp. 44-54 (\$), October 1936 .

Delo, David Marion.

1017. Locomotive habits of some trilobites: Am. Midland Naturalist, vol. 16, no. 3, pp. 406-409, May 1935.

1018. Genotype of Dalmanites [abstract]: Geol. Soc. America Proc., 1984, p. 360 , June 1935.

1019. A revision of the phacopid trilobites: Jour. Paleontology, vol. 9, no. 5, pp. 402-420, 45 figs., July 1935.

1020. New Phacopinae from the Devonian of Oklahoma and Iowa: Jour. Paleontology, vol. 9, no. 5, pp. 421-423, 5 figs., July 1935; abstract, Geol. Soc. America Proc., 1934, p. 360, June 1935.

1021. Heliocephalus, new name for Malvernia Delo [not Jacoby] : Jour. Paleontology, vol. 10, no. 5, p. 417, July 1936.

De Lury, Justin Sarsfield.

1022. (and Spivack, Joseph). Locus of magma formation: Fifth Pacific Sci. Cong., Canada, 1933, Proc., vol. 3, pp. 2285-2290, 1934.

1023. Causes of crustal elevation and depression: Pan-Am. Geologist, vol. 63, no. 2, pp. 81-89, March 1935; abstract, Geol. Soc. America Proc., 1934, p. 443, June 1935.

1024. Deductions from geothermal evidence [abstract]: Geol. Soc. America Proc., 1934, p. 74, June 1935.

1025. (and Lane, H. C.). Radioactivity and geothermal gradients: Pan-Am. Geologist, vol. 64, no. 2, pp. 99-105, September 1935.

1026. (and Spivack, Joseph). Concomitants of diverse geothermal gradients : Pan. Am. Geologist, vol. 64, no. 3, pp. 185-192, 2 figs., October 1935.

1027. Geologic deductions from earthquakes of deep focus: Jour. Geology, vol. 43, no. 7, pp. 759-764, October-November 1935; abstract, Royal Soc. Canada Proc, 3d ser, vol, 29, sec, 4, p, c, 1935,

1028. Geologic deductions from a thermal equation: Jour. Geology, vol. 44, no. 4, pp. 479-495, 4 figs., May-June 1936. 
De Lury, Ralph Emerson.

1029. Fluctuation in earthquakes in relation to phenomena of the earth and solar system [abstract] : Earthquake Notes, vol. 7, nos. 1-2, p. 13 ( $¥)$, September 1935 .

Denham, R. I. See Tolman, 4136.

Denis, Bertrand T.

1030. The northwest portion of the Lac-Saint-Jean region: Quebec Bur. Mines Ann. Rept., 1933, pt. D. pp. 55-91, 2 pls. (incl. geol. map), 2 figs., 1934.

1031. Sabourin map area, Témiscamingue County: Quebec Bur. Mines Ann. Rept., 1934, pt. C, pp. 3-18, 1 pl. (geol. map), 1935 ; also in French ed., 1935.

Denny, C. S.

1032. Perjglacial phenomena in southern Connecticut: Am. Jour. Sci., 5th ser., vol. 32 , no. 191, pp. 322-342, 13 figs. (incl. index and geol. maps), November 1936.

Deussen, Alexander.

1033. Oil-producing horizons of Gulf coast in Texas and Louișiana: Am. Assoc. Petroleum Geologists Bull., vol. 18, no. 4, pp. 500-518, 10 figs. incl. maps), April 1934; reprinted in Gulf coast oil fields (see Barton and Sawtelle), pp. 1-19, 1936.

1034. (and Leonardon, Eugene Gilbert). Electrical exploration of drill holes [with discussion]: Drilling and production Practice, 1935, pp. 47-59, 14 figs., Am. Petroleum Inst., 1936.

1035. Thirty-five years of progress in the knowledge of the geology of Texas: Texas Univ. Bull. 3501, January 1, 1935, pp. 37-57, 4 figs. (geol. maps), February 1936.

1036. (and Andrau, E. W. K.). Orange, Tex., oil field: Am. Assoc. Petroleum

- Geologists Bull., vol. 20, no. 5, pp.e531-559, 9 figs. (incl. index maps), May 1936; abstract, World Petroleum, vol. 7, no. 8, p. 404, August 1936 ; reprinted in Gulf coast oil fleld (see Barton and Sawtelle), pp. 880-908, 1936.

DeVarigny, $\mathbf{H}$.

1037. Une énigme géophysique: Rev. gén. sci. pures et nat., tome 45 , no. 12 , pp. 355-356, June $30,1934$.

DeWolf, Frank Walbridge.

1038. [Review of Branson and Tarr's] Introduction to geology: Am. Assoc. Petroleum Geologists Bull., vol. 19, no. 8, pp. 1240-1241, August 1935 .

Dice, Dora S. See Dice, L. R., 1039.

Dice, Lee Raymond.

1039. (and Dice, Dora S.). The lower cheek teeth of the fossil hare Palaeolagus haydeni: Michigan, Acad. Sci. Papers, vol. 20, pp. 455-463, 19 figs., 1 pl., 1935.

Dicken, Samuel Newton.

1040. A Kentucky solution cuesta: Jour. Geology, vol. 43, no. 5, pp. 539-544, 4 figs. (incl. sketch map), July-August 1935.

1041. Kentucky karst landscapes: Jour. Geology, vol. 43, no. 7, pp. 708-728, 8 figs. (incl. sketch maps), October-November 1935.

1042. Ground water and settiement in the middle Sierra Madre Oriental, Mexico [abstract] : Assoc. Am. Geographers Annals, vol. 26, no. 1, pp. 47-48, March 1936. 
Dickerson, Roy Ernest.

1043. (and Butt, W. H.). Cuban Jurassic: Am. Assoc. Petroleum Geologists: Bull., vol. 19, no. 1, pp. 116-118, January 1935.

Dickey, Robert I. See Wentworth, 4402.

Dickey, Robert M.

1044. The granitic sequence in the southern complex of Upper Michigan: Jour. Geology, vol. 44, no. 3, pp. 317-340, 4 figs. (incl. geol. map), April-May 1936.

Dickson, James.

1045. Submarine coal mining at Nanaimo, Vancouver Island, British Columbia: Canadian Inst. Min. Metallurgy Trans., vol. 38, pp. 465-472, 1935.

Diepenbrock, Alex.

1046. Mount Poso oil field: California Oil Fields, vol. 19, no. 2, pp. 4-35, 7 pls. (incl. maps), 1 fig., October, November, December 1933.

1047. Round Mountain field [Kern County]: California Oil Fields, vol. 19, no. 4, April, May, June 1934, pp. 5-19, 4 pls. (incl. index map), 1 flg., 1935.

Dillard, William Reese. See Bass, $220,221,222$; U. S. G. S., 4235, 4236, 4237, 4238.

Dix, Charles Hewitt.

1048. Note on the theory of seismic prospecting: Soc. Petroleum Geophysicists Jour., vol. 6, no. 1, p. 34-43, 5 figs., July 1935.

Doan, Donald J. See Cooke, S. R. B., 853.

Dobbin, Carroll Edward.

1049. (and Larsen, Raymond M.). Geologic and structure-contour map of the southern half of the Cedar Creek anticline, Fallon County; Mont., and Bowman ${ }^{\circ}$ County, N. Dak., U. S. Geol. Survey, 1934. Accompanied by U. S. Dept. Interior Press Mem. 94227, 2 pp. ( $¥$ ), February 1, 1935.

1050. Geology of natural gas rich in helium, nitrogen, carbon dioxide; and hydrogen sulphide: Geology of natural gas, pp. 1053-1072, $1 \mathrm{fig}$. (map), Am. Assoc. Petroleum Geologists, [June] 1935.

1051. (and Miller, John Charles, and Walter, K. L.). Geologic and structurecontour map of Garland anticline, Big Horn and Park Counties; Wyo., U. S. Geol. Survey, 1935. Accompanied by U. S. Dept. Interior Press Mem. 102882, June 24, 1935.

1052. (and Miller, John Charles, and Walter, K. L.). Geologic and structurecontour map of the Osage oil field, Weston County, Wyo., U. S. Geol. Survey, 1935. Accompanied by U. S. Dept. Interior Press Mem. 109045, November 15, 1935.

Dobson, G. C. See Eakin, 1105.

Dodge, Theodore A.

1053. A rapid microscopic method for distinguishing quartz from untwinned oligoclase-andesine: Am. Mineralogist, . vol. 21, 8, pp. 531-532, August 1936.

Doering, John.

1054. Post-Fleming surface formations of coastal southeast Texas and south

Louisiana: Am. Assoc. Petroleum Geologists Bull., vol. 19, no. 5, pp. 651-688, 15 figs. (incl. maps), May 1935; reprinted in Gulf coast oil flelds (see Barton and Sawtelle), pp. 432-469, 1936. 
Dollen, B. H. See Leggette. 2377, 2378.

Dolmage, victor.

1055. The Cariboo and Bridge River gold fields, British Columbia: Canadian Inst. Min. Metallurgy Trans., vol. 37, pp. 405-435, 7 figs. (incl. geol. map) [1935].

Donald, Edward McHenry.

1056. Earthquake, Grand Canyon: Grand Canyon Nature Notes, vol. 9, no. 11, pp. 372-377 (\$), 2 figs. (incl. sketch map), February 1935.

Donald, Robert T.

1057. Geological study at Cusi [Mexico] reveals new ore: Eng. and Min. Jour., vol. 136, no. 12, pp. 614-617, 5 figs. (incl. sketch map), December 1935.

Donnay, Joseph Désiré Hubert. See also Morse, 2804.

1058. Friedel's law of mean indices [abstract]: Am. Mineralogist, vol. 20, no. 3, pp. 211-212, March 1935; Geol. Soc. America Proc., 1934, p. 433 , June 1935 .

1059. On the application of determinants to crystallography: Am. Mineralogist, vol. 20, no. 8, pp. 601-602, August 1935.

1060. Alternating axes and symmetry symbols in crystallography: Washington Acad. Sci. Jour., vol. 25, no. 11, pp. 476-488, 6 figs., November $15,1935$.

1061. (and Mélon, J.). Crystallography of lithium molybdo-tellurate: Am. Mineralogist, vol. 21, no. 2, pp. 125-127, 2 figs., February 1936.

1062. (and Mélon, J.). Crystallography of ammonium molybdo-ditellurate: Am. Mineralogist, vol. 21, no. 4, pp. 250-257, 5 figs., April 1936.

1063. (and Mélon, J.). Crystallography of caesium molybdo-tellurates: Am. Mineralogist, vol. 21, no. 5, pp. 299-311, 5 figs., May 1936.

Donnelly, Maurice. -

1064. Geology and mineral deposits of the Julian district, San Diego County, Calif. : California Jour. Mines and Geology, vol. 30, no. 4, October 1934, pp. 331-370, 13 figs., 1 pl. .(geol. map), 1935.

1065. Orthoclase from San Diego County pegmatites [abstract]: Pan-Am. Geologist, vol. 63, no. 4, p. 320, May 1935; Geol. Soc. America Proc., 1935, pp. 341-342, June 1936.

1066. Economic geology of the Julian region, Calif. [abstract]: Geol. Soc. America Proc., 1934, p. 321, June 1935.

1067. Notes on the lithium pegmatites of Pala, Calif.: Pacific Mineralogist, vol. 3 , no. 1, pp. 8-12, June 1936.

Doorninck, Nicholaas Hendricus van.

1068. Het vulcanisme van de Hawaii-Eilanden: Geologie \& Mijubouw, 12 Jaarg., Nr. 6, pp. 283-284, September 1, 1933; Nr. 8, p. 285, November 1, 1933.

Dorf Erling.

1069. Flora from the Idaho beds [abstract] : Geol. Soc. America Proc., 1935., p. 382, June 1936.

1070. Contributions to palaeontology; 2, A late Tertiary flora from southwestern Idaho: Carnegie Inst. Washington Pub. 476, pp. 73-124, 3 pls. 2 figs. (incl. geol. map), preprint, November 20, 1936.

Dorisy, C. E. See Anonymous, 4667. 
Dott, Robert Henry.

1071. (and Swindell, Floyd). Fitts pool is most important Oklahoma discovery in six years: Oil Weekly, vol. 76 , no. 10, pp. 16-17, 51-54, 2 figs. (maps), February 18, 1935.

1072. Structural history of the Arbuckle Mountains, Okla., in Pennsylvanian: time [abstract, with discussion] : 16th Internat. Geol. Cong. (1933) Rept., vol. 2, p. 997, 1936.

Dougherty; Ellsworth $\mathbf{Y}$.

1073. Mining geology of the Vipond gold mine, Porcupine district, Ontario: Canadian Inst. Min. Metallurgy Trans., vol. 37, pp. 260-284, 7 figs.. (incl. maps) [1935].

1074. Geologic problems of the Canadian pre-Cambrian gold fields: Econ. Geology, vol. 30, no. 8, pp. 879-889, December 1935.

Douglas, George Vibert.

1075. (and Sheppard, E. P.). Further notes concerning ore shoots: Canadian Inst. Min. Metallurgy Trans., vol. 38, pp. 217-221; discussion, pp. 389-390, 6 figs., 1935.

1076. (and Howse, Claude K.). Concerning ore shoots: Canadian Inst. Min. Metallurgy Trans., vol. 37, pp. 392-397; discussion, pp. 513515, 7 figs. [1935].

Douglas, John Gray. See Prouty, 3141.

Douville, Henri.

1077. Notice sur Henry Fairfield Osborn: Acad. sci. Paris Comptes rendus, tome 201, no. 23, pp. 1074-1076, December 2, 1935.

Dow, Richard B. See Birch, 324.

Drane, Brent Skinner.

1078. Surface and ground-water planning: Assoc. Am. State Geologists Jour., vol. 7, no. 2, pp. 32-37 ( $\$$ ), April 1, 1936.

Dresser, John Alexander.

1079. Abitibi : Canadian Min. Jour., vol. 57, no. 10, pp. 463-466, index map, October 1936.

Drew, William B. See Boyd, 409.

Dreyer, F. E.

1080. Geology of a portion of the Mount Pinos quadrangle [Calif.] [abstract] : Pan-Am. Geologist, vol. 64, no. 1, pp. 74-75, August 1935; Geol. Soc. America Proc., 1935, p. 351, June 1936.

Dreyer, R. M. See Behre, 256.

Drindak, Joseph J.

1081. Insoluble residues from Wisconsin sedimentary rocks; pt. 2, Studies. of Wisconsin sedimentary rocks, no. 2, The insoluble residues of the Oneota dolomite of western Wisconsin: Wisconsin Acad. Sci. Trans., vol. 29, pp. 262-266, 1 fig., 1935.

Drosdoff, Matthew.

1082. (and Truog, Emil). A method for removing iron oxide coatings from minerals: Am. Mineralogist, vol. 20, no. 9, pp. 669-673, September 1935. 
Dryden, Abraham Lincoln, Jr.

1083. A statistical method for the comparison of heavy-mineral suites: Am. Jour. Sci., 5th ser., vol. 29, no. 173, pp. 393-408, May 1935.

1084. Structure of the Coastal Plain of southern Maryland: Am. Jour. Sci., 5th ser., vol. 30 , no. 178, pp. 321-342, 6 figs. (incl. maps), October 1935.

\section{Dudley, Paul H.}

1085. Geology of a portion of the Perris block, southern California: California Jour. Mines and Geology, vol. 31, no. 4, pp. 487-506, 1 pl. (geol. map), 10 figs. (incl. index map), October 1935.

1086. Physiographic history of a portion of the Perris block, southern California: Jour. Geology, vol. 44, no. 3, pp. 358-378, 9 figs. (incl. geol. and index maps), April-May 1936.

Duelo, L. Trelles.

1087. Restos fosilizados de un manati extinguido del periodo oligoceno inferior: Soc. cubana hist. nat. Mem., vol. 9, no. 4, pp. 269-270, January 1936.

Dufresne, A. O.

1088. Annual report of the Quebec Bureau of Mines for the calendar year 1934, pt. A, Mining operations and statistics, 202 pp., 9 pls., 1935; also in French as Rapport ann. Service des mines de Québec pour l'année 1.934, Pt. A, Industrie minière et statistiques, .217 pp., 9 pls., 6 figs., 1935.

Duling, John F.

1089. Geophysics as an aid in gold placer drift mining: Min. Jour., vol. 18, no. 21, pp. 5-6, 6 figs., March 30, 1935.

Dunbar, Carl Owen. See also Longwell, 2444.

1090. Fusulines as an aid in Permian and Pennsylvanian correlations [abstract] : 16th Internat. Geol. Cong. (1933) Rept., vol. 2, p. 1106 1936.

1091. (and Skinner, John W., and King, Robert Evans). Dimorphism in Permian fusulines: Texas Univ. Bull. 3501, January 1, 1935, pp. 173-190, 3 pls., 1 fig. February 1936; abstract, Geol. Soc. American Proc. 1934, p. 368, June 1935.

1092. (and Skinner, John W.). Schwagerina versus Pseudoschwagerina and Paraschwagerina: Jour. Paleontology, vol 10, no. 2, pp. 83-91, 2 pls., March 1936.

1093. [Review of] Tertiary faunas, a text-book for oil field paleontologists and students of geology ; vol. 1, The composition of Tertiary faunas, by A. Morley Davies, 1935: Am. Jour. Sci., 5th ser., vol. 31, no. 185, p. 396, May 1936.

Dunham, Kingsley Charles.

1094. The geology of the Organ Mountains, with an account of the geology and mineral resources of Doña Ana County, N. Mex.: New Mexico School of Mines Bull. 11, 272 pp., 17 pls. (incl. geol. maps), 21 figs. (incl. geol. maps), 1935.

1095. Crystal cavities in lavas from the Hawaiian Islañds: Am. Mineralogist, vol. 20, no. 12, pp. 880-882, December 1935.

1096. Xenoliths in the Organ batholith, N. Mex.; with A morphological description of diopside crystals by M. A. Peacock: Am. Mineralogist, vol. 21, no. 5, pp. 312-320, 4 figs. (incl. geol. map), May 1936.

Dunn, Paul Heaney. See Howell, 1852. 
Durward, Robert.

1097. (and Willson, Kenneth). Melvin J. Collins [1897-1936] : Am. Assoc. Petroleum Geologists Bull., vol. 20, no. 6, pp. 841-842, 1 fig. (port.), June 1936.

Tustin, Fred.

1098. A study of the Bayport chert: Michigan Acad. Sci. Papers, vol. 20, pp. $465-475,1935$.

1099. The gems of Isle Royale, Mich.; the chlorastrolite: Mineralogist, vol. 3, no. 2, pp. 5-6, 31, February 1935.

1100. Agates of the Lake Superior region: Rocks and Minerals, vol. 11, no. 9, pp. 152-155, September-October 1936.

Dutton, Carl Evans.' See also Thiel, 4068.

1101. (and Schwartz, George Melvin). Notes on the jointing of the Devil's tower, Wyo.: Jour. Geology, vol. 44, no. 6, pp. 717-728, 5 figs., August-September 1936.

Dyk, H. See Heck, 1678.

Dyk, Karl.

1102. On the reduction of seismograms obtained in shaking-table experiments :

Seismol. Soc. America Bull., vol. 25, no. 2, pp. 119-137, 3 pls., 4 figs., April 1935.

1103. The California earthquake of April 15, 1928: Seismol. Soc. America Bull., vol. 26, no. 3, pp. 239-244, 1, fig. (index map), July 1936.

Eakin, Henry Miner, 1883-1936.

1104. The twin problem of erosion and flood control: Am. Geophy's. Union Trans. 17th Ann. Meeting, pt. 2, pp. 436-439 (\$), Nat. Research Council, 1936.

1105. Instructions for reservoir sedimentation surveys; revised January 1, 1936, by G. C. Dobson and Carl B. Brown: U. S. Soil Cons. Service S. S. 2, 36 pp. ( $\ddagger), 1$ pl., January 1, 1936.

1106. Silting of reservoirs: U. S. Dept. Agri. Tech. Bull. 524, 141 pp., 29 pls. (incl. maps), 13 figs., July 1936.

Eardley, Armand John. See also U. S. G. S., 4228, 4230, 4234.

1107. (and Haas, Merrill). Oil and gas possibilities in the Great Salt Lake Basin: Utah Acad. Sci. Proc., vol. 13, pp. 61-80, 6 figs. (incl. geol. maps), 1936.

1108. Late geologic history of the lower Yukon Valley [abstract] : Geol. Soc. America Proc., 1935, p. 74, June 1936.

Eargle, Dolan Hoye.

1109. Advance report on the sedimentation survey of Lake Harris, Tuscaloosa, Ala., October 30-November 6, 1935: U. S. Soil Cons. Service S. S. 4, 7 pp. ( $\$), 1$ pl. (map), May 15, 1936.

1110. Advance report on the sedimentation survey of Lake Purdy, Birmingham, Ala., November 6-28, 1935: U. S. Soil Cons. Service S. S. 5, 11 pp. (\$), 1 pl. (map), July 1936.

Easton, Harry Drapex.

1111. North Louisiana surface structure evidence is small: Oil Weekly, vol. 77, no. 2, pp. 35-38, 2 figs. (geol. maps), March 25, 1935.

1112. Volcanoes of northeastern Louisiana account for accumulation of oil: Oil and Gas Jour., vol. 33, no. 45, pp. 28, 30, 43, 2 figs. (incl. geol. map), March 28, 1935. 
Easton, Harry Draper-Continued.

1113. Rodessa indicates low Cretaceous shore line possibilities in Arkansas: Oil Weekly, vol. 80, no. 12, pp. 19-22, 3 figs. (incl. maps), March $2,1936$.

Easton, Harry Draper, Jr. See also Stamey, 3817.

1114. Four Permian producing areas now indicated by Snow Hill discovery: Oil and Gas Jour., vol. 35, no. 7, pp. 12-14, 3 figs. (incl. geol. map), July 2, 1936.

1115. Economic importance of the Sabine uplift, an outline: Oil and Gas Jour., vol. 35 , no. 28 , pp. $22-24,34,1$ pl. (index map), 2 figs., November 26, 1936.

Eaton, Joseph Edmund.

1116. California oil reserves: Oil Weekly, vol. 78, no. 3, pp. 23-26, 27, 2 figs., July 1, 1935 ; no. 4, pp. 31-32, 34-36, 38, 4 figs., July 8, 1935.

Eavenson, Howard Nichols.

1117. Mineral fuels and civilization: Mining and Metallurgy, vol. 16, no. 340, pp. 173-176, 2 figs., April 1935; abstract, Year Book sec., p. 47, January 1936.

Ebaugh, William Clarence. See Wright, 4624.

Ebbutt, Frank.

1118. Relationship of structure to ore deposition at the Brittania mines [British Columbia]: Canadian Inst. Min. Metallurgy Trans., vol. 38, pp. 123-133, 12 figs., 1935.

Ebert, Fred C.

1119. Symposium on fluctuations of ground water; An interpretation of water-table fluctuations at four wells in southern California: Am. Geophys. Union Trans. 17th Ann. Meeting, pt. 2, pp. 371-378 ( $\$$ ), 5 figs., Nat. Research Council, 1936.

Eby, James Brian. See also Barret, 194.

1120. (and Clark, Robert P.). Relation of geophysics to salt-dome structure: Am. Assoc. Petroleum Geologists Bull., vol. 19, no. 3, pp. 356-377, 18 figs., March 1935, reprinted in Gulf coast oil fields (see Barton and Sawtelle), pp. 170-191, 1936.

1121. Relation of geophysics to Gulf coast domes and oil fields [abstract] : Geol. Soc. America Proc., 1934, pp. 443-444, June 1935.

1122. The geophysics of the Tomball oil field, Harris County, Tex. [with discussion by Lewis Winslow MacNaughton]: Geophysics, vol. 1, no. 1, pp. 149-158, 5 figs., January 1936; abstract, World Petroleum, vol. 7, no. 9, p. 442, September 1936.

Eby, J. H.

1123. The importance of outcrops to the prospector and miner: Mining Jour., vol. 20, no. 11, pp. 5-7, 36-37, Phoenix, Ariz., October 30, 1936.

Eckel, Edwin Butt. See also U. S. G. S., 4229.

1124. (and Purcell, Paul Edward Murphy). Geology of Texas, vol. 2, pt. 3, Economic geology (exclusive of petroleum) ; The iron ores of east Texas: Texas Univ. Bull. 3401, pp. 482-503, 3 figs. (incl. geol. map), December 1935 .

1125. Resurvey of the geology and ore deposits of the La Plata mining district, Colo.: Colorado Sci. Soc. Proc., vol. 13, no. 9, pp. 508-547, 2 pls. (incl. geol. map), 1 fig. (index map), 1936. 
Eckel, Edwin Butt-Continued.

1126. Progress report on the study of the iron-ore deposits of northeast Texas: Texas Univ. Bur. Econ. Geology Min. Res. Circ. 8, 3 pp. (†), February 1936 .

Eckel; Edwin Clarence.

1127. Preliminary report on the mineral development of Puerto Rico: Revista de obras públicas de Puerto Rico, Año 12, no. 4, pp. 895, 898-900, April 1935.

1128. Geological work of the Tennessee Valley Authority: Tennessee Valley Authority, Div. Geology Bull. 3, 1933-35, 20 pp. ( $\ddagger)$, December 1935 ; abstract, Geol. Soc. America Proc., 1935, p. 75, June 1936.

1129. (and Kelly, Junea W.). Extent and limits of glacial migration in eastern America [abstract, with discussion]: 16th Internat. Geol. Cong. (1933) Rept., rol. 2, pp. 813-814, 1936.

1130. Clay resources of Tennessee Valley Authority region, pt. 1; Origin, distribution, and production of clay in T. V. A. region: Tennessee Valley Authority, Div. Geology Bull. 4, pp. 1-9 ( $)$, October 1936.

Eckis, Rollin. See also Gross, 1552.

1131. South Coastal-basin investigation; Geology and ground-water storage capacity of valley fill: California Dept. Public Works, Water Res. Div. Bull. 45, 279 pp., 14 pls. (incl. geol. maps), 22 figs., 1934.

1132. Late Quaternic geology of Los Angeles Basin area [abstract]: PanAm. Geologist, vol. 64, no. 1, p. 74, August 1935 ; Geol. Soc. America Proc., 1935, p. 350, June 1936.

Eddy, G. E.

1133. Geology of Crystal field [Michigan] shows importance of folding in oil accumulation: Oil and Gas Jour., vol. 35 , no. 16 , pp. $32,35,38,3$ figs. (incl. contour map), September 3, 1936.

Eddy, Samuel.

1134. (and Jenks, Albert Ernest). A kitchen midden with bones of extinct animals in the upper Lakes area: Science, new ser., vol. 81, no. 2109, p. 533, May 31, 1935.

Edelshtein, Ya. S.

1135. William Morris Davis [1850-1934]: Problemi Physiocheskoi Geographii (Akad. Nauk, U. S. S. R.), II, pp. 43-52, 1935. (In Russian.)

Edmunson, Raymond S.

1136. Barite deposits of Virginia: Am. Inst. Min. Met. Eng. Tech. Pub. 725, 17 pp., 10 figs. (incl. geol. sketch map), 1936.

1137. Phosılhatic concretions near Junction City, Ky.; Am. Mineralogist, vol. 21, no. 8, pp. 529-531, 2 figs., August 1936.

Edson, Fanny Carter. See also Kans. Geol. Soc., 2020.

1138. The "Sooy" conglomerate of Kansas [abstract, with discussion] : Tulsa Geol. Soc. Digest, 1934, pp. 30-32.

1139. Résumé of St. Peter stratigraphy: Am. Assoc. Petroleum Geologists Bull., vol. 19, no. 8, pp. 1110-1130, 8 figs. (correlation tables), August 1985; abstract, Geol. Soc. America Proc., 1934, p. 75, June 1035.

Edwards, Ira. See also Kansas Geol. Soc., 2020.

1140. Isopach maps of the Trempealeau, Franconia, and Dresbach formations [upper Mississippi Valley] : Kansas Geol. Soc. Guidebook 9th Ann. Field Conf., 2 pls. (isopach maps), opp. p. $352(\ddagger), 1935$.

Edwards, Patricia G. See Cushman, 942. 
Effinger, William Lloyd.

1141. Outline of the geology and paleontology of Scotts Bluff National Monument and the adjacent region. 37 pp. ( $¥), 4$ pls., Berkeley, Calif., Nat. Park Service, Field Div. Education, 1934.

1142. A report on the geology of Devils Tower National Monument. $14 \mathrm{pp}$. $(\ddagger), 4$ pls., Berkeley, Calif., Nat. Park Service, Field Div. Education, 1934.

1143. A report on the geology of Rocky Mountain National Park, $28 \mathrm{pp.} \mathrm{(} \ddagger$ ), 3 pls., Berkeley, Calif., Nat. Park Service, Field Div. Education, 1934.

1144. The geology of the southwestern United States. 52 pp. ( $\$)$, Berkeley, Calif., Nat. Park Service, Field Div. Education, 1935.

1145. Gries Ranch horizon; division of Tertic of Washington [abstract] : Pan-Am. Geologist, vol. 63, no. 5, pp. 372-373, June 1935; Geol. Soc. America Proc., 1935, p. 411, June 1936.

1146. Gavióta formation of Santa Barbara County [Calif.] [abstract] : PanAm. Geologist, vol. 64, no. 1, pp. 75-76, August 1935; Geol. Soc. America Proc., 1935, pp. 351-352, June 1936.

Ehlers, George Marion.

1147. A new eurypterid from the Upper Devonian of Pennsylvania : Michigan Univ. Mus. Paleontology Contr., vol. 4, no. 18, pp. 291-295, i pl., February 20, 1935 ; abstract, Geol. Soc. America Proc., 1934, p. 362, June 1935.

Ehrenburg, David Otto.

1148. (and Watson, R. J.). Mathematical theory of electrical flow in stratifled media with horizontal, homogeneous and isotropic layers [with discussion] ; Am. Inst. Min. Met. Eng. Trans., vol. 97, Geophysical Prospecting, pp. 423-442, 6 figs., 1932.

Ehrenfeld, Frederick.

1149. Factors in the determination of Pleistocene sedimentation in the Philadelphia area [abstract]: Geol. Soc. America Proc., 1934, p. 444, June 1985.

Eickelberg, E. W.

1150. Progress report in seismology for the United States Coast and Geodetic Survey: Am. Geophys. Union Trans. 17th Ann. Meeting, pt. 1, pp. 77-80 ( $¥), 1$ fig. (index map), Nat. Research Council, July 1936; Earthquake Notes, vol. 8, nos. 1-2, pp. 77-80 ( $)$, June 1936.

1151. Review of earthquakes for the past year [April 1935-March 1936] : Am. Geophys. Union Trans. 17th Ann. Meeting, pt. 1, pp. 93-95 ( $)$, 1 fig. (distribution map), Nat. Research Council, July 1936; Earthquake Notes, vol. 8, nos. 1-2, pp. 93-95 ( $¥), 1$ fig., June 1936.

Eisenhart, Churchill.

1152. A note on "A statistical method for the comparison of heavy mineral suites": Am. Jour. Sci., 5th ser., vol. 30, no. 180, pp. 549-553, December 1935.

1153. A test for the significance of lithological variations: Jour. Sedimentary Petrology, vol. 5, no. 3, pp. 137-145, December 1935.

Ekblaw, George Elbert.

1154. (and Grim, Ralph Early). Some geological relations between the constitution of soil materials and highway construction: Illinois Geol. Survey Rept. Investigations 42, 16 pp., 4 figs. (incl. geol. maps), 1936. 
Elias, Maxim Konrad. See also Kansas Geol. Soc., 2022; Moore, 2786, 2788, 2790.

1155. Tertiary grasses and other prairie vegetation from High Plains of North America: Am. Jour. Sci., 5th ser., vol. 29, no. 169, pp. 24-33, 5 figs., January 1935.

1156. Late Paleozoic plants of Kansas as time indicators [abstract]: Geol. Soc. America Proc., 1934, p. 370, June 1935.

1157. Correlation of upper Carboniferous and Artinskian in Russia with American late Paleozoic rocks [abstract]: Geol. Soc. America Proc., 1934, pp. 370-371, June 1935.

1158. Late Paleozoic plants of the Midcontinent region as indicators of timeand of environment [with discussion] : 16th Internat. Geol. Cong. (1933) Rept., vol. 1, pp. 691-700, chart, 1936.

1159. Depth of deposition of the Big Blue sediments [abstract] : Geol. Soc.. America Proc., 1935, p. 375, June 1936.

Eliel, Leon $\mathbf{T}$.

1160. Aerial reconnaissance and contour mapping in mining: Am. Inst. Min. Met. Eng. Tech. Pub. 756, pp. 4-20, discussion, pp. 26-27, 10 figs., 1936 ; abstract, Mining and Metallurgy, vol. 17; no. 359, p. 547, November 1936.

Eller, Eugene Rudolph.

1161. Annelid jaws from the Hamilton group of Ontario County, N. Y.: Carnegie Mus. Annals, vol. 24, serial no. 164, December 1934. August 1935, art. 2, pp. 51-56, 1 pl., December 3, 1934.

1162. Remarkable assemblage of Paleozoic sponges: Pan-Am. Geologist, vol. 63, no. 3, pp. 203-206, 1 pl., April 1935; abstract, Geol. Soc. America Proc., 1934, pp. 364, 445, June 1935.

1163. New species of Echinocaris from the Upper Devonian of Alfred Station, N. Y.: Carnegie Mus. Annals, vol. 24, serial no. 164, December 1934-August 1935, art. 8, pp. 263-274, 1 pl., May 29, 1935.

1164. Scolecodonts, trails and burrows [abstract]: Geol. Soc. America Proc., 1934, pp. 364-365, June 1935.

1165. Upper Devonian sponges [New York and Pennsylvania] : Science, new ser., vol. 84 , no. 2167 , p. 41, July 10, 1936.

Ellermeier, G. B.

1166. Some New Mexico agates: Rocks and Minerals, vol. 11, no. 9, p. 167, September-October 1936.

1167. Sweetwater River [WJoming] moss agates: Rocks and Minerals, vol. 11, no. 9, pp. 172-173, September-October 1936.

Ellestad, Reuben B. See Graham, 1492.

Ellis, Brooks Fleming.

1168. Illustrated catalogue of Foraminifera [abstract]: Geol. Soc. America Proc., 1934, p. 369, June 1935.

1169. The master key to oil: Nat. History, vol. 38, no. 5, pp. 369-373, 442, illus., December 1936.

Ellis, Robert Walpole.

1170. Glaciation in New Mexico: New Mexico Univ. Bull., Geol. ser., rol. 5, no. 1, 31 pp., 4 pls. (incl. geol. map), November 15, 1935. 
Ellisor, Alva Christine.

1171. Jackson group of formations in Texas, with notes on Frio and Vicksburg: Am. Assoc. Petroleum Geologists Bull., vol. 17, no. 11, pp. 1293-1350, 8 figs., 6 pls., November 1933; reprinted in Gulf coast oil fields (see Barton and Sawtelle), pp. 470-527, 1936.

1172. "Potamides matsoni" zone of Texas (Burkville beds): Am. Assoc. Petroleum Geologists Bull., vol. 20, no. 4, pp. 494-495, April 1936.

1173. [Review of] Tertiary faunas, vol. 1, The composition of Tertiary faunas by A. M. Davies, 1935 : Am. Assoc. Petroleum Geologists Bull., vol. 20, no. 4, p. 505, April 1936.

Fllsworth, Elmer William. See Blackwelder, 337.

Emery, Wilson Barton.

1174. Gas fields of Big Horn Basin structural province, Wyoming and Montana: Geology of natural gas, pp. 277-296, 1 fig. (map), Am. Assoc. Petroleum Geologists, [June] 1935.

Emigh, G. D.

1175. An improved Vanderwilt rock saw: Am. Mineralogist, vol. 21, no. 10, pp. 670-675, 2 figs., October 1936.

Emmons, William Harvey.

1176. On the origin of certain systems of ore-bearing fractures [with discussion] : Am. Inst. Min. Met. Eng. Trans., vol. 115 (Mining geology), pp. 9-35, 13 figs., 1935 ; abstract, Year Book Section, p. 83, January 1935.

1177. Memorial of Warren Upham [1850-1934] : Geol. Soc. America Proc., 1934, pp. 281-294, port., June 1935.

1178. (and Grout, Frank Fitch). Granitic stocks and related auriferous veins near Goudreau, Ontario: Geol. Soc. America Bull., vol. 46, no. 10, pp. 1457-1466, 4 figs. (incl. maps), October 31, 1935.

1179. Hypogene zoning in metalliferous lodes: 16th Internat. Geol, Cong. (1933) Rpt., vol. 1, pp. 417-432, 7 figs. (incl. geol. sketch maps), 1936.

Enck, Ernest G. See Chambers, 724.

Engel, Rene.

1180. Geochemical relations between waters in the Elsinore region [abstract] : Geol. Soc. America Proc., 1934, p. 321, June 1935.

Engeln, Oscar Diedrich, von. See also Flint, 1284.

1181. The motion of glaciers: Science, new ser., vol. 81 , no. 2106 , pp. $459-461$, May 10, 1935.

1182. Flood erosion [abstract] : Geol. Soc. America Proc., 1935, p. 115, June 1936.

1183. Early observation and attempted explanation of the glacial drift: Science, new ser., vol. 84, no. 2171, August 7, 1936.

Engels, William L.

1184. Status of Toxostoma redivivum in the Rancho La Brea fauna: Condor, vol. 37, no. 5, p. 258, September-October 1935.

Erdmann, Charles Edgar. See also Bartram, 216.

1185. The Book Cliffs coal field in Garfield and Mesa Counties, Colorado: U. S. Geol. Survey Bull. 851, 150 pp., 7 figs. (incl. maps), 21 pls. (incl. geol. map), 1934. 
Erdmann, Charles Edgar-Continued.

1186. (and Larsen, Raymond M.). Geologic and structure map of the northern half of the Cedar Creek anticline, Dawson, Prairie, Wibaux and Fallon Counties, Mont., U. S. Geol. Survey, 1934. Accompanied by U. S. Dept. Interior Press Mem. 94227, 2 pp., February 1, 1935.

Erwin, Homer D.

1187. Phenoclast, new petrographic term: Pan-Am. Geologist, vol. 63, no. 1, pp. 31-32, February 1935.

1188. Retroactive movement along faults: Econ. Geology, vol. 31, no. 6, pp. 639-641, September-October 1936.

Evans, Gaynor. See Gregory, 1528.

Evans, Oren Frank.

1189. Bathymetric studies of the Lake Michigan Basin: Geog. Rev., vol. 25, no. 4, pp. 667-670, 2 figs. (incl. index map), October 1935; abstract, Oklahoma Acad. Sci. Proc., 1934, vol. 15, pp. 80-81, 1935.

1190. Mineral provinces of Oklahoma: Rocks and Minerals, vol. 11, no. 6, pp. 86-88, June 1936.

Evans, Richard X.

1191. Dr. John Evans [1812-1861], U. S. geologist, 1851-1861: Washington Univ. [Seattle] Hist. Quart., vol. 26, no. 2, pp. 83-89, April 1935.

Evans, Robley D.

1192. (and Williams, Howel). The radium content of lavas from Lassen Volcanic National Park, Calif.: Am. Jour. Sci., 5th ser., vol. 29, no. 173, pp. 441-452, 1 fig., May 1935.

1193. The age of the earth from radioactive disintegration and related problems [abstract] : Science, new ser., vol. 82, no. 2116, p. 52, July 19, 1935.

1194. (and Raitt, Russell W.). The radioactivity of the earth's crust and its influence on cosmic-ray electroscope observations made near ground level: Physical Rev., 2d ser., vol. 48, no. 3, pp. 171-176, 2 figs., August 1, 1935.

Ewing, Maurice.

1195. (and Crary, Albert Paddock, and Lohse, J. M.). Seismological observations on quarry blasting: Am. Geophys. Union Trans. 15th Ann. Meeting, pt. 1, pp. 91-94 ( $\ddagger$ ), 3 figs. (incl. index map), National Research Council, June 1934.

1196. (and Crary, Albert Paddock). Propagation of elastic waves in limestone: Am. Geophys. Union Trans. 16th Ann. Meeting, pt. 1, pp. 100-103 (†), 4 figs. (incl. index map), Nat. Research Council, August 1935 .

1197. (and Crary, Albert Paddock, Peoples, Joe Webb, and Peoples, James A., Jr.). Prospecting for anthracite by the earth-resistivity method: Am. Inst. Min. Met. Eng. Tech. Pub. 683, 36 pp., 19 figs. (incl. index map), 1936 ; with discussion, Trans., Coal Div., vol. 119 , pp. 443-483, 23 figs., 1936.

1198. (and Crary, Albert Paddock, and Rutherford, Homer Morgan). Geophysical investigations in the emerged and submerged Atlantic Coastal Plain; pt. 1, Methods and results [abstract]: Geol. Soc. America Proc., 1985, p. 75, June 1936. 
Ewing, Maurice-Continued.

1199. (and Pentz, H. H.). Magnetic survey in the Lehigh Valley: Am. Geophys. Union Trans. 17th Ann. Meeting, pt. 1, pp. 186-191 ( $)$, 4 figs. (incl. geol. maps), Nat. Research Council, July 1936.

1200. (and Crary, Albert Paddock). Study of emergence angle and propagation paths of seismic waves [abstract] : Mines Mag., vol. 26, no. 12, p. 27, December 1936.

Exworthy, Alice.

1201. Enormous salt deposits in Michigan: Mineralogist, vol. 3, no. 4, p. 22, April 1935.

Fabiani, Ramiro.

1202. (and Stefanini, Giuseppe). La partecipazione dell' Italia alla XVI sessione del Congresso Geologico Internazionale: La Ricerca Scientifica ([Italy] Consiglo nazionale delle Ricerche), Anno 6, vol. 1, no. 2, pp. 109-122, January 31, 1935-XIII.

Faessler, Carl.

1203. Geological exploration of the north shore [of the St. Lawrence], Manigouagan to Godbout: Quebec Bur. Mines Ann. Rept., 1933, pt. D, pp. 149-166, 3 pls. (incl. geol. map), 1 fig. (sketch map), 1934.

1204. Geological exploration along the Laflamme River, Abitibi County: Quebec Bur. Mines Ann. Rept., 1934, pt. C, pp. 35-44, 1 pl. (geol. map), 1935; also in French ed., 1935.

Fairbairn, Harold William. See also Clark, 766.

1205. Introduction to petrofabric analysis. $142 \mathrm{pp}$. ( $\ddagger), 47$ figs., Kingston, Canada, Queen's University, Dept. Geology, 1935.

1206. Structural petrology of the Claire River syncline, Tweed, Ontario: Royal Soc. Canada Trans., 3d ser., vol. 29, sec. 4, pp. 21-25, 2 figs. (incl. geol. map), May 1935.

1207. Petrofabric analysis and some possible applications: Canadian Min. Jour., vol. 56, no. 7, pp. 263-267, 2 figs., July 1935.

1208. Notes on the mechanics of rock foliation: Jour. Geology, vol. 43, no. 6, pp. 591-608, 4 figs., August-September 1935.

1209. Elongation in deformed rocks: Jour. Geology, vol. 44, no. 6, pp. 670-680, 4 figs., August-September 1936; abstract, Geol. Soc. America Proc., 1935 , p. 76, June 1936.

Fairbanks, H. R.

1210. Geologists, their distribution and background: Geol. Soc. America Proc., 1935, pp. 443-468, 13 figs., abstract, p. 76, June 1936.

Fairchild, Herman Leroy.

1211. Genesee Valley hydrography and drainage: Rochester Acad. Sci. Proc., vol. 7, no. 6, pp. 157-188, 11 figs. (incl. maps), March 1935.

1212. The Genesee River [abstract] : Geol. Soc. America Proc. 1934, p. 75, June 1935.

1213. Cause and result of Pleistocene glaciation [abstract] : Geol. Soc. America Proc., 1934, pp. 75-76, June 1935.

Fancher, George Homer.

1214. (and Lewis, James A., and Barnes, Kenneth Boyd). Physical tests and properties of oil and gas sands: World. Petroleum Cong. (London. 1933) Proc., vol. 1, pp. 322-333, 4 figs., 1934. 
Fanning, Leonard M. See Goodrich, 1474 .

Farish, Linn C. See Snider, 3781.

Farrar, Willard.

1215. (and Grenfell, Donald S., and Allen, Victor Thomas). The geology and bleaching clays of southeast Missouri: Missouri Geol. Survey 5Sth Bienn. Rept., appendix 1, 78 pp., 6 figs., 7 pls. (incl. geol. map), 1935.

Faull, Anna F. See Bailey, 129.

Faust, George $\mathbf{T}$.

1216. The fusion relations of iron orthoclase, with a discussion of the evidence for the existence of an iron-orthoclase molecule in feldspar: Am. Mineralogist, vol. 21, no. 12, pt. 1, pp. 735-763, 7 figs., December 1936.

Faust, Lawrence Yoder. See Weatherby, 4366.

Faux, F. R.

1217. Aragonite at Allentown, Pa. : Rocks and Minerals, vol. 10, no. 11, p. 174, November 1935 .

Feinstein, Herman. See Lavine, 2353.

Felts, Wayne M. See Hodge, 1765.

1218. Analysis of Willamette Valley fill [Oregon] [abstract] : Pan-Am. Geologist, rol. 64, no. 1, p. 69, August 1935; Geol. Soc. Oregon Country News Letter, vol. 2, no. 12, p. 6 ( $\$)$, June 25, 1936; Geol, Soc. America Proc., 1935, p. 346, June 1936.

Fenneman, Nevin $\mathbf{M}$.

1219. Cyclic and noncyclic aspects of erosion: Science, new ser., vol. 83, no. 2144, pp. 87-94, January 31, 1936 ; Geol. Soc. America Bull., vol. 47, no. 2, pp. 173-185, February 29, 1936.

Fenner, Clarence Norman.

1220. Extraordinary contact effects of rhyolite upon basalt [abstract, with discussion] : Geol. Soc. America Proc., 1934, pp. 76-77, June 1935.

1221. Life history of the Sudbury nickel irruptive: Geol. Mag., no. 854 (vol. 72, no. 8), pp. 381-382, August 1935.

1222. [Review of] Origin of the copper deposits of the Ducktown type in the southern Appalachian region, by Clarence S. Ross, 1935: Econ. Geology, vol. 30, no. 8, pp. 928-936, December 1935.

1223. Bore-hole investigations in Yellowstone Park: Jour. Geology, vol. 44, no. 2, pt. 2, pp. 225-315, 15 figs., February-March 1936; also issued as Carnegie Inst. Washington, Geophysical Lab., Paper 895 [1936].

Fenton, Carroll Lane.

1224. (and Fenton, Mildred Adams). Lumbricaria; a holothuroid casting?: Pan-Am. Geologist, vol. 61, no. 4, pp. 291-292, 1 pl., 1 fig., May 1934.

1225. Along the hill. 96 pp., illus.; New York, Reynal \& Hitchcock [1935].

12:26. Athyris and Cyrtina of Cedar Valley age: Am. Midland Naturalist, vol. 16, no. 1, pp. 114-116, 11 figs., January 1935.

1227. Viewpoint and objects of paleoecology: Jour. Paleontology, vol. 9, no. 1, pp. 63-78, January 1935.

1228. The mountains of Glacier Park: Nat. History, pol. 35, no. 3, pp. 213-220, 12 figs., March 1935. 
Fenton, Carroll Lane-Continued.

1229. Factors of evolution in fossil series: Am. Naturalist, vol. 19, no. 721, pp. 139-173, 22 figs., March-April 1935.

1230. (and Fenton, Mildred Adams). Glacier Park facies of the Belt series [abstract] : Geol. Soc. America Proc., 1934,.p. 77, June 1935.

1231. (and Fenton, Mildred Adams). "Tabulate" corals of Hall's "Illustrations of Devonian fossils" [abstract]: Geol. Soc. America Proc., 1934, p. 360, June 1935.

1232. (and Fenton, Mildred Adams). Atrypae described by Clement L. Webster and related forms (Devonian, Iowa) : Jour. Paleontology, vol. 9, no. 5, pp. 369-384, 1 fig., 7 pls., July 1935.

1233. (and Fenton, Mildred Adams). Walcott's "Pre-Cambrian Algonkian algal flora" and associated animals: Geol. Soc. America Bull., vol. 47, no. 4, pp. 609-620, 3 pls., 1 fig., April 30, 1936; abstract, Proc., 1934, p. 350, June 1935.

Fenton, Mildred Adams. See also Fenton, C. L., 1224, 1230, 1231, 1232, 1233.

1234. Nitrocellulose sections of fossils and rocks : Am. Midland Naturalist, vol. 16, no. 3, pp. $410-412$, 1 fig., May 1935 .

Fergus, Preston.

1235. Monroe gas field, Lonisiana: Geology of natural gas, pp. 741-772, 12 figs. (incl. maps), Am. Assoc. Petroleum Geologists [June] 1935.

Ferguson, Henry Gardiner. See also Muller, 2824.

1236. (and Muller, Siemon William). Jurassic thrust faults in west-central Nevada [abstract]: Washington Acad. Sci. Jour., vol. 26, no. 9, p. 394, September 15, 1936.

Ferguson, William Boyd.

1237. (and Minton, Joseph W.) Clay Creek salt dome, Washington, County, Tex.: Am. Assoc. Petroleum Geologists Bull., vol. 20, no. 1, pp. 68-90, 9 figs. (incl. geol. and sketch maps), January 1936; abstract, World Petroleum, vol. 7, no. 3, p. 150, March 1936; reprinted in Gulf coast oil fields (see Barton and Sawtelle), pp. 757779, 1936.

Fernquist, Charles 0 .

1238. Tin found near Spokane, Wash.: Mineralogist, vol. 3, no. 7, p. 14, July 1935.

1239. Grand Coulee, Wash. : Mineralogist, vol. 3, no. 12, pp. 5-6, December 1935.

Fettke, Charles Reinhard. See also Ashley, 100.

1240. (and Cathcart, Stanley Holman). Geology and possibility of deep-sand oil and gas production in northwestern Pennsylvania: Pennsylvania State College, Min. Indus. Exper. Sta. Bull. 19, pp. 91-122, 8 figs. (incl. geol. and sketch maps), 1935.

1241. Gas and oil possibilities of Oriskany sandstone, northwest Pennsylvania: Oil and Gas Jour., vol. 33, no. 37, pp. 113-114, 2 figs. (incl. sketch map), January 31, 1935.

1242. Subsurface stratigraphy of northwestern Pennsylvania and a résumé of gas and oil possibilities of deeper sands: Pennsylvania Topog. and Geol. Survey Bull. 114, 23 pp. ( $\ddagger$ ), 2 pls. (incl. geol. map), 2 figs. (incl. map), March 1935. 
Fettke, Charles Reinhard-Continued.

1243. (and Cathcart, Stanley . Holman). Possibility of deep production in northwestern Pennsylvania: Oil and Gas Jour., vol. 33, no. 50, pp. 19-20, 38-39, 4 figs. (incl. geol. map), May 2, 1935; no. 51, pp. 57, 59-61, 4 figs., May 9, 1935.

1244. Subsurface stratigraphy of the northern Appalachian plateau province [abstract] : Geol. Soc. America Proc., 1934, pp. 445-446, June 1935.

Fidlar, Marion M.

1245. Some features of a small cavern at Marengo, Crawford County, Ind.: Indiana Acad. Sci. Proc., vol. 44, pp. 150-160, 4 figs., 1935.

1246. Features of the valley floor of the Wabash River near Vincennes, Ind.: Indiana Acad. Sci. Proc., 1935, vol. 45, pp. 175-182, 1 fig. (geol. map), 1936.

Fiedler, Albert George.

1247. The occurrence of ground water with reference to contamination: Am. Water Works Assoc. Jour., vol. 28, no. 12, pp. 1954-1962, December 1936.

Field, Richard $F$.

1248. Glacial-till borders of Washington [abstract]: Pan-Am. Geologist, vol. 65, no. 3, p. 240, April 1936.

Field, Richard Montgomery.

1249. An outline of the principles of geology (complete). Revised ed. 198 pp., 1 pl., 116 figs., New York, Barnes \& Noble, Inc., 1935.

1250. (and others). Report of special committee on geophysical and geological study of oceanic basins: Am. Geophys. Union Trans. 16th Ann. Meeting., pt. 1, pp. 6-9 ( $\ddagger)$, Nat. Research Council, August 1935.

1251. Role of geophysics in submarine geology [abstract] : Geol. Soc. America Proc., 1935, pp. 76-77, June 1936.

1252. (and others). Report of special committee on geophysical and geological study of oceanic basins: Am. Geophys. Union Trans. 17th Ann. Meeting, pt. 1, pp. 8-9 (\$), Nat. Research Council, July 1936.

1253. Symposium on recent trends in geophysical research; Recent developments in the geophysical study of oceanic basins: Am. Geophys. Union Trans. 17th Ann. Meeting, pt. 1, pp. 20-23 ( $\ddagger$ ), Nat. Research Council, July 1936.

Field, Ross.

1254. Stream-carved slopes and plains in desert mountains: Am. Jour. Sci., 5th ser., vol. 29; no. 172, pp. 313-322, 2 figs., A pril 1935.

Field, William Osgood, Jr. See Cooper, 873.

Fieldner, Arno Carl.

1255. (and others). Carbonizing properties and constitution of Alma bed coal from Spruce River No. 4 mine, Boone County, W. Va.: U. S. Bur. Mines Tech. Paper 562, iv, 41 pp., 25 figs., 1935.

Figgins, Jesse Dade.

1256. New World man: Colorado Mus. Nat. History Proc., vol. 14, no. 1, pp. 1-5, 4 pls., July 22, 1935.

1257. Folsom and Yuma artifacts, pt. 2: Colorado Mus. Nat. History Proc., vol. 14, no. 2, pp. 2-7, 5 pls., October $3,1935$.

Finch, Elmer Harrison.

1258. Vachel Harry McNutt [1888-1936]: Am. Assoc. Petroleum Geologists Bull., vol. 20, no. 6, pp. 842-844, 1 fig. (port.), June 1936. 
Finch, John Wellington.

1259. Sedimentary copper deposits of the Western States: Copper resources of the world, pp. 375-378, Washington, 16th Internat. Geol. Cong., 1935 .

1260. The United States Bureau of Mines: Assoc. Am. State Geologists Jour., vol. 6, no. 3, pp. 4-9 (\$), July 1935.

Finch, Ruy Herbert.

1261. 'Shishaldin volcano: Fifth Pacific Sci. Cong., Canada, 1933, Proc., vol. 3, pp. 2369-2376, 5 figs., 1934.

1262. On the mechanics of nuées ardentes: Jour. Geology, vol. 43, no. 5, pp. 545-550, 4 figs., July-August 1935.

1263. Akutan volcano: Zeitschr. Vulkanologie, Band 16, Heft 3, pp. 155-160, 4 pls., 2 figs. (incl. sketch map), August 1935.

Fink, Donald G.

1264. Methods of electrical prospecting: Elec. Eng., vol. 54, no. 3, pp. 293-296, 3 figs., March 1935.

Fischer, Richard Philip.

1265. Peculiar hydrothermal copper-bearing veins of the northeastern Colorado Plateau: Econ. Geology, vol. 31, no. 6, pp. 571-599, 22 figs. (incl. index map), September-October 1936.

Fish, Charles John.

1266. Marine biology and paleoecology : Jour. Paleontology, vol. 9, no. 1, pp. 92 100, January 1935.

Fishel, Vinton Crews. See Meinzer, 2639.

Fisher, Daniel Jerome.

1267. Crystal classification and symbolism: Am. Mineralogist, vol. 20, no. 4, pp. 292-306, 1 pl., April 1935; abstracts, no. 3, p. 211, March 1935; Geol. Soc. America Proc., 1934, p. 432, June 1935.

1268. Geologic dating of time of coalification: Illinois Acad. Sci. Trans., vol. 28, no. 2 , pp. 179-180, December 1935.

1269. The Book Cliffs coal field in Emery and Grand Counties, Utah: U. S. Geol. Survey Bull. 852, 104 pp., 15 pls. (incl. geol. maps), 2 figs. (incl. index map), 1936.

1270. Carbon ratios north of the Ouachitas: Am. Assoc. Petroleum Geologists Bull., vol. 20, no. 1, pp. 102-105, 1 fig. (map), January 1936.

1271. [Review of] Problems of petroleum geology; a sequel to Structure of typical American oil fields, edited by W. E. Wrather and F. $\mathbf{H}$. Lahee, 1934 : Jour. Geology, vol. 44, no. 5, pp. 647-648, July-August 1936.

1272. [Review of] Petroleum investigation, pt. 2 (U. S. 73d Cong., H. R. Committee on Interstate and Foreign Commerce, Hearings before a subcommittee on H. Res. 441), by David White and others, 1934 : Jour. Geology, vol. 44, no. 6, pp. 760-761, August-September 1936.

Fisher, Lloyd Wellington.

1273. Minerals in the Bates limestone, Lewiston, Maine: Am. Mineralogist, vol. 21, no. 5, pp. 321-326, 1 fig., May 1936; abstract, no. 3, p. 200, March 1936.

1274. New England intercollegiate field trip: Science, new ser., vol. 84, no. 2189, pp. 534-535, December 11, 1936. 
Fisher, Reginald Gilbert.

1275. The relation of North American prehistory to postglacial climatic fluctuations: New Mexico Univ. Bull., Monograph ser., vol. 1, no. 2, 91, x, pp., 32 figs. (incl. maps), Albuquerque, October 1, 1936.

Fitts, John.

1276. Correlations and mountain-making movements in the Ouachita Mountains [abstract] : Tulsa Geol. Soc. Digest, 1934, p. 36.

Fitzhugh, Edward Fuller, Jr.

1277. Treasures in the earth. 130 pp., 16 pls., 6 figs., Caldwell, Idaho, The Caxton Printers, Ltd., 1936.

Flaherty, G. F.

1278. Mechanics of structure at Tashota Goldfields mine, Tashota, Ontario: Canadian Inst. Min. Metallurgy Bull. 295, pp. 733-738, 10 figs. (incl. geol. map), November 1936.

Fleischer, Michael.

1279. The formula of aenigmatite: Am. Jour. Sci., 5th ser., vol. 32, no. 191, pp. 343-348, November 1936.

Fleming, John Adam.

1280. Earth physics and geographical papers; pt. 1, Contribution from special branches of earth physics; pt. 2, Contribution through study of earth's magnetic field: Carnegie Inst. Washington News Serv. Bull., School ed., vol. 3, nos. 28, 29, pp. 229-238, 1 pl. (front.), 13 figs. (incl, maps), December 22, 1935.

Fleming, W. L. S.

1281. Glacial geology of central Long Island: Am. Jour. Sci., 5th ser., vol. 30, no. 177, pp. 216-238, 3 figs. (incl. geol. map), August 1935.

Flinsch-Buba, Margret.

1282. H. F. Osborn; Ein Nachdruf aus America: Natur u. Volk, Band 66, Heft 2, p. 54, February 1, 1936.

Flint, Howard Raymond, 1882-1935.

1283. Dr. Charles Horace Clapp [1883-1935]: Northwest Sci., vol. 9, no. 2, pp. 17-18, May 1935.

Flint, Richard Foster. See also Longwell, 2442 ; Tarr, 4017.

1284. Glacial features of the southern Okanogan region: Geol. Soc. America Bull., vol. 46, no. 2, pp. 169-194, 2 figs. (incl. map), 6 pls., discussion by O. D. von Engeln, pp. 2016-2017, February 28, 1935; abstract, Proc., 1933, p. 81, June 1934.

1285. Climates of the Pleistocene; a review: Am. Jour. Sci., 5th ser., rol. 29, no. 172, pp. 381-385, 1 fig., April 1935.

1286. "White silt" deposits in the Okanagan Valley, British Columbia: Royal Soc. Canada Trans., 3d ser., vol. 29, sec. 4, pp. 107-114, 3 figs. (incl. sketch map), May 1935; abstract, Proc., 3d ser., vol. 29, p. xcic, 1935.

1287. How many glacial stages are recorded in New England?: Jour. Geology, vol. 43, no. 7, pp. 771-777, October-November 1985.

1288. [Review of] The history of the upper Mississippi River in the late Wisconsin and postglacial time, by William S. Cooper: Am. Jour. Sci., 5th ser., vol. 31, no. 185, pp. 394-396, May 1936. 
Flint, Richard Foster-Continued.

1289. Stratified drift and deglaciation of eastern Washington: Geol. Soc. America Bull., vol. 47, no. 12, pp. 1849-1884, 8 pls. (incl. geol. map), 2 figs. (incl. geol. map), December 31, 1936; abstract, Proc., 1935, p. 77 , June 1936 .

Flores, Teodoro.

1290. Los cuerpos de pirita cuprífera de Campo Morado, Estado de Guerrero, México: 16th Internat. Geol. Cong. (1933) Rept., vol. 2, pp. 10131027, 4 figs., 1936.

Flower, Rousseau Hayner. See also Miller, 2709.

1291. (and Caster, Kenneth E.). The stratigraphy and paleontology of northwestern Pennsylvania; part 2, Paleontology, section $A$, The cephalopod fauna of the Conewango series of the Upper Devonian in New York and Pennsylvania: Bull. Am. Paleontology, vol. 22, no. 75, pp. 199-270, 8 pls., August 23, 1935.

1292. Cherrs Valley [New York] cephalopods: Bull. Am. Paleontology, vol. 22, no. 76, 96 pp., 9 pls., August 4, 1936.

Floyd, F. W.

1293. (and Nufer, D. C.). Stratigraphy in the Ardmore area [abstract, with discussion] : Tulsa Geol. Soc. Digest, 1934, pp. 10-11.

Flude, J. W.

1294. Exploring in marsh and water areas of Louisiana and Texas Gulf coast: Oil and Gas Jour., vol. 34, no. 48, pp. 142, 144, 2 figs., April $16,1936$.

Foerste, August Frederick, 1862-1936. See also Ulrich, 4210, 4215.

1295. Big Horn and related cephalopods: Denison Univ. Bull., vol. 35, no. $` 5$ (Sci. Lab. Jour., vol. 30, art 1-2), pp. 1-96, 22 pls., April 27, 1935.

1296. Structure of the earliest cephalopods [abstract]: Geol. Soc. America Proc., 1934, p. 353, June 1935.

1297. Primitive cephalopods [abstract] : Geol. Soc. America Prcc. 1935, p. 370, June 1936.

1298. Correlation of Silurian formations in southwestern Ohio, southeastern Indiana, Kentucky, and western Tennessee: Denison Univ. Bull., vol. 35, no. 14 (Sci. Lab. Jour., vol. 30, art 3), pp. 119-205, October 18, 1935.

1299. The cephalapods of the Maquoketa shale of Iowa: Denison Univ. Bull., vol. 35, no. 17 (Sci. Lab. Jour., vol. 30), pp. 231-258, 11 pls., December 1935.

1300. Silurian cephalopods of the Port Daniel area on Gaspé Peninsula, in: eastern Canada: Denison Univ. Bull., vol. 36, no. 4 (Sci. Lab. Jour., vol. 31), pp. 21-92, 22 pls., April 30, 1936.

1301. (and Cox, Ian H.). Cephalopods and a Beatricea from Akpatok Island : Geol. Mag., no. 865 (vol. 73, no. 7), pp. 289-307, 1 pl., 19 figs., July 1936.

1302. Cephalopods from the Upper Ordovician of Percé, Quebec: Jour. Paleontology, vol. 10, no. 5, pp. 373-384, 4 pls., July 1936.

1303. Several new Silurian cephalopods and crinoids, chiefly from Ohio and Hudson Bay: Ohio Jour. Sci., vol. 36, no. 5, pp. 261-275, 2 pls., 3 figs., September 1936. 
Forbes, Alexander.

1304. A flight to Cape Chidley, with appendix 1, Notes on the construction of the Cape Chidley sheet by Osborn Maitland Miller, and app. 2, Physiography of the Cape Chidley sheet by Charles B. Hitcheock: Geog. Rev., vol. 26, no. 1, pp. 48-58, 1 pl. (topog. map), 5 figs. (incl. sketch map), January 1936.

Forbes, P. L.

1305. Petrified woods of central Oregon: Rocks and Minerals, vol. 10, no. 1, pp. 1-2, January 1935.

1306. Polka-dot agate-in Oregon: Rocks and Minerals, vol. 11, no. 9, pp. 168169, September-October 1936.

Ford, William Ebenezer.

1307. Edward Salisbury Dana [1849-1935]: Science, new ser., vol. 82, no. 2128, pp. 342-344, October 11, 1935; abstract, Am. Philos. Soc. Proc., vol. 76 , no. 2, pp. 237-241, 1936.

1308. Memorial of Edward Salisbury Dana [1849-1935]: Am. Mineralogist, vol. 21, no. 3, pp. 173-177, 1 fig. (port.), March 1936.

Forrester, J. Donald.

1309. Structure of the Uinta Mountains [abstract] : Geol. Soc. America Proc., 1935, pp. 77-78, June 1936.

Foshag, William Frederick.

1310. Mineralogical investigations in Mexico: Smithsonian Inst. Explorations and Field Work in 1934, Pub. 3300, pp. 5-8, 4 figs., 1935.

1311. Burkeite, a new mineral species from Searles Lake, Calif.: Am. Mineralogist, vol. 20, no. 1, pp. 50-56, 3 figs., January 1935.

1312. Ganophyllite and zincian amphibole from Franklin Furnace, N. J.: Am. Mineralogist, vol. 21, no. 1, pp. 63-67, January 1, 1936.

1313. (and Woodford, Alfred Oswald). Bentonitic magnesian clay mineral from California: Am. Mineralogist, vol. 21, no. 4, pp. 238-244, 2 figs. (index maps), April 1936.

Foster, Margaret Dorothy. See Sayre, 3524.

Fourmarier, Paul F.

1314. Note sur une serie d'échantillons du Tertiaire de Californie: Soc. géol. Belgique Annales, tome 58, Bull. 9-10, pp. B 263-265, juin-juillet 1935.

1315. Recherches complémentaires sur l'existence d'une règle de symétrie dans l'architecture de l'écorce terrestre: 16th Internat. Geol. Cong. (1933) Rept., vol. 2, pp. 925-936, 4 figs. (maps), 1936.

Fowler, Claude S.

1316. The geology of the Mount Adams Country [abstract] : Geol. Soc. Oregon Country News Letter, vol. 2, no. 1, pp. 2-5 ( $\$)$, January 8, 1936.

Fowler, George Malcolm.

1317. (and Lyden, Joseph P., Gregory, F. E., and Agar, William Macdonough). Chertification in the Tri-State (Oklahoma-Kansas-Missouri) mining district [with discussion] : Am. Inst. Min. Met. Eng. Trans., vol. 115 (Mining geology), pp. 106-163, 32 figs. (incl. sketch map), 1985 ; abstract, Year Book sec., pp. 82-83, 1935.

1318. New trends in mining geology: Mining and Metallurgy, vol. 16, no. 337, pp. 18-19, 1 fig. (port), January 1935.

1319. (and Lyden, Joseph P.). The ore deposits of the Tri-State district: Econ. Geology, vol. 30, no. 5, pp. 565-575, August 1935. 
Fowler, Helen.

1320. The most accurate means of computing the age of the earth: Mineralogist, vol. 3, no. 9, pp. 16-17, September 1935.

F'ox, Charles Kirby.

1321. The Colorado Delta: A discussion of the Spanish explorations and maps, the Colorado River silt load, and its seismic effect on the Southwest. 75 pp. ( $\ddagger$ ), 18 pls. (incl. maps), Los Angeles, 1936.

Fox, Ernest F. See Cleaves, 772 .

Fox, Jay T.

1322. T'eredo lignite on Long Island, N. Y.: Rocks and Minerals, vol. 11, no. 10, pp. 225-226, November 1936.

Foye, Wilbur Garland, 1886-1935.

1323. A spatter cone in the main trap sheet, Farmington, Conn.: Am. Jour. Sci., 5th ser., vol. 31, no. 184, pp. 296-300, 3 figs., April 1936.

Franke, Herbert' $A$.

1324. Mines and mineral resources of San Luis Obispo County: California Jour. Mines and Geology, vol. 31, no. 4, pp. 402-461, 1 pl., 16 figs., October 1935.

1325. Mineral resources of portions of Monterey and Kings County : California Jour. Mines and Geology, vol. 31, no. 4, pp. 462-464, October 1935.

Franks, W. Ernest.

1326. Native mercury in Mexico: Eng. and Min. Jour., vol. 136, no. 5, p. 237, May 1935.

Fraser, Donald McCoy. See also Stose, 3937.

1327. Microscopic investigation of Friedensville, Pa., zinc ore: Am. Mineralogist, vol. 20, no. 6, pp. 451-461, 6 figs., June 1935 ; abstracts, no. 3, p. 203, March 1935; Geol. Soc. America Proc., 1934, pp. 426-427, June 1935.

1328. Shearing action in the Durham and Reading Hills, Pa. [abstract] : Geol Soc. America Proç., 1935, p. 78, June 1936.

1329. Faleozoic pegmatites in the Pennsylvania highlands: Am. Mineralogist, vol. 21, no. 10, pp. 662-666, 3 figs. (incl. geol. map), October 1936.

Fraser, F. J.

1330. (and McLearn, F. H., Russell, L. S., Warren, P. S., and Wickenden, R. T. D.). Geology of southern Saskatchewan: Canada Dept. Mines, Geol. Survey Mem. 176, Pub. 2373, 137 pp., 7 pls. (incl. geol. map), 4 figs., 1935.

Fraser, Horace John. See also Graton, 1501 ; Muskat, 2838 ; Smith, 3754.

1331. Experimental study of porosity and permeability of clastic sediments:

Jour. Geology, vol. 43, no. 8, pt. 1, pp. 910-1010, 11 figs., NovemberDecember 1935.

Frebold, Hans. See also Bøggild, 360.

1332. Obere Kreide in Ostgrönland: Meddelelser om Grönland, Band 84, Nr. 8 32 pp., 4 pls., 11 figs. (incl. sketch maps), 1934.

1333. Marines Aptien vòn der Koldewey Insel (nördliches Ostgrönland) : Meddelelser om Grönland, Band 95, Nr. 4, 112 pp., 8 pls., 20 figs., (incl. index map), 1935.

Frederickson, C. S.

1334. Ground subsidence of Bellingham coal mines [abstract] : Pan-Am. Geologist, vol. 65, no. 1, p. 78, February 1936. 
Freehan, P. A.

1335. Agates in the Canal Zone: Rocks and Minerals, vol. 11, no. 9, pp. 170171, September-October 1936.

Freeman, Bruce Clark.

1336. Mineral deposits in Renfrew County and vicinity [Ontario]: Canada Dept. Mines, Geol. Survey Mem. 195, Pub. 2417, 34 pp., 1 pl. (index map), 1936.

Freeman, Correll H.

1337. Natural bonded molding sands of Canada: Canada Dept. Mines, Mines Branch, no. 767, 144 pp., 13 pls. (incl. index maps), 5 figs. (incl. index maps), 1936: abstract, Ceramic Abstracts, vol. 15, no. 8, p. 256, August 1936.

Freeman, Louise Barton. See McFarlan, 2520.

Freeman, Otis Willard.

1338. Geologic and geographic interrelations of Washington? Pan-Am. Geologist, vol. 66 , no. 5, pp. 347-362, 9 pls. (incl. geol. maps), December 1936 ; abstract, no. 2, pp. 157-158, September 1936.

French, A. J.

1339. Columbia County, Oreg., has large 'iron deposits: Mineralogist, vol. 3, no. 7 , p. 15, July 1935 .

Friant, Madeleine.

1340. Sur les molaires vierges de l' Ischyromys: Annals and Mag. Nat. History, 10th ser., no. 93, (vol. 16, no. 93), pp. 392-394, 6 figs., September 1935.

1341. Interprétation de la molaire supérieure jeune de l' Éohippus et considérations sur la phylogénie des Équides: Mus. nat. histoire nat., Bull., sér. 2, tome 8, no. 2, pp. 200-204, 6 figs., March 1936.

Fridley, Harry Marion.

1342. (and Sherrill, Richard Ellis). Relation between slope of peneplains and regional dip of the Allegheny Plateau [abstract] : Geol. Soc. America Proc., 1934, p. 446, June 1935.

Fritz, Madeleine A.

1343. Restorations recently made for the Royal Ontario Museum of Paleontology [abstract] : Geol. Soc. America Proc., 1935, p. 381, June 1936.

Frizzell, Donald Leslie. See also Miller, 2725 ; Schenck, 3553.

1344. Bivalves of the genus Protothaca [abstract]: Geol. Soc. America Proc., 1934, pp. 387-388, June 1935.

1345. Classification of Veneracean pelecypods [abstract] : Pan-Am. Geologist, vol. 63, no. 5, pp. 377-378, June 1935; Geol. Soc. America Proc., 1935, p. 415, June 1936.

1346. (and Wheeler, Harry Edgar). Neotypes in zoological nomenclature: Jour. Paleontology, vol. 9, no. 5, pp. 453-454, July 1935; abstracts, Pan-American Geologist, vol. 63, no. 5, pp. 370-371, June 1935; Geol. Soc. America Proc., 1935, pp. 409-410, June 1936.

1347. Phylogeny of venerid pelecypods [abstract]: Geol. Soc. America Proc., 1935, p. 365 , June 1936.

1348. Genera of the Veneracea [abstract]; Geol. Soc, America Proc., 1935, pp. 365-366, June 1936. 
Frondel, Clifford.

1349. Mineralogy and petrography: Am. Year Book, 1934, pp. 733-736, 1935.

1350. Catalogue of mineral pseudomorphs in the American Museum: Am. Mus. Nat. History Bull., vol. 67, art. 9, pp. 389-426, February 26, 1935.

1351. The size of crystals : Am. Mineralogist, vol. 20, no. 6, pp. 469-473, June 1935.

1352. Oriented intergrowth and overgrowth in relation to the modification of crystal habit by adsorption: Am. Jour. Sci., 5th ser., vol. 30, no. 175, pp. 51-56, July 1935.

1353. Vectoral chemical alteration of crystals: Am. Mineralogist, vol. 20, no. 12, pp. 852-862, 1 fig., December 1935.

1354. Twisted crystals of pyrite and smoky quartz: Am. Mus. Novitates, no. 829, 6 pp., 5 figs., March 19, 1936.

1355. Oriented inclusions of tourmaline in muscovite: Am. Mineralogist, vol. 21, no. 12, pt. 1, pp. 777-799, 6 figs., December 1936.

Fry, William Henry, 1888-1932.

1356. Petrographic methods for soil laboratories: U. S. Dept. Agr. Tech. Bull. 344, 5 figs., January 1933.

Fryxell, Fritiof Melvin.

1357. The Teton peaks : Mountaineering Jour., vol. 2, no. 3, pp. 150-156, 5 figs., June, July, August, 1934.

1358. Glaciers of the Grand Teton National Park of Wyoming: Jour. Geology, vol. 43, no. 4, pp. 381-397, 9 figs. (incl. sketch map), May-June 1935 .

Fuller, George Damon.

1359. Postglacial vegetation of the Lake Michigan region: Ecology, vol. 16, no. 3, pp. 473-487, 8 figs. (incl. geol. map), July 1, 1935.

Fuller, Harry C. See Vanderwilt, 4261.

Fuller, Richard Eugene.

1360. Collapsed pumice [abstract]: Geol. Soc. America Proc., 1934, p. 329, June 1935.

1361. Variations in alkaline content of acidic lava [abstract] : Pan-Am. Geologist, vol. 64, no. 1, pp. 68-69, August 1935; Geol. Soc. Oregon Country News Letter, vol. 2, no. 12, pp. 6-7 ( $\ddagger$ ), June 25, 1936; Geol. Soc. America Proc., 1935, p. 345, June 1936.

Fulton, H. K. See Cassinet, 700 .

Furcron, Aurelius Sydney.

1362. James River iron and marble belt, Virginia : Virginia Geol. Survey Bull. 39, 124 pp., 12 figs. (incl. index map), 6 tables, 15 pls. (incl. geol. map), 1935.

1363. (and Woodward, Herbert Preston). A basal Cambrian lava flow in northern Virginia: Jour. Geology, vol. 44, no. 1, pp. 45-51, 2 figs. (incl. sketch map), January-February 1936.

1364. The theory of lakes and mountain barriers in early American geology: Ohio Jour. Sci., vol. 36, no. 6, pp. 307-314, November 1936.

Furlong, Eustace Leopold.

1365. New merycodonts from the upper Miocene of Nevada: Carnegie Inst. Washington Pub. 453, pp. 1-10, 5 pls., July 1935 [preprint May 25, 1934.]

1366. Pliocene antelopes of the pronghorn type: Science, new ser., vol. 82 , no. 2124, pp. 250-251, September 13, 1935. 
Furness, James Wilson.

1367. Introduction; History of the development of the copper industry of the world: Copper resources of the world, pp. 1-20, 1 pl. (map), 1 fig. (map), Washington, 16th Internat. Geol. Cong., 1935.

Furnish, W. M.

1368. Oneota conodonts [abstracts] : Pan-Am. Geologist, vol. 65, no. 4, p. 315, May 1936.

1369. (and Barragy, E. J., and Miller, Arthur K.). Ordovician fossils from upper part of type section of Deadwood formation, South Dakota: Am. Assoc. Petroleum Geologists Bull,, ,vol. 20, no. 10, pp. 13291341, 2 pls., 1 fig., October 1936.

Furnival, George M.

1370. The large quartz veins of Great Bear Lake, Canada: Econ. Geology, vol. 30, no. 8, pp. 843-859, 7 figs., December 1935.

Gabriel, Vitally Gavrilovich.

1371. Concept of peneplanation and existing land forms: Pan-Am. Geologist, vol. 65, no. 4, pp. 269-271, May 1936.

1372. Seismic prospecting in exploration for oil: Louisiana Cons. Rev., vol. 5, no. 4, pp. 4-8, 6 figs., October 1936.

Galbraith, Frederic William, $3 d$.

1373. Geology of the Silver King area, Superior, Ariz. viii, 153 pp. (\$), 29 pls. (incl. geol. map), 1935.

Galliher, Edgar Wayne.

1374. Interstitial sedimentation [abstract] : Pan-Am. Geologist, vol..63, no. 4, p. 302, May 1935; Geol. Soc. America Proc., 1935, pp. 326-327, June 1936.

1375. Glauconite genesis: Geol. Soc. America Bull., vol. 46, no. 9, pp. 13511366, 2 pls. 1 fig. (map), September 30, 1935; abstract, Am. Assoc. Petroleum Geologists Bull., vol. 19, no. 1, p. 135, January 1935.

1376. Geology of glauconite: Am. Assoc. Petroleum Geologists Bull., vol. 19, no. 11, pp. 1569-1601, 16 figs. (incl. maps), November 1935.

Galloway, John.

1377. Accumulation of oil in the Coalinga district [abstract]: Am. Assoc. Petroleum Geologists Bull., vol. 19, no. 12, p. 1843, December 1935.

Gamble, William B.

1378. Asbestos; a list of references to material in the New York [City] Public Library. 71 pp. New York, New York Public Library, 1929.

Gandrud, Bennie William. See Prindle, 3137.

Gardner, James Henry.

1379. Origin and development of limestone carerns: Geol. Soc. America Bull., vol. 46, no. 8, pp. 1255-1274, 1 fig., August 31, 1935; abstracts, Proc., 1934, p. 78, June 1935; with discussion, Tulsa Geol. Soc. Digest, 1934, pp. $57-58$.

1380. Talihina chert section at Atoka, Okla. [with discussion by Ira $H$. Cram ] : Am. Assoc. Petroleum Geologists Bull., vol. 19, no. 8, pp. 1231-1233, August 1935.

1381. Tectonics in Arbuckle and Ouachita Mountains: Am. Assoc. Petroleum Geologists Bull., vol. 20, no. 8, pp. 1127-1129, August 1936. 
Gardner, Julia Anna.

1382. The Midway group of Texas; including a chapter on the coral fauna by Thomas Wayland Vaughan and Willis Parkison Popenoe: Texas Univ. Bull. 3301, January 1, 1933, 403 pp., 4 figs., 28 pls. [May 1935 ].

1383. Additions to the molluscan fauna of the Alum Bluff group of Florida: Florida Dept. Cons., Geol. Dept. Bull. 14, 82 pp., 10 pls., February 26, 1936.

Garfias, Valentin Richard.

1384. Proven reserves of mineral fuels in the United States: Am. Inst. Min. Met. Eng. Trans., vol. 114, Petroleum Development and Technology, pp. 243-244, 1936.

Garlough, J. L.

1385. Gas fields of Kansas west of Nemaha granite ridge, exclusive of Hugoton district: Geology of natural gas, pp. 459-482, 3 figs., Am. Assoc. Petroleum Geologists [June] 1935.

Garner, Kenneth B.

1386. Concretions near Mount Signal, Lower California: Am. Jour. Sci., 5th ser., vol. 31, no. 184, pp. 301-311, 5 figs., April 1936.

Garrett, Julius B., Jr. See also Mornhinveg, 2799.

1387. Occurrence of Nonionella cockfieldensis at Claiborne, Ala.: Jour. Pa-

- leontology, vol. 10, no. 8, pp. 785-786, December 1936.

Garretson, Mary Welleck.

1388. The cardinal spines of Spirifer mucronatus; Lake Wrie specimen, answers geological query: Hobbies, vol. 17, no. 1, pp. 12-13, 1 fig., October 1936.

Gaudin, Antoine Marc.

1389. Staining minerals for easier identification in quantitative mineragraphic problems : Econ. Geology, vol. 30, no. 5, pp. 552-562, August 1935.

1390. The identification of sulphide minerals by selective iridescent filming: Gliick Auf (Butte, Mont.), vol. 1, no. 5, pp. 5-6, June 1936.

Gazin, Charles Lewis.

1391. Fossil hunting in southern Idaho: Smithsonian Inst., Explorations and field work 1934, Pub. 3300, pp. 9-12, 3 figs., 1935.

1392. A marsupial from the Florissant beds (Tertiary) of Colorado: Jour. Paleontology, vol. 9, no. 1, pp. 57-62, 1 pl., January 1935; abstract, Washington Acad. Sci. Jour., vol. 24, no. 11, p. 487, November 15, 1934.

1303. Gravigrade sloth remains from the late Pliocene and Pleistocene of Idaho: Jour. Mammalogy, vol. 16, no. 1, pp. 52-60, 7 figs., February 1935.

1394. A new antilocaprid from the upper Pliocene of Idaho: Jour. Paleontology, vol. 9, no. 5, pp. 390-393, 1 fig., July 1935.

1395. Annotated list of Pleistocene Mammalia from American Falls, Idaho: Washington Acad. Sci. Jour., vol. 25, no. 7, pp. 297-307, 1 fig., July 15, 1935.

1396. A taeniodont skull from the lower Eocene of Wyoming: Am. Philos. Soc. Proc., vol. 76, no. 5, pp. 597-612, 5 pls., 2 figs., 1936.

1397. A study of the fossil horse remains from the upper Pliocene of Idaho: U. S. Nat. Mus. Proc., vol. 83 , no. 2985, pp. 281-320, 11 pls., 4 figs, 1936. 
Gazin, Charles Lewis-Continued.

1398. A new mustelid carnivore from the Neocene beds of northwestern Nebraska : Washington Acad. Sci. Jour., vol. 26, no. 5, pp. 199-207, 3 figs., May 15, 1936.

Gebhardt, R. E.

1399. Improvements in strong-motion seismograph equipment: Earthquake Notes, vol. 8, nos. 1-2, pp. 84-85, (\$) 3 figs., June 1936.

Gehman, George W.

1400. Some minerals of the Serpentine Range near Easton, Pa.: Rocks and Minerals, vol. 11, no. 6, pp. 90-91, June 1936.

Geis, Harold Lorenz. See also Croneis, 919.

1401. Recent and fossil Pedicellariae: Jour. Paleontology, vol. 10, no. 6, pp. 427-448, 4 pls., 1 fig., September 1936.

George, William 0 .

1402. (and Bay, Harry X.). Subsurface data on Covington County, Miss.: Am. Assoc. Petroleum Geologists Bull., vol. 19, no. 8, pp. 1148-1161, 1 fig. (index map), August 1935; reprinted in Gulf coast oil fields (see Barton and Sawtelle), pp. 369-382, 1936.

Gerber, Winifred $\mathrm{D}$.

1403. (and others). Data on the ground waters of Lake County, Ill.: Illinois Dept. Registration and Education, State Water Survey Div. Circ. 17, 65 pp., 6 figs. (maps), 1935.

1404. (and others). A survey of the ground-water resources of Illinois: Illinois Dept. Registration and Education, State Water Survey Div. Circ. 18, 47 pp., 1935.

Germann, John C.

1405. (and Germann, Louise). Color records of the Badlands: Nat. History, vol. 37, no. 4, pp. 353-361, 10 figs., April 1936.

1406. Pictorial geological columnar sections [abstract]: Geol. Soc. America Proc., 1935, pp. 78, 402, June 1936.

Germann, Louise. See Germann, 1405.

Gerth, Heinrich.

1407. The evolution of reef corals during the Cenozoic period: Fourth Pacific Sci. Cong., (Batavia-Bandoeng, Java, 1929), vol. 2A, pp. 333$350,1930$.

Gesner, Abraham.

1408. First report on the geology of Grand Manan, ed. by Charles Buchanan: Grand Manan Historian, no. 3, vi, 10 pp., 3 pls. (incl. index map), [St. John?], Grand Manan Hist. Soc., 1936.

Getty, Harry T.

1409. Prehistoric man in the Southwest: Grand Canyon Nat. Hist. Assoc. Bull. 7, pp. 1-19 ( $\ddagger$ ), 13 figs., August 1936.

Getzendaner, A. E.

1410. McFaddin-O'Conner, Greta, Fox, Refugio, White Point, and Saxet fields, Tex. : Am. Assoc. Petroleum Geologists Bull., vol. 18, no. 4, pp. 519530, 4 figs. (incl. map), April 1934; reprinted in Gulf coast oil fields (see Barton and Sawtelle), pp. 664-675, 1936. 
Geyn, Wilhemina A. E. van de.

1411. (and Vlerk, I. M. van der). A monograph on the Orbitoididae, occurring in the Tertiary of America, compiled in connection with an examination of a collection of larger Foraminifera from Trinidad : Leidsche geol. Mededeel., deel 7, afl. 2, pp. 221-272, 10 pls. (incl. index map, XII- 1935.

Giannella, Vincent Paul. See also Callaghan, 627.

1412. Geology of the Comstock region [Nevada] [abstract]: Pan-Am. Geologist, vol. 63, no. 4, pp. 317-318, May 1935; Geol. Soc. America Proc., 1935, pp. 339-340, June 1936.

1413. New features of the geology of the Comstock lode [abstract] : Geol. Soc. America Proc., 1934, pp. 338-339, June 1935; abstract, Mining and Metallurgy, Year Book sec., p. 83, January 1935.

1414. (and Callaghan, Eugene). The earthquake of December 20, 1932, at Cedar Mountain, Nev.; its bearing on the genesis of Basin Range structure [abstract with discussion]: 16th Internat. Geol. Cong. (1933) Report, vol. 2, pp. 1107-1108, 1936.

1415. A meteorite from Quartz Mountain, Nev.; Popular Astronomy, vol. 44, no. 8, pp. 448-450, 1 fig., October 1936.

1416. Occurrences, thulite in Nevada: Mineralogist, vol. 4, no. 12, pp. 5-6, December 1936.

Gibson, Russell.

1417. (and Campbell, Ian). Preliminary report on the granodiorite and related rocks of the Libby quadrangle, Mont. [abstract] : Geol. Soc. America Proc., 1934, pp. 329-330, June 1935.

1418. (and Jenks, William F., and Campbell, Ian). Belt sediments in the Libby quadrangle, Mont. [abstract]: Geol. Soc. America Proc., 1935, p. 79, June 1936.

Gidel, Murl Harold. See Hart, 1647.

Gierhart, Guy Balcer. See Kane, 2016.

Gilbert, C. S. See Beath, 248.

Gilbert, Frederick Chester.

1419. The first silver production of Montana: Gliick Auf (Butte, Mont.), vol. 1, no. 1, pp. 6-7, 15, 1 fig., October 1935.

1420. Gold production in Montana : Glück Auf (Butte, Mont.), vol. 1, no. 2, pp. 6-8, 24, 1 fig., December 1935.

1421. Manganese in Montana and the nation: Glück Auf (Butte, Mont.), vol. 1, no. 3, pp. 7-11, 25-27, 2 figs., February 1936.

Giles, Albert William.

1422. Boone chert: Geol. Soc. America Bull., vol. 46, no. 12, pp. 1815-1878; 11 pls., 4 figs. (incl. sketch map) ; discussion by E. R. Pohl, pp: 2073-2075, December 31, 1935.

1423. Classification of oceans and seas [abstract] : Pan-Am. Geologist, vol. 65, no. 3, pp. 231-232, April 1936; Geol. Soc. America Proc., 1935, pp. 436-437, June 1936.

Gill, James Edward.

1424. (and Tolman, Carl, and Bannerman, Harold MacColl), Wapussakatoo. Mountains of Labrador [abstract] : Geol. Soc. America Proc:, 1934; p. 78, June 1935 . 
Gill, James Edward-Continued.

1425. Normal and reverse faults: Jour. Geology, vol. 43, no. 8, pt. 2, pp. 1071-1079, 10 figs., November-December 1935.

1426. Flaws and tear faults: Am. Jour. Sci., 5th ser., vol, 30, no. 180, pp. 553-554, 1 fig., December 1935.

Gillespie, Dean.

1427. The nature and work of the Nininger Laboratory: Popular Astronomy, vol. 43, no. 3, pp. 184-187, March 1935; Soc. Research on Meteorites Contr., fasc. 1, pp. 14-17, January 1936.

Gillespie, J. S. See Stout, 3949.

Gilluly, James.

1428. Copper in Oregon: Copper resources of the world, pp. 345-346, Washington, 16th Internat. Geol. Cong., 1935.

1429. Minor copper-producing districts in Utah: Copper resources of the world, p. 369, Washington, 16th Internat. Geol. Cong., 1935.

1430. Kerntophyres of eastern Oregon and the spilite problem: Am. Jour. Sci., 5th ser., vol. 29, no. 171, pp. 225-252, 2 figs., March 1935; no. 172, pp. 336-352, April 1935.

1431. [Review of] Geology and mineral resources of the Hammond, Antwerp, and Lowville quadrangles, N. Y., by A. F. Buddington, 1934: Econ. Geology, vol. 30, no. 5, pp. 576-577, August 1935.

1432. [Review of] Structural geology, with special reference to economic deposits, by Bohuslaw Stočes and Charles Henry White, 1935: Econ., Geology, vol. 31, no. 4, pp. 433-435, June-July 1936.

1433. Pediments of the Ajo region, Ariz. [abstract] : Washington Acad. Sci. Jour., vol. 26, no. 9, pp. 388-389, September 15, 1936.

Gilmore, Charles Whitney.

1434. On the Reptilia of the Kirtland formation of New Mexico, with descriptions of new species of fossil turtles: U. S. Nat. Mus. Proc., vol. 83, no. 2978, pp. 159-188, 17 figs., 6 pls., 1935.

1435. A new occurrence of the flying reptile, Pteranodon: Science, new ser., vol. 82 , no. 2129 , p. 371 , October $18,1935$.

1436. Fossil hunting in Montana and Wyoming: Smithsonian Inst. Explorations and Field Work, 1935, Pub. 3382, pp. 1-4, 3 figs., 1936.

1437. Osteology of Apatosaurus, with special reference to specimens in the Carnegie Museum : Carnegie Mus. Mem. vol. 11, no. 4, pp. 177-298, 15 pls., 34 figs. (incl. geol. map), February 1, 1936.

Girty, George Herbert.

1438. An unrecorded structure in certain semi-reticulate Producti: Jour. Paleontology, vol. 9, no. 1, pp. 7-9, 4 figs., January 1935.

Gislén, Tortsen.

1439. A reconstruction problem; analysis of fossil comatulids from North America, with a survey of all known types of comatulid arm ramifications: Univ. Årssk. (Acta Univ. Lundensis), neue Folge, Band 30, Avd. 2 (K. Fys. Sällsk. Lund Handl., neue Folge, Band 45), Nr. 11, 59 pp., 63 figs., Lund, 1934.

Glass, J. P. See Newhouse, 2864.

Glass, Jewell Jeannette. See also Goddard, 1459; Graham, 1492; Henderson, 1696, 1699.

1440. The occurrence of zinnwaldite at the Morefield mine, Amelia, Va. [abstract] : Virginia Acad. Sci. Proc. 1934-35, p. 61 [1935]. 
Glass, Jewell Jeanette-Continued.

1441. The pegmatite minerals from near Amelia, Va.: Am. Mineralogist, vol. 20, no. 11, pp. 741-768, 2 figs., November 1935.

1442. Anorthite from Duke Island, Alaska [abstract] : Am. Mineralogist, vol. 21, no. 3, p. 201, March 1936.

Gleason, Charles D., 1908-1935.

1443. Underground waters in St. Louis County and City of St. Louis, Mo.: Missouri Geol. Survey 58th Bienn. Rept., app. 5, 24 pp., 4 figs. 2 pls. (incl. geol. map), 1935.

Glenn, Leonidas Chalmers.

1444. Relation of buried gorges in the Mississippi drainage system to engineering works [abstract]: Geol. Soc. America Proc., 1934, pp. 78-79, June 1935.

Glennie, E. A.

1445. Crustal warping in the United States: Gerlands Beitr. Geophysik, Band 46, Heft 1-2, pp. 193-197, 2 figs. (incl. map), 1935.

1446. Gravity anomalies in the United States: Jour. Geology, vol. 44, no. 7, pp. 765-782, 4 figs. (incl. index maps), October-November 1936.

Glock, Waldo Sumner.

1447. Native copper masses in glacial tills: Pan-Am. Geologist, vol. 63, no. 1, pp. 24-26, February 1935.

1448. Copner and rare types of lost stones in glacial tills: Pan-Am. Geologist, vol. 63, no. 2, pp. 90-96, March 1935 .

1449. Desert cliff recession and lateral regional plantation: Pan-Am. Geologist, vol. 66, no. 2, pp. 81-86, 2 pls., 4 figs., September 1936.

Glover, Sheldon Latta.

1450. Oil and gas possibilities of western Whatcom County: Washington Dept. Cons., Div. Geology Rept. Inv. 2, 69 pp., 1 pl. (map), 1 fig., 1935.

1451. Present status of topographic mapping in Washington: Washington Dept. Cons. and Devel., Div. Geology Inf. Circ. 1, 10 pp. ( ), August 1935.

1452. Summary report on Washington minerals, production and resources: Washington Dept. Conș. and Devel., Div. Geology Inf. Circ. 2, 10 pp. ( $\ddagger)$, October 1935 .

1453. Hammar Bluff formation of western Washington [abstract] : Pan-Am. Geologist, vol. 65, no. 1, pp. 77-78, February 1936.

Glymph, Louis M., Jr.

1454. (and Jones, Victor Harlan). Advance report on the sedimentation survey of Lake Booneville, Booneville, Ark., November 22-December 4, 1935: U. S. Soil Cons. Service S. S. 3, 7 pp., 1 pl. (map), May 1, 1936.

1455. (and Jones, Victor Harlan). Advance report on the sedimentation survey of Lake Sapulpa, Sapulpa, Okla., December 5, 1935 to January 10, 1936: U. S. Soil Cons. Service S. S. 7, 9 pp. 1 pl. (map), August 1936.

1456. (and Jones, Victor Harlan). Advance report on the sedimentation survey of Lake Bennett, Conway, Ark., November 2-22, 1985: U. S. Soil Cons. Service S. S. 9, 5 pp. ( $¥), 1$ pl. (map), October 1936. 
Goddard, Edwin Newell. See also Burbank, 572; Lovering, 2471; U. S. G. S., 4229.

1457. The influence of Tertiary intrusive structural features on mineral deposits at Jamestown, Colo. : Econ. Geology, vol. 30, no. 4, pp. 370386, 6 figs. (incl. geol. map), June-July 1935.

1458. The geology and ore deposits of the Tincup mining district, Gunnison County; Colo. : Colorado Sci. Soc. Proc., vol. 13, no. 10, pp. 551595, 3 figs. (incl. geol. sketch map), 1936.

1459. (and Glass, Jewell Jeannette). Deposits of cerite near Jamestown, Colo. [abstract] : Am. Mineralogist, vol. 21, no. 3, p. 199, March 1936.

Goldich, Samuel S. See Tolman, 4138.

Goldman, Marcus Isaac. See also Hanna, 1621.

1460. (and Merwin, Herbert Eugene). Explanation of the color chart for the description of sedimentary rocks, prepared under the auspices of the Division of Geology and Geography of the National Research Council. 2 pls. [Washington, D. C., 1928].

1461. Origin of anhydrite cap rock: Econ. Geology, vol. 31, no. 8, p. 881, December 1936.

Goldring, Winifred. See also Cooper, 862.

1462. Der älteste versteinerte Wald aus der Devon-Zeeit von New York: Natur u. Volk, Band 65, Heft 4, pp. 151-155, 3 figs., April 1935.

1463. Geology of the Berne quadrangle; with a chapter on glacial geology by John H. Cook: New York State Mus. Bull. 303, 238 pp., 50 pls. (incl. geol. maps), 23 figs., August 1935.

1464. Some Upper Devonian crinoids from New York: Carnegie Mus. Annals, vol. 24, serial 164, December 1934-August 1935, art. 10, pp. 337-348, 3 pls., August 12, 1935.

1465. New and previously known Middle Devonian crinoids of New York: Carnegie Mus. Annals, vol. 24, serial 164, December 1934-August 1985, art. 11, pp. 349-368, 3 pls., August 12, 1935.

1466. Some Hamilton (Devonian) crinoids from New York: Jour. Paleontology, vol. 10, no. 1, pp. 14-22, 2 pls., 1 fig., January 1936.

Goldston, Walter L., Jr.

1467. (and Stevens, George D.). Esperson dome, Liberty County, Tex.: Am. Assoc. Petroleum Geologists Bull., vol. 18, no. 12, pp. 16321654, 14 figs. (incl. maps), December 1934; reprinted in Gulf coast oil fields (see Barton and Sawtelle), pp. 857-879, 1936.

Goldstone, F.

1468. Mapping of geological structure by the reflection of elastic waves: World Petroleum Congress (London, 1933) Proc., vol. 1, pp. 155164, 17 figs., 1934.

Goldthwait, James Walter.

1469. Salt marshes as indicators of coastal stability [abstract]: Geol. Soc. America Proc., 1935, pp. 79-80, June 1936.

1470. Stability. of land and sea at Salem, Mass. [abstract]: Geol. Soc. America Proc., 1935, p. 80, June 1936.

Goldthwait, Richard Parker.

1471. The Damariscotta shell heaps and coastal stability: Am. Jour. Sci., 5th ser., vol. 30, no. 175, pp. 1-13, 3 figs., July 1935.

1472. Seismic sounding on South Crillon and Klooch glaciers [with discussion] : Geog. Jour., vol. 87, no. 6, pp. 406-517, 1 pl. (reconnaissance map), 6 figs., June 1936. 
Gonyer, F. A. See Larsen, 2340.

Goodman, A. J.

1473. Notes on the petroleum geology of western Canada: Inst. Petroleum Technologists Jour., vol. 21, no. 138, pp. 221-258, 4 pls., 35 figs. (incl. geol. maps), discussion, pp. 259-273, April 1935.

Goodrich, Harold Beach. See also U. S. G. S., 4237, 4238.

1474. [Review of] The rise of American oil, by Leonard M. Fanning, 1936: Am. Așsoc. Petroleum Geologists Bull., vol. 20, no. 8, pp. 1130-1131, August 1936.

Goodspeed, George Edward.

1475. Tellurides at Cornucopia: Eng. and Min. Jour., vol. 136, no. 2, pp. 72-73, 4 figs., February 1935.

1476. Recrystallization replacement of small dikes and sills [abstract]: Geol. Soc. America Proc., 1934, p. 329, June 1935.

1477. Development of quartz porphyroblasts in a siliceous hornfels [abstract] : Pan-Am. Geologist, vol. 64, no. 1, p. 69, August, 1935; Geol. Soc. America Proc., 1935, p. 346, June 1936.

1478. Microstructures and metallization of the gold-quartz veins of Cornucopia, Oreg.: Econ. Geology, vol. 31, no. 4, pp. 398-416, 9 figs., June-July 1936.

Gordon, Bertha $\mathrm{F}$.

1479. A fossil mystery [Geography of Chicago plain]: Mineralogist, vol. 4, no. 11, pp. 3-4, 22-27, November 1936.

Gordon, Dugald.

1480. Richland gas field, Richland Parish, La.: Geology of natural gas, pp. 773-786, 3 figs., (incl. maps), Am. Assoc. Petroleum Geologists, [June] 1935 .

Goudey, Hatfield.

1481. Minerals, Ritter Range, Calif. : Mineralogist, vol, 4, no. 5, pp. 7-8, 26-29, May 1936.

Goudge, Monson Fraser.

1482. Limestones of Canada, their occurrence and characteristics, pt. 3, Quebec: Canada Dept. Mines, Mines Branch, Pub. 755, 274 pp., 40 pls. (incl. geol. maps), 11 figs. (incl. geol. maps), 1935.

1483. Rock wool: Canadian Min. Met. Bull. 293, pp. 623-634, 4 figs., September 1936.

Gould, Charles Newton.

1484. Caliche, a neglected Oklahoma resource: Oklahoma Acad. Sci. Proc., 1934, vol. 15, pp. 82-84, 1935.

1485. The discovery of the Panhandle oil and gas field [abstract]: Drilling and Production Practice, 1935, p. 274, Am. Petroleum Inst., 1936.

Gould, Donald Boyd. See also Stark, 3834, 3836.

1486. Terraced deposit of an extinct thermal spring in South Park, Colo. [abstract]: Iowa Acad. Sci. Proc., 1934 (rol. 41), p. 241, 1934.

1487. Stratigraphy and structure of Pennsylvanian and Permiam rocks in Salt Creek area, Mosquito Range, Colo.: Am. Assoc. Petroleum Geologists Bull., vol. 19, no. 7, pp. 971-1009, 5 figs. (incl. geol. map), July 1935.

Gould, L. O. See Leggette, 2378.

$311-37-8$ 
Gow, Kenneth L.

1488. The geology of the Mountain View oil field [abstract]: Am. Assoc. Petroleum Geologists Bull., vol. 19, no. 1, p. 135, January 1935.

Grabau, Amadeus William.

1489. Oscillation or pulsation [with discussion] : 16th Internat. Geol. Cong. (1933) Rept., vol. 1, pp. 539-553, 1 fig., 1936.

1490. Classification of Paleozoics on pulsation theory: Pan-Am. Geologist, vol. 66, no. 1, pp. 19-38, August 1936.

Graham, Roy.

1491. Pennsylvanian flora of Illinois as revealed in coal balls, pt. 2: Bot. Gazette, vol. 97, no. 1, pp. 156-168, 24 figs., September 1935.

Graham, William Armstrong Patterson, 1899-1934.

1492. An occurrence of narsarsukite in Montana: Am. Mineralogist, vol. 20, no. 8, pp. 598-601, August 1935.

Graham-Smith, W.

1493. Scaumenella mesacanthi, gen. et sp. n., a peculiar organism from the Upper Devonian of Scaumenac Bay, Province Quebec, Canada: Annals and Mag. Nat. History, 10th ser., no. 94 (vol. 16), pp. 473476, 1 fig., October 1935.

Granger, Walter Willis.

1494. (and Gregory, William King). Revised restoration of Baluchitherium

[abstract]: Geol. Soc. America Proc., 1934, pp. 378-379, June 1935.

Grant, Ulysses Sherman, 1867-1932.

1495. (and Behre, Charles Henry, Jr., and Ball, John Rice). Memorial of Daniel Franklin Higgins [1882-1930]: Geol. Soc. America Proc., 1934, pp. 237-244, port., June 1935.

Grant, Ulysses Simpson IV. See also Soper, 3788.

1496. (and Putnam, William C.). Barrancos and arroyos in California [abstract] : Pan-Am. Geologist, vol. 63, no. 4, pp. 307-308, May 1935 ; Geol. Soc. America Proc., 1935, p. 331, June 1936.

1497. (and Strong, A. M.). Pliocene and Pleistocene Mollusca of Santa Barbara [abstract] : Geol. Soc. America Proc., 1934, pp. 386-387, June 1935.

1498. Summary of marine Pleistocene of California [abstract]: Pan-Am. Geologist, vol. 64, no. 1, pp. 73-74, August 1935; Geol. Soc. America Proc., 1935, pp. 349-350, June 1936.

Grassmuck, G.

1499. Die Golderzlagerstätten im Staate Montana, U. S. A. : Freiberger geol. Gesell. Ber., Band 15, pp. 83-85, May 1935.

Graton, Louis Caryl. See also Muskat, 2838.

1500. (and Harcourt, G. A.). Spectographic evidence on origin of ores of Mississippi Valley type: Econ. Geology, vol. 30, no. 7, pp. 800-824, 1 fig., November 1935.

1501. (and Fraser, Horace John). Systematic packing of spheres, with particular relation to porosity and permeability: Am. Assoc. Petroleum Geologists Bull., vol. 43 , no. 8, pt. 1, pp. 785-909, 37 figs., November-December 1935.

1502. [Review of] Ore deposits of the Western States (Lindgren volume), Am. Inst. Min. Met. Eng., 1933: Econ. Geology, vol. 31, no. 2, pp. 222-226, March-April 1936. 
Graton, Louis Caryl-Continued.

1503. [Review of] Economic geology of mineral deposits, by Eruest Raymond Lilley, 1936: Econ. Geology, vol. 31, no. 8, pp. 882-884, December 1936.

Grave, Oliver $\mathbf{R}$.

1504. Iron sulphide ores of northern Ozarks [abstract] : Pan-Ain. Geologist, vol. 65 , no. 2 , p. 159 , March 1936.

Gravell, Donald Winchester.

1505. The genus Orbitoides in America, with description of a new species from Cuba: Jour. Paleontology, vol. 4, no. 3, pp. 268-270, 1 pl., September 1930 .

1506. (and Hanna, Marcus Albert). Larger Foraminifera from the Moody's Branch marl, Jackson Eocene, of Texas, Louisiana, and Mississippi: Jour. Paleontology, vol. 9, no. 4, pp. 327-340, 1 fig. (sketch map), 4 pls., June 1935.

1507. (and Hanna, Marcus Albert). Conroe oil field, Tex.: Am. Assoc. Petroleum Geologists Bull., vol. 20, no. 7, pp. 985-986, July 1936.

Grawe, Oliver Rudolph.

1508. Ice as an agent of rock weathering; a discussion: Jour. Geology, vol. 44, no. 2, pt. 1, pp. 173-182, February-March 1936.

1509. Commercial iron sulphide deposits of the northern Ozark Plateau, Missouri [abstract]: Geol. Soc. America Proc. 1985, p. 437, June 1936.

Gray, Francis William.

1510. Note on the attitude and conjectural shape of the submarine portion of Sydney coal field: Canadian Inst. Min. Metallurgy Trans., vol. 37,.pp. 1-23, 1 pl., 1 fig. [1935].

Gray, William D. See Boeshore, 364.

Green, Darsie A.

1511. Permian and Peunsylvanian sediments exposed in central and westcentral Oklahoma [with discussion] : Am. Assoc. Petroleum Geologists Bull., vol. 20, no. 11, pp. 1454-1475, 1 pl., 2 figs., November 1936.

Greene, Frank Cooke. See also Moore, 2788.

1512. Oil and gas possibilities of the Savannah area [Missouri]: Missouri Geol. Survey 58th Bienn. Rept., App. 2, 26 pp., 1 fig. (map), 1 pl. (geol. map), 1935.

1513. Oil and gas developments in Missouri in 1933-34: Missouri Geol. Survey 58th Bienn. Rept., App. 3, 21 pp., 3 figs., 1935.

1514. (and Trowbridge, Raymond M.). Preglacial drainage pattern of northwest Missouri: Missouri Geol. Survey 58th Bienn. Rept., åp. 7, 7 pp., 1 map, 1935.

Greene, Gerald U.

1515. The occurrence of sphalerite at Ellsworth, Ohio: Am. Mineralogist, vol. 20 , no. 12 , pp. $882-883$, December 1935 .

Greger, Darling K.

1516. Inarticulate brachiopods from the Grassy Creek shale of Pike County, Mo.: Am. Midland Naturalist, vol. 16, no. 1, pp. 110-114, 14 figs., January 1935. 
Greger, Darling K.-Continued.

1517. Dr. Benjamin Franklin Shumard (1820-1869): St. Louis Acad. Sci. Bull., vol. 1, no. 2, p. 13, 1 fig. (port.), February 1935.

1518. Hiram Augustus Prout, M. D. (1808-1862) : St. Louis Acad. Sci. Bull., vol. 1, no. 8, pp. 59-61, December 1935.

1519. (and Born, Kendall Eugene). Stratigraphy and fauna of the Fernvale formation [Illinois]: Washington Univ. [St. Louis] Studies, new ser., no. 9, pp. 67-77, 2 pls., 1 fig., February 1936.

1520. On the occurrence of the genus Gruenewaldtia in the Devonian of central Missouri: Washington Univ. [St. Louis] Studies, new ser., no. 9, pp. 93-97, 1 pl., February 1936.

Gregersen, Albert.

1521. The Cuyama fault [abstract] : Am. Assoc. Petroleum Geologists BulI, vol. 19, no. 11, p. 1841, December 1935.

Gregory, F. E. See Fowler, 1317.

Gregory, Herbert Ernest.

1522. (and Wentworth, Chester Keeler). Glacial geology of Mauna Kea, Hawaii [abstract]: Geol. Soc. America Proc., 1935, pp. 80-81, June 1936.

Gregory, J. N. See Cunningham, 934.

Gregory, William King. See Granger, 1494.

1523. From fish to man: Nat. History, vol. 32 , no. 4, pp. $440,442,10$ figs., July-August 1932.

1524. Further observations on the pectoral girdle and fin of Sauripterus taylori Hall, a crossopterygian fish from the Upper Devonian of Pennsylvania, with special reference to the origin of the pentadactylate extremities of Tetrapoda: Am. Philos. Soc. Proc., vol. 75, no. 7 , pp. 673-390, 7 figs., 1935.

1525. On the evolution of the skulls of vertebrates with special reference to heritable changes in proportional diameters (anisomerism) : Nat. Acad. Sci. Proc., vol. 21, no. 1, pp. 1-9, 3 figs., January 15, 1935.

1526. Building a super-giant rhinocerus: Nat. History, vol. 35, no. 4, pp. 340-343, 3 figs., April 1935.

1527. The pelvis from fish to man; a study in paleomorphology: Am. Naturalist, vol. 29, no. 722, pp. 193-210, 12 figs., May-June 1935.

1528. (and others). Williston's law relating to the evolution of skull bones in the vertebrates: Am. Jour. Phys. Anthropology, vol. 20, no. 2, pp. 123-152, 16 figs., July-September 1935.

1529. Henry Fairfield Osborn [1857-1935]: Science, new ser, vol. 82, no. 2133 , pp. 452-454, November 15, 1935.

1530. Henry Fairfield Osborn [1857-1935] : Nat. History, vol. 36, no. 5, pp. 370-373, 1 fig. (port.), December 1935.

1531. Henry Fairfield Osborn [1857-1935], an appreciation: Sci. Monthly, vol. 41, no. 6, pp. 566-569, 1 pl. (port.), December 1935.

1532. Henry Fairfield Osborn [1857-1935] : Am. Philos. Soc. Proc., vol. 76, no. 3, pp. 395-408, 1936.

1533. Habitus factors in the skeleton of fossil and recent mammals: Am. Philos. Soc. Proc., vol. 76, no. 4, pn. 420-444, 1 pl., 13 figs., 1936.

1534. Dr. Merriam's contributions to the development of vertebrate paleontology on the Pacific coast: Sci. Monthly, vol. 42, no. 4, pp. 377-380, 1 fig. (port.), April 1936.

1535. On the meaning and limits of irreversibility of evolution: Am. Naturalist, vol. 70, no. 731, pp. 517-528, November-December 1936. 
Greig, Joseph Wilson.

1536. (and Posnjak, Eugen, Merwin, Herbert Eugene, and Sosman, Robert Browning). Equilibrium relationships of $\mathrm{Fe}_{3} \mathrm{O}_{4}, \mathrm{Fe}_{2} \mathrm{O}_{3}$, and oxygen : Am. Jour. Sci., 5th ser., vol. 30, no. 177, pp. 239-316, 12 figs., September 1935 .

1537. (and Merwin, Herbert Eugene, and Posnjak, Eugen). Separation planes in magnetite: Am. Mineralogist, vol. 21, no. 8, pp. 504-510, 3 figs., August 1936; abstract, no. 3, p. 193, March 1936.

Grenfell, Donald S. See Farrar, 1215 ; Smith, 3745.

Grieger, John M.

1538. Good tourmaline specimens can be collected at Mesa Grande, Calif.: Mineralogist, vol. 3, no. 4, pp. 11-12, April 1935.

Griffin, Edward L. See Anonymous, 4665.

Griffith, John Howell.

1539. Physical properties of earths: Iowa State Coll. Agr. and Mechanic Arts, Eng. Exper. Sta. Bull. 101, 128 pp., 80 figs., June 3, 1931.

1540. Thermal expansion of typical American rocks: Iowa State College, Eng. Exper. Sta. Bull. 128, 36 pp., 21 figs., October 7, 1936.

Griggs, David Tressell. See Larsen, 2339.

1541. Plasticity of rocks under high pressure (abstract): Geol. Soc. America Proc., 1934, p. 79, June 1935.

1542. The strain ellipsoid as a theory of rupture: Am. Jour. Sci., 5th ser., vol. 30, no. 176, pp. 121-137, 1 fig., August. 1935.

1543. Strength of rocks under high pressure (abstract) : Geol. Soc. America Proc., 1935, p. 81, June 1936.

1544. Deformation of rocks under high confining pressures; I, Experiments at room temperature: Jour. Geology, vol. 44, no. 5, pp. 541-577, 5 pls., 14 figs., July-August 1936.

1545. The factor of fatigue in rock exfoliation: Jour. Geology, vol. 44, no. 7, pp. 783-796, 3 pls., 3 figs., October-November 1936.

Grim, Ralph Early. See Bray, 451: Ekblaw, 1154.

1546. Petrology of the Pennsylvanian shales and noncalcareous underclays associated with Illinois coals [including $X$-ray studies by $P$. F. Kerr and chemical studies by 0 . W. Rees] : Am. Ceramic Soc. Bull., vol. 14, no. 3 , pp. 113-119, 1 fig., March 1935 ; no. 4, pp. 129-134, 2 figs., April 1935; no. 5, pp. 170-176, 4 figs., May 1935.

1547. Petrography of fuller's earth deposits: Econ. Geology, vol. 30, no. 7, pp. 825-829, 1 fig., November 1935.

1548. The Eocene sediments of Mississippi : Mississippi Geol. Survey Bull. 30, 240 pp., 35 figs. (incl. geol. sketch maps), 1936.

1549. (and Allen, Victor Thomas). Pennsylvanian underclays of Illinois [abstract] : Geol. Soc. America Proc., 1935, pp. 81-82, June 1936.

1550. (and Bray, Roger Hammond). The mineral constitution of various ceramic clays: Am. Ceramic Soc. Jour., vol. 19, no. 11, pp. 307-315, November 1936.

Grimes, Glenn.

1551. Tatums pool, Carter County, Okla. [with discussion by C. W. Tomlinson]: Am. Assoc. Petroleum Geologists Bull., vol. 19, no. 3, pp. 401-411, 3 figs., March 1935; abstract, with discussion, Tulsa Geol. Soc. Digest, 1934, pp. 28-29. 
Grimes-Graeme, R. See Osborne, 2966.

Grimsdale, Thomas Francis. See Barker, 183.

Gross, Paul Luther Karl.

1552. (and Eckis, Rollin). Porosity and sorting of California fanglomerates [abstract] : Pan-Am. Geologist, vol. 64, no. 1, p. 77, August 1935; Geol. Soc. America Proc., 1935, p. 353, June 1936.

Grout, Frank Fitch. See also Emmons, 1178.

1553. (and Longley, W. W.). Relations of anorthosite to granite: Jour. Geology, vol. 43, no. 2, pp. 133-141, 2 figs., February-March 1935.

1554. (and others). Report of the committee on batholiths: Nat. Research Council, Div. Geol. and Geog. Ann. Rept., 1934-35, app. A, exhibit A, 15 pp. (\$), April 27, 1935.

1555. Memorial of William A[rmstrong] P[atterson] Graham [1899-1934] : Geol. Soc. America Proc., 1934, pp. 233-236, port., June 1935.

1556. (and others). Comments on magmatic stoping: Nat. Research Council, Div. Geol. and Geog., Ann. Rept., 1934-35, app. A, exhibit C, 47 pp. (\$), 1 pl., October 1935.

1557. Structural features of the Saganaga granite of Minnesota-Ontario: 16th Internat. Geol. Cong. (1933) Rept., vol. 1, pp. 255-270, 5 pls. (incl. geol. maps), 9 figs. (incl. index map), 1936.

Grove, Brandon Hambright. See also Romer, 3346.

1558. Studies in Paleozoic corals; pt. 3, A revision of some Mississippian zaphrentids: Am. Midland Naturalist, vol. 16, no. 3, pp. 337-378, 6 pls., 4 figs., May 1935.

Grove, Clinton Sheely.

1559. (and Tucker, Rietz Courtney). A study of North Carolina clays in reclaiming motor oils [abstract] : Elisha Mitchell Sci. Soc. Jour., vol. 49, no. 1, pp. 24-25, September 1933.

Grover, Nathan Clifford. See Stevens, 3894.

Gruner, John Walter.

1560. The structural relationship of nontronites and montmorillonite: $\mathbf{A m}$. Mineralogist, vol. 20, no. 7, pp. 475-483, July 1935.

1561. The structural relationship of glauconite and mica: Am. Mineralogist, vol. 20 , no. 10 , pp. $699-714$, October 1935 .

1562. Some notes on the structure. of stilpnomelane [abstract] : Am. Mineralogist, vol. 21, no. 3, pp. 204-205, March 1936.

1563. The structure and chemical composition of greenalite: Am. Mineralogist, vol. 21, no. 7, pp. 449-455, July 1936; abstract, no. 3, p. 205, March 1936.

1564. Eydrothermal alteration of montmorillonite to feldspar at temperatures from $245^{\circ}$ C. to $300^{\circ}$ C.: Am. Mineralogist, vol. 21 , no. 8 , pp. 511515, Auguist 1936; abstract, no. 3, p. 201, March 1936.

Gry, Helge. See Bøggild, 360.

Guild, Frank Nelson.

1565. Piedmontite in Arizona: Am. Mineralogist, vol. 20, no. 10, pp. 679-692, 12 figs., October 1935.

Gunn, Ross.

1566. The forces responsible for continental motions and Pacific type mountain building: Phys. Rev., 2d ser., vol. 49, no. 2. p. 192, January 15, 1936. 
Gunn, Ross-Continued.

1567. On the origin of the continents and their motions: Franklin Inst. Jour., vol. 222, no. 4, pp. 475-492, October 1936.

Gunnell, E. Mitchell.

1568. Historical notes-mineral luminescence: Mineralogist, vol. 3, no. 1, pp. 5-6, January 1935.

1569. (and Shrader, John S.). New Jersey willemite shows spectacular fluorescence: Mineralogist, vol. 3, no. 1, 1p. 9-10, 22, January 1.935.

1570. Notes on triboluminescent zinc sulphides, both natural and synthetic: Mineralogist, vol. 3, no. 5, pp. 11-12, 34, May 1935.

1571. The important types of mineral luminescence: Mineralogist, vol. 3, no. 6 , pp. 5-6, 23, 24-26, June 1935 .

1572. Origin of silica and depositional environment of chert and flint; pt. 1 , The source of silica: Mineralogist, vol. 3, no. 7, pp. 5-6, 24-25, July 1935 ; pt. 2 , Depositional environment of chert and flint; no. 8, pp. 9-10, 28-29, August 1935.

\section{Gunning, Henry Cecil.}

1573. (and Ambrose, John Willis). Notes to accompany preliminary map of the Cadillac belt from Pandora to Pan Canadian [Quebec]: Canada Dept. Mines, Geol. Survey Paper $36-9,10$ pp. (\$), 1 pl. (geol. map), 1936.

1574. Knebelite at Bluebell mine, Kootenay Lake, British Columbia: Royal Soc. Canada Trans., $3 d$ ser., sec. 4, vol. 30, pp. 19-22, 2 pls., May 1936.

Gunter, Herman.

1575. [Administrative report] : Florida State Board Cons. 1st Bienn. Rept., pt. 4, State Geol. Survey, 25 pp., 4 figs., Biennium ending December 31, 1934 [1935].

1576. [Mineral production in Florida, 1932 and 1933] : Florida State Board Cons. 1st Bienn. Rept., pt. 4, State Geol. Survey, p. 10, Biennium ending December 31, 1934 [1935].

Gutenberg, Beno. See also Buwalda, 601; Heck, 1678; Wood, 4585.

1577. Crustal deformations of gradual type: Fifth Pacific Sci. Cong., Canada, 1933, Proc., vol. 2, pp. 1297-1304, 1934.

1578. The structure of the earth's crust as indicated by seismological data [with discussion by J. B. Macelwane, pp. 2533-2538] : Fifth Paciffc Sci. Cong., Canada, 1933, Proc., vol. 3, pp. 2511-2522, 1934.

1579. (and Richter, Charles Francis). On seismic waves: Gerlands Beitr. Geophysik, Band 45, Heft 3, pp 280-360, 16 figs., 1935.

1580. (and Buwalda, John Peter). Seismic reflection profile across Los Angeles Basin [abstract]: Pan-Am. Geologist, vol. 63, no. 4, p. 303, May 1935; Geol. Soc. America Proc. 1935, pp. 327-328, June 1936.

1581. (and Buwalda, John Peter). Seismic methods applied to the Bighorn Basin [abstract]: Geol. Soc. America Proc., 1934, pp. 79-80, June 1935.

1582. The age of the earth from the changes in its temperature and elastic properties [abstract]: Science, new ser., vol. 82 , no. 2116, p. 52 , July 19, 1935.

1583. Velocities of elastic waves in rocks of various ages and at various depths [abstract] : Am. Assoc. Petroleum Geologists Bull., vol. 19, no. 12 , p. 1842 , December 1935 . 
Gutenberg, Beno-Continued.

1584. On some problems concerning the seismic field methods: Beitr. angew. Geophysik, Band 6, Heft 2, pp. 125-140, 5 figs., 1936.

1585. (and Richter, Charles Francis). Magnitude and energy of earthquakes: Science, new ser., vol. 83, no. 2147, pp. 183-185, February 21, 1936.

1586. On microseisms: Seismol. Soc. America Bull., vol. 26, no. 2, pp. 111-117, April 1936.

1587. The amplitudes of waves to be expected in seismic prospecting: Geophysics, vol. 1, no. 2, pp. 252-256, 1 fig., June 1936.

1588. (and Richter, Charles Francis). Materials for the study of deep-focus earthquakes: Seismol. Soc. America Bull., vol. 26, no. 4, pp. 341390, 1 pl., October 1936.

1589. Structure of the earth's crust and the spreading of the continents: Geol. Soc. America Bull., vol. 47, no. 10, pp. 1587-1610, 2 figs., October 31, 1936.

Gwynne, Charles Sumner.

1590. Weathering of sandstone in the Iowa State Capitol building: Iowa Acad. Sci. Proc., 1934 (vol. 41), pp. 177-190, 1934.

Haas, Merrill. See Eardley, 1107.

Haase, F. M. See Anonymous, 4665.

Hacquaert, Armand L.

1591. Notes sur les genres Sycidium et Trochiliscus: Mus. royal histoire nat. Belgique Bull., tome 8, no. 30, 22 pp., 10 figs., November 1932.

1592. De expedities van de Princeton Universiteit: Natuurk. tidjschr., Jaarg. 17, Nr. 7, pp. 221-226, 1 pl., 2 figs. (sketch maps), 1935.

1593. Présentation de trochilisques nord-américains : Soc. belge géologie Bull., tome 66, fasc. 1, pp. 16-18, July 1, 1936.

Hadley, Wade Hampton.

1594. Seven new species of Foraminifera from the Tertiary of the Gulf coast: Bull. Am. Paleontology, vol. 22, no. 74, 10 pp., 1 pl., March 11, 1935.

Haenseler, Conrad Martin. See Chrysler, 751.

Haff, John C.

1595. The dikes of Cape Neddick, Maine [abstract] : Am. Mineralogist, vol. 31, no. 3, p. 197, March 1936.

1596. Igneous rock names and their evaluation: Am. Mineralogist, vol. 21, no. 7 , pp. 427-441, July 1936.

Hage, Conrad Olai. See Hume, 1885.

Hagelstein, Robert.

1597. Albert Mann, 1853-1935: Science, new ser., vol. 81, no. 2100, pp. 308309, March 29, 1935.

Hager, Dilworth S.

1598. The northeast Texas fault line [abstract]: Am. Assoc. Petroleum Geologists Bull., vol. 20, no. 11, p. 1514, November 1936.

Hager, Dorsey.

1599. Southwestern Kentucky Counties are studied for their oil and natural gas possibilities: Oil Weekly, vol. 32 , no. 14, pp. 18, 33, 1 fig. (index map), August 24, 1933.

Haight, Frank J. See Thorp, 4118. 
Hake, B. F.

1600. (and Willis, Robin, and Addison, C. C.). Folded sheet thrusts in the foothills of Alberta [abstract]: Geol. Soc. America Proc., 1934, p. 324, June 1935.

Halbouty, Michel T.

1601. Geology and geophysics of southeast flank of Jennings dome, Acadia Parish, La., with special reference to overhang: Am. Assoc. Petroleum Geologists Bull., vol. 19, no. 9, pp. 1308-1329, 9 figs. (incl. contour maps), September 1935; reprinted in Gulf coast oil fields (see Barton and Sawtelle), pp. 961-982, 1936.

1602. Petrographic and physical characteristics of sands from seven Gulf coast producing horizons: Oil Weekly, vol. 83, no. 11, pp. 21-22, 24, November 23,1936 ; no. 12 , pp. 22-24, 26, November 30, 1936; no. 13, pp. 36-38, 40, 42, 44, 46, 48, 48 figs., December 7, 1936; vol. 84, no. 1 , pp. $34,36,38,40,42,44,46,48,50,50$ figs., December 14 , 1936 ; no. 2, pp. $36,40,42,44$, December 21,1936 ; no. 3 , pp. 36, 38, 40, 42, December 28, 1936 ; no. 4, pp. 39-40, January 4, 1937.

1603. Geology and geophysics showing cap rock and salt overhang of High Island dome, Galveston County, Tex. : Am. Assoc. Petroleum Geologists Bull., vol. 20, no. 5, pp. 560-611, 27 figs. (incl. index map), May 1936; correction, no. 6, p. 818 , June 1936 ; abstract, World Petroleum, vol. 7, no. 8, p. 404, August 1936; reprinted in Gulf coast oil fields (see Garton and Sawtelle), pp. 909-960, 1936.

Hall, B. F. (Mrs.).

1604. (and Hall, W. F.). Arkansas; a study of its growth and characteristics, 1836-1936: 74th Cong., 2d session, S. Doc. 191, 46 pp., 1 fig., 1936.

Hall, Courtney Robert.

1605. A scientist in the early Republic, Samuel Latham Mitchell, 1764-1831. vi, 162 pp., front. (port.), New York, Columbia Univ. Press, 1934.

Hall, Eugene Raymond.

1606. A new mustelid genus from the Pliocene of California: Jour. Mammalogy, vol. 16, no. 2, pp. 137-138, 3 figs., May 1935.

Hall, George Martin. See also Thom, 4074.

1607. Magnetite in Tennessee [abstract]: Am. Mineralogist, vol. 20, no. 3, p. 199, March 1935; Geol. Soc. America Proc., 1934, p. 423, June 1935.

1608. (and Amick, Harold Clyde). Mica peridotite in Tennessee [abstract] : Am. Mineralogist, vol. 20, no. 3, pp. 204-205, March 1935; Geol. Soc. America Proc., 1934, pp. 80-81, June 1935.

1609. Memorial of Charles Henry Gordon [1857-1934], first President of the Tennessee Academy of Science: Tennessee Acad. Sci. Jour., vol. 10, no. 2, pp. 100-103, 1 pl. (port.), April 1935.

1610. Memorial of Charles Henry Gordon [1857-1934]: Geol. Soc. America Proc., 1934, pp. 225-232, port., June 1935.

1611. The economic and cultural value of geology: Tennessee Acad. Sci. Jour., vol. 11, no. 1, pp. 1-7, January 1936.

Hall, W. F. See Hall, B. F., 1604.

Halse, G. W.

1612. Notes on the geology of south Trinidad, with special reference to Palo Seco [with discussion]: Inst. Petroleum Technologists Jour., vol. 21, no. 145, pp. 940-951, 1 fig., November 1935. 
Hamilton, S. Harbert.

1613. Meteorite studies; an epitome of the literature, with an annotated list of the falls in the collection of the Academy of Natural Sciences, Philadelphia: Mineral Collector, vol. 8, no. 7, pp. 97-101, 1 pl., September 1901 ; no. 8, pp. 120-126, October 1901.

Hammar, Harald Edwin. See Trask, 4149; 4151.

Hancock, E. G. See Langford, 2336.

Hanna, G. Dallas. See also Anderson, 65; Vonsen, 4298.

1614. The dates of publication of Tempère and Pergallo's Diatomées du monde entier, edition 2: Jour. Paleontology, vol. 4, no. 3, pp. 296-297, September 1930.

1615. Additional notes on diatoms from the Cretaceous of California: Jour. Paleontology, vol. 8, no. 3, pp. 352-355, 1 pl., September 1934.

1616. (and Taff, Joseph Alexander, and Cross, C. M.). Chico [Calif.] Cretaceous at the type locality [abstract] : Pan-Am. Geologist, vol. 64, no. 1, p. 72, August 1935; Geol. Soc. America Proc., 1935, pp. 348-349, June 1936.

1617. Interesting whale jaw from Kern County [Calif.] [abstract] : Pan-Am. Geologist, vol. 64, no. 1, pp. 79-80, August 1935; Geol. Soc. America Proc., 1935, p. 419, June 1936.

1618. A new land shell from the Eocene of California: Jour. Paleontology, vol. 10, no. 5, pp. 416-417, 1 fig., July 1936.

Hanna, Marcus Albert. See also Gravell, 1506, 1507.

1619. (and Wolf, Albert G.). Texas and Louisiana salt-dome cap-rock minerals: Am. Assoc. Petroleum Geologists Bull., vol. 18, no. 2, pp. 215-225, 10 pls., February 1934; reprinted in Gulf coast oil fields (see Barton and Sawtelle), pp. 119-132, 1936.

1620. Barite concretions from the Yazoo clay, Eocene, of Louisiana: Jour. Sedimentary Petrology, vol. 6, no. 1, pp. 28-30, 1 pl., April 1936.

1621. [Review of] Origin of the anhydrite cap rock of American salt domes, by Marcus I. Goldman, 1933: Econ. Geology, vol. 31, no. 6, pp. 642-644, September-October 1936.

Hansell, James Myron. See also Reed, 3218, 3219.

1622. (and Reed, John Calvin). Quicksilver deposits near Little Missouri River, southwest Arkansas [with discussion] : Am. Inst. Min. Met. Eng. Trans., vol. 115 (Mining geology), pp. 229-246, 4 figs. (maps), 1935 ; abstract, Year Book sec., p. 62, January 1936.

Hansen, Ethel $\mathbf{B}$.

1623. A pre-Kansan record of Picea canadensis for Missouri: Rhodora, vol. 37, no. 433, pp. 16-19, 1 fig., 1 pl., January 1935.

Hansen, George Henry. See Bissell, 327.

Hanson, George. See also Canada G. S., 655.

1624. Willow River map area, Cariboo district, British Columbia; general geology and lode deposits: Canada Dept. Mines, Geol. Survey, Summary Rept., 1933, pt. A, Pub. 2350, pp. 30-48, 1934.

1625. The recent volcanoes of Canada: Fifth Pacific Sci. Cong., Canada, 1933, Proc., vol. 3, pp. 2291-2294, 1934.

1626. Portland Canal area, British Columbia: Canada Dept. Mines, Geol. Survey Mem. 175, Pub. 2371, 179 pp., 15 figs. 4 pls. (incl. geol. maps), 1935. 
Hanson, George-Continued.

1627. Barkerville gold belt, Cariboo district, British Columbia: Canada Dept. Mines, Geol. Survey Mem. 181, Pub. 2396, 42 pp., 5 pls. (incl. geol. maps), 4 figs., 1935.

Hanzawa, Shoshiro. See Cushman, 942.

Harbicht, Darwin.

1628. Dinosaur hunting near Fort Peck [Montana]: Glück Auf (Butte, Mont.), vol. 2, no, 2, pp. 8, 11, 21, December 1936.

Harcourt, G. A. See Graton, 1500.

Hares, Charles Joseph. See also Wood, 4586.

1629. Deeply weathered pre-Cambrian peneplain a basic factor in the genesis of the Sherman flat surface, Laramie Mountains, Wyo. [abstract] : Geol. Soc. America Proc., 1934, p. 81, June 1935.

1630. Charles Thomas Lupton [1878-1935]: Am. Assoc. Petroleum Geologists Bull., vol. 20, no. 4, pp. 512-515, 1 fig. (port.), April 1936.

Harkness, Robert B.

1631. Natural gas in 1933: Ontario Dept. Mines 43d Ann. Rept. (vol. 43, pt. 5), 1934, pp. 1-51, 1935.

1632. Petroleum in 1933: Ontario Dept. Mines 43d Ann. Rept. (vol. 43, pt. 5), 1934, pp. 52-56, 1935.

1633. Natural-gas fields of Ontario: Geology of natural gas, pp. 59-87, 1 pl., 9 figs. (incl. maps), Am. Assoc. Petroleum Geologists, [June] 1935.

Hariton, Bruce $\mathrm{H}$.

1634. Carboniferous stratigraphy of the Ouachitas, with special study of the Bendian [abstract, with discussion]: Tulsa Geol. Soc. Digest, 1934, pp. 21-23, 1 fig.

Harper, Frances.

1635. (and Sutton, Arle Herbert). Ostracodes of the Morrison formation from the Black Hills, S. Dak.: Jour. Paleontology, vol. 9, no. 8, pp. 623-628, 1 pl., December 1935.

Harper, Francis.

1636. Physiographic and faunal areas in the Athabasca and Great Slave Lakes region [Canada]: Ecology, vol. 11, no. 1, pp. 18-32, 4 figs. (incl. index map), January 1931.

Harper, Margaret Frances.

1637. Problems in the origin of manganese, with foreword by Howard Augustus Meyerhoff: Rev. obras públicas de Puerto Rico, vol. 13, no. 8 , pp. 1383-1385, August 1936; no. 10 pp. 1436-1440, October 1936; no. 11, pp. 1462-1466, 4 figs., November 1936; no. 12, pp. 1488-1494, December 1936.

Harper, Roland McMillan.

1638. Bibliography of Alabama geology: Alabama Geol. Survey Bull. 42, pp. 59-108, January 1935.

1639. Precocity and longevity of American geologists (abstract): Pan-Am. Geologist, vol. 65, no. 3, p. 232, April 1936; Geol. Soc. America Proc., 1935, pp. 437-438, June 1936.

Harrell, Marshall Allen.

1640. Ground water in Indiana: Indiana Dept. Cons. Pub. 133, 504 pp. ( $\ddagger)$, 8 pls. (incl. geol. map), 1935. 
Harrington, Mark Raymond.

1641. Gypsum Cave, Nev.: Southwest Museum [Los Angeles] Papers, no. 8, ix, 197 pp., 19 pls., 77 figs. (incl. sketch map), April 1933.

Harris, D. V. See Howland, 1868.

Harris, Reginald Wilson.

1642. (and Worrell, Frank). A fossiliferous horizon from the lower Permian of Caddo County, Okla.: Jour. Paleontology, vol. 10, no. 6, pp. 518-519, 7 figs., September 1936.

Harris, Thomas Maxwell.

1643. The fossil flora of Scoresby Sound, east Greenland; pt. 4, Ginkgoales; Coniferales, Lycopodiales, and isolated fructifications: Meddelelser om Grönland, Band 112, Nr. 1, 176 pp., 29 pls., 53 figs., 1935 ; Copenhague Univ. Mus. minéralogie et géologie Comm. paléont. $54,1935$.

Harriss, Trewhitt Fairman.

1644. Reconnaissance in Sierra San Pedro Mártir [Mexico] [abstract] : Pan-Am. Geologist, vol. 63, no. 4, p. 317, May 1935; Geol. Soc. America Proc., 1935, p. 339, June 1936.

Harrold, L. L.

1645. Relation of stream flow to ground-water levels: Am. Geophys. Union Trans. 15th Ann. Meeting, pt. 2, pp. 414-416 ( $¥), 1$ fig., Nat. Research Council, June 1934.

Harstad, A. J.

1646. "Agates" and such: Rocks and Minerals vol., 11, no. 9, pp. 140-150, September-October 1936.

Hart, Lyman Herbert.

1647. (and Gidel, Murl Harold, and Perry, Eugene Sheridan). The Butte mining district, Mont.: Copper resources of the world, pp. 287-305, 1 pl. (geol. map), 4 figs. (iucl. maps), Washington, 16th Internat. Geol. Cong., 1935.

Hart, R. C. See Conolly, 840; Hawley, 1656.

Hart, Raymond M. See Knechtel, 2228 ; U. S. G. S., 4231.

Flartnagel, Chris Andrew. See Newland, 2868, 2869.

Hatton, J. $\mathbf{H}$.

1648. An inexpensive table for polishing ores: Am. Mineralogist, vol. 21, no. 12, pt. 1, pp. 800-808, 4 figs., December 1936.

Haury, Peter $\mathrm{S}$.

1649. (and Kelly, R. B.). Engineering report on the Smackover oil and gas field, Union and Ouachita Counties, Ark., 30 pp. (\$) , 9 pls. (incl. mans). U. S. Bur. Mines, in cooperation with the Chamber of Commerce, El Dorado, Ark., August 1924.

Hausman, Leon Augustus.

1650. Further studies of the hair of the fossil ground sloth (Nothotherium shastense) and of its problematical "ovate bodies": Am. Jour. Sci., 5th ser., vol. 31, no. 183, pp. 223-228, 4 figs., March 1936.

Hawkins, Alfred Cary. See also Berry, 299; Lewis, 2408.

1651. The book of minerals, $161 \mathrm{pp.,} 1 \mathrm{pl}$. (front.), 67 figs., New York, John Wiley \& Sons, Inc., 1935. 
Hawkins, Alfred Cary-Continued.

1652. Distribution of the heavy minerals in the clays of Middlesex County, N. J. : Am. Mineralogist, vol. 20, no. 5, pp. 334-353, 3 figs., May 1935 ; abstracts, no. 3, p. 208, March 1935; Geol. Soc. America Proc. 1934, p. 429, June 1935 .

1653. Some minerals of Delaware: Rocks and Minerals, vol. 11, no. 10, pp. 216-217, November 1936.

1654. Calcite twins from North Plainfield, N. J.: Am. Mineralogist, vol. 21, no. 12, pt. 1, 1 fig., pp. 809-811, December 1936; abstract, no. 3, p. 204, March 1936.

Hawkins, Herbert Leader.

1655. Paleontology and humanity: Pan-Am. Geologist, vol. 56, no. 3, pp. 161178, October 1936; no. 4, pp. 264-278, November 1936.

Hawley, James Edwin.

1656. (and Hart, R. C.). Cylindrical structures in sandstone; discussions by Hugh D. Miser, George Gaylord Simpson, and J. E. Hawley: Geol. Soc. America Bull., vol. 46, pp. 2008-2015, 1935.

Hayasaka, Ichirô.

1657. On some North American species of Lithostrotionella: Taihoku Imp. Univ. Mem., vol. 13, no. 5, Geol. no. 12, pp. 47-73, 7 pls., September 1936.

Haycock, Maurice Hall. See also Kidd, 2190.

1658. Microscopical character of pitchblende ore from Beaverlodge and Hottah Lakes, Northwest Territories, Canada: Canadian Min. Jour., vol. 56, no. 4, pp. 146-147, 2 figs., April 1935.

Haynes, Eli Stuart.

1659. The Archie, Mo., meteorite: Popular Astronomy, vol. 43, no. 3, pp. 181184, March 1935; Soc. Research on Meteorites Contr., fasc. 1 , pp. 11-14, January 1936.

Hazzard, John Charles.

1660. (and Mason, John Frederick). Middle Cambrian formations of the Providence and Marble Mountains, Calif.: Geol. Soc. America Bull., vol. 47, no. 2, pp. 229-240, 1 fig., February 29, 1936; abstract, Pan-Am. Geologist, vol. 63, no. 5, pp. 369-370, June 1935.

1661. (and Mason, John Frederick). "Goodsprings dolomite" of Nevada and its faunas [abstract] : Geol. Soc. America Proc., 1935, p. 378, June 1.936.

1662. (and Mason, John Frederick). Stratigraphy and lithology of the Middle Cambrian formations of the Providence and Marble Mountains, San Bernardino County, Calif. [abstract]: Geol. Soc. America Proc., 1935, pp. 408-409, June 1936.

Heald, Kenneth Conrad.

1663. Deep-rvell drilling problems and their solution: Oil Weekly, vol. 81, no. 13, pp. 19-20, 24, 26, 28-30, June 8, 1936; abstract, World Petroleum. vol. 7, no. 8, pp. 406, 408, August 1936.

Hecht, Franz E. See Bayley, 244.

Heck, Nicholas Hunter. See also Macelwane, 2519.

1664. Strong-motion records of Long Beach earthquake: Eng. News-Record, vol. 110, no. 14, pp. 442-443, 3 figs., April 6, 1933.

1665. (and Neumann, Frank). Destructive earthquake motions measured for the first time: Eng. News-Record, vol. 110, no. 25, pp. 804-807, 3 figs., June 22, 1933. 
Heck, Nicholas Hunter-Continued.

1666. The earthquake service of the northeast Pacific region: Fifth Pacific Sci. Cong., Canada, 1933, Proc., vol. 3, pp. 2357-2363, 3 figs. (maps), 1934.

1667. Recording strong earthquake motions: Fifth Pacific Sci. Cong., Canada, 1933, Proc., vol. 3, pp. 2429-2442, 15 figs., 1934.

1668. Seismological progress report: Am. Geophys. Union Trans. 15th Ann. Meeting, pt. 1, pp. 58-61 (京), National Research Council, June 1934.

1669. A new map of earthquake distribution: Geog. Rev., vol. 25, no. 1, pp. 125-130, 1 pl., map, January 1935.

1670. Earthquakes of the Appalachian Mountain region [abstract] : Geol. Soc. America Proc., 1934, pp. 446-447, June 1935.

1671. Progress in seismology of U. S. Coast and Geodetic Survey and cooperating institutions: Am. Geophys. Union Trans. 16th Ann. Meeting, pt. 1, pp. 96-99 (\$), Nat. Research Council, August 1935.

1672. Status of seismology in North America; special report for the Coast and Geodetic Survey [abstract]: Earthquake Notes, vol. 7, nos. 1-2, p. 22 (\$), September 1935.

1673. Symposium; Ishimoto's proposal for listing additional information from the seismograms [abstract]: Earthquake Notes, vol. 7, nos. 1-2, p. 24, (市), September 1935 .

1674. A review of outstanding problems in strong-motion vibration work: Seismol. Soc. America Bull., vol. 25, no. 4, pp. 343-347, October 1935.

1675. Investigations of strong earthquake motions in California [abstract]: Washington Acad. Sci. Jour., rol. 25, no. 11, p. 513, November 15, 1935.

1676. Montana earthquake of October 18, 1935: U. S. Coast and Geodetic Survey Field Eng. Bull. 9, pp. 38-39 (\$), 1 fig., December 1935.

1677. Earthquakes. xi, 222 pp., 88 figs. (incl. index maps), Princeton, N. J., Princeton Univ. Press, 1936.

1678. (and others). Earthquake investigations in California, 1934-35; U. S. Coast and Geodetic Survey Special Pub. 201, 231 pp., 2 pls. (index maps), 122 figs., 3 tables., 1936.

1679. (and McComb, Harold Edgar). Observations on recent progress in seismology [abstract] : Pan-Am. Geologist, vol. 65, no. 2 pp. 157158, March 1936; Geol. Soc. America Proc. 1935, p. 436, June 1936.

1680. The seismograph station at the University of Alaska at College, near Fairbanks: Seismol. Soc. America Bull., vol. 26, no. 2, pp. 125-127, 3 figs. (incl. index map), April 1936.

1681. Relation of earthquake belts of the Pacific and Indian Oceans to submarine topography: Am. Geophys. Union Trans. 17th Ann. Meeting, pt. 1, pp. 92-93 (t), 1 fig. (map), Nat. Research Council, July 1936 ; Earthquake Notes, vol. 8, nos. 1-2, pp. 92-93 ( $), 1$ fig. (map), June 1936.

Hedberg, Hollis Dow. See also Cushman, 942; Schenck, 3545.

1682. Gravitational compaction of clays and shales: Am. Jour. Sci., 5th ser., vol. 31, no. 184, pp. 241-287, 6 figs., April 1936; abstracts, PanAm. Geologist, vol. 63, no. 4, pp. 301-302, May 1935; Geol. Soc. America Proc., 1935, p. 326, June 1936.

1683. [Review of] Historical geology of the Antillean region, by Charles Schuchert, 1935: Jour. Paleontology, vol. 10, no. 6, pp. 535-537, September 1936. 
Hedley, J. D.

1684. Placedo oil field, Victoria County, Tex.: Am. Assoc. Petroleum Geologists Bull., vol. 19, no. 11, pp. 1693-1694, November 1935.

Hedley, M. S.

1685. Geological structure at Bralorne mine [British Columbia]: Canadian Inst. Min. Metallurgy Bull. 282, pp. 525-532, 3 figs. (incl. geol. sketch map of mine), October 1935.

Heiland, Carl August.

1686. Exploring with explosives; development and application of the seismic methods of geophysical prospecting: Explosives Engineer, vol. 13, no. 12 , pp. 359-371, 379, 19 figs., December 1935.

1687. Geophysical mapping from the air; its possibilities and advantages: Eng. and Min. Jour., vol. 136, no. 12, pp. 609-610, December 1935.

Heim, Arnold.

1688. Energy sources of the earth's crustal movements: 16th Internat. Geol. Cong. (1933) Rept., vol. 2, pp. 909-924, 4 figs., 1936.

Heineman, Robert Emil S.

1689. Sugarloaf Butte alunite: Eng. and Min. Jour., vol. 136, no. 3, pp. 138139, 2 figs. (incl. sketch map), March 1935.

1690. Petrography of the Roy, Harding County, N. Mex., meteorite: Am. Mineralogist, vol. 20, no. 6, pp. 438-442, 7 figs., June 1935.

Hellman, Edith. See Gregory, 1528.

Helson, Harry.

1691. On statistical methods of comparing heavy-mineral suites: Am. Jour. Sci., 5th ser., vol. 32, no. 191, pp. 392-395, November 1936.

Henbest, Lloyd George. See also U. S. G. \$., 4228.

1692. Nanicclla, a new genus of Devonian Foraminifera: Washington Acad. Sci. Jour., vol. 25, no. 1, pp. 34-35, January 15, 1935.

1693. Cyclical sedimentation and the stratigraphy of the Bloyd shale, Morrow group, near Fayetteville, Ark. [abstract] : Washington Acad. Sci. Jour., vol. 25, no. 11, pp. 511-513, November 15, 1935.

1694. Radiolaria in the Arkansas novaculite, Caballos novaculite, and Bigfork chert: Jour. Paleontology, vol. 10, no. 1, 76-78, January 1936.

Henderson, C. F. See Powers, 3120.

Henderson, Charles William.

1695. Mineral resources of Colorado: Mines Mag., vol. 26, no. 9, pp. 16-19, 3 figs. (incl. sketch mąps), September 1936.

Henderson, Edward Porter.

1696. (and Glass, Jewell Jeannette). Pyroxmangite from Idaho [abstract] : Am. Mineralogist, vol. 20, no. 3, p. 196, March 1935; Geol. Soc. America Proc., 1934, pp. 419-420, June 1935.

1697. Steigerite, a new vanadium mineral: Am. Mineralogist, vol. 20, no. 11, pp. 769-772, November 1935.

1698. (and Davis, Harry Towles). Moore County, N. C., meteorite, a new eucrite: Am. Mineralogist, vol. 21, no. 4, pp. 215-229, 1 fig., April 1936.

1699. (and Glass, Jewell Jeannette). Pyroxmangite, new locality; identity of sobralite and pyroxmangite: Am. Mineralogist, vol. 21, no. 5 , pp. 273-294, 3 figs., May 1936. 
Henderson, George Hugh.

1700. New types of pleochroic halos [abstract] : Royal Soc. Canada Proc., 3d ser., vol. 29, sec. 4, p. xcriii, 1935.

Henderson, James Fenwick.

1701. Guillet (Mud) Lake area, northern Quebec: Canada Dept. Mines, Geol. Survey Paper 36-11, 8 pp. ( $\$$ ), 1 pl. (geol. map dated April 1936), March 1936.

Henderson, John $\mathbf{R}$.

1702. Occurrences of hyalite in North Carolina: Rocks and Minerals, vol. 11. no. 4, pp. 56-58, April 1936.

Henderson, Junius, 1865-1937.

1703. Fossil nonmarine Mollusca of North America: Geol. Soc. America Special Paper 3, 313 pp., 1935.

1704. Are fishes the principal source of petroleum?: Science, new ser., vol. 81, no. 2094, pp. 176-177, February 15, 1935.

1705. Helisoma ammon (Gould) : Nautilus, vol. 50, no. 2, pp. 41-42, October 1936.

Henderson, Lyle $\mathbf{H}$.

1706. A geophysical survey on the Santa Rita [Calif.] ore body: Mining Cong. Jour., vol. 17, no. 2, pp. 77-78, 87, 3 figs. (incl. geol. map), February 1931.

Hendricks, Thomas Andrews. See also Dane, 971 ; Knechtel, 2228; U. S. G. S. $4230,4231,4232,4234$.

1707. Some features of stratigraphy in the Arkansas-Oklahoma coal basin [abstract, with discussion] : Tulsa Geol. Soc. Digest, 1934, pp. 24-27.

1708. Carbon ratios in part of Arkansas-Oklahoma coal field: Am. Assoc. Petroleum Geologists Bull., vol. 19, no. 7, pp. 937-947, 1 fig. (isocarb map), July 1935.

1709. (and Dane, Carle Hamilton, and Knechtel, Maxwell McMichael). Stratigraphy of Arkansas-Oklahoma coal basin: Am. Assoc. Petroleum Geologists Bull., vol. 20, no. 10, pp. 1342-1356, 5 figs. (incl. index map), October 1936.

Hengst, Jess H. See Bass, 221 ; U. S. G. S., 4237, 4238.

Hennebique, J. J.

1710. Littoral drift; an explanation of its action in denuding and building up ocean beaches: Civil Eng., vol. 4, no. 3, pp. 159-161, 3 figs., March 1934.

Hennes, Robert Graham.

1711. Analysis and control of landslides: Washington Univ., Eng. Exper. Sta. ser., Bull. 91, 57 pp., 17 figs., June 1936.

Heritsch, Franz.

1712. A new species of Waagenophyllum from the Permian of the Glass Mountains, Tex.: Am. Jour. Sci., 5th ser., vol. 31, no. 182, pd. 144-148, 1 fig., February 1936.

1713. A new rugose coral from the lower Permian of Texas, with remarks on the stratigraphic significance of certain Permian coral genera: Am. Jour. Sci., 5th ser., vol. 82, no. 188, pp. 134-144, 17 figs., August 1936.

Hernon, Robert M.

1714. The Paradise formation and its fauna: Jour. Paleontology, vol. 9, no. 8, pp. 653-696, 3 pls. 1 fig. (index map), December 1935. 
Herold, C. Lathrop.

1715. Geology of Salinas quadrangle, Calif. [abstract] : Pan-Am. Geologist, vol. 63, no. 4, pp. 315-316, May 1935; Geol. Soc. America Proc., 1935, pp. 337-338, June 1936.

1716. Distribution of Eocene rocks in Santa Lucia Mountains, Calif.: Am. Assoc. Petroleum Geologists Bull., vol. 20, no. 4, pp. 491-494, 1 fig. (geol. map), April 1936.

Herold, Stanley Carrollton. See Hoots, 1792.

Heroy, William Bayard.

1717. [The petroleum reserves of the United States]: Am. Assoc. Petroleum Geologists Bull., vol. 19, no. 5, pp. 717-725, 4 figs., May 1935.

Herrera y Fritot, René.

1718. Excursiones geológicas en las provincias de la Habana y Pinar del Río [Cuba] : Soc. cubana hist. nat. "Felipe Poey", Mem., vol. 6, nos. 1-2, pp. 63-74, 6 figs. ; nos. 3-4, pp. 157-164, 5 figs., 1924.

Hertlein, Leo George. See also Palmer, 2995.

1719. Three new sections and rectifications of some specific names in the Pectinidae: Nautilus, vol. 50, no. 1, pp. 24-27, July 1936; no. 2, pp. 54-58, October 1936.

Hershey, H. Garland. See Cloos, E., 783.

Hess, Frank L.

1720. Lithium in North Carolina : Eng. and Min. Jour., vol. 137, no. 7, pp. 339-342, 3 figs. (incl. index map), July 1936.

Hess, Harry Hammond. See aiso Phillips, 3073; 3074.

1721. The problem of serpentinization: Econ. Geology, vol. 30, no. 3, pp. 320-325, 1 fig., May 1935.

1722. Plagioclase; pyroxene, and olivine variation in the Stillwater complex [Montana] [abstract] : Am. Mineralogist, vol. 21, no. 3, pp. 198199, March 1936.

1723. (and MacClintock, Paul). Submerged valleys on continental slopes and changes of sea level: Science, new ser., vol. 83, no. 2153, pp. 332-443, April 3, 1936.

Hesse, Curtis Julian.

1724. An immatare mastodon from the Ogallala Pliocene: Jour. Mammalogy, vol. 16, no. 1, pp. 61-63, 2 figs., February 1935.

1725. A vertebrate fauna from the type locality of the Ogallala formation: Kansas Unir. Sci. Bull., vol. 22, no. 5, pp. 79-118, 8 pls., April 15, 1935 ; abstract, Geol. Soc. America Proc., 1934, p. 382, June 1935.

1726. Capromeryx altidens (Matthew) possible ancestor of Antilocapra americana [abstract]: Geol. Soc. America Proc., 1934, p. 383, June 1935.

1727. Seminotus cf. gigas, from the Triassic of Zion Park, Utah: Am. Jour. Sci., 5th ser., vol. 29, no. 174, pp. 526-531, 1 fig., June 1935.

1728. Triassic fish fauna of western North America [abstract] : Pan:Am. Geologist, vol. 63, no. 5, pp. 379-380, June 1935 ; Geol. Soc. America Proc., 1935, p. 417, June 1936.

1729. New evidence on the ancestry of Antilocapra americana: Jour. Mammalogy, vol. 16, no. 4, pp. 307-315, 4 figs., November $15,1935$.

1730. (and Welles, S. P.). The first record of a dinosaur from the west coast: Science, new ser., vol. 84 , no. 2172, pp. 157-158; August 14, 1936.

$311-37-9$ 


\section{Hesse, Curtis Julian-Continued.}

1731. A new species of the genus Priscacara from the Eocene of Washington: Jour. Geology, vol. 44, no. 6, pp. 745-7.50, 1 pl., August-September 1936.

1732. Lower Pliocene vertebrate fossils from the Ogallala formation (Lavern zone) of Beaver County, Okla.: Carnegie Inst. Washington Contr. Paleontology, Pub. 476, pp. 47-72, 10 figs. (incl. geol. sketch map), preprint, October 30, 1936.

Hewett, Donnel Foster.

1733. Economic geology : Am. Year Book, 1934, pp. 730-731, 1935.

1734. Manganese oxides and the circulation of ground water [abstract]: Washington Acan. Sci. Jour., vol. 25, no. 12, pp. 565-566, December $15,1935$.

1735. (and Callaghan, Eugene, Moore, B. N., Nolan, T. B., Rubey, W. W., and Schaller, W. T.). Mineral resources of the region around Boulder Dam: U. S. Geol. Survey Bull. 871, 197 pp. 17 pls. (incl. geol. maps), 52 figs. (incl. sketch maps), 1936.

Heyl, George Richard.

1736. Geology and mineral deposits of the Bay of Exploits area [Newfoundland] : Newfoundland Dept. Nat. Res., Geol. Sec. Bull. 3, 66 pp. (\$), 1 pl. (geol. map), 14 figs: (incl. geol. maps), 1936.

Hickey, Maude. See Barton, 203.

Hiestand, T. C.

1737. Regional investigations, Oklahoma and Kansas: Am. Assoc. Petroleum Geologists Bull., vol. 19, no. 7, pp. 948-970, 12 figs (incl. paleogeologic maps), July 1935.

Higgy, Robert C.

1738. (and Shipley, E. D.). Radio-transmission survey of Ohio: Ohio State Univ., Eng. Exper. Sta. Bull. 92, 18 pp., 13 figs. (incl. index maps), May 1936.

Hilder, A. E.

1739. Mattagami River [Ontario] refractory clays; recent investigations and future development: Canadian Inst. Min. Metallurgy Trans., vol. 38, pp. 110-122, 4 figs. (incl. index maps), 1935.

Hill, Mason Lowell.

1740. Origin of faulting in the Kettleman Hills, Calif. [abstract]: Geol. Soc. America Proc., 1934, pp. 322-323, June 1935.

Hillis, Donuil.

1741. A colorimetric method for determination of relative saturation of oil sands [abstract]: Am. Assoc. Petroleum Geologists Bull., vol. 19, no. 12, p. 1842, December 1935.

Hills, John Moore.

1742. The insoluble residues of the Cambro-Ordovician limestones of the Lehigh Valley, Pa.: Jour. Sedimentary Petrology, vol. 5, no. 3, pp. 123-132, 3 figs. (incl. geol. map), December 1935.

Hinchey, Norman.

1743. (and Ray, Louis L.). New Mississippian species of Strophalosia from Missouri : Jour. Paleontology, vol. 9, no. 3, pp. 247-250, 21 figs., April 1935. 
Hind, S. R.

1744. Some factors in the weathering of clay shales: Ceramic Age, vol. 22, no. 6, pp. 169-171, December 1933.

Hinds, Norman Ethan Allen.

1745. Researches on Algonkian formations of Grand Canyon National Park [abstract] : Carnegie Inst. Washington Year Book 34, pp. 326-329, 1935.

1746. Mesozoic and Cenozoic eruptive rocks of the southern Klamath Mountains, Calif.: California Univ., Dept. Geol. Sci. Bull., vol. 23, no. 11, pp. 313-380, 1 pl. (geol. map), 16 figs., April 20, 1935.

1747. Geology of the Weaverville district, northern California [abstract] : Geol. Soc. America Proc., 1934, pp. 315-316, June 1935.

1748. Late Cenozoic history of the southern Klamath Mountains [abstract]: Geol. Soc. America Proc., 1934, p. 319, June 1935.

1749. Ep-Archean and ep-Algonkian intervals in western North America: Carnegie Inst. Washington Pub. 463, pp. 1-52, 11 pl., 7 figs., preprint, August 20, 1935; abstract, Geol. Soc. America Proc., 1934, pp. 319-320, June 1935.

1750. Cambrian-Algonkian uuconformity in western North America [abstract] : Geol. Soc. America Proc., 1935, pp. 353-354, June 1936.

Hitchcock, Charles B. See Boyd, 409; Forbes, 1304.

Hitchin, Charles Stanfield.

1751. The pegmatites of Fitchburg, Mass. : Am. Mineralogist, vol. 20, no. 1, pp. 1-24, 7 figs., 1 pl., January 1935.

Hite, Thomas $\mathrm{H}$.

1752. (and Waring, Gerald Ashley). Gold-placer mining on Snake River in Idaho: Econ. Geology, vol. 30, no. 6, pp. 695-699, SeptemberOctober 1935.

Hlauscheck, Hans.

1753. [Review of] Naphthene and methane oils, their geological occurrence and origin, by Hans Hlauscheck, 1936: Am. Assoc. Petroleum Geologists Bull., vol. 20, no. 11, pp. 1499-1501, November 1936.

Ho, T. L.

1754. A rapid method for the determination of plagioclase by the Federov universal stage: Am. Mineralogist, vol. 20, no. 11, pp. 790-798. 3 figs., November 1935.

Hoagland, A. D. See Stark, 3831.

Hobbs, William Herbert.

1755. The glaciers of mountain and continent: Zeitschr. Gletscherkunde, Band 22, pp. 1-19, 1 fig., March 1935.

1756. Glacial anticyclones about Pleistocene continental glaciers of North America [abstract] : Geol. Soc. America Proc., 1934, pp. 81-82, June 1935.

1757. A call for information concerning etched erratic boulders: Jour. Geology, vol. 43, no. 5, pp. 551-552, 2 figs., July-August 1935.

1758. [Review of] Geologie von Grönland, by Lauge Koch, 1935: Jour. Geology, vol. 44, no. bै, pp. 758-760, August-September 1936.

Hobson, Henry David. See also Cushman, 942.

1759. (and Rankin, W. D.). Notes on the stratigraphy of the Sespe CreekPiru Creek area [Calif.] [abstract] : Am. Assoc. Petroleum Geologists Bull., vol. 20, no. 11, p. 1519, November 1936. 
Hodge, Edwin Thomas. See also Treasher, 4160 .

1760. Volcanic and seismic history of Oregon: Fifth Pacific Sci. Cong.; Canada, 1933, Proc., vol. 3, pp. 2451-2460, 4 figs. (incl. maṕs), 1934.

1761. Report on available raw materials for a Pacific coast iron industry. War Dept., Corps of Engineers, U. S. Army, Office of Division Engineer, North Pacific Div., 4 vols. (\$), illus., Portland, Oreg., October 15, 1935.

1762. The mines and ore deposits of Oregon [abstract]: Geol. Soc. Oregon Country News Letter, vol. 1, no. 18, pp. 1a-4 (†), 1 fig. (geol. sketch), December 21, 1935.

1763. Origin of the Washington scablands [abstract] : 16th Internat. Geol. Cong. (1933) Rept., vol. 2, p. 1105, 1936.

1764. Bibliography of Oregon geology: Geol. Soc. Oregon Country News Letter, vol. 2, no. 6, pp. 1-21 ( $\$)$, March 9, 1936.

1765. (and Wilkinson, W. D., and Felts, Wayne M.) Igneous-rock relations: Geol. Soc. Oregon Country News Letter, vol. 2, no. 11, pp. 11-12 (\$), 1 chart, June 10, 1936 .

Hodgkins, Blanche.

1766. Hawaii lava-flow observations: Mineralogist, vol. 4, no. 9, pp. 9-10, September 1936.

Hodgson, Ernest Atkinson.

1767. The precision of the seismological evidence as to the structure of the deep interior of the earth [abstract]: Earthquake Notes, vol. 7, nos. 1-2, p. 16, (\$), September 1935.

1768. Status of seismology in North America, special report for the Dominion of Canada [abstract] : Earthquake Notes, vol. 7, nos. 1-2, p. 21 ( $)$, September 1935.

1769. The Timiskaming earthquake of November 1, 1935; the location of the epicenter and determination of focal depth: Royal Astron. Soc. Canada Jour., vol. 30 , no. 4, pp. 113-123, 7 pls., 3 figs. (incl. index map), January 9, 1936; abstract, Pan-Am. Geologist, vol. 65, no. 3, pp. 235-236, April 1936.

1770. Preliminary report of the earthquake of November 1, 1935: Earth= quake Notes, vol. 7, no. 4, pp. 1-4 ( $\$)$, March 1936 ; abstract, Geol. Soc. America Proc., 1935, pp. 438-439, June 1936.

1771. Progress report on the research connected with the Timiskaming earthquake of November 1, 1935; Am. Geophys. Union Trans. 17th Ann. Meeting, pt. 1, p. 76 ( $\ddagger)$, Nat. Research Council, July 1936; Earthquake Notes, vol. 8, nos. 1-2, p. 76 ( $\$)$, June 1936.

Høeg, Ove Arbo.

1772. Notes on some arctic fossil wood, with a redescription of Cupressinoxylon polyommatum Cramer: Norges Svalbard- $\emptyset \mathrm{g}$ Ishavs-unders $\phi-$ kelser Meddelelse, Nr. 17, 9 pp., 3 pls., 1 fig., 1932.

Hoffmeister, John Edward. See also Ladd, 2286.

1773. (and Ladd, Harry Stephen). The foundations of atolls; a discussion: Jour. Geology, vol. 43, no. 6, pp. 643-665, August-September 1935.

Hohl, C. D. See Broderick, 462, 465.

Holden, Roy Jay.

1774. The silicification of a fault surface in the vicinity of Blacksburg, Va.

[abstract]: Virginia Acad. Sci., Proc. 1934-35, p. 59 [1935]. 
Holden, Roy Jay-Continued.

1775. Algonkian formations of the Blue Ridge of Virginia [abstract] : Virginia Acad. Sci. Proc., 1935-36, p. 66, 1936.

1776. A Devonian fold in Virginia [abstract]: Virginia Acad. Sci. Proc., 1935-36, pp. 66-67, 1936.

1777. Time location of orogeny in the central Appalachians [abstruct, with discussion] : 16th Internat. Geol. Cong. (1933) Rept., vol. 2, pp. 994-995, 1 fig., 1936.

Holdredge, Claire.

1778. Crescent Lake and vicinity [Oregon]: Geol. Soc. Oregon Country News Letter, vol. 2, no. 17, pp. 6-8, September 10, 1936.

Holland, Wilbur C.

1779. The ostracods of the Nineveh limestone of Pennsylvania and West Virginia [abstract] : Pittsburgh Univ. Bull., vol. 30, no. 2, pp. 508509, November 15, 1933.

Hollick, Charles Arthur, 1857-1933.

1780. The Tertiary floras of Alaska, with a chapter on the geology of the Tertiary deposits, by Philip: S. Smith: U. S. Geol. Survey Prof. Paper 182, 185 pp., 122 pls. (incl. geol. map), 1936.

Hollister, John Chamberlain.

1781. Some notes on reflection seismology: Engineers' Bull. (Colorado Soc. Eng.), vol. 19, no. 3, pp. 4, 30, March 1935.

Hollister, Joseph Steffens. See Ashauer, 98; Reed, 3221, 3228, 3231.

Holman, George E.

1782. Mineral collecting at Newry, Maine, past and present: Rocks and Minerals, vol. 10, no. 7, pp. 97-99, July 1935.

Holmes, Arthur.

1783. When will Lassen Peak again erupt?: Sci. Monthly, vol. 40, no. 1, pp. 21-32, 16 figs., January 1935.

1784. Geological time and former glaciations in relation to evolution of solar system [abstract] : Pan-Am. Geologist, vol. 56, no. 3, pp. 230-231, October 1936.

Holmes, Chauncey D.

1785. Glacial and interglacial development of Chittenango Falls State Park in central New York: Am. Jour. Sci., 5th ser., vol. 29, no. 169, pp. 41-47, 2 figs. (incl. topog. map), January 1935; abstract, Geol. Soc. America Proc., 1934, pp. 82-83, June 1935.

Holmes, Ralph J.

1786. X-ray study of arsenides and antimonides of nickel and cobalt [abstract]: Am. Mineralogist, vol. 20, no. 3, p. 198, March 1935; Geol. Soc. America Proc. 1934, p. 422, June 1935.

Holmgren, L. E. See Andrews, 70.

Holtedahl, Olaf.

1787. A new example of submarine fault line along a continental border [Greenland] : Norske vidensk. selskab. Forh., Band 8, 1935, Nr. 27, pp. 91-93, 1 map, 1936.

Honess, Arthur Pharoah.

1788. (and Williams, Francis J.). Dickite from Pennsylvania: Am. Mineralogist, vol. 20, no. 6, pp. 462-466, June 1935; Pennsylvania State College, Min. Indus. Exper. Sta. Tech Paper 18, 1935. 
Hooton, Earnest Albert.

1789. Homo sapiens-whence and whither?: Science, new ser., vol. 82, no. 2115, pp. 19-31, July 12, 1935.

Hoots, Harold William. See also Barton, 212.

1790. (and Blount, A. L; and Jones, P. H.). Marine oil shale, source of oil in Playa del Rey field, Calif., Am. Assoc. Petroleum Geologists Bull., vol. 19, no. 2, pp. 172-205, 11 flgs. (incl. maps), February 1935.

1791. (and Blount, A. L., and Jones, P. H.). Determination of carbon and hydrogen in substances of a bituminous or pyro-bituminous nature occurring in shales: Am. Assoc. Petroleum Geologists Bull., vol. 19, no. 2, pp. 293-295, February 1935.

1792. (and Herold, Stanley Carrollton). Natural-gas resources of California : Geology of natural gas, pp. 113-220, 4 pls., 32 figs. (incl. geol. maps), Am. Assoc. Petroleum Geologists, [June] 1935.

1793. Recent discoveries and present oil supply in California: Am. Assoc. Petroleum Geologists Bull., vol. 20, no. 7, pp. 939-950, 4 figs., July 1936.

Hoover, Jonas Wenger.

1794. Physiographic provinces of Arizona: Pan-Am. Geologist, vol. 65, no. 5, pp. 321-335; abstract, p. 379, June 1936.

Hoover, W. Farrin.

1795. Petrography and distribution of a highly weathered drift in the Kansas River Valley: Jour. Sedimentary Petrology, vol. 6, no. 3, pp. 143153, 3 figs., 5 tables, December 1936.

Horton, Robert Elmer. See also Baker, 154.

1796. Symposium on fluctuations of ground-water; Maximum ground-water levels: Am. Geophys. Union Trans. 17th Ann. Meeting, pt. 2, pp. $344-357$ ( $\$), 10$ figs., Nat. Research Council, 1936.

1797. Natural stream-channel storage: Am. Geophys. Union Trans. 17th Ann. Meeting, pt. 2, pp. 406-415 (\$), 5 figs., Nat. Research Council, 1936.

Horwood, Hereward Clarence.

1798. A pre-Keewatin (?) tonalite: Royal Soc. Canada Trans., 3d ser., vol. 29, sec. 4, pp. 139-147, 1 fig. (geol. map), May 1935; abstract, Proc., vol. 29 , p. c, 1935.

1799. Geology and mineral deposits at the mine of B. C. Nickel Mines, Ltd., Yale district, B[ritish] C[olumbia]: Canada Dept. Mines, Geol. Survey Mem. 190, Pub: 2414, 15 pp., 1 pl. (geol. map), 1936.

1800. South part of Fraser River-Harrison Lake region, British Columbia: Canada Dept. Mines, Geol. Survey Paper 36-4, 8 pp. (†), 1 pl. (geol. map), February 1936.

1801. Nahatlatch region [British Columbia] : Canada Dept. Mines, Geol. Survey Paper 36-7, 5 pp. ( $\$), 1$ pl. (geol. map), February 1936.

1802. Granitization in the Cross Lake region, Manitoba: Royal Soc. Canada Trans., 3d ser., sec. 4, vol. 30, pp. 99-117, 8 figs. (incl. geol. map). May 1936; abstract, Proc. p. xcvii, 1936.

Hoskins, E. E. See Byerly, 617, 618.

Hoskins, Homer A. See Price, 3130.

Hoskinson, Albert J.

1803. Gravity survey at Crosbyton, Tex.: Jour. Geology, vol. 43, no. 4, pp. 436439, 1 fig. (map), May-June 1935. 
Hoskinson, Albert J.-Continued.

1804. Recent developments in gravity instruments : Am. Geophys. Union Trans. 17th Ann. Meeting, pt. 1, pp. 44-45 ( $\$)$, Nat. Research Councll, July 1936.

Houdek, Paul King.

1805. Pollen statistics from two bogs in southwestern Michigan: Michigan Acad. Sci. Papers, vol. 20, pp. 49-56, 2 figs., 1935.

1806. Pollen analysis of some water-deposited sediments: Ecology, vol. 16, no. 1, pp. 28-32, 3 figs., January 29, 1935.

Hougen, Bernhard Orlando.

1807. Insoluble residues from Wisconsin sedimentary rocks; pt. 2, Studies of Wisconsin sedimentary rocks, no. 3, A sedimentational study of part of the Trempealeau formation in southern Wisconsin: Wisconsin Acad. Sci. Trans., vol. 29, pp. 266-268, 1 fig., 1935.

Hough, Frederick H.

1808. The morphology of phenacite from two new occurrences: Am. Mineralogist, vol. 20, no. 12, pp. $863-874,8$ figs., December 1935.

Hough, Jack Luin.

1809. The bottom deposits of southern Lake Michigan: Jour. Sedimentary Petrology, vol. 5, no. 2, pp. 57-80, 4 figs. (incl. sketch maps), August 1935; abstract, Illinois Acad. Sci. 'Trans., vol. 28 , no. 2, p. 197, December 1935.

Houghland, Everett.

1810. A report on a geologic reconnaissance of the St. Helens mining district, Wash.: Washington Dept. Cons. and Devel., Geol. Rept. Inv. 3, 4 pp. ( $\$), 1$ pl. (geol. map), October 1, 1935.

Houk, Lawrence G.

1811. [Review of] Mining geology outlined, by S. Frank Hunt, 1936; Mining and Metallurgy, vol. 17, no. 360, p. 592, December 1936.

Howard, Arthur David.

1812. The deposits of Hayden Valley, in Yellowstone National Park: Science, new ser., vol. 83, no. 2143, p. 80, January 24, 1936.

1813. History of the Grand Canyon of the Yellowstone [abstract]: Geol. Soc. America Proc., 1934, p. 83, June 1935.

Howard, Edgar Billings. See also Schultz, 3591.

1814. Evidence of early man in North America: Museum Jour., vol, 24, nos. 2-3, pp. 61-175, 26 pls. (incl. contour maps), 1935.

1815. Present status of the problem of early man in America [abstract]: Geol. Soc. America Proc., 1934, pp. 83-84, June 1935.

1816. The occurrence of flints and extinct animals in pluvial deposits near Clovis, N. Mex., pt. 1, Introduction: Acad. Nat. Sci. Philadelphia Proc., 1935, vol. 87, pp. 299-303, October 10, 1935.

1817. Early man in America: Am. Philos. Soc. Proc., vol. 76, no. 3, pp. 327$333 ; 1936$.

1818. Early human remains in the southwestern United States: 16th Internat. Geol. Cong. (1983) Rept., vol. 2, pp. 1325-1333, 1936.

1819. (and others). Early man in America, with particular reference to the southwestern United States [a symposium]: Am. Naturalist, vol. 70, no. 729, pp. 313-371, 22 figs., July-August 1936.

1820. The association of a human culture with an extinct fauna in New Mexico: Am. Naturalist, vol. 70, no. 729, pp. 314-323, 3 figs., JulyAugust 1936. 
Howard, Edgar Billings-Continued.

1821. The antiquity of man in America: Sci. Monthly, vol. 43, no. 4, pp. 367371 , 3 figs., October 1936; reprinted in Carnegie Inst. Washington Suppl. Pub. 26, October 15, 1936.

Howard, Hildegarde.

1822. A new species of eagle from a Quaternary cave deposit in eastern Nevada : Condor, vol. 37, no. 4, pp. 206-209, 3 figs., July-August 1935.

1823. The Rancho La Brea wood ibis: Condor, vol. 37, no. 5, pp. 251-253, 4 figs., September-October 1935.

1824. Further studies upon the birds of the Pleistocene of Rancho La Brea : Condor, vol. 38, no. 1, pp. 32-36, January-February 1936.

1825. A new fossil bird locality near Playa del Rey, Calif., with description of a new species of sulid: Condor, vol. 38 , no. 5, pp. 211-214, 1 fig., September-October 1936.

1826. A new record for Parapavo californicus (Miller): Condor, vol, 38, no. 6, pp. 249-250, November-December 1936.

Howard, Joseph Whitney.

1827. The search for sapphires: Rocks and Minerals, vol. 11, no. 8, pp. 118-120, August 1936.

Howard, Paul J.

1828. Report on Buena Vista Hills, a portion of the Midway-Sunset oil field [Calif.] : California Oil Fields, vol. 20, no. 4, pp. 5-22, 7 pls. (incl. geol. sketch maps), April, May, June, 1935.

Howard, Waldorf Vivian. See also Can. G. S., 662.

1829. Crystallographic expression of results of the theory of space groups [abstract] : Am. Mineralogist, vol. 20, no. 3, p. 212, March 1935; Geol. Soc. America Proc. 1934, p. 433, June 1935.

1830. (and David, Max W.). Development of porosity in limestones: Am. Assoc. Petroleum Geologists Bull., vol. 20, no. 11, pp. 1389-1412, 11 figs., November 1936.

1831. Possibilities for oil production in the Illinois basin: Oil and Gas Jour., vol. 35 , no. 26 , pp. $76,78,80,195,3$ figs. (incl. geol. sketch maps), November 12, 1936.

Howe, Henry Van Wagenen. See also Russell, 3442.

1832. The genus Bolivinella in the Oligocene of Mississippi: Jour. Paleontology, vol. 4, no. 3, pp. 263-267, 1 pl., September 1930.

1833. Review of Tertiary stratigraphy of Lousiana: Am. Assoc. Petroleum Geologists Bull., vol. 17, no. 6, pp. 613-655, June 1933; reprinted in Gulf coast oil fields (see Barton and Sawtelle), pp. 383-424, 1936.

1834. Bairdia subdeltoidea (Münster) in the American Tertiary: Jour. Paleontology, vol. 8, no. 3, pp. 388-389, 1 fig., September 1934.

1835. (and McGuirt, James Holland). Salt domes of Cameron and Vermilion Parishes: Louisiana Dept. Cons. Geol. Bull. 6, pp. 73-166, 1 pl., 16 figs. (incl. index maps), 1935.

1836. (and others). Geology of Cameron and Vermilion Parishes; Bibliography : Louisiana Dept. Cons. Geol. Bull. 6, pp. 205-216, 1935.

1837. The relationship of the Vicksburg group to the formations which overlie it in Mississippi [abstract] : Am. Assoc. Petroleum Geologists Bull., vol. 19, no. 1, pp. 138-139, Januar.; 1935. 
Howe, Henry Van Wagenen-Continued.

1838. (and Chambers, Jack). Louisiana Jackson Eocene Ostracoda: Louisiana Dept. Cons. Geol. Bull. 5, vii, 65 pp., 6 pls., August 1, 1935.

1839. (and others). Ostracoda of the Arca zone of the Choctawhatchee Miocene of Florida: Florida Dept. Cons. Geol. Bull. 13, 47 pp., 4 pls., September 10, 1935.

1840. (and Russell, Richard Joel, and McGuirt, James Holland). . Geology of Cameron and Vermilion Parishes; Physiography of coastal southwest Louisiana: Louisiana Dept. Cons. Geol. Bull. 6, pp. 1-72, 7 pls. (incl. phys. maps), 1 fig. (index map), November 1, 1935; reviewed by Donald C. Barton, Am. Assoc. Petroleum Geologists Bull., vol. 20, no. 6, p. 838, June 1936.

1841. Ostracoda of the genus Eucythere from the Tertiary of Mississippi: Jour. Paleontology, vol. 10, no. 2, pp. 143-145, 7 figs., March 1936.

1842. Louisiana petroleum stratigraphy: Oil and Gas Jour., vol. 34, no. 48, pp. 98-111, 124-126, 9 figs. (maps), April 16, 1936.

1843. Stratigraphic evidence for-Gulf coast geosyncline [abstract]: Geol. Soc. America Proc., 1935, p. 82, June 1936.

1844. The foraminiferal genus Palmula Isaac Lea, 1833 : Jour. Paleontology, .vol. 10, no. 5, pp. 415-416, 2 figs., July 1936; abstract, Geol. Soc. America Proc., 1935, p. 363, June 1936.

1845. Karl Etienne Young [1903-1936]: Am. Assoc. Petroleum Geologists Bull., vol. 20, no. 8, pp. 1150-1152, 1 fig. (port.), August 1936.

1846. (and Law, John, and others). Louisiana Vicksburg Oligocene Ostracoda : Louisiana Dept. Cons. Geol. Bull, 7, 96 pp., 6 pls., August 18, 1936.

Howe, Oliver $\mathrm{H}$.

1847. The Hingham red felsite boulder train: Science, new ser., vol. 84, no. 2183, pp. 394-396, October 30, 1936.

Howell, Alfred Brazier.

1848. On the faunal position of the Pacific coast of the United States: Ecology, vol. 8, no. 1, pp. 18-26, January 1927.

Howell, Benjamin Franklin. See also Lochman, 2432 ; Ruedemann, 3413.

1849. New Middle Cambrian agnostian trilobites from Vermont: Jour. Paleontology, vol. 9, no. 3, pp. 218-221, 1 pl., April 1935; abstract, Geol. Soc. America Proc., 1934, p. 351, June 1935.

1850. Some New Brunswick Cambrian agnostians: Wagner Free Inst. Sci. Bull., vol. 10, no. 2, pp. 13-16, 1 pl., May 1935.

1851. Proceedings of the 26th annual meeting of the Paleontological Society, held at Rochester, N. Y., December 27, 28, and 29, 1934: Geol. Soc. America Proc., 1934, pp. 341-394, June 1935.

1852. (and Dunn, Paul Heaney). Early Cambrian Foraminifera from Greenland and Labrador [abstract]: Geol. Soc. America Proc., 1934, pp. 350-351, June 1935.

1853. (and Resser, Charles Elmer). Genera of the order Agnostia [abstract] : Geol. Soc. America Proc., 1934, pp. 353-354, June 1935.

1854. (and Richards, Horace Gardiner). Fauna of the Pleistocene Champlain sea in Vermont [abstract]: Geol. Soc. America Proc., 1934, p. 374, June 1935.

1855. A new Paradoxides from the Cambrian of New Brunswick: Wagner Free Inst. Sci. Bull., vol. 10, no. 4, pp. 37-38, 1 pl., November 1935; abstract, Geol. Soc. America Proc., 1935, p. 370, June 1936. 
Howell, Benjamin Franklin-Continued.

1856. (and Landes, R. W.). New monactellid sponges from the Ordovician of Wisconsin: Jour. Paleontology, vol. 10, no. 1, pp. 53-59, 21 figs., January 1936; abstract, Geol. Soc. America Proc., 1935, pp. 364-36y, June 1936.

1857. (and Knight, James Brookes). Harttites, new name for Harttia Walcott, preoccupied: Wagner Free Inst. Sci. Bull,, vol. 11, no: 2, pp. 5-8, 2 figs., May 1936.

1858. Proceedings of the 27th annual meeting of the Paleontological Society, held at New York, N. Y., December 26-28, 1935: Geol. Soc. America Proc., 1935, pp. 355-406, June 1936.

1859. (and Landes, R. W.). Allogenotype, a new term [abstract] : Geol. Soc. America Proc., 1935, p. 372, June 1936.

1860. (and Shimer, Hervey Woodburn, and Lord, G. S.). New Cambrian Paradoxides fauna from eastern Massachusetts [abstract]: Geol. Soc. America Proc., 1935, p. 385, June 1936.

1861. (and Lochman, Christina). Upper Cambrian faunas of Montana and Wyoming [abstract]: Geol. Soc. America Proc., 1935, pp. 388-389, June 1936.

1862. (and Lochman, Christina). Succession of late Cambrian faunas in the northern hemisphere [abstract]: Geol. Soc. America Proc., 1935, pp. 389-390, June 1936.

1863. A new trilobite from the Lower Cambrian of Alberta: Wagner Free Inst. Sci. Bull., vol. 11, no. 4, pp. 29-30, 2 pls.; November 1936; abstract, Geol. Soc. America Proc., 1935, p. 373, June 1936.

Howell, Jesse V. See also Kansas Geol. Soc., 2020.

1864. (and Thwaites, Frederik Turville). Structural map on top of the preCambrian [upper Mississippi Valley]: Kansas Geol. Soc. Guide. book 9th Ann. Field Conf., pl. opp. p. 354 ( $¥), 1935$.

1865. (and Thwaites, Frederik Turville, and Jones, Daniel Johnathan). Structural map on top of the St. Peter sandstone [upper Missis. sippi Valley] : Kansas Geol. Soc. Guidebook 9th Ann. Field Conf., pl. opp. p. $360(\ddagger), 1935$.

1866. The Mississippi River arch: Kansas Geol. Soc. Guidebook 9th Ann. Field Conf., pp. 386-389 ( $¥$ ), 2 pls. (geol. maps), 3 flgs., 1935.

Howells, H. C.

1867. Foremost-Skiff area, southern Alberta: Canada Dept. Mines, Geol. Survey Paper 36-13, 12 pp. ( $\ddagger), 1$ pl., April 1936.

Howland, Arthur Lloyd. See aiso Stark, 3834, 3836.

1868. (and Harris, D. V., and Stark, John Thomas). Bedrock geology of southern South Park [Colo.] [abstract] : Geol. Soc. America Proc., 1934, p. 84, June 1935.

1869. (and Peoples, Joe Webb, and Sampson, Edward). The Stillwater igneous complex and associated occurrences of nickel and platinumgroup metals: Montana Bur. Mines and Geology Misc. Contr. 7, v. 15 pp. ( $\ddagger), 1$ pl. (geol. map), April 1936.

1870. An occurrence of barite in the red beds of Colorado: Am. Mineralogist, vol. 21 , no. 9, pp. 584-588, 3 figs. (incl. index map), September 1936 ; abstract, Geol. Soc. America Proc., 1934, p. 423, June 1935.

Howse, Claude K. See Douglas, 1076. 
Hoyt, John Clayton.

1871. Droughts of 1930-34: U. S. Geol. Survey Water-Supply Paper 680, 106 pp., 4 pls., 102 figs., 1936.

Hrdlička, Aleš.

1872. Anthropological excavations on .Kodiak Island [Alaska] [abstract]:

Science, new ser., vol. 82, no. 2139, pp. 620-621, December 27, 1935.

Hubbard, George David.

1873. Sketch of the life and work of Dr. Frank Carney [1868-1934]: Ohio Jour. Sci., vol. 35, no. 4, pp. 273-274, July 1935.

Hubbert, Marion King.

1874. (and Weller, James Marvin). Location of faults in Hardin County, Ill., by earth-resistivity method [abstract]: Am. Inst. Min. Met. Eng. Year Book Sec., p. 90, 1935.

1875. Determination of certain structural features in Illinois, Kentucky, and Alabama by electrical resistance methods [abstract] : Washington Acad. Sci. Jour., vol. 25, no. 11, pp. 506-507, November 15, 1935.

Hudson, Noel Paul. See Roy, 3396.

Huene, Friedrich von.

1876. Ein Plesiosaurier-rest aus grönlandischen oberem Jura: Meddelelser om Grönland, Band 99, Nr. 4, 11 pp., 5 figs. (incl. sketch map), 1935.

Huey, Arthur S:

1877. The stratigraphy of the Tesla quadrangle near Tracy, Calif. [abstract] : Am. Assoc. Petroleum Geologists Bull., vol. 20, no. 11, p. 1520, November 1936.

Hughes, Guy.

1878. Rare petrified wood: Mineralogist, vol. 3, no. 9, p. 21, September 1935,

Hughes, Harry Herbert.

1879. A green building stone: Stone, vol. 55, no. 4, pp. 160-162, April 1934.

Hughson, W. G. See Miller, 2695.

Hulin, Carlton D.

1880. Geologic features of the dry placers of the northern Mojave Desert: California Jour. Mines and Geology, vol. 30, no. 4, October 1934, pp. 416-426, 2 figs., 1935 :

1881. Mechanics of fault movements [abstract] : Geol. Soc. America Proc., 1934, p. 323, June 1935.

Hull, Callie.

1882. (and West, Clarence Jay). Doctorates conferred in the sciences by American universities, 1932-33: Nat. Research Council Reprint and Circ. ser. 105, 63 pp., 1933.

Hume, George Sherwood.

1883. Central Turner Valley and some types of foothills' faults: Royal Soc. Canada Trans., 3d ser., vol. 29, sec. 4, pp. 129-138, 3 figs., May 1935.

1884. The west half of Wildcat Hills map area, Alberta: Canada, Dept. Mines, Geol. Survey Mem. 188, Pub. 2412, 15 pp., 4 pls. (incl. geol. maps), 2 figs., 1936. 
Hume, George Sherwood-Continued.

1885. (and Hage, Conrad Olai), Eagle Hills anticline, Battleford area, Saskatchewan: Canada Dept. Mines, Geol. Survey Paper 35-3, 13 pp. (\$) 1 pl. (geol. map), 1936.

1886. Battleview anticline, Wainwright area, Alberta: Canada Dept. Mines, Geol. Survey Paper 36-10, 16 pp. ( $\$$ ), 1 pl. (geol. map), 1936.

Humphrey, Harry Baker.

1887. The phytogeography of the Coeur d'Alene flood plain of northern Idaho: Ecology, vol. 5, no. 1, pp. 6-13, 4 figs. (incl. index map), January 1924.

Hunt, Charles Butler.

1888. Geology and fuel resources of the southern part of the San Juan Basin, N. Mex. ; pt. 2, The Mount Taylor coal field: U. S. Geol. Survey Bull. 860-B, pp. vi, 31-80, 20 pls. (incl. geol. maps), 2 figs., 1936.

Hunt, S. Frank. See also Houk, 1811.

1889. Mining geology outlined. 129 pp., 1 fig. (port.). Privately printed, complimentary ed., [1936].

Hunt, Walter Frederick. See Kraus, 2258.

Hunter, Charles Eugene.

1890. (and Mattocks, Philip Ward). Clay resources of Tennessee Valley Authority region, pt. 1; Geology and kaolin deposits of Spruce Pine and Linville Falls quadrangles, North Carolina: Tennessee Valley Authority, Div. Geology Bull. 4, pp. 10-23, 1 pl. (index - map), October 1936.

Hunter, Coleman D.

1891. Natural gas in eastern Kentucky: Geology of natural gas, pp. 915-939, 10 figs. (incl. geol. maps), Am. Assoc. Petroleum Geologists, [June] 1935.

Huntington, Richard Lee.

1892. Estimation of oil and gas reserves: California Oil World, vol. 29, no. 20, pp. 24-26, December 3, 1936.

Huntsman, Archibald Gowanlock.

1893. On the formation of lake balls: Science, new ser., vol. 82 , no. 2122, pp. 191-192, August 30, 1935.

Hunzicker, A. A. See Shrock, 3700.

Hurlbut, Cornelius Searle, Jr. See also Larsen, 2339.

1894. Dark inclusions in a tonalite of southern California : Am. Mineralogist, vol. 20 , no. 9 , pp. 609-630, 10 figs. (incl. geol. map), September 1933 ; abstracts, no. 3, p. 205, March 1935 ; Geol. Soc. America Proc., 1934, pp. 84-85, June 1935.

1895. Differentiation in the Shonkin Sag laccolith [Montana] [abstract]: Am. Mineralogist, vol. 21, no. 3, p. 198, March 1936.

1896. A new phosphate, bermanite, occurring with triplite in Arizona: Am. Mineralogist, vol. 21, no. 10, pp. 656-661, 2 figs., October 1936.

1897. X-ray determination of the silica minerals in submicroscopic intergrowths: Am. Mineralogist, vol. 21, no. 11, pp. 727-730, 4 figs., November 1936.

Hurst, Macleod Ewart.

1898. Vein formation at Porcupine, Ontario: Econ. Geology, vol. 30, no. 2, pp. 103-127, 8 figs., March-April 1935. 
Hurst, Macleod Ewart-Continued.

1899. Recent studies in the Porcupine area [Ontario]: Canadian Min. Met. Bull. 291, pjp. 448-458, 1 pl. (geol. map), 1 fig., July 1936.

Hutt, G. M.

1900. (and Seibert, Fred V.). Industrial and fuel minerals of Manitoba: Canadian Min. Met. Bull. 266, pp. 316-332, June 1936.

Hyatt, Don. L.

1901. Preliminary report on the Fitts pool, Pontotoc County, Okla.: Am. Assoc. Petroleum Geologists Bull., vol. 20, no. 7, pp. 951-974, 14 figs., (incl. geol. sketch maps), July 1936; abstract, World Petroleum, vol. 7, no. 9, p. 442, September 1936.

Ide, John McDonald.

1902. Comparison of statically and dynamically determined Young's modulus of rocks: Nat. Acad. Sci. Proc., vol. 22, no. 2, pp. 81-92, 1 fig., February 15, 1936.

1903. The elastic properties of rocks; a correlation of theory and experiment: Nat. Acad. Sci. Proc., vol. 22, no. 8, pp. 482-496, 1 fig., August 1936.

Imbeaux, Charles Edouard Augustin.

1904. Les eaux souterraines et leurs gîtes: Cong. internat. mines, mét., Geol. appliquée, sec. Géol. appliquée, $7^{\circ}$ sess., tome 2 , pp. 635-644, 2 figs. (geol. maps), 1936.

Imlay, Ralph Willard. See also Kellum, 2057.

1905. Evolution of the Coahuila Peninsula, Mexico; pt. 4, Geology of the western part of the Sierra de Parras: Geol. Soc. America Bull., vol. 47, no. 7, pp. 1091-1152, 10 pls. (incl. geol. map), 3 figs. (index and physiographic maps), July 31, 1936; abstract, Proc., 1935, p. 83, June 1936.

Ingerson, Earl. See also Morey, 2795.

1906. Layered peridotitic laccoliths of the Trout River area, Newfoundland: Am. Jour. Sci., 5th ser., vol. 29 , no. 173 , pp. 422-440, 6 figs. (incl. geol. map), May 1935.

Ireland, Hubert Andrew.

1907. Use of insoluble residues for correlation in Oklahoma: Am. Assoc. Petroleum Geologists Bull., vol. 20, no. 8, pp. 1086-1121, 14 figs. (incl. index map), August 1936.

Irland, George Allison.

1908. A study of some seismometers [abstract] : Am ;. Geophys. Union Trans. 16th Ann. Meeting, pt. 1, pp. 99-100 ( $\$)$, Nat. Research Council, August 1935.

Irving, John. See Larsen, 2340.

Isham, Charles A.

1909. Geophysics and modern divining-rod bunk; Min. Jour., vol. 19, no. 10, p. 5, 1 fig., Phoenix, Ariz.; October 15, 1935.

Israelsky, Merle Catheart.

1910. Upper Cretaceous Ostracoda: Arkansas Geol. Survey Bull. 2, pp. 475496, 4 pls. (Extract, 20 pp., published by Arkansas Geol. Survey, 1929 ; revised, 1931; Appendix to Spooner, W. C., Oil and gas geology of the Gulf Coastal Plain in Arkansas), Little Rock, Ark., 1935 . 
Israelsky, Merle Catheart-Continued.

1911. [Review of] Guidebook of the 11th annual field trip of the Shreveport Geological Society in southeast Mississippi : Am. Assoc. Petroleum Geologists Bull., vol. 19, no. 4, pp. 571-575, April 1935.

1912. Tentative foraminiferal zonation of subsurface Claiborne of Texas and Louisiana: Am. Assoc. Petroleum Geologists Bull., vol. 19, no. 5, pp. $689-695$; 5 figs., Maý 1935; reprinted in Gulf coast oil fields (see Barton and Sawtelle), pp. 425-431, 1936.

Iversen, Johannes.

1913. Moorgeologische Untersuchungen auf Grönland: Dansk geol. Forening Meddel., Bind 8, Hefte 4, pp. 341-358, 6 figs., 1934.

Ives, Ronald L.

1914. Fluorine minerals of Colorado: Rocks and Minerals, vol. 10, no. 6, pp. 83-85, 3 figs., June 1935.

1915. Recent volcanism in northwestern Mexico: Pan-Am. Geologist, vol. 63, no. 5, pp. 335-338, 1 pl., 1 fig. (geol. map), June 1935.

1916. The Boulder, Colo., tungsten area: Rocks and Minerals, vol. 10, no. 8 , pp. 113-115, 1 fig., August 1935.

1917. Some past and present glaciers of Colorado: Rocks and Minerals, vol. 10, no. 9, pp. 129-137, 5 figs., September 1935.

1918. Desert floods in the Sonoyta Valley [Sonora, Mexico]: Am. Jour. Sci., 5 th ser., vol. 32 , no. 191, pp. 349-360, 4 figs. (incl. index map), November 1936.

1919. The radium-mining area of southwestern Colorado: Rocks and Minerals, vol. 11, no. 10, pp. 223-224, November 1936.

Ivy, John Smith.

1920. The Rodessa fleld [Tex.] : Oil Weekly, vol. 81, no. 5, pp. 21-28; 7 figs. (incl. index map), April 13, 1936.

1921. The Rodessa field: Oil and Gas Jour., vol. 34, no. 48, pp. 70, 72, 75, 9 figs. (incl. index and structure maps), April 16, 1936.

Jackson, Floretta A. See Gregory, 1528.

Jackson, R. J.

1922. (and others). Memorial to Dr. Cleophas C. O'Harra [1866-1935]: Black Hills Eng., vol. 22, no. 4, pp. 213-228, port., June 1935.

Jackson, Robert Tracy.

1923. Report on the fossil echinoderms: Harvard Coll. Mus. Comp. Zoology Ann. Rept., 1934-35, pp. 45-46, 1935.

1924. Report on the fossil echinoderms: Harvard Coll. Mus. Comp. Zoology Ann. Rept., 1935-36, p. .45, 1936.

Jacobs, Elbridge Churchill.

1925. Vermont peneplain [abstract]: Geol. Soc. Ameria Proc., .1934, p. 85, June 1935.

1926. Green Mountains of, northern Vermont [abstract] : Geol. Soc. America Proc., 1934, p. 85, June 1935.

Jacy, Stephen.

1927. Gold prospecting (quartz and placer); a practical field book for beginners as well as the more experienced class of prospectors. 145 pp., 12 figs., Portland, Oreg., Ryder Printing Co., 1934; 2d ed., 244 pp., 15 figs. [1936]. 
Jaggar, Thomas Augustus, Jr.

1928. The bombing of Mauna Loa, 1935: Military Engineer, vol. 28, no. 160, pp. 241-245, 8 figs. (incl. index map), July-August, 1936.

Jakosky, John Jay.

1929. (and Wilson, Clyde H.). Electrical mapping of oil structures : Mining and Metallurgy, vol. 17, no. 353, pp. 231-237, 10 figs., May 1936; abstract, Worid.Petroleum, vol. 7, no. 6, p. 331, June 1936.

1930. (and Armstrong, H. K.). Geoelectric exploration in the Tejon Ranch area, Calif. [abstract] : Am. Assoc. Petroleum Geologists Bull., vol. 20, no. 11, p. 1519, November 1936.

James, William Fleming. See Canada, G. S. 649.

Jarvis, P. W. See Cushman, 942.

Jeffreys, Harold.

1931. The seismology of the Pacific [with discussion by J. B. Macelwane, pp. 2533-2538] : Fifth Pacific S'ci. Cong., Canada, 1933, Proc., vol. 3 , pp 2523-2526, 1934.

Jenkins, Harold D. See U. S. G. S., 4237, 4238.

Jenkins, Olaf Pitt.

1932. Geologic branch, current notes: California Jour. Mines and Geology, vol. 30, no. 4, October 1934, p. 329, 1935.

1933. Geologic branch, current notes: California Jour. Mines and Geology, vol. 31, no. 1, p. 50, January 1935.

1934. Progress of the State geologic map of California [abstract]: Am. Assoc. Petroleum Geologists Bull., vol. 19, no. 1, p. 135, January 1935; Pan-Am. Geologist, vol. 63, no. 4, pp. 314-315, May 1935; Geol. Soc. Oregon Country News Letter, vol. 2, no. 11, pp. 6-7 ( $)$ June 10, 1936; Geol. Soc. America Proc., 1935, p. 337, June 1936.

1935. Geologic branch, current notes: California Jour. Mines and Geology, vol. 31, no. 2, pp. 112-114, April 1935.

1936. New technique applicable to the study of placers: California Jour. Mines and Geology, vol. 31, no. 2, pp. 143-210, 1 pl. (geol. map), 33 flgs. (incl. geol. and sketch maps), April 1935.

1937. Resurrection of early surfaces in the Sierra Nevada [abstract]: Geol. Soc. America Proc., 1934, p. 338, June 1935.

1938. Geologic branch, current.notes: California Jour. Mines and Geology, vol. 31, no. 3, p. 339, July 1935.

1939. Geologic branch, current notes: California Jour. Mines and Geology, vol. 31 , no. 4, p. 486 , October 1985.

1940. Geologic branch, current notes: California Jour. Mines and Geology, vol. 32, no. 1, p. 98, January 1936.

1941. Geologic branch, current notes: California Jour. Mines and Geology, vol. 32, no. 2, p. 127, April 1936.

Jenks, Albert Ernest. See Eddy, 1134.

Jenks, Wiliam F. See also Gibson, 1418.

1942. Pegmatites at Collins Hill, Portland, Conn.: Am. Jour. Sci., 5th ser., vol. 30, no. 177, pp. 177-197, 7 figs., September 1935.

Jenney, Phillip. See also Kerr, 2079. 
Jenney, Charles Phillip.

1943. Geology of the central Humboldt Range, Nev.: Nevada Univ. Bull. vol. 29 , no. 6, 73 pp., 1 pl. (geol. map), 33 figs. (incl. sketch map), December 28, 1935.

Jennings, Philip Hennen.

1944. A microfauna from the Monmouth and basal Rancocas groups of New Jersey: Bull. Am. Paleontology, vol. 23, no. 78, 76 pp., 7 pls., October 21, 1936.

Jenny, William Paul.

1945. Some practical examples of magnetic prospecting: Oil and Gas Jour., vol. 33, no. 49, pp. 33-34, 48, 8 figs., April 25, 1935.

1946. Micromagnetic surveys: Oil Weekly, vol. 81 , no. 7, pp. 23-31, 8 figs., April 27, 1936; abstract, World Petroleum, vol. 7, no. 6, p. 331, June 1936.

Jepsen, Glenn Lowell. See also Scott, 3612.

1947. A revision of the American Apatemyidae and the description of a new genus, Sinclairella, from the White River Oligocene of South Dakota: Am. Philos. Soc. Pro., vol. 74, no. 4, pp. 287-305, 3 pls., 4 figs., August 1934.

Jessen, Knud. See Bøggild, 360.

Jewett, John M.

1948. Some measurements at the Sun City natural bridge: Kansas Acad. Sci. Trans., vol. 38, pp. 189-190, 1935.

1949. (and Williams, Charles C.). Water resources of Johnson County during the drought of 1934: Kansas Acad. Sci. Trans., vol. 38, pp. 191-198, 11 figs., 1935.

1950. (and Newell, Norman Dennis). Geology of Wyandotte County, Kans.: Kansas Geol. Survey Bull. 21, pp. 151-205, 11 pls. (incl. geol. maps), 2 figs. (index maps), May 15, 1935.

Jewitt, W. See Bruce, 502.

Jillson, Willard Rouse.

1951. The big bones of northern Kentucky: Kentucky State Hist. Soc. Register, vol. 33, no. 104, pp. 181-190, July. 1935.

1952. Big Bone Lick; an outline of its history, geology, and paleontology, to which is added an annotated bibliography of 207 titles. 164 pp., 3 pls. (incl. maps), 1 fig. (map), Louisville, Ky., Standard Printing Co., Inc., 1936.

Joerg, Wolfgang Louis Gottfried.

1953. The geography of North America; a history of its regional exposition: Geog. Rev., vol. 26, no. 4, pp. 640-663, October 1936.

Johansson, A. Erik V.

1954. Upper Devonian fossiliferous localities in Parallel Valley on Gauss Peninsula, east Greenland, investigated in the summer of 1934: Meddelelser om Grönland, Band 96, Nr. 3, 36 pp., 3 pls. (incl. geol. maps), 6 figs., 1935.

Johnson, Bertrand Leroy.

1955. Potash : U. S. Bur. Mines Econ. Paper 16, 78 pp., 1 fig., 1933.

1956. Glacial launching of the Fort Liscum landslide [abstract]: Geol. Soc. America Proc., 1934, p. 447, June 1935.

Johnson, Bradley.

1957. Autunite in Mitchell County, N. C.: Rocks and Minerals, vol. 11, no. 5, pp. 76-77, May 1936. 
Johnson, Curtis Herman.

1958. Nomographic solution for apparent dip in vertical section not perpendicular to strike: Am. Assoc. Petroleum Geologists Bull., vol. 20, no. 6, pp. 816-818, 1 fig., June 1936.

Johnson, Douglas Wilson. See also Moore, 2776.

1959. Peneplain or peneplane? [abstract] : Geol. Soc. America Proc., 1934, p. 86, June 1935.

1960. The changing sea level; a review and discussion: Geog. Rev., vol. 26, no. 2, pp. 299-301, April 1936.

1961. (and Bates, Robert E.). Correlation of erosion surfaces in southwestern Wisconsin [abstract]: Science, new ser., vol. 83, no. 2160, pp. 484-485, May 22, 1936.

1962. Interpretation of knickpoints and valley-in-valley forms [abstract] : Geol. Soc. America Proc., 1935, pp. 83-84, June 1936.

1963. Origin of the supposed meteorite scars of [South] Carolina: Science, new ser., vol. 84, no. 2166, pp. 15-18, July 3, 1936 ; abstract, Geol. Soc. America Proc., 1935, p. 84, June 1936.

Johnson, Earl s.

1964. History, geology, and mining methods of the Moscow silver mines in Utah: Mining and Metallurgy, vol. 17, no. 352, pp. 187-190, 4 figs., April 1936.

Johnson, F. A.

1965. Merced formation from Santa Rosa Valley to the Pacific [abstract] : Geol. Soc. America Proc., 1934, p. 315, June 1935.

Johnson, Frank Walker.

1966. The status of the name "Valentine" in Tertiary geology and paleontology : Am. Jour. Sci., 5th ser., vol. 31, no. 186, pp. 467-475, 2 figs. (incl. index map), June 1936.

Johnson, Helgi.

1967. New species from the Cataract formation of Ontario [abstract]: Geol.

Soc. America Proc., 1935, p. 391, June 1936.

Johnson, James Franklin.

1968. Geology of the Marshall district, Boulder County, Colo. [abstract]: Colorado Univ. Studies, vol. 23, no. 1, p. 36, November 1935.

Johnson, James H. See also Stow, 3957.

1969. Heavy minerals from some Paleozoic formations [abstract] : Virginia Acad. Sci. Proc., 1934-35, p. 68 [1935].

Johnson, Jesse Harlan. See also Bryant, 530; Stark, 3834, 3836.

1970. Paleozoic formations of the Mosquito Range, Colo.: U. S. Geol. Survey Prof. Paper 185-B, pp. 15-43, 1 fig., 7 pls., 1934.

1971. Introduction to the geology of the Golden area, Colo., Colorado School of Mines Quart., vol. 29, no. 4, 36 pp., 3 pls., 9 figs., October 1934.

1972. Stratigraphy of South Park [Colo.] [abstract]: Geol. Soc. America Proc., 1.934, p. 86, June 1935.

1973. Discovery of graptolites in Colorado [abstract]: Geol. Soc. America Proc., 1934, pp. 354-355, June 1935.

1974. Stratigraphy of northeastern and east-central parts of South Park, Colo.: Am. Assoc. Petroleum Geologists Bull., vol. 19, no. 9, pp. 1339-1356, 1 fig. (index map), September 1935.

1975. Algae as rock builders, with notes on some algal limestones from Colorado: Colorado Univ. Studies, vol. 23, no. 3, pp. 217-222, 3 figs., April 1936.

$311-37-10$ 
Johnson, Meredith E.

1976. The mineral industry of New Jersey for 1933 : New Jersey Dept. Cons.; Geol. ser. Bull. 42, 20 pp., 4 pls., 1935.

1977. The mineral industry of New Jersey for 1934 : New Jersey Dept. Cons., Geol. ser. Bull. 43, 24 pp., 4 pls., 1936.

Johnson, William Russell.

1978. The Ostracoda of the Missouri series in Nebraska: Nebraska Geol. Survey Paper 11, 52 pp., 5 pls., 1936.

Johnson, W. R., Jr.

1979. (and Straley, Harrison Wilson, III). An attempt to locate the boundaries of the Durham [N. C.] Triassic basin with a magnetometer: Am. Geophys. Union Trans. 16th Ann. Meeting, pt. 1, pp. 176-181 ( $\ddagger$ ), 5 figs., Nat. Research Council, August 1935; abstract, Elisha Mitchell Sci. Soc. Jour., vol. 50, no. 1/2, pp. 222-223, December 1934.

Johnston, Ashton William.

1980. Preliminary report on a geological exploration of Seal River, northern Manitoba: Canada Dept. Mines, Geol. Survey Paper 35-2, 3 pp. ( $\$)$, 1 pl. (geol. map), December 1935.

Johnston, C. Stuart. See also Stovall, 3951.

1981. An extension in the range of fossil peccaries: Am. Midland Naturalist, vol. 16, no. 1, pp. 117-119, 2 figs., January 1935.

Johnston, Leslie A.

1982. Pre-Pennsylvanian stratigraphy of the Hollow Pool and adjacent areas of the central Kansas basin [abstract, with discussion]: Tulsa Geol. Soc. Digest, 1934, pp. 12-17, 2 pls.

Johnston, William Alfred.

1983. Western extension of Patrician glaciation: Pan-Am. Geologist, vol. 63, no. 1, pp. 13-18, 1 fig. (geol. map), February 1935.

Johnston, William Drumm, .Jr. See also Prindle, 3137; Urry, 4244.

1984. Copper in Trinity County, Calif.: Copper resources of the world, p. 251, Washington, 16th Internat. Geol. Cong., 1935.

1985. Hydrothermal mineralization at Graves Mountain [Ga.] [abstract] : Am. Mineralogist, vol. 20, no. 3, p. 201, March 1935; Geol. Soc. America Proc., 1934, pp. 86-87, June 1935.

1986. Nodular, orbicular, and banded chromite in northern California : Econ. Geology, vol. 31, no. 4, pp. 417-427, 7 figs., June-July 1936.

Jolliffe, Fred.

1987. A study of greenalite: Am. Mineralogist, vol. 20 , no. 6 , pp. $405-425,4$ figs., June 1935; abstract, no. 3, p. 207, March 1935; Geol. Soc. America Proc., 1934, p. 428, June 1935.

1988. Yellowknife River area, Northwest Territories: Canada Dept. Mines, Geol. Survey Paper 36-5, 10 pp. ( $\$), 1$ pl. (geol. map), 1936.

Jonas, Anna Isabel. See also Stose, 3947, 3948.

1989. Hypersthene granodiorite in Virginia: Geol. Soc. America Bull., vol. 46, no. 1, pp. 47-60, 1 fig. (geol. map), 4 pls., January 31, 1935; abstract, Washington Acad. Sci. Jour., vol. 24, no. 11, pp. 489-490, November 15, 1934.

1990. Pre-Devonian structural zones in Scotland and eastern North America : Washington Acad. Sci. Jour., vol. 25, no. 4, pp. 166-173, April 15, 1935. 
Jonas, Anna Isabel-Continued.

1991. (and Stose, George Willis). Appalachian structure in southeastern Pennsylvania [abstract]: Geol. Soc. America Proc., 1934, p. 87, June 1935.

1992. Pre-Triassic volcanic rocks of the southern Appalachians [abstract] : Am. Geophys. Union Trans. 16th Ann. Meeting, pt. 1., p. 284 ( $\ddagger)$, Nat. Research Council, August 1935.

1993. (and Stose, George Willis). Age reclassification of the Frederick Valley (Maryland) limestones: Geol. Soc. America Bull., vol. 47, no. 10, pp. 1657-1674, 7 figs., (incl. geol. maps), October 31,1936 ; abstract, Proc., 1935, pp. 84, 379, June 1936.

Jones, Arthur C.

1994. Minerals in medicine: Geol., Soc. Oregon Country News Letter, vol. 2, no. 18, pp. 3-11 ( $)$, September 25, 1936.

Jones, Austin Emery.

1995. A seismologic study of the Kilauea eruption, 1931-32: Hawaii Univ. Research Pub. 9, 60 pp., 9 figs., 1935.

1996. Hawaiian travel times: Seismol. Soc. America Bull., vol. 25, no. 1, pp. 33-61, 4 figs. (incl. sketch map), January 1935.

1997. Earthquakes associated with the 1934 eruption of Kilauea, Hawaii : Washington Acad. Sci. Jour., vol. 25, no. 10, pp. 429-435, 2 figs. (incl. index map), October 15, 1935.

Jones, B. G.

1998. Common errors of inexperienced personnel in the compilation of air photographs: U. S. Coast and Geodetic Survey Field Eng. Bull. 9, pp. $40-43(\ddagger)$, December 1935.

Jones, Daniel John.

1999. Some asteriaform fossils from the Francis formation of Oklahoma: Am. Midland Naturalist, vol. 16, no. 3, pp. 427-428, May 1935.

Jones, Daniel Johnathan. See also Howell, 1865 ; Kansas Geol. Soc., 2020.

2000. (and Wilder, N. M., and Maurice, John F.). Mountain bumps in the coal fields of Harlan County, Ky.: Kentucky Dept. Mines and Minerals, Geol. Div., ser. 8, Bull. 1, 26 pp. ( $), 11$ pls., December 1, 1934.

Jones, Islwyn Winwaloc.

2001. Marsoui map area, Gaspé Peninsula: Quebec Bur. Mines Ann. Rept., 1933, pt. D, pp. 1-40, 5 pls. (incl. geol. map), 1934.

2002. Summary report on north-central Gaspé: Quebec Bur. Mines Ann. Rept., 1933, pt. D, pp. 41-54, 1934.

2003. Darthmouth River map area, Gaspé Peninsula: Quebec Bur. Mines. Ann. Rept., 1934, pt. D, pp. 3-44, 4 pls. (incl. geol. map), 1935; also in French ed., 1935.

2004. Geology of north central Gaspé [abstract] : Geol. Soc. America Proc., 1934, pp. 447-448, June 1935.

2005. Microscopic features of certain Alberta coals: Canadian Jour. Research, vol. 14, sec. B, no. 8, pp. 277-298, 3 pls., August 1936.

Jones, Jeannette A.

2006. Ordovician starfish of Wisconsin: Jour. Paleontology, vol. 9, no. 7, pp. 593-595, 1 pl. (in part), October 1935.

Jones, Owen Thomas. See Thom, 4076.

Jones, P. H. See Hoots, 1790, 1791; Pyle, 3155. 
Jones, Richard $\cdot A$.

2007. The Sarnosa oil field [Tex.]; the geological features and development: Oil Weekly, vol. 75, no. 8, pp. 55-57, 2 figs. (incl. sketch map), November 5, 1934.

2008. Interesting features in Somerset [Tex.] field, one of country's big shallow pools: Oil and Gas Jour., vol. 34, no. 48, pp. 175-176, 1 fig. (index map), April 16, 1936.

Jones, Verner Everett.

2009. Origin of the gypsum deposits near Sandusky, Ohio: Econ. Geology, vol. 30, no. 5, pp. 493-501, 6 figs., August 1935.

Jones, Victor Harlan. See Glymph, 1454, 1455, 1456.

Jones, Walter Bryan.

2010. History and work of geological surveys and industrial development in Alabama: Alabama Geol. Survey Bull. 42, pp. 1-58, 7 pls., January 1935.

Jongmans, Willem Josephus.

2011. (and Van der Gracht, W.). Carboniferous floras of the United States and of western Europe [abstract]: Geol. Soc. America Proc., 1984, p. 366, June 1935 .

2012. Major divisions of the Paleozoic era, Middle Paleozoic; Floral correlations and geobotanic provinces within the Carboniferous [with discussion] : 16th Internat. Geol. Cong. (1933) Rept., vol. 1, pp. 519-527, 2 pls. (correl. tables), 1936.

Joralemon, Ira Beaman.

2013. Veins and faults in the Bralorne mine [with discussion]: Am. Inst. Min. Met. Eng. Trans., vol. 115 (Mining geology), pp. 90-105, 3 figs., 1935; abstract, Year Book sec., p. 60, January 1936.

Juárez, J. Vicente.

2014. (and Arreola, Vicente). Estudio de la zona minera de Indé y Santa María del Oro, Estado de Durango: Rev. industrial [Mexico], vol. 1, no. 1, pp. 1-34, 28 figs. (incl. maps), July 1933.

Judson, Sidney Arthur.

2015. (and Stamey, Roderick A.). Overhanging salt on domes of Texas and Louisiana : Am. Assoc. Petroleum Geologists Bull., vol. 17, no. 12, pp. 1492-1520, 13 figs., December 1933; reprinted in Gulf coast oil fields (see Barton and Sawtelle), pp. 141-169, 1936.

Jung, F. W. See Fieldner, 1255.

Kane, William G. See also Kellum, 2057.

2016. (and Gierhart, Guy Balcer). Areal geology of Eocene in northeastern Mexico: Am. Assoc. Petroleum Geologists Bull., vol. 19, no. 9, pp. 1357-1388, 4 figs. (incl. geol. map), September 1935; reprinted in Gulf coast oil fields (see Barton and Sawtelle), pp. 588-619, 1936. 2017. Structural geology of border province of northeastern Mexico adjacent to Zapata and Starr Counties, Texas: Am. Assoc. Petroleum Geologists Bull., vol. 20, no. 4, pp. 403-416, 2 figs. (incl. geol. map), April 1936 ; abstract, World Petroleum, vol. 7, no. 7, p. 368, July 1936.

2018. Wells drilled in northeastern Mexico: Am. Assoc. Petroleum Geologists Bull., vol. 20, no. 4, p. 478, April 1936.

Kania, Joseph Ernest Anthony.

2019. Some notes on the origin of pyritic copper deposits of the mesothermal type: Econ. Geology, vol. 31, no. 5, pp. 453-471, August 1936. 
Kansas Geological Society. See also item 2024.

2020. Guidebook 9th annual field conference, upper Mississippl Valley, Iowa City, Iowa, to Duluth, Miss., August 25 to September 1, $471 \mathrm{pp}$. ( $¥)$, illus. (incl. geol. maps), 1935. Includes the following papers:

Atwater, Gordon I. The Keweenawan-Upper Cambrian unconformity in the upper Mississippi Valley, pp: $316-319,1 \mathrm{pl}$. (geol. map) ; A summary of the stratigraphy and structure of the Gogebic iron range; Michigan and Wisconsin, pp. 417-420, 4 figs.

Ball, John Rice. Isopach map of the Galena, Decorab, and Platteville, pp. 346-347, 1 map.

Bays, .Carl A. (and Raasch, Gilbert 0.). Mohawkian relations in Wisconsin, pp. 296-301.

Behre, Charles Henry, Jr. The geology and development of the Wisconsin-Illinois lead-zinc district, pp. 377-382, 3 figs. (incl. index map).

Bevin, Arthur Charles. Cambrian inlier at Oregon, Ill., pp. 383-385.

Edwards, Ira. Isopach maps of the Trempealeau, Franconia, and Dresbach formations, 2 maps opp. p. 352.

Howell, Jesse V. (and Thwaites, Fredrik Turville). Structural map on top of the pre-Cambrian, opp. p. 354; (and Thwaites, Fredrik Turville, and Jones, Daniel Johnathan). Structural map on top of the St. Peter sandstone, opp. p. 360 ; The Mississippi River arch, pp. 386-389, 2 pls. (geol. maps), 3 figs.

Kay, George Marshall. Ordovician system in the upper Mississippi Valley, pp. 281-295, 1 fig. (correl. table).

Ladd, Harry Stephen. Isopach map of the Maquoketa shale, pp. 342344, map.

Lamar, John Everts. Isopach map of St. Peter formation, opp. p. 348.

Laudon, Lowell Robert. Supplemental statement on the Mississippian system in Iowa, pp. 246-247.

Leith, Andrew. The pre-Cambrian of the Lake Superior region, the Baraboo district, and other isolated areas in the upper Mississippi Valley, pp. 320-332, 1 pl,, 1 fig. (geol. maps).

Moore, Raymond Cecil. The Mississippian system in the upper Mississippi Valley region, pp. 239-245.

Powers, Elliot H. Isopach map of the Prairle du Chien group, opp. p. 350 ; Stratigraphy of the Prairie du Chien, pp. 390-394, 2 figs. (geol. and isopach maps).

Raasch, Gilbert O. Devonian of Wisconsin, pp. 261-267, 1 flg.; Stratigraphy of the Cambrian system of the upper Mississippi Valley, pp. 302-315, 2 figs.; Paleozoic strata of the Baraboo area, pp. 405-414, 1 pl. (geol. map by J. M. Wanenmacher), 1 fig.

Stainbrook, Merrill Addison. Stratigraphy of the Devonian of the upper Mississippi Valley, pp. 248-260, 4 figs.

Sutton, Arle Herbert. Stratigraphy of the Silurian of the upper Mississippi Valley, pp. 268-280, 3 figs. (incl. geol. sketch map).

Tester, Allen Crawford. Isopach map of the post-Kinderhook-Mississipplan, opp. p. 334; Isopach map of the KInderhook group, opp. p. 336; Isopach map of the Devonian system, opp. p. 338 .

Thwaites, Fredrik Turville. Structural map on top of the Dreshach formation, opp. p. 356 ; Physlography of the Baraboo district, Wis., pp. 395-404, 2 pls. (incl. geol. map), 12 figs. (incl. geol. map); Zones of mineralization of underground waters in Minnesota, Iowa, Illinols, and Wisconsin, pp. 415-416, 3 flgs. (incl. geol. máps).

Trowbridge, Arthur Carleton. Structural map on top of the Jordan sandstone, opp. p. 358 .

Workman, Lewis Edwin. Isopach map of the Silurian system in the Mississippi Valley, opp. p. 340; (and others) Mississippl Valley geologic cross section, pp. $362-372,3$ pls. 
Kansas University, Geological Survey.

2021. Contour map showing topography of pre-Cambrian surface underlying eastern two-thirds of Kansas. . Contour interval 200 feet. Datum mean sea level. 1935.

2022. Preliminary edition of geologic map of Kansas; northwestern Kansas. Scale 1: 500,000. 1935.

2023. Preliminary edition of geologic map of Kansas; southwestern Kansas Scale 1: 500,000. 1935 .

2024. Guidebook 10th annual field conference [Pennsylvanian and Permian rocks of northeastern Kansas and northwestern Missouri], September 4 to September $7,74 \mathrm{pp}$. ( $¥), 47$ figs. (incl. stratigraphic columns), 1936. Includes the following paper:

Moore, Raymond Cecil. Pennsylvanian and lower "Permian" rocks of the Kansas-Missouri region, with collaboration of Maxim Konrad Elias, Frank Cooke Greene, and Norman Dennis Newell.

Karcher, John Clarence.

2025. (and McDermott, Eugene). Deep electrical prospecting: Am. Assoc. Petroleum Geologists Bull., vol. 19, no. 1, pp. 64-77, 7 figs., January 1935.

Kay, George Frederick.

2026. Loveland and Peoria loesses of Iowa [abstract] : Pan-Am. Geologist, vol. 65 , no. $\dot{4}$, pp. $317-318$, May 1936 .

2027. (and Miller, Paul T.). Pleistocene loesses of Iowa [abstract]: Geol. Soc. America Proc., 1935, pp. 84-85, June 1936.

Kay, George Marshall. See also Kansas Geol. Soc., 2020.

2028. Mohawkian Ostracoda; species common to Trenton faunules from the Hull and Decorah formations: Jour. Paleontology, vol. 8, no. 3, pp. 328-343, 1 fig., 3 pls., September 1934.

2029. Ordovician system in the upper Mississippi Valley: Kansas Geol. Soc. Guidebook 9th Ann. Field Conf., pp. 281-295 ( $), 1$ fig. (correl, table), 1935.

2030. (and Atwater, Gordon I.) Basal relations of the Galena dolomite in the upper Mississippi Valley lead and zinc district: Am. Jour. Sci., 5th ser., vol. 29, no. 170, pp. 98-111, 4 figs., February 1935.

2031. Distribution of Ordovician altered volcanic materials and related clays : Geol. Soc. America Bull., vol. 46, no. 2, pp. 225-244, 14 figs. (incl. paleogeog. maps), 3 pls., February 28, 1935 ; abstract, Proc., 1933, .p. 381, June 1934.

2032. Ordovician Stewartville-Dubuque problems: Jour. Geology, vol. 43, no. 6, pp. 561-590, 8 figs. (incl. sketch map), August-September 1935; abstract, Geol. Soc. America Proc., 1934, p. 356, June 1935.

2033. Taconic thrusting and paleogeographic base maps: Science, new ser., vol. 82 , no. 2139 , pp. 616-617, December $27,1935$.

2034. Later Ordovician history of the Adirondack foreland arch [abstract] : Geol. Soc. America Proc., 1935, p. 390, June 1936.

Kay, John A.

2035. (and Pettigrew, Virgil, Roth, Robert, and Powell, Ralph Sterling). Major unconformities in the Wichita Falls district of north-central Texas: Texas Unir. Bull. 3501; January 1, 1935, pp. 136-137, February 1936.

Kearfott, Karl.

2036. Virginia perthites [abstract] : Virginia Acad. Sci. Proc., 1934-35, p. 69, [1935]. 
Keen, A. Myra. See also Schenck, 3452.

2037. A new pelecypod genus of the family Cardidae: San Diego Soc. Nat. History Trans., vol. 8, no. 17, pp. 119-120, March 12, 1936.

2038. Revision of cardiid pelecypods [abstract] : Geol. Soc. America Proc., 1935, p. 367, June 1936.

Keith, Arthur. See also Leavitt, 2364:

2039. (and others). Report of the Division of Geology and Geography [Nutional Research Council] for the year 1930-31, $171 \mathrm{pp.} \mathrm{( \ddagger )} \mathrm{[1935].}$

Contains reports on historical and physical geology, sedimentation, measurement of geologic time, paleontology, geophysical prospecting, etc.

2040. Preliminary geologic map of Maine, 1933. Scale 1:1,000,000. Maine Geol. Survey [1935]. Issued as Supplement to Maine Tech. Exper. Sta. Bull. 30, vol. 2, 1935.

2041. Reconnaissance of the Appalachians in Quebec [abstract]: Geol. Soc. American Proc., 1935, p. 85, June 1936.

Keller, Walter David. See also Tarr, 4018.

2042. The occurrence of mendozite and tamarugite in Missouri: Am. Mineralogist, vol. 20 , no. 7 , pp. 537-539, July 1935.

2043. Removal of bubbles from. old thin sections: Am. Mineralogist, vol. 20, no. 7 , p. 540, July, 1935.

2044. Clay colloids as a cause of bedding in sedimentary rocks: Jour. Geology, vol. 44, no. 1, pp. 52-59, January-February 1936.

Kellett, Betty.

2045. Ostracodes of the upper Pennsylvanian and the lower Permian strata of Kansas ; 3, Bairdiidae (concluded), Cytherellidae, Cypridinidae, Entomoconchidae, Cytheridae and Cypridae; Jour. Paleontology, vol. 9, no. 2, pp. 132-166, 1 fig., 3 pls., March 1935.

2046. Carboniferous- ostracodes: Jour. Paleontology, vol. 10, no. 8, pp. 769784, December 1936.

Kelley, Vincent C.. See also .Soske, 3791:

2047. Mineralogy and geology. tables.. 82 pp. ( $\$$.), Pasadena, Calif., 1935.

2048. Geology :of the westernmost Santa Monica Mountains, Calif. [abstract] : Geol. Soc. America Proc., 1934, pp. 311-312, June 1935.

2049. Paragenesis of the Colorado copper sulphides, Cananea, Mexico: Econ. Geology, vol. 30, no. 6, pp. 663-688, 12 figs., September-October 1935 ; abstracts; Pan-Am. Geologist, vol. 63, no. 4, pp. 312-313, May 1935 ; Geol. Soc. America Proc., 1935, p: 335, June 1936.

2050. Occurrence of claudetite in Imperial County, Calif., Am. Mineralogist, vol. 21, no. 2, pp. 137-138, February 1936.

2051. (and Soske, Joshua Lawrence). Origin of the Salton volcanic domes, Salton Sea, California: Jour. Geology, vol. 44, no. 4, pp. 496-509, 9. figs. (incl. index maps), May-June 1936.

Kellum, Lewis Burnett.

2052. Structural studies in Sierra del Rosario, [Mexico] [abstract]: Geol. Soc. America Proc., 1934, p. 448, June 1935.

2053. University of Michigan geological expeditions to. Mexico: Science, new ser., vol. 83, no. 2146, pp. 163-164, February 14, 1936.

2054. Paleogeography of parts of border province of Mexico adjacent to west Texas: Am. Assoc. Petroleum Geologists Bull., vol. 20, no. 4, pp. 417-432, 3 flgs. (incl. geol. maps), April 1936; abstract, World Petroleum, vol. 7, no. 7, p. 368, July 1936 ; extracted, in part, and transl. by Gonzalo Vivar in Soc. geol. mexicana Bol., tomo 9, no. 2, pp. 113-117, 1936. 
Kellum, Lewis Burnett-Continued.

2055. Geology of . Sierra del Rosario, Durango [Mexico] [abstract]: Geol. Soc. America Proc., 1935, p. 85, June 1936.

2056. Mesozoic faunas of northern Mexico [abstract]: Geol. Soc. America Proc., 1935, p. 86, June 1936.

2057. (and Imlay, Ralph Willard, and Kane, William G.). Evolution of the Coahuila Peninsula, Mexico; pt. 1, Relation of structure, stratigraphy, and igneous activity to an early continental margin: Geol. Soc. America Bull., vol. 47, no. 7, pp. 969-1008, 4 pls. (incl. geol. map), 3 figs. (incl. geol. map), July 31, 1936; abstract, Proc., 1934, pp. 87-88, June 1935.

2058. Erolution of the Coahuila Peninsula, Mexico; pt. 3, Geology of the mountains west of the Laguna district: Geol. Soc. America Bull., vol. 47, no. 7, pp. 1039-1090, 14 pls. (incl. geol. map), 2 figs. (index maps), July 31, 1936.

2059. [Review of] Geology of the Tampico region, Mexico, by John M. Muir, 1936: Am. Assoc. Petroleum Geologists Bull., vol. 20, no. 8, pp. 1134-1141, August 1936.

Kelly, Junea W. See also Eckel, 1129.

2060. Geologic factors in the distribution of birds: Condor, vol. 37, no. 1, pp. 11-15, 2 figs., January-February 1935.

Kelly, Louis A. See U. S. G. S., 4227.

Kelly, R. B. See Haury, 1649.

Kelly, Sherwin F.

2061. (and Zuschlag, Theodor, and Low, Bela). Discovering gold-quartz veins electrically [abstract]: Mining and Metallurgy, Year Book sec., p. 89, January 1935.

2062. Widening use of geophysics in geology observed: Mining and Metallurgy, vol. 16, no. 337, pp. 20-21, 4 figs., January 1935.

2063. Geophysics, the geologist's new tool : Min. Jour., vol. 18, no. 19, p. 4, Phoenix, Ariz., February 28, 1935.

2064. The role of geophysics in the exploration for gold: Canadian Min. Jour., vol. 56, no. 3, pp. 99-105, 9 figs., March 1935; abstract, Mines Mag., vol. 26, no. 12, p. 27, December 1936.

2065. Exploring down: Explosives Engineer vol. 13, no. 9, pp. 263-270, 12 figs., September 1935; no. 10, pp. 303-312, 19 figs., October 1935.

2066. Study of structural problems by geophysical means gains in importance: Mining and Metallurgy, vol. 17, no. 349, pp. 9-11, 2 figs., January 1936.

Kelly, William Aultin.

2067. Middle and Upper Paleozoic formations in the Canadian Rockies [abstract]: Geol. Soc. America Proc., 1935, pp. 380-381, June 1936.

2068. Evolution of the Coahuila Peninsula, Mexico; pt. 2, Geology of the mountains bordering the valleys of Acatita and Las Delicias: Geol. Soc. America. Bull., vol. 47, no. 7, pp. 1009-1038, 13 pls. (incl. geol. maps), 2 figs. (index and geol. maps), July 31, 1936.

Kelsey, Lewis.

2069. The Marsalis terrace; a high-level terrace of the Trinity River, Dallas, Tex.: Field and Laboratory (Southern Methodist Univ.), vol. 3, no. 2, pp. 54-56, 2 figs., April 1935. 
Kemnitzer, Luis E.

2070. The geology of San Nicolas Island, Calif. [abstract] : Am. Assoc. Petroleum Geologists Bull., vol. 20, no. 11, p. 1519, November 1936.

Kendrick, Frank E.

2071. (and Russell, Philip G.). Natural gas in Bend arch district, Texas: Geology of natural gas, pp. 609-650, 9 figs. (incl. maps), Am. Assoc. Petroleum Geologists, [June] 1935.

Kennard, Theodore Gladden.

2072. Spectographic examination of smoky and ordinary quartz from Rincon, Calif. : Am. Mineralogist, vol. 20, no. 5, pp. 392-399, 1 fig., May 1935.

Kennedy, Luther E. See Bass, 220 ; U. S. G: S., 4237, 4238.

Kent, H. M. See Brandenthaler, 436.

Kerr, Albert R. See Wheeler, 4446.

Kerr, Forrest Alexander. See also Canada G. S., 657, 658, 659.

2073. The development of a gneiss zone in the Flinflon area, Manitoba [abstract] : Royal Soc. Canada Trans. vol. 30, sec. 4, Proc., p. xcviii, 1936.

2074. Extraordinary natural floods of Talsekwe River, Taku district, northern British Columbia and southeastern Alaska: Royal Soc. Canada Trans., 3d ser., sec. 4, vol. 30, pp. 133-135, May 1936.

2075. The physiography of the Cordilleran region of northern British Columbia and adjacent areas : Royal Soc. Canada Trans., 3d ser., sec. 4, vol. 30, pp. 137-154, 1 fig. (physiographic map), May 1936.

2076. Quaternary glaciation in the Coast Range, northern British Columbia, and Alaska: Jour. Geology, vol. 44, no. 6, pp. 681-700, 7 figs. (incl. index map), August-September 1936.

Kerr, Paul Francis. See also Bray, 451; Grim, 1546.

2077. Proceedings of the 15th annual meeting of the Mineralogical Society of America, at Rochester, N. Y.: Am. Mineralogist, vol. 20, no. 3, pp. 188-227, March 1935.

2078. Scheelite-beryl deposit at Oreana [Nev.] [abstract] : Am. Mineralogist, vol. 20, no. 3, p. 207, March 1935; Geol. Soc. America Proc., 1934, pp. 428-429, June 1935.

2079. (and Jenney, Phillip). The dumortierite-andalusite mineralization at Oreana, Nev.: Econ. Geology, vol. 30, no. 3, pp. 287-300, 13 figs., May 1935.

2080. Proceedings of the 15th annual meeting of the Mineralogical Society of America, held at Rochester, N. Y., December 27, 28, and 29, 1934: Geol. Soc. America Proc., 1934, pp. 409-434, June 1935.

2081. U-galena and uraninite in: Bedford, N. Y.: Am. Mineralogist, vol. 20, no. 6, pp. 443-450, 3 figs., June. 1935.

2082. (and Callaghan, Eugene). Scheelite-leuchtenbergite vein in Paradise Range,.Nev.: Geol. Soc. America Bull., vol. 46, no. 12, pp. 1957-1974, 2 pls., 5 figs. (incl. geol. and sketch maps), December 31, 1935; abstract, Am. Mineralogist,' vol. 21, no. 3, p. 198, March 1936.

2083. An improved specific-gravity balance: Am. Mineralogist, vol. 21, no. 2, pp. 121-124, 2 figs., February 1936. 
Kerr, Paul Francis-Continued.

2084. Proceedings of the 16th annual meeting of the Mineralogical Society of America, at New York, N. Y. [December 26, 1935] : Am. Mineralogist, vol. 21, no. 3, pp. 183-210, March 1936.

2085. (and Cameron, Eugene N.). Fuller's earth of bentonitic origin from Tehechapi, Calif.: Am. Mineralogist, vol. 21, no. 4, pp. 230-237, 5 figs., April 1936.

2086. The tungsten mineralization at Silver Dyke, Nev.: Nevada Univ. Bull., vol. 30 , no. 5 , 70 pp., 4 pls. (inc. geol. màp), 33 figs. (incl. index maps), June 15, 1936.

Kesler, Thomas L.

2087. Granitic injection processes in the Columbia quadrangle, S. C.: Jour. Geology, vol. 44, no. 1, pp. 32-44, 1 fig. (geol. sketch map), January-February 1936; abstract, Washington Acad. Sci. Jour., vol. 25, no. 2, pp. 90-91, February 15, 1935.

2088. Advance report on the sedimentation' survey of Lake Spavinaw, Okla.: U. S. Soil Cons. Service S. S. 1, 5 pp. ( $¥), 1$ pl. (map), March 15, 1936.

2089. Advance report on the sedimentation survey of Lake Taneycomo, Taney County, Mo., July 23-November 2, 1935: U. S. Soil Cons. Service, S. S. 8,8 pp. ( $\ddagger), 1$ pl. (map), September 1936.

Kessler, Jane.

2090. Mineralogy of a Virginia marble [abstract]: Virginia Acad. Sci. Proc., 1935-36, pp. 70-71, 1936.

Kester, Ernest Bowman. See Fieldner, 1255.

Keyes, Charles Rollin.

2091. Reconstruction of Iowa's Cretaceous stratigraphy [abstract]: Iowa Acad. Sci. Proc., 1934 (vol. 41), pp. 239-240, 1934.

2092. Extent of Patrician glaciation [abstract] : Iowa Acad. Sci. Proc., 1934 (vol. 41), p. 240, 1934.

2093. What is the Loveland loess? [abstract] : Iowa Acad. Sci. :Proc., 1934 (vol. 41), pp. 240-241, :1934.

2094. Patrician glaciation interval in Iowa: Pan-Am. Geologist, vol. 63, no. 1 , pp. 11-13, February 1935.

2095. Strategic role of Patrician glaciation in cosmic scheme: Pan-Am. Geologist, vol. 63, no. 1, pp. 26-30, 1 flg. (geol. map), February 1935.

2096. Rocky Mountain Cretacic geosyncline: Pan-Am. Geologist, vol. 63, no. 1, pp. 41-72, 6 pls., 3 figs. February 1935.

2097. Stratigraphic disuse of group rank: Pan-Am. Geologist, vol. 63, no. 1, pp. 73-76, February 1935.

2098. Mesa Verde terranal title in redefinition: Pan-Am. Geologist, vol. 63, no. 1, pp. 77-78, February 1935.

2099. Taxonomic rank of: Niobrara chalk: Pan-Am. Geologist, vol. 63, no. 1, pp. 78-80, February 1935.

2100. Last epochal glaciations in cosmical paradigm: Pan-Am. Geologist, vol. 63, no. 2, pp. 119-150, 11 pls. (incl. geol. maps), 3 figs., March 1935.

2101. Terranal nomenclature of Owen's Lower Magnesian limestone: Pan-Am. Geologist, vol. 63, no. 2, pp. 155-160, March 1935.

2102. Glacial origin of the Grand Coulee: Pan-Am. Geologist, vol. 63, no. 3, pp. 189-202, 5 pls. (incl. geol. map), 1 fig. (geol map), April 1935. 
Keyes, Charles Rollin-Continued.

2103. Wisconșin glaciation in original deflnition: Pan-Am. Geologist, vol. 63, no. 3, pp. 217-222, 1 pl. (geol. map), April 1935; abstract, Geol. Soc. America Proc., 1934, pp. 448-449, June 1935.

2104. Possibility of early Carbonic Oshawanan sediments in Arizona : Pan-Am. Geologist, vol. 63, no. 3, pp. 223-240, April 1935.

2105. What shall Permian be?: Pan-Am. Geologist, vol. 63, no. 3, pp. 230-235, April 1935.

2106. Dakotan sandstone at type section and as basinal basilium: Pan-Am. Geologist, vol. 63, no. 3, pp. 236-240, April 1935.

2107. Terranal resolution of Iowa's rock column : Pan-Am. Geologist, vol. 63, no. 4, pp. 271-290, 1 pl. (geol. map), May 1935.

2108. Transmigration of pre-Cambric faunas: Pan-Am. Geologist, vol. 63, no. 4, pp. 291-294, May 1935.

2109. First American discovery of Cretacic rocks: Pan-Am. Geologist, vol. 63, no. 4, pp. 295-297, May 1935.

2110. Farly discovery of Mississippian Burlington limestone fauna in Arizona : Pan-Am. Geologist, vol. 63, no. 4, pp. 297-299, May 1935.

2111. Fault-faced Basin Range of El Picacho in Arizona [abstract] : Pan-Am. Geologist, vol. 63, no. 4, p. 309, May 1935; Geol. Soc. America 'Proc., 1935, p! 332, June 1936.

2112. Glaciations of western mountains [abstract] : Pan-Am. Geologist, vol. 63, no. 4, p. 312, May 1935; Geol. Soc. America Proc., 1935, pp. 334-335, June 1936.

2113. Life before the Cambric: Pan-Am. Geologist, vol. 63, no. 5, pp. 341364,3 pls., June 1935 ; abstract; vol. 66, no. 2, p. 158, September 1936.

2114. Eolation of the Great Plains [abstract]: Geol. Soc. America Proc., 1934, p. 88, June 1935.

2115. Periodicity in American orogenesis [abstract]: Geol. Soc. America Proc., 1934, pp. 326-327, June 1935.:

2116. Beginning and end of Basin Range hypothesis: Pan-Am. Geologist, ' vol. 64, no.: 1, pp. 8-34, 5 pls.; 1 fig., August 1935.

2117. Rothpletz and pre-Cambric of Rocky: Mountains: Pan-Am. Geologist, vol. 64, no. 1, pp. 55-58, August 1935 .

2118. Comanche in synonymy as terranal title: Pap-Am. Geologist, vol. 64, no. 1, pp: 59-62, August 1935.

2119. Earliest recognition of Cretacic rocks in Arizona region: Pan-Am. Geologist, vol. 64, no. 1, pp. 62-64, August 1935.

2120. Early Cretacic prospect from southeastern Arizona : Pan-Am. Geologist, vol. 64 , no. 2 , pp. 125-140, 1 pl., 2 figs. (incl. geol. map), September 1935.

2121. Priority: vs. usage in geological terminology: Pan-Am. Geologist, vol. 64, no. 2, pp. 141-144, 1 chart, September 1935.

2122. Biostratigraphy of Chouteau limestone in Iowa: Pan-Am. Geologist, vol. 64, no. 2, pp. 145-148, September 1935.

2123. Great Cretacic succession in New Mexico [abstract]: Pan-Am. Geologist, vol. 64, no. 2, pp. 152-153, September 1935.

2124. Recency of some New Mexican basalt flows. [abstract]: Pan-Am. Geologist, vol. 64, no. 2, p. 153, September 1935.

2125. Ultimate test of Duttonian isostasy: Pan-Am. Geologist, vol. 64, no. 3, pp. 193-220, 2 pls.; 4 figs., October 1935. 
Keyes, Charles Rollin-Continued.

2126. Isostasy in the proving: Pan-Am. Geologist, vol. e4, no. 3, pp. 221-224, October 1935.

2127. Age of Ceja Glorieta sandstone: Pan-Am. Geologist, vol. 64, no. 4, pp. 263-278, 6 figs. November 1935.

2128. Strategic role of Taconic in paleontological geology : Pan-Am. Geologist, vol. 64, no. 4, pp. 297-300, November 1935.

2129. Where is Shakopee dolomite?: Pan-Am. Geologist, vol. 64, no. 4, pp.

- 301-305, November 1935.

2130. Invalidity of Chupadera as terranal title : Pan-Am. Geologist, vol. 64, no. 4, pp. 305-306, November 1935.

2131. Southern tectonic ending of Rocky Mountains: Pan-Am. Geologist, vol. 64, no. 5, pp. 355-372, 4 pls. (incl. maps), 8 figs., December 1935.

2132. Permian as a world problem: Pan-Am. Geologist, vol. 64, no. 5, pp. 373-376, December 1935.

2133. Measure of late geologic time [abstract]: 16th Internat. Geol. Cong. (1933) Rept, vol. 1, p. 233, 1936.

2134. Guadalupan series, its span and affinities: Pan-Am. Geologist, vol. 65. no. 1, pp. 35-56, 4 pls., February 1936.

2135. Resolution of our pre-Cambric transition rocks : Pan-Am. Geologist, vol. 65 , no. 1 , pp. $57-60$, February 1936 .

2136. Taxonomic status of Triassic Chinle formation: Pan-Am. Geologist, vol. 65, no. 1, pp. 61-63, February 1936.

2137. Taxonomic redundancy of Prairie du Chien title: Pan-Am. Geologist, vol. 65, no. 1, pp. 63-66, February 1936.

2138. Terranal equivalence of Hueco limestone: Pan-Am. Geologist, vol. 65, no. 1, pp. 66-68, February 1936.

2139. Eastward extension of Shinarump basilium : Pan-Am. Geologist, vol. 65, no. 1, pp. 68-71, February 1936.

2140. Incongruity of Chupadera formation: Pan-Am. Geologist, vol. 65, no. 1, pp. 71-74, February 1936.

2141. Proper title of so-called Lewis shales in Arizona : Pan-Am. Geologist, vol. 65, no. 1, pp. 74-75, February 1936.

2142. Biotic sequence verifiable by volcanic ash falls: Pan-Am. Geologist, vol. 65, no. 1, pp. 75-76, February 1936.

2143. Developmental stages of the peneplain: Pan-Am. Geologist, vol. 65, no. 2, pp. 125-148, 5 pls., (incl. geol. map), 2 figs., March 1936; abstract, Geol. Soc. America Proc., 1935, pp. 86-87, June 1936.

2144. Coon Butte's little brother [Zuni volcanic crater] : Pan-Am. Geologist, vol. 65, no. 2, pp. 149-154, 3 pls., March 1936.

2145. Use of volcanic ash falls in geological correlation [abstract] : Pan-Am. Geologist, vol. 65, no. 2, pp. 156-157, March 1936 ; Geol. Soc. America Proc., 1935, p. 439, June 1936.

2146. Henry Fairfield Osborn [1857-1935], modern paleontologist: Pan-Am. Geologist, vol. 65, no. 3, pp. 161-178, 1 pl. (port.), April 1936.

2147. Reorganization of the peneplane, a symposium: Pan-Am. Geologist, vol. 65, no. 3, pp. 179-181, April 1936; no. 4, pp. 259-271, May 1936.

2148. Tectonic paradigm of southern Rocky Mountains: Pan-Am. Geologist, vol. 65, no. 3, pp. 209-228, 4 pls., 2 figs., April 1936.

2149. Passing of Lyell's Pleistocene term from glacial geology: Pan-Am. Geologist, vol. 65, no. 3, pp. 229-230, April 1936. 
Keyes, Charles Rollin-Continued.

2150. Role of Baconian cycle in secular glaciation: Pan-Am. Geologist, vol. 65, no. 4, pp. 273-294, 5 pls. (geol. maps), May 1936.

2151. Is Texan Malone formation Jurassic?: Pan-Am. Geologist, vol. 65, no. 4, pp. 295-300, 1 fig., May 1936.

2152. Naviajo sandstone in synonymy: Pan-Am. Geologist, vol. 65, no. 4, pp. 301-302, May 1936.

2153. Validity of Dutton's Jurassic Zunian series in Arizona: Pan-Am. Geologist, vol. 65, no. 4, pp. 302-306, May 1936.

2154. Mesa Verde coal formation in Arizona : Pan-Am. Geologist, vol. 65, no. 4, pp. 306-310, 1 pl. (geol. map), May 1936.

2155. Redefinition of Cambric in Iowa [abstract] : Pan-Am. Geologist, vol. 65, no. 4, pp. 314-315, May 1936.

2156. Ice departure rate during last glacial stage in Iowa [abstract:] Pan-Am. Geologist, vol. 65, no. 4, pp. 318-319, May 1936.

2157. Deglaciation effects on Des Moines River [abstract] : Pan-Am. Geologist, vol. 65, no. 4, p. 319, May 1936.

2158. Correlation in European and American glaciation: Pan-Am. Geologist, vol. 65, no. 5, pp. 348-366, 9 pls. (incl. geol. maps), 1 fig., June 1936.

2159. Redefinition of our Cambric: Pan-Am. Geologist, vol. 65, no. 5, pp. 367-370, June 1936.

2160. Present doming of Grand Canyon region not first Colorado Plateau [abstract] : Pan-Am. Geologist, vol. 65, no 5, p 374, June 1936.

2161. Reorganization of the peneplane, a symposium ; Peneplanation in driftless area of Iowa: Pan-Am. Geologist, vol. 66, no 1, pp 14-18, 3 figs., August 1936.

2162. Peneplane; realistic vs. theoretic: Pan-Am. Geologist, vol. 66, no. 1, pp. 41-62, 5 pls., August 1936.

2163. American paradigm for European glaciations: Pan-Am. Geologist, vol. 66, no. 1, pp. 63-68, August 1936.

2164. Tertic basilium of northwestern New Mexico : Pan-Am. Geologist, vol. 66, no. 1, pp. 69-71, 1 fig., August 1936.

2165. Tyende title as substitute for Lohali formation: Pan Am. Geologist, vol. 66, no. 1, pp. 71-72, August 1936.

2166. Age and synonymy of Animas sandstone of New Mexico Pan-Am. Geologist, vol. 66, no. 1, pp. 72-74, August 1936.

2167. Todilto limestone in unique pose: Pan-Am. Geologist, vol. 66, no. 1, pp. 74-77, August 1936,

2168. Discovery of Conrad's type fossils-localities of the United States and Mexico Boundary Survey: Pan-Am. Geologist, vol. 66, no. 1, pp. 77-80, August 1936.

2169. Terranal terminology in Rocky Mountains: Pan-Am. Geologist, vol. 66, no. 2, pp. 89-94, September 1936.

2170. Assiniboine great sedimental cycle: Pan-Am. Geologist, vol. 66, no. 2, pp. 113-136, 4 pls., September 1936.

2171. Communications to the XVIth International Geological Congress: PanAm. Geologist, vol. 66, no. 2, pp. 137-148, September 1936.

2172. Horizon of type section of Benton formation: Pan-Am. Geologist, vol. 66, no. 2, pp. 149-150, September 1936.

2173. Nuttall and first recognition of Cretacic rocks in America: Pan-Am. Geologist, vol. 66, no. 2, pp. 151-154, September 1936.

2174. Yanktonian series for so-called Benton shales of Iowa: Pan-Am. Geologist, vol. 66, no. 2, pp. 154-156, September 1936. 
Keyes, Charles Rollin-Continued.

2175. Foundation of peneplane theory [abstract] : Pan-Am. Geologist, vol. 66, no. 2 , pp. 159-160, September 1936.

2176. Geological age of rim rocks of the Grand Canyon: Pan-Am. Geologist, vol. 66, no. 3, pp. 195-216, 5 pls. (incl. geol. sketch.map), October 1936.

2177. Drifting are the continents?: Pan-Am. Geologist,. vol. 66, no. 3, pp. 217-220, October 1936.

2178. Earliest recognition of Dakota sandstone as a geological formation: Pan-Am. Geologist, vol. 66, no. 3, pp. 221-222. October 1936.

2179. Primary usage of Aubrey as terranal title: Pan-Am. Geologist, vol. 66, no. 3, pp. 222-224, October 1936.

2180. Marine Jurassic horizon of Montezuma: Pan-Am. Geologist, vol. 66, no. 3, pp. 224-226, 1 fig., October 1936.

2181. Midcontinental diastrophism in late Paleozoic times: Pan-Am. Geologist, vol. 66, no. 4, pp. 279-306, 7 pls. (incl. index map), November 1936.

2182. Origin of the oceans: Pan-Am. Geologist, vol. 66, no. 4, pp. 307-310, November 1936 .

2183. Passing of Supai as terranal title: Pan-Am. Geologist, vol. 66, no. 4, pp. 311-313, November 1936.

2184. Validity of Kask̈askia limestone title: Pan-Am. Geologist, vol. 66, no. 4, pp. 313-316, November 1936.

2185. Iowa Rockford fauna reported from Arizona: Pan-Am. Geologist, vol. 66, no. 4, p. 316, November 1936.

2186. Diastatic measure of biotic chronology : Pan-Am. Geologist, vol. 66, no. 5, pp. 363-376, December 1936.

Keys, David Arnold.

2187. The application of magnetometric measurements to the location and determination of geological structure: Fifth Pacific Sci. Cong., Canada, 1933, Proc.; vol. 3, pp. 1909-1918, 11 'figs., 1934.

2188. A magnetic survey of the Ivry [Quebec] ilmenite deposits: Am. Inst. Min. Met. Eng. Contr. 102, 7 pp., 5 figs. (incl. sketch map), July 1936.

Keyte, W. Ross. See Trask, 4154.

Kidd, D. F. See also Canada G. S., 668, 669, 670.

2189. Mineralization in the Great Bear Lake district [Northwest Territories] : Eng. Jour., vol. 17, no. 4, pp. 167-170, 5 flgs., April 1934.

2190. (and Haycock, Maurice Hall). Mineragraphy of the ores of Great. Bear Lake: Geol. Soc. America Bull., vol. 46, no. 6, pp. 879-960, 2 figs. (incl. geol. map), 16 pls., June 30, 1935.

2191. Rae to Great Bear Lake, MacKenzie district, Northwest Territories: Canada Dept. Mines, Geol. Survey Mem: 187; Pub. 2410, 44 pp., 3 pls. (geol. maps), 1936.

Kihlstedt, Folke H. See Lundberg, 2488.

Kimball, Kent K.

2192. Nebraska's chances for finding oil improving: Oil and Gas Jour., vol. 35, no. 3, pp. 13-14, 4 figs. (incl. geol. map), December 17, 1936.

Kindle, Cecil Haldane. See also Cooper, G. A., 867.

2193. A geological map of southeastern Gaspé: Eastern Geologist, no. 1, 8 pp. (\$), 4 figs., (index and geol. maps), April 1936; abstract; Geol. Soc. America Proc., 1984, p. 354, June 1985. 
Kindle, Cecil Haldane-Continued.

2194. Fauna from the upper thrust block at Highgate Falls, Vt. [abstract] : Geol. Soc. America Proc., 1935, p. 386, June 1936.

Kindle, Edward Darwin. See älso Collins, 812.

2195. Gold occurrences of Ontario east of Lake Superior: Canada Dept. Mines, Geol. Survey Mem. 192, Pub. 2416, 167 pp., 1 pl: (index map), 1936.

Kindle, Edward Martin. See also Canada, G. S., 662.

2196. Manganese concretions in Nova Scotia lakes, with a comparative list of diatoms from the Lake Osisipee, N. H., concretion and a Ship Harbour Lake, N. S., concretion, by Kenneth Elmo Lohmann: Royal Soc. Canada Trans., 3d ser., vol. 29, sec. 4, pp. 163-180, 2 pls., May 1935.

2197. American Indian discoveries of vertebrate fossils: Jour. Paleontology, vol, 9 , no. 5 , pp. $449-452$, July 1935 .

2198: A note on lime-separating álgae from subarctic Canada: Geol. Mag., vol. 72, no. 11 (no. 857), pp. 519-521, 1 pl., November 1935.

2199. Observations on chance experiments in consolidation of sediments: Am. Jour. Sci., 5th ser., vol. 30, no. 180, pp. 537-540, 2 figs.,' December 1935 .

2200. Concerning "lake balls", "Cladophora balls" and "coal balls" [abstract] : 16th Internat. Geol. Cong. (1933) Rept., vol. 2, p. 1105, 1936.

2201. Formation names in the Mackenzie River Valley: Sclence, new ser., vol. 83 , no. 2140 , pp. 13-15, January 3, 1936.

2202. Dominant factors in the formation of firm and soft sand beaches: Jour. Sedimentary Petrology, vol. 6, no. 1, pp. 16-22, 3 figs., April 1936.

2203. Notes on shallow-water sand structures: Jour. Geology, vol. 44, no. 7, pp. 861-869, 5 figs., Octobèr-November 1936.

2204. The occurrence of lake-bottom manganiferous deposits in Canadian lakes : Econ. Geolog., vol. 31, no.' 7, pp. 755-760, 4 figs., November 1936.

2205. Memoir of Reginald Walter Brock. [1874-1935] : Assoc. Am. Geographers Annals, vol. 26, no. 4, pp. 194-196, December 1936.

King, Arthur. Scott.

2206. The spectra of meteorites: Popular Astronomy, vol. 44, no. 9, pp. 507-511, November 1936.

King, . Elizabeth.

2207. Pleochroic halos: Rocks and Minerals, vol. 10, no. 7, p. 104, 1 fig., July 1935.

2208. Transported pebbles: Rocks and Minerals, vol. 11, no. 10, p. 228, November 1936.

2209. The Goldenville-Halifax boundary' at Fairview, Nova Scotia: Nova Scotian Inst. Sci. Proc., vol. 19, no. 1, pp. 114-118, 1 fig. (sketch map), December 31, 1935.

King, J. E.

2210. Aerial surveys: Engineers' Bull. (Colorado Soc. Eng.), vol. 18, no. 12, p. 5, December 1934 .

King, Philip Burke. See also Kramer, 2255.

2211. Outline of structural development of trans-Pecos Texas: Am. Assoc. Petroleum Geologists Bull.; vol. 19, no. 2, pp. 221-261, 7 figs. (geol. maps), February 1935. 
King, Philip Burke-Continued.

2212. Age of Bisset conglomerate: Am. Assoc. Petroleum Geologists Bull., vol. 19, no. 10, pp. 1544-1546, October 1935.

2213. Unconformities in the later Paleozoic of trans-Pecos Texas: Texas Univ. Bull. 3501, January 1, 1935, pp. 131-135, February 1936.

2214. [Review of] Early history of Texas red-beds vertebrates, by A. S. Romer, 1935: Am. Assoc. Petroleum Geologists Bull., vol. 20, no. 6, pp. 832-837, June 1936.

2215. Permian of the Guadalupe Mountains [abstract]: Washington Acad. Sci. Jour., vol. 26, no. 9, p. 385, September 15, 1936.

King, Robert Evans. See Dunbar, 1091.

Kingman, Eugene. See Atwood, 119, 120.

Kingsbury, Francis H.

2216. Public ground-water supplies in Massachusetts: New England Water Works Assoc., Jour., vol. 50, no. 2, pp. 149-196, 20 figs., 1936.

Kinkel, A. R., Jr. See Brownell, 499.

Kinkel, William Constant.

2217. Notes on the southern part of Permian basin [Texas]: Am. Assoc. Petroleum Geologists Bull., vol. 20, no. 9, pp. 1250-1252, September 1936.

Kipp, Egbert M. See Alter, 56, 57.

Kirby, J. M. See also Crook, 922.

2218. Geology of the Vacaville-Rumsey Hills area Solano, Yolo, and Colusa Counties, (Calif.) [abstract] : Am. Assoc. Petroleum Geologists Bull., vol. 19, no. 12, p. 1841, December 1935.

Kirk, Charles Townsend. See U. S. G. S., 4237.

Kirk, Edwin. See also Foerste, 1295.

2219. A new Allagecrinus from Oklahoma: Washington Acad. Sci. Jour., vol. 26, no. 4, pp. 162-165, 10 figs., April 15, 1936.

Kirkham, Virgil Raymond Drexel.

2220. Natural gas in Washington, Idaho, eastern Oregon, and northern Utah : Geology of natural gas, pp. 221-244, 1 fig. (map), Am. Assoc. Petroleum Geologists, [June] 1935.

Kirkpatrick, Ralph Zenas.

2221. Canal Zone instrument seismic records: Earthquake Notes, vol. 7, no. 3, p. 1, December 1935.

Kirwan, M. J.

2222. (and Schwarzenbek, F. X.). Petroleum engineering in the Deaner oil field, Okfuskee County, Okla., 72 pp. ( $\ddagger), 16$ pls. (incl. maps), U. S. Bur. Mines in cooperation with the State of Oklahoma and the Bartlesville Chamber of Commerce, July 1921.

Kitson, John E.

2223. Two occurrences of babingtonite in Massachusetts: Rocks and Minerals, vol. 11, no. 8, p. 124, August 1936.

Kjellesvig, Erik N.

2224. Note on a new eurypterid from the Moscow shales of New York [abstract] : Elisha Mitchell Sci. Soc. Jour., vol. 49, no. 1, p. 29, September 1933. 
Kjellesvig, Erik N-Continued.

2225. Variations in the test of Nonion pizarrensis Berry and Nonionella auris (D'Orbigny) from the Miocene of North Carolina [abstract]: Elisha Mitchell sci. Soc. Jour., vol. 49, no. 1, p. 24, September 1933.

Kleinpell, Robert Minssen. See also Schenck, 3545, 3546, 3549; Woodring, 4603. 2226. Discussion of Miocene history and faunas [abstract]: Am. Assoc. Petroleum Geologists Bull., vol. 19, no. 1, p. 136, January 1935.

2227. Proposed biostratigraphic classification of California Miocene [abstract] : Geol. Soc. America Proc., 1934, pp. 390-391, June 1935.

Kleinpell, W. D. See Noble, 2899.

Klug, Harold Philip. See Pauling, 3030.

Knebel, Moses G. See Wendlandt, 4394.

Knechtel, Maxwell McMichael. See also Hendricks, 1709; U. S. G. S., 4228, 4231 ; Waring, 4340.

2228. (and Hendricks, Thomas Andrews, Read, Charles Brian, Anderson, Carl Bernard, Hart, Raymond M., Christian, Walton, and Metcalf, Thomas Larkin). Geologic map of the Lehigh district, Coal, Atoka, and Pittsburg Counties, Okla. (preliminary edition). Scale 1 inch to 1 mile. U. S. Dept. Interior, Geol. Survey, Washington, 1935. (Contains sections.)

2229. (and Rothrock, Howard Eugene). Apparent recent crustal movement at western end of Ouachita Mountains, Okla.: Am. Assoc. Petroleum Geologists Bull., vol. 19, no. 8, pp. 1219-1225, 4 figs. (incl. geol. map), August 1935; abstract, Washington Acad. Sci Jour., vol. 25, no. 12, pp. 567-568, December 15, 1935.

2230. Indian Hot Springs, Graham County, Ariz.: Washington Acad. Sci. Jour., vol. 25 , no. 9, pp. 409-413, 2 figs. (incl. index map), September 15, 1935.

2231. Geologic relations of the Gila conglomerate in southeastern Arizona: Am. Jour. Sci., 5th ser., vol. 31, no. 182, pp. 81-92, 2 figs. (incl. sketch map), February 1936.

Kniffen, Fred Bowerman.

2232. Bayou Manchac, a physiographic interpretation: Geog. Rev., vol. 25, no. 3, pp. 462-466, 1 fig. (physiographic map), July 1935.

Knight, Charles Robert.

2233. Before the dawn of history. 119 pp., 48 pls., New York, McGraw-Hill Book Co., 1935.

Knight, Elmer W. See Scofield, 3602.

Knight, James Brookes. See also Howell, 1857.

2234. New nomenclatural type name, diplotype [abstract] : Geol. Soc. America Proc. 1935, p. 372, June 1936.

2235. Notes on Paleozoic Gastropoda: Jour. Paleontology, vol. 10, no. 6, pp. 520-534, September 1936.

Knopf, Adolph. See also Longwell, 2442.

2236. The Plumas County copper belt, Calif.: Copper resources of the world, pp. 241-245, Washington, 16th Internat. Geol. Cong., 1935.

2237. The copper deposits of Yerington, Nev.: Copper deposits of the world, pp. 323-324, Washington, 16th Internat. Geol. Cong., 1935.

$311-37-11$ 
Knopf, Adolph-Continued.

2238. The world's gold resources: Sci. Monthly, vol. 42, no. 1, pp. 62-67, January 1936.

2239. Igneous geology of the Spanish Peaks region, Colo.: Geol. Soc. America Bull., vol. 47, no. 11, pp. 1727-1784, 5 pls., November 1936.

Knopf, Eleanora Bliss.

2240. Recognition of overthrusts in metamorphic terranes: Am. Jour. Sci., 5th ser., vol. 30, no. 177, pp. 198-209, 2 figs., September 1935.

Knute, Nicholas Vaksvik. See Stearns, 3849.

Kobayashi, Teiichi.

2241. The Ozarkian question and my view, pt. 2 : Geol. Soc. Tokyo Jour., vol. 41, no. 486, pp. 97-118 (Japanese, English résumé, pp. 119124), 1 fig. (paleogeographic map), March 20, 1934.

2242. The Briscoia fauna of the late Upper Cambrian in Alaska, with descriptions of a few Upper Cambrian trilobites from Montana and Nevada: Japanese Jour. Geology and Geography, vol, 12, nos. 3, 4, pp. 39-57, 3 pls., October 1935.

2243. Cambrian and Lower Ordovician trilobites from rorthwestern Canada: Jour. Paleontology, vol. 10, no. 3, pp. 157-167, 1 pl., April 1936.

Koch, H. L. See Tolman, 4137.

Koch, Lauge. See also Backlund, 127 ; Hobbs, 1758.

2244. Geologie der Erde; Geologie von Grönland. viii, 158 pp., 12 figs. (incl. index and geol. maps), Berlin, Gebrüder Borntraeger, 1935; critical review by Ove Balthasar Bøggild and others, Dansk geol. Förening Meddel., Bind 8, Hefte 5, pp. 483-512 (English transl., pp. 497-510), 1935.

2245. Ueber den Bau Grönlands: Geol. Rundschau, Band 27, Heft 1, pp. 9-30, 1 pl., 10 figs. (incl. geol. map); April 14, 1936.

Koester, Edward A. See also Anonymous, 4665.

2246. Geology of central Kansas uplift: Am. Assoc. Petroleum Geologists Bull., vol. 19, no. 10, pp. 1405-1426, 5 figs. (incl. maps), October 1935.

Kohanowski, Nicholas N.

2247. Notes on geology of the Cripple Creek district: Mines Mag., vol. 25, no. 4, pp. 11-12, 21, April 1935.

Kohler, J. P.

2248. Dust storms in the United States, June 1936: Monthly Weather Rev., vol. 64, no. 6, p. 206, June 1936.

Kollida, M. $\mathrm{H}$.

2249. Comments on tourmaline: Mineralogist, vol. 3 , no. 12 , pp. $7-8$, December 1935 .

2250. Genuine and imitation turquoise: Mineralogist, vol. 4 , no. 3 , pp. 16,18 , March 1936.

Koschmann, Albert Herbert. See also Behre, 260; Loughlin, 2459.

2251. Minor copper-producing districts of New Mexico: Copper resources of the world, p. 343, Washington, 16th Internat. Geol. Cong., 1935.

2252. Hornblendite and related rocks of Annette and Duke Islands, southeastern Alaska: Am. Geophys. Union Trans. 16th Ann. Meeting, pt. 1, pp. 268-274 ( $\ddagger), 6$ figs., Nat. Research Council, August 1935. 
Kovarik, Alois Francis.

2253. (and McKeehan, Louis Williams). Radioactivity; report of committee on X-rays and radioactivity: Nat. Research Council Bull. 51 (2d printing), 203 pp., 1929.

Kramer, William.

2254. Some central Texas wells that filled with water: Jour. Geology, vol. 43, no. 6, pp. 644-652, 2 figs. (incl. geol. map), August-September 1935.

2255. (and King, Philip Burke, and Miser, Hugh Dinsmore). Ouachita boulder problem [Oklahoma and Arkansas]: Am. Assoc. Petroleum Geologists Bull:, vol. 20, no. 4, pp. 479-491, 1 fig. (geol. map), April 1936.

Kranck, Ernst Hákan.

2256. On the crystalline complex of Liverpool Land: Meddelelser om Grönland, Band 95, Nr. 7, 122 pp. 4 pls. (incl. geol. maps), 22 flgs., 1935.

Kraskovsky, S. A.

2257. Geotermicheskie ezmereniya $\mathrm{v}$ mednykh rudnikakh $\mathrm{u}$ verkhnego Ozera [Geothermal temperatures in copper mines at Lake Superior]: Priroda. Akad. Nauk, U. S. S. R., no. 5, pp. 18-21, 1935 . [In Russian].

Kraus, Edward Henry.

2258. (and Hunt, Walter Fred, and Ramsdell, Lewis Stephen). Mineralogy ; an introduction to the study of minerals and crystals. 3d ed., 638 pp., 812 figs., New York, McGraw-Hill Book Co., Inc., 1936.

Krejci-Graf, Karl. See Barton, 213; Brauchli, 449.

Krick, Harriette Valetta.

2259. Theories regarding the decline of the seed-bearing ferns of the Paleozoic [abștract] : Kentucky Acad. Sci. Trans., vol. 6, 1933-34, p. $48,1935$.

Kriegel, w. Wurth.

2260. Nonmetallic minerals of Montana: Glück Auf, vol. 1, no. 2, pp. 5, 21, 1 fig., Butte, Mont., December 1935.

Krieger, Philip.

2261. Primary silver mineralization at Sabinal, Chihuahua, Mexico: Econ. Geology, vol. 30, no. 3, pp. 242-259, 11 figs., May 1935.

2262. Primary native silver ores at Batopilas, Mexico and Bullard's Peak, New Mex.: Am. Mineralogist, vol. 20, no. 10, pp. 715-723, 8 flgs., October 1935.

2263. Roy J. Colony [1870-1936]; an appreciation: Mining and Metallurgy, vol. 17, no. 353, p. 275, May 1936.

Kristofferson, $\mathrm{O} . \mathrm{H}$.

2264. Hydrothermal experiments with lead and zinc minerals: Econ. Geology, vol. 31, no. 2, pp. 185-204, 3 flgs., March-April 1936.

Kroenlein, George A.

2265. Progress of the west Texas search for Ordovician production shows possibilities: Oil Weekly, vol. 78 , no. 6 , pp. 31-34, 1 flg. (map), July 22, 1985. 
Krueger, Max L.

:2266. The Sycamore Canyon formation [Calif.] [abstract]: Am. Assoc. Petroleum Geologists Bull., vol. 20, no. 11, p. 1520, November 1936.

Krumbein, William Christian. See also Bayley, 246; Croneis, 917; Mather 2605 ; Snider, 3783.

2267. Thin-section mechanical analysis of indurated sediments: Jour. Geology, vol. 43, no. 5, pp. 482-496, 7 figs., July-August, 1935.

2268. A time chart for mechanical analysis by the pipette method: Jour. Sedimentary Petrology, vol. 5, no. 2, pp. 93-95, 1 fig., 1 table, August 1935.

2269. Application of logarithmic moments to size-frequency distributions of sediments: Jour. Sedimentary Petrology, vol. 6, no. 1, pp. 35-47, 5 figs., 2 tables, April 1936.

2270. The use of quartile measures in describing and comparing sediments: Am. Jour. Sci., 5th ser. vol. 32, no. 188, pp. 98-111, 5 figs., August 1936.

2271. Rejoinder to Wentworth's discussion of the method of moments: Jour. Sedimentary Petrology, vol. 6, no. 3, pp. 159-160, December 1936.

Krynine, Paul Dimitri.

2272. Arkose deposits in the humid Tropics; a study of sedimentation in southern Mexico: Am. Jour. Sci., 5th ser., vol. 29, no. 172, pp. 353-363, 3 figs., April 1935.

2273. Formation and preservation of desiccation features in a humid climate: Am. Jour. Sci., 5th ser., vol. 30, no. 176, pp. 96-87, 2 figs., August 1935.

2274. Genetic significance of arkose deposits (abstract) : Geol. Soc. America Proc., 1935, p. 87, une 1936.

2275. Geomorphology and sedimentation in the humid Tropics: Am. Jour. Sci., 5th ser., vol. 32, no. 190, pp. 297-306, October 1936.

Krystofovich, African.

2276. Fossil forests as a compass of the past: 16th Internat. Geol. Cong. (1933) Rept., vol. 2, p. 1103, 1936.

2277. Universal geological terminology : Pan-Am. Geologist, vol. 66, no. 2, pp. 87-89, September 1936.

Ksanda, Charles Jaroslav. See also Tunell, 4182, 4183, 4184, 4185.

2278. (and Barth, Thomas Fredrik Weybye). Note on the structure of dickite and other clay minerals: Am. Mineralogist, rol. 20, no. 9, pp. 631-637, 1 fig., September 1935.

Kümmel, Henry Barnard.

2279. Geology of the Coastal Plain of New Jersey: Shore and Beach, vol. 3, no. 3, pp. 70-75, July 1935.

Kugler, H. G.

2280. Summary digest of geology of Trinidad: Am. Assoc. Petroleum Geologists Bull., vol. 20, no. 11, pp. 1439-1453, 2 figs. incl. geol. map), November 1936; correction, vol. 21, no. 5, p. 630, May 1937.

Kurtenacker, Karl S.

2281. Some practical applications of resistivity measurements to highway problems: Am. Inst. Min. Met. Eng. Trans., vol. 110, Geophysical Prospecting, pp. 49-59, 8 figs., 1934.

2282. Use of resistivity methods for, locating and exploring deposits of stone and gravel : Rock Products, vol. 37, no. 7, pp. 32-35, 15 figs., July 1934. 
Ladd, George Edgar.

2283. Bank slide in deep cut caused by drought: Eng. News-Record, vol. 112, no. 10, pp. 324-326, 4 figs., March 8, 1934.

2284. Landslips, subsidences and rock falls: Am. Railroad Engineers' Assoc. Proc., vol. 36, pp. 1091-1162, 25 figs., 1935.

Ladd, Harry Stephen. See also Hoffmeister, 1773; Kansas Geol. Soc., 2020.

2285. Isopach map of the Maquoketa shale [upper Mississippi Valley] :

Kansas Geol. Soc. Guidebook 9th Ann. Field Conf., pp. 342-344 ( $\$)$, 1 pl. (isopach map), 1935.

2286. (and Hoffmeister, John Edward). A criticism of the glacial-control theory: Jour. Geology, vol. 44, no. 1, pp. 74-92, January-February 1936.

Lahee, Frederick Henry. See also Barton, 212; Fisher, 1271; Ver Wiebe, 4287.

2287. Geology and the new conception in pool development [with discussion] : Am. Petroleum Inst. Production Bull. 209, pp. 4-8, 4 figs., June 1982.

2288. Ground waters in or associated with oil fields: Am. Geophys. Union Trans. 16th Ann. Meeting, pt. 2, pp. 438-441 ( $\$)$, Nat. Research Council, August 1935.

Laird, H. C.

2289. Geology of the Makwa-Churchill area: Ontario Dept. Mines 43d Ann. Rept., (vol. 43, pt. 3), 1934, pp. 37-80, 23 figs. (incl. sketch maps), 2 pls. (geol. maps), 1935.

2290. The nature and origin of chert in the Lockport and Onondaga formations of Ontario: Royal Canadian Inst. Trans., vol. 20, pt. 2 (no. 44), pp. 231-304, 7 pls., 12 figs. (incl. sketch and paleogeographic maps), December 1935.

Lalicker, Cecil Gordon. See also Cushman, 942.

2291. Larval stages of trilobites from the Middle Cambrian of Alabama: Jour. Paleontology, vol. 9, no. 5, pp. 394-399, 1 pl., July 1935.

2292. Cavellina nebrascensis (Geinitz) : Jour. Paleontology, vol. 9, no. 8, pp. 744-745, 7 figs., December 1935.

Lamar, John Everts. See also Kansas Geol. Soc., 2020.

2293. Isopach map of St. Peter formation [upper Mississippi Valley] : Kansas Geol. Soc. Guidebook 9th Ann. Field Conf., p. 348 (¥), 1 pl. (isopach map), 1935.

Lambert, Jules.

2294. (and Sanchez Roig, Mario). Nueva especie fosil del género "Olypeaster": Rev. agricultura, comercio $y$ trabajo, año 14, vol. 14, no. 51, pp. 22-24, 2 figs., March 1934.

2295. Quelques nouveaux échinides fossiles du Crétacé du Mexique: Soc. géol. France Bull., 5th ser., tome 6, fasc. 1-2-3, pp. 3-6, 1 pl., 1936.

Lambert, Walter Davis.

2296. Geoid, spheroid, and isostasy [abstract]: Geol. Soc. America Proc., 1934, p. 449, June 1935.

2297. The figure of the earth from gravity observations: Washington Acad.

Sci. Jour., vol. 26, no. 12, pp. 491-506, 2 figs., December 15, 1936.

Lamborn, Raymond Ellwood. See Stout, 3949.

Lambrecht, Kalman.

2298. In memoriam, Robert Wilson Shufeldt, 1850-1934: Auk, vol. 52, no. 4, pp. 359-361, 1 pl. (port.), October 1935. 
Iamey, Carl Arthur.

2299. The intrusive relations and metamorphic effects of the Repubilic granite [abstract] : Northwestern Univ. Summaries, Doctoral Dissertations, vol. 1, pp. 207-215, 1933.

2300. The Palmer gneiss: Geol. Soc. America Bull., vol. 46, no. 7, pp. 11371162, 1 pl., 8 figs. (incl. geol. map), July 31, 1935.

LaMotte, Robert Smith.

2301. Climatic implications of Sapindus oregonianus: Carnegie Inst. Washington Pub. 455, pp. 31-38, 3 pls., 2 flgs. (incl. distrib. map), 1936; preprint, January 30, 1935.

2302. Early Tertiary sequence in the vicinity of Seattle [abstract]: Geol. Soc. America Proc., 1934, pp. 336-337, June 1935.

2303. Upper Miocene flora from $49 \mathrm{Camp}$, Nev. [abstract] : Geol. Soc. America Proc., 1934, p. 389, June 1935.

2304. The Miocene Tilias of western America: Carnegie Inst. Washington Pub. 455, pp. 41-48, 3 pls., 1936 ; preprint, July 10, 1935.

2305. An upper Oligocene florule from Vancouver Island [British Columbia] : Carnegie Inst. Washington Pub. 455, pp. 51-56, 1 pl., 1936; preprint, July 10, 1935; abstracts, Pan-Am. Geologist, vol. 63, no. 5, p. 379, June 1935 ; Geol. Soc. America Proc., 1935, p. 416, June 1936.

2306. Ellensburg flora of central Washington [abstract] : Pan-Am. Geologist, vol. 63, no. 5, p. 379, June 1935; Geol. Soc. America Proc., 1935, p. 417, June 1936.

2307. Two upper Miocene florules from central Washington [abstract] : Geol. Soc. America Proc., 1984, pp. 389-390, June 1935.

2308. Plant fossils in a marine upper Miocene deposit near Aberdeen, Wash. [abstract] : Pan-Am. Geologist, vol. 64, no. 1, pp. 71-72, August 1935 ; Geol. Soc. America Proc., 1935, p. 348, June 1936.

2309. The upper Cedarville flora of northwestern Nevada and adjacent California [with a section on the diatoms from 49 Camp, by Kenneth E. Lohman] : Carnegie Inst. Washington Pub. 455, Contr. Paleont. 5, pp. 57-142, 14 pls., 2. figs. (incl. index map), 1936; preprint, August 12, 1936.

2310. Some systematic revisions in Miocene palebotany, 1934-36: Carnegie Inst. Washington Pub. 455, pp. 145-148, 1936 ; preprint, October 24, 1936.

Landes, Kenneth Knight. See also Bucher, 534; Howell, 1856, 1859.

2311. Age and distribution of pegmatites: Am. Mineralogist, vol. 20, no. 2, pp. 81-105, 2 figs. (maps), February 1935; no. 3, pp. 153-175, 3 figs. (maps), March 1935.

2312. Colorado pegmatites: Am. Mineralogist, vol. 20, no. 5, pp. 319-333. May 1935.

Landsberg, $\mathrm{H}$.

2313. The problem of earthquake prediction: Science, new ser., vol. 82 , no. 2115 , p. 37 , July 12, 1935.

2314. Some correlations between the occurrence of deep- and shallow-focus earthquakes: Am. Geophys. Union Trans. 16th Ann. Meeting, pt. 1, pp. 91-93 (\$), Nat. Research Council, August 1935; Pennsylvania State College, Min. Indus. Exper. Sta. Tech. Paper 19, 1935.

2315. Note on earthquake intensities on different floors of houses: Gerlands Beitr. 'Geophysik, Band 48, pp. 84-85, 1936; Pennsylvania State College Min. Expr. Sta. Tech. Paper 30, 1936. 
Landsberg, H.-Continued.

2316. A genetic system of earthquake origin: Am. Geophys. Union Trans. 17th Ann. Meeting, pt. 1, pp. 89-92 ( $\ddagger$, Nat. Research Council, July 1936; Earthquake Notes, vol. 8, nos. 1-2, pp. 89-92 ( $\ddagger)$, June 1936; Pennsylvania State College Min. Indus. Exper. Sta. Tech. Paper 30, 1936.

2317. Remarks on the diurnal variation of earthquake occurrence with reference to the Helena, Mont., swarm: Seismol. Soc. America Bull., vol. 26, no. 3, pp. 235-237, July 1936; Pennsylvania State College Min. Exper. Sta. Tech Paper 30, 1936.

Lane, Alfred Church. See also Born, 374 ; Sederholm, 3630 ; Spence, 3802.

2318. Normal geothermal gradient in United States: Am. Assoc. Petroleum Geologists Bull., vol. 19, no. 4, p. 560, April 1935.

2319. (and others). Report of the committee on the measurement of geologic time: Nat. Research Council Ann. Rept. app. H, 1934-35, 85 pp. (\$), April 27, 1935.

2320. (and Urry, William Donald). Age of traps by the helium method [abstract, with discussion]: Geol. Soc. America Proc., 1934, pp. 88-90, June 1935.

2321. Memorial of George H. Barton [1852-1933] : Geol. Soc. America Proc., 1934, pp. 161-172, port., June 1935.

2322. Killärnean and earlier granite: Science, new ser., vol. 82, no. 2116, pp. 60-61, July 19, 1935.

2323. (and Urry, William Donald). Ages by the helium method; 1 , Keeweenawan: Geol. Soc. America Bull., vol. 46, no. 7, pp. 1101-1120, July 31, 1935.

2324. Differentiation in traps and ore deposition: Econ. Geology, vol. 30, no. 8, pp. 924-927, December 1935.

2325. Rating the geologic clock: 16th Internat. Geol. Cong. (1933) Rept., vol. 1, pp. 145-167, 1936; Tufts College Studies, vol. 6, no. 1, Sci. ser. no. 51, October 1936.

2326. John Caspar Branner (1850-1922) : Am. Acad. Arts Sci. Proc., vol. 70, no. 10 , pp. 500-501, March 1936.

2327. The Algonkian error [abstract] : Geol. Soc. America Proc., 1935, p. 88, June 1936.

2328. (and others). Report of the committee on the measurement of geologic time, 1935-36: Nat. Research Council Ann. Rept., 1935-36. App. K, 87 pp. (†), September 1936.

2329. (and Sterne, T. E.). Accurate geologic time determinations: Nat. Research Council Ann. Rept. App. K, pp. 68-75 (\$), September 1936 ; abstract, Geol. Soc. America Proc. 1935, pp. 87-88, June 1936.

2330. Eutopotropism: Scientia, vol. 57, no. 276, pp. 279-284, 1935; Tufts College Studies, vol. 6, no. 1, Sci. ser. no. 53, 6 pp., October 1936.

Lane, Bernard Harlin.

2331. Suggestions to authors of papers submitted for publication by the United States Geological Survey, with directions to typists, by George McLane Wood, editor, 1908-1925; Fourth edition, revised and enlarged, by Bernard H. Lane, editor, 1925-1937. 126 pp., Washington, U. S. Geol. Survey, 1935.

Lane, Emory Wilson. See Stevens, 3894. 
Lane, George $\mathbf{H}$.

2332. A preliminary pollen analysis of the East McCulloch [Iowa] peat bed: Ohio Jour Sci., vol. 31; no. 3, pp. 165-171, 2 figs., May 1931.

Lane, H. C. See De Lury, 1.025.

Lang, Arthur Hamilton. See also Canada G. S., 649.

2333. Keithley Creek map area, Cariboo district, British Columbia: Canada Dept. Mines, Geol. Survey Paper 36-15, 28 pp. ( $¥), 1$ pl. (geol. map), May 1936.

Lang, Walter Barnes. See also Mansfield; 2569.

2334. Upper Permian formation of Delaware Basin of Texas and New Mexico: Am. Assoc. Petroleum Geologists Bull., vol. 19, no. 2, pp. 262270, 7 figs. (incl. map), February 1935.

Lang, William Dickson.

2335. [Francis Arthur Bather, 1863-1934] : Geol. Soc. London Quart. Jour., vol. 91, pt. 3 (no. 363), pp. lxxxvii-lxxxix, September 30, 1935.

Langford, George Burwash.

2336. (and Hancox, E. G.). Hypogene anhydrite from McIntyre mine, Porcupine district, Ontario: Econ. Geology, vol. 31, no. 6, pp. 600609, September-October 1936.

Langton, Claude Maurice.

2337. Geology of the northeastern part of the Idaho batholith and adjacent region, in Montana: Jour. Geology, vol. 43, no. 1, pp. 27-60, 1 pl. (geol. map), 5 figs. (incl. index map), January-February 1935.

Larsen, Esper Signius. See also Cross, 925.

2338. (and Miller, Franklin S.). The Rosiwal method and the modal determination of rocks: Am. Mineralogist, vol. 20, no. 4, pp. 260-273, April 1935.

2339. (and Hurlbut, Cornelius Searle, Jr., Burgess, C. Harry, Griggs, David Tressell, and Buie, Bennett Frank). The igneous rocks of the Highwood Mountains of central Montana: Am. Geophys. Union Trans. 16th Ann. Meeting, pt. 1, pp. 288-292 (\$), 1 fig., Nat. Research Council, August 1935.

2340. (and Irving, John, Gonyer, F. A., and Larsen, Esper Signius, 3d). Petrologic results of a study of the minerals from the Tertiary volcanic rocks of the San Juan region; Colo.: Am. Mineralogist, vol. 21, no. 11, pp. 679-701, 7 figs., November 1936.

Larsen, Esper Signius, 3d. See Larsen, E. S., 2340.

Larsen, Raymond M. See Dobbin, 1049; Erdmann, 1186; U. S. G. S., 4227.

Lasky, Samuel Grossman.

2341. Distribution of silver in base-metal ores [with discussion] : Am. Inst. Min. Met. Eng. Trans., vol. 115 (Mining geology), pp. 69-80, 1 fig., 1935 ; abstract, Year Book sec., p. 82, 1935.

2342. The Lordsburg district, N. Mex.: Copper resources of the world, pp. 337-341, 2 figs. (incl. geol. map), Washington, 16th Internat. Geol. Cong., 1935.

2343. Igneous assimilation and associated contact metamorphism in the Virginia mining district, N. Mex, : Am, Mineralogist, Yol, 20, no, 8, pp. 552-561, 5 figs. (incl. geol. map), August 1935; abstract, Am. Geophys. Union Trans. 16th Ann. Meeting, pt. 1, p. 302 ( $\ddagger)$, Nat. Research Council, August 1935. 
Lasky, Samuel Grossman-Continued.

2344. Geology and ore deposits of the Bayard area, Central mining district, N. Mex.: U. S. Geol. Survey Bull. 870, vi, 144 pp. 17 pls. (incl. geol. maps), 21 figs. (incl. index and geol. maps), 1936.

2345. Hydrothermal leaching in the Virginia mining district, N. Mex.: Econ. Geology, vol. 31, no. 2, pp. 156-169, 7 figs. (incl. index and geol. maps), March-April 1936.

Laudermilk, Jerome Douglas. See also Merriam, 2675.

2346. (and Munz, Philip Alexander). Plants in the dung of Nothotherium from Gypsum Cave, Nev. : Carnegie Inst. Washington Pub. 453, pp. 29-37, 11 pls., July 1935 [preprint, December 20, 1934] ; abstract, Geol. Soc. America Proc., 1934, p. 333, June 1935.

2347. Soda alunite from Molokai, Hawaiian Islands: Am. Mineralogist, vol. 20, no. 1, pp. 57-58, January 1935.

2348. (and Woodford, Alfred Oswald). Black iron sulphide in a California crystalline limestone [abstract]: Pan-Am. Geologist, vol. 63, no. 4, p. 320, May 1935; Geol. Soc. America Proc., 1935, p. 342, June 1936.

Laudon, Lowell Robert. See also Kansas Geol. Soc., 2020.

2349. Supplemental statement on the Mississippian system in Iowa: Kansas Geol. Soc. Guidebook 9th Ann. Field Conf., pp. 246-247 ( ), 1935.

2350. Notes on the Devonian crinoid fauna of the Cedar Valley formation of Iowa: Jour. Paleontology, vol. 10, no. 1, pp. 60-66, 1 pl., January 1936.

Lausen, Carl.

2351. The occurrence of minute quantities of mercury in the Chinle shales at

Lees Ferry, Ariz: Econ Geology, vol. 31, no. 6, pp. 610-617, September-October 1936.

Laverdière, Joseph-Willie. See also Ruedemann, 3405.

2352. The Paleozoic of the Deschambault region Portneuf County: Quebec

Bur. Mines Ann. Rept., 1934, pt. D, pp. 45-62, 3 figs. (incl. geol. map), 1935; also in French ed., 1935.

Lavine, Irvin.

2353. (and Feinstein, Herman). Natural deposits of sodium sulphate in North Dakota: Am. Inst. Min. Met. Eng. Contr. 97, 8 pp. 5 figs. (incl. index map), February 1936; abstract, Mining and Metallurgy. vol. 17, no. 350, p. 118, February 1.936.

Lavington, Charles S. See Brainerd, 434.

Law, John. See Howe, 1846.

Law, Russell L. See Birch, 323.

Lawrence, Donald B.

2354. The submerged forests of the Columbia River gorge: Geog. Rev., vol. 26, no. 4, pp. 581-592, 8 figs. (incl. index map), October 1936.

Lawson, Andrew Cowper. See also Day, 987, 989.

2355. Is the Killarney granite different in age from the Algoman?: Science, new ser., vol. 81 , no. 2108 , p. 515, May 24, 1935.

2356. The Sierra Nevada in the light of isostasy: Geol. Soc. America Bull., vol. 47 , no. 11, pp. 1691-1712, November 30, 1936. 
Lay, Douglas.

2357. The pre-Mississippian veins and deposits of the Cariboo district [British Columbia]: Canadian Inst. Min. Metallurgy Trans., vol. 38 (also appeared in Bull. 283, November 1935), pp. 475-477, 1 pl., 1935.

Layfield, Robert A.

2358. Geology of Saddle Mountain State Park and vicinity : Geol. Soc. Oregon Country News Letter, vol. 2, no. 24, pp. 4-10 (\$), December 25, 1936.

Lazell, Ellis Warren. See also Cassirer, 701.

2359. Elementary crystallography: Mineralogists, vol. 3, no. 1, pp. 28, 52, January 1935; no. 2, pp. 11-12, 3 figs., February 1935; no. 3, pp. 14-15, March 1935; no. 4, pp. 16, 18, 6 figs.; April 1935; no. 5, pp. 14-16, 12 figs., May 1935; no. 6, p. 12, 1 fig., June 1935.

2360. How old is a teredo?: Mineralogists, vol. 3, no. 11, p. 14, 2 figs., November 1935.

2361. Diatomite deposits in Oregon: Mineralogist, vol. 4, no. 4, pp. 9-10, 2 figs., April 1936.

2362. A unique petrifaction: Mineralogist, vol. 4, no. 5, pp. 14, 26, 1 fig., May 1936.

Leathercock, Constance. See also Bass. 220 ; U. S. G. C., 4235, 4236.

2363. (and Bass, Nathan Wood). Chattanooga shale in Osage County, Okla., and adjacent areas: Am. Assoc. Petroleum Geologists Bull., vol. 20, no. 1, pp. 91-101, 5 figs. (incl. sketch map), January 1936.

Leatherock, Otto. See U. S. G. S., 4237, 4238.

Leavitt, Harold Walter. See also White, 4458.

2364. (and Perkins, Edward Henry). A survey of road materials and glacial geology of Maine; vol. 1, pt. 1, A survey of road materials of Maine, their occurrence and quality, 487 pp., 39 figs.; pt. 2, Maps (128) showing locations of road materials; vol. 2, Glacial geology of Maine, 230 pp., 39 figs. : Maine Tech. Exper. Sta., Bull. 30, vol. 1, June 1934 ; vol. 2, June 1935. Supplements, Official map of Maine, glacial deposits, by Edward H. Perkins, and Preliminary geologic map of Maine, by Arthur Keith.

Lee, Charles Hamilton.

2365. (and others). Report of the committee on absorption and transpiration, 1933-34: Am. Geophys. Union Trans. 15th Ann. Meeting, pt. 2, pp. 286-296 ( $\ddagger$ ), National Research Council, June 1934 .

2366. Report of the committee on absorption and transpiration, 1935-36: Am. Geophys. Union Trans. 17th Ann. Meeting, pt. 2, pp. 296-302 ( Nat. Research Council, 1936.

Lee, Frederick William. See also Wenner, 4398.

2367. (and Vanderberg, William 0.). Survey of the possible application of geophysical methods to mineral occurrences in the Boulder Dam area, and notes on the mineral deposits visited. 13 pp. ( $\ddagger), 3$ pls. (index maps), [Washington, D. C., 1935 (?)].

Lee, O. Ivan.

2368. A new property of matter; Reversible photosensitivity in hackmanite from Bancroft, Ontario: Am. Mineralogist, vol. 21, no. 12, pt. 1, pp. 764-776, 1 fig., December 1936.

Lees, Everett John. See Canada G. S., 665, 674. 
Lees, James Henry.

2369. Additional deep wells: Iowa Geol. Survey, vol. 36, pp. 365-420, 1b, 2b, 1935.

Leet, Lewis Don.

2370. Earthquakes and volcanoes: Am. Year Book, 1934, pp. 729-730, 1935.

2371. The Provincetown, Mass., earthquake of April 23, 1935, and data for investigating New England's seimicity: Nat. Acad. Sci. Proc., vol. 21, no. 6, pp. 308-313, 4 figs. (incl. sketch map); June 15, 1935.

2372. Prospecting with seismographs; oil, gold, glaciers and local earthquakes [abstract]: Earthquake Notes, vol. 7, nos. 1-2, p. 15 ( $)$, September 1935.

2373. Present status of seismology in New England [abstract] : Earthquake Notes, vol. 7, nos. 1-2, pp. 22-23 ( $\$)$, September 1935.

2374. Seismological data on surface layers in New England: Seismol. Soc. America Bull., vol. 26, no. 2, pp. 129-145, 7 figs, April 1936; abstract, Earthquake Notes, vol. 7, nos. 1-2, p. 16 ( $\ddagger$, September 1935.

Leggette, Ralph Maxwell. See also Meinzer, 2639; Taylor, 4025.

2375. (and Taylor, George Holmes). Earthquakes instrumentally recorded in artesian wells: Seismol. Soc. America Bull., vol. 25, no. 2, pp. 169-175, 3 figs., April 1935.

2376. (and others). Report of the committee on observation wells, U. S. Geological Survey; a preliminary manual of methods. ii, 58 pp. (\$), 8 pls., May 1935 .

2377. (and Dollen, B. H.). Effect of preglacial topography on ground-water conditions in the Rochester region [abstract]: Geol. Soc. America Proc., 1934, pp. 90-91, June 1935.

2378. (and Gould, L. O., and Dollen, B. H.). Ground-water resources of Monroe County, N. Y., 141 pp. ( $\ddagger$ ), 45 pls. (incl. maps), 14 flgs. (incl. maps), Monroe County Regional Planning Board, August 1, 1935.

2379. (and Taylor, George Holmes). The artesian-water supply of Ogden, Utah: U. S. Dept. Interior Press Mem. 106377, 5 pp. ( $¥)$, September 17, 1935.

2380. Symposium on fluctuations of ground water; Long-time records of ground-water levels on Long Island, N. Y.: Am. Geophys. Union Trans. 17th Ann. Meeting, pt. 2, pp. 341-344 (\$), 2 figs., Nat. Research Council, 1936.

Lehner, Ernst.

2381. Introduction a la géologie de Trinidad et bigliographie géologique: Office nat. combust. liquides Annales, dixième année, fasc. 4, pp. 693-730, 3 pls. (incl. geol. map), July-August 1935; correction, Am. Assoc. Petroleum Geologists Bull., vol. 21, no. 5, p. 630, May 1937.

Leighton, Morris Morgan.

2382. Some geological conditions governing location, drilling, and casing of wells [abstract]: Water Works and Sewerage, vol. 80, no. 5, p. 174, May 1933.

2383. (and Townley, Enid, and others). Studies in glacial sediments, 1932-33, with brief mention of related matters: Nat. Research Councll Bull. 98, pp. 82-145, July 1935. 
Leighton, Morris Morgan-Continued.

2384. Research program of the Illinois State Geological Survey: Science, new ser., vol. 82, no. 2138, pp. 594-595, December 20, 1935.

2385. Researches in rock-wool resources: Texas Univ. Bull. 3501, pp. 65-86, 16 figs. (incl. geol. map), February 1936.

2386. A model State resource survey : Texas Univ. Bull. 3501, January 1, 1935, pp. 163-171, February 1936.

Leith, Andrew. See also Leith, C. K., 2390 ; Kansas Geol. Soc., 2020.

2387. The pre-Cambrian of the Lake Superior region, the Baraboo district, and other isolated areas in the upper Mississippi Valley: Kansas Geol. Soc. Guidebook 9th Ann. Field Conf.: pp. 320-322 ( $\ddagger), 1$ pl. (geol. map), 1 fig. (geol. map), 1935.

2388. (and Sharpe, Joseph Audley). Deep-focus earthquakes and the strength of the earth [abstract]: Geol. Soc. America Proc., 1935, pp. 88-89, June 1936.

2389. (and Sharpe, Joseph Audley). Deep-focus earthquakes and their geological significance: Jour. Geology, vol. 44, no. 8, pp. 877917, 10 figs. (incl. index maps), November-December 1936.

Leith, Charles Kenneth.

2390. (and Lund, Richard J., and Leith, Andrew). Pre-Cambrian rocks of the Lake Superior region; a review of newly discovered geologic features with a revised geologic map: U. S. Geol. Survey Prof. Paper 184, 34 pp., 2 pls. (incl. geol. map), 1935.

2391. Conservation of minerals: Science, new ser., vol. 82 , no. 2119 , pp. 109 117, August 9, 1935.

Lemmon, Dwight $M$.

2392. Augelite from Mono County, Calif.: Am. Mineralogist, vol, 20, no. 9, pp. 664-668, 2 figs., September 1935.

Leonard, Frederick Charles.

2393. (and Webb, Robert William). Bibliography of meteorites; first 1935 list: Popular Astronomy, vol. 43, no. 4, pp. 251-252, April 1935; Soc. Research on Meteorites Contr., fasc. 1, pp. 18-19, January 1936.

2394. (and Webb, Robert William). Progress in meteoritical research [abstract] : Pan-Am. Geologist, vol. 63, no. 4, pp. 313-314, May 1935; Geol. Soc. America Proc., 1935, pp. 335-336, June 1936.

2395. (and Webb, Robert William). Bibliography of meteorites; second 1935 list : Popular Astronomy, vol. 43, no. 10, pp. 658-660, December 1935; Soc. Research on Meteorites Contr., fasc. 1, pp. 43-45, January 1936.

2396. (and Webb, Robert William). Bibliography of meteorites; first 1936 list: Popular Astronomy, vol. 44, no. 1, pp. 47-49, January 1936.

Leonardon, Eugene Gilbert. See also Deussen, 1034 ; Schlumberger, 3562, 3563. 2397. Schlumberger method of well surveying [abstract, with discussion] : Tulsa Geol. Soc. Digest, 1934, pp. 46-50.

2398. The economic utility of thermometric measurements in drill holes in connection with drilling and cementing problems: Geophysics, vol. 1 , no. 1 , pp. 115-126, 6 figs., January 1936; abstract, World Petroleum, vol. 7, no. 7, p. 368, July 1936.

2399. In memoriam [Conrad Schlumberger, 1878-1936]: Geophysics, vol. 1, no. 2, pp. 296-297, July 1936. 
Levereault, Philip.

2400. The segmental condition in the trunk of trilobites: Am. Jour. Sci., 5th ser., vol. 31, no. 185, pp. 386-390, 7 flgs., May 1936.

Leverett, Frank.

2401. (and MacLachlan, Donald Claude). Variations in tilt lines in the Huron-Erie district [abstract] : Science, new ser., vol. 80, no. 2085, p. 550, December 14, 1934.

2402. Patrician ice movements: Pan-Am. Geologist, vol. 63, no. 1, pp. 5-8, February 1935.

Levorsen, Arville Irving.

2403: Studies in paleogeology [abstract] : 16th Internat. Geol. Cong. (1933) Rept., vol. 2, p. 1008, 1936.

2404. Stratigraphic versus structural accumulation: Oil and Gas Jour., vol. 34, no. 45, pp. 41-44, 48, 2 figs., March 26, 1936; Am. Assoc. Petroleum Geologists Bull., vol. 20, no. 5, pp. 521-530, May 1936; abstract, World Petroleum, vol. 7, no. 5, p. 282, May 1936.

2405. Symposium on Mexico; foreword: Am. Assoc. Petroleum Geologists Bull., vol. 20, no. 4, p. 385, April 1936.

2406. Petroleum geology and the American Association of Petroleum Geologists: Am. Assoc. Petroleum Geologists Bull., vol. 20, no. 4, pp. 387-393, 1 fig., April 1936.

Lewis, James A. See Fancher, 1214.

Lewis, H. P.

2407. The Lower Carboniferous corals of Nova Scotia: Annals and Mag. Nat. History, 10th ser., no. 91 (vol. 16), pp. 118-142, 3 pls., July 1935.

Lewis, Joseph Volney. See also Ross, 3362.

2408. (and Hawkins, Alfred Cary). Supplement to Lewis and Hawkins' Determinative mineralogy, fourth edition. 23 pp., April 10, 1934.

2409. Memorial of Henry Stephens Washington [1867-1934]: Am. Mineralogist, rol. 20, no. 3, pp. 179-184, port., March 1935.

Ley, Henry A. See also De Golyer, 1007.

2410. Geology of natural gas. [Edited, with foreword by Henry A. Ley]. xii, 1227 pp., illus., Tulsa, Okla., Am. Assoc. Petroleum Geologists [June] 1935.

2411. Natural gas in eastern Kansas: Geology of natural gas, pp. 483-510, 10 figs., Am. Assoc. Petroleum Geologists, [June] 1935.

2412. (and Willson, Kenneth M.). Gas fields in northeast Texas embayment: Geology of natural gas, pp. 651-682, 13 figs. (incl. maps), Am. Assoc. Petroleum Geologists, [June] 1935.

2413. Lima-Indiana district, Indiana and Ohio: Geology of natural gas, pp. 843-852, 1 fig. (geol. map), Am. Assoc. Petroleum Geologists, [June] 1935.

2414. Natural gas: Geology of natural gas, pp. 1073-1150, 10 figs. (incl. maps), Am. Assoc. Petroleum Geologists, [June] 1935 ; extract, Pan-Am. Geologists, vol. 64, no. 3, pp. 161-178, 2 pls. (maps), 1 flg., October 1935.

Lilley, Ernest Raymond. See also Bain, 141 ; Graton, 1503.

2415. Economic geology of mineral deposits. x, 811 pp., 301 figs. (incl. geol. maps), New York, Henry Holt \& Co., [1936]. 
Lilley, Ernest Raymond-Continued.

2416. [Review of] Geology of the Tampico region, Mexico, by John M. Muir, 1936 : Mining and Metallurgy, vol. 17, no. 359, pp. 591-592, December 1936.

Lindberg, George D. See Newcomb, 2854.

Lindgren, Waldemar.

2417. Biographical memoir of George Perkins Merrill, 1854-1929: Nat. Acad. Sci. Biog. Mem., vol. 17, no. 2, 53 pp., 1 pl. (port.), 1935.

2418. Waters, magmatic and meteoric: Econ. Geology, vol. 30, no. 5, pp. 463477, August 1935.

2419. Harry Cyril Boydell [1879-1935], in memoriam : Eng. and Min. Jour., vol. 136 , no. 11, p. 583 , November 1935.

2420. Frederick Leslie Ransome, 1868-1935; a memorial: Econ. Geology, vol. 30, no. 7, pp. 841-842, November 1935.

2421. Succession of minerals and temperatures of formation in ore deposits of magmatic affiliations: Am. Inst. Met. Eng. Tech. Pub. 713, 23 pp., May [1936] ; abstract, Mining and Metallurgy, vol. 17, no. 353, p. 270, May 1936.

Lindsay, Robert Bruce. See Archibald, 83.

Lindscheid, A. See Miser, 2750.

Link, Theodore August.

2422. Types of foothills structures of Alberta, Canada: Am. Assoc. Petroleum Geologists Bull., vol. 19, no. 10, pp. 1427-1471, 33 figs. (incl. index and geol. maps), October 1935.

Linneman, Joseph P.

2423. Some gold occurrences in South Carolina : Rocks and Minerals, vol. 11, no. 3, pp. 38-39, March 1936.

Linton, Edwin.

2424. Coal and natural oil in the Pittsburgh region: Science, new ser., vol. 81, no. 2097, p. 252, March 8, 1935.

Lipman, Charles Bernard.

2425. Bacteria in meteorites: Popular Astronomy, vol. 44, no. 8, pp. 442-446, October 1936.

Little, Homer Payson.

2426. Orodvician fossils from Laborador: Science, new ser., vol. 83 , no. 2177, pp. 268-269, September 18, 1936.

Livingston, Burton Edward.

2427. Background and origin of the American Association [for the Advancement of Science]: Science, new ser., vol. 81, no. 2098, pp. 270-271, March 15, 1935.

Livingston, Douglas Clermont.

2428. Opportunities in Thunder Mountain district, Idaho: Mining and Metallurgy, vol. 14, no. 318, p. 271, June 1933.

Livingston, Penn P. See also Turner, 4190.

2429. (and Sayre, Albert Nelson, and White, Walter Noy). Water resources of the Edwards limestone in the San Antonio area, Tex.: U. S. Geol. Survey Water-Supply Paper 773-B, pp. 1, 59-113 (†), 1 pl. (geol. map), 4 figs., 1936. 
Livingston, Penn P-Continued.

2430. (and Bridges, Thomas W.). Ground-water resources of Kleberg County, Tex. : U. S. Geol. Survey Water-Supply Paper 773-D, pp. ii, 197-232 (†), 5 pls. (incl. map), 1 fig. (geol. map), 1936.

Lochman, Christina. See also Howell, 1861, 1862; Myerhoff, 2687, 2690.

2431. New trilobite genera from the Bonneterre dolomite (Upper Cambrian) of Missouri: Jour. Paleontology, vol. 10, no. 1, pp. 35-43, 1 pl., January 1936.

2432 (and Howell, Benjamin Franklin). Widespread occurrence of galena in Cambrian limestones of the central and western United States [abstract] : Geol. Soc. America Proc., 1935, p. 387, June 1936.

Locke, Augustus. See also Billingsley, 322.

2433. The Boleo copper area, Baja California, Mexico: Copper resources of the world, pp. 407-412, 2 figs. (geol. maps), Washington, 16th Internat. Geol. Cong., 1935.

Lockett, J. R. See Stout, 3949.

Loewinson-Lessing, Franz.

2434. A contribution to the mechanics of intrusion: 16th Internat. Geol. Cong. (1933)' Rept, vol. 1, pp. 333-346, 1 fig., 1936.

Logan, Clarence August.

2435. Mother Lode gold belt of California: California Dept. Nat. Res., Div. Mines Bull. 108, November 1934, 240 pp., 11 pls. (incl. geol. maps), 33 figs. (incl. maps), 1935.

Logan, Jack.

2436. Ten new fields opened on Gulf coast during past 16 months: Oil Weekly, vol. 74, no. 5, pp. 65-66, July 16, 1934.

2437. Gulf coast oil fields, salt domes, and prospects: Oil Weekly, vol. 74, no. 5, pp. 67-138, July 16, 1934.

Logue, Thomas A.

2438. Survey [of Pennsylvania] reaches 100th birthday: Pennsylvania Dept. Internal Affairs Monthly Bull., vol. 1, no. 5, pp. 3-4, April 1936.

Lohman, Kenneth Elmo. See also LaMotte, 2309; Oliver, 2950.

2439. Diatoms from Quaternary lake beds near Clovis, New Mex.: Jour. Paleontology, vol. 9, no. 5, pp. 455-459, July 1935.

2440. Pliocene diatoms from the Kettleman Hills, Calif. [abstract]: Geol. Soc. America Proc., 1935, p. 382, June 1936.

Lohman, Stanley William. See also Leggette, 2376.

2441. Geology and ground-water resources of the Elizabeth City area, N. C.: U. S. Geol. Survey Water-Supply Paper 773-A, pp. ii, 1-57 ( $)$, 4 pls. (incl. phys. map), 5 figs. (incl. index map), 1936.

Lohr, Edwin Wallace. See Cady, 621.

Lohse, J. M. See Ewing, 1195.

Longley, W. W. See Grout, 1553.

Xongwell, Chester Ray.

2442. (and Knopf, Adolph, and Flint, Richard Foster). Outlines of physical geology, v, 356 pp., front., 296 figs., New York, John Wiley \& Sons, Inc., 1934.

2443. Is the "roots-of-mountains" concept dead?: Am. Jour. Sci., 5th ser., vol. 29, no. 170, pp. 81-92, 2 figs., Februarv 1935. 
Longwell, Chester Ray-Continued.

2444. (and Dunbar, Carl Owen). Problems of Pennsylvanian-Permian boundary in southern Nevada: Am. Aissoc. Petroleum Geologists Bull., vol. 20, no. 9, pp. 1198-1207, 6 figs. (incl. index map), September 1936; abstract, Geol. Soc. America Proc., 1935, pp. 89, 374-375. June 1936.

2445. Geology of the Boulder Reservoir floor: Geol. Soc. America Bull., vol. 47, no: 9, pp. 1393-1476, 21 pls. . (incl. geol. maps), 10 figs. (incl. index maps), September 30, 1936 ; abstract, Proc., 1934; p. 91, June 1935.

Lonsdale, John Tipton.

2446. Geology and ground-water. resources of Atascosa and Frio Counties, Tex.: U. S. Geol. Survey Water-Supply Paper 676, 90 pp.; 8 pls. (incl. geol. map), 4 figs. (incl. index map), 1935.

2447. Investigation of underground water resources [abstract]: Pan-Am. Geologist, rol. 65, no. 4, May 1936.

Loomis, Frederic Brewster, 1873-1937.

2448. Report of the Geology Department of Amherst College to the Alumni Visiting Committee of the Alumni Council, November 16, 1928: Amherst Alumni Council News, vol. 2, no. 3, pp. 5-8, February 1929.

2449. New lower Miocene skeleton, Protomeryx [abstract]: Geol. Soc. America Proc., 1934, p. 376, June 1935.

2450. Three New Miocene dogs and their phylogeny: Jour. Paleontology, vol. 10, no. 1, pp. 44-52, 6 figs., January 1936 ; 'abstract, Geol. Soc. America Proc., 1934, pp. 376-377, June 1935.

2451. Are conodonts gastropods?: Jour. Paleontology, vol. 10, no. 7, pp. 663-664, 40 figs., October 1936; abstract, Geol. Soc. America Proc., 1935, pp. 383-384, June 1936.

2452. [Review of] Proboscidea, a monograph of the discovery, evolution, migration, and extinction of the mastodonts and elephants of the world, by Henry. Fairfield Osborn, 1936: Science, new ser., vol. 84, no. 2191, pp. 576-577, December 25, 1936.

Lopatkin, Ivan A. : See Bowden, 384.

Lord, Clifford S. See Warren, 4344.

Lord, G. S. See Howell, 1860.

Louderback, George Davis.

2453. River action in the San Gabriel Mountains .[abstract]: Pan-Am. Geologist, vol. 63, no. 4, pp. 305-306, May. 1935; Geol. Soc. America Proc., 1935, p. 327, June 1936.

2454. The age of the earth from sedimentation: Sci. Monthly, vol. 42, no. 3 , pp. 240-246, March 1936 ; abstract, Science, new ser., vol. 82, no. 2116, pp. 51-52, July 19, 1935.

Lougee, Richard Jewett.

2455. Time measurements of an ice readvance at Littleton, N. H.: Nat. Acad. Sci. Proc., vol. 21, no. 1, pp. 36-41, 4 figs. (incl. sketch map), January 15, 1935.

2456. Hanover submerged: Dartmouth Alumni Mag., vol: 27, no. 8, pp. 5-8, 6 figs. (incl. geol. maps), May, 1935. 
Loughlin, Gerald Francis. See also Behre, 260.

2457: (and McKnight, Edwin Thor). Lead and zinc resources of western United States: Fifth Pacific Sci. Cong., Canada, 1933, Proc., pp. 1401-1424, 3 figs. (incl: map), 1934.

2458. (and others). The U. S. Geological Survey's point of view on relations between surveys and the mining industry [with discussion]: Am. Inst. Min. Met. Eng. Trans., vol. 115 (Mining geology), pp. 407-414, discussion, pp. 452-459, 1935.

2459. (and Koschmann, Albert Herbert). Geology and ore deposits of the Cripple Creek district, Colo.: Colorado Sci. Soc. Proc., vol. 13, no. 6, pp. 217-435, 48 figs. (incl. geol. map), 1935.

2460. Cripple Creek todaỳ: Eng. and Min. Jour., vol. 136, no. 8, pp. 372375, 4 figs. (incl. geol. map), August 1935.

2461. Relation of structure to surface features in the Pikes Peak quadrangle, Colo. [abstract] : Washington Acad. Sci. Jour., vol. 25, no. 12, pp. 573-574, December 15, 1935.

2462. (and Butler, Bert Sylvenus, Burbank, Wilbur Swett, Behre, Charles Henry, Jr., and Singewald, Quentin Dreyer). Zoning in certain mining districts in the Mosquito and San Juan Mountains, Colo, rado: 16th Internat. Geol. Cong. (1933) Rept., vol. 1, pp. 433-446, 3 figs. (incl, geol. sketch maps), 1936.

2463. The origin of lamprophyres [abstract]: Am. Geophys. Union Trans. 17th Ann. Meeting, pt. 1, p. 235, ( $\ddagger)$. Nat. Research Council, July 1936.

Louisiana, Geological Survey.

2464. Map of Louisiana showing oil, gas, and sulphur flelds, salt domes, etc. Scale $1: 10,000,000$. Geol. Survey. 1935.

Lovering, Thomas Seward. See also Buddington, 547 ; U. S. G. S., 4229 ; Van Tuyl, 4268, 4269, 4270.

2465. Copper-bearing ores. of Colorado; Northeast half of the mineral belt: Copper resources of the world, pp. 257-260, Washington, 16th Internat. Geol. Cong., 1935.

2466. Geology and ore deposits of the Montezuma quadrangle, Colo.: U. S. Geol. Survey Prof. Paper 178, 119 pp., 41 pls., (incl. geol. maps), 30 figs. (incl. index and geol. maps), 1935.

2467. Theory of heat conduction applied to geological problems: Geol. Soc. American Bull., vol. 46, no. 1, pp. 69-94, 6 figs., 4 pls., January 31, 1935 ; abstract, Proc., 1933, pp. 95-96, June 1934.

2468. Endothermic reactions and the heat of radioactive disintegration [abstract] : Geol. Soc. American Proc., 1934, p. 92, June 1935.

2469. Structure controls deposition of ore in Front Range area: Eng. and Min. Jour., vol. 136, no. 8, pp. 411-413, 2 figs. (incl. geol. map), August 1935.

2470. Heat conduction in dissimilar rocks and the use of thermal models: Geol. Soc. America Bull., vol. 47, no. 1, pp. 87-100, 2 pls., January 31, 1936.

2471. (and Goddard, Edwin Newell). Eocene igneous sequences in the Front Range of Colorado [abstract]: Geol. Soc. American Proc., 1935, pp. 89-90, June 1936.

$311-37-12$ 
Loving, G. H.

2472. (and Smith, Gilbert Havens). Explosives and electric blasting caps for geophysical prospecting: Soc. Petroleum Geophysicists Jour., vol, 6, no. 1, pp. 27-33, July 1935.

Low, Bela. See Kelly, 2061.

Lowdermilk, Walter Clay.

2473. Accelerated erosion, its effect on soil and water resources: Sci. Monthly, vol. 41, no. 1, pp. 19-28, 13 figs., July 1935.

Lowe, Ephraim Noble, 1864-1933.

2474. Fourteenth biennial report, 1932-33, of the director of the State Geological Survey to the Mississippi Legislature. 4 pp. [1934?].

Lowther, G. Kenneth. See Osborne, 2967.

Lozano, E. Díaz. See Barker, 182.

Lucas, Elmer Lawrence.

2475. Petrographic character of the Pennsylvanian sandstones in the Ardmore Basin: Jour. Sedimentary Petrology, vol. 5, no. 2, pp. 96-105, 1 pl. (geol. map), 3 tables, August 1935.

Luce, John W.

2476. A field trip to Tick and Red Rock Canyons : Pacific Mineralogist, vol. 2, no. 1, pp. 14-17, June 1935.

Lucke, John Becker.

2477. Bottom conditions in a tidal lagoon: Jour. Palentology, vol. 9, no. 1, pp. 101-107, 1 fig. (map), January 1935.

Lugn, Alvin Leonard. See also MacClintock, 2505, 2506.

2478. The Pleistocene geology of Nebraska : Nebraska Geol. Survey Bull. 10, $2 d$ ser., 223 pp., 4 pls. (incl. geol. and index maps), 22 figs. (incl. geol. maps), 1935.

2479. The Nebraska earthquake of March 1, 1935: Science, new ser., vol. 81, no. 2101, pp. 338-339, April 5, 1935.

2480. Geologic evidence bearing on Pleistocene man in Nebraska [abstract] : Geol. Soc. America Proc., 1934, pp. 92-93, June 1935.

2481. Cycles of erosion in Rocky Mountains and of sedimentation on the Great Plains [abstract] : Pan-Am. Geologist, vol. 65, no. 3, p. 231, April 1936.

2482. Relation of cycles of erosion to cycles of sedimentation in the Rocky Mountains and the northern Great Plains [abstract]: Geol. Soc. America Proc., 1935, p. 90, June 1936.

2483. Cycles of erosion and sedimentation in the northern Great Plains and Rocky Mountains [abstract]: Geol. Soc. American Proc., 1935, pp. 439-440, June 1936.

Lukens, R. R.

2484. Bogoslof volcano [Alaska]: Military Engineer, vol. 28, no. 159, pp. 205-206, 4 figs., May-June 1936.

Lukesh, J. S. See Buerger, 561.

Lull, Richard Swann.

2485. Fossils, what they tell us of plants and animals of the past. $114 \mathrm{pp}$., 58 figs., New York, The University Society, Inc., [c 1935].

2486. Henry Fairfield Osborn [1857-1935]: Am. Jour. Sci., 5th ser., vol. 31, no. 182 , pp. 158-159, February 1936. 
Lull, Richard Swann-Continued.

2487. William Arthur Parks [1867-1936] : Am. Jour. Sci., 5th ser., vol. 32, no. 192, pp. 470-471, December 1936.

Lund, Richard J. See Leith, 2390.

Lundberg, Hans.

2488. (and Zuschlag, Theodor, and Kihlstedt, Folke H.). Expansion and progress of electrical prospecting: Canadian Min. Met. Bull. 232, Trans. sec., pp. 932-962, 4 pls., 11 figs., August, 1931.

Lyden, Joseph P. See Fowler, 1317, 1319.

Lynch, J. Joseph.

2489. The geographical distribution of deep-focus earthquakes: Seismol. Soc. American Bull., vol. 26, no. 3, pp. 197-199, 1 fig. (index map), July 1936.

Lynn, William Gardner. See Berry, 296; Collins, 809.

Lyon, Marcus Ward, Jr.

2490. Mammals of Indiana: Am. Midland Naturalist, vol. 17, no. 1, 384 pp., 125 figs. (incl. index and geol. maps), January 1936.

McAdams, R. E.

2491. The accessory minerals of the Wolf Mountain granite, Llano County, Tex. : Am. Mineralogist, vol. 21, no. 2, pp. 128-135, 1 fig. (index map), February 1936; abstract, no. 3, p. 207, March 1936.

McCabe, Louis Cordell.

2492. Significance of banded ingredients in coal: Illinois Acad. Sci. Trans., vol. 28, no. 2, pp. 188-190, 2 flgs. (incl. index map), December 1935.

McCabe, W. S.

2493. Results obtained by chrome-sulphuric acid etching of Illinois coals: Illinois Acad. Sci. Trans., vol. 28, no. 2, pp. 177-178, 1 fig., December 1935 .

McCann, Duane Carroll. See Waldbauer, 4311.

McCann, Franklin T. See Bryan, 525.

McCanne, Rolland $\mathbf{W}$.

2494. Medicine Bow oil field, Carbon County, Wyo.: Mines.Mag., vol. 26, no. 2, pp. 30-34, 1 pl. (aerial photograph), 2 figs. (incl. structural map), February 1936.

McCarter, W. Blair.

2495. (and O'Bannon, P. H.). Sugarland oil fleld, Fort Bend County, Tex. : Am. Assoc. Petroleum Geologists Bull., vol. 17, no. 11, pp. 13621386, 4 figs., November 1933; reprinted in Gulf coast oil fields (see Barton and Sawtelle), pp. 709-733, 1936.

MacCarthy, Gerald Raleigh. See also Prouty, 3138.

2496. (and Prouty, William Frederick, and Alexander, John Andrew). Some magnetometer observations in the Coastal Plain area of South Carolina [abstract] : Elisha Mitchell Sci. Soc. Jour., vol. 49, no. 1, pp. 20-21, September 1933.

:2497. (and Alexander, John Andrew). What lies under the Coastal Plain? [abstract] : Elisha Mitchell Sci. Soc. Jour., vol. 50, no. 1/2, p. 50, December 1934.

2498. Eolian sands, a comparison: Am. Jour. Sci., 5th ser., vol. 30, no. 176, pp. 81-95, 7 figs., August 1935. 
MacCarthy, Gerald Raleigh-Continued.

2499. Magnetic anomalies and geologic structures of the Carolina Coastal Plain: Jour. Geologý, vol. 44, no. 3, pp. 396-406, 4 figs. (incl. sketch map), April-May 1936; abstract, Elisha Mitchell Sci. Soc. Jour., vol. 52, no. 2, pp. 167-168, December 1936.

2500. "The Carolina bays" [abstract]: Geol. Soc. America Proc., 1935, . pp. 90-91, June 1936.

2501. Meteors and the Carolina bays [abstract]: Elisha Mitchell Sci. Soc. Jour., vol. 50, no. 1/2, p. 211, December 1936.

MacClary, John Stewart.

2502. Perpetual ice under lava: Nat. History, vol. 37, no. 6, pp. 56-59, 3 figs., June 1936.

MacClintock, Paul. See also Hess, 1723.

2503. Investigation of the geology of the Yuma-Folsom sites in western Nebraska [abstract]: Carnegie Inst. Washington Year Book 34, pp. 318-319, 1935.

2504. (and Richards, Horace Gardiner). Correlation of late Pleistocene marine and glacial deposits of New Jersey and New York: Geol. Soc. Amërica Bull., vol. 47, no. 3, pp. 289-338, 2 pls., 4 figs. (incl. index maps), March 31, 1936; abstract with disciussion, Proc., 1934, pp. 98-94, June 1935.

2505. (and Barbour, Erwin Hinckley, Schultz, Charles Bertrand, and Lugn, Alvin Leonard). Possibilities of dating new fossil mammal-artifact localities [abstract] : Geol. Soc. America Proc., 1935; pp. 396397, June 1936.

2506. (and Barbour, Erwin Hinckley, Schultz, Charles Bertrand, and Lugn, Alvin Leonard). A Pleistocene lake in the White River Valley: Am. Naturalist, vol. 70 , no. 729 , pp. 346-360, 9 figs. (incl. index map), July-August 1936.

McClure, J. C. See U. S. G. S., 4227, 4228.

McClure, J. H.

2507. Wilson Keyes [1901-1936]: Am. Assoc. Petroleum Geologists Bull., vol. 20, no. 9, pp. 1272-1273, September 1936.

McComb, Harold Edgar. See also Heck, 1678, 1679; Wenner, 4398.

2508. (and West, Clarence Jay). List of seismological stations of the world: Nat. Research Council Bull. 82, 2d ed., 119 pp., Washington, 1931.

2509. A tilt-compensation seismometer: Fifth Pacific Sci.:Cong., Canada, 1933, Proc., vol. 3, pp. 2489-2494, 7 figs., 1934.

2510. Selection, installation, and operation of seismographs: U. S. Coast and Geodetic Survey Special Pub. 206, 42 pp., 37 figs. (incl. index maps), 1936.

McConnell, Duncan. See also Thwaites, 4126.

2511. Sperulitic concretions of dahllite from Ishawooa, Wyo.: Am. Mineralogist, vol. 20 , no. 10, pp. 693-698, 3 figs., October 1935 ; abstracts, vol. 20, no. 3, p. 200, March 1935; Geol. Soc. America Proc., 1934, p. 425 , June 1935 .

2512. "Petrified walnuts" vs. concretions: Science, new ser., vol. 83, no. 2146, pp. 161-162, February 14, 1936.

McConnell, Richard George. See Canada G. S., 655.

McCoy, Elizabeth. See Williams, 4505. 
McCue, John B. See Price, 3130.

McCurdy, Richard Clark. See Tickell; 4127.

McDavid, Duncan. See Smith, 37771.

McDermott, Eugene. See Karcher, 2025.

MacDill, Marjorie E. See Gregory, 1528.

McDonald, G. A. See Shepard, 3670.

Macelwane, James Bernard. See also Bradford, 418; Brunner, 512 ; Jeffreys, 1931; Wenner, 4398.

2513. Studies of earthquake action promise better structures: Eng. NewsRecord, vol. 111, no. 26, p. 779, December 28, 1933 .

2514. The seismological work of the Jesuit Seismological Association in the United States: Fifth Pacific Sci. Cong., Canada, 1933, Proc., vol. 3, pp. 2365-2368, 1934.

2515. The structure of the outer crust of the earth in the Pacific Ocean region: Fifth Pacific Sci. Cong., Canada, 1933, Proc., vol. 3, pp. 2533-2538, 1934.

2516. Progress report of the Jesuit Seismological Association [abstract]: Earthquake Notes, vol. 7, nos. 1-2, p. 23 ( $\$)$, September 1935.

2517. Problems and progress on the geologico-seismological frontier. Science, new ser., vol. 83, no. 2148, pp. 193-198, February 1936; abstract, Pan-Am., Geologist, vol. 65, no. 2, pp. 155-156, March 1936.

2518. Symposium on recent trends in geophysical research; Modern trends in seismological research: Am. Geophys. Union trans. 17th Ann. Meeting, pt. 1, pp. 23-25 ( $\ddagger)$, Nat. Research Council, July 1936.

2519. [Review of] Earthquakes, by Nicholas Hunter Heck, 1936: Seismol. Soc. America Bull., vol. 26, no. 4, pp. 395-396, October 1936.

McFarlan, Arthur Crane.

2520. (and Freeman, Louise Barton). Rogers Gap and Fulton formations in central Kentucky: Geol. Soc. America Bull., vol. 46, no. 12, pp. 1975-2006, 3 pls., 2 figs. (incl. geol. map), December 31, 1935; abstract, Proc., 1934, p. 359, June 1935.

2521. Memorial of Arthur McQuiston Miller [1861-1929]: Geol. Soc. America Proc., 1935, pp. 283-287, 1 pl. (port.), June 1936.

McGavock, Cecil Billups.

2522. Distribution and description of active volcanoes and volcanic peaks; being a report in partial fulfillment for final honors at the University of Virginia from the School of Geology, June 1934, 437 pp. ( $\ddagger)$ (Ms.). Charlottesville, Va., 1934.

McGavock, Cecil B., Jr.

2523. An analysis of the Yorktown pelecypods [abstract] : Virginia Acad. Sci. Proc. 1934-35, p. 71 [1935].

McGerrigle, Harold William. See also Clark, 767.

2524. Western Temiscouata, with parts of Kamoụraska and Rivière-dụ-Loup Counties: Quebec Bur. Mines Ann. Rept., 1933, pt. D, pp. 93-128, 9 pls. (incl. geol. map), 1934.

2525. Mount Megantic area, southeastern Quebec, and its placer-gold deposits : Quebec Bur. Mines Ann. Rept., 1934, pt. D, pp. 63-104, 1 pl. (geol. map), 1935; also in French ed., 1935. 
McGill, William Mahone.

2526. Present operations in the Virginia gold belt [abstract] : Virginia Acad. Sci. Proc., 1934-35, pp. 60-61, [1935].

2527. Underground wonderlands in Virginia: Mines Mag. vol. 25, no. 2, pp. 13-16, 23, 4 figs. (incl. sketch map), February 1935.

2528. Mineral resources in State planning [abstract]: Virginia Acad. Sci. Proc., 1935-36, p. 65, 1936.

2529. Outline of the mineral resources of Virginia: Virginia Geol. Survey Bull. 47 (Educational ser. no. 3), 81 pp., 16 pls. (incl. geol. sketch maps), 1 fig. (map), xii, 1936.

Mac Gillavry, Hugo J.

2530. Remarks on rudists: K. Akad. Wetensch. Amsterdam Proc., vol. 38, no. 5 , pp. 558-565, 1935.

MacGinitie, Harry $\mathrm{D}$.

2531. Tertiary floras of Trinity County, Calif. [abstract]: Geol. Soc. America Proc., 1934, p. 390, June 1935.

McGrew, Paul Orman. See also Stirton, 3906.

2532. A new Cynodesmus from the lower Pliocene of Nebraska, with notes on the phylogeny of the dogs: California Univ., Dept. Geol. Sci. Bull., vol. 23, no. 10, pp. 305-312, 4 figs., March 15, 1935.

2533. Phylogenetic relationships of Nannippus gratum [abstract]: Pan-Am. Geologist, vol. 64, no. 1, p. 78, August 1935; Geol. Soc. America Proc., 1935, p. 418, June 1936.

MicGuirt, James Holland. See also Howe, 1835, 1840.

2534. Geology of Cameron and Vermilion Parishes; Salt-dome prospects: Louisiana Dept. Cons. Geol. Bull. 6, pp. 167-179, 4 figs. (index maps), 1935.

2535. A partial list of maps dealing with Cameron and Vermilion Parishes: Louisiana Dept. Cons. Geol. Bull. 6, pp. 197-203, 1935.

McGuinness, C. L. See Northrop, 2919.

McKay, Bertram Reid. See also Canada G. S., 645, 646.

2536. Coal deposits of the Cordilleran region in Canada: Fifth Pacific Sci. Cong., Canada, 1933, Proc., vol. 2, pp. 1467-1482, 1934.

McKee, Edwin Dinwiddie.

2537. Occurrence of Triassic sediments on the rim of Grand Canyon: Washington Acad. Sci. Jour., vol. 25, no. 4, pp. 184-187, 1 fig., April 15, 1985.

2538. Some observations on the middle Permian marine formations of northern Arizona [abstract] : Washington Acad. Sci. Jour., vol. 25, no. 11, p. 504, November 15, 1935.

2539. A Conularia from the Permian of Arizona: Jour. Paleontology, vol. 9, no. 5, pp. 427-429, 2 figs., July 1935.

MacKenzie, G. S.

2540. Pusticamica Lake map area, Abitibi district: Quebec Bur. Mines Ann. Rept., 1934, pt. C, pp. 45-64, 2 pls. (incl. geol. map), 1935; also in French ed., 1935.

2541. Madeline Lake gold discovery: Canadian Min. Jour., vol. 56, no. 8, pp. 324-326, 2 figs. (sketch and geol. maps), August 1935.

2542. The Roselake district [Quebec]: Canadian Min. Jour., vol. 57, no. 3, pp. 130-132, 1 fig. (geol. map), March 1936. 
Mackin, J. Hoover.

2543. New type of stream capture in Big Horn Basin [abstract] : Pan-Am. Geologist, vol.: 63, no. 4, p. 307, May 1935; Geol. Soc. America Proc., 1935, pp. 330-331, June 1936.

2544. The problem of the Martic overthrust and the age of the Glenarm series in southeastern Pennsylvania: Jour. Geology, vol. 43, no. 4, pp. 356-380, 4 figs. (incl. geol. map), May-June 1935.

2545. The capture of the Greybull River: Am. Jour. Sci., 5th ser., vol. 31, no. 185, pp. 373-385, 1 fig. (geol. map), May 1936.

2546. A method of mounting maps: Science, new ser., vol. 84, no. 2175, pp. 233-234, September 4, 1936.

McKinley, William C.

2547. Some interesting irregular crystallizations in geodes from Hamilton, Ill. : Rocks and Minerals, vol. 10, no. 1, p. 2, January 1935.

2548. The gems of Georgia: Mineralogist, vol. 3, no. 1, pp. 44-45, January 1935.

2549. Muscovite crystal cavity flling at Mount Mica, Maine: Rocks and Minerals, vol. 10, no. 2, p. 22, February 1935.

2550. Marcasite not found as a magnetic mineral: Mineralogist, vol. 3, no. 5, pp. 18-19, May 1985.

2551. Some iron occurrences of West Virginia : Rocks and Minerals, vol. 10, no. 11, p. 168, Norember 1935.

McKnight, Edwin Thor. See also Bucher, 534; Loughlin, 2457; Miser, 2749; U. S. G. S., 4226.

2552. Zinc and lead deposits of northern Arkansas: U. S. Geol. Survey Bull. 853, 311 pp., 15 pls. (incl. geol. maps), 19 figs. (incl. sketch maps), 1935.

2553. Occurrence of enargite and wulfenite in ore deposits of northern Arkansas: Econ. Geology, vol. 30, no. 1, pp. 61-66, 1 fig., JanuaryFebruary 1935.

MacLachlan, Donald Claude. See Leverett, 2401.

McLaughlin, Roy Parmelee.

2554. Arthur Sidney Henley [1879-1936] : Am. Assoc. Petroleum Geologists: Bull., vol. 20, no. 10, p. 1384, October 1936.

McLean, R. S. See Heck, 1678.

McLearn, Frank Harris. See also Canada G. S., 656; Fraser, 1330.

2555. (and Wickenden, Robert Thomas Daubigny). Oil and gas possibilities of the Hudson Bay Junction area, Saskatchewan: Canada Dept. Mines, Geol. Survey Paper 36-8, 10 pp. ( $\$$ ), 3 pls. (incl. index map), February 1936.

McLeish, John.

2556. (and others). The Canadian mineral industry in 1934: Canada, Dept. Mines, Mines Branch, Pub. 760, 119 pp., 1935.

2557. (and others). The Canadian mineral industry in 1935: Canada Dept. Mines, Mines Branch, Pub. 773, 100 pp., 8 figs., 1936.

McMasters, John Herbert. See Cushman, 946; Schenk, 3554.

MacNaughton, Lewis Winslow. See Eby, 1122.

MacNeil, Anna.

2558. Worlds underground : Nat. History, vol. 38, no. 3, pp. 249-264, 28 figs.r Octoher 1936. 
McNeil, Francis Stearns.

2559. Fresh-water mollusks from the Catahoula sandstone (Miocene) of Texas: Jour. Paleontology, vol. 9, no. 1, pp. 10-17, 3 pls., January 1935.

2560. A new crassatellid from the Waccamaw formation of North and South Carolina and the Caloosahatchee marl of Florida: Washington Acad. Sci. Jour., vol. 26, no. 12, pp. 528-530, 3 figs., December 15, 1936.

MacNider, Williạm deBerniere. See Prouty, 3146.

McQueen, Henry Silliman. See also Kansas Geol. Soc., 2020; Smith, 3745; Workman, 4618.

2561. Insoluble residues as a guide in stratigraphic studies: Missouri Bur. Geology and Mines Bienn. Rept. State Geologist [1929-1930], pp. 102-131, 11 pls. [1931].

2562. Charles D. Gleason [1908-1935] : Am. Assoc. Petroleum Geologists Bull., vol. 20, no. 3, p. 382, March 1936.

Macqueen, P. O.

2563. Sand craters and their possible significance: Am. Geophys. Union Trans. 17th Ann. Meeting, pt. 1, pp. 85-89 ( $) ; 4$ figs., Nat. Research Council, July 1936; Earthquake Notes, vol. 8, nos. 1-2, pp. 85-89 (†), 4 figs., June 1936.

McVay, Thomas Newkirk. See Parmelee, 3016.

Madsen, Victor. See also Bøggild, 360.

2564. Et Menneske fra Istiden i Minnesota: Naturens Verden, 17. aarg., Hefte 8, pp. 363-368, 3 figs., October 1933.

Malkin, Doris S. See Coryell, 881.

Malmquist, David. See Backlund, 126.

Mandy, Joseph T.

2565. Gold-bearing black-sand deposits of Graham Island, Queen Charlotte Islands: Canadian Inst. Min. Metallurgy Trans. vol. 37, pp. 563573, 3 figs. (incl. geol. map) [1935].

Mann, Albert, 1853-1935. See Thorp, 4118.

Mansfield, George Rogers.

2566. (and Ross, Clarence Samuel). Welded rhyolite tuffs in southeastern Idaho: Am. Geophys. Union Trans. 16th Ann. Meeting, pt. 1, pp. 308-321 ( $\ddagger), 15$ figs., Nat. Research Council, August 1935.

2567. Important discoveries in Florida by United States Geological Survey; P. W. A. investigations add new mineral resource to State's list: U. S. Dept. Interior Press Mem. 109266, 7 pp. ( $\ddagger)$, November 25, 1935.

2568. United States Geological Survey studies Alabama ceramic clays; P. W. A. investigations reveal presence of high-grade kaolin and plastic refractory clay: U. S. Dept. Interior Press Mem. 109267, November 25, 1935.

2569. (and Lang, Walter Barnes). Geology of Texas, vol. 2, pt. 3, Economic geology of Texas (exclusive of petroleum); The Texas-New Mexico potash deposits: Texas Univ. Bull. 3401, pp. 641-832, 3 pls.; 3 figs: (incl. geol. map), December 1935. 
Mansfield, George Rogers-Continued.

2570. Bleaching and ceramic clays of western Tennessee and Kentucky studied by U. S. Geological Survey; P. W. A. investigations reveal large bodies of low-grade bleaching clay and some ball clays, besides clay of lower grade: U. S. Dept. Interior Press Mem. 115010, 7 pp. $(\ddagger)$, March $30 ; 1936$.

Mansfield, Wendell Clay.

2571. (and Ponton, Gerald Mungo). Faunal zones in the Miocene Choctawhatchee formation of Florida: Washington Acad. Sci. Jour., vol. 22, no. 4, pp. 84-88, 1 fig., February 19, 1932.

2572. New Miocene gastropods and schaphopods from Alaqua Creek Valley, Florida : Florida Dept. Cons., Geol. Dept., Geol. Bull. 12, 64 pp., 5 pls., June $7,1935$.

2573. Stratigraphic significance of Miocene, Pliocene, and Pleistocene Pectinidae in the southeastern United States: Jour. Paleontology, vol. 10, no. 3, pp. 168-192, 2 pls., 1 fig., April 1936.

2574. Additional notes on the molluscan fauna of the Pliocene Croatan sand of North Carolina: Jour.: Paleontology, vol. 10, no. 7, pp. 665-668, October 1936:

2575. A new species of "Crassatellites" from the upper Miocene of Florida:

- Washington Acad. Sci. Jour., vol. 26, no. 10, p. 395 , October 15 r 1936.

Manter, John. See Gregory, 1528.

Maple, A: F.

2576. Discovering oil from 20,000 feet: World Petroleum, vol. 7 , no. 4, pp. 181-184, 4 figs., April 1936; abstract, no. 7, p. 368, July 1936.

Marble, John Putnam.

2577. Age of allanite from Amherst County [Va.] : Am. Jour. Sci., 5th ser., vol. 30, no. 178, pp. 349-352, October 1935.

2578. Lead-uranium ratio of siliceous pitchblende, from Great Bear Lake, Northwest Territories, Canada, and its possible age: Am. Chem. Soc. Jour., vol. 58, no. 3, pp. 434-437, March 1936.

2579. Possible age of monazite from Mars Hill, N. C.: Am. Mineralogist, rol. 21, no. 7, pp. 456-457, 1 fig., July 1936.

2580. Bibliography on geologic time, April 1935 to April 1936: Nat. Research Council Ann. Rept., 1934-35, App. K, Report of the committee on: geologic time, pp. $9-34(\$)$, September 1936.

Marelli, Carlos A.

2581. La excursión de Nueva York, organizada por el Congreso de Geología de Washington, EE. UU., sesion de 1933: Jardín zool. de La Plata Mem., tomo 5, pt. 2a, 92 pp., 1 pl., 106 figs. (incl. geol. maps), 1936.

Margerie, Emmanuel de.

2582. A propos d'un ouvrage récent du Dr. Lauge Koch: Soc. géol. France Compte rendu, fasc. 6, p. 97, March 16, 1936.

Marsden, Ralph W.

2583. Discussion of the paper "Heavy minerals in the syenites of Pleasant Mountain, Maine": Am. Mineralogist, vol. 20, no. 2, pp. 132-125, February 1935.

Marshall; I. M. See Schofield, 3573.

Marshap, Richard. See Gregory, 1528. 
Martens, James Hart Curry.

2584. Beach sands between Charleston, S. C., and Miami, Fla.: Geol. Soc. America Bull., vol. 46, no. 10, pp. 1563-1596, 7 flgs. (incl. map), - October 31, 1935.

2585. Petrography of Oriskany and Corniferous sands in West Virginia: Oil and Gas Jour., vol. 35, no. 20, pp. 21, 23, 1 fig. (index map), October 1, 1936.

Martin, Helen M. See Rawlins, 3187.

Martin, Lawrence.

2586. Patrician ice sheet on North American glacial maps: Pan-Am. Geologist, vol. 63, no. 1, pp. 8-11, 1 fig. (geol. map), February 1935.

2587. Cuesta vs. peneplane driftless area: Pan-Am. Geologist, vol. 65, no. 4, pp. 259-265, May 1936.

Martin, Lois T. See Cushman, 942.

Martin, Robert Joseph.

2588. Dust storms in the United States, April 1936: Monthly Weather Rev., vol. 64, no. 4, p. 137, 1 fig., April 1936.

2589. Dust storms of May 1936 in the United States: Monthly Weather Rev., vol. 64 , no. 5, p. 176, 1 fig., May 1936.

2590. Dust storms of July 1936 in the United States: Monthly Weather Rev., vol. 64, no. 7, p. 239, July 1936.

Martin, Viva $\mathrm{D}$.

2591. The Ginkgo Petrified Forest: Indiana Acad. Sci. Proc., vol. 44, pp. 166-167, 1935.

Martindale, Roy $\mathrm{E}$.

2592. The determination of gems: Pacific Mineralogist, vol. 2, no. 1, pp. 6-7, June 1935.

Martonne, Emmanuel de.

2593. W. M. Davis [1850-1934] : Annales de géographie $43^{\circ}$ année, no. 243, pp. 326-329, May 15, 1934.

Marx, Archer H.

2594. Hoskins Mound salt dome, Brazoria County, Tex. : Am. Assoc. Petroleum Geologists Bull., vol. 20, no. 2, pp. 155-178, 2 pls., 5 figs., February 1936 ; abstract, World Petroleum, vol. 7, no. 4, p. 204, April 1936; reprinted in Gulf coast oil fields (see Barton and Sawtelle), pp. 833-856, 1936.

Marxel, John G.

2595. Sixteenth biennial report of the State geologist of the State of Wyoming, for the period October 1, 1930-September 30, 1932. $114 \mathrm{pp}$., pls., 1933.

Mason, Herbert Louis. See also Chaney, 731.

2596. A fossil hazelnut: Madroño, vol. 3, no. 2, pp. 50, 51, April 1935.

Mason, John Frederick. See also Hazzard, 1660, 1661, 1662.

2597. Fauna of the Cambrian Cadiz formation, Marble Mountains, Calif.: Southern California Acad. Sci. Bull., vol. 34, pt. 2, pp. 97-119, 1 pl., September 15, 1935 .

2598. Cambrian faunas of the Goodsprings and Sheep Mountain districts, Nev. [abstract] : Geol. Soc. America Proc., 1935, pp. 384-385, June 1938. 
Mather, Kirtley Fletcher.

2599. Dynamic and structural geology: Am. Year Book, 1934, pp. 727-729, 1935.

2600. American Association for the Advancement of Science, section $\mathrm{E}$ (Geology and Geography) [Proceedings Pittsburgh meeting] : Science, new ser., vol. 81, no. 2092, pp. 117-118, February 1, 1935.

2601. Memorial of Thomas Clachar Brown [1882-1934]: Geol. Soc. America Proc., 1934, pp. 203-208, port., June 1935.

2602. Proceedings of a joint session of section $\mathbf{E}$ of the American Association for the Advancement of Science and members of the Geological Society of America, held at Pittsburgh, Pa., December 31, 1934, and January 1, 1935: Geol. Soc. America Proc., 1934, pp. 435-456, June 1935.

2603. (and others). American Association for the Advancement of Science, section [E] on Geology and Geography [proceedings St. Louis meeting] : Science, new ser., vol. 83, no. 2145, pp. 124-126, February $7,1936$.

2604. Thomas Chrowder Chamberlin [1843-1928] : Am. Acad. Arts. Sci. Proc., vol. 70, no. 10, pp. 505-508, March 1936.

2605. [Review of] Down to earth, by Carey Croneis and William Krumbein, 1935: Science, new ser., vol. 84 , no. 2187 , pp. $486-487$, November 27, 1936.

Mathews, Albert A.

2606. The gypsum industry of Grand Rapids, Mich.: Mining and Metallurgy, vol. 17, no. 357 , pp. $427-430,6$ figs. (incl. geol. map), September 1936.

Mathews, Asa A. Lee.

2607. "Clipfold", a new structural term [abstract] : Virginia Acad. Sci. Proc., 1934-35, pp. 59-60, [1935].

2608. Honeycomb structure below river beds [abstract] : Virginia Acad. Sci. Proc., 1934-35, p. 60, [1935].

2609. Evidence of a flying reptile from the Permian [abstract]: Geol. Soc. America Proc., 1935, p. 397, June 1936.

Mathews, Edward Bennett.

2610. Memorial of George Burbank Shattuck [1869-1934] : Geol. Soc. America Proc., 1934, pp. 271-276, port., June 1935.

Mathiasen, R. L. See Schwartz, 3594.

Matley, Charles Alfred.

2611. The basal complex in Jamaica; a reply: Geol. Mag., no. 865 (vol. 73, no. 7), pp. 331-333, July 1936.

Matthes, François Emile.

2612. Why we should measure our glaciers: Sierra Club Bull., vol. 20, no. 1, pp. 20-27, February 1935.

2613. Evaporation of snow on our western mountain ranges [abstract] : Assoc. Am. Geographers Annals, vol. 25, no. 1, pp. 49-50, March 1935.

2614. Report of the committee on glaciers, 1934-35: Am. Geophys. Union Trans. 16th Ann. Meeting, pt. 2, pp. 387-392 ( $\ddagger)$, Nat. Research Council, August 1935.

2615. Report of the committee on glaciers, 1935-36: Am. Geophys. Union Trans. 17th Ann. Meeting, pt. 2, pp. 286-294 ( $\ddagger)$, Nat. Research Council 1936. 
Mattice, W. A.

2616. Dust storms, November 1933 to May 1934 : Monthly Weather Rev., vol. 63, no. 2 pp. 53-55, 1 pl., February 1935.

Mattocks, Philip Ward. See Hunter, 1890.

Maurice, John F. See Jones, 1999.

Mawdsley, James Buckland. See also Canada G. S., 647, 649.

2617. (and Norman, George William Hal): Chibougamau. Lake map area, Quebec: Canada Dept. Mines, Geol. Survey. Mem. $185 ; 95$ pp., 7 pls. (incl. geol. maps), Pub. 2409, 1935.

2618. The washboard moraines of the Opawica-Chibougamau area, Quebec: Royal Soc. Canada Trans., 3d ser., sec. 4, vol. 30, pp. 1-8, May 1936 ; abstract, Proc., p. xcvii, 1936.

Maxson, John Haviland. See also Anderson, 66 ; Campbell, 636, 637; Davis, 985. 26i9. (and Anderson, George Harold). Terminology of surface forms of the erosion cycle: Jour. Geology, vol. 43, no. 1, pp. 88-96, JanuaryFebruary 1935.

2620. Pre-Cambrian stratigraphy of the Inyo Range [Calif.] [abstract]: Geol. Soc. America Proc., 1934, p. 314, June 1935.

2621. (and Campbell, Ian). Stream fluting and stream erosion : Jour. Geology, vol. 43, no. 7, pp. 729-744, 10 figs., October-November 1935; abstracts, Pan-Am. Geologist, vol. 63, no. 4, pp. 306-307, May 1935; Geol. Soc. America Proc., 1935, p. 330, June 1936.

Maxwell, Ross A. See Ball, 170.

Mayfield, Samuel Martin.

2622. Geology of Fordsville and Cannelton quadrangles [Ky.]. Dissertation, Univ. Chicago, 181 pp. (\$), private ed., Chicago, Ill., 1934.

Maynard, Thomas Poole.

2623. Bentonite deposits and uses: Manufacturers Record, vol. 104, no. 11, p. 27, November 1935.

Mayo, Evans Blakemore. See also Nevin, 2851.

2624. Some intrusions and their wall rocks in the Sierra Nevada: Jour. Geology, vol. 43, no. 7, pp. 673-689, 4 figs. (incl. geol. map), OctoberNovember 1935.

2625. Some recent studies of Sierra Nevada pluton [abstract] : Am. Geophys. Union Trans. 17th Ann. Meeting, pt. 1, p. 256 ( $\$)$, Nat. Research Council, July 1936.

2626. (and Conant, Louis Cowles, and Chelikowsky, Joseph Rudolph). Southern extension of the Mono Craters, Calif.: Am. Jour. Sci., 5th ser., vol. 32, no. 188, pp. 81-97, 6 figs: (incl. maps), Auyust 1936.

Mechem, O. \#. See Tickell, 4127.

Meen, V. Ben.

2627. The etching of alpha and beta quartz: Toronto Univ. Studies, Geol. ser. 36, pp. 37-43, 2 figs., 1 pl. (part), 1934.

2628. The temperature of formation of quartz and some associated minerals: Toronto Univ. Studies, Geol. ser. 38, pp. 61-68, 1935.

Megathlin, G. R.

2629. Faulting in the Mohawk Valley: Science, new ser., vol. 82, no. 2134, p. 492, November 22, 1935. 
Mehl, Maurice Goldsmith. See also Branson, 443, 444, 445, 446.

2630. Hierosaurus coleii; a new aquatic dinosaur from the Niobrara Cretaceous of Kansas: Denison Univ. Bull., vol. 36, no. 4 (Sci. Lab. Jour., vol. ' 31), pp. 1-20, 2 pls., April 30, 1936.

Meinzer, Oscar Edward. See also Leggette, 2376.

2631. Progress in the control of artesian-water supply: Eng. News-Record, vol. 113, no. 6, pp. 167-169, August 9, 1934

2632. Water-supply conditions in the drought-stricken regions: Public Works, vol. 65 , no. 9 , pp. 19-20, September 1934 .

2633. Ground water in the Midwest drought area : Eng. News-Record, vol. 113, no. 16, pp. 495-498, 2 figs. (incl. index map), October 18, 1934.

2634. Ground-water problems of the Coastal Plain: Am. Water Works Assoc. Jour., vol. 27, no. 4, pp. 479-484, April 1935.

2635. Ohio Valley well supplies subject to slow reduction of capacity: Eng. News-Record, vol. 114, no. 18, pp. 621-622, 2 figs. (geol. maps), May 2, 1935.

2636. The need for a nation-wide program of observation wells [abstract]: Am. Geophys. Union Trans. 16th Ann. Meeting, pt. 2, pp. 498-499 ( $\ddagger$, Nat. Research Council, Augúst 1935 .

2637. (and Wenzel, Leland Keith). Water levels and artesian pressure in observation wells in the United States in 1935, with statements concerning previous work and results: U. S. Geol. Survey Water-Supply Paper 777, 268 pp. ( $\ddagger), 1936$.

2638. Symposium on fluctuations of ground-water; Review of the work of W J McGee on ground-water levels: Am. Geophys. Union Trans. 17th Ann. Meeting, pt. 2, pp. 386-390 ( $\ddagger)$, Nat. Research Council, 1936.

2639. (and Cady, Richard Carlysle, Leggette, Ralph Maxwell, and Fishel, Vinton Crews). The channel-storage method of determining effuant seepage: Am. Geophys. Union Trans. 17th Ann. Meeting, pt. 2, pp. 415-418 (\$), 2 figs., Nat. Research Council, 1936.

2640. Movements of ground water: Am. Assoc. Petroleum Geologists Bull., vol. 20, no. 6, pp. 704-725, 9 figs., June 1936; abstract, Am. Geophys. Union Trans. 17th Ann. Meeting, pt. 2, pp. 478-479 ( $\ddagger)$, Nat. Research Council, 1936.

Melhase, John.

2641. Fluorescent minerals of California : Mineralogist, vol. 3, no. 1, pp. $3-4$, 38, January 1935.

2642. Nevada, the mineral collector's Mecca: Mineralogist, vol. 3, no. 2, pp. 9-10, 28, February 1935; no. 3, pp. 9-10, 26-27, March 1935; no. 4, pp. 9-10, 37-38, April 1935; no. 5, pp. 9-10, 20-21, May 1935 ; no. 7 , pp. 3-4, 30-31, July 1935.

2643. Discovery of sanbornite in California: Mineralogist, vol. 3, no. 9, pp. 3-4, 28-29, September 1935.

2644. Some garnet localities of California: Mineralogist, vol. 3, no. 11, pp. 7-8, 22-24, November 1935.

2645. The occurrence of native iron near Klamath Falls, Oreg. : Mineralogist, vol. 3, no. 12, pp. 17-18, December 1935.

2646. A new occurrence of rare-earth minerals in California: Mineralogist; vol. 4, no. 1, p. 11, January 1936.

2647. Fluorescence as an aid in correlating oil sands: Mineralogist, vol. 4, no. 2, p. 9, February 1936. 
Melhase, John-Continued.

2648. New zeolite locality found in Oregon: Mineralogist, vol. 4, no. 3, pp. 22, 24, March 1936.

2649. Industrial uses of nonmetallic minerals [wollastonite] : Mineralogist, vol. 4, no. 8, pp. 7-8, August 1936.

2650. The story of petroleum: Mineralogist, vol. 4, no. 5, pp. 5-6, 29, May 1936 ; no. 9, pp. 7-8, 30-31, September 1936.

Mellen, Frederic Francis.

2651. The bentonite deposits of Mississippi : Rocks and Minerals, vol. 11, no. 10, pp. 220-222, 1 fig. (index map), November 1936.

Mélon, J. See Donnay, 1061, 1062, 1063.

Melton, Frank Armon.

2652. Meander scroll and meander-bar plains [abstract] : Assoc. Am. Geographers Annals, vol. 25, no. 1, pp. 50-51, March 1935.

2653. Stream erosion and dune ridges in northeastern Arizona [abstract] : Geol. Soc. America Proc., 1934, p. 450, June 1935.

2654. Vegetation and soil mounds: Geog. Rev., vol. 25, no. 3, pp. 430-433, 4 figs. (aerial maps), July 1935.

2655. The geology of Texas, vol. 2, pt. 1, Major structural features of Texas east of Pecos River; Fracture systems in central Texas: Texas Univ. Bull. 3401, pp. 118-124, 1 fig., December 1935.

2656. Wind effects on headward elongation of canyons [abstract] : Pan-Am. Geologist, vol. 65, no. 2, p. 160, March 1936.

2657. Parabolic, wind-rift, and longitudinal dunes [abstract]: Geol. Soc. America Proc., 1935, p. 91, June 1936.

2658. Rock plain, base plain, and depositional plain [abstract]: Geol. Soc. America Proc., 1935, pp. 91-92, June 1936.

2659. Wind-activity influence on headward elongation of plateau summit canyons in Arizona [abstract]: Geol. Soc. America Proc., 1935, p. 440, June 1936.

2660. An empirical classification of flood-plain streams: Geog. Rev., vol. 26, no. 4, pp. 593-609, 15 figs., October 1936; abstract, Geol: Soc. America Proc., 1934, p. 94, June 1935.

Mendenhall, Walter Curran.

2661. [Fifty-sixth annual report of the Director of the United States] Geological Survey: U. S. Dept. Interior Ann. Rept., 1935, pp. 233-274, 1935.

2662. David White [1862-1935] : Science, new ser., vol. 81, no. 2097, pp. 244246, March 8, 1935.

2663. David White [1862-1935] ; an appreciation: Sci. Monthly, vol. 40, no. 4, pp. 380-382, 1 fig. (port.) April 1935.

2664. Establishment of Pennsylvania Survey an outstanding event in development of sciences in U. S. : Pennsylvania Dept. Internal Affairs Monthly Bull,, vol. 2, no. 1, pp. 17-18, June 1936.

2665. [Fifty-seventh annual report of the Director of the United States] Geological Survey: U. S. Dept. Interior Ann. Rept., 1936, pp. 309345, 1936.

Merkel, A.

2666. Ueber den Thoriumgehalt von Pechblenden vom Great Bear Lake, Northwest Territories, Canada: Centralbl. Mineralogie, 1934, Abt. A, Nr. 10, pp. 312-315. 
Merriam, Charles Warren.

2667. Devonian of east-central Nevada [abstract] : Geol. Soc. America Proc., 1934, pp. 314-315, June 1935.

2668. Middle Eocene faunas of northern California [abstract]: Geol. Soc. America Proc., 1934, p. 392, June 1935.

2669. Devonian section in central Nevada [abstract]: Geol. Soc. America Proc., 1935, pp. 92, 377-378, June 1936.

2670. Nodules resembling coal balls from the Ordovician of Nevada [abstract] : Geol. Soc. America Proc., 1935, p. 391, June 1936.

Merriam, John Campbell.

2671. (and others). Continuation of paleontological researches: Carnegie Inst. Washington Year Book 34, pp. 313-318, 1935.

2672. A review of evidence relating to the status of the problem of antiquity of man in Florida [abstract] : Science, new ser., rol. 82, no. 2118, p. 103, August 2, 1935.

2673. Early man in America: Carnegie Inst. Washington News Serv. Bull., School ed., vol. 3, no. 23, pp. 185-190, 33 figs., August 11, 1935.

2674. Present status of knowledge relating to antiquity of man in America; with list of references compiled by Frank Harold Hanna Roberts, Jr.: 16th Internat. Geol. Cong. (1933) Rept., vol. 2, pp. 1313-1323, 1936.

Merriam, Richard.

2675. (and Laudermilk, Jerome Douglas). Two diopsides from southern California : Am. Mineralogist, vol. 21, no. 11, pp. 715-718, 1 index map, November 1936.

Merritt, Clifford Addison.

2676. Gypsum crystals from Alfalfa County, Okla.: Am. Mineralogist, vol. 20, no. 9 , p. 674, September 1935 .

2677. "Castellated dolomites" from Major County, Okla.: Mineralogist, rol. 21, no. 9, pp. 604-607, 3 figs., September 1936.

Merritt, George.

2678. Correlations between tilting of the ground and the tides in Chesapeake Bay: Am: Geophys. Union Trans. 17th Ann. Meeting, pt. 1, pp. 103-104 ( $¥), 1$ fig., Nat. Research Council, July 1936 ; Earthquake Notes, vol. 8, n̈os. 1-2, pp. 103-104 ( $), 1$ fig., June 1936.

Merten, Hermann.

2679. Talc deposits of Washington: Mineralogist, vol. 4, no. 8 , pp. 12, 22, August 1936.

Mertie, John Beaver, Jr.

2680. Pre-Cambrian and Paleozoic volcanism of interior Alaska: Am. Geophys. Union Trans. 16th Ann. Meeting, pt. 1, pp. 292-302 (\$), 1 pl., Nat. Research Council, August 1935.

2681. Mineral deposits of the Ruby-Kuskokwim region, Alaska: U. S. Geol. Survey Bull. 864-C, pp. v, 115-245, 6 pls. (incl. geol. sketch map), 1 fig. (index map), 1936.

Merwin, Herbert Eugene. See Allen, 37; Goldman, 1460; Grieg, 1536, 1537.

Metcalf, Thomas Larkin. See Knechtel, 2228 ; U. S. G. S., 4230, 4232, 4234.

Meyer, Dorothy Babcock.

2682. A sericite of unusual composition: Am. Mineralogist, vol. 20, no. 5, pp. 384-388, 1 fig., May 1935. 
Meyer, William Henry, Jr.

2683. Development of aerial photographic equipment: Am. Inst. Min. Met. Eng. Tech. Pub. 756, pp. 21-25, discussion, pp. 26-27, 1986; abstract, Mining and Metallurgy, vol. 17, no. 359, p. 547, November 1936.

Meyerhoff, Howard Augustus. See also Colony, 817 ; also Harper, 1637.

2684. Report of the committee on mineral resources of Puerto Rico, $34 \mathrm{pp}$., San Juan, [January 31], 1935; also issued in Rev. obras publicas de Puerto Rico, año 12, no. 3, pp. 867-871, 874-875, March 1935; no. 4, pp. 889-\$94, April 1935.

2685. Geología de Puerto Rico: Rev. obras públicas de Puerto Rico, año 12, no. 6, pp. 952-962, 1 pl. (map), 3 tigs. (maps), June 1935 ; no. 7, pp. 990-994, 3 figs., July 1935; no. 8, pp. 1008-1015, 4 figs., August 1935 ; no. 9, pp. 1047-1057, September 1935; no. 10, pp. 1071-1081, 3 figs. (incl. map), Oct. 1935; no. 11, pp. 1104-1106, November 1935; no. 12, pp. 1134-1138, 1 fig., December 1935; año 13, no. 2, pp. 1196-1201, February 1936; no. 3, pp. 1224-1226, March 1936 ; no. 4, pp. 1259-1261, April 1936; no. 5, pp. 1299-1300, May 1936 ; no. 6 , pp. 1311-1313, June 1936; no. 7, pp. 1354-1355, July 1936. [In part translated by Martín López Sanabria.]

2686. (and Collins, Robert F.). Mississippian-Pennsylvanian contact in western South Dakota [abstract]: Geol. Soc. America Proc., 1934, pp. 94-95, June 1935.

2687. (and Lochman, Christina). Faunal zones in the Deadwood formation of South Dakota [abstract]: Geol. Soc. America Proc., 1934, pp. 352-353, June 1935.

2688. (and Olmsted, Elizabeth W.). Wind- and water-gap systems in Pennsylvania: Am. Jour. Sci., 5th ser., vol. 31, no. 185, pp. 391-393, May 1936.

2689. (and Olmsted, Elizabeth W.). Structural determinants in Appalachian drainage [abstract]: Geol. Soc. America Proc., 1935, pp. 92-93, June 1936.

2690. (and Lochman, .Christina). Deadwood faunas in South Dakota and eastern Wyoming [abstract]: Geol. Soc. America Proc., 1935, pp. 386-387, June 1936.

2691. Floods and dust storms: Science, new ser., vol. 83 , no. 2165, p. 622 , June 26, 1936.

2692. (and Olmsted, Elizabeth $W_{\text {.) }}$. The origins of Appalachian drainage: Am. Jour. Sci., 5th ser., voi. 32, no. 187, pp. 21-42, 3 figs. (incl. sketch map), July 1936.

Meyers, J. C.

2693. Some notes on fluorescence: Rocks and Minerals, vol. 11, no. 8, pp. 123124, August 1936.

Michaux, Frank W., Jr.

2694. (and Buck, E. O.). Conroe oil ,fleld, Montgomery County, Tex.: Am. Assoc. Petroleum Geologists Bull., vol. 20, no. 6, pp. 736-779, 11 figs. (incl. index and geol. structure maps), June 1936; abstract, World Petroleum, vol. 7, no. 8, p. 404, August 1936; reprinted in Gulf coast oil fields (see Barton and Sawtelle), pp. 789-832, 1938. 
Miller, Andrew Howard.

2695. (and Hughson, W. G.). The isostatic equilibrium of the Paciflc coast of Canada: Fifth Paciflc Sci. Cong., Canada, 1933, Proc., vol. 2, pp. 1169-1173, 2 figs. (incl. sketch map), 1934.

2696. Geophysical prospecting in Canada [abstract]: Earthquake Notes, vol. 7, nos. 1-2, p. 17 ( $\$$ ), September 1935.

2697. Gravity anomalies in Canada [abstract]: Earthquake Notes, vol. 7, nos. 1-2, p. 17 ( $\ddagger$ ), September 1935.

2698. (and Norman, George William Hal). Gravimetric survey of the Malagash salt deposit, Nova Scotia: Am. Inst. Min. Met. Eng. Tech. Pub. 737, 11 pp., 2 figs. (incl. geol. map), 1936.

Miller, Arthur K. See also Teichert, 4038.

2699. (and Cline, L. M.). The cephalopods of the Phosphoria formation of northwestern United States: Jour. Paleonitology, vol. 8, no. 3, pp. 281-302, 1 pl., September 1934.

2700. Devonian ammonoids of America [abstract] : Geol. Soc. America Proc., 1934, p. 361, June 1935.

2701. Devonic ammonoids of Iowa: Pan-Am. Geologist, vol. 65, no. 5, pp. 336-338, June 1935; abstract, no. 4, p. 316, May 1936.

2702. (and Thompson, Marcus Luther). The nautiloid genus Aturoidea in America: Jour. Paleontology, vol. 8, no. 7, pp. 563-571, 2 pls., 2 figs., October 1935.

2703. Burlington goniatites: Am. Jour. Sci., 5th ser.; vol. 30, no. 179, pp. 432-437, 3 figs., November 1935.

2704. 'Type invertebrate fossils of North America (Devonian)'; Ammonoidea. 50 cards, figs. [1936].

2705. (and Butts, Charles). A Mississippian goniatite from Virginia: Jour. Paleontology, vol. 10, no. 1, pp. 69-72, 3 figs., January 1936.

2706. (and Crockford, M. B. B.). Permian cephalopods from British Columbia: Royal Soc. Canada Trans., 3d ser., sec. 4, vol. 30, pp. 23-28, 1 pl., May 1936.

2707. (and Owen, John Britts). New Pennsylvanian cephalopod fauna from the Nowata shale of Oklahoma [abstract]: Geol Soc. America Proc., 1935, p. 369, June 1936.

2708. Permian cephalopods from British Columbia [abstract]: Geol. Soc. America Proc., 1935, p. 370, June 1936.

2709. (and Flower, Rousseau Hayner). A Sporadoceras from America: Jour. Geology, vol. 44, no. 6, pp. 751-757, 1 fig., August-September 1936.

2710. A species of the ammonoid genus Artinskia from the lower Permian of Kansas: Jour. Paleontology, vol. 10 , no. 6, ṕp. 490-496, 1 pl., 6 figs., September 1936.

2711. (and Warren, Percival Sidney). A Timanites from Upper Devonian beds of America: Jour. Paleontology, yol. 10, no. 7, pp. 632-636, 7 figs., October 1936.

2712. (and Thomas, Horace Davis). The Casper formation (Pennsylyanian) of Wyoming and its cephalopod fauna: Jour. Paleontology, vol. 10, no. 8, pp. 715-738, 4 pls., 4 figs. (incl. index map), December 1936.

Miller, Buford Maxwell.

2713. Cambrian trilobites from northwestern Wyoming: Jour. Paleontology, vol. 10, no. 1, pp. 23-34, 1 pl., January 1936.

$311-37-13$ 
Miller, Buford Maxwell-Continued.

2714 Gambrian stratigraphy of northwestern. Wyoming: Jour. Geology, vol,

$\therefore$.1. 44, no. 2, pt: 1, pp. 113-144, 10 figs. (incl. index map), FebruaryMarch 1936; abstract, Geol.. Soc. America Proc., 1934, p. 352, June 1935. $\because: \quad:$

2715. Brachyaspidion, new name for Brachyaspis Miller (not Salter) : Jour. Paleontology, vol. 10, no. 5, p..417, July 11936.

Miller, Benjamin Leroy. See also Stose, 3947.

2716. Practical value of economic geology in the manufacture of cement: Pit and Quarry, vol: 126, no. 10, pp. 29-36, 40, 14 figs., April 1931.

2717. Unsolved problems of eastern Pennsylvania geology : Pan-Am. Geologist, vol. 63, no. 3, pp. 161-172, April 1935; abstract, Geol. Soc. America. Proc, 1934, p. 450, June 1935.

2718. Age of the schists of the South Valley Hills, Pa.: Geol. Soc. America Bull., vol. 46, no. 5, pp. 715-756, 7 figs., discussion by George W. Stose and W. H. Bucher, and reply, pp. 2021-2031, 1 fig., May 31, 1935 ; abstract, with discussion, Proc., 1934, pp. 95-98, June 1935.

2719. Geophysical investigations in the emerged and submerged Atlantic Coastal Plain; pt. 2, Geologic significance of the geophysical data [abștract] : Geol. Soc. America Proc., 1935, pp. 93-94, June 1936.

Miller, Charis R. See Teas, 4032.

Miller, Franklin S. See also Larsen, 2338.

2720. Anorthite from California : Am. Mineralogist rol. 20, no. 3, pp. 139-146, 2.figs., March 1935.

Miller, John Charles. See Dobbin, 1051, 1052.

Miller; Loye Holmes.

2721. New bird horizons in California : California Univ. Pub. Biol. Sci., vol. 1, no. 5, pp. 73-80, 2 figs.; March 12, 1935.

2722. A second avifauna from the McKittrick Pleistocene: Condor, vol 37, no. 2, pp. 72-79, 3 figs. March-April 1935.

Miller, Osborn Maitland. See also Boyd, 409 ; Forbes, 1304.

2723. Surveying from the air, its scope and limitations: Eng. and Min. Jour., vol. 136, no. 11, pp. 555-557, 2 figs., November 1935.

Miller, Paul T. See Kay, 2027.

Miller, Ralph Lester. See also U. S. G. S., 4228.

2724. Martinsburg limestones in eastern Pennsylvania [abstract]: Geol. Soc. America Proc., 1934, pp. 356-357, June 1935.

Miller, Robert Cunningham.

2725. (and Frizzell, Donald Leslie). Key to pelecypod genera of Puget Sound [abstract] : Pan-Am Geologist, vol. 63, no. 5, p. 377, June 1935 ; Geol. Soc. America Proc., 1935, p. 415, June 1936.

Miller, William John.

2726. Magmatic intrusion or the rise of molten rock into the earth's crust: California Univ, Faculty Research Lectures, 35 pp., 1932.

2727. Mode of emplacement of anorthosite [abstract]: Geol. Soc. America Proc., 1934, p. 99, June 1935.

2728. A geologic section across the sonthern Peninsular Range of California : California Jour. Mines and Geology, vol. 31, no. 2, pp. 115-142, 1 pl. (geol. map), 8 figs., April 1935. 
Miller, William John-Continued.

2729. Pre-Cambrian and associated rocks near Twenty-nine Palms, Calif: [abstract]: Geol. Soc. America Proc., 1934, p. 99, June 1935.

2730. Geomorphology of the southern Peninsular Range of California: Geol. Soc. America Bull., vol. 46, no. 10, pp. 1535-1562, 5 pls. (incl. fault map), 1 fig. (sketch map), October .31, 1335 ; abstract, Proc., 1934, pp. 317-318, June 1935.

Millikan, C. V. : See Barton, 212.

Millikan, Robert Andrew. See Day, 987, 989.

Mills, Brad.

2731. Geophysical operations have been very successful in San Joaquin Valley during past year: Oil Weekly, vol. 78, no. 4, pp. 28-29, 1 fig., July $8,1935$.

2732. New coast discoveries throw additional light on salt-dome area as future reserve: Oil Weekly, vol. 78 , no. 10, pp. 19-23, 2 figs., August 19, 1935.

2733. Rodessa's posibilities [Louisiana and Texas]: Oil Weekly, vol. 78, no. 11. pp. 20-30, 1 pl. (geol. map), 2 figs. (incl. geol. map), August $26,1935$.

2734. Geophysical programs in Gulf coast district are exacting technica operations: Oil Weekly, rol. 79, no. 4, pp. 21-26, 2 figs., October 7, 1935 ; no. 5, pp. 22-27, 4 figs., October 14, 1935.

2735. Deep possibilities of the Gulf coast: Oil Weekly, vol. 80, no. 6, pp. 19-22, 1 fig., January 20, 1986; abstract, vol. 81, no. 1, pp. 70-71, 1 fig., March 16, 1936.

2736. Rodessa [Louisiana and Texas] a big reserve: Oil Weekly vol. 80. no. 9, pp. 28-34, 3 figs. (incl. index map), February 10, 1936.

2737. No pollution problem in development of submerged leases along [Gulf] coastal belt: Oil Weekly, vol. 81, no. 11, pp. 17-22, 5 figs., May 25. 1936 ; abstract, World Petroleum, vol. 7, no. 8, p. 406, August 1936.

2738. Paleontology playing increasingly important role in Gulf coast drilling: Oil Weekly, vol. 82, no. 6, pp. 19-20, 22, 2 figs., July 20, 1936.

2739. Talco's future status of greater importance than is generally thought= Oil Weekly, vol. 83, no. 8, pp. 29-32, 2 figs. (incl. index map), November 2, 1936.

2740. The Gulf coast as a deep oil reserve: Oil Weekly, vol. 83, no. 9, pp. 46, 48 , 50, November 9,1936 .

Milner, Robert $\mathbf{L}$.

2741. The solubility of gold in ferric sulphate and its geological applications : Nova Scotian Inst. Sci. Proc., vol. 18, pt. 4, pp. 267-271, 1 fig., June $20,1935$.

Milton, Charles.

2742. Metamorphism of a granitic dike at Franklin, N. J. [abstract] : Washington Acad. Sci. Jour., vol. 25, no. 12, p. 565, December 15, 1935.

2743. A foraminiferal analcite shale from Texas [abstract]: Washington Acad. Sci. Jour., vol. 26, no. 9, p. 386, September 15, 1936.

Miner, Ernest Lavon.

2744. A new Laccopteris from the Cretaceous of Kansas: Michigan Univ. Mus. Paleontology Contr., vol. 4, no: 17, pp. 287-290, 1 pl., February 20, 1935 . 
Miner, Ernest Lavon-Continued.

2745. Paleobotanical examinations of Cretaceous and Tertiary coals: Am. Midland Naturalist, vol. 16, no.. 4, pp. 585-625, 7 figs., 7 pls., July 1935.

2746. An interesting "Dadoxylon" from northern Illinois: Am. Midland Naturalist, vol. 17, no. 2, pp. 455-459, 7 figs., March 1936.

Minton, Joseph W. See Ferguson, 1237.

Miser, Hugh Dinsmore. See also Hawley, 165்; Kramer, 2255.

2747. David White [1862-1935]: Am. Assoc. Petroleum Geologists Bull., 'vol. 19 , no. 6, pp. 925-931, port., June 1935.

2748. Structural relations of the Ouachita geosyncline of Arkansas, Oklahoma, and adjacent States [abstract, with discussion] : 16th Internat. Geol. Cong. (1933) Rept., vol. 2, pp. 997-998, 1936.

2749. [Review of] Zinc and lead deposits of northern Arkansas, by E. T. McKnight, 1935: Am. Assoc. Petroleum Geologists Bull., vol. 20, no. 3, pp. 322-324, March 1936.

2750. (and others). [Memorial to] David White: Am. Assoc. Petroleum Geologists Bull., vol. 20, no. 5, pp. 625-632, 1 fig., May 1936.

Mitchell, Lane. See also Crickmay, 902, 904, 908.

2751. The common rocks and minerals of Georgia; a description of the specimens included in the school museums distributed by the Division of Geology : Georgia Div. Geology Inf. Circ. 5, 4 pp., 2 figs. (incl. index map), [1935].

2752. Geological museums in Georgia: Forestry-Geol. Rev., vol. 5, no. 7, pp. 7-8, 1 fig. (index map), July 1935 ; no. 8, pp. 7-8, 1 flg., August 1935.

2753. Mammoths and mastodonts at Savannah, Ga. [abstract]: Geol. Soc. America Proc., 1935, p. 402, June 1936.

Mitchell, Robert Hamilton.

2754. Residues of some Pennsylvanian limestones: Am. Assoc. Petroleum Geologists Bull., vol. 19, no. 3, pp. 412-415, 4 flgs., March 1935.

2755. Some observations on slumping and gully formation: Science, new ser., vol. 84 , no. 2184, p. 420, November 6, 1936.

Modell, David.

2756. Ring-dike complex of the Belknap Mountains, N. H.: Geol. Soc. America Bull., vol. 47, no. 12, pp. 1885-1932, 3 pls. (incl. geol. map), 4 figs., December 31, 1936.

Moehlman, Robert S.

2757. Quartz paramorphs after tridymite and cristobalite: Am.. Mineralogist, vol. 20, no. 11, pp. 808-810, 2 figs., November 1935.

2758. Dikes and veins of the Alamo gold district, Lower California : Econ. Geology, vol. 30, no. 7, pp. 750-764, 9 flgs. (incl. sketch map), November 1935.

2759. Amygdaloidal dikes: Am. Mineralogist, vol. 21, no. 5, pp. 329-331, 2 figs., May 1986.

2760. Ore deposition south of Ouray, Colo., pt. 1: Econ. Geology, vol. 31, no. 4, pp. 377-397, 6 figs., (incl. index map), June-July 1936; pt. 2, no. 5, pp. 488-504, 10 figs., August 1936.

Mofft, Fred Howard.

2761. Copper resources of Alaska : Copper resources of the world, pp. 137-150, 1 pl. (index map), Washington, 16th Internat. Geol. Cong., 1935. 
Moffit, Fred Howard-Continued.

2762. Geology of the Tonsina district, Alaska : U. S. Geol. Survey Bull. 866, 38 pp., 1 pl. (geol. map), 4 figs. (incl. sketch map), 1935.

2763. Upper Copper and Tanana Rivers, Alaska: U. S. Geol. Survey Bull. 868-C, pp. ii, 135-143, 1 pl. (sketch map), 1936.

Mohler, Nora May.

2764. A spectrophotometric study of smoky quartz: Am. Mineralogist, vol. 21, no. 4, pp. 258-263, April 1936.

Moldenke, Harold Norman.

2765. The flora of the Watchung Mountains; pt. 1, Geology of the region: Torreya, vol. 36, no. 3, pp. 57-61, 2 figs. (incl. geol. sketch map), May-June 1936.

Monnig, Oscar Edwin. See also Sellards, 3639.

2766. (and Brown, Robert). The Odessa, Tex., meteorite crater: Popular Astronomy, vol. 43, no. 1, pp. 34-37, 1 fig. (topog. map), January 1935 ; Soc. Research on Meteorites Contr., fasc. 1, pp. 1-4, January 1936.

2767. Geology of Texas, vol. 2, pt. 3, Economic geology of Texas (exclusive of petroleum); Preliminary check list of Texas meteorites: Texas Univ. Bull. 3401, pp. 220-223, December 1935.

2768. (and Brown, Robert). The meteorite fall in Oklahoma [August 17, 1936] : Popular Astronomy, vol. 44, no. 10, pp. 568-569, December 1936.

Monroe, Watson Hiner.

2769. Carboniferous rocks at Jackson, Miss.: Am. Assoc. Petroleum Geologists Bull., vol. 20, no. 1, p. 106, January 1936.

2770. Structure of the Coastal Plain of southern Maryland; a discussion: Am. Jour. Sci., 5th ser., vol. 32, no. 187, pp. 70-72, 2 figs: (geol. sketch maps), July 1936.

2771. Upper Cretaceous and lower Tertiary history of the Jackson area, Miss. [abstract] : Washington Acad. Sci. Jour., vol. 26, no. 9, pp. 386-387, September 15, 1936.

Montgomery, Arthur.

2772. Minerals of Thomas Range, Utah: Rocks and Minerals, vol. 10, no. 11, pp. 161-168, 2 figs., November 1935.

Montgomery, J. C. See Stamey, 3817.

Moody, Clarence Lemuel.

2773. [Review of] Oil and gas geology of the Gulf Coastal Plain in Arkansas, by William C. Spooner, 1935: Am. Assoc. Petroleum Geologists Bull., rol. 19, no. 4, pp. 575-581, April 1935.

Moody, Graham B.

2774. The geology of Santa Rosa Island [Calif.] [abstract]: Am. Assoc. Petroleum Geologists Bull., vol. 19, no. 1, p. 136, January 1935; Pan-Am. Geologist, vol. 63, no. 4, pp. 316-317, May 1935; Geol. Soc. America Proc., 1935, pp. 338-339, June 1936.

2775. Unconformity exposed in Santa Ana Mountain foothills [abstract] : Am. Assoc. Petroleum Geologists Bull., vol. 19, no. 12, pp. 1841-1842, December 1935.

Moon, C. Lloyd. See Schofield, 3602. 
Moore, Barrington.

2776. [Review of] The New England-Acadian shore line, by D. W. Johnson, 1925: Ecology, vol. 7, no. 2, pp. 232--234, April 1926.

Moore, Bernard Nettleton. See also Hewett, 1735.

2777. Nonmetallic mineral resources of eastern Oregon: U. S. Dept. Interior Press Mem. 65121, 4 pp. ( $\ddagger), 1$ pl. (index map), August 26, 1932.

2778. Some strontium deposits of southeastern California and western Arizona : Am. Inst. Min. Met. Eng. Tech. Pub. 599, 24 pp., 8 figs. (incl. geol. sketch maps), 1935; Trans., vol. 115 (Mining geology), pp. 356-377, 8 figs. (incl. sketch maps), 1935; abstracts; Mining and Metallurgy, vol. 16, no. 338, p. 115, February 1935, Year Book sec., p. 58, January 1936.

2779. Diatomite and pumice in eastern Oregon (abstract): Mining and Metallurgy, Year Book sec., p. 80, January 1935.

Moore, Charles H., Jr.

2780. Development of ideas on the origin of the Natural Bridge of Virginin [abstract] : Virginia Acad. Sci. Proc., 1935-36, p. 69, 1936.

Moore, Elwood S. See also Butts, 598.

2781. Gold deposits of the Afton-Scholes area, Ontario : Canadian Min. Met. Bull. 293, pp. 615-622, 3 figs. (incl. geol. map), September 1936.

Moore, Fred Holmsley.

2782. Marbles and limestones of Connecticut: Connecticut Geol. Nat. History Survey Bull. 56, 56 pp., 14 pls. (incl: index map), 1935.

Moore, Raymond Cecil. See also Kansas Geol. Soc., 2020, 2024.

2783. Relation of cyclic depositional units to classification of the Pennsylvanian and Permian of the northern midcontinent area [abstract, with discussion]: Tulsa Geol. Soc. Digest, 1934, pp. 18-20.

2784. The Mississippian system in the upper Mississippi Valley region: Kansas Geol. Soc. Guidebook 9th Ann. Field Conf., pp. 239-245 $(\ddagger), 1935$.

2785. Correlation of phases in sedimentation cycles in Pennsylvanian and "Permian" rocks of Kansas [abstract, with discussion] : Geol. Soc. America Proc., 1934, p. 100, June 1935.

2786. (and Elias, Maxim Konrad, and Newell, Norman Dennis). Zone fossils of the Kansas Pennsylvanian and "Permian" section [abstract]: Geol. Soc. America Proc., 1934, p. 368, June 1935.

2787. Late Paleozoic crustal movements of Europe and North America [with discussion]: Am. Assoc. Petroleum Geologists Bull., vol. 19, no. 9, pp. 1253-1307, 14 figs., September 1935.

2788. Pennsylvania and lower "Permian" rocks of the Kansas-Missouri region: Kansas Geol. Soc. Guidebook 10th Ann. Field Conf., pp. 7-73 ( $\ddagger), 47$ figs. (incl. stratigraphic columns), 1936. With collaboration of Maxim K. Elias, Frank C. Greene, and Norman D. Newell. .

2789. "Carboniferous" rocks of North America [with discussion]: 16th Internat. Geol. Cong. (1933) Rept., vol. 1, pp. 593-616, 3 pls. 9 figs., 1936.

2790. (and Elias, M. K., and Newell, Norman D.). A "Permian" flora from the Pennsylvanian rocks of Kansas: Jour. Geology, vol. 44, no. 1, pp. 1-31, 12 figs. (incl. geol. maps); January-February 1936; Kansas Geol. Survey Contr. Paleontology no. 4, 1936. 
Moore, Raymond Cecil-Continued.

2791. Stratigraphic classification of the Peunsylvanian rocks of Kansas: Kansas Univ. Bull. 22, November 15, 1935, 256 pp., 12 figs., August 31, 1936.

Section on the Douglas Group (Haworth, 1898), Moore, 1932, pp. 144-159. by R. C. Moore and N. D. Newell.

2792. Stratigraphic evidence bearing on problems of continental tectonics: Geol. Soc. America Bull., vol. 47, no. 11, pp. 1785-1808, 6 flgs., November 30, 1936 ; abstract, Proc., 1935, p. 94, June 1936.

Moore, Thomas G. See Wandke, 4328.

Moore, W. W. See Heck, 1678.

Morero, J. E. See Rettger, 3254.

Moresi, Cyril K.

2793. Report of the Louisiana Geological Survey: Louisiana Dept. Cons. 12th Bienn. Rept. (Gen. Conservation Bull.), 1934-35, pp. 527-538, 1 fig. (index map), 1936.

27S4. Warping of formations along the Gulf coast makes gravity survey desirable: Oil Weekly, vol. 80, no. 9, p. 48, February 10, 1936.

Morey, George Washington.

2795. (and Ingerson, Earl). The melting of danburite [abstract]: Am. Minerologist, vol. 21, no. 3, p. 194, March 1936.

Morey, Philip S.

2796. Ostracoda from the basal Mississippian sandstone in central Missouri : Jour. Paleontology, vol. 9, no. 4, pp. 316-326, 1 pl., Jume 1935.

2797. Ostracoda from the Amsden formation of Wyoming: Jour. Paleontology, vol. 9 , no. 6 , pp. 474-482, 1 pl., September 1935 .

2798. Ostracoda from the Chouteau formation of Missouri: Jour. Paleontology, vol. 10, no. 2, pp. 114-122, 1 pl., March 1936.

Mornhinveg, A. $\mathbf{R}$.

2799. (and Garrett, Julius B., Jr.). Study of Vicksburg group at Vicksburg, Miss.: Am. Assoc. Petroleum Geologists Bull., vol. 19, no. 11, pp. 1645-1667, 5 figs. (incl. index map), November 1935; reprinted: in Gulf coast oil fields (see Barton and Sawtelle), pp. 335-357, 1936.

Morris, Frederick Kuhne.

2800. The making of the valley; a billion years along the Hudson. $75 \mathrm{pp}$, 18 figs., illus. lining papers. New York, Thomas Nelson \& Sons, 1936.

2801. The eastern Appalachian geosyncline [abstract, with discussion] : 16th Internat. Geol. Cong. (1933) Rept., p. 996, 1936.

Morris, S. W. See Swarts, 3987.

Morrison, Roger B.

2802. The occurrence and origin of celestite and fluorite at Clay Center, Ohto: Am. Mineralogist, vol. 20, no. 11, pp. 780-790, 4 figs., November 1935.

Morrow, A. Lyndon.

2803. Cephalopods from the Upper Cretaceous of Kansas: Jour. Paleontology, vol. 9, no. 6, pp. 463-473, 5 pls., September 1935.

Morse, Harry Wheeler.

2804. (and Donnay, Joseph Désiré Hubert). Optics and structure of threedimensional spherulites: Am. Mineralogist, vol. 21, no. 7, pp. 391426, 26 figs., July 1936; abstract, no. 3, pp. 201-202, March 1936. 


\section{Morse, Hugh McDonald.}

2805. A supplementary report on bentonite in Mississippi: Mississippi Geol. Survey Bull. 22-A, 32 pp. (\$), 10 pls. (incl. sketch map), 1934.

Morse, Roy Robert.

2806. (and Bailey, 'Thomas Laval): Geological observations in the Petaluma district, Calif.: Geol. Soc. America Bull., vol. 46, no. 10, pp. 14371456, 1 pl., 2 figs. (incl. maps), October 31, 1935; abstract, Proc., 1934, p. 100, June 1935.

Morse, William Clifford.

2807. Fifteenth biennial report, 1934-35, of the director of the State Geological Survey to the Mississippi Legislature. 8 pp. [1935?].

2808. The Highland Church sandstone as a building stone: Mississippi Geol. Survey Bull. 26, 30 pp., 16 figs. (incl. maps), 1935.

2809. Geologic conditions governing sites of bridges and other structures: Mississippi Geol. Survey Bull. 27, 19 pp., 9 figs. (incl. map), 1935.

2810. The geologic history of the Vicksburg National Military Park area: Mississippi Geol. Survey Bull. 28, 20 pp., 1 pl. (map), 6 figs., 1935.

Moss, Rycroft Gleason.

2811. Buried pre-Cambrian surface in the United States: Geol. Soc. America Bull., vol. 47, no. 6, pp. 935-966, 5 pls. (incl. geol. maps), June 30, 1936.

Moulton, Gail Francis: See Thom, 4074.

Müllerried, Friedrich K. G. See also Rènz, 3249.

2812. Échinides du Mexique: Soc. géol. France Bull., 5th ser., tome 5, fasc. 4-5, pp. 365-368, 4 figs., 1935.

2813. The geographic distribution of Mexican meterorites; The abundance of siderites in the Americas: Popular Astronomy, vol. 43, no. 9, pp. 601-602, November 1935 : Soc. Research on Meteorites Contr., fasc. 1, pp. 41-42, January 1936.

2814. Carlos Burckhardt, 1869-1935: Soc. geol. mexicana Bol., tomo 9, no. 1, pp. 23-29, 1 flg. (port.), 1936.

2815. Estratigrafía preterciaria prèliminar del Estado de Chiapas : Soc. geol. mexicana Bol., tomo 9, no. 1, pp. 31-41, 1936.

2816. Dr. Carl Burckhardt, 1869-1935: Jour. Paleontology, vol. 10, no. 2, pp. 146-147, March 1936.

Muench, Oscar Brauer. See also Spence, 3802.

2817. The analysis of cyrolite for lead and uranium: Am. Jour. Sci., 5th ser., vol. 21, no. 124, pp. 350-357, April 1931.

2818. Analysis and age of a Quebec monazite [abstract] ; Pan-Am. Geologist, vol. 64 , no. 2, p. 156, September 1935.

2819. Sulfur in cyrtolite and its indication of galena (with a note by Alfred Church Lane) : Am. Mineralogist, vol. 21, no. 6, pp. 374-378, June 1936.

Muir, John Malcolm. See also Lilley, 2416; Plummer, 3101; Ver Wiebe, 4289 ; White, 4460.

2820. Occurrence of natural gas in Mexican oil fields, with notes on Lake Chapala region and Valley of Mexico: Geology of natural gas, pp. 997-1010, 2 figs. (maps), Am. Assoc. Petroleum Geologists, [June] 1935. 
Muir, John Malcolm-Continued.

2821. Geology of the Tampico region, Mexico. xix, $280 \mathrm{pp}$, 19 pls. (incl. geol. maps), 37 figs. (incl. geol. maps), Tulsa, Okla., Am. Assoc. Petroleum Geologists, 1936. [Introduction by Lloyd William Stephenson.]

2822. The limestone reservoir rocks in the Mexican oil fields, with a discussion on the source of the oil [abstract]: 16th Internat. Geol. Cong. (1933) Rept., vol. 2, p. 1010, 1936.

Mulchay, R. B. See Shenon, 3664.

Muller, Siemon William. See also Ferguson, 1236; Schenck, 3550.

2823. North American upper Triassic pelecypod, Pseudomonotis subcircularis (Gabb) [abstract]: Geol.. Soc. America Proc., 1934, p. 388, June 1935.

2824. (and Ferguson, Henry Gardiner). Triassic and Jurassic formations of west-central Nevada: Geol. Soc. America Bull., vol. 47, no. 2, pp. 241-251, February 29, 1936.

2825. Triassic coral reefs in Nevada: Am. Jour. Sci., 5th ser., vol. 31, no. 183, pp. 202-208, 1 fig., March 1936; abstracts, Pan-Am. Geologist, vol. 63, no. 5, pp. 371-372, June 1935; Geol. Soc. America Proc., 1935, p. 410, June 1936.

Mulryan, Henry.

2826. Godfrey, mining and processing of diatomite at Lompoc, Santa Barbara County, Calif: Am. Inst. Min. Eng. Tech. Pub. 687, 30 pp., 14 figs. (incl. index map), 1936; California Jour. Mines and Geology, vol. 32, no. 2, pp. 133-166, 19 figs., April 1936.

Munday, W. A. Don.

2827. Glaciers of Mt. Waddington region [British Columbia]: Canadian Alpine Jour., vol. 23, 1934-35, pp. 68-75, 2 pls., June 1936.

Mundorf, I. Dean. See U. S. G. S., 4232.

Munroe, Donald James.

2828. Jackson gas field, Hinds and Rankin Counties, Miss.: Geology of natural gas, pp. 881-896, 3 figs., Am. Assoc. Petroleum Geologists, [June] 1935.

Mumroe, George w.

2829. Power to move continents: Science, new ser., vol. '82, no. 2134, pp. 488-490, November 22, 1935.

Munyan, Arthur Claude. See Bay, 241.

Munz, Philip Alexander. See Laudermilk, 2346.

Murata, Kiguma Jack.

2830. A neglected method for making thin sections of fossils: Jour. Paleontology, vol. 9, no. 4, pp. 359-361, June 1935.

Murdoch, Joseph.

2831. Quartz-fluorite pseudomorphs [abstract] : Pan-Am. Geologist, vol. 64, no. 1, pp. 69-70, August 1935; Geol. Soc. America Proc. 1935, pp. 346-347, June 1936.

2832. Silica-fluorite pseudomorphs: Am. Mineralogișt, vol. 21, no. 1, pp. 18-32, 12 figs., January 1936. 
Murdoch, Joseph-Continued.

2833. Andalusite in pegmatite: Am. Mineralogist, vol. 21, no. 1, pp. 68-69, January 1936.

2834. (and Webb, Robert William): Bustamite from Inyo County, Calif.: Am. Mineralogist, vol. 21, no. 1, pp. 69-70, January 1936.

2835. Adamite from Chloride Cliff, Calif.: Am. Mineralogist, vol. 21, no. 12, pt. 1, pp. 811-813, 3 figs., December 1936.

Murray-Hughes, $\mathbf{R}$.

2836. Making thin sections; simplified method: Econ. Geology, vol. 30, no. 2, pp. 192-193, March-April 1935.

Muskat, Morris.

2837. The seepage of water through porous media under the action of gravity: Am. Geophys. Union Trans. 17th Ann. Meeting, pt. 2, pp. 391-395 ( $\ddagger), 3$ figs., Nat.. Research Council, 1936.

2838. [Review of] Systematic packing of spheres, with particular relation to porosity and permeability, by L. C. Graton and H. J. Fraser, 1935: Am.. Assoc. Petroleum Geologists Bull., vol. 20, no. 3, pp. 324-327, March 1936.

Myers, Richmond E.

2839. The Mauch Chunk carnotite: Rocks and Minerals, vol. 10, no. 10, p. 155, October 1935.

Nace, Raymond $\mathbf{L}$.

2840. Summary of the late Cretaceous and early Tertiary stratigraphy of Wyoming: Wyoming Geol. Survey Bull. 26, 271 pp. ( $\ddagger), 4$ pls., 5 figs., April 1936.

National Research Council, Division of Geology and Geography.

2841. Annual report, year 1930-31, 201 pp. ( $\ddagger), 1$ fig. [1985].

Contains reports on historical, economical and physical geologi, sedimentation, measurement of geologic time, paleontology, mineralogy, etc.

2S42. Annual report, year 1934-35, 329 pp. ( $\ddagger)$, 8 figs., December 1935.

Contains reports on historical and physical geology, sedimentation, measurement of geologic time, paleontology, geophysical prospecting, etc.

Needham, Claude Ervin.

2843. Ventifacts from New Mexico [abstract]: Pan-Am. Geologist, vol. 64, no. 2, pp. 150-151, September 1935.

2844. Vertebrate remains from Cenozoic rocks [New Mexico]: Science, new ser., vol. 84, no. 2189, p. 537, December 11, 1936.

Nelson, H. E.

2845. The Hidden Creek [British Columbia] ore bodies: Canadian Inst. Min. Metallurgy Trans., vol. 38, pp. 349-357, 4 figs. (incl. geol. maps), 1935.

Nelson, Nels Christian.

2846. The antiquity of man in America in the light of archeology : Smithsonian Inst. Ann. Rept., 1935, Pub., 3348, pp. 471-506, 1936.

Nettleton, Lewis Lomax.

2847. Fluid mechanics of salt domes: Am: Assoc. Petroleum Geologists Bull., vol. 18 , no. 9 , pp. 1175-1204, 9 figs., September 1934, no. 12, p. 1712, December 1934; reprinted in Gulf coast oil fields (see Barton and Sawtelle), pp. 79-108, 1936.

Netzeband, W. F. See Crabtree, 887. 
Neumann, Frank. See also Heck, 1665.

2S48. United States earthquakes, 1933: U. S. Coast and Geodetic Survey serial 579, 82 pp., 17 figs. (incl. maps); 1935.

2849. Some new data on long-period waves in epicentral areas [abstract]: Earthquake Notes, vol. 7, nos. 1-2, p. 13 (\$), September 1935.

2850. United States earthquakes 1934: U. S. Coast and Geodetic Survey serial 593, 99 pp., 1 pl. (index map), 26 figs. (incl. maps), 1936.

Nevin, Charles Merrick. See also Snider, 3784.

2851. (and Mayo, Evans Blakemore). Nature and genesis of batholiths [abstract] : Geol. Soc. America Proc., 1934, p. 101, June 1935.

2852. Principles of structural geology,, 2d ed., 348 pp., 165 figs., New York, John Wiley \& Sons, Inc., 1936.

Newcombe, Robert John Burgoyne.

2853. Natural gas fields of Michigan: Geology of natural gas, pp. 787-812, 3 pls. (maps), 3 figs. (incl. maps), Am. Assoc. Petroleum Geologists, [June] 1935.

2854. (and Lindberg, George D.). Glacial expression of structural features in Michigan; preliminary -study : Am. Assoc. Petroleum Geologists Bull., vol. 19, no. 8, pp. 1173-1191, 2 pls., 2 fịgs. (all maps), August 1935 .

Newell, Norman Dennis. See also Jewett, 1950; Kansas Geol. Soc., 2024; Moore, 2786, 2788, 2790, 2791.

2855. The geology of Johnson and Miami Counties, Kans.: Kansas Geol. Survey Bull. 21, pp. 7-150, 12 pls. (incl. geol. maps), 1 fig. (index map), May 15, 1935.

2856. Some mid-Pennsylvanian invertebrates from Kansas and Oklahoma: 2, Stromatoporoidea, Anthozoa, and Gastropoda: Jour. Paleontology, vol. 9, no. 4, pp. 341-355, 4 pls., June 1935.

2857. Morphology of upper Paleozoic Pectinacea [abstract]: Geol. Soc. America Proc., 1934, p. 365, June 1935.

2858. Classification of upper Paleozoic Pectinacea [abstract]: Geol. Soc. America Proc., 1934, pp. 365-366, June 1935.

2859. Some mid-Pennsylvania invertebrates from Kansas and Oklahoma; 3, Cep̀halopoda : Jour. Paleontology, vol, 10, no. 6, pp. 481-489, 5 pls., 2 figs., September 1936.

Newhouse, Walter Harry. See also Ross, 3369.

2860. [Review of] The geology and ore deposits of the Horne mine, Noranda, Quebec, by Peter Price, 1934: Econ. Geology, vol. 30, no. 3, pp. 326-327, May 1935.

2861. Mineral zoning in the New Jersey, Pennsylvania, and Virginia Triassic area [abstract, with discussion] : 16th Internat. Geol. Cong. (1933) Rept., vol. 1, p. 460, 1936.

2862. Opaque oxides and sulphides in common igneous rocks: Geol. Soc. America Bull., vol. 47, no. 1, pp. 1-52, 18 pls., 2 figs., January 31. 1936.

2863. [Review of] The minerals of Franklin and Sterling Hill, Sussex County, N, J., by Charles Palache, 1935: Econ. Geology, vol. 31, no. 5, pp. 531-532, August 1936.

2864. (and Glass, J. P.). Some physical properties of certain iron oxides: Econ. Geology, vol. 31, no. 7, pp. 699-711, 3 figs., November 1936.

2865. A zonal gold mineralization in Nova Scotia: Econ. Geology, vol. 31, no. 8, pp. 805-831, 8 figs. (incl. geol. sketch map), December 1936. 
Newland, David Hale.

2866. Minerals of Whiteface Mountain: Rocks and Minerals, vol. 10, no. 6, pp. 81-82, June 1935.

2867. Mineralogy and origin of the Taconic limonites, Econ. Geology, vol. 31, no. 2, pp. 133-155, 4 figs., March-April 1936.

2868. (and Hartnagel, Chris Andrew). The mining and quarry industries of New York State for 1930 to 1933: New York State Mus. Bull. 305, pp. 3-95, April 1936.

2869. (and Hartnagel, Chris Andrew). Recent natural-gas developments in New York State: New York State Mus. Bull. 305, pp. 97-161, April 1936.

New York Botanical Garden, Board of Managers.

2870. Nathaniel Lord Britton [1859-1934]: Science, new ser., vol. 81, no. 2091, pp. 87-88, January 25, 1935.

Nichols, D. A.

2871. Post-Pleistocene fossils of the uplifted reaches of the eastern Arctic regions of Canada: Canadian Field Naturalist, vol. 50, no. 8, pp. 127-129, November 1936.

Nichols, Frances. See Nichols, R. L., 2872.

Nichols, Robert L.

2872. (and Nichols, Frances). Polygonboden on Mount Desert Island, Maine: Science, new ser., vol. 83, no. 2146, p. 161, February 14, 1936; Tufts College Studies, vol. 6, no. 1, Sci. ser. no. 54, October 1936. 2873. Flow units in basalt: Jour. Geology, vol. 44, no. 5, pp. 617-630, 9 figs., July-August 1936; Tufts College Studies, vol. 6, no. 1, Sci. ser. 56, October 1936; abstract, Geol. Soc. America Proc., 1935, pp. 91-95, June 1936.

Nickle, Harry G. See Stevens, 3894.

Nickles, John Milton (editor).

2874. Annotated bibliography of economic geology for 1928, vol. 1, nos. 1-2, x, 380 pp., Nat. Research Council, Lancaster, Pa., Economic Geology Pub. Co., July 1929.

2875. Annotated bibliography of economic geology for 1929, vol. 2, no. 1, pp. vi, 1-208, Nat. Research Council, Lancaster, Pa., Economic Geology Pub. Co., January 1930; no. 2, pp. ix, 209-574, July 1930. 2876. Annotated bibliography of economic geology for 1930, vol. 3, no. 1, pp. ix, 1-248, Nat. Research Council, Lancaster, Pa., Economic Geology Pub. Co., January 1931; no. 2, pp. ix, 249-477, July 1931.

2877. Annotated bibliography of economic geology, for 1931, vol. 4, no. 1, pp. ix, 1-189, Nat. Research Council, Lancaster, Pa., Economic Geology Pub. Co., January 1932 ; no. 2, pp. viii, 191-390, July 1932.

2878. Annotated bibliography of economic geology for 1932, vol. 5, no. 1, pp. viii, 1-228, Nat., Research Council, Lancaster, Pa., Economic Geology Pub. Co., January 1933; no. 2, pp. viii, 229-431, July 1933.

2879. Annotated bibliography of economic geology for 1933, vol. 6, no. 1, pp. viii, 1-165, Nat. Research Council, Lancaster, Pa., Economic Geology Pub. Co., January 1934 ; no.. 2, pp. viii, 167-372, July 1934. 2880. Annotated bibliography of economic geology for 1934, vol. 7, no. 1, pp. viii, 1-191, National Research Council, Lancaster, Pa., Economic Geology Pub. Co., Januáry. 1935; no. 2, pp. viii, 193-382, July 1935. 
Nickles, John Milton (editor)-Con.

2881. Annotated bibliography of economic geology for 1935, vol. 8, no. 1, pp. viii, 1-243, National Research Council, Lancaster, Pa., Economic Geology Pub. Co., January 1936; no. 2, pp. viii, 245-429, July 1936.

Nietsen, Eiğil.

2882. The Permian and Eotriassic vertebrate-bearing beds at Godthaab Gulf (east Greenland) : Meddelelser om Grönland, Bank 98, Nr. 1, 111 pp., 1 pl. (geol. sketch map), 34 figs., 1935.

2883. Some few preliminary remarks on Triassic fishes from east Greenland: Meddelelser om Grönland, Band 112, Nr. 3, 55 pp., 19 figs., 1936.

Nielsen, Etlar L.

2884. A study of a pre-Kansan peat deposit: Torreya, vol. 35, no. 3, pp. 53-56, 6 figs., May-June 1935.

Nightingale, William Thomas.

2885. Geology of Baxter Basin gas fields, Sweetwater County, Wyo.: Geology of natural gas, pp. 323-340, 4 figs., Am. Assoc. Petroleum Geologists, [June] 1935.

2886. Geology of Hiawatha gas flelds, southwest Wyoming and northwest Colorado: Geology of natural gas, pp. 341-362, 5 figs., Am. Assoc. Petroleum Geologists, [June] 1935.

Nininger, Harvey Harlow.

2887. The Roy aërolite: Popular Astronomy, vol. 42, no. 10, pp. 599-600, December 1934.

2888. How to recognize meteorites: Mines. Mag., vol. 25, no. 1, p. 24, 5 figs., January 1935.

2889. The surface features of meteorites: Popular Astronomy, vol. 43, no. 2, pp. 121-126, February 1935; Soc. Research on Meteorites Contr., fasc. 1, pp. 5-9, abstract, pp. '26-27, January 1936.

2890. Proposed national institute of meteoritical research : Pan-Am. Geologist, vol. 64, no. 2, pp. 107-124, September 1935; abstract, Geol. Soc. America Proc., 1934, pp. 450-451, June 1935.

2891. Depth of meteorites and gradation of the Great Flains: Jour. Geology, vol. 44, no. 1, pp. 66-67, January-February 1936.

2892. The meteorite fall of August 10, 1932, near Archie, Cass County, Mo.: Popular Astronomy, vol. 44, no. 2, pp. 93-97, February 1936.

2893. Directions for the etching and preservation of metallic meteorites: Colorado Mus. Nat. History Proc., vol. 15, no. 1, 8 pp., 8 figs., Februäry 1, 1936.

2894. The Bruno meteorite [Saskatchewan]: Am. Jour. Sci., 5th ser., vol. 31, no. 183, pp. 209-222, 7 figs., March 1936.

2895. Terminology in meteorites: Popular Astronony, vol. 44, no. 4, pp. 194 203, April 1936; abstracts, vol. 43, no. 7, p. 4C4, August-September 1935; Soc. Research on Meteorites Contr., fasc. 1, p. 27, January 1936.

2896. The Pasamonte, N. Mex., meteorite: Popular Astronomy, vol. 44, no. 6, pp. 331-338, 5 figs., June-July 1936.

2897. Further studies in the surface features of meteorites: Am. Jour. Sci., . 5th ser., rol. 32, no. 187, pp. 1-20, 9 figs., July. 1936; abstract, Popular Astronomy, vol. 43, no. 7, p. 464, August-September 1935.

2898. Importance of meteorite collections: Mineralogist, vol. 4, no. 8, pp. 9-10, 27, August 1936. 
Noble, E. B.

2899 (and Kleinpell, W. D.). The geology of the Edison oil field [abstract] : Am. Assoc. Petroleum Geologists Bull., vol. 19, no. 1, pp. 134-135, January 1935.

Noe, Adolf Carl.

2900. Une forêt de l'époque carbonifère au Musée Field d'histoire naturelle à Chicago: La Nature, no. 2918, pp. 510-512, 6 figs., December 1, 1933.

2901. Some recent attempts to correlate the later Paleozoic of America and Europe: Illinois Acạd. Sci. Trans., vol. 28, no. 2, pp. 171-172, 1 fig., December 1935.

2902. Fossil palms: Field Mus. Nat. History Pub. 355, Bot. ser. vol. 14, pp. 439-456, April 30, 1936.

Noe-Nygaard, Arne. See also Bøggild, 360.

2903. En nyopdaget Ishule i $\emptyset$ st-Grønland: Geog. Tidssk. (K. Dansk. geog. Selsk.), Band 38, Hefte 3-4, pp. 181-186 (Danish-English summary, p. 186), 3 figs., September-December 1935.

Nolan, Thomas Brennan. See also Hewett, 1735; Singewald, 3727.

2904. Epithermal precious-metal deposits: Ore deposits of the Western States (Lindgren volume), pp. 623-640, Am. Inst. Min. Met. Eng., 1933.

2905. The Gold Hill mining district, Utah: U. S. Geol. Survey Prof. Paper 177, viii, 172 pp., 15 pls. (incl. geol. maps), 31 figs., 1935.

2906. Minor copper-producing districts in Nevada: Copper resources of the world, p. 325, Washington, 16th Internat. Geol. Cong., 1935.

2907. The underground geology of the Tonopah mining district, Ner. : Nevada Univ. Bull., vol. 29 , no. 5, 49 pp., 3 pls., 1 fig., September 1 , 1935.

2908. The Tuscarora mining district, Elko County, Nev. : Nevada Univ. Bull., rol. 30 , no. 1,38 pp., 2 pls. (incl. geol. sketch map), 3 figs. (incl. index map), March 1, 1936.

Noll, William Clarence. See Weaver, 4370.

Norburn, Martha Elizabeth.

2909. The influence of the physiographic features of North Carolina on the settlement and development of the region [abstract]: Elisha Mitchell Sci. Soc. Jour., vol. 47, no. 1, January 1932.

Noren, C. A.

2910. Fine chiastolite is found in California : Mineralogist, vol. 3, no. 1, pp. 34, 51, January 1935.

Norman, George William Hal. See also Canada G. S., 647; Mawdsley, 2617 ; Miller, 2698.

2911. Lake Ainslie map area, Nova Scotia: Canada Dept Mines, Geol. Survey Mem. 177, Pub. 2374, 103 pp., 3 figs., 6 pls. (incl. geol. map), 1935.

2912. Summary report on surveys in Waswanipi map orea, northern Quebec [1935] : Canada Dept. Mines, Geol. Survey Paper 36-3, 8 pp. ( ), 1 pl. (geol. map), January 1936.

2913. Opawica-Chibougamau map area, northern Quebec: Canada Dept. Mines, Geol. Survey Paper 36-6, 24 pp. ( $\$$ ), 1 pl. (geol. map), 1936.

2914. The northeast trend of late pre-Cambrian tectonic features in the Chibougamau district, Quebec: Royal Soc. Canada Trans., 3d ser., sec. 4, vol. 30, pp. 119-128, 2 figs. (index and geol. sketch maps), May 1936; abstract, Proc., p. xcix, 1936.

2915. Geology and mineral deposits of the Chibougamau-Waswanipi district, Quebec [with discussion]: Canadian Min. Met. Bull. 296, pp. 767-781, 6 figs. (incl. index and geol. map), December 1936. 
Northrop, Stuart Alvord.

2916. Hypsometric map of New Mexico [abstract]: Pan-Am. Geologist, rol. 64, no. 2, p. 151, September. 1935.

2917. Thulite in New Mexico: Ám. Mineralogist, vol, 20, no. 11, jp. 805-807, :November 1935.

2918. Analysis of thulite: Am. Mineralogist, vol. 21, no. 1, p. 73, January 1936.

2919. (and McGuinness, C. L.). Guidebook of minerals of Neiv Mexico [abstract]: Pan-Ain. Geologist, vol. 65, no. 5, pp. 379-380, June 1936.

Norton, William Harmon.

2920. Deep wells drilled in Iowa, 1928-32: Iowa Geol, Survey, Jol 36, pp. 312-364, 1935.

Notman, Arthur.

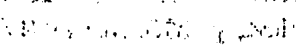

2921. Estimated world reserves of copper : Copper resources of the world, pp. 31-35, Washington, 16th Internat. Geol. Cong., 1935.

Nufer, D. C. See Floyd, 1293.

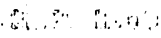

Nussbaum, Fritz.

2922. Erinnerungen an Professor W. M. Davis [1850-1934]: Der Schweizer Geograph, Bern, Jahr. 11, Heft 5, pp. 105-115, 1 fig., September 1934.

Nuttall, Winfred Laurence Falkiner.

2923. Eocene Foraminifera from Mexico: Jour. Paleontology, vol, , 4, no. . 3, pp. 271-293, 1 fig., 3 pls., September 1930.

2924. The application of micropaleontology to petroleum geology: World Petroleum Congress (London, 1933) Proc., vol. 1, pp. 270-273, 1 fig., 1934.

2925. Micropaléontologie appliquée aux parallélisations géologiques en Amérique: Cong. Internat. mines, mêt. géol. appliquée, sec. Géol. appliquée, $7^{\mathrm{e}}$ sess., tome 1 , pp. $413-418,1936$.

Nutting, Perley Gilman.

2926. Technical basis of bleaching-clay industry: Am. Assoc. Petroleum Geologists Bull., vol. 19, no: 7, pp. 1043-1052, July 1935.

Nygren, Walter Eric.

2927. An outline of the general geology and physiology of the Grand Valley district [Colorado] [abstract]: Colorado Univ. Studies, vol. 23, no. 1, p. 54, November 1935.

Oakeshott, Gordon B. See Clements, 775.

Oakley, Kenneth P.

2928. An Ordovician species of Chaetetes [Northwest Territories]: Geol. Mag., no. 868 (vol. 73, no. 10), pp. 440-444.1. pl., October 1936.

O'Bannon, P. H. See McCarter, 2495:

Obenshain, S. S.

2929. Soil classification in Virginia [abstract]: Virginia Acad. Sci. Proc., 1934-35, p. 71 [1935].

2930. A key to the soils of Halifax County, Va. [abstract]: Virginia Acad. Sci. Pros: 1925-36 n 701936 
C'Brien, Morrough Parker. See also Stevens, 3894.

2931. Notes on the transportation of silt by streams: Am. Geophys. Union Trans. 17th Ann. Meeting, pt. 2,.pp. 431-436 ( $\ddagger)$, Nat. Research Council, 1936.

2932. The coast of California as a beach-erosion laboratory: Shore and Beach, vol. 4, no. 3, pp. 74-79, 2 figs. (index maps), July 1936.

Ockerman, John William.

2933. Subsurface studies in northeastern Kansas: Kansas Univ. Bull. 20, 78 pp., 13 pls. (incl. maps), 4 figs. (incl. geol. maps), May 1, 1935.

O'Connell, Daniel T.

2934. Plesiosaur bones in Arizona [abstract]: Geol. Soc. America Proc., 1934, p. 376, June 1935.

2935. Rainbow Bridge, the largest natural bridge in the world: Mus. Northern Arizona.Mus. Notes, vol. 8, no. 6, pp. 29-32, 1 fig., December 1985.

Odell, N. E.

2936. The structure of the Franz Joseph region of northeast Greenland [abstract] : British Assoc. Adv. Sci. Rept. Ann. Meeting, 105th year, p. 378,1935 :

Oder, Charles Rollin Lorain.

2937. New types of Tennessee marble: Stone, rol. 55, no. 5, pp. 204-205, May 1934.

O'Donnell, Lawrence.

2938. Jefferson İsland salt dome, Iberia Parish, La.: Am. Assoc. Petroleum Geologists Bull., vol. 19, no. 11, pp. 1602-1644, 16 figs. (incl. maps), November 1935; reprinted in Gulf coast oil fields (see Barton and Sawtelle), pp. 983-1025, 1936.

Oehser, Paul $\mathbf{H}$.

2939. Homonyms and nomenclators: Am. Midland Naturalist, vol. 16, no. 6, pp. 962-964, November 1935.

Ogryzlo, Stephen Peter.

2940. Hydrothermal experiments with gold: Econ. Geology, vol. 30, no. 4, pp. 400-424, 4 figs., June-July 1935.

O'Harra, Cleophas Cisney, 1866-1935.

2941. A new South Dakota meteorite: Science, new ser., vol. 81 , no. 2090, p. 72, January 18, 1935.

Uklahoma City Geological Society.

2942. Appreciation of Dr. David White: Am. Assoc. Petroleum Geologists. Bull., vol. 19, no. 6, pp. 931-932, June 1935.

Oklahoma Geological Survey.

2943. Sylvan shale in Johns Valley : Am. Assoc. Petroleum Geologists Bull., vol. 19, no. 11, p. 1694, November 1935.

Okulitch, Vladimir $\mathbf{J}$.

2944. Tetradidae; a revision of the genus Tetradium: Royal Soc. Canada Trans., 3d ser., vol. 29, sec. 4, pp. 49-74, 2 pls., 4 figs., May 1935; abstract, Proc., 3d ser., vol. 29, p. c, 1935.

2945. Cyathospongia; a new class of Porifera to include the Archaeocyathinae: Royal Soc. Canada Trans., 3d ser., vol. 29, sec. 4, pp. 75106, 2 pls., 4 figs., May 1935: abstract, Proc., 3d ser., vol. 29, p. xсix, 1935. 
Okulitch, Vladimir J.-Continued.

2946. Fauna of the Black River Group in the vicinity of Montreal : Canadian Field Naturalist, vol. 49, no. 6, pp. 96-107, 2 pls. September 1935. 2947. Some Chazyan corals: Royal Soc. Canada Trans., 3d ser., sec. 4, vol. 30, pp. 59-73, 1 pl., 2 figs., May 1936; abstract, Proc., p. xcix-c, 1936.

2948. On the genera Heliolites, Tetradium, and Chaetetes: Am. Jour. Sci.. 5th ser., vol. 32, no. 191, pp. 361-379, 1 fig., Norember. 1936.

Olcott, Perry.

2949. Talco, a new oil field in northeastern Texas: Mining and Metallurgy, vol., 17, no. 359, pp. 519-520, 3 figs., November 1936.

Oliver, Elizabeth.

2950. A Miocene flora from the Blue Mountains, Oregon [with a section on Diatoms in the Mascall formation from Tipton and Austin, Oreg., by Kenneth Elmo Lohman]: Caruegie Inst. Washington Pub. 455, pp. 1-27, 5 pls., October 1936, preprint, November 22, 1934.

Olmsted, Elizabeth W. See Meyerhoff, 2688, 2689, 2692.

Olson, Everett Claire.

2951. The ilio-sacral attachment of Eryops: Jour. Paleontology, vol. 10, no. 7, pp. 648-651, 6 figs., October 1936.

Olsson, Axel Adolf.

2952. (and Caster, Kenneth E.). Occurrence of Baculites ovatus zone of upper Alberta shales in southeastern British Columbia: Am. Assoc. Petroleum Geologists Bull., vol. 19, no. 2, pp. 295-299, February 1935; abstract Geol. Soc. America Proc., 1934, pp. 363-364, July 1985.

O'Neill, John Johnston, See also Canada G. S., 655.

2953. Geology of the Beattie gold mine, Duparquet Township, Quebec: Canadian Inst. Min. Metallurgy Trans., vol. 37, pp. 299-315, 8 figs. (incl. geol. map) [1935].

2954. The Canadian Malartic gold mine: Quebec Bur. Mines Ann. Rept., 1934, pt. B, pp. 61-84, 6 pls. (incl. geol. map), 1935; also in French as Rapport annuel du Service des mines de Québec pour l'année 1934, partie B, La mine d'or Canadien Malartic comté d'Abitibi, pp. 69-95, 3 pls. (incl. geol. map), 1935.

O'Neill, J. Pat.

2955. Simple inverted metallographic microscope: Pan-Am. Geologist, vol. 64, no. 1. pp. 41-42, 1 pl., August 1.985; abstract, no. 2, p. 154, September 1935.

Ordoñez, Ezequiel.

2956. Principal physiographic provinces of Mexico: Am. Assoc. Petroleum Geologists Bull., vol. 20, no. 10, pp. 1277-1307, 1 fig. (index map), October 1936.

Orr, James M.

2957. Coal, Colorado's greatest asset: Engineers' Bull. (Colorado Soc. Eng.), vol. 19, no. 5, pp. 9-10, 28-29, May 1935.

Ortega, Gustavo.

2958. Campos petrolíferos mexicanos actualmente explotados y reglones donde se supone que pueda haber petróleo: Rev. industrial, tomo 1, no. 3, pp. 311-318, 1 pl. (table), September 1933.

Osborn, E. F. See Behre, 262.

811-37-14 
Osborn, Henry Fairfield, 1857-1935. 'See also Loomis, 2452.

2959. The ancestral tree of the Proboscidea, discovery, evolution, migration, and extinction over a 50,000,000-year period: Nat. Acad. Sci. Proc., vol. 21, no. 6, pp. 404-412, 5 figs. (incl. sketch map), June 15, 1935; abstract, Science, new ser., vol. 81, no. 2105, p. 423, May 3, 1935.

2960. Thomas Jefferson as a paleontologist: Science, new ser., vol. 82 , no. 2136, pp. 533-538, December 6, 1935.

2961. Proboscidea; a monograph of the discovery, evolution, migration, and extinction of the mastodonts and elephants of the world, vol. 1 , Moeritheroidea, Deinotherioidea, Mastodontoidea. Edited by Mabel Rice Percy, 802 pp., illus. New York, American Mus. Press, 1936.

Osborne, Freleigh . Fitz.

2962. Commercial granites of Quebec; part 3, North of St: Lawrence River (second section) : Quebec Bur. Mines Ann. Rept., 1933, pt. E., 59 pp., 5 figs. (incl. maps), 9 pls. (incl. geol. maps), 1934.

2963. Labelle-L'Annonciation map area [Quebec]: Quebec Bur. Mines Ann. Rept., 1934, pt. E, 52 pp., 9 pls. (incl. geol. map), 6 figs. (incl. geo!. maps), 1935; also in French ed., 1935.

2964. Rift, grain, and hardway in some pre-Cambrian granites, Quebec: Econ. Geology, vol. 30 , no. 5, pp. 540-551, 3 figs. (incl. sketch map), August 1935.

2965. Petrology of the Shawinigan Falls district [Quebec]: Geol. Soc. America Bull., vol. 47, no. 2, pp. 197-227, 6 pls. (incl. geol. map), 1 fig. (index map), February 29, 1936; abstract, Proc., 1935, p. 95, June 1936.

2966. (and Grimes-Graeme, R.). The breccia on St. Helen Island, Montreal: Am. Jour. Sci., 5th ser., vol. 32, no. 187, pp. 43-54, 2 figs. (incl. geol. sketch map), July 1936; abstract, Royal Soc. Canada Proc. 3d ser., vol. 29, sec. 4, pp. xcvii-xcviii, 1935.

2967. (and Lowther, G. Kenneth). Petrotectonics at Shawinigan Falls, Quebec: Geol. Soc. America Bull., vol. 47, no. 9, pp. 1343-1369, 4 pls., 2 figs. (incl. geol. map), September 30, 1936; abstract, Proc., 1935, p. 95, June 1936.

2968. The investigation of the cleavage of granites: Econ. Geology, vol. 31, no. 6, pp. 636-639, September-October 1936.

2969. Intrusives of part of the Laurentian complex in Quebec: Am. Jour. Sci., 5th ser., vol. 32, no. 192, pp. 407-434, 3 figs. (incl. index map), December 1.936.

Osvald, Hugo.

2970. A bog at Hartford, Mich. : Ecology, vol. 16, no. 3, pp. 520-528, 4 figs., July 1, 1935.

Oswald, J.

2971. Meteoritic glasses-tectites: Mineralogist,, vol. 4, no. 6, pp. 5-6, June 1936.

Over, Edwin, Jr.

2972. Further explorations on Mount Antero, Colo.: Rocks and Minerals, vol. 10, no. 2, pp. 27-29, 2 figs., February 1935.

Overman, V. K.

2973. Collecting in the Black Hills: Rocks and Minerals, vol, 10, no. 10, pp. 145-148, 4. figs., October 1935. 
Owen, J. E. See Born, 377.

Owen, John Britts. See Miller, 2707.

Owen, R. M. S. See Calder, 625.

Owens, Frith C.

2974. (and Calohan, William F.). Claiborne possibilities of the Laredo area [abstract] : Am. Assoc. Petroleum Geologists Bull., vol. 19, no. 1, p. 140, January 1935 .

Pabst, Adolph.

2975. Measurement of flow structures [abstract] : Geol. Soc. America Proc., 1934, p. 328, June 1935.

2976. Vesuvianite from Georgetown, Calif.: Am. Mineralogist, vol. 21, no. 1, pp. 1-10, January 1936.

2977. Orientation of minerals in "autoliths": Am. Mineralogist, vol. 21, no. 1, p. 68, January 1936.

2978. The development of crystallography: Mineralogist, vol. 4, no. 1, pp. 3-4, 54-59, 19 figs., January 1936; no. 2, pp. 7-8, 22-25, February 1936.

Packard, Earl Leroy.

2979. Additional cetacean material from Astoria formation: Mineralogist, vol. 3, no. 6, pp. 9-10, 1 fig., June 1935.

2980. Marine Oligocene in northwestern Oregon: Geol. Soc. Oregon Country News Letter, vol. 1 , no. 6 , pp. $41,43(\ddagger)$, June 28,1935 ; no. 7, pp. 46, 47 (\$), July 5, 1935.

Page, Ben M.

2981. Basin-range faulting of 1915 in Pleasant Valley, Nev.: Jour. Geology, vol. 43 , no. 7 , pp. $690-707,13$ figs. (incl. sketch maps), OctoberNovember 1935; abstract, Geol. Soc. America Proc., 1934, pp. 316317, June 1935.

Paige, Sidney. See also Spencer, 3803.

2982. Santa Rita and Tyrone, N. Mex.: Copper resources of the world, pp. 327-335, 2 pls. (geol. maps), Washington, 16th Internat. Geol. Cong., 1935.

2983. Effect of a sea-level canal on the ground-water level of Florida: Econ. Geology, vol. 31, no. 6, pp. 537-570, 14 figs. (incl. index and geol. maps), September-October 1936.

Palache, Charles. See also Newhouse, 2863.

2984. The form relations of the lead oxychlorides laurionite, paralaurionite, and fiedlerite: Mineralog. Mag., vol. 23, no. 146, pp. 573-586, 22 figs., September 1934 .

2985. The minerals of Franklin and Sterling Hill, Sussex County, N. J.: U. S. Geol. Survey Prof. Paper 180, pp. vi, 135, 20 pls. (incl. geol. map), 199 figs., 1935.

2986. Victor Goldschmidt (1853-1933) : Am. Acad. Arts and Sci.. Proc., vol. 69, no. 13, pp. 509-510, February 1935.

2987. Lindgrenite, a new mineral: Am. Mineralogist, vol. 20 , no. 7, pp. 484 491, 6 figs., July 1935 ; abstract, no. 3, p. 187, March 1935.

2988. Additional notes on pseudobrookite: Am. Mineralogist, vol. 20, no. 9, pp. 660-663, 3 figs., September 1935.

2989. Edward Salisbury Dana (1849-1935): Am. Acad. Arts and Sci. Proc., vol. 70, no. 10, pp. 517-518, March 1936. 
Palache, Charles-Continued.

2990. Babingtonite and epidote from Westfield, Mass.: Am. Mineralogist, vol. 21, no. 10, pp. 652-655, 1 fig., October 1936, abstract, no. 3, p. 193, March 1936.

Palmer, Dorothy Bryant Kemper.

2991. (and Bermúdez, Pedro J.) Late Tertiary Foraminifera from the Matanzas Bay region, Cubá: Soc. cubana hist. nat. Mem., vol. 9, no. 4, pp. 237-258, 3 pls., January 1936.

Palmer, Harold Schjöth.

2992. The heights and ruggedness of the Hawaiian Islands and the fortyeight States: Hawaii Univ. Occasional Papers no. 23, 10 pp., January 1935.

2993. (and Powers, Howard Adorno). Pits in coastal pahoehoe lavas controlled by gas bubbles: Jour. Geology, vol. 43, no. 6, pp. 639-643, 6 figs., August--September 1935.

Palmer, Katherine Evangeline Hilton Van Winkle.

2994. [Review of] Timothy Abbott Conrad, with particular reference to his work in Alabama one hundred years ago, by Harry Edgar Wheeler, 1935: Am. Assoc. Petroleum Geologists Bull., vol. 20, no. 3, pp. 321-322, March 1936.

Palmer, Robert Hastings.

2995. (and Hertlein, Leo George). Marine Pleistocene mollusks from Oaxaca, Mexico: Southern California Acad. Sci. Bull., vol. 35, pt. 2, pp. 65-81, 1 pl., 1 fig., May-August 1936.

Palmer, Walter Stanley.

2996. Gold in petrified wood: Rocks and Minerals, vol. 10, no. 7, pp. 102103, July 1935; abstract, Year Book sec., pp. 60-61, January 1936.

2997. Gold in petrified wood: Mining and Metallurgy, vol. 16, no. 344, p. 335, August 1935.

2998. Beryl and scheelite associated together: Rocks and Minerals, vol. 10, no. 9, p. 137, September 1935.

Panhandle Geological Society.

2999. History of development and general geology of the Panhandle field of Texas [abstract] : Drilling and Production Practice, 1935, p. 274, Am. Petroleum Inst., 1936.

Parades, Trinidad.

3000. El petróleo en los límites de los Estados de Oaxaca, Puebla y Guerrero: Rev. industrial, tomo 4, no. 4, pp. 311-313, April 1935.

Parat, Maurice.

3001. Sur l'Oxfordien et le Kimmeridgien de Milne Land (Groënland oriental) : Acad. sci. Paris Comptes rendus, tome 202, no. 26, pp. 21672169, June 29, 1936 .

Pardee, Joseph Thomas.

3002. Deposits of gold, copper, quicksilver, and associated metals in western Oregon: U. S. Dept. Interior Press Mem. 45355, 14 pp. (\$), 1 pl. (index map), August 7, 1930.

3003. Copper in Washington: Copper resources of the world, pp. 371-373, Washington, 16th Internat. Geol. Cong., 1985.

3004. Preliminary report on gold deposits in North and South Carolina: U. S. Dept. Interior Press Mem. P. W. 29021, 43 pp. ( $\$)$, map, March 18, 1935. 
Pardee, Joseph Thomas-Continued.

3005. Phosphate rock near Maxville, Philipsburg, and Avon, Montana: U. S. Geol. Survey Bull. 847-D, pp. 175-188, 7 pls. (incl. geol. maps), 1 fig. (index map), 1936.

Park, Charles Frederick, Jr. See also Piper, 3088.

3006. Copper in the Tintic district, Utah: Copper resources of the world, pp. 361-367, 2 figs., Washington, 16th Internat. Geol. Cong., 1935.

3007. Hog Mountain gold district, Ala.: Am. Inst. Min. Met. Eng. Tech. Pub. 598, 19 pp., 8 figs., 1935; with discussion, Trans., vol. 115 (Mining geology), pp. 209-228, 1935 ; abstracts, Year Book sec., p. 60, January 1936; Mining and Metallurgy, vol. 16, no. 338, p. 115, February 1935.

3008. Notes on the structure of the Erin shale of Alabama: Washington Acad. Sci. Jour., vol. 25, no. 6, pp. 276-279, 1 fig. (geol. sketch map), June 15, 1935.

3009. Preliminary report on gold deposits of the Virginia Piedmont: Virginia Geol. Survey Bull. 44, viii, 42 pp., 9 pls. (incl. geol. map), 14 figs. (incl, index map), 1936.

3010. (and Wilson, Roy Arthur). The Battle Branch gold mine, Auraria, Ga.: Econ. Geology, vol. 31, no. 1, pp. 73-92, 8 figs. (incl. sketch maps), January-February 1936; abstract, Washington Acad. Sci. Jour., vol. 25, no. 12, pp. 569-570, December 15, 1935.

Parker, Ben Hutchinson. See also Van Tuyl, 4266, 4267, 4271.

3011. The application of geology to ore finding: Mines Mag., vol. 25, no. 3, pp. 9-10, 14 March 1935.

Parker, Frances L. See Cushman, 942.

Parker, Frank S.

3012. The Richey-Lambert coal field, Richland and Dawson Counties, Montana: U. S. Geol. Survey Bull. 847-C, pp. iv, 121-174, 6 pls. (incl. geol. map), 23 figs. (incl. index and geol. maps), 1936.

Parks, William Arthur.

3013. New species of trachodont dinosaurs from the Cretaceous formations of Alberta, with notes on other species: Toronto Univ. Studies, Geol. ser. 37, 45 pp., 11 figs., 8 pls., 1935.

3014. Systematic position of the Stromatoporoidea: Jour. Paleontology, vol. 9, no. 1; pp. 18-29, 2 pls., January 1935.

3015. Devonian stromatoporoids of North America, pt. 1: Toronto Univ. Studies, Geol. ser. 39, 125 pp., 19 pls., 1936.

Parmelee, Cullen Warner.

3016. (and McVay, Thomas Newkirk). An investigation of the properties of some feldspars; a report of an investigation conducted by the Engineering Experiment Station, University of Illinois, in cooperation with the Consolidated Feldspar Corporation: Illinois Univ. Bull., vol. 29, no. 9 (Eng. Exper. Sta. 233), 48 pp., 4 pls., 16 figs., September 29, 1931.

3017. Clays and some other ceramic materials, iii, 120 pp. ( $\ddagger$ ), 46 figs. (iucl. geol. sketch maps), Ann Arbor, Mich., Edwards Brothers, Inc., 1935.

Parsons, Arthur Barrette.

3018. Gold in the Land of Cotton: Mining and Metallurgy, vol. 16, no. 342, pp. 251-255, 260, 5 figs. (incl. sketch map), June 1935; abstract, Year Book sec., p. 21, January 1936. 
Parsons, Arthur Leonard.

3019. The utilization of the semiprecious and ornamental stones of Canada: Toronto Univ. Studies, Geol. ser. 36, pp. 13-21, 1 pl., 1934.

3020. An unusual calcite crystal from Godfrey, Ontario: Toronto Univ. Studies, Geol. ser. 36, pp. 23-24, 1 pl. (part), 1934.

3021. Trisoctahedral garnet from West Thetford mines, P. Q. : Toronto Univ. Studies, Geol. ser. 38, pp. 33-36, 1935.

Pask, Joseph A. See Wilson, 4539.

Patnode, Homer Whitman. See Trask, 4157.

Patterson, Bryan.

3022. Second contribution to the osteology and affinities of the Paleocene amblypod Titanoides: Am. Philos. Soc. Proc., vol. 75, no. 2, pp. 143-162, 7 figs., June 1935; abstract, Geol. Soc. America Proc., 1934, pp. 379-380, June 1935 .

3023. Mounted skeleton of Titanoides, with notes on the associated fauna [abstract] : Geol. Soc. America Proc., 1935, pp. 397-39S, June 1936.

Patton, John F.

3024. The shoestring oil sands: Mines Mag., vol. 25, no. 12, pp. 17-23, 12 figs. (incl. sketch map), December 1935; abstract, World Petroleum, vol. 7 , no. 6, p. 331, June 1936.

Patton, J. W.

3025. The Mint Canyon agate beds in California: Rocks and Minerals, voI. 11, no. 9, pp. 156-159, 3 figs., September-October 1936.

Patton, Leroy Thompson.

3026. Earth science and military education : Military Engineer, vol. 27, no. 152, pp. 87-89, March-April 1935.

3027. Some observations on the so-called "lakes" of the Llano Estacado of Texas [abstract] : Geol. Soc. America Proc., 1934, p. 451, June 1935.

3028. Natural glasses of the insoluble residues of the Pennsylvanian limestones of Texas: Science, new ser., vol. 83, no. 2143, pp. 83-84, January 24, 1936.

Patton, Raymond Stanton.

3029. Recent progress in air photosurveying and its application to Pacific mapping problems: Fifth Pacific Sci. Cong., Canada, 1933, Proc., vol. 2, pp. 1191-1195, 1934.

Pauling, Linus.

3030. (and Klug, Harold Philip, and Winchell, Alexander Newton). The crystal structure of swedenborgite, $\mathrm{NaBe}_{4} \mathrm{SbO}_{7}$ : Am. Mineralogist, vol. 20, no. 7, pp. 492-501, 5 figs., July 1.935.

Peacock, Martin Alfred. See also Dunham, 1096.

3031. On pectolite: Zeitschr. Kristallographie, Band 90, Heft 2, pp. 97-111, 13 figs., February 1935.

3032. On johannite from Joachimsthal and Colorado: Zeitschr. Kristallographie, Band 90, Heft 2, pp. 112-119, February 1935.

3033. Choice of crystallographic elements [abstract]: Am. Mineralogist, vol. 20, no. 3, p. 212, March 1935; abstract, Geol. Soc. America Proc., 1934, pp. 433-434, June 1935.

3034. Topaz from Devil's Head, Colo. : Am. Mineralogist, vol. 20, no. 5, pp. 354-363, 12 figs., May 1935; abstracts, no. 3, p. 196, March 1935; Geol. Soc. America Proc., 1934, p. 419, June 1935. 
Peacock, Martin Alfred-Continued.

3035. Fiord-land of British Columbia: Geol. Soc. America Bull., vol. 46, no. 4, pp. 683-696, 2 pls. (maps), April 30, 1935; abstracts, Proc., 1934, p. 1.01, June 1935; Fifth Pacific Sci. Cong., Canada, 1933, Proc., vol. 1 , pp. $719-720,1934$.

3036. On wollastonite and parawollastonite: Am. Jour. Sci., 5th ser., vol. 30, no. 180, pp. 495-529, 17 figs., December 1935.

3037. (and Yatsevitch, Gratian Michael). Cubanite from Sudbury, Ontario: Am. Mineralogist, vol. 21, no. 1, pp. 55-62, 5 figs., January 1, 1936.

3038. Cyclic permutation of crystallographic axes: Am. Mineralogist, vol. 21, no. 2, pp. 136-137, February 1936.

3039. On roselite and the rule of highest pseudosymmetry: Am. Mineralogist, rol. 21, no. 9, pp. 589-603, 9 figs., September 1936 ; abstract, no. 3, p. 202, March 1936.

Peck, Albert Becker. See Slawson, 3739.

Peck, Raymond Elliot.

3040. The North American trochiliscids, Paleozoic Charophyta: Jour. Paleontology, vol. 8, no. 2, pp. 83-119, 5 pls., June 1934.

3041. Growth stages of Allagecrinus americamis Rowley: Jour. Geology, vol. 43, no. 7, pp. 765-770, 11 figs., October-November 1935.

3042. Lower: Mississippian microcrinoids of the Kinderhook and Osage groups of Missouri: Jour. Paleontology, vol. 10, no. 4, pp. 282-293, 2 pls., June 1936.

3043. Structural trends of the Trochiliscaceae: Jour. Palentology, vol. 10, no. 8, pp. 764-768, 8 figs., December 1936; abstracts, Pan-Am. Geologist, vol. 65, no. 3, p. 234, April 1936; Geol. Soc. America Proc., 1935, p. 440-441, June 1935 .

Pegau, Arthur August.

3044. The age of the Virginia pegmatites [abstract]: Virginia Acad. Sci. Proc., 1934-35, p. 62 [1935].

3045. Minerals occurring in the Virginia diabases [abstract]: Virginia Acad. Sci. Proc., 1935-36, p. 69, 1936.

Pelloux, Alberto.

3046. Henry Stephens Washington [1867-1934]: Soc. geol. italiana Boll., vol. 53, fasc. 2, pp. ciii-cvii, 1935.

3047. Henry Stephens Washington [1867-1934] : Bull. volcanologique, $8^{\circ}$ année, nos. 1-4, pp. 151-158, 1 pl. (port.), August 1936.

Pendleton, Thomas P.

3048. Preparing new maps of the Tennessee River Basin: Eing. News-Record, vol. 114, no. 7, pp. 243-244, February 14, 1935.

3049. Planimetric maps of the Tennessee Valley: Military Engineer, vol. 27. no. 155, pp. 371-375, 4 figs., September-October 1935

Pentz, H. H. See Ewing, 1199.

Peoples, James A., Jr. See Ewing, 1.197.

Peoples, Joe Webb. See also Ewing, 1197; Howland, 1869.

3050. Gravity stratification as a criterion in the interpretation of the structure of the Stillwater complex, Montana : 16th Internat. Geol. Cong. (1933) Rept., vol. 1, pp. 353-360, 2 pls., 3 figs. (incl. geol. sketch map and index map), 1936.

Percy, Mabel Rice. See Osborn, 2951. 
Perkins, Edward Henry, 1886-1936. See also Leavitt, 2364; White, 4458.

3051. The official map of Maine; glacial deposits, State of Maine, scale 1: 400,000 , or 20 miles to $2 \%$ inches, [1935] : Issued as Supplement to Maine Tech. Exper. Sta. Bull. 30, vol. 2 (1934), [1935].

3052. Summary of the Pleistocene history of Maine [abstract]: Geol. Soc. America Proc., 1934, p. 372, June 1935.

3053: The 31st annual New England intercollegiate geological excursion: Science, new ser., vol. 82, no. 2133 , p. 456, November $15,1935$.

3054. Memorial of Wilbur Garland Foye [1886-1935]: Geol. Soc. America Proc., 1935, pp. 249-254, 1 pl. (port.), June 1936.

Perret, Frank Alvord.

3055. The eruption of Mont Pelée, 1929-32: Carnegie Inst. Washington Pub. 458, 126 pp., 2 pls. (incl. front.), 72 figs., 1935.

Perrine, Irving.

3056. Responsibility of geologist in sale of oil and gas securities under new Securities Act: Am. Assoc. Petroleum Geologists Bull., rol. 19, no. 7, pp. 1038-1042, July 1935.

Perry, Elwyn Lionel.

3057. Flaws and tear faults: Am. Jour. Sci., 5th ser., vol. 29 , nu. 170, pp. 112-124, 2 figs., February 1935.

Perry, Eugene Sheridan. See also Hart, 1647.

3058. Geology and artesian-water resources along Missouri and Milk Rivers in northeastern Montana: Montana Bur. Mines and Geology Mem. 11, 34 pp. (\$), 15 figs. (incl. maps), 1 pl. (geol. map), December 1934.

3059. Geology and ground-water resources of southeastern Montana: Montana Bur. Mines and Geology Mem. 14, 67 pp. (莐), 3 pls. (incl. geol. maps), 27 figs. (incl. geol. maps), December 1935.

3060. High lights on geology of Montana: Glück Auf, vol. 2, no. 2, pp. 6-7, 6 figs. (incl. index map), Butte, Mont., December 1936.

Perry, V. D.

3061. Copper deposits of the Cananea district, Sonora, Mexico: Copper resources of the world, pp. 413-418, Washington, 16th Internat. Geol. Cong., 1935.

Peters, F. H.

3062. Aerial surveying in Canada: Fifth Pacific Sci. Cong., Canada, 1933, Proc., vol. 2, pp. 1213-1220, 1934.

Peterson, R. A. 。

3063. Instrument for rapid measurements of gravity [abstract]: Pan-Am. Geologist, vol. 63, no. 4, p. 318, May 1935; Geol. Soc. America Proc., 1935, p. 340, June 1936.

Petsch, Bruno C. See Rothrock, 3380.

Pettigrew, Virgil. See Kay, 2035.

Pettijohn, Francis John.

3064. The mineralogy of the sedimentary rocks: Nat. Research Council Bull. 98, pp. 162-171, July 1935.

3065. Stratigraphy and structure of Vermilion Township, District of Kenora, Ontario: Geol. Soc. America Bull., vol. 46, no. 12, pp. 1891-1908, 3 pls. (incl. geol. map), 1 fig. (geol. map), December 31, 1935. 
Pettijohn, Francis John-Continued.

3066. Early pre-Cambrian varved slate in northwestern Ontario: Geol. Soc. America Bull., vol. 47, no. 4, pp. 621-628, 1 pl., 2 figs. (incl. index map), April 30, 1936.

3067. Geology of East Bay, Minnitaki Lake, district of Kenora, Ontario: Jour Geology, vol. 44, no. 3, pp. 341-357, 1 pl. (geol. sketch map), 1 fig. (geol. map), April-May 1936.

3068. Determination and calculation of sphericity ralues of pebbles: Jour. Sedimentary Petrology, vol. 6, no. 3, pp. 154-157, 1 fig., December 1936.

Petty, Julian Jay.

3069. The origin and occurrence of fulgurites in the Atlantic Coastal Plain: Am. Jour. Sci., 5th ser., vol. 31, no. 183, pp. 188-201, 6 figs., March 1936 ; abstracts, Am. Mineralogist, vol. 20, no. 3; p. 207, March 1935 ; Geol. Soc. America Proc., 1934, p. 428, June 1935.

Pew, J. Edgar.

3070. (and others). Petroleum production and supply: Am. Assoc. Petroleum Geologists Bull., vol. 20, no. 1, pp. 1-14, 1 fig., January 1936.

Philbrick, Shailer S.

3071. The geology of the Appalachian Trail in Maine: Guide to the Appalachian Trail in Maine, pp. 197-215, Washington, D. C., The Appalachian Trail Conference, 1936.

3072. The contact metamorphism of the Onawa pluton, Piscataquis County, Maine: Am. Jour. Sci., 5th ser., vol. 31, no. 181, pp. 1-40, 11 figs. (incl. geol. map), January 1936.

Phillips, Alexander Hamilton, 1866-1937.

3073. (and Hess, Harry Hammond). Chemical composition and optical properties of some calcic plagioclases [abstract]: Am. Mineralogist, vol. 21, no. 3, p. 194, March 1936.

3074. (and Hess, Harry Hammond). Metamorphic differentiation at contacts between serpeutinite and siliceous country rocks: Am. Mineralogist, vol. 21, no. 6, pp. 333-362, 10 figs. (incl. index map), June 1936; abstracts, vol. 20, no. 3, p. 201, March 1935; Geol. Soc. America Proc., 1934, pp. 425-426, June 1935.

Phillips, Drury McNeill.

3075. (and Phillips, L. V.). Production and utilization of Texas bleaching clays: Texas Univ. Bull. 3501, January 1, 1935, pp. 105-112, February 1936.

Phillips, Kenneth N.

3076. (and Collins, J. Russell). Fumaroles on Mount Hood: Mazama, vol. 17, no. 12 , pp. 19-21, 2 figs., December 1.935.

3077. Recent changes in Hood's glaciers: Mazama, vol. 17 , no. 12 , pp. 45-50, 8 figs., December 1935 .

Phillips, L. V. See Phillips, D. M., 3075.

Phleger, Fred B., Jr.

3078. Method of paleontological description [abstract]: Geol. Soc. America Proc., 1935, p. 384, June 1936.

3079. An Ordovician auluroid from California: Southern California Acad. Sci. Bull., vol. 35, pt. 2, pp. 82-83, 2 figs., May-August 1936.

3080. Lichadian trilobites: Jour. Paleontology, vol. 10, no. 7, pp. 593-615, 83 figs., October 1936. 
I'ierce, William Gamewell. See also Anonymous, 4665; Dane, 972.

3081. (and Courtier, William Henry). Englevale channel sandstone of Pennsylvanian age, southeastern Kansas: Am. Assoc. Petroleum Geologists Bull., vol. 19, no. 7, pp. 1061-1068, 3 figs. (incl. geol. map), July 1935.

3082. Contour map of the base of the Cherokee shale in the zinc-lead district of southeastern Kansas: U. S. Dept. Interior Press Mem. 103188, 4 pp. ( ), 1 pl. (geol. map), July 19, 1935.

3083. Some significant features of the Mississippian-Pennsylvanian contact in the Tri-State district [abstract] : Washington Acad. Sci. Jour., vol. 25, no. 12, pp. 572-573, December 15, 1935.

3084. The Rosebud coal field, Rosebud and Custer Counties, Mont.: U. S. Geol. Survey Bull. 847-B, pp. $43-120,17$ pls. (incl. geol. map), 26 figs. (incl. index and structure maps), 1936.

Piggot, Charles Snowden. See Anonymous, 4716.

3085. Apparatus to secure core samples from the ocean bottom: Geol. Soc. America Bull., vol. 47, no. 5, pp. 675-684, 3 pls., 1 fig., May 31, 1936 ; Carnegie Inst. Washington, Geophys. Laboratory Paper 902, 1936.

Pilsbry, Henry Augustus.

3086. Mollusks of the fresh-water Pliocene beds of the Kettleman Hills and neighborìng oil fields, California: Acad. Nat. Sci. Philadelphia Proc., 1984, vol. 86, pp. 541-570, 2 figs., 1935.

Pinkley, George R.

3087. Numerous types of structures, multiple sands, and deep producing possibilities outstanding features of south 'Texas geology: Oil Weekly, vol. 83 , no. 3 , pp. 51-53, 56, 58, 60, 8 figs., September $28,1936$.

Piper, Arthur Maine.

3088. (and Robinson, Thomas William, Jr., and Park, Charles Frederick, Jr.). Geology and ground-water resources of the Harney Basin, Oreg.: U. S. Dept. Interior Press Mem. 102557, 5 pp. ( $\ddagger)$, June 1935.

3089. Hydrologic and hydrographic investigations that bear on sedimentation, 1932-33: Nat. Research Council Bull. 98, pp. 172-194, July 1935.

3090. Résumé of the geologic history of the Harney Basin, Oregon: Geol. Soc. Oregon Country News Letter, vol. 2, no. 8, pp. 9-12 (\$), April 25, 1936.

Pirson, Sylvain Joseph.

3091. Interpretation of three-layer resistivity curres: Am. Inst. Min. Met. Eng. Trans., vol. 110, Geophysical Prospecting, pp. 148-158, 6 figs., 1934.

3092. La méthode de prospection séïsmique par réflexion: Soc. belge ing. et industriels, no. 4, 40 pp., 21 figs., année 1935.

3093. Effect of anisotrophy on apparent resistivity curres: Am. Assoc. Petroleum Geologists Bull., vol. 19, no. 1, pp. 37-57, 7 figs., January 1935; abstract, Mines May., vol. 26, no. 12, p. 27, 1936.

3094. Polar charts for interpreting magnetic anomalies: Am. Inst. Min. Met. Eng. Contr. 91, 13 pp., 11 figs., Norember 1935.

Pittelkow, Joh.

3095. Die eiszeitliche Trockengrenze Nordamerikas: Geog. Zeitschr., Jahrg. 42, Heft 6, pp. 201-212, 1 fig. (sketch map), Leipzig, 1936.

Ploger, Louis W.

3096. Memorial of Thomas. Cramer Hopkins [1861-1935]: Geol. Sor: America Proc., 1935, pp. 255-261, 1 pl. (port.), June 1936. 
Plummer, F. M.

3097. The geology of the Chittim anticline, Maverick County, Tex. [abstract] : Anf. Assoc. Petroleum Geologists Bull., vol. 20, no. 11, p. 1513, November 1936.

Plummer, Frederick Byron.

3098. (and Hornberger, Joseph, Jr.). Geology of Palo Pinto County, Tex.: Texas Univ. Bull. 3534, September 8, 1935, 240 pp., 7 pls. (incl. geol. map), 28 figs. (incl. index map), 1936.

Plummer, Helen Jeanne.

3099. Microscopical evidence of the Navarro-Taylor contact in subsurface sections in central Texas: Texas Univ. Bull. 3501, January 1, 1935, pp. 281-292, 1 pl., 2 figs., February 1936.

3100. Structure of Ceratobulimina: Am. Midland Naturalits, vol. 17, no. 2, pp. 460-463, 10 figs., March 1936.

3101. [Review of] Geology of the Tampico region, by John Muir, 1936: Jour. Paleontology, vol. 10, no. 4, p. 324, June 1936.

Pohl, Erwin Robert. See also Giles, 1422.

3102. Development of vertical shafts in limestone caves [abstract]: Geol. Soc. America Proc., 1935, p. 96, June 1936.

3103. (and Born, Kendall Eugene). Development of gypsum in limestone caves [abstract] : Geol. Soc. America Proc., 1935, p. 96, June 1936.

Poindexter, O. Floyd.

3104. A study of underground waters bearing on the source of "Big Spring", Schoolcraft County, Mich.: Michigan Acad. Sci. Papers, vol. 20, pp. 477-483, 1 pl., 1935.

3105. Sink holes in the Indian Lake region, Schoolcraft County, and other Michigan sinks: Michigan Acad. Sci. Papers, vol. 21, 1935, pp. 439444, 3 pls., 3: figs. (incl. index maps), 1936.

Ponton, Gerald Mungo. See Mansfield, 2571.

Poor, Russell Spurgeon.

3106. Some mineralogical data on the dust storm of November 13,1933 , at Birmingham, Ala.: Am. Meteorol. Soc. Bull., vol. 15, no. 8-9, pp. 194198, August-September 1.934.

3107. The geological making of Alabama: Rocks and Minerals, vol. 10, no. 5, pp. 65-67, May 1935 .

Popenoe, Willis Parkison. See Gardner, 1382.

Posnjak, Eugen. See Greig, 1536, 1537.

Post, Earl s.

3108. [Map of the] South Texas district, showing oil and gas fields and prospects, pipe lines, refineries, railroads, and highways. Scale $1: 950,000$, or 1 inch to 15 miles. Supplement to Oil Weekly, vol. 83, no. 3, September 28, 1936.

Postley, Olive Clara.

3109. Natural-gas developments and possibilities east of the main oil and gas field of Appalachian region: Am. Assoc. Petroleum Geologists Bull., vol. 19, no. 6, pp. 853-875, 3 figs. (maps), June 1935.

Potbury, Susan Stevens.

3110. La Porte flora of Plumas County [Calif.] [abstract] : Pan-Am. Geologist, vol. 63, no. 5, pp. 378-379, June 1935; Geol. Soc. America Proc., 1935, p. 416, June 1936.

Poteat, William Louis. See Prouty, 3143. 
Pough, Frederick Harvey.

3111. The morphology of phenacite from two new occurrences: Am. Mineralogist, vol. 20 , no. 12 , pp. 863-874, 8 figs., December 1935 ; abstracts, no. 3, p. 198, March 1935; Geol. Soc. America Proc., 1934, p. 422, June 1935.

3112. Bertrandite and epistilbite from Bedford, N. Y.: Am. Mineralogist, vol. 21, no. 4, pp. 264-265, April 1936.

3113. Phenakit, seine Morphologie und Paragenesis: Neues Jahrb., BeilageBand 71, Heft 2, pp. 291-341, 8 pls., 10 figs., June 19, 1936.

Poulsen, Christian. See Boggild, 360.

Powell, Louis Harrey.

3114. A study of the Ozarkian faunas of southeastern Minnesota: St. Paul Inst. Sci. Museum Bull. 1, 80 pp., 4 figs., 17 pls., 1935.

Powell, Ralph Sterling. See Kay, 2035.

Powers, Elliot H. See also Kansas Geol. Soc., 2020.

3115. Isopach map of the Prairie du Chien group [upper Mississippi Valley] : Kansas Geol. Soc. Guidebook 9th Ann. Field Conf., p. 350 ( $\$), 1$ pl. (isopach map), 1935.

3116. Stratigraphy of the Prairie du Chien [upper Mississippi Valley] : Kansas Geol. Soc. Guidebook 9th Ann. Field Conf., pp. 390-394, ( $), 2$ figs. (geol. and isopach maps), 1935.

3117. The Prairie du Chien problem: Iowa Univ. Studies in Nat. History, vol. 16, no. 6 (new ser. 298 ), pp. $419-450,3$ pls., 1 fig. (map), May 1 , 1935 ; abstract, Geol. Soc. America Proc., 1934, pp. 101-102, June 1935.

Powers, Howard Adorno. See also Palmer, 2993.

3118. Differentiation of Hawaiian lavas: Am. Jour. Sci., 5th ser., vol. 30, no. 175, pp. 57-71, July 1935.

Powers, William Edwards. See also Stark, 3834, 3836.

3119. Physiographic history of the upper Arkansas River valley and the Royal Gorge, Colo.: Jour. Geology, vol. 43, no. 2, pp. 184-199, 13 figs. (incl. sketch maps), February-March 1935.

3120. (and Henderson, C. F., and Behre, Charles Henry, Jr.). Physiographic surfaces in South Park, Colo. [abstract] : Geol. Soc. America Proc., 1934, p. 102, June 1935.

3121. Geological setting of the Aurora mastodon remains : Illinois Acad. Sci. Trans., vol. 28 , no. 2, pp. 193-194, December 1935.

3122. The evidences of wind abrasion: Jour. Geology, vol. 44, no. 2, pt. 1, pp. 214-219, 3 figs., February-March 1936.

3123. (and Behre, Charles Henry, Jr.). The origin of South Park, Colo. [abstract]: Assoc. Am. Geographers Annals, vol. 26, no. 1, pp. 73-74, March 1936.

3124. (and Behre, Charles Henry, Jr.) Physiographic history of South Park, Colo. [abstract] : Pan-Am. Geologist, vol. 65, no. 3, pp. 238239, April 1936.

Pratt, Allyne F.

3125. Geology of the Skamania mining district: Geol. Soc. Oregon Country News Letter, vol. 1, no. 11, pp. 6-7, 1 fig., Angust 19, 1935.

Pratt, Joseph Hyde.

3126. Mineralogical notes on North Carolina minerals [abstract]: Elisha Mitchell Sci. Soc. Jour., vol. 49, no. 1, pp. 38-39, September 1933. 
Pratt, Wallace Everett.

3127. Hydrogenation and the origin of oil [abstràct]: 16th Internat. Geol. Cong. (1933) Rept., vol. 2, pp. 1009-1010, 1936.

Price, Llewellyn Ivor.

3128. Notes on the brain case of Captorhinus: Boston Soc. Nat. History Proc., vol. 40, no. 7, pp. 377-385, 4 pls., April 1935.

Price, Paul Holland.

3129. James Donaldson Sisler [1896-1935] : Am. Assoc. Petroleum Geologists Bull., vol. 19, no. 11, pp. 1717-1718, November 1935.

3130. (and McCue, John B., and Hoskins, Homer A.). Springs of West Virginia. 146 pp., 38 pls. (incl. geol. map), Morgantown, W. Va., West Virginia Geol. Survey, 1936.

Price, Peter. See also Newhouse, 2860.

3131. The geology and ore deposits of the Horne mine, Noranda, Quebec: Canadian Inst. Min. Metallurgy Trans., vol. 37, pp. 108-140, discussion pp. 389-391, 11 figs. [1935].

3132. Géologie et gisements minéraux de la mine Horne, Noranda, Québec, Canada: Cong. internat. mines mét. géol. appliquée, sec. Géol. appliquée, $7^{\circ}$ sess., tome 1 , pp. 79-93, 11 figs. (incl. geol. maps), 1936.

Price, William Armstrong.

3133. Reynosa problem of south Texas, and origin of caliche: Am. Assoc.

Petroleum Geologists Bull., vol. 17, no. 5, pp. 488-522, 5 figs., May 1933 ; discussion, no. 10, pp. 1277-1281, October 1933 ; reprinted in Gulf coast oil fields (see Barton and Sawtelle), pp. 550-587, 1936.

3134. Role of disastrophism in topography of Corpus Christi area, south Texas: Am. Assoc. Petroleum Geologists Bull., vol. 17, no. 8, pp. 907-962, 17 figs., August 1933 ; reprinted in Gulf coast oil fields (see Barton and Sawtelle), pp. 205-250, 1936.

3135. Corpus Christi structural basin postulated from salinity data: Am. Assoc. Petroleum Geologists Bull., vol. 19, no. 3, pp. 317-355, 7 figs., March 1935; abstract, no. 1, p. 139, January 1935; discussion vol. 20, no. 3, pp. 315-316, March 1936; reprinted in Gulf coast oil fields (see Barton and Sawtelle), pp. 270-308, 1936.

3136. Discovery of oil and gas in Mercedes field, Hidalgo County, Tex.: Am. Assoc. Petroleum Geologists Bull., vol. 19, no. 8, pp. 1226-1231, I fig. (geol. map), August 1935.

Prindle, Louis Marcus.

3137. (and others). Kyanite and vermiculite deposits of Georgia: Georgia Geol. Survey, Dept. Forestry and Geol. Devel. Bull. 46, 50 pp., 11 pls. (incl. sketch maps), 4 figs. (incl. sketch maps), 1935.

Prouty, William Frederick. See also MacCarthy, 2496.

3138. (and MacCarthy, Gerald Raleigh). Aucient fossils on modern beach [abstract] : Elisha Mitchell Sci. Soc. Jour., vol. 49, no. 1, pp. 22-23, September 1933.

3139. Foundation problems in the Morgan Creek Dam of the University of North Carolina [abstract]: Elisha Mitchell Sci. Soc. Jour., vol. 49, no. 1, pp. 27-29, September 1933.

3140. "Meteor craters" of the Carolinas [abstract] : Elisha Mitchell Sci. Soc. Jour., vol. 50, no. 1/2, p. .48, December 1934. 
Prouty, William Frederick-Continued.

3141. (and Douglas, John Gray). Notes on the Silurian system of eastern Tennessee [abstract] : Elisha Mitchell Sci. Soc. Jour., vol. 50, no. $1 / 2$, p. 51, December 1.934.

3142. Fossil whales of the North Carolina Miocene [abstract]: Elisha Mitchell Sci. Soc. Jour., vol. 50, no. 1/2, p. 52, December 1934.

3143. (and Poteat, William Louis, and Stuckey, Jasper Leonidas). Dr. Collier Cobb [1862-1934] ; Elisha Mitchell Sci. Soc. Jour., vol. 50, no. 1/2, pp. 197-198, December 1934.

3144. Further observations concerning the origin of Carolina Bays [abstract] : Elisha Mitchell Sci. Soc. Jour., vol. 50, no. 1/2, pp. 210-211, December 1934 .

3145. Silurian of eastern Tennessee [abstracts]: Elisha Mitchell Sci. Soc. Jour., vol. 50, no. 1/2, pp. 219-220, December 1934; Geol. Scc. America Proc. 1935, p. 97, June 1936.

3146. (and MacNider, William deBerniere, and Wilson, Henry Van Peters). Dr. Collier Cobb [1862-1934] : Elisha Mitchell Sci. Soc. Jour., vol. 50, no. 1/2, pp. 246-247, December 1934.

3147. Origin of folded mountains: Smithsonian Inst. Ann. Rept., 1933, pp. $293-305,1935$.

3148. "Carolina bays" and elliptical lake basins: Jour. Geology, rol. 43, no. 2, pp. 200-207, 4 figs., February-March 1935.

31.49. Collier Cobb [1862-1934] : Science, new ser., vol. 81, no. 2096, p. 219, March 1, 1935.

3150. Geology of the Coastal Plain of North Carolina: Am. Water Works Assoc. Jour., vol. 28, no. 4, pp. 484-491, 5 figs. (incl. geol. map), April 1936; abstract, Elisha Mitchell Sci. Soc. Jour., vol. 50, no. 1/2, pp. 244-246, December 1934.

3151. Further evidence in regard to the origin of "Carolina bays" and elliptical lake basins [abstract] : Geol. Soc. America Proc., 1935, pp. 96-97, June 1936.

3152. Memorial of Collier Cobb [1862-1934] : Geol. Soc. America Proc., 1935, pp. 189-194, 1 pl. (port.), June 1936.

Pulver, C. S.

3153. A national park in embryo [Circle Cliffs, Utah] : Nat. History, vol. 36, no. 5, pp. 438-444, 11 figs. (incl sketch map), December 1935.

Purcell, Paul Edward Murphy. See Eckel, 1126.

Putnam, William C. See Grant, 1496.

Pyle, Howard C.

3154. Connate water in oil sands [abstract] : Am. Assoc. Petroleum Geologists Bull., vol. 20, no. 11, p. 1520, Norember 1936.

3155. (and Jones, P. H.). Quantitative determination of the connate water content of oil sands [abstract]: World Petroleum, rol. 7, no. 12, p. 636, December 1936 .

Quinn, Alonzo Wallace.

3156. A petrographic use of fluoresence: Am. Mineralogist, vol, 20 , no. 6 , pp. 466-468, 2 tigs., June 1935.

3157. Syenite and related rocks of Red Hill, N. H. [abstract]: Geol. Soc. America Proc., 1935, pp. 97-98, June 1936.

Quinn, William D.

3158. Sewer stalactites: Rocks and Minerals, vol. 11, no. 10, p. 229, November 1936. 
Quirke, Terence Thomas.

3159. Origin of watercourses near French River, Ontario: Geol. Soc. America Bull., vol. 47, no. 2, pp. 267-287, 4 pls., 2 figs., February 29, 1936.

Raasch, Gilbert O. See also Bays, 247 ; Kansas Geol. Soc., 2020 ; Shrock, 3702 ; Twenhofel, 4196.

3160. Deronian of Wisconsin: Kansas Geol. Soc. Guidebook 9th Ann. Field Conf., pp. 261-26т (\$), 1 fig., 1935.

3161. Stratigraphy of the Cambrian system of the upper Mississippi Valley (Upper Cambrian St. Croixan series) : Kansas Geol. Soc. Guidebook 9th Ann. Field Conf., pp. 302-315 ( $\$), 2$ figs., 1935.

3162. Paleozoic strata of the Baraboo area: Kansas Geol. Soc. Guidebook 9th Amm. Field Conf., pp. 405-414 ( $\$), 1$ pl. (geol. map by J. M. Wanenmacher), 1 fig., 1935.

3163. Upper Cambrian (St. Croixan) faunas of the type region [abstract] : Geol. Soc. America Proc., 1935, pp. 385-3\$6, June 1936.

Rabot, Charles.

3164. Découverte d'une chaîne de montagnes [Gंreenland]: L'Illustration, tome 187, no. 4756, pp. 485-489, 17 figs. (incl. index map), April $28,1934$.

Rach, E. C. See Whisenant, 4447.

Raguin, Eugene.

3165. Observations sur les gîtes métallifères de contact: Soc. géol France Bull., $5^{\mathrm{e}}$ sér., tome 4 , fasc. $6-7$, pp. 563-571, 1935.

Rainwater, E. H. See Behre, 262.

Raitt, Russell W. See Evans, 1194.

Ralston, Wallace.

3166. Development and production, East Texas district: Am. Assoc. Petroleum Geologists Bull., vol. 20, no. 7, pp. 975-978, 1 fig. (geol. sketch map), July 1936.

Rama Rao, B.

31.67. The 16th International Geological Congress and two of its organized excursions: Mysore Geol. Dept. Records, vol. 33, pp. 44-79, 1935.

Ramos, Ramiro Robles.

31.68. Hipotesis isostática sobre la génesis de los continentes y océanos: Soc. .geol. mexicana Bol., tomo 9, no. 2, pp. 63-11.1, 8 figs. (incl. geol. map), 1936.

Riımsdell, Lewis Stephen. See Kraus, 2258.

3169. Deriration of the 14 Bravais space lattices [abstract] : Am. Mineralogist, vol. 20, no. 3, p. 211, March 1935 ; abstract, Geol. Soc. America Proc., 1934, p. 432, June 1935.

3170. An X-ray study of the system $\mathrm{K}_{2} \mathrm{SO}_{4}-\mathrm{MgSO}_{4}-\mathrm{CaSO}_{4}$ : Am. Mineralogist, vol. 20, no. 8, pp. 569-574, 1 fig., August 1935.

Randolph, Gladys Cora.

3171. Cryptocrystalline or amorphous varieties of quartz; agate (chalcedony) : Mineralogist, vol. 3, no. 1, pp. 30, 51, Januạry 1935.

3172. (and Dake, Henry Carl). Extensive areas of silification predominate in the West: Mineralogist,' vol. 3, no. 4, pp. 5-6, 30-33, April 1935.

3173. Electrical prospecting reveals hidden mineral deposits: Mineralogist, vol. 3 , no. 7, pp. 9-10, July 1935. 
Randolph, Gladys Cora-Continued.

3174. (and Dake, Henry Carl). Opal, color composite of all gems : Mineralogist, vol. 3, no. 9, pp. 5-6, 24, September 1935; no. 10, pp. 9-10, 18-19, October 1935.

3175. Gemlike obsidian of Glass Buttes, Oreg.: Mineralogist, vol. 3, no. 11, pp. 11-12, 26-27, November 1935.

3176. Ancient peoples of the Northwest: Mineralogist, vol. 4, no. 1, pp. 21-22, 40, 42, 44, 46, January 1936.

3177. Prehistoric journeys via scenic routes; The story of fossils : Mineralogist, vol. 4, no. 7, pp. 11-12, 29-32, July 1936.

Rankin, W. D. See Hobson, 1759.

Ransome, Alfred Leslie.

3178. Enargite and plumbojarosite at Picher, Okla.: Am. Mineralogist, vol. 20, no. 11, pp. 799-805, 1 fig., November 1935; abstracts, no. 3, p. 200, March 1935; Geol. Soc. America Proc., 1934, pp. 424-425, June 1935.

Ransome, Frederick Leslie, 1868-1935.

3179. The geologic features of the occurrence of copper in North America: Copper resources of the world, pp. 37-64, Washington, 16th Internat. Geol. Cong., 1935.

3180. Verde fault, Arizona [abstract] : Pan-Am. Geologist, vol. 64, no. 1, p. 70, August 1935; Geol. Soc. America Proc., 1935, p. 347, June 1936.

Rappenecker, Caspar.

3181. The Moneague Valley, Jamaica; site of a temporary karst lake [abstract] : Assoc. Am. Geographers Annals, vol. 26, no. 1, p. 77, March 1936.

Rappleye, Howard Snyder. See also Heck, 1678.

3182. Recent areal subsidence found in releveling [San Jose area, California] : Eng. News-Record, vol. 110, no. 26, p. 845, 1 fig. '(index map), June 29, 1933.

3183. First-order leveling as an aid in seismological investigations in the United States: Am. Geophys. Union Trans. 15th Ann. Meeting, pt. 1, pp. 69-72 ( $¥)$, Nat. Research Council, June 1934.

Rathbun, Mary Jane.

3184. Fossil Crustacea of the Atlantic and Gulf Coastal Plain: Geol. Soc. America Special Paper 2, 160 pp., 2 figs., 26 pls., 1935.

3185. A new xanthid crab from the Cretaceous of New Jersey: Acad. Nat. Sci. Philadelphia Proc., 1935, vol. 87, pp. 165-166, 4 figs., July 11, 1935.

3186. Corrections of names of fossil decapod crustaceans: Biol. Soc. Washington Proc., vol. 49, p. 37, March 9, 1936.

Rawlins, Edwin Lee.

3187. (and Schellhardt, M. A.)'. Extent and availability of natural-gas reserves in Michigan "stray" sandstone horizon of central Michigan: U. S. Bur. Mines Rept. Inv. 3313, v, 139 pp. ( $\ddagger$ ), 16 pls. (incl. geol. map by Helen M. Martin), July 1936.

Ray, H'oracio C.

3188. Los recursos minérales de Puerto Rico: Rev. obras públicas de Puerto Rico, año 12, no. 12, p. 1132, December 1935. 
Ray, Horacio C.-Continued.

3189. Los minérales de Puerto Rico: Rev. obras públicas de Puerto Rico, año 13, no. 1, pp. 1160-1163, January 1936. (Translated by Martín López Sanabria.)

3190. Los minérales petreos de Puerto Rico: Rev. obras públicas das Puerto Rico, año 13, no. 4, pp. 1262-1264, April 1936. (Translated by Martín Lopez Sanabria:)

3191. Las rocas de Puerto Rico : Rev. obras públicas de Puerto Rico, año 13, no. 6, pp. 1314-1317, June 1936 [Translated by Martín López Sanabria].

Ray, Louis L. See also Hinchey, 1743 ; Wentworth; 4409."

3192. Some minor features of valley glaciers and valley glaciation: Jour. Geology, vol. 43, no. 4, pp. 297-322, 18 figs., April-May 1935. ."

Raymond, Louis C.

3193. Small native-sulphur deposits associated with gossans: Mining ...and Metallurgy, vol. 16, no. 346; p. 414, October 1935; abstract, Year Book sec., p. 62, January 1936.

Raymond, Percy Edward.

3194. Report on invertebrate paleontology : Harvard Coll. Mus. Comp. Zoology Ann. Rept., 1934-35; pp: 33-36, 1935: .

3195. John Mason Clarke (1857-1925). Am. Acad. Arts and Sci. Proc., vol. 69, no. 13, pp. 498-502, February 1935.

3196. Pre-Cambrian life: Geol. Soc. America Bull., vol. 46, no. 3, pp. 375-392, March 31, 1935.

3197. Herdman Fitzgerald Cleland [1869-1935] : Science, new. ser., vol. 81, no. 2101, pp. 330-331, April 5, 1935.

3198. Memorial of F[rancis] A[rthur] Bather [1863-1934]: Geol. Soc. Amërica Proc., 1934; pp. 173-186, June 1935.

3199. Leanchoilia and other mid-Cambrian Arthropoda: Harvard Coll. Mus. Comp. Zoology Bull., vol. 76, no. 6, pp. 205-230, 3 figs., July 1935.

3200. Protaspides of trilobites: Jour. Paleontology, vol. 9, no. 5, pp. 400-401, July 1935.

3201. Report on invertebrate paleontology: Harvard Coll. Mus. Comp. Zoology Ann. Rept., 1935-36, pp. 38-39, 1936.

3202. Herdman Fitzgerald Cleland (1869-1935) : Am. Acad. Arts Sci. Proc., vol. 70, no. 10, pp. 508-510, March 1936.

3203. Memorial of Herdman Fitzgerald Cleland [1869-1935]: Geol. Soc. America Proc., 1935, pp. 183-188, 1 pl. (port.), June 1936.

3204. Upper Cambrian faunas of northwestern Vermont (abstract): Geol. Soc. America Proc., 1935, p. 385, June 1936.

3205. Paleoecology of the Arthropoda: Nat. Research Council Ann. Rept., 1935-36, app. J. Report of the Committee on Paleoecology, pp. 22-28 ( () , October 1936.

Read, Charles Brian. See also Knechtel, 2228; U. S. G. S., 4230, 4231, 4232, 4234.

3206. An occurrence of the genus Cladoxylon Unger in North America: Washington Acad. Sci. Jour., vol. 25, no. 11, pp. 493-497, 3 figs., November 15, 1935.

3207. The flora of the New Albany shale, pt. 1, Diichnia kentuckiensis, a new representative of the Calamopityeae: U. S. Geol. Survey Prof. Paper 185-H, pp. 149-161, 4 pls., 2 figs., 1936.

$311-37-15$ 
Read, Charles Brian-Continued.

3208. A Devonian flora from Kentucky: Jour. Paleontology, rol. 10, no. 3, pp. 215-227, $3 \cdot$ pls., 16 figs., April 1936.

Read, J. Burns.

3209. (and Underhill, James, and Signer, M. I.). The experimental mine: Colorado School of Mines Quart., vol. 30, no. 4, 23 pp., 3 pls. (incl. geol. map), 15 flgs. (incl. index map), October 1935.

Reagan, Albert B., 1871-1986.

3210. Utilization of the Navajo country : Iowa Acad. Sci. Proc., 1934 (vol. 41), pp. 215-238, 2 figs. (geol. maps), 1934.

Reamer, Louis.

3211. Agates found in an old abandoned [trap rock] quarry: Rocks and Minerals, vol. 4, no. 4, p. 109, 1 fig., December 1929.

Reberholt, B. 0 .

3212. The preparation of rocks and minerals for study and exhibition: Rocks and Minerals, rol. 10, no. 4, pp. 52-55, April 1935.

Reck, Hans.

3213. (and Türkheim, O. G. von). Der. Zustand der Vulcane Fuego, Atitlan, und Sta. Maria in Guatemala am Ende 1934 : Zeitschr. Vulkanologie, Band 16, Heft 4, pp. 259-263, 3 pls., July 1936.

Redden, Richard E.

3214. (and Crawford, Arthur Lorenzo): Two basal Cambrian sections west of Morgan, Utah [abstract]: Utah Acad. Sci. Proc., vol. 12, p. 169, 1935.

3215. Ground-water recharge possibilities in Davis and Weber Counties [abstract] : Utah Acad. Sci. Proc. vol. 13, p. 57, 1936.

Reed, Charles Merton. See Singewald, 3730.

Reed, D. W. See Botset, 382.

Reed, Eugene Ćlifton. See Condra, 834, 835.

Reed, Fredda Doris.

3216. Lepidocarpon sporangia from the Upper Carboniferous of Illinois: Bot. Gazette, vol. 98, no. 2, pp. 307-316, 10 figs., December 1936.

Reed, John Calvin. See also Hansell, 1622 ; Shenon, 3659, 3660, 3663.

3217. Geology of the Potsdam quadrangle: New York State Mus. Bull. 297, 98 pp., 6 pls. (incl. geol. maps), 52 figs. (incl. key map), December 1934.

3218. (and Hansell, James Myron). Quicksilver deposits near Little Missouri River, southwest Arkansas: Am. Inst. Min. Met. Eng. Tech. Pub. 612, 5 sketch maps, 1935 ; abstracts, Mining and Metallurgy, vol. 16, no. 339, pp. 158-159, March 1935 ; Washington Acad. Sci. Jour., vol. 25, no: 11, pp. 504-505, November 15, 1935.

3219. (and Hansell, James Myron). Quicksilver deposits near Little Missouri River and near Antoine Creek; southwestern Arkansas: U. S. Dept. Interior Press Mem. 99554, 16 pp. (\$), 5 figs. (incl. index map), April 30, 1935.

3220. Cinnabar deposits in southwestern Arkansas: Econ. Geology, vol. 31. no. 3, pp. 314-317, May 1936. 
Reed, Ralph Daniel. See also Ashauer, 98; Stille, 3904.

3221: (and Hollister, Joseph Steffens). Geology of the Transverse Ranges [abstract]: Am. Assoc. Petroleum Geologists Bull., vol. 19, no. 1, p. 136, January 1935.

3222. [Review of] The Dinosaurs, by 'William Elgin Swinton, 1934: Am. Assoc. Petroleum Geologists Bull., vol. 19, no. 4, pp. 562-567, Aprib 1935.

3223. [Review of] Paleozoic plankton of North America, by Rudolph Ruedemann; 1934: Am. Assoc. Petroleum Geologists Bull., vol. 19, no: 4, pp. 567-570, April 1935 .

3224. Miocene orogenies in Callfornia Coast Ranges [abstract]: Pan-Am. Geologist, vol. 63, no. 4, pp. 303-304, May 1935; Geol. Soc. America Proc., 1935, p. 328, June 1936.

3225. Tertic limestones of the San Rafael Mountains [Calif.] [abstract] : Pan-Am. Geologist, vol. 64, no. 1, p. 76, August 1935; Geol. Soc. America Proc., 1935, p. 352, June 1936.

3226. Miocene breccias of Santa Barbara district [abstract] : Pan-Am. Geologist; vol. 64, no. 1, pp. 76-77, Angust 1935 ; Geol. Soc. America Proc., 1935 , p. 353, June 1936.

3227. Geology of California ; some corrections : Am. Assoc. Petroleum Geologists Bull., vol. 19, no. 12, pp. 1819-1824, 2 figs. (incl. sketch map), December 1935.

3228. (and Hollister, Joseph Steffens). Paleogeology of southern California [abstract] : Am. Assoc. Petroleum Geologists Bull., vol. 19, no. 12. p. 1841, December 1935.

3229. [Review of] La constitution géologique des Antilles, by L. Barrabé; July 1, 1936; Am. Assoc. Petroleum Geologists Bull., vol. 20, no. 11. pp. 1497-1498, November 1936.

3230. Eocene paleogeography in southern California [abstract]: Am. Assoc. Petroleum Geologists Bull., vol. 20, no. 11, p. 1520, November 1936.

3231 (and Hollister, Joseph Steffens). Structural evolution of southern California : Am. Assoc. Petroleum Geologists Bull., vol. 20, no. 12, pp. 1529-1704, 10 pls. (incl. geol. map), 56 figs. (incl. geol. sketch maps), December 1936.

Rees, O. W. See Grim, 1546.

Reeside, John Bernard, Jr. See also Baker, 143; Schuchert, 3588.

3232. The preparation of paleontologic illustrations: Jour. Paleontology, vol. 4, no. 3, pp. 299-308, 1 pl., September 1930.

Reeves, Frank.

3233. Manganese deposits of eastern West Virginia: West Virginia Geol. Survey Mimeograph ser., Bull. 6, 22 pp. ( $\ddagger), 7$ pls. (incl. geol. maps), 1935.

Reeres, John Robert.

3234. Hebron gas field, Potter County, Pa.: Am. Assoc. Petroleum Geologists Bull., vol. 20, no. 8, pp. 1019-1027, 2 figs. (incl. geol. sketch map), August 1936 ; abstract, World Petroleum, vol. 7, no. 12, p. 637, December 1936.

Reịche, Parry.

3235. Geology of the Lucia quadrangle, Monterey County, Calif. [abstract] : Geol. Soc. America Proc., 1934, p. 313, June 1935. 
Reid, G. A.

3236. Restorations of geological landscapes. 6 pls. Toronto, Royal Ontario Mus., 1934.

Reid, Harry Fielding. See Day, 987, 989.

Reid, John A.

3237. Vein formation at Porcupine, Ontario: Econ. Geology, vol. 30, no. 7, pp. 829-830, November 1935 .

3238. Central Patricia gold mine, Ontario: Econ. Geology, vol. 31, no. 5, pp. 527-530, August 1936.

Reimann, : Irving G,

3239. Pseudohydnoceras, a new Hamilton dictyosponge Buffalo Soc. Nat. Sci. Bull., vol. 17, no. 1, pp. 13-17, 2 pls., 1935.

3240. New'species and some new occurrences of Middle Devonian blastoids: Buffalo-Soc. Nat. Sci. Bull., vol. 17, no. 1, pp. 43-45, 4 pls., 1935.

3241. Time tells its story, geological time clock installed: Hobbies, vol. 15, no. 5, pp. 89-93, 2 figs., June 1935.

3242. Invertebrate giants: Hobbies, vol. 15 , no. 5 , pp. 96, 105, 1 fig. (on cover), June 1935.

Reinhart, Philip W. See also Schenck, 3541.

3243. Classification of the pelecypod family Arcidae: Mus. royale histoire nat. Belgique Bull., tome 11, no. 13, 68 pp. 5 pls., August 1935.

3244. Pacific slope species incorrectly assigned to the pelecypod family Arcidae [abstract] : Geol. Soc. America Proc., 1935, pp. 366-367, June 1936.

Renger, J. J.

3245. Excavation of Cretaceous reptiles in Alabama: Sci. Monthly, vol. 41, no. 6, pp. 560-565, 5 figs., December 1935.

Renick, Brink Coleman.

3246. The Jackson group and the Catahoula and Oakville formations in a part of the Texas Gulf Coastal Plain: Texas Univ. Bull. 3619, 104 pp., 10 pls. (incl. geol. maps); May 15; 1936.

Renton, J. Lewis.

3247. Colored hyalite opal found in large masses at Opal Butte, Oreg.: Mineralogist, vol. 3, no. 1, pp. 36-37, January 1935.

3248. Opal- or agate-filled "thunder eggs"; Mineralogist, vol. 4, no. 1, pp. 12-13, 46, 48, 50, 52, 7 figs., January 1936.

Renz, Hans H.

3249. Neue Cephalopoden aus der oberen Kreide vom Rio Grande del Norte (Mexico und Texas), mit einer Einführung von Walther Staub: Schweizer. palaeont. Gesell. Abh., vol. 57, pp. 1-16, 4 pls., 1 fig. (index map), 1936; extracted, in part, and transl. by Friedrich K. G. Müllerried in Soc. geol. mexicana Bol., tomo 9, no. 2, 1936 .

Resser, Charles Elmer. See Howell, 1853.

3250. Nomenclature of some Cambrian trilobites: Smithsonian Misc. Coll., vol. 93, no. 5, Pub. 3295, 46 pp., February 14, 1935.

3251. Geologic studies in the Appalachian Mountains: Smithsonian Inst. Explorations and Field Work, 1935, Pub. 3382, pp. 5-8, 4 figs., 1936.

3252. Second contribution to nomenclature of Cambrian trilobites: Smithsonian Misc. Coll., vol. 95, no. 4, Pub. 3383, 29 pp.; April 1, 1936. 
Rettger, Robert Ernest.

3253 Experiments on soft-rock. deformation: Am. Assoc. Petroleum Geologists Bull., vol. 19, no. 2, pp. 271-292, 16 figs., February 1935.

3254. (and Carsey, J. Ben, and Morero, J. E.). Natural gas in west Texas and southeast New Mexico: Geology of natural gas, pp. 417-458; 8 figs. (incl.:maps)., Am. Assoc. Petroleum Geologists [June] 1935.

Retty, Joseph Arlington.

3255. Upper Gatineau region and vicinity: Quebec Bur. Mines Ann. Rept., 1933, pt. D, pp. 129-148, 3 pls. (incl. geol. map), 1934.

3256. Travers Lake map àrea; Témiscamingue County: Quebec Bur. Mines Ann. Rept., 1934, pt: C, pp. 19-34, 1 pl. (geol. map), 1935.

Retzek, Henry.

3257. Memorial of the Rev. Stephen Richarz, S, V: D. [1874-1934] Geol. Soc. America Proc, 1934, pp. 253-258, port., June 1935.

Reynolds, Dewey A. See Fieldner, 1255.

Reynolds, Dexter H. See Clark, 761.

$\mathbf{R}$ [eynolds], D[oris] L[ivesey].

3258. [Review of] Life history of the Sudbury nickel irruptive; pt. 1 , Petrogenesis, by w. H. Collins, 1935: Geol. Mag., no. 852 (vol. 72, no. 6), pp. 285-287, June 1935.

Reynolds, J. M.

3259. A new contribution to the problem of segmentation in the Arthropoda: Am. Jour. Sci., 5th ser., vol. 30, no. 178, pp. 373-382, October 1935.

Reynolds, T. Emmett.

3260. Two new insectivores from the lower Paleocene of New Mexico: Jour. Paleontology, vol. 10, no, 3, pp. 202-209, 1. pl., 2 figs., April 1936.

Reynolds, Walter Ford: See Heck; 1678.

Rice, George S., Jr.

3260-A. (and Atkinson, James C.). Aerial maps, greatly improved, simplify work of geologist and engineer: Mining and Metallurgy, vol. 17, no. 360, pp. 569-572, 4 flgs., December 1936.

Rice, Harington 'Molesworth Anthony.'

3261. Amphibole from the Purcell sills, British Columbia : Am. Mineralogist, vol. 20, no. 4, pp. 307-309, April 1935.

3262. Tertiary gravels in Cranbrook area, British Coiumbia: Canada Dept. Mines, Geol. Survey Paper 36-1, 2 pp. ( $\ddagger)$, Jànuary 9, 1936:

3263. Glacial phenomena near Cranbrook, British Columbia: Jour. Geology, vol. 44, no. 1, pp. 68-73, Jánuary-February 1936.

Rice, Howard, E.

3264. The Hagerman, Idaho, fossil locality: Mineralogist, rol. 4, no. 7, pp. ( 3-4, 34-35, July 1936.

Rich, John Lyon. See also -Van Tuyl, 4268.

3265. Soil mottling's and mounds in northeastern Texas as seen from the air : Jour. Geography; vol. 24, no. 4, pp. 576-583, 9 figs. (incl. sketch map), October 1934.

3266. Glacial geology of the Catskills : New York State Mus. Bull. 299, December 1934, 180 pp., 2 pls. (geol. maps), 79 figs. (incl. sketch map), 1935. 
Rich, John Lyon-Continued.

3267. Drainage changes and reexcavated valleys as measures of interstream degradation [abstract]: Geol. Soc. America Proc., 1934, pp. 102103, June 1935.

3268. Origin and evolution of rock fans and pediments: Geol. Soc. America Bull., vol. 46, no. 6, pp. 999-1024, 11 flgs., June 30, 1935.

3269. Graphical method for eliminating regional dip: Am. Assoc. Petroleum Geologists Bull., vol. 19, no. 10, pp. 1538-1540, 1: fig. (map), October 1935.

3270. Fault-block nature of Kansas structures suggested by elimination of regional dip: Am. Assoc. Petroleum Geologists Bull., vol. 19, no. 10, pp. 1540-1543, 3 figs. (maps), October 1935.

3271. Questioning too many peneplains [abstract] : Geol. Soc. America Proc., 1935, pp. 98-99, June 1936.

3272. Graphic method for determining true dip from two components: Am. Assoc. Petroleum Geologists Bull., vol. 20, no. 11, p. 1496, November 1936.

Richard, L. M.

3273. Note on the discovery of a kaolin deposit in New Mexico. Am. Ceramic Soc. Jour., vol. 16, no. 12, pp. 632-633, December 1933.

3274. Pyrophyllite in San Diego County, Calif: : Am Ceramic Soc. Bull., vol. 14, no. 10, p. 353, October 1935.

Richards, Carl Price.

3275. Glaciers studied from an airplane: Mazama, vol. 18, no. 12, pp. 47-56, 13 figs. (incl. index map); December 1936.

Richards, George L., Jr.

3276. Revision of some California species of Astrodapsis: San Diego Soc. Nat. History Trans., vol. 8, no. 9, pp. 59-66, 1 pl., March 21, 1935.

3277. Astrodapsis faunal zones of California upper Miocene and lower Pliocene formations [abstract]: Pan-Am. Geologist, vol. 63, no. 5; pp. 374-375, June 1935; Geol. Soc. America Proc., 1935, pp. 412-413, June 1936.

Richards, Horace Gardiner. See also Howell, 1854 ; MacClintock; 2504.

3278. Is the coast of New Jersey sinking?: Nature Mag., vol. 24, pp. 225-226, 3 figs., November 1934.

3279. A new Miocene locality in New Jersey: Am. Midland Naturalist, vol. 16, no. 2, pp. 208-209, 1 fig., March 1935.

3280. Pleistocene mollusks from western Cuba: Jour. Paleontology, vol. 9, no. 3, pp. 253-258, 8 figs., April 1935.

3281. Recent and Pleistocene marine shells of James Bay [Hudson Bay]: Am. Midland Naturalist, vol. 17, no. 2, pp. 528-545, 3 figs., March 1936 ; abstract, Geol. Soc. America Proc., 1934, p. 373, June 1935.

3'282. Pleistocene mollusks from Newfoundland [abstract]: Geol. Soc. America Proc., 1935, p. 366, June 1936.

3283. Mollusks associated with early man in the Southwest: Am: Naturalist; vol. 70, no. 729, pp. 369-371, July-August 1936.

3284. Fauna of the Pleistocene Pamlico formation of the southern Atlantic Coastal Plain: Geol. Soc. America Bull., vol. 47, no. 10, pp. 16111656, 4 pls., 1 fig. (geol. sketch map), October 31, 1936.

Richardson, Davis Payne.

3285. The Fayetteville, Ark., meteorite: Popular Astronomy, vol. 43, no. 6, pp. 384-385, 1 fig., June-July 1935. 
Richardson, George Burr.

3286. Geology and mineral resources of the Butler and Zelienople quadrangles, Pa.: U. S. Geol. Survey. Bull. 873, , 93 pp., 8 pls. (incl. geol. maps), 10 figs. (incl. index and geol. maps), 1936.

Richmond, A. M.

3287. British Columbia's industrial and nonmetallic minerals : Canadian Inst. Min. Metallurgy Trans., vol. 38, pp. 373-388, 21 figs., 1935.

Richmond, Wallace Everett, Jr.

3288. Type mineral-localities of Nalne : Mineralogist, vol. 3, no. 1, pp. 32, 49, January 1935.

3289. Crystallography of livingstonite: Am. Mineralogist,. vol. 21, no. 11, pp. 719-720, 1 fig., November 1936; abstract, no. 3, p. 204, March 1936.

Richter, Charles Francis. See also Gutenberg, 1579, 1585, 1588.

3290. An instrumental earthquake-magnitude scale: Seismol. Soc. America Bull., vol. 25, no. 1, pp. 1-32, January 1935.

Richter, Rudolf.

3291. "Das grösste Ding der Erde"; die Colorado-Schlucht Grand Canyon: Natur u. Volk, Band 65,"Heft 1, pp. 1-22, 11 figs. (incl. cover), May 1, 1935.

3292. Henry Fairfleld Osborn [1857-1935]: Natur u. Volk, Band 66, Heft 2, pp. 51-53, 1 fig. (port.), February: 1, 1936.

Richtmyer, Floyd Karker.

3293. Borderlands in science: Science, new ser., vol. 82, no. 2130, pp. 379-382, October 25, 1935.

Rickaby, Harold Colman. See also Burrows, 585.

3294. Geology of the Swayze gold area : Ontario Dept. Mines 43d Ann. Rept. (vol. 48, pt. 3), 1934, pp. 1-36, 23 figs. (incl. sketch maps), 2 pls. (geol. maps), 1935.

Ridge, John.

3295. The genesis of the Tri-State zinc and lead ores: Econ. Geology, vol. 31, no. 3, pp. 298-313, 1 flg., May 1936.

Rieber, Frank.

3296. A new reflection system with controlled directional sensitivity: Geophysics, vol. 1, no..1, pp. 97-106; 7 figs., January 1936; abstract, World Petroleum, vol. 7, no. 6, pp. 330-331, June 1936.

3297. Visual presentation of. elastic wave patterns under various structural conditions: Geophysics, vol, 1, no. 2, pp. 196-218, 24 figs., June 1936.

3298. Geological causes of poor reflection records [abstract]: Am. Assoc. Petroleum Geologists Bull., vol. 20, no. 11, p. 1520, November 1936.

Ries, Heinrich.

3299. Geology and clay research : Am. Ceramic Soc. Bull., vol. 14, no. 9, pp. 279-290, 12 figs., September 1935.

3300. (and Watson, Thomas Leonard). Engineering geology. 5th ed., vil, 750 pp., 271 figs. (incl. geol. maps), New York, John Wiley \& Sons, Inc., 1936:

Rigdon, Vera E.

3301. Physiographic nomenclature a la William Morris Davis [abstract]: Assoc. Am. Geographers Annals, vol. 25, no. 1, pp. 52-53, March 1935. 
Riggs, C. Harold.

3302. Geology of the Hart oil field: Michigan Acad. Sci. Papers, vol, 20, pp. 485-496, 7 figs.; 1935.

Riggs, Elmer Samuel.

3303. Occurrence of the extinct moose, Cervalces, in Indiana and Illinois: Am. Midland Naturálist, vol. 17, no. 3, p. 664, Mày 1936.

Riley, Christopher.

3304. The granite porphyries of Great Bear Lake, Northwest Territories, Canada: Jour. Geology, vol. 43; no: 5, pp. 497-523, 1 pl. (geol. map), 12 figs. (incl. sketch map), July-August 1935.

Riley, L. B.

3305. Ore-body zoning: Econ Geology, vol. 31, no. 2, pp. 170-184, 1 fig., MarchApril 1936.

Ring, Dewitt Talmadge. See Stout, 3949.

Ringsleben, William C.

3306. Geology [Hollinger gold mine, Ontario] : Canadian Min. Jour., vol. 56, no. 9, pj. 364-372, 11 figs. (incl. geol. maps), September 1935.

Rison, C. 0 .

3307. (and Bunn, John R.). Petroleum engineering in the Cromwell oil field, Seminole and Okfuskee Counties, Okla. (reprint from MidContinent Oil and Gas Assoc. Year Book), 38 pp., 5 pls., 5 figs., December 1, 1924.

Riter, J. R. See Debler, 995 .

Rittenhouse, Gordon.

3308. Geology of a portion of the Savant Lake area, Ontario: Jour. Geology, vol. 44, no. 4, pp. 451-478; 1 pl: (geol. map), 1 fig. (geol. map), MayJüne 1936.

Ritz, C. H. See also Barton, 203.

3309. Geomorphology of Gulf coastal salt structures and its economic application: Am. Assoc: Petroleum Geologists Bull., vol. 20, no. 11, pp. 1413-1438, 14 figs. (incl. maps), November 1936.

Roberts, Frank Harold Hanna, Jr. See also Merriam, 2674.

3310. A Folsom camp site and workshop: Smithsonian Inst. Explorations and Field Work in 1934, Pub. 3300, pp. 61-64, 4 figs., 1935.

3311. A habitation site and workshop attributable to so-called' Folsom man [abstract]: Science,' new ser., vol. 81, no. 2105, p. 425, May 3, 1935.

3312. A Folsom complex: preliminary report on investigations at the Lindenmeier site in northern Colorado: Smithsonian Misc. Coll., vol. 94, no. 4, Pub. 3333, 35 pp., 16 pls., 3 figs. (incl. sketch map), June 20, 1935 .

3313. Further investigations at a Folsom campsite in northern Colorado: Smithsoniạn Inst. Explorations and Field Work, 1935, Pub. 3382, pp. 69-74, 6 figs., 1936.

3314. Additional information on the Folsom complex; report on the second season's investigations at the Lindenmeier site in northern Colorado: Smithsonian Misc: Goll., vol. 95, no. 10, Pub. 3390, 13 pls. (incl. map), 5 figs., June 20, 1936.

3315. Recent discoveries of the material culture of Folsom man: Am. Naturalist, vol. 70, no. 729, pp. 337-345, 3 flgs., July-August 1936. 
Roberts, Hugh Marine.

3316. Value of the geological surveys [with discussion] : Am. Inst. Min. Met. Eng. Trans., vol. 115 (Mining geology), pp. 436-442; discussion, pp. 452-459, 1935.

Roberts, Joseph Kent. :

3317. Memorial of Henry Donald Campbell. [1862-1934]: Geol. Soc. America Proc., 1934, pp. 209-212, port., June 1935.

3318. The Patuxent sandstone of northeastern Virginia [abstract]: Virginia Acad. Sci. Proc., 1935-36, p. 68, 1936.

3319. William Barton Rogers [1835-1882] and his contribution to the geology of Virginia: Geol. Soc. America Proc., 1935, pp. 305-310, abstract, p: 99, June 1936.

Robertson, George $M$.

3320. New cephalaspids from Canada: Am. Jour. Sci., 5th ser., vol. 31, no. 184, pp. 288-295, 4 figs., April 1936.

3321. Sensory canal system in Osteostrachi [abstract] : Geol. Soc. America Proc., 1935, p. 399, June 1936.

Robinson; Arthur Herbert Ashburner.

3322. The mineral industries of Canada, 1933: Canada Dept. Mines, Mines Branch, Pub. 738, 116 .pp., 35 pls. (incl. mineral map), 1934.

3323. Gold in Canada: Canada Dept. Mines, Mines Branch, Pub. 769, viii, 127 pp., 7 figs. (incl. index maps), 1935.

Robinson, J. H.

3324. The occurrence and distribution of the diatoms in the oceanic beds of Barbados: Barbados Mus. and Hist. Soc. Jour., vol. 3, no. 3, pp. 149-152, May 1936; vol. 4, no. 1, pp. 9-11, November 1936.

Robinson, Samuel.

3325. Early American agate localities; extracts from A catalogue of American minerals with their localities, 1825: Rocks and Minerals, vol. 11, no. 9, pp. 178-180, September-October 1936.

Robinson, Thomas William,..Jr. See also Piper, 3088; Rothrock, 3384.

3326. Symposium on fluctuations of ground water; Decline of artesian head in west-central South Dakota: Am. Geophys. Union Trans. 17th Ann. Meeting, pt. 2, pp. 363-366 (\$), 2 figs., Nat. Research Council, 1936.

3327. Artesian conditions in west-central South Dakota; Hydrology : S. Dak. Geol. Survey Rept. Inv. 26, pp. 35-93 ( $¥), 4$ pls. (incl. index and piezometric maps), 1 flg., July 1936.

Robson, W. T.

3328. Lake Shore [mine area] geology [Ontario]: Canadian Inst. Min. Metallurgy Bull. 287, pp. 99-141, 25 flgs. (incl. geol. map), 2 pls., March 1936.

Rockie, William Allan.

3329. Snowdrifts and the Palouse topography: Geog. Rev., vol. 24, no. 3, pp. $380-385,6$ figs. (incl. maps), July 1934.

Rode, Karl.

3330. Unsymmetrische Regenrunsen: Geol. Rundschau, Band 27, Heft 4, pp. 380-388, 5 figs., 1936.

Rodeck, Hugo G. See Toepelman, 4134. 
Roedder, Edwin.

3331. Black sulphur at Hillburn, N. Y.: Rocks and Minerals, vol. 10, no. 11, p. 173, November 1935 .

Rogatz, Hen'ry.

3332. Geology of Texas Panhandle oil and gas field: Am. Assoc. Petroleum Geologists Bull., vol. 19, no. 8, pp. 1089-1109, 5 figs. (incl. maps), August 1935.

Rogers, Austin Flint.

3333. The chemical formula and crystal system of alleghanyite: Am. Mineralogist, vol. 20, no. 1 , pp. 25-35, 10 figs., January 1935; abstracts, no. 3, p. 197, March 1935 ; Geol. Soc. America Proc. 1934, p. 421, June 1935 .

3334. Unique occurrence of vein quartz in Mariposa County, Calif. [abstract] : Geol. Soc. America Proc., 1934, pp. 327-328, June 1935.

3335. Salton volvanic domes of Imperial County, Calif. [abstract] : Geol. Soc. America Proc., 1934, p. 328, June 1935.

3336. Use of the term syngony in geometrical crystallography [abstract]: Geol. Soc. America Proc., 1934, pp. 431-432, June 1935.

3337. Precious stones: Mineralogist, vol. 3 , no. 11 , pp. 3-4, 27-29, November 1935.

3338. A tabulation of erystal forms and discussion of form names: Am. Mineralogist, vol. 20, no. 12, pp. 838-851, December 1935; abstract, vol. 21, no. 3, p. 207, March 1936.

3339. Mineraloids [abstract] : Am. Mineralogist, vol. 21, no. 3, pp. 184-195, March 1936.

Rogers, Austin R.

3340. Cypridella and Cypridinella from the Kansas-Missouri Pennsylvanian [abstract]: Geol. Soc. America Proc., 1934, p. 385, June 1935.

Roigneau, Marcelle. See Gregory, 1528.

Rolshausen, F. W.

3341. Occurrence of siderite in cap rock at Carlos dome, Grimes County, Tex.: Am. Assoc. Petroleum Geologists Bull., vol. 18, no. 4, pp. 543-546, April 1934; reprinted in Gulf coast oil fields (see Barton and Sawtelle), pp. 133-135, 1936.

Roman, Irwin.

3342. Some interpretations of earth-resistivity data [with discussion]: Am. Inst. Min. Met. Eng. Trans., vol. 110, Geophysical Prospecting; pp. 183-200, 27 figs. 1934 .

3343. (and Sermon, Thomas Crotford). A magnetic gradiometer [with discussion] : Am. Inst. Min. Met: Eng. Trans., vol. 110, Geophysical Prospecting, pp. 373-390, 6 figs., 1934.

3344. Analysis of seismic profiles: Am. Inst. Min. Met. Eng. Trans., vol. 110, Geophysical Prospecting, pp. 493-527, 5 figs., 1934.

Romer, Alfred Sherwood.

3345. Report on vertebrate paleontology : Harvard Coll. Mus. Comp. Zoology Ann. Rept., 1934-35, pp. 37-40, 1935.

3346. (and Grove, Brandon Hambright). Environment of the early vertebrates: Am. Midland Naturalist, vol. 16, no. 6, pp. $805-856,2$ figs., November 1935.

3347. Early history of Texas red-beds vertebrates: Geol. Soc. America Bull.,, vol. 46, no. 11, pp. 1597-1658, 5 figs. (incl. index map), November 30, 1935; abstract, Proc., 1934, pp. 375-376, June 1935. 
Romer, Alfred Sherwood-Continued.

3348. Report on vertebrate paleontology : Harvard Coll. Mus. Comp: Zoology Ann. Rept., 1935-36, pp. 40-41, 1936.

3349. [Review of] On the dermal bones of the head in labyrinthodont stegocephalians and primitive Reptilia, by G. Säve-Söderbergh, 1935 : Jour. Geology, vol.: 44, no. 4, pp. 534-536, May-June 1936.

3350. (and Smith, Homer). Dipnoan :skull roof [abstract] : Geol. Soc. America Proc., 1935, p. 393, . June 1936.

3351. The dipnoan cranial roof: Am.: Jour. Sci., 5th ser., vol. 32, no. 190. pp. 241-256, 4 figs., October 1936.

Romer, M:

3352. La dernière éruption de la montagne Pelée: Bull. volcanologique, $8^{*}$ ànèe, nos. 1-4, pp. 83-84, August 1936.

Rosaire, Esme Eugene.

3353. On the strategy and tactics of exploration for petroleum: Soc. Petroleum Geophysicists Jour., vol. 6, no. 1, pp. 11-26, July 1935.

3354. (and Stiles, M. E.). Exploration on the Guif coast to 1936: Geophysics, vol. 1, no. 1, pp. 141-148, 3 pls., 4 figs., January 1936; abstract, World Petroleum, vol. 7, no. 8, p. 404, August 1936.

3355. Geophysical prospecting, for petroleum: Military Engineer, vol. 28, no. 161, pp: 351-354, 2 figs." (maps); September-October 1938.

Rose, John Lawyer.

3356. (and Stranathan, Robert $K$.). Geologic time and isotopic constitution of radiogenic lead: Phys. Rev., vol. 50, no. 9, pp. 792-796, 2 flgs., November 1, 1936.

Rose, Pat. See U. S. G. S., 4233:

Rosenholtz, Joseph Leon.

3357. (and Smith, Dudley T.). The dielectric constant of mineral powders: Am. Mineralogist, vol. 21, no. 2, pp. 115-120, February 1936.

Rosenkrans, R. R. See also Whitcomb, 4450 .

3358. The role of bentonite correlation in stratigraphic studies of the Ordovician of eastern North America: 16th Internat. Geol. Cong. (1933) Rept. vol. 2, pp. 1085-1087, 1936.

3359. Stratigraphy of the Ordovician bentonite occurrences [abstract] : Geol. Soc. America.Proc., 1935, pp. 99-100, June 1936.

Rosenkrantz, Alfred. See Bøggild, 360, 361.

Rosevear, Francis Burt.

3360. Science craft mineralogy manual. 143 pp., illus., front., Hagerstown; Md., Porter Chemical Co. [ $\left.{ }^{c} 1935\right]$.

Rosewarne, Pearce Victor:

3361. (and Chantler, Howard McDougall, and Swinnerton, Aylmer Aberffraw). Analyses of Canadian crude oils, naphthas, shale oil, and bitumen: Canada Dept. Mines, Mines Branch Pub. 765, 21 pp., 6 pls. (incl. index map), 2 figs., 1936.

Ross, Clarence Samuel. See also Fenner, 1222; Mansfield, 2566.

3362. (and Lewis, Joseph Volney). Sulphide deposits of southwest Virginia [abstract] : Virginia Acad. Sci. Proc., 1934-35, pp. 62-63 [1935].

3303. Copper deposits in the eastern United States: Copper resources of the world, pp. 151-166, 1 pl. (map), 1 fig. (map), Washington, 16th Internat. Geol. Cong., 1935. 
Ross, Clarence Samuel-Continued.

3364. Origin of the copper deposits of the Ducktown type in the southern Appalachian region: U. S. Geol. Survey Prof. Paper 179, 165 pp., 5 figs., 44 pls., 1935.

3365. Genetic relations of sphalerite in pegmatite [abstract] : Am. Mineralogist, vol. 20, no. 3, p. 203,, March 1935 ; abstract, Geol. Soc. America Proc., 1934, p. 103, June 1935.

3366. Mineralization of the Virginia titanium deposits: Am. Mineralogist, vol. 21 ; no. .3, „pp. 143-149; abstract, p. 192, March 1936.

3367. [Review of] Hot springs of the Yellowstone National Park, by E. T. Allen and Arthur L. Day, February 1936: Econ. Geology, vol. 31, no. 3, pp. 322-325, May 1936.

3368. Copper deposits of the southern Appalachian region: Econ. Geology, vol. 31, no. 4, pp. 428-432, Jüne-July 1936.

Ross, Clyde Polhemus. See also Shenon, 3665.

3369. Geology and ore deposits of the Casto quadrangle, Idaho: U. S. Geol. Survey Bull. 854, 135 pp., 8 pls. (incl. geol. map), 5 figs. (incl. maps), 1934. [1935.]

3370. Copper in Idaho: Copper resources of the world, pp. 261-269, 4 flgs. (incl. geol. maps.), Washington, 16th Internat. Geol. Cong., 1935.

3371. Copper in the West Indies and Central America: Copper resources of the world, pp. 435-441, 1 fig. (map), Washington, 16th Internat. Geol. Cong., 1935.

3372. Geomorphology of south-central Idaho [abstract]': Geol. Soc. America Proc., 1934, p. 103, June 1935.

3373. [Rare mercury chlorides at Terlingua, Texas] [abstract] : Washington Acad. Sci. Jour., vol. 25, no. 12, p. 572; December 15, 1935.

3374. Geology of Texas, vol. 2, pt. 3, Economic geology of Texas (exclusive of petroleum); Preliminary report on the Terlingua quicksilver district, Brewster County, Tex.: Texas Univ. Bull. 3401, pp. 558573, 2 figs. (index maps), December 1935.

3375. (and Cartwright, Weldon E.) Geology of Texas, vol. 2, pt. 3, Economic geology of Texas (exclusive of petroleum) ; Preliminary report on the Shafter mining district, Presidio County, Tex.: Texas Univ. Bull. 3401, pp. 573-608, 3 figs. (incl. geol. map), December 1935.

2376. Some features of the Idaho batholith [with discussion] : 16th Internat. Geol. Cong. (1933) Rept., vol. 1, pp. 369-385, 6 figs. (incl. index and geol. maps), 1936.

Ross, J. S. See Schwarzenbeck, 3600.

Ross, Ralph B.

3377. Structures in the Conemaugh formation near Bakerstown station, Pa. [abstract] : Pittsburgh Univ. Bull., vol. 30, no. 2, p. 509, November $15,1933$.

Ross, Roland Case.

\%. 3378. A new genus and species of pigmy goose from the McKittrick Pleistocene: San Diego Soc. Nat. Histöry Trans.; vol. 8, no. 15, pp. 107114, 6 figs.; August 24, 1935.

Roth, Robert. See Kay, 2035.

Rothrock, Edgar Paul. :

3379. The biennial report of the State geologist, 1932-34: 20 pp., Vermillion,

S. Dak., South Dakota Geol. Survey, [1835]. 
Rothrock, Edgar Paul-Continued.

3380. (and Petsch, Bruno C.). A shallow water supply for Huron, S. Dak.: South Dakota Geol. Survey Rept. Inv. 24, 9 pp. ( $\$), 12$ pls., January 1935.

3381. Geology and water resources of Day County, S. Dak.: South Dakota Geol. Survey Rept. Inv. 25; 42 pp. ( ), 12 pls. (incl. geol. and sketch maps), November 1935 .

3382. The biennial report of the State geologist, 1934-36, $20 \mathrm{pp}$., Vermillion, S: Dak., South Dakota Geol. Survey, [1936].

3383. Logs of some deep wells in western South Dakota: South Dakota Geol. Survey Rept. Inv. 4, 44 pp. ( $¥), 1$ pl. (map), March 1936.

3384. (and Robinson, Thomas William, Jr.). Artesian conditions in westcentral South Dakota; Geology: South Dakota Geol. Survey Rept. Inv. 26, pp. 1-34 ( $)$, July 1936.

Rothrock, Howard Eugene. See also Dane, 969 ; Knechtel, 2229.

3385. Geological activities in State parks: Assoc. Am. State Geologists Jour., vol. 7 , no. 2, pp. 37-39, ( $\$)$, April 1, 1936.

Rouse, John Thomas.

3386. Genesis and structural relations of Absaroka volcanics [abstract] : Am. Mineralogist, vol. 20, no. 3, p. 206, March 1935; Geol. Soc. America Proc., 1934, pp. 103-104, June 1935.

3397. 'The volcanic rocks of the valley area, Park County, Wyo.: Am. Geophys. Union Trans. 16th Ann. Meeting, pt. 1, pp. 274-284 ( $\ddagger), 6$ figs., Nat. Research Council, August 1935.

338s. Structural types associated with the Absaroka volcanics [abstract]: Geol. Soc. America Proc., 1935, p. 100, June 1936.

Rowland, Helen Ione. See also Tucker, Helen Ione, 4178.

3389. The Atlantic and Gulf coast Tertiary Pectinidae of the United States: Am. Midland Naturalist, vol. 17, no. 6, pp. 985-1017, 6 pls., November 1936.

Rowley, Elmer B.

3390. How old is the earth?: Mineralogist, vol. 3, no. 4, p. 28, April 1935. 3391. The mica group; characteristics, occurrence, mining, and use: Mineralogist, vol. 3 , no. 9 , pp. 9-10, 27, September 1935 .

3392. Gore Mountain garnet: Mineralogist, vol. 4, no. 1, p. 26, January 1936.

Roy, Sharat Kumar.

3393. A new Silurian phyllopodous crustacean: Field Mus. Naț. History Pub., Geol. ser., vol. 6, no. 9, pp. 141-146, 1 fig., May 15, 1935.

3394. A new Niagaran Conularia: Field Mus. Nat. History Pub., Geol. ser., vol. 6, no. 10, pp. 147-154, 3 figs., May 15, 1935.

3395. Description of a Silurian phyllopod mandible, with related notes: Field Mus. Nat. History Pub., Geol. ser., vol. 6, no. 11, pp. 155-160, 1 fig.; May 15, 1935.

3396. The question of living bacteria in stony meteorites (with preface by Noel Paul Hudson) : Field Mus. Nat. History Pub., Geol. ser., vol. 6, no. 14, pp. 179-198, 4 figs., December 12, 1935.

Royce, Stephen.

3397. Geology of the Lake Superior iron deposits: Min. Cong. Jour., vol. 22, no. 3, pp. 16-30, 41, 14 figs., March 1936.

3398. Some applications of magnetic surveying to exploration: Min. Cong. Jour., vol. 22, no. 12, pp. 24-26, 48, 6 figs., December 1936. 
Rubey, William Walden. See also Hewett, 1735.

3399. [Review of] National Research Council, Division of Geology and Geography, Annual report for 1933-34, 1934: Am. Assoc. Petroleum Geologists Bull., vol. 19, no. 2, pp. 302-303, February 1935.

3400. The force required to move particles on a stream bed [abstract]: Washington Acad. Sci. Jour., vol. 25, no. 12, pp. 571-572, December 15, 1935.

Ruedemann, Rudolf. See also Buddington, 543; Reed, 3223; Schuchert, 3581. 3401. Paleozoic rocks of the Lowville quadrangle: New York State Mus. Bull. 296, pp. 183-194, 1 fig. (map), 1934.

3902. (and Decker, Charles Elijah). The graptolites of the Viola limestone: Jour. Paleontology, vol. 8, no. 3, pp. 303-327, 4 pls., September 1934.

3403. Ecology of black mud shales of eastern New York: Jour. Paleontology, vol. 9, no. 1, pp. 79-91, January 1935.

3404. A review of the eurypterid rami of the genus Pterygotus, with the descriptions of two new Devonian species: Carnegie Mus. Annals, vol. 24, serial 164, December 1934-August 1935, art. 6, pp. 69-72, 1 pl., 2 figs., March 21, 1935.

3405 (and Laverdière, Joseph-Willie). Notes sur quelques graptolites nouveaux des environs de Québec: Naturaliste Canadien, 3d ser., vol. 6, no. 1, [vol. 62, no. 1], pp. 6-12, 1 pl. January 1935.

3406. (and Chadwick, George Halcott). Ordovician black shales of New York: Science, new ser., vol. 81, no. 2104, p. 400, April 26, 1935.

3407. The eurypterids of Beartooth Butte, Wyo.: Am. Philos. Soc. Proc., vol. 75, no. 2, pp. 129-141, 12 figs., 4 pls., June 1935.

3408. Memorial of George Henry Hudson [1855-1934]: Geol. Soc. America Proc., 1934, pp. 245-250, port., June 1935.

3409. Silurian phyllocarid crustaceans from Oklahoma: Jour Paleontology, vol. 9, no. 5, pp. 447-448, 4 figs., July 1935.

3410. (and Smith, Edward Staples Cousens). The Ordovician in Maine: Am. Jour. Sci., 5th ser., vol. 30, no. 178, pp. 353-355, October 1935.

3411. (and Wilson, T. Yates). Radiolarian cherts of the Deepkill and Normanskill graptolite shales [New York] [abstract] : Geol. Soc. America Proc., 1935, pp. 100, 377, June 1936.

3412. Memorial of Charles Henry Richardson [1862-1935] : Geol. Soc. America Proc., 1935, pp. 301-305, 1 pl. (port.), June 1936.

3413. (and Howell, Benjamin Franklin). Impression of a worm(?) on the cheek of a Cambrian trilobite [abstract]: Geol. Soc. America Proc., 1935, p. 373, June 1936.

3414. Revision of Oldhamia and the Rensselaer grit problem [abstract]: Geol. Soc. America Proc., 1935, p. 383, June 1936.

3415. Ordovician graptolites from Quebec and Tennessee: Jour. Paleontology, vol. 10, no. 5, pp. 385-387, 13 flgs., July 1936.

3416. (and Wilson, T. Yates). Eastern New York Ordovician cherts: Geol. Soc. America Bull., vol. 47, no. 10, pp. 1535-1586, 7 pls., 2 figs. (geol. maps), October 31, 1936.

Ruedy, R. See Sánchez, 3484, 3485.

Ruggles, John P.

3417. Oil in Oriskany; Warren County discovery marks new era of activity in Pennsylvania: Oil Weekly, vol. 83, no. 2, pp. 43-44, 46, 3 figs., September 21, 1936. 
Ruiz, Federico Ramos.

3418. El yacimiento de East Texas (EE.U.U.) : Bol. informaciones petroleras,

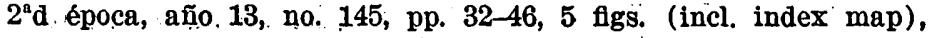
September 1936.

Runner, Delmar G.

3419. The relation of geological formations and road-material surveys: Roads and Streets, vol. 76. no. 8, pp. 301-303, 10 figs., August 1933.

3420. The origin and composition of metamorphic rocks: Roads and Streets, vol. 76 , no. 11, pp. $405-407,6$ flgs. (incl. geol. sketch map), November 1933.

3421. The origin and composition of sedimentary rocks: Roads and Streets, vol. 77, no. 2, pp. 55-58, 4 figs. (incl. index map), February 1934.

3422. The origin and composition of igneous rocks : Roads and Streets, vol. 77, no. 5, pp. 179-183, 7 figs., May 1934.

3423. Fundamentals of practical engineering geology : Roads and Streets, vol. 77, no. 8, pp. 309-312, 7 figs., August 1934.

Runner, Joseph James.

3424. Morinite from Black Hills pegmatite [abstract] : Am. Mineralogist, vol. 20, no. 3, p. 196, March 1935; Geol. Soc. America Proc., 1934, p. 419, June 1935.

Rusk, W. W.

3425. Major unconformities in the geologic section of the Texas Panhandle:

Texas Univ. Bull. 3501, January 1, 1935, pp. 139-140, February 1936.

Russell, George A.

3426. Crystal growth and solution under local stress: Am. Mineralogist, vol. 20, no. 10, pp. 733-737, 2 figs.; October 1935.

Russell, John William.

3427. Devonian fossil wood from Kettle Point, Lake Huron: Canadian Field Naturalist, vol. 50, no. 7, pp. 111-112, 2 figs., October 1936.

Russell, Loris Shano. See also Fraser, 1330.

3428. Musculature and function in the Ceratopsia: Canada Nat. Mus. Bull. 77, pp. 39-48, 9 figs., 1935.

3429. A middle Eocene mammal from British Columbia: Am. Jour. Scl., 5th ser., vol. 29, no. 169, pp. 54-55, 4 figs., January 1935.

3430. Fauna of the upper Milk River beds, southern Alberta: Royal Soc. Canada Trans., 3d ser., vol. 29, pp. 115-128, 5 pls., May 1935 ; abstract, Proc., vol. 29, p. xcix, 1935.

3431. Dinosaur restoration group in the National Museum of Canada [abstract] : Geol. Soc. America Proc., 1934, p. 378, June 1935.

3432. A plesiosaur from the Upper Cretaceous of Manitoba: Jour. Paleontology, vol. 9, no. 5, pp. 385-389, 3 pls., July 1935; abstract, Geol. Soc. America Proc., 1934, p. 378, June 1935.

3433. Oil and gas possibilities along Milk River, southeastern Alberta: Canada Dept. Mines, Geol. Survey Paper 36-12, 24 pp. ( $¥) ; 4$ pls. (geol. maps), April 1936.

3434. New and interesting mammalian fossils from western Canada: Royal Soc. Canada Trans., 3d ser., sec. 4, vol. 30, pp. 75-80, 1 pl., May 1936 ; abstract, Proc. p. x́cix, 1936.

3435. Second multituberculate from the Belly River formation of Alberta [abstract] : Geol. Soc. America Proc., 1935, p. 403, June 1936.

Russell, Philip G. See Kendrick, 2071: 
Russell, Richard Dana.

3436. Mineral composition of Mississippi River bed materials .[abstract] : Geol. Soc. Anerica Proc,, 1934, p. 105, June 1935.

3437. Frequency percentage determinations of detrital quartz and feldspar: Jour. Sedimentary Petrology, vol. 5, no. 3, pp. 109-114, December 1935.

3438. The size distribution of minerals in Mississippi River sands: Jour. Sedimentary. Petrology, vol. 6, no. 3, pp. 125-142, 2 figs., 4 tables, December 1936 ; abstract, Geol. Soc. America Proc., 1934, p. 452, June 1935.

3439. The mineral composition of atmospheric dust collected at Baton Rouge, La.: Am. Jour. Sci., 5th ser., vol. 31, no. 181, pp. 50-66, January 1936.

Russell, Richard Joel. See also Howe, 1840.

3440. Coastal marshes of southwestern Louisiana [abstract]: Assoc. Am. Geographers Annals, vol. 25, p. 54, March 1935.

3441. Slump near Fort Adams, Miss. [abstract]: Geol. Soc, America Proc., 1934, p. 104, June 1935.

3442. (and Howe, Henry Van Wagenen). Cheniers of southwestern Louisiana : Geog. Rev., vol. 25, no. 3, pp. 449-461, 5 figs. (incl. geol. and sketch maps), July 1935.

3443. The desert-rainfall factor in denudation: 16th Internat. Geol. Cong. (1933) Rept., rol. 2, pp. 753-763, 4 figs., 1936.

3444. Deltas of Mississippi River [abstract] : Pan-Am. Geologist, vol. 65, no. 3, pp. 236-237, April 1936.

3445. Climatology of Brown's hypothesis on origin of Gulf border salt deposits: Am. Assoc. Petroleum Geologists Bull., vol. 20, no. 6, pp. 821-824; discussion by Levi Stanley Brown, pp. 824-826, June 1936.

Rust, George W.

3446. Colloidal primary copper ores at Cornwall mines, southeastern Missouri : Jour. Geology, rol. 43, no. 4, pp. 398-426, 9 figs. (incl. index map), May-June 1935.

3447. Post-Cambric volcanism in southeastern Missouri [abstract] : Pan-Am. Geologist, vol. 65, no. 2, p. 158, March 1936.

3448. Preliminary notes on post-Cambrian explosive volcanism in southeastern Missouri [abstract]: Geol. Soc. America Proc., 1935, p. 441, June 1936.

Rutherford, Homer Morgan. See also Ewing, 1198.

3449. Interpretation of reflection seismograms [abstract]: Pittsburgh Univ. Bull., vol. 30, no. 2, pp. 509-510, November 15, 1933.

3450. A formula for weathering correction: Am. Geophys. Union Trans. 15th Ann. Meeting, pt. 1, pp. 78-80, 1 fig., Nat. Research Council, June 1934.

3451. Method for the reduction of seismic reflection data [abstract] : Geol. Soc. America Proc., 1934, p. 452, June 1935.

3452. Reflection dip-shooting methods in seismic prospecting: Am. Geophys. Union Trans. 17th Ann. Meeting, pt. 1, pp. 96-100 ( $¥), 1$ fig., Nat. Research 'Council, Jùly 1936; Earthquake Notes, vol. 8, nos. 1-2, pp. 96-100 (\$), June 1936 .

Rutherford, Ralph Leslie. See also Allan, 31.

3453. Geological examination in the district between Smith and Cold Lake, Alberta: Alberta Research Council 11th Ann. Rept. (no. 28), 1932, pp. 33-38, 1935. 
Rutherford, Ralph Leslie-Continued.

3454. Optically positive cordierite in the Kisseyenew gneiss at Sherridon, Manitoba : Am. Mineralogist, vol. 21, no. 6, pp. 386-388, June 1936.

3455. Geologic age of potash deposits : Geol. Soc. America Bull., vol. 47, no. 8, pp. 1207-1215, August 31, 1936.

3456. Preliminary report on some gravels and sands in the Edmonton; district, Alberta : Canada Geol. Survey Paper 22, 8 pp. ( $\ddagger)$, September 1936.

Rutsch, Rolf.

3457. Beiträge zur Kenntnis tropisch-amerikanischer Tertiärmoliusken; 4, Die stratigraphische Bedeutung der Venericardia planicosta und ihrer Verwandten: Eclogae geol. Helvetiae, vol. 29, no. 1, pp. 151-186, 1 pl., 2 figs. (incl. index map), June 1936.

3458. Beiträge sur-Kenntnis tropisch-amerikanischer Tertiärmollusken; 5, Ist Venericardia beaumonti auf die Oberkreide beschränkt?: Ecolgae geol. Helvetiae, vol. 29, no. 1; pp. 187-207, 1 pl., June 1936:

Rutten, Louis Martin Robert.

3459. Geology of Isla de Pinos, Cuba: K. Akad. Wetensch. Amsterdam, Sec. Sci. Proc., vol. 37, no. 7, pp. 401-406, 1 fig. (sketch map), 1934.

3460. Alte Land- und Meeresberbingungen in West-Indien und Zentralamerika: Geol. Rundschau, Band 26, Heft 1/2, pp. 65-94, 2 pls. (incl. map), 3 figs. (maps), 1935 ; also pub. in K. Nederl. aardr. Genootsch., Amsterdam, Tidschr., vol. 51, pt. 2, no. 4, pp. 551-600, 5 figs."(maps), 2 pls. (incl. maps), 1934.

3461. Ueber den Antillenbogen: K. Akad. Wetensch. Amsterdam, Sec. Sci. Proc., vol. 38, no. 10, pp. 1046-1058, 3 figs. (geol. maps), 1935.

Rutten, Martin Gerard.

3462. Larger Foraminifera of northern Santa Clara Province, Cuba: Jour. Paleontology, vol. 9, no. 6, pp. 527-545, 4 pls., 3 figs., September 1935.

3463. Geology of the northern part of the Province of Santa Clara, Cuba: Geog. geol. Mededeel., Phys.-geol. Reeks, no. 11, 59 pp., 3 pls. (incl. geol. and index maps), 12 figs., 1936.

3464. Rudistids from the Cretaceous of northern Santa Clara Province, Cuba : Jour. Paleontology, vol. 10, no. 2, pp. 134-142, 4 figs. (incl. sketch map), March 1936.

Ryder, Harry M.

3465. Permeability measurements without cores [with discussion] : Pennsyl vania State College, Min. Indus, Exper. Sta. Bull. 20, pp. 43, 15 figs., 1936.

S-, J. H.

3466. Albert B. Reagan [1871-1936] : Science, new ser., vol. 84, no. 2180 애. 525-526, December 11, 1936.

Sabin, Florence Rena.

3467. Biographical memoir of Franklin Paine Mall, 1862-1917: Nat. Acad. Sci. Biog. Mem., vol. 16, no. 3, pp. 63-122, 1 pl. (port.), 1936.

Säve-Söderbergh, G. See also Romer, 3349 .

3468. Further contributions to the Devonian stratigraphy of east Greenland;

2, Investigations on Gauss Peninsula during the summer of 1933, with an appendix, Notes on the geology of the Passage Hills (east Greenland) : Meddelelser om Grönland, Band 96, Nr. 2, 7.4 pp., 10 pls. (incl. geol. maps), 16 figs., 1934.

$311-37-16$ 
Säve-Söderbergh, G.-Continued.

3469. On the dermal bones of the head in labyrinthodont stegocephalians and primitive Reptilia, with special reference to Eotriassic stegocephalians from east Greenland: Meddelelser om Grönland, Band 98, Nr. 3, 211 pp., 68 figs., 15 pls., 1935.

Sahinen, Uuno M.

3470. Résumé of the mineral resources of Montana: Glück Auf, vol. 2, no. 1, pp. 13-15, 1 pl. (mineral distribution map), Butte, Mont., October 1936.

Sahlstein, Thure George.

3471. Petrographie der Eklogiteinschlüsse in den Gneisen des südwestlichen Liverpool-Landes in. Ostgrönland nebst anhang; Granulitartiger Gneis nordöstlich von Kap Hope: Meddelelser om Grönland, Band 95, Nr. 5, 43 pp.; 1 pl., 5 figs., 1935.

3472 Zur Regelung der Gesteine im Kristallin von Liverpool-Land in Ostgrönland: Meddelelser om Grönland, Band 95, Nr. 6, 27 pp., 40 figs. (incl. index map), 1935.

St. Clair, Donald W.

3473. The use of acetic acid to obtain insoluble residues: Jour. Sedimentary Petrology, vol. 5, no. 3, pp. 146-149, 1 pl., December 1935.

St. Clair, Stuart.

3474. Commercial tin in [North] Carolina: Mining and Metallurgy, vol. 16, no. 343, pp. 302-303, July 1935.

Salazar Salinas, Leopoldo.

3475. Nota sobre los temblores cuyo foco se encuentra dentro del Valle de México: Soc. cient. Antonio Alzate Mem., tomo 53, nos. 6, 7, 8, pp. 261-275, 1934.

Sales, Reno Haber.

3476. The ore deposits of the Tri-State district: Econ. Geology, vol. 28, no. 8, pp. 780-786, December 1933.

3477. Government surveys and the mining industry from the viewpoint of the mining geologist [with discussion] : Am. Inst. Min. Met. Eng. Trans., vol. 115 (Mining geology), pp. 393-406; discussion, pp. $452-459,1935$.

Salo, O. J.

3478. Hell Roaring [Creek] Montana chromite deposits, largest in North America : Mineralogist, vol. 3, no. 6, pp. 7-8, 22-23, June 1935.

Sampson, Edward. See Howland, 1869.

Sampson, Reid J.

3479. Mineral resources of a portion of the Perris block, Riverside County, Calif.: California Jour. Mines and Geology, vol. 31, no. 4, pp. 507: 521, 5 figs., October 1935.

Sanabria, Martín López. See Ray, 3189, 3190; 3191.

San Antonio Geological Society.

3480. Geologic road log in Tamaulipas and Nuevo León, Mexico: Am. Assoc. Petroleum Geologists Bull., vol. 20, no. 4, pp. 467-477, 1 fig. (map), April 1936. 
Sanborn, Ethel Ida.

3481. Comstock flora of western Oregon [abstract] : Geol. Soc. America Proc., 1934, pp. 388-389, June ; 1935 .

3482. The prehistoric forests of Oregon: Geol. Soc. Oregon Country News Letter, vol. 2, no. 20, pp. 3-8 ( $\ddagger)$, October 25, 1936.

Sánchez, Pedro C.

3483. A brief contribution on the possibility of the existence of flords on the Mexican coast : Fifth Pacific Sci. Cong., Canada, 1933, Proc., vol. 1, p. 735, 1933.

3484. Studies on the Bay of Acapulco (trans. by R. Ruedy) : Fifth Pacific Sci. Cong., Canada, 1933, Proc., rol. 2, pp. 901-905, 1 fig. (relief map), 1934.

3485. Gravity anomalies in the Republic of Mexico (trans. by R. Ruedy) : Fifth Pacific Sci. Cong., Canada, Proc., vol 2, pp. 1159-1164, 1934.

3486. Métodos geofísicos de prospección: Acad. nac. cient. Antonio Alzate Mem. y rev., tomo 53, 1931, no. 4, pp. 101-133, 1934.

Sánchez Roig, Mario. See Lambert, 2294.

Sanberg, Adolph E.

3487. Notes on ore minerals from the Sugar Loaf district, Lake County, Colo.: Colorado Sci. Soc. Proc., vol. 13, no. 8, pp. 495-504, 1 pl., 1935.

Sander, Bruno.

3488. Petrofabrics (Gefiigekunde der Gesteine) and orogenesis [abstract] : 16th Internat. Geol. Cong. (1933) Rept., p. 998, 1936.

Sanders, T. P.

3489. Secondary fault found present in Pennsylvania gas field: Oil and Gas Jour., vol. 35, no. 21, p. 54, 3 flgs., October 8, 1936.

3490. Many formations in Illinois have oil possibilities: Oil and Gas Jour., vol. 35, no. 29, pp. 40-41, 3 figs., December 3, 1936.

Sanford, John Theron. See also Seiwell, 3634.

3491. The "Clinton" in western New York: Jour. Geology, vol. 43, no. 2, pp. 169-183, 6 figs., February-March 1935.

3492. The Richmond mastodon: Rochester Acad. Sci. Proc., vol. 7, no. 5, pp. 137-156, 8 figs., March 1935; abstract, Geol. Soc. America Bull., vol. 44 , pt. 1, p. 200, February 28, 1933.

3493. Thorold sandstone : Am. Assoc. Petroleum Geologists Bull., vol. 19, no. 9, p. 1390 , September 1935.

3494. Textural studies of lithified sediments [abstract] : Geol. Soc. America Proc., 1935, p. 381, June 1936.

3495. The Clinton in New York: Jour. Geology, vol. 44, no. 7, pp. 797-814, 2 figs., October-November 1936.

Santillán, Manuel.

3496. El cobre en México : Copper resources of the world, pp. 379-406, $1 \mathrm{pl}$. (index map), 1 fig., Washington, 16th Internat. Geol. Cong., 1935.

3497. Berilo y berilio en México: 16th Internat. Geol. Cong. (1933) Rept., vol. 2, pp. 1091-1097, 1 fig. (geol. map), 1936.

3498. Algunas investigaciones sobre platino en México [abstract] : 16th Internat. Geol. Cong. (1933) Rept., vol. 2, pp. 1110-1111, 1936.

3499. Développement et importance de la géologie appliquée au Mexique: Cong. internat. mines, mét., géol. appliquée, sec. Géol. appliquée, $7^{\circ}$ sess., tome 2, pp. 1035-1043, 1936. 
Santinnan, Manuel-Continued.

3500. Synopsis of the geology of Mexico: Oil Weekly, vol. 81, no. 2, pp. 35-37, 40-41, 2 figs. (incl. index map), March 23, 1936.

3501. Synopsis of the Geology of Mexico: Am. Assoc. Petroleum Geologists Bull., vol. 20, no. 4, pp. 394 402, April 1936; abstract, World Petroleum, vol. 7, no. 7, p. 368, July 1936.

Sardeson, Frederick William.

3502. Patrician glaciation in Minnesota: Pan-Am. Geologist, vol. 63, no. 1, pp. 19-24, 1 fig. (geol. map), February 1935.

3503. Behavior of the Bryozoan Prasopora simulatrix: Pan-Am. Geologist, vol. 63, no. 3, pp. 173-188, 1 pl., April 1935.

3504. Behavior of Monticulipora: Pan-Am. Geologist, vol. 64, no. 1, pp. 43-54, $1 \mathrm{pl}$. , August 1935.

3505. Defense of Shakopee title: Pan-Am. Geologist, vol. 64, no. 4, pp. 279285, November 1935.

3506. Behavior of Homotrypa of Decorah shales: Pan-Am. Geologist, vol. 64, no. 5, pp. 343-354, 1 pl., December 1935.

3507. Behavior of Delayella of Decorah shales: Pan-Am. Geologist, vol. 65, no. 1, pp. 19-30, 1 pl., February 1936.

3508. Bryozoan Hallopora behavior : Pan-Am. Geologist, vol. 65, no. 2, pp. 97112, March 1936.

3509. Glacial Minnesota man a damsel: Pan-Am. Geologist, vol. 63, no. 2, pp. 115-118, March 1936.

3510. Pleistocene St. Croix River: Pan-Am. Geologist, vol. 65, no. 3, pp. 189208, 3 pls. (geol. maps), April 1936.

3511. Cambric of upper Mississippi region: Pan-Am. Geologist, vol. 65, no. 5, pp. 339-347, June 1936.

3512. Early Batostoma behavior and Hemiphragma: Pan-Am. Geologist, vol. 66. no. 2. pp. 95-111, 1 pl., September 1936.

3513. Early bryozoans; Monotrypa and Eridotrypa: Pan-Am. Geologist, vol. 66, no. 3, pp. 179-190, 1 pl., October 1936.

3514. Fossil bryozoans; Leptotrypa to Fustulipora: Pan-Am. Geologist, vol. 66, no. 4, pp. 251-263, 1 pl., November 1936.

3515. Early bryozoans; Batostoma to Fenestella: Pan-Am. Geologist, vol. 66, no. 5, pp. 329-346, 1 pl., December 1936.

Saunders, Richardson. See U. S. Com., 4214, 4225.

Savage, W. S.

3516. Solution, transportation, and precipitation of manganese : Econ. Geology, vol. 31, no. 3, pp. 278-297, May 1936.

Saville, Caleb Mills.

3517. Symposium on fluctuations of ground water; The underground water index, its relation to surface runoff: Am. Geophys. Union Trans. 17th Ann. Meeting, pt. 2, pp. 382-386 (\$), 3 figs., Nat. Research Council, 1936.

Sawa, $K$.

3518. On the geological surveying and the recent mining industry in Canada:

South Manchuria Ry. Co., Geol. Inst., no. 85, pp. 18-37, June 1, 1936.

[In Japanese.]

Sawtelle, George. See also Barton, 215.

3519. Salt-dome statistics: Am. Assoc. Petroleum Geologists Bull., vol. 20, no. 6, pp. 726-735, 1 fig. (index map), June 1936 ; reprinted in Gulf coast oil fields (see Barton and Sawtelle), pp. 109-118, 1936. 
Sayles, E. B.

3520. Texas River terraces containing artifacts [abstract] : Pan-Am. Geologist, vol. 64, no. 2, p. 157, September 1935 .

Sayles, Robert Wilcox.

3521. Jay Backus Woodworth (1865-1925) : Am. Acad. Arts Sci. Proc., vol. 70, no, 10, pp. 604-608, March 1936.

3522. Dunes on the Florida east coast [abstract] : Geol. Soc. America Proc., 1935, p. 101, June 1936 .

Saylor, Charles Proffer.

3523. A thin cell for use in determining the refractive indices of crystal grains : U. S. Nat. Bur. Standards Jour. Research, vol. 15; no. 1, pp. 97-98, 1 fig., July 1935.

Sayre, Albert Nelson. See also Livingston, 2429.

3524. Geology and ground-water resources of Uvalde and Medina Counties, Tex. : U. S. Geol. Survey Water-Supply Paper 678, 146 pp., 11 pls. (incl. geol. map), 3 figs. (incl. index maps), 1936. [Water analyses by Margaret D. Foster.]

3525. Symposium on fluctuations of ground water; The relation of the drought of 1934 to ground-water supplies in the James and Cheyenne River basins of North and South Dakota: Am. Geophys. Union Trans. 17th Ann. Meeting, pt. 2, pp. 366-370 (\$), 1 fig., Nat. Research Council, 1936.

Schafer, Paul Abbott.

3526. Geology and ore deposits of the Neihart mining district, Cascade County, Mont.: Montana Bur. Mines and Geology Mem. 13, 62 pp. ( $\ddagger), 8$ pls. (incl. geol. map), 14 figs. (incl. geol. maps), July 1935.

3527. Some geological aspects of Montana water conservation projects : Glïck Auf, vol. 1, no. 5, pp. 2, 4, 30, Butte, Mont., June 1936.

Schairer, John Frank. See also Bowen, 385, 387, 388, 389.

3528. (and Bowen, Norman Levi). Fusion relations of feldspathoids, alkali feldspars, and silica [abstract]: Am. Mineralogist, vol. 20, no. 3, p. 201, March 1935; abstract, Geol. Soc. America Proc., 1934, p. 425, June 1935 .

3529. (and Bowen, Norman Levi). Preliminary report on equilibrium relations between feldspathoids, alkalifeldspars, and silica: Am. Geophys. Union Trañs. 16th Ann. Meeting, pt. 1, pp. 325-328 ( $¥), 3$ figs., Nat. Research Council, August 1935.

3530. (and Bowen, Norman Levi). Pseudowollastonite and wollastonite solid solutions with diopside and akermanite [abstract] : Am. Mineralogist, vol. 21, no. 3, p. 193, March 1936.

Schaller, Waldemar Theodore. See also Graham, 1492 ; Hewett, 1735.

3531. Monticellite from San Bernardino County, Calif., and the monticellite series: Am. Mineralogist, vol. 20, no. 12, pp. 815-827, December 1935.

3532. The origin of kernite and borax in the Kramer borate field, Calif. [abstract] : Am. Mineralogist, vol. 21, no. 3, p. 192, March 1936.

3533. The chemical composition of sepiolite (meerschaum) [abstract]: Am. Mineralogist, vol. 21, no. 3, p. 202, March 1936.

3534. Volcanological boron compounds: Am. Geophys. Union Trans. 17th Ann. Meeting, pt. 1, pp. 234-235 ( $\ddagger$, Nat. Research Council, July 1936. 
Scharf, David W. See also Campbell, 635.

3535. A Miocene mammalian fauna from Sucker Creek, southeastern Oregon: Carnegie Inst. Washington Pub. 453, pp. 97-118, 2 pls., 11 flgs. (incl. index map), July 1935 [preprint, July 20, 1935].

Scheid, Vernon Edward.

3536. A recent back-shore and shore-face terrace along the Severn River, Md.: Washington Acad. Sci. Jour., vol. 25, no. 4, pp. 180-184, 1 fig., April 15, 1935.

Schellhardt, M. A. See Rawlins, 3187.

Schenck, Hubert Gregory.

3537. Classification of nuculid pelecypods: Mus. royal histoire nat. Belgique Bull., tome 10, no. 20, 78 pp., 5 pls., June 1934.

3538. Literature on the shell structure of pelecypods: Mus. royal histoire nat. Belgique Bull., tome 10, no. 34, 20 pp., August 1934.

3539. What is the Vaqueros formation of California and is it Oligocene?: Am. Assoc. Petroleum Geologists Bull., vol. 19, no. 4, pp. 521-536, April 1935; abstract no. 1, p. 137, January 1935.

3540. Valid species of the nuculid pelecypod Acila: Mus. royal histoire nat. Belgique Bull., tome 11, no. 14, 5 pp., 1 pl. (table), May 1935.

3541. (and Reinhart, Philip W.). Oligocene arcid pelecypods of genus Anadara [abstract]: Pan-Am. Geologist, vol. 63, no. 5, pp. 373-374, June 1935; Geol. Soc. America Proc., 1935, p. 412, June 1936.

3542. (and Keen, A. Myra). West American marine molluscan provinces [abstract] : Pan-Am. Geologist, vol. 63, no. 5, pp. 375-376, June 1935 ; Geol. Soc. America Proc., 1935, p. 413, June 1936.

3543. Classification of glycymerid pelecypods [abstract] : Pan-Am. Geologist, vol. 63, no. 5, pp. 376-377, June 1935; Geol. Soc. America Proc. 1935, p. 414, June 1936.

3544. (and Turner, F. Earl). Eocene pleurotomarid from Oregon [abstract] : Geol. Soc. America Proc., 1934, p. 387, June 1935.

3545. (and Hedberg, Hollis Dow, and Kleinpell, Robert Minssen). Stage as a stratigraphic unit [abstract] : Pan-Am. Geologist, vol. 64, no. 1, pp. 70-71, August 1935; Geol. Soc. America Proc., 1935, pp. 347348, June 1936.

3546. (and Kleinpell, Robert Minssen). Foraminifera from Gaviota formation [Calif.] [abstract] : Pan-Am. Geologist, vol. 64, no. 1, p. 76, August 1935; Geol. Soc. America Proc., 1935, p. 352, June 1936.

3547. Beiträge zur Kenntnis tropisch-amerikanischer Tertiärmollusken; pt. 3, Nuculid pelecypods of the genus Acila in the Tertiary of Venezuela, northern Colombia, and Trinidad: Eclogae geol. Helvetiae, vol. 28, Nr. 2, pp. 501-510, December 1935.

3548. Signiflcance of Lepidocyclina in California [abstract] : 16th Internat. Geol. Cong. (1933) Rept., vol. 2, pp. 1105-1106, 1936.

3549. (and Kleinpell, Robert Minssen); Refugian stage of Pacific coast Tertiary: Am. Assoc. Petroleum Geologists Bull., vol. 20, no. 2, pp. 215-225, February 1936.

3550. (and Muller, Siemon William). Stratigraphic terminoligy [abstract]: Geol. Soc. America Proc., 1935, pp. 101-102, 376, June 1936.

3551. Evolution of the Pelecypoda [abstract] : Geol. Soc. America Proc., 1935, p. 368, June 1936. 
Schenck, Hubert Gregory-Continued.

3552. Revision of nuculid pelecypods [abstract]: Geol. Soc. America Proc., 1935 , p. 368, June 1936.

3553. (Frizzell, Donald Leslie). Subgeneric nomenclature in Foraminifera: Am. Jour. Sci., 5th ser. vol. 31, no. 186, pp. 464-466, June 1936 .

Schenk, Edward Theodore.

3554. (and McMasters, John Herbert). Procedure in taxonomy, including a reprint of the International rules of zoölogical nomenclature.with Summaries of opinions rendered to the present date, completely indexed. 72 pp., Stanford Univ., Calif., Stanford Univ. Press, [1936].

3555. A new ammonite genus from the upper Triassic of central Oregon: Am. Midland Naturalist, vol. 16, no. 3, pp. 401-405, 1 pl., May 1935; abstract, Pan-Am. Geologist, vol. 63, no. 5, u. 372, June 1935; Geol. Soc. America Proc., 1935, p. 410, June 1936.

Scheville, William E.

3556. Habits of trilobites: Nat. Research Council Ann. Rept., 1935-36, App. J. Report of the committee on paleoecology, pp. 29-43, October 1936.

Schiefer, H. V.

3557. Gems of Ohio: Mineralogist, vol. 4, no. 1, pp. 7-8, 52-53, January 1936.

Schlaikjer, Erich Maren.

3558. Contributions to the stratigraphy and paleontology of the Goshen Hole area, Wyoming; II, The Torrington member of the Lance formation and a study of a new Triceratops: Harvard Coll. Mus. Comp. Zoology Bull., vol. 76, no. 2, pp. 33-68, 5 figs., 6 pls. (incl. geol. map), January 1935.

3559. Contributions to the stratigraphy and paleontology of the Goshen Hole area, Wyoming; III, A new basal Oligocene formation: Harvard Coll. Mus. Comp. Zoology Bull,, vol. 76, no. 3, 10. figs., 8 pls., January 1935.

3560. Contributions to the stratigraphy and paleontology of Goshen Hole area, Wyoming; IV, New vertebrates and the stratigraphy of the Oligocene and early Miocene: Harvard Coll. Mus. Comp. Zoology Bull., vol. 76, no. 4, pp. 97-189, 13 figs., 41 pls. (incl. geol. maps), May 1935.

3561. New tapir from the lower Miocene of Wyoming [abstract]: Geol. Soc. Ámẹrica Proc., 1935, p. 399, June 1936.

Schlumberger, Conrad, 1878-1936.

3562. (and Schlumberger, Marcel, and Leonardon, Eugene Gilbert). Some observations concerning electrical measurements in anisotropic media and their interpretation [with discussion]: Am. Inst. Min. Met. Eng. Trans., vol. 110, Geophysical Prospecting, pp. 159-182, 18 figs., 1934.

3563. (and Schlumberger, Marcel,•and Leonardon, Eugene Gilbert). Electrical coring; a method of determining bottom-hole data by electrical measurements : Am. Inst. Min. Met. Eng. Trans., vol. 110, Geophysical Prospecting, pp. 237-272, 22 figs., 1934.

Schlumberger, Marcel. See Schlumberger, C., 3562, 3563. 
Schlundt, Herman.

3564. The radioactivity of the spring water on the Hot Springs Reservation, Hot Springs, Ark. Am. Jour. Sci., 5th ser., vol. 30, no. 175, pp. 45-50, July 1935.

Schmitt, Harrison.

3565. Structural associations of certain metalliferous deposits in sonthwestern

- United States and northern Mexico: Am. Inst. Min. Met. Eng. Trans., vol. 115 (Mining geology), pp. 36-58, 19 figs., 1935.

3566. The Central mining district, N. Mex. [with discussion] : Am. Inst: Min. Met. Eng. Trans., vol. 115 (Mining geology), pp. 187-208, 8 figs., 1935 .

S.chneider, Hyrum.

3567. Geologic processes and their relation to human activities in Utah: Utah Acad. Sci. Proc., vol. 12, pp. 159-162, 1935.

3568. The origin of petroliferous materials near Thistle, Utah [abstract] : Utah Acad. Sci. Proc., vol. 13, p. 59, 1936.

Schneiderhöhn, Hans.

3569. Time-temperature curves in relation to mineral associations in cooling intrusions : Econ. Geology, vol. 29, no. 5; pp. 471-480, 8 figs., August 1934.

Schoch, Eugene Paul.

3570. A history of the Division of Natural Resources: Texas Univ. Bull. 3501, January 1, 1935, pp. 11-19, February 1936.

Schoenlaub, Robert Arnold.

3571. Equilibrium studies in the system of monticellite, glaucochroite and calcium fayalite [abstract]: Ohio State Univ. Abstracts Doctors Dissertations, no. 14, pp. 88-97, 7 figs., 1935.

Schoewe, Walter Henry. See also Bryan, 519.

3572. Fluctuation of the water table in the glaciated part of Kansas: Kansas Acad. Sci. Trains., vol. 38, pp. 201-204, 1935.

Schofeld, Stuart James. See also Canada G. S., 655 .

3573. (and Marshall, I. M.). Ore depth in British Columbia mines: Canadian Inst. Min. Metallurgy Trans., vol. 38, pp. 519-525, 2 figs., 1935.

3574. Coast Range composite batholith of British Columbia [abstract] : Geol. Soc. America Proc., 1935, p. 102, June 1936.

Schopf, James M.

3575. Spores characteristic of Illinois coal No. 6: Illinois Acad. Sci. Trans., vol. 28, no. 2, pp. 173-176, 3 figs., December 1935.

Schottenlohr, Rudolf. See Brown, 483.

Schrader, Frank Charles.

- 3576. The Contact mining district, Nev.: U. S. Geol. S'urrey Bull. 847-A, pp. 1-41, 6 figs. (incl. maps), 4 pls. (incl. geol. map), 1935.

Schreiter, Rudolf.

3577. Oelschifer in Amerika: Bohrtechniker-Zeitung, Jahrg. 53, Heft 7, pp. 188-191, July. 15, 1935.

Schroter, G. Austin.

3578. A geologist visits the Mojare mining district: Eng. and Min. Jour., vol. 136, no. 4, pp. 185-188, 3 figs. (incl. geol. sketch map), April 1935.

Schubert, Carl Edward. See Casberg, 690. 
Schuchert, Charles. See also Baker, 149; Chamberlin, 722; Hedberg; 1683; Trask, 4156.

3579. Historical geology of the Antillean-Caribbean region, or the lands bordering the Gulf of Mexico and the Caribbean'Sea. 811 pp., 33 pls. (incl. geol. maps), 91 figs. (incl. geol. maps). New York, John Wiley \& Sons, Inc., 1935.

3580. Correlation of more important marine Permian sequences: Geol. Soc. America Bull., vol. 46 , no. 1, pp. 1-46, 1 pl. (paleogeog. map), 1 fig. (paleogeog. map), January 31, 1935; abstracts, Pan-Am. Geologist, vol. 60 , no. 3 , p. 240 , October $1933 ; 16$ th Internat. Geol. Cong. (1933) Rept., vol. 1, p. 701, 1936.

3581. [Review of] Paleozoic plankton of North America, by Rudolf Ruedemann, 1934: Am. Jour. Sci., 5th ser., vol. 29, no. 173, pp. 462-464, May 1935.

3582. Cambrian and Ordovician stratigraphy and faunas of northwestern Vermont [abstract] : Geol. Soc. America Proc., 1934, p. 105, June 1935.

3583. Edward Salisbury Dana [1849-1935] : Am. Jour. Sci., 5th ser., vol, 30, no. 177, pp. 161-176, 1 pl: (port.), September 1935.

3584. Anton Handlirsch, 1864-1935: Am. Jour. Sci., 5th.ser., vol. 30, no. 180, pp. 565-566, December 1935 .

3585. Carlos Burckhardt [1869-1935] : Am. Jour. Sci., 5th ser., vol. 31, no. 181 , p. 79, January 1936.

3586. Memorial of Edward Salisbury Dana [1849-1935]: Geol. Soc. America Proc. 1935, pp. 201-214, 1 pl. (port.), June 1936.

3587. Some recent geologic philosophy: Am. Jour. Sci., 5th ser., vol. 32, no. 188, pp. 147-150, August 1936.

3588. [Review of] Correlation of the Jurassic formations of parts of Utah, Arizona, New Mexico, and Colorado, by A. A. Baker, C. H. Dane, and J. B. Reeside, Jr., 1936 : Am. Jour. Sci., 5th ser., vol. 32, no: 191, pp. 398-399, November 1936.

Schürmann, H. M. E:

3589. Massengesteine aus Cuba: Neues Jahrb., Beilage-Band 70, Abt. A, pp. 335-355, 2 figs. (incl. sketch map), November 22, 1935.

3590. Lawsonit aus Cuba: Zentralbl. Mineralogie, 1936, Abt. A, no: 8, pp. 245-251, 5 figs.

Schultz, Charles Bertrand. See also Barbour, 177; MacClintock, 2505, 2506.

3591. (and Howard, Edgar Billings). The fauna of Burnet Cave, Guadalupe Mountains, N. Mex.: Acad. Nat. Sci. Philadelphia Proc., vol. 87, pp. 273-298, 6 pls., October 4, 1935.

Schultz, John R.

3592. Plesippus francescana (Frick) from Coso Mountains [Calif.] [abstract] : Pan-Am. Geologist, vol. 64, no. 1, p. 79, August 1985; Géol. Soc. America Proc., 1935, p. 419, June 1936.

Schumacher, Friedrich.

3593. Bericht über den XVI. Internationalen Geologenkongress in Vereinigten Staaten, 1933 : Freiberger geol. Gesell. Ber., Band 15, pp. 52-59, May 1935.

Schwade, I. 'T. See Behre, 256. 
Schwartz, Frederick. William.

3594. (and Mathiasen, R. L.). A study of the composition of black concretions in Onondaga limestone: Science, new ser., vol. 80, no. 2071, p. 232, September 7, 1934.

Schwartz, George Melvin. See also Atwater, 114; Dutton, 1101; Stauffer, 3839.

3595. Relations of chalcocite-stromeyerite-argentite: Econ. Geology, vol. 30, no. 2, pp. 128-146, 9 figs., March-April 1935.

3596.: Silicification of shale in the Mogul mine' [S. Dak.] : Jour. Geology, vol. 43, no. 5, pp. 524-529, 3 figs., July-August 1935.

3597. The geølogy of the Minneapolis-St. Paul metropolitan area: Minnesota Geol. Survey Bull. 27, xi, 267 pp., 8 pls. (incl. geol. map), 45 figs. (incl: geol. maps), 1936.

3598. Structure of the Minneapolis-St. Paul artesian basin [abstract] : Geol. Soc. America Proc., 1935, pp. 102-103, June 1936.

3599. Magnetite metacrysts: Am. Mineralogist, vol. 21, no. 10, pp. 635-641, 7 figs., October 1936.

Schwarzenbek, F. X. See also Kirwan, 2222.

3600. (and Ross, J. S.). Petroleum engineering in the Slick oil field, Creek County, Okla., with a chapter on dehydration methods used in the Slick fleld by J. H.: Cable. $\nabla, 67$ pp. ( $\$), 18$ pls. (incl. geol. sketch map), U. S. Bur. Mines in cooperation with the State of Oklahoma and the Bartlesville [Okla.] Chamber of Commerce, 1922.

Schweizer, Charles W.

3601. Topographic mapping of the alluvial valley of the Mississippi River: Assoc. Am. State Geologists Jour., vol. 6, no. 1, pp. 13-23 ( $)$, January 1, 1985

Sclater, K. C. See Brandenthaler, 436.

Scofield, Carl S.

3602. (and Moon, C. Lloyd, and Knight, Elmer W.). Subsoil waters of Newlands (Nev.) field station: U. S. Dept. Agr. Tech. Bull. 533, 30 pp., 1 tig., October 1936.

Scott, A. Winifred. See Belyea, 274.

Scott, Dukinfield Henry, 1855-1934.

3603. Lepidostrobus kentuckiensis, nomen nov., formerly Lepidostrobus fischeri Scott and Jeffrey; a correction: Royal Soc. London Proc., ser. B, vol. 88, no. B605, pp. 435-436, March 1, 1915.

Scott, Harold W.

3604. Conodont assemblages [abstract]: Geol. Soc. America Proc., 1934, p. 367, June 1935.

3605. Upper Mississippian and lower Pennsylvanian stratigraphy in Montana [abstract] : Geol. Soc. America Proc., 1934, p. 367, June 1935.

3606. The Helena earthquakes: Mining and Contracting Rev., vol. 37, no. 45, p. 7, November 12, 1935.

3607: The epicenter of the Helena, Mont., earthquake: Science, new ser., vol: 82 , no. 2135 , pp. 516-517, November 29, 1935.

3608. Some Carboniferous stratigraphy in Montana and northwestern Wyoming: Jour. Geology, vol. 43, no. 8, pt. 2, pp. 1011-1032, 3 figs., November-December 1935.

3609. Earthquakes, terrors of nature: Gliick Auf, vol. 1, no. 2, pp. 2, 4, 15, 2425, Butte, Mont., Derember 1935. 
Scott, Harold W.-Continued.

3610. The Montana earthquakes of 1935: Montana Bur. Mines and Geology Mem. 16, vi, 47 pp. ( $), 9$ pls. (incl. geol. map), 5 flgs., June 1936; abstract, Glück Auf, vol. 2, no. 1, p. 7, Butte, Mont., October 1936.

Scott, Irving Day. See Case, 691.

Scott, Walter W.

3611. The trend of oil production and petroleum engineering: Texas Univ. Bull. 3501, January 1, 1935, pp. 151-158, February 1936 .

Scott, William Berryman.

3612. (and Jepsen, Glenn Lowell). The mammalian fauna of the White River Oligocene [S. Dak.]; pt. 1, Insectivora and Carnivora: Am. Philos. Soc. Trans., vol. 28, pt. 1, 153 pp., 22 pls., 7 figs., 1936.

3613. The laws of mammalian evolution: Sci. Monthly, vol. 43, no. 5, pp. 421-429, November' 1936.

Scrase, Frederick John.

3614. Modern seismology : Snithsonian Inst. Ann. Rept., 1934, Pub. 3305, pp. 193-204, 1935.

Seagle, Edward F.

3615. Exploration of Roaring Springs cave: Grand Canyon Nature Notes, vol. 9, no. 12, pp. 391-394 ( $\ddagger), 2$ figs., March 1935.

Seaman, David Martin. .

3616. Crystallized tetrahedrite and chalcopyrite from Lake City, Colo.: Mineralogist, vol. 3, no. 4, p. 14, April 1935.

3617. Fluorite deposits of Wagon Wheel Gap, Colo.: Mineralogist, vol. 3, no. 5 , pp. 7-8, May 1935 .

3618. Fluorescent minerals from little-known localities: Rocks and Minerals, vol. 11, no. 4, pp. 52-53, April ${ }_{\circ} 1936$.

Seaman, Wyllys Arthur. See also Staples, 3826.

3619. Mineral classification according to cleavage and crystal habit. 4th ed., 51 pp. Houghton, Mich., Michigan Coll. Min. and Tech. [ $\left.{ }^{c} 1935\right]$.

Sears, Charles E. Jr.

3620. Petrography of the Blue Ridge hematite [abstract]: Virginia Acad. Sci., Proc. 1934-35, p. 69 [1935].

Sears, Julian Ducker.

3621. Geology and fuel resources of the southern part of the San Juan Basin, N. Mex.; pt. 1, The coal fleld from Gallup eastward toward Mount Taylor, with a measured section of pre-Dakota (?) rocks near Navajo Church: U. S. Geol. Survey Bull., 860, pp. 1-29, 17 pls. (incl. geol. maps), 1934.

3622. Progress of topographic mapping in the United States: Assoc. Am. State Geologists Jour., vol. 6, no. 4, pp. 10-13 ( $\ddagger)$, October 1, 1935.

Sears, Paul Bigelow.

3623. Pollen analysis of Mud Lake bog in Ohio: Ecology, rol. 12, no. 4, pp. 650-655, 1 fig., October 1931.

3624. Postglacial climate in eastern North America:- Ecology, vol. 13, no. 1, pp. 1-6, January 1932.

3625. (and Couch, Glen C.). Humus stratigraphy as a clue to past vegetation in Oklahoma [abstract]: Oklahoma Acad. Sci. Proc., 1934, vol. 15, pp. 43-44, 1 pl., 1 fig. (index map), 1935. 
Sears, Paul Bigelow-Continued.

3626. Glacial and postglacial regetation: Botanical Rev., vol. 1; no. 2, pp. 37-51 (Oklahoma Univ. Bot. Lab. Contr. 31), February 1935.

3627. Types of North American pollen profiles: Ecology, vol. 16, no. 3, pp. 488-499, 8 figs. (incl. index map), July 1, 1935.

Secrist, Mark Howard.

3628. Laboratory manual for general geology (physical and historical). 295 pp. (\$), 52 figs., 15 pls., New York, Macmillan Co., 1935.

3629. Perspective block diagrams: Econ. Geology, vol. 31, no. 8, pp. 867-880, 9 figs., December 1936; abstract, Geol. Soc. America Proc., 1935, p. 103, June 1936.

Sederholm, Jakob Johannes, 1863-1934.

3630. Measurement of geologic time from a pre-Cambrian point of view [abstract, with discussion by A. C. Lane]: 16th Internat. Geol. Cong. (1933) Rept., rol. 1, p. 233, 1936.

Seeburger, Merze Marvin (Mrs.)

3631. Teleseismic recording in Iowa: Iowa Acad. Sci. Proc., vol. 42, pp. 133$138,1935$.

3632. Deciphering an earthquake message [abstract] : Pan-Ạm. Geologist, vol: 65, no. 4, p. 314, May 1936.

Seibert, Fred V. See Hutt, 1900.

Seidl, Erich.

3633. Randspaltung und Knick-Druck als Ursache der Gebirgsbildung am Ost- und Westraude des nordamerikanischen Kontinents [abstract] : 16th Internat. Geol. Cong. (1933) Rept., vol. 2, p. 1003, 1936.

Seiwell, Harry Richard.

3634. (and Sanford, John Theron)? Phosphatic nodules in Silurian sediments of western New York [abstract] : Geol. Soc. America Proc., 1934, p. 362 , June 1935.

Self, J. Teague. See Stovall, 3955.

Selfridge, George C., Jr.

3635. An X-ray and optical inrestigation of the serpentine minerals: Am. Mineralogist, vol. 21, no. 8, pp. 463-503, 3 pls., 6 figs., August 1936.

Sellards, Elias Howard. See also Baker, 156.

3636. Stream-terrace building coincident with human occupany in central Texas [abstract]: Geol. Soc. America Proc., 1934, p. 106, June 1935.

3637. (and Baker, Charles Laurence, and others). The geology of Texas, vol. 2, Structural and economic geology: Texas Univ. Bull. 3401, January 1, 1934, 884 pp., 7 pls. (incl. geol. structural maps), 41 figs. (incl. maps), December 1935.

3638. The geology of Texas, vol. 2, pt. 1, Major structural features of Texas east of Pecos River: Texas Univ. Bull. 3401, January 1, 1934, pp. 11-136, 2 pls. (incl. geol. map), 14 figs. (incl. geol. maps), December 1935. 
Sellards, Elias Howard-Continued.

3639. Geology of Texas, vol. 2, pt. 3, Economic geology of Texas (exclusive of petroleum) ; Mineral production in Texas: Texas Univ. Bull. 3401, January 1, 1934, pp. 215-220, 1 fig., December 1935.

3640. The Texas-Oklahoma earthquake of April 11, 1934: Texas Univ. Bull. 3501, January 1, 1935, pp. 259-266, 1 fig. (index map), February 1936; abstract, Geol. Soc. America Proc., 1934, p. 453, June 1935.

3641. Recent studies of early man in the southwestern part. of the United States: Am. Naturalist, rol. 70, no. 729, pp. 361-369, 5 figs. (incl. sketch map), July-August 1936.

Selvig, Walter Alfred. See Fieldner, 1255.

Sermon, Thomas Croxford. See Roman, 3343.

Setchell, William Albert.

3642. Marine plants and Pacific paleogeography: Fifth Pacific Sci. Cong. (Canada, 1933) Proc., vol. 4, pp. 3117-3132, 11 figs., 1934.

Seton, Henry. See Wood, 4586.

Seward, Albert Charles. Sir

3643. (and Conway, Verona M.) Fossil plants from Kingigtok and Kagdlunguak, west Greenland: Meddelelser om Grönland, Band 93, Nr. 5, 41 pp., 5 pls., 21 figs., 1935.

3644. (and Conway, Verona M.) Additional Cretaceous plants from western Greenland: K. svenska retensk, akad, Handl., 3d ser., Band 15, Nr. 3, 41 pp., 6 pls., 32 figs. [December 31, 1935].

Shamblin, William Earle. See U. S. G. S., 4237, 4238.

Shand, Samuel James.

3645 . The mineralogical classification of igneous rocks; a comparison of recent proposals: Jour. Geology, vol. 43, no. 6, pp. 609-617, 1 fig., August-September 1935.

Shappell, Maple Delos.

3646. Cleavage of ionic minerals: Am. Mineralogist, vol. 21, no. 2, pp. 75-102, 2 figs., February 1936; Supplementary note, no. 6, p. 390, June 1936.

Sharp, Henry Staats.

3647. Silver Springs and the Florida ship canal: Science, new ser., vol. 83, no. 2161, pp. 520-522, May 29, 1936.

Sharp, R. P.

3648. Geology of Ravenna quadrangle, Calif. [abstract] : Pan-Am. Geologist, vol. 63, no. 4, p. 314, May 1935; Geol. Soc. America Proc., 1935, p. 336, June 1936.

Sharpe, Charles Farquharson Stewart.

3649. Landslides and related phenomena [abstract]: Geol. Soc. America Proc., 1935, pp. 103-104, June 1936.

Sharpe, Joseph Audley. See also Leith, 2388, 2389.

3650. Motion of the surface of the earth in the compressional phase of a deep-focus earthquake, and the effect of a layered crust: Seismol. Soc. America Bull., vol. 25, no. 3, pp. 199-222, 10 figs., July 1935; abstract, Am. Geophys. Union Trans. 16th Ann. Meeting, pt. 1, p. 93 ( $\$)$, Nat. Research Council, August 1935. 
Shaub, Benjamin Martin.

3651. Color photography in mineralogy [abstract] : Am. Mineralogist, vol. 20, no. 3, p. 199, March 1935; Geol. Soc. America Proc., 1934, p. 422-423, June 1935.

3652. Replacement in filled fissure veins: Am. Mineralogist, vol. 20, no. 12, pp. $875-880,6$ figs., December 1935.

3653. An inexpensive rock-slicing machine: Econ. Geology, vol. 30, no. '8, pp. 916-922, 4 figs., December 1935.

3654. A simple method of making, mounting, and filing polished sections: Econ. Geology, vol. 31, no. 2, pp. 212-218, 2 figs., March-April 1936.

3655. On the use of "polaroid" for photographing large thin sections in crossed polarized light: Am. Mineralogist, vol, 21, no. 6, pp. 384-386, 2 figs., June 1936.

Shearer, M. H.

3656. The Matanuska Valley of southern Alaska: Jour. Geography, vol. 35, no. 5, pp. 186-193, 3 figs. (incl. sketch maps), May 1936.

Sheets, Martin M.

3659. Structural detail near the western border of the thrust sheets north of Shoshone River, Wyo.: Am. Jour. Sci., 5th ser., vol. 29, no. 170, pp. 144-150, 1 fig. (geol. map), February 1935.

Sheldon, Israel $\mathbf{R}$.

3658. Driscoll pool, Duval County, Tex.: Am. Assoc. Petroleum Geologists Bull., vol. 17, no. 7, pp. 816-826, 4 figs. (incl. sketch map), July 1933 ; reprinted in Gulf coast oil fields (see Barton and Sawtelle), pp. 620-630, 1936.

Shenon, Philip John.

3659. (and Reed, John Calvin). Geology of Elk City mining district, Idaho, with special reference to the structural setting of the veins [with discussion] : Am. Inst. Min. Met. Eng. Trans., vol. 115 (Mining geology), pp. 164-186, 7 figs. (incl. geol. map), 1935; abstract, Year Book sec., pp. 81-82, January 1935.

3660. (and Reed, John Calvin). Topographic and geologic map of the Elk City mining district, Idaho: U. S. Dept. Interior Press Mem., 4 pp. ( $\$), 1$ pl. (geol. map), April 5, 1935.

3661. Genesis of the ore at the Flathead mine, northwestern Montana : Econ. Geology, vol. 30, no. 6. pp. 585-603, 9 figs. (incl. geol. maps), September-October 1935.

3662. Utah earthquake of March 24, 1934 [abstract]: Washington Acad. Sci. Jour., vol. 25, no. 11, pp. 508-509, November 15, 1935.

3663. (and Reed, John Calvin). Down Idaho's River of No Return: Nat. Geog. Mag., vol. 70, no. 1, pp. 94-136, 46 figs., July 1936.

3664. (and Taylor, A. V.). Geology and ore occurrence of the Hog Heaven mining district, Flathead County, Mont.: Montana Bur. Mines and Geology Mem. 17, 26 pp. ( $\ddagger), 6$ pls. (incl. geol. maps), 5 figs. (incl. index and geol. maps), July 1936.

3665. (and Ross, Clyde Polhemus). Geology and ore deposits near Edwardsburg and Thunder Mountain, Idaho: Idaho Bur. Mines and Geology Pamph. 44, 45 pp. ( $\ddagger$ ), 19 pls. (incl. index and geol. maps), December 1936.

Shepard, Ann. See Cushman, 942. 
Shepard, Edgar Raymond.

3666. Physical methods of exploration for oil-bearing structures [abstract]: Acoustical Soc. America Jour., vol. 5, no. 3, p. 63, July 1933.

3667. Subsurface exploration by earth-resistivity and seismic methods: Am. Geophys. Union Trans. 16th Ann. Meeting, pt. 1, pp. 78-91 ( $\$)$, 15 figs., Nat. Research Council, August 1935:

3668. Searching for foundation beds by electricity and sound: Eng. NewsRecord, vol. 115, no. 7, pp. 228-232, 7 figs., August 15, 1935.

Shepard, Francis Parker. See also Wanless, 4331.

3669. (and Wanless, Harold Rollin). Permo-Carboniferous series related to Southern Hemisphere glaciation: Science, new ser., vol. 81, no. 2108, pp. 521-522, May 24, 1935.

3670. (and McDonald, G. A.). Sediments of Santa Monica Bay [abstract] : Geol. Soc. America Proc., 1934, p. 322, June 1935.

3671. Exploration of California submarine canyons: Am. Geophys. Union Trans. 16th Ann. Meeting, pt. 1, pp. 245-246 ( $)$, Nat. Research Council, August 1935; abstract, Geol. Soc. America Proc., 1934, pp. 106-107, June 1935.

3672. Submarine canyons of the American coasts: Zeitschr. Geomorphologie, Band 9, Heft 2/3, pp. 99-105, 3 figs. (maps), September 1935.

3673. Gravel cusps on the California coast related to tides: Science, new ser., vol. 82, no. 2124, pp. 251-253, 1 fig., September 13, 1935.

3674. Geological mapping of the ocean bottom: Science, new ser., vol. 82, no. 2139, pp. 614-615, December 27, 1935.

3675. (and Cohee, George Vincent). Continental Shelf sediments off the midAtlantic States: Geol. Soc. America Bull., vol. 47, no. 3, pp. 441457, 4 pls. (index maps), 2 figs., March 31, 1936; abstract, Proc., 1934, p. 107, June 1935.

3676. The underlying causes of submarine canyons [abstract]: Science, new ser., vol. 83, no. 2160 , p. 484, May 22, 1936.

3677. Changes of sea level as the cause of submarine canyons [abstract]: Geol. Soc. America Proc., 1935, p. 104, June 1936.

3678. New discoveries from the California submarine canyons [abstract]: Geol. Soc. America Proc., 1935, pp. 104-105, June 1936.

3679. Northward continuation of the San Andreas fault [abstract] : Geol: Soc. America Proc., 1935, p. 105, June 1936.

3680. Submerged valleys on continental slopes and changes of sea level: Science, new ser., vol. 83, no. 2165, pp. 620-621, June 26, 1936.

3681. Continued exploration of California submarine canyons: Am. Geophys. Union Trans. 17th Ann. Meeting, pt. 1, pp. 221-223 (\$), 1 fig., Nat. Research Council, July 1936.

3682. The underlying - causes of submarine canyons: Nat. Acad. Sci. Proc., vol. 22 , no. 8, pp. 496-502, 1 pl. (map), 4 figs. (incl. maps), August 1936 ; abstract, Science, new ser., vol. 83 , no. 2160 , p. 484 , May 22, 1936.

3683. Undertow, rip tide or "rip current": Science, new ser., vol. 84, no. 2173, pp. 181-182, August 21, 1936.

Shepherd, George Frederick.

3684. A new medium for teaching geology in the Middle West: Illinols Acad.

Sci. Trans., vol. 28, no. 2, p. 198, December 1935. 
Shepherd, George Frederick-Continued.

3685. Rifting and volcanic activity in the Craters of the Moon, Idaho [abstract] : Geol. Soc. America Proc., 1935, pp. 105-106, June 1936.

3686. Philology of volcanism: Pan-Am. Geologist, vol. 66, no. 3, pp. 191-194, October 1936:

Sheppard, E. P. See Douglas, 1075:

Sherrill, Richard Ellis. See also Fridley, 1342.

3687. Local unconformities in Allegheny and Conemaugh formations of southwestern Pennsylvania [abstract]: Geol. Soc. America Proc., 1934, p. 453, June 1935 .

Shideler; William Henry.

3688. Fauna and correlations of the Cumberland "sandstone" [abstract] : Geol. Soc. America Proc., 1934, p. 357, June 1935.

3689. Fulton fauna [abstract] : Geol. Soc. America Proc., 1934, p. 359, June 1935.

Shimek, Bohumil, 1862-1937.

3690. Comparative studies of loess and recent mollusks: Nautilus, vol. 49, no. 3, pp. 71-73, January 1936; no. 4, pp. 119-127, April 1936.

Shimer, Hervey Woodburn. See also Howell, 1860.

3691. Sir Archibald Geikie (1835-1924) : Am. Acad. Arts Sci. Proc., vol. 69, no. 13, pp. 507-508, February 1935.

: 3692. David White (1862-1935) : Am. Acad. Arts Sci. Proc., vol. 70, no. 10, pp. 600-602, March 1936.

Shipley, E. D. See Higgy, 1738.

Shoenfelt, C. E."

- 3693. Discovery of oil at Big Medicine Bow anticline, Carbon County, Wyo.: Am. Assoc. Petroleum Geologists Bull., vol. 19, no. 8, pp. 1238-1239, 1 fig. (map), August 1935.

Short, Maxwell Naylor.

3694. Public geological surreys and geological education [with discussion] : Am. Inst. Min. Met. Eng. Trans., vol. 115 (Mining geology), pp. 445-447, discussion, pp. 452-459, 1935.

Shört, Richard Thomas.

3695. The Cole field, Webb County, Tex. [abstract] : Am. Assoc. Petroleum Geologists Bull., vol. 19, no. 1, p. 140, January 1935.

Shortle, Walter C.

3696. Radioactive minerals, New Hampshire: Mineralogist, vol. 4, no. 12 , pp. 3-4, December 1936.

Shrader, John S: See Gunnell, 1569.

Shrader, John Joseph Shambora.

3697. Halotrichite found near Freeland, Pa.: Rocks and Minerals, vol. 11, no. 1, p. 11, January 1936.

Shrock, Robert Rakes. See also Bucher, 534 ; Croneis, 921; Decker, 999 ; Twenhofel, 4192, 4197.

3698. Probable worm castings ("coprolites") in the Salem limestone of Indi'. ana: Indiana Acad. Sci. Proc., vol. 44, pp. 174-175, 3 figs., 1935.

3699. Insoluble residues from Wisconsin sedimentary rocks; pt. 1 , Insoluble residues as an aid in the study of sedimentary rocks: Wisconsin Acad. Sci. Trans., rol. 29, pp. 257-260, 1 pl. 1935. 
Shrock, Robert Rakes-Continued.

3700 (and Hunzicker, A. A.). A study of some Great Basin lake sediments of California, Nevada, and Oregon: Jour. Sedimentary Petrology, vol. 5, no. 1., pp. 9-30, 5 figs. (incl. maps), 17 tables, April 1935.

3701. Silurian geology of Wisconsin [abstract]: Geol. Soc. America Proc., 1934, pp. 107-108, June 1935.

3702. (and Raasch, Gilbert 0.). Correlation of Ordovician sequence at Kentland, Ind. [abstract] : Geol. Soc. America Proc., 1934, pp. 355-356, June 1935.

Shue, George Llewellyn.

3703. Earth-resistivity measurement and its application to layer problems: Glück Auf, vol. 2, no. 1, pp. 4-5, 27, 1 fig., Butte, Mont., October 1936; no. 2, pp. 10-11, 21-28, 4 figs., December 1936.

Shuler, Ellis William.

3704. Terraces of the Trinity River, Dallas County, Tex. Field and Laboratory (Southern Methodist Univ.), vol. 3, no. 2, pp. 44-53, 2 figs. (maps), April 1935.

3705. Dinosaur tracks mounted in the band stand at Glen Rose, Tex. : Field and Laboratory (Southern Methodist Univ.), vol. 4, no. 1, pp. 9-13, 4 figs., November 1935.

3706. The influence of the shore line, rivers, and springs on the settlement and early development of Texas: Field and Laboratory (Southern Methodist Univ.), vol. 5, no. 1, pp. 23-32, 1 fig. (map), November 1936.

Shulits, Samuel.

3707. Fluvial morphology in terms of slope, abrasion, and bed load: Am. Geophys. Union Trans. 17th Ann. Meeting, pt. 2, pp. 440-444 ( $)$, 1 fig., Nat. Research Council, 1936.

Shull, Charles Albert.

3708. The formation of a new island in the Mississippi River: Ecology, vol. 3, no. 3, pp. 202-206, 2 figs., July 1922.

Sidwell, Raymond.

3709. Mineral study of Kiamichi formation of west Texas: Jour. Sedimentary Petrology, vol. 6, no. 1, pp. 31-34, 3 figs. (incl. sketch map), April 1936.

Siegfus, Stanley S. See Cushman, 942.

Signer, M. I. See Read, 3209.

Silica Products Company.

3710. Bentonite; properties, sources, geology, production, uses: Silica Products Co. Bull. 107, 1930; revised ed., 40 pp., 24 figs., 1934.

Simons, W. H.

3711. Thirty-sixth annual réport of the mining industry of Idaho, for the year 1934. 287 pp., illus. [1935].

Simonson, Russell R.

3712. Piedmontite from Los Angeles County, Calif.: Am. Mineralogist, vol. 20 , no. 10 , pp. 737-738, October 1935.

Simpson, Edward C.

3713. Geology and mineral deposits of the Elizabeth Lake quadrangle, Calif.: California Jour. Mines and Geology, vol. 30, no. 4, October 1934, pp. 371-415, 15 figs. (incl. relief map), 1935.

$311-37-17$ 
Simpson, George Gaylord. See also Hawley, 1656.

3714. Paleobiology of Jurassic mammals: Paleobiologica, Jahr. 5, Band 5, pp. 127-158, 6 figs., 1933.

3715. New Paleocene mammals from the Fort Union of Montana: U. S. Nat. Mus. Proc., vol. 83, no. 2981, pp. 221-244, 1935.

3716. The Tiffany fauna, upper Paleocene; 1, Multituberculata,. Marsupialia, Insectivora, and ?Chiroptera: Am. Mus. Novitates, no. 795, 19 pp., 6 figs., April 20, 1935.

3717. Note on the classification of recent and fossil opossums: Jour. Mammalogy, vol. 16, no. 2, pp. 134-137, May 1935.

3718. The Tiffany fauna, upper Paleocene; 2 , Structure and relationships of Plesiadapis: Am. Mus. Novitates, no. 816, 30 pp., 11 figs., August $16,1935$.

3719. The Tiffany fauna, upper Paleocene; 3, Primates, Carnivora, Condylarthra, and Amblypoda: Am. Mus. Novitates, no. 817, 28 pp., 14 figs., August 16, 1935.

3720. A specimen of the Upper Cretaceous multituberculate Meniscoëssus: Am. Mus. Novitates, no. 825, 4 pp., 2 figs., March 14, 1936.

3721. Census of Paleocene mammals: Am. Mus. Novitates, no. 848,15 pp., May 15, 1936.

3722. Additions to the Puerco fauna, lower Paleocene: Am. Mus. Novitates, no. 849,11 pp., 6 figs., May 18, 1936.

3723. Data on the relationships of local and continental mammaliau faunas: Jour. Paleontology, vol. 10, no. 5, pp. 410-414, 2 figs., July 1936 ; abstract, Geol. Soc. America Proc., 1935, p. 394, June 1936.

3724. A new fauna from the Fort Union of Montana: Am. Mus. Novitates, no. 873, 27 pp., 16 figs., July 13, 1936.

3725. Carsioptychus, new name for Plagioptychus Matthew, nec Matheron: Am. Jour. Sci., 5th ser., vol. 32, no. 189, p. 234, September 1936.

Simpson, R. B. See Andrews, 70.

Sinclair Refining Co., Inc.

3726. The Sinclair dinosaur book. 12 pp., illus., geologic chart, New York (?) [ $\left.{ }^{c} 1934\right]$.

Singewald, Joseph Theophilus, Jr.

3727. [Review of] The Gold Hill mining district, Utah, by T. B. Nolan, 1935 : Econ. Geology, vol. 31, no. 1, pp. 122-125, January-February 1936.

Singewald, Quentin Dreyer. See also Löughin, 2462.

3728. Geological reconnaissance north of Mapimí; [Mexico] [abstract] : Geol. Soc. America Proc., 1934, p. 108, June 1935.

3729. Relations of hydrothermal alteration of porphyries to ore deposition in the Alma district, Colo.: Econ. Geology, vol. 30, no. 5, pp. 518-539, 2 figs. (incl. sketch map), August 1935.

3730. (and Reed, Charles Merton). Insoluble residues from Paleozoic limestones of the Mosquito Range, Colo.: Jour. Paleontology, vol. 5, no. 3, pp. 115-122, 2 pls., December 1935.

3731. (and Butler, Bert Sylvenus). Structure and mineralization along the London fault, Colo. : Am. Inst. Min. Met. Eng: Tech. Pub. 754, 18 pp., 4 figs. (incl. geol. map), 1936; abstract, Mining and Metallurgy, vol. 17, no. 359, p. 546, November 1936.

3732. Evolution of the Coahuila Peninsula, Mexico; pt. 5, Igneous phenomena and geologic structure near Mapimi: Geol. Soc. America Bull., vol. 47, no. 7, pp. 1153-1176, 5 pls. (incl. geol. reconnaissance map), 1 fig. (index map), July 31, 1936. 
Singewald, Quentin Dreyer-Continued.

3733. American Association for the Advancement of Science, section E, Geology and Geography [Proceedings Rochester meeting] : Science, new ser., vol. 84, no. 2170, p. 101, July 31, 1936.

Singleton, F. L.

3734. New geophysical prospecting in southwest of Dickinson [Tex.] : Oil and Gas Jour., vol. 34, no. 10, pp. 129-130, 1 fig. (map), July 25, 1935.

3735. Geophysical exploration of Galveston Bay requires novel engineering: Oil and Gas Jour., vol. 35, no. 2, p. 28, May 28, 1936.

Sisler, James Donaldson, 1894-1935.

3736. (and Tucker, Rietz Courtney). Natural gas in West Virginia : Geology . of natural gas, pp. 989 996, 1 fig. (map), Am. Assoc. Petroleum Geologists, [June] 1935.

Skinner, John W. See Dunbar, 1091, 1092.

Slawson, Chester Baker.

3737. The fluorescence of minerals: Cranbrook Inst. Sci. Bull. 5, 13 pp., 1 pl. (front.), December 1935.

3738. High-iron tourmaline from the Marquette iron range [abstract] : Am. Mineralogist, vol. 21, no. 3, p. 195, March 1936.

3739. (and Peck, Albert Becker). The dtermination of the refractive indices of minerals by the immersion method: Am. Mineralogist, vol. 21, no. 8, pp. 523-528, 1 fig., August 1936.

Sleight, Virgil George.

3740. The geology of Ogishkemuncie Lake and vicinity [abstract] : Northwestern Univ. Summaries Doctoral Dissertations, vol. 1, pp. 216$223,1933$.

Slichter, Louis Byrne.

3741. Progress report on a three-component seisinometer and tiltmeter: Am. Geophys Union Trans. 17th Ann. Meeting, pt. 1, p. 76 ( $\ddagger)$, Nat. Research Council, July 1936 ; Earthquake Notes, vol. 8, nos. 1-2, p. 76 ( $\ddagger)$ June 1936; abstract, Am. Geophys. Union Trans. 16th Ann. Meeting, pt. 1, p. 78 ( $¥)$, Nat Research Council, August 1935.

Slipper, Stanley Eades.

3742. Natural gas in Alberta : Geology of natural gas, pp. 1-57, 28 figs. (incl. maps), 1 pl., Am. Assoc. Petroleum Geologists [June] 1935.

Smiser, Jerome Standley.

3743. (and Wintermann, David). Character and possible origin of producing rock in Hilbig oil field, Bastrop County, Tex.: Am. Assoc. Petroleum Geologists Bull., vol. 19, no. 2, pp. 206-220, 13 figs. (incl. maps), February 1935.

3744. Cretaceous echinoids from trans-Pecos Texas: Jour. Paleontology, vol. 10, no. 6, pp. 449-480, 6 pls., 1 fig. (index map), September 1936.

Smith, Arthur Frank.

3745. (and Grenfell, Donald S., and McQueen, Henry Silliman). The occurrence of halloysite in Lawrence County, Mo.: Missouri Geol. Survey 58th Bienn. Rept., app. 6, 11 pp., 2 figs., 1 pl., 1935.

Smith, Burnett.

3746. Geology and mineral resources of the Skaneateles quadrange: New York State Mus. Bull. 300,120 pp. 61 pls. (incl. geol. maps), 4 figs., Norember 1935. 
Smith, Clarence Raymond.

3747. Mastodon and other remains at Aurora, Ill.: Science, new ser., vol. 81, no. 2103, pp. 379-380, April 19, 1935.

3748. Mastodon and other finds at Aurora : Illinois Acad. Sci. Trans., vol. 28. no. 2, pp. 195-196, December 1935.

Smith, Dudley T. See Rosenholtz, 3357.

Smith, Edward Staples Cousens. See Ruedemann, 3410.

Smith, Gilbert Havens. See Loving, 2472.

Smith, Gene R.

3749. Talco fault zone: Oil Weekly, vol. 81, no. 13, pp. 55-58, 2 figs. (incl. index map), June 8, 1936.

Smith, George C.

3750. Industrial decentralization in relation to raw materials: Assoc. Am. State Geologists Jour., vol. 7, no. 2, pp. 14-21 (\$), April 1, 1936.

Smith, Guy-Harold.

3751. The relative relief of Ohio: Geog. Rev., vol. 25, no. 2, pp. 272-284, 1 fig. (relief map), April 1935.

3752. Cartographical history of the Great American Desert [abstract] : PanAm. Geologist, vol. 65, no. 3, p. 236, April 1936; Assoc. Am. Geographers Annals, vol. 26, no. 1, p. 81, March 1936.

Smith, Hampton.

3753. Origin of some siliceous Miocene rocks of California [abstract] : Geol. Soc. America Proc., 1934, p. 334, June 1935.

Smith, Harold Theodore Uhr.

3754. (and Fraser, Horace John). Loess in the vicinity of Boston, Mass.: Am. Jour. Sci., 5th ser., vol. 30, no. 175, pp. 16-32, 3 figs., July 1935.

3755. Periglacial landslide topography of Canjilon Divide, Rio Arriba County, N. Mex.: Jour. Geology, vol. 44, no. 7, pp. 836-860, 10 figs. (incl. index and topographic maps), October-November 1936.

Smith, Homer. See Romer, 3350.

Smith, J. Hiram.

3756. Insoluble residues in some Ordovician limestones near Lexington, Va. [abstract]: Virginia Acad. S'ci. Proc., 1935-36, p. 70, 1936.

Smith, John Eliphalet.

3757. The "Ledges" and Pennsylvanian problems in Iowa [abstract]: Iowa Acad. Sci. Proc., 1934 (vol. 41), p. 239, 1934.

3758. Geology and the science of teaching [abstract]: Pan-Am. Geologist, vol. 65, no. 4, pp. 319-320, May 1936.

3759. Geology, geography, and soils [abstract]: Pan-Am. Geologist, vol. 65, no. 3, p. 232, April 1936; Geol. Soc. America Proc., 1935, pp. 441-442, June 1936.

Smith, Leon Perdue.

3760. The weathering of flint artifacts: Science, new ser., vol. 84, no. 2173, pp. 183-184, August 21, 1936.

Smith Maxwell.

3761. New Tertiary shells from Florida: Nautilus, vol. 49, no. 4, pp. 135-139, 1 pl., April 1936; vol. 50, no. 1, pp. 20-22, July 1936. 
Smith, Norman.

3762. Geologic theory in mine examinations: Pan-Am. Geologist, vol. 63, no. 1, pp. 33-40, 1 fig., February 1935.

Smith, Philip Sidney. See also Hollick, 1780.

3763. Geographic and geologic evidence relating to the connection of Siberia and northwestern Alaska: Fifth Pacific Sci. Cong., Canada, 1933, Proc., vol. 1, pp. 753-758, 1933.

3764. Airplanes expedite Alaskan survey: Eng. and Min. Jour., vol. 136, no. 11, pp. 565-566, 1 fig., November 1935.

3765. Mineral industry of Alaska in 1934: U. S. Geol. Survey Bull. 868-A, pp. 1-91, 3 figs., 1936.

Smith, Richard Wellington. See also Prindle, 3137.

3766. The mineral production of Georgia for 1933: Forestry-Geol. Rev., vol. 5, no. 4, pp. 7-8, April 1935.

3767. The kyanite industry of Georgia: Am. Inst. Min. Met. Eng. Tech. Pub. 742, 11 pp., 8 figs. (incl. geol. map), 1936; abstract, Mining and Metallurgy, vol. 17, no. 358, p. 500, October 1936.

3768. The mineral production of Georgia for 1934: Forestry-Geol. Rev., vol. 6, no. 2, pp. 7-8, February 1936.

3769. Water, Georgia's unknown natural resource: Georgia Dept. Forestry and Geol. Development, Div. Geology, Inf., Cir. 8, 2 pp., 1 fig., July 1936.

Smith, Stanley.

3770. Two anthracolithic corals from British Columbia and related species from the Tethys: Jour. Paleontology, vol. 9, no. 1, pp. 30-42, January 1935.

Smith, W. C.

3771. (and McDavid, Duncan). Heavy minerals from some Virginia sediments [abstract] : Virginia Acad. Sci. Proc., 1934-35, pp. 67-68, [1935].

Smith, Warren Du Pré.

3772. Leopoldo [Alcaraz] Faustino [1892-1935] : Science, new ser., vol. 83, no. 2146, p. 152, February 14, 1936.

3773. Hiram Dryer McCaskey [1871-1936]: Science, new ser., vol. 84, no. 2173, pp. 174-175, August 21, 1936.

3774. (and Swartzlow, Carl R.). Mount Mazama [Oregon]; explosion versus collapse: Geol. Soc. America Bull., vol. 47, no. 12, pp. 18091830, 6 pls., 5 figs. (incl. index map), December 31, 1936; abstracts, Proc. 1935, p. 329, June 1936; Pan-Am. Geologist, vol. 63, no. 4, p. 305, May 1935; vol. 65, no. 3, pp. 239-240, April 1936.

Smith, William Sidney Tangier.

3775. Fluid inclusions in sphalerite and galena of the Joplin region [abstract]: Am. Mineralogist, vol. 20, no. 3, p. 204, March 1935; abstract, Geol. Soc. America Proc., 1934, pp. 108-109, June 1935.

3776. Secondary character of pebble and ruby jack of the Joplin district: Econ. Geology, vol. 30, no. 6, pp. 699-702, September-October 1935.

Sneigr, Denis Sabinus.

3777. Applications for aerial photography: Oil Weekly, vol. 80, no. 8, pp. 19-21, 3 figs., February 3, 1936; abstract, World Petroleum, vol. 7, no. 4, p. 204, April 1936. 
Sneigr, Denis Sabinus-Continued.

3778. Photomicography; value of such laboratory work is gaining recognition in [oil] industry: Oil Weekly, vol. 82, no. 3, pp. 41-42, 3 figs.,

- June 29, 1936.

Snelgrove, Alfred Kitchener.

3779. Geology of gold deposits of Newfoundland: Newfoundland Dept. Nat. Res., Geol. Sec. Bull. 2, 46 pp. ( $\ddagger$ ), 2 pls. (geol. maps), 11 figs.

(incl. geol. maps), 1935.

3780. An aerial photographic survey of the Blow-Me-Down area in Newfoundland: Eng. and Min. Jour., vol. 137, no. 1, pp. 8-9, 2 figs., January 1936.

Snider, Luther Crocker.

3781. (and Farish, Linn C.). Natural gas in Quebec and the maritime provinces: Geology of natural gas, pp. 89-111, 3 figs. (incl. geol. sketch maps), Am. Assoc. Petroleum Geoloxists. [Junel 1925.

3782. (and Brooks, Benjamin Talbott). Probable petroleum shortage in the United States and methods for its alleviation: Am. Assoc. Petroleum Geologists Bull., vol. 20, no. 1, pp. 15-20, 2 figs., January 1936.

3783. [Review of] Down to earth; an introduction to geology by Carey Gardiner Croneis and William Christian Krumbein, 1936: Am. Assoc. Petroleum Geologists Bull., vol. 20, no. 8, pp. 1131-1133, August 1936.

3784. [Review of] Principles of structural geology, by Charles Merrick Nerin, 2d ed., 1936: Am. Assoc. Petroleum Geologists Bull., vol. 20, no. 10, pp. 1374-1375, October 1936.

3785. An editorial note [Suggestions to authors] : Am. Assoc. Petroleum Geologists Bull., vol. 20, no. 11, pp. 1516-1518, November 1936.

Snow, Leroy G. See U. S. G. S., 4227.

Sohon, Frederick Wyatt.

3786. Report on 24 weeks of microseismic activity [abstract] : Earthquake Notes, vol. 7, nos. 1-2, p. 21 ( $\ddagger)$, September 1935.

3787. A first approximation for deep-focus seismograms: Seismol. Soc. America Bull., vol. 25, no. 4, pp. 311-312, 1 fig., October 1935.

Soper, Edgar Kirke.

3788. (and Grant, Ulysses Simpson, IV). Stratigraphy of part of the western Santa Monica Mountains, Calif. [abstract]: Geol. Soc. America Proc., 1934, pp. 310-311, June 1935.

Sorre, Maxémilien.

3789. Mexique, Amerique centrale: Géographie universelle, tome 14, 234 pp., 49 pls. (incl. map), 48 figs. (incl. geol. maps), 1928.

Soske, Joshua Lawrence. See also Kelley, 2051.

3790. Magnetometer survey of southern portion of San Andreas fault [Callf.] [abstract]: Pan-Am. Geologist, vol. 63, no. 4, pp. 318-319, May 1935 ; Geol. Soc. America Proc., 1935, pp. 340-341, June 1936.

3791. (and Kelley, Vincent C.). Wave-built pumice deposits and Salton rhyolitic hills [Calif.] [abstract] : Pan-Am. Geologist, vol. 63, no. 4, pp. 319-320, May 1935; Geol. Soc. America Proc., 1935, p. 341, June 1936.

Sosman, Robert Browning. See Greig, 1536.

Southwick, E. A.

-3792. A drusy agate find: Rocks and Minerals; vol. 11, no. 11, p. 251, December 1936. 
Spain, Ernest Lynwood, Jr. See also Wilson, 4533, 4534.

3793. Tripoli deposits of the western Tennessee Valley: Am. Inst. Min. Met. Eng. Tech. Pub. 700, 17 pp., 8 figs. (incl. geol. and sketch maps), 1936.

3794. Clay resources of Tennessee Valley Authority region, pt. 1, Clays of the western Tennessee Valley: Tennessee Valley Authority, Div. Geology Bull. 4, pt. 1, pp. 24-32 (\$), 1 pl. (index map), October 1936.

Sparks, Frederick William.

3795. Some new types of pleochroic halos [abstract] : Nova Scotian Inst. Sci. Proc., vol. 19, no. 1, p. 154, December 31, 1935.

Sparks, Neil R. See also Byerly, 604.

3796. The Eureka [Calif.] earthquake of June 6, 1932: Seismol. Soc. America Bull., vol. 26, no. 1, pp. 13-27, 6 figs. (incl. index map), January 1936.

Spath, Leonard Frank.

3797. Additions to the Eo-Triassic invertebrate fauna of east Greenland: Meddelelser om Grönland, Band 98, Nr. 2, 115 pp., 23 pls., 5 figs., 1935.

3798. The upper Jurassic invertebrate faunas of Cape Leslie, Milne Land; 1, Oxfordian and lower Kimmeridgian: Meddelelser om Grönland, Band 99, Nr. 2, 82 pp., 15 pls., 1935; Copenhague, Mus. minéralogie et géologie, Comm. paléont. 53, 1935.

3799. The upper Jurassic invertebrate faunas of Cape Leslie, Milne Land; 2, Upper Kimmeridgian and Portlandian: Meddelelser om Grönland, Band 99, Nr. 3, 180 pp., 50 pls., 1936.

Spearman, Charles.

3800. A system of numerical tabulation of igneous rocks for field purposes: Canadian Min. Jour., vol. 56, no. 6, pp. 229-230, 1 fig., June 1935.

Spence, Hugh Swaine.

3801. Radium discoveries in Northwest Canada: Sands, Clays, and Minerals, vol. 2, no. 3, pp. 8-23, 14 figs. (incl. index maps), June 1935.

3802. (and Muench, Oscar Brauer). Monazite from West Portland Township, Quebec (with note by Alfred Church Lane): Am. Mineralogist, vol. 20 , no. 10 , pp. 724-732, October 1935.

Spencer, Arthur Coe.

3803. (and Paige, Sidney). Geology of the Santa Rita mining area, N. Mex.: U. S. Geol. Survey Bull. 859 , iv, 78 pp., 6 pls. (incl. geol. map), 1 fig., 1935.

Spencer, Leonard James.

3804. Meteorite craters as topographical features on the earth's surface: Smithsonian Inst. Ann. Rept., 1933, pp. 307-325, 3 figs. (incl. maps), 5 pls., 1935.

Spicer, H. Cecil.

3805. Rock temperatures and depths to normal boiling points of water in the United States: Am. Assoc. Petroleum Geologists Bull., vol. 20, no. 3, pp. 270-279, March 1936; abstract, World Petroleum, vol. 7, no. 6, p. 330, June 1936.

Spieker, Edmund Maute.

3806. The orogenic history of central Utah: Science, new ser., vol. 83, no. 2142, pp. 62-63, January 17, 1936. 
Spieker, Edmund Maute-Continued.

3807. Late Cretaceous-early Eocene history of central Utah [abstract] : Geol. Soc. America Proc., 1935, pp. 106-107, 374, June 1936.

3808. Radio transmission and geology : Am. Assoc. Petroleum Geologists Bull., vol. 20, no. 8, pp. 1123-1124, August 1936.

Spivack, J. See De Lury, 1022, 1026.

Spivey, Robert S.

3809. Comparative progressive metamorphism of igneous and sedimentary rocks [abstract] : Pan-Am. Geologist, vol. 65, no. 4, p. 320, May 1936.

Spooner, William C. See also Moody, 2773.

3810. Oil and gas geology of the Gulf coastal plain in Arkansas: Arkansas Geol. Survey Bull. 2, pp. xxxii, 1-474, 95 figs. (incl. maps), 22 pls. (incl. geol. maps), 57 tables (not a State report), Little Rock, Ark., privately printed by Parke-Harper Printing Co., 1935.

Spratt, J. Grant.

3811. (and Taylor, Vernon). Oil prospects along the west flank of Turner Valley gas field: Canadian Inst. Min. Metallurgy Bull. 295, pp. 713-722, 4 figs. (incl. geol. sketch maps), November 1936.

Sprunk, George C. See Fieldner, 1255; Thiessen, 407:.

Stabler, Herman. See Stevens, 3894.

Stach, Erich. See Standnichenko, 3813.

Stadnichenko, Taisia Maximovna. See also Miser, 2750.

3812. Experimental studies bearing on the origin of petroleum [abstract] : 16th Internat. Geol. Cong. (1933) Rept., vol. 2, p. 1009, 1936.

3813. [Review of] Lehrbuch der Kohlenpetrographie, by Erich Stach, 1935: Am. Assoc. Petroleum Geologists Bull., vol. 20, no. 6, pp. 830-832, June 1936.

3814. Petrography and microstructure of coal [abstract] : Washington Acad. Sci. Jour., vol. 26, no. 9, p. 384, September 15, 1936.

Stainbrook, Merrill Addison. See also Kansas Geol. Soc., 2020.

3815. Stratigraphy of the Devonian of the upper Mississippi Valley: Kansas Geol. Soc. Guidebook 9th Ann. Field Conf., pp. 248-260 (\$), 4 figs., 1935.

3816. A Devonian fauna from the Sacramento Mountains near Alamogordo, N. Mex.: Jour. Paleontology, vol. .9, no. 8, pp. 709-714, 1 pl., December 1935 .

Stamey, Roderick A. See also Judson, 2015.

3817. (and Montgomery, J. C., and Easton, Harry Draper, Jr.). Greta oil field, Refugio County, Tex. : A.m. Assoc. Petroleum Geologists Bull., vol. 19, no. 4, pp. 544-559, 7 figs. (incl. maps), April 1935; reprinted in Gulf coast oil fields. (See Barton and Sawtelle), pp. 648-663, 1936.

Stanley, George M. See also Case, 694.

3818. Abrupt decline of the Whittlesey beach at Birmingham, Mich.: Michigan Acad. Sci. Papers, vol. 21, 1935, pp. 445-452, 1 pl., 4 figs. (incl. geol. maps), 1936.

3819. Geology of the Cranbrook area [Mich.] : Cranbrook Inst. Sci. Bull. 6, 56 pp., 12 pls. (incl, geol. map), 12 figs., March 1936. 
Stanley, George M.-Continued.

3820. Lower Algonquin beaches of Penetanguishene Peninsula: Geol. Soc. America Rull., vol. 47, no. 12, pp. 1933-1960, 4 pls., 5 figs., December 31, 1936 ; abstract, Proc. 1935, p. 107, June 1936.

Stanley, Robert C.

3821. Nickel, past and present: Canadian Inst. Min. Metallurgy Trans., vol. 38, pp. 176-208, 3 charts, 1935.

Stanley, T. R.

3822. Foundry sands : Canadian Inst. Min. Metallurgy Trans., vol. 38, pp. 391$396,1935$.

Stanton, Timothy William.

3823. David White [1862-1935] : Jour. Geology, vol. 43, no. 7, pp. 778-780, October-November 1935.

Staples, Lloyd w.

3824. Austinite, a new arsenate mineral from Gold Hill, Utah : Am. Mineralogist, vol. 20, no. 2, pp. 112-119, 3 figs., February 1935; abstract, no. 3, pp. 199-200, March 1935; Geol. Soc. America Proc., 1934, p. 424, June 1935.

3825. Adamite from Gold Hill, Tooele County, Utah: Am. Mineralogist, vol. 20, no. 5, pp. 371-376, 2 figs., May 1935; abstract, no. 3, p. 200, March 1935; Geol. Soc. America Proc., 1934, p. 424, June 1935.

3826. [Review of] Mineral classification according to cleavage and crystal habit, by W. A. Seaman, 4th ed., 1935: Am. Mineralogist, vol. 21, no. 2, p. 139, February 1936.

3827. A simple microchemical test for silicon: Am. Mineralogist, vol. 21, no. 6, pp. 379-383, 3 figs., June 1936.

3828. Mineral determination by microchemical methods: Am. Mineralogist, vol. 21 , no. 10, pp. 613-634, 12 figs., October 1936; abstract, no. 3, p. 195, March 1936.

Stark, John Thomas. See also Howland, 1868.

3829. (and Barnes, Farrell Francis). Geology of the Sawatch Range, Colo.: Colorado Sci. Soc. Proc., vol. 13, no. 8, pp. 467-479, 1 pl. (geol. map), 1935.

3830. Migmatites of the Sawatch Range, Colo.: Jour. Geology, vol. 43, no. 1, pp. 1-26, 20 figs. (incl. geol. map), January-February 1935.

3831. (and Hoagland, A. D.). Bedrock geology of central South Park, [Colo.] [abstract]: Geol. Soc. America Proc., 1934, pp. 109-110, June 1935.

3832. (and Barnes, F. F.). The correlation of pre-Cambrian granites by means of heavy-mineral analyses: Geol. Mag., vol. 72, no. 8 (no. 854), pp. 341-350, 4 figs. (incl. geol. map), August 1935.

3833. (and Behre, Charles Henry, Jr.). Tomichi dome flow: Geol. Soc. America Bull., vol. 47, no. 1, pp. 101-110, 3 pls. (incl. geol. map), 1 fig. (index map), January 31, 1936; abstracts, Proc., 1934, p. 109, June 1935; Am. Mineralogist, vol. 20, no. 3, p. 202, March 1935.

3834. (and others). Vertebrate localities in South Park, Colo.: Science, new ser., vol. 83, no. 2153, pp. 327-328, April 3, 1936.

3835. [Review of] Structural geology, with special reference to economic deposits, by Bohuslav Stočes and Charles Henry White, 1985: Jour. Geology, vol. 44, no. 4, pp. 536-538, May-June 1936. 
Stark, John Thomas-Continued.

3836. (and Johnson, Jesse Harlan, Behre, Charles Henry, Jr.; Powers, William Edwards, Howland, Arthur Lioyd, and Gould, Donald Boyd). History of South Park, Colo. [abstract] ; Geol. Soc. America Proc., 1935, pp. 107-108, June 1936.

Staub, Walther. See Renz, 3249.

Stauffer, Clinton Raymond.

3837. Conodonts of the Glenwood beds : Geol. Soc. America Bull., vol. 46, no. 1, pp. 125-168, 4 pls., January 31, 1935; abstract, Proc., 1933, pp. 340-341, June 1934.

3838. Diminutive fauna in the Shakopee dolomite [abstract]: Geol. Soc. America Proc., 1934, p. 358, June 1935.

3839. (and Burch, Edward P., and Schwartz, George Melvin). A reinterpretation of the Stillwater deep-well records: Jour. Geology, vol. 43, no. 6, pp. 630-638, 1 fig., August-September 1935.

3840. The conodont fauna of the Decorah shale (Ordovician) : Jour. Paleontology, vol. 9, no. 7, pp. 596-620, 5. pls., October 1935.

3841. Pravognathus, a new name for Heterognathus Stauffer (not Girard): Jour. Paleontology, vol. 10, no. 1, p. 79, January 1936.

3842. Shakopee Mollusca from Minnesota [abstract]: Geol. Soc. America Proc., 1935, p. .365, June 1936.

Stauss, Henry Emanuel.

3843. The cooling of the earth as a problem in metallurgy: Sci. Monthly, vol. 42, no: 4, pp. 371-373, April 1936.

Stearn, Noel Hudson.

3844. Stibnite in quartz: Am. Mineralogist, vol. 20, no. 1, pp. 59-62, 1 fig.; January 1935.

3845. Structure and creep: Jour. Geology, vol. 43, no. 3, pp. 323-327, 3 tigs., April-May 1935.

3846. The cinnabar deposits in southwestern Arkansas: Econ. Geology, vol. 31, no. 1, pp. 1-28, 12 figs. (incl. sketch, relief, and geol. maps), January-February 1936.

Stearns, Harold Thornton. See also Chamberlin, 723.

3847. (and Bryan, Lester L., and Crandall, Lynn). Water resources of the Mud Lake region, Idaho: U. S. Dept. Interior Press Mem. 79318, 7 pp., (\$) January 8, 1934.

3848. The geologic history of Oahu (Hawaiian Islands) [abstract]: Washington Acad. Aci. Jour., vol. 25, no. 2, pp. 89-90, February 15, 1935.

3849. (and Vaksvik, Knute Nicholas). Geology and ground-water resources of the island of Oahu, Hawaii: Hawaii (Terr.) Dept. Public Lands, Div. Hydrography Bull. 1, 479 pp., 34 figs., 36 pls. (incl. maps), May 1935.

3850. Shore benches on the island of Oahu, Hawaii: Geol. Soc. America Bull., vol. 46 , no. 10 , pp. 1467-1482, 6 pls., 4 figs., October 31, 1935; abstract, Proc., 1934, p. 111, June 1935.

3851. Pleistocene shore lines on the islands of Oahu and Maui, Hawaii: Geol. Soc. America Bull., vol. 46, no. 12, pp. 1927-1956, 3 pls., 5 figs. (incl. sketch maps), December 31, 1935; abstract, Proc., 1934, pp. 110-111, June 1935.

3852. (and Crandall, Lynn, and Steward, Willard G.). Records of wells on the Snake River Plain, southeastern Idaho: U. S. Geol. Survev Water-Supply Paper 775, 139 pp. (†) 1936. 
Stearns, Harold Thornton-Continued.

3853. Origin of the large springs and their alcoves along the Snake River in southern Idaho: Jour. Geology, vol. 44, no. 4, pp. 429-450, 8 figs. (incl. index map), May-June 1936.

3854. Remarkable lava floods in Soda Springs valley, Idaho [abstract]: Geol. Soc. America Proc., 1935̄, p. 108, June 1936.

Stearns, Norah Dowell.

3855. An island [Oahu] is born. 115 pp., illus., Honolulu, Star-Bulletin Co., 1935.

3856. Annotated bibliography and index of geology and water supply of the island of Oahu, Hawaii : Hawaii (Terr.) Dept. Public Lands, Div. Hydrography Bull. 3, 74 pp., December 1935.

Stechschulte, Victor C.

3857. Deep-focus earthquakes and isostasy: Science, new ser., vol. 83, no. 2148, p. 206, February 28, 1936.

3858. Deep-focus earthquake of June 29, 1934 [abstract] : Pan-Am. Geologist, vol. 65, no. 3, p. 234, April 1936.

3859. Geological implication of deep-focus earthquakes: Am. Geophysical Union Trans. 17th Ann. Meeting, pt. 1, pp. 81-83 ( $\ddagger)$, Nat. Research Council, July 1936; Earthquake Notes, vol. 8, nos. 1-2, pp: 81-83 ( $\$)$, June 1936.

Stefanini, Giuseppe. See Fabiani, 1202.

Steidtmann, Edward.

3860. Travertine-depositing waters near Lexington, Va.: Science, new ser., vol. 82, no. 2127, pp. 333-334, October 4, 1935; abstracts, Am. Mineralogist, vol. 20, no. 3, p. 206, March 1935; Geol. Soc. America Proc., 1934, pp. 111-112, June 1935; Virginia Acad. Sci. Proc., 1934-35, p. 70 [1935].

3861. Humidity and waters of a limestone cavern near Lexington, Va. [abstract] : Virginia Acad. Sci. Proc., 1935-36, p. 69, 1936.

3862. Travertine-depositing waters near Lexington, Va.: Jour. Geology, vol. 44, no. 2, pt. 1, pp. 193-200, February-March 1936.

Steiger, George.

3863. Chemical papers bearing on sedimentation: Nat. Research Council Bull. 98, pp. 195-198, July 1935.

Steinberg, Samuel Sidney.

3864. Mapping from the air: Sci. Monthly, vol. 40, no. 4, pp. 363-366, April 1935.

Stensiö, Erik Andersson.

3865. On the Placodermi of the Upper Devonian of east Greenland: Meddelelser om Grönland, Band 97, Nr. 2, 52 pp., 30 pls., 26 figs. (incl. index map), supplement to pt. 1, 1936.

Stenzel, Hendryk Bronislaw.

3866. Middle Eocene and Oligocene decapod crustaceans from Texas, Louisiana, and Mississippi: Am. Midland Naturalist, vol, 16, no. 3, pp. 379-400, 3 pls., 1 fig., May 1935.

3867. Nautiloids of the genus Aturia from the Eocene of Texas and Alabama: Jour. Paleontology, vol. 9, no. 7, pp. 551-562, 2 pls., 6 figs., October 1935 . 
Stenzel, Hendryk Bronislaw-Continued.

3868. The geology of Texas, vol. 2, pt. 1, Major structural features of Texas east of the Pecos River; Pre-Cambrian structural conditions in the Llano region: Texas Univ. Bull. 3401, pp. 74-79, 1 fig. (geol. map), December 1935.

3869. Structural study of a phacolith [with discussion] : 16th Internat. Geol. Cong. (1933) Rept., vol. 1, pp. 361-367, 1 fig. (geol. map), 1936.

3870. Pre-Cambrian unconformities in the Llano region: Texas Univ. Bull. 3501, January 1, 1935, pp. 115-116, 1 fig., February 1936.

3871. A new formation in the Claiborne group: Texas Univ. Bull. 3501, January 1, 1935, pp. 267-279, 2 figs., February 1936.

3872. Correlation of the Claiborne of southwest Texas with the East Texas section; a discussion by the field-trip committee, led by H. B. Stenzel, Austin, Tex.: Am. Assoc. Petroleum Geologists Bull., vol. 20 , no. 11, p. 1513, November 1936.

Stephens, Maynard Moody.

3873. The identification of types of chalcocite by use of the carbon arc; Econ. Geology, vol. 30, no. 6, pp. 604-629, 12 figs., September-October 1935.

Stephenson, Eugene Austin.

3874. Valuation of natural-gas properties: Geology of natural gas, pp. 10111034, 2 figs., Am. Assoc. Petroleum Geologists, [June] 1935.

Stephenson, Lloyd William. See also Muir, 2821.

3875. Notes on the genus Breviarca: Washington Acad. Sci. Jour., vol. 25, no. 8, pp. 362-363, August 15, 1935.

3876. Further notes on the Cretaceous pelecypod genus Diploschiza: Jour. Paleontology, vol. 9, no. 7, pp. 58s-592, 1 pl. (in part), October 1935.

3877. New Upper Cretaceous Ostreidae from the Gulf region: U. S. Geol. Survey Prof. Paper 186-A, pp. 1-12, 3 pls., 1936.

3878. Geology and paleontology of the Georges Bank canyons; pt. 2, Upper Cretaceous fossils from Georges Bank (including species from Banquereau, Nova Scotia) : Geol. Soc. America Bull., vol. 47, no. 3 , pp. 367-410, 5 pls., March 31, 1936.

3879. Cardium nixicollis and Ostrea battensis substituted for preoccupied names: Jour. Paleontology, vol. 10, no. 7, p. 669, October 1936.

3880. Bentonite in the Upper Cretaceous of New Jersey: Science, new ser., vol. 84, no. 2187, pp. 489-490, November 27, 1936.

Stephenson, Morton B.

3881. Some microfossils of the Potamides matsoni zone of Louisiana: Louisiana Dept. Cons. Geol. Bull 6, pp. 187-196, 22 figs., 1935.

3882. Shell structure of the ostracode genus Cytheridea: Jour. Paleontology, vol. 10, no. 8, pp. 695-703, 1 pl., 2 figs., December 1936.

\section{Sternberg, Charles M.}

3883. Notes on certain recently described dinosaurs: Canadian Field Naturalist, vol. 48 , no. 1 , pp. 7-8, January 1934 .

3884. Hooded hadrosaurs of the Belly River series of the Upper Cretaceous; a comparison, with description of new species: Canada Nat. Mus. Bull. 77, pp. 1-37, 7 pls., 2 figs., 1€35; abstract, Geol. Soc. America Proc., 1984, p. 377, June 1935. 
Sternberg, Charles M.-Continued.

3885. The systematic position of Trachodon: Jour. Paleontology, vol. 10, no. 7. pp. 652-655, 11 figs., October 1936; abstract, Geol. Soc. America Proc., 1935, p. 403, June 1936.

Sternberg, George Fryer. See Barbour, 176.

Sterne, T. E. See Lane, 2329.

Stetson, Harlan True.

3886. The correlation of deep-focus earthquakes with lunar hour angle and declination: Science, new ser., vol. 82, no. 2135, pp. 523-524, 1 fig., November 29, 1935.

Stetson, Henry Crosby.

3887. Bedrock from the continental margin on Georges Bank: Am. Geophys. Union Trans. 16th Ann. Meeting, pt. 1, pp. 226-228 ( $\ddagger)$, Nat. Research Council, 1935.

3888. Marine erosion of glacial deposits in Massachusetts Bay: Jour. Sedimentary Petrology, vol. 5, no. 1, pp. 40-51, 2 figs. (incl. sketch map), April 1935.

3889. Bedrock from the Georges Bank canyons [abstract] : Geol. Soc. America Proc., 1934, p. 112, Jume 1935.

3890. Geology and paleontology of the Georges Bank canyons; pt. 1, Geology : Geol. Soc. America Bull., vol. 47, no. 3, pp. 339-366, 3 pls. (incl. mạps), 3 figs. (incl. sketch maps), March 31, 1936.

3891. Age of the submarine valleys off the central Atlantic coast [abstract] = Geol. Soc. America Proc., 1935, pp. 108-109, June 1936.

3892. Dredge samples from the submarine canyons between the Hudson George and Chesapeake Bay: Am. Geophys. Union Trans. 17th Ann. Meeting, pt. 1, pp. 223-225 ( $\$)$, Nat. Research Council, July 1936.

Stevens, E. H.

3893. Inertia as a possible factor in the mechanics of low-angle thrust faulting: Jour. Geology, vol. 44, no. 6, pp. 729-736, 3 figs., August-September 1936.

Stevens, George D. See Goldston, 1467.

Stevens, John Cyprian.

3894. The silt problem: Am. Soc. Civil Eng. Proc., vol. 60, no. 8, pt. 1, pp. 1179-1218, 9 figs., 1934; with discussions by Harry G. Nickle, vol. 61. no. 2, pp. 270-274, February 1935 ; E. W. Lane and Frank E. Bonner, no. 3, pp. 404-411, March 1935; Morrough P. O'Brien, Harry F. Blaney, W. W. Waggoner, and Philip R. R. Bisschop, no. 5, pp. 707-721, May 1935; Herman Stabler, no. 7, pp. 1075-1082, 1 map, September 1935 ; N. C. Grover, no. 8, pt. 1, pp. 1207-1209, October 1935 ; J. C. Stevens, no. 9, pp. 1376-1378, November 1935 ; reprinted, with discussions, vol. 62 , no. 8 , pt. 2 (Trans. no. 101), pp. 207-288, 11 figs. (incl. index maps), 1936.

Steward, Willard G. See Stearns, 3852.

Stewart, Grace Anne.

3895. Corals of the family Cyathophyllidae from the Middle Devonian of Ohio [abstract] : Geol. Soc. America Proc., 1934, p. 360, June 1935.

3896. A new coral from the Olentangy shale of Ontario: Am. Midland Naturalist, vol. 17, no. 5, pp. 878-880, 4 flgs., September 1936. 
Stewart, Grace Anne--Continued.

3897. Ostracodes of the Silica shale, Middle Devonian, of Ohio: Jour. Paleontology, vol. 10, no. 8, pp. 739-763, 3 pls., December 1936.

Stewart, Hugh A.

3898. The Cut Bank oil field, Glacier County, Mont.: Mines Mag., vol. 26, no. 2, pp. 44-46, 1 fig. (index map), February 1936.

Stewart, Lincoln.

3899. The petrology of the Prospect porphyritic gneiss of Connecticut: Connecticut Geol. and Nat. History Survey Bull. 55, 9 pls. (incl. geol. map), 1 fig. (index map), 1935.

Stiles, M. E. See Rosaire, 3354.

Stille, Hans.

3900. Der derzeitige tektonische Erdzustand: Preuss. Akad. Wiss., Phys.Math. KI., Sitzungsber., Nr. 13, pp. 179-219, 3 figs., April 11, 1935.

3901: Tektonische Beziehungen zwischen Nordamerika und Europa [with discussion] : 16th Internat. Geol. Cong. (1933) Rept., vol. 2, pp. 829838, 1 fig. (geol. map), 1936.

3902. Die Entwicklung des amerikanischen Kordillerensystems in Zeit und Raum: Preuss. Akad. Wiss., Phys.-Math. Kl., Sitzungsber., Nr. 15, pp. 134-155, 3 figs., May 7, 1936.

3903. Der Wechsel der Faltungsräume im Kordillerensystem Amerikas: Naturwissenschaften, Jahrg. 24, Heft 36, pp. 568-569, 2 figs., 4 pls., Berlin, 1936.

3904. The present tectonic state of the earth: Am. Assoc. Petroleum Geologists Bull., vol. 20, no. 7, pp. 849-880, 2 figs., July 1936. [Translated by Hans Ashauer and Ralph Daniel Reed.]

Stipp, T. F.

3905. (and Tolman, F. B.). Eocene geology and stratigraphy of the north side of Simi Valley [abstract] : Geol. Soc. America Proc., 1934, pp. 393-394, June 1935.

Stirton, Ruben Arthur.

3906. (and McGrew, Paul Orman). A preliminary notice on the Miocene and Pliocene mammalian faunas near Valentine, Nebr.: Am. Jour. Sci., 5th ser., vol. 29, no. 170, pp. 125-132, 2 figs., February 1935.

3907. A review of the Tertiary beavers: California Univ., Dept. Geol. Sci. Bull., vol. 23, no. 13, pp. 391-458, 1 pl., 144 figs. (incl. map), May 8, 1935.

3908. Phylogeny of North American Miocene and Pliocene Equidae [abstract] : Geol. Soc. America Proc., 1934, pp. 382-383, June 1935.

3909. New evidence on the ancestry of Equus [abstract] : Geol. Soc. America - Proc., 1935, p. 395, June 1936.

3910. A new beaver from the Pliocene of Arizona, with notes on the species of Dipoides: Jour. Mammalogy, vol. 17, no. 3, pp. 279-281, 2 figs., August 1936.

3911. Succession of North American continental Pliocene mammalian faunas: Am. Jour. Sci., 5th ser., vol. 32, no. 189, pp. 161-206, September 1936 ; abstracts, Pan-Am. Geologist, vol. 64, no. 1, pp. 78-79, August 1935; Geol. Soc. America Proc., 1935, pp. 401-402, 419, June 1736 3912. A new ruminant from the Hemphill middle Pliocene of Texas: Jour. ;: Paleontology, vol. 10, no. 7, pp. 644-647, 3 figs., October 1936.

Stoces, Bohuslav. . See Stark, 3835. 
Stock, Chester.

3913. The vertebrate paleontology of the Sespe formation [abstract]: Am. Assoc. Petroleum Geologists Bull., vol. 19, no. 1, p. 135, January 1935.

3914. New genus of rodent from the Sespe Eocene: Geol. Soc. America Bull., vol. 46, no. 1, pp. 61-68, 1 fig., 1 pl., January 31, 1935; abstracts, Proc., 1934, p. 384, June 1935; Pan-Am. Geologist, vol. 62, no. 1, p. 69, August 1934.

3915. Plesiomiacis, a new creodont from the Sespe upper Eocene, Calyiifornia: Nat. Acad. Sci. Proc., vol. 21, no. 2, pp. 119-122, 3 figs., February $15,1935$.

3916. Insectivora from the Sespe uppermost Eocene, California: Nat. Acad. Sci. Proc., vol. 21, no. 4, pp. 214-219, 9 figs., April 15, 1935.

3917. Sespe faunas [abstract] : Pan-Am. Geologist, vol. 63, no. 4, p. 315, May 1935 ; Geol. Soc. America Proc., 1935, p. 337, June 1936.

3918. Eocene rertebrate faunas from the Sespe, north of Simi Valley [abstract] : Geol. Soc. America Proc., 1934, p. 332, June 1935.

3919. Deep-well record of fossil mammal remains in California : Am. Assoc. Petroleum Geologists Bull., vol. 19, no. 7, pp. 1064-1068, 2 figs., July 1935.

3920. Titanothere remains from the Sespe of California: Nat. Acad. Sci. Proc., vol. 21, no. 7, pp. 456-462, 2 pls., July 15, 1935.

3921. Artiodactyla from the Sespe of the Las Posas Hills, Calif.: Carnegie Inst. Washington Pub. 453, pp. 119-125, 1 pl., July 1935 [preprint, July 20, 1935].

3922. New type of ground sloth from later Cenozoic of Mexico [abstract] : Pan-Am. Geologist, vol. 64, no. 1, p. 78, August 1935; Geol. Soc. America Proc., 1935, p. 418, June 1936.

3923. Exiled elephants of the Channel Islands, Calif.: Sci. Monthly, vol. 41, no. 3, pp. 205-214, 10 figs. (incl. geol. map), September 1935.

3924. (and Bode, Francis D.). Occurrence of lower Oligocene mammalbearing beds near Death Valley, Calif.: Nat. Acad. Sci. Proc., vol. 21, no. 10, pp. 571-579, 4 figs. (incl. geol. reconnaissance map), October 15, 1935.

3925. Antiquity of man in the southwestern United States in. the light of recent cave explorations in New Mexico and Nevada [abstract] : 16th Internat. Geol. Cong. (1933) Rept., vol. 2, p. 813, 1936.

3926. Sespe Eocene didelphids: Nat. Acad. Sci. Proc., vol. 22, no. 2, pp. 122-124, 6 figs., February 15, 1936.

3927. When Titans roamed prehistoric Death Valley: Westways, vol. 28, no. 3, pp. 28-29, 6 figs. (incl. index map), March 1936.

3928. Hesperomeryx, a new artiodactyl from the Sespe Eocene, California: Nat. Acad. Sci. Proc., vol. 22, no. 3, pp. 177-182, 11 figs., March 1936.

3929. Perissodactyla of the Sespe Eocene, California: Nat. Acad. Sci. Proc., vol. 22 , no. 5, pp. 260-265, 2 figs, May 1936.

3930. Ice-age elephants of the Channel Islands [Calif.]: Westways, vol. 28, no. 6, pt. 1, pp. 14-15, 5 figs. (incl. index map), June 1936.

3931. (and Bode, Francis D.). The occurrence of flints and extinct animals in pluvial deposits near Clovis, N. Mex: ; pt. 3, Geology and vertebrate paleontology of the late Quaternary near Clovis, N. Mex. : Acad. Nat. Sci. Philadelphia Proc., 1936, vol. 88, pp. 219-241, 6 pls., 6 figs. (incl. geol. sketch maps), June 15, 1936. 
Stock, Chester-Continued.

3932. Sloth tracks in the Carson prison: Westways, vol. 28 , no. 7, pp. 26-27, 6 figs., July 1936.

3933. The succession of mammalian forms within the period in which human remains are known to occur in America: Am. Naturalist, vol. 70, no. 729, pp. 324-331, July-August 1936.

3934. Titanotheres from the Titus Canyon formation, California: Nat. Acad. Sci. Proc., vol. 22, no. 11, pp. 656-661, 5 figs., November 1936.

3935. Ursus, or the past of the California bears: Westways, vol. 28, no. 11 , p. 30, 3 figs., November 1936.

3936. Mojave's petrified forest: Westways, vol. 28 , no. 12 , pp. 24-25, 7 figs. (incl. sketch map). December 1936.

Stockdale, Paris Buell.

3937. Montlake, an amazing sink hole: Jour. Geology, rol. 44, no. 4, pp. 515-522, 3 figs. (incl. index map), May-June 1936.

3938. Rare stylolites: Am. Jour. Sci., 5th ser., vol. 32, no. 188, pp. 129-133, 1 fig., August 1936.

Stockwell, Clifford Howard. See also Canada G. S., 642, 648.

3939. Gold deposits of Elbow-Morton area, Manitoba, Canada: Canada Dept. Mines, Geol. Survey Mem. 186, 74 pp. 6 pls. (geol. maps), 5 figs. (incl. geol. maps), Pub. 2407, 1935.

3940. Preliminary geological map of Great Slave Lake, east arm (east and west sheets), Northwest Territories: Canada Dept. Mines, Geol. Survey Paper 36-16, 2 pls. (geol. maps), 1936.

Stone, Ralph Walter.

3941. Asbestos, barite, corundum, rutile, and vermiculite in Pennsylvania [abstract]: Am. Mineralogist, vol. 20, no. 3, p. 198, March 1935; Geol. Soc: America Proc., 1934, pp. 112-113, 1935.

3942. Lime in the Mauch Chunk formation [Pennsylvania] [abstract] : Geol. Soc. America Proc., 1935, p. 109, June 1936.

3943. Susveys created after people of State [Pennsylvania] demanded information on. Commonwealth's resources: Pennsylvania Dept. Internal Affairs Monthly Bull., vol. 2, no. 1, pp. 14-16, June 1936.

Stoner, O. E.

3944. Discussion of Upper Cretaceous surface structure and its interpretation in western Kansas [abstract, with discussion]: Tulsa Geol. Soc. Digest, 1934, pp. 39-45.

Storms, Walter Rex.

3945. Prospecting for placer gold: Min. Jour., vol. 20, no. 1, pp. 3-4, 30-31, 3 figs., May 30, 1936.

Stose, George Willis. See also Jonas, 1991, 1993; Miller, 2718; U. S. G. S., 4229.

3946. Comparison of Cambrian rocks of northwest Scotland with equivalent formations of the Appalachians: Washington Acad. Sci. Jour., vol. 25 , no. 4 , pp. 174-180. April 15, 1935.

3947. (and Jonas, Anna Isabel): Highlands near Reading, Pa., an erosion remnant of a great overthrust sheet: Geol. Soc. America Bull., vol. 46, no. 5, pp. 757-779, 2 pls. (geol. maps), 9 figs. (incl. geol. maps); discussion by B. L. Miller, D. M. Fraser and authors' reply, pp. 2031-2040, May 31, 1935; abstracts; with discussion, Proc., 1934, pp. 113-114, June 1935; Washington Acad. Sci. Jour., vol. 25 , no. 11 , pp. 509-510, November $15,1935$. 
Stose, George Willis-Continued.

3948. (and Jonas, Amna Isabel). Limestones of Frederick Valley, Md.: Washington Acad. Sci. Jour., vol. 25, no. 12, pp. 564-565, December 15, 1935.

Stout, Wilber Elihu.

3949. (and Lamborn, Raymond Ellwood, Ring, Dewitt Talmadge, Gillespie, J. S., and Lockett, J. R.). Natural gas in central and eastern Ohio: Geology of natural gas, pp. 897-914, 3 figs. (maps), Am. Assoc. Petroleum Geologists, [June] 1935.

3950. Source material for petroleum and natural gas: Am. Assoc. Petroleum Geologists Bull., vol. 20, no. 6, pp. 797-804, June 1936; abstract, World Petroleum, vol. 7, no. 9, p. 442, September 1936.

Stovall, John Willis.

3951. (and Johnston, C. Stuart). Two fossil grizzly bears from the Pleistocene of Oklahoma : Jour. Geology, vol. 43, no. 2, pp. 208-213, 4 figs., February-March 1935.

3952. (and Strain, W. S.). A hitherto undescribed coprolite from the White River badlands of South Dakota: Jour. Mammalogy, vol. 17, no. 1, pp. 27-2S, February 1936.

3953. (and Wharton, Jay B., Jr.). A new species of phytosaur from Big Spring, Tex.: Jour. Geology, vol. 44, no. 2, pt. 1, pp. 183-192, 2 figs., February-March 1936.

3954. A recent grizzly-bear skull found fossil in Oklahoma: Am. Midland Naturalist, vol. 17, no. 4, pp. 781-783, 2 figs., July 1936.

3955. (and Self, J. Teague). A new specimen of Symbos from Chickasha, Okla.: Jour. Mammalogy, vol. 17, no. 4, p. 422, November 1936.

Stow, Marcellus Henry.

3956. An ebb and flow spring near Fairfield, Va. [abstract]: Virginia Acad. Sci. Proc., 1934-35, p. 70 [1935].

3957. (and Johnson, James H.). Pyroelectricity in tourmaline and its relationship to authigenic growth [abstract]: Virginia Acad. Sci. Proc., 1935-36, p. 70, 1936.

Stoyanow, Alexander A.

3958. Occurrence of the Malone and Torcer faunas at the base of the Arizona Comanchean: Science, new ser., vol. 83, no. 2153, p. 328, April 3, 1936.

3959. Correlation of Arizona Paleozoic formations: Geol. Soc. America Bull., vol. 47, no. 4, pp. 459-540, 1 pl., 5 figs. (index maps), April 30, 1936.

3960. Jurassic and early Cretacic faunas from Arizona [abstract]: Pan-Am. Geologist, vol. 65, no. 5, pp. 375-376, June 1936.

Strachan, Clarice B.

3961. Biographical sketches of recently elected honorary members [of American Association of Petroleum Geologists, W. A. J. M. van Waterschoot van der Gracht, and E. O. Ulrich]: Am. Assoc. Petroleum Geologists Bull, vol. 20, no. 9, pp. 1265-1268, 2 figs. (ports.), September 1936.

Strain, W. S. See Stovall, 3952.

Straley, Harrison Wilson, III.

3962. Nomenclature of folds: Pan-Am. Geologist, vol. 64, no. 5, pp. 335-342, December 1935.

Stranathan, Robert K. See Rose, 3356.

$311-37-18$ 
Stratham, Louis.

3963. Electric earth transients in geophysical prospecting: Geophysics, vol. 1, no. 2, pp. 271-277, 4 figs., July 1936.

Straub, C. E. See Anonymous, 4665 .

Straub, Lorenz George.

3964. Report of the committee on dynamics of streams, 1934-35: Am. Geophys. Union Trans. 16th Ann. Meeting, pt. 2, pp. 443-451 ( $\$)$, Nat. Research Council, August 1935.

3965. Some observations of sorting of river sediments: Am. Geophys. Union Trans. 16th Ann. Meeting, pt. 2, pp. 463-467 ( $\$), 6$ figs., Nat. Research Council. August 1935.

3966. Report of the committee on dynamics of streams, 1935-36: Am. Geophys. Union Trans. 17th Ann. Meeting, pt. 2, p. 334 (†), Nat. Research Council, 1936.

Stringfield, Victor Timothy. See Legette, 2376.

3967. Ground water in Seminole County, Fla.: Florida Board Cons., Geol. Dept., Rept. Inv. no. 1, 14 pp. (\$), 1 pl. (index map), 1934.

3968. The piezometric surface of artesian water in the Florida Peninsula: Am. Geophys. Union Trans. 16th Ann. Meeting, pt. 2, pp. 524-529, 4 figs., National Research Council, June 1935.

3969. Artesian water in the Florida Peninsula: U. S. Geol. Survey WaterSupply Paper 773-C, pp. iv, 115-195 (\$), 11 pls. (incl. topographic and water maps), 9 figs. (incl. index map), 1936.

Stringham, Bronson.

3970. An occurrence of feldspar replacing fossils [abstract]: Am. Mineralogist, vol. 21, no. 3, p. 200, March 1936.

Strong, A. M. See Grant, 1497.

Stuckey, Jasper Leonidas. See Prouty, 3143.

3971. North Carolina talc deposits [abstract] : Elisha Mitchell Sci. Soc. Jour., vol. 50, no. 1/2, pp. 41-42, December 1934.

3972. (and Davis, Harry Towles). Barite deposits in North Carolina [with discussion] : Am. Inst. Min. Met. Eng. Trans., vol, 115 (Mining geology), pp. 346-355, 3 figs. (incl. map), 1935.

3973. Origin of cyanite: Econ. Geology, vol. 30, no. 4, pp. 444-450, June-July 1935.

Sueno, T.

3974. Microscope with universally movable tube: Am. Mineralogist, vol. 21, no. 5, pp. 295-298, 2 figs., May 1936.

Suess, Franz Eduard.

3975. Europäische und nordamerikanische Gebirgszusammenhänge: 16th Internat. Geol. Cong. (1933) Rept., vol. 2, pp. 815-828; discussion, p. 838, 1936.

3976. Tectonic affinities between. European and North American mountain systems: Pan-Am. Geologist, vol. 65, no. 2, pp. 81-96, March 1936.

Suffel, George Gordon.

3977. Relations of later gabbro to sulphides at the Horne mine, Noranda, Quebec: Econ. Geology, vol. 30, no. 8, pp. 905-915, 3 figs., December 1935.

Sumner, James Batcheller.

3978. Memorial of Cleveland Abbe, Jr. [1872-1934] : Geol. Soc. America Proc., 1934, pp. 151-160, port., June 1935. 
Sundeen, S. W.

3979. (and others). Annotations of selected papers on the mechanics of igneous invasion: Nat. Research Council, Div. Geology and Geography Ann. Rept. 1934-35, app. A, exhibit B, 54 pp. ( $¥$ ), October 1935.

Sundstrom, Raymond W. See Barksdale, 184; Leggette, 2376.

Sundt, Olaf Francis.

3980. Recent developments in gravity prospecting on Gulf coast: Am. Assoc. Petroleum Geologists Bull., vol. 19, no. 1, pp. 19-24, January 1935.

Sutherland, J. Clark.

3981. Geological investigation of the clays of Riverside and Orange Counties, southern California: California Jour. Mines and Geology, vol. 31 , no. 1, pp. 51-87, 23 figs. (incl. sketch map), 1 pl. (map), January 1935.

Sutherland, M. G.

3982. The relative ages of the Virginia granites [abstract]: Virginia Acad. Sci. Proc., 1934-35, p. 69 [1935].

Sutton, Arle Herbert. See also Harper, 1635; Kansas Geol. Soc. 2020.

3983. Stratigraphy of the Silurian system of the upper Mississippi Valley: Kansas Geol. Soc. Guidebook $9 \mathrm{th}^{\circ}$ Ann. Field Conf., pp. 268-280, (\$), 3 figs. (incl. geol. sketch map), 1935.

3984. Ovoviviparous reproduction of Miocene Turritellidae: Am. Midland Naturalist, vol. 16, no. 1, pp. 107-109, January 1935; abstract, Illinois Acad. Sci. Trans., vol. 27, no. 2, p. 118, December 1934.

Suzuki, Francis T. See Wentworth, 4406.

Swanson, Clarence Otto.

3985. Use of magnetic data in Michigan iron ranges [abstract]: Am. Inst. Min. Met. Eng. Year Book sec. p. 91, 1935.

3986. The dip needle as a magnetometer: Geophysics, vol. 1, no. 1, pp. 48-96, 25 figs., January 1936; abstract, World Petroleum, vol. 7, no. 8, p. 406, Angust 1936.

Swarts, C. R.

3987. (and Bopp, Charles Robert, and Morris S. W.). Preliminary engineering report on the Seminole pool, Seminole County, Okla., $57 \mathrm{pp}$. ( ), 9 pls. (incl. geol. sketch map), U. S. Bur. Mines in cooperation with the State of Oklahoma, July 1928.

Swartz, Charles Kephart.

3988. Geological education: Geol. Soc. America Bull., vol. 47, no. 2, pp. 187196, February 29, 1936.

Swartz, Frank McKim.

39S9. Silurian sections in north-central Pennsylvania [abstract] : Geol. Soc. America Proc., 1934, p. 114, June 1935.

3990. Relations of the Silurian Rochester and McKenzie formations near Cumberland, Md., and Lakemont, Pa.: Geol. Soc. America Bull., vol. 46, no. 8, pp. 1165-1194, 4 figs. (incl: index map), August 31, 1935 ; Pennisylviania State College, Min. Indus. Exper. Sta. Tech. Paper 17, 1935.

3991. Revision of the Primitiidae and Beyrichiidae, with new Ostracoda from the Lower: Devoniạn of Pennsylvania: Jour. Paleontology, vol. 10, no. 7, pp. 541-586, 12 pls., October 1936; abstract, Geol. Soc. America Proc., 1935, p. 371, June 1936. 
Swartz, Joel Huward.

3992. Some risults of electrical prospecting for oil and gas [abstract]: Elisha Mitchell Sci. Soc. Jour., vol. 48, no. 1, p. 24, October 1932.

Swartzlow, Carl R. See also Smith, 3774.

3993. Ice caves in northern California: Jour. Geology, vol. 43, no. 4, pp. 440 442, May-June 1935.

Swick, Clarence Herbert.

3994. Recent progress in gravity work: Am. Geophys. Union Trans. 15th Ann. Meeting, pt. 1, pp. 53-56 ( $\$$ ), 1 fig. (index map), June 1934.

Swigart, Theodore Earl.

3995. Underground problems in the Comanche oil and gas field, Stephens County, Okla., 42 pp. (\$), 2 pls. (incl. geol. sketch map), U. S. Bur. Mines in cooperation with the State of Oklahoma, September 1919.

Swindell, Floyd. See Dott, 1071.

Swinnerton, Allyn Coats.

3996. Structure-control classification of limestone caverns [abstract]: Geol. Soc. America Proc. 1934, p. 115, June 1935.

3997. Cathedral domes in Mammoth Cave [abstract]: Geol. Soc. America Proc., 1935, p. 109, June 1936.

Swinnerton, Ayler Aberffraw. See Rosewarne, 3361.

Swinton, William Elgin. See Reed, 3222.

Sykes, Godfrey.

3998. Continuation of study of the Colorado Delta and the lower Colorado River: Carnegie Inst. Washington Year Book 34, pp. 351-353, 1935.

Syromyatnikov, F. V.

3999. The problem of the transfer of silica by water vapors: Econ. Geology, vol. 30, no. 1, pp. 89-92, January-February 1935.

4000. The micropycnometric method for the determination of specific gravities of minerals: Am. Mineralogist, vol. 20, no. 5, pp. 364-370, 1 fig., May 1935.

Taber, Charles Austin Mendell, 1824-

4001. The coming ice age. 94 pp., Boston, Geo. H. Ellis, 1896.

Taber, Stephen.

4002. Geology of the Santee-Cooper project [abstract] : South Carolina Acad. Sci. Bull., vol. 1, pp. 9-10, 1935.

4003. The origin of cyanite: Econ. Geology, vol. 30, no. 8, pp. 923-924, December 1935 .

4004. Frozen ground in Alaska [abstract] : Geol. Soc. America Proc., 1935, pp. 109-110, June 1936.

Taff, Joseph Alexander. See also Clark, 755; Hanna, 1616.

4005. Geology of Mount Diablo and vicinity: Geol. Soc. America Bull., vol. 46, no. 7, pp. 1079-1100, 1 pl. (geol. map), 1 fig. (structural map); discussion by Bailey Willis and reply, pp. 2040-2045, 1 fig. July 31, 1935 ; abstract, Proc., 1934, p. 115, June 1935.

Taft, H. H.

4006. Magnesite in Doña Ana County, N. Mex. : Eng. and Min. Jour., vol. 137, no. 3, p. 137, 1 fig., March 1936. 
Taliaferro, Nicholas Lloyd.

4007. Geology of San Simeon, Adelaida, and Paso Robles quadrangles [Calif.] [abstract] : Pan-Am. Geologist, vol. 63, no. 4, p. 316, May 1935; Geol. Soc. America Proc., 1935, p. 338, June 1936.

4008. Some properties of opal: Am. Jour. Sci., 5th ser., vol. 30, no. 179, pp. 450-474, 9 figs., November 1935; abstract, Geol. Soc. America Proc., 1934, p. 320, June 1935.

Talley, B. B.

4009. Recent developments in aerial mapping: Military Engineer, vol. 28, no. 161, pp. 346-348, 4 figs., September-October 1936.

4010. Mapping by the use of aerial photographs [with discussion by Majors Charles H. Cunningham and James W. Bagley] : Military Engineer, vol. 27, no. 155, pp. 357-361, 6 figs., September-October 1935.

Talmadge, Sterling Booth.

4011. Folding of Chupadera beds near Lincoln, N. Mex. [abstract] : Pan-Am. Geologist, vol. 64, no. 2, pp. 153-154, September 1935.

Taning, Å. Veder.

4012. A supposed submarine ridge along the southeast coast of Greenland: Nature, vol. 133, no. 3357 , p. 326, 2 figs. (incl. sketch map), March 3 , 1934.

Tanton, Thomas Leslie. See also Canada G. S. 666 .

4013. Geology of Sturgeon River area [Ontario] [with discussion] : Canadian Inst. Min. Metallurgy Trans., vol. 38, pp. 341-348, 5 flgs., 1935.

4014. Copper-nickel mineral occurrences in Pigeon River area, Ontario: Canada Dept. Mines, Geol. Survey Paper 35-1, 11 p. ( $\ddagger)$, December 1935.

Tarr, Ralph Stockman, 1864-1912.

4015. Insecurity of peneplanal hypothesis in New England: Pan-Am. Geologist, vol. 65, no. 3, pp. 181-18s, April 1936 ; reprinted, with changes, from Am. Geologist, vol. 21, pp. 351-370, 1898.

Tarr, William Arthur. See also Branson, 441.

4016. The linnaeite group of cobalt-nickel-iron-copper sulfides: Am. Mineralogist, vol. 20, no. 2, pp. 69-80, 4 figs., February 1935.

4017. Concretions in the Champlain formation of the Connecticut River Valley : Geol. Soc. America Bull., vol. 46, no. 10, pp. 1493-1534, 11 pls., 2 figs., discussion by Richard Foster Flint and author's reply, pp. 2057-2059, October 31, 1935.

4018. (and Keller, Walter David). Dickite in Missouri: Am. Mineralogist, vol. 21 , no. 2, pp. 109-114, February 1936; abstract, no. 3, p. 195, March 1936.

4019. Notes on 1934-35 articles on siliceous sediments: Nat. Research Council Ann. Rept., 1934-35, app. I, Report of committee on sedimentation, pp. 13-17 $(\$)$, September 1936.

4020. Origin of the southeastern Missouri lead deposits, pt. 1: Econ. Geology, vol. 31, no. 7, pp. 712-754, 18 figs. (incl. index map), November 1936 ; pt. 2, no. 8, pp. 832-S66, December 1936.

Tatum, J. L.

4021. Geology and exploration in northeastern Mexico: Oil Weekly, vol. 77, no. 13, pp. 35-40, 1 fig. (map), June 10, 1935. 
Tatum, J. L.-Continued.

4022. (and Dawson, Joseph M.). Geologic road log of Pan-American Highway, Laredo to Mexico City: Am. Assoc. Petroleum Geologists Bull., vol. 20, no. 4, pp. 457-466, 1 pl. (map), 1 fig. (geol. map), April 1936.

Taylor, A. V. See Shenon, 3664.

Taylor, Colin A.

4023. Debris flow from canyons in Los Angeles County flood: Eng. NewsRecord, vol. 112, no. 13, pp. 439-440, 5 figs., April 5, 1934.

Taylor, Garvin Lawrence.

4024. Pre-Cambrian granites of the Black Hills: Am. Jour. Sci., 5th ser., vol. 29, no. 171, pp. 278-291, 1 fig., March 1935.

Taylor, George Holmes. See also Leggette, 2375, 2379.

4025. (and Leggette, Ralph Maxwell). Ground water relieves drought emergency : Eng. News-Record, vol. 115, no. 11, pp. 359-361, 2 figs. (incl. geol. map), September 12, 1935.

4026. Some effects of earthquakes on ground-water levels [abstract]: Utah Acad. Sci. Proc., vol. 13, p. 91, 1936.

4027. Symposium on fluctuations of ground water; Fluctuations of groundwater levels in Utah: Am. Geophys. Union Trans. 17th Ann. Meeting, pt. 2, pp. 378-382 ( $\$$ ), 2 figs., Nat. Research Council, 1936.

Taylor, James $\mathbf{H}$.

4028. A contact metamorphic zone from the Little Belt Mountains, Mont.: Am. Mineralogist, vol. 20, no. 2, pp. 120-128, 2 figs., February 1935.

Taylor, Josiah.

4029. Intensive seismic exploration in north Louisiana district: Oil and Gas Jour., vol. 35, no. 22, pp. 79, 82, 5 figs., October 15, 1936.

Taylor, Nelson Woodsworth.

4030. (and Williams, Francis J.). Reactions between solids in the system $\mathrm{CaO}-\mathrm{MgO}-\mathrm{SiO}_{2}$ in the temperature range $600^{\circ}$ C. $-1,200^{\circ}$ O.: Geol. Soc. America Bull., vol. 46, no. 7, pp. 1121-11.36, 1 pl., 1 fig., July 31, 1935; Pennsylvania State College, Min. Indus. Exper. Sta., Tech. Paper 15, 1935 ; abstracts, Am. Mineralogist, vol. 20, no. 3, p. 209, March 1935; Geol. Soc. America Proc., 1934, pp. 115-116, June 1935.

Taylor, Vernon. See Spratt, 3811.

Teas, Livingston Pierson.

4031. Hockley salt shaft, Harris County, Tex.: Am. Assoc. Petroleum Geologists Bull., vol. 15, no. 4, pp. 465-469, 3 figs., April 1931; reprinted in Gulf coast oil fields (see Barton and Sawtelle), pp. 136-140, 1936.

4032. (and Miller, Charis R.). Raccoon Bend oil field, Austin County, Tex.: Am. Assoc. Petroleum Geologists Bull., vol. 17, no. 12, pp. 14591491, 7 figs., December 1933 ; reprinted in Gulf coast oil fields (see Barton and Sawtelle), pp. 676-708, 1936.

4033. Natural gas of Gulf coast salt-dome area: Geology of natural gas, pp. 683-740, 12 figs. (incl. maps), Am. Assoc. Petroleum Geologists, [June] 1935.

4034. New Hardin field, Liberty County, Tex.: Am. Assoc. Petroleum Geologists Bull., vol. 19, no. 9, p. 1389, September 1935. 
Teichert, Curt. See also Bøggild, 360 .

4035. Untersuchungen an actinoceroiden Cephalopoden aus Nordgrönland: Meddelelser om Grönland, Band 92, Nr. 10, 48 pp., 22 figs., 1934; Copenhague Univ., Mus. minéralogie et géologie, Comm. paléont. 52, 1934.

4036. Structures and phylogeny of actineroid cephalopods: Am. Jour. Sci., 5th ser., vol. 29, no. 169, pp. 1-23, 4 figs., January 1935.

4037. Nordostgrönland: Gesell. Erdkunde Berlin Zeitschr., Heft 5/6. pp. 169-215, 9 figs. (incl. geol. maps), September 1935.

4038. (and Miller, Arthur K.). What is Orthoceras?: Am. Jour. Sci., 5th ser., vol. 31, no. 185, pp. 352-362, May 1936.

Ten Eyck, Richard G.

4039. Late Tertiary Foraminifera of San Jose Hills, Los Angeles County, Calif. [abstract]: Geol. Soc. America Proc., 1935, p. 364, June 1936.

Tenney, James Brand.

4040. The copper deposits of Arizona: Copper resources of the world, pp. $167-235,8$ pls. (incl. geol. map), 8 figs. (incl. geol. map), Washington, 16th Internat. Geol. Cong., 1935.

4041. The Pilares mine, Los Pilares de Nacozari, Sonora, Mexico: Copper resources of the world, pp. 419-424, 3 figs., Washington, 16th Internat. Geol. Cong., 1935.

Terpstra, $\mathbf{P}$.

4042. (and Van Weerden, W. J.). Crystallographic orientation of sodium molybdotellurate: Am. Jour. Sci., 5th ser., vol. 19, no. 6, pp. 275278, 1 fig., June 1934.

Terzaghi, Ruth Doggett.

4043. The origin of the potash-rich rocks: Am. Jour. Sci., 5th ser., vol. 29, no. 172, pp. 369-380, 4 figs., April 1935; correction, vol. 30, no. 176, pp. 141-142, August 1935.

Tester, Allen Crawford. See also Kansas Geol. Soc., 2020.

4044. Isopach map of the post-Kinderhook-Mississippian [upper Mississippi Valley]: Kansas Geol. Soc. Guidebook 9th Ann. Field Conf., p. 334 ( $), 1$ pl. (isopach map), 1935.

4045. Isopach map of the Kinderhook group [upper Mississippi Valley]: Kansas Geol. Soc. Guidebook 9th Ann. Field Conf., p. 336 ( $\ddagger)$, 1 pl. (isopach map), 1935.

4046. Isopach map of the Deronian system [upper Mississippi Valley]: Kansas. Geol. Soc. Guidebook 9th Ann. Field Conf., p. 338 ( $)$, 1 pl. (isopach map), 1935.

4047. Subsurface correlation in Jowa [abstract] : Pan-Am. Geologist, vol. 65, no. 4, p. 316, May 1936.

Texas University, Bureau of Economic Geology.

4048. Geological maps (blue prints), scale 1: 48,000, 1929-1932, of the following Texas counties: Baylor, Brown, Callahan, Coleman, Eastland, Fisher, Jack, Jones, King, Palo Pinto, Shackleford, Stephenson, Stonewall, Taylor, Throckmorton, Wichita, Wise, and Young.

Thalmann, Hans Ernst.

4049. Bibliography and index to new genera and species of Foraminifera for the year 1932: Jour. Paleontology, vol. 8, no. 3, pp. 356-387, September 1934. 
Thalmann, Hans Ernst-Continued.

4050. Miocene Agueguexquite formation in the Isthmus of Tehuantepec region [abstract]: Geol. Soc. America Proc., 1934, p. 116, June 1935.

4051. Age of the Velasco formation in eastern Mexico [abstract]: Geol. Soc. America Proc., 1934, p. 371, June 1935.

4052. Die Miozäne Tuxpan-Stufe im Gebiete zwischen Rio Tuxpan und Rio Tecolutla (Staat Veracruz, Ost-Mexico) : Eclogae geol. Helvetiae, vol. 28 , pt. $\&$ (no. 44), pp. 543-546, December 1935.

4053. Mitteilungen über Foraminiferen, pt. 2, Nrs. 5-8: Eclogae geol. Helvetiae, vol. 28, no. 2, pp. 592-606, 1. fig., December 1935.

4054. Bibliography and index to new genera, species, and varieties of Foraminifera for the year 1933: Jour. Paleontology, vol. 9, no. 8, pp. 715-743, December 1935.

4055. Bibliography and index to new genera, species, and varieties of Foraminifera for the year 1934: Jour. Paleontology, vol. 10, no. 4, pp. 294-322, June 1936.

4056. Synecological studies in Foraminifera [abstract]: Geol. Soc. America Proc., 1935, p. 346, June 1936.

Thaxter, B. A.

4057. A brief geological history of Glacier National Park: Mazama, vol. 18, no. 12, pp. 20-22, December 1936.

Thayer, Lewis $\dot{\mathbf{A}}$.

4058. Present status of the hypothesis of biogenesis of petroleum [abstract]: Oil and Gas Jour., vol. 35, no. 28, p. 45, November 26, 1936; World Petroleum, vol. 7, no. 12, p. 636, December 1936.

Thayer, Thomas Prence.

4059. Geology of the North Santiam River district, Oregon [abstract]: Geol. Soc. Oregon Country News Letter, vol. 2, no. 11, pp. 7-9. ( ), June 10, 1936.

4060. Structural relation of the central Willamette Valley to the Cascade Mountains [abstract]: Geol. Soc. Oregon Country News Letter, vol. 2, no. 11, p. 9 (\$), June 10, 1936.

4061. Structure of the North Santiam River section of the Cascade Mountains in Oregon: Jour. Geology, vol. 44, no. 6, pp. 701-716, 3 figs. (incl. geul. maps), August-September 1936; abstracts, Geol. Soc. America Proc., 1934, pp. 324-325, June 1935; Geol. Soc. Oregon Country News Letter, vol. 2, no. 11, p. 10 (\$), June 10, 1936.

Theis, Charles Vernon.

4062. (and Burleigh, H. P., and Waite, Herbert Ames.) Ground water in the southern High Plains: U. S. Dept. Interior Press Mem. 108720, 4 pp. ( $\ddagger), 1$ pl. (map), October 30,1935 .

4063. Ground water in south-central Tennessee: U. S. Geol. Survey WaterSupply Paper 677, 182 pp., 7 pls. (incl. geol. and index maps), 2 figs., 1936.

4064. Possible effects of ground water on the Ogallala formation of Llano Estacado [abstract] : Washington Acad. Sci. Jour., vol. 26, no. 9. pp. 390-392, September 15, 1936.

Thibault, Newman W.

4065. The origin of disseminated celestite near Syracuse, N. Y. [abstract] : Virginia Acad. Sci. Proc., 1934-35, p. 62, [1935].

4066. Celestite from Chittenango Falls, N. Y.: Am. Mineralogist, vol. 20, no. 3, pp. 147-152, 2 figs., March 1935. 
Thibault, Newman W.-Continued.

4067. The crystallography of a phenacite from Amelia Court House, Va.: Virginia Polytechnic Inst. Bull., vol. 29, no. 3 (Eng. Exper. Sta. ser., Bull. 22), 10 pp., 2 figs., January 1936; abstract, Virginia Acad. Sci. Proc., 1934-35, p. 61 [1935].

Thiel, George Alfred.

4068. (and Dutton, Carl Evans). The architectural, structural, and monumental stones of Minnesota: Minnesota Geol. Survey Bull. 25, ix, 160 pp., 13 pls., 78 figs. (incl. maps), 1935.

4069. Sedimentary and petrographic analysis of the St. Peter sandstone: Geol. Soc. America Bull., vol. 46, no. 4, pp. 559-614, 16 figs. (incl. sketch map), April 30, 1935.

Thiesmeyer, Lincoln $\mathbf{R}$.

4070. Vein-quartz pseudomorphs after asbestiform actinolite from the Blue Ridge of Fauquier County, Va. [abstract]: Ám. Mineralogist, vol. 21, no. 3, p. 198, March 1936.

Thiessen, Gilbert.

4071. Temperature during coal formation: Illinois Acad. Sci. Trans., vol. 28, no. 2, pp. 184-185, December 1935.

Thiessen, Reinhardt. See also Fieldner, 1255.

4072. (and Sprunk, George C.). Microscopic and petrographic studies of certain American coals : U. S. Bur. Mines Tech. Paper 564, 71 pp., 42 figs., 1935.

Thom, Emma Mertins.

4073. Bibliography of North American geology, 1933 and 1934: U. S. Geol. Survey Bull. 869, 389 pp., 1935 [1936].

Thom, William Taylor, Jr. See also U. S. G. S., 4233.

4074. (and Hall, George Martin, Wagemann, Carroll Harvey, and Moulton, Gail Francis). Geology of Big Hom County and the Crow Indian Reservation, Mont., with special reference to the water, coal, oil, and gas resources: U. S. Geol. Survey Bull. 856, 200 pp., 13 figs. (incl. maps), 15 pls. (incl. geol. maps), 1935.

4075. Gravity observations and basement structure [abstract]: Geol. Soc. America Proc., 1934, p. 117, June 1935.

4076. (and Jones, O. T., and Chamberlin, Rollin Thomas). Morphology of the Beartooth Mountain uplift [abstract]: Geol. Soc. America Proc., 1934, p. 117, June 1935.

4077. (and others). Report of special committee on geophysical and geological study of continents: Am. Geophys. Union Trans. 16th Am. Meeting, pt. 1, pp. 17-18 (\$), Nat. Research Council, August 1935.

4078. Deep-focus earthquakes and isostasy: Science, new ser., vol. 83, no. 2141, p. 32, January 10, 1936.

4079. Possibility of determining position, extent, and structural make-up of Appalachia through geophysical-geological research in the Middle Atlantic States [abstract]: Geol. Soc. America Proc., 1935, p. 110, June 1936.

4080. (and others). Report of special committee on geophysical and geological study of continents: Am. Geophys. Union Trans. 17th Ann. Meeting, pt. 1, pp. 9-12 ( $¥$ ), 1 pl. (reconnaissance geol. map), Nat. Research Council, July 1936. 
Thom, William Taylor, Jr.-Continued.

4081. Deep-focus earthquakes from a geologist's point of view : Am. Geophys. Union Trans. 17th Ann. Meeting, pt. 1, pp. 108-111 ( $\$)$, Nat. Research Council, July 1936; Earthquake Notes, vol. 8, nos. 1-2, pp. 108-111 ( $)$, June 1936.

Thomas, C. $\mathbf{R}$.

4082. Relation of structure to production in the oil fields of western Kansas: Oil and Gas Jour., vol. 34, no. 35, pp. 14-15, 2 figs. (maps), January 16, 1936.

Thomas, Dale Edmund.

4083. A new species of Calamopitys from the American Devonian: Bot. Gazette, vol. 97, no. 2, pp. 334-345, 2 pls., December 1935.

Thomas, Henry Dighton.

4084. On some sponges and a coral of Upper Cretaceous age from Toco Bay, Trinidad: Geol. Mag., no. 850 (vol. 72 , no. 4), pp. 175-179, 2 pls., April 1935.

Thomas, Horace Davis. See also Miller, 2712.

4085. The brachiopod Punctospirifer pulchra (Meek) : Am. Midland Naturalist, vol. 16, no. 2, pp. 203-207, 1 pl., March 1935.

4086. Frontier-Niobrara contact in Laramie Basin, Wyo.: Am. Assoc. Petroleum Geologists Bull., vol. 20, no. 9, pp. 1189-1197, 1 fig., September 1936.

Thomas, John Elmer.

4087. Robert Brooks Whitehead [1889-1936]: Am. Assoc. Petroleum Geologists Bull., vol. 20, no. 9, pp. 1270-1271, 1 fig. (port.), September 1936.

Thomas, Norman Louis.

4088. Frank Carney [1868-1934] : Am. Assoc. Petroleum Geologists Bull., vol. 19, no. 5, pp. 761-765, port., May 1935.

4089. East Texas correlations [abstract] : Geol. Soc. America Proc., 1934, pp. 117-118, June 1935.

4090. Memorial of Frank Carney [1868-1934]: Geol. Soc. America Proc., 1934, pp. 213-220, port., June 1935.

4091. Texas index microfossils [abstract] : Geol. Soc. America Proc., 1934, pp. 369-370, June 1935.

Thompson, David Grosh.

4092. (and others). Report of the committee on underground water, 1934-35: Am. Geophys. Union Trans. 16th Ann. Meeting, pt. 2, pp. 433-437 (\$), Nat. Research Council, August 1935 .

4093. (and others). Report of the committee on underground water, 193536: Am. Geophys. Union Trans. 17th Ann. Meeting, pt. 2, pp. 326334 ( $\$)$, Nat. Research Council, 1936.

4094. Symposium on fluctuations of ground water; Introduction, Some problems relating to fluctuations of ground water level: Am. Geophys. Union Trans. 17th Ann. Meeting, pt. 2, pp. 337-341 (\$), Nat. Research Council, 1936.

4095. (and Wells, Francis Gerritt, and Blank, Horace R.). Recent geological studies on Long Island (New York), with respect to ground-water supplies [abstract] : Geol. Soc. America Proc., 1935, pp. 110-111, June 1936. 
Thompson, Henry D.

4096. Hudson gorge in the Highlands: Geol. Soc. America Bull., vol. 47, no. 12, pp. 1831-1848, 4 pls., 9 figs. (incl. index naps), December 31, 1936; abstract, Proc. 1935, p. 111, June 1936.

Thompson, Joseph Ellis. [In error for Joseph Ellis Thomson, q. v.]

4097. The minerals that surround us: Royal Canadian Inst. Proc., 3d ser., vol. 1, pp. 7-25, 1936.

Thompson, Marcus Luther. See also Miller, 2702.

4098. The fusulinid genus Staffella in America: Jour. Paleontology, vol. 9, no. 2, pp. 111-120, 1 pl., March 1935.

4099. Fusulinids from the lower Pennsylvanian Atoka and Boggy formations of Oklahoma: Jour. Paleontology, vol. 9, no. 4, pp. 291-306, 1 pl., June 1935.

4100. Fusulinids from the Black Hills and adjacent areas in Wyoming: Jour. Paleontology, vol. 10, no. 2, pp. 95-113, 4 pls., March 1936.

4101. Pennsylvanian fusulinids from Ohio: Jour. Paleontology, vol. 10, no. 8, pp. 673-683, 2 pls., December 1936.

Thompson, Sheridan A.

4102. Fredericksburg group of Lower Cretaceous with special reference to north-central Texas [with discussion] : Am. Assoc. Petroleum Geologists Bull., vol. 19, no. 10, pp. 1508-1537, 9 figs. (incl. index map), Octaber 1935.

4103. Clyde M. Bennett [1881-1935] : Am. Assoc. Petroleum Geologists Bull., vol. 19, no. 11, pp. 1715-1717, 1 pl. (port.), November 1935.

Thompson, Warren Osborne.

4104. Original structures of beaches [abstract]: Geol. Soc. America Proc., 1935, pp. 111-112, June 1936.

Thomson, Joseph Ellis. See also Thompson, 4097.

4105. The mineralogy of the silver-uraninite deposits of Great Bear Lake, Northwest Territories: Toronto Univ. Studies, Geol. ser. 36, pp. 25$31,1 \mathrm{pl}$. (in part), 1934 .

4106. Telluride ores at Straw Lake, Ontario, and Eureka mine, Quebec: Toronto Univ. Studies, Geol. ser. 36, pp. 33-36, 1 pl. (part), 1934.

4107. Mineralization of the Little Long Lac and Sturgeon River areas: Toronto Univ. Studies, Geol. ser. 38, pp. 37-45, pl. 3, figs. 1, 2, 1935.

4108. Telluride ores in Ontario and Quebec: Toronto Unir. Studies, Geol. ser. 38 , pp. $47-49$, pl. 3, figs. $3-5$, 1935.

Thomson, James Edgar.

4109. Geology of the Straw-Manitou Lakes area: Ontario Dept. Mines 43d Ann. Rept. (vol. 43, pt. 4), iii, 32 pp., 1 pl. (geol. map), 14 figs. (incl. geol. sketch maps), 1934.

4110. On the origin of the syenites of Coldwell, Ontario: Am. Geophys. Union Trans. 16th Ann. Meeting, pt. 1, pp. 350-363 (\$), 3 figs. (incl. geol. map), Nat. Research Council, August 1935.

4111. Gold deposits of the belt extending from Manitou Lake to Lake of the Woods, Ontario [with discussion by Everend Lester Bruce]: Canadian Min. Met. Bull. 294, pp. 686-701, 1 fig. (geol. sketch map), October 1936.

Thomson, John Prentiss.

4112. Palouse topography and its relation to stream history : Northwest Sci., vol. 9, no. 3, pp. 16-17, September 1935. 
Thomsan, John Prentiss-Continued.

4113. Some relationships between the soil canyons of certain southeastern Washington valleys and summer-fallow cultivation: Northwest Sci., vol. 10, no. 1, pp. 8-11, 2 figs., February 1936; abstract, PanAm. Geologist, vol. 65, no. 1, p. 79, February 1936.

Thomson, Robert.

4114. Nickel eruptive of Sudbury, Ontario: Pan-Am. Geologist, vol. 63, no. 4, pp. 248-264, 5 figs. (incl. geol. and sketch maps), May 1935.

4115. Sudburite, a metamorphic rock near Sudbury, Ontario: Jour. Geology, vol. 43 , no. 4 , pp. 427-435, 2 figs. (incl. index map), May-June 1935.

4116. The "offset dikes" of the nickel intrusive, Sudbury, Ontario: Am. Jour. Sci., 5th ser., vol. 30, no. 178, pp. 356-367, 1 fig., October 1935.

Thorndyke, John T.

4117. Mineral wool from wollastonite: Mining and Metallurgy, vol. 17, no. 351, pp. 133-135, 3 figs., March 1936; Am. Inst. Min. Met. Eng. Contr. 89, 3 pp., 3 figs., 1936.

Thorp, Eldon Marion.

4118. Calcareous shallow-water marine deposits of Florida and the Bahamas [with appendices by Albert Mann, T. W. Vaughan, and Frank J. Haight] : Carnegie Inst. Washington Papers from Tortugas Laboratory, vol. 29, Pub. 452, pp. 37-119, 4 pls. (incl. map), 10 figs., 1936, preprint, December $9,1935$.

4119. The sediments of the Pearl and Hermes reef [Hawaii]: Jour. Sedimentary Petrology, vol. 6, no. 2, pp. 109-118, 1 fig. (index map), 4 tables, August 1936.

Thorpe, Malcolm Rutherford.

4120. A fossil fish in the Connecticut red sandstone: Am. Jour. Sci., 5th ser., vol. 32, no. 191, pp. 319-321, 1 fig., November 1936.

Throckmorton, Ray Iams.

4121. Dust storms; their cause and suggested remedies: Eng. News-Record, vol. 114, no. 19 , pp. 669-671, May 9, 1935 .

Thwaites, Fredrik Turville. See also Howell, 1864, 1865; Kansas Geol. Soc., 2020 ; Twenhofel, 4196 ; Workman, 4618.

4122. Structural map on top of the Dresbach formation [upper Mississippi Valley]: Kansas Geol. Soc. Guidebook 9th Ann. Field Conf., pl. opp. p. 356 (\$), 1935.

4123. Physiography of the Baraboo district, Wis. : Kansas Geol. Soc. Guidebook 9th Ann. Field Conf., pp. 395-404 ( $), 2$ pls. (incl. geol. map), 12 figs. (incl. geol. map), 1935.

4124. Zones of mineralization of underground waters in Minnesota, Iowa, Illinois, and Wisconsin: Kansas Geol. Soc. Guidebook 9th Ann. Field Conf., pp. 415-416 ( $\$$ ), 3 figs. (incl. geol. maps), 1935.

4125. Ground-water supplies of Alleghany State Park, 1932: New York State Mus. Cir. 11, 62 pp., 1 pl. (index map), 16 figs., January 1935.

4126. Field photography for geologists: Am. Assoc. Petroleum Geologists Bull., vol. 20, no. 2, pp. 186-214, 15 figs., February 1936; discussion by Duncan McConnell, with reply by author, no 6 , pp. 827-828, June 1936; abstract, World Petroleum, vol. 7, no. 8, p. 278, May 1936. 
Tickell, Frederick George.

4127. (and Mechem, O. E., and McCurdy, Richard Clark). Some studies on the porosity and permeability of rocks: Am. Inst. Min. Met. Eng. Trans., vol. 103, pp. 250-250, 8 figs., 1933.

4128. Permeability: of unconsolidated rocks: Am. Assoc. Petroleum Geologists Bull., vol. 19, no. 8, pp. 1233-1238, 4 figs., August 1935.

Tillotson, Allen W.

4129. Gas fields of Lost Soldier district, Carbon and Sweetwater Counties, Wyo.: Geology of natural gas, pp. 305-322, 4 figs., Am. Assoc. Petroleum Geologists [June] 1935.

Tillyard, Robin John, 1S81-1937.

4130. Evolution of progoneate and opisthogoneate types in the myriapodhexapod group of terrestrial Arthropoda: Am. Jour. Sci., 5th ser., vol. 30 , uo. 179, pp. 438-449, November 1935.

4131. Kansas Permian insects; pt. 16, The order Plectoptera (continued), the family Doteridae, with a note on the affinities of the order Protohymenoptera : Am. Jour. Sci., 5th ser., vol. 32, no. 192, pp. 435-453, 4 figs., December 1936.

Toepelmann, Walter Carl.

4132. Fragmentary trachodont jaw from the Laramie of Colorado [abstract] : Geol. Soc. America Proc., 1935, p. 393, June 1936.

4133. Fossil bird egg from northeastern Colorado [abstract] : Geol. Soc. Amer ica Proc., 1935, p. 394, June 1936.

4134. (and Rodeck, Hugo G.). Footprints in late Paleozoic red beds near Boulder, Colo.: Jour. Paleontology, vol. 10, no. 7, pp. 660-662, 2 figs., Uctober 1936; abstract, Geol. Soc. America Proc., 1935, p. 393, June 1936.

Tokuda, Sadakazu.

4135. Three types of mountain arcs: 16th Internat. Geol. Cong. (1933) Rept.. vol. 2, pp. 839-846, 8 pls. (incl. maps), 3 figs. (maps), 1936.

Tolman, Carl. See also Gill, 1424.

4136. (and Denham, R. L.). Granitic intrusion in the St. Francis Mountain, [Mo.] [abstract] : Am. Mineralogist, vol. 20, no. 3, p. 202, March 1935; Geol. Soc. America Proc., 1934, p. 118, June 1935.

4137. (and Koch, H. L.). The heavy accessory minerals of the granites of Missouri : Washington Univ. [St. Louis] Studies, new ser., no. 9, pp. 11-50, 5 pls. (incl. geol. map), 13 figs. (incl. sketch map), February 1936; abstracts, Am. Mineralogist, vol. 20, no. 3, p. 208, March 1935; Geol. Soc. America Proc., 1934, p. 429, June 1935.

4138. (and Goldich, Samuel S.). The granite, pegmatite, and replacement veins in the Sheahan quarry, Graniteville, Mo.: Am. Mineralogist, vol. 20, no. 4, pp. 229-239, 6 figs., April 1935.

4139. Volcanic activity in southenstern Missouri [abstract] : Pan-Am. Geologist, vol. 65, no. 2, p. 160, March 1936; Geol. Soc. America Proc., 1935, p. 442, June 1936.

Tolman, Cyrus Fisher.

4140. The foothill copper belt of California: Copper resources of the world, pp. 247-250, 3 pls. (incl. geol. map), 1 fig., Washington, 16th Internat. Geol. Cong., 1935.

Tolman, F. B. See glso Stipp, 3905. 
Tomlinson, Charles Weldon. See also Grimes, 1551.

4141. (and White, Maynard Pressly). Bucher's laws applied to' Arbuckle and Ouachita Mountains [abstract]: Geol. Soc. America Proc., 1984, p. 118, 1935.

4142. Natural-gas pools of southern Oklahoma: Geology of natural gas, pp. 575-608, 1 fig. (map), Am. Assoc. Petroleum Geologists, [June] 1935.

4143. Ardmore district has great prospects for future oil development: Oil and Gas Jour., vol. 34, no. 47, pp. 32-34, 5 figs., April 9, 1936.

Toothaker, Charles $\mathbf{R}$.

4144. Treatment of fragile specimens: Rocks and Minerals, vol. 11, no. 1, p. 10, January 1936.

Toppan, Frederick Willcox.

41.45. The physiography of Maine: Jour. Geology, vol. 43, no. 1, pp. 76-87, 5 figs. (incl. sketch map), January-February 1935.

Torrey, Paul Dwight. See also Caster, 702.

4146. Summary of geology of natural-gas fields of New York and Pennsylvania: Geology of natural gas, pp. 949-988, 6 figs. (maps), Am. Assoc. Petroleum Geologists, [June] 1935.

Torrey, Raymond Hezekiah.

4147. John Boyd Thacher State Park, [New York]: Scenic and Historic America, vol. 4, no. 2, pp. 3-28, 11 figs., July 1935.

Townley, Enid. See Leighton, 2383.

Tozzer, Alfred Marston.

4148. Biographical memoir of Frederic Ward Putnam, 1839-1915: Nat. Acad. Sci. Biog. Mem., vol. 16, no. 4, pp. 123-153, 1 pl. (port.), 1936.

Trask, Parker Davies.

4149. (and Hammar, Harald Edwin. Organic content of sediments : Drilling and Production Practice, 1934, pp. 117-130, 3 figs. (sketch maps), Am. Petroleum Inst., 1935; abstracts, Production Bull. 214, p. 9, 1934 ; Washington Acad. Sci. Jour., vol. 25, no. 11, p. 508, November $15,1935$.

4150. Current bibliography of recent sediments and source beds of petroleum: Nat. Research Council Bull. 98, pp. 199-209, July 1935.

4151. (and Hammar, Harald Edwin). The degrees of reduction and volatility as indices of source beds [with discussion]: 'Drilling and Production Practice, 1935, pp. 250-266, 15 figs., Am. Petroleum Inst., 1936; abstract, Production Bull. 216, p. 10, 1935.

4152. Some studies of source beds of petroleum [abstract]: 16th Internat. Geol. Cong. (1933) Rept., vol. 2, p. 1011, 1936.

4153. Proportion of organic matter converted into oil in Santa Fe Springs field, Calif.: Am. Assoc. Petroleum Geologists Bull., vol. 20, no. 3, pp. 245-257, March 1936; abstracts, World Petroleum, vol. 7, no. 5, p. 278, May 1936; Washington Acad. Sci. Jour., vol. 26, no. 9, p. 392, September 15, 1936.

4154. (and Keyte, W. Ross). Degree of reduction of sediments in the East Texas basin as an index of source beds: Oil Weekly, vol. 81, no. 10, pp. 60-70. 3 figs. (maps), May 18, 1936; Oil and Gas Jour., vol. 35 , no. 1, pp. 84-89, 3 figs. (maps), May 21, 1936; abstracts, World Petroleum, vol. 7, no. 7, p. 368, July 1936; Am. Petroleum Inst. Production Bull. 217, pp. 12-13, 1936. 
Trask, Parker Davies-Continued.

4155. (and others). Report of the committee on sedimentation, 1935-36: Nat. Research Council Ann. Rept., 1935-36, App. I, 47 pp. (;), September 1936.

4156. [Review of] Historical geology of the Antillean-Carribbean region or the lands bordering the Gulf of Mexico and the Caribbean Sea, by Charles Schuchert, 1935: Econ. Geology, vol. 31, no. 7, pp. 770-773, November 1936.

4157. (and Patnode, Homer Whitman). Means of recognizing source beds: California Oil World, vol. 29, no. 20, pp. 8-12, 3 figs., December 3, 1936 ; no. 21, pp. 6-9, 7 figs., December 10, 1936; abstract, Oil and Gas Jour., vol. 35, no. 27, p. 46, November 19, 1936.

Trauth, Friedrich.

4158. Ueber Aptychenfunde auf Cuba: K. Akad. Wetensch. Amsterdam, Sec. Sci. Proc., vol. 39, no. 1, pp. 66-76, 1936.

Treasher, Ray Clarence.

4159. Impressions of the physiography and geology of the southern Cascades, Washington: Geol. Soc. Oregon Country News Letter, vol. 2, no. 15, pp. 12-15, August 10, 1935.

4160. (and Hodge, Edwin Thomas). Bibliography of the geology and mineral resources of Oregon, with digests and index to July 1, 1936. 224 pp. ( ), Portland, Oreg., Oregon States Planning Board, September 1936.

Trechmann, C. T.

4161. Fossils from the Northern Range of Trinidad: Geol. Mag., no. 850, (vol. 72, no. 4), pp. 166-175, 2 figs. (incl. sketch map), April 1935. 4162. The geology and fossils of Carriacou, West Indies: Geol. Mag., no. 858, (vol. 72 , no. 12), pp. 529-555, 3 pls., 4 figs. (incl. sketch map). December 1935 .

4163. The basal-complex question in Jamaica: Geol. Mag., no. $\$ 64$ (vol. 73, no. 6), pp. 251-267, 4 figs. (incl. geol. sketch map), June 1936.

Trefethen, Joseph M.

4164. A peculiar type of zoning in feldspar: Am. Mineralogist, vol. 21, no. 5, pp. 327-329, 6 figs., May 1936.

4165. A method for geographic surveying: Am. Jour. Sci., 5th ser., vol. 32, no. 192 , pp. 454-464, 4 figs., December 1936.

Trenchard, John. See also Whisenant, 4447.

4166. (and Whisenant, J. Barney). Government Wells oil field, Duval County, Tex.: Am. Assoc. Petroleum Geologists Bull., vol. 19, no. 8, pp. 1131-1147, 6 figs. (incl. maps), August 1935; abstract, no. 1, p. 140, January 1935; reprinted in Gulf coast oil fields (see Barton and Sawtelle), pp. 631-647, 1936.

Trengove, S. A.

4167. The hydrothermal oxidation of manganese minerals: Econ. Geology, vol. 31, no. 1, pp. 29-47, 2 figs., January-February 1936.

Trioche, George N.

4168. Mineral possibilities of Newfoundland: Canadian Min. Jour., vol. 56, no. 4, pp. 148-151, 1 fig. (sketch map), April 1935. 
Trowbridge, Arthur Carleton. See also Kansas Geol. Soc., 2020.

4169. Structural map on top of the Jordan sandstone [upper Mississippi Valley]: Kansas Geol. Soc. Guidebook 9th Ann. Field Conf., pl. opp. p. $358(\ddagger), 1935$.

4170. Report of the committee on sedimentation, 1932-34; Introduction : Nat. Research Council Bull. 98, pp. 5-1.5, July 1935.

4171. Cenozoic history of upper Mississippi River [abstract] : Pan-Am. Geologist, vol. 65, no. 4, p. 317, May 1936.

4172. Eugene Wesley Shaw [1881-1935]: Am. Assoc. Petroleum Geologists Bull., vol. 20, no. 2, pp. 239-240, February 1936.

4173. Current early Paleozoic classification in Iowa [abstract]: Pan-Am. Geologist, vol. 65, no. 4, p. 315, May 1936.

4174. The third annual Tri-States (Illinois, Wisconsin, Iowa) Geological Field Conference: Science, new ser., vol. 83, no. 2148, p. 209, February 28, 1936.

4175. New exposures of upland Nebraskan till in northeastern Iowa [abstract] : Pan-Am. Geologist, vol. 65, no. 4, p. 317, May 1936.

Trowbridge, Raymond M. See Greene, 1514.

Trudell, Harry W.

4176. Philadelphia Museum fluorescent exhibit the best in the world: Min. eralogist, vol. 3, no. 1, pp. 13-14, 1 fig., January 1935.

Truog, Emil. See Drosdoff, 1082.

Tuck, Ralph. See also Capps, 678.

4177. Asymmetrical topography in high latitudes resulting from Alpine glacial erosion: Jour. Geology, vol. 43, no. 5, pp. 530-538, 4 figs. (incl. sketch maps), July-August 1935.

Tucker, Helen Ione. See also Rowland, Helen Ione, 3389.

4178. The Atlantic and Gulf coast Tertiary Pectinidae of the United States: Am. Midland Naturalist, vol. 17, no. 2, pp. 471-490, 4 pls., March 1936.

Tucker, Mitchell.

4179. Deep production horizon is found in Cotton Valley [La.] : Oil and Gas Jour., vol. 35, no. 16, pp. 13-14, 2 figs., September 3, 1936.

Tucker, Rietz Courtney. See also Grove, 1559; Sisler, 3736.

4180. Deep-well records, xvi, 560 pp., 3 pls. (incl. geol. maps), West Virginia Geol. Survey, 1936.

Tucker, William Burling.

4181. Mining activity at Soledad Mountain and Middle Buttes, Mojave mining district, Kern County: California Jour. Mines and Geology, vol. 31, no. 4, pp. 465-485, 2 pls. (incl. index map), 10 figs., October 1935 .

Türkheim, O. G. von. See Reck, 3213.

Tunell, George.

4182. (and Ksanda, Charles Jaroslav). The crystal structure of calaverite: Washington Acad. Sci. Jour., vol. 25, no. 1, pp. 32-33, January 15, 1935 ; abstracts, Am. Mineralogist, vol. 20, no. 3, p. 211, March 1935; Geol. Soc. America Proc., 1934, pp. 432-433, June 1935.

4183. (and Ksanda, Charles Jaroslav). The relationship between the structural and morphological elements of krennerite, calaverite, and sylvanite [abstract]: Am. Mineralogist, vol. 21, no. 3, p. 203, March 1936. 
Tunnell, George-Continued.

4184. (and Ksanda, Charles Jaroslav). The crystal structure of krennerite: Washington Acad. Sci. Jour., vol. 26, no. 12, pp. 507-509, December 1936.

4185. (and Ksanda, Charles Jaroslav). The strange morphology of calaverite in relation to its internal properties: Washington Acad. Sci. Jour., vol. 26 , no. 15 , pp. 509-52S, December 15, 1936.

Turley, Jay.

4186. Meteoritic impact scars in New Mexico [abstract]: Pan-Am. Geologist, vol. 64, no. 2, pp. 151-152, September 1935.

4187. New Grand Canyon of Colorado River [abstract]: Pan-Am. Geologist, vol. 65 , no. 5 , p. 373 , June 1936.

Turner, F. Earl. See also Schenck, 3544.

4188. Tentative correlation of the marine Eocene of western Oregon [abstract] : Geol. Soc. America Proc., 1934, pp. 391-392, June 1935.

Turner; F. J.

4189. Contribution to the interpretation of mineral facies in metamorphic rocks: Am. Jour. Sci., 5th ser., vol. 29, no. 173, pp. 409-421, May 1935.

Turner, Samuel Foster. See also Leggette, 2376.

4190. (and Livingston, Penn P.). Ground-water studies in the humid and semiarid parts of the Texas Coastal Plain: Am. Geophys. Union Trans. 16th Ann. Meeting, pt. 2, pp. 503-507 ( $¥$ ), 4 figs. (incl. geol. map), Nat. Research Council, August 1935.

Twardy, Stanley A.

4191. A synopsis of Gastropoda of the Yorktown formation [abstract] : Virginia Acad. S'ci. Proc., 1935-36, p. 68, 1936.

Twenhofel, William Henry. See also Croneis, 921; Decker, 999.

4192. (and Shrock, Robert Rakes). Invertebrate paleontology. 1st ed., 511 pp., 175 figs., New York, McGraw-Hill Book Co., Inc., 1935.

4193. The ecology of sand areas: Jour. Paleontology, vol. 9, no. 3, pp. 272283, April 1935.

4194. Geology and paleontology of the Mingan Islands, Canada [abstract] : Geol. Soc. America Proc., 1934, p. 355, June 1935.

4195. Notes on various types of sediments: Nat. Research Council Bull. 98, pp. 210-217, July 1935.

4196. (and Raasch, Gilbert O., and Thwaites, Fredrik Turville). Cambrian strata of Wisconsin: Geol. Soc. America Bull., vol. 46, no. 11, pp. 1687-1744, 1 pl., 1 fig., November 30, 1935.

4197. (and Shrock, Robert Rakes). Silurian strata of Notre Dame Bay, northern Newfoundland [abstract] : Geol. Soc. America Proc., 1935,

- pp. 112, 379, June 1936.

4198. Marine unconformities, marine conglomerates, and thicknesses of strata : Am. Assoc. Petroleum Geologists Bull., vol. 20, no. 6, pp. 677-703, June 1936.

4199. The greensands of Wisconsin: Econ. Geology, vol. 31, no. 5, pp. 472487, 1 fig. (geol. map), August 1936.

4200. Organisms and their environment: Nat. Research Council Ann. Rept., 1935-36, app. J, Report of the committee on paleoecology, pp. 1-9 (\$), October 1936 . 
Twenhofel, William Henry-Continued.

4201. (and others). Report of the committee on paleoecology, 1935-36: Nat. Research Council Ann. Rept., 1935-36, app. J, 64 pp. (市), October 1936.

Tyler, Stanley A.

4202. Heavy minerals of the St. Peter sandstone in Wisconsin: Jour Sedimentary Petrology, vol. 6, no. 3, pp. 55-84, 1 fig. (index map), 13 tables, Angust 1936; abstract, Geol. Soc. America Proc., 1935, pp. 112-113, June 1936.

Tyrrell, Joseph Burr.

4203. Patrician center of glaciation; Discovery of Patrician center of ice dispersion : Pan-Am. Geologist, vol. 63, no. 1, pp. 1-5, 1 fig. (geol. map), February 1935.

Uber, Fred Murray.

4204. Illuminator for critical microscopy utilizing automobile headlight lamps: Science, new ser., vol. 82, no. 2139, pp. 624-625, 1 fig., December 27, 1935.

Ulke, Titus.

4205. An early check list of Black Hills minerals: Rocks and Minerals, rol. 10, no. 8, pp. 120-122, 2 figs., August 1935.

4206. Minerals of the District of Columbia and vicinity, with pertinent bibilography: Rocks and Minerals, vol. 11, no. 1, pp. 7-9, January 1936 ; no. 2 , pp. 26-28, February 1936 ; no. 3 , pp. 42-44, March 1936.

4207. Sites of minerals, mines, and quarries found within 50 miles of Washington, D. C.: Rocks and Minerals, vol. 11, no. 8, pp. 120-122, August 1936.

4208. The agates and jaspers of the Atlantic Coastal Plain: Rocks and Minerals, vol. 11, no. 9, pp. 174-175, September-October 1936.

Ulrich, Edward Oscar.

4209. Physical and time relations of lower Paleozoic systems and formations [abstract, with discussion]: Geol. Soc. America Proc., 1934, p. 119, June 1935.

4210. (and Foerste, August Frederick). New genera of Ozarkian and Canadian cephalopods: Denison Univ. Bull., vol. 35 , no. 17 (Sci. Lab. Jour., vol. 30), pp. 259-290, 1 pl., December 1935.

4211. Principles for the correlation and classification of strata, and their application to the lower Paleozoic [abstract, with discussion]: 16th Internat. Geol. Cong. (1933) Rept., vol. 1, pp. 516-518, 1936.

4212. Norwalk-Jordan-Madison sandstone question [Wisconsin] [abstract]: Geol. Soc. America Proc., 1935, pp. 113, 379-380, June 1936.

4213. Relations of the Mazomanie and the "Franconia" formations [Wisconsin?] [abstract] : Geol. Soc. America Proc., 1935, pp. 113-114, 380, June 1936.

4214. (and Cooper, Gustav Arthur). New Silurian brachiopods of the family Triplesiidae: Jour. Paleontology, vol. 10, no. 5, pp. 331-347, 3 pls., 1 fig., July 1936.

4215. (and Foerste, August Frederick). Parendoceras, new name for Saffordoceras Ulrich and Foerste (not Foerste and Teichert) : Jour. Paleontology, vol. 10, no. 5, p. 417, July 1936.

4216. (and Cooper, Gustav Arthur). New genera and species of Ozarkian and Canadian brachiopods: Jour. Paleontology, vol. 10, no. 7, pp. 616-631, October 1936. 
Ulrich, Franklin P. See also Heck, 1678.

4217. The California strong-motion program of the Coast and Geodetic Survey : Seismol. Soc. America Bull., vol. 25, no. 1., pp. \$1-95, 14 figs. (incl. sketch map), January 1985; abstract, Earthquake Notes, vol. 7 , nos. 1-2, p. 22 (†), September 1935.

4218. A progress report of the California seismological program of the Coast and Geodetic Surrey: Seismol. Soc. America Bull., vol. 25, no. 4, pp. 349-359, 4 figs. (incl. index maps), October 1935.

4219. Man-made earthquakes: Eng. News-Record, vol. 115, no. 20, pp. 680682, 4 figs., November 14, 1935.

4220. Progress report for 1935 of the California seismological program of the United States Coast and Geodetic Survey: Seismol. Soc. America Bull., vol. 26, no. 3, pp. 215-227, 12 figs. (incl. index maps), July 1936.

4221. Helena [Montana] earthquakes: Seismol. Soc. America Bull., vol. 26, no. 4, pp. 323-339, 2 pls., 9 figs. (incl. index maps), October 1936.

Umpleby, Joseph Bertram. See also Barton, 212.

4222. Scientific methods locate structures on which to drill for oil : Nat. Petroleum News, vol. 28, no. 6, pp. 378-383, 4 figs., February 5, 1936.

Ưnderhill, James. See Read, 3209.

United States Bureau of Reclamation.

4223. Bibliography on the subject of transportation of solids by flowing water in open channels, pts. 1 and 2, 116 pp. ( $\ddagger)$, Denver, Colo., March 1933.

United States Committee on the Upper Monongahela Valley, W. Va.

4224. Report of the Committee on the Upper Monongahela Valley, W. Va. 226 pp. ( $\ddagger), 2$ pls. (maps), diagrams, [Washington], November 7 , 1934.

4225. Summary of the report of the Committee on the Upper Monongahela Valley, W. Va. 61 pp. ( $\ddagger), 1$ pl. (map), [Washington], November 7, 1935.

United States Geological Survey.

4226. Preliminary map showing geologic structure of parts of Grand and San Juan Counties, Utah; compiled from U. S. Geol. Survey reports in preparation by A. A. Baker, C. H. Dane, and E. T. McKnight, surveyed in 1926, 1927, and 1929. Scale, 1:125,000 (1 inch to 2 miles), 1931.

4227. Preliminary map showing geologic structure of the Monument ValleyNavajo Mountain region, San Juan County, Utah; surveyed in 1928 by Arthur Alan Baker, assisted by Laurence Willis Clark, Louis A. Kelly, Leroy G. Snow, and Raymond M. Larsen. Formation table shown on sheet. Scale 1:125,000 ( 1 inch to 2 miles), 1931 .

4228. Preliminary map showing geologic structure of parts of Emery, Wayne, and Garfield Counties, Utah; surveyed in 1930 and 1931 by Arthur Alan Baker, assisted by Maxwell McMichael Knechtel, David Arthur Andrews, Armand John Eardley, Lloyd George Henbest, Louis S. Bumgardner, H. Donald Curry, and Ralph Lester Miller. Formation table shown on sheet. Scale $1: 125,000$ ( 1 inch to 2 miles), 1933. 
United States Geological Survey-Continued.

4229. Geologic map of Colorado, by the U. S. Geological Survey in cooperation with the Colorado State Geological Survey Board and Colorado Metal Mining Fund, compiled by W. S. Burbank, T. S. Lovering, E. N. Goddard, and E. B. Eckel, edited by G. W. Stose. Scale, 1: 500,000. [Washington, D. C.], 1935.

4230. Coal map of the Howe district, Le Flore and Latimer Counties, Okla.; surveyed in 1931 by T. A. Hendricks, assisted by C. B. Read, A. J. Eardley, and Thomas Larkin Metcalf. Scale 1:125,000 (1 inch to 2 miles), 1935.

4231: Coal map of the Lehigh district, Coal and Atoka Counties, Okla.; surveyed in 1934 and 1935 by Thomas Andrews Hendricks, Charles Brian Read, Maxwell McMichael Knechtel, Carl Bernard Anderson, Raymond M. Hart, and Walton Christian. Scale 1:125,000 (1 inch to 2 miles), 1935.

4232. Coal map of the McAlester district, Pittsburg and Latimer Counties, Okla.; surveyed in 1930 and 1931 by Thomas Andrews Hendricks, assisted by Charles Brian Read, Charles William Wilson, Jr., Charles R. Williams, Thomas Larkin Metcalf, T. Dean Mundorf, and Bruce M. Choate. Scale 1:125,000 (1 inch to 2 miles), 1935.

4233. Coal map of the Stigler-Poteau district, Pittsburg, Haskell, and Le Flore Counties, Okla.; surveyed in 1927 and 1928 by William Taylor 'Thom, Jr., assisted by Pat Rose. Scale 1:63,360 (1 inch to 1 mile), 1935.

4234. Coal map of the Wilburton district, Latimer County, Okla.; surveyed in 1931 by Thomas Andrews Hendricks, assisted by Charles Brian Read, Armand John Eardley, and Thomas Larkin Metcalf. Scale 1: 125,000 (1 inch to 2 miles), 1935.

4235. Map of parts of Oklahoma and Kansas, showing the distribution of the Bartlesville and Burbank (Red Fork) sands, sheet $3 \mathrm{~A}$; prepared by Nathan Wood Bass and William Reese Dillard, assisted by Constance Leatherock. Kansas portion, except Cowley County, prepared in cooperation with the Kansas Geological Survey. Compiled in 1934 and 1935. Scale $1: 125,000$ (1 inch to 2 miles), 1935.

4236. Map of parts of Oklahoma and Kansas, showing the distribution of the Bartlesville and Burbank (Red Fork) sands, sheet 3B; prepared by Nathan Wood Bass and William Reese Dillard, assisted by Constance Leatherock. Kansas portion, except Cowley County, prepared in cooperation with the Kansas Geological Survey. Compiled in 1934 and 1935. Scale 1:125,000 (1 inch to 2 miles), 1935.

4237. Map of Osage County, Okla., showing the subsurface geologic structure of the top of the Fort Scott limestone (Oswego lime), the producing rocks in oil and gas wells, and the deepest rocks penetrated in dry holes, sheet 1 ; prepared by Nathan Wood Bass and Luther E. Kennedy, assisted by J. C. McClure, Harold Beach Goodrich, Charles Townsend Kirk, Otto Leatherock, William Reese Dillard, William Earle Shamblin, J. N. Conley, Jess H. Hengst, and Harold D. Jenkins. Compiled in 1934 and 1935. Scale 1:125,000 (1 inch to 2 miles), 1935.

4238. Map of Osage County, Okla., showing the subsurface geologic structure of the top of the Fort Scott limestone (Oswego lime), the wells producing oil or gas from Ordovician rocks, and dry holes that found Ordovician rocks barren of oil and gas, sheet 2 ; prepared by 
United States Geological Survey-Continued.

4238. Map of Osage County, Okla., etc.-Continued.

Nathan Wod Bass and Luther E. Kennedy, assisted by J. C.

McClure, Harold Beach Goodrich, Charles Townsend Kirk, Otto Leatherock, William Reese Dillard, William Earle Shamblin, J. N. Conley, Jess H. Hengst, and Harold D. Jenkins. Compiled in 1934 and 1935. Scale 1:125,000 (1 inch to 2 miles), 1935.

United States National Resources Committee.

4239. Progress report, with statements of coordinating committees. vi, 61 pp., illus., Washington, June 15, 1936.

United States Soil Conservation Service.

4240. Soil erosion, a critical problem in American agriculture: Nat. Res. Board, Land Planning Comm., Suppl. Rept., pt. 5, v, 112 pp., 6 pls. (maps), 17 figs., 1935.

Upson, Merlin Edward.

4241. The Ostracoda of the Big Blue series in Nebraska: Nebraska Geol. Survey Bull. 8, 2 d ser., 54 pp., 4 pls., June 1933.

Urry, William Donald. See also Lane, 2320, 2323.

4242. Astronomical and geological ages [abstract]: Geol. Soc: America Proc., 1934 , p. 454, June 1935.

4243. The helium method applied to pre-Cambrian chronology [abstract] : Science, new ser., vol. 83, no. 2160, p. 485, May 22, 1936.

4244. (and Johnston, William Drumm, Jr.). Age of the Sierra Nevada granodiorite [California] [abstract]: Geol. Soc. America Proc., 1935, p. 114, June 1936.

4245. Ages by the helium method; 2, Time scale [abstract]: Geol. Soc. America Proc., 1935, p. 114, June 1936.

4246. Ages by the helium method; 2, Post-Keweenawan: Geol. Soc. America Bull., vol. 47, no. 8, pp. 1217-1233, August 31, 1936.

Vaksvik, Knute Nicholas. See Chamberlin, 723 ; Stearns, 3849.

Valentine, Wilbur G.

4247. Geology of the Cananea Mountains, Sonora, Mexico: Geol. Soc. America Bull., vol. 47, no. 1, pp. 53-86, 1 pl. (geol. map), 27 figs., January 31, 1936.

Valentine, William Winchester.

4248. Semitropic gas field [abstract] : Am. Assoc. Petroleum Geologists Bull., vol. 19, no. 12, pp. 1843-1844, December 1935.

Van Amringe, Edwin Verne.

4249. The forms of quartz: Mineralog. Soc. Southern California Bull., vol, 2, no. 4, 4 pp., December 1932.

4250. Fine colemanite specimens found in California: Mineralogist, rol. 3, no. 1, p. 51, January 1935 .

4251. A geological excursion on the Angeles Crest Highway, San Gabriel Mountains, Calif.: Mineralogist, vol. 3, no. 10, pp. 5-6, 20-23, 5 figs., October 1935.

Van Dall, John. See Wardwell, 4338.

Vánderberg, William 0 . See also Lee, 2367.

4252. Placer mining in Nevada: Nevada Univ. Bull., vol. 30, no. 4, 180 pp., 1 pl. (index map), 65 figs., May 15, 1936. 
Van der Gracht, William Anton Joseph Maria van Waterschoot. See also Jongmans, 2011.

4253. The late Paleozoic orogeny in the North American continent [abstract] : 16th Internat. Geol. Cong. (1933) Rept., vol. 2, p. 993, 1936.

4254. Ouachita boulder problem: Am. Assoc. Petroleum Geologists Bull,, vol. 20, no. 8, pp. 1125-1127, August 1936.

Vander Hoof, Vertress Lawrence. See also Camp, 631.

4255. Seasonal bandings in an asphalt deposit at McKittrick, [Calif.] [abstract]: Geol. Soc. America Proc., 1934, p. 332, June 1935.

4256. Pleistocene vertebrates from northern California [abstract] : Geol. Soc. America Proc., 1934, pp. 383-384, June 1935.

4257. Nature and distribution of Demostylus, a marine Tertic mammal [abstract] : Pan-Am. Geologist, vol. 64, no. 1, p. 80, August 1935; Geol. Soc. America Proc., 1935, p. 420, June 1936.

4258. Notes on the type of Borophagus diversidens Cope: Jour. Mammalogy, vol. 17, no. 4, pp. 415-416, 3 figs., November 1936.

Vanderpool, Harold $\mathrm{C}$.

4259. Cretaceous section of Maverick County, Tex.: Jour. Paleontology, vol. 4, no. 3, pp. 252-258, September 1930.

4260. Geological conditions in the Naval Reserve oil field, Osage County, Okla.: Oklahoma Acad. Sci. Proc., 1934, pp. 84-86, 1 fig. (geol. sketch map), 1935.

Vanderwilt, John W.

4261. (and Fuller, Harry C.). Correlation of Colorado Yule marble and other early Paleozoic formations on Yule Creek, Gunnison County, Colo.: Colorado Sci. Soc. Proc., vol. 13, no. 7, pp. 439-464, 3 figs. (incl. sketch map), 1935.

4262. Revision of structure and stratigraphy of the Aspen district, Colo., and its bearing on the ore deposits: Econ. Geology, vol. 30, no. 3, pp. 223-241, 4 figs., May 1935.

4263. Stratigraphy of Pennsylvanian Hermosa formation in Elk Mountains, Gunnison County, Colo.: Am. Assoc. Petroleum Geologists Bull., vol. 19, no. 11, pp. 1668-1677, 1 fig. (index map), Norember 1935.

Van Doorninck, Nicholaas Hendricus. See Doorninck, Nicholaas Hendricus, van, 1068 .

Van Orstrand, Charles Edwin.

4264. Normal geothermal gradient in United States: Am. Assoc. Petroleum Geologists Bull., vol, 19, no. 1, pp. 78-115, 2 figs., January 1935; abstract, Geol. Soc. America Proc., 1934, p. 445, June 1935.

Van Royen, William.

4265. Stream terraces and human occupancy in western Nebraska [abstract] : Geol. Soc. America Proc. 1934, pp. 119-120, June 1935.

Van Tuyl, Francis Maurice.

4266. (and Parker, Ben Hutchinson). The problem of petroleum genesis: Mines Mag., vol. 25, no. 1, pp. 17-22, January 1935.

4267. (and Parker, Ben Hutchinson), Extraterrestrial hydrocarbons and petroleum genesis: Am. Assoc. Petroleum Geologists Bull., vol. 19, no. 6, pp. 900-902, June 1935 .

4268. (and Lovering, Thomas Seward). Physiographic development of the Front Range: 'Geol. Soc. America Bull., vol. 46, no. 9, pp. 12911350, 18 pls., 2 figs. (incl. index map), discussion by John L. Rich and authors' reply, pp. 2046-2054, September 30, 1935. 
Van Tuyl, Francis Maurice-Continued.

4269. (and Lovering, Thomas Seward). The evolution of the Front Range:

Mines Mag., vol. 26, no. 1, pp. 30, 40, 1 fig., January 1936.

4270. (and Lovering, Thomas Seward). Reorganization of the peneplane, a symposium; Inland phases of the peneplane: Pan-Am. Geologist, vol. 66, no. 1, pp. 12-14, August 1936.

4271. (and Parker, Ben Hutchinson). The time of, petroleum formation: Mines Mag., vol. 26, no. 12, pp. 7-8, 23, December 1936.

Van Weerden, W. J. See Terpstra, 4042.

Vaughan, Heury.

4272. Minerals: Young Geologist's Handbook series, no. 2, 40 pp., Schenectady, N. Y., Frost \& Reynolds, 1935.

Vaughan, Thomas Wayland. See also Gardner, 1382; Thorp, 4118.

4273. (and Cole, William Storrs). New Tertiary Foraminifera of the genera Operculina and Operculinoides from North America and the West Indies : U. S. Nat. Mus. Proc., vol. 83, no. 2996, pp. 487-496, 4 pls., 1936.

4274. Stolon systems of communication between the equatorial chambers of orbitoidal Foraminifera [abstract] : Science, new ser., vol. 83, no. 2160, p. 485, May 22, 1936.

4275. Helicolepidina nortoni, a new species of Foraminifera from a deep well in St. Landry Parish, La.: Jour. Paleontology, vol. 10, no. 4, pp. 248252, 2 pls., June 1936.

4276. New species of orbitoidal Foraminifera of the genus Discocyclina from the lower Eocene of Alabama: Jour. Paleontology, vol. 10, no. 4, pp. 253-259, 3 pls., June 1936.

4277. (and Wells, John West). Check list of generic names applied to the Madreporaria Hexacoralla, 1758-1935. 36 pp. ( $\ddagger)$, [La Jolla, Calif.], June 15, 1936.

Ver Steeg, Karl.

4278. The State parks of Hocking County, Ohio: Ohio Jour. Sci., vol. 33, no. 1, pp. 19-36, 2 pls., January 1933.

4279. The Paint Creek meteorite: Science, new ser., vol. 81 , no. 2104, pp. 403404, April 26, 1935.

4280. Wind gaps and water gaps; their value as indicators of erosion surfaces: Am. Jour. Sci., 5th ser., vol. 30, no. 176, pp. 98-105, 1 chart, August 1935.

4281. (and Yunck, George). Geography and geology of Kelley's Island [Lake Erie, Ohio] : Ohio Jour. Sci., vol. 35, no. 6, pp. 421-433, 4 figs. (incl. maps), November 1935 .

4282. Peneplanes and peneplanation : Pan-Am. Geologist, vol. 65, no. 4, pp. 266269, May 1936.

4283. The preglacial physiography of western Ohio: Science, new ser., vol. 84, no. 2174, pp. 201-202, August 28, 1936.

4284. Mohican Forest Park [Ohio] : Ohio Jour. Sci., vol. 36, no. 6, pp. 321-331, 7 figs. (incl. maps), November 1936.

4285. The buried topography of western Ohio: Jour. Geology, vol. 44, no. 8, pp. 918-939, 3 figs. (incl. index map), November-December 1936.

Ver Wiebe, Walter August.

4286. Historical geology. $2 d$ ed., v, 316 pp. ( $\ddagger), 223$ figs. Chicago, John S. Swift Co., Inc., 1935. 
Ver Wiebe, Walter August-Continued.

4287. [Review of] Problems of petroleum geology; a symposium, edited by W. E. Wrather and F. H. Lahee, 1934 : Econ. Geology, yol. 31, no. 2, pp. 194-196, March-April 1936.

4288. Geosynclinal boundary faults: Am. Assoc. Petroleum Geologists Bull., vol. 20, no. 7, pp. 910-938, 16 figs. (incl. geol. maps), July 1936.

4289. [Review of] Geology of the Tampico region, Mexico, by John Malcolm Muir, 1936; Econ. Geology, vol. 31, pp. S85-886, December 1936.

Vivar Gonzalo. See Kellum, 2054.

Vlerk, I. M. van der. See Geyn, van de, 1411.

Vokes, Harold Ernest. See also Clark, 759.

4290. Notes on the variation and synonymy of Ostrea idriaensis Gabb: California Univ., Dept. Geol. Sci. Bull., vol. 23, no. 9, pp. 291-304, 3 pls:, March 15, 1935; abstract, Geol. Soc. America Proc., 1934, p. 386, June 1935.

4291. The genus Velates in the Eocene of California : California Univ., Dept. Geol. Sci., Bull., vol. 23, no. 12, pp. 381-390, 2 pls., March 15, 1935.

4292. A new species of Haliotis from the Pliocene of southern California: Jour. Paleontology, vol. 9, no. 3, pp. 251-252, 2 figs., April 1935.

4293. Stratigraphic position of the Turritella andersoni zone north of Coalinga [abstract] : Geol. Soc. America Proc., 1934, p. 393, June 1935.

4294. Middle Eocene molluscan faunas of Vallecitos and Coalinga areas [Calif.] [abstract] : Pan-Am. Geologist, vol. 63, no. 5, p. 372, June 1935 ; Geol. Soc. America Proc., 1935, p. 411, June 1936.

4295. Notes on genus Ancilla of Lamarck [abstract]: Pan-Am. Geologist, vol. 63, no. 5, p. 376, June 1935; Geol. Soc. America Proc., 1935, p. 414, June 1936.

Von Engeln, O. D. See Engeln, O. D., von.

Von Osinski, William $P$.

4296. Karst windows: Indiana Acad. Sci. Proc., vol. 44, pp. 161-165, 2 figs., 1935.

Vonsen, $\mathrm{M}$.

4297. The discovery of borates in California: Mineralogist, vol. 3, no. 12, pp. 3-4, 21-25, December 1935.

4298. (and Hanna, G. Dallas). Borax Lake, Calif.: California Jour. Mines and Geology, vol. 32, no. 1, pp. 99-108, 5 figs. (incl. index map), January 1936.

Waagen, Lukas.

4299. Pater Stephan Richarz, S. V. D. [1874-1934] : Geol. Gesell. Wien Mitt., Band 27, 1934, pp. 147-149, 1935.

Wade, Arthur.

4300. The distribution of oil fields from the view point of the theory of continental spreading: World Petroleum Cong. (London, 1933) Proc., vol. 1, pp. 73-77, 6 figs. (incl. paleogeol. maps), 1934.

Wadell, Hakon A.

4301. The coefficient of resistance as a function of Reynolds number for solids of various shapes: Franklin Inst. Jour., vol. 217, no. 4, pp. 459-490, 3 figs., April 1934.

4302. Some new sedimentation formulas: Physics, vol. 5, no. 10, pp. 281-291, 5 figs., October 1934. 
Wadell, Hakon A.-Continued.

4303. Volume, shape, and roundness of quartz particles: Jour. Geology, vol. 43, no. 3, pp. 250-280, 6 figs., April-May 1935.

4304. Volume, shape, and shape position of rock fragments in open-work gravel : Geol. Annaler, Arg. 18, Haft 1, pp. 74-92, 15 figs., 1936.

Wadleigh, Francis Rawle.

4305. A list of books and other sources of information regarding coal and coal products. 63 pp., [Washington, D. C., W. F. Roberts Co.], 1935.

Wager, Laurence Rickard.

4306. Geological investigations in east Greenland, pt. 2, Geology of Kap Dalton: Meddelelser om Grönland, Band 105, Nr. 3, 32 pp., 7 pls. (incl. geol. map), 3 figs., 1935.

Waggoner, W. W. See Stevens, 3894.

Wagner, Norman $\mathbf{S}$.

4307. Terreplein geology of Pocono Plateau: Pan-Am. Geologist, vol. 63, no. 4, pp. 241-247, 4 figs. (geol. maps), May 1935.

Wahlstrom, Ernest Eugene.

4308. The minerals of the White Raven mine, Ward, Colo.: Am. Mineralogist, vol. 20, no. 5, pp. 377-383, 7 figs.; May 1935.

4309. The age relations of the Ward ores, Boulder County, Colo.: Econ. Geology, vol. 31, no. 1, pp. 104-114, 3 figs. (incl. geol. mup), January-February 1936.

Waite, Herbert Ames. See also Theis, 4062.

4310. Ground-water level survey in Nebraska: Nebraska Geol. Survey Paper 7, 14 pp., 1 pl. (map), 1935.

Waldbauer, Louis.

4311. (and McCann, D. C.). Crystal structure of common zoisite: Am. Mineralogist, vol. 20, no. 2, pp. 106-111, 3 figs., February 1935.

Waldo, Allen W.

4312. Identification of the copper ore minerals by means of $X$-ray powder diffraction patterns: Am. Mineralogist, vol. 20, no. 8, pp. 575-597, 1 pl., August 1935.

4313. X-ray powder diffraction data for antlerite and brochantite: Am. Mineralogist, vol. 21, no. 1, pp. 71-73, January 1936.

Waldron, F. R. See Andrews, 70.

Walker, Bryant, 1856-1936.

4314. [Review of] Life of the Pleistocene or glacial period, by Frank C. Baker, 1920: Ecology, vol. 2, pp. 73-75, January 1920.

Walker, John Fortune.

4315. Annual report of the Minister of Mines of the Province of British Columbia for the year ended 31st December, 1934. 295 pp., figs., pls., Victoria, B. C., 1935.

4316. Annual report of the Minister of Mines of the Province of British Columbia for the year ended 31st December, 1935. 293 pp., 15 pls. (incl. geol. and sketch maps), 26 figs. (incl. geol. and sketch maps), 1936.

Walker, Paul.

4317. Fossil redwood from Nevada: Mineralogist, vol. 4, no. 6, pp. 7-8, June 1936. 
Walker, Stanley M.

4318. Ore deposition in the Columbia and Dew Drop vein systems, Ward district, Boulder County, Colo.: Engineers' Bull. (Colorado Soc. Eng.), vol. 19, no. 6, pp. 6, 20-21, June 1935; no. 7, pp. 4-6, 26, 1 fig. (map), July 1935.

Walker, Thomas Leonard.

4319. Chemawinite or Canadian amber: Toronto Univ. Studies, Geol. ser. 36, pp. 5-12, 2 pls., 1934; abstracts, Am. Mineralogist, vol. 20, no. 3, p. 1935, March 1935; Geol. Soc. America Proc., 1934, pp. 419-420, June 1935.

4320. A study of the mineral composition of mine dust: Toronto Univ. Studies, Geol. ser. 38, pp. 5-11, 1935; abstract, Am. Mineralogist, vol. 21, no. 3, p. 193, March 1936.

4321. Magmatic differentiation as shown in the nickel intrusive of Sudbury, Ontario: Toronto Univ. Studies, Geol. ser. 38, pp. 23-30, 2 figs. (incl. index map), 1935.

4322. An unusual type of quartz: Toronto Univ. Studies, Geol. ser. 38, pp. 31-32, pl. 2, fig. 1, 1935.

4323. The amber from Cedar Lake, Manitoba, and its fossil fauna [abstract] : Royal Soc. Canada Trans. vol. 30, sec. 4, Proc. p. xcrii, 1936.

4324. An unusual quartz from the pre-Cambrian mine, Vernon, British Columbia [abstract]: Royal Soc. Canada Trans. vol. 30, sec. 4, Proc., p. xcvii, 1936.

Walling, R. W.

4325. Report on Newhall oil field: California Oil Fields, vol. 20, no. 2, pp. 5-58, 4 pls., 11 tables, Oct., Nov., Dec., 1934 [1936].

Walls, James Gray.

4326. Geology laboratory manual, minerals and rocks. 61 pp. ( $)$, St. Louis, John S. Swift Co., Inc., 1935.

Walter, K. L. See Dobbin, 10.51, 1.052.

Walther, Paul.

4327. Fluorescent minerals from many localities: Mineralogist, vol. 4, no. 1, pp. 5-6, 10, January 1936.

Wandke, Alfred.

4328. (and Moore, Thomas G.). Pyrometasomatic rein deposits at Tepezala, Aguascalientes, Mexico: Econ. Geology, rol. 30, no. 7, pp. 765-782, 3 figs. (incl. geol. map), November 1935.

Wanenmacher, Joseph Melching. See Kansas Geol. Soc., 2020; Raasch, 3162; Thwaites, 4123.

Wanless, Harold Rollin. See also Shepard, 3669.

4329. Laboratory exercises in geology for students of agriculture at the University of Illinois. 38 pp. (†), 2 figs., Ann Arbor, Mich., Edwards Brothers, Inc., 1935.

4330. Pennsylvanian correlation between the Eastern Interior and the Appalachian coal fields [abstract]: Geol. Soc. America Proc., 1935, p. 115, June 1936.

4331. (and Shepard, Francis Parker). Sea level and climatic changes related to late Paleozoic cycles: Geol. Soc. America Bull., vol. 47, no. 8, pp. 1177-1206, 3 figs., Angust 31, 1936 ; abstract, with discussion, Proc., 1934, pp. 120-1.21, June 1935. 
Ward, T. W.

4332. Effect of manganese on fluorescence: Mineralogist, vol. 3 , no. 1, pp. 19-20, January 1935.

4333. The geological ages of the earth: Mineralogist, vol. 3, no. 5, pp. 5-6, 21-25, May 1935.

4334. Fossil egg filled with colemanite: Mineralogist, vol. 3, no. 6, pp. 12-13, June 1935.

4335. Copper minerals as fossilizing agents: Mineralogist, vol. 3, no. 7, pp. 7-8, July 1985.

Warde, John M.

4336. Montana hedenbergite: Glïck Auf, vol. 1., no. 4, pp. 11-12, 3 figs., Butte, Mont., April 1936.

4337. Clay prospecting in Montana: Gliick Auf, vol. 2, no. 1, pp. 8-10, 26, 4 figs., Butte, Mont., October 1936.

Wardwell, D. P.

4338. (and Brandenthaler, Rudolph Richard, Williams, W. L., and Van Dall, John). Water problems in the northern part of the Cushing field, Creek County, Okla., 65 pp. (:), 11 pls. (incl. index maps), U. S. Bur. Mines in cooperation with State of Oklahoma, February 1927.

Waring, Gerald Ashley. See also Hite, 1752.

4339. (and Andrews, David Arthur). Ground-water resources of northwestern New Mexico: U. S. Dept. Interior Press Mem. 108556, 2 pp. ( $\$), 1$ pl. (geol. map), Norember S, 1935.

4340. (and Knechtel, Maxwell McMichael). Water supplies from wells in southeastern Utah and southwestern Colorado: U. S. Dept. Interior Press Mem. 115346, 4 pp. (\$), April 7, 1936.

4341. Two thermal springs in Idaho and Oregon [abstract]: Geol. Soc. America Proc., 1935, pp. 115-116, June 1.936.

Warner, J. Laird.

4342. Geology of a portion of the Tertiary of northeastern Mexico [abstract] : Am. Assoc. Petroleum Geologists Bull., vol. 19, no. 1, p..140, January 1935.

Warner, 'T. W., Jr.

4343. Spectrographic analysis of tourmalines with correlation of color and composition: Am. Mineralogist, vol. 20, no. 7, pp. 531-536, 1 fig., July 1935.

Warren, Harry Verney.

4344. (and Lord, Clifford S.). An occurrence of schwatzite in British Columbia: Econ. Geology, vol. 30, no. 1, pp. 67-71, January-February 1935.

4345. Distribution of silver in base-metal ores [with discussion]: Am. Inst. Min. Met. Eng. Trans., rol. 115 (Mining geology), pp. 81-89, 1935 ; abstract, Year Book sec., p. 61, January 1936.

4346. (and Cummings, J. M.). The relationship between gold and metallic minerals in British Columbia [abstract]: Royal Soc. Canada Trans., vol. 30, sec. 4, Proc., p. c., 1936.

4347. A gold-bismuth occurrence in British Columbia: Econ. Geology, vol. 31, no. 2, pp. 205-211, March-April 1936.

Warren, Percival Sidney. See also Canada G. S., 656; Crockford, 916; Fraser, 1330 ; Miller, 2711. 
Warren, Percival Sidney-Continued.

4348. The fauna of the Lea Park shale: Royal Canadian Inst. Trans., vol. 20, pt. 2 (no. 44), pp. 223-229, December 1935.

4349. Two new fossil fish from the Canadian Rockies: Royal Soc. Canada Trans., 3d ser., vol. 30, sec. 4, pp. 55-58, 2 pls., May 1936.

Warren, Walter.

4350. Tertiaries of the Washington Cascades: Pan-Am. Geologist, vol. 65, no. 4, pp. 241-247, May 1936; abstract, no. 1, p. 77, February 1936.

Warthin, Aldred Scott, Jr. See also Cooper, 866.

4351. (and Cooper, Gustav Arthur). Devonian studies in southwestern Ontario and Michigan: Smithsonian Inst. Explorations and Field Work, 1934, Pub. 3300, pp. 13-16, 2 pls., 1935; abstract, Geol. Soc. America Proc., 1934, pp. 362-363, June 1935.

4352. (and Cooper, Gustav Arthur). New formation names in the Michigan Devonian: Washington Acad. Sci. Jour., vol. 25, no. 12, pp. 524-526. December 15, 1935.

Washburn, Henry Bradford, Jr.

4353. Morainic bandings of Malaspina and other Alaskan glaciers: Geol. Soc. America Bull., vol. 46, no. 12, pp. 1879-1890, 7 pls., 1 fig., December 31, 1935.

4354. Exploring Yukon's glacial stronghold : Nat. Geog. Mag., vol. 69, no. 6, pp. 715-748, 1 pl. (index map), 28 figs., June 1936.

4355. The Harvard-Dartmouth Alaskan expeditions, 1933-34 [with discussion] : Geog. Jour., London, vol. 87, no. 6, pp. 481-495, 9 pls. (incl. reconnaissance map), 1 fig., June 1936.

4356. Motion of South Crillon glacier, Alaska [abstract] : Geol. Soc. America Proc., 1935, p. 116, June 1936.

Waters, Aaron Clement. See also Wells, 4389.

4357. (and Campbell, Charles Duncan). Mylonites from the San Andreas fault zone: Am. Jour. Sci., 5th ser., vol. 29, no. 174, pp. 473-503, 8 figs., June 1935; abstract, Geol. Soc. America Proc., 1934, p. 325, June 1935.

4358. Transverse folding, Cascade Range [abstract]: Geol. Soc. America Proc., 1935, pp. 116-117, June 1936.

Watson, Edward Hahn.

4359. (and others). Fifth annual meeting, Field conference of Pennsylvania geologists in the Philadelphia area of southeastern Pennsylvania. 43 pp. (\$), 1 fig., 3 pls. (incl. geol. map), [1935].

4360. Alteration of gabbro near Philadelphia, Pa. [abstract] : Am. Mineralogist, vol. 21, no. 3, pp. 200-201, March 1936.

4361. Emplacement of granite at Springfield, near Philadelphia [abstract] : Geol. Soc. America Proc., 1935, p. 117, June 1936.

Watson, Fletcher, Jr.

4362. Meteor Crater: Popular Astronomy, vol. 44, no. 1, pp. 2-17, 6 figs., January 1936.

Watson, R. J. See also Ehrenburg, 1148.

4363. A contribution to the theory of the interpretation of resistivity measurements obtained from surface potential observations: Am. Inst. Min. Met. Eng. Tech. Pub. 518, 34 pp., 26 figs., 1934; with discussion, Trans., vol. 110, Geophysical Prospecting, pp. 201-236, 26 figs., 1934.

Watson, Thomas Leonard. See Ries, 3300. 
Watts, William Whitehead.

4364. Form, drift, and rhythm of the continents: Science, new ser., vol. 82, no. 2123, pp. 203-213, September 6, 1935; Pan-Am. Geologist, vol. 64 , no. 2 , pp. 81-98, September 1935 ; no. 3, pp. 179-184, October 1935.

Wayland, Russell G.

4365. Cummingtonite frois the Black Hills, S. Dak.: Am. Mineralogist, voI. 21, no. 9 , pp. 607-610, September 1936.

Weatherby, B. B.

4366. (and Faust, Lawrence Yoder). Influence of geological factors on longitudinal seismic velocities: Am. Assoc. Petroleum Geologists Bull., vol. 19, no. 1, pp. 1-8, 3 figs., January 1935.

Weaver, Charles Edwin.

4367. Stratigraphy of the northern border of the Olympic Peninsula [abstract] : Geol. Soc. America Proc., 1934, pp. 335-336, June 1935.

4368. Tertic stratigraphy of western Washington and Oregon [abstract] : Pan-Am. Geologist, vol. 64, no. 1, pp. 72-73, August 1935; vol. 66, no. 2, pp. 158-159, September 1936; Geol. Soc. Oregon Country News Letter, vol. 2, no. 12, p. 6 ( $\ddagger)$, June 25, 1936; Geol. Soc. Amer-ica Proc., 1935, p. 349, June 1936.

4369. Tertiary history of western Washington and Oregon [abstract] : Geol. Soc. America Proc., 1935, pp. 117-118, June 1936.

Weaver, John Ernest.

4370. (and Noll, William Clarence). Comparison of run-off and erosion in prairie, pasture, and cultivated land: Nebraska Univ., Cons. Dept., Bull. 11, 37 pp., 11 figs., November 1935.

Webb, J. B.

4371. Occurrence of Baculites ovatus zone of upper Alberta shales in southeastern British Columbia: Am. Assoc. Petroleum Geologists Bull., vol. 19, no. 5, pp. 703-704, May 1935.

Webb, Robert William. See also Leonard, 2393, 2394, 2395, 2396; Murdoch, 2834. 4372. Tetradymite from Inyo Mountains, Calif: Am. Mineralogist, vol. 20, no. 5, pp. 399-400, May 1935.

4373. The Cerro Gordo mining district [Calif.] : Pacific Mineralogist, vol, 2, no. 1, pp. 9-11, June 1935.

4374. Kern Canyon fault, southern Sierra Nevada: Jour. Geology, vol. 44, no. 5, pp. 631-638, 1 fig. (index map), July-August 1936.

Webber, Benjamin N.

4375. Bajada placers of the arid southwest: Am. Inst. Min. Met. Eng. Tech. Pub. 588, 16 pp., 1935; abstracts, Mining and Metallurgy, vol. 16, no. 338, p. 114, February 1935; Year Book sec., p. 61, January 1936.

Weed, Walter Harvey.

4376. Copper and other ores of mineral pipes and disseminations [abstract] : 16th Internat. Geol. Cong. (1933) Rept., vol. 2, p. 1030, 1936.

Weeks, Ludlow J. See Canada G. S., 643.

Wegemann, Carroll Harvey. See Thom, 4074.

Wegmann, C. Eugene.

4377. Preliminary report on the Caledonian orogeny in Christian X's Land (north-east Greenland) : Meddelelser om Grönland, Band 103, $\mathrm{Nr}$. 3, 59 pp., 3 pls., 11 figs. (incl. sketch map), 1935. 
Weidhaus, Ernest.

4378. Freak simulations in agate: Rocks and Minerals, vol. 11, no. 9, pp. 131136, 7 figs.; September-October 1936.

Weinzierl, John F.

4379. Possibilities of shore-line or shoestring fields on Texas-Louisiana Gulf coast: Oil and Gas Jour., vol. 34, no. 48, pp. 155-159, 15 figs., April 16, 1936.

Weir, John A.

4380. Solving the strike and pitch of intersecting formations by a formula: Eng. and Min. Jour., vol. 137, no. 1, pp. 12-13, January 1936.

Weisbord, Norman Edward.

4381. Graphic method for determination of true dip in pits: Am. Assoc. Petroleum Geologists Bull., vol. 19, no. 6, pp. 908-911, 2 figs., June 1935.

Weller, James Marvin. See also Hubbert, 1874.

4382. Siliceous sponge spicules of Pennsylvanian age from Illinois and Indiana: Jour. Paleontology, vol. 4, no. 3, pp. 233-251, 6 pls., September 1930.

4383. Adolescent development of Ditomopyge: Jour. Paleontology, vol. 9, no. 6, pp. 503-513, 31 figs., September 1935.

4384. "Grassy Creek" shale: Illinois Acad. Sci. Trans., vol. 28, no. 2, pp. 191192, December 1935.

4385. (and Bell, Alfred Hannam). The geology and oil and gas possibilities of parts of Marion and Clay Counties, with a discussion of the central portion of the Illinois basin: Illinois Geol. Survey Rept. Inv. 40, 54 pp., 1 pl. (geol. map), 9 figs. (incl. index map), 1936.

4386. Geology and oil possibilities of the Illinois basin: Illinois Geol. Survey Press Bull. ser., no. 27, 19 pp., 1 pl. (geol. map), 9 figs. (incl. geol. map), July 11, 1936.

4387. Carboniferous trilobite genera: Jour. Paleontology, vol. 10, no. .8, pp. 704-714, 1 pl., December 1936.

Welles, S. P. See Hesse, 1730.

Wells, Francis Gerritt. See also Thompson, 4095.

4388. Reconsideration of the Pleistocene geology of Long Island [abstract]: Geol. Soc. America Proc., 1934, pp. 121-122, June 1935.

4389. (and Waters, Aaron Clement). Basaltic rocks in the Umpqua formation: Geol. Soc. America Bull., vol. 46, no. 6, pp. 961-972, 1 fig. (geol. sketch map), 2 pls., June 30, 1935.

Wells, John West. See also Vaughan, 4277.

4390. Corals from the Cretaceous and Eocene of Jamaica: Annals and Mag. Nat. History, 10th ser., vol. 15, no. 86, pp. 183-194, 3 pls., February 1935.

4391. The nomenclature and type species of some genera of recent and fossil corals : Am. Jour. Sci., 5th ser., vol. 31, no. 182, pp. 97-134, February 1936.

Wells, Roger Clark.

4392. The thermal decomposition of some carbonate minerals: Am. Geophys Union Trans. 15th Ann. Meeting, pt. 1, pp. 237-240 ( $\$), 6$ figs., Nat. Research Council, June 1934. 
Wells, Roger Clark-Continued.

4393. The abundance of certain elements, especially radioactive elements, and related geologic problems [abstract]: Washington Acad. Sci. Jour., vol. 25, no. 2, pp. 88-89, February 15, 1935.

Wendlandt, E. A.

4394. (and Knebel, Moses G.). Mount Sylvan dome, Smith County, Texas: Gulf coast oil fields (see Barton and Sawtelle), pp. 1041-1049, 3 figs. (incl. geol. and structure maps), 1936.

4395. Talco field, Titus and Franklin Counties, Tex.: Am. Assoc. Petroleum Geologists Bull., vol. 20, no. 7, pp. 978-979, July 1936.

Wendler, Arno P. See Bowling, 407 .

Wendling, A. V. See Barnes, 188, 189, 190.

Wenner, Frank.

4396. A method of measuring earth resistivity: U. S. Bur. Standards Bull., vol. 12, no. 3 (Sci. Paper 258), pp. 469-478, 4 figs., February 3, 1916.

4397. A small seismometer with galvanometer registration: Fifth Pacific Sci. Cong., Canada, 1933, Proc., vol. 3, pp. 2495-2497, 1934.

4398. (and Lee, Frederick William, and McComb, Harold Edgar, and Macelwane, James Beruard). Report of the Section of Seismology of the American Geophysical Union to the Association of Seismology of the International Union of Geodesy and Geophysics, 1933: Union géod. géophys, internat., Sec., seismologie, Travaux sci., sér. A, fasc. 10, pp. 54-76, 1934.

4399. Theory of usual type of seismometer from standpoint of determining ground movements from records [abstract] : Pan-Am. Geologist, vol. 65, no. 3, p. 234, April 1936.

Wentworth, Chester Keeler. See also Gregory, 1522.

4400. Types of marine benches on Oahu shores [Hawaii] [abstract]: Bernice P. Bishop Mus. Special Pub. 26, pp. 9-10, 1935.

4401. Geologic structure of Nuuanu Valley [Oahu, Hawaii] [abstract] : Bernice P. Bishop Mus. Special Pub. 26, pp. 11-12, 1935.

4402. (and Dickey, Robert I.). Ventifact localities in the United States: Jour. Geology, vol. 43, no. 1, pp. 97-104, January-February 1935.

4403. Striated rock surfaces in the St. Francis River Valley: Am. Jour. Sci., 5th ser., vol. 20, no. 172, pp. 264-368, 2 figs., April 1935.

4404. Modern bench-forming processes on Oahu [abstract] : Geol. Soc. America Proc., 1934, p. 122, June 1935.

4405. The terminology of coarse sediments, with notes by P. G. H. Boswell : Nat. Research Council Bull. 98, pp. 225-246, July 1935.

4406. (and Suzuki, Francis T.). Multiple grinding of thin-section chips: Am. Jour. Sci., 5th ser., vol. 31, no. 182, pp. 93-96, 1 fig., February 1936.

4407. Geomorphic divisions of the island of Hawaii: Hawaii Univ. Occ. Paper 29, 15 pp., 1 fig. (map), June 1936.

4408. Is geology a science?: Science, new ser., vol. 83, no. 2162 , pp. 550-551, June 5, 1936.

4409. (and Ray, Louis L.). Studies of certain Alaskan glaciers in 1931: Geol. Soc. America Bull., vol. 47, no. 6, pp. 879-934, 11 pls., 18 figs. (incl. index :map), June 30, 1936.

4410. A note on chink-faceted pebbles [Hawaii] : Jour. Geology, vol. 44, no. 5, p. 645 , July-August 1936 : 
Wentworth, Chester Keeler-Continued.

4411. An analysis of the shapes of glacial cobbles: Jour. Sedimentary Petrology, vol. 6, no. 2, pp. 85-96, 5 figs., 10 tables, August 1936.

4412. The shapes of glacial and ice-jam cobbles: Jour. Sedimentary Petrology, vol. 6, no. 2, pp. 97-108, August 1936.

4413. The method of moments: Jour. Sedimentary Petrology, vol. 6, no. 3, pp. 158-159, December 1936.

Wenzel, Leland Keith. See also Leggette, 2376 ; Meinzer, 2637.

4414. Four-year decline of the ground-water level in the Platte Rirer Valley, in central Nebraska, caused by subnormal precipitation: U. S. Dept. Interior Press Mem. 98079, 2.pp. ( $¥), 2$ pls., May 1, 1935.

4415. Ground-water resources of south-central Nebraska, with special reference to the Platte River valley between Chapman and Gothenburg: U. S. Dept. Interior Press Mem. 106376, 2 pp. (\$), September 16, 1935.

4416. The Thiem method for determining permeability of water-bearing ma. terials and its application to the determination of specific yield; results of investigations in the Platte River Valley, Nebraska: U. S. Geol. Surrey Water-Supply Paper 679-A, pp. iv, 1-57, 6 pls., 7 figs. (incl. index map), 1936.

4417. Symposium on fluctuations of ground water; The recovery of groundwater levels in Nebraska in 1935: Am. Geophys. Union Trans. 17th Ann. Meeting, pt. 2, pp. 370-371 ( $\$)$, Nat. Research Council, 1936. 4418. Several methods of studying fluctuations of ground-water levels: Am. Geophysical Union Trans. 17th Ann. Meeting, pt. 2, pp. 400-405 $(\ddagger), 3$ figs., Nat. Research Council, 1936.

Werber, Benjamin N.

4419. Bajada placers of the arid Southwest [with discussion] : Am. Inst. Min. Met. Eng. Trans., vol. 115, Mining geology, pp. 378-392, 1935.

Werner, Courtney.

4420. Synonymy of the mid-Devonian tabulate corals of the Falls of the Ohio: Washington Univ. [St. Louis] Studies, new ser., no. 9, pp. 53-64, February 1936.

4421. Mesozoic plant foods and mammalian evolution: Washington Univ. [St. Louis] Studies, new ser., no. 9, pp. 81-90, Fehruary 1936.

West, C. D.

4422. Immersion liquids of high refractive index: Am. Mineralogist, vol. 21, no. 4, pp. 245-249, 2 figs., April 1936; abstract, no. 3, p. 194, March 1936.

West, Clarence Jay. See Hull, 1882; McComb, 2508.

West, Gladys F.

4423. A post-Wisconsin record of Fraxinus nigra: Rhodora, vol. 37, no. 433, pp. 20-22, 1 pl., January 1935.

Westby, Gerald Halinbeck.

4424. Problems in reflection seismology [abstract, with discussion]: Tulsa Geol. Soc. Digest, 1934, pp. 5-9,

4425. Alex M. Alexander [1898-1934] : Am. Assoc. Petroleum Geologists Bull., vol. 19, no. 1, pp. 147-148, January 1935.

4426. The discovery by reflection seismograph of a small producing structure in Okmulgee County, Okla.: Soc. Petrolenm Geophysicists Jour., vol. 6, no. 1, pp. 44-59, 9 figs., July 1935. 
Westby, Gerald Halinbeck-Continued.

4427. [Review of] Geophysical prospecting, 1934: Am. Soc. Petroleum Geololists Bull., vol. 19, no. 1, p. 119, January 1936.

Western, Forrest.

4428. The atomic weights of radioactive substances, actinouranium, and the problem of geologic time: Pittsburgh Univ. Bull., vol. 30, no. 2r pp. 295-302, November 15, 1933.

Westgate, Lewis Gardner.

4429. Memorial of Eugene Wesley Shaw [1881-1935]: Geol. Soc. America Proc., 1935, pp. 311-318, 1 pl. (port.), June 1936.

Westland, Anthony J.

4430. A comparison of old and new methods in the analysis of the September 9, 1931, earthquake: Seismol. Soc. America Bull., vol. 26, no. 2, pp. 119-124, 3 figs., April 1936; abstract, Pan-Am. Geologist, vol. $65_{\text {r }}$ no. 3, pp. 234-235, April 1936.

Wetmore, Alexander.

4431. On the genera Oligocorax and Miocorax: Auk, vol. 52, no. 1, pp. 75-76, January 1935.

4432. A record of the trumpeter swan from the late Pleistocene of Illinois: Wilson Bull., vol. 47, p. 237, September 1935.

4433. Two new species of hawks from the Miocene of Nebraska: U. S. Nat. Mus. Proc., vol. 84. no. 3003, pp. 73-78, 2 flgs., 1936.

4434. How old are our birds? Bird-Lore, vol. 38, pp. 321-326, 1 pl., 6 figs., September-October 1936.

Weymuller, F.

4435. Observations sur le relief du versant méridional du plateau mexicain: Assoc. géog. francaise Bull. 97, pp. 72-74, May 1936.

Wharton, Jack.

4436. Teredo wood found in Oregon: Mineralogist, vol. 3, no. 12, p. 14, December 1935.

Wharton, Jay B., Jr. See Stovall, 3953.

Wharton, J. R.

4437. Petrified "Teredo" wood near Roseburg, Oreg.: Rocks and Minerals, vol. 11, no. 3, p. 41, March 1936.

4438. Fossil-fern locality: Mineralogist, vol. 4, no. 8, p. 16, August 1936.

Wheeler, E. P., $2 d$.

4439. An amazonite aplite dike from Labrador: Am. Mineralogist, vol. 20, no. 1, pp. 44-49, January 1935.

4440. The Nain-Okak section of Labrador: Geog. Rev., vol. 25, no. 2, pp. 240-254, 1 pl. (reconnaissance map), 11 figs., April 1935.

Wheeler, Harry Edgar. See also Frizzell, 1346; Palmer, 2994.

4441. Otarion halli, a new name for a trilobite species from the Hamilton of New York: Am. Midland Naturalist, vol. 16, no. 1, pp. 104-106, January 1935.

4442. New trilobite species from the anthracolithic of northern California: San Diego Soc. Nat. History, Trans., vol. 8, no. 8, pp. 47-52, 1 pl. (in part), March 21, 1935; abstract, Geol. Soc. America Proc., 1934, p. 386, June 1935.

4443. Griffithides conwayensis, a new name for a trilobite species from the Atoka formation of Arkansas: San Diego Soc. Nat. History, Trans., vol. 8 , no. 8 , pp. 53-56, 1 pl. (in part), March 21,1935 . 
Wheeler, Harry Edgar-Continued.

4444. Stratigraphy and fauna of McCloud limestone [Calif.] [abstract]: Pan-Am. Geologist, vol. 63, no. 5, p. 370, June 1935; Geol. Soc. America Proc., 1935, p. 409, June 1936.

4445. Timothy Abbott Conrad [1803-1877], with particular reference to his work in Alabama one hundred years ago: Bull. Am. Paleontology, vol. 23, no. 77, 29 pls. (incl. geol. map and ports.), 4 figs., September 2, 1935.

Wheeler, Russell B.

4446. (and Kerr, Albert R.). Preliminary report on the Tonto group of the Grand Canyon, Ariz.: Grand Canyon Nat. History Assoc. Bull. 5, pp. 1-16 (\$), 4 figs. (incl. geol. and index maps), May 1936.

Whisenant, J. Barney.

4447. (and Trenchard, John, Crandall, Kenneth Hartley, and Rach, E C.). Symposium on the Government Wells field, Duval County [Tex.] [abstract]: Am. Assoc. Petroleum Geologists Bull., vol. 19, no. 1, p. 140, January 1935 .

Whitcomb, Lawrence.

4448. Possible volcanic sources of Ordovicic bentonites: Pan-Am. Geologist, vol. 63, no. 4, pp. 265-270, May 1935.

4449. Synonymy of petrographic term phenoclast: Pan-Am. Geologist, vol. 63 , no. 4, p. 300, May 1935.

4450. (and Rosenkrans, R. R.). Bentonite beds in the lower Chambersburg: Geol. Soc. America Bull., vol. 46, no. 8, pp. 1251-1.254, 2 figs. (incl. index maps), August 31, 1935.

White, Charles David, 1862-1935. See also Fisher, 1272.

4451. Effects of geophysical factors on the evolution of oil and coal : Inst. Petroleum Technologists Jour., vol. 21, no. 138, pp. 301-310, 1 pl. (port.), April 1935.

4452. Outstanding features of petroleum development in America: Am. Assoc. Petroleum Geologists Bull., vol. 19, no. 4, pp. 469-502, April 1935.

4453. Metamorphism of organic sediments and derived oils: Am. Assoc. Petroleum Geologists Bull., vol. 19, nc. 5, pp. 589-617, May 1935.

4454. Some features of the early Permian flora of America: 16th Internat. Geol. Cong. (1933) Rept., vol. 1, pp. 679-689, 1 pl. (correl, table), 1936.

White, Charles Henry. See Gilluly, 1432 ; Stark, 3835.

White, Ella Marie. See Cushman, 942.

White, George M.

4455. The Crystal Peak region near Florissant, Colo.; Rocks and Minerals, vol. 10, no. 12, pp. 184-187, 1 fig., December 1935.

White, George Willard.

4456. Profile studies of end moraines of the Scioto glacial lobe [abstract]: Geol. Soc. America Proc., 1934, pp. 122-123, June 1935.

4457. The Powell and Broadway end moraines: Am. Jour. Sci., 5th ser., vol. 30, no. 175, pp. 33-44, 3 figs., July 1935.

4458. [Review of] A survey of road materials and glacial geology of Maine, by $H$. Walter Leavitt and Edward H. Perkins, pt. 1, 1934, pt. 2, 1935: Jour. Geology, vol. 44, no. 3, pp. 425-426, April-May 1936. 
White, Maynard Pressly. See also Tomlinson, 4141.

4459. Some fusulinid problems: Jour. Paleontology, vol. 10, no. 2, pp. 123-133, 3 pls., March 1936.

4460. [Review of] Geology of the Tampico region, Mexico, by John M. Muir, 1936: Am. Assoc. Petroleum Geologists Bull., vol. 20, no. 11, pp. 1494-1495, November 1936.

White, Theodore Elmer. See Case, 691.

White, Walter Noy. See also Livingston, 2429.

4461. Summary report on the survey of the underground waters of Texas, 28 pp. ( $\ddagger), 2$ pls. (incl. geol. map), Texas State Board Water Eng., Austin (?), March 1935.

Whiteside, Robert M. See Barton, 212.

Whitlatch, George Isaac.

4462. Under clays of the commercial coals of Teunessee: Tennessee Acad. Sci. Jour., vol. 10, no. 3, pp. 205-224, July 1935.

4463. Sand lenses in the Porters Creek formation of west Tennessee: Tennessee Acad. Sci. Jour., vol. 11, no. 2, pp. 131-140, 1 fig., April 1936.

4464. Mileposts in Tennessee's clay industry: Tennessee Acad. Sci. Jour., vol. 11, no. 3, pp. 153-163, July 1936.

Whitlock, Herbert Percy.

4465. Concerning phantoms; a series of illustrations of crystal growth with explanatory notes: Nat. History, vol. 33, no. 3, pp. 271-277, 13 figs., May-June 1933.

Whitman, Alfred Russell.

4466. Reconnaissance on Eparchaean plain in Arizona [abstract] : Pan-Am. Geologist, vol. 63, no. 4, pp. 309-310, May 1935; Geol. Soc. America Proc., 1935, pp. 332-333, June 1936.

Whitney, Dudley Joseph.

4467. Some relations of volcanism to geologic history: Pan-Am. Geologist, vol. 64 , no. 4 , pp. 287-296, November 1935 .

4468. Rubidium and a young earth: Pan-Am. Geologist, vol. 65, no. 1, pp. 31-34, February 1936; abstract, no. 3, pp. 232-233, April 1936.

4469. How old is earth? Some conservative factors: Pan-Am. Geologist, vol. 65 , no. 2, pp. 113-124, March 1936.

4470. Rubidium and geologic time [abstract] : Geol. Soc. America Proc. 1935, p. 442, June 1936.

Wickenden, Robert Thomas Daubigny. See also Fraser, 1330, McLearn, 1555.

4471. Some possible sources of ground water in southern Saskatchewan: Eng. Jour., vol. 18, no. 4, pp. 193-195, 1 fig. (geol. sketch map), April 1935.

Wickwire, Grant Townsend.

4472. Crinoid stems on fossil wood: Am. Jour. Sci., 5th ser., vol. 32, no. 188, pp. 145-146, 1 fig., August 1936.

Wièland, George Reber.

4473. Cycadeoid investigations [abstract] : Carnegie Inst. Washington Year Book 34, pp. 321-323, 1935.

4474. Petrifaction, petrified forests: Mineralogist, vol. 3, no. 10, pp. 3-4, 24-25, October 1935.

4475. Twenty-five years of paleobotany, 1910-1935: Brooklyn Bot. Garden Mem., vol. 4, pp. 87-95, 2 pls., 2 figs., May 7, 1936. 
Wieland, Lillian Helen.

4476. Soil-erosion bibliography, 124 pp. (†) [Washington], U. S. Dept. Interior, Soil Erosion Serv., 1935.

Wilcox, Ray E.

4477. Insoluble residues from Wisconsin sedimentary rocks; pt. 2, Studies of Wisconsin sedimentary rocks, no. 4, Insoluble residues of the Mendota (St. Lawrence) dolomite: Wisconsin Acad. Sci. Trans., vol. 29, pp. 268-271; 1 fig., 1935.

4478. Occurrence of large zircon needles in a basic pegmetite: Am. Mineralogist, vol. 21, no. 7, p. 459, July 1936.

Wilcox, Stanley W.

4479. Prospecting for road metals by geophysics: Eng. News-Record, vol. 114, no. 8, pp. 271-274, 5 figs., February 21, 1935 ; abstract, Mines Mag., vol. 26, no. 12, p. 27, December 1936.

Wild, George 0 .

4480. How agates form in nature: Rocks and Minerals, vol. 11, no. 9, pp. 176-177, September-October 1936.

4481. Moss agate: Rocks and Minerals, vol. 11, no. 9, pp. 189, 196, SeptemberOctober 1936.

Wilder, N. M. See Jones, 2000.

Wilgus, Wallace La Fetra. See Burpee, 583.

Wilkinson, W. D. See also Hodge, 1765.

4482. Spherulites in the Clarno formation acid lavas [abstract]: Geol. Soc. America Proc.,.1934, p. 330, June 1935; Geol. Soc. Oregon .Country News Letter, vol. 2, no. 11, p. 10 ( $\ddagger)$, June 10, 1936.

Willard, Bradford. See also Ashley, 100, 106 ; Chadwick. 706.

4483. [Second annual] field conference of Pennsylvania geologists: Science, new ser., vol. 75 , no. 1995 , pp. 631-632, June 17, 1932.

4484. [Third annual] field conference of Pennsylvania geologists: Science, new ser., vol. 77, no. 2009, pp. 629-630, June 30, 1933.

4485. Fourth [annual] field conference of Pennsylvania geologists: Science, new ser., vol. 79, no. 2058, pp. 517-518, June 8, 1934.

4486. Studies of Bermuda geology : Bermuda Biol. Sta. Research Repts. of Officers, 1933-34, pp. 79-81, 1935.

4487. Chemung tracks and trails from Pennsylvania: Jour. Paleontology, vol. 9, no. 1, pp. 43-56, 1 fig., 2 pls., January 1935.

4488. Hypothyridina venustula (Hall) in Pennsylvania: Am. Jour. Sci., 5th ser. vol. 29, no. 170, pp. 93-97, 1 fig., February 1935.

4489. Pennsylvania geology summarized: Pennsylvania Topog. and Geol. Survey Bull. 113, 13 pp. (\$), 4 figs. (incl. geol. and relief maps), February 1935.

4490. Hamilton group of central Pennsylvania : Geol. Soc. America Bull., vol. 46, no. 2, pp. 195-224, 3 figs., 1 pl., February 28, 1935; abstract, Proc., 1933, p. 348, June 1934.

4491. Deronian ice in Pennsylvania: Jour. Geology, vol. 43, no. 2, pp. 214-219, 2 figs., February-March 1935.

4492. Educational geologic trips in Pennsylvania: Science, new ser., vol. 81, no. 2110 , pp. 553-554, June 7, 1935.

4493. Fifth annual field conference of Pennsylvania geologists: Science, new ser., vol. 82, no. 2115, pp. 31-32, July 12, 1935. 
Willard, Bradford-Continued.

4494. Portage group in Pennsylvania : Geol. Soc. America Bull., vol. 46, no. 8, pp. 1195-1218, 2 pls., 2 figs. (incl. map), August 31, 1935; abstract, Proc., 1934, p. 123, June 1935.

4495. Hamilton group along the Allegheny front, Pennsylvania: Geol. Soc. America Bull., vol. 46, no. 8, pp. 1275-1290, 2 figs. (incl. sketch map), August 31, 1935; abstract, Proc., 1934, p. 361, June 1935.

4496. (and Caster, Kenneth E.). Age of Devonian of southwestern Pennsylvania: Am. Assoc. Petroleum Geologists Bull., vol. 19, no. 10, pp. 1546-1550, October 1935.

4497. An "antidune" phase of eolian ripple marks: Jour. Sedimentary Petrology, vol. 5, no. 3, pp. 133-136, 1 fig., December 1935.

4498. Spirifer divaricatus Hall in Pennsylvania: Jour. Paleontology, vol. 10, no. 1, pp. 67-69, 3 figs., January 1936.

4499. Continental Upper Devonian of northeastern Pennsylvania: Geol. Soc. America Bull., vol. 47, no. 4, pp. 565-607, 3 pls. (incl. geol. map), 3 figs. (incl. index map), April 30, 1936 ; abstract, Proc., 1935, p. 118, June 1936.

4500. Tully limestone and fauna in Pennsylvania [abstract]: Geol. Soc. America Proc., 1935, p. 376, June 1936.

4501. The Onondaga formation in Pennsylvania : Jour. Geology, vol. 44, no. 5, pp. 578-603, 5 figs. (incl. geol. sketch map), July-August 1936.

4502. Fossils in Pennsylvania: Sci. Monthly, vol. 43, no. 4, pp. 335-340, October 1936.

4503. Why geology? The answer to an undergraduate question as seen through the eyes of one who has followed it through: Lehigh Alumni Bull., vol. 24, no. 1, pp. 6-7, 1 fig., October 1936.

Williams, A. J.

4504. Hematite in the Reagan sandstone along the northeastern edge of the Wichita Mountains and the Arbuckle Mountains: Oklahoma Acad. Sci. Proc. 1934, vol, 15, pp. 81-82, 1935.

Williams, Charles C. See Jewett, 1949.

Williams, Charles R. See Chapman, 733 ; Billings, 317 ; U. S. G. S., 4232.

Williams, Francis J. See Honess, 1788 ; Taylor, 4030.

Williams, Fred T.

4505. (and McCoy, Elizabeth). The microflora of the mud deposits of Lake Mendota [Wis.]: Jour. Sedimentary Petrology, vol. 5, no. 1, pp. 31-36, 2 tables, April 1935.

Williams, Howard R.

4506. What do you think? [pink feldspar in a sandstone block] : Rocks and Minerals, vol. 11, no. 7, p. 106, July 1936.

Williams, Howel. See also Evans, 1192.

4507. Newberry volcano of central Oregon: Geol. Soc. America Bull., vol. 46, no. 2, pp. 253-304, 8 figs. (incl. geol. map), February 28, 1935; abstracts, Proc., 1934, p. 331, June 1935; Pan-Am. Geologist, vol. 61, no. 5, pp. 373-374, June 1934.

4508. Denuded volcanoes of Navajo-Hopi country [abstract] : Pan-Am. Geologist, vol. 64, no. 1, pp. 67-68, August 1935; Geol. Soc. America Proc., 1935, p. 344, June 1936. 
Williams, Howel-Continued.

4509. Pliocene rolcanoes of the Navajo-Hopi country: Geol. Soc. America. Bull., rol. 47 , no. 1, pp. 111-172, 4 pls., 16 figs. (incl. geol. and. sketch maps), January 31, 1936.

Williams, J. F. See Bucher, 534.

Williams, James Steele. See also Dane, 969.

4510. Robert Rossell Rowley [1854-1935]: Jour. Paleontology, vol. 10, no. 3, p. 228, April 1936.

4511. Stratigraphic sections and faunules of some western Carboniferous. formations at or near the type localities [abstract]: Geol. Soc.. America Proc., 1935, pp. 118-119, June 1936.

4512. (and Bridge, Josiah). Large coiled cephalopods from the Pennsylvanian. of north-central Texas [abstract] : Geol. Soc. America Proc., 1935, p. 369, June 1936.

4513. Carboniferous formations in the northern Blue Springs Hills, near Malad, Idaho [abstract]: Geol. Soc. America Proc., 1935, p. 373, June 1936.

Williams, James Stuart. See Cooper, 862.

Williams, J. W.

4514. Memorial of Ira A[braham] Williams [1876-1934] : Geol. Soc. America Proc., 1934, pp. 295-306, port., June 1935.

Williams, L. H.

4515. Successful magnetometer survey of Conroe area [Tex.] : Oil Weekly, vol. 70 , no. 10, pp. 47-48, 1. fig., August 21, 1933.

Williams, Merton Yarwood.

4516. Distribution of life around the Pacific: Fifth Pacific Sci. Cong., Canada, 1933, Proc., vol. 4, pp. 3107-3114, 1934.

4517. Mineral resources of the Peace River area, British Columbia : Canadian Inst. Min. Metallurgy Trans., vol. 37, pp. 351-357 [1935].

4518. Frost circles, with an introduction by William Henry Collins: Royal Soc. Canada Trans., 3d ser., vol. 30, sec. 4, pp. 129-132, 2 figs., May 1936 ; abstract, Proc., p. xcviii, 1936.

4519. Memorial of Reginald Walter Brock [1874-1935]: Geol. Soc. America Proc., 1935, pp. 157-170, 1 pl. (port.), June 1936.

Williams, Neil.

4520. Conroe field ['Tex.] presents many interesting unusual physical and geological characteristics: Oil Weekly, vol. 31 , no. 38 , pp. 10, 34, 1 fig. (cross section), February 9, 1933.

4521. Sixty-three discoveries of pools on Gulf coast are credited to the use of geophysics: Oil Weekly, rol. 32, no. 20, pp. 10-11, 34, 2 figs. (index maps), October 5, 1933.

4522. Exploration for oil out in the Gulf within engineering possibilities : Oil and Gas Jour., vol. 34 , no. 8, pp. 42, 45, 5 figs. (incl. map), July 11, 1935.

Williams, W. L. See Wardwell, 4338.

Williamson, Marjorie. See Coryell, 880.

Willis, Bailey. See also Clark, 755; Cloos, 782; Day, 987, 988; Taff, 4005. 4523. Unthrust-a geologic term: Science, new ser., rol. 81, no. 2095, pp. 197-198, February 22, 1935. 
Willis, Bailey-Continued.

4524. Rift-valley types [abstract] : Pan-Am. Geologist, rol. 63, no. 4, p. 304, May 1935; Geol. Soc. America Proc., 1935, p. 328, June 1936.

4525. The living globe: Science, new ser., vol. 82 , no. 2132 , pp. $427-433$, November 8, 1935 .

4526. Biographical memoir of Raphael Pumpelly, 1837-1923: Nat. Acad. Sci. Biog. Mem., vol. 16, no. 2, pp. 23-62, 1 pl. (port.), 1936.

Willis, Robin. See also Cloos, 782 ; Hake, 1600.

4527. Development of thrust faults: Geol. Soc. America Bull., vol. 46, no. 3, pp. 409-424, 14 figs., March 31, 1935; abstracts, Proc., 1933, p. 310, June 1934 ; Pan-Am. Geologist, vol. 59, no. 4, p. 319, May 1933.

Willson, Kenneth M. See Durward, 1097 ; Ley, 2412.

Wilshire, L. M. See Anonymous, 4665.

Wilson, Ben Hur.

4528. Pre-Dana and contemporary mineralogical literature: Mineralogist. vol. 3 , no. 6,.pp. 3-4, 26r-27, June 1935.

Wilson, Clyde H. See Jakosky, 1929.

Wilson, Charles William, Jr. See also U. S. G. S., 4232.

4529. The Great Smoky thrust fault in the vicinity of Tuckaleeche, Wear, and Cades Coves, Blount and Sevier Counties, Tenn.: Tennessee Acad. Sci. Jour., vol. 10, no. 1, pp. 57-63, 3 figs. (incl. geol. map), January 1935.

4530. Age and correlation of Pennsylvanian surface formations and of oil and gas sands of Muskogee County, Okla.: Am. Assoc. Petroleum Geologists Bull., vol. 19, no. 4, pp. 503-520, 4 figs. (incl. map), April 1935.

4531. 'The pre-Chattanooga development of the Nashville dome: Jour. Geology, vol. 43 , no. 5 , pp. $449-481,1$ pl., 8 figs. (incl. geol. map), JulyAugust 1935; abstract, Tennessee Acad. Sci. Jour., vol. 10, no. 2 , pp. 104-105, April 1935.

4532. 'The ostracode fauna of the Birdsong shale, Helderberg, of western Tennessee: Jour. Paleontology, vol. 9, no. 8, pp. 627-646, 3 pls., December 1935 .

4533. (and Spain, Ernest Lynwood, Jr.). Age of Mississippian "Ridgetop shale" of central Tennessee: Am. Assoc. Petroleum Geologists Bull., vol. 20 , no. 6. pp. $805-809$, June 1936 ; abstract, Geol. Soc. America Proc., 1935, p. 375, Jume 1936.

4534. (and Spain, Ernest Lynwood, Jr.). Upper Paleozoic development of Nashville dome, Tenn.: Am. Assoc. Petroleum Geologists Bull., vol. 20, no. 8, pp. 1071-1085, 4 figs. (incl. geol. maps), August 1936.

4535. Geology of Nye-Bowler lineament, Stillwater and Carbon Counties, Mont.: Am. Assoc. Petroleum Geologists Bull., vol. 20, no. 9, pp. 1161-1188, 6 figs. (incl. geol. maps), September 1936.

4536. (and Born, Kendall Eugene). The Flynn Creek disturbance, Jackson. County, Tenn.: Jour. Geology, vol. 44, no. 7, pp. 815-835, 11 figs. (incl. geol. map), October-November 1936.

Wilson, Harold Stockdale.

4537. The geology of Lamaque mine [Quebec]: Canadian Min. Jour., vol. 57, no. 10, pp. 511-516, 4 figs. (incl. geol. maps), October 1936.

Wilson, Henry Van Peters. See Prouty, 3146. 
Wilson, Hewitt.

4538. (and Zvanut, Frank Joseph). Properties of quartz sands washed from kaolins of the Pacific Northwest: Washington Univ. [Seattle], Eng. Exper. Sta. ser., Bull. 88, 42 pp., 14 figs., January 1936.

4539. (and Pask, Joseph A.). Talc and soapstone in Washington: Am. Inst. Min. Met. Eng. Contr. 99, 25 pp., 11 figs. (incl. index map), February 1936; abstract, Mining and Metallurgy, vol. 17, no. 350, p. 118, February 1936.

Wilson, James T. See also Byerly, 605, 608, 609, 610, 612, 613, 615.

4540. (and Annis, Wilbert): Earthquakes in northern California and the registration of earthquakes at Berkeley, Mount Hamilton, Palo Alto, San Francisco, Ferndale, from April 1, 1935, to June 30, 31, 1935: California Univ., Seismog. Sta., Bull., vol. 4, no. 4, pp. 244-338 ( $\ddagger)$, February 18, 1936.

4541. (and Annis, Wilbert). Earthquakes in northern California and the registration of earthquakes at Berkeley, Mount Hamilton, Palo Alto, San Francisco, Ferndale, from April 1, 1935, to June 30, 1935: California Univ., Seismog. Sta. Bull., vol. 5, no. 1, pp. 1-38 (\$), April 1, 1936.

4542. Foreshocks and aftershocks of the Nevada earthquake of December 20, 1932, and the Parkfield, Calif., earthquake of June 7, 1934: Seismol. Soc. Ameríca 'Bull., vol.. 26, no. 3, pp. 189-194; 2 figs., July 1936.

Wilson, John Human.

4543. A proposed geophysical program of exploration for Nebraska and the Dakotas: Geophysics, vol. 1, no. 2, pp. 189-195, 1 fig. (geol. sketch map), June 1936.

Wilson, $\mathbf{L}$. R.

4544. The Nipissing flora of the Apostle Islands [Wis.] region: Torrey Bot. Club Bull., vol. 62, no. 9, pp. 533-535, December 1935; abstract, Iowa Acad. Sci. Proc., vol. 42, p. 138, 1935.

4545. Further fossil studies of the Two Creeks forest bed, Manitowoc County, Wis. : Torrey Bot. Club Bull., vol. 63, no. 6, pp. 317-325, 1 fig., June 1936.

Wilson, Leslie Edwin.

4546. Miocene marine mammals from the Bakersfield region, Calif.: Peabody Mus. Nat. History Bull. 4, 143 pp., 23 figs., 1935.

Wilson, Morley Evans.

4547. Rock alteration at the Amulet mine, Noranda district, Quebec: Econ. Geology; vol. 30, no. 5, pp. 478-492, 2 figs., August 1935.

Wilson, Robert W. See also Wood, 4578.

4548. Two rodents and a lagomorph from the Sespe of the Las Posas Hills, Calif.: Carnegie Inst. Washington Pub. 453, pp. 11-17, 1 pl., 1 fig., July 1935, preprint, July 1934.

4549. A new species of Dipoides from the Pliocene of eastern Oregon: Carnegie Inst. Washington Pub. 453, pp. 19-28, 1 pl., 1 fig., July 1935, preprint, December 20, 1934.

4550. Cricetine-like rodents from the Sespe Eocene of California: Nat. Acad. Sci. Proc., vol. 21, no. 1, pp. 26-32, 2 figs., January 15, 1935. 
Wilson, Robert W.-Continued.

4551. Simmys, a new name to replace Eumysops Wilson, preoccupied; a correction: Nat. Acad. Sci. Proc., vol. 21, no. 3, pp. 179-180, March. $15,1935$.

4552. New fauna from the Sespe of Las Posas Hills, Calif. [abstract]: Geol. Soc. America Proc., 1934, p. 384, June 1935.

4553. A new species of porcupine from the later Cenozoic of Idaho: Jour. Mammalogy, vol. 16, no. 3, pp. 220-222, 1 fig., August 1935.

4554. Rodent fauna from Smiths Valley, Nev. [abstract] : Pan-Am. Geologist, vol. 64, no. 1, pp. 77-78, August 1935; Geol. Soc. America Proc., 1935, p. 418, June 1936.

4555. A new Pleistocene deer-mouse from Santa Rosa Island, Calif.: Jour. Mammalogy, vol, 17, no. 4, pp. 408-410, 1 fig., November 1936.

Wilson, Ronald M.

4556. Ground surface movements at Kilauea Volcano, Hawaii : Hawaii Univ. Research Pub. 10, 56 pp., 5 pls., 3 figs., 1935.

Wilson, Roy Arthur. See also Park, 3010.

4557. The gold deposits of Georgia: Georgia Dept. Forestry and Geol. Development, Div. Geol. Inf., Circ. 4 [1935].

4558. The gold deposits of Georgia : Forestry-Geol. Rev., vol. 5, no. 1, pp. 7-8, 1 fig. (sketch map), January 1935 ; no. 2, pp. 7-8, 1 fig., February 1935.

Wilson, T. Yates. See Ruedemann, 3411, 3416.

Wilson, Walter Byron. See Adams, 4 ; Barton, 212.

Wimmer, Joe.

4559. Meteorites: Geol. Soc. Oregon Country News Letter, vol. 2, no. 16, pp. 10-12 ( $\ddagger)$, August 25, 1936.

4560. Facts and theories of earthquake phenomena: Geol. Soc. Oregon Country News Letter, vol. 2, no. 21, pp. 3-13 ( $)$, November 10, 1936.

Winchell, Alexander Newton. See also Pauling, 3030.

4561. Further studies in the pyroxene group: Am. Mineralogist, vol. 20, no. 8, pp. 562-568, 5 figs., August 1935 ; abstracts, vol. 20, no. 3, p. 195, March 1935 ; Geol. Soc. America Proc., 1934, p. 419, June 1935.

4562. A third study of chlorite: Am. Mineralogist, vol. 21 , no. 10, pp. $642-$ 651, 4 figs., October 1936: abstract, no. 3, p. 194, March 1936.

4563. The biotite system : Am. Mineralogist, vol. 20, no. 11, pp. 773-779, 2 figs., November 1935.

Winchester, Dean Eddy, 1883-1936.

4564. Natural gas in Colorado, northern New Mexico, and Utah: Geology of natural gas, pp. 363-384, 8 figs., Am. Assoc. Petroleum Geologists [June] 1935.

4565. Oil and gas map of New Mexico (1931), revised by A. Andreas to July 15, 1936. New Mexico Bur. Mines and Min. Res. [1936]. Scale about 16 miles to 1 inch.

Wintermann, David. See Smiser, 3743.

Wisker, A. L.

4566. The gold-bearing veins of Meadow Lake district, Nevada County [Calif.]: California Jour. Mines and Geology, vol. 32, no. 2, pp. 189-204, 2 figs. (incl. index map), April 1936. 
Wisser, Edward.

4567. Formation of the north-south fractures of the Real del Monte area, Pachuca silver district, Mexico: Am. Inst. Min. Met. Eng. Tech. Pub. 753, 47 pp., 19 figs. (incl. index and fracture map), 1936; abstract, Mining and Metallurgy, vol. 17, no. 359, pp. 546-547, November 1936.

withers, Thomas Henry.

4568. A new cirripede from the Claiborne Eocene of U. S. A.: Geol. Mag., ser. 10, vol. 18, no. 108, pp. 587-588, 1 fig., December 1936.

Wittich, Ernst Ludwig Maximilian Emil.

4569. Höhlen und Karsterscheinungen in Mexico: Mitt. Höhlen- u. Karstforschung, Jahrg. 1935, Heft 3, pp. 81-87; pt. 2, Jahrg. 1936, Heft 1. pp. 1-16, 2 pls.

Wodehouse, Roger Philip.

4570. Pollen grains, their structure, identification, and significance in science and medicine. 1st ed., xv, 574 pp., 137 figs., New York. McGraw Hill Book Co., Inc., 1935.

Wolf, Albert G. See Hanna, 1619.

Wolff, John Eliot.

4571. Crazy Mountains of Montana-superalkaline and subalkaline Tertiary intrusive rocks and their problems [abstract]: Am. Mineralogist, vol. 20, no. 3, pp. 193-195, March 1935; Geol. Soc. America Proc., 1934, pp. 417-418, June 1935.

Wood, Albert Elmer. See also Wood, Horace Elmer, 2d., 4587.

4572. Two new genera of cricetid rodents from the Miocene of western United States: Am. Mus. Novitates, no. 789, 3 pp., 2 figs., April 10, 1935.

4573. Evolution and relationship of the heteromyid rodents, with new forms from the Tertiary of western North America: Carnegie Mus. Annals, vol. 24, serial 164, December 1934-August 1935, art. 7, pp. 73262, 2 pls. (tables), 157 figs. (incl. maps), May 13, 1935.

4574. Two new rodents from the John Day Miocene: Am. Jour. Sci., 5th ser., vol. 30 , no. 178, pp. 368-372, 3 figs., October 1935.

4575. A new subfamily of the heteromyid rodents from the Miocene of western United States: Am. Jour. Sci., 5th ser., vol. 31, no. 181, pp. 4149, 8 figs., January 1936.

4576. The cricetid rodents described by Leidy and Cope from the Tertiary of North America: Am. Mus. Novitates, no. 822, 8 pp., 5 figs., March $9,1936$.

4577. Cuyama Tertiary fauna of California [abstract]: Geol. Soc. America Proc., 1935, pp. 395-396, June 1936.

4578. (and Wilson, Robert W.) A suggested nomenclature for the cusps of the cheek teeth of rodents: Jour. Paleontology, vol. 10, no. 5, pp. 388-391, 2 figs., July 1936; abstract, Geol. Soc. America Proc., 1935, p. 400, June 1936.

4579. A new rodent from the Pliocene of Kansas: Jour. Paleontology, vol. 10, no. 5, pp. 392-394, 2 figs., July 1936; abstract, Geol. Soc. America Proc., 1935, p. 401, June 1936.

4580. Geomyid rodents from the Middle Tertiary: Am. Mus. Novitates, no. 866, 31 pp., 33 figs., July 2, 1936. 
Wood, Albert Elmer-Continued.

4581. Fossil heteromyid rodents in the collections of the University of California : Am. Jour. Sci., 5th ser., vol. 32, no. 188, pp. 112-119, 10 tigs., August 1936; abstract, Geol. Soc. America Proc., 1935, p. 401, June 1936.

4582. An additional record of the giant beaver: Jour. Maimmalogy, vol. 17, no. 4, p. 420, November 1936 .

Wood, Harry Oscar.

4583. Seismological research in southern California: Fifth Pacific Sci. Cong. Canada, 1933, Proc., vol. 3, pp. 2347-2354, 1934.

4584. Earthquakes in California: Sci. Monthly, vol. 39, no. 4, ip. 323-344, 20 figs., October 1934; also pub. as Earthquake study in southern California, in Carnegie Inst. Washington Suppl. Pub. 12, pp. 1-222, 20 flgs., February 15, 1985.

4585. (and Gutenberg, Beno). Earthquake prediction: Science, new ser., vol. 82 , no. 2123, pp. 219-220, September 6, 1935.

Wood, Horace Elmer, 2 d.

4586. (and Seton, Henry, and Hares, Charles Joseph). New data on the Eocene of the Wind River Basin, Wyoming [abstract] : Geol. Soc. America Proc., 1935, pp. 394-395, June 1936.

4587. (and Wood, Albert Elmer). Middle Tertiary vertebrates from the Texas Coastal Plain [abstract]: Geol. Soc. America Proc., 1935, p. 396, June 1936.

4588. Evolution of the elasmotheres [abstract]: Geol. Soc. America Proc., 1935, p. 399, June 1936.

4589. Amynodont rhinoceroses [abstract]: Geol. Soc. America Proc., 1935, p. 400, June 1936.

Wood, Lyman Wentsch.

4590. A pre-Wisconsin valley in southwestern Hancock County: Iowa Acad. Sci. Proc., 1934 (vol. 41), pp. 199-201, 1 flg. (sketch map), 1934.

4591. The road and concrete materials of southern Iowa: Iowa Geol. Survey, vol. 36, pp. 8-310, 1a-4a, 39 pls. (incl. geol. map), 34 figs. (incl. sketch maps), 4 tables, 1935.

4592. An Osage area north of Mount Pleasant, Henry County, Iowa: Iowa Acad. Sci. Proc., vol, 42, pp. 127-132, 1 fig. (geol. map), 1935.

4593. Pennsylvania [n] section at Crescent [abstract] : Pan-Am. Geologist, vol. 65 , no. 4, p. 316, May 1936.

Wood, Walter A. See also Boyd, 409.

4594. The Wood Yukon expedition of 1935; an experiment in photographlc mapping: Geog. Rev., vol. 26, no. 2, pp. 228-246, 22 figs. (incl. sketch map), April 1936.

Woodford, Alfred Oswald. See also Foshag, 1313; Laudermilk, 2348.

4595. Proceedings of the 33d annual meeting of the Cordilleran section of the Geological Society of America, held at the University of California, Berkeley, Calif., April 12, 13, and 14, 1834: Geol. Soc. America Proc., 1934, pp. 307-340, June 1935.

4596. Rhomboid ripple mark: Am. Jour. Sci., 5th ser., vol. 29, no. 174, pp. 518-525, 6 figs., June 1935.

4597. Historical introduction to geology : Pan-Am. Geologist, vol. 64, no. 1, pp. 1-7, 3 pls. (incl. geol. map), 2 figs., August 1935; abstracts, vol. 63, no. 4, pp. 304-305, May 1935; Geol. Soc. America Proc., 1935, p. 329, June 1936. 
Woodford, Alfred Oswald-Continued.

4598. Proceedings of the 34th annual meeting of the Cordilleran section of the Geological Society of America, held at Stanford University, April 12, and 13, 1935: Geol. Soc. America Proc., 1935, pp. 323-354, June 1936.

Woodhouse, C. D.

4599. Change them every 10,000 miles: Mineralogist, vol. 4, no. 3, pp. 3-4, 37-38, March 1936.

Woolnough, Walter George.

4600. Simplification of the John L. Rich dip construction: Am. Assoc. Petroleum Geologists Bull., vol. 19, no. 6, pp. 903-908, 3 figs., June1935.

Woodring, Wendell Phillips.

4601. Fossils from the marine Pleistocene terraces of the San Pedro Hills, Calif.: Am. Jour. Sci., 5th ser., vol. 29, no. 171, pp. 292-305, 1 fig., March 1935.

4602. Pliocene viviparoid calcareous operculum from Kettleman Hills [abstract] : Pan-Am. Geologist, vol. 63, no. 5, p. 375, June 1935; Geol. Soc. America Proc., 1985, p. 413, June 1936.

4603. (and Bramlette, Milton Nunn, and Kleinpell, Robert Minssen). Miocene stratigraphy and paleontology of Palos Verdes Hills, Calif.: Am. Assoc. Petroleum Geologists Bull., vol. 20, no. 2, pp. 125-159, 1 pl. (geol. map), 2 figs., February 1936; abstracts, vol. 19, no. 12, p. 1842, December 1935; World Petroleum, vol. 7, no. 4, p. 204, April 1936.

4604. New Miocene fauna from the California Coast Ranges [abstract] : Geol. Soc. America Proc., 1935, p. 366, June 1936.

Woodruff, Elmer Grant.

4605. Barton arch in central Kansas indicates major oil province: Oil and! Gas Jour., vol. 33, no. 42, pp. 12-14, 32, 6 figs. (incl. geol. map), March 7, 1935.

4606. Oil fields of Gulf coast area found in sediments of late geoiogical age : Oil and Gas Jour., vol. 33, no. 46, pp. 38-39, 149, 4 tigs. (incl. index. map), April 4, 1935.

Woodward, Sir Arthur Smith.

4607. Recent progress in the study of early man: Science, new ser., vol. 8c: no. 2131, pp. 399-407, November 1, 1935.

4608. Prof. Henry Fairfield Osborn [1857-1935] : Nature, vol. 136, no. 3446; pp. 784-785, November 16, 1935.

Woodward, Herbert Preston. See also Furcron, 1363.

4609. Paleozoic formations east of main' axis of Appalachian uplift: Pan-Am: Geologist, vol. 63, no. 2, pp. 97-114, March 1935; abstract, Geol. Soc. America Proc. 1934, p. 455, June 1935.

4610. Salem block of Pulaski overthrust: Pan-Am. Geologist, vol. 63, no. 5, pp. 321-333, 1 pl. (geol. map), June 1935.

4611. Fault-line phenomena near Eagle Rock, Va.: Am. Jour. Sci., 5th ser., vol. 31 , no. 182 , pp. $135-143,6$ figs. (incl. geol. map), February 1936.

4612. Natural Bridge and Natural Tunnel, Virginia: Jour. Geology, vol. 44, no. 5, pp. 604-616, 5 figs. (incl. geol. sketch maps), July-August 1936. 
Woollard, G. P.

4613. An interpretation of gravity anomalies in terms of local and regional geologic structures: Am. Geophys. Union Trans. 17th Ann. Meeting, pt. 1, pp. 63-74 ( $), 4$ figs. (incl. geol. maps), Nat. Research Council, July 1936.

Worcester, Philip George.

4614. Origin of debris-covered mesas of Boulder, Colo. [abstract] : Pan-Am. Geologist, vol. 64, no. 2, p. 152, September 1935.

Work, P. Murray.

4615. Some observations on the thermal springs of the southeastern Black Hills of South Dakota: Iowa Acad. Sci. Proc., 1934 (vol. 41), pp. 203-208, 1934.

4616. Cycles of erosion in the central Black Hills: Iowa Acad. Sci. Proc., 1934 (vol. 41), pp. 209-214, 1934.

Workman, Lewis Edwin. See also Kansas Geol. Soc., 2020.

4617. Isopach map of the Silurian system in the Mississippi Valley: Kansas Geol. Soc. Guidebook 9th Ann. Field Conf., p. 340 ( $\ddagger), 1$ pl. (isopach map), 1935.

4618. (and others) : Mississippi Valley geologic cross section: Kansas Geol. Soc. Guidebook 9th Ann. Field Conf., pp. 362-372 ( $\$), 3$ pls., 1935.

Wormington, Marie.

4619. A brief survey of Pleistocene epoch in Europe and America [abstract] : Pan-Am. Geologist, vol. 64, no. 2, pp. 157-158, September 1935.

Worrell, Frank. See Harris, 1642.

Worthington, R. S. See Anonymous, 4665.

Wrather, William Embrey. See also Fisher, 1271; Ver Wiebe, 4287.

4620. Trends in petroleum-production practice: Econ. Geology, vol. 30, no. 7. pp. 735-749, November 1935.

Wright, Chilton Austin.

4621. Experimental study of the scour of a sandy river bed by clear and by muddy water: Nat. Bur. Standards Jour. Research, vol. 17, no. 2, pp. 193-206, 5 pls., 6 figs., August 1936; abstract, Am. Geophys. Union Trans. 17th Ann. Meeting, pt. 2, pp. 439-440 ( $¥)$, Nat. Research Council, 1936.

Wright, Donald G.

4622. New California iridescent obsidian: Mineralogist, vol. 4, no. 1, p. 14, January 1936.

Wright, Frank James.

4623. Coosa lowlands of the South [abstract]: Geol. Soc. America Proc., 1935, p. 119, June 1936.

4624. (and Chamberlin, W. A., and Ebaugh, William Clarence). August F. Foerste [1862-1936]: Science, new ser., vol. 83, no. 2163, p. 568, June 12, 1936.

4625. The newer Appalachians of the South, pt. 2; South of the New River: Denison Univ. Bull., vol. 36, no. 6 (Sci. Lab. Jour., vol. 31, art. 3), pp. 98-142, 17 pls. 1 fig. (index map), August 1936.

Wright, Frederick Eugene.

4626. Identification of rocks by. reflected light [abstract] : Am. Mineralogist, vol. 21, no. 3, p. 200, March 1936. 
Wright, John Frank. See also Canada G. S., 642.

4627. General geological features of the mining fields of Manitoba and adjoining districts: Canadian Inst. Min. Metallurgy Trans., vol. 38, pp. 255-260, 1935.

Wright, John Kirtland. See Boyd, 409.

Wright, Lawrence $B$.

4628. A new view of factors governing distribution of ore deposits of eastern Canada: Canadian Min. Jour., vol. 56, no. 6, pp. 219-222, 2 figs. (geol. maps), June 1935.

4629. Gold deposition in the Black Hills of South Dakota and Wyoming: Am. Iust. Min. Met. Eng. Tech. Pub. 699, 28 pp., 11 figs, (incl. index maps), 1936.

Wright, William Josiah.

4630. Geology of the Grand Lake coal field, Queens and Sunbury Counties, New Brunswick: Canadian Inst. Min. Metallurgy Trans., vol. 38, pp. 209-216, 4 figs. (incl. geol. map), 1935.

Wright, Willis Isaac.

4631. Notes to accompany preliminary map of Papaonga River area, Kenora district (Patricia portion) [Ontario], scale 1 inch to 2 miles: Canada Dept. Mines, Geol. Survey Paper 35-4, 1 p. ( $\ddagger$ ), 1 pl. (geol. map), 1935.

wuestner, Herman.

4632. Fluorescent and phosphorescent glacial conglomerate: Rocks and Minerals, vol. 11, no. 4, pp. 49-50, 1 fig., April 1936.

Wycoff, Ralph Dewey.

4633. Study of earth tides by gravitational measurements: Am. Geophys. Union Trans. 17th Ann. Meeting, pt. 1, pp. 46-52 ( $), 4$ figs., Nat. Research Council, July 1936.

Wyckoff, Ralph Walter Graystone.

4634. The structure of crystals; Supplement for 1930-34 to the $2 d$ ed., 240 pp., 341 figs., New York, Reinhold Pub. Corp., 1935.

Wylie, Charles Clayton.

4635. Rate of fall of meteoric material on the earth: Phys. Rev., 2d ser., vol. 47, no. 2, p. 192, January 15, 1935.

4636. The annual deposit of meteoric material: Popular Astronomy, vol. 43, no. 2, pp. 120-121, 1 fig., February 1935.

Yatsevitch, Gratian Michael. See also Peacock, 3037.

4637. The crystallography of herderite from Topsham, Maine: Am. Mineralogist, vol. 20, no. 6, pp. 426-437, 4 figs., June 1935; abstract, no. 3, p. 198, March 1935; Geol. Soc. America Proc., 1934, pp. 421-422, June 1935.

Yedlin, Leo Neal.

4638. Some notes on fluorescence: Rocks and Minerals, vol. 11, no. 4, p. 62, April 1936.

Young, Clinton Mason.

4639. Pennsylvanian coals of the southeastern margin of the Western Interior province: Am. Inst. Min. Met. Eng. Contr. 92, 19 pp., November 1935 ; Trans., Coal Div., vol. 119, pp. 484-503, 1 fig., 1936; abstracts, Mining and Metallurgy, vol. 16, no. 347, p. 488, November 1935, Year Book sec., p. 47, January 1936. 
Young, F. S.

4640. The romance of halite: Mineralogist, vol. 3 , no. 12, pp. 9-10, 20-21, December 1935.

Yunck, George. See Ver Steeg, 4281.

Yuster, Samuel Terrill.

4641. A theoretical consideration of ideal liquid inclusions: Am. Jour. Sci., 5th ser., vol. 31, no. 185, pp. 363-372, May 1936; Pennsylvania State College, Min. Ind. Exper. Sta. Tech. Pub. 25, 1936.

Zavoico, Basil $B$.

4642. Geology and economic significance of the Lucien field [abstract] : 'Tulsa Geol. Soc. Digest, 1934, pp. 59-62.

4643. The geology and economic significance of the Conroe field [T'ex.]: World Petroleum, vol. 6, no. 3, pp. 144-157, 12 figs. (incl. maps), March 1935.

4644. Geology and economic significance of central Michigan fields: World Petroleum, vol. 6, no. 5, pp. 309-324, 16 figs. (incl. geol. map), May 1935 .

4645. Geology and economic significance of Hobbs, N. Mex., field: World Petroleum, vol. 6, no. 8, pp. 459-472, 13 figs. (incl. geol. map), August 1935.

4646. Geology and economic significance of East Texas [oil field]: World Petroleum, rol. 7, no. 3, pp. 94-136, illus. (incl. maps), March 1936.

Zeihen, Lester G.

4647. The agate: Glück Auf, vol. 1, no. 5, pp. 21-24, 2 figs., Butte, Mont., June 1.936.

Zodac, Peter.

4648. How to collect minerals: [Rocks and Minerals], Bull. 2, 80 pp., illus., Peekskill, N. Y., Rocks and Minerals, April 1934.

4649. Ilmenite at Bedford, N. Y. : Rocks and Minerals, vol. 10, no. 6, pp. 86-87, June 1935.

4650. Tourmaline at Buchanan, N. Y.: Rocks and Minerals, vol. 10, no. 10, pp. 149-150, October 1935.

4651. Phosphorescent selenite from Hudson, N. Y. : Rocks and Minerals, rol. 11, no. 4, p. 59, April 1936.

4652. The fluorescent and phosphorescent minerals of Bedford, N. Y.: Rocks and Minerals, vol. 11, no. 5, pp. 65-66, Mas 1936.

4653. Some observations on fluorescence and phosphorescence: Rocks and Minerals, vol. 11, no. 5, pp. 68-72, May 1936.

4654. The importance of fluorescence and phosphorescence: Rocks and Minerals, vol. 11, no. 5, pp. 74-75, May 1936.

4655. Some interesting phosphorescent minerals: Rocks and Minerals, vol. 11, no. 5, pp. 75-76, May 1936.

4656. Agate, some facts and uses: Rocks and Minerals, vol. 11, no. 9, pp. 137-138, 2 figs., September-October 1936.

4657. Agates along the Atlantic coast: Rocks and Minerals, vol, 11, no. 9, pp. 182-186, 188, 2 figs., September-October 1936.

4658. Agate glossary: Rocks and Minerals, vol. 11, no. 9, pp. 190-192, September-October 1936.

4659. Agate bibliography: Rocks and Minerals, vol. 11, no. 9, pp. 197-200. September-October 1936. 
Zuschlag, Theodor. See Kelly, 2061; Lundberg, 2488.

Zvanut, Frank Joseph. See Wilson, 4538.

Anonymous.

4660. Progress made in mineral survey of Oregon: U. S. Dept. Interior Press Mem. 50894, 17 pp. (†), 1 pl. (index map); March 2, 1931.

4661. Idaho beryl deposits found important: Ceramic Age, vol. 21, no. 5, p. 141, May 1933.

4662. Litteraturfortnegnelse omfattende Skrifter af geologisk eller lignende Natur og som Emne, Fortfatter eller Udgivelsessted er knyttede til Danmark og Grønland samt Island: Dansk geol. Forening Meddel., Bind 8, Hefte 4, pp. xiii-xvi, 1934.

4663. Les gisements de potasse du Nouveau-Mexique et du Texas (EtatsUnis) : Le génie civil, tome 104, no. 21, pp. 474 475, May 1934.

4664. Death Valley National Monument, Calif., 31 pp., illus. (incl. index and phys. maps), U. S. Nat. Park Service, 1935.

4665. Map showing geologic structure of southeastern Kansas coal fields and the Kansas zinc-lead district (including Cherokee County and parts of Crawford and Labette Counties). Scale $1: 127,720$, or 1 inch to 2 miles. 1935.

4666. Nathaniel Lord Britton [1859-1934] : Staten Island Inst. Arts and Sci. Proc., vol. 7, pts. 3-4, October 1933-May 1934, pp. 101-108, 1935.

4667. Underground water in Kleberg County, Tex. : U. S. Dept. Interior Press Mem. 97078, 1 p. ( $\ddagger$, March 9, 1935.

4668. [Charles David White, 1862-1935] : Washington Acad. Sci. Jour., vol. 25, no. 3, p. 155, March 15, 1935.

4669. The record proboscidean tusk: Nat. History, vol. 35, no. 4, p. 357, April $193 \overline{0}$.

4670. A preliminary report on water conservation and utilization, $131 \mathrm{pp}$. ( $\ddagger)$, 27 pls. (incl. index and geol. maps), North Dakota State Planning Board, April 10, 1935.

4671. A preliminary report on water conservation and utilization; Water Resources Committee report to Federal consultant, North Dakota State Planning Board, 131 pp. (\$), 28 pls. (incl. geol. maps), North Dakota State Planning Board, April 10, 1935.

4672. Prof. W. J. Sinclair [1877-1935] : Nature, vol. 135, no. 3417, p. 645. April 27, 1935.

4673. The mineral resources of North Dakota; Gold: North Dakota State Planning Board Circ. Rept. 7, 6 pp. (\$), July 10, 1935.

4674. The mineral resources of North Dakota; Bentonite: North Dakota State Planning Board Circ. Rept. 8, 8 pp. (\$), July 15, 1935.

4675. The bending of the earth's crust due to Boulder Dam construction: Science, new ser., vol. 82, no. 2120, Supplement p. 7, August 16, 1935.

4676. Giant turtle and mososaur found in Alabama: Science, new ser., vol. 82, no. 2120, Supplement p. 7, August 16, 1935.

4677. Index of mineral occurrences in the State of Washington: Washington State Planning Council Research Pub. 3, 40 pp., October 1935.

4678. Labradorite from Nepoktulegatsuk [Tabor's Island] : Rocks and Minerals, vol. 10, no. 10, pp. 150-151, 2 figs., October 1935.

4679. Geological history of Turkey Run State Park [Indiana] unusually interesting: Outdoor Indiana, vol. 2, no. 10, pp. 25, 31, November 1935. 
Anonymous-Continued.

4680. Consistent gain in use of geophysical methods shown in Galifornia fields : Oil Weekly, vol. 30, no. 25, pp. 158, 161-162, 2 figs., November 7,1935 .

4681. [Frederick Leslie Ransome, 1868-1935] : Washington Acad. Sci. Jour., vol. 25. no. 11, p. 16, November $15,1935$.

4682. Earthquakes in Helena, Mont.: Earthquake Notes, vol. 7, no. 3, pp. 2-5 (\$), 2 figs., December 1935 .

4683. Montana Bureau of Mines and Geology: Glück Auf, vol. 1, no. 2, pp. 9, 26-29, 1 fig., (port.), Butte, Mont., December 1935.

4684: Recovery of Foraminifera by means of flotation: Jour. Paleonotology, vol. 9, no. 8, pp. 745-746, December 1935.

4685. Bibliography, Federal and State Geological Surveys' publications on iron ores; Eastern and Southeastern States and Cuba, 8 pp. ( $¥)$, U. S. Geol. Survey, 126059, [1936?]

4686. The floods of March 1936 in Pennsylvania, $129 \mathrm{pp.} \mathrm{(} \ddagger$ ), 5 pls. (incl. maps), 27 figs., Pennsylvania Dept. Forests and Waters, 1936.

4687. Publications on the geology, mineral resources, and mineral industries of Illinois, 95 pp., Illinois Geol. Survey, 1936.

4688. Florida canal: Eng. News-Record, vol. 116, no. 1, p. 26, January 2, 1936.

4689. Ground water in the Butter Creek aren, Umatilla County, Oreg.: U. S. Dept. Interior Press Mem. 1109S5, 1 p. (\$), January 4, 1936.

4690. Limited effect on water supplies expected from Florida canal: Eng. News-Record, vol. 116, no. 2, pp. 59-61, 2 figs. (incl. index map), January 9, 1936.

4691. William Battle Phillips [1857-1918] : Texas Univ. Bull. 3501, January 1, 1935, p. 10, 1 pl. (port.), February 1936.

4692. Gold in the southern Appalachians. U. S. Dept. Interior Press Mem. 113781, 10 pp. ( $\$$ ), February 1, 1936.

4693. Edward Salisbury Dana [1849-1935]: Mineralogist, vol. 4, no. 3, pp. 20, 22, March 1936.

4694. Geological Survey [of Pennsylvania] completes first century of work; studies continue: Pennsylvania Dept. Internal Affairs Monthly Bull., vol. 1, no. 5, pp. 5-8, April 1936.

4695. Mount Davis, 3,213 feet above level of sea, is [Pennsylvania] State's highest peak: Pennsylvania Dept. Internal Affairs Monthly Bull., vol. 1, no. 5, pp. 16-22, April 1936.

4696. A geologists' Mecca, eastern Washington: Mineralogist, vol. 4, no. 5, pp. 9-10, May 1936.

4697. Pennsylvania rocks trace back over period of $1,000,000,000$ years: Pennsylvania Dept. Internal Affairs Monthly Bull., vol. 1, no. 6, pp. 18-21, May 1936.

4698. A simplified table for the recognition of some of the common minerals: Geol. Soc. Oregon Country News Letter, vol. 2, no. 11, pp. 12-19 (\$), June 10, 1936.

4699. August Frederick Foerste [1862-1936]: Washington Acad. Sci. Jour., vol. 26, no. 6, p. 266, June 15, 1936.

4700. Chehalis fossil wood: Mineralogist, vol. 4, no. 7, p. 22, July 1936.

4701. Commercial and scientific values attached to finds of meteorites: Pennsylvania Dept. Internal Affairs Monthly Bull., vol. 2, no. 2, pp. 8-12, July 1936.

$311-37-21$ 
Anonymous-Continued.

4702. Memorial of Conrad Schlumberger [1878-1936]; Seismol. Soc. America Bull., vol. 26, no. 3, p. 287, July 1926.

4703. Rocks: Geol. Soc. Oregon Country News letter, vol. 2, no. 14, pp. 6-12 ( $\ddagger$, July 25, 1936.

4704. The dust-bowl area: Science, new ser., vol. 84 , no. 2170 , pp. 113-114, July 31, 1936.

4705. Potter County [Pa.] waters travel to Quebec, Norfolk, and New Orleans: Pennsylvania Dept. Internal Affairs Monthly Bull.,' vol. 2, no. 3, pp. 11-13, August 1936 .

4706. Geology of White Point field [Tex.] requires careful drilling: Oil and Gas Jour., vol. 35, no: 14, pp. 75-76, 1 fig., August 20, 1936.

4707. Subsurface geology in Saxet field [Tex.]: Oil and Gas Jour., vol. 35, no. 14, pp. 72, 74, August 20, 1936.

4708. Crooked River Basin, Oreg., jields Tertiary fossils: Mineralogist, vol. 4, no. 9, p. 18, September 1936.

4709. Spruce cones found [in Illinois]: Mineralogist, vol. 4, no. 9, p. 38, September 1936.

4710. Charles Kenneth Leith, a biography: Explosives Engineer, vol. 14, no. 10, pp. 288-289, 1 pl. (port.), October 1936.

4711. The Fossil Cycad National Monument: Science, new ser., vol. 84, no. 2182 , pp. $367-368$, October $23,1936$.

4712. Black Hills petrified cycad forest: Mineralogist, vol. 4, no. 11, pp. 7-8, November 1936.

4713. The sedimentary rocks: Geol. Soc. Oregon Country News Letter, vol. 2 , no. 22 , pp. 6-8 ( ), November $25,1936$.

4714. Over 1,000 gallons of water per minute discharged by 24 springs: Pennsylvania Dept. Internal Affairs Monthly Bull., vol. 3, no. 1, pp. 31-32, December 1936.

4715. The Timiskaming earthquake: Earthquake Notes, vol. 7 , no. 3, pp. 5-6 $(\ddagger)$, December 1936 .

4716. Core samples of the ocean bottom: Carnegie Inst. Washington News Service Bull., vol. 4, no. 9, pp. 83-87, 1 pl. (front.), 6 figs. (incl. index map), December 6, 1936. 


\section{INDEX}

[The numbers refer to entries in the bibliography]

Ablation of snow, western mountains: Matthes. 2613.

Accessory minerals, Wolfe Mountain granite, Texas; McAdams, 2491.

Adamite, Gold Hill, Tooele County, Utah : Staples, 3825 .

Addresses. See also Miscellaneous.

Borderlands in science: Rightmyer, 3293.

Canada, mining history: Allan, 30.

Continents, form, drift, and rhythm: Watts, 4364.

Crazy Mountains of Montana: Wolff, 4571 .

Early man in North America: Woodward, 4607 .

Earth physics and geographical papers: Fleming, 1280.

Erosion, cyclic and noncyclic aspects : Fenueman, 1219.

Eutopotropism : Lane, 2330.

Folded mountains, origin : Prouty. 3147.

Geologic classifications and correlations: Chamberlin, 718.

Geologico-seismological frontier, progress: MacElwane, 2517.

Geological education: Swartz, 3988.

Geology and clay researches: Ries, 3299.

Geology and literature: Collins, 811.

Geology, economic and cultural value: Hall, 1611.

Glaciers, mountain and continent : Hioblos, 1755.

Globe, the living: Willis, 4527.

Homo sapiens, whence and whither: Hooton, 1789.

Marine unconformities and conglomerates: Twenhofel, 41.98 .

Mineral fuels and civilization: Earenson, 1117.

Mineral veins, origin: Behre, 258.

Minerals around us: Thompson, 4097. Conservation: Leith, 2391.

In medicine: Jones, 1994.

National Academy of Sciences, history of : Campbell, 639.

Natural law in geology : Bucher, 536.

New England, surface layers, data : Leet, 2374 .

Paleontology and humanity: Hawkins, 1655.
Addresses-Continued.

Petroleum, exploration for: Rosaire, 3353.

Geology and the A. A. P. G.: Levorsen, 2406.

Possibilities, Illinols basin: Weller, 4386.

Production and engineering: Scott, 3611.

Production practice: Wrather, 4620 .

Reserves of the United States: Heroy, 1717.

Stratigraphic vs. structural accumulation: Levorsen, 2404.

Pre-Cambriun life: Raymond, 3196.

State-resource survey, model: Lelghton $r$ 2386.

Titanium deposits, Virginia, mineralization: Ross, 3366.

Trend of geoloty : Allan, 35.

Water conservation, relation of geology and engineering: Bartlett, 200.

Aerial mapping: Atkinson, 111; Rice, 3260A. See also Aerial photography.

Airplanes in geologic studies: Alcock, 14.

California, placers: Jenkins, 1936.

Canada, Yukon Territory: Wood, 4594.

Developments, recent: Talley, 4009.

Labrador, Cape Chlldley area: Forbes, 1304.

Mapping from the air: Steinberg, 3864.

Mounds, soil : Melton, 2654.

Newfoundland, Blow-Me-Down area : Snelgrove, 3780.

Reconnaissance and contour mapping: Eliel, 1160.

Surveying from air, scope and limits : Miller, 2723.

Texas, northeastern, mounds and soll mottlings: Rich, 3265.

Aerial plotography: Sneigr, 3777. Sce also Aerial mapping.

Airplanes in geologic studies: Alcock, 14.

Alaska: Smith, 3764.

Barbers Hill area, Texas, mosaic map: Barton, 210.

Canada, Yukon Territory: Wood, 4594.

Development, photographic equipment : Meyer, 2683. 
Aerial photography-Continued.

Errors, compiling maps from air photographs: Jones, 1998.

Glaciers from an airplane: Richards, 3275.

Mapping by use of: Talley, 4010.

Topographic, by means of: Banks, 175.

Michigan, Indian Lake and other regions: Poindexter, 3105.

Mississippi River, upper : Cooper, 872.

Newfoundland, Blow-Me-Down area: Snelgrove, 3780 .

Pacific region: Patton, 3029.

Petroleum discovery from the air: Maple, 2576.

Plotting maps from aerial photographs: Birdseye, 325.

Reconnaissance and contour mapping: Eliel, 1160.

South Carolina, Coastal Plain: Cooke, 847.

Surveying from air, scope and limits: Miller, 2723.

Tennessee River Basin, mapping: Pendleton, 3048.

Tennessee Valley, planimetric maps: Pendleton, 3049.

Uses of : Sneigr, 3777.

Wyoming, Medicine Bow oil fleld : McCanne, 2494.

Agate: Blair, 340; Harstad, 1646; Zeihen, 4647, Zodac, 4656, 4658.

Atlantic Coast: Zodac, 4657.

Atlantic Coastal Plain: Ulke, 4208.

Bibliography: Zodac, 4659.

California, Mint Canyon: Patton, 3025 .

Formation: Wild, 4480.

Experimental investigation: Cahen, 622.

Theory: Cassirer, 701.

Freak simulations: Weidhaus, 4378.

Lake Superior beaches: Alessi, 21.

Lake Superior region: Dustin, 1100.

Localities, early American: Robinson, 3325.

Moss, formation of : wild, 4481.

New Jersey, in trap-rock quarry: Reamer, 3211.

New Mexico, Laguna: Ellermeier, 1166.

Oregon, Jefferson County, drusy specimens: Southwick, 3792.

Pony Butte, Jefferson County : Forbes, 1306.

Panama, Canal Zone: Freehan, 1335.

Washington, blue: Clinesmith, 780 .

Wyoming, Sweetwater River area moss agates: Ellermeier, 1167.

Age of the earth. See Earth, age.

Agullarite, Comstock lode, Virginia City, Nev., Coats, 788 .

Airplanes in geologic studies: Alcock, 14.
Alabama.

Bibliography : Harper, 1638.

Elconomic geology.

Barite, origin, Appalachian Valley: Crickmay, 905.

Birmingham district: Blair, 338.

Clays, ceramic : Mansfield, 2568.

Clays, western Tennessee Valley: Spain, 3794.

Copper deposits, Ducktown type, southern Appalachians: Ross, 3364.

Gold, Hog Mountain: Park, 3007.

Southern Appalachians: Anonymous, 4692 .

Natural gas, Paleozoic horizons, Cincinnati arch region : Bailey, 132.

\section{Historical geology.}

Erin shale, structure: Park, 3008.

General : Poor, 3117.

Hog Mountain gold district: Park, 3007

Ordovician altered volcanic materials and related clays: Kay, 2031.

Talladega series pre-Cambrian: Crickmay, 909.

Southern Appalachians: Crickmay, 910.

Vicksburg group : Cooke, 846.

Mineralogy.

Dust storm, November 13, 1933, Birmingham: Poor, 3106.

Paleontology.

Bairdia subdeltoidea, oligocene, old Fort Stephens: Howe, 1834.

Diploschiza melleni, Cretaceous : Stephenson, 3876.

Discocyclina, Eocene, Salt Mountain : Vaughan, 4276.

Foraminifera, Tertiary, Gulf coast : Hadley, 1594.

Upper Eocene: Cushman, 941.

Invertebrates, Eocene: Aldrich, 19.

Nonionella cockfleldensis, Claiborne, Eocene : Garrett, 1387.

Ostreidae, Upper Cretaceous, Gulf region: Stephenson, 3877.

Pectinidae, Tertiary: Rowland, 3389 ; Tucker, 4628.

Reptiles, Cretaceous, Greene County : Renger, 3245.

Trilobites, larval stages, Cambrian, Cherokee County: Lalicker, 2291.

Turtle, giant, and mososaur, Cretaceous: Anonymous, 4676.

Venericardia planicosta: Chavan, 741. Variations: Chavan, 740.

Verneuilinidae, Valvulinidae, and Virgulinidae: Cushman, 945.

Zeugmatolepas americana, Eocene : Withers, 4568.

Physical geology.

Erin shale, structure: Park, 3008.

Structure, determination by electrical resistance methods : Hubbert, 1875. 
Alabama-Continued.

Physiographia geology.

Coosa lowlands: Wright, 4623.

Alaska:

Aerial photography: Smith, 3764 .

,: Frozen ground: Taber, 4004.

\section{Areas described.}

Alaska Range, southern: Capps, 677.

Matanuska Valley: Shearer, 3656.

Ruby-Kuskokwim region, mineral deposits: Mertie, 2681.

Willow Creek-Kashwitna dist ri ct : Capps, 678.

\section{Economic geology.}

Alaska Range, southern: Capps, 677.

Copper resources: Moffit, 2761.

Copper, Upper, and Tanana Rivers area : Moffit, 2763.

Mineral industly, 1934: Smith, 3765.

Ruby-Kuskokwim region, mineral deposits: Mertie, 2681.

Tonsina district: Moffit, 2762.

Historical geology.

Alaska Range, southern: Capps, 677.

Copper, Upper, and Tanana Rivers area : Moffit, 2763.

Ruby-Kuskokwim; region, mineral deposits: Mertie, 2681.

Tertiary: Hollick, 1780.

Tonsina district: Moffit, 2762.

Yukon Valles, lower: Eardley, 1108.

Mineralogy.

Anorthite, Duke Island: Glass, 1442.

Palcontology.

Brachiopods, Cambrian : Cooper, 865.

Briscoia fauna, Upper Cambrian: Kobayaski, 2242.

Flora, Pleistocene, Fairbanks : Chaney, 731.

Floras, Tertiary : Hollick, 1780."

Forests, interglacial, Glacier Bay: Cooper, 870, 871.

1 Irory, fossil: Buddhue, 541.

Petrology.

Hornblendite, Annette and Duke Islands : Koschmann, 2252.

Physical geology.

Akutan volcano, Aleutian Islands: Finch, 1263.

Bogoslof volcano: Lukens, 2484.

Microseisms, January 1, 1929-December 31, 1931, Sitka: Bradford, 419.

Ruby-Kuskokwim region, mineral de posits: Mertie, 2681.

Shishaldin volcano, eruption 1932 : Finch, 1261.

Volcanism, pre-Cambrian and Paleozolc, interior Alaska : Mertie, 2680.

Physiographic geology.

Alpine glaciation : Tuck, 4177 .

Fort Liscum landslide: Johnson, 1956.
Alaska-Continued.

Physiographic geology-Continued.

Glacial studies, southern Alaska : Cooper, 873.

Glaciation, Quarternary, Coast Range : Kerr, 2076.

Glaciers in 1931: Wentwortb, 4409.

Land bridge, Siberia to Alaska: Smith, 3763.

Lituya Bay and Mount Crillon district: Washburn, 4355.

Matanuska Valley: Shearer, 3656.

Melaspina glacier, morainic bandings: Washburn, 4353.

Ruby-Kuskokwim region, mineral deposits: Mertie, 2681.

Shapes, glacial and ice-jam cobbles: Wentworth, 4412.

South Crillon glacier, motion: Washburn, 4356.

Talsekwe River, Taku district, extraordinary floods: Kerr, 2074.

Tonsina district: Moffit, 2762.

Valley glaciers and valley glaciation: Ray, 3192.

Alberta.

Geological Survey Division report, 1932 : Allan, 31.

1933: Allan, 32.

1934: Allan, 33.

1935 : Allan, 34.

Economic geology.

Athabasca oll sands, Cretaceous: Ball, 171.

Foremost-Skiff area : Howells, 1867.

Gravels and sands, Edmonton district: Rutherford, 3456 .

Milk River area: Russell, 3433.

Natural-gas flelds: Slipper, 3742.

Oil and gas derelopment: Calder, 625:.

Turner Valley gas and oil fleld: Hume, 1883.

Turner Valley gas-fleld oll prospects: Spratt, 3811.

Historical geology.

Battleview anticline, Wainwright area : Hume, 1886.

Canmore area, north portion: Canada G. S., 645.

south portion: Canada G. S., 646.

Foremost-Skiff area: Howells, 1867.

Gravels and sands, Edmonton district: Rutherford, 3456.

Lea Park shale, Cretaceous: Warren, 4348.

Milk River area : Russell, 3433.

Natural-gas fields: Slipper, 3742.

Oil and gas development: Calder, 625 .

Smith and Cold Lake distriet: Rutherford, 3453 .

Turner Valley gas field oil prospects:Spratt, 3811.

Wildcat Hills area, west half: Hume; 1884. 
Alberta-Continued.

Paleontology.

Cepbalopods, Ozarkian and Canadian: Ulrich, 4210.

Coals, microscopic features: Jones, 2005.

Dinosaurs, Cretaceous : Parks, 3013.

Fauna, Milk River Cretaceous: Russell, 3430.

Fish, Triassic and Devonian; Canadian Rockies: Warren, 4349.

Hooded hadrosaurs; Upper Cretaceous : Sternberg, 3884 .

Inglefieldia? birdsalli, Lower Cambrian : Howell, 1863.

Lea Park shale fauna, Cretaceous : Warren, 4348.

Multituberculate, Belly River: Russell, 3435.

Ornithomimus edmonticus and Struthiomomus currelli, cospecific: Sternberg, 3883.

Timanites occidentalis, Upper Devonian, Jasper Park: Miller, 2711.

\section{Physical geology.}

Folded sheet thrusts: Hake, 1600.

Foothills, structures: Link, 2422.

Turner Valley gas and oil field: Hume, 1883.

Wildcat Hills area, west half: Hume, 1884.

Algae.

Lime-secreting algae: Kindle, 2198.

Montana, pre-Cambrian flora: Fenton, 1233.

Rock builders: Johnson, 1975.

Alum.

Washington, Mount Adams area : Fowler, 1316.

Aluminum.

Georgia, kyanite and vermiculite deposits : Prindle, 3137.

Nevada, alunite, Surgarloaf Butte: Heineman, 1689.

Alunite. See Potash.

Amber : Blair, 339.

Manitoba, Cedar Lake: Walker, 4323.

Manitoba, chemawinite : Carpenter, 681 ; Walker, 4319.

Mexico: Buddhue, 537.

American Indian discoveries, vertebrate fossils: Kindle, 2197.

Ammonites. See Cephalopoda.

Amphibia. See also Vertebrata.

Chemung, Pa., tracks and trails: Willard, 4487.

Eryops, illo-sacral attachment: Olson, 2951.

Footprints, Boulder, Colo. : Toepelmann, 4134.

Labyrinthodont stegocephalians, Greenland: Romer, 3349 ; Säve-Soderbergh, 3469 .
Amphibia-Continued.

Trimerorhachis, Permo-Carboniferous, Texas : Case, 692.

Amphibole, Franklin Furnace, N. J.: Foshag, 1312.

Analysis, mechanical, of sediments: Krumbein, 2270.

Andalusite.

California, White Mountain Peak, Mono County: Woodhouse, 4599.

Annelida.

Annelid Jaws, New York, Devonian: Eller, 1161.

Scolecodonts, trails and burrows: Eller, 1164.

Anthozoa

Anthracolitbic, Permian, British Columbia: Smith, 3770.

Calapoecia, revision: Cox, 886 .

Chaetetes akpatokensis, Ordovician, Northwest Territories: Oakley, 2928.

- Chazyan corals: Okulitch, 2947.

Cretaceous and Eocene, Jamaica: Wells, 4390.

Devoniau. Falls of the Onio, Kentucky and Indiana: Werner, 4420.

Eridophyllum, Devonian, Ohio: Stewart, 3895.

Heliolites, Tetradium and Chaetetes: Okulitch, 2948.

Homalophyllum thedfordensis, Devonian, Ontario: Stewart, 3896 .

Kansas and Oklahoma, Pennsylvanian invertebrates: Newell, 2856.

Lithostrotionella, Carboniferous: Ha. yasaka, 1657 .

Madreporaria Hexacoralla check list, 1758-1935: Vaughan, 4277.

Mississippian corals: Grove, 1558.

Nevada, coral reefs, Triassic: Muller, 2825.

New York, Berne quadrangle : Goldring, 1463.

Portage: Chadwick, 713.

Skaneateles quadrangle: Smith, 3746 .

Nomenclature and type species: Wells, 4391.

Nova Scotia, Carboniferous: Lewis, 2407.

Quebec, Black River group: Okulitch, 2946.

Reef corals, evolution, Cenozoic: Gerth, 1407.

Rugose coral, Permian, Texas: Heritsch, 1713.

Stromatoporoidea, relationships: Parks, 3014.

Tabulata and Alcyonaria : Fenton, 1231.

Tetradium, revision: Okulitch, 2944.

Texas, Midway group: Gardner, 1382.

'Trinidad, Toco Bay, Upper Cretaceous : Thomas, 4084.

Waagenophyllum, Permian, Texas: Heritsch, 1712. 
Antigua.

Paleontology.

Operculina and Operculinoides, Tertiary : Vaughan, 4273.

Antillean-Caribbean region: Bakẹ, 149.

Antilles.

Historical geology.

General : Reed, 3229.

Antimony.

Idaho, Yellow Pine district, Valley County : Currier, 938.

Newfoundland, Bay of Exploits area: Heyl, 1736.

Antiquity of man in America: Merriam, 2674.

Appalachia, possible position, determination: Thom, 4079.

Appalachians, southern, structure: Boesch, 363.

Archean. See Pre-Cambrian.

Arizona.

Navajo country: Reagan, 3210.

-Areas described.

Silver King area: Galbraith, 1373.

Economic geology.

Bajada placers: Werber, 4419.

Boulder Dam region, mineral resources: Hewett, 1735.

Copper districts: Tenney, 4040.

Copper, pyritic deposits, Jerome : Kania, 2019.

Ore deposits : Schmitt, $\mathbf{3 5 7 5}$.

Silver King area: Galbraith, 1373.

Strontium, western Arizona: Moore, 2778.

Historical geology.

Algonkian formations, Grand Canyon : Hinds, 1745 .

Archean rocks at Grand Canyon : Campbell, 636 .

Aubrey as terranal title: Keyes, 2179.

Boulder Reservoir floor: Longwell, 2445.

Chinle formation, Triassic: Keyes, 2136.

Copper, districts: Tenney, .4040.

Cretaceous, earliest recognition : Keyes, 2119.

Cretaceous, early : Keyes, 2120.

Ep-Archean and Ep-Algonkian intervals: Hinds, 1749.

Eparchaean plain, reconnaisance: Whitman, 4466.

Gila conglomerate, southeastern Arlzona : Knechtel, 2231.

Grand Canyon: Richter, 3291.

RIm rocks, age : Keyes, 2176 ; McKee, 2537.

Guadalupan series : Keyes, 2134.

Jurassic formation, correlation: Baker, 143.

Zunian series: Keyes, 2153.

Lewis shale: Keyes, 2141.
Arizona-Continued.

Historical geology-Continued.

Mesa.Verde Cretaceous coal formation : Keyes, 2154.

Moencopi sandstone, Triassic: Brady, 428.

Montezuma, marine Jurassic: Keyes, 2180.

Navajo country : Reagan, 3210.

Navajo sandstone: Keyes, 2152.

Oshawanan, early Curboniferous : Keyes, 2104.

Paleozoic formations, correlations: Stoyanow, 3959 .

Paradise formation, Carbontferous : Hernon, 1.714.

Perminn, middle, marine formations, northern Arizona: McKee, 2538.

Silver King area: Galbraith, 1373 .

Supai as terranal title: Keyes, 2183.

Todilto limestone: Keyes, 2167.

Tonto group, Grand Canyon: Wheeler, 444.6.

Tyente sandstone and Montezuma shales: Keyes, 2165.

\section{Mineralogy.}

Barite, Redwall, Grand Canyon: Bryan, 516.

Bermanite, new phosphate, with triplite : Hurlbut, 1896.

Mercury in Chinle shales, Lees Ferry: Lausen, 2351.

Meteor Crater: Colvocoresses, 821.

Pielmontite, Tucson Mountains : Guild, 1565.

Sillimanite and staurolite, Grand Canyon: Campbell, 638.

Paleontology.

Conrad's type fossil locallties: Keyes, 2168.

Conujaria kaibabensis, Permian : McKee, 2539.

Dinosaur, bipedal, Jurassic: Camp, 631.

Dipoides williamsi, Pliocene : Stirton, 3910.

Egg, filled with colemanite: Ward, 4334.

Fauna, Burlington Mississippian : Keyes, 21.1.0.

Iowa* Rockford fauna, Bisbee: Keyes, 2185.

Jurassic and early Cretaceous faunas, Bisbee: Stoyanow, 3960.

Malone and Torcer faunas, base Comanchean: Stoyanow, 3958.

Paradise formation, Carboniferous, fauna: Hernon, 1714.

Plesiosuur, Cretaceous, Black Mesa: O'Connell, 2934.

Theropod, Navajo sandstone: Brady, $430,432$.

Tracks, Moenkopl sandstone: Brady, 429.

\section{Petrology.}

Piedmontite, Tucson Mountains: Gulld, 1565.

Silver King area: Galbraith, 1373. 
Arizona-Continued.

Physical geology.

Bajada placers : Werber, 4419.

Boulder Reservoir "floor: Longwell, 2445.

Canyons, headward elongation, wind work : Meltón, 2659

Colorado Delta : Fox, 1321.

Copper districts: Tenney, 4040.

Pyritic deposits, Jerome: Kania, 2019.

Earthquake, Grand Canyon, January 4, 1935 : Donald, 1056.

El Picacho, fault-faced Basin Range: Keyes, 2111.

Grand Canyon region, Colorado Plateaus: Keyes, 2160.

Meteor Crater: Colvocoresses, 821.

Roaring Springs cave: Seagle, 3615.

Stream fluting and erosion, Grand Canyon : Maxson, 2621.

Verde fault: Ransome, 3180.

Volcanoes, denuded, Navajo-Hopi country : Williams, 4508.

Pliocene, Navajo-Hopi country: Williams, 4509.

Zuni volcanic crater: Keyes, 2144.

Physiographic geology.

Boulder Reservoir floor: Longwell, 2445.

Colorado Delta : Fox, 1321.

Grand Canyon: Richter, 3291.

Meteor Crater: Spencer, 3804; Watson, 4362.

Moenkopi Plateau, erosion and dune ridges : Melton, 2653.

Pediments, Ajo region: Gilluly, 1433.

Provinces, physiographic: Hoover, 1794.

Rio de Flag Arroyo, erosion: Brady, 433.

Underground wates

Indian Hot Springs, Graham County : Knechtel, 2230.

Arkansas : Hall, 1604.

Economic geology.

Carbon ratios, Arkansas-Oklahoma coal field: Hendricks, 1708.

North of the Ouachitas: Fisher, 1270.

Cinnabar deposits: Stearn, 3846.

Southwestern Arkansas: Reed, 3220.

Coal fields, Pennsylvanian : Hendricks, 1709.

Hempstead County, shore-line oil possibilities: Easton, 1113.

Natural-gas fields, interior highlands : Croneis, 918.

Oil and gas, Gulf Coastal Plain : Moody, 2773 ; Spooner, 3810.

Quicksilver deposits near Little Missouri River: Hansell, 1622; Reed, $3218,3219$.

Smackover oil and gas field: Haury, 1649.

Snow Hill, Permian oil field, Ouachita County: Easton, 1114.
Arkansas-Continued.

Economic geology-Continued.

Zinc and lead, northern Arkansas : Mc- 。 Knight, 2552 ; Miser, 2749.

Historical geology.

Bloyd shale, stratigraphy and cyclical sedimentation: Henbest, 1693 .

Boone chert: Giles, 1422.

Carboniferous, proposed dismemberment : Keyes, 2186.

Cinnabar deposits: Stearn, 3846.

Coal fields, Pennsylvania, correlations: Hendricks, 1707, 1709.

Correlations by graptolites: Decker, 1000.

Lower Paleozoics: Decker, 1001.

Gulf Coastal Plain: Spooner, 3810.

Midway group, Eocene: Alexander, 25.

Natural-gas fields, interior highlands: Croneis, 918.

Novaculite, origin, Radiolaria : Henbest, 1694.

Ouachita boulder problem: Kramer, 2255 ; Van der Gracht, 4254.

Ouachita Mountains and Bucher's laws: Tomlinson, 4141.

Ouachita Mountains, structural history : Miser, 2748.

Polk Creek shale: Decker, 998.

Smackover oil and gas field: Haury, 1649.

Zinc and lead deposits, northern Arkansis : McKnight, 2552.

Mineralogy.

Enargite and wulfenite, northern Arkansas: McKnight, 2553.

Meteorite, Fayetteville, December 26, 1934: Richardson, 3285.

Radioactivity of spring water, Hot Springs : Schundt, 3564.

Stibnite in quartz: Stearn, 3844.

Titanium, Magnet Cove: Brock, 460.

Paleontology.

Brachiopods, Silurian, Triplesiidae: U1rich, 4214.

Cásteroides ohioensis, distribution: Cahn, 623.

Conodonts, Mississippian, Caddo Gap: Cooper, 857.

Corals, Mississippian : Grove, 1558.

Foraminifera : Cushman, 942.

Graptolites, Polk Creek shale: Decker, 998.

Griffithides conwayensis, Pennsylvanian, Conway County: Wheeler, 4443.

Ostracoda, Cretaceous, Gulf Coastal Plain : Israelsky, 1910.

Verneuilinidae, Valvulinidae and Virgulinidae: Cushman, 945.

Physical geology.

Cinnabar deposits: Stearn, 3846.

Cylindrical structures in sandstone: Hawley, 1656. 
Arkansas-Continued

Physical geology-Continued.

Zinc and lead deposits, northern Arkansas : MeKnight, 2552.

Arsenic.

Arkansas, northern, enargite and wulfenite: McKnight, 2553.

Newfoundland, Bay of Exploits area: Heyl, 1736.

Ore deposits: Butler, 592.

Arthropoda.

Ceratiocaris leesi, Sllurlan, Illinois: Roy, 3395.

Ceratiocaris markhami, Silurian, Illinois : Roy, 3393.

Echinocaris, Upper Devonlan, New York: Eller, 1163.

Eurypterus arnoldi, Devonion, Pennsylvania : Ehlers, 1147.

Evolution, segmentation: Reynolds, 3259.

Terrestrial types: Tillyard, 4130.

Mid-Cambrian, British Columbia ; Raymond, 3199 .

Paleoecology: Raymond, 3205.

Xanthias lenolensis, Cretaceous, New Jersey : Rathbun, 3185.

Artesion water, Florida : Stringfield, 3969.

Asbestos

Bibliography : Gamble, 1378.

Newfoundland, Bay of Islands igneous complex: Cooper, 869.

Quebec, Thetford district: Cooke, 85i, 852.

Asphalt

California, McKittrick, seasunal bandIngs: Vander Hoof, 4255.

Mexico, Tampico region: Muir, 2821.

Missouri, asphalt-bearing sandstones, Vernon County: Crabtree, 887.

Trinidad: Kugler, 2280 ; Lehner, 2381.

Associations, meetings.

American Association for the Advancement of science, section $E$, and others, meeting at Pittsburgh, December 31,1934 , and January 1 , 1935 : Mather, 2600, 2602.

Meeting at Rochester: Singewald, 3733.

Meeting at St. Louis : Mather, 2603.

Geological Society of America, Cordilleran section, University of California, Berkeley, $\mathbf{3 3 d}$ meeting: Woodford, 4595.

Stanford University, 34th meeting, 1935 : Woodford, 4508.

Geological Society of America, proceedings, 46th annual meeting, Chicago: Berkey, 289.

47th annual meeting, Rochester: Berkey, 290.

48th annual meeting, New York : Berkex. 291.
Associations, meetings-Continued.

Mineralogical Society of America, proceedings of 15 th annual meeting, Rochester: Kerr, 2077, 2080.

16th annual meeting; New York, N. Y.: Kerr 2084.

Paleontological Society, 26th annual neeting, Rochester, 1934: Howell, 1849.

27th annual meeting, New. Yolk, 1935 : Howell, 1858.

Asteroldea. See also Echinodermata.

Ophioderma, Pliccene, Trinidad: Berry, 295.

Starfish, Ordovician, Wisconsin: Jones, 2006.

Atlantic rift: Baker, 152, 153.

Austinlte, Gold Hill, Utah: Staples, 3824.

Autunite, Mitchell County, N. C.: Johnson, 1957.

Aves.

Age of birds: Wetmore, 4434.

Anabernicula gracilenta, Pleistocene, California: Ross, 3378.

Anserine bird, Pliocene, Nebraska : Compton, 826.

Avian and other remains, Aurora, Ill. : Smith, 374.6 .

California, Manix Lake Beds, Mojave Desert: Compton, 824

Miocene: Miller, 2721.

Pleistocene, McKittrick: Miller, 2722.

Burnet Cave, Pleistocene, New Mexico: Schultz, 3591.

Distribution, geologic factors in: Kelly, 2060.

Egg, Gila River, Ariz.: Ward. 4334

Tertiary, Colorado: Toepelmann, 4133.

Hawks, Miocene, Nebraska: Wetmore, 4433.

Moris reyana, Pleistocene, Playa del Rey, Calif. : Howard, 1825.

Moris vagabundis, Mtocene, California : Compton, 828.

Mycteria wetmorel, Pleistocene, Callfornia : Howard, 1823.

Oligocorax and Miocorax genera, not valid for North America: Wetmore, 4431.

Parapavo californicus, Pleistocene, California: Howard, 1826.

Pleistocene, Rancho La Brea, Callf.: Compton, 825 ; Howard, 1824.

Pliocene and Pleistocene, Femphill County, Tex.: Compton, 823.

Spizaëtus willetti, Pleistocene, Nevada : Howard, 1822.

Toxostoma redivivum, Pleistocene, Callfornia : Engels, 1184.

Trumpeter swan,. Pleistocene, Illinois: Wetmore, 4432.

Turkey, Tertiary, New Mexico: Needham, 2844. 
Aves-Continued.

Vultures, Pliocene, South Dakota : Compton, 827.

Williams Cave, Guadalupe Mountains, Tex. : Ayre, 125.

Babingtonite.

Massachusetts : Kitson, 2223 ; Palache, 2990.

Bacteria in meteorites : Lipman, 2425 ; Roy, 3396.

Bahamas.

Physiographic geology.

Calcareous shallow-water marine deposits : Thorp, 4118.

Barbados.

Paleontology.

Diatoms: Robinson, 3324.

Barite.

Appalachian Valley: Crickmay, 905.

Arizona, Redwall, Grand Canyon: Bryan, 516.

Colorado, South Park: Howland, 1870.

Montana, Flathead mine: Shenon, 3661.

North Carolina: Stuckey, 3972.

Nova Scotia, Lake Ainslie area: Norman, 2911.

Origin, Appalachian Valley: Crickmay, 905.

Virginia : Edmunson, 1136.

Basalt.

Crystallization process : Barth, 197.

New Mexico, flow units: Nichols, 2873.

Batholiths. See also Intrusions: Grout, 1554.

British Columbla, Const Range: Schofield, 3574 .

Osoyoos batholith : Cockfield, 795.

Ymir-Nelson area: Cockfield, 796.

California, Mother Lode and Sierra Nevada batholiths: Cloos, 781 .

Sierra Nevada pluton: Cloos, 784 .

Colorado, Front Range, pre-Cambrian : Boos, 373.

Migmatites, Sawatch Range: Stark, 3830 .

Montezuma quadrangle: Lovering, 2466.

Sawatch Range: Stark, 3829.

Twin Lakes and Clear Creek districts: Chapman, 732.

Georgia, pink granite; Elberton: Calhoun, 626 .

Idaho : Ross, 3376.

Casto quadrangle: Ross, 3369 .

Edwardsburg and Thunder Mountain area: Shenon, 3665 .

Intrusions, mechanics of : LoewinsonLessing, 2434.

Kansas, Central uplift: Koester, 2246.

Montana, Idaho batholith, northeastern part: Langton, 2337.

Nature and genesis : Nevin, 2851.

Batholiths-Continued.

Newfoundland, Bay of Exploits area : Heyl, 1736.

New Mexico, Organ Mountains and Doña Ana County: Dunbam, 1094.

Organ, New Mexico: Dunham, 1096.

Saganaga granite, Minnesota-Ontario : Grout, 1557.

Sierra Nevada, Calif.: Lawson, 2356.

South Carolina, Columbia quadrangle, granite: Kesler, 2087.

South Dakota, Black Hills: Wright, 4629.

Texas, Llano region : Stenzel, 3868.

Wyoming, Black Hills: Wright, 4629.

Beaches. See also Changes of level: Glacial lakes; Shore lines; Terraces.

California, erosion: O'Brien, 2932.

Gravel cusps, tide relations: Shepard, 3673 .

California coast: Buwalda, 603.

Canada, eastern Arctic regions: Nichols, 2871.

Ecology of sand areas: Twenhofel, 4193.

Erosion studies: Barden, 180.

Firm and soft sand, factors in formation: Kindle, 2202.

Littoral drift: Hennebique, 1710.

Louisiana, southwestern coast: Howe, 1840.

Michigan, Whittlesey beach: Stanley; 3818.

New Jersey, Coastal Plain: Kümmel, 2279.

Ontario, Algonquin beaches, Penetanguishene Peninsula: Stanley, 3820.

Rip currents: Shepard, 3683.

South Carolina, Georgia, and Florida: Martens, 2584.

Structures, original : Thompson; 4104.

Bentonite: Maynard, 2623.

British Columbia, industrial and nonmetallic minerals : Richmond, 3287 .

Mississippi : Mellen, 2651 ; Morse, 2805.

New Jersey, Upper Cretaceous clays : Stephenson, 3880.

Ordovician, eastern North America, correlation by : Rosenkrans, 3358, 3359.

Possible volcanic sources: Whitcomb, 4448.

Bermuda.

Historical geology.

General : Willard, 4486.

Beryl, Idaho, Latah County: Anonymous, 4661.

Beryllium, Mexico: Santillán, 3497.

Bibliography.

Abbe, Jr., Cleveland, writings: Sumner, 3978.

Agate: Zeihen, 4647 ; Zodac, 4659.

Alabama geology : Harper, 1638.

Alaska, Tertiary : Hollick, 1780.

Antillean-Caribbean region: Schuchert, 3579. 
Bibliography-Continued.

Arkansas, Gulf Coastal Plain: Spooner, 3810.

Asbestos: Gamble, 1378.

Barton, G. H., writings : Lane, 2321.

Bather, F, A., writings: Raymond, 3198.

Bell, J. M., writings: Collins, 813.

Bentonite: Morse, 2805.

Big Bone Lick, Kentucky : Jillson, 1952.

Britton, N. L., writings : Anonymous, 4666.

Brock, R. W., writings: Willams, 4519.

Brown, T. C.; writings: Mather, 2601.

Burckhardt, Carlos, writings: Miillerried, 2814.

Caliche, Texas: Price, 3133.

California, placers: Jenkins, 1936.

Sierra Nevada pluton: Cloos, 784.

Campbell, H. D., writings: Roberts, 3317 .

Carney, Frank, writings: Thomas, 4088, 4090.

Catskill name, history and value in geology: Chadwick, 715 .

Cenozoic floras, succession and distribution, northern Pacific basin : Chaney, 728.

Chaleur Bay region, Canada: Alcock, 12.

Chemical papers bearing on sedimentation : Steiger, 3863.

Chert, nature and origin : Laird, 2290.

Chlorite system: Winchell, 4562.

Clapp, C. H., writings : Deiss, 1010.

Clays, fire, distribution in U. S.: Chelikowsky, 743.

Clays and shales. gravitational compaction: Hedberg, 1682.

Cleland, H. F., writings: Raymond, 3203.

Coal and coal products: Wadleigh, 4305.

Cobb, Collier, writings: Prouty, 3152. .

Colorado Delta : Fox, 1321.

Conrad, 'I. A., writings: Wheeler, 4445.

Cryptovoleanic structures: Bucher, 534.

Crystallography: Wyckoff, 4633.

Dake, C. L., writings: Bridge, 455 ; Brown, 485.

Dana, E. S., writings : Schuchert, 3586.

Davis, W. M., writings : Block, 349 .

D'Invillers, E. V., writings : Ashley, 104.

District of Columbia nnd vicinity, min. erals: Ulke, 4206.

Dynamics of streams: Straub, 3964.

Economic geology, annotated: Nickles, $2874,2875,2876,2877,2878,2879$, 2880,2881 .

European and North American mountain systems : Suess, 3975 .

Foraminifera : Cushman, 942.

Index, genera, species, and varleties, new ; 1932 : Thalmann, $4049 ; 1933$ : Thalmann, 4054 ; 1934 : Thalmann, 4055 .

Mexico: Barker, 182.

Foye, W: G., writings :- Perkins, 3054.
Bibliography-Continued.

Fulgurites: Petty; 3069.

Geologic names and correlations: Cram, 891.

Geologic time: Lanc, 2328; Marble, 2580.

Glacial and postglacial vegetation : Sears, 3626 .

Gold, southern Appalachians: Anonymous, 4692.

Gordon, G. H., writings : Hall, 1610.

Graham, W. A. P., writings : Cram, 890 ; Grout, 1555.

Greenland: Anonymous, 4662.

Livelpool Land, crystalline complex: Kranck, 2256.

Hayford, J. F., writings : Burger, 577.

Heteromyid rodents, Tertiary, western North America: Wood, 4573.

Higgins, D. F., writings: Grant, 1495.

Hopkins, T. C., writings : Ploger, 3096.

Hudson, G. H., writings : Ruedemann, 3408.

Idaho: Ross, 3376.

rllinois, publications on: Anonymous, 4687.

Intrusions, mechanics of: LoewinsonLessing, 2434.

Iron, Eastern and Southeastern States and Cuba: Anonymous, 4685.

Lake Superior region: Leith, 2390.

Landslips, subsidences, and rock falls : Ladd, 2284.

Louisiana, Cameron and Vermilion Parishes, geology : Howe, 1836.

Lupton, C. T., writings : Ball, 172; Hares, 1630.

Maine, Alpine zone, Mount Washington Range: Antevs, 76.

Mall, F. B., writings: Sabin, 3467.

Mammals, Paleocene: Simpson, 3721.

Man, early, in North America: Howard, 1814.

Manganese, origin : Harper, 1637.

Mechanics of igneous invasion: Sundeen, 3979 .

Mendenhall, T. C., writings: Crew, 897.

Merrill, G. P., writings : Lindgren, 2417.

Meteorites : Hamilton, 1613.

First 1935 list : Leonard, 2393.

Second 1935 list: Leonard, 2395.

First 1936 list : Leonard, 2396.

Mexico, paleontology and geology : Barker, 182.

State of Chiapas, pre-Tertiary: Müllerried, 2815.

Miller, A. M., writinge: McFurlan, 2521.

Mineralogy of sedimentary rocks: Pettijohn, 3064 .

Minneapolis-St. Paul metropo'itan area : Schwartz, 3597 .

Mitchill, S. L., Writings : Hall, 1605.

Mollusca. Cretaceous and Tertiary : Rutsch, $34 \overline{8}$.

Venericardia planicosta grou p : Rutsch, 3457. 
Bibliography-Continued.

Montana, Butte mining district: Hart, 1647.

Mylonites: Waters, 4357.

Newer Appalachians, south of New River: Wright, 4625.

Newfoundland : Betts, 306 .

North American geology, 1933 and 1934 ; Thom, 4073.

North America regional exposition: Joerg, 1953.

Oahu : Stearns, 3856.

O'Harra, C. C., writings : Connolly, 842 ; Jackson, 1922.

Oklahoma, soutbern, natural-gas flelds: Tomlinson, 4142.

Oligocene faunas and formations, northwest Oregon: Packard, 2980.

-Oregon geology : Hodge, 1764.

Geology and mineral resources: Treasher, 4160.

Osborn, H. F., writings : Keys, 2146.

Ostracoda, Primitidae and Beyrichiidae, Devonian, revision: Swartz, 3991.

Palms, fossil : Noe, 2902.

Pegmatites, age and distribution: Landes, 2311.

Pelecypods, nuculid: Schenck, 3537. Shell structure: Schenck, 3538.

Perry, J. H., writings : Alden, 16.

Petrofabric analysis: Fairbairn, 1205.

Petroleum genesis: Van Tuyl, 4266.

Pre-Dana and contemporary mineralogical literature: Wilson, 4528.

Principles of geology : Field, 1249.

Proboscidea : Osborn, 2961.

Prout, H. A., writings : Greger, 1518.

Pumpelly, Raphael, writings: Willis, 4526 .

Putnam, F. W., writings : Tozzer, 4148.

Quebec, Abitibi area: Dresser, 1079.

Recent sediments and source beds of petroleum : Trask, 4150.

Richardson, C. H., writings : Currier, 940 ; Ruedemann, 3412.

Richarz, Stephen, writings : Allen, 43; Retzek, 3257.

Shattuck, G. B., writings: Mathews, 2610.

Shaw, E. W., writings: Westgate, 4429.

Shepard, E. M., writings : Buehler, 553.

Shufeldt, R. W., writings : Lambrecht, 2298.

Sisler, J. D., writings : Ashley, 109.

Soil erosion: Wieland, 4476.

Solids, transportation by water in open channels; U. S. Bur. Reclamation, 4273.

Southwestern U. S: : Effinger, 1144.

Spilite problem : Gilluly, 1430.

Stegocephalia and Reptilia, east Greenland: Säve-Söderbergh, 3469 .

Talc and soapstone: Wilson, 4539.

Trinidad: Lebner, 2381.
Bibliography-Continued.

Upham, Warren, writings: E m mons, 1177.

Valentine, Tertiary: Johnson, 1966.

Van der Gracht, W. A. J. M. van Waterschoot, writings: Strachan, 3961.

Vertebrata, skull evolution: Gregory, 1528.

Virginia, southwestern, zinc and lead region: Currier, 936.

Washington, H. S., writings : Pellour, 3047.

Washington, Mount Rainier National Park : Coombs, 856.

Williams, I. A., writings: Williams, 4514.

Wyoming, late Cretaceous and early Tertiary: Nace, 2840.

X-ray identification of ore minerals: Waldo, 4312.

Biography.

Abbe, Jr., Cleveland: Sumner, 3978.

Alexander, A. M. : Westby, 4425.

Barton, G. H. : Lane, 2321.

Barus, Carl : Archibald, 83.

Bather, F. A. : Lang, 2335 ; Raymond, 3198.

Bell, J. M. : Collins, 813.

Bennett, C. M.: Thompson, 4103.

Boydell, H. C. : Lindgren, 2419.

Branner, J. C. : Lane, 2326.

Britton, N. L. : N. Y. Bot. Garden, Bd. Mgrs., 2870 ; Anonymous, 4666.

Brock, R. W. : Kindle, 2205; Williams, 4519.

Brown, T. C. : Mather, 2601.

Burckardt, Carlos: Müllerried, 2814, 2816 ; Schuchert, 3585.

Campbell, H. D. : Roberts, 3317.

Carney, Frank : Hubbard, 1873 ; Thomas, 4088, 4090.

Chamberlin, T. C. : Mather, 2604.

Clapp, C. H. : Deiss, 1010 ; Flint, 1283.

Clarke, J. M. : Raymond, 3195.

Cleland, H. F.: Raymond, 3197, 3202, 3203.

Cobb, Collier : Prouty, 3143, 3146, 3149, 3152.

Collins, M. J. : Durward, 1097.

Colony, R. J. : Krieger, 2263.

Conrad, T. A. : Palmer, 2994; Wheeler, 4445.

Dake, C. L. : Bridge, 455; Brown, 485.

Dana, E. S.: Anonymous, 4693 ; Ford, 1307, 1308; Palache, 2989; Schuchert, 3583, 3586 .

Davis, W. M. : Block, 349 ; Bryan, 520 ; Buwaldo, 600 ; Davies, 982 ; Edelshtein, 1135; Martoune, 2595; Nussbaum, 2922 .

D'Invilliers, E. V.: Asbley, 104.

Evans, John : Evans, 1191.

Faustino, L. A. : Smith, 3772.

Foerste, A. F. : Wright, 4624 ; Anonymous, 4.699 .

Foye, W. G. : Perkins, 3054. 
Biography-Continued.

Geikie, A. : Shimer, 3691.

Gleason, C. D. : McQueen, 2562.

Goldschmidt, V.: Palache, 2986.

Gordon, C. H. : Hall, 1609, 1610.

Graham. W. A. P.: Cram, 890 ; Grout, 1555.

Handlirsch, Anton: Schuchert, 3584 .

Harris, G. D. : Cheney, 746.

Hayford, J. F.: Burger, 577.

Henley, A. S. : McLaughlin, 2554.

Higgins, D. F. : Grant, 1495.

Hopkins, T. C. : Ploger, 3096.

Horne, J.: Daly, 963.

Hudson, G. H. : Ruedemann, 3408.

Keyes, Wilson : Butcher, 589 ; McClure, 2507.

Leith, C. K. : Anonymous, $4 \dot{7} 10$.

Lupton, T. C. : Ball, 172 ; Hares, 1630

McCaskey, H. D.: Smith, 3773.

McNutt, V. H. : Finch, 1258.

Mall, F. B.: Sabin, 3467.

Mann, Albert: Hagelstein, 1597.

Mendenhall, 'T. C. : Clew, 897.

Mendenhall, W. C.: Cheney, 747.

Merrill, G. P. : Lindgren, 2417.

Miller, A. M. : McFarlan, 2521.

Mitchell, S. L. : Hall, 1605.

Osborn, H. F.: Andrews, 75 ; Douvllee. 1077 ; Flinsch-Buba, 1282 ; Gregory, 1529, 1530, 1531, 1532; Keyes. 2146 ; Lull, 2486 ; Richter,' 3292 : Woodward, 4608.

O'Harra, C. C. : Connolly, 842 ; Jackson, 1922.

Parks, W. A. : Lull, 2487.

Perry, J. H. : Alden, 16.

Phillips, W. B. . Anonymous, 4681.

Prout, H. A. : Greger, 1518.

Pumpelly, Raphael: Willis, 4526.

Putnam, F. W. : Tozzer, 4148.

Ransome, F. L. : Lindgren, 2420 ; Anonymous, 4681.

Reagan, A. B.: S-, 3466.

Richardson, C. H. : Currier, 940 : Ruedemann, 3412 .

Richarz, Stephen: Allen, 43; Retzek, 3257 ; Waagen, 4289.

Rogers, W. B. : Bevan, 308; Roberts, 3319.

Rowley, R. R. : Williams, 4510.

Ryan, R. F.: Coltes, 878.

Schlumberger, Conrad: I e o n a r d o n, 2399 ; Anonymous, 4702.

Shattuck, G. B. : Mathews, 2610.

Shaw, E. W.: Trowbridge, 4172 ; Westgate, 4429.

Shepard, E. M.: Buehler, 552, 553.

Shufeldt, R. W. : Lambrecht, 2298.

Shumard, B. F.: Greger, 1517.

Sinclair, W. J. : Anonymous, 4672.

Sisler, J. D.: Ashley, 109; Price, 3129.

Ulrich, E. O.: Strachan, 3961.

Upham, Warren : Emmons, 1177.

Vogt, J. H. L. : Daly, 964.
| Biography-Continued.

Washington, H. S.: Barth, 195 ; Lewis, 2409 ; Pelloux, 3046, 3047.

White, C. D.: Berry, 301 ; Mendenhall, 2662, 2663; Miser, 2747, 2750 ; Oklahoma City Geol. Soc., 2942; Shimer, 3692; Stanton, 8823; Anonymous, 4668 .

Whitehead, R. B. : Thomas, 4087.

Williams, I. A. : Williams, 4514.

Woodworth, J. B. : Sayles, 3521.

Young, K. E. : Howe, 1845.

Birds. See Aves.

Bismuth.

British Columbia, gold-bismuth occur rence, Cariboo gold quartz mine: Warren, 4347.

Colorado, batholith, Twin Lakes and Clear Creek districts: Chapman. 732.

Sugar Loaf district, Lake County, ore minerals: Sandberg, 3487.

Newfoundland, Bay of Exploits area : Heyl, 1736.

Bitumens. See also Asphalt. Canada, analyses : Rosewarne, 3361..

Bituminous rocks and sands. See also Asphalt; Oil shales; Petroleum.

Carbon and hydrogen determination:: Hoots, 1791.

Black mud shales, eastern New York, paleoecology : Ruedemann, 3403.

Blastoldea.

Devonlan, New York: Reimann, 3240:.

Ontogeny: Croneis, 919.

Schizoblastus genus, emended, Missigsippi Valley, Osage group: Cline, 778.

Borax.

Boulder Dam area, mineral occurrences: Lee, 2367.

California: Vonsen, 4397.

Borax Lake: Vonsen, 4298.

Ceramic materials other than clays: Burchflel, 574.

Kramer borate field: Schaller, 3532 .

Tick and Red Rock canyons: Luce, 2476.

Borings.

Bore-hole investigations, Yellowstone Park: Fenner, 1223.

Iowa, deep wells: Lees, 2369 ; Norton, 2920.

Minnesota, Stillwater deep-well records: Stauffer, 3839.

West Virginia, deep-well records: Tucker, 4180.

Yellowstone National Park: Allen, 37.

Boron compounds, volcanologic: Schaller, 3534.

Botany, fossil. See Paleobotany. 
Boulders.

Arkansas and Oklahoma, Ouachitas : -Kramer, 2255; Van der Gracht, 4254 .

Etched erratic: Hobbs, 1757.

Oklahoma and Arkansas, Ouachitas: -Kramer, 2255; Van der Gracht, 4254.

Ouachitas, Arkansas and Oklahoma: Vain der Gracht, 4254.

Boulder trains, White's Hill, Allegany County, N. Y. : Chadwick, 710.

Brachiopoda.

Argyrotheca gardnerae, new name: Cooke, 844

Athyris and Cyrtina, Devonian, Iowa : Fenton, 1226.

Atrypa, Devonian, Iowa: Fenton, 1232.

Cache Creek Permian, British Columbia : Crockford, 916.

Cambrian, Alaska : Cooper, 865.

Fernvale formation, Ordovician, fauna: Greger, 1519.

Gruenewaldtia, Devonian, Missouri : Greger, 1520.

Hypothyridina venustula, Devonian, Penusylvania: Willard, 4488.

Inarticulate, Ordovician, M 1 s s ou r 1: Greger, 1516.

Michigan, southeastern, Dundee limestone: Bailey, 223.

Montana, pre-Cambrian: Fenton, 1233.

New Hampshire, mica schist, Devonian : Billings, 319.

Oligorhynchia, Ordovician, Tennessee: Cooper, 860 .

Ordovician, Labrador: Little, 2426.

Ozarkian and Canadian, new genera: Ulrich, 4216.

Productella wayensis, Carboniferous, Kentucky: Brill, 459.

Productus coloradoensis, Pennsylvanian, Missouri : Girty, 1438.

Punctospirifer pulchra, Permian,. Wyoming : Thomas, 4085.

Quebec, Perce, Upper Ordovician, Whitehead formation: Cooper,

- 867.

Spirifer mucronatus, cardinal spines: Garretson, 1388.

Strophalosia, Mississippian, Missouri : Hinchey, 1743.

Triplesiidae, Silurian: Ulrich, 4214.

Branchiopoda.

Schizodiscus antecrenulus, Devonian, Pennsylvania: Cleaves, 771 .

Breccias.

California, mylonites from San Andreas fault zone: Waters, 4357 .

Pinnacles National Monument: Andrews, 74.

Quebec, St. Helen Island, Montreal : Osborne, 2966.

Tennessee, Flynn Creek disturbance, Jackson County: Wilson, 4536.
British Columbia.

Economic geology.

Barkerville gold belt, Cariboo district: Hanson, 1627.

Bralorne mine area: Hedley, 1685:

Veins and faults: Joralemon, 2013.

Cariboo and Bridge River gold fields: Dolmage, 1055.

Copper, pyritic deposits: Kania, 2019.

Fraser River-Harrison Lake region: Holwood, 1800.

Gold and metallic minerals, relationship : Warren, 4346.

Gold-bismutb, occurrence, Cariboo gold quartz mine: Warren, 4347.

Gold deposits, Graham Island, Queen Charlotte Islands: Mandy, 2565.

Hidden Creek ore bodies: Nelson, 2845.

Keithley Creek area, Cariboo district: Lang, 2333.

Lode-gold deposits, Similkameen : and Lillooet districts: Cockfield, 795.

Ymir-Nelson area: Cockfleld, 796.

Minerals, industrial and nonmetallic: Richmond, 3287 .

Mining industry, 1934: Walker, 4315; 1935 : Walker, 4316.

Nickel mines, Yale district: Horwood, 1799.

Ore depth in mines: Schofield, 3573.

Peace River area: Williams, 4517.

Fortland Canal area: Hanson, 1626.

Pre-Mississippian veins and deposits, Cariboo district: Lay, 2357.

Schwatzite. Windemere district: Warren, 4344 .

Slocan mining camp area : Cairnes, 624.

Structure, relation to ore deposition, Brittania mines: Ebbutt, 1118.

Submarine coal mine, Nanaimo, Vancouver Island: Dickson, 1045.'

Tertiary gravels, Cranbrook area, gold possibilities: Rice, 3262.

Willow River area, Cariboo district: Hanson, 1624.

Historical geology.

Baculites ovatus zone, Alberta shales: Webb, 4371.

Barkerville gold belt, Cariboo district: Hanson, 1627.

Batholith, composite, Coast Range: Schofield, 3574.

Bralorne mine, veins and faults: Joralemon, 2013.

Cache Creek Permian series: Crockford, 916.

Cadwallader Creek area, Lillooet district: Canada G. S., 644.

Cate Creek, Cretaceous: Olsson, $29 \dot{2} 2$.

Fraser River-Harrison lake region: Horwood, 1800.

Keithley Creek area, Cariboo district: Lang, 2333.

Kruger syenites, southern British $\mathrm{Co}$. lumbia: Campbell, 633. 
British Columbia-Continued.

Historical geology-Continued.

Lode-gold deposits, Similkameen and Lillooet districts : Cockfleld, 795.

Ymir-Nelson area : Cockfield, 796.

Nahatlatch region: Horwood, 1801.

: $\therefore$. Nickel mines, Yale district: Horwood, 1799.

:... Portland Canal area: Hanson, 1626.

Cassiar district: Canada G. S., 655 .

Pre-Mississippian veins and deposits, Cariboo district: Lay, 2357.

Stikine River area, center shect, Cassiar $\therefore$ district: Canada, G. S., 657.

North sheet, Cassiar district: Canada G. S., 658.

South sheet, Cassiar district: Canada G. S., 659 .

Structure, relation to ore deposition, Brittania mines : Ebbutt, 1118.

Willow River area, Cariboo district: Hanson, 1624.

\section{: Mineralogy.}

Amphibole, Purcell sills : Rice, 3261.

$\therefore$.. Gold and metallic minerals, relationship: Warren, 4346.

Gold-bismuth, occurrence, Cariboo gold quartz mine: Warren, 4347.

Knebelite, Bluebell mine, Kootenay Lake : Gunning, 1574

Minerals, industrial and nohmetallic: Richmond, 3287.

Schwatzite, Windemere district: Warrèn, 4344

\section{Paleontology.}

Cache Creek Permian, fauna: Crockford, 916.

Cephalopods, Permian: Miller, 2706, 2708.

Corals, anthracolithic, Fermian, Simil. kameen district: Smith, 3770.

Florule, Oligocene, Vancouver Island: LaMotte, 2305.

Mid-Cambrian Arthropoda: Raymond, 3199.

Trogosus minor, Eocene: Russell, 3429.

\section{Petrology.}

Amphibole, Purcell sills : Rice, 3261.

Quartz, pre-Cambrian, Vernon: Walker, 4324.

\section{Physical geology.}

Batholith, composite, Coast Range: Schofield, 3574 .

Bralorne mine area : Hedley, 1685.

Veins and faults: Joralemon, 2013.

Hidden Creek ore bodies : Nelson, 2845.

Nickel mines, Yale district: Horwood, 1799.

Pre-Mississippian veins and deposits, Cariboo district: Lay, 2357.

\section{Physiographic geology.}

Cordilleran region : Kerr, 2075.

.Fiord-land: Peacock, 3035.

Fiords: Carter, 689.
British Columbia-Continuer.

Physiographic geology-Continued.

Glaciation, Cranbrook area: Rice, 3263 ,

Quaternary, Coast Range: Kerr, 2076.

Glaciers, Mount Waddington region: Munday, 2827.

Keithley Creek area, Cariboo district: Lang, 2333.

Talsekwe River, Taku district, extraordinary floods: Kerr, 2083.

White silt, Okanagan Valley: Flint, 1286.

Willow River area, Cariboo district: Hanson, 1624.

Brunner focal depth-time-distance chart: Brunner, 512 .

Bryozon.

Batostoma and Hemiphragma, Ordovician, Minnesota: Sardeson, 3512.

Batostoma to Fenestella: Sardeson, 3515.

Dekayella praenuntia, Ordovician : Minnesota: Sardeson, 3507.

Hallopora, Ordovician, Minnesota: Sardeson, 3508.

Homotrypa minnesotensis, Ordovician, Minnesota : Sardeson, 3506.

Leptotrypa to Fistulipora: Sardeson, 3514.

Monotrypa and Eridotrypa, Ordovician,

$\therefore$ Minnesota : Sardeson, 3513.

Monticulipora grandis and $M$. arborea, Ordovician, Minn.: Sardeson, 3504.

Nomenclature: Bassler, 231.

Plethopola americana, Upper Cretaceous, Georges Bank: Bassler, 230.

Prasopora simulatrix, Ordovician, Minnesota: Sardeson, 3503.

Bullding stone.

British Columbia, industrial and nonmetallic minerals : Richmond, 328t.

California, southern Peninsular Range: Miller, 2728.

Perris block : Dudley, 1085.

Colorado: Balcom, 158

Connecticut, marbles and limestones: Moore, 2782.

Granite, Manitoba : Cole, 803.

Manitoba: Cole, 803 ; Hutt, 1800.

Marble, Tennessee : Oder, 2937.

Minnesota, architectural, structural, and monumental stones: Thiel, 4068.

Texas, Palo Pinto County: Plummer, 3098.

Virginia, greenstone : Hughes, 1879

James River iron and marble belt: Furcron, 1362.

West Virginia, upper Monongahela Valley: U. S. Com., 4224.

Burkeite, Searles Lake, Calif. : Foshag, 1311.

Burrows, Montana, pre-Cambrian: Fenton, 1233.

Caesium, Maine: Burbank, 568. 
Calcite, crystal, Godfrey, Ontario: Parsons, 3010.

California.

Paragenesis at Crestmore: Daly, 962.

State mineralogist, biennial report: Bradley, 422.

Areas described.

Julian district, San Diego County : Dounelly, 1064.

Economic geology.

Andalusite, White Mountain Peak, Mono County: Woodhouse, 4599.

Borates : Vonsen, 4297.

Borax Lake: Vonsen, 4298.

Boulder Dam region, mineral resources: Hewett, 1735.

Buena Vista Hills oil field: Howard, 1828.

Ceramic materials other than clays: Burchfiel, 574.

Cerro Gordo mining district: Webb, 4373.

Chromite, nodular, orbicular, and banded : Jobnston, 1986.

Clays, Riverside and Orange Counties: Sutherland, 3981.

Clear Lake area : Anderson, 64.

Coalinga district, accumulation of oil : Galloway, 1377.

Connate water in ofl sands: Pyle. 3154.

Copper, foothill belt : Tolman, 4140.

Plumas County: Knopf, 2236.

Shasta County : Averill, 123.

Trinity County : Johnston, 1984.

Diatomite, Lompoc: Mulryan, 2826.

Edison oil field: Carter, 688; Noble, 2899.

Elizabeth Lake quadrangle: Simpson, 3713.

Fuller's earth, Tehachapi : Kerr, 2085.

Gold, dry placers, Mojave Desert : Hulin, 1880.

Julian district, San Diego County: Donnelly, 1064.

Julian region: Donnelly, 1066.

Lithium ores: Chambers, 724.

Meadow Lake district gold veins, Nevada County: Wisker, 4566.

Mineral resources, Monterey and Kings Counties: Franke, 1325.

Mineral wool from wollastonite: Thorndyke, 4117.

Mojave mining district: Schroter, 3578; Tucker, 4181.

Mother Lode gold belt: Logan, 2435.

Mountain View oll fleld : Gow, 1488.

Mount Poso oil field : Diepenbrock, 1046.

Natural-gas fields: Hoots, 1792.

Newhall oil field: Walling, 4325.

Nonmetallic minerals: Bradley, 421.

Oil conversion, Santa Fe Springs field : Trask, 4153.

Oil flelds, geophysical prospecting: Anonymous, 4680.

Oil reserves: Eaton, 1116.
California-Continued.

Economic geology-Continued.

Perris block, mineral resources: Dudley, 1085 ; Sampson, 3479.

Petroleum, recent discoveries and present supply: Hoots, 1793.

Placers in Tertiary river channels: Duling, 1089.

- Placers, new study technique: Jenkins, 1936.

Playa del Rey oil field : Hoots, 1790.

Pyrophyllite, San Diego County: Richard, 3274.

Round Mountain oil field, Kern County : 'Diepenbrock, 1047.

San Joaquin Valley, geophysical prospecting: Mills, 2731.

San Luis Obispo County, mineral resources: Franke, 1324.

Santa Rita ore body: Henderson, 1706.

Semitropic gas field: Valentine, 4248.

Sierra Nevada placers: Jenkins, 1937.

Siskiyou County, mineral resources: Averill, 124.

Strontium, southeastern California : Moore, 2778.

Tick and Red Rock Canyons : Luce, 2476.

Venice and Del Rey fields, Miocene correlation : Corey, 875.

Wollastonite, Kern County: Melhase, 2649.

Historical geology.

Astrodapsis faunal zones, Miocene and Pliocene: Richards. 3277 .

Breccias, Miocene, Santa Barbara district: Reed, 3226.

Buena Vista Hills oil field: Howard, 1828.

Cambrian, Middle, Providence and Marble Mountains : Hazzard, 1662.

Capay Valley, Eocene formations: Crook, 922.

Cedarville formation, Tertiary : LaMotte, 2309.

Chico Creek, Cretaceous, Butte County: Hanna, 1616.

Clays, Riverside and Orange Counties: Sutherland, 3981.

Clear Lake area: Anderson, 64.

Coast: Buwalda, 603.

Coastal basin, south : Eckis, 1131.

Corrections: Reed, 3227.

Death Valley National Monument: Anonymous, 4664.

Diatomite, Lompoc: Mulryan, 2826.

Edison oil field: Carter, 688; Noble, 2899.

Elephants, Channel Islands: Stock, 3923.

Elizabeth Lake quadrangle: Simpson, 3713.

Eocene, Santa Lucla Mountains : Herold, 1716.

Eocene paleogeography: Reed, $\mathbf{3 2 3 0}$.

Eocene sequence: Clark, 759. 
California-Continued.

Historical geology-Continued.

Gaviota formation, Santa Barbara County : Effinger, 1146.

Geologic formations, table: Jenkins, 1935.

Inyo Range, Wyman Canyon: Maxson, 2620.

Klamath Mountains, southern: Hinds, $1746,1748$.

Kreyenhagen shale, Oligocene, Cantua Creek-Panoche Creek district: Condit, 832 .

Lepidocyclina, significance: Schenck, 3548.

Los Angeles Basin, late Quaternary: Eckis, 1132.

Lucia quadrangle, Monterey County: Reiche, 3235 .

McCloud limestone, fauna and strat1grapby: Wheeler, 4444

Merced formation: Johnson, 1965.

Miocene: Ḱleinpell, 2226, 2227.

Mojave mining district : Schroter, 3578.

Mojave River investigation: Conkling, 839.

Mother Lode gold belt : Logan, 2435.

Mother Lode and Sierra Nevada batholiths: Cloos, 781.

Mount Diablo and Coalinga areas: Clark, 755.

Mount Diablo and vicinity: Taff, 4005.

Mount Pinos quadrangle: Dreyer, 1080

Mount P'oso oil field : Diepenbrock, 1046.

Natural-gas fields: Hoots, 1792.

Oligocene mammal-bearing beds, Death Valley : Stock, 3924.

Palos Verdes Hills, Miocene: Woodring, 4603.

Paragenesis, Crestmore: Daly, 962.

Peninsular Range, southern: Miller, 2728. .

Perris block, Elsinore quadrangle : Dudley, 1086.

Southern California: Dudley, 1085.

Petaluma district: Morse, 2806.

Pinnacles National Monument: Andrews, 74.

Placers, dry, Mojave Desert: Hulin, 1880.

Tertiary river channels: Duling, 1089.

Study technique, new : Jenkins, 1936.

Flaya del Rey field: Hoots, 1790.

Pleistocene, marine, summary: Grant, 1498.

Terraces, San Pedro Hills : Woodring, 4601.

Pleistocene correlations, Pacific coast: Allison, 54.

Providence and Marble Mountains, Cambrian : Hazzard, 1660.

Ravenna quadrangle: Sharp, 3648 .

Refugian stage, Pacific coast: Schenck, 3549.

Salinas quadrangle: Herold, 1715.

\footnotetext{
$311-37-22$
}

California-Continued.

Historical geology-Continued.

San Gabriel Mountains, Martinez: Clements, 775.

San Joaquin Hills, eastern half, Orange County : Bode, 356.

San Nicolas Island: Kemnitzer, 2070.

San Simeon, Adelaida, and Paso Robles quadrangles: Taliaferro, 4007.

Santa Monica Bay: Shepard, 3670.

Santa Monica Mountains, western: Kelley, 2048, Soper, 3788.

Santa Rita ore body: Henderson, 1706.

Santa Rosa Island: Moody, 2774.

Santa Susana and lower Llajas fauna, Ventura County: Clark, 757.

Sedimentation and faulting: Ashauer, 98.

Sespe Creek-Piru Creek area: Hobson, 1759.

Sierra Nevada, early surfaces: Jenkins, 1937.

Sierra Nevada pluton: Cloos, 784; Mayo, 2625.

Simi Valley, north side, Eocene: Stipp, 3905.

Structure, southern California : Reed, 3231.

Sycamore Canyon formation: Krueger, 2266.

Tebachapi region, Tertiary: Buwálda, 602.

Tertiary, Ventura area: Fourmarier, 1314.

Tertiary limestones, San Rafael Mountains: Reed, 3225.

Tesla quadrangle, near Tracy: Huey, 1877.

Tick and Red Rock Canyons: Luce, 2476.

Tumey formation, Oligocene: Atwill, 116.

Turritella andersoni zone, correlation: Applin, 82.

Stratigraphic position: Vokes, 4293.

Transverse Ranges: Reed, 3221.

Twenty-nine Palms region, Mohave Desert : Miller, 2729.

Vacaville-Rumsey Hills area: Kirby, 2218.

Vaqueros, age: Schenck, 3548. Oligocene(?) : Schenck, 3539.

Temblor Range: Clark, 762.

Venice and Del Rey fields, Miocene, correlation : Corey, 875 .

Ventura County: Conkling, 837.

Waltham Valley region: Reed, 3227.

Weaverville district, northern California: Hinds, 1747.

\section{Mineralogy,}

Adamite, Chloride Cliff: Murdoch, 2835.

Agate beds, Mint Canyon : Patton, 3025.

Andalusite in pegmatite: Murdoch, 2833.

Anorthite, San Marcos gabbro, San Luis Rey quadrangle: Miller, 2720.

Augelite, Mono County: Lemmon, 2392. 
California-Continued.

Mineralogy-Continued.

Bonsal tonalite, origin of dark inclusions : Hurlbut, 1894.

Borates: Vonsen, 4297.

Borax Lake: Vonsen, 4298.

Burkeite, Searles Lake: Foshag, 1311.

Bustamite, Inyo County : Murdoch, 2834.

Cerro Gordo mining district: Webb, 4373.

Chiastolite: Noren, 2910.

Crystals, Mađera: Brown, 497.

Claudetite, Imperial County: Kelley, 2050.

Clay, bentonitic magnesian, Mojave Desert: Foshag, 1313.

Colemanite, Ventura County: Van Amringe, 4250 .

Diopsides, Crestmore quarries, Riverside: Merriam, 2675.

Fluorescent minerals: Melbase, 2641.

Fuller's earth, Tehachapi : Kerr, 2085.

Garnet: Melhase, 2644.

Kernite and borax, origin, Kramer borate field: Schaller, 3532.

Kunzite, Pala district: Buranek, 567.

Maghemite and ferric oxides : Newhouse, 2864.

Minerals, Ritter Range: Goudey, 1481.

Monticellite, San Bernardino County: Schaller, 3531.

Nodules, opal- or agate-flled : Renton, 3248.

Nonmetallic minerals: Bradley, 421.

Obsidian, iridescent: Wright, 4622.

Paragenesis, Crestmore :.Daly, 962.

Pegmatites, lithium, Pala: Donnelly, 1067.

Piedmontite, Los Angeles County: Simonson, 3712 .

Pseudomorphs, quartz-fluorite : Murdoch, 2831.

Silica-fluorite: Murdoch, 2832.

Quartz, smoky and ordinary, Rincon, Spectrographic examination: Kennard, 2072.

Radium content, lavas from Lassen Volcanic National Park: Evans, 1192.

Rare-earth minerals: Melhase, 2646.

Sanbornite: Melhase, 2643.

Sulphur, native, with gossans: Raymond, 3193.

Tetradymite, Injo Mountains: Webb, 4372.

Tourmaline, Mesa Grande: Grieger, 1538.

Vein quartz, Mariposa County : Rogers, 3334.

Vesuvianite, Georgetown: Pabst, 2976.

Wollastonite, Kern County: Melhase, 2649.

Wollastonite and parawollastonite : Peacock, 3036.

Paleontology.

Anabernicula gracilenta, Pleistocene. McKittrick : Ross, 3378.
California-Continued.

Paleontology-Continued.

Arctothere, Pliocene, Eden Hot Springs : Stock, 3935.

Artiodactyla, Oligocene, Las Posas Hills : Stock, 3921.

Aśtrodapsis faunal zones, Miocene and Pliocene: Richards, 3277.

Monterey County, Miocene: Richards, 3276.

Aturoidea, Eocene : Miller, 2702.

Auluroid, Ordovician, Barrell Springs : Phleger, 3079.

Birds, Manix Lake beds, Mojave Desert: Compton, 824.

Miocene: Miller, 2721.

Pleistocene, McKittrick : Miller, 2722.

Pleistocene, Rancho La Brea : Compton, 825; Howard, 1824.

Cedarville flora, Tertiary: LaMotte, 2309.

Cernictis hesperus, Pliocene, San Pablo Bay : Hall, 1606.

Change of : fauna, lateral, Ventura, Pleistocene: Bailey, 131.

Corylus, Pleistocene, Montecito, Santa Barbara County : Mason, 2596.

Diatoms,. Cretaceous, Panoche Hills: Hanna, 1615.

Pliocene, Kettleman Hills: Lolıman, 2440.

Dinosiur, Cretaceous, Patterson : Hesse, 1730.

Elephants, Channel Islands: Stock, $3923,3930$.

Eohaplomys, Sespe Eocene: Stock, 3914.

Eumysops simplex, Sespe Eocene: Wilson, 4550 .

Fauna, Cambrian, Marble Mountains: Mason; 2597.

Cuyama, Tertiary : Wood, 4577.

Eocene Middle: Melriam, 2668.

Miocene, Coast Ranges: Woodring, 4604.

Floras, Tertiary, Trinity County : MacGinitie, 2531.

Foraminifera : Cushman, 942.

Eocene, Ventura County: Cushman, 946.

Tertiary, San Jose Hills: Ten Eyck, 4039.

Fossils from marine Pleistocene terraces, San Pedro Hills: Woodring, .4601 .

Geomyid rodents, Middle Tertiary : Wood, 4580.

Haliotis elsmerensis, Pliocene, Elsmere Canyon: Vokes, 4292.

Helicina vokesi, Eocene, Fresno County : Hanna, 1618.

Heteromyid rodents, Miocene and Pliocene: Wood, 4581.

Insectivora, Sespe Eocene: Stock, 3916.

Leptoreodon (Hesperomeryx) edwardsi, Sespe Eocene: Stock, 3928. 
California-Continued.

Paleontology-Continued.

McCloud limestone, fauna and stratigraphy: Wheeler, 4444.

Mammals, lower Oligocene, Death Valley: Stock, 3924.

Miocene marine, Bakersfleld region: Wilson, 4546.

Man, Pleistocene, near Los Angeles: Bowden, 384.

Merychippus zone fauna, Coalinga district, Tertiary : Bode, 355.

Mojave petrified forest: Stock, 3936 .

Mollusca, Eocene, Vallecitos and Coalinga areas: Vokes, 4294.

Fresh-water, Pliocene, K e t $\mathrm{t}$ l e m a n Hills : Pilsbry, 3086.

Moris reyana, Pleistocene, Playa del Rey: Howard, 1825.

Moris vagabundis, Miocene, Granite Creek: Compton, 828.

Mycteria wetmorei, Rancho La Brèa, Pleistocene : Howard, 1823.

operculum, Fliocene viviparoid calcareous, Kettleman Hills: Woodring, 4602 .

Ostrea idriaensis, Eocene: Vokes, 4290.

Palos Verdes Hills, Miocene: Woodring, 4603.

Parapavo californicus, Pleistocene, La Habra : Howard, 1826.

Peratherium .californicum, Sespe Eocene: Stock, 3926.

Perissodactyla, Sespe Eocene: Stock, 3929.

Peromyscus nesodytes, Pleistocene, Sinta Rosa Island: Wilson, 4555.

Pinto Basin site, Pleistocene: Campbell, 635 .

Protitanops curryi, Oligocene, Titus Canyon formation: Stock, 3934.

Protohippus tehoensis. Tertiary, San Joaquin Valley : Stock, 3919.

Rodents, Oligocene, Las Posas Hills: Wilson, 4548 .

Sespe faunas: Stock, 3913, 3915, 3917, $3918,3920$.

Vertebrate paleontology: Stock, 3913.

Teeth, protohippine horses, Miocene, Coalinga district: Bode, 354.

releodus californicus, Sespe Eocene: Stock, 3920

Titanotheres, Death Valley region: Stock, 3927.

Toxostoma redivivum, Pleistocene, Rancho La Brea: Engels, 1184.

Trilobites, Carboniferous, Shasta County: Wheeler, 4442.

Velates, Eocene: Vokes, 4291.

Venericardia planicosta, variations: Chavan, 740.

Verneuilinidae, Valvulinidae and Virgulinidae: Cushman, 945.

Vertebrates, Pleistocene, northern California: Vander Hoof, 4256.
California-Continued.

Paleontology-Continued.

Vertebrates from Sespe beds, north of Simi Valley: Stock, 3918.

Viverravus (Plesiomiacis) progressus, Sespe Eocene: Stock, 3915.

\section{Petrology.}

Alteration, lavas, around hot springs, Lassen Volcanic National Park: Anderson, 63.

Bonsal tonalite, origin of dark inclusions : Hurlbut, 1894.

Cherts, San Pedro Hills, origin: Smith, 3753.

Chromite, nodular, orbicular, and banded: Johnston, 1986.

Clear Lake area, volcanic history: Anderson, 64 .

Granltes, Inyo Range: Anderson, 67.

Heavy-mineral zones, Modelo formation, Santa Monica Mountains : Cogen, 798.

Iron sulphide, black, in crystalline, limestone: Laudermilk, 2348.

Mylonites from San Andreas fault zone, Crystal Springs Lakes: Wạters, 4357.

Orthoclase from pegmatites, San Diego County : Donnelly, 1065.

Paragenesis, Crestmore: Daly, 962.

Pegmatites, lithium, Pala: Donnelly, 1067.

Piedmontite, Los Angeles County: Simonson, 3712 .

Pyrophillite, San Diego County: Richard, 3274 .

Radium content, lavas from Lassen Vol. canic National Park: Evans, 1192.

Salton volcanic domes, Imperial County : Rogers, 3335.

Sierra Nevada pluton: Cloos, 784.

\section{Physical geology.}

Alteration, lavas, around hot springs, Lassen Volcanic National Park: Anderson, 63.

Asphalt deposit, McKittrick; seasonal bandings: Vander Hoof, 4255.

Clear Lake area, volcanic history: $\mathbf{A u}$ derson, 64.

Coast: Buwalda, 603.

Coast and Gecdetic Survey, selsmologic program : Ulrich, 4218.

Coast Ranges, Miocene orogenies: Reed, 3224.

Colorado Delta: Fox, 1321.

Cuyama fault: Gregersen, 1521.

Death Valley National Monument Anonymous, 4664.

Debris flow from canyons, Los Angeles County : Taylor, 4023.

Earthquake, April 15, 1928 : Dyk, 1103. Investigations, 1934-35: Heck, 1678.

Eureka, June 6, 1932 : Sparks, 3796.

Parkfleld, June 7, 1934: Wilson, 4542 . 
California-Continued:

Physical geology-Continued.

Earthquakes: Wood, 4584.

April 1, 1934-December 31, 1935 : Byerly, 615.

Registration : Byerly, 604, 607, 610, $612,613,614,616,617,618$; Wilson, 4540, 4541.

Folding, Mount Diablo and Coalinga areas, Coast Ranges: Clark, 756.

Gravel beach cusps, tide relations: Shepard, 3673.

Great Basin lake sediments: Shrock, 3700 .

Intra-septum intrusions, Sierra Nevada': Mayo, 2624.

Kern Canyon fault, southern Sierra Nevada: Webb, 4374.

Kettleman Hills faulting, origin : Hill, 1740.

Lassen Peak, eruptions: Holmes, 1783.

Long Beach eartbquake strong-motion records: Heck, 1664, 1665.

Los Angeles Basin, seismic reflection profile: Gutenberg, 1580.

Mojave mining district: Schroter, 3578 .

Mono Craters, southern extension: Mayo, 2626.

Moon, effect on earthquakes, southern California: Allen, 41.

Monterey Bay, interstitial sedimentation: Galliher, 1374.

Mount Diablo and Coalinga areas: Clark, 755.

Movements, reverse, along faults: Erwin. 1188.

Niles and Parkfield earthquakes, May 16, 1933, June 7, 1934 : Byerly, 608.

Orogeny : Stille, $3900,3904$.

Panamint Mountains, valleys: Davis, 985.

Peninsular Range, southern: Miller, 2728.

Perris block, Elsinore quadrangle : Dudley, 1086.

Pinnacles National Monument: Andrews, 74.

River action, San Gabriel Mountains: Louderback, 2463.

Salton volcanic domes, Salton Sea : Kelley, 2051.

San Andreas fault, magnetometer survey : Soske, $\mathbf{3 7 9 0}$.

Northward extension: Shepard, 3679.

Sedimentation and faulting: Ashauer, 98.

Seismological program : Ulrich, 4220.

Seismological research, southern Callfornia: Wood, 4583.

Sierra Nevada pluton: Cloos, 784 ; Mayo, 2625.

Strong earthquake motions : Heck, 1675.

Structure, southern California: Reed, 3231.

Subsidence, recent, San Jose area: Rappleye, 3182 .
California-Continued.

Physical geology-Continued.

Tick and Red Rock Canyons: Luce, - 2476.

Unconformity, Santa Ana Mountain foothills: Moody, 2775.

Velocities, $P$ and $S$ waves, Long Beach earthquake: Dahm, 951.

Physiographic geology.

Alluvial-fan flooding, Montrose: Chawner, 742 .

Barrancos and arroyos: Grant, 1496.

Beaches, erosion : O'Brien, 2932.

Coast: Buwalda, 603.

Coastal basin, south: Eckis, 1131.

Colorado Delta : Fox, 1321.

Death Valley National Monument: Anonymous, 4664.

Erosion channels, unsymmetrical, San Francisco: Rode, 3330.

Fanglomerates, porosity and sorting: Gross, 1552.

Ice caves, northern California: Swartzlow, 3993.

Inyo Range, northern: Anderson, 66.

Lakes, Pleistocene, Afton Basin: Blackwelder, 337.

Lake Tecopa, Pleistocene: Blackwelder, 332.

Mono Craters, southern extension : Mayo, 2626.

Mounds, soil, origin: Melton, 2654.

Peninsula Range, geomorphology : Miller, 2730.

Perris block, Elsinore quadrangle : Dudley, 1086.

Pinnacles National Monument: Andrews, 74.

Pleistocene, marine terraces, San Pedro Hills: Woodring, 4601.

Rhomboid ripple mark, Laguna Beach : Woodford, 4596.

Salton region, pumice deposits and rhyolitic hills: Soske, 3791.

San Nicolas Island: Kemnitzer, 2070.

Submarine canyons: Shepard, 3671, $3678,3681,3682$.

Subsidence, recent, San Jose area: Rappleye, 3182.

Unilerground water.

Coastal basin, south : Eckis, 1131.

Elsinore region, ground and thermal waters: Engel, 1180.

Mojave River investigation: Conkling, 839.

Ventura County : Conkling, 837, 838.

Water-table fuctuations, southern California : Ebert. 1119.

Cambrian. See also Paleontology, Cambrian. Appalachian Mountains : Resser, 3251.

Appalachians and Scotland, correlations : Stose, 3916.

Antillean-Caribbean region: Schuchert, 3579. 
Cambrian-Continued.

Arizona, Grand Canyon, Tonto group: Wheeler, 4446.

Paleozoic formations: Stoyanow, 3959.

California, Providence and Marble Mountains : Hazzard, $1660,1662$.

Canada, western : Goodman, 1473.

Chaleur Bay region, Quebec and New Brunswick : Alcock, 12.

Clays, fire, distribution, in U. S. : Chellkowsky, 743 .

Colorado, Mosquito Range Paleozolc limestones: Johnson, 1970; Singewald, 3730 .

Rocky Mountain National Park: Effinger, 1143.

San Juan region: Cross, 925.

Yule Creek formations: Vanderwilt. 4261.

Correlations, Texas and Missouri: Bridge, 456.

Gaspe, southeastern: Kindle, 2193.

Greenland: Koch, 2244, 2245.

Northeast: Teichert, 4037.

Idaho, Edwardsburg and Thunder Mountain area: Shenon, 3665.

Illinois, inlier, Oregon: Bevan, 307.

Illinois Basin: Weller, 4386.

Iowa : Keyeŝ, 2155.

Jordan sandstone, upper Mississippi Valley : Trowbridge, 4169.

Kansas, northeastern: Ockerman, 2933.

Keweenawan, age by helium method: Lane, 2323.

Maine, Appalachian Trail: Philbrick, 3071.

Maryland, Frederick Valley limestones: Jonas, 1993.

Piedmont intrusives: Cloos, 783.

Massachusetts, Taconic limonites: Newland, 2867.

Mazomanie and Franconia formations, relations: Ulich, 4213.

Mexico: Santillán, 3500, 3501.

Michigan, natural-gas fields: Newcombe, 2853.

Minnesota, Minneapolis-St. Paul metropolitan area: Schwartz, 3597.

Minnesota River Valley: Couser, 885.

St. Croix River, Paleozolc: Clement, 774.

Southeastern : Powell, 3114.

Stillwater deep-well records : Stauffer 3839.

Upper Mississippl Valley: Atwater, 114.

Mississippi Valley, cross sections : Workman, 4618.

Upper: Atwater, 114; Kans. Geol. Soc., 2020 ; Raach, 3161.

Missouri, cross section, Forest City to Du Bois, Neb.: Condra, 833.

Insoluble residues, correlation: McQueen, 2561.
Cambrian-Continued.

Montana, Big Horn County and Crow Indian Reservation: Thom. 4074.

Idaho batholith, northeastern part: Langton, 2337.

Revision type formations: Deiss, 1012.

Western, unconformity: Deiss, 1009. Nebraska, cross section, DuBois to Forest City, Mo.: Condra, 833.

Water-bearing formations: Condra, 835.

Nevada, Chief district, Lincoln County : Callaghan, 629.

Newfoundland, gold deposits: Snelgrove, 3779 .

New Mexico, Bayard area: Lasky, 2344.

Organ Mountains and Doña., Ana County : Dunham, 1094.

Santa Rita mining area: 'Spencer, 3803.

New York, Dutchess County: Balk, 162.

Hammond, Antwerp, and. Lowville quadrangles: Buddington, 543.

Natural-gas flelds: Torrey, 4146.

Potsdam quadrangle, St. Lawrence County : Reed, 3217.

Russell quadrangle: Dale, 958.

Taconic limonites: Newland, 2867.

Oklahoma, Cambrian-Ordovician boundary, Arbuckle limestone, Murray County: Bridge, 457.

Correlation by insoluble residues : Ireland, 1907.

Pennsylvania, Bellefonte quadrangle: Butts, 598.

Chester Valley: Mackin, 2544, Miller, 2718.

Eastern region: Miller, 2717.

Lehigh Valley Cambro-Ordovician limestones: Hills, 1742.

Pegmatites, Morgan Hill: Fraser, 1329.

Philadelphia area: Watson, 4359.

Southeastern, Appalachian structure: Jonas, 1991.

Post-Keweenawan, age by helium method: Urry, 4246.

Prairie du Chien beds, Upper Mississippi Valley: Powers, 3117.

Pre-Devonian structural zones, Scotland and eastern North America: Jonas, 1990.

Quebec, southern : Clark, 768.

Redefinition : Keyes, 2159.

St. Pierre and Miquelon: Aubert de la Rue, 121.

Scotland and Appalachians, correlatlons: Stose, 3196.

South Dakota, Black Hills: Wright, .4629.

West central : Rothrock, 3384.

Southwestern U. S. : Effinger, 1144. 
Cambrian-Continued.

Tennessee, Blount and Sevier Counties: Wilson; 4529.

Nashville dome: Wilson, 4531.

Zinc deposits, southern Appalachians : Currier, 937.

Texas, trans-Pecos, unconformities: Arick, 84.

Thickness in U. S. : Ver Wiebe. 4288.

Unconformity, Cambrian-Algonkian, western North America: Hinds, 1750.

Upper Mississippi Valley: Atwater, 112

Utah, Gold Hill mining district: Nolan, 2905.

Vermont, Taconic limonites: Newland, 2867.

Virginia, Austinville mine, Wythe County, zoning of ores: Brown, 498.

Eagle Rock, Pulaski overthrust: Woodward, 4611.

James River iron and marble belt: Furcron, 1362.

Lava flow: Furcron, 1363.

Southwestern, zinc and lead region: Currier, 936.

Zinc deposits, southern Appalachians : Currier, 937.

West Virginia, eastern : Reeves, 3233.

Wisconsin: Twenhofel, 4196.

Baraboo area: Raasch, 3162 Thwaites; 4123.

Upper Mississippi Valley: Atwater, 114.

Wyoming, Black Hills: Wright, 4629.

Northwestern : Miller, 2714.

Yellowstone National Park, revision type formations: Deiss, 1012.

Canada: Baulig, 239. Sawa, 3518.

Aerial surveying: Peters, 3062.

Department of Mines Report, 1935 : Camsell, 640 .

1936 : Camsell, 641.

Geological Survey report, 1935: Collins, 810 .

Lime-secreting algae: Kindle, 2198.

Economic geology.

Analyses, crude oils, naphthas, shale oil, bitumen : Rosewarne, 3361.

Canadian shield gold fields, pre-Cambrian: Dougherty, 1074.

Coal, Cordilleran region : Mackay, 2536.

Copper: Alcock, 11.

Gold: Danloux-Dumesnil, 974; Robinson, 3323 .

Canadian Shield: Bruce, 503; Bruet, 510.

Lake-bottom manganiferous deposits : Kindle, 2204.

I ead and zinc, Cordilleran region : $\mathrm{Al}$ cock, 10.

Mineral industry, 1935: McLeish, 2557. 1934 : McLeish, 2556.
Canada-Continued.

Economio geology-Continued.

Mineral resources, 1933: Robinson, 3322.

Mining industry, history: Allan, 30.

Natural bonded molding sands: Freeman, 1337.

Ore deposits, eastern Canada: Wright, 4628.

Synclines : Bichan, 314.

Petroleum geology, western Canada: Goodman, 1473

Sydney coal fleld: Gray, 1510.

Historical geology.

Canadian Shield, pre-Cambrian: Brock, 461.

Copper : Alcock, 11.

General: Baulig, 239.

Gold deposits, Canadian Shield : Bruce, 503.

Gold-producing areas: Danloux-Dumesnil, 974.

Killarney and Algoman granites, age differences: Chamberlin, 720 ; Lane. 2322 ; Lawson, 2355.

Mingan Islands: Twenhofel, 4194.

Ore deposits, eastern Canada: Wright, 4628.

Petroleum geology, western Canada:: Goodman, 1473.

Sudbury series, pre-Cambrian, Canadian Shield : Collins, 816.

\section{Mineralogy.}

Semipreclous and ornamental stones: Parsons, 3019 .

\section{Paleontology.}

Manmals, Cretaceous and Miocene, western Canada: Russell, 3434.

Marine shells, Recent and Pleistocene, James Bay : Richards, 3281.

Mingan Islands: Twenhofel, 4194.

Post-Pleistocene fossils, eastern Arctic regions: Nichols, 2871.

Trilobites, Cambrian and Ordovician : Kobayashi, 2242.

\section{Physical geology.}

Timiskaming earthquake, November 1 , 1935 : Hodgson, 1771

Volcanoes, recent: Hanson, 1625.

Physiographic geology.

Athabasca-Great Slave Lakes region : Harper, 1636.

General : Baulig, 239 ; Sawa, 3518.

Patrician glaciation, western extension: Johnston, 1983.

Yukon Territory, photographic mapping: Wood, 4594.

Canal Zone. See Panama.

Carbonates in veins, nature and occurrence: Charlewood, 739.

Carbon ratios, Arkansas-Oklahoma coal fleld : Hendricks, 1708.

North of the Ouachitas: Fisher, 1270. 
Carbonlferous. See also Paleontology, Carboniferous.

Alabama Erin shale, structure: Park, 3008.

Alaska, interior, : volcanism" Mertie, 2680.

Ruby-Kuskokwim regi on: Mertie, 2681.

'Tonsina district: Moffit, 2762.

Upper Copper and Tanana Rivers area : Moffit, 2763.

Alberta : Calder, 625.

Foremost-Skiff area: Howells, 1867.

Milk River area: Russell, 3433.

Antillean-Caribbean region: Schuchert, 3579.

Appalachian province and Europe, correlatlons: Darrah, 977.

Arizona, Grand Canyon rim rocks : Keyes, 2176.

Northern, middle Permian formatlons: McKee, 2538.

Oshawanan : Keyes, 2104.

Paleozoic formations: $\mathrm{S}$ t o y a n o w, 3959.

Paradise formation: Hernon, 1714.

Silver King area, Superior: Galbraith, 1373.

Arizona and Nevada, Boulder Reservoir floor: Longwell, 2445.

Arkansas, northern: McKnight, 2552.

Snow Hill Permian field: Easton, 1114.

Southwestern, Little Missouri River: Hansell, 1622.

Arkansas and Oklahoma fields, Pennsylvanian : Hendricks, 1709.

Big Blue sediments, depth, Midcontinent: Elias, 1159.

British Columbia, Cache Creek Permian series: Crockford, 916.

Keithley Creek area, Cariboo district: Lang, 2333.

California, Death Valley National Monument: Anonymous, 4664.

Mother Lode and Sierra Nevada batholiths: Cloos, 781.

South coastal basin : Eckis, 1131.

Canada, western: Goodman, 1473.

Chaleur Bay region, Quebec and New Brunswick: Alcock, 12.

Classifications and correlations: Chamberlin, 718.

Coal flora: Bertrand, 305.

Coal, Pennsylvanian, Western Interior province: Young, 4639.

Permo-carboniferous, re la t ed to southern hemisphere glaciation: Shepard, 3669.

Colorado, Golden area: Johnson, 1971.

Hermosa formation, Pennsylvanian : Vanderwilt, 4263.

La Plata mining district: Eckel, 1126.

Montezuma quadrangle: Lovering, 2466 .
Carboniferous-Continued.

Colorado-Continued.

Mosquito Kange, Paleozolc formations: Johnson, 1970.

Mosquito Range Paleozolc limestones: Singewald, 3730.

Salt Creek area, Mosquito Range: Gould, 1487.

San Juan region: Cross, 925.

South Park: Johnson, 1974.

Yule. Creek formations: Vanderwilt, 4261.

Correlations and provinces, floral: Jongmans, 2012.

Deformation of earth's crust, Paleozolc: Moore, 2787.

Diastrophism, mid-continent: Keyes, 2181.

Faunal stratigraphy and goniatite phylogeny : Bisat, 326.

Floras, eastern U. S. and western Europe: Jongmans, 2011.

Fusulinidae in Permian and Pennsyl-

vanian correlations: Dunbar, 1090.

Gaspe, southeastern : Kindle, 2193.

Greenland: Koch, 2244, 2245.

East, Posidonomya slate, age : Aldinger, 17.

Northeast: Teichert, 4037.

Ymer Island: Cleaves, 772.

Guadalupe Mountains, Permian, west Texas: King, 2215.

Idabo, Blue Springs Hills: Williams, 4513.

Casto quadrangle: Ross, 3369.

Illinois, Marion and Clay Counties: Weller, 4385.

Mississippian system : Moore, 2784.

Illinois Basin: Howard, 1831, Weller, 4386.

Iowa, Chouteau limestone: Keyes, 2122.

Mississippian system : Laudon, 2349 ; Moore, 2784.

Osage area, Henry County: Wood, 4592.

Southern: Wood, 4591.

Kansas, Central uplift: Koester, 2246.

Johnson and Miami Counties: Newell, 2855.

Northeastern : Ockerman, 2933.

Pennsylvanian, classification: Moore, 2791.

Regional investigations in oil fields: Hiestand, 1737.

Southeastern, Englevale channel. sandstone, Pennsylvanian: Pierce, 3081.

Wyandotte County : Jewett, 1950.

Kansas-Missouri region, Pennsylvanian and lower Permian: Kansas Geol. Soc., 2024 ; Moore, 2788.

Kentucky, Fordsville and Cannelton. quadrangles: Mayfield, 2622.

Kinderhook group isopach map, upper Mississippi Valley: Tester, 4045.

Maine, geologic mup: Keith, 2040. 
Carboniferous-Continued.

Metamorphism, organic sediments and derived oils: White, 4453.

Mexico: Santillán, 3500, 3501.

Coahuila Peninsula: Kellum; 2057 ; Kelly, 2068.

State of Chiapas, pre-Tertiary : Müllerried, 2815.

Tampico region : Muir, 2821.

Michigan, central : Rawlins, 3187.

Central oil flelds: Zavoica, 4644.

Crystal oil field: Eddy, 1133.

Grand, Rapids, g y p s u m deposits : Mathews, 2606.

Mississippi : Morse, 2805.

Mississippi Valley cross sections : Workman, 4618.

Mississippi Valley, upper : Kans. Geol. Soc., 2020.

Mississippian-Pennsylvanian contact, Tri-State district: Pierce, 3083.

Missouri, asphalt-bearing sandstones, Vernon County: Crabtree, 887.

Central, lower Peunsylvania: Bailey, 133.

Cross section, Forest City, Mo., to Du Bois, Neb.: Condra, 833.

Mississippian system : Moore, 2784.

St. Louis County and City of $\mathbf{S t}$. Louis: Gleason, 1443.

Savannah area: Greene, 1512.

Montana: Scott, 3605 .

Big Horn Basin gas fields: Emery, 1174.

Big Horn County and Crow Indian Reservation: Thom, 4074.

Nye-Bowler lineament, Stillwater and Carbon Counties: Wilson, 4535.

Western, phosphate rocks: Pardee, 3005.

Nebraska, cross-section, Du Bois, Nebr., to Forest City, Mo.: Condra, 833 .

Water-bearing formations: Condra, 835.

Nevada, southern, Pennsylvanian-Permian boundary: Longwell, 2444.

Tuscarora mining district, Elko County : Nolan, 2908.

New. Brunswick, Grand Lake coalfield: Wright, 4630.

New Mexico, Bayard area : Lasky, 2344. Delaware basin, Permian : Lang, 2334.

Hobbs field: Zavoica, 4645.

Organ Mountains and Doña Ana County: Dunham, 1094.

Santa Rita mining area: Spencer, 3803.

New York, Allegany State Park: Thwaites, 4125.

Natural-gas fields: Torrey, 4146.

North America: Moore, 2789.

Nova Scotia, Lake Ainslie area: Norman, 2911.

Malagash salt deposit: Miller, 2698.
Carboniferous-Continued.

Ohio, Hocking County State parks: Ver Steeg, 4278.

Insoluble residues, correlations: Mitchell, 2754.

Oklahoma, Arbuckle Mountains, Pennsylvanian: Dott, 1072.

Ardmore area : Floyd, 1293

Boone chert : Giles, 1422.

Central and west-central : Green, 1511.

Cromwell oil ffeld: Rison, 3307 .

Fitts pool, Pontotoc County : Hyatt, 1901.

Lucien field : Zavoico, 4642.

Naval Reserve field, Osage: County: Vanderpool, 4260.

Osage County: Bass, 220.

Ouachitas, Bendian: Harlton, 1634.

Pennsylvanian sandstones, Ardmore Basin : Lucas, 2475.

Regional investigations in oil fields: Hiestand, 1737.

Ripple marks, Ardmore: De Béthune, 994.

Seminole pool, Seminole County: Swarts, 3987.

Tatums pool, Carter County : Grimes, 1551.

Ozarks, Pennsylvanian transgression: Dake, 952.

Pennsylvania, Bellefonte quadrangle: Butts, 598.

Bradfordian series discontinued : Caster, 702.

Butler and Zelienople quadrangles: Richardson, 3286.

Eastern region: Miller, 2717.

Natural-gas fields : Torrey, 4146.

Pittsburgh region: Linton, 2424.

Pocono formation: Ashley, 106; Chadwick, 708 .

Shales and under clays associated with Illinois coals: Grim, 1546.

Pennsylvanian-Permian b o u nd a r $\mathbf{y}$ : Romer, 3347.

Permian, general: Keyes, 2132.

Sequences, . correlation: Schuchert, 3580.

Petroleum, New Mexico and west Texas: Bentz, 282.

Post-Keweenawan, age by helium method: Urry, 4246.

Restorations; geologic landscapes: Reid, 3236.

Saskatchewan, southern, Regina area: Fraser, 1330.

South. Dakota, west-central : Rothrock, 3384.

Southwestern U. S. : Effinger, :1144.

Tennessee, Flynn Creek disturbance, Jackson County: Wilson, 4536.

Nashville dome, Upper Paleozoic development: Wilson, .4534, . 
Carboniferous-Continued.

Tennessee-Continued.

Ridgetop shale, Mississippian: Wilson; 4533.

South-central : Theis, 4063.

Texas, Bend arch district natural-gas fields: Kendrick, 2071.

Colorado River Valley, upper Pennsylvanian and lower Permian: Bullard, 566.

Delaware Basin, Permian: Lang, 2334.

North-central, late Paleozolc unconformities: Cheney, 748.

Palo Pinto County : Plummer, 3098.

Panhandle oil and gas field: Rogatz, 3332.

Shafter mining district: Ross, $\mathbf{3 3 7 5}$.

Southern Permian basin: Kinkel, 2217.

Trans-Pecos, structural features : King, 2211.

Trans-Pecos unconformities : King, 2213.

West, dolomite in Permian limestones: Cunningham, 933.

West, Permian basin : Adams, 3.

Texas, Wheat oil pool: Adams, 4.

Type sections and faunules, western formations: Williams, 4511.

Utah, Gold Hill mining district: Nolan, 2905.

Mississippian-Pennsylvanian contact, Wasatch Mountains: Bissell, 327.

Monument Valley-Navajo Mountain region: Baker, 144.

Salt Valley anticline area : Dane, 970.

Virginia, Shenandoah Valley: Cady, 621.

West Virginia, eastern : Reeves, 3233.

Wyoming: Branson, 440.

Alcova Dam and reservoir sites, North Platte River, Natrona County: Bradley, 423.

Big. Horn Basin gas flelds: Emery, 1174.

Casper formation, Cephalopoda: Miller, 2712

Quadrant formation, Pennsylvanian : Scott, 3608 .

Pelmo-Pennsylvanian section, Hart. ville area : Condra, 834 .

Tensleep formation: Branson, 437.

Carboniferous rocks of North America: Moore, 2789 .

Cártography.

Aerial maps: Atkinson, 111; Rice, 3260-A.

Aerial photographs used for topographic mapping: Banks, 175.

Aerial photography: Sneigr, 3777.

Aerial reconnaissance and contour mapping: Eliel, 1160.

Aerial surveys: King, 2210.

Camerón and Vermillion Parishes, La.: McGuirt, 2535.
Cartography-Cuntiused.

Canada, aerial surveying: Peters, 3062.

Desert, Great American: Smitb, 3752.

Errors, compiling maps from air photographs: Jones, 1998.

Fault-block structures, Kansas: Rich, 3270.

Geodetic operations, U. S., 1933-35 : Bowie, 401 .

Geodetic surveys: Bowie, 394, 403.

Mapping by use of aerial photographs : Talley, 4010.

From the air: Steinberg, 3864.

Mapping Plan, national: Bowie, 402.

Mapping the country: Bowie, 396.

Method, graphic, to eliminate regional dip: Rich, 3269.

Mississippi River, alluvial valley, topographic mapping: Schweizer, 3601.

National mapping plan : Bowie, 398.

Patrician ice sheet on glacial maps: Martin, 2586.

Photo-mosaic map, Barbers Hill area, Texas: Barton, 210.

Plotting maps from aerial photographs : Birdseye, 325.

Rosiwal petrographic analysis and geographic mapping: Trefethen, 4165.

Tennessee River Basin, mapping: Pendleton, 3048 .

Tennessee Valley, planimetric maps: Pendleton, 3049.

Topographic mapping, U. S.: Sears, 3622 .

Triangulation of North American continent: Bowie, 391 .

Washington, status of topographic mapping: Glover, 1451.

Caves.

Arizona, Roaring Springs cave: Seagle, 3615.

California, northern, ice caves: Swartzlow, 3993.

Pinnacles National Monument: An-drews. 741.

Georgia : Crickmay, 911.

Gyjpsum, development in : Pohl, 3103.

Indiana, Crawford County : Fidlar, 1245.

Kentucky, cathedral domes, Mammoth. Cave: Swinnerton, 3997.

Limestone, classification: Swinnerton, 3996.

Limestone caverns, origin and development: Gardner, 1379.

Mexico, karst topography and lava. caves: Wittich, 4569.

Oregon, Malheur Cave, ice stalagmites: Dake, 957.

Pennsylvania, Allentown : Frux, 1217.

Shafts, vertical, development in: $\mathrm{Pohl}_{r}$ 3102.

Underground - water report, 1935-36 : Thompson, 4093

Virginia, Grèt Valley: McGill, 2527.

Worlds underground: MacNeil, 2558. 
Celestite, Chittenango Falls, N. X.: Thibault, 4066:

Central America: Sorre, 3789. See also Costa Rica, Guatemala, ete

Economic geology.

Copper: Ross, 3371:

..Historical geology.

General : Sorre, 3789.

Land and sea connections with West Indies: Rutten, 3460 .

Physical geology.

General : Sorre, 3789.

Physiographic geology.

General: Sorre, 3789.

Cephalopoda. See also Mollusca.

Akpatok Island, Quebec, Ordovician : Foerste, 1301.

Ammonoidea Devonian : Miller, 2704. Iowa, Devonian: Miller, 2701.

Aptychus species, Cuba: Trauth, 4158.

Artinskia whortani, Permian, Kansas : Miller, 2710.

Astineroids, structure and phylogeny: Teichert, 4036.

Aturia, Eocene, Texas and North Carolina : Stenzel, 3867.

Aturoidea, Eocene, New Jersey and California: Miller, 2702.

Big Horn, Wyoming, O r dovician : Foerste, 1295.

British Columbia, Permian : Miller, 2706, $2 \pi 08$.

Cherry Valley, Devonian, New York: Flower, 1292.

Cretaceous, Rio Grande, Mexico and Texas: Renz, 3249.

Devonian ammonoids of America : Miller, 2700.

Devonian, Upper, New York and Pennsylvania: Flower, 1291.

Goniatite phylogeny: Bisat, 326.

Greenland, east, Cretaceous : Bøgvad; 361.

Iowa, Maquoketa shale: Foerste, 1299.

Kansas, Upper Cretaceous: Morrow, 2803.

Lea Park shale fauna, Alberta : Warren, 4348.

Saskatchewan: Warren, 4348.

Mexico, Lower California, Cretaceous : Anderson, 65.

Münsteroceras mitchelli, Carboniferous, Missouri : Miller, 2703.

Ordovician, Labrador: Little, 2426.

Ozarkian and Canadian: Ulrich, 4210.

Parendoceras for Saffordoceras Ulrich and Foerste : Ulrich, 4215.

Pennsylvania fauna, Nowata shale, Oklahoma : Miller, 2707.

Kansas and Oklahoma : Newell, 2859.

Phosphoria formation. Permian, Wyoming: Miller, 2699.

Primitive forms : Foerste, 1297.
Cephalopoda-Continued.

Quebec, Black River group: Okulitch, 2946.

Percé. Upper Ordovician: Foerste, 1302.

Silurian, Gaspe Peninsula, Quebec: Foerste, 1300.

Ontario: Foerste, 1303.

Sporadoceras milleri, Devonian, Pennsylvania: Miller, 2709.

Structure, earliest forms : Foerste, 1290.

Texas, Pennsylvanian: Williams. 4512.

Timnnites occidentals; Devonian, Alberta : Miller, 2711.

Tritropidoceras packardi, Triassic, Oregon: Schenk, $\mathbf{3 5 5 5}$.

Washington Land, north Greenland, Ordovician : Teichert, 4035.

Wyoming, Casper formation, Pennsylvanian: Miller, 2712.

Jurassic: Crickmay, 901.

Cetacea. See Mammalia.

Changes of level. See also Beaches; Shore lines; Terraces.

British Columbia, fiord-land: Peacock, 3035.

Changing sea level : Johnson, 1960.

Knickpoints and valley-in-valley forms : Johnson, 1962.

Louisiana, cheniers : Russell, 3442.

New Jersey, tidal lagoon, bottom conditions, Barnegat Bay: Lucke, 2477.

Submarine canyons, origin: Shepard, 3677.

Chattanooga shale, Osage County, Okla.: Leatherock, 2363.

Cheek teeth of rodents, cusps nomenclature : Wood, 4568.

Chelonia. See Reptilia.

Chert.

Arkansas, Boone chert: Giles, 1422.

Chertiflcation, Tri-State district: Fowler, 1319.

Depositional environment, chert and flint : Gunnell, 1572.

Michigan, Bayport chert: Dustin, 1098.

Nature and origin, Ontario : Laird, 2290.

Oklahoma, Boone chert: Giles, 1422.

Talihina chert, Atoka : Gardner, 1380.

Ontario, Lockport and Onondago formations : Laird, 2290.

Tri-State mining district, chertification : Fowler, 1317, 1319.

Chromite.

Montana, Hell Roaring Creek; Salo, 3478 :

Newfoundland, Bay of Islands igneous complex : Cooper, 869.

Cirripedia. See also Crustacea.

Zeugmatolepas americana, Eocene, Alabama: Withers, 4568. 
Classification.

Arcidae, pelecypods : Reinhart, 3243.

Geologic classifications and correlations : Chamberlin, 718.

Limestone caverns: Swinnerton, 3996.

Mineral associations, high-temperature, shallow : Butler, 591.

Minerals, by cleavage and crystal habit: Staples, 3826.

Oceans and seas: Giles, 1423.

Opossums, recent and fossil: Simpson, 3717.

Pennsylvanian, Kansas: Moore, 2791.

Silicates: Berman, 293.

Streams, flood-plain: Melton, 2660.

Clastic sediments, porosity and permeability : Fraser, 1331; Muskat, 2838.

Clay : Parmelee, 3017 ; Ries, 3299.

Alabama, ceramic: Mansfield, 2568.

Bentonite deposits: Maynard, 2623; Silica Products Co., 3710.

Ordovician, correlation, eastern North America : Rosenkrans, 3358.

Bleaching: Nutting, 2926.

Bleaching and ceramic, Kentucky : Mansfield, 2570.

Western Tennessee: Mansfield, 2570.

British Columbia, industrial and nonmetallic minerals: Richmond, 3287.

California, Mojave Desert, bentonitic magnesian : Foshag, 1313.

Nonmetallic minerals: Bradley, 421.

Perris block : Dudley, 1085 ; Sampson, 3479.

Riverside and Orange Counties: Sutherland, 3981 .

Ceramic, mineral constitution: Grim, 1550.

Compaction, gravitational: Hedberg, 1682.

Fire, geologic distribution in U. S. : Chelikowsky, 743.

Geologic distribution in U. S.: Chelfkowsky, 743.

Georgia : Bay, 241.

Illinois, investigations of argillaceous sediments : Bray, 451.

Pennsylvanian, under clays: Grim, 1549.

Soil materials, constitution : Ekblaw, 1154.

Kentucky, Fordsville and Cannelton quadrangles: Mayfleld, 2622.

Manitoba: Futt, 1900.

Mississippi, bleaching: Bay, 242.

Missouri, Cheltenham fireclay with spherulitic limestone: Allen, 45.

Flint and diaspore clays: Allen, 42, 44.

Lawrence County, halloysite: Smith, 3745.

Southeast: Farrar, 1215.

Montana: Warde, 4337.
Clay-Continued.

New Jersey, Middlesex County, heavy minerals in Cretaceous clays: Hawkins, 1652.

Upper Cretaceous bentonite: Stephenson, 3880.

New Mexico, kaolin, Doña Ana County : Richard, 3273.

North Carolina, for bleaching oils : Grove, 1559.

Spruce Pine and Linville Falls quadrangles: Hunter, 1890.

North Dakota; bentonite: Anonymous, 4673.

Ontario, Mattagami River area, refractory : Hilder, 1739.

Pennsylvania, Bellefonte quadrangle: Butts, 598.

Shales and under clays associated with Illinois coals: Grim, 1546.

South Carolina, Coastal Plain: Cooke, 847.

Tennessee: Whitlatch, 4464.

Origin and distribution: Eckel, 1130.

Under clays of commercial coals : Whitlatch, 4462.

Tennessee Valley, western: Spain, 3794.

Texas, bleaching clays: Phillips, 3075.

Palo Finto County: Plummer, 3098.

Washington and Idaho, sands, quart\%, washed from kaolins: Wilson, 4538.

Weathering condtions: Hind, 1744.

West Virginia, upper Monongahela Valley: U. S. Com., 4224.

Cleavage.

Granites : Bell, 266, Osborne, 2968.

Ionic minerals: Shappell, 3646.

Climate, geologic. See Paleoclimatology.

Climates of the Pleistocene: Flint, 1285.

Coal. See also Lignite.

Alberta, microscopic features: Jones, 2005.

Anthracite, prospecting by earth-resistivity method: Ewing, 1197.

Arkansas and Oklahoma flelds, Pennsylvanian: Hendricks, 1709.

Arkansas-Oklahoma coal fleld, carbon ratios: Fisher, : 1270; Hendricks, 1708.

British Columbia, submarine mine, Nanaino, Vancouver Island: Dickson, 1045.

Canada, Cordilleran region: MacKay, 2536.

Sydney coal field: Gray, 1510.

Carbon-ratio theory, status in Illinots: Bell, 264.

Coalification, geologic dating of: Fisber, 1268.

Colorado: Orr, 2957.

Book Cliffs coal fleld: Erdmann, 1185.

Correlations by cyclothems: Young, 4639 . 
Coal-Continued.

Effects of geophysical factors on coal and oil: 'White, 4451.

Evolution of, and geophysical factors : White, 4451.

Fuels, mineral, reserves, U. S.: Garfias, 1384

Fusain, nature and origin: Crickmay, 899.

Greenland, Cretaceous: Miner, 2745.

Illinois; ash correction formulas by petrographic analysis: Ball, 164.

No. 6: McCabe, 2492.

Caloriflc variations : Benson, 280.

Kentucky, Fordsville and Cannelton quadrangles: Mayfield, 2622.

Harlan County coal fields: Jones, 2000.

Manitoba: Hutt, 1900.

Metamorphism, organic sediments and : derived olls: White, 4453.

Mineral matter, relation to coalification: Ball, 165

Montana, Big Horn County and Crow Indian Reservation: Thom, 4074.

Cretaceous and Tertiary : Miner, 2745.

Richey-Lambert coal fleld: Parker, 3012.

Rosebud coal field: Pierce, 3084 .

Southeastern: Perry, 3059.

New Brunswick, Grand Lake coal fteld: Wright, 4630.

New Mexico, Mount Taylor field: Hunt, 1888.

San Juan Basin: Sears, 3621.

North. Dakota, Minot area: Andrews, 70.

Nova Scotia, Lake Ainslie area: Norman, 2911.

Oklahoma, coal map, Howe district: U. S. G. S., 4230.

Lehigh district: U. S. G. S., 4231.

McAlester district: U. S. G. S. 4232.

Stigler-Poteau district: U. S. G. S. 4233.

Wilburton district: U. S. G. S., 4234.

Pacific coast: Hodge, 1761.

Pennsylvania, Butler and Zelienople quadrangles: Richardson, 3286.

Pittsburgh region: Linton, 2424; Rama Rao, 3167.

Permo-Carboniferous coal related to Southern Hemisphere glaciation Shepard, 3669.

Petrography: Stadnichenko, 3813.

Petrography and microstructure: Stadnichenko, 3814 .

Saskatchewan, southern, Regina area: Irraser, 1330.

Studies, microscopic and petrographic: Thiessen, 4072

Temperature during formation: Thiessen, 4071.

Texas, Palo Pinto County: Plummer, 3098.
Coal-Continued.

Utah, Book Cliffs coal fleld: Fisher, 1269.

Washington: Daniels, 973.

West Virginia, Alma bed coal, Spruce River no. 4 mine: Fieldner, 1255.

Upper .Monongahela Valley : U. S. Com., 4224.

Western Interior province; Pennsylvánian: Young, 4639.

Yukon, Carmacks district: Bostock, 379.

Coal Measures. See Carboniferous.

Cobalt.

Colorado, stainlerite, Swansea mine, Goodsprings: Cooke, 853.

Ontario, aplites with cobalt-silver ores: Bastin, . 234.

Coelenterata. See Anthozoa; Hydrozoa; Invertebrates (general).

Nova Scotia, Banquereau, Cretaceous : Stephenson, 3878 .

Collections.

District of Columbia and vicinity, minerals : Ulke, 4206.

Georgia geological museums: Mitchell, 2752 .

Georgia State Museum: Crickmay, 908.

Meteorites: Nininger, 2898.

Philadelphia: Hamilton, 1613.

Report on fossil echinoderms : Jackson, 1923.

Invertebrate paleontology: Raymond, 3194.

Vertebrate paleontology: Romer. 3345 .

U. S. National Museum report 1934: Bassler, 225.

1935 : Bassler, 229.

Colorado.

Areas described.

Book Cliffs coal field, Garfield and Mesa Counties: Erdmann, 1185.

San Juan region, southwestern Colorado: Cross, 925.

Economic geology.

Anticlines between Hiawatha gas field, Colo., and Baggs, Wyo.: Bradles, 424.

Batholith, Twin Lakes and Clear Creek districts: Chapman, 732.

Book Cliffs coal field, Garfield and Mesa Counties: Erdmann, 1185.

Breckenridge mining district: Behre, 259.

Building stones: Balcom, 158.

Calumet iron mine, contact ore deposition: Behre, 262.

Coal : Orr, 2957.

Continental Divide region: Behre, 257.

Copper, northeast half mineral belt: Lovering, 2465.

San Juan Mountains: Burbank, 570 . 
Colorado-Continued.

Economic geology-Continued.

Copper-silver . veins, hydrothermal, northeastern plateau: Fischer, 1265.

Cripple Creek district: Behre, 260; Kohanowski, 2247; . Loughlin, $2459,2460$.

Front Range area: Lovering, 2469.

Gold in Juratrias : Burdick, 575.

Eiawatha gas fields : Nightingale, 2886.

Jamestown district, influence of Tertiary intrusives on mineral deposits : Goddard, 1457.

La Plata mining district: Eckel, 1.126.

London fault, structure and mineralization : Singewald, 3731.

Mineral resources: Henderson, 1695.

Minerals, White Raven mine, Ward: Wahlstrom, .4308.

Molybdenite, Climax: Coulter, 883.

Montezuma quadrangle: Buddington, 547 ; Lovering, 2466.

Natural-gas flelds: Winchester, 4564.

Ore deposition, Columbia and Dew Drop vein systems, Boulder County : Wálker, 4318.

South of Ouray, Moehlman, 2760.

Paragenesis, Ward district ores: Wahlstrom, 4309.

Porphyries and ore deposition, relations, Alma district: Singewald, 3729.

San Juan region: Burbank, 571.

Tellurides and associated minerals: Caplan, 676.

Tincup mining district, Gunnison County: Goddard, 1458.

Zoning, Mosquito Range and San Juan Mountains : Loughlin, 2462.

Historical geology.

Anticlines between Hiawatha gas field, Colo., and Baggs, Wyo.: Bradley, 424.

Aspen district: Vanderwilt, 4262.

Breckenridge mining district: Behre, 259.

Calumet iron mine, contact ore deposition: Bebre, 262.

Chinle formation, Triassic: Keyes, 2136.

Columbia and Dew Drop vein systems, Boulder County: Walker, 4318.

Continental Divide region: Behre, 257.

Correlation by heavy minerals, preCambrian granites: Stark, 3832.

Insoluble residues, Paleozoic limestones: Singewald, 3730.

Cripple Creek district: Behre, 260; Loughlin, 2459, 2460.

Dawson and Laramie formations, Denver basin: Dane, 972.

Eocene igneous sequence, Front Range: Lovering, 2471.

Front range, evolution: Van Tuyl, 4269.
Colorado-Continued.

Historical geology-Continued.

Front Range area : Lovering, 2469.

Geologic map : U. S. G. S., 4228.

Golden area: Johnson, 1971.

Grand Valley district, Mesa County : Nygren, 2927.

Hermosa formation, Pennsylvanian, Elk Mountains: Vanderwilt, 4263.

Hiawatha gas flelds: Nightingale, 2886.

Independence Pass district, fissure eruptions : Burbank, 572.

Jurassic formations, correlation: Baker, 143.

Lake Uinta, Eocene : Bradley, 427.

La Plata mining district: Eckel, 1126.

London fault, structure: Singewald, 3731.

Marshall district, Boulder County : Johnson, 1968.

Mesa Verde group: Keyes, 2098.

Migmatites, Sawatch Range: Stark, 3830.

Miocene lake, Creede: Caplan, 675.

Montezuma quadrangle: Buddington, 547; Lovering, 2466.

Mosquito Range, Paleozoic formations: Johnson, 1970.

Ore deposition south of Ouray: Moehlman, 2760 .

Pikes Feak quadrangle, structure and surface features: Loughlin, 2461.

Porphyries and ore deposition, rela. tions, Alma district: Singewald, 3729.

Rocky Montain National Park: Effinger, 1143.

Salt Creek area, Mosquito Range, Carbontferous: Gould, 1487.

San Juan region : Burbank, 571 ; Cross, 925.

Sáwatch Range: Stark, 3829.

Pre-Cambrian : Barnes, 186.

Shinarump, eastward extension : Keyes, 2139.

South Park: Behre, 256; Johnson, 1972 ; Stark, 3836.

Central: Stark, 3831.

Northeastern and east-central : Johnson, 1974.

Origin: Powers, 3123.

Southern : Howland, 1868.

Tincup mining district, Gunnison County : Goddard, 1458.

Tomichi dome flow: Stark, 3833.

Yule Creek formations, correlation: Vanderwilt, 4261.

Zoning, Mosquito Range and San Juan Mountains: Loughlin, 2462.

\section{Mineralogy.}

Barite, South Park: Howland, 1870.

Cerite, Jamestown: Goddard, 1459.

Copper-silver velns, h y droth e r m a l, northeastern plateau : Fischer, 1265.

Crystal Peak region: White, 4455. 
Colorado-Continued.

Mineralogy-Continued.

Fluorine minerals: Ives, 1914.

Fluorite deposits, Wagon Wheel Gap: Seaman, 3617

Johannite: Peacock, 3032.

Minerals, Tertiary volcanic rocks, San Juan region: Larsen, 2340.

White Raven mine, Ward: Wahlstrom, 4308.

Montezuma quadrangle : Lovering, 2466.

Mount Antero and White Mountains : Over, 2972.

Pegmatites: Landes, 2312.

Radium area : Ives, 1919.

Stainierite, Swansea mine, Goodsprings : Cooke, 853.

Steigerite, Gypsum Valley, San Miguel County: Henderson, 1697.

Tetrahedrite and chalcopyrite, crystallized, Lake City : Seaman, 3616.

Topaz, Devil's Head: Peacock, 3034.

Tungsten area, Boulder: Ives, 1916.

Paleontology.

Astraspis and Eriptychius, Ordovician, Canyon City: Bryant, 529.

Berberis caplani, Miocene, Creede: Cockerell, 793.

Bird egg, Tertiary, Willard: Toepelmann, 4133.

Chrysopidae, Tertiary, Florissant and Creede: Carpenter, 682.

Fish, Upper Devonian: Bryant, 530.

Footprints, red beds near Boulder : Toepelmann, 4134.

Graptolites, Pitkin County : Johnson, 1973.

Grasses, Tertiary : Elias, 1155.

Helisoma ammon, Pleistocene, Indio: Henderson, 1705.

Ischyromys, Oligocene, molars: Friant, 1340.

Miocene lake, Creede: Caplan, 675.

Mosquito Range, Paleozoic formations: Johnson, 1970

Nemestrinidae, Miocene, Florissant : Bequaert, 283.

Perątherium huntii, Miocene, Florissant: Gazin, 1392.

Plesiadapis gidleyi, upper Paleocene: Simpson, 3718.

Sequoioxylon pearsallii, Miocene, Florissant: Andrews, 73.

Staffella, Pennsylvanian: Thompson, 4.098 .

Tiffany fauna, upper Paleocene: Simpson, 3716,3719

Titanoides faberi, Paleocene, Mesa County : Patterson, 3023.

Titanoides, osteology : Pattérson, 3022.

Trachodont jaw, Laramie: Toepelmann, 4122.

Vertebrate localities, South Park: Stark, 3834 .
Colorado-Continued.

Petrology.

Batholith, Twin Lakes and Clear Creek districts : Chapman, 732.

Calumet iron mine, contact ore deposition : Behre, 262.

Copper-silver veins, h y d r ot h e r m a l, noltheastern plate a $u$ : Fischer, 1265.

Correlation by heavy minerals, preCambrian granites: Stark, 3832 .

Insoluble residues, Paleozoic limestones: Singewald, 3730 .

Dikes, amygdaloidal: Moehlman, 2759.

Heavy minerals, Front Range granites : Boos, 371.

Minerals, Tertiary volcanic rocks, San Juan region: Larsen, 2340.

Ore minerals, Sugar Loaf district, Lake County : Sandberg, 3487.

Phenacite, morphology and paragenesis : Pough, 3113.

Porphyries and ore deposition, relations, Alma district : Singewald, 3729.

Sawatch Range: Stark, 3829.

Spanish Peaks region: Knopf, 2239.

\section{Physical geology.}

Abrasion, wind : Powers, 3122.

Aspen district: Vanderwilt, 4262.

Batholiths, pre-Cambrian, Front Range: Boos, 373.

Twin Lakes and Clear Creek districts : Chapman, 732 .

Calumet iron mine, contact ore deposition : Behre, 262.

Continental Divide region: Belure, 25i.

Cripple Creek district: Kohanowski, 2247 : Loughlin, 2459, 2460.

Eocene igneous sequence, Front Range: Lovering, 2471.

Front Range area : Lovering, 2469.

Independence Pass district, fissure eruptions: Burbank, 572.

Indian Creek plutons, Front Range: Boos, 372 .

Jamestown district, influence of Tertiary intrusives on mineral deposits : Goddard, 1457.

La Plata mining district: Eckel, 1126.

Iondon fault, structure and mineralization: Singewald, 3731.

Migmatites, Sawatch Range: Stark, 3830. Montezuma quadrangle: Lovering, 2466.

Ore deposition south of Ouray: Moehlman, 2760.

I'aragenesis. Ward district ores: Wahlstrom. 4309.

Pikes Peak quadrangle, structure and surface features: Loughlin. 2461.

San Juan region: Burbank, 571.

Sawatch Range: Stark, 3829.

South Park, origin: Powers, 3123.

Spanish Peaks region : Knopf, 2239.

Tomichi dome flow: Stark, 3833. 
Colorado-Continued.

Physiographic geology.

Arkansas River Valley and Royal Gorge: Powers, 3119.

Book Cliffs, rock fans and pediments: Rich, 3268.

Colorado River, upper, Pleistocene terraces: Blackwelder, 331.

Front Range: Van Tuyl, 4268.

Glaciers, past and present: Ives, 1917.

Mesas, debris-covered, near Boulder: Worcester, 4614.

South Park: Powers, 3120, 3124.

Undergiround water.

Cripple Creek district: Loughlin, 2459.

Ground water in southern High Plains: Theis, 4062.

Water from wells: Waring, 4340.

Compaction, gravitational, clays and shales: Hedberg, 1682 .

Concretions: Bassler, 228.

Barite, in Yazoo clay, Eocene, Louisiana : Hanna, 1620.

Connecticut, Champlain formation : Tarr, 4017.

Cylindrical structures in sandstone: Hawley, 1656.

Kentucky, Junction City, phosphatic: Edmunson, 1137.

Massachusetts, Champlain formation:

(5)...Tarr, 4017.

Mexico, Mount Signal, Lower California : Garner, 1386.

New Hampshire, Champlain formation : Tarr, 4017.

Manganese with diatoms:- Kindle, 2196.

New York, Onondaga limestone, composition of concretions: Schwartz 3594.

Nova Scotla, manganese with diatoms: Kindle, 2196.

Sphalerite, in ironstone concretions, Ohlo: Greene, $\mathbf{1 5 1 5 .}$

Vermont, Champlain formation: Tarr, 4017.

Vishnu schist, Arizona : Campbell, 637.

Wyoming: McConnell, 2512.

Dahllite, Ishawooa: McConnell, 2511.

Red Desert: Cassinet, 700 .

Conglomerate. See also Sedimentation.

Congresses. See also Associations.

16th Internat. Geol. Congress: Fabiani, 1202.

Proceedings: Keyes, 2171.

Connate water in sands: Pyle, 3155.

Connecticut.

Economic geology.

Marbles and limestones: Moore, 2782.

Historical geology.

Fifteen Mile Falls dam, Connecticut River: Crosby, 924.
Connecticut-Continued.

Mineralogy.

Minerals: Brown, 495.

Paleontology.

Seminotus fultus, Triassic: Thorpe, 4120.

Petrology.

Concretions, Champlain formation : Tarr, 4017.

Marble, with pegmatite minerals, Falls Village: Agar, 8.

Marbles and limestones: Moore, 2792.

Pegmatites, Collins Hill, Portland: Jenks, 1942.

Prospect Forphyritic gneiss: Stewart, 3899.

Physical geology.

Pegmatites, Collins Hill, Portland : Jenks, 1942.

Spatter cone in trap sheet, Farmington : Foye, 1323.

Physiographic geology.

Fifteen Mile Falls dam, Connecticut River: Crosby, 924.

Periglacial phenomena, southern Connecticut: Denny, 1032.

Conodonts.

Actinopterygian faws, Mississippian, Oklahoma and Ohio: Cooper, 859.

Affinities, geological, and taxonomy : Branson, 445.

Caddo Gap, Mississippian, Arkansas: Cooper, 857.

Decorah shale, Iowa and Minnesota : Stauffer, 3840.

Gastropods, relationship to: Loomis, 2451.

Glenwood beds, Minnesota: Stauffer, 3837.

Icriodus, stratigraphic and geographic range: Branson, 446.

Methods, problems and results of studies: Branson, 444.

Montana, Mississippian: Scott, 3604.

Ordovician, South Dakota: Furnish, 1369.

Pennsylvanian, lower, central Missouri : Bailey, 133.

Possibly gastropods: Loomis, 2451.

Pravognathus for Heterognathus Stauffer: Stauffer, 3841.

Value as index fossils: Branson, 443.

Conrad's type fossil localities: Keyes, 2168.

Continental drifting: Bruet, 509; Keyes, 2177.

Atlantic rift: Baker, 152, 153.

Continents and oceans, origin: Bowie, 399.

Continents, form, drift, and rhythm : Watts, 4364.

Deformations, crustal, gradual type: Gutenberg, 1577.

Earth's crust : Gutenberg, 1589. 
Continental drifting-Continued.

Oil fields, distribution: Wade, 4300.

Power to move continents: Munroe, 2829.

Fre-Devonian structural zones, Scotland and eastern Nörth America: Jonas, 1990.

Continents.

Continents and oceans, origin: Bowie, 399.

Continents, form, drift, and rhythm: Watts, 4364.

Geophysical and geological study: Thom, 4080.

Origin and motion: Gunn, 1567:

Stratigraphic evidence on tectonics: Moore, 2792.

Copper.

Alaska : Moffit, 2761.

Southern Alaska Range: Capps, 677.

Upper Copper and Tanana Rivers area: Moffit, 2763.

Appalachian belt: Ransome, 3179.

Appalachians, southern : Ross, 3368 .

Ducktown type deposits: Fenner, 1222 ; Ross, 3364.

Arizona : Tenney, 4040.

Pyritic deposits: Kania, 2019.

British Columbia, Brittania mines : Ebbutt, 1118.

Fraser River-Harrison Lake region: Horwood, 1800.

Hidden Creek ore bodies: Nelson, 2845.

Ore depth in mines: Schofleld, 3573.

Portland Canal area: Hanson, 1626.

Pyritic deposits: Kania, 2019.

Slocan mining camp area: Cairnes, 624.

Windemere district, schwatzite: Warren, 4344.

Yale district: Horwood, 1799.

California, foothill belt: Tolman, 4140.

Plumas County: Knopf, 2236.

Shasta County: Averill, 123.

Trinity County: Johnston, 1984.

Canada: Alcock, 11.

Canadian Shield, pre-Cambrian: Ransome, 3179.

Central America: Ross, 3371.

Chalcocite-stromeyerite-argentite, relations: Schwartz, $\mathbf{3 5 9 5}$.

Colorado, batholith, Twin Lakes and Clear Creek districts: Chapman, 732.

Cripple Creek district : Loughlin, 2459, 2460.

Hydrothermal veins, northeastern plateau : Fischer, 1265.

Northeast half mineral belt : Lovering, 2465

San Juan Mountains: Burbank, 570, 571 ; Cross, 925.

Ward district ores: Wahlstrom, 4309.

Cuba : Allende, 48.

Development of industry : Furness, 1367.
Coper-Continued.

Eastern United States: Ross, 3363.

Glacial till, containing: Glock, 1448.

Idaho, Casto quadrangle: Ross, 3369.

Copper districts: Ross, 3370.

Edwardsburg and Thunder Mountain area : Shenon, 3665.

Lake Superior region: Ransome, 3179 .

Manitoba, Flin Flon mine: Brownell, 499.

Mexico : Santillán, 3496.

Boleo region, Baja California : Locke, 2433.

Campo Morado, State of Guerrero: Flores, 1290.

Cananea district, Sonora: Perry, 3061.

Colorado mine, Cananea : Kelley, 2049.

Northern: Ransome, 3179.

Pilares mine, Sonora: Tenney, 4041.

Tepezala, Aguascalientes, pyrometasomatic vein deposits: Wandke, 4328.

Michigan: Broderick, 465.

Copper Range: Broderick, 462.

Lake Superior area: Kraskovsky, 2257; Leith, 2390; Rama Rao, 3167.

Mineral pipes and disseminations, ores : Weed, 4376.

Missouri, Cornwall mines : Rust, 3446 .

Ozark region: Bridge, 454.

Southeastern: Tarr, 4020.

Montana, Butte mining district : Hart, 1647 ; Ransome, 3179.

Neihart mining district, Cascade County : Schafer, 3526.

Native copper masses in glacial tills: Glock, 1447.

Nevada, Contact mining district : Schrader, 3576.

Ely district: Bateman, 236.

Minor districts : Nolan, 2906.

Yerington district: Knopf, 2237.

Newfoundland, Bay of Islands igneous complex: Cooper, 869.

New Mexico, Bayard area : Lasky, 2344. Lordsburg district: Lasky, 2342.

minor copper districts: Koschmann, 225.

Organ Mountains and Doña Ana County: Dunham, 1094.

Santa Rita and Tyrone districts: Paige, 2982.

Santa Rita mining area: Spencer, 3803.

Virginia mining district, hydrothermal leaching: Lasky, 2345.

Northwest Territories, mineralization, Great Bear Lake district: Kidd, 2189.

Rae to Great Bear Lake, Mackenzie district: Kidd, 2191.

Ontario, Pigeon River area: Tanton, 4014.

Ore deposits: Butler, 592.

Oregon: Gilluly, 1428.

Pacific coast region: Ransome, 3179. 
Copper-Continued.

Puerto Rico: Meyerhoff, 2685.

Quebec, Abitibi area: Dresser, 1079.

Chibougamau Lake area: Mawdsley, 2617.

Chibougamau - Waswanipi district: Norman, 2915.

Western : Bell, 269.

Replacement minerals: Ward, 4335 .

Reserves, world: Notman, 2921.

Souhwestern U. S. : Ransome, 3179.

Stromeyerite: Schwartz, 3595.

Tennessee, Ducktown Basin minerals: Blackemore, 343 .

Ducktown district: Rama Rao, 3167.

Utah, Bingham: Boutwell, 383.

Gold Hill mining district: Nolan, 2905.

Minor copper districts : Gilluly, 1429.

Monument Valley-Navajo Mountain region: Baker, 144.

Tintic district: Park, 3006.

Vermont, Orange County : Buerger, 564.

Washington: Pardee, 3003.

Western States, sedimentary deposits : Finch, 1259.

West Indies: Ross, 3371.

World reserves: Barbour, 178.

World resources: Bayley, 245.

Wyoming, South Pass and Atlantic City district, Fremont County : Abbott, 1.

$X$-ray Identification of ore minerals: Waldo, 4312.

Coprolites.

South Dakota, Oligocene, White River badlands: Stovall, 3952.

Coral islands and reefs.

Glacial-control theory : Ladd, 2286.

Origin of extinct reefs: Hoffmeister, 1773.

Corals, See Anthozoa.

Correlation. See also Geologic formations, tables; Historical geology.

American paradigms for European glaciations : Keyes, 2163

Appalachians, southern, Talladega series : Crickmay, 910.

Arizona, Paleozoic formations: Stoyanow, 3959.

Silver King area, Superior: Galbraith, 1373.

Arkansas and Oklahoma coal fields, Pennsylvanian: Hendricks, 1707, 1709.

Ash falls, volcanic, as criteria: Keyes, 2145.

Atlantic Constal Plain, Pleistocene Pamlico: Richards, 3284.

Bainbridge and Henryhouse formations : Ball, 170 .

Bentonite, Ordovician, eastern North America : Rosenkrans, 3358, 3359.

Birdsong shale, Tennessee: Wilson, 4532 ,

$311-37-23$
Correlation-Continued.

Bluejacket sandstone, Oklahoma: Dane, 971.

British Columbia, Cache Creek Permian series: Crockford, 916.

California, Oligocene Tumey formation : Atwill, 116.

Venice and Del Rey flelds, Miocene: Corey, 875.

Cambrian, Mississippi Valley, upper : Raasch, 31.61.

Cambrian type formations revised, Montana and Yellowstone National Park: Deiss, 1012.

Carboniferous, Appalachian province and western Europe: Dariah; 977.

Europe, western, and North America : Bisat, 326.

Catskill name, history and value in geology : Chadwick, 715.

Coals, Pennsylvanian, Western Interior Province: Young 4639.

Colorado, Mosquito Range Paleozolc limestones: Singewald, 3730.

Yule Creek formations: Vanderwilt, 4261.

Cretaceous rocks, Texas: Thompson, 4102.

Cross section, Forest City, Mo., to Du Bois, Neb. : Condra, 833.

Deformation of earth's crust, Paleozolc : Moore, 2787.

Devonian, Upper, New York : Chadwick, 714.

Earthquakes, deep- and shallow-focus, occurrence : Landsberg, 2314.

Deep-focus, and moon phases: Stetson, 3886.

Eocene, marine, western North America : Clark, 758, 759.

Faunas, late Cambrian, Northern Hemlsphere: Howell, 1862.

Foraminifera as index fossils: Nuttall, 2925.

Fusulinidae in Permian and Pennsylvanian : Dunbar, 1090.

Glacial geology, European and American : Keyes, 2158.

Glaciation, northern and southern hemispheres: Coléman, 806 .

Gogebic iron district, Michigan and Wisconsin: Atwater, $\mathbf{1 1 5}$

Goticlagial broadmapping, Sweden-New York-Manitoba: De Geer, 1004.

Granites, Colorado, pre-Cambrian, by heavy minerals: Stark, 3832.

Greenland, Jurassic, Milne Land : Parat, 3001 ; Spath, 3799.

Hamilton: Cooper, 866.

Heavy-mineral suites, statistical method : Dryden, 1083; Eisenhart, 1152.

Hull and Decorah formation, Ontario and Iowa : Kay, 2026.

Illinois, Pennsylvanian coals: Young, 4639.

Iowa, Pennsylvanian coals: Young, 4639 . 
Correlation-Continued.

Jurassic, Utab, Arizona, Colorado and New Mexico: Baker, 143; Schuchert, 3588 .

Kansas, Hollow Pool area : Johnston, 1982.

Northeastern : Ockerman, 2933.

Lake Superior region and Mysore, India, pre-Cambrian: Rama Rao, 3167.

Lea Park shale, Alberta and Saskatchewan: Warren, 4348.

Louisiana, Claiborne tentative foraminiferal zonation: Israelsky, 1912.

Magnesian limestone, lower: Keyes, 2101.

Mammals, continental Pliocene: Stirton, 3911.

Maryland, bentonite beds, lower Chambersburg: Whitcomb, 4450.

Frederick Valley limestones: Jonas, 1993.

Mexico, Lower California, Cretaceous: Anderson, 65.

Mapimí, Coahuila Peninsula: Singewald, 3732 .

Northern, Mesozoic faunas: Kellum, 2056.

Sierra de Parras, Coahuila Peninsula : Imlay, 1905.

Tampico region: Muir, 2821.

Mississippi, Eocene : Grim, 1548.

Mississippi Valley, upper: Kans. Geol. Soc., 2020, Leith, 2387.

Lake Superior and Baraboo areas: Leitb, 2387.

Montana and Wyoming, Cambrian faunas: Howell, 1861.

Nebraska, Cherry County, Valentine: Johnson, 1966.

Nevada, soutliern, Pennsylvanian-Permian boundary : Longwell, 2444.

New Jersey, Monmouth and Rancocas groups: Jennings, 1944

New Mexico, Arizona and Mexico, ore deposits : Schmitt, 3565 .

New York, Chemung is Portage: Chadwick, 707.

Southwestern, Upper Devonian : Chadwick, 712 .

Oil sands, by fluorescence: Melhase, 2647.

Oklahoma and Arkansas, by graptolites : Decker, 1000.

Cambrian-Ordovician boundary, Arbuckle limestone, Murray County : Bridge, 457.

Mayes-Boone : Brant, 447.

Muskogee County, Pennsylvanian oil and gas sands: Wilson, 4530.

Ouachita Mountains: Fitts, 1276.

Pennsylvanian coals: Young, 4639.

Pennsylvanian sandstones, Ardmore Basin: Lucas 2475.

Talihina chert, Atoka: Gardner, 1380.

Ontario and Michigan, Hamilton beds: Warthin, 4351.
Correlation-Continued.

Ontario, East Bay, Minnitaki Lake, Kenora district: Pettijohn, 3067.

Savant Lake area: Rittenhouse, 3308.

Paleozoics, later, America and Europe: Noe, 2901.

Lower : Ulrich, 4211.

Lower, by graptolites: Decker, 1001.

Peat deposits, U. S. and Europe, time and climatic changes: DachnowskiStokes, 947.

Pennsylvania, Bellefonte quadrangle: Butts, 598.

Bentonite beds, lower Chambersburg: Whitcomb, 4450.

Coal flora, Wilkes-Barre and Pittsburgh region: Darrah, 975.

Lehigh Valley Cambro-Ordovician limestones: Hills, 1742.

Northwestern: Fettke, 1240.

Pennsylvanian and Permian, Midcontinent, by fossil plants: White, 4454.

Pennsylvanian, Eastern Interior and Appalachian coal fields: Wanless, 4330.

Permian, geologic classifications: Chamberlin, 718 .

Pleistocene, late, marine and glacial deposits, New York and New Jersey : MacClintock, 2504.

Pacific coast: Allison, 54.

Prairie du Chien formation: Powers, 3116.

Pre-Cambrian, geologic classiflcations : Chamberlin, 718 .

Pre-Cambrian and Cambrian, upper Mississippi Valley: Atwater, 114.

Pre-Devonian structural zones, Scotland and eastern North America: Jonas, 1990.

Quaternary, late, by glacial varves: Antevs, so.

Quebec, Lacolle conglomerate: Clark, 767.

Residues; insoluble, as guides : Burpee, 583 ; Hills, 1742 ; Ireland, 1807 ; McQueen, 2561 ; Mitchell, 2754 ; Shrock, 3699 ; Singewald, 3730.

Wisconsin dolomites: Burpee, 582.

Russian upper Carboniferous and ArtInskian, with American late Paleozoic: Elias, 1157.

St. Peter series : Edson, 1139.

Silurian formations, Ohio. Indiana. Kentucky, and Tennessee: Foerste, 1298.

South Carolina, Coastal Plain: Cooke, 847.

South Dakota, west-central: Rothrock, 3384.

Sylvan shale, Oklahoma, and Polk Creek shale, Arkansas: Decker, 998.

Sylvania sandstone, Devonian, northwestern Ohio: Carman, 680 
Correlation-Continued.

Teleconnection, geochronology and historic time: De Geer, 1003.

Texas, east: Thomas, 4089.

West, Permian, with Panhandle: Adams, 3.

Texas and Missourl, Upper Cambrian : Bridge, 456.

Texas Claiborne, southwest and east: Stenzel, 3872.

Tentative foraminiferal zonation: Israelsky, 1912.

Tilting of ground and tides, Chesapeake Bay : Merritt, 2678.

Utah, Gold Hill mining district: Nolan, 2905.

Virginia, southwestern, zinc and lead region : Currier, 936.

Wisconsin, erosion surfaces: Johnson, 1961.

Mohawkian relations: Bays, 247.

Wyoming, Frontier-Niobrara contact, Laramie basin: Thomas, 4086.

Northwestern, Cambrian: Miller, 2714.

Tables.

Alabama, Cincinnati arch region: Bailey, 132.

Alberta, natural gas flelds: Slipper, 3742.

American paradigms for European glaciations: Keyes, 2163.

Antillean-Caribbean region: Schuchert, 3579.

Arizona, Paleozoic formations: Stoyanow, 3959.

Paradise formation: Hernon, 1714.

Arkansas, Boone chert: Giles, 1422.

Gulf Coastal Plain: Spooner, 3810.

Natural-gas fields, interior highlands : Croneis, 918.

Northern: McKnight, 2552.

California, southern: Reed, 3231.

Southern Klamath Mountains: Hinds, 1746.

Cambrian, northwest Scotland and Appalachians: Stose, 3916.

Carboniferous : Romer, 3347.

Floral provinces: Jongmans, 2012.

Midcontinent: Keyes, 2181.

Western Europe and North America: Bisat, 326.

Colorado, Montezuma quadrangle : Lovering, 2466.

Decorah shale: Stauffer, 3840.

Devonian, upper Mississippi Valley : Stainbrook, 3815.

Devonian, Upper, New York : Chadwick, 714.

Eocene sequence, western North America : Clark, 759.

Florida, gastropods and schaphopods, Miocene, Alaqua Creek Valley: Mansfleld, 2572.

Greenland : Koch, 2244.

Jurassic, Milne Land: Spath, 3799.

Scoresby Sound : Aldinger, 18.
Correlation-Continued.

Tables-Continued.

Illinois, Mississippian system: Moore, 2784.

Iowa, Mississippian system : Moore, 2784.

Jurassic formations, Utah, Alizona, Colorado and New Mexico: Baker, 143.

Kentucky, Cincinnati arch region: Bailey, 132.

Eastern : Hunter, 1891.

Lake Superior region: Leith, 2390.

Lake Superior region and Mysore, India, pre-Cambrian: Rama Rao, 3167.

Maryland, Frederick Valley limestones : Jonas, 1993.

Mexico, Coahuila Peninsula: Kellum, 2057.

Northeastern, Eocene : Kane, 2016.

Northwestern : Kellum, 2054.

Sierra de Parras, Coahulia Peninsula: Imlay, 1905.

Tampico region : Muir, 2821.

Michigan, Lake Superior region: Leith, 2390.

Minnesota, Lake Superior region : Leith, 2390.

Southeastern: Powell, 3114.

Mississippi, Cincinnati arch region : Bailey, 132.

Mississippi Valley, upper: Kansas Geol. Soc., 2020.

Ordovician : Kay, 2027.

Missouri, Mississippian system: Moore, 2784.

Montana, Belt sediments, Libby quadrangle: Gibson, 1418.

Southeastern : Perry, 3059.

Nevada, southern, Pennsylvanian-Permian boundary: Longwell, 2444.

Newfoundland, Bay of Exploits area : Heyl, 1736.

Oklahoma : Ireland, 1907.

Ardmore area, Carboniferous: Floyd, 1293.

Boone chert: Giles, 1422.

Ontario, East Bay, Minnitaki Lake, Kenora district: Pettijohn, 3067.

Lockport and Onondaga formations: Laird, 2290.

Nataul'al-gas fields : Harkness, 1633.

Savant Lake area: Rittenhouse, 3308.

Ordovician altered volcanic materials and related clays: Kay, 2029.

Paleozoics, later, America and Europe: NoG, 2901.

Lower, by graptolites: Decker, 1001.

Pennsylvania, Bellefonte quadrangle: Butts, 598.

Central, Hamilton group: Willard, 4490.

Northeastern, continental, Devonian : Willard, 4499.

Pennsylvania and Maryland, Middle Devonian: Willard, 4501. 
Correlation-Continued.

Tables-Continued.

Pennsylvanian and Devonian: Willard, 4501.

Pennsylvanian and Permian, Midcontinent, by fossil plants: White, 4454.

Permian sequences, correlation: Schuchert, 3580 .

Pre-Cambrian: Brock, 461.

St. Peter series: Edson, 1139.

Silurian, central and eastern U. S.: Sutton, 3983.

Upper Mississippi Valley: Sutton, 3983.

South Carolina, Coastal Plain: Cooke, 847.

Tennessee, Cincinnati arch region: Bailey, 132.

Tertiary, Atlantic and Gulf Coastal Plains: Mansfield, 2573.

Texas, Amarillo district gas fields : Cotner, 882 .

Northeast embayment, natural gas flelds: Ley, 2412.

Tertiary: Wendlandt, 4394.

Trinidad: Lehner, 2381.

Vicksburg group : Cooke, 846.

Wisconsin, Lake Superior region: Leith, 2390.

Wyoming, late Cretaceous and early Tertiary: Nace, 2840.

Yukon, Carmacks district : Bostock, 379.

Cretaceous. See also Paleontology, Cretaceous.

Alaska, Ruby-Kuskokwim region: Mertic, 2681.

Southern Alaska Range: Capps, 677.

Tonsina district: Moffit, 2762,

Upper Copper and Tanana Rivers area : Moffit, 2763.

Alberta, Athabasca sands: Ball, 171.

Battleview anticline, Wainwright area : Hume, 1886.

Foothills structures: Link, 2422.

Foremost-Skiff area: Howells, 1867.

Milk River area: Russell, 3433.

Smith and Cold Lake district: Rutherford, 3473.

Wildcat Hills area, west half : Hume, 1884.

Antillean-Càribbean region: Schuchert, 3579.

Arizona and Mexico, earliest recognition: Keyes, 2119.

Arizona, Mesa Verde coal formation: Keyes, 2154.

Southeastern: Keyes, 2120.

Arkansas, Gulf Coastal Plain: Spooner, 3810.

Assiniboine great sedimentation cycle: Keyes, 2170.

British Columbia, Baculites ovatus zone, Alberta shales: Webb, 4371.

Cate Creek: Olsson, 2952.

Fraser River-Harrison Lake region: Horwood, 1800.

Portland Canal area: Hanson, 1626.
Cretaceous-Continued.

California, Mesozoic and Cenozoic eruptive rocks, Klamath Mountains: Hinds, 1746.

Mount Diablo and Coalinga areas: Clark, 755.

Mount Diablo and vicinity: Taff, 4005.

Natural-gas fields: Hoots, 1792.

Riverside and Orange Counties; clays: Sutherland, 3981.

South coastal basin: Eckis, 1131.

Southern: Reed, 3231.

Ventura County: Conkling, 837.

Canada, western: Goodman, 1473.

Clays, fire, distribution in U. S.: Chelikowsky, 743.

Colorado, Book Cliffs coal field: Erdmann, 1185.

Dawson and Laramie formations, Denver basin: Dane, 972.

Golden area : Johnson, 1971.

Hiawatha gas fields: Nightingale, 2886.

La Plata mining district: Eckel, 1126.

Montezuma quadrangle: Lovering, 2466.

Rocky Mountain National Park: Eefinger, 1143.

San Juan region: Burbank, 571.

South Park: Johnson, 1974.

Spanish Peaks region: Knopf, 2239.

Comanche, terranal title: Keyes, 2118.

Crefaceous rocks, first American discovery: Keyes, 2109.

Cuba: Schürmann, 3589.

Santa Clara Province, northern : Rutten, 3463.

Georges Bank canyons: Stetson, 3889 , 3890.

Greenland: Koch, 2244, 2245.

East: Bøgvad, 361 ; Frebold, 1332.

Northeast: Teichert, 4037.

Idaho, Casto quadrangle: Ross, 3369.

Illinois Basin : Weller, 4386.

Iowa : Keyes, 2091.

Southern: Wood, 4591.

Jamaica, basal complex: Trechmann, 4163.

Kansas, Central uplift: Koester, 2246.

Louisiana: Howe, 1842.

Gulf coast fields: Woodruff, 4606.

Monroe gas field: Fergus, 1235.

Richland gas field: Gordon, 1480.

Mexico: Santillán, 3500, 3501.

Coahuila Peninsula: Kellum, 2057, 2058.

Lower California : Anderson, 65.

Mapimí district: Singewald, 3728 .

Mountains of Coahuila Peninsula : Kelly, 2068.

Northeastern, oil flelds: Tatum, 4021.

Northwestern : Kellum, 2054.

Sierra de Parras, Coahuila Peninsula: Tmlay, 1905. 
Cretaceous-Continued.

Mexico-Continued.

State of Chiapas, pre-Tertiary: Müllerried, 2815.

Tampico region : Kellum, 2059 ; Muir, 2821.

Mississippi : Morse, 2805.

Covington County: George, 1402.

Missouri, southeast: Farrar, 1215.

Montana, Big Horn Basin gas flelds: Emery, 1174.

Big Horn County and Crow Indian Reservation: Thom, 4074.

Natural-gas fields: Bartram, 216.

Northeastern, Missouri and Milk Rivers: Perry, 3058.

Nye-Bowler lineament, Stillwater and Carbon Counties: Wilson, 4535.

Southeastern : Perry, 3059.

Nebraska, water-bearing formations: Condra, 835.

Nevada, central Humboldt Range: Jenney, 1943.

New Jersey, Coastal Plain: Kïmmel, 2279.

Middlesex County, heavy minerals in clays: Hawkins, 1652.

Watchung Mountains: Moldenke, 2765.

New Mexico, Bayard area: Lasky, 2344.

Mount Taylor coal field: Hunt, 1888.

San Juan Basin: Sears, 3621.

Santa Rita mining area: Spencer, 3803.

North Carolina, Coastal Plain: Prouty, 3150.

Nuttall's first recognition in America : Keyes, 2173.

Pennsylvania, Philadelphia area: Watson, 4359.

Post-Keweenawan, age by helium method: Urry, 4246.

Puerto Rico: Meyerhoff, 2685.

Restorations, geological landscapes: Reid, 3236.

Rocky Mountain geosynclines: Keyes, 2096.

Sabine uplift, importance : Easton, 1115.

Saskatchewan, Hudson Bay Junction area : McLearn, 2555.

Southern, Regina area : Fraser, 1330.

South Carolina, Coastal Plain: Cooke, 847.

South Dakota, west central: Rothrock, 3384.

Southwestern U. S. : Effinger, 1144.

Tennessee, south-central: Theis, 4063. Tripoli deposits, western Tennessee Valley: Spain, 3793.

Tuscaloosa formation outliers: Born, 375.

Western: Born, 376.

Texas, Atascosa and Frio Counties: Lonsdale, 2446.

East Texas oil field: Zavoico, 4646.

Frederlcksburg group: Thompson, 4102.
Cretaceous-Continued.

Texas-Continued.

Gulf coast fields: Woodruff, 4606 .

Hilbig oil fleld, Bastrop County : Blackburn, 329.

Maverick County: Vanderpool, 4259.

Mexia-Talco fault zone: Smith, 3749.

Northeast embayment, natural gas flelds : Ley, 2412.

Shafter mining district: Ross, $\mathbf{3 3 7 5}$.

Terlingua district: Ross, 3374.

Trans-Pecos, structural features: King, 2211.

Unconformities : Adkins, 5.

Uvalde and Medina Counties: Sayre, 3524.

White and Baker well, Pccos County, unconformities: Carsey, 687.

Texas-Louisiana, Rodessa field: Iry, 1921.

Trinidad: Kugler, 2280 ; Lehner, 2381. Northern Range: Trechmann, 4161.

Utah : Spieker, 3807 .

Book Cliffs coal fleld: Fisher, 126.

Monument Valley-Navajo Mountain region: Baker, 144.

Salt Valley anticline area : Dane, 970.

Southeastern : Baker, 142.

West Indies: Rutten. 3461.

Wyoming: Nace, 2840.

Baxter Basin gas fields: Nightingale, 2885.

Big Horn Basin gas fields: Emery, 1174.

Big Medicine Bow oil fleld, Carbon County: Shoenfelt, 2693.

Devils Tower National Monument: Effinger, 1142.

Frontier-Niobrara contact, Laramio basin: Thomas, 4086.

Hiawatha gas flelds; Nightingale, 2886.

Lance Creek field: Brainerd, 434.

Lost Soldier district gas fields : Tillotson, 4129.

Yukon, Carmacks district: Bostock, 379.

Crinoidea. See also Echinodermata.

Allagecrinus americanus, Mississippian : Peck, 3041.

Allagrecrinus strimplei, Pennsylvanian, Oklahoma: Kirk, 2219.

Comatulids, arm ramiflcations: Gislen, 1439.

Eocene, North Carolina : Gislén, 1439.

Iowa, Devonian: Laudon, 2350.

Micro-crinoids, Lower Mississippian, Missouri : Peck, 3042.

New York, Devonian: Goldring, 1464, 1465, 1466.

Pennsylvanian, lower, central Missouri : Bailey, 133.

Silurian, Ohio: Foerste, 1303.

Stems on fossil wood, Devonian, Indiana: Wickwire, 4472. 
Criteria, gold quartz mines: Anderson, 69. Criteria for tops of stratified beds: Belyea, 275.

Crocodiles. See Reptilia.

Crustacea. See also Cirripedia; Ostracoda; Trilobites.

Atlantic and Gulf Coastal Plain, Cretaceous and Tertiary: Rathbun, 3184.

Decapods, name changes: Rathbun, 3186.

Phyllocarid crustaceans, Sidurian, Oklahoma : Ruedemann, 3409.

Tertiary, Texas, Louisiana, and Mississippi : Stenzel, 3866.

Cryptogams. See Paleobotany.

Crystallography. Kraus, 2258 ; Lazell, 2359. See also Mineralogy.

Adamite, Chloride Cliff, California : Murdoch, 2835.

Agate formation: Cassirer, 701.

Albite-fayalite system: Bowen, 389.

Ammonium molybdo-ditellurates: Donnay, 1062.

Arsenopyrite group, structure: Buerger, 558.

Atoms, arrangement in crystals, models : Buerger, 557.

Augelite, Mono County, Calif.: Lemmon, 2392.

Axes, cyclic permutation: Peacock, 3038.

Basalt, crystallization process: Barth, 197.

Caesfum molybdo-tellurates: Donnay, 1063.

Calaverite, crystal structure: Tunell, 4182.

Morphology and internal properties: Tunell, 4185.

Calcite twins, North. Plainfield, New Jersey : Hawkins, 1654.

California, vesuvianite: Pabst, 2976.

Wollastonite and parawollastonite, Crestmore: Peacock, 3036.

Celestite, Chitenango Falls, N. Y.: Thibault, 4066 .

Cell to determine refractive indices of crystal grains: Saylor, 3523.

Chiastolite crystals, California: Brown, 497.

Chlorite system: Winchell, 4562.

Choice of crystallographic elements: Peacock, 3033.

Colorado, johannite: Peacock, 3032.

Topaz, Devil's Head : Peacock, 3034.

Copper ore minerals, identification by $\mathrm{X}$-ray : Waldo, 4312.

Crystal, classification and symbolism: Fisher, 1267.

Forms and form names: Rogers, 3338.

Growth and solution under local stress : Russell, 3426.

Crystallographic expression, theory of space groups: Howard, 1829.
Crystallography-Continued.

Crystals, twisted, pyrite and smoky quartz : Frondel, 1354.

Vectoral chemical alteration: Frondel, 1353.

Cubanite, crystal structure: Buerger, 559.

Development : Pabst, 2978.

Dickite, structure : Ksanda, 2278.

Diopside crystals: Dunham, 1096.

Equilibrium studies, monticellite, glaucochroite, calcium fayalite: Schoenlaub, 3571.

Form relations, laurionite, paralaurionite, and fiedlerite: Palache, 2984.

Garnet, trisoctahedral, West Thetford, Quebec: Parsons, 3021.

Glauconite and mica, structural relationships: Gruner, 1561.

Growth of crystals: Whitlock, 4465.

Gypsum crystals, Alfalfa County, Okla. : Merritt, 2676.

History, condensed : Colcord, 802 .

Illinois, irregular crystallizations in geodes: McKinley, 2547.

Krennerite, structure: Tunell, 4184.

Krennerite, calaverite, and sylvanite: Tunell, 4183.

Laue symmetry of orthogonal crystals : Barnes, 190.

Law of complication: Buerger, 562.

Linnaeite group of cobalt-nickel-ironcopper sulphides: Tarr, 4016.

Lithium molybdo-tellurate: D o n $\mathbf{n}$ a y, 1061.

Livingstonite, Huitzuco, Guerrero, Mexico: Richmond, 3289.

Magnetite metacrysts: Schwartz, 3599. Separation planes: Greig, 1537.

Maine, herderite, Topsham : Yatsevitch, 4637.

Mineral classification: Seaman, 3619; Staples, 3826.

Modification of crystal habit by adsorption: Frondel, 1352.

Narsarsukite, East Butte, Montaną: Graham, 1492.

New Jersey, minerals, Franklin and Sterling Hill, Sussex County : Palache, 2985.

Pectolite: Peacock, 3031.

Nomenclature: Boldyrev, 365.

North Carolina, alleghanyite: Rogers, 3333.

Ontario, cubanite, Sudbury : Peacock, 3037.

Feldspar twinning, differentiated sill ; Chapman, 736.

Pennsylvania, dickite, Schuylkill County : Honess, 1788.

Piedmontite, Los Angeles County, Calif. : Simonson, 3712.

Phenacite, Amelia County, Virginia: Pough, 3111; Thibault, 4067.

Plane groups to interpret Weissenberg photographs: Buerger, 555. 
Crystallography-Continued.

Pseudobrookite, Juab County, Utah: Palache, 2988.

Quartz, Okanagan district, Ontario: Walker, 4322.

Realgar type crystals, sulphide of nitrogen : Buerger, 560.

Roselite, rule of highest pseudosymmetry : Peacock, 3039.

Sections, polished oriented, sman single crystals: Buerger, 561.

Silica framework crystals and their stability fields: Buerger, 554.

Size of crystals: Frondel, 1351.

S o d i u m molybdo-tellurate: Terpestra, 4042.

Spherulites, three-dimenslonal, structure: Morse, 2804.

Structure of crystals: Wyckoff, 4633.

Swedenborgite, crystal structure: Pauling, 3030.

Symbols, alternating axes and symmetry : Donnay, 1060.

Syngony, use of term : Rogers, 3336 .

Theory of determinants: Aloisi, 55; Donnay, 1059.

Tourmaline, oriented, in moscovite: Frondel, 1355.

pyroelectricity and a uthigenic growth : Stow, 3957.

Space group : Barnes, 189.

Vivianite group: Barth, 196.

$X$-ray identification, antlerite and brochantite: Waldo, 4313.

Method to distinguish space gioups, hexagonal system: Barnes, 188.

Study, pucherite: De Jong, 1013.

Study of system $\mathrm{K}_{2} \mathrm{SO}_{4}-\mathrm{MgSO}_{4}-\mathrm{CaSO}_{4}$ : Ramsdell, 3170 .

Zoisite, crystal structure: Waldbauer, 4311.

Cuba. See also West Indies.

Provinces of Habana and Pinar del Rfo, excursions: Herrera y Fritot, 1718.

Economio geology.

Copper: Allende, 48.

Historical geology.

Isla de Pinos: Rutten, $\mathbf{3 4 5 9 .}$

Jurassic : Dickerson, 1043.

Massif: Schürmann, 3589.

Santa Clara Province, northern: Rutten, 3463.

Mineralogy.

Lawsonite, Santa Clara Province: Schürmann, 3589.

\section{Paleontology.}

Aptychus species: Trauth, 4158.

Clypeaster pinarensis, Oligocene: Lambert, 2294.

Foraminifera: Cushman, 942.

Santa Clara Province: Rutten, 3462.

Tertiary, Matanzas Bay region: Palmer, 2991.

Manati, Oligocene: Duelo, 1087.

Mecoliotia berm udezi, Pleistocene: Clench, 778.
Cuba-Continued.

Paleontology-Continued.

Mollusks, Pleistocene, Matanzas and Pinar del Rio provinces: Richards. 3280.

Orbitoides, Cretaceous, Havanna Province: Gravell, 1505.

Rudistids, Cretaceous, Santa Clura Province: Rutten, 3464.

Santa Clara Prorince, northern: Rutten, 3463.

Petrology.

Lawsonite, Santa Cla r a Province: Schürmann, 3690.

Massif : Schürmann, 3689 .

Santa Clara Province, northern: Rutten, 3463.

Physical geology.

Massif : Schürmann, 3689.

Santa Clara Province, northern: Rutten, 3463.

Cubanite, Sudbury, Ontario: Peacock, 3037.

Cuesta vs. Peneplane, Wisconsin drifties area : Martin, 2587.

Cusps. See Shore lines.

Cyanite.

North Carolina: Stuckey, 3973.

Virginia: Taber, 4003.

Cycads. See Paleobotany.

Cylindrical structures in sandstone: Hawley, 1656.

Cyrtolite, analysis: Muench, 2819.

Cystoidea.

Edrioasteroidea, Cambrian, Devonian, Ordovician : Bassler, 232.

Classiflcation : Bassler, 226.

Dams.

South Carolina, Santee-Cooper power project : Taber, 4002.

Wyoming, Alcova Dam and reservolr sites, North Platte River, Natrona County: Bradley, 423.

Damariscotta shell heaps and coastal stability : Goldthwait, 1471.

Dating possibilities, fossil mammal-artifact localities: MacClintock, 2505.

Deductions from thermal equation: De Lury, 1029.

Deep-focus earthquakes and isostasy: Stechschulte, 3857 ; Thom, 4078.

Deductions: De Lury, 1028; Stechschulte, 3859.

Deep wells. See Borings.

Deformation.

Continents, stratigraphic evidence on tectonics: Moore, 2792.

Rocks, experimental investigations: Griggs, 1544.

Southeastern Utah : Baker; 142.

Delaware.

Mineralogy.

General: Hawkins, 1653. 
Delaware-Continued.

Paleontology.

Fauna, Pleistocene Pamlico, southern Atlantic Coastal Plain: Richards, 3284.

Deltas.

Colorado Delta and lower Colorado River: Sykes, 3998.

Louisiana, Mississippi River: Russell, 3444.

Dendrochronology and geochronology: De Geer, 1003.

Densities, rocks, from chemical analyses: Daly, 966.

Denudation. See Desert; Erosion.

Deposition. See Sedimentation.

Desert.

Denudation, uesert-rainfall factor: Russell, 3443 .

Geomorphology, mountainous: Davis, 986.

Mountains, stream-carved slopes and plains : Field, 1254.

Desiccation features in humid climate: Krynine, 2273.

Devonian. See also Paleontology, Devonian

Alaska, interior, volcanism: Mertie, 2680.

Ruby-Kuskokwim regi o n : Mertie, 2681.

Upper Copper and Tanana Rivers area : Moffit, 2763.

Alberta : Calder, 625 .

Antillean-Caribbean region: Schuchert, 3579.

Arizona, Paleozoic formations: Stoyanow, 3959.

Silver King area, Superior: Galbraith, 1373.

California, Death Valley National Monument : Anonymous, 4664.

Canada, western: Goodman, 1473.

Catskill, name, history and value in geology: Chadwick, 715.

Chaleur Bay region, Quebec and New Brunswick: Alcock, 12.

Clays, fire, distribution in U. S. : Chelikowsky, 743.

Colorado, Mosquito Range, Paleozoic formations: Johnson, 1970.

Mosquito Range, Paleszoic limestones: Singewald, 3730 .

Rocky Mountain National Park: Effinger, 1143.

San Juan region: Cross, 925.

Yule Creek formations: Vanderwilt 4261.

Deformation of earth's crust, Paleozoic: Moore, 2787.

Gaspé, southeastern: Kindle, 2193.

Greenland: Koch, 2244, 2245.

Christian X's Land: Wegmann, 4377.

East: Butler, 593.

Gauss Peninsula and Passage Hills : Siive-Söderbergh, 3468.
Devonian-Continued.

Greenland-Continued.

Northeast: Teichert, 4037.

Parallel Valley, Gauss Peniusula : Johansson, 1954.

Ymer Island: Cleaves, 772.

Illinois, Marion and Clay Counties: Weller, 4385.

Illinois Basin : Howard, 1831; Weller, 4386.

Kansas, Central uplift: Koester, 2246. Hollow Pool area : Johnston, 1982.

Northeastern : Ockerman, 2933.

Maine, geologic map: Keith, 2040

Onawa pluton, Piscataquis County: Philbrick, 3072.

Mexico : Santillán, 3500 .

Michigan, central oil fields: Zavoica, 4644 .

Hart oil field, Oceana County : Riggs, 3302.

Natural-gas fields: Newcombe, 2853.

Southeastern, Dundee limestone : Bailey, 223.

Traverse group, Thunder Bay region : Warthin, 4352

Mississippi : Morse, 2805.

Mississippi Valley, cross sections: Workman, 4618.

Upper: Kans. Geol. Soc., 2020 ; Stainbrook, 3815 ; Tester, 4045.

Missouri, cross section, Forest City, Mo. to $\mathrm{Du}$ Bols, Neb. : Condra, 833 .

Montana, Big Snowy Mountains : Deiss, 1011.

Nebraska, cross section, Du Bois, Nebr., to Forest City, Mo.: Condra, 833.

Newfoundland, gold deposits: Snelgrove, 3779.

New Hampshire, Franconia quadrangle : Billings, 317.

Littleton and Moosilauke quadrangles : Blllings, 318 .

Percy ring-dike complex: Chapman, 734.

New Mexico, Bayard area : Lasky, 2344. Organ Mountains and Doña Ana County: Dunham, 1094

New York: Chadwick, 706.

Allegany State Park: Thwaites, 4125.

Berne quadrangle: Goldring, 1463.

Chemung is Portage: Chadwick, 707.

Correlation : Chadwick, 714 .

Hamilton group, facies relationships : Cooper, 863.

John Boyd Thacher State Park: Torrey, 4147.

Natural-gas fields: Torrey, 4146.

Skaneateles quadrangle: Smitb, 3746.

Southwestern, Upper Devonian : Chadwick, 712.

Tully formation: Cooper, 862 .

Upper Devonian: Chadwick, 711.

Watkins quadrangle : Bradley, 425. 
Devonian-Continued.

Ohio, Kelley's Island: Ver Steeg, 4281. Northwestern, Sylvania sandstone: Carman, 680.

Oklahoma, correlation by insoluble residues: Ireland, 1907.

Fitts pool, Pontotoc County: Hyatt, 1901.

Ontario, Lockport and Onondaga formations: Laird, 2290.

Pennsylvania, Appalachian geosyncline, delta deposits: Burroughs, 584.

Bellefonte quadrangle: Butts, 598.

Bradfordian serles discontinued : Caster, 702.

Butler and Zelienople quadrangles: Richardson, 3286.

Central, Hamilton group: Willard, 4490.

Eastern region: Miller, 2717.

Glacial ice: Willard, 4491.

Hebron gas field : Reeves, 3234.

Natural-gas fields: Torrey, 4146.

Northeastern, continental: Willard, 4499.

Northwestern: Fettke, 1240.

Onondaga formation: Willard, 4501.

Oriskany sand: Cathcart, 705.

Pittsburgh region: Linton, 2424.

Portage group: Willard, 4494.

Southwestern: Willard, 4496.

Tioga region: Ashley, 100.

Post-Keweenawan, age by helium method: Urry, 4246.

Quebec, Darthmouth River. area, Gaspe Peninsula: Jones, 2003.

Marsoui area, Gaspe Peninsula: Jones, 2001.

Mount Megantic region: McGerrigle, 2525.

North-central Gaspe : Jones, 2002.

Témiscouata area : McGerrigle, 2524.

Restorations, geological landscapes: Reid, 3236.

Saskatchewan, Hudson Bay Junction area: McLearn, 2555.

Southern, Regina area: Fraser, 1330.

Southwestern U. S. : Effinger, 1144.

Tennessee, Nashville dome: Wilson, 4531.

South-central : Theis, 4063.

Texas, t r a n s-Pecos, unconformities: Arick, 84 ; King, 2213.

Utah, Gold Hill mining district: Nolan, 2905.

Virginia, Devonian fold, Botetourt County : Holden, 1776.

Eagle Rock, Pulaski overthrust: Woodward, 4611.

Shenandoah. Valley: Cady, 621.

West Virginia, eastern : Reeves, 3233.

Wisconsin : Raasch, 3160. 347.

Diamonds. See also Precious stones Blank, Diastrophism.

Antillean-Caribbean region: Schuchert, 3579 .
Diastrophism-Continued

California, soutbern: Reed, 3231.

Carboniferous, mid-continent: Keyes, 2181.

Mexico, northwestern : Kellum, 2054.

Texas, Corpus Christi area: Price, 3134.

Diatomaceae. See also Diatomaceous earth.

Barbados: Robinson, 3324.

Blue Mountains, Miocene, Oregon: Oliver, 2950.

California, diatomite, Lompoc: Mulryan, 2826.

Kettleman Hills, Pliocene: Lohman, 2440.

Palos Verdes Hills: Woodring, 4603.

Cedarville formation, Tertiary: LaMotte, 2309.

Cretaceous, Panoche Hills, California : Hanna, 1615.

Diatomées du monde entier, $2 d$ ed., dates of publication: Hanna, 1614.

Greenland, moor : Iversen, 1913.

New Hampshire, in manganese concretions: Kindle, 2196.

Nova Scotia, in manganese concretions: Kindle, 2196.

Quaternary lake beds, New Mexico: Lohman, 2439.

Diatomaceous earth.

British Columbia, industrial and nonmetallic minerals : Richmond, $\mathbf{3 2 8 7}$.

California, diatomite, Lompoc: Mulryan, 2826.

Diatomite.

Oregon : Lazell, 2361.

Eastern: Moore, 2779.

Dickite.

Missouri : Tarr, 4018.

St. Louis County : Allen, 46.

Pennsylvania, Schuylkill County: Honess, 1788.

Differentiation in traps and ore deposition: Lane, 2324.

Dikes. See also Intrusions.

British Columbia, Hidden Creek ore bodies: Nelson, 2845 .

Keithley Creek area, Cariboo district : Lang, 2333.

Ymir-Nelson area: Cockfield, 796.

California, paragenesis at Crestmore: Daly, 962.

Pinnacles National Monument: Andrews, 74 .

Southern Peninsular Range: Miller, 2728.

Colorado, Amygdaloidal: Moeblman, 2759.

Spanish Peaks region: Knopf, 2239.

Idaho, batholith: Ross, 3376 .

Labrador, amazonite aplite dike: Wheeler, 4439.

Maine, Bates limestone, Lewiston : Fisher, 1273.

Cape Neddick: Haff, 1595.

Onawa pluton, Piscataquis County: Philbrick, 3072. 
Dikes-Continued.

Manitoba, God's Lake gold mine: Baker, 155.

Manitoba and Ontario mining districts : Wright, 4627.

Mexico,-Alamo district, Lower California: Moeblman, 2758.

Mapimi, Coahuila Peninsula: Singewald, 3732.

Minnesota, Ogishkemuncie Lake region : Sleight, 3740.

Montana, Highwood Mountains: Larsen, 2339

Nevada, Paradise Range : Callaghan, 628. Scheelite-leuchtenbergite vein, Paradise Range: Kerr, 2082.

Silver Dyke area: Kerr, 2086.

Newfoundland, Bay of Exploits area: Heyl, 1736.

Bay of Islands igneous complex : Cooper, 869.

New Hamphire, Belknap Mountains ring-dike complex: Modell, 2756.

Franconia quadrangle: Billings, 317 .

Percy ring dike complex: Chapman, 734.

Northwest Territories, Rae to Great Bear Lake, Mackenzie district, Kidd, 2191.

Yellowknife River area : Jolliffe, 1988.

Ontario, offset dikes, nickel intrusive, Sudbury : Thomson, 4116.

Porcupine area : Hurst, 1899

Sucbury nickel field : Burrows, 585.

Quebec, Chibougamau Lake area : Mawds. ley, 2617.

Guillet (Mud) Lake area : Henderson, 1701.

Horne mine, gabbro and sulphides, relations: Suffel, 3977.

Lamaque-Sigma mines area, Bourlamaque Township, Abitibi County: Bell, 267.

Malartic gold mine area, Abitibi : O'Neill, 2954.

Mount Megantic region: McGerrigle, 2525.

Pre-Cambrian tectonic features, Chibougamau district: Norman, 2914.

Pusticamica Lake area, Abitibi district : MacKenzie, 2540.

Shawinigan Falls district: Osborne, 2965.

Waswanipi map area: Norman, 2912.

Saganaga batholith, Minnesota-Ontario: Grout, 1557.

Texas, Llano region: Stenzel, 3868.

Vermont, devitrifled felsite dikes, Ascutney Mountain : Balk. 163.

Diopside, Crestmore quarries, Riverside, California : Merriam, 2675.

District of Columbia.

Geologist's paradise: Bassler, 224.

Mineralogy.

Minerals : Ulke, 4206.

Minerals, mines, and quarries near Washington: Ulke, 4207.

Vivianite : Benn, 279.
Dinosauria. See Reptilia,

Dislocations. See Faulting.

Dolomite.

Pseudomorphs, castellated : Merritt, 2677.

Texas, west, Permian limestones: Cunningham, 933.

Domes. See also SaIt domes.

Structure, intrusive igneous, salt, and oil : Balk, 160.

Tennessee, Nashville dome: Wilson, 4531.

Texas, Hardin dome, Liberty County: Brace, 413.

Drainage changes. See also Glacial geology; Physiographic geology (general).

Alaska: Tuck, 4177.

Appalachian drainage: Meyerhoff, 2689. 2692.

Appalachian mountain sculpture: Ashley, 107.

Appalachians, southern: Wright, 4625.

California, Perris block, Elsinore quadrangle: Dudley, 1086.

Des Moines River, deglaciation effects on : Keyes, 2157.

Forests, submerged, Columbla River gorge : Lawrence, 2354.

Idaho, Grimes Creek, Payette Canyon: Anderson, 61.

Snake River springs and alcoves, origin: Stearns, 3853.

Louisiana, Bayou Manchac: Kniffen, 2232.

Michigan, glacial Lake Mogodore, Cass County : Case, 691.

Huron River, abandoned channels : Bay, 243.

Minnesota, Minneapolis-St. Paul metropolitan area: Schwartz, 3597.

St. Croix River, Pleistocene : Sardeson, 3510 .

Mississippi River, Cenozoic history: 'Trowbridge, 4171.

Missouri, nortbwest, preglacial drainage: Greene, 1514.

New Mexico, upper Rio Puerco: Bryan, 525.

New York, Genesee Valley: Fairchild, 1211.

Hudson gorge in Highlands : Thompson, 4096.

Kaaterskill piracy, 1934: Cressey, 896.

Ohio, Mohican Forest Park: Ver Steeg, 4284.

Scioto Valley: Rich, 3267.

Southern : Braun, 450.

Wostern, preglacial physiography : Ver Steeg, 4283, 4285.

Ohio, Kentucky, and West Virginia: Cole, 805.

Ontario, origin of watercourses near French River: Quirke, 3159.

Pediments, formation: Bryan, 523. 
Drainage changes--Continued.

Pennsylvania, eastern region: Miller, 2727.

Texas, trans-Pecos, structural features: King, 2211.

Utah, Monument Valley-Navajo Mountain region: Baker, 144.

Uinta Mountains, north flank: Bradley, 426 .

Washington, Columbia River course, Miocene: Chappell, 738.

Grand Coulee : Fernquist, 1239.

Mount Rainier National Park: Coombs, 856.

Southern Cascades: Treasher, 4159.

Drift deposits. See Glacial geology; Ice ages (ancient) ; Drumlins.

Dunes.

Dune sands, wind-blown soils, Mississippi Basin : Cobb, $\mathbf{7 8 9}$.

Florida, east coast: Sayles, 3522.

Michigan, Grand Sable dunes, Lake Superior, Alger County : Bergquist, 288.

Parabolic, wind-rift and longitudinal : Melton, 2657.

Dunite intrusion, and olivine: Bowen, 388 .

Dust falls and storms : Throckmorton, 4121.

Cause and remedy: Throckmorton, 4121.

In the Southwest: Boon, 368 .

November 1933-May 1934; Mattice, 2616.

Loulsiana, mineral composition : Russell, 3439 .

Plains area, southwestern: Choun, 750.

United States, April 1936: Martin, 2588.

May 1936: Martin, 2589.

June 1936: Kohler, 2248: Martin, 2590.

Dynamic geology. See Physical geology.

Eurth.

Gencral : Bradley, 420.

Age.

Cyrtolite, analysis : Muench, 2817, 2819.

From sedimentation: Louderback, 2454.

General : Rowley, 3390 ; Whitney, 4469.

Geological ages: Ward, 4333.

Helium method, pre-Cambrian : Urry, 4243,4245 .

Keweenawan, age by helium method: Lane, 2323.

Lead, radiogenic, isotoplc constitution: Rose, 3356.

Plant distribution as guide to age determination: Chaney, 730.

Post-Keweenawan, age by helium method : Urry, 4246.

Radioactive disintegration calculations: Evans, 1193.

Radioactivity methods of determination: Fowler, 1320.

Rudidium accumulation : Whitney, 4468, 4470 .

Sedimentation: Louderback, 2454.
Earth-Continued.

Age-Continued.

Sierra Nevada granodiorite, Calıfornla : Urry, 4244.

Temperature changes: Gutenberg, 1582.

Traps, age by helium method: Lane, 2320.

Crust.

Bending, due to Boulder Dam construction: Anonymous, 4675.

Continents, stratigraphic evidence on tectonics: Moore, 2792.

Deformations, gradual type: Gutenberg, 1577.

Paleozolc: Moore, 2787.

Earthquakes, deep-focus, and earth strength : Leith, 2388 ; 'Lhom, 4081.

Elevation and depression, crustal, causes: De Lury, 1023.

Energy sources of movements : HeIm, 1688.

General : Daly, 965.

Intrusions, magmatic: Miller, 2726.

Law of symmetry in development: Fourmarier, 1315.

Motion, compressional phase, deep-focus earthquakes: Sharpe, 3650 .

Movements, vertical, determined by leveling: Bowie, 404.

Oklahoma, Ouachita Mountains, crustal movement: Knechtel, 2229.

Periodicity in epeirogenic movements: Born, 374.

Radioactivity : Evans, 1194.

Rock temperatures in deep mines Ontario: Cleland, $\mathbf{7 7 3}$.

"Roots-of-mountains" theory : Longwell, 2443.

Stability of earth's surface : Bowle, 393.

Strength of the earth: Daly, 987.

Structure: Macelwane, 2515.

Indicated by seismologic data: Gutenberg, 1578, 1584; Macelwane, 2515.

Structure and continental spreading: Gutenberg, 1589.

Thermal distortion and deformation: De Lury, 1029.

Warping in United States: Glennle, 1445.

Interior.

General : Daly, 965

Structure, seismologic evidence: Hodgson, 1767 .

Temperature.

Bore-hole investigations, Yellowstone Park : Fenner, 1223.

Deductions from geothermal evidence : De Lury, 1024, 1.028.

Drill holes, thermometric measurements : Leonardon, 2398.

Geothermal gradients, diverse, concomitants: De Lury, 1026.

Normal, United States: Lane, 2318 United States: Van Orstrand, 4264.

Heat conduction, dissimilar rocks : Lovering, 2470.

Michigan, copper mines, Lake Superior: Kraskovsky, 2257. 
Earth-Continued.

Temperature-Continued.

Radioactivity and geothermal gradients: De Lury, 1025.

Rock temperatures and depths: Spicer, 3805 .

Succession of minerals and temperatures of formation: Lindgren, 2421.

Earth figure: Lambert, 2297.

Earth movements. See Changes of level; Landslides.

Earth physics and geographical papers: Fleming, 1280.

Earthquạkes, Córdova, 874; Heck, 1677 ; Leet, 2370; Macelwane, 2519; Scott, 3609; Wimmer, 4560. See also Seismology.

Action: Macelwane, 2513.

Appalachian Mountain region: Heck, 1670.

Belts, relation to submarine topography : Heck, 1681.

Brunner focal depth-time-distance chart: Brunner, 512.

California, April 15, 1928 : Dyk, 1103.

April 1, 1934-December 31, 1935 : Byerly, 615.

Investigations, 1934-35; Heck, 1678.

Registration: Byerly, 604, 607, 610, $612,613,614,616,617,618$; Wilson, $4540,4541$.

Southern: Wood, 4584.

Southern, effect of moon on: Allen, 41.

Strong earthquake motions: Heck, 1675.

Strong-motion program: Ulrich, 4217.

Characteristics, deep-focus: Brunner, 513.

Colorado Delta : Fox, 1321.

Correlation, occurrence of deep- and shallow-focus : Landsburg, 2314.

Deep-focus : Gutenberg, 1588; Stechschulte, 3859 ; Thom, 4081.

And earth strength: Leith, 2388.

And moon phases: Stetson, 3886 .

Deductions from: De Lury, 1022.

Geological significance: Leith, 2389.

June 29, 1934 : Stechschulte, 3858.

Seismograms, approximation: Sohon, 3787.

Distribution: Heck, 1669 ; Lynch, 2489. April 1935-March 1936: Eickelberg, 1151.

Epicenter work: Bodle, 358.

Eureka, Calif., June 6, 1932 : Sparks, 3796.

Excelsior Mountains, Nevada, January 30, 1934 : Callaghan, 627.

Fall of columns: Clements, 777.

Georgia, January 1, 1935: Crickmay, 902 .

Grand Canyon, Arizona, January 4, 1936 : Donald, 1056.

Hawaii, Kilauea, 1934 eruption : Jones, 1997.
Earthquakes-Continued.

Hawaiian travel times: Jones, 1996.

Helena, Montana: Scott, 3586; Ulrich, 4221.

Diurnal variation: Lansberg, 2317.

Epicenter : Scott, 3587.

Illinois, southern, October 29, 1934 : Dahm, 950.

Intensities on different floors of houses: Landsberg, 2315.

Isostasy and deep-focus earthquakes: Stechschulte, 3857 ; Thom, 4078.

Jamaica : Brennan, 452.

June 24, 1935 : Blum, 352.

Kelly Well, Nevada, December 20, 1932 : Wilson, 4542.

Long Beach, Calif., strong-motion records : Heck, 1664, 1665.

Velocities $\mathbf{P}$ and $\mathbf{S}$ waves: Dahm, 951.

Magnitude and energy: Gutenberg, 1585.

Magnitude scale, instrumental : Richter, 3290.

Mexico, Valley of: Salazar Salinas, 3475.

Missouri : Bradford, 418.

Montana, 1935: Anonymous, 4682.

Helena region, 1935 : Scott, 3610.

October 18, 1935 : Heck, 1676.

Moon phases and deep-focus earthquakes : Stetson, 3886.

Motion, compressional phase, deepfocus: Sharpe, 3650.

Nebraska, March 1, 1935: Lugn, 2479.

Nevada, Cedar Mountain, December 20, 1932: Byerly, 605; Ginanella, 1414.

New England, 1934-35: Collins, 808.

Niles and Parkfield, Calif., May 16, 1933, June 7, 1934: Byerly, 608.

Ontario, November 1, 1935, Ottawa : Hodgson, 1770.

Oregon: Hodge, 1760.

Origin, genetic. system: Landsberg, 2316.

Pacific region, northeast, earthquake service: Heck, 1666.

Panama, November 30,1935 : Bodle, 357.

Parkfield, Calif., June 7, 1934 : Byerly, 608 ; Wilson, 4542.

Predictions: Lansberg, 2313; Wood, 4585.

Provincetown, Mass., April 23, 1933 : Leet, 2371.

Recording strong motions: Heck, 1667.

Rhode Island, November 3, 1913 : Brown, 479.

Rodney, Mo., August 20, 1934 : Bradford, 416 .

Seaquake, Hawaii: Brown. 478.

Seismologic research, southern California: Wood, 4583.

Teleseismic recording in Iowa: Seeburger, 3631. 
Earthquakes-Continued.

Texas-Oklahoma, April 11, 1934 : Sellards, 3640 .

Timiskaming, Quebec, November 1, 1935 : Anonymous, 4715 ; Hodgson, $1769,: 1771$.

United States, 1933 : Neumann, 2848. 1934: Neumann, 2850.

Utah, effects on ground-water Ievels: Taylor, 4026.

March 24, 1934 : Shenon, 3662.

Water level in wells, effect on: Blanchard, 345.

Wells, artesian, records of : Leggette, 237 J.

Young Harris, Georgia, January 1, 1935 : : Orickmay, 904.

Earth resistivity and geological structure: Card, 679.

Earth tides: Wycoff, 4634.

Echinodermata. See also Asteroidea; Blastọidea ; Crinoidea ; Echinoidea ; Invertebrates (general).

Astrodapsis, Miocene, California: Richards, 3276.

Auluroid, Ordovician, Califor n i a : Phleger, 3079.

Clypeaster pinarensis, Oligocene, Cuba: Lambert, 2294.

Georges Bank, Upper Cretaceous : Stephenson, 3878.

Lumbricaria, holothuroid casting, Washington : Fenton, 1224.

Mexico, Cretaceous, San Louis Potosi: Lambert, 2295.

Report on fossil echinoderms : Jackson, $1923,1924$.

Texas, Midway group : Gardner, 1382.

Echinoidea.

Cretaccous, trans-Fecos Texas: Smiser, 3744.

Mexico, Cretaceous: Müllerried, 2812.

Pedicellariae, Carboniferous, T e $x$ a s, Illinois, Missouri: Geis, 1401.

Trinidad, Northern Range: Trechmann, 4161.

Ecology of sand arens: Twenhofel, 4193.

Economic geology (general). For areal see under the various States. See also Ore deposits, origin, and the particular products: Fitzhugh, 1277; Hewett, 1733 ; Ries, 3300.

Bentonites: Maynard, 2623; Silica Products Co., 3710.

Bibliography, annotated: Nickles, 2874, $2875,2876,2877,2878,2879,2880$, 2881.

Bleaching clays: Nutting, 2926.

Boulder Dam area mineral occurrences: Lee, 2367.

Carbonates in veins: Charlewood, 739.

Chalcocite - stromeyerite-argentite, relations: Schwartz, 3595.
Economic geology (general)-Continued.

Clay : Parmelee, 3017 ; Ries, 3299.

Ceramic, mineral constitution: Grim, 1550.

Fire, distribution in U. S.: Chelịkowsky, 743 .

Shales, weathering: Hind, 1774.

Coal and oil, evolution: White, 4451.

Contour method, mapping ore bodies: Conolly, 841 .

Copper, North America : Ransome, 3179.

World resources: Bayley, 245.

Copper industry, development : Fùrness, 1367.

Criteria, gold-quartz mines: Anderson, 69.

Deep-well drilling: Heald, 1663.

Degree of reduction and volatility, source beds: Trask, 4151.

Domes, fracture systems : Balk, 160.

Earths, physical properties: Griffith, 1539.

Electrical mapping, oil structures: Jakosky, 1929.

Electrical prospecting: Randolph, $\mathbf{3 1 7 3}$.

Epithermal . precious-metal deposits : Nolan, 2904.

Exploring down : Kelly, 2065.

Feldspars: Parmelee, 3016.

Fluid phenomena, porous strata: Boatright, 353.

Fluorescence of oil sands, correlation ald : Melhase, 2647.

Foraminifera as guide fossils: Ellis, 1169.

Geologic formations, relation to road materials : Runner, 3419.

Geology, application to ore finding: Parker, 3011.

Geomorphology, Gulf coast salt structures: Ritz, 3309 .

Geothermal gradient, United States: Van Orstrand, 4264.

Gold placers, prospecting: Storms, 3945 .

Government surveys and mining industry: Sales, $\mathbf{3 4 7 7}$.

Gravel channels, buried, location: Crampton, 892.

Gulf border salt deposits, origin : Russell, 3445 .

Gulf coast, deep oil reserve : Mills, 2740. Oil flelds: Barton, 209.

Hydrocarbons, extraterrestrial, and pe. troleum genesis: Van Tuyl, 4267.

Iron, native, and alloys: Buddhue, 538.

Iron ores of U. S. : Cooke, 854.

Lead and zinc resources, western United States: Loughlin, 2457.

Liquid inclusions: Yuster, 4641.

Magnetic surveying: Royce, 3398.

Manganese, solution, transportation and precipitation: Savage, 3516.

Mechanics of metasomatism: Bain, 138.

Metalliferous 'deposits, southwestern United States and northern Mexico : Schmitt, $\mathbf{3 5 6 5}$. 
Economic geology (general)-Continued. Metamorphism, organic sediments and derived oils: White, 4453.

Micromagnetic surveys : Jenny, 1946.

Mineral deposits: Graton, 1503; Lilley, 2415.

Mineral industry, development: Loughlin, 2458.

Mineral veins, origin: Behre, 258.

Minerals, conservation : Leith, 2391.

Mississippi Valley type ores, origin : Graton, 1500.

Molding sands, durability : Casberg, 690.

Naphthene and methane oils, occurrence and origin: Hlauscheck, 1753.

Natural gas: De Golyer, 1007.

Possibilities, east of Appalachian region: Postley, 3109.

Nickel, development and use: Stanley, 3821.

Oil fields, distribution, and continental spreading: Wade, 4300.

Oil wells, economic spacing: Cheney, 745.

Ore bodies, localization: Bruce, 504.

Ore deposits, outcrops: Eby, 1123.

Succession of minerals: Lindgren, 2421.

Western States: Graton, 1502.

Paleontology, importance in Gulf coast drilling: Mills, 2738.

Permeability measurements wit hou t cores: Ryder, $\mathbf{3 4 6 5}$.

Petroleum, development in America: White, 4452.

Exploration for: Rosaire, 3353.

Formation, time: Van Tuyl, 4271.

Genesis : Van Tuyl, 4266.

Geology, problems: Ver Wiebe, 4287.

Geophysical prospecting for: De Golyer, 1006.

Migration: Barton, 212.

Origin: Barton, 213.

Permeability measurements: Clough, 785.

Pool development: Lahee, 2287.

Probable shortage: Snider, 3782.

Production practice: Wrather, 4620.

Reserves: Pew, 3070.

Reserves of the United States: Heroy, 1717.

Stratigraphic vs. structural accumulation: Levorsen, 2404.

Petroleum and coal, evolution: White, 4451.

Photomicrography in oil industry: Sneigr, 3778.

Physical methods, exploration for oil : Shepard, 3666.

Porosity and permeability: Graton, 1501.

Potash : Johnson, 1955.

From polybalite: Ramsdell, $\mathbf{3 1 7 0}$.

Pressure phenomena in oil fields : Clark, 769.

Raw materials, Pacific coast iron industry : Hodge, 1761.
Economic geology (general)-Continued

Reserves, method of estimation : Huntington, 1892.

Resistivity methods for stone and gravel deposist : Kurtenacker, 2282.

Road metals, search for: Wilcox, 4479.

Sabine uplift importance: Easton, 1115.

Salt domes, Gulf coast : Brown, 488.

Selsmographs, prospecting: Leet, 2372.

Structural geology and economic deposits : Gilluly, 1432 ; Stark, 3835.

Tectonic position of Rocky Mountain ore districts: Billingsley, 322.

Tertiary faunas: Dunbar, 1093.

Texas, Corpus Christi basin, waters: Price, 3135.

Tri-State zinc and lead ores: Ridge, 3295.

Value of, in cement manufacture: Miller, 2716.

Waters, magmatic and meteoric: Lindgren, 2418.

Economic geology of mineral deposits: Lilley, 2415.

Educational. See also Textbooks.

Doctorates in science, 1932-33: Hull, 1882.

Experimental mine, Idaho Springs, Colo. : Read, 3209.

Geological education: Swartz, 3988.

Surveys, public geological, and geological education : Butler, 590; Short, 3694.

Elastic properties of rocks: Ide, 1903.

Elevation and subsidence. See Changes of level.

Elongation in deformed rocks: Fairbairn, 1209.

Emery, Peekskill region, N. Y.: Butler, 595.

Endothermic reactions and heat of radioactive disintegration: Lovering, 2468.

Energy sources, crustal movements: Helm, 1688.

Engineering geology: Ries 3300; Runner, 3423.

Bridge sites: Morse, 2809.

Criteria, gold-quartz mines: Anderson, 69.

Deep-well drilling: Heald, 1663.

Earthquake action: Macelwane, 2513.

Gorges, buried, in Mississippl drainage system : Glen, 1444.

Oil production and petroleum engineering: Scott, 3611.

Strike and pitch, intersecting formations, formula: Weir, 4380.

Tennessee Valley Authority region: Eckel, 1128.

Water conservation, relation of geology and engineering: Bartlett, 200.

Enrichment. See Ore deposits, origin.

Environment, early vertebrates: Romer, 3346 . 
Eocene. See Tertiary.

Eolian sands: McCarthy, 2498.

Ep-Archean and Ep-Algonkian intervals: Hinds, 1749 .

Equus. See Mammalia.

Erosion. See also Floods; Sedimentation. Accelerated : Lowdermilk, 2473.

Appalachians, southern: Wright, 4625. Arizona. Ajo region pediments: Gilluly, 1433.

Bajada placers: Werber, 4419.

Grand Canyon, stream fluting and erosion: Maxson, 2621.

Rio de Flag arroyo: Brady, 433.

Assiniboine great sedimentation cycle: Keyes, 2170.

Basin Range hypothesis: Keyes, 2116.

Beach studies: Barden, 180.

Bibliography, soil erosion: Wleland, 4476.

California, beaches: O'Brien, 2932.

Montrose, alluvial fan flooding: Chawner, 742.

Perris block, Elsinore quadrangle: Dudley, 1086.

River action, San Gabriel Mountains : Louderback, 2453.

Unsymmetrical channels, San Francisco : Rode, 3330.

Canyons, soll and summer-fallow cultivation: Thomson, 4113

Continents and oceans, origin: Bowle, 399.

Cyclic and noncyclic: Fenneman, 1219.

Denudation, desert-rainfall factor : Russell, 3443.

Desert cliff recession, lateral regional planation: Glock, 1449.

Dust-bowl area: Anonymous, 4704.

Dust storms: Throckmorton, 4121.

Flood control: Eakin, 1104.

Flood erosion: Engeln, von, 1182.

Geomorphology, mountainous deserts : Davis, 986.

Georgia : Crickmay, 906.

Hawall, chink-faceted pebbles: Wentworth, 4410.

Hydrologic and hydrographic investigations: Piper, 3089.

Idaho, snowdrifts and Palouse topography : Rockie, 3329.

Limestones, development of porosity: Howard, 1830.

Littoral drift: Hennebique, 1710.

Massachusetts, marine erosion, glacial deposits, Massachusetts Bay: Stetson, 3888.

Mexico, desert floods, Sonoyta Valley: Ives, 1918.

Missouri, striated rock surfaces, St. Francis River -Valley: Wentworth, 4403.

Mounds, soil, origin: Melton, 2654.

Nebraska land conservation: Condra, 836.
Erosion-Continued.

New York, Hudson River Valley: Morris, 2800.

Ohio, Hocking County State parks : Ver Steeg, 4278.

Pediments, formation: Bryan, 523.

Granite Gap, N. Mex. : Bryan, 524.

Peneplain, inland phases: Van Tuyl, 4270.

Peneplains : Keyes, 2147.

Pennsylvania floods, March 1936 : Anonymous, 4686.

Rip currents : Shepard, 3683.

Rock fans and pediments, origin and evolution: Rich, 3268.

Rocky Mountains and Great Plains, cycles : Lugn, 2481, 2482, 2483.

Run-off and erosion, comparisons : Weaver, 4370.

Scour, sandy river bed, experiments: Wright, 4621.

Silt problem: Stevens, 3894

Silting of reservoirs: Eakin, 1106.

SIumping and gully formation: Mitchell, 2755.

Soil erosion: U. S. Soil Cons. Service, 4240.

South Dakota, central Black Hills : Work, 4616.

Streams, flood-plain: Melton, 2660.

Talsekwe River, Taku district, British Columbia and Alaska: Kerr, 2074.

Transportation of silt by streams: O'Brien, 2931.

United States: Boesch, 362.

Utab, southern: Bailey, 130.

Uinta Mountains erosion surfaces: Bradley, 426.

Virginia, Natural Bridge and Natural Tunnel: Woodward, 4612.

Washington, Palouse topography and stream history: Thomson, 4112.

Wyoming, Wind River Range: Atwood, 118.

Erosion and flood control: Eakin, 1104.

Eruptlve rocks. See Igneous and volcanic rocks.

Essays. See Addresses.

Eurypterida.

Eurypterus (Stylonurus?) maccarthyl, Devonian, New York : Kjellesvig, 2225.

New York, Berne quadrangle: Goldring, 1463

Ordovician, Labrador: Little, 2426.

Pterygotus, Devonlan, New York and Montana : Ruedemann, 3404.

Strobilopterus princetonii for Pterygo. tus princetonil : Ruedemann, 3407 .

Wyoming, Beartooth Butte, Devonian: Ruedemann, 3407.

European and North American mountain systems : Suess, $\mathbf{3 9 7 5}$.

Eutopotropism : Lane, 2330. 
Evaporation, high altitudes and latitudes: Church, 752.

Evolution: Ashley, 110.

Antilocapra americana, a n cestr y : Hesse, 1729.

Artbropoda, segmentation: Reynolds, 3259.

Terrestrial : Tillward, 4130.

Elasmotheres: Wood, 4588.

Eohippus tooth compared to Hyracotherium tooth: Friant, 1341.

Factors in fossil series: Fenton, 1229.

Fish to man: Gregory, 1523.

Heteromyid rodents, Tertiary, western North America: Wood, 4573.

Irreversibility : Gregory, 1535.

Mammals : Scott, 3613.

New Hampshire, White Mountain magma series: Chapman, 733 .

Pelecypoda : Schenck, 3551.

Pelvis, from fish to man: Gregory, 1527.

Proboscidea : Osborn, 2961.

Ancestral tree: Osborn, 2957.

Reef corals, Cenozoic: Gerth, 1407.

Skulls, vertebrates: Gregory, 1525.

Vertebrata, skulls : Gregory, 1528.

Evolution and the moral order : Ashley, 105.

Excursions.

Angeles Crest highway, California: Van Amringe, 4251.

Geologic trips in Pennsylvania : Willard, 4492.

Kansas Geological Society 9th field con. ference : Ball, 167.

New England Intercollegiate field trip, 1936: Fisher, 1274; geologic excursion: Perkins, 3053.

New York: Marelli, 2581.

Pennsylvania geologists, 2d annual field conference: Willard, 4483.

3d annual field conference: Willard, 4484.

4th annual field conference: Willard, 4485.

5th annual field conference: Willard, 4493.

Tri-States geologica! field conference, 3d, Upper Mississippi Valley: Trowbridge, 4174.

Experimental investigations.

Agates, possible method of formation: Cahen, 622.

Albite-fayalite system: Bowen, 389.

California, maghemite and ferric oxides: Newhouse, 2864.

Chalcocite-stromeyerite-argentite, r e I ations : Schwartz, 3695.

Clastic sediments, porosity and permeability: Fraser, 1331; Muskat, 2838.

Clay shales, weathering: Hind, 1744.

Colloids, clay, cause of bedding: Keller, 2044.
Experimental investigations-Continued.

Compressibility, measurement at bigh pressures and temperatures: Birch, 323.

Rocks and glasses, high temperatures and pressures: Birch, 324.

Copper, pyritic deposits, mesothermal type, origin : Kania, 2019.

Crystal growth and solution under local : stress: Russell, 3426.

Deformation of rocks, high confining pressures : Griggs, 1544.

Determination of saturation of oil sands: Hillis, 1741.

Earthquake, man-made: Uirich, 4219.

Elastic properties of rocks: Ide, 1903.

Equilibrium relationships, iron and oxygen : 'Greig, 1536.

Erosion, sandy river: bedı: Wright, 4621.

Exfoliation of rocks, fatigue factor: Griggs, 1545.

Fall of columns in earthquakes : Clements, 777.

Fractures, formation in clay cake: Wisser, 4567.

Gold, hydrothermal experiments : Ogryzlo, 2940.

Solubility, and geologic application: Milner, 2741.

Heat conduction, dissimilar rocks : Lovering, 2470.

Igneous rocks and high temperature: Bowen, 386.

Lead and zinc minerals, hydrothermal experiments : Kristofferson, 2264.

Limestones, development of porosity : Howard, 1830.

Magmatic stoping: Grout, 1556.

Manganese minerals, hydrothermal oxidation: Trengove, 4167.

Mine, Colorado School of Mines : Read, 3209.

Minerals and superheated water: Crowley, 926.

Minerals determined by microchemical methods: Staples, 3828.

Molding sands, durability : Casberg, 690.

Montmorillonite to feldspar, hydrothermal alteration : Gruner, 1564.

Oil sands, Gulf coast, characteristics : Halbouty, 1602.

Ore shoots: Douglas, 1075, 1076.

Origin of petroleum: Stadnichenko, 3812 .

Porosity and permeability: Graton, 1501.

Propagation, elastic waves in limestone: Ewing, 1196.

Pyrite oxidation: Bain, 135.

Quarry blasting, observations : Ewing, 1195.

Quartz-cristobalite, temperature of conversion: Cole, 804.

Reflection seismology: Hollister, 1781. 
Experimental investigations-Continued.

Richmond, Calif., quarry blast, August 16, 1934: Byerly, 609.

Salt-dome structures: Ritz, 3309 .

Sand, compressibility : Botset, 382.

Sand craters, possible significance: Macqueen, 2563.

Seismograms, from shaking table, reduction: Dyk, 1102.

Serpentine minerals, X-ray and optical investigations: Selfridge, 3635.

Shearing phenomena at high pressure: Bridgman, 458.

Soft-rock deformation : Rettger, 3253.

System $\mathrm{CaO}-\mathrm{MgO}_{\mathrm{SiO}}$, reactions between solidis: Taylor, 4030.

System $\mathrm{MgO}-\mathrm{FeO}-\mathrm{SiO}_{2}$ : Bowen, 385.

Thermal expansion, typical rocks: Griffith, 1540.

Visual presentation, wave patterns: Rieber, 3297.

Well gage as seismograph : Blanchard, 344.

X-ray method to distinguish space groups, hexagonal system: Barnes, 188.

Young's modulus of rocks, determination: Ide, 1902.

Exploring with explosives: Heiland, 1686. Fake methods of geophysical prospecting: Blau; 348.

Faulting.

Alabama, Erin shale, structure: Park, 3008.

Alberta, foothills structures: Link, 2422.

Turner Valley gas and oil field: Hume, 1883.

Wildcat Hills area, west half : Hume, 1884.

Appalachian geosyncline: Ver Wiebe, 4288.

Arizona, El Pichacho, fault-faced Basin Range : Keyes, 2111.

Arizona and Nevada, Boulder Reservoir floor : Longwell, 2445.

Arkansas, cinnabar deposits: Stearn, 3846.

Northern: McKnight, 2552.

Basin Range hypothesis: Keyes, 2116.

British Columbia, Bralorne mine: Joralemon, 2013.

Bralorne mine area: Hedley, 1685.

Fiord-land: Peacock, 3035.

Hidden Creek ore bodies: Nelson, 2845.

Yale district: Horwood, 1799.

California, Cuyama fault: Gregersen, 1521.

Death Valley National Monument: 。 Anonymous, 4664.

Kern Canyon, southern Sierra Nevada: Webb, 4374.

Kettleman Hills : Fill, 1740.
Faulting-Continued.

California-Continued.

Los Angeles Basin, seismic reflection profile: Gutenberg, 1580.

Mount Diablo and Coalinga areas: Clark, 755 .

Reverse movements along faults: Erwin, 1188.

Mount Diablo and vicinity: Taff, 4005.

Mylonites from San Andreas fault zone: Waters; 4357.

Panamint Mountains, valleys : Davis, 985.

Peninsular Range: Miller, 2728, 2730.

Perris block, Elsinore quadrangle: Dudley, 1086.

Petaluma district: Morse, 2806.

Pinnacles National Monument: Andrews, 74.

Southern: Ashauer, 98: Reed, 3231. Chaleur Bay: region, Quebec and New Brunswick: Alcock, 12.

Colorado, Aspen district: Vanderwilt, 4262.

Columbia and Dew Drop vein systems, Boulder County: Walker, 4318.

Continental Divide region: Behre, 257.

Cripple Creek district: Loughlin, 2459.

Front Range area : Lovering, 2469.

London fault: Singewald, 3731.

Ore deposition south of Ouray: Moehlman, 2760.

San Juan region: Burbank, 571; Cross, 925.

Sawatch Range: Stark, 3829.

Tomichl dome: Stark, 3833.

Cuba : Schürmann, 3589.

Domes, structure elements: Balk, 160.

Epithermal precious-metal deposits : Nolan, 2904.

Fault movement, rate, Great Basin Province: Blackwelder, 333.

Flaws and tear faults: Gill, 1426.

Glaciers, Mount Crillon district, Alas$\mathrm{ka}$ : Washburn, 4355.

Greenland: Koch, 2245.

Scoresby Bay area: Bentham, 281.

Sulbmarine, along continental border: HoltedahI, 1787.

Ymer Island: Cleaves, 772.

Idaho, batholith : Ross, 3376 .

Inertia in low-angle thrust faulting: Stevens, 3893.

Kansas, fault-block structures: Rich, 3270 .

Kentucky, Harlan County coal flelds: Jones, 2000.

Manitoba, Missi series, Flinflon: Ambrose, 58.

Mechanics of : Hulin, 1881.

Mexico, Cananea Mountains, Sonora: Valentine, 4247.

$311-37-24$ 
Faulting-Continued.

Mexico-Continued.

Coahuila Peninsula: Kellum, 2057.

Cusihuiriachic, Chihuahua: Donald, 1057.

Mountains bordering Acatita and Las Delicias valleys, Coahuila Peninsula : Kelly, 2068.

Northeastern, Eocene: Kane, 2017. .

Pachuca silver district: Wisser, 4567.

Slerra de Parras, Coahuila Peninsula: Imlay, 1905.

Minnesota, Ogishkemuncie Lake region: Sleight, 3740 .

Missouri, southeastern: Tarr, 4020.

Montana, Beartooth Mountains: Perry, 3057.

Butte mining district: Hart, 1647.

Idaho batholith, northeastern part: Langton, 2337.

Nye-Bowler lineament, Stillwater and Carbon Counties: Wilson, 4535.

Western : Pardee, 3005.

Nevada, central Humboldt Range: Jenney, 1943.

Chief district, Lincoln County: Callaghan, 629.

Pleasant Valley : Page, 2981.

Silver Dyke area: Kerr, 2086.

Tonopah mining district: Nolan, 2907.

Tuscarora mining district, Elko County : Nolan, 2908.

West - central, Jurassic: Ferguson, 1236.

Newfoundland, Bay of Exploits area : Heyl, 1736.

Bay of Islands igneous complex : Cooper, 869.

New Hampshire, Littleton and Moosilauke quadrangles; thrust fuults : Billings, 318.

New Mexico, Bayard area : Lasky, 2344. Mount Taylor coal field : Hunt, 1888. Organ Mountains and Doña Ana County: Dunham, 1094.

Santa Rita and Tyrone districts: Paige, 2982.

New York, Dutchess County : Balk, 162.

Mohawk Valley : Megathlin, 2629.

Normal and reverse faults: Gill, 1425.

North Carolina, Morgan Creek Dam area: Prouty, 3139.

Northwest Territories, Rae to Great Bear Lake, Mackenzie district: Kidd, 2191.

Oklahoma, Fitts pool, Pontotoc County : Hyatt, 1901.

Oil field, en échelon faults: Hiestand, 1737.

Ouachita Mountains, crustal move'ment: Knechtel, 2229.

Pennsylvanian: Cram, 889.

Ontario, belt Manitou Lake-Lake of the Woods: Thomson, 4111.

East Bay, Minnitaki Lake, Kenora district: Pettijohn, 3067.
Faulting-Continued.

Ontario-Continued.

Hollinger gold mine: Ringsleben, 3306.

Lake Shore mine area: Robson, 3328. Porcupine area: Hurst, 1899.

Savant Lake area: Rittenhouse, 3308. Vermilion Township, Kenora district: Pettijohn, 3065.

Oregon, Cascade Mountains, North Santiam River section: Thayer, 4061.

Overthrust faults, investigation by seismic methods: Buwalda, 601 .

Overthrusts in metamorphic terranes: Knopf, 2240.

Pennsylvania, Conemaugh formation: Ross, 3377.

Eastern region: Miller, 2717.

Farmington gas field: Sanders, 3489.

Reading overthrust: Stose, 3947.

Quebec, Cadillac belt, Pandora to Pan Canadian : Gunning, 1573.

Chibougamau Lake area: Mawdsley, 2617.

Labelle-L'Annonciation a rea : Osborne, 2963.

Malartic gold mine area, Abitibi : O'Neill, 2954.

Osisko Lake area: Conolly, 840.

Pre-Cambrian tectonic features, Chibougamau district: Norman, 2914.

Siscoe gold mine aréa : Backman, 128.

Thetford district: Cooke, 852.

Saganaga batholith, Minnesota-Ontario: Grout, 1557.

Sierra Nevada pluton, California : Mayo, 2625.

Strain ellipsoid theory of rupture : Griggs, 1542.

Tennessee, Great Smoky thrust fault, Blount and Sevier Counties: Wilson, 4529 .

Nashville dome: Wilson, 4531.

Texas, central, fracture systems: Melton, 2655.

Conroe field: Zavoica, 4643.

East of Pecos River: Sellards, 3638.

Government Wells district: Cooper, 868.

Mexia-Talco zone: Smith, 3749.

Northeast: Hager, 1598.

Palo Pinto County : Plummer, 3098.

Recent movements, Balcones fault system : Bryan, $\mathbf{5 1 4 .}$

Surface fractures:, Barton, 202.

Trans-Pecos: Baker, 145.

Trans-Pecos, structural features: King, 2211.

Uvalde and Medina Counties: Sayre, 3524.

Thrust faults: Willis, 4527.

Trinidad: Lehner, 2381.

Utah, Book Cliffs coal field: Fisher, 1269.

Salt Valley anticline area: Dane, 970.

Southeastern: Baker, 142. 
Faulting-Continued.

Virginia, Eagle Rock, Pulaski overthrust: Woodward, 4611.

Salem block, Pulaski overthrust: Woodward, 4610.

Southwestern, zinc and. lead region Currier, 936.

West Indies: Rutten, 3461.

Wyoming, Permo-Pennsylvanian section, Hartville area: Condra, 834.

Feldspars: Parmelee, 3016.

Boulder Dam area, mineral occurrences : Lee, 2367.

California, anorthite, San Marcos gabbro, San Luis Rey quadrangle: Miller, 2720.

Ceramtc materials other than clays: Burchfiel, 574.

Maine : Trefethen, 4164.

Molecule, possible iron-orthoclase in: Faust, 1216.

Ontario, Renfrew County: Freeman, 1336.

Twinning, Ontario: Chapman, 736.

Felsite, devitrifled dikes, Ascutney Mountain, Vt. : Balk, 163

Field work.

Field photography for geologists : Thwaites, 4126.

Fiords.

British Columbia: Carter, 689.

Fiord-land : Peacock, 3035.

Greenland, east: Boyd, 409.

Mexican coast, possibility of : Sánchez, 3483 .

Fishes. See Pisces.

Fissures. See Faulting.

Floods.

Erosion by: Engeln, von. 1182.

Idaho, Coeur d'Alene flood plain: Humphreys, 1887.

Mexico, desert, Sonoyta Valley: Ives, 1918.

Pennsylvania, March 1936: Anonymous, 4686.

Talsekwe River, Taku district, British Columbia and Alaska: Kerr, 2074.

Floods and dust storms: Meyerhoff, 2691. Florida.

Geological Survey administrative report: Gunter, 1575.

Economic geology.

Mineral production, :1932-33: Gunter, 1576.

Mineral resources : Mansfield, 2567.

Historical geology.

Faunal zones, Miocene Choctawhatchee formation: Mansfleld, 2571.

Suwanneè limestone: Cooke, 848 .

Paleontology.

Crassatellites (Hybolophus?) leonensis, Miocene: Mansfield, 2575.

Eucrassatella mansfleldi, Pliocene : MacNeil, 2560.
Florida---Continued.

Paleontology-Continued.

Fauna, Pleistocene Pamlico, southern Atlantic Coastal Plain: Richards, 3284.

Foraminifera, upper Eocene: Cushman, 941.

Gastropods and schaphopods, Miocene, Alaqua Creek Valley: Mansfleld, 2572.

Mammalian fauna, local and continentail, relationships: Simpson, 3723 .

Mollusca, Alum Bluff Miocene : Gardner, 1383.

Ostracoda, Choctawhatchee Miocene: Howe, 1839.

Ovoviviparous reproduction, Mlocene Turritellidae: Sutton, 3984.

Pectinidae, Tertiary : Rowland, 3389 ; Tucker, 4178.

Tertiary Mollusca, Okeechobee district : Smith, 3761.

Physical geology.

Beach sands: Martens, 2584.

Physiographic geology.

Calcareous shallow-water marine deposits : Thorp, 4128.

Dunes, east coast: Sayles, 3522.

Underground water.

Artesion water, Florida Peninsula: Stringfield, 3969.

Piezometric surface: Stringfield, 3968 .

Canal, effect on water resources: Anonymous, 4688, 4690.

Sea level, effect on ground-water level : Paige, 2983.

Seminole County: Stringfleld, 3967.

Silver Springs affected by ship canal: Sharp, 3647.

Fluorescense: Meyers, 2693.

Calcites, manganiferous : Brown, 496.

Minerals: Slawson, 3737.

Oll sands, correlation ald: Melhase, 2647.

Opal : Dake, 955. .

Fluorescence and phosphorescence, impor tance: Zodac, 4654.

Fluorspar.

British Columbia, Industrial and nonmetallic minerals: Richmond, 3287.

Illinois-Kentucky field: Currier, 939. Folding.

California, Mount Diablo and Coalinga areas, Coast Ranges: Clark, 756.

Southern: Reed, 3231.

Mexico, Coahuila Peninsula, mountains west of Laguna district: Kellum, 2058.

Sierra de Parras, Coahuila Peninsula : Imlay, 1905.

New Hampshire, Franconla quadrangle: Billings, 317 .

Littleton and Moosilaulse quadran. gles: Billings, 318 .

New Ýork, Dutchess County: Balk, 162.

Nomenclature: Straley, 3962. 
Folding--Continued.

Ontario, East Bay, Minnitaki Lake, Kenora district: Pettijohn, 3067.

Tashota-Sturgeon R i $\mathrm{v}$ e $\mathbf{r}$ district: Flaherty, 1278.

Tennessee, Nashville dome: Wilson, 4531.

Utah, southeastern: Baker, 142.

Wyoming, Shoshone River area near Cody : Bucher, 535.

Footprints. See Tracks and trails.

Foraminifera : Cushman, 942.

Bibliography : Cushman, 942.

Bibliography and index, new genera and species, 1932 : Thalmann, 4049.

New genera, species, and varieties, 1933: Thalmann, 4054; 1934: Thalmann, 4055.

Bolivinella, o $11 \mathrm{~g}$ o c e n e, Mississippi : Howe, 1832.

Bulimina, Cretaceous : Cushman, 942.

Eocene: Cushman, 942.

Tertiary: Cushman, 942.

California, Cretaceous: Cushman, 942.

Tertiary: Cushman, 942; San Jose Hills : Ten Eyck, 4039.

Canada, post-Pleistocene fossils, eastern Arctic regions: Nichols, 2871.

Catalogue, illustrated: Ellis, 1168.

Ceratobulimina, Eocene, Texas: Plummer, 3100 .

Chilostomellidae, Cretaceous: Cushman, 942.

Chrysalogomum texanum, Cretaceous, Texas: Cushman, 942.

Contributions from Cushman Laboratory: Cushman, 942.

Correlation, Cambro-Ordovician limestones, Lehigh Valley: Hills, 1742.

Cretaceous and late Tertiary, Georges Bank: Cushman, 944.

Cribrogloborotalia, Eocene, Cuba : Cushman, 942.

Cuba, Eocene: Cushman, 942.

Santa Clara Province, northern : Rutten, 3463; Tertiary and Cretaceous: Rutten, 3462.

Tertiary, Matanzas Bay region: Palmer, 2991.

Dimorphism, Permian fusulines: Dunbar, 1091.

Discocyclina, Eocene, Alabama : Vaughan, 4266.

Ellipsonodosaria, Cretaceous, Texas: Cushman, 942.

Elphidium and related genera: Cushman, 942.

Eocene, Ventura County, California: Cushman, 946.

Flabellina, Cretaceous: Cushman, 942.

Frondicularia, Cretaceous: Cushman, 942.

Fusulinidae, in Permian and Pennsylvanian correlations: Dunbar, 1090.

Pennsylvanian, Black Hills : Thompson, 4100; Oklahoma: Thompson, 4099 .
Foraminifera-Continued.

Fusulinidae in Permian and Pennsylvanian correlations-Continued.

Permian, Ohio: Thompson, 4101.

Fusulinid problems: White, 4459.

Gaviota formation, Tertiary, California : Schenck, 3546.

Georges Bank, Tertialy : Cushman, 942.

Greenland and Labrador, early Cambrian : Howell, 1852.

Guide fossils, Mexico, Tampico region: Muir, 2821.

Gulf coast, Tertiary, Alabama and Mississippi : Hadley, 1594.

Helicolepidina, Eocene, Trinidad: Barker, 181

Helicolepidina nortoni, Eocene, Louisiana: Vaughan, 4275.

Index fossils, correlations by : Nuttall, 2925.

Jackson, Eocene, Texas, Louisiana, and Mississippi : Gravell, 1506.

Jamaica, Miocene: Cushman, 942.

Louisiana, Claiborne tentative foraminiferal zonation: Israelsky, 1912.

Mexico, Eocene : Nuttall, 2923.

Tampico embayment: Barker, 182 ; Index fossils: Nuttall, 2924.

Tertiary : Thalmann, 4053.

Microfauna, Monmouth and Rancocas groups, New Jersey : Jennings, 1944.

Microfossils, Potamides matsoni zone, Loulsiana: Stephenson, 3881.

Mississippl, Tertiary : Cushman, 942.

Nanicella, Devonian, for Endothyra gallowayi : Henbest, 1692.

Navarro-Taylor formations, Texas: Plummer, 3099.

New Jersey, Cretaceous: Cushman, 942.

Nomenclature, subgeneric: Schenck, 3553.

Nonionella cockfieldensis, Eocene, Alabama : Garrett, 1387.

Nonion pizarrensis and Nonionella auris, Miocene, North Carolina: Kjellesvig, 2224.

Operculina and Operculinoides, Tertiary, Mexico and Antigua: Vaughan, 4273.

Orbitoides, Cretaceous, Cuba: Gravell, 1505.

Oregon, western, Eocene: Berthiaume, 304.

Palmula Lea for Flabellina D'Orbigny: Howe, 1844.

Palos Verdes Hills, California: Woodring 4603 .

Pennsylvanian, lower, central Missouri : Bailey, 133.

Petroleum, guide fossils for : Ellis, 1169.

Phylogeny, orbitoidal, Eocene, Mexico: Barker, 183.

Prints of, making : Bakx, 157.

Pyrgaella, Pleistocene, California : Cushman, 942.

Reclassification, Tertiary : Geyn, van de, 1411.

Recovery by flotation: Anonymous, 4684. 
Foraminifera-Continued.

Relationships and ecology, Paleozoic: Cushman, 943.

Robertina, Tertiary: Cushman, 942.

Schwagerina vs. Pseudoschwagerina, Paraschwagerina: Dunbar, 1092.

Siphogenerinoides, Cletaceous, California: Cushman, 942.

Southeastern United States, upper Eocene : Cushman, 941.

Staffella, Pennsylvanian, Oklahoma and Colorado: Thompson, 4098.

Stolon systems, orbitoidal forms : Vaughan, 4274.

Stromatoporoidea, relationships : Parks, 3014.

Synecological studies in: Thalmann, 4056 .

Tennessee, Cretaceous: Cushman, 942.

Texas, Claiborne tentative foraminiferal zonation: Israelsky, 1.012.

Conroe oil fleld index fossils: Gravell, 1507.

Foraminiferal analcite shale: Milton, 2743.

Jackson group : Ellisor, 1171.

Tertiary: Cusbinan, 942.

Textulariidae, Cretaceous: Cushman, 942.

Tertiary, California and Texas: Cushman, 942.

Trinidad Bulimina, Eocene: Cushman, 942.

Tertiary : Geyn, van de, 1411.

Verneuilinidae, Valvulinidae, and Virgulinidae: Cushman, 945.

Vicksburg . group, Vicksburg, Miss. : Mornhinveg, 2799.

Force required to move particles on stream bed : Rubey, 3400 .

Formation names, index: Field, 1249.

Mackenzie River Valley: Kindle, 2201.

Formations. See Geologic formations.

Fossils. See Paleontology.

Fossil forests. See Petrified forests:

Compass of the past: Krystofovich, 2276.

Fulgurites, Atlantic Coastal Plain, Cretaceous : Petty, 3069.

Fuller's earth.

California, Tehachapi : Kerr, 2085.

Ollinois, Olmstead: Grim, 1547.

Mississippi : Bay, 242.

Texas, bleaching clays: Phillips, 3075 .

Fumaroles, Mount Hood, Oreg.: Phillips, 3076.

Fusain, nature and origin: Crickmay, 899.

Galena.

Cyrtolite, analysis: Muench, 2819.

Missouri, Joplin region, fluid inclusions : Smith, 3775 .

Garnet.

California : Melhase, 2644.

New Hampshire, Merrimack County : Conant, 830 .
Garnet-Continued.

New York, Gore Mountain: Rowley, 3392.

Quebec, Labelle-L'Annonciation area: Osborne, 2963.

Trisoctahedral, West Thetford, Quebec: Parsons, 3021.

Gas. See Natural gas.

Gaspe, southeastern : Kindle, 2193.

Gastropoda.

Alaqua Creek Valley, Miocene, Florida : Mansfield, 2572.

Alberta, Milk River Cretaceous : Russell, 3430.

Carboniferous : Kuight, 2235.

Carriacou, West Indies: Trechmann, 4162.

Conodonts possibly gastropods : Loomis, 2451.

Conularia manni, Silurian, Illinois : Roy, 3394.

Conularia kaibabensis, Permian, Arizona: McKee, 2539.

Georges Bank and Banquereau, Nova Scotia, Cretaceous:. Stephenson 3878.

Haliotis elsmerensis, , Pliocene, California: Vokes, 4292.

Helicina vokesi, Eocene, California : Hanna, 1618.

Helisoma ammon, Pleistocene, Colorado: Hender'son, 1705.

Kansas and Oklahoma, Pennsylvanian invertebrates: Newell, 2856.

Mecolitia bermudezi, Pleistocene, Cuba : Clench, 778.

Michigan, southeastern, Dundee limestone: Bassett, 223.

Pennsylvanian, lower, central Missouri : Bailey, 133.

Pleistocene and recent mollusks: Shlmek, 3690 .

Pleurotom arid, Eocene, Oregon: Schenck, 3544.

Protocanites lyoni, Mississippl, Virginia: Miller, 2705.

Turritellidae, Miocene, Florida: Sutton, 3984.

Velates, Eocene, California: Vokes, 4291.

Wisconsin, Guttenberg beds: Ball, 169.

Gems: Clements, 776. See also Precious stones.

Analysis by fluorescence: Ackoff, 2.

Determination of : Martindale 2592.

Georgia : McKinley, 2548.

Idaho : Carpenter, 686

Michigan, chlorastrolite, Isle Royale: Dustin, 1099.

Montana, sapphires: Howard, 1827.

Ohio: Schiefer, 3557.

Topaz, Devil's Head, Colo.: Peacock, 3034.

Genesis of ores. See Ore deposits, origin. 
Geochemistry.

Glauconite from biotite: Galliher, $\mathbf{1 3 7 5}$, 1376.

Potash-rich rocks, origin: Terzagh1, 4043 .

Geodes.

Illinois, ir regular crystallizations in geodes: McKinley, 2547.

Geodesy in geophysical research : Bowie, 406.

Geodetic operations, U. S., 1933-35: Bowie, 401.

Geoid, spheroid, and isostasy: Lambert, 2296.

Geologic climate. See Paleoclimatology.

Geologic formations, tables. See also Historical geology.

Alberta, Battleview anticline, Wainwright area : Hume, 1886.

Foremost-Skiff area: Howells, 1867.

Milk River area : Russell, 3433.

Natural-gas fields: Slipper, 3742.

Northern: Ball, 171.

Antillean-Caribbean region: Schuchert, 3579.

Appalachians, southern, structure : Boesch, 363.

Arizona, Aubrey group : Keyes, 2179.

Chinle shales, Lees Ferry: Lausen, 2351.

Copper districts: Tenney, 4040.

Grand Canyon rim-rocks: Keyes, 2176.

Paleozoic formations: Stoyanow, 3959.

Arkansas, Gulf Coastal Plain: Spooner, 3810 .

Natural-gas fields, interior highlands : Croneis, 918.

Northern: McKnight, 2552.

Atlantic Coastal Plain, Pleistocene Pamlico: Richards, 3284.

British Columbia, Keithley Creek area, Cariboo district: Lang, 2333.

California : Jenkins, 1935.

Buena Vista Hills oil field: Howard, 1828.

Natural gas flelds: Hoots, 1792.

Palos Verdes Hills: Woodring, 4603.

Perris block, Elsinore quadrangle: Dudley, 1086.

South coastal basin : Eckis, 1131.

Southern: Reed, 3241.

Canada: Alcock, 11.

Canadian Shield pre-Cambrian : Brock, 461.

Sudbury series, Canadian Shield : Collins, 816

Western : Goodman, 1473.

Carboniferous, Midcontinent: Kejes, 2181.

Proposed dismemberment: Keyes, 2186.

Chaleur Bay region, Quebec and New Brunswick: Alcock, 12.

Clays, fire, geologic distribution in U. S.: Chelikowsky, $\mathbf{7 4 3 .}$
Geologic formations, tables-Continued.

Colorado, Book Cliffs coal field: Erdmann, 1185.

Calumet iron mine : Behre, 262.

Golden area: Johnson, 1971.

Hiawatha gas fields: Nightingale, 2886.

London fault: Singewald, 3731 .

Mosquito Range, Paleozoic formations: Johnson, 1970.

Natural-gas flelds: Winchester, 4564.

Rocky Mountain National Park Effinger, 1143.

Salt Creek area, Mosquito Range: Gould, 1487.

San Juan region: Burbank, 571; Cross, 925.

South Park: Johnson, 1974.

Cuba, Santa Clara Province, northern: Rutten, 3463.

Eastern Interior coal basin: Bell, 263.

Ep-Archean and Ep-Algonkian intervals: Hinds, 1749

Florida : Stringfield, 3969

Greenland: Koch, 2244, 2245.

East, Gauss Peninsula and Passage Hills : Säve-Søderbergh, 3468.

Northeast: Teichert, 4037.

Idaho, natural-gas fields: Kirkham, 2220.

Illinois, Fernvale formation: Greger, 1519.

Marion and Clay Counties: Weller, 4385.

Illinois Basin : Howard, 1831.

Indiana : Harrell, 1640.

Lima-Indiana district: Ley, 2413.

Iowa : Keyes, 2107.

Chouteau limestone: Keyes, 2122.

Deep wells, 1928-32: Norton, 2920.

Pennsylvanian coals: Young, 4639.

Southern: Wood, 4591.

Kansas, Central uplift: Koester, 2246.

Eastern, natural-gas flelds: Ley, 2411.

Garnet area : Moore, 2790.

Gas fields west of Nemaha granite ridge, except Hugoton district: Garlough, 1385.

Hollow Pool area: Johnston, 1982.

Johnson and Miami Counties: Newell, 2855 .

Northeastern : Ockerman, 2933.

Wyandotte County : Jewett, 1950.

Kentucky, Cincinnati arch region : Bailey, 132.

Louisiana, Jennings salt dome, Acadia Parish: Halbouty, 1601

Monroe gas field: Fergus, 1235.

Post-Fleming coastal surface formations : Doering, 1054.

Richland gas field: Gordon, 1480.

Louisiana and Texas Gulf coast: Deussen, 1033

Maine, Bates limestone, Lewiston : Fisher, 1273

Manitoba, Flin Flon mine: Brownell, 499. 
Geologic formations, tables-Continued.

Mexico, mountains bordering Acatita and Las Delicias Valleys, Coahuila Peninsula : Kelly, 2068.

Tampico region: Muir, 2821.

Michigan, central: Rawlins, 3187.

Granitic sequence, southern complex : Dickey, 1044.

Minnesota, Minneapolis-St. Paul metropolitan area: Schwartz, 3597.

Minnesota River Valley : Couser, 885.

Mississippi : Morse, 2815.

Mississippi, Covington County : George, 1402.

Highland Church sandstone: Morse, 2808.

Vicksburg National Military Park area : Morse, 2810.

Mississippi Valley, upper: Kansas Geol. Soc., 2020 ; Stainbrook, 3835.

Ordovician : Kay, 2029.

Missouri, cross section, Forest City, Mo., to Du Boise, Nebr. : Condra, 833 .

Insoluble residues, correlation: McQueen, 2561.

St. Louis County and City of St. Louis: Gleason, 1443.

Southeast: Farrar, 1215.

Montana, Big Horn Basin gas flelds: Emery, 1174.

Big Horn County and Crow Indian Reservation: Thom, 4074.

Idaho batholith, northeastern part: Langton, 2337.

- Natural-gas flelds : Bartram, 216.

Richey-Lambert coal field: Parker, 3012.

Southeastern : Perry, 3059.

Western : Pardee, 3005; unconiormity : Delss, 1009.

Nebraska, cross section, Du Bois, Nebr., to Forest City, Mo.: Condra, 833 .

Pleistocene: Lugn, 2478.

Scotts Bluff National Monument: Effinger, 1141.

Nebraska and the Dakotas: Wilson, 4543.

Nevada, central Humboldt Range: Jenney, 1943.

S o u the r n, Pennsylvanian-Permian boundary : Longwell, 2444.

New Brunswick, Grand Lake coalfleld: Wright, 4630.

Newfoundland, Bay of Exploits area: Heyl, 1736.

New Mexico, central mining district: Scbmitt, 3566.

Guadalupan series: Keyes, 2134.

Natural-gas fields: Winchester, 4564.

Santa Rita mining area: Spencer, 3803.

Southeastern, natural-gas flelds : Rett( ger, 3254 .

New York, Allegany State Park: Thwaites, 4125.

Berne quadrangle: Goldring, 1463.

Clinton group: Sanford, 3495 .
Genlogic formations, tables-Continued.

New York-Continued.

Eastern, cherts : Ruedemann, 3416.

Natural-gas flelds : Torrey, 4146.

Skaneateles quadrangle: Smith, 3746.

Western, Clinton formation: Sand. ford, 3491.

North Dakota : Anonymous, 4671.

Water-bearing formations: Anonymous, 4670.

Oil sands, Gulf coast, characteristics : Halbouty, 1602.

Oklahoma, Ardmore area, Carbuniferous : Floyd, 1293.

Cambrian-Ordovician boundary, $\Delta r$ buckle limestone, Murray County: Bridge, 457.

Correlation by insoluble residues: Ireland, 1907.

Fitts pool: Dott, 1071.

Seminole pool, Seminole County : Swarts, 3987.

Ontario, Afton-Scholes area: Moore, 2781.

East Bay, Minnitaki Lake, Kenora district: Pettijohn, 3067.

Little Long Lac-Jellicoe area: Bruce, 505.

Makwa-Churchill area : Laird, 2289.

Natural-gas fields : Harkness, 1633.

Porcupine area: Hurst, 1899.

Renfrew County : Freeman, 1336.

Savant Lake area : Rittenhouse, 3308.

Swayze gold aren: Rickaby, 3294.

Vermilion Township, Kenora district: Pettijohn, 3065.

Ozarkian: Kobayashi, 2241.

Pennsylvania, Chester Valley: Miller, 2718.

Lehigh Valley Cambro-Ordovician limestones: Hills, 1742.

Natural-gas flelds: Torrey, 4146.

Oriskany sand: Cathcart, 705 .

Tioga region: Asbley, 100.

Pleistocene, late, marine and glacial deposits, New York and New Jersey: Macclintock, 2504.

Pulsation theory: Grabau, 1489, 1490.

Quebec, Chibougam a Lake area: Mawdsley, 2617.

Despinassy area, Abitibi County : Faessler, 1204.

Lamaque-Sigma mines area, Bourlamaque Township, Abitibi County: Bell, 267.

Mount Megantic region: McGerrigle, 2525.

Natural-gas fields: Snider, 3781.

Pusticamica Lake area, Abitibl district: MacKenzie, 2540.

Sabourin area, Témiscamingue County: Denis, 1031.

Siscoe gold mine area : Backman, 128,

Témiscouata area: McGerrigle, 2524.

Travers Lake area, Témiscamingue County : Retty, 3256.

Western : Bell, 269. 
Geologic formations, tables-Continued.

Sabine uplift, importance: Easton, 1115.

Saskatchewan, Hudson Bay Junction area : McLearn, 2555 .

Lake Athabaska area: Alcock, 15.

Southern, Regina area: Fraser, 1330.

Snake River Valley above Idaho Falls: Debler, 995.

Tennessee, Cincinnati arch region: Bailey, 132.

Nashville dome, Upper Paleozoic development: Wilson, 4534.

South-central: Theis, 4063.

Western : Born, 376.

Texas, Atascosa and Frio Counties: Lonsdale, 2446.

Clay Creek salt dome, Washington County: Ferguson, 1237.

Colorado River Valley, upper Pennsylvanian and lower Permian: Bullard, 566.

Driscoll pool, Duval County: Sheldon, 3658.

Texas, Eocene and Miocene formations, Walker and Gonzales Counties : Renick, 3246.

Greta oil field, Refugio County : Stamey, 3817.

Maverick Coụty: Vanderpool, 4259.

Orange field: Deussen, 1036.

Post-Fleming coastal surface formations: Doering, 1054.

San Antonio area : Livingston, 2429.

Shafter mining district: Ross, 3375 .

Terlingua district: Ross, 3374 .

Underground waters: White, 4461.

Uvalde and Medina Counties: Sayre, 3524.

West, natural gas fields: Rettger, 3254.

Texas and Loulsiana, Gulf Coast: Deussen, 1033.

Rodessa field: Ivy, 1921.

Trinidad: Kugler, 2280 ; Lehner, 2381.

Utah, Book Cliffs coal field: Fisher, 1269.

Gold Hill mining district : Nolan, 2905.

Grand and San Juan Counties: U. S. G. S., 4226.

Monument Valley-Navajo Mountain region: Baker, 144 ; U. S. G. S., 4227.

Moscow silver mines: Johnson, 1964.

Natural-gas fields: Winchester, 4564.

Tintic district: Park, 3006.

Virginia, Shenandoah Valley : Cady, 621.

Southwestern, zinc and lead region: Currier, 936.

Washington, natural-gas fields: Kirkham, 2220.

West Virginia: Sisler, 3736.

Wisconsin, Devonian: Raasch, 3160.

Wyoming, Alcova Dam and reservoir sites, North Platte River, Natrona County : Bradley, 423.
Geologic formations, tables-Continued.

Wyoming-Continued.

Baxter Basin gas fields: Nightingale, 2885.

Big Horn Basin gas fields : Emery, 1174.

Cretaceous, late, and early Tertiary: Nace, 2840.

Frontier-Niabrara contact, Laramie basin: Thomas, 4086 .

Hiawatha gas fields: Nightingale, 2886.

Lost Soldier district gas fields : Tillotson, 4129.

Medicine Bow oil field: McCanne, 2494.

Quadrant formation, Pennsylvanian: Scott, 3608 .

Trout Creek Canyon, Park County : Sheets, 3657 .

Yukon, Carmacks district: Bostock, 379.

Geologic history. See also Paleoclimatology ; Paleogengraphy.

Alaska, Tonsina district: Moflit, 2762.

Antillean-Caribbean region: Schuchert, 3579 .

California, coast : Buwalda, 603 .

Julian district, San Diego County: Donnelly, 1064.

Carboniferous, proposed dismemberment: Keyes, 2186.

Colorado, Book Cliffs coal field: Erdmann, 1185 .

Montezuma quadrangle: Lovering, 2466.

San Juan region. Cross, 925.

Criteria for tops of stratified beds: Belyea, 275.

Helium, nitrogen, carbon dioxide, and hydrogen sulphide gases: Dobbin, 1050.

Idaho, Casto quadrangle : Ross, 3369.

Kansas, Central uplift: Koester, 2246.

Mexico, Coahuila Peninsula: Kellum, 2057.

Mountains bordering Acatita and Las Delicias Valleys, Coahuila Peninsula : Kelly, 2068.

Montana, Big Horn County and Crow Indian Reservation: Thom, 4074.

New Hampshire, Franconia quadrangle: Billings, 317.

Littleton and Moosilauke quadrang!es : Billings, 318 .

New Mexico, San Juan Basin: Sears, 3621.

Oklahoma, Fitts pool, Pontotoc County: Hyatt, 1901.

Pennsylvania, Bellefonte quadrangle: Butts, 59s.

South Carolina, Coastal Plain: Cooke, 847.

Structural geology and economic deposits : Gilluly, 1432 ; Stark, 3835.

Tables : Kelley, 2047.

Tennessee, western: Born, 376. 
Geologic history-Continued.

Utah, Monument Valley-Navajo Mountain region: Baker, 144.

Virginia, James River iron and marble belt: Furcron, 1362.

Geologic maps.

Alabama, Cincinnati arch region: Bailey, 132.

Alaska, Ruby-Kuskokwim region: Mertie, 2681.

Southern Alaska Range: Capps, 677,

Tertiary: Hollick, 1780.

Tonsina district: Moffit, 2762.

Alberta : Calder, 625 .

Battleview anticline, Wainwright area : Hume, 1886.

Canmore area: Canada G. S., 645, 646.

Foothills structures : Link, 2422.

Milk River area: Russell, 3433.

Sounding Creek and Shearness coal areas: Allan, 34.

Turner Valley gas field: Spratt, 3811.

Wildcat Hills area, west balf : Hume, 1884.

Antillean-Caribbean region : Baker, 149 ; Schuchert, 3579.

Appalachian geosyncline: Ver Wiebe, 4288.

Appalachians, southern, structure: Boesch, 363.

Talladega series: Crickmay, 910.

Arizona, copper districts: Tenney, 4040.

Grand Canyon, rim rocks: Keyes, 2176 ; Tonto group : Wheeler, 4446.

Mesa Verde coal formation: Keyes, 2154.

Navajo country: Reagan, 3210.

Navajo-Hopi country, Pliocene: Willjams, 4509.

Silver King area, Superior: Galbraith, 1373.

Southeastern: Keyes, 2120.

Western : Moore, 2778.

Arizona and Nevada, Boulder Reservolr floor: Longwell, 2445.

Arkansas, cinnabar deposits: Stearn, 3846.

Gulf Coastal Plain : Spooner, 3810.

Northern : McKnight, 2552.

Baraboo area, Wisconsin: Leith, 2387.

Barite deposits, Virginia: Edmunson, 1136.

Bartlesville and Burbank sands, Oklahoma and Kansas: U. S. G. S., $4235,4236$.

Boulder Dam region: Fewett, 1735.

British Columbia, Cache Creek Permian series: Crockford, 916.

Cadwallader Creek area, Lillooet district: Canada G. S., 644 .

Cariboo and Bridge River gold fields: Dolmage, 1055.

Cordilleran region: Kerr, 2075.

Fraser River-Harrison Lake region: Horwood, 1800.
Geologic maps-Continued.

British Columbia, Cache Creek Permian series: Crockford, 916-Con.

Keithley Creek area, Cariboo district : Lang, 2333.

Mining districts : Walker, 4316.

Nahatlatch region: Horwood, 1801.

Portland Canal area: Canada G. S. 655 ; Hanson, 1626.

Queen Charlotte Islands: Mandy, 2565.

Similkameen and Lillooet districts: Cockfield, 795.

Stikine River area, Cassiar District: Canada, G. S., 657, 658, 659.

Yale district: Horwood, 1799.

Ymir-Nelson area: Cockfield, 796.

California, Buena Vista Hills oll fleld: Howard, 1828.

Clear Lake area: Anderson, 64.

Eocene, Santa Lucia Mountains : Herold, 1716.

Foothill belt: Tolman, 4140.

Intra-septum intrusions, $\quad \mathrm{S}$ i e r r a Nevada: Mayo, 2624.

Julian district, San Diego County: Donnelly, 1064.

Klamath Mountains: Finds, 1746.

Mojave mining district: Schroter, 3578.

Mother Lode gold belt: Logan, 2435.

Mount Diablo and Coalinga areas: Clark, 755.

Mount Diablo and vicinity: Taff, 4005 .

Natural-gas flelds: Hoots, 1792.

oligocene mammal-bearing beds, Death Valley: Stock, 3924.

oligocene Tumey formation: Atwlll, 116.

Palos Verdes Hills: Woodring, 4603.

Paragenesis at Crestmore: Daly, 962.

Peninsular Range: Miller, 2728.

Perris block: Dudley, 1085, 1086.

Pinnacles National Monument: An. drews, 74

Placers : Jenkins, 1936

Pleistocene lakes, Afton basin : Blackwelder, 337.

Progress on map: Jenkins, 1934.

Santa Rita ore body: Henderson, 1706.

Sierra Nevada pluton: Cloos, 784.

South coastal basin: Eckis, 1131.

Southeastern : Moore, 2778.

Southern: Ashauer, 98 ; Reed, 3231.

Ventura County: Conklin, 837.

Cambrian, thickness in U. S. : Ver Wiebe, 4288.

Cameron and Vermilion Parishes, La.: McGuirt, 2535.

Canada : Alcock, 11; Baulig, 239.

Canadian Shield: Wright, 4628.

Sudbury series, Canadian Sbield : Collins, 816.

Western : Goodman, 1473. 
Geologic maps-Continued.

Cedar Creek anticline, Montana and South Dakota: Dobbin, 1049.

Northern half, Mont. : Erdmann, 1186. Central America: Sorre, 3789.

Chaleur Bay region, Quebec and New Brunswick : Alcock, 12.

Colorado: U. S. G. S., 4229.

Colorado, anticlines between Hiawatha gas field, Colo., and Baggs, Wyo. : Bradley, 424.

Batholith Twin Lakes and Clear Creek districts : Chapman, 732.

Book Cliffs coal fleld : Erdmann, 1185.

Calumet iron mine: Bebre, 262.

Continental Divide region: Behre, 257.

Cripple Creek district: Loughlin, $2459,2460$.

Dawson and Laramie formations: Dane, 972.

Front Range area : Lorering, 2469.

Jamestown district: Goddard, 1457.

La Plata mining district: Eckel, 1126.

London fault: Singewald, 3731.

Migmatites, Sawatch Range: Stark, 3830.

Montezuma qùađrangle: Lovering, 2466.

Pre-Cambrian granites, $\mathbf{S}$ a w a t $\mathbf{c h}$ Range: Stark, 3832.

Salt Creek area, Mosquito Range: Gould, 1487.

San Juan region: Burbank, 571; Cross, 925.

Sawatch Range: Stark, 3829.

Spanish Peaks region: Knopf, 2239.

Tincup mining district, Gunnison County : Goddard, 1458.

Tomichi dome: Stark, 3833.

Zoning, Mosquito Range and San Juan Mountains : Loughlin, 2462.

Connecticut, Fifteen Mile Falls dam, Connecticut River: Crosby, 924.

Prospect porphyritic gneiss : Stewart, 3899.

Soutbern: Denny, 1032.

Cryptovolcanic structures, Midcontinent region: Bucher, 534.

Cuba, Santa Clara Province, northern: Rutten, 3463.

Devonian, upper Mississippi Valley, isopach map : Tester, 4046

Dresbach formation, upper Mississippi Valley: Thwaites, 4122.

Florida, proposed sea-level canal area: Paige, 2983.

Galena, Decorah and Platteville formations, upper Mississippi Valley: Ball, 166.

Garland anticline, Big Horn and Park. Counties, Wyo.: Dobbin, 1051.

Gaspe, southeastern: Kindle, 2193.

Georges Bank, canyons: Stetson, 3890.

G e orgia, kyanite-mica schist belt : Smith, 3767.
Geologic maps-Continued.

Glacial geology, European and American: Keyes, 2158.

Glacial tills: Keyes, 2100.

Gold-producing areas : Danloux-Dumesnil, 974.

Gotiglacial broadmapping, Sweden-New York-Manitoba: De Geer, 1004.

Gravity anomalies and geologic structures: Woollard, 4613.

Greenland : Koch, 2245.

Basalt formation, Kap Franklin : Backlund, 126.

East, Devonian : Butler, 593 ; Gauss Peninsula and Passage Hills : Sïve-Söderbergh, 3468 .

Kap Dalton region: Wager, 4306.

Liverpool Land, crystalline complex: Kranck, 2256.

Northeast: Teichert, 4037.

Scoresby Sound: Aldinger, 18.

Ground water, North America: Im. beaux, 1904.

Guadeloupe: Barrabe, 191.

Idaho, batholitb : Ross, 3376.

Casto quadrangle: Ross, 3369.

Copper districts: Ross, 3370.

Edwardsburg and Thunder Mountain area: Shenon, 3665.

Elk City mining district: Shenon, 3659,3660 .

Southwestern: Dorf, 1070.

Yellow Pine district, Valley County : Currier, 938.

Illinois, Marion and Clay Counties: Weller, 4385.

Rock-wonl resources : Leighton, 2385.

Illinois Basin: Howard, 1831; Weller, 4386.

Indiana: Harrell, 1640.

Lima-Indiana district : Ley, 2413.

Wabash River Valley floor: Fldlar, 1246.

Iowa : Keyes, 2107.

Osage area, Henry County: Wood, 4592.

Southern: Wood, 4591.

Isopach map, post-Kinderhook-Mississippian, upper Mississippi Valley: Tester, 4044.

Jamaica, basal complex: Trechmann, 4163.

Jordan sandstone, upper Mississippl Valley: Trowbridge, 4169.

Jurassic formations, Utah, Arizona, Colorado and New Mexico: Baker, 143.

Kansas, Barton arch oil fleld: Woodruff, 4605 .

Cherokee shale zinc-lead district: Pierce, 3082.

Coal fields and zinc-lead district: Anonymous, 4665.

Eastern, pre-Cambrian : Kansas G. S., 2021.

Galnet area: Moore, 2790. 
Geologic maps-Continued.

Kansas-Continued.

Johnson and Miaml Counties : Newell, 2855.

Northeastern : Ockerman, 2933.

Northwestern: Kansas G. S., 2022.

Southwestern : Kansas G. S., 2023.

Wyandotte County: Jewett, 1950.

Kentucky, Cincinnati arch region: Bailey, 132.

Eastern : Hunter, 1891.

Rogers Gap and Fulton formátions: McFarlan, 2520.

Kinderhook group, isopach map, upper Mississippi Valley : Tester, 4045.

Lake Michigan region, drift sheets: Fuller, 1359.

Lake Superior region: Leith, 2387, 2390.

Lehigh Valley, magnetic survey: Ewing, 1199.

Louisiana, northeastern : Easton, 1112. Northern, oil fields : Easton, 1111.

Oil, gas, and sulphur fields : Louisiana Geol. Survey, 2464.

Rodessa oil field: Mills, 2733.

Maine : Keith, 2040.

Glacial deposits: Perkins, 3051.

Onawa pluton, Piscataquis County: Philbrick, 3072.

Manitoba, Cross Lake area, pre-Keewatin (?) tonalite: Horwood, 1798.

Elbow-Morton area: Canada G. S., 648; Stockwell, 3939.

Granitization, Cross Lake region : Horwood, 1802.

Missi seriess, Flinflon: Ambrose, 58, 59.

Northern, Seal River: Johnston, 1980.

Maquoketa shale, isopach map, upper Mississippi Valley: Ladd, 2285.

Maryland, Frederick Valley limestones: Jonas, 1993.

Piedmont instrusives: Cloos, 783.

Mexico: Sorre, 3789.

Boleo region, Baja California : Locke, 2433.

Cananea Mountains, Sonora: Valentine, 4247.

Coahuila Peninsula: Kellum, 2057, 2058.

Hidalgo : Santillán, 3497.

Laredo to Mexico City : Tatum, 4022.

Mapimi, Coahuila Peninsula: Singewald, 3732.

Mountains bordering Acatita and Las Delicias valleys, Coahuila Peninsula : Kelly, 2068.

Northeastern, Eocene: Kane, 2016, 2017.

Northwestern : Kellum, 2054.

Pinacates region: Ives, 1915.

Sierra de Parras, Coahulla Peninsula : Imlay, 1905.

Tampico region: Muir, 2821.

Tepezala, Aguascalientes, pyrometasomatic vein deposits: Wandke, 4328 .
Geologic maps-Continued.

Michigan, central: Rawlins, 3187.

Central oil fields: Zavoica, 4644.

Copper Range: Broderick, 462.

Cranbrook area: Stanley, 3819.

Granitic sequence, southern complex : Dickey, 1044.

Grand Sable dunes, Lake Superior, Alger County : Bergquist, 288.

Huron River, abandoned channels: Bay, 243.

Lake Superior region: Leith, 2390.

Valley-train deposits, Iron County : Bergquist, 287.

Whittlesey beach: Stanley, 3818 .

Minnesota, Lake Superior region : Leith, 2390.

Minneapolis-St: Paul metropolitan area: Schwartz, 3597.

Patrician glaciation: Sardeson, 3502.

Croix River, Paleozoic: Clement, 774; Pleistocene: Sardeson, 3510.

Upper Mississippi River : Cooper, 872.

Mississippi, Cincinnati arch region : Bailey, 132.

Eocene: Grim, 1548.

Mississippi River, upper: Cooper, 872.

Mississippi River arch : Howell, 1866.

Mississippi Valley, upper: Atwater, 112 ; Kans. Geol. Soc., 2020.

Missouri, granites: Tolman, 4137.

St. Louis County and City of St. Louis: Gleason, 1443.

Southeast: Farrar, 1215.

Montana: Scott, 3610 .

Big Horn County and Crow Indian Reservation: Thom, 4074.

Butte mining district: Hart, 1647.

Flathead mine: Shenon, 3661.

Hog Heaven mining district, Flathead County : Shenon, 3664.

Idaho batholith, northeastern part: Langton, 2337.

Neihart mining district, Cascade County: Schafer, 3526.

Northeastern, Missouri and $M 11$ k. Rivers: Perry, 3058.

Nye-Bowler lineament, Stillwater and Carbon Counties: Wilson, 4535.

Richey-Lambert coal field: Parker, 3012.

Rosebud coal field: Pierce, 3084.

Southeastern: Perry 3059.

Stillwater complex: Howland, 1869 ; Peoples, 3050.

Western: Pardee, 3005.

Nebraska, Pleistocene: Lugn, 2478.

Water-bearing formations: Condra, 835.

Nevada, central Humboldt Range: Jenney, 1943.

Chief district, Lincoln County : Callaghan, 629 .

Contact mining district: Schrader, 3576. 
Geologic maps-Continued.

Nevada-Continued.

Ely district: Bateman, 236.

Silver Dyke area : Kerr, 2086.

Tonopah mining district, block diagrams: Nolan, 2907.

Tuscarora mining, district, Elko County: Nolan, 2908.

New Brunswick, Grand Lake coal fleld: Wright, 4630.

New England ground-water supply : Bryan, 522.

Newfoundland: Snelgrove, 3779.

Bay of Exploits area : Heyl, 1736.

Bay of Islands igneous complex: Cooper, 869.

Trout River area: Ingerson, 1906.

New Hampshire, Franconia quadrangle: Billings, 317.

Grand Monadnock : Chamberlain, 717.

Littleton and Moosilauke quadrangles : Billings, 318.

White Mountain magma series : Chapman, 733.

New Jersey, ground-water supply: Critchlow, 914.

Minerals, Franklin and Sterling Hill, Sussex County: Palache, 2985.

New Mexico, Bayard area : Lasky, 2344.

Clovis area: Stock, 3931.

Lordsburg district: Lasky, 2342.

Mount Taylor coal field: Hunt, 188.

Navajo-Hopi country, Pliocene: Williams, 4509.

Northern, glaciation : Ellis, 1170.

Northwestern : Waring, 4339.

Oil and gas map: Winchester, 4565.

Organ batholith: Dunbam, 1096.

Organ Mountains and Doña Ana County : Dunbam, 1094.

San Jaun Basin: Sears, 3621.

Santa Rita and Tyrone districts: Paige, 2982.

Santa Rita mining area: Spencer, 3803.

Upper Rio Puerco: Bryan, 525.

Virginia mining district : Lasky, 2343.

New York, Adirondacks, intrusive complexes : Buddington, 546.

Berne quadrangle: Cook, 843 ; Goldring, 1463.

Catskill area : Chadwick, 715; Rich, 3266.

Dutchess County : Balk, 162 ; Barth, 198.

Eastern, cherts : Ruedemann, 3416.

Hammond, Antwerp, and Lowville quadrangles: Buddington, 543.

Oswegatchie quadrangle: Dale, 961.

Peekskill region: Butler, 595.

Potsdam quadrangle, St. Lawrence County : Reed, 3227.

Russell quadrangle: Dale, 958.

Skaneateles quadrangle: Smith, 3746 .

Watkins quadrangle: Bradley, 425.

Zinc mine, Balmat: Brown, 484.

North America : Baulig, 239.
Geologic maps-Continued.

North American glaciation: Keyes, 2150.

North Carolina, Coastal Plain: Prouty, 3150.

North Dakota: Anonymous, 4671.

Northwest Territories, Great Bear Lake area: Kidd, 2190 ; Riley, 3304.

Great Slave Lake, east arm: Stockwell, 3940.

Rae-Great Bear Lake area, Mackenzie district: Canada G. S., 668, 669, 670 ; Kidd, 2191.

Yellowlnife River area : Jolliffe, 1988.

Nova Scotia, gold zonal mineralization : Newhouse, 2865.

Lake Ainslie area: Norman, 2911.

Malagash salt deposit: Miller, 2698.

Ohio, Lima-Indiana district: Ley, 2413.

Southern: Braun, 450.

Ohio River Valley: Meinzer, 2635.

Oklahoma, coal map, Howe district: U. S. G. S., 4230 ; Lehigh district: U. S. G. S., 4231; MCAlester district: U. S. G. S., 4232 ; Stigler-Poteau district: U. S. G. S., 4233; Wilburton district: U. S. G. S., 4234.

Comanche field: Swigart, 3995.

Fitts pool, Pontotoc County: Hyatt, 1901.

Lehigh district: Knechtel, 2228.

Osage County: Bass, 221; oil and gas fields: U. S. G. S., 4237, 4238.

Pennsylvanian sandstones, Ardmore Basin : Lucas, 2475.

Quinton-Scipio district: Dane, 969.

Slick field: Schwarzenbeck, 3600.

Ontario, Afton-Scholes area: Moore, 2781.

Claire River syncline: Fairbairn, 1206.

Coldwell district: Thomson, 4110.

East Bay, Minnitaki Lake, Kenora district: Pettijohn, 3067.

Hollinger gold mine: Ringsleben, 3306.

Lake Nipigon area : Canada G. S. 650 .

Lake Shore mine area: Robson, 3328.

Makwa-Churchill area: Laird, 2289.

Manitou Lake-Lake of the Woods belt: Thomson, 4111.

Mine Centre area, Rainy River district: Canada G. S., 666.

Papaonga River area, Patricia portion, Kenora district: Wright, 4631.

Renfrew County: Freeman, 1336.

Savant Lake area : Rittenhouse, 5308.

Sudbury nickel eruptive: Thomson, 4114.

Sudbury nickel field: Burrows, 585.

Swayze gold area: Rickaby, 3294.

Tashota-Sturgeon River dis trict: Flaherty, 1278.

Vermilion Township, Kenora district: Pettijohn, 3065. 
Geologic maps-Continued.

Oregon, Cascade Mountains, North Santiam River Section: Thayer, 4061.

Cascade Range: Buddington, 549.

Patrician glaciation, center: Tyrell, 4203.

Strategic role: Keyes, 2095.

Western extension: Johnston, 1983.

Patrician ice sheet: Martin, 2586.

Pennsylvania: Willard, 4489.

Bellefonte quadrangle: Butts, 598.

Butler and Zelienople quadrangles: Richardson, 3286.

Cambrian pegmatites, Morgan Hill : Fraser, 1329.

Chester Valley: Mackin, 2544.

Febron gas field: Reeves, 3234.

Léhigh Valley Cambro-Ordovician limestones: Hills, 1742.

Northwestern: Fettke, 1240, 1242, 1243.

Oriskany sand: Cathcart, 705.

Philadelphia area: Watson, 4359.

Focono Plateau: Wagner 4307.

Reading-Boyertown area: Stose, 3947.

Tioga Region: Ashley, 100.

Permian Basin, Arkansas and Louisiana: Easton, 1114.

Prairie du Chien formation : Powers, 3116.

Prairle du Chien group, isopach map, upper Mississippi Valley: Powers, 3115.

Pre-Cambrian buried surface in U. $\mathbf{S}$. : Moss, 2811.

Pre-Cambrian structural map, upper Mississippi Valley : Howell, 1864.

Quebec: Goudge, 1482.

Quebec, Amos sheet, Abitibi County : Canada G. S., 643.

Beattie mine, Duparquet Township : O'Neill, 2953.

Bolton series: Clark, 766.

Cadillac belt, Pandora to Pan Canadlan: Gunning, 1573.

Chibougamau area: Canada G. S., 647 ; Norman 2914.

Chibougamau Lake area: Mawdsley, 2617.

Chibougamau-Waswanipi dist r ic t: Norman, 2915.

Dartmouth River area, Gaspe Peninsula: Jones, 2003.

Deschambault region, Portne uf County : Laverdière, 2352.

Despinassy area, Abitibi County: Faessler, 1204.

Escuminac area, Bonaventure County : Canada G. S., 662.

Gatineau region: Retty, 3255 .

Guillet (Mud) Lake area : Henderson, 1701.

Horne mine, Noranda : Price, 3132.

Kinofevis sheet, Témiscamingue and -Abitibi Counties: Canada G. S., 649.
Geologic maps-Continued.

Quebec-Continued.

Labelle-L'Announciation area : Osborne, 2963.

Lacolle conglomerate: Clark, 767 .

Lac-Saint-Jean region, northwest part: Denis, 1030.

Lamaque mine Bourlamaque Township: Wilson, 4537.

Lamaque-Sigma mines area, Bourlamaque Township, Abittbi County: Bell, 267.

Malartic gold mine area, Abitibl : $0^{\prime}$ Neill, 2954.

Marsoui area, Gaspe Peninsula : Jones, 2001.

Mount Megantic region: McGerrigle, 2525.

North of. St. Lawrence River (second section) : Osborne, 2962.

Opawica-Chibougamau map area: Norman, 2913.

Osisko Lake area: Conolly, 840.

Peridotities and pyroxenites, eastern townships: Cooke, 850.

Pre-Cambrian tectonic features, Chibougamau district: Norman, 2914.

Pusticamica Lake area, Abitibi district : MacKenzie, 2540.

Roselake district: MacKenzie, 2542.

Rouyn-Bell River area: Canada G. S., 671.

Sabourin area Témiscamingue County : Denis, 1031.

St. Lawrence, north shore, Manigouagan to Godbout: Faessler, 1203.

Shawinigan Falls district: Osborne, $2965,2967$.

Siscoe gold mine area: Backman, 128.

Southern, Lower Cambrian: Clark, 768.

Témiscouata area: McGerrigle, 2524.

Thetford district: Cooke, $\mathbf{8 5 2}$.

Travers Lake area: Témiscamingue County : Retty, 3256.

Waswanipi map area: Norman, 2912.

Western : Bell, 269, 270.

Quebec and New Brunswick, Chaleur Bay area: Canada G. S., 661.

Saganaga batholith, Minnesota-Ontario : Grout, 1557.

St. Peter formation, 1sopach map upper Mississippi Valley: Lamar, 2293.

St. Peter sandstone, upper Mississippi Valley: Howell, 1865.

Saskatchewan, Amisk Lake area: Canada, G. S., 642.

Eagle Hills anticline, Battleford area ; Hume, 1885.

Mudjatik-Haultain area: Alcock, 13 ; Canada G. S., 651, 652, 653, 654.

Northern, Fond-Du-Lac area: Canada G. S., 663 ; Goldfields area : Canada G. S., 664 . 
Geologic maps-Continued.

Saskatchewan-Continued,

Regina area : Canada G. S., 656 ; Fraser, 1330.

Southern: Wickenden, 4471.

Stony Raplds area, west half: Canada G. S., 672 .

Tazin Lake area: Canada G. S. 673.

Silurian isopach map, upper Mississippi

Valley: Workman, 4617.

South Carolina, Coastal Plain: Cooke, 847.

Columbia quadrangle, granite : Kesler, 2087.

South Dakota, Day County: Rothrock, 3381.

Sudbury nickel irruptive, Ontario: Collins, 814, 815.

Tennessee, Cincinnati arch region: Bailey, 132.

Flynn . Creek disturbance, Jackson County: Wilson, 4536.

Nashville dome: Wilson, 4531, 4534.

South-central: Theis, 4063.

Tennessee Valley: Spain, 3793.

Tuscaloosa formation outliers: Born, 375.

Western: Born, 376.

Texas: Deussen, 1035; Sellards, 3637.

Atascosa and Frio Counties: Lonsdale, 2446

Central: Kramer, 2254.

Clay Creek salt dome, Washington County : Ferguson, 1237.

Coastal Plain: Turner, 4190.

Colorado River Valley, upper Pennsylvania and lower Permian: Bullard, 566.

Conroe oil field, Montgomery County : Michaux, 2694.

County maps: Tex. Univ., Bur. Ec. Geol., 4048.

East: Eckel, 1125.

East of Pecos River: Sellards, 3638

East Texas district: Ralston, 3166.

Eocene and Miocene formations, Walker and Gonzales Counties: Renick, 3246.

Kleberg County : Livingston, 2430.

Llano region: Stenzel, 3868.

Mercedes fleld, Hidalgo County : Price, 3136.

Mount Sylvan dome: Wendlandt, 4394.

Palo Pinto County: Plummer, 3098.

Permian basin: Cunningham, 934.

Rodessa oll field: Mills, 2733.

San Antonio area : Livingston, 2429.

Trans-Pecos: Baker, 145.

Underground waters: White, 4461.

Uvalde and Medina Counties: Sayre, 3524.

Wolf Mountain phacolith : Stenzel, 3869.

Texas-New Mexico potash deposits : Mansfield, 2569.
Geologic maps-Continued.

Trempealeau, Franconia, and Dresbach formations, upper Mississippi Valley : Edwards, 1140.

Trinidad: Kugler, 2280; Lehner, 2381.

Underground waters, zones of minerallzation, upper Mississippi Valley: Thwaites, 4124.

United States: Baulig, 240.

Basement crystallines: Thom, 4080.

Utah: Taylor, 4025.

Bingham : Boutwell, 383.

Book Cliffs coal field: Fisher, 1269.

Dinosaur National Monument: Gilmore, 1437.

Gold Hill mining district: Nolan, 2905.

Grand and San Juan Counties: U. S. G. S., 4226.

Great Salt Lake basin : Eardley, 1107.

Monument Valley-Navajo Mountain region: Baker, 144; U. S. G. S., 4227.

Navajo-Hopi country, Pliocene: Williams, 4509.

Salt Valley anticline area: Dane, 970.

Southeastern: Baker, 142.

Uinta Mountains, north flank: BradIey, 426.

Vermont, ultrabasics : Bain, 140.

Virginia, barite deposits: Edmunson, 1136.

Coal measures: McGill, 2529.

Eagle Rock; Pulaski overthrust: Woodward, 4611.

James River iron and marble belt: Furcron, 1362

Natural Bridge and Natural Tunnel area : Woodward, 4612.

Piedmont region: Park, 3009.

Salem block, Pulaski overthrust: Woodward, 4610.

Shenandoah Valley: Cady, 621.

Southwestern, zinc and lead region: Currier, 936.

Washington, eastern : Flint, 1289.

Grand Coulee : Keyes, 2102.

Mount Rainier National Park: Coombs, 856.

St. Helens mining district: Houghland, 1810.

West Indies : Hacquaert, 1522 ; Rutten, 3461 ; Sorre, 3789.

Guadeloupe, Martinique : Barrabe, 192.

West Virginia : Tucker, 4180.

Eastern: Reeves, 3233.

Springs: Price, 3130.

Wisconsin, Baraboo area : Raasch, 3162 : Thwaites, 4123.

Glacial tills : Keyes, 2103.

Lake Superior region: Leith, 2390.

Wyoming, Alcova Dam and reservoir sites, North Platte River, Natrona County: Bradley, 423. 
Geologic maps-Continued.

Wyoming-Continued.

Anticlines between Fiawatha gas field and Baggs, Wyo.: Bradley, 424.

Goshen Hole area: Schlaikjer, 3558, 3560 .

Greybull River : Mackin, 2545.

Osage oil field: Dobbin, 1052.

Permo-Pennsylvanian section, Hartville area: Condra, 834.

Trout Creek Canyon, Park County: Sheets, 3657.

Yukon, Carmacks district: Bostock, 379 ; Canada G. S., 660 .

Laberge area : Canada G. S., 665.

Ogilvie area: Canada G. S., 667.

Teslin-Quiet Lake area : Canada G. S., 674.

Teslin-Quiet Lake-Big Salmon area ; Bostock, 381.

Geologic processes and human activities, Utah : Schneider, 3567.

Geologic theory in mine examinations: Smith, 3762.

Geologic time: Lane, 2325.

Atomic weights, actinouranium and radioactive substances: Western, 4428.

Bibliography : Marble, 2580.

Carboniferous, proposed dismemberment: Keyes, 2186.

Correlation by glacial varves, late Quaternary: Antevs, 80.

Determinations, accurate, of : Lane, 2329.

Geochronology, international: De Geer, 1005.

Geologic time measurement: Lane, $2319,2328$.

Glaciations and evolution of solar system : Holmes, 1784.

Gotiglacial broadmapping, Sweden-New York-Manitoba: De Geer, 1004.

Lead, radiogenic, isotopic constitution: Rose, 3356.

Lead-uranium ratio a!teration, effect: Alter, 56.

Measure of glacial epochs by varves: Keyes, 2133.

North Carolina, monazite, Mars Hill, age: Marble, 2579.

Periodicity in epeirogenic movements: Born, 374

Pitchblende, age, Great Bear Lake, Canada: Marble, 2578.

Pre-Cambrian, measurement by varves: Sederbolm, 3630

Rubidium accumulation: Whitney, 4470.

Teleconnection, geochronology and bistoric time: De Geer, 1003.

Virginia, allanite, Amherst County, age: Marble, 2577.

Geological education: Swartz, 3988.

Geological time clock, Buffalo Museum: Reimann, 3241.
Geological surveys. See Surveys.

Geologico-seismological frontler, progress: Macelwane, 2517.

Geologists, distribution and background : Fairbanks, 1210.

Geologists, responsibility of, under Securlties Act, 1933 : Perrine, 3056.

Geology, application to ore flnding: Parker, 3011.

Geology of natural gas: Ley, 2410.

Geology and clay research: Rles, 3299.

Geology and education: Bevan, 311.

Geology, geography and soils: Smith, 3759.

Geomorphogeny. See Physiographic geology.

Geomorphology. See also Physiographic geology.

Mountainous deserts: Davis, 986.

Tropics, humid: Krynine, 2275.

Geomorphology and sedimentation, humid Tropics : Krynine, 2275.

Geophysical prospecting: Belluigl, 273; Bergman, 285 ; Clark, 763 ; Isham, 1909 ; Kelly, 2062, 2063; Sánchez, 3486 ; Wenner, 4398 ; Westby, 4427.

Amberst sandstone, moisture content : Born, 377.

Analysis, seismic profiles: Roman, 3344.

Anisotrophy, effect on apparent resistivity curves: Pirson, 3093.

Anthracite, prospecting by earth-resistivity method: Ewing, 1197.

Appalachia, possible position determination: Thom, 4079.

Atlantic Coastal Plain: Ewing, 1198.

Barbers Hill salt dome, Chambers County, Texas : Barton, 205.

Bottom-hole data, electrica! determination : Schlumberger, 3563.

Boulder Dam area, mineral occurrences : Lee, 2367.

California, maghemite and ferric oxides: Newhouse, 2864.

Oil fields: Anonymous, 4680.

Placers: Jenkins, 1936.

San Joaquin Valley: Mills, 2731.

Santa Rita ore body: Henderson, 1706.

Tejon Ranch area: Jakowsky: 1930. Canada : Miller, 2696.

Cap rock, Hoskins Mound salt dome, Texas : Barton, 208.

Carolina Coastal Plain, anomalies and structure: MacCarthy, 2499.

Triassic basin: MacCarthy, 2497.

Continents, geophysical and geological study: Thom, 4077.

Dip needle as magnetometer: Swanson, 3986.

Drill holes, electrical exploration : Deussen, 1034.

Thermometric measurements : Leonardon, 2398.

Earth crust, structure determination: Gutenberg, 1584. 
Geophysical prospecting-Continued.

Earth resistivity, measurements: Wenner, 4396.

Measurement and layer problems : Shue, 3703 .

Earth resistivity and geological structure: Card, 679.

Earth-resistivity method, location of faults by : Hubbert, 1874.

Earth transients, electric: Stratham, 3963.

Elastic properties of rocks: Ide, 1903.

Electrical measurements in anisotropic media: Schlumberger, 3562.

Electrical prospecting, deep: Karcher, 2025.

For gold quartz veins: Kelly, 2061.

Instruments : Bruckshaw, 507.

Methods : Fink, 1264.

Progress : Lundberg, 2488.

Exploring down : Kelly, 2065.

Exploring with explosives: Heiland, 1686.

Explosives for : Loving, 2472.

Fake methods: Blau, 348.

Faults, location by earth-resistivity method, Illinois : Hubbert, 1874.

Geodetic operations, U. S., 1933-35 : Bowie, 401.

Geodetic surveys: Bowie, 403.

Geodesy in geophysical research : Bowle, 406.

Geological causes of poor reflection records : Rieber, 3298.

Geomagnetic surveying: Alexander, 29.

Geophysical mapping from the air : Heiland, 1687.

Glaciers, South Crillon, and Klooch, Alaska, seismic sounding: Goldthwait, 1472 .

Gold, exploration: Kelly, 2064.

Gradiometer, magnetic: Roman, 3343.

Gravity prospecting, Gulf Coast: Sundt, 3980 .

Gravity work, progress: Swick, 3994.

Gulf Coast district: Mills, 2734.

Exploration to 1936: Rosaire, 3354.

Oil fields: Barton, 209, 215 ; Williams, 4521.

Gulf Coast States, gravity survey: Baker, 156.

Interpretation, reflection seismograms: Rutherford, 3449.

Lehigh Valley, magnetic survey : Ewing, 1199.

Louisiana : Barton, 214.

Gulf coast marsh and water areas: Flude, 1294

Jennings salt dome, Acadia Parish: Halbouty, 1601.

Seismic exploration for oil: Taylor, 4029.

Valentine (LaRose) dome, Lafourche Parish : Buchanan, 533.

Magnetic surveying: Royce, 3398.

Magnetometric measurements applied to geological structure: Keys, 2187.
Geophysical prospecting-Continued.

Mapping geologic structure by reflection waves: Goldstone, 1468.

Michigan, magnetic data, use in iron ranges: Swanson, 3985.

Montana, Bighorn Basin, investigation by seismic methods: Gutenberg, 1581.

Nebraska and the Dakotas: Wilson, 4543.

North Carolina, Durham Triassic basin : Johnson, 1979.

Nova Scotia, Malagash salt deposit: Miller, 2698.

Oceanic basins: Field, 1251, 1253.

Ohio, radio transmission survey : Higgy, 1738.

Oil and gas: Swartz, 3992.

Oil fleld, Okmulgee County, Okla.: Westby, 4426.

Oil-field discovery : Jenny, 1945.

Oil in Gulf off Texas coast: Williams, 4522 .

Oil in 1935 : De Golyer, 1008.

Oil structures, electrical mapping: Jakosky, 1929.

Ore deposits : Butler, 592.

Overthrust faults, investigation by seismic methods: Buwalda, 601.

Petroleum : Umpleby, 4222.

Exploration for: Rosaire, 3353.

Gulf coast: Rosaire, 3355 .

Seismic exploration for : Gabriel, 1372.

Petroleum industry: De Golyer, 1006.

Physical methods, exploration for oil : Shepard, 3666.

Placers, Tertiary, location of : Duling, 1089.

Polar charts, interpreting magnetic anomalies: Pirson, 3094.

Quebec, Ivry ilmenite deposit: Keys, 2188.

Reflection dip-shooting method: Rutherford, 3452 .

Reflection seismology: Hollister, 1781.

Reflection system, controlled directional sensitivity: Rieber, 3296 .

Resistivity curves, three-layer, interpretation : Pirson, 3091.

Data, Interpretations: Roman, 3342.

Measurements, interpretation: Watson, 4363.

Measurements and highway problems: Kurtenacker, 2281.

Methods for stone and gravel deposits: Kurtenacker, 2282.

Road metals, search for: Wilcox, 4479.

Salt domes and oil fields, Gulf Coast: Eby, 1121.

Salt-dome structures : Barret, 194 ; Eby, 1120.

Seismic prospecting by reflection: Pirson, 3092.

Seismic reflection data reduction : Rutherford, 3451.

Seismic velocities, longitudinal: Weatherby, 4366. 
Geophysical prospecting-Continued.

Seismic waves, emergence ángle and propagation paths : Ewing; 1200.

Seismographs, prospecting: Leet, 2372.

South Carolina, Coastal Plain: MacCarthy, 2496.

Stratified media resistivity : Ehrenburg, 1148.

Structure, determination by' electrical resistance methods: Hubbert, 1875.

Study of: Kelly, 2066.

Subsurface exploration, earth resistivity methods: Shepard, 3667.

Subsurface surveys for road work: Shepard, 3668 .

Texas, : Barton, 214.

Conroe ofl field: Williams, 4515.

Galveston Bay : Singleton, : 3735.

Galveston County: Singleton, 3734.

Gulf coast marsh: and water areas: Flude, 1294.

High Island dome: Halbouty, 1603

- Prospecting in Gulf of Mexico: Mills, 2737.

Theory of seismic prospecting: Dix, 1048.

Tomball oil field, Harris County, 'Tex. Eby, 1122.

Visual presentation, wave patterns: Rieber, 3297.

Water-table location: Alexander, 28.

Waves, amplitude: Gutenberg, 1587.

Well surveying :- Leonardon, 2397.

Geophysics.

Earth, interior: Daly, 965.

Equilibrium relations, feldspathoids, alkali feldspars, and silica: Schairer, 3529.

Fusion relations, feldspathoids, alkali feldspars, and . sillca:- Schairer, 3528.

Geophysical laboratory reports: Day, 988.

Potash-rich rocks, origin: Terzaghi, 4043.

Silica, transfer by 'water vapors: Syrömyatnikov, 3999. . .,.,

System $\mathrm{CaO}-\mathrm{MgO}^{-} \mathrm{SiO}_{2}$, reactions between solids : Taylor, 4030.

System: lime-potash-alumina: Brown. miller, 500.

System $\mathrm{MgO}-\mathrm{FeO}-\mathrm{SiO}_{2}$ : Bowen, 385.

Young's modulus of rocks, determination: Ide, 1902.

Georges Bank.

Paleontology.

Cretaceous; Upper, fossils : : Stephenson, 3878.

Foraminifera, Cretaceous and late Tertiary : Cushman, 944.

Plethopora americana, Upper Cretaceous : Bassler, 230.

Physiographic geology.

Canyons: Stetson, $\mathbf{3 8 9 0 .}$
Georgia.

Eccoñomic geology.

Barite, origin Áppalachian Valley : Crickmay, 905 .

- Battle Bránch gold mine: Park, 3010.

Clays, bleaching: Bay, 241.

Copper deposits, Ducktown type, south-

$\therefore$ ern Appalachians : Ross, 3364.

Gold deposits: Wllson, 4557, 4558.

Souther $\ddot{n}$ Appalachíans: Anónymous, 4692.

Kyanite: S̈mith, 3767.

And vermiculite deposits: Prindle, 3137.

$\because \because$ Mineral production, 1933: Smith, 3766.

1934 : Smith, 3768.

Talc deposits: Crickmay, 812.

Historicat geology.

Kyanite: Smith, 3767.

Ordovician altered volcanic materials and related clays: Kay, 2029.

Talladega series, pre-Cambrian: Crickmay, 809.

Southern Appalachians; Crickmay, 910.

Mineralogy.

Gems: McKinley, 2548.

General: Mitchell, 2751.

Hydrothermal mineralization, Graves Mountain: Johnston, 1985.

Kyanite and vermiculite deposits: ... Prindle, 3137.

Paleontralogy.

Casteroides ohioensis, distribution:

; , Cahn, 623.

Fauna, Pleistocene Pamlico, southern Atlantic Coastal Platn : Richards, 3284.

Foraminifera, upper Eocene: Cushman, 941.

Mammoths and mastodonts, Savannah : Mitchell, 2753.

Pectinidae, Tertiary: Rowland, 3389; Tucker, 4178.

:Physical geology.

Beach sands: Martens, 2584.

Caves: Crickmay, 911 .

Eärthquake, January 1, 1935 : Crickmay, 902 .

Young Harris, January 1, 1935 :

$\therefore$ Crickmay, 904.

Elberton batholith, plnk granite, orlgin : Calhoun, 626.

"Physiographic geology.

Coosa lowlands : Wright, 4623.

Erosion : Crickmay, 906.

Stone Mountain : Crickmay, 903.

Underground water.

General : Smith, 3769.

Crystalline rocks, ground water: Crickmay, , 913.

Geothermal evidence, deductions: De Lury, 1024.

Geysers. See also Underground water.

Basins and igneous emanations: Allen, 38.

$311-37-25$ 
Geyser-Continued.

Bore-hole investigations, Yellowstone $\because$ Park: Fenner, 1223.

Mechanism: Day, 990.

Yellowstone National Park: Allen, 37.

Glacial erosion. See Erosion.

Glacial geology : Ries, 3300. See also Glacial lakes; : Quarternary.

Ablation of snow, western mountains: Matthes, 2613.

Alaska Range : Capps, 677.

Alaska, Coast Range, glaciation: Kerr, 2076.

-Ruby-Kụskokwim region: Mertle, 2681.

Southern: Cooper, 873.

Tonsina district : Mofft, 2762.

Valley glaciers and valley glaciation: Ray, 3192.

Willow Creek-Kashwitna district: Capps, 678.

Alaska and Yukon, shapes, glacial and ice fam cobbles: Wentworth, 4412.

American paradigms for European glaciations: Keyes, 2163.

Arid regions during ice age: Pittelkow, 3095.

Baconian cycle in secular glaciation : Keyes, 2150.

British Columbia, Caribob district : Hanson, 1624:

Coast Range, glaciation: Kerr, 2076.

Cranbrook area: Rice, 3263.

Fiord-land : Peacock, 3035.

Keithley Creek area; Cariboo district: Lang, 2333.

Queen Charlotte Islands : Mandy, 2565.

White silt, Okanagan Valley: Flint, 1286.

Canada: Baulig, 239.

Chaleur Bay region, Quebec and New Brunswick : Alcock, 12.

Climates of the: Pleistocene : Fint, 1285.

Coal, Permo-Carboniferous, related to southern hemisphere glaciation: Shepard, 3669.

Colorado: Ives; 1917.

Arkansas, River Valley: and Royal Gorge : Powers, 3118.

Front Range: Van Tuyl, 4268.

Montezuma quadrangle: Lovering, 2466.

San Juan region: Cross, 925.

Connecticut, Fifteen Mile Falls. dam, Connecticut River: Crosby, 824.

Southern : . Denny, "1032.

Copper and lost stones in glacial tull : Glock; 1448.

Coral reefs, .. glacial-control theory: Ladd, 2286.

Correlation, by glacial varves, late Quaternary : Antevs, 80.

European and American : Keyes, 2158.

Glacial terraces by means of soils: Allison, 52.

Northern and Southern Hemispheres: Coleman, 806.

Glacial geology-Continued.

Dating glacial varves: De Geer, 1003.

Des Moines River, deglaciation effects on : Keyes, . 2157.

Evaporation, high altitudes and latitudes: Church, 752 .

Fauna, Paciflc coast, evolution : Howell, 1848.

Geochronology, international: De Geer, 1005.

Glacial migration, eastern America, extent and limits : Eckel, 1129.

Glaciations; western mountains: Keyes, 2112.

Gotiglacial broadmapping, Sweden-New York-Manitoba: De Geer, 1004.

Greenland: Church, 752.

East: Boyd, 409.

Northeast: Teichert, 4037.

Ymer Island: Cleaves, $\mathbf{7 7 2}$.

Hawaii, Mauna Kea: Gregory, 1522.

Ice age, coming: Taber, 4001.

Idaho, Casto quadrangle: Ross, 3369.

Edwardsburg and Thunder Mountain area : Shenion, 3665.

Illinois, soil materials, constitution: Ekblaw, 1154.

Indiana : Harrell, 1640.

Wabash River valley floor: Fidlar, 1246.

Iowa, pre-Wisconsin valley, southwestern Hancock County: Wood, 4590.

Southern: Wood, 4591.

Kansas, Johnson and Miami Counties : Newell, 2855.

Kansas River Valley, weathered till : Hoover, 1795.

Wyandotte County : Jewett, 1950.

Labrador, Nain-Okak section: Wheeler, 4440.

Lake Michigan region, drift sheets : Fuller, 1359.

Lake Souris, N. Dak., glacial lakes: Andrews, 71.

Loveland and Peoria loesses, Iowa : Kay, 2026, 2027.

Maine : Leavitt, 2364.

Alpine 'zone, Mount Washington :Range: Anters, 76.

Appalachian Trail : Philbrick, 3071.

Map: of glacial deposits: Perkins, 3051.

Pleistocene:: Perkins, 3052.

Manitoba, Elbow-Morton area : Stockwell, 3939..

Northern, older glaciations: Burwash, 587.

Massachusetts, Hingham red felsite boulder train : Howe, 1847.

Mexico : Coleman, 807.

Michigan : Newcombe, 2854.

Cranbrook area: : Stanley, 3819.

High plain's: Davis, 983.

Huron River, abandoned channels: Bay, 243.

Valley-train deposits, Iron County: Bergquist, 287. 
Glacial geology-Continued.

Minnesota, Minneapolis-St. Paul metropolitan area: Schwartz, 3597.

Patrician glaciation: Sardeson, 3502.

St.: Croix River, Pleistocene: Sardeson, 3510 .

Mississippi - River, Cenozoic history : Trowbridge, 4171.

Upper : Cooper, 872; Flint, 1288.

Mississippl Valley, upper: Kans." Geol. Soc., 2020.

Montana, Glacier National Park: Thaxter, 4057.

Richey-Lambert, coal fleld: Parker, 3012.

Moraines, washboard, Opawica-Chibougamau area, Quebec: Mawdsley, 2619.

Native copper masses in glacial tills: Glock, 1447.

Nebraska, Pleistocene:. Lugn, 2478.

Water-bearing formations: Condra, 835.

Nevada: Church, 752.

New Brunswick, Grand Lake coalfleld : Wright, 4630.

Grand Manan Island: Gesner, 1408.

New England: Flint, 1287.

Ground-water supply: Bryan, 522.

Southeastern: Bryan, 526.

Newfoundland, Bay of Exploits area : Heyl, 1736.

New Hampshire, Eranconia quadrangle: Blllings, , 317.

Ice readvance at Littleton: Lougee, 2455.

Littleton and Moosilauke quadrangles: Billings, 318.

New Jersey, Watchung Mountains : Moldenke, 2765.

New Jersey and New York, late Pleistocene marine and glaclal: MacClintock; 2504.

New Mexico, Canjilon Divide, Rio Arriba County: Smith, $\mathbf{3 7 7 5}$.

Cloris lake clays, Pleistocene: Antevs, 79.

Northern : . Ellis, 1170.

New York: Engeln, von, 1183.

Antwerp, Hammond, and Low ville quadrangles : Buddington, 543.

Berne quadrangle: Cook, 843; Goldring, 1463.

Catskills: Rich, 3266.

Central Long Island: Fleming, 1281.

Chittenango Falls $\mathrm{State}$ Park: Holmes, 1785.

Genesee Valley: Fairchild, 1211.

Oswegatchle quadrangle : Dale, 861.

Potsdam quadrangle, St. Lawrence County : Reed, 3217.

Skaneateles quadrangle: Smith, 3746.

Nomenclature: Keyes, 2100.

North America : Baulig, 239.

Ohio, Kelley's Island: Ver Steeg, 4281.

Mohican Forest Park: Ver Steeg, 4284 .
Glacial geology-Continued.

Ohio-Continued.

Plant migrations: Braun, 450.

Powell and Broadway end moraines: White, 4457.

Scioto glacial lobe: White, $\mathbf{4 4 5 6 .}$

Western, preglacial physiography : .. Ver Steeg, 4283, 4285.

Oregon, Crescent Lake and vicinity : :Holdredge, 1778.

Glacial history, Mount Mazama, Crater Lake National Park: Atwood, 117.

Northwest, Pleis t o c e n e alluvial stages: Allison, 53.

Willamette Valley, glacial erratics: Allison, 51.

$\therefore$ Patrician glacial interval, Iowa : Keyes, 2094.

Patrician glaciation, center: Tyrrell, 4203.

Extent: Keyes, 2092.

Strategic role: Keyes, 2095.

Western extension: Johnston, 1983.

Patrician ice movements: Leverett, 2402.

Patrician ice sheet: Martin, 2586.

Peat deposits, correlation, time units and climatic changes: DachnowskiStokes, 947.

Pennsylvania, Devonian ice: Willard, 4491.

Pleistocene: Keyes, 2149.

Correlations, Pacifc Coast: Allison, 54.

Glaciation, cause and result: Fairchlld, 1213.

Lake, White River Valley, Nebriska and North Dakota: MacClintock, 2506.

Succession, North America: Stanley, 8810.

Tentative ages: Cooke, 845.

Prehistory relation to postglacial cllmatic fuctuations: Fisher, 1275.

Pre-Kansan Minnesotá peat bog: Nielsen, 2884.

Quebec, Gatineau region : Retty, 3255.

Labelle-L'Annonciation area : Osborne, 2963.

Mount Megantic region: McGerrigle, 2525.

St. Lawrence, north shore, Manigouagan to Godbout: Faessler, 1203.

Sedimentation cycles, Paleozoic: Wanless, 4331.

Sediments, glacial : 'Leighton, 2383.

South Dakota, Day County: Rothrock, 3381.

Submarine canyons; causes: Shepard, 3682 .

Utah, Uinta Mountains, north flank: Bradley, 426.

Varves, measure of geologic time: Keyes, 2133.

Volume, shape, position, rock fragments in openwork gravel: Wadell, 4304. 
Glacial geology-Continued.

Washington, eastern : Flint, 1289.

Glacial till borders:- Field, 1248.

Grand Coulee: Fernquist, 1239 ; Keyes, 2102.

Mount Ranier National Park : Coombs, 856.

Scablands area: Hodge, 1763.

Southern Cascades : Treasher, 4159.

Southern Okanogan region: Flint, 1284.

Wisconsin, Baraboo district: Thwaites, 4123.

Glacial cobbles, shape: Wentworth, 4411.

Two Creeks forest bed, Manitowoc County: Wilson, 4545.

Yukon, Carmacks district: Bostock, 379.

Glacial and postglacial vegetation: Sears, 3626.

Glacial lakes. See also Beaches; Lakes (extinct) ; Shore lines; Terraces.

Huron-Erie district, tilt-line variations : Leverett, 2401.

Illinois, Lake Chicago: Gordon, 1479.

Lake Algonquin beaches: Stanley, 3820 .

Lake Mogodore, Cass County, Michigan : Case, 691.

Lake Souris, North Dakota: Andrews, 71.

Michigan, Whittlesey beach : Stanley, 3818.

Montana, Glacier National Park : Thaxter, 4057.

Hog Heaven mining district; Flathead County: Shenon, 3664.

Nebraska, Pleistocene, White River Valley: MacClintock, 2506.

New Hampshire, Lake' Hitchcock: Lougee, 2456.

Washington, southern Okanogan region : Flint, 1284.

Glacial period. See Glacial geology.

Glaclers.

Airplane photographs: Richards, $\mathbf{3 2 7 5}$.

Alaska: Tuck, 4177.

Glacier Bay : Cooper, 870, 871.

Malaspina and other glaciers: Washbul'n, 4353.

Mount Crillon district: Washburn, $4355,4356$.

Southern Alaska Range: Capps; 677.

Studies in 1931: Wentworth, 4409.

Valley glaciers and valley glaciation: Ray, 3192.

British Columbia, Mount Wadaington region: Munday, 2827.

Colorado: Ives, 1917.

Greenland, east: Boyd, 409.

Northeast: Teichert, 4037.

Measurement of glaciers necessary : Matthes, 2612.

Montana, Glacier National Park: Thax. ter, 4057.

Motion : Engeln, Von, 1181.

Mountain and continent: Hobbs, 1755.
Glaciers-Continued.

Mount Hood: Phillips, 3077.

Movements, typical rock deformation: Chamberlin, 721 .

Report of committee, 1934-35 : Matthes, 2614.

1935-36 : Matthes, 2615.

Washington, Mount Rainier National Park: Coombs, 856.

Wyoming, Grand Teton National Park : Fryxell, 1358.

Yukon: Washburn, 4354.

Glauconite.

California, Monterey Bay: Galliher, $1375,1376$.

Wisconsin, Cambrian : Twenhofle, 4199.

Glenarm "series, "Chester Valley, 'Pennsylvania, age: Mackin, 2544 ; Miller, 2718.

Globe, the living: Willis, 4515 .

Gneiss, eklogite inclusions, Liverpool Land, Greenland : Sahlstein, 3471.

Gold.

Alabama, Hog Mountain district : Park, 3007.

Alaska, Ruby-Kuskokwim region: Mertie, 2681.

Tonsina district: Moffit, 2762.

Upper Copper and Tanana Rivers area : Mofflt, 2763.

Appalachians, southern: Anonymous, 4692.

Gold belt : Parsons, "3018.

Arizona, bajada placers: Werber, 4419.

Chinle shales, Lees Ferry: Lausen, 2351.

Boulder Dam area, mineral occurrences : Lee, 2367.

British Columbia, Barkerville gold belt: Hanson, 1627.

Bralorne mine area: Hedley, 1685 ; Joralemon, 2013.

Carlboo and Bridge River gold fields: Dolmage, 1055.

Cariboo district: Hanson; 1624.

Fraser River-Harrison Lake region: Horwood, 1800.

Gold-bismuth occurrence, Cáriboo gold quartz mine: Warren, 4347.

Graham Island, Queen Charlotte Islands : Mandy, 2565.

Keithley Creek area, Cariboo district: Lang, 2333.

Lode gold deposits : Cockfield, 795.

Nahatlatch region: Horwood, 1801.

Ore depth in mines: Schofield, 3573.

Portland Canal area: Hanson, 1626.

Pre-Mississippian veins and deposits, Cariboo district: Lay, 2357.

Relationship to metallic minerals: Warren, 4346.

Slocan mining camp area: Cairnes, 624.

Tertiary gravels, Cranbrook area, possibilities : Rice, 3262. 
Gold-Continued.

British Columbia-Continued.

Yinir-Nelson area, lode deposits : Cockfield, 796.

California, diy placers, Mojave Desert: Hulin, 1880.

Elizabeth Lake quadrangle: Simpson, 3713.

Julian region : Donnelly, 1064, 1066.

Meadow Lake district, Nevada County: Wisker, $\mathbf{4 5 6 6 .}$

Mojave mining district, Kern County : Schroter, 3578 ; Tucker, 4181.

Monterey and Kings Counties: Franke, 1325.

Mother Lode gold belt: Logan, 2435 .

Perris block: Sampson, 3479.

Placers: Jenkins, 1936.

Tertlary river channels: Duling, 1089.

Sierra Nevada placers : Jenkins, 1937.

Siskiyou County : Averill, 124.

Southern Peninsular Range: Miller, 2728.

Southern, Perris block: Dudley, 1085.

Canada: Danloux-Dumesnil, 974; Robinson, 3323 .

Canadian Shield: Bruce, 503 ; Bruet, 510 ; pre-Cambrian flelds: Dougherty, 1074.

Synclines: Bichan, 314.

Carbonates in veins: Charlewood, 739.

Colorado, Continental Divide region: Bebre, 257.

Cripple Creek district: Kohanowski, 2247 ; Loughlin, 2459, 2460.

Front Range area : Lovering, 2469.

Jamestown district: Goddard, 1457.

La Plata mining district : Eckel, 1126.

London fault: Singewald, 3731.

Montezuma quadrangle: Lovering, 2466.

Oré dèposition south of Ouray": Móeh]man, 2760.

San Juan region: Burbank, 571; Cross, 925.

Southwestern : Burdick, 575.

Tincup mining district, Gunnison County: Goddard, 1458.

Ward district ores: Wahlstrom, 4309.

Criteria, gold quartz mines: Anderson, 69.

Electrical prospecting for gold quartz veins : Kelly, 2061.

Epithermal precious-metal deposits : Nolan, 2904.

Experiments, hydrothermal: Ogryzlo, 2940.

Geophysical prospecting for: Kelly, 2064.

Georgia : Wilson, 4557, 4558.

Battle Branch mine: Park, 3010.

Idaho, Casto quadrangle : Ross, 3369.

Edwardsburg and Thunder Mountaln area: Shenon, 3665.

Elk City mining district: Shenon, $3659,3660$.
Gold-Continued.

Idaho-Continued.

Placer mining, Snake River: Hite, 1752.

Resources: Bell, 271.

Thunder Mountain mining district : Livingston, 2428 .

Yellow Pine district, Valley County : Currier, 938.

Manitoba, Elbow-Morton area : Stockwell, 3939.

Flin Flon mine : Brownell, 499.

God's Lake gold mine: Baker, 155.

Manitoba and Ontario mining districts : Wright, 4627.

Mexico, Alamo district, Lower Callfornia : Moehlman, 2758.

Bajada placers: Webber, 4375 .

Placers: Barrera, 193.

Montana : Gilbert, 1420 ; Grassmuck, 1499.

Neihart mining district, Cascade County: Schafer, 3526.

Nevada, central Humboldt Range: Jenney, 1943.

Chief district, Lincoln County: Callaghan, 629 .

Contact mining district: Schrader, 3576.

Gold in petrifled wood, Aspen district, Churchill County: Palmer, 2996, 2997.

Placer's: Vanderburg, 4252.

Tus a rora mining district, Elko County: Nolan, 2908.

Newfoundland: Snelgrove, 3779.

New Mexico, Bayard area: Lasky, 2344.

Organ Mountains and Doña Ana County : Dunham, 1094.

North Carolina: Bryson, 532; Pardee, 3004.

North Dakota: Anonymous, 4674.

Northwest Territories, Rae to Great Bear Lake, Mackenzie d is t r 1 c t : KIdd, 2191.

-Yellowknife River area : Jolliffe, 1988.

Nova Scotla, zonal mineralization: Newhouse, 2865 . 2781.

Ontario, Afton-Scholes area : Moore,

Central Patricia gold mine: Cormie, 876 ; Reid, 3238.

East of Lake Superior: Kindle, 2195.

Goudreau, granitic stocks, and veins: Emmons, 1178.

Hollinger gold min e: Ringsleben, 3306.

Hypogene anhydrite : Langford, 2336.

Lake Shore mine area: Robson, 3328.

Little Long Lac-Jellicoe area: Bruce, 505.

Little Long Lac and Sturgeon River areas: Thomson, 4107.

Makwa-Churchill area : Laird, 2289.

Manitou Lake-Lake of the Woods belt : Thomson, 4111.

Porcupine district : Hurst, 1898, 1899. 
Gold-Continued.

Ontario-Continued.

Porphyry and quartz diabase, metallogenetic relations: Burwash, $\mathbf{5 8 6}$,

Renfrew County : Freeman, 1336.

Straw Lake, telluride ores: Thomson, 4106.

Straw-Manitou Lake area: Thomson, 4109.

Sturgeon River area : Tanton, 4013.

Swayze gold area: Rickaby, 3294.

Tashota-Sturgeon River district: Flaherty, 1278.

Telluride ores: Thomson, 4108.

Vipond gold mine, Porcupine district : Dougherty, 1073.

Ore deposits: Butler, 592.

Oregon, gold-quartz veins, Cornucopia : Goodspeed, 1478.

Tellurides, Cornucopia: Goodspeed, 1475.

Placers, prospecting: Storms, 3945.

Prospecting, quartz and placer: Jacy, 1927.

Puerto Rico: Meyerhoff, 2685; Ray, 3188.

Quebec, Abitibi area: Dresser, 1079.

Beattie mine, Duparquet Township : O'Neill, 2953.

Cadillac belt, Pandora to Pan Canadian : Gunning, 1573.

Chibougamau Lake area: Mawdsley, 2617.

Chibougamau-Opawica map area : Norman, 2913.

Chibougamau-Waswantpl dis t r i c t: Norman, 2915.

Eureka mine, telluride ores: Thomson, 4106.

Guillet (Mud) Lake area : Henderson, 1701.

Horne mine, Noranda: Price, 3131, 3132.

Lamaque mine, Bourlamaque Township : Wilson, 4537.

Lamaque-Sigma mines area, Bourlamaque Township, Abitibi County: Bell, 267.

Madeline Lake, Abitibi : MacKenzie, : 2541.

Malartic gold mine area, Abitibi: O'Neill, 2954.

Mount Megantic region: McGerrigle, 2525.

Roselake district : Mackenzie, 2542.

Siscoe gold mine area : Backman, 128.

Waswanipi map area: Norman, 2912.

Western : Bell, 268, 269, 270.

Saskatchewan, Beaverlodge area: Cameron, 630.

Lake Athabaska area : Alcock, 15.

South Carolina : Linneman, 2423 ; Pardee, 3004.

South Dakota, Black Hills: Wright, 4629.

Succession of minerals and temperatures of formation : Lindgren, 2421.
Gold-Continued.

Utah, Gold Hill mining district: Nolan, 2905.

Monument Valley-Navajo Mountain region : Baker, 144.

Virginia, Piedmont region: Park, 3009.

World's resources: Knopf, 2238.

Wyoming Black Hills: Wright, 4629.

Centennial district: Coulter, 884.

South Pass and Atlantic City district, Fremont County :: Abbott, 1.

Yukon, Carmacks district: Bostock, 379.

Teslin-Quiet Lake-Big Salmon area : Bostock, 381.

Graben, Fitts pool, Pontotoc County, Oklahoma : Hyatt, 1901.

Grand Canyon. See Arizona.

Granite.

Front Range, heavy minerals: Boos, 371.

Magmas and formation of : Collins, 814 .

Maine, Appalachian Trail: Philbrick, 3071.

Manitoba: Cole, 803.

Missouri, heavy accessory minerals: Tolman, 4137.

Sheahan quarry, Granitevllle: Tolman, 4138.

New York, Potsdam quadrangle, St. Lawrence County: Reed, 3217.

Quebec: Osborne, 2974.

North of St. Lawrence River (second section) : Osborne, 2962.

South Carolina, Columbia quadrangle: Kesler, 2087.

Graphite.

New Jersey, minerals, Franklin and Sterling Hill: Palache, 2985.

Graptolitoidea.

Colorado, Pitkin County: Johnson, 1973.

New York, black Ordovician shales, Mohawk Valley: Ruedemann, 3406.

Oklahoma, Silurian: Decker, 997.

Simpson group: Decker, 996.

Oklahoma and Arkansas, correlations by : Decker, 1000.

Ordovician, Labrador: Little, 2426.

Quebec: Ruedemann, 3405.

Utah : Clark, 704.

Paleozoles, Lower, correlations by: Décker, 1001.

Sylvan shale, Oklahoma, and Polk Creek shale, Arkansas: Decker, 998.

Tennessee and Quebec, Ordovician : Ruedemann, $\mathbf{3 4 1 5}$.

Viola limestone,. Oklahoma: Ruedemann, 3402 .

Gravel.

Alberta, Edmonton district : Rutherford, 3456.

British Columbia, industrial and nonmetallic minerals : Richmond, $\mathbf{3 2 8 7}$. 
Gravel-Continued.

California, nonmetallic minerals : Bradley, $\mathbf{4 2 1}$.

Iowa, southern, road and concrete materials: Wood, 4591:

Mánitoba : Hutt, 1900.

Resistivity exploration for: Kurtenacker, 2282.

Texas, Palo Pinto County: Plunimer, 3098.

West Virginia, upper Monongabela Valley : U. S. Com., 4224.

Gravity surveys.

Anomalies, affected by local densities : Bowie, 405.

Near Carolina bays: Prouty, 3148, 3151:

West Indies: Bowie, 395.

Anomalies and geologic structures: Woolard, 4613.

Black Hills-Bighorn-Beartooth region:Chamberlln, 719.

Crosbyton, Texas: Hoskinson, 1803.

Earth, figure: Lambert, 2297.

Gulf Coast States: Baker, 156.

Observations and basement structures Thom, 4075 .

Potsdam, Germany, and Wasbington, relative gravity, values: Brown, 481.

United States: Glennie, 1446.

Virginia, Maryland, and vicinity : Bowle, 405.

Greenalite, Minnesota : Gruner, 1563.

Greenland : Iioch! 2244.

Bibliography : Anonymous; 4662.

Lauge Koch, defense of his work: Margerie, 2582.

Areas described.

Northeast Greenland: Teichert, 4037.

Economic geology.

Iron, native, west Greenland: Carpenter, 685 .

Mineral resources: Bliuthen, 351.

Historical geology.

Basalt formation, northeast Greenland : Backlund, 126.

Christian X's Land, Caledonian orogeny : Wegmann, 4377.

Cretaceous, Upper, east Greenland : Frebold, 1332.

Crystalline complex, Liverpool Land: Kranck, 2256.

Devonian, east Greenland: Butler, 593.

East Greenland, Lowèr Cretaceous: Bপgvad, 361 .

Franz Joseph region: Odell, 2936.

Gauss Peninsula and" Passage 'Hills, Devonian, east Greènlánd: SäveSïderbergh, 3468 .

General: Backlund, 127 ; B $\phi g g i l d, 360$; Hobbs, 1758 ; Koch, 2245.

Godthaab Gulf, east Greenland, Permian and Eotriassic vertebrate beds: Nielsen, 2882.

Kap Dalton region: Wager, 4306.
Greenland-Continued

Koldewey Island, Cretaceous: Frebold, 1333.

Milne Land, Upper Jurassic: Parat, 3001 .

Northeast Greenland : Telchert, 4037.

Parallel Válley, Gaușs Peninsula, Devonian: Johansson: 1954.

Posidonomya' slate, : east Greenland, age Aldinger, 17.

Scoresby 'Bay area: Bentham, 281.

Scoresby Sound, upper 'Jurassic: Aldin$\therefore \quad \therefore \quad$ ger, 18 ?

Succession "In crystallines, Liverpool $\therefore$ Land: :Sahlstein, 3472:

Ymer Island, west end Cleaves, 772.

Mineralogy.

Igalikite and naujakasite: Bøggild, 359.

Paleontology.

Actinoceroid Cephalopoda, Ordovician, north Greenland: Teichert, 4035.

Cape Leslie, Milne Land, Jurassic invertebrates: Spath, 3798.

Coals, Cretaceous, paleobotanical examination: Miner, 2745.

Cretaceous, Upper,, east Ǵreenland : Frebold, 1332.

East Greenland, Lower Cretaceous: Bøgvad, 361.

Fishes, Triassic, east Greenland: Nielsen, 2883.

Foraminifera, early Cambrian : Howell, 1852:

Gauss Peninsula and - Passage Hills, Devonian, east Greenland: SüveSöderbergh, 3488.

Godthaab: Gulf, east Greenland, Permian and Eotriassic vertebrate beds : Nielsen, 2882.

Invertebrates, Eo-Triassic, east Greenland: Șpath, 3797.

Jurassic invertebrates, Cape Leslle, Milne Land: Spath, 3799.

Koldewey İsland, marine Cretaceous fauna : Frebold, 1333.

Laby,rinthodont stegocephalians and primitive Reptilia: Siive-Siider. . bergh, 3479 .

Milne Land, Upper Jurassic: Parat, 3001 .

Piceoxylon cf. laricinoides, Jackson Island, east Greenland: Høeg, 1772.

Placodermi, Devonlan, east Greenland : Stensio, $\mathbf{3 8 6 5}$.

Plants, Cretaceous, western Greenland: Seward, 3644.

Plants, Kingigtok and Kagdlunguak, west Greenland: Seward, 3643.

Plesiosaur, Jurassic: von Huene, 1876.

Pollen and diatoms from moor: Iversen, 1913.

Scoresby Sound, eașt Greenland, flora : Harris, 1643.

- Stegocephallans and primitive Reptllia: Romer, 3349.

Ymer Island, west end : Cleaves, 772. 


\section{Greenland-Continued.}

Petrology.

Basalt formation, northeast Greenland : Backlund, 126.

Crystalline complex, Liverpool Land :

Kranck, . 2256.

Eclogite inclusions in gneiss, Liverpool Land : Sablstein, 3471.

Kap Dalton region: Wager, 4306.

Succession in crystallines, Liverpool Land: Sahlstein, 3472.

Physical geology.

Christian X's Land, Caledonian orogeny: Wegmann, 4377.

Crystalline complex, Liverpool Land: Kranck, 2256.

Fault, submarine, along continental border : Holtedahl, 1787.

Franz Joseph region: Odell, 2936.

General : Koch, 2245.

Scoresby Bay area : Bentham, 281.

Physiographic geology.

Fiord region, east Greenland: Boyd, 409.

Ice cave, Canning Land: Noe-Nygaard, 2903.

Mountain chain, eàstern coast: Rabot, 3164.

Scoresby Bay area: Bentham, 281.

Submarine ridge, southeast coast: Tanlng, 4012.

Greensand. See Glauconite.

Ground motion, determination from seismograms: Blake, 342.

Ground water. See Underground water.

Group, use of term: Keyes, 2097.

Guadeloupe : Barrabé, 191.

Guatemala. See also Central America.

Paleontology.

Rudistae, Barrettia : Mac Gillarry, 2530.

Physical geology.

Fuego, Atitlan and Santa Maria volcanoes, 1934: Reck, 3213 .

Gulf coast geosyncline, stratigraphic evidence : Howe, 1843.

Gulf coast oil flelds : Barton, 209, 215.

Guns of Seneca Lake, New York : DeVarigny, 1037.

Gypsum.

Boulder Dam area, mineral occurrences : Lee, 2367.

Limestone caves, development in: Pohl, 3103.

Manitoba : Hutt, 1900.

Michigan, Grand Rapids:- Mathews, 2606.

Ohio, Silurian : Jones, 2009.

Hackmanite, photosensitivity, reversible : Lee, 2368.

Hawailan Islands.

Arc, Hawatian Island : Bartsch, 217.

Oahu : Stearns, $\mathbf{3 8 5 5}$.
Hawaiian Islands-Continued.

Historical geology.

Kauai, island of: Clark, 770 .

Nuuanu Valley, Oahu: Wentworth, 4401.

Oahu : Chamberlin, 723 ; Stearns, 3849.

Oahu and Maui, Pleistocene shore lines: Stearns, 3851.

Mineralogy.

Soda alunite, Molokai : Laudermilk, 2347.

Petrology.

Differentiation of Hawaian lavas Powers, 3118.

Crystal cavities in Hawailan lavas: Dunham, 1095.

Gas-bubble pits in coastal pahoehoe lavas: Palmer, 2993.

Physical geology.

Chink-faceted pebbles: Wentworth, 4410.

Differentiation of : Hawailan lavas: Powers, 3118.

Earthquakes accompanying 1934 eruption of Kilauea : Jones, 1997.

Earthquakes, travel times: Jones, 1996.

Kauai, island of: Clark, $\mathbf{7 7 0 .}$

Kilaúea eruption, 1931-32: Jones, 1905.

Kilauea: Volcano, ground surface movements: Wilson, 4556.

Lava flows, Mauno Loa: Hodgkins, '? 1766.

Mauna Loa, eruption, November 21, 1935 : Jaggar, 1928.

Nuuanu Valley, Oahu: Wentworth, 4401.

Pearl and Hermes reef sediments : Thorp, 4119.

Seaquake, off Hawail : Brown, 478.

Volcanism : Doorninck, van, 1068.

Physiographic geology.

Geomorphic divisions: Wentworth, 4407.

Heights and ruggednes, Hawaii and U. S. : Palmer, 2992

Mauna Kea glacial geology: Gregory, 1522.

Oahu, marine benches: Wentworth, 4400 .

Modern bench-forming processes : Wentworth, 4404.

Shore benches : Stearns, 3850 .

Oahu and Maui, Pleistocene shore lines: Stearns, 3851.

Underground water.,

Artesian-water supply control : Meinzer, 2631.

Oahu : Chamberlin; 723 ; Stearns, 3849.

Heat conduction, dissimilar rocks : Lovering, 2470.

Hedenbergite, Montana: Warde, 4336.

Heavy minerals.

Cambrian, upper Mississippi Valley : Raasch, 3161.

Canadian Shield granites : Bruce, 502. 
Heavy minerals-Continued.

Comparison, statistical methods: Helsoñ"' 1691.

Colorado, Front Range granites : Boos, 371.

Granites, pre-Cambrian, correlation : Stark, 3832.

Mississippi, Eocene: Grim, 1548.

Missouri, granites, heavy accessory minerals : Tolman, 4137.

Paleozoic formations, Virginia: Johnson, 1969.

Sampling: Cogen, 797.

Suites, statistical methods of 'comparison: Helson, 1691:

Wisconsin, St. Peter sandstone: Tyler, 4202.

Wyoming, Front Range granites: Boos, 371.

Zones of, Modelo formătion, Santa Monica Mountains, Calif.: Cogen, 798.

Historical (stratigraphic) geology: Mather, 2599 ; Willis, 4525. For areal see names of States. See also the different systems; Correlation ; Geologic formations, tables.

Ages, tentative, Pleistocene shore lines: Cooke, 845.

Algonkian error: Lane, 2327.

Antillean-Caribbean region : Chamberlin, 722 ; Hedberg, 1083; - Schuchert 3579 ; Trask, 4156.

Appalachians, s o u th er n, structure: Boesch, 363.

Arkose deposits in humid Tropics : Krynine, 2274.

Atlantic Coastal Plain', signiflcance of geophysical data : Miller, 2719.

Bentonite, Ordovician, correlation, eastern North America: Rosenkrans, 3358,3359 .

Cambrian, redefinition: Keyes, 2159.

Carboniferous rocks of North America : Moore, 2789.

Classifications and correlations': Chamberlin, 718 .

Continents and oceans, origin: Bowie, 399.

Continents, stratigraphic evidence on tectonics : Moore, 2792.

Correlation by insoluble residues: McQueen, 2561.

Pennsylvanian limestones: Mitchell, 2754.

Cretaceous, Nuttall's first recognition of : $\therefore$ Keyes, 2173.

Devonian, Middle, mid-West: Cooper, 864.

Eocene sequence, western North America : Clark, 759.

Ep-Archean and Ep-Algonkian intervals : Hinds, 1749.

Fusulinidae in Permian and Pennsylvanian correlations: Dunbar, 1090.

Gravity anomalies, United States : Glennie, 1446.

Historical (stratigraphic) geology-Con

Group, use of term : Keyes, 2097.

Gulf coast geosyncline, stratigraphic evidence: Howe, 1843.

Oil flelds, distribution; and continental spreading: Wade, 4300.

Paleoecology, effect on : Twenhofel, 4200.

Pảleozolc, 'Canadian .Rockies:' Kelly, 2067.

Pectinfare, index fossils, southeastern U. S. : Mansfield, 2573.

Permian: : Keyes; 2105! 2132.

Sequences, correlation: Schuchert, 3580 .

Plant distribution as guide to age deter. mination : Chaney, 730 .

Pleistocene, Europe and America : Worm. ington, 4619 .

Pre-Cambrian buried surface in U. S.: Moss, 2811.

Priority vs. usage, geological terminol- ogy": Keyes, 2121.

Pulsation theory: Grabau, 1489, 1490.

Rocky Mountain geosyncline, Cretaceous : Keyes, 2096.

St. Peter series : Edson, 1139.

Stage as stratigraphic unit: Schenck, 3545.*...' : is.

Submarine valleys, age, central Atlantic coast : Stetson, 3891.

Upthrust-geologic term: Willis, 4523.

Volcanism, relation to geologic history: Whitney, 4467.

History : Ries, 3300. See also Surveys.

American Association for the Advancement of Science : Clark, 754 ; Livingstón, 2427.

Canada mining: Allan, 30.

Clay industry of Tennessee: Whitlatch, 4464.

Copper industry, development : Fiurness, 1367.

Cretaceous rocks, Texas, nomenclature: Thompson, 4102.

Crystallography:"Pabst, 2978.

Deformation of earth's crust, Paleozoic : Moore, 2787.

Geophysics, applled, petroleum industry : De Golyer, 1006.

'Grand 'Canyon of' the Yellowstone : Howard, 1813.

Micropaleontology in Mexico : Barker, 182.

Montana, gold production : Gilbert, 1420. Silver production: Gllbert, 1419.

National Academy of Sciences: Campbell, 639 .

Nickel, development and use: Stanley, 3821.

North America regional exposition : Joerg, 1953.

Origin of springs and ground water, ideas on: Baker, 154.

Pennsylvania Geological Survey : Anonymous, 4694; Ashley, 108; Logue, 2438 ; Stone, 3943. 
History-Continued.

Petroleum development in America : Goodrich, 1474 ; White, 4452.

Petroleum: geology and the A. A. P. G.: Levorsen, 2406.

Frecious stones, valuation and prices: Ball, 174

Texas, Division of Natural Resources: Schoch, 3570.

Virginia, mineral resources, development: Boyle, 411.

Homonyms and nomenclators: Oehser, 2939.

Hot springs. See also Thermal waters.

Yellowstone National Park: Alłen, 36, 37 ; Day, 992 ; Ross, 3367.

Huronian. See Pre-Cambrian.

Hydrothermal alteration.

Colorado, Alma district, porphyries and ore deposition, relations: Singewald, 3729.

Lead and zinc minerals, hydrothermal experiments : Kristofferson, 2264.

New Mexico, Virginia mining district: Lasky, 2345.

Ontario, aplites with cobalt-silver ores: Bastin, 234.

Silicate minerals: Syromyatnikiv, 3999.

Ice age. See Glaciạl geology.

Coming: Taber, 4001.

Ice, agent of rock weathering: Grawe, 1508.

Ice caves.

California, northern : Swartzlow, 3993.

Greenland, east, Canning Land: NoeNygaard, 2903.

New Mexico, perpetual ice under lava: MacClary, 2502.

Idaho.

Areas desoribed.

Casto quadrangle: Ross, $\mathbf{3 3 6 9}$.

Economic geology.

Beryl, Latah County : Anonymous, 4661.

Casto quadrangle : Ross, 3369.

Copper districts: Ross, 3370.

Edwardsburg and Thunder Mountain area: Shenon, 3665.

Elk City mining district: Shenon, 3659, 3660.

Gold placer mining, Snake River: Hite, 1752 .

Gold résources : Bell, 271.

Mining industry, 1934 : Simons, 3711.

Natural-gas flelds : Kirkham, 2220.

Rare metals: Bell, 272.

Sands, quartz washed from kaolins: Wilson, 4538.

Thunder Mountain mining district: Liv. ingston, 2428.

Yellow Pine district, Valley County: Currier, 938

\section{Historical geology.}

Carboniferous, Blue Springs Hills : Williams, 4513.

Casto quadrangle: Ross, 3369.

Copper districts: Ross, $\mathbf{3 3 7 0 .}$
Idaho-Continued.

Historical geology-Continued.

Edwardsburg and Thunder Mountain area : Shenon, 3665.

Elk City mining district: Shenon, 3669, 3670.

Flora, Tertiary, southwestern Idaho: $\therefore$ Dorf, 107:0.

Idaho batholith: Ross, 3376 .

Natural-gas fields: Kirkham, 2220.

Șnake River valley above Idaho Falls: Debler, 995.

South-central Idaho: Ross, 3372.

Springs and alcoves, origin, Snake River: Stearns, 3853.

Tuffis, welded rhyolite, southeastern Idaho: Mansfield, 2566.

Yellow Pine district, Valley County: Currier, 938.

\section{Mineralogy.}

Beryl, Latah County : Anonymous, 4661.

Gems: Carpenter, 686.

Pyroxmangite, Homedale: Henderson, 1696.

Willamette meteorite : Dake, 956.

\section{Paleontology.}

Ceratomeryx prenticei, Pliocene, Hagerman : Gazin, 1394.

Erethizon bethygnathum, Cenozolc, Grand View : Wilson, 4553.

Flora, Tertiary : Dorf, 1069, 1070.

Fossil hunting: Gazin, 1391.

Horses, Pliocene : Gazin, 1397.

Mammalia, American Falls, Pleistocene : Gazin, 1395.

Pliocene, Snake River Valley: Rice, 3264.

Miocene leaves, fruits, and seeds : Brown, 489.

Plants, .Sucker Creek, Miocene : Brooks, 470 .

Pleistocene Mammalia, American Falls : Gazin, 1395.

Sloths, Pliocene and Pleistocene: Gazin, 1393.

\section{Petrology.}

Edwardsburg and Thunder Mountain area: Shenon, 3665 .

Idaho batholith: Ross, 3376 .

Pearl-Horseshoe Bend porphyry belt : Anderson, 62.

Tuffs, welded rhyolite, southeastern Idabo: Mansfield, 2566.

Yellow Plne district, Valley County : Currier, 938.

Physical geology.

Edwardsburg and Thunder Mountaln area : Shenon, $\mathbf{3 6 6 5}$.

Grimes Creek, Payette Canyon: Anderson, 61 .

Idaho batholith : Ross, 3376 .

Lava floods, Soda Springs valley : Stearns, 3854 .

Rifting and volcanic activity, Craters of the Moon: Shepherd, 3685.

Springs and alcoves, origin, Snake River : Stearns, 3853. 
Idaho-Continued.

Physiographic geology.

Coeùr d'Alene flood plain: Humphrey, 1887.

Glacial till : Field, 1248.

Grimes Creek, Payette Canyon: Anderson, 61.

Salmon River canyon: Shenon, 3663.

Snowdrifts and Palouse topography: Rockie, 3329.

Underground water.

Mud Lake region, water resources: Stearns, 3847 .

Snake River Plain, well records : Stearns, 3852.

Snake River valley above Idaho Falls: Debler, 995.

Springs and alcoves, origin, Snake River: Stearns, 3853.

Thermal springs: Waring 4341.

Igneous and volcanic rocks. See also Batholiths; Dikes; Intrusions; Laccoliths; Magmas: Daly, 965.

Alabama, Hog Mountain district: Park, 3007.

Alaska, hornblendite, Annette and Duke Islands: Koschmann, 2252.

Ruby-Kuskokwim region: Mertie, 2681.

Southern Alaska Range: Capps, 677.

Upper Copper and Tanana Rlvers area : Moffit, 2763.

Willow Creek-Kashwitna district: Capps, 678.

Anorthosite, origin: Buddington, 550 . Antillean-Caribbean region: Schuchert, 3579.

Arizona, Navajo-Hopi country, Pliocene : Williams, 4509.

Silver King area, Superior : Galbraith, 1373.

British Columbia, amphibole, Purcell sills: Rice, 3261 .

Kruger seyenites: Campbell, 633.

Similkameen and Lillooet districts : Cockfield, 795.

California, Clear Lake area: Anderson, 64.

Content of lavas, Lassen Volcanic National Park: Evans, 1192.

Mesozoic and Cenozoic eruptive rocks, Klamath Mountains: Hinds, 1746.

Mount Diablo and Coalinga areas: Clark, 755.

Mount Diablo and vicinity: Taff, 4005.

Peninsular Range : Miller, 2728.

Perris block: Dudley, 1085.

Petaluma district: Morse, 2806.

Pinnac'es National Monument: Andrews, 74.

South coastal basin : Eckis, 1131.

Carriacou, West Indies: Trechmann, 4162.

Chaleur Bay region, Quebec and New Brunswick : Alcock, 12.
Igneous and volcanic rocks-Continued.

Classification, mineralogical: $\mathbf{S}$ h a $\mathbf{n}$, 3645.

Colorado, batholith, Twin Lakes and

Clear Creek districts: Chapman, 732.

Columbia and Dew Drop vein systems, Boulder County : Walker, 4318.

Eocene, Front Range: Lovering, 2471.

Indian Creek plutons, Front Range: Boos, 372.

Jamestown district, Tertiary intrusives: Goddard, 1457.

La Plata mining district: Eckel, 1126.

Sawatch Range: Stark, 3829.

South Park: Howland, 1868.

Spanish Peaks region: Knopf, 2239.

Tincup mining district, Gunnison County : Goddard, 1458.

Tomichl dome: Stark, 3833.

Connecticut, Prospect porphyritic gneiss: Stewart, 3899.

Spatter cone in trap sheet: Foye, 1323.

Cuba, Isla de Pinos: Rutten, 3459.

Dunite intrusion, and olivine: Bowen, 388.

Evaluation of names: Haff, 1596.

Flow units in basalt: Nichols, 2873.

Greenland : Koch, 2244, 2245.

Kap Dalton region: Wager, 4306.

Liverpool Land, crystalline complex : Kranck, 2256.

Northeast, basalt formation: Backlund, 126.

Scoresby Bay area: Bentham, 281.

Hawail, Island of Oahu : Stearns, 3849.

Differentiation of lavas: Powers, 3118.

Heat conduction, theory: Lovering, 2467.

Idaho, Casto quadrangle: Ross, 3369.

Edwardsburg and Thunder Mountain area: Shenon, 3665.

Snake River springs and alcores, orfgin : Stearns, 3853.

Yellow Pine district, Valley County: Currier, 938.

Jamaica, basal complex: Trechmann, 4163.

Labrador, amazonite-aplite dike : Wheeler, 4439.

Magmatic stoping: Grout, 1556.

Manitoba, Elbow-Morton area: Stockwell, 3939.

God's Lake gold mine: Baker, 155

Manitoba and Ontario mining districts : Wright, 4627.

Maryland, Piedmont intrusives: Cloos, 783.

Mechantcal analysis, thin-section: Krumbeln, 2267.

Mexico; Cananea Mountains, Sonora: Valentine, 4247.

Chlapas, pre-Tertiary : Müllerried, 2815. 
Igneous and volcanic rocks-Continued.

Mexico-Continued.

Coahuila Peninsula : Kellum, 2057; Kelly, 2061; Singewald, 3732.

Cusihuiriachic, Chibuahua: Donald, 1057.

Tampico region: Muir, 2821.

Tepezala, Aguascalientes, pyrometasomatic vein deposits: Wandke, 4328.

Michigan, granitic sequence, : southern complex: Dickey, 1044.

Republic granite, intrusive relations: Lamey, 2299.

Minnesota, Ogishkemuncie Lake region: Sleight, 3740 .

Missouri, St. Francis Mountain, granitic intrusion: Tolman, 4136.

Montana, Highwood Mountains: Larsen, 2339.

Hog Heaven mining district, Flathead County: Shenon, 3664.

Idaho batholith, northeastern part: Langton, 2337.

Libby quadrangle: Gibson, 1417.

Stillwater igneous complex : Howland, 1869.

Nevada, dikes, Paradise Range: Callaghan, 628.

Scheelite-leuchtenbergite vein, Paradise Range: Kerr, 2082.

Tonopab mining district: Nolan, 2907.

T u s c a r or a mining district, Elko County : Nolan, 2908.

New Brunswick, Grand Manan Island: Gesner, 1408.

Newfoundland, Bay of Exploits area : Heyl, 1736.

Bay of Islands igneous complex : Cooper, 869.

Trout River area: Ingerson, 1906.

New Hampshire, Belknap Mountains ring-dike complex : Modell, 2756.

Franconia quadrangle: Billings, 317 .

Iittleton and $\mathrm{M}$ o o sil a u ke quadrangles: Billings, 318.

Percy ring-dike complex: Chapman, 734.

White Mountain magma series : Chapman், 733 .

New Jersey, Palisades sill : Butler, 594.

Watchung Mountains: Moldenke, 2765.

New Mexico, Bayard area: Lasky, 2344.

Central mining district: Schmitt, 3566.

Mount Taylor coal field : Hunt, 1888.

Navafo-Hopi country, Pliocene: Williams, 4509.

Santa Rita mining area: Spencer, 3803.

New York, Dutchess County : Balk, 162. New York, Hammond, Antwerp, and Lowville quadrangles: Buddington, 543.

Oswegatchie quadrangle: Dale, 961.
Igneous and volcanic rocks-Continued. New York-Continued.

Potsdam quadrangle, St. Lawrence County: Reed, 3212.

Poundridge granite: Bell, 265.

Russell quadrangle: Dale, 958.

Zinc mine, Balmat: Brown, 484.

Northwest Territories, Great Bear Lake granite-porphyries: Riley, 3304.

Yellowknife River area: Jolliffe, 1988.

Numerical ffeld tabulation: Spearman, 3800 .

Ontario; Lake Shore mine area: Robson, 3328 .

Makwa-Churchill area: Laird, 2289.

Porcupine area: Hurst, 1899.

Straw-Manitou Lakes area: Thomson, 4109.

Sturgeon River area: Tanton, 4013.

Swayze gold area: Rickaby, 3294 .

Syenites, Coldwell district: Thomson, 4110.

Vermilion Township, Kenora district: Pettijohn, 3065.

Oregon, central, Newberry volcano: Williams, 4507.

Eastern: Gilluly, 1430.

Saddle Mountain State Park: Layfleld, 2358 .

Unpqua"formation: Wells, 4389.

Origin and composition: Runner, 3422.

Oxides, opaque, and sulphides: Newhouse, 2862 .

Pennsylvania-Maryland Blue RidgePiedmont igneous complex : Bascom, 218.

Philadelphia area: Watson; 4359.

Petrology : Alling, 49. Interpretative : Bowen, 390.

Pre-Cambrian, eastern Pennsylvania and Maryland : Bascom, 219.

Primary banding, basic plutonic rocks: Coats, 787

Puerto Rico: Meyerhoff, 2685; Ray, 3191.

Quebec, Abitibi area : Dresser, 1079.

Bolton series: Clark, 766.

Chibougamau Lake area: Mawdsley, 2617.

Chibougámau-Opawica map area : Norman, 2913.

Chibougamau - Waswanipi district : Norman, 2915.

Guillet (Mud) Lake area : Henderson, 1701.

Lamaque mine, Bourlamaque Township : Wilson, 4537 .

Lamaque-Sigma mines area, Bónrlamaque Township, Abitibi County: Bell, 267.

Malartic gold mine area, Abitibi: O'Neill, 2954.

Marsoui area, Gaspé Peninsula : Jones, 2001.

Noranda district, Amulet mine, rock alteration: Wilson, 4547.

Osisko Lake area: Conolly, 840. 
Igneous and volcanic rocks-Continued.

Quebec-Continued.

Sabourin area, Témiscamingue County : Denis, 1031.

Shawinigan Falls district: Osborne, 2965.

Siscoe gold mine area: Backman, 128.

Travers Lake area, Témlscamingue County: Retty, 3256.

Waswanipi map area: Norman, 2912.

Western, gold.in intrusives : Bell, 268.

Relations of : Hodge, $\mathbf{1 7 6 5}$.

Saskatchewan, Lake Athabaiska area: Alcock, 15.

Succession of minerals and temperatures of formation: Lindgren, 2421.

Temperatures, high, effect on: Bowen, 386.

Trinidad: Kugler, 2280.

Utah, Gold Hill mining district : Nolan, 2905.

Navajo-Hopi country, Pliocene: Willlams, 4509.

Virginia, gold deposits, Piedmont region: Park 3009.

James River iron and marble belt: Furcron, 1362.

Southwestern, hypersthene granodiorite: Jonas, 1989.

West Indies, Guadeloupe, Martinque: Barrabe, 192.

Wyoming; Trout Creek Canyon, Park County: Sheets, 3657.

Yellowstone National Park lava cliffs: Brouwer, 472.

Rhyolite structure: Brouwer, 473.

Yukon, Carmacks district: Bostock, 379.

Igneous intrusions. See Intrusions.

Igneous rocks and high temperature: Bowen, 386.

tllinois.

Economic geology.

Ash correction formulae of coal, by petrographic analysis: Ball, 164.

Carbon-ratio theory, status in Illinois: Bell, 264.

Coal No. 6, : banded ingredients: McCabe, 2492.

Calorific variations: Benson; 280.

Fluorspar fleld, Illinois-Kentucky, struc. ture: Currier; 939

Lead - zinc district, Wisconsin - Illinois : Behre, 255.

Natural gas, Eastern Interior coal basin : Bell, 263.

Oil and gas "possibilities, Marion and Clay Counties: Weller, 4385.

Oil possibilities, Eastern Interior Basin : Sanders, 3490.

Illinois Basin : Howard, 1831 ; Weller, 4386.

Publications on : nonymous, 4687 .

Rock-wool resources: Lelghton, 2385.

Sediments, argillaceous, investigations : Bray 451.

Underclays, Fennsylvanian ; Grim, 1549.
Illinois-Continued.

Historical geology.

Cambrian inlier, Oregon:-Bevan, 307.

Devonian, upper Mississippi Valley: Stainbrook, 3815.

E'ernvale formation, Valmeyer: Greger, 1519.

Fluorspar field, Illinois-Kentucky, structure : Currier, 939.

Galena dolomite, Upper Mississippi Valley: Kay, 2028.

General : Kansas Geol. Soc., 2020 ; Trowbridge, 4174.

Illinois Basin : Weller, 4386.

Isopach.map, Galena, Decorah, and, Platteville formations: Ball, 166.

Trempealeau, Dresbach, and Franconia formations: Edwards, 1140.

Kaskaskia "limestone, title, validity : Keyès, 2184.

Lead-zinc district, - Wisconsin-Illinois : Behre, 255.

Marion and Clay Counties : Weller, 4385 .

Mississippi River arch : Howell, 1866.

Mississippi Valley cross sections : Workman, 4618.

Mississippian system, upper Mississippl - Valley: Moore, 2784.

Molluscan fauna, Pleistocene loess: Baker, 151.

Oil in Illinois Basin, possibilities : Howard, 1831.

Ordovician, upper Mississippi Valley: Kay, 2027.

Prairie du Chien beds, upper Mississippi Valley: Powers, 3117.

Publications on : Anonymous, 4687.

Silurian, upper Mississippi Valley: Sutton, 3983.

Stewartville and Dubuque formations : Kay, 2032.

$\therefore$ Mineralogy.

Crystallizations in geodes, Hamilton: McKInley, 2547.

Under clays, Pennsylvanian : Grim, 1549.

\section{Paleontology.}

Aurora mastodon : Powers, 3121.

Carboniferous forest, Mazon Creek : Noe, 2900.

Casteroldes ' ohloensis, distribution : Cahn, 623.

Ceratiocaris: leese, 'Silurian : Roy,' 3495.

Ceratiocaris markhami, Silurian: Roy, …: : 3493 .

Conularia manni, Silurian: Roy, 3494.

Corals, Mississippian : Grove, 1558.

Dadoxylon steidtmannii, Carboniferous: Miner; 2746.

Fernvale formation, Valmeyer: Greger, 1519.

Flora, Peńnsylvanian, in coal balls : $\because$ Graham, 1491.

Lepidocarpon sporangia, Carboniferous : Reed, 3216.

Mastodon, avian, and other remains, Aurora: Smith, 3746, 3748. 
Illinois-Continued.

Paleontology-Continued.

Mollusca, sequence in loess deposits: Baker, 150,.151.

Pedicellariae, Carboniferous : Gels, 1401.

Postglacial vegetation, Lake Michigan region: Fuller, 1359.

Sponge spicules, silliceous, Pennsylvanian: Weller, 4382.

Spores of Illinois coal No. 6: Schope, 3575.

Spruce cones, Grass Lake: Anonymous, 4709.

Trumpeter swan; Plelstocene, Aurora: Wetmore, 4482.

Volo bog, Lake County : Artist, 97.

\section{Petrology.}

Ash correction formulae of coal, by petrographic analysis: Ball, 164.

Fuller's earth, Olmstead: Grim, 1647.

Physical geology.

Cylindrical structures in sandstone: Hawley, 1656.

Earthquake, southern Illinois, October 29, 1934 : Dahm, 950.

Faults, location by earth-resistivity method: Hubbert, 1874.

Fluorspar field, Illinois-Kentucky, strueture: Currier, 939.

Structure, determination by electrical resistance methods : Hubbert, 1875.

Physiographic geology.

Lake Chicago, glacial : Gordon, 1479.

Soil materials, constitution and highway construction: Ekblaw, 1164.

Volume, shape, position, rock fragments in openwork gravel: Wadell, 4304.

Underground water.

Lake County: Gerber, 1403.

Survey, ground-water resources : Gerber, 1404.

Wells, location, drilling, casing : Leighton, 2382.

Zones of mineralization: Thwaites, 4124.

Index fossils.

Conodonts, value in stratigraphic determinations: Branson, 443.

Devonian, Middle, midwest : Cooper, 864.

Foraminifera: Nuttall, 2925.

Fusulinidae in Permian and Pennsylvanian correlations: Dunbar, 1090.

Graptolites in Ordovician black shales, New York: Ruedemann, 3406.

Mexico, Chiapas, pre-Tertiary : Mullerried, 2815.

Tampico region, Foraminifera: Muir, 2821.

Micropaleontology and petroleum geology : Nuttall, 2924.

Pectinidae, Tertiary, southeastern U. S.: Mansfleld, 2493.

Texas, Foraminifera, Conroe oil field; Gravell, 1507.

Microfossils: Thomas, 4091.

Navarro-Taylor diagnostic Foramin:fera : Plummer, 3099.
Index fossils-Continued.

Texas-Continued.

Venericardia planicosta group, Tertiary: Rutsch, 3457.

Index liquids.

Immersion liquids, high refractive index : West, .4422.

Indiana.

Economic geology.

Natural gas, Eastern Interior coal basin : Bell, 263.

Lima-Indiana district: Ley, 2413.

Petroleum possibilities, Illinois Basin : Weller, 4386.

Historical geology.

Correlations by graptolites, Lower Paleozoics : Decker, 1001.

General: Harrell, 1640; Kansas Geol. Soc., 2020.

Iilinois Ba'sin: Weller, 4386.

Isopach map, Galena, Decorab, and Platteville formations: Ball, 166.

Kentland area, Ordovician: Shrock, 3702.

Silurian formations, correlation: Foerste, 1298.

Turkey Run State Park: Anonymous, 4679.

Wabash River Valley floor: Fidlar, 1246.

Paleontology.

Cervalces, Oakland City: Riggs, 3303.

Coprolites, Salem limestone: Shrock, 3698.

Corals, Mississippian : Grove, 1558.

Tabulate, Devonian, Falls of the Ohlo: Werner, 4420.

Crinoid stems on fossil wood: Wickwire, 4472.

Ditomopyge, adolescent development : Weller, 4383.

Mammals, Pleistocene : Lyon, 2490.

Mastodon, Noble County : Sanford, 3492.

Ostracoda, Waldron shale, Flat Rock Creek : Coryell, 880.

Physical geology.

Cave, Marengo, Crawford County : Fidlar, 1245 .

Karst windows: Von Osinski, 4296.

Physiographic geology.

Wabash River Valley floor: Fidlar, 1246.

Underground water.

Ground water: Harrell, 1640.

Inertia in low-angle thrust faulting: Stevens, 3893

Influence of potential in ore deposition: Dadson, 949.

Insecta.

Amber, Cedar Lake, Manitoba: Walker, 4323.

Borings in fossil wood: Brues, 508.

Chrysopidae, Tertiary, Colorado: Carpenter, 682 .

Kansas, Permian: Tillyard, 4131.

Larval chambers, fossil, of mining bees : Brown, 491. 
Insecta-Continued.

Manitoba, Canadian amber with insects : Carpenter, 681 .

Chemawinite, Canadian amber: Walker, 4319.

Nemestrinidae, Miocene, Florissant, Colrado: Bequaert, 283.

Permlan, Kansas: Carpenter, 683.

Raphidiodea, Neartic, revision : Carpenter, 684.

Insoluble residues.

Oklahoma, correlation by: Ireland, 1907.

Ordovician limestones near Lexington, Va.: Smith; 3756.

Texas, natural glasses, Pennsylvanian limestones: Patton, 3028.

Interglacial periods. See Glacial geology.

Intrusions. See also Batholiths; Dikes; Igneous and volcanic rocks; Laccollths; Magmas.

Alaska, southern Alaska Range: Capps, 677.

Arizona, copper districts : Tenney, 4040.

Bibliography : Sundeen, 3979.

Bore-hole investigations, Yellowstone Park : Fenner, 1223.

British Columbia, Keithley Creek area, Cariboo district: Lang, 2333.

Pre-Mississippian veins and deposits, Cariboo district: Bay, 2357.

Yale district: Horwood, 1799.

California, intra-septum in t $\mathrm{ru}$ s i o $\mathrm{s}$, Sierra Nevada: Mayo, 2624.

Paragenesis at Crestmore: Daly, 962.

Sierra Nevada pluton: Cloos, 784; Mayo, 2625.

Southern, Perris block: Dudley, 1085.

Canada, eastern, ore deposits: Wright, 4628.

Colorado, Continental Divide region: Behre, 257.

Cripple Creek district: Kohanowskl, 2247.

Front Range: Boos, 373; Lovering, 2469.

London fault: Singewald, 3731.

Migmatites, Sawatch . Range : Stark, 3830.

Montezuma quadrangle: Lovering, 2466.

Ore deposition south of Ouray : Moehlman, 2760.

San Juan region: Burbank, 571; Cross, 925.

Domes, structure elements : Balk, 160.

Fractures, ore-bearing, origin : Emmons, 1176.

Greenland, Franz Joseph region: Odell, 2936.

Lirerpool Land, crystalline complex: Kranck, 2256.

Heat conduction, theory: Lovering, 2467.

Idaho, batholith : Ross, 3376 .
Intrusions-Continued.

Jamaica, basal complex : Trechmann, 4163.

Maine, Appalachian Trail: Philbrick, '3071.

- Onawa pluton, Piscataquis County: Philbrick, 3072.

Manitoba, Flin Flon mine: Brownell, 499.

Cross Lake area, pre-Keewatin(?) tonalite: Horwood, 1798.

Manitoba and Ontario mining district: Wright, 4627.

Mechanies of : Loewinson-Lessing, 2434.

Mexico, Cananea Mountains, Sonora : Valentine, 4247.

Coahuila Peninsula: Kellum, 2057, 2058; Kelly, 2068; Singewald, 3732.

Pachuca silver district: Wisser, 4567.

Pllares mine, Sonora: Tenney, 4041.

Michigan, granitic sequence, southern complex : Dickey, 1044.

Minnesota, Ogishkemuncie Lake region: Sleight, 3740 .

Montana, Highwood Mountains : Buie, 565.

Stillwater complex: Peoples, 3050.

Nevada, central Humboldt Range: Jenney, 1943.

Chief district, Lincoln County : Callaghan, 629.

Ely district: Bateman, 236.

Silver Dyke area: Kert, 2086.

Newfoundland, Bay of Exploits area: Heyl, 1736.

Bay of Islands igneous complex : Cooper, 869.

New Hampshire, Red Hill : Qulnn, 3157.

New Mexico, Organ Mountains and Dona Ana County : Dunham, 1094.

Santa Rita and Tyrone districts: Paige, 2982.

Santa Rita mining area: Spencer, 3803.

Virginia mining đistrict: Lasky, 2343.

New York, Adirondacks, northwestern : Buddington, 546.

Oswegatchie quadrangle: Dale, 961.

Northwest. Territorles, Rae to Great Bear Lake, . Mackenzie district : Kldd, 2191.

Ontario; belt Manitou Lake-Lake of the Woods : Thomson, 4111.

East Bay, Minnitaki Lake, Kenora district: Pettijohn, 3067.

Hollinger gold mine: Ringsleben, 3306.

Porcupine area : Hurst, 1899.

Renfrew County: Freeman, 1336.

Sudbury nickel fleld: Burrows, 585.

Sudbury nickel intrusive: Walker, 4321.

Sudbury nickel irruptive: Collins, 812 ; Thomson, 4104. 
Intrusions-Continued.

Oregon, Cascade Mountains, North Santiam River section: Thayer, 4061.

Cascade Range : Buddington, 549.

Harney Basin : Piper, 309,0.

Skamania mining . district: Pratt, 3125.

Pennsylvania, granite, near Philadelphia: Watson, 4361

Quebec, Appalachians: Keith, 2041.

Cadillac belt, Pandora to Pan Canadian:: Gunning, 1573.

Chibougamau Lake area: Mawdsley, 2617.

Chibougamau-Opawica map area : Norman, 29.13.

Chibougamau-Waswanipi dist $\mathrm{r}$ i c $t$ : Norman, 2915.

Despinassy area," Abitibi : County : Faessler, 1204.

Horne mine, Noranda: Price, 3132.

Lamaque-Sigma mines area, Bourlamaque Township, Abitibi County : Bell, 267.

Laurentian complex: Osborne, 2969.

Peridotites and-pyroxenites, eastern townships: Cooke, 850.

Pusticamica Lake area, Abitibi district: MacKenzie, 2540.

Travers Lake area, : Temiscamingue County : Retty, 3256.

Rise of molten rock: Miller, 2726.

Saskatchewan, Beaverlodge area : Cameron, 630 .

Lake Athabaska area : Alcock, 15.

Mudjatik-Haultain area.: Alcock, 13.

South Carolina, Columbla quadrangle, granite: Kesler, 2087.

Texas, east of Pecos River; Sellards, 3638.

Trans-Pecos : Baker, 145.

Uvalde and Medina Countles: Sayre, 3524.

Wolf Mountain granite: McAdams, 2491.

Wolf Mountain phacolith:. Stenzel, 3869.

Time-temperature curves, cooling intrusions: Schneiderhöhn, 3569.

Utah, southeastern : Baker, 142.

Tintic district: Park, 3006.

Wyoming, Devil's Tower : Dutton; 1101 ; Effinger, 1142.

Invertebrates (genera1). See also, the classes of the invertebrates.

Alabama, Eocene : Aldrich; 19.

Alaska; Briscoia fauna, Cambrian : Kobayashi, 2242.

Arizona, Paradise formation: Hernon, 1714.

Atlantic Coastal Plain, southern, Pleistocene fauna: Richards; 3284.

Cambrian, Marble Mountains, California: Masón, 2597.

Cardium nixicollis and Ostrea battensis: Stephenson, 3879.
Invertebrates (general)-Continued.

Chemung, Pennsylvania, tracks and trails: Willard, 4487.

Chert; .. Lockport formation, Ontario, fauna : Laird, 2290.

Cretaceous, Myrtle Beach, South Carolina:Prouty, 3138.

Eocene, northeastern Mexico: Kane, 2016.

Eo-Triassic, east Greenland: .Spath, 3797.

Greenland, Cape Leslie, Milne Land, Juràssíc:'Spatb, 3798, 3799.

Koldewey Island, Cretaceous : Fre$\therefore$ bold, 1333 .

Hamilton groüp, Allegheny front: Willard, 4495.

Kansas, easitern, Pennsylvanian : Moore, 2790.

Kentucky, Rogers Gap and Fulton formations: McFarlan, 2520.

New Jerséy and New York, late Pleistocene marine and glacial: Macclintock, 2504.

New Mexico, Sacramento Mountains, Devonian: Stainbrook, 3816.

New York, Berne quadrangle: Goldring, 1463.

Skaneateles quadrangle: Smith, 3746.

Oregon, northwestern, marine oligocene: Packard, 2980.

Paleontology:- Croneis, 921; Decker, 999 ; Raymond, 3201; Twenhofel, 4192.

Paleozoic fossils, Ordovician, Tennes see: Basslèr, 227.

Pennsylvania, Bellefonte quadrangle: Butts, 598.

Onondaga faunas: Willard, 4501.

Portage group : Willard, 4494.

Report on invertebrate paleontology : Raymond, 3194.

South-Carolina, Coastal Plain: Cooke, 847.

Stewartville and Dubuque formations: Kay, 2032.

Texas, Palo Pinto County: 'Plummer, 3098.

Tully formation, Devonian, New York: Cooper, 862:

Utah, Gold Hill mining district: Nolan, 2905.

Monument Valley-Navajo Mountain region : Baker, 144.

Wyoming, Jurassic: Branson, 438. Iowa.

Economio geology.

Coals, Pennsyiranian, Western Interior province: Young, 4639.

Road and concrete materials, southern Iowà: Wood, 4591.

Wells, deep : Lees, 2369 ; Norton, 2920.

Historical geology.

Cambrian, redefinition: Keyes, 2155.

Chouteau limestone: Keyes, 2122.

Cretaceous stratigraphy : Keyes, 2091. 
Iowa-Continued.

Historical geology-Continued.

Dakotan sandstone: Keyes, 2106, 2178.

Decorah shale: Stauffer, 3840.

Deep wells, 1928-32 : Norton, 2920.

Devonian, upper Mississippi Valley: Stainbrook, 3815.

Galena dolomite, Upper Mississippi Valley ; Kay, 2028.

General: Kansas Geol. Soc., 2020 ; Trowbridge; 4174.

Geologicat clässification : Keyes, 2107. Isopach map Trempealeau, Dresbach and Franconia formations: Edwards, 1140.

The Ledges State Park, and Pennsylvanian problems: Smith, 3757.

Magnesian limestone, lower: Keyes, 2101.

Mississippi River arch: Howell, 1866.

Mississippian system : Landon, 2349.

Upper Mississippi Valley: Moore, 2784.

Ordovician, upper Mississippi, Valley : Kay, 2027.

Osage area, Henry County : Wood, 4592.

Prairie du Chien beds, upper Mississippi valley : Powers, 3117.

Prairie du Chien formation: Powers, 3116.

Silurian, upper Mississippi Valley : Sutton, 3983.

Southern Iowa: Wood, 4591.

Stewartville and Dubuque formations: Kay, 2032.

Yanktonian series for Benton shales: Keyes, 2174.

Paleontology.

Ammonoids, Devonian : Miller, 2701.

Athyris and Cyrtina, Devonian: Fenton, 1226.

Atrypa; Deronian : Fenton, 1232.

Cephalopods, Maquoketa shale: Foerste, 1299.

Charophyta, Paleozoic: Peck, 3040.

Conodonts, Decorah shale: Stauffer, 3840 .

Corals, Mississippian : Grove, .1558.

Crinoids, Devonian: Laudon, 2350.

Mastodon americanus tusk, Pleistocene, Franklin County: Cable, 619.

Ostracoda, Ordovician, in Hull and Decorah formations: Kay, 2028.

Phacopinae, Devonian: Delo, 1020.

Pollen analysis, East McCulloch peat bed : Lane, 2332

Schizoblastus, Osage group : Cline, 779. Petrology.

St. Peter sandstone, sedimentary and petrographic analysis: Thiel, 4069 .

Physical geology.

Teleseismic recording:: Seeburger, 3631.

Physiographio geology.

Loveland loess: Keyes, 2093.

Loveland and Peoria loesses: Kay, 2026, 2027.

$311-37-26$
Iowa-Continued.

Physiographic geology-Continued.

Patrician glacial interval: Keyes, 2094

Peneplanation, driftless area: Keyes, 2161.

Pre-Wisconsin vaile y, southwestern Fancock County: Wood, 4590.

Underground water,

Wells, deep : Lees, 2369 ; Norton, 2920.

Zones of mineralization: Thwaltes, .4124.

Iron.

Alabama, Birmingham district: Blair, 338: Rama Rao, 3167

Alaska : Hodge, 1761.

Bibliography, eastern and southeastern States and Cuba: Anonymous, 4685.

Boulder Dam area, mineral occurrences : Lee, 2367.

British Columbia : Hodge, 1761.

Amphibo!e, Purcell sills: Rice, $\mathbf{3 2 6 1}$.

California, northern, chromite, nodular, orbicular and banded: Johnston, 1986.

Central America: Hodge, 1761.

Colorado, Calumet mine : Bebre, 262.

Tincup mining district, Gunnison County : Goddard, 1458.

Equilibrium relationships, experimental investigations: Greig, 1536.

Gogebic iron range, Michigan and Wis consin : Atwater, 113

Greenland, west: Carpenter, 685.

Lake Superior region: Royce, 3397.

Magnetite metacrysts: Schwartz, 3599.

Massachusetts, Taconic limonites : Newland, 2867.

Michigan, Lake Superior region: Broderick, 463; Leith, 2390 ; Rama Rao, 3167.

Magnetic data use in iron ranges: Swanson, 3985.

Negaunee iron formation, Marquette County : Adler, 6.

Minnesota, greenalite, Mesabi range: Jolliffe, 1987.

Lake Supertor region: Broderick: 463 ; Leith, 2390.

Missouri, Iron Mountain and Pilot Knob Districts: Rama Rao, 31.67.

Sulphide ores, Ozark region: Grave, $1504,1509$.

Native, and alloys': Buddhue, $\mathbf{5 3 8 .}$

New Mexico, Bayard area: Lasky, 2344.

Santa Rita mining area: Spencer, 3803.

New York, Hammond, Antwerp, and Lowville quadrangles: Buddington, 543.

Oswegatchie quadrangle : Dale, 961 .

Supergène minerals at Balmat: Brown, 486.

Taconic limonites: Newland, 2867.

Oklahoma, hematite, Reagan sandstone, Wichita, and Arbuckle Mountains : William's, 4504. 
Iron-Continued.

Ontario, Litțle Long Lac and Sturgeon River areas: Thomson, 4107.

Oregon, Columbia County: French, 1339.

Klamatb Falls : Melhase, 2645.

Ores of U. S. : Cooke, 854.

Paciflc coast! Hodge, 1761.

Pennsylvania, Bellefonte quadrangle: Butts, 598.

Puerto Rico: Meyerhoff, 2685.

Magnetite, Humacao: Colony, 817.

Quebec, Ivry ilmenite deposit: Keys, 2188.

Labelle-L'Annonciation ' area : Osborne, 2963.

Succession of minerals and temperatures of formation: Lindgren, 2421.

Structure and concentratablity, ores, U. S.: Cooke, 854.

Tennessee, Ducktown Basin minerals: Blakemore, 343 .

Texas, east : Eckel, 1125.

Northeast: Eckel, 1124.

Vermont, Taconic limonites: Newland, 2867.

Virginia, Blue Ridge hematite: Sears, 3620.

James River iron and marble belt: Furcron, 1362 .

Southwestern : Currier, 936.

Western States: Hodge, 1761.

West Virginia: McKinley, 2551.

Wisconsin, Lake Superior region : Leith, 2390.

Yukon : Hodge, 1761.

Iridium, Wroming, Centennial district : Coulter, 884.

Irreversibility of erolution: Gregory, 1535.

Island, formed. in .Mississippi River; Columbus, Ky. : Shull, 3708 .

Isopach maps.

Mississippi Valley, upper: Kans. Geol. Soc., 2020.

Isostasy : Bowie, 392, 397, 405 ; Keyes, 2125.

Basin Range hypothesis : Keyes, 2116.

Black Hills-Bighorn-Beartooth region, gravity anomalies: Chamberlin, 719 .

California coast: Buwalda, 603 .

Canada, gravity anomalies: Miller, 2697.

Pacific coast: Miller, 2695.

Continents and oceans, origin : Bowie, 399 ; Ramos, 3168.

Origin and motion: Gunn, 1567.

Stable platform areas: Moore, 2792.

Continents, motion, and mountain building: Gunn, 1566.

Deep-focus earthquakes and isostasy: Stechschulte, 3857 ; Thom, 4078.

Deformation of earth's crust, Paleozoic : Moore, 2787.
Isostasy-Continued.

Earth's crust, bending, due to Boulder Dam construction: Anonymous, 4675.

Warping in United States: Glennie, 1445.

Earth, interior: Daly, 965.

Gravity anomalies, United States : Glennie, 1446

Sierra Nevada: Lawson, 2356.

Isostasy and origin of continents and oceans : Ramos, 31.68

Isostasy in the proving: Keyes, 2126.

Jamaica.

Historical geology.

Basal complex: Matley, 2611; Trechmann, 4163.

Paleontology.

Corals, Cretaceous and Eocene: Wells, 4390.

Foraminifera : Cushman, 942.

Physical geology.

Basal complex: Trechmann, 4163.

Sỳnchronism of earthquakes: Brennan, 452.

Physiographio geology.

Moneague Valley, temporary karst lake : Rappenecker, 3181

Jasper.

Atlantic Coastal Plain: Ulke, 4208.

Jointing and joints.

Caltfornia,. Kern Canyon, southern Sierra Nevada: Webb, 4374.

New York, Oswegatchie quadrangle : Dale, 961

North Carolina, Morgan Creek Dam area: Prouty, 3139.

Saganaga batholith, Minnesota-Ontario : Grout, 1557.

Tennessee, Nashrille dome: Wilson, 4531.

Strain ellipsoid theory of rupture : Griggs, 1542.

Virginla, southwestern, zinc and lead region: Currier, 936.

Wyoming, Devil's Tower: Dutton, 1101.

Jurassic. See also Paleontology, Jurassic.

Alaska, southern Alaska Range: Capps, 677.

Alberta, Foremost-Skiff area : Howells, 1867.

Milk River area : Russell, 3433.

Antillean-Caribbean region: Schuchert, 3579.

Arizona, Zunian series : Keyes, 2153.

British Columbia, Keithley Creek area, Cariboo district: Lang, 2333.

Portland Canal area: Hanson, 1626.

Similkameen and Lillooet districts : Cockfield, 795.

California, Julian district, San Diego County : Donnelly, 1064.

Mesozoic and Cenozoic eruptive rocks, Klamath Mountains: Hinds, 1746.

Mount Diablo and vicinity: Taff, 4005. 
Jurassic-Continued.

California-Continued.

Natural-gas fields; Hoots, 1792.

South coastal basin: Eckis, 1131.

Canada, western: Goodman, 1473.

Colorado, Book Cliffs coal fleld: Erdmann, 1185.

Golden area : Johnson, 1971.

La Plata mining district: Eckel, 1126.

Montezuma quadrangle: Lovering, 2466.

San Juan region: Burbank, 571; Cross, 925.

South Park: Johnson, 1974.

Correlations, Utah, Arizona, Colorado and New Mexico: Baker, 143; Schuchert, 3588.

Cuba: Dickerson, 1043; Schürmann, 3589.

Isla de Pinos: Rutten, 3459.

Greenland: Koch, 2244.

Milne Land: Parat, 3001.

Northeast: Teichert, 4037.

Scoresby Sound : Aldinger, 18.

Ymer Island: Cleaves, 772.

Mexico : Santillan, $\mathbf{3 5 2 1 .}$

Coabuila Peninsula: Kellum, 2057, 2058.

Northwestern: Kellum, 2054.

Sierra de Parras, Coahuila Peninsula: Imlay, 1905.

State of Chiapas, pre-Tertiary: Mullerried, 2815.

Tampico 'region: Muir, 2821.

Montana, Big Horn Basin gas fields: Emery, 1174.

Big Horn County and Crow Indian Reservation: Thom, 4074.

Nevada, central Humboldt Range: Jenney, 1943.

West-central, formations: Muller, 2824; thrust faults: Ferguson, 1236.

New Jersey, Watchung Mountains : Moldenke, 2765.

New Mexico, Mount Taylor coal fleld: Hunt, 1888.

Post-Keweenawan, age by helium method: Urry, 4246.

Restorations, geologic landscapes : Reld, 3236.

South Dakota, west-central: Rothrock, 3384.

Southwestern U. S.: 'Effinger, 1144.

Texas, trans-Pecos, structural features : King, 2211.

White and Baker well, Pecos County, unconformities : Carsey, 687.

Utah, Monument Valley-Navajo Mountain region: Baker, 144.

Salt Valley anticline area: Dane, 970.

Southeastern : Baker, 142.

Wyoming: Crickmay, 901.

Baxter Basin gas flelds : Nightingale, 2885.
Jurassic-Continued.

Wyoming-Continued.

Big Horn Basin gas flelds: Emery, 1174.

Devils Tower National Monument: Effinger, 1142.

Lost Soldier cistrict gas flelds : TH1lotson, 4129 .

Yukon, Carmacks district: Bostock, 379.

Kansas.

Areas described.

Johnson and Miaml Counties: Newell, 2855.

Wyandotte County : Jewett, 1950.

Economio geology.

Barton arch oil fleld : Woodruff, 4605.

Gas fields west of Nemaha granite ridge, except Hugoton district: Garlough, 1385.

Midcontinent oil fields, regional investigations: Hiestand, 1737.

Midcontinent shoestring ofl flelds : Bass, 222.

Natural gas : Cadman, 620 .

Natural-gas flelds, eastern Kansas : Ley, 2411.

Northeastern Kansas: Ockerman, 2933.

Oil fields, structure and production, western Kansas: Thomas, 4082.

Ore deposits, Tri-State district: Fowler, 1319.

Shoestring oil sands: Patton, 3024.

Tri-State mining district, chertification : Fowler, 1317.

Uplift, Central : Koester, 2246.

Historical geology.

Bartlesville and Burbank sands: U. S. G. S., $4235,4236$.

Cherokee shale, zinc-lead district, southeastern Kansas: Plerce, 3082.

Coal fields and zinc-lead district, geologic map: Anonymous, 4665.

Englevale channel sandstone, Pennsylvanian, southeastern Kansas: Pierce, 3081.

General : Kansas Geol. Soc., 2020.

Geologic map, northwestern Kansas: Kanșas G. S., 2022.

Southwestern Kansas: Kansas G. S., 2023.

Guidebook 9th Ann. Field Conf.: Ball, 168.

Hollow Pool area, pre-Pennsylvanian: Johnston, 1982.

Johnson and Miaml Counties: Newell, 2855.

Midcontinent ofl flelds, regional investlgations: Hiestand, 1737.

Mississippian-Pennsylvanian c o $\mathrm{n}$ t a c t Tri-State district: Pierce, 3083.

Northeastern Kansas: Ockerman, 2933.

Oil flelds, structure and production, western Kansas: Thomas, 4082.

Paleozoic, late, plants: Ellas, 1156.

Pennsylvanian, classiflcation: Moore. 2791. 
Kansas-Continued.

Historical geology-Continued.

Pennsylvanian and lower Permian rocks: Kansas Geol. Soc., 2024; Moore, 2788.

"Permian" flora from Pennsylvanian rocks: Moore, 2790.

Pre-Cambrian, eastern Kansas: Kansas G. S., 2021.

Sedimentation cycles, Pennsylvanian and Permian rocks: Moore, 2783, 2785.

Sooy conglomerate: Edson, 1138.

Uplift, Central : Koester, 2246.

Upper Cretàceous : Stoner, 3944.

Wyandotte County: Jewett, 1950.

Zone fossils, Pennsylvanian and Permian: Moore, 2786.

Mineralogy.

Kansas River Valley, weathered till: Hoover, 1795.

Paleontology.

Artinskia whortani, Permian : Miller, 2710.

Capromeryx altidens, possible ancestor of Antilocapra americana: Hesse, 1726.

Cephalopoda, Cretaceous, Upper: Morrow, 2803.

Pennsylvanian: Newell, 2859.

Ditomopyge, adolescent development: Weller, 4383.

Elephants, extinct, analysis of tusks : Brubaker, 501.

Gnathabelodon thorpei, Pliocene, Trego County: Barbour, 176.

Grasses, Tertiary : Elias, 1155.

Hierosaurus coleii, Cretaceous, Gove County : Mehl, 2630.

Insecta, Permian: Carpenter, 683.

Invertebrates, Pennsylvanian: Newell, 2856.

Kansasimys dubius, Pliocene, Edson: Wood, . 4579 .

Laccopteris galleyi, Cretaceous, Mankato : Miner, 2744.

Ostracodes, Pennsylvanian and Permian : Kellett, 2045.

"Permian" flora from Pennsylvanian rocks: Moore, 2790.

Permian insects: Tillyard, 4131.

Zone fossils, Pennsylvanian and Permian: Moore, 2786.

Petrology.

Kansas River Valley, weathered till:

- Hoover, 1795.

Physical geology.

Fault-block structures: Rich, 3270.

Uplift, Central : Koester, 2246.

Physiographic geology.

Johnson and Miami Counties: Newell, 2855.

Kansas River Valley, weathered till: Hoover, 1795.

Natural bridge, Sun City : Jewett, 1948.
Kansas-Continued.

Underground water.

Ground water in southern High Plains: Theis, 4062.

Johnson County, water resources : Jewett, 1949.

Water-table fluctuation, glaciated section: Schoewe, 3572.

Kaolin. See also Clay.

Illinois, Pennsylvanian under clays: Grim, 1549.

New Mexico, Doña Ana County: Richard; 3273.

North Carolina, Spruce Pine and Linville Falls quadrangles: Hunter, 1890.

Karst topography.

Indiana, karst windows: Von Osinski, 4296.

Jamaica, Moneague Valley: Rappenecker, 3181.

Kentucky, karst landscapes: Dicken, 1041.

Solution cuesta: Dicken, 1040.

Mexico: Wittich, 4569.

Kentucky.

Areas described.

Fordsville and Cannelton quadrangles: Mayfield, 2622.

Economic geology.

Bleaching and ceramic clays: Mansfield, 2570.

Clays, western Tennessee Valley: Spain, 3794.

Fluorspar field, Illinois-Kentucky, structure : Currier, 939.

Harlan County coal flelds: Jones, 2000.

Natural gas, Eastern Interior coal basin : Bell, 263.

Kentucky, eastern : Hunter, 1891.

Paleozoic horizons, Cincinnati arch region: Bailey, 132.

Oil, Illinois Basin, possibilities : Howard, 1831; Weller, 4386.

Oil and gas possibilities: Hager, 1599.

Historical geology.

Fluorspar field, Illinois-Kentucky, structure : Currier, 939.

General : Kansas Geol. Soc., 2020.

Illinois Basin: Howard, 1831; Weller, 4386.

Natural gas, eastern Kentucky : Hunter, 1891.

Rogers Gap and Fulton formations: McFarlan, 2520.

Silurian formations, correlation: Foerste, 1298.

Mineralogy.

Concretions, phosphatic, Junction City: Edmunson, 1137.

Paleontology.

Big Bone Lick: Jillson, 1951, 1952.

Charophyta, Paleozoic: Peck, 3040.

Corals, Mississippian: Grove. $\mathbf{1 5 5 8}$

Tabulate, Devonian, Falls of the Ohio: Werner, 4420. 
Kentucky-Continued.

Paleontology-Continued.

Devonian flora: Read, 3208.

Diichnia kentuckiensis, Devonian : Read, 3207.

Productella wayensis, Carboniferous, Mill Springs: Brill, 459.

Trochiliscus, Falls of the Ohio, Devonian : Hacquaert, 1591.

Plyysical geology.

Fluorspar field, Illinois-Kentucky, structure: Currier, 939.

Harlan County coal fields: Jones, 2000.

Mammoth Cave, cathedral domes: Swinnerton, 3997.

Structure, determination by electrical resistance methods: Hubbert, 1875.

\section{Pliysiographic geology.}

Cuesta, solution: Dicken, 1040.

Erosion surfaces, eastern Kentucky: Cole, 805 .

Island, formed in Mississippi River: Shull, 3708.

Karst landscapes : Dicken; 1041.

Keratophyres, eastern Oregon, and the spilite problem: Gilluly, 1430.

Kernite, California, Kramer borate field: Schaller, 3532 .

Knebelite, British Columbia, : Bluebell mine, Kootenay Lake: Gunning, 1574.

Koch, Lauge, defense of his work: Margerie, 2582.

Kunzite, California, Pala district: Buranek, 567.

Kyanite.

Georgia: Prindle, 3137 ; Smith, 3767.

Labrador.

Historical geology.

Wapussakatoo Mountains: Gill, 1424.

Mineralogy.

Labradorite, Tabor's Island: Anonymous, 4678.

Paleontology.

Cyathospongia, new class of Porifera: Okulitch, 2945.

Foraminifera, early Cambrian : Howell, 1852.

Ordovician fossils : Little, 2426.

\section{Petrology.}

Amazonite aplite dike: Wheeler, 4439.

Physiographic geology.

Cape Chidley area: Forbes, 1304.

Nain-Oak section: Wheeler, 4440.

Laccoliths. See also Intrusions.

Montana, Highwood Mountains : Larsen, 2339.

Shonkin Sag laccolith : Hurlbut, 1895.

Newfoundland, Trout River area: Ingerson, 1906.

Wyoming, Devils Tower Nat. Monument : Effinger, 1142.

Lakes.

Lake Michigan Basin, bathymetric studies: Evans, 1189.
Lake balls, formation : Allen, 39 ; Huntsman, 1893.

Lakes, extinct. See also Glacial lakes.

California, Pleistocene, Afton basin: Blackwelder, 337.

Colorado, Miocene lake, Creede: Caplan, 675.

Lake, Souris, North Dakota, glacial lakes: Andrews, 71.

Lake Tecopa, Pleistocene, Calif. : Blackwelder, 332 .

Ijake Uinta, Eocene, Utah and Colorado: Bradley, 427.

Yelowstone National Park, Hayden Valley : Howard, 1812.

Lakes, glacial. See Glacial lakes.

Lamellibranchiata. See Pelecypoda.

Landslides.

Alaska, Fort Liscum : Johnson, 1956.

Analysis and control: Hennes, 1711.

California, debris flow from canyons, Los Angeles County: Taylor, 4023.

Forests, submerged, Columbia River gorge: Lawrence, 2354.

Landslips, subsidences, and rock falls : Ladd, 2284.

Mississippi, slump near Fort Adams: Russell, 3441.

New, Mexico, Canjilon Divide, Rio Arriba County : Smith, 3775 .

Virginia, Cherry Hill: Ladd, 2283.

Landslides and related phenomena: Sharpe, 3649 .

Landslips, subsidences, and rock falls : Ladd, 2284.

Lavas. See also Intrusions.

California, alteration of lavas around hot springs, Lassen Volcanic $\mathrm{Na}$ tional Park: Anderson, 63.

Colorado, Tomichi dome: Stark, 3833.

Flow units in basalt: Nichols, 2873.

Hawaii, crystal cavities in lava: Dunham, 1095.

Differentiation of lavas : Powers, 3118.

Gas-bubble pits in coastal pahoehoe lavas : Palmer, 2993.

Mauna Loa lava flows: Hodgking, 1766.

Mexico, Cananea Mountains, Sonora: Valentine, 4241.

M o n t a ins, Coahuila Peninsula : Kelly, 2068.

Michigan, Keweenawan, differentiation : Broderick, 464.

Oregon, Crater Lake, dacitic flow structure: Allen, 40.

Virginia, northern, Cambrian : Furcron, 1363.

Washington, Columbia River course, Miocene: Chappell, 738.

Law of symmetry in development of earth's crust : Fourmarier, 1315. 
Lead.

Arkansas, northern: McKnight, 2552 ; Miser, 2749.

Boulder Dam area, mineral occurrences : Lee, 2367.

British Columbia, ore depth in mines: Schofleld, 3573.

Portland Canal area: Hanson, 1626.

Slocan mining camp area: Cairnes, 624.

California, Cerro Gordo mining district : Webb, 4373.

Canada, Cordilleran region: Alcock, 10.

Colorado, batholith, Twin Lakes and Clear Creek districts: Chapman, 732.

Continental Divide region: Behre, 257.

Cripple Creek area: Loughlin, 2460.

Front Range area: Lovering, 2469.

Jamestown district: Goddard, 1457.

London fault: Singewald, 3731.

Montezuma quadrangle: Lovering, 2466.

San Juan region: Cross, 925.

Sugar Loaf district, Lake County, ore minerals: Sandberg, 3487.

Tincup mining district, Gunnison County: Goddard, 1458.

Ward district ores: Wahlstrom, 4309.

White Raven mine, Ward: Wahlstrom, 4308.

Cyrtolite, analysis: Muench, 2817.

Galena in Cambrian limestone: Lochman, 2432.

Hydrothermal experiments with minerals: Kristofferson, 2264.

Manitoba, Flin Flon mine: Brownell, 499.

Mexico, Cusihuiriachic, Chihuahua: Donald, 1057.

Ore-body zoning, Sierra Mojada, Coahuila: Riley, 3305.

Missouri, southeastern: Tarr, 4010.

Montana, Flathead mine: Shenon, 3661.

Hog Heaven mining district, Flathead County: Shenon, 3664.

Neihart mining district, Cascade County: Schafer, 3526.

Nevada, Contact mining district: Schrader, 3576 .

Chief district, Lincoln County: Callaghan, 629 .

New Mexico, Bayard area : Lasky, 2344. Oregon Mountains and Doña Ana County: Dunham, 1094.

New York, U-galena and uraninite in Bedford cyrtolite: Kerr, 2081.

Ontario, Little Long Lac and Sturgeon Rirer areas: Thomson, 4.107.

Renfrew County: Freeman, 1336.

Ore deposits; Butler, 592.

Pebble and ruby jack, Joplin district, formation temperature: Smith, 3776.

Quebec, north-central Gaspé: Jon̈es, 2002.
Lead-Continued.

Saskatchewan, Beaverlodge area: Cameron, 630 .

Texas, Shafter mining district: Ross, 3375.

Tri-State district: Fowler, 1317, 1319 : Rama Rao, 3167.

Til-State ores, genesis : Ridge, 3295 .

Utah, Gold Hill mining district: Nolan, 2905.

Park City ore deposits: Bryan, $\mathbf{5 1 5}$.

Virginia, southwestern : Currier, 936.

Western United States, resources: Loughlin, 2457.

Wisconsin-Illinois lead-zinc district : Behre, 255.

Wyoming, South Pass and Atlantic City district, Fremont County: Abbott, 1 .

Lignite. See Coal.

Limestone.

Alaska : Hodge, 1761.

Boulder Dam area, mineral occurrences: Lee, 2367.

British Columbia, industrial and nonmetallic minerals : Richmond, 3287.

Connecticut : Moore, 2782.

Iowa, southern, road and concrete materials: Woodı 4591.

Kentucky, Fordsville and Cannelton quadrangles : Mayfleld, 2632.

Manitoba: Hutt, 1900.

Missouri, Cheltenham fireclay with spherulitic limestone: Allen, 45.

Ohio, Kelley's Island: Ver Steeg, 4281.

Paciflc coast: Hodge, 1761.

Pennsylvania, Bellefonte quadrangle: Butts, 598.

Porosity, development of : Howard, 1830.

Quebec: Goudge, 1482.

Virginia, James River iron and marble belt: Furcron, 1362.

West Virginia, upper Monongahela Valley : U. S. Com., 4274.

Lithium. '

North Carolina, spodumene pegmatites, Kings Mountain : Hess, 1720.

Lithology. See also Petrology.

Variations in, statistical test: Eisenhart, 1153.

Loess.

Illinois, soil materials, constitution: Ekblaw, 1154

Iowa, Loveland loess : Keyes, 2093.

Kansas, Johnson and Miami Counties: Newell, 2855.

Wyandotte County: Jewett, 1950 .

Massachusetts : Smith, 3754.

Nebraska, Pleistocene : Lugn, 2478.

Wyoming, Permo-Pennsylvanian section, Hartville area: Condra, 834.

Logs of deep wells, western South Dakota: Rothrock, 3383 . 
Louislana.

Economic geology.

Belle Isle salt dome, St. Mary Parish: Barton, 207.

Cameron and Vermilion Parishes: Craft, 888.

Colrelations by Foraminifera: Nuttall, 2925.

Cote Blanche salt dome, St. Mary .Par1sh: Barton 211.

Cotton Valley oil fleld: Tucker, 4179.

Geological Survey report, 1934-35: Moresi, 2793.

Geophysics, relation to salt domes and ofl fields: Eby, 1120, 1121.

Gulf coast, deep oil possibilities : Mills, 2735.

Oil fields : Barton, 215 ; Easton, 1111 ; Logan, 2436 ; Williams 4521; Woodruff, 4606.

Salt domes, prospects: Logan, 2437. Oil horizons : Deussen, 1033.

Salt-dome area, natural-gas fields: Teas, 4033.

Jefferson Island salt dome, Iberia Parish : O'Donnell, 2938.

Jennings salt dome, Acadia Parish : Halbouty, 1601.

Map of oil, gas, and sulphur flelds : Louisiana Geol. Survey, 2464.

Monroe gas field: Fergus, 1235.

Petroleum-bearing strata: Howe, 1842.

Possibilities, Texas-Louisiana, shoreline or shoestring oil field's: Weinzierl, 4379.

Prospecting, Gulf coast marsh and water areas: Flude, 1294.

Richland gas fleld: Gordon, 1480.

Rodessa oil fleld : Ivy, 1921; Mills, 2733, 2736.

Salt domes: Sawtelle', 3519.

Cameron and Vermilion Parishes: Howe, 1835.

Salt, overhanging, on salt domes: Judson, 2015.

Seismic exploration for oil: Taylor, 4029.

Valentine (LaRose) dome, Lafourche Parish: Buchanan, 533.

Volcanoes and oil accumulation : Easton, 1112 .

Historical geology.

Claiborne, tentative foraminiferal zonation: Israelsky, 1912.

Correlations by Foraminifera: Nuttall, 2925.

Côte Blanche salt dome, St. Mary Parish : Barton, 211.

Deltas, Mississippi River: Russell, 3444.

Gulf coast, geosyncline: Barton, 203.

Oil horizons : Deussen, 1033.

Jennings salt dome, Acadia Parish : Halbouty, 1601.

Midway group, Eocene: Alexander, 25.

Monroe gas fleld: Fergus, 1235.

Oil flelds, northern Louisiana: Easton, 1111.
Louisiana-Continued.

Historical geology-Continued.

Petroleum-bearing strata: Howe. 1842.

Post-Fleming ' coastal surface formations: Doering, 1054.

Richland gas fleld: Gordon, 1480.

Rodessa field: Ivy, 1921.

Salt domes, mechanics : Barton, 201.

Tertiary : Howe, 1833.

Mineralogy.

Dust storms, Baton Rouge, mineral composition: Russell, 3439 .

Salt-dome cap-rock minerals: Hanna, 1619.

\section{Paleontology.}

Claiborne, tentative foraminiferal zonation: Israelsky, 1912.

Decapod crustaceans, midale Eocene and Oligocene: Stenzel, 3866.

Foraminifera, larger, Jackson Eocene: Gravell, 1506.

Helicolepidina nortoni, Eocene, St. Landry Parish:'Vaughan, 4275.

Microfossils, Potamides matsoni zone: Stephenson, 3881.

Ostracoda, Jackson Eocene : Howe, 1838.

Vicksburg Oligocene: Howe, 1849.

Pectinidae, Tertiary : Rowland, 3389.

Verneuilinidae, Valvulinidae and Virgulinidae: Cushman, 945.

\section{Petrology.}

Concretions, barite, Yazoo clay, Eocene : Hanna, 1620.

\section{Physical geology.}

Oil fields, northern Louisiana : Easton, 1111.

Volcanoes, and oll accumulation : Easton, 1112.

Warping of formations, Gulf Coast: Moreși, 2794.

Physiographic geology.

Bayou Manchac, genetic history: Kniffen, 2232.

Cheniers, southwestern Louislana: Russell, 3442 .

Coast, southwest Louisiana : Howe, 1840.

Deltas, Mississippi River ; Russell, 3444.

Marshes, coastal, southwestern Louisiana: Russell, 3440.

Post-Fleming coastal surface formations: Doering, 1054 .

Lower Silurian. See Ordovician.

Magmas and magmatic differentiation: Burbank, 573 ; Fitzhugh, 1277. See also Batholiths; Dikes; Igneous and volcanic rocks; Intrusions; Laccoliths; Lavas.

Adirondack rocks, metamorphism vs. flowage: Buddington, 548 .

Anorthosite, origin: Buddington, 550.

Basalt, crystallization process: Barth, 197.

California, Bonsal tonalite, origin of dark inclusions: Hurlbut, 1894.

Salton volcanic domes, Salton Sea : Kelley, 2051. 
Magmas and magmatic differentiation-Con. Colorado, Front Range area : Lovering, 2469.

Ward district ores: Wahlstrom, 4309.

Connecticut, pegmatites, Collins Hill, Portland : Jenks, 1942

Cuba : Schürmann, 3589.

Differentiation in traps and ore deposition : Broderick, 465 ; Lane, 2324.

Dunite intrusion and olivine: Bowen, 388.

Generation, migration, intrusion, and deformation: De Lury, 1029.

Granitic rocks, derivations: Collins, 814.

Hawaii, differentiation of lavas: Powers, 3118.

Heat-conduction theory: Lovering, 2467.

Igneous rocks and high temperature: Bowen, 386.

Intrusions, mechanics of : LoewinsonLessing, 2434.

Locus of formation: De Lury, 1022.

Magmatic stoping : Grout, 1556.

Manitoba, granitization, Cross Lake region: Horwood, 1802.

Michigan, Keweenawan lavas, differentiation: Broderick, 464 .

Mineral veins, origin : Behre, 258.

Minnesota, anorthosite, relations to granite: Grout, 1553.

Mississippi Valley type ores: Graton, 1500.

Missouri, southeastern, lead deposits: Tarr, 4020.

New Hampshire, Belknap Mountains ring-dike complex : Modell, 2756.

Percy ring-dike complex: Chapman, 734.

White Mountain magma series : Chapman, 733.

New Mexico, Organ Mountains and Doña Ana County: Dunham, 1094.

Nova Scotia, gold zonal mineralization: Newhouse, 2865.

Ontario, aplites with cobalt-silver ores: Bastin, 234.

Gondreau, granitic stocks, and veins : Emmons, 1178.

Offset dikes, Sudbury nickel intrusive : Thomson, 4116.

Sudbury nickel fleld: Burrows, 585.

Sudbury nickel intrusive: Walker, 4321.

Sudbury nickel irruptive: Collins, 812 ; Fenner, 1221 ; Reynolds, 3258.

Ore bodies, localization: Bruce, 504; Butler, 592

Orientation of minerals, autoliths: Pabst, 2977.

Pennsylvaniá-Maryland Blue Ridge-Piedmont igneous complex: Bascom, 218.

Primary banding, basic plutonic rocks: Coats, 787.

Rise of molten rock : Miller, 2726.
Magmas and magmatic differentiation-Con. Saganaga batholith, Minnesota-Ontario : Grout, 1557.

Sierra Nevada: Lawson, 2356.

Sillcification : Randolph, 3172.

Succession of minerals and temperatures of formation: Lindgren, 2421.

Magmatic differentiation.

Mineral associations, high temperature : Buddington, 544.

Sudbury nickel intrusive: Walker, 4321.

Magmatic stoping: Grout, 1556.

Magnesite.

Boulder Dam area, mineral occurrences: Lee, 2367.

New Mexico, Doña Anna County : Taft, 4006.

Magnetite. See also Iron.

Planes, separation: Greig, 1537. Maine.

Polygonboden, Mount Desert Island : Nichols, 2872.

Economic geology.

Appalachian Trail : Philbrick, 3071.

Road materials : Leavitt, 2364.

Road materials and glacial geology: White, 4458.

Historical geology.

Appalachian 'Trail : Phiłbrick, 3071.

Bates limestone, Lewiston : Fisher, 1273.

Glacial deposits: Perkins, 3051.

Onawa pluton, Piscataquis Counts: Philbrick, 3072.

Ordovician: Ruedemann, 3410.

Pleistocene: Perkins, 3052.

Mineralogi.

Caesium: Burbank, 568.

Herderite, crystallography, Topsham : Yatsevitch, 4637 .

Mineral locations, Newry: Holman, 1782.

Mount Mica, muscovite crystal cavity filling: McKinley, 2549.

Pleasant Mountain, heavy minerals in syenites: Marsden, 2583.

Type mineral localities: Richmond, 3288.

Petrology.

Bates limestone, Lewiston: Fisher, 1273.

Dikes, Cape Neddick: Haff, 1595.

Feldspar, zoning: 'Trefethen, 4164.

Onawa pluton, Piscataquis County: Philbrick, 3072.

Physical geology.

Dikes, Cape Neddick: Haff, 1595.

Onawa pluton, Piscataquis County, contact metamorphism: Philbrick, 3072.

Physiographic geology.

Alpine zone, Mount Washington Range: Anters, 76.

Appalachian Trail : Philbrick, 3071.

Damariscotta shell heaps and coastal stabllity : Goldthwait, 1471. 
Maine-Continued.

Physiographio geology-Continued. General: Toppan, $\mathbf{4 1 4 5 .}$

Glacial deposits: Perkins, 3051.

Glacial geology : Leavitt, 2364.

Road. materials " and "' glacial geology : White, 4458.

Mammalia.

Alaska, fossil ivory: Buddhue, 541.

Amblypoda, relationships: Patterson, 3022:

Antelopes, Pliocene, Nebraska : Furlong, 1366.

Antilocapra a m e r ica a a, ancestry : Hesse, 1729.

Artiodactyla, Oligocene, California : Stock, 3921.

Arctothere, Pliocene, California : Stock, 3935.

Beavers, Tertiary: Stirton, 3907.

Borophgaus diversidens, Pli ocene; Texas: Vander Hoof, 4258.

California, oligocene mammal-bearing beds, Death Valley: Stock, 3924 .

Pleistocene: Vander Hoof, 4256.

Camel, Miocene, Nevada : Cockerell, 791.

Canada, western, Cretaceous and Miocene: Russell, $\mathbf{3 4 3 4}$.

Capromeryx altidens, possible ancestor of Antilocapra americana: Hesse, 1726.

Carsioptychus for Plagioptychus Matthew : Simpson, $\mathbf{3 7 2 5}$.

Casteroides o h i o e n s is, distribution; Cahn, 623.

Casteroides, Pleistocene, $\mathbf{N}$ eb r a s k a : Wood, 4582

Ceratomeryx prenticei, Pliocene, Idaho: Gazin, 1394.

Cernictis hesperus, Pliocene, California : Hall, 1606.

Cervalces, Indiana: Riggs, 3303.

Cetacen miocenè;: North Carolina: Prouty, 3142.

Cophocetus oregonensis, Miocene, Oregon : Packard, 2979.

Cricetidae, Miocene, South Dakota and Montana: Wood, 4572.

Cupidinus, Pliocene, Nevada: Chaffee, 716.

Cynodesmus, Pliocenc, Nebraska: McGrew, 2532.

Demostylus, Miocene, California:- Vander Hoof, 4257.

Dipoides stirtoni, Pliocene, Oregon: Wilson, 4549.

Dipoides williamsi, Pliocene, Arizona : Stirton, 3910.

Dogs, Miocene, Nebraska and South Dakota: Loomis, 2450.

Ectoganus gliriformis, Eocene, Wyoming: Gazin, 1396.

Elasmotheres, evolution: Wood, 4588.

Elephants, Channel Islands, Callf. : Stock, 3923, 3930.

Elephas primigenius americanus, Cass County, Mich.: Case, 691.
Mammalia-Continued.

Eohaplomys, Eocene, California: Stock, 3914.

Eohippus tooth compared to Hyracotherium tooth : Friant, 1341.

Equidỏe, Miocene and Pliocene, phylogeny : Stirton, 3908.

'Equus; phylogeny : Stirton, 3909.

E r e th i z o n bethygnathum, Cenozoic, Idaho: Wilson, 4553.

Eumysops simplex, Eocene, California: Wilson, 4550.

Evolution: Scott, 3613.

Fauna, Burnet Cave, Pleistocene, New Mexico: Schultz, 3591.

Cuyama, Tertiary, California: Wood, 4577.

Local and continental, relationships: Simpson, 3723.

Pleistocene, Clovis, New Mexico: Howard, 1816.

Williams Cave, Guadalupe Mts., Texas: Ayre, 125.

Fish to man: Gregory, 1523.

Florentiamyinae, Miocene, Wyoming : Wood, 4575.

Geomyld †rodents, western .U. S., Middle Tertiary : Wood, 4580.

Goshen Hole area, Oligocene, Wyoming: Schlaikjer, 3559.

Gnathabelodon thorpei, Pliocene, Kansas: Barbour, 176.

Graterogale simus, Tertiary, Nebraska : Gazin, 1398.

Ground sloth, later Cenozoic, Mexico : Stock, 3922.

Hair, fossil : ground sloth, and ovate bodies: Hausman, 1650.

Horses, Pliocene, Idaho: Gazin, 1397.

Idaho, Pleistocene, American Falls: Gazin, 1395.

Southern, fossil hunting: $\mathrm{G}$ a $\mathrm{z}$ i $\mathrm{n}$, 1391.

Indiana, Pleistocene: Lyon, 2490.

Insectivora, Eocene, California : Stock, 3916.

Paleocene, Mexico: Reynolds, 3260.

Isochyromys, Oligocene, Colorado: Friant, 1340.

Jurassic, paleobiology: Simpson, 3714.

Kansas, analysis of extinct elephant tusks: Brubaker, 501.

Kansasimys dubius, Pliocene, Kansas: Wood, 4579.

Kentucky, Big Bone Lick: Jillson, 1951, 1952.

Lambdotherium, Eocene, Wyoming: Bonillas, 367.

Lambdotherium popoagicum, Eocene, Wyoming: Bonillas, 366 .

Leptoreodon (Hespelomeryx) edwardsi, Eocene, California : Stock, 3928.

Mammoths and mastodonts, Savannah, Géorgia : Mitchell, 2753.

Manati, Oligocene, Cuba: Duelo, 1087.

Mastodon, Aurora, Ill.: Powers, 3121; Smith, 3748. 
Mammalia-Continued.

Mastodon-Continued.

Bloomfleld Hills, Mich.: Case, 694.

Noble County, Ind.: Sanford, 8492.

Pliocene, Nebraska: Hesse, 1724.

Mastodon and other remains, Aurora, Illinois: Smith, 3746.

Mastodon americanus tusk. Pleistocene, Iowa: Cable, 619 .

Meniscoëssus, Cretaceous, Montana : Simpson, 3720 .

Merychippus zone faina, Tertiary, California: Bode, 355 .

Merycodonts, Miocene, Nevada : Furlong, 1365.

Mesocyon geringensis, Miocene, Nebraska : Barbour, 17.7.

Mesozoic plant food and mammalian evolution: Werner, 4421.

Minnesota, kitchen midden with extinct Bison americanus bones: Eddy, 1134

Miocene, marine, Bakersfield region, California: Wilson, 4546.

Miocene and Pliocene, Nebraska: Stirton, 3906.

Montana, Fort Union: Simpson, 3715.

Paleocene, Fort Union: Simpson, 3724.

Mylodon tracks, Carson prison, Nevada: Stock, 3932.

Multituberculate, Belly River, Alberta : Russell, 3435 .

Nannippus gratum, Pllocene, Nebraska, phylogenetic relationships: McGrew, 2533.

Nebraska, Miocene, restorations: Colbert, 799 :

Pleistocene: Lugn, 2478.

Scotts Bluff. Nat. Monument: Effinger, 1141.

New Mexico, Clovis lake clays, Pleistocene: Antevs, 79.

Opossums, recent and fossil, classification : Simpson, $\mathbf{3 7 1 7}$

Oregon, Miocene, Sucker Creek: Scharf, 3535.

Palaeolagus haydeni, Oligocene, Nebraska : Dice, 1039.

Paleocene, census : Simpson, 3721.

Peccary, Pleistocene, Oklahoma : Johnston, 1981.

Pediomeryx bemphillensis, Pliocene, Texas: Stirton, 3912.

Pelvis, from fish to man: Gregory, 1527.

Peratherium, Eocene, California : Stock, 3926.

Peratherium huntli, Miocene, Colorado: Gazin, 1392

Perissodactyla, Sespe Eocene, California: Stock, 3929.

Per o m y s c u nesodytes, Pleistocene, Santa Rosa Island, California: Wilson, 4555 .

Plesiadapis - gidleyi, : upper Paleocene, Colorado: Simpson, 3718
Mammalia-Continued.

Plesippus francescana, Pliocene, California: Schultz, 3592.

Pliocene, Snake River Valley, Idaho: Rice, 3264 .

Proboscidea: Loomis, 2452 ; Osborn, 2961.

Ancestral tree: Osborn, 2959.

Prosthennops: niobrarensis, Tertiary, Nebraska : Colbert, 800.

Protitanops curryi, Oligocene, California : Stock, 3934.

Protohippus tehonensis, Tertiary, California: Stock, 3919.

Protomeryx, Miocene, Wyoming: Loomis, 2449.

Pseudocylindrodon neglectus, Oligocene, Montana: Burke, 580.

Puerco, Paleocene, New Mexico: Simpson, 3722 .

Rhinoceroses, a m y o d o $\mathrm{nt}$, Tertiary : Wood, 4589

Rodents, cricetid, Tertiary : Wood, 4576.

Eocene, Utah: Burke, 581.

Heteromyid. Tertiary, Californla : Wood, 4581 ; western North America: Wood, 4573 .

Miocene, Oregon: Wood, 4574.

Nomenclature for cusps, cheek teeth : Wood, 4578.

oligocene, Çalifornia : Wilson, 4548

Pliocene, Smiths Valley, Ner.: Wilson, 4554:

Simmys, replacing Eumysops, preoccupied: Wilson, 4551.

Sinclairella, Oligocene, South Dakota: Jepsen, 1947.

Skeletons, habitus factors in : Gregory, 1533

Sloths, Pliocene and Pleistocene, Idaho : Gazin, 1393.

South Dakota, White River Oligocene: Scott, 3612 .

Succession and correlation, continental Pliocene faunas: Stirton, 3911.

Associated with early man: Stock, 3933.

Symbos, Pleistocene, Oklahoma: Stovall, 3955 .

Tapir, Miocene, Wyoming: Schlaikjer, 3561.

Teeth, 'protohippine horses, Miocene, California: Bode, 354.

Teleodus californicus, Eocene, California: Stock, 3920.

Texas, Archidiskodon imperator tusk : Anonymous, 4669.

Tiffany fauna, upper Paleocene, Colorado: Simpson, 3716, 3719.

Titanotheres, Death Valley, Calif. : Stock, 3927.

Titanoides, Colorado: Patterson, 3022.

Titanoides faberi, Paleocene, Colorado: Patterson, 3023.

Trogosus minor, Eocene, British Columbia : Russell, 3429 . 
Mammalia-Continued

Ursus horribilis. Man-Continued. Stovall, 3954.

Ursus horribilis oklahomaensis, Oklahoma: Stovall, 3951.

Vertebrates, Tertiary, Texas: Wood, 4587.

Viverravus (Plesiomiacis) progressus, Eocene, California : Stock, 3915.

Washington, Yakima basalts with fossils : Beck, 250.

Whale Jaw, Miocene, California : Hanna, 1617.

Wyoming, Goshen Hole area, Oligocene and Miocene vertebrates: SchlaikJer, 3560 .

Mammalian fauna, local and continental, relationships: Simpson, 3723.

Mammals, succession of, associated with early man : Stock, 3933.

Man, fossil.

America, early man: Merriam, 2673.

America's earliest man: Amsden, 60.

Ancient peoples of the Northwest: Randolph, 3176.

Antiquity of man in America : Merriam, 2674 ; Nelson, 2846.

Artifacts, associated with extinct animals : Howard, 1815.

In Pleistocene varves, Nebraska and North Dakota: MacClintock, 2506.

River terraces, Texas: Sayles, 3520.

California, Pleistocene, near Los Angeles: Bowden, 384.

Clovis area, New Mexico: Stock, 3931.

Colorado, Folsom complex, Lindenmeier site : Roberts, 3312, 3313, 3314.

Date of early man in the Southwest: Antevs, 81.

Dating possibilities, fossil mammal-artifact locadities: MacClintock, 2505.

Early man in America: Howard, 1817 ; Woodward, 4607.

Round Rock, Texas: Sellards, 3641

Southwestern U. S. : Howard, 1819.

Evidence of, North America: Howard, 1814.

Fauna, Pleistocene, Clovis, N. Mex. : Howard, 1816.

Folsom, N., Mex. : Figgins, 1256.

Folsom and Yuma artifacts: Figgins, 1257.

Folsom artifacts, Fort Collins, Colo.: Roberts, 3315 .

Folsom camp and workshop; Fort ColIins, Colo.: Roberts, 3310

Folsom culture; New Mexico: Brown, 475.

Folsom man, habitation and workshop sites, Colorado: Roberts, 3311.

Gypsum Cave, Nevada, Pleistocene: Harrington, 1641.

Homo sapiens, whence and whither: Hooton, 1789.

Human remains, early, in Southwest : Howard, 1818.

Kodiak Island, Alaska: Hrdlicka, 1872.

Landscapes showing ancient life: Knight, 2233.

Mammals, succession of, associated with early man: Stock, 3933.

Minnesota, kitchen midden with extinct Bison americanus bones: Eddy, 1134.

Pleistocene : Sardeson, 3509.

Minnesota man: Bryan, 521; Madsen, 2564.

Mollusks associated with early man: Richards, 3283.

Nebraska, Pleistocene man : Lugn, 2480.

New Mexico, Clovis artifacts: Howard, 1821.

Clovis lake clays, Pleistocene: Antevs, 79.

Folsom points and extinct bison, Clovis and Carlsbad: Howard, 1820.

North Platte Valley region, Nebr.: Van Royen, 4265.

Pleistocene man, Arizona: Cummings, 932.

Pinto Basin site, Calif.: Campbell, 635.

Prehistoric man in the Southwest: Getty, 1409.

Prehlstory relation to postglacial climatic fluctuations : Fisher, 1275.

Southwestern U. S. : Stock, 3925.

Spread, aboriginal man, to North America : Anters, 77, 78.

Stone age, early, Little Colorado River terraces: Bartlett, 199.

Texas, Round Rock, Williamson County, Cretaceous : Sellards, 3636.

Williams Cave, Guadalupe Mountains, Texas: Ayre, 125.

Yuma-Folsom sites, western Nebraska, age : MacClintock, 2503.

Man, antiquity in America: Howard, 1821

Man, early in North America: Howard, $1814,1817$.

Manganese.

Arizona, piedmontite, Tucson Mountains: Guild, 1565.

Boulder Dam area, mineral occurrences : Lee, 2367 .

Canada, manganiferous lake-bottom de. posits: Kindle, 2204.

Montana: Gilbert, 1421.

Newfoundland, Bay of Exploits area: Heyl, 1736.

New Hampshire, concretions: Kindle, 2196.

New Mexico, Bayard area: Lasky, 2344.

Nova Scotia, concretions: Kindle, 2196.

oxidation, hydrothermal: Trengove, 4167.

Oxides, manganese, and ground-water circulation : Hewett, 1734.

Pacific coast: Hodge, 1761.

Puerto Rico: Harper, 1637 ; Meyerhoff, 2685 ; Ray, 3188.

Solution, transportation and precipitation: Savage, 3516 
Manganese-Continued.

Virginia, southwestern : Currier, 936.

West Virginia, eastern: Reeves, 3233.

Manitoba.

Economic geology.

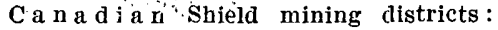
Wright, 4627.

Elbow-Morton area, gold deposits : Stockwell, 3939.

Flin Flon mine: Brownell, 499.

Foundry sands: Stanley, 3822.

God's Lake gold mine: Baker, 155.

Granite, monumental and building: Cole, 803.

Minerals, Industrial and fuel: Hutt, 1900.

Historical geology.

C a n a d a n Shield mining districts: Wright, 4627.

Cross Lake area, pre-Keewatin(?) tonalite: Horwood, 1798.

Elbow-Morton area: Canada G. S., 648; Stockwell, 3939.

Flin Flon mine: Brownell, 499.

God's Lake gold mine: Baker, 155.

Missi series, Flinflon area: Ambrose, 59.

Seal River, northern Manitoba: Johnston, 1980.

Structure Missi series, Flinflon: Ambrose, 58.

Mineralogy.

Chemawinite, Canadian amber: Walker, 4319.

Cordierite, positive, Kisseyenew gneiss : Rutherford, 3454 .

Paleontology.

Amber, Cedar Lake, fauna: Walker, 4323.

Insects in Canadian amber: Carpenter, 681.

Trinacromerum kirki, Cretaceous : Russell, 3432.

Petrology.

Gneiss zone, Flinflon area: Kerr, 2073.

Metamorphism, progressive $\mathrm{k}$ in et $\mathrm{i} \mathrm{c}$, Missi series, Flinflon area: Ambrose, 59.

Physical geology.

$\mathrm{C}$ a $\mathrm{n}$ ad i a n Shield mining districts: Wright, 4627.

Cross Lake area, pre-Keewatin(?) tonalite: Horwood, 1798.

Flin Flon mine: Brownell, 499.

Gneiss zone, Flinflon area: Kerr, 2073.

God's Lake gold mine: Baker, 155.

Granitization, Cross Lake region: Horwood, 1802.

Metamorphism, progressive $\mathrm{k}$ in etic, Missi series, Flinflon area: Ambrose, 59.

Structure, Missi series, Flinflon : Ambrose, 58.

Physiographio, geology.

Elbow-Morton area : Stockwell, 3939.

Glaciations, older : Burwash, 587.

Gotiglacial broadmapping: De Geer, 1004.

Maps. See Geologic maps; Isopach maps; Relief maps.

Map making. See Cartography.

Marble.

California, nonmetallic minerals : Bradley, 421.

Connecticut: Moore, 2782.

Newfoundland, Canada Bay and White Bay area: Bain, 139.

Petrology of : Bain, 136.

Tennessee : Oder, 2937.

Virginia, James River iron and marble belt: Furcron, 1362.

Marine biology and paleoecology : Fish, 1266.

Marine plants and Pacific paleogeography : Setchell, 3642.

Marine unconformities and conglomerates : Twenhofel, 4198.

Martic overthrust: Mackin, 2544; Miller, 2718.

Martinique.

Physical geology.

Mont Pelee, eruption: Arsandaux, 96; Romer, 3352 ; Perret, 3055.

Maryland.

Historical geology.

Bentonite beds, lower Chambersburg • Whitcomb, 4450.

Coastal Plain, structure, southern Maryland : Monroe, 2770.

Igneous rocks, pre-Cambrian: Bascom, 219.

Limestones, Frederick Valley: Jonas, 1933 ; Stose, 3948.

Overlap relations, Cretaceous and Tertiary: Darton, 979, 980.

Piedmont intrusives, age : Cloos, 783.

Silurian Rochester and McKenzie formations, relation: Swartz, 3990 .

Volcanic rocks, pre-Triassic, southern Appalachians: Jones, 1992.

\section{Mineralogy.}

Minerals : Ulke, 4206.

Mines and quarries near Washington: Ulke, 4207.

\section{Paleontology.}

Archaeomonadaceae: Deflandre, 1002.

Conifers, Lower Cretaceous, Northwest Branch : Brown, 490.

Fauna, Pleistocene Pamlico, southern Atlantic Coastal Plain: Richards, 3284.

Pearl, Miocene, Jones Wharf, St. Mary's County : Berry, 297.

Pectinidae, Tertialy: Rowland, 3389 ; Tucker, 4178.

Pinus collinsi, Calvert Miocene, Plum Point: Berry, 303.

Turtles, Calvert County, Miocene: Col-

- lins, 809 .

Venericardia planicosta, variations: Chavan, $\mathbf{7 4 0}$.

\section{Petrology.}

Pledmont intrusives, age: Cloos, 783. 
Maryland-Continued.

Physical geology.

Piedmont intrusives, age: Cloos, 783.

Physiographic geology.

Coastal Plain, southern Maryland: Dryden, 1084.

Structure: Monroe, 2770.

Terraces: Cooke, 849.

Severn River: Scheid, 3536.

Massachusetts.

Economic geology.

Limonites, Taconic, origin: Newland, 2867.

Mineral resources : Crosby, 923.

Mineralogy.

Babingtonite : Kitson, 2223.

Babingtonite and epldote, Westfleld: Palache, 2980.

Grünerite, Rockport : Bowen, 387.

Limonites, Taconic, origin: Newland, 2867.

Pegmatites, Fitchburg: Hitchin, 1751.

Stalactites in sewer, West Roxbury: Quinn, 3158.

\section{Paleontology.}

Paradoxides fauna, Cambrian: Howell, 1860.

Petrology.

Concretions, Champlain formation : Tarr, 4017.

Grïnerite, Rockport: Bowen, 387.

Limonites, Taconic, origin: Newland, 2867.

Physical geology.

Earthquake, Provincetown, April 23, 1935 : Leet, 2371.

Erosion, marine, glacial deposits, Massachusetts Bay: Stetson, 3888.

Stability, land and sea, Salem: Goldthwait, 1470.

Physiographic geology.

Felsite, red, boulder train, Hingham: Howe, 1847.

Loess near Boston: Smith, 3754.

Underground water.

Ground-water supplies: Kingsbury, 2216.

Measurement of glaciers necessary : Matthes, 2612.

Mechanical analysis, lithifield sediments : Sanford, 3494.

Mechanics of metasomatism : Bain, 138.

Meetings. See also Associations.

16th International Geological Congress, U. S. 1933 : Schumacher, 3593.

Mercury. See Quicksilver.

Mesozoic (undifferentiated).

Pegmatites, age and distribution: Landes, 2311.

Mesozoic plant. foods and mammalian evoIution: Werner, 4421.

Metallurgy.

Earth, cooling: Stauss, 3843.
Metamorphic rocks, origin and composition: Runner, 3420.

Metamorphism.

Alaska, Ruby-Kuskokwim region: Mertie, 2681.

Appalachians, southern, Talladega series: Crickmay, 910

Arizona, SHlver King area, Superior : Galbraith, 1373.

Bore-hole investigations, Yellowstone Park : Fenner, 1223.

California, southern, Perris block : Dudley, 1085.

Connecticut, marbles and limestones: Moore, 2782.

Cuba, Isla de Pinos: Rutten, 3459.

General : Runner, 3420.

Glenarm series, Chester Valley, Pa.: Miller, 2718.

Granitic rocks, derivations: Collins, 814.

Greenland, crystallines, Liverpool Land : SahIstein, 3472 ; Kranck, 2256.

Idaho, Casto quadrangle: Ross, 3369.

Igneous and sedimentary rocks, comparative progression: Spivey, 3809 .

Jamaica, basal complex: Trechmann, 4163.

Malne, Onawa pluton, Piscataquis County : Fhilbrick, 3072.

Manitoba, granitization, Cross Lake region: Horwood, 1802.

Missi series, Flinflon area: Ambrose, 59.

Mexico, Cananea Mountains, Sonora: Valentine, 4247.

Mapimr, Coahuila Peninsula: Singewald, 3732 .

Mineral facies, interpretation, in metamorphic rocks: Turner, 4189.

Montana, Little Belt Mountains, contact metamorphic zone: Taylor, 4028.

Nevada, Chief district, Lincoln County : Callaghan, 629 .

Ely district: Bateman, 236.

Newfoundlaind, Bay of Exploits area : Heyl, 1736.

Bay of Islands igneous cómplex : Cooper, 869.

New Hampshire, Franconia quadrangle: Billings, 317.

Littleton-Moosilauke area : Billings, 320.

New Jersey, granitic dike, Franklin : Milton, 2742.

New Mexico, Bayard area : Lasky, 2344. Organ Mounțains and Doña Ana County: Dunham, 1094.

Santa Rita mining area: Spencer, 3803.

Virginia mining district: Lasky, 2343.

New York, Dutchess County : Balk, 162 ; Barth, 198.

Oswegatchie quadrangle: Dale, 961 
Metamorphism-Continued.

Ontario, Porcupine district, vein formation : Hurst, 1898; Reid, 3237.

Sudburite: Thomson, 4115.

Oregon, Cascade Range: Buddington, 549.

Organic sediments and derived oils: White, 4453.

Quebec, Chibougamau Liake area : Mawdsley, 2617.

Intrusives, Laurentian . complex : Osborne, 2969.

Shawinigan Falls district: Osborne, 2965, 2967.

Replacement of dikes and sills: Goodspeed, 1476 .

Serpentine-country rock contacts, differentiation: Phillips, 3074

South Carolina, Columbia quadrangle, granite: Kesler, 2087.

System CaO-MgO-SiO, reactions between solids: Taylor, 4030.

Texas, Llano region: Stenzel, 3868 .

Ultrabasic intrusions, alteration: Hess, 1721 .

Vermont, ultrabasics: Bain, 140.

Yellowstone National Park, rhyolite contact effects on basalt: Fenner, 1220 .

Yukon, Carmacks district : Bostock, 379.

Meteor craters.

Arizona : Spencer, 3804.

Meteorite craters and cryptovolcanic structures: Boon, 370.

Meteorite scars, so-called, South Carolina Coastal Plain: Cooke, 847.

Meteorites.

Annual deposit on earth: Wylie, 4636.

Archie, Mo., August 10, 1932 : Haynes, 1659 ; Nininger, 2892.

Arizona, Meteor Crater: Colvocoresses, 821.

Bacteria in : Lipman, 2425 ; Roy, 3406.

Bennet County, South Dakota : O'Harra, 2941.

Bibliography : Hamilton, 1613; First 1935 list: Leonard, 2393; Second 1935 list: Leonard, 2395; First .1936 list: Leonard, 2396.

Collections: Nininger, 2898.

Crater, Odessa, Tex.: Monnig, 2766.

Depth, and gradation of Great Plains : Nininger, 2891.

Fayetteville, Ark., December 26, 1934 : Richardson, 3285.

How to recognize: Nininger, 2888.

Impact : Boon, 369.

Institute, national, for research on: Nininger, 2890.

Iron, structure and composition: Buddhue, 540

Metallic, etching and preserving: Nininger, 2893.

Meteorite scars (?), South Carolina: Johnson, 1963.

Mexico, geographic distribution: Müllerried, 2813.
Meteorites-Continued

Moore County, N. C. : Henderson, 1698.

- Nininger Laboratory, work of: Gillespie, 1427.

Oklahoma, August 17, 1936: Monnig, 2768.

Paint Creek, Ohio: Ver. Steeg, 4279.

Pasamonte, N. Mex. : Nininger, 2896.

Pennsylvania: Anonymous, 4701.

Quartz Mountain, Nev.: Gianella, 1415.

Rate of fall, meteoric material: Wylie, 4635.

Reseàrch progress: Leonard, 2394.

Rbyolite, Nevada: Dake, 954.

Roy, Harding County, N. Mex. : Heineman, 1690; Nininger, 2887.

Saskatchewan, Bruno: Nininger, 2894.

Siderites, abundance in the Americas: Müllerried, 2813.

Spectra : King, 2206

Surface features: Nininger, 2889, 2897.

Tectites, meteoric glass: Oswald, 2971.

Terminology : Nininger, 2895.

Texas, pleliminary check list: Monnig, 2767.

Willamette, Idaho: Dake, 956.

Willamette, Wash., 1902 : Wimmer, 4559. Mexico.

Michigan University expeditions: Kellum, 2053.

Areas described.

General : Sorre, 3789.

Mountains west of Laguna district, Coahuila Peninsula: Kellum, 2058.

Sierra de Parras, Coahuila Peninsula: Imlay, 1905.

\section{Economic geology.}

Bajada placers: Webber, 4375.

Beryl and berillium: Santillán, 3497.

Copper: Santillán, 3496.

Boleo region, Baja California : Locke, 2433.

Cananea district, Sonora: Perry, 3061.

Pilares mine, Sonora: Tenney, 4041.

Pyrite, Campo Morado, State of Guerrero: Flores, 1290.

Sulphides, Colorado mine, Cananea : Kelley, 2049.

Correlations by Foraminifera: Nuttall, 2925.

Cusihuiriachic, Chihuahua: Donald, 1057.

Dikes, veins, Alamo gold district, Lower California : Moehlman, 2758.

Eocene, northeastern Mexico: Kane, 2017.

Fractures, formation, Pachuca silver district: Wisser, 4567.

Gold placers : Barrera, 193.

Gulf coast oil fields: Barton, 215.

Mercury, native, 'San Luis Potosi : Franks, 1326.

Micropaleontology : Barker, 182.

Mineral resources: Santillán, 3499.

Indé and Santa María del .Oro, Durango: Juarez, 2014. 
Mexico-Continued.

Economic geology-Continued.

Natural gas in Mexican oil fields : Muir, 2820.

Oil fields, northeastern Mexico: Tatum, 4021.

Possibilities : Ortega, 2958.

Ore deposits: Schmitt, 3565.

Petroleum, Oaxaca, Puebla, and Guerrero: Parades, 3000.

Origin, limestone reservoir rocks: Muir, 2822.

Platinum : Santillán, 3498.

Sabinal silver district, Chibuahua : Krieger, 2261.

Silver ores, primary, Batopilas: Krieger, 2262.

Tampico region: Kellum, 2059; Muir, 2821 ; Plummer, 3101.

Tepezala, Aguascalientes, pyrometasomatic vein deposits: Wandke, 4328.

Wells, petroleum, northeastern Mexico: Kane, 2018.

Zoning, ore-body, Sierra Mojạda, Coahuila : Riley, 3305.

Historical, geology.

Agueguexquite formation, $M$ i o c e $\mathbf{n}$, Vera Cruz: Thalmann, 4050.

Arkose deposits in humid tropics: Krynine, 2272.

Beryl and berillium : Santillán, 3497.

Boleo copper region, Baja California: Locke, 2433.

Cananea Mountains, Sonora: Valentine, 4247.

Coahuila Peninsula: Kellum, 2057; Singewald, 3732.

Correlations by Foraminifera : Nuttall, 2925.

Cretaceous, earliest recognition : Keyes, 2119.

Lower California: Anderson, 65.

Cusihuiriachic, Chibuahua: Donald, 1057.

Eocene, northeastern Mexico: Kane, 2016, 2017.

General: Santilián, 3499, 3500, 3501; Sorre, 3789.

Mapimi district: Singewald, 3728.

Mountains, Coahuila Peninsula: Kellum, 2058; Kelly, 2068.

Oil field, northeastern Mexico: Tatum, 4021.

Paleogeography, northwestern Mexico: Kellum, 2054.

Pre-Tertiary, State of Chiapas: Müllerried, 2815.

Road log, geologic, Laredo to Mexico City: Tatum, 4022.

Tamaulipas and Nuevo Leon: San Antonio G. S., 3480 .

Sierra del Rosario, Cretaceous : Kellum, 2052.

Durango: Kellum, 2055.

Sierra de Parras; Coahuila Peninsula: Imlay, 1905.
Mexico-Continued.

Historical geology-Continued.

Șierra Fedro Mártir : Harriss, 1644.

Symposium: Levorsen, 2405.

Tampico region: Kellum, 2059; Lilley, 2416; Muir, 2821; Plummer, 3101 ; Ver Wiebe, 4289.

Tertiary, northeastern Mexico:: Warner, 4342.

Tuxpan and Papantla Miocene formations, Vera Cruz: Thallman, 4052.

Unconformities and transitional zones, Tampico region: White, 4460.

Velasco, Tertiary formation, Tampico region: Thalmann, 4051 .

\section{Mineralogy.}

Beryl and beriliuim : Santillán, 3497.

Dikes, veins, Alamo gold district, Lower California: Moehlmain, 2758.

Livingstonite, Huitzuco, Guerrero : Richmond, 3289.

Meteorites, geographic distribution: Müllerried, 2813.

Mineralogical investigations 1934 : Foshag, 1310.

Silver ores, primary, Batopilas : Krieger, 2262.

\section{Paleontology.}

Cephalopoda, Upper Cretaceous, Rio Grande : Renz, 3249.

Conrad's type fossil localities: Keyes, 2168.

Echinodermata, San Luis Potosi, Cretaceous: Lambert, 2295.

Echinoids, Cretaceous : Müllerried, 2812.

Faunas, Mesozoic, northern Mexico: Kellum, 2056.

Foraminifera, Eocene: Nuttall, 2923.

Orbitoidal, Eocene, phylogeny: Barker, 183.

Tertiary: Thalmann, 4053.

Micropaleontology : Barker, 182.

Mollusca; Cretaceous, Lower California: Anderson, 65.

Marine, Pleistocene, Oaxaca: Palmer, 2995.

Operculina and .Operculinoides, Tertiary: Vaughan, 4273.

Parafusulina, Permian, dimorphism : Dunbar, 1091.

Verneuilinidae, Valvulinidae and Virgulinidae: Cusbman, 945.

\section{Petrology.}

Cananea Mountains, Sonora: Valentine. 4247.

Coahuila Peninsula, Mapimt, igneous phenomena and structure: Singewald, 3732.

Concretions, Mount Signal, Lower Callfornla: Garner, 1386.

\section{Physical geology.}

Acapulco, Bay of: Sánchez, 3484.

Cananèa Mountains, Sonora: Valentine 4247. 
Mexico-Continued.

Physical geology-Continued.

Coahuila Peninsula : Kellum, 2057.

Mamipf, igneous phenomena and structure : Singewald, 3732.

Colorado Delta: Fox, 1321.

Copper, Pilares mine, Sonora: Tenney, 4041.

Cusihuiriachic, Chihuahua: Donald, 1057.

Earthquakes, Valley of Mexico : Salazar Salinas, $\mathbf{3 4 7 5}$.

Eocene, northeastern Mexico: Kane, 2017.

Fractures, formation, Pachuca silver district: Wisser, 4567.

General : Sorre, 3789.

Karst topography and lava caves: Wittich, 4569.

Mountains, Coahuila Peninsula: Kellum, 2058; Kelly, 2068.

Pre-Tertiary, State of Chiapas : Müllerried, 2815.

Sierra de Parras, Coahuila Peninsula: Imlay, 1905.

Unconformities and transitional zones, Tampico region: White, $\mathbf{4 4 6 0}$.

Volcanism, recent, Pinacates region: Ives, 1915.

Volcanoes, extinct: Coleman, 807.

Physiographic geology.

Coahuila Peninsula: Kellum, 2057.

Colorado Delta : Fox, 1321.

Colorado Delta and : lower Colorado River: Sykes, 3998.

Desert floods, Sonoyta Valley: Ives, 1918.

Fiords, possibility of: Sánchez, 3483.

General: Sánchez, 3485; Santillán, 3500,3501 ; Sorre, 3789 .

Karst topography and lava caves: Wittich, 4569.

Mountains west of Laguna district, Coahuila Peninsula : Kellum, 2058.

Paleogeography, northwestern Mexico: Kellum, 2054

Physiographic provinces : Ordonez, 2956.

Plateau, southern slope: "Weymuller, 4435:

Volcanoes, extinct, and glaciation : Coleman, 807.

Underground water.

Sierra Madre Oriental: Dicken, 1042.

MIca : Rowley, 3391.

Michigan.

Areas described.

High plains : Davis, 983.

Economic geology.

Copper deposits, origin: Broderick, 465.

Copper Range: Broderick, 462.

Crystal oil fleld: Eddy, 1133.

Gogebic iron range: Atwater, 113.

Geothermal temperatures, copper mines, Lake Superior : Kraskovsky, 2257.

Gypsum deposits, Grand Rapids : Mathews, 2606.
Michigan-Continued.

Economic geology-Continued.

Hart oil fleld, Oceana County : Riggs, 3302.

Lake Superior region: Broderick, 463; Leith, 2390; Rama Rao, 3167; Royce, 3397.

Lavas, Keweenawan, differentiation: Broderick, 464.

Magnetic data, use in iron ranges: Swanson, 3985 .

Natural-gas flelds : Newcombe, 2853.

Natural-gas reserves, central Michigan: Rawlins, 3187.

Negaunee iron formation, Marquette County : Adler, 6.

Oil fields, central Michigan: Zavoica, 4644.

Salt: Exworthy, 1201.

Historical geology.

Copper Range : Broderick, 462.

Correlations by graptolites, Lower

Paleozoics : Decker, 1001.

Cranbrook area : Stanley, 3819.

Crystal oil field: Eddy, 1133.

Dundee limestone, southeastern Michigan : Bailey, 223.

General : Kans. Geol. Soc., 2020.

Gogebic iron range: Atwater, 113.

Grand Sable dunes, Lake Superior, Alger County: Bergquist, 288.

Granites, sequence, southern complex, Upper Michigan : Dickey, 1044.

Gypsum deposits, 'Grand Rapids : Mathews, 2606.

Hamilton correlations: Warthin, 4351.

Hart oil field, Oceana County: Riggs, 3302 .

Lake Superior iron deposits: Royce, 3397.

Natural-gas fflelds: Newcombe, 2853.

Natural-gas reserves, central Michigan : Rawlins, 3187.

Negaunee iron formation, Marquette County: Adler, 6.

Oil fields, central Michigan: Zavoica. 4644.

Palmer gneiss, Huronian : Lamey, 2300.

Pre-Cambrian, Lake Superior region: Rama Rao, 3167.

Republic granite, intrusive relations: Lamey, 2299.

Traverse group, Devonian, Thunder Bay region: Warthin, 4352.

Whittlesey Beach decline, Birmingham: Stanley, 3818.

Mineralogy.

Chlorastrolite, Isle Royale: Dustin, 1099.

Serpentine, Ishpeming: Alessi, 20.

Tourmaline, high iron, Marquette fron range: Slawson, 3738.

\section{Paleontology.}

Casteroides obioensis, distribution: Cahn, 623.

Dundee limestone, southeastern Michigan : Bailey, 223. 
Michigan-Continued.

Paleontology-Continued.

Elephas primigenius americanus, Cass County : Case, 691.

Mastodon, Bloomfield Hills: Case, 694.

Pollen analysis, Fartford bog: Osvald, 2970.

Pollen from bogs, southwestern Michigan: Houdek, 1805.

Postglacial vegetation, Lake Michigan region: Fuller, 1359.

\section{Petrology.}

Bayport chert: Dustin, 1098.

Traverse group, Devonian, Thunder Bay region: Warthin, 4352.

\section{Physical geology.}

Geothermal temperatures, copper mines, Lake Superior : Kraskovsky, 2257.

Granites, sequence, soutbern complex, Upper Michigan: Dickey, 1044.

Lake Michigan, southern, bottom deposits: Hough, 1809.

Lavas, Keweenawan, differentiation: Broderick, 464.

\section{Physiographic geology.}

Boulders, etched erratic: Hobbs, 1757.

Glacial expression of structure: Newcombe, 2854.

Grand Sable Dunes, Lake Superior, Alger County : Bergquist, 288.

High plains: Davis, 983.

Huron River, abandoned channels: Bay, 243.

Sink holes, Indian Lake and other regions: Poindexter, 3105.

valley-train deposits, Iron County: Bergquist, 287.

Whittlesey Beach decline, Birmingham : Stanley, 3818.

Underground vater.

Big Spring, Schoolcraft County: Poindexter, 3104.

Micromagnetic surveys: Jenny, 1946.

Mineral fuels and civilization: Eavenson, 1117.

Mineral matter, relation to coaliflcation : Ball, 165.

Mineral resources (general) : Fitzhugh, 1277. See also Economic geology under the names of the States.

Alaska, 1934: Smith, 3765.

Boulder Dam region: Hewett, 1735.

British Columbia, Peace River area: Williams, 4517.

California, Perris block : Sampson, 3479. San Luis Obispo County: Franke, 1324.

Siskiyou County: Averill, 124.

Canada: Sawa, 3518; 1933 : Robinson, 3322 ; 1934 : McLeish, 2556; 1935 : McLeish, 2557.

Colorado: Henderson, 1695.

Copper, wolld reserves: Barbour, 178.
Mineral resources (general)-Continued.

Florida: Mansfield, 2567.

Mineral production, 1932-33: Gunter, 1576.

Georgia, mineral production, 1933 : Smith, 3766; 1934 : Smith, 3768.

Gold: Knopf, 2238.

Greenland: Blüthen, 351.

Idaho, mining industry, 1934 : Simons, 3711.

Illinois, publications on: Anonymous, 4687.

Louisiana, Cameron and Vermilion Parishes: Craft, 888.

Massachusetts: Crosby, 923.

Mexico: Santillán, 3499.

Inde and Santa María del Oro, Durango: Juarez, 2014.

Miquelon: Aubert de la Rue, 122.

Montana: Sahinen, 3470 .

Nonmetallic: Kriege!, 2260.

Newfoundland: Trioche, 4168.

New Jersey, mineral industry, 1934: Johnson, 1977 ; 1933: Johnson, 1976.

New York, mining and quarry industries, 1930-33: Newland, 2868.

North Carolina: Pratt, 3126.

North Dakota, glauber salt: Lavine, 2353.

Oregon: Anonymous, 4660.

Bibliography: Treasher, 4160.

Eastern, nonmetallic: Moore, 2777.

Western : Pardee, 3002.

Pennsylvania: Ashley, 101.

Bellefonte quadrangle: Butts, 598.

Butler and Zelienople quadrangles: Richardson, 3286.

Puerto Rico: Eckel, 1127; Meyerhoff, 2684 ; Ray, 31.88, 3189.

Quebec, western: Bell, 270.

St. Pierre: Aubert de la Rue, 122.

South Carolina, Coastal Plain: Cooke, 847.

Tennessee Valley Authority region: Eckel, 1128.

Texas: Baker, 146, 147.

Mineral production, 1882-1933: Sellards, 3639.

United States: U: S. Nat. Res. Com., 4239.

Reserves of mineral fuels: Garfias, 1384.

Virginia: McGill, 2528, 2529.

Washington: Anonymous, 4677 ; Glover, 1452.

Wyoming: Marxel, 2595.

Yukon; mining industry, 1934; Bostock, 378 ; 1935 : Bostock, 380. .

Mineralogy (general) : Buddhu, 539; Frondel, 1349 ; Hawkins, 1651; Kraus, 2258 ; Lewis, 2408; Milhase, 2642 ; Thompson, 4097 ; Vaughan, $: 4272$. For areal see names of States. See also Crystallography; Meteorites; Technique. 
Mineralogy (general)-Continued.

Aenigmatite : Fleischer, 1279.

Agates: Blair, 340; Randolph, 3171; Zeihen, 4647.

Formation: Cahen, 622 ; Wild, 4480.

Agates and jaspers, Atlantic Coastal Plain: Ulke, 4280.

Age of minerals, pleochroic halos: King, 2207.

Amber : Blair, 339.

Analysis by fluorescence: Ackoff, 2 .

Biotite system: Winchell, 4563.

Chalcocite-stromeyerite-argentite, relations : Schwartz, 3595.

Chlorite system: Winchell, 4562.

Classification by cleavage and crystal habit: Staples, 3826.

Minerals : Seaman, 3619.

Clays, ceramic, constitution: Grim, 1550 .

Cleavage, Ionic minerals: Shappell, 3646.

Color photography : Shaub, 3651 .

Copper ore minerals, identification by $X$-ray: Waldo, 4312.

Copper replacement minerals: Ward, 4335.

Crystal forms and form names: Rogers, 3338.

Crystals, vectoral chemical alteration: Frondel, 1353.

Cyrtolite, analysis: Muench, 2817, 2819.

Danburite, melting: Morey, 2795.

Determination of specific gravities of minerals : Syromyatnikov, 4000 .

Dickite, structure: Ksanda, 2278.

Dunite intrusion, and olivine: Bowen, 388.

Equilibrium studies, monticellite, glaucochroite, calcium fay a lite: Schoenlaub, 3571.

Etching of alpha and beta quartz: Meen, 2627.

Feldspar, possible iron-orthoclase molecule : Faust, 1216.

Fluorescence: Meyers, 2693; Slawson, 3737 ; Yedlin, 4638.

Effect of manganese on : Ward, 4332.

Manganiferous calcites: Brown, 496.

Opal: Dake, 955.

Fluorescence and phosphorescence: $\mathbf{Z}_{0}$ dac, 4653, 4654.

Fluorescent minerals: Seaman, 3618; Walther, 4327.

Philadelphia Museum: Trudell, 4176.

Gems, determination of: Martindale, 2592.

Georgia geological museums: Mitchell, 2752.

Glauconite, genesis from biotite: Galliher, 1376.

Glauconite and mica, structural relationships: Gruner, 1561.

Gold, isotropic or isometric: Crawford, 893.

Gypsum, development in limestone caves: Pohl, 3103
Mineralogy (gencral)-Continued.

Igneous rocks, classification: Shand, 3645 .

Immersion liquids, high refractive in dex: West, 4422.

Iron ores of U. S. : Cooke, 854.

Lead and zinc minerals, bydrothermal experiments : Kristofferson, 2264.

Limonite derived from molybdenite: Blanchard, 346.

Lindgrenite: Palache, 2987.

Linnaeite group of cobalt-nickel-ironcopper sulphides: Tarr, 4016.

Luminescence, mineral : Gunnell, 1568, 1571.

Magnetite, separation planes : Greig, 1537.

Manganese, origin : Harper, 1637.

Manual: Rosevear, 3360.

Marcasite: McKinley, 2550.

Meteorites, iron, structure and composition: Buddhue, $\mathbf{5 4 0}$

National institute for research on: Nininger, 2890.

Philadelphia : Hamilton, 1613.

Spectra : KIng, 2206.

Mica group: Rowley, 3391.

Microchemical determination of minerals : Staples, 3828.

Mineral associations, high-temperature, shallow to moderate depths: Buddington, 544.

Mineral facies, interpretation, in metamorphic rocks: Turner, 4189.

Mineraloids: Rogers, 3339.

Mineral suites, heavy, statistical correlation: Dryden, 1083; Eisenhart, 1152

Minerals, collecting and preserving: $\mathbf{Z}_{\mathbf{0}}$ dac, 4648 .

Minerals in medicine: Jones, 1994.

Mississippi River bed materials, composition : Russell, 3436.

Monticellite series: Schaller, 3531.

Moss agates, formation: Wild, 4481.

Night prospecting with argon bulb: Burbank, 569.

Nontronites and montmorillonite, relationship : Gruner, 1560.

Ontario, Canadian Shield granites, heavy minerals: Bruce, 502.

Opal : Taliaferro, 4008.

Ore deposits: Butler, 592.

Phosphorescent minerals: Zodac, 4655.

Platinum group: Buddhus, 542.

Pleochroic halos, new type: Henderson, 1700.

Pre-Dana and contemporary literature : Wilson, 4528.

Pyrite oxidation: Bain, 135.

Pyroxene group: Winchell, 4561.

Quartz paramorphs: Moehlman, 2757.

Smoky, spectrophotometric study: Mohler, 2764.

Temperature of formation: Meen, 2628. 
Mineralogy (general)-Continued.

Radioactive elements, abundance, and related geologic problems:. Wells, 4393.

Refractive indices, detcrmination by immersion method: Slawson, 3739.

Residues, insoluble, obtained by acetic acid: St. Clair, 3473.

Rock-slicing machine: Shaub, 3653.

Rosiwal method and modal determination of rocks: Larsen, 2338.

Schiller structure: Colony, 819.

Sedimentary rocks: Pettijohn, 3064.

Sepiolite (meerschaum) composition : Schaller, 3533.

Serpentine minerals, $\mathrm{X}$-ray and optical investigations: Selfridge, 3635.

Silica in chert and flint, origin: Gunnell, 1572 .

Silicates, classification: Berman, 293.

Silicon, test for: Staples, 3827.

Silicosis : Colony, 818.

Silicification: Randolph, 3172 .

Silver, distribution in base-metal ores: Lasky, 2341; Warren, 4345.

Sphalerite: Mitchell, 1570.

Spherulites, three-dimensional, structure: Morse, 2804.

Staining minerals: Gaudin, 1389, 1390.

Stilpnomelane, structure: Gruner, 1562.

Succession of minerals and temperatures of formation : Lindgren, 2421.

Table of minerals: Anonymous, 4698; Kelley, 2047.

I'hulite, analyses: Northrop, 2918.

Triboluminescent zinc sulphides: Mitchell, 1570.

Tourmaline, oriented, in muscovite : Frondel, 1355.

Turquoise, genuine and imitation: Kollida, 2250 .

Wollastonite, pseudowollastonite, diopside and akermanite: Schairer, 3530 .

$\boldsymbol{X}$-ray identifacation, antlerite and brochantite: Waldo, 4313.

X-ray method for estimating quartz: Clark, 761.

Silica minerals: Hurlbut, 1897.

$\mathrm{X}$-ray study of arsenides and antimonides of nickel and cobalt: Holmes, 1786 .

Minerals, in medicine: Jones, 1994.

Minerals, magnetic properties: Davis, 984.

Mining geology : Hunt, 1889.

New trends: Fowler, 1318.

Minnesota.

Areas described.

Minnenpolis-St. Paul metropolitan area : Schwartz, 3597.

Economic geology.

Architectural, structural, and monumental stones: Thiel, 4068.

Greenalite, Mesabi Range: Jolliffe, 1987.
Minnesota-Continued.

Economic geology-Continued.

Lake Superior region: Rama Rao, 3167. Iron: Broderick, 463; Royce, 3397.

Minneapolis-St. Paul metropolitan area: Schwartz, 3597.

\section{Historical geology.}

Cambrian formation names in upper Mississippi region: Sardeson, 3511 .

Decorah shale: Stauffer, 3840.

Devonian, upper Mississippi Valley: Stainbrook, 3815 .

Generai: Kansas Geol. Soc., 2020.

Glenwood beds: Stauffer, 3837.

Isopach map, Galena, Decorah, and Platteville formations: Ball, 166.

Trempealeau, Dresbach and Franconia formations: Edwards, 1140.

Lake Superior iron deposits: Royce, 3397.

Lake Superior region: Leith, 2390.

Magnesian limestone, lower: Keyes, 2101.

Minneapolis-St. Paul artesian basin: Schwartz, 3598.

Minneapolis-St. Paul metropolitan area : Schwartz, 3597 .

Minnesota River Valley, Paleozoic: Couser, 885.

Mississippi River, upper: Cooper, 872.

Mississippi Valley, upper: Atwater, 114.

Ogishkemuncie Lake region: Sleight, 3740 .

Ordovician, upper Mississippi Valley: Kay, 2029.

Prairie du Chien beds, Upper Mississippi Valley: Powers, 3117.

Prairie du Chien Formation: Powers, 3116.

Saganaga granite batholith: Grout, 1557.

St. Croix River, Paleozoic: Clement, 774 ; Pleistocene: Sardeson, 3510.

Shakopee dolomite: Keyes, 2129.

Shakopee t1tle: Sardeson, 3505.

Southeastern Minnesota: Powell, 3114.

Stewartville and Dubuque formations: Kay, 2032.

Stlllwater deep-well records, reinterpre. tation : Stauffer, 3839 .

\section{Mineralogy.}

Agates, Lake Superior beaches: Alessi, 21.

Greenalite, Mesabi range:.Jolliffe, 1987.

Structure: Gruner, 1563.

Thomsonite, Lake Superior: Combs, 822.

\section{Paleontology.}

Batostoma and Hemiphragma, Ordovivician: Sardeson, 3512 .

Conodonts, Decorah shale: Stauffer, 3840.

Glenwood beds : Stauffer, 3837 .

Dekayella praenuntia Ordovician: Sardeson, 3507 .

Hallopora, Ordovician : Sardeson, 3508. 
Minnesota-Continued.

Paleontology-Continued.

Homotrypa minnesotensis, Ordovician: Sardeson, 3506.

Kitchen midden with extinct Bison americanus bones: Eddy, 1134.

Man, fossil : Madsen, 2564.

Mollusca, Shakopee: Stauffer, 3842.

Monotrypa and Eridotrypa, Ordovician : Sardeson, 3513.

Monticulipora grandis and M. arborea, Ordovician: Sardeson, 3504.

Ozarkian faunas, southeastern Minnesota: Powell, 3114.

Pleistocene man: Sardeson, 3509.

Prasopora simulatrix, Ordovician : Sardeson, 3503.

Petrology.

Anorthosite, relations to granite: Grout, 1553.

St. Peter sandstone, sedimentary and petrographic analysis: Thiel, 4069 .

Physical geology.

Ogishkemuncie Lake region: Sleight, 3740.

Saganaga granite batholith: Grout, 1557.

Physiographic geology.

Minneapolis-St. Paul metropolitan area : Schwartz, 3597.

Mississippi River, upper: Cooper, 872.

Patrician glaciation: Sardeson, 3502.

St. Croix River, Pleistocene: Sardeson, 3510.

Underground water.

Minneapolis-St. Paul artesian basin : Schwartz, 3598.

Minneapolis-St. Paul metropolitan area : Schwartz, 3597.

Zones of mineralization: Thwaites, 4124.

Miocene. See Tertiary.

Miscellaneous. See also Addresses.

Decentralization, industrial, in relation to raw materials: Smith, 3750.

Doctorates in science, 1932-33: Hull, 1882.

Manuscript, preparation: Lane, 2331.

State park geological activities: Rothrock, 3385 .

Mississippi.

Bridge site, Yazoo River: Morse, 2809.

State geologist, report 1932-33: Lowe, 2474 ; 1934-35 : Morse, 2807.

Economic geology.

Bentonite deposits: Mellen, 2651; Morse, 2805.

Bleaching clays: Bay, 242.

Clays, western Tennessee Valley : Spain, 3794.

Gulf coast oil flelds: Barton, 215 .

Highland Church sandstone as a building stone : Morse, 2808.

Jackson gas fleld, Hinds and Rankin Counties: Munroe, 2828.

Natural gas, Paleozoic horizons, Cincinnati arch region: Bailey, 132.
Mississippi-Continued.

Historical geology.

Carboniferous rocks at Jackson, correction: Monroe, 2769.

Clarke and Wayne Counties, Tertiary ! Israelsky, 1911.

Covington County: George, 1402.

Eocene sediments : Grim, 1548.

General : Morse, 2805.

Jackson area, Cretaceous and Tertiary : Monroe, 2771.

Vicksburg group: Cooke, 846. Overlying formations: Howe, 1837.

Vicksburg: Mornhinveg, 2799.

Vicksburg National Military Park area : Morse, 2810.

\section{Paleontology.}

Bolivinella, Oligocene: Howe, 1832

Clarke and Wayne Counties, Tertiary: Israelsky, 1911.

Decapod crustaceans, middle Eocene and Oligocene: Stenzel, 3866.

Diploschiza melleni, Cretaceous: Stephenson, 3876.

Eucythere, Tertiary : Howe, 1841.

Foraminifera: Cushman, 942.

Eocene: Cushman 941.

Larger, Jackson Eocene: Gravell, 1506.

Tertiary, Gulf coast : Hadley, 1594.

Pectinidae, Tertiary: Rowland, 3389 ; Tucker, 4178.

Verneullinidae, Valvulinidae, and Virgulinidae: Cushman, 945.

Vicksburg group at Vicksburg: Mornhinveg, 2799.

Petrology.

Eocene sediments: Grim, 1548.

Physical geology.

Slump, Fort Adams: Russell, 3441.

Mississippian. See Carboniferous.

Missouri.

Report of State geologist : Buehler, 551.

Economic geology.

Asphalt-bearing sandstones, Vernon County : Crabtree, 887.

Clays, bleaching, southeast Missouri : Farrar, 1215.

Diaspore deposits: Allen, 44.

Flint and diaspore, origin and min. eral composition: Allen, 42.

Copper, Cornwall mines : Rust, 3446.

Ozark region: Bridge, 454.

Halloysite, Lawrence County: Smith, 3745 .

Iron sulphide ores, Ozarks: Grave, 1504, 1509.

Lead deposits, origin : Tarr, 4020.

Limestone, spheru!itic, in Cheltenham fireclay: Allen, 45

Oil and gas, 1933-34: Greene, 1513.

Ore deposits, Tri-State district : Fowler, 1319.

Savannah área, oil and gas possibilities : Greene, 1512.

Tri-State mining district, chertiflcation : Fowler, 1317. 
Missouri-Continued.

Historical geology.

Asphalt-bearing sandstones, Vernon County : Crabtree, 887.

Correlation, Bainbridge and Henryhouse formations: Ball, 170.

By insoluble residues: McQueen, 2561.

Upper Cambrian : Bridge, 456.

Cross section, Forest City, Mo., to Du Bois, Nebr.: Condra, 833.

General : Kansas Geol. Soc., 2020.

Grassy Creek shale: Weller, 4384 ,

Isopach map, Galena, Decorah, and Platteville formations: Ball. 166.

Lead deposits, origin: Tarr, 4020.

Mississippi River arch: Howell, 1866.

Mississippi Valley cross sections : Workman, 4618 .

Mississippian system, upper Mississippi Valley: Moore, 2784.

Pennsylvanian, lower, central Missouri : Bailey, 133.

Pennsylvanian and lower Permian rocks: Kansas Geol. Soc., 2024 ; Moore, 2788.

Savannah area: Greene, 1512.

Southeast Missouri : Farrar, 1215.

Mineralogy.

Dickite: Tarr, 4018; St. Louis County: Allen, 46.

Granite, heavy accessory minerals: Tolman, 4137.

Granite, pegmatite and replacement veins, Sheaban quarry, Graniteville: Tolman, 4138 .

Mendozite and tamarugite, occurrence: Keller, 2042.

Meteorite fall, August 10, 1932, Archie: Haynes, 1659 ; Nininger, 2892.

Sericite, Pilot Knob: Meyer, 2682.

Sphalerite and galena, fluid inclusions, Joplin region: Smith, 3775 .

Paleontology.

Allagecrinus americanus, Mississippian : Peck, 3041 .

Brachiopods, inarticulate, Grassy Creek shale, Pike County: Greger, 1516.

Silurian, Triplesildae: Ulrich, 4214.

Cephalopods, Ozarkian and Canadian : Ulrich, 4210.

Charophyta, Paleozoic: Peck, 3040.

Corals, Mississippian: Grove, 1558.

Cordaites missouriense, Carboniferous: Cribbs, 898.

Gruenewaldtia, Devonian: Greger, 1520.

Microcrinoids, Lower Mississippian : Peck, 3042.

Münsteroceras mitchelli, Burlington : Miller, 2703.

Ostracoda, Chouteau formation: Morey, 2798.

Mississippian, Callaway County : Morey, 2796.

Pedicellariae, Carboniferous: Geis, 1401.

Pennsylvanian, lower, central Missouri : Bailey, 133.

Picea canadensis, Pleistocene, Macon County: Hansen, 1623.
Missouri-Continued.

Paleontology-Continued.

St. Louis Pennsylvanian outlier fauna : Kellett, 2046.

Schizoblastus, Osage group: Cline, 779.

Strophalosia, Mississippian, St. Louis County : Hinchey, 1743.

Structure in Productus coloradoensis, Pennsylvanian : Girty, 1438.

Trilobites, Bonneterre dolomite: Loch. man, 2431.

Trochlliscaceae, Devonian : Peck, 3043.

Petrology.

Clays, diaspore deposits: Allen, 44.

Flint and diaspore, origin and mineral composition: Allen, 42.

Correlation by insoluble residues: McQueen, 2561.

Granite, pegmatite and replacement veins, Sheahan quarry, Graniteville: Tolman, 4138.

St. Francis Mountain, granitic intrusion : Tolman, ' 4136.

'Physical geology.

Earthquake, Rodney, August 20, 1934 : Bradford, 416.

History, seismic: Bradford, 418.

Lead deposits, origin: Tarr, 4020.

Post-Cambrian explosive volcanism : Rust, 3448.

St. Francis Mountain, granitic intrusion: Tolman, 4136.

- Volcanism, post-Cambrian : Rust, 3447. Southeastern Missouri : Tolman, 4139.

Striated rock surfaces, $S t$. Francis River Valley: Wentworth, 4403.

Physiographio geology.

Drainage, preglacial, northwest Missouri : Greene, 1514.

Underground water.

St. Louis County and City of St. Louis : Gleason, 1443.

Molding sand. See Sand.

Mollusca.

Alum Bluff Miocene, Florida: Gardner, 1383.

Associated with early man: Richards, 3283.

California, Eocene, Vallecitos and Coalinga areas: Vokes, 4294.

Imperial formation, San Gorgonia Pass: Bramkamp, 435.

Miocene, Coast Ranges: Woodring, 4604.

Santa Barbara, Pliocene and Pleistocene : Grant, 1497.

Florida, Pliocene, Okeechobee district: Smith, 3761.

Fresh-water, Miocene, Texas: McNell, 2559.

Illinois, fauna, Pleistocene loess : Baker, 151.

James Bay region, Canada, marine, Recent and Pleistocene: Richards, 3291.

Loess deposits, sequence in : Baker, $\mathbf{1 5 0}$. 
Mollusca-Continued.

Mexico, Lower California, Cretaceous : Anderson, 65.

Minnesota, Shakopee: Stauffer, 3842.

Nebraska, Pleistocene : Lugn, 2478.

Newfoundland, Pleistocene: Richards, 3282.

Nonmarine: Henderson, 1703.

Ozarkian faunas, southeastern Minnesota : Powell, 3114.

Palos Verdes Hills, California: Woodring, 4603.

Pennsylvania, Harmonsburg marl: Brooks, 471.

Pleistocene, marine, Oaxaca, Mexico: Palmer, 2995.

Matanzas and Pinar del Rio provinces, Cuba : Richards, 3280.

Pliocene Croatan sand, North Carolina : Mausfeld, 2574.

Fresh-water, California : Pilsbry, 3086.

Shakopee dolomite, diminutive fauna: Stauffer, 3838.

Texas, Midway group: Gardner, 1382.

Trinidad, Northern Range: Trechmann, 4161.

Venericardia beaumonti, Cretaceous: Rutsch, 3458.

Venericardia planicosta group, Tertlary : Rutsch, 3457.

West American provinces: Schenck, 3542.

Molybdenum.

Arkansas, northern, enargite and wulfenite : McKnight, 2553.

Colorado, batholith, Twin Lakes and Clear Creek districts: Chapman, 732 .

Climax : Coulter, 883.

Tincup mining district, Gunnison County : Goddard, 1458.

Idaho, rare metals: Bell, 272.

Ontario, Renfrew County: Freeman, 1336.

Quebec, western : Bell, 269.

Montana.

Areas described.

Big Horn County and Crow Indian Reservation: Thom, 4074.

Rosebud coal field: Pierce, 3084.

Economic geology.

Big Horn Basin, natural gas fields: Emery, 1174.

Big Horn County and Crow Indian Reservation: Thom, 4074.

Butte mining district: Hart, 1647.

Chromite, Hell Roaring Creek: Salo, 3478.

Clay: Warde, 4337.

Cut Bank oil field, Glacier County : Stewart, 3898.

Gold : Grassmuck, 1499.

Production : Gilbert, 1420.

Flog Heaven mining district, Flathead County: Shenon, 3664 .
Montana-Continued.

Economic geology-Continued.

Manganese : Gilbert, 1421.

Mineral resources: Sahinen, 3470 .

Natural-gas fields: Bartram, 216.

Neihart mining district, Cascade County : Schafer, 3526.

Nonmetallic minerals: Kriegel, 2260.

Ore genesis, Flathead mine: Shenon, 3661.

Phosphate rock, western Montana : Pardee, 3005 .

Richey-Lambert coal field: Parker, 3012. Rosebud coal field: Pierce, 3084.

Sapphires: Howard, 1827.

Silver production, first: Gilbert, 1419.

Southeastern Montana: Perry, 3059.

Stillwater igneous complex, nickel and platinum metals : Howland, 1869.

Historical geology.

Beartooth Mountain uplift: Thom, 4076.

Belt sediments, Libby quadrangle: Gibson, 1418.

Benton formation, type section: Keyes, 2172.

Big Horn Basin, natural gas fields: Emery, 1174.

Big Horn County and Crow Indian Reservation: Thom, 4074.

Black Hills-Bighorn, Beartooth region, gravity anomalies : Chamberlin, $\mathbf{7 1 9}$.

Butte mining district: Hart, 1647.

Cambrian - Algonkian unconformity : Deiss, 1009.

Cambrian type formations, revision : Deiss, 1012.

Carboniferous: Scott, 3605.

Cedar Creek anticline, northern half : Erdmann, 1186; Southern half: Dobbin, 1049.

Crazy Mountains: Wolff, 4571.

Devonian, Big Snowy Mountains: Deiss, 1011.

General: Perry, 3060.

Glacier National Park: Thaxter, 4057.

Glacier Park facies of Belt series: Fen. ton, 1230.

Glacier Park mountains : Fenton, 1228.

Granodiorite rocks, Libby quadrangle: Gibson, 1417.

Hog Heaven mining district, Flathead County : Shenon, 3664.

Idaho batholith, northeastern part: Langton, 2337.

Natural-gas fields: Bartram, 216.

Neihart mining district, Cascade County: Schafer, 3526 .

Nye-Bowler lineament, Stillwater and Carbon Counties: Wilson, 4535.

Richey-Lambert conl field: Parker, 3012. Rosebud coal field: Pierce, 3084 .

Rothpletz and pre-Cambrian, Rocky Mountains : Keyes, 2117.

Southeastern Montana: Perry, 3059.

Stillwater igneous complex, gravity stratification : Peoples, 3050 . 
Montana-Continued.

Historical geology-Continued.

Water resources, artesian, Missouri and Milk Rivers, northeastern Montana: Perry, 3058.

Western Montana: Pardee, 3005.

Mineralogy.

Hedenbergite: Warde, 4336.

Narsarsukite, East Butte: Graham, 1492.

Plagioclases, Stillwater igneous complex: Phillips, 3073.

Sapphires: Howard, 1827.

Shonkin Sag laccolith: Hurlbut, 1895.

Stlliwater complex: Hess, 1722.

Nickel and platinum metals: Howland, 1869.

Paleontology.

Coals, Cretaceous and Tertiary, paleobotanical examination : Miner, 2745.

Conodonts, Mississippian : Scott, 3604 .

Dinosaurs, Cretaceous : Gilmore, 1436.

Fort Peck: Harbicht, 1628.

Faunas, Upper Cambrian : Howell, 1861.

Geomyid rodents, Middle Tertiary : Wood, 4580 .

Glyptostrobus in America: Brown, 493.

Horatiomys montanus, Miocene: Wood, 4572.

Mammals, Paleocene, Fort Union : Simpson, 3715,3724 .

Meniscoëssus, Upper Cretaceous, Ekalaka: Simpson, 3720.

Pre-Cambrian algal flora: Fenton, 1233.

Pseudocylindrodon neglectus, Oligocene, Pipestone Springs: Burke, 580.

Pterygotus, Devonian: Ruedemann, 3404.

Trilobites, Upper Cambrian : Kobayashi, 2242.

\section{Petrology.}

Igneous rocks, Highwood Mountains: Larsen, 2339.

Little Belt Mountains, contact metamorphic zone: Taylor, 4028.

Plagioclases, Stillwater igneous complex : Phillips, 3073.

Stillwater complex: Hess, 1722.

Physical geology.

Beartooth Mountains, flaws and tear faults: Perry, 3057.

Beartooth overthrust, investigation by seismic methods: Buwalda, 601.

Bighorn Basin investigation by seismic methods : Gutenberg, 1581.

Butte mining district: Hart, 1647.

Earthquake, October 18, 1935 : Heck, 1676.

Diurnal variation, Helena : Landsberg, 2317.

Helena : Anonymous, 4682; Scott, 3606 ; 3610 ; Ulrich, 4221 .

Helena, epicenter : Scott, 3607.

Glacier Park mountains : Fenton, 1228.

Idaho batholith, northeastern part: Langton, 2337.
Montana-Continued.

Physical geology-Continued.

Igneous intrusion, Highwood Mountains : Buie, 565; Larsen, 2339.

Little Belt Mountains, contact metamorphic zone: Taylor, 4028.

Nye-Bowler lineament, Stillwater and Carbon Counties: Wilson, 4535.

Shonkin Sag laccolitb: Hurlbut, 1895.

Stillwater igneous complex, gravity stratification : Peoples, 3050 .

Western Montana: Pardee, 3005.

Physiographic geology.

Glacier National Park: Thaxter, 4057.

Hog Heaven mining district, Flathead County: Shenon, 3664.

Richey-Lambert coal field: Parker, 3012.

Rosebud coal field: Pierce, 3084.

Underground water.

Big Horn County and Crow Indian Reservation: Thom, 4074.

Southeastern Montana: Perry, 3059.

Water conservation: Schafer, 3527.

Water resources, artesian, Missouri and Milk Rivers, nortbeaster'n Montana: Perry, 3058.

Moraines.

Alaska, Melaspina and other glaciers: Washburn, 4353.

Glaciers, Mount Crillon district, Alaska : Washburn, 4355 .

Michigan, high plains: Davis, 983.

Ohio, Powell and Broadway end moraines: White, $\mathbf{4 4 5 7 .}$

Scioto glacial lobe: White, 4456.

Quebec, Opawica-Chibougamau area, washboard form: Mawdsley, 2618.

Morphology.

Rivers: Shulits, 3707 .

Mother Lode gold belt, California: Logan, 2435.

Mountains. See Orogeny.

Mountain ares, types: Tokuda, 4135.

Mountain building, phenomenon resembling: Broggi, 466.

Mud flows, California, debris flow from canyons, Los Angeles County: Taylor, 4023.

Multiple grinding, thin-section chips: Wentworth, 4406 .

Naphtha, Canada, analyses: Rosewarne, 3361.

Natural bridges.

Kansas, Sun City: Jewett, 1948.

Utah, Rainbow Bridge: O'Connell, 2935.

Virginia: Woodward, 4612.

Natural gas: Ley, 2414.

Alabama, Cincinnati arch region: Bailey, 132.

Alberta : Calder, 625 .

Battleview anticline, Wainwright area, possibilities: Hume, 1886.

Foremost-Skiff area, possibilities : How* ells, 1867 . 
Natural gas-Continued.

Alberta-Continued.

Gas fields: Slipper, 3742.

Milk Rivel area: Russell, 3433.

Turner Valley gas and oil field: Hume, 1883 ; Spratt, 3811.

Arkansas, Gulf Coastal Plain: Moody, 2773 ; Spooner, 3810.

Interior highlands fields : Croneis, 918.

Smackover field : Haury, 1649.

Bartlesville and Burbank sands, Oklahoma and Kansas: U. S. G. S., 4235 , 4236.

California : Hoots, 1792.;

Buena Vista Hills oil field: Howard, 1828.

Semitropic gas field: Valentine, 4248.

Canuda, western : Goodman, 1473.

Colorado, anticlines between Hiawatha gas field and Baggs, Wyo. : Bradley, 424.

Book Cliffs coal field : Erdmann, 1185.

Gas fields: Winchester, 4564.

Hiawatha gas fields: Nightingale, 2886.

Eastern Interior coal basin : Bell, 263.

Electrical prospecting: Swartz, 3992.

Fluid phenomena, porous strata: Boatright, 353.

Fuels, mineral, reserves, U. S. : Garflas, 1384.

Geology : De Golyer, 1007 ; Ley, 2410.

Gulf coast, exploration to 1936 : Rosaire, 3354.

Louisiana and Texas: Logan, 2437. Oil fields : Barton, 209, 215.

Salt domes : Ritz, 3309 ; Teas, 4033.

Helium, nitrogen, carbon dioxide, and hydrogen sulphide gases: Dobbin, 1050.

Idaho, natural-gas fields: Kirkham, 2220.

Illinois, Marion and Clay Counties, possibilities: Weller, 4385.

Illinois Basin, possibilities: Weller, 4386.

Indiana, Lima-Indiana district: Ley, 2413.

Iowa, deep wells, oil and gas possibilities: Lees, 2369.

Kanșas: Cadman, 620.

Eastern, natural gas fields : Ley, 2411.

Gas fields west of Nemaha granite ridge, except Hugoton district : Garlough, 1385.

Northeastern : Ockerman, 2933.

Kentucky, Cincinnati arch region: Bailèy, 132.

Eastern : Hunter, 1891.

Fordsville and Cannelton quadrangles : Mayfleld, 2622.

Oil and gas possibilities: Hager, 1599.

Louisiana, Cameron and Vermilion Parishes, salt domes : Howe, 1835.

Monroe gas field : Fergus, 1235.

Northern, oil fields: Easton, 1111.

Richland gas fleld: Gordon, 1480.
Natural gas-Continued.

Manitoba : Hutt, 1900.

Metamorphism, organic sediments and derived oils : White, 4453.

Mexico: Muir, 2820.

Northeastern : Kane, 2017, 2018.

Tampico region: Muir, 2821.

Michigan, central, reserves: Rawlins, 3187.

Crystal oil fleld : Eddy, 1133.

Gas fields : Newcombe, 2853.

Mississippi, Cincinnati arch region : Bailey, 132.

Jackson gas fleld: Munroe, 2828.

Missouri, 1933-34 : Greene, 1513.

Savannah area, possibilities: Greene, 1512 .

Montana, Big Horn Basin gas fields: Emery, 1174.

Big Horn County and Crow Indian Reservation: Thom, 4074.

Gas fields : Bartram, 216.

New Mexico, natural gas fields: Winchester, 4564.

Hobbs field: Zavoica, 4645.

Southeast, natural-gas flelds : Rettger, 3254 .

New York : Newland, 2869.

Gas fields: Torrey, 4146

Watkins quadrangle : Bradley, 425.

Ohio, central and eastern: Stout, 3949.

Lima-Indiana district: Ley, 2413.

Source material: Stout, 3950 .

Oklahoma, Comanche field: Swigart, 3995.

Deaner fleld, Okfuskee County : Kirwan, 2222.

Eastern, natural gas fields in Arkansas basin : Colton, 820 .

Muskogee County, Pennsylvanian oil and gas sands: Wilson, 4530

Naval Reserve fleld, Osage County: Vanderpool, 4260.

Oil field, Okmulgee County: Westby, 4426.

Osage County, oil and gas fields: Bass, 220 ; U. S. G. S., 4237, 4238.

Seminole pool, Seminole County: Swarts, 3987.

Slick field: Schwarzenbeck, 3600.

Southern gas fields: Tomlinson, 4142.

Ontario: Harkness, 1631, 1633.

Oregon, natural-gas fields: Kirkham, 2220.

Pennsylvania, Butler and Zelienople quadrangles: Richardson, 3286.

Farmington gas field: Sanders, 3489.

Gas fields: Torrey, 4146.

Hebron gas fleld: Reeves, 3234.

Nortbwestern, deep sands, possibility : Fettke, 1240, 1241, 1242, 1243 .

Oriskany sand: Cathcart, 705 .

Tioga region: Ashley, 100.

Possibilities, east of Appalachian re. gion: Postley, 3109

Quebec, natural-gas fields: Snider, $\mathbf{3 7 8 1 .}$ 
Natural gas-Continued.

Reserves, estimation of : Biddison, $\mathbf{3 1 5}$.

Method of estimation: Huntington, 1892.

Sands, physical tests of : Fancher, 1214. Saskatchewan, Eagle Hills anticline, Battleford area, possibilities: Hume, 1885.

Hudson Bay Junction area possibilities : McLearn, 2555.

Tennessee, Cincinnati arch region: Bailey, 132.

Texas: Deussen, 1035.

Amarillo district gas fields: Cotner, 882.

Bend arch district: Kendrick, 2071.

Clay Creek salt dome, Washington County : Ferguson, 1237.

Conroe oil field, Montgomery County : Michaux, 2694 ; Zavoica, 4643.

Mercedes fleld, Hidalgo County : Price, 3136.

Northeast embayment, natural gas flelds : Ley, 2412.

Palo Pinto County : Plummer, 3098.

Panhandle oil and gas fleld: Rogatz, 3332.

Raccoon Bend oil field, Austin County : Teas, 4032.

Rodessa field: Ivy, 1920.

Source beds shown by reduction of sediments, East $\mathbf{T}$ exas bas in: Trask, 4154.

South, oll and gas fields: Post, 3108.

Tomball oil field, Harris County: Eby, 1122 .

West, natural-gas fields: Rettger, 3254.

Wheat oil pool: Adams, 4.

Utah, Great Salt Lake basin, possibillties : Eard!ey, 1107.

Gas fields : Kirkham, 2220; Winchester, 4564

Valuation of properties: Stephenson, 3874.

Washington, natural-gas fields: Kirkham, 2220.

Western Whatcom County, possibilities: Glover, 1450.

West Virginia: Sisler, 3736.

Upper Monongahela Valley: $U$. $\mathbf{S}$. Com., 4224.

Wyoming: Marxel, 2595.

Anticlines between Hiawatha gas field and Baggs, Wyo.: Bradley, 424.

Baxter Basin gas fields: Nightingale, 2885.

Big Horn Basin gas fields: Enery, 1174.

Billy Creek gas fleld, Johnson County : Boyer, 410.

Hiawatha gas flelds: Nightingale, 2886.

Lance Creek field: Brainerd, 434.

Lost Soldier district gas flelds: Tillotson, 4129.
Natural law in geology: Bucher, 536.

Nebraska.

Land and water resources, conservation: Condra, 836.

\section{Economio geology.}

Geophysical exploration: Wilson, 4543.

Petroleum possibilities: Kimball, 2192.

Historical geology.

Badlands, color records : Germann, 1405.

Cross section, Forest City, Mo., to Du Bols, Nebr. : Condra, 833.

Dakotan sandstone: Keyes, 2106.

General: Kansas Geol. Soc., 2020.

Isopach map, Galena, Decorah, and Platteville formations: Ball, 166.

Trempealeau, Dresbach and Franconia formations: Edwards, 1140.

Niobrara chalk : Keyes, 2099.

Pleistocene : Lugn, 2478.

Scotts Bluff National Monument: Efflnger, 1141.

Terraces, stream, and human occupancy : Van Royen, 4265.

Valentine, Tertiary : Johnson, 1966.

Water-bearing formations : Condra, $\mathbf{8 3 5}$.

\section{Paleontology.}

Anserine bird, Pliocene, Keith County : Compton, 826.

Antelopes, Pliocene, Cherry County : Furlong, 1366.

Casteroides, Pleistocene, Ainsworth: Wood, 4582.

Cavellina nebrascensis, Pennsylvanian: Lalicker, 2292.

Craterogale simus, Tertiary, Dawes County: Gazin, 1398

Cynodesmus, Pliocene: McGrew, 2532.

Dogs, Mlocene, phylogeny: Loomis, 2450.

Geomyid rodents, Míddle Tertiary: Wood, 4580.

Grasses, Tertiary: Elias, 1155.

Hawks, Miocene: Wetmore, 4433.

Mammals, Miocene and Pliocene, Valentine: Stirton, 3906 .

Mastodon, Ogallala, I'liocene: Hesse, 1724.

Mesocyon geringensis, Morrill County, Miocene : Barbour, 177.

Miocene mammals, restorations: Colbert, 799 .

Ostracoda, Big Blue series: Upson, 4241.

Missourl serles: Johnson, 1978.

Palaeolagus haydeni, Oligocene, Sioux County : Dice, 1039.

Pleistocene : Lugn, 2478.

Prosthennops niobrarensis, Tertiary, Brown County : Colbert, 800 .

Scotts Bluff National Monument: Effinger, 1141.

Vertebrate fauna, Feldt Ranch, Ogallala: Hesse, 1725.

Physical geology.

Earthquake, March 1, 1935 : Lugn, 2479. 
Nebraska-Continued.

Physiographic geology.

Lake, Pleistocene, White River Valley : MacClintock, 2506.

Land and water resources, conservation: Condra, 836.

Pleistocene : Lugn, 2478.

Water-bearing formations : Condra, $\mathbf{8 3 5}$.

Underground water.

Ground water, south-central Nebraska : Wenzel, 4415.

Ground-water level survey: Waite, 4310.

Permeability, water-bearing materials, Platte River Valley: Wenzel, 4416.

Platte River Valley, ground-water level, decline: Wenzel, 4414.

Pleistocene: Lugn, 2478.

Recovery of levels, 1935 : Wenzel, 4417.

Resources : Condra, 836.

Water-bearing formations: Condra, 835 .

Nevada.

Economic geology.

Alunite, Sugarloaf Butte: Heineman, 1689.

Boulder Dam region, mineral resources: Hewett, 1735.

Chief district, Lincoln County: Callaghan, 629 .

Comstock lode: Gianella, 1413.

Contact mining district: Schrader, 3576.

Copper, Ely district: Bateman, 236.

Minor districts: Nolan, 2906.

Yerington district: Knopf, 2237.

Humboldt Range, central: Jenney, 1943.

Placer mining: Vanderburg, 4252.

Scheelite-leuch tenbergite vein, Paradise Range: Kerr, 2082.

Tonopah mining district: Nolan, 2907.

Tungsten, Silver Dyke : Kerr, 2086.

Tuscarora mining district, Ells. County : Nolan, 2908.

Historical geology.

Boulder Reservoir floor: "ngwell, 2445

Cedarville formation, certiary: La. Motte, 2309.

Chief district, Lincoln .County: Calla ghan, 629.

Comstock lode: Gianella, 1413.

Comstock region: Giannella, 1412.

Devonian, central Nevada: Merriam, 2669.

East-central Nevada: Merriam, 2667.

Dikes, pre-granodiorite in granodiorite, Paradise Range: Callaghan, 628.

Ely district: Bateman, 236.

Goodsprings dolomite and faunas: Hazzard, 1661.

Humboldt Range, central : Jenney, 1943.

Pensylvanian-Permian boundary, southern Nevada: Longwell, 2444.

Placer mining: Vanderburg, 4252.

Tonopah mining district: Nolan, 2907.

Triassic and Jurassic formations, west central Nevada: Muller, 2824.

Tungsten, Silver Dyke : Kerr, 2086.

Tuscarora mining district, Elko County : Nolan, 2908.
Nevada-Continued.

Mineralogy.

Aguilarite, Comstock Lode, Virginia City : Coats, 788.

Beryl and scheelite associated: Palmer, 2998.

Dumortierite-andalusite mineralization, Oreana : Kerr, 2079.

Gold in petrified wood, Aspen district: Palmer, 2996, 2997.

Meterorite, iron, Rhyolite: Dake, 954.

Quartz Mountain: Gianella, 1415.

Scheelite-beryl deposit, Oreana: Kerr, 2078.

Stibnite in quartz: Stearn, 3844.

Thulite: Gianella, 1416

Tungsten, Silver Dyke: Kerr, 2086.

Paleontology.

Camel, Miocene, Eureka County : Cockerell, 791 .

Cedarville flora, Tertiary: LaMotte, 2309.

Coral reefs, Triassic: Muller, 2825.

Cupidinimus, Pliocene, Willow Creek: Chaffee, $\mathbf{7 1 6}$

Cyathospongia, new class of Porifera: Okulitch, 2945.

Faunas, Cambrian, Goodsprings and Sheep Mountain : Mason, 2598.

Flora, Miocene, from 49 Camp: LaMotte, 2303.

Geomvid rodents, Middle Tertiary: Wood, 4580.

Goodsprings dolomite and faunas: Hazzard, 1661.

Gypsum Cave, Las Vegas, Pleistocene: Härington, 1641.

Merycodonts, Tonopah, upper Miocene : Furlong, 1365.

Mylodon tracks, Carson prison: Stock, 3932.

Nodules like coal balls, Ordovícian: Merriam, 2670.

Plants in Nothotherium dung, Gypsum Cave: Laudermilk, 2346.

Redwood, fossil, Nye County: Walker, 4317.

Rodents, Pliocene, Smiths Valley: Wilson, 4554.

Sapindus oregonianus, Miocene, climatic implications: LaMotte, 2301.

Spizaëtus willetti, Pleistocene, Smith Creek cave: Howard, 1822.

Trilobites, Upper Cambrian : Kobayashi, 2242.

Petrology.

Dumortierite-andalusite mineralization, Oreana : Kerr, 2079.

Physical geology.

Boulder Reservolr floor: Longwell, 2445.

Cedar Mountain earthquake, December 20, 1932: Byerly, 605; Gianella, 1414.

Domes, intrusive, Washoe district: Coats, 786. 
Nevada-Continued.

Physical geology-Continued.

Dumortierite-andalusite mineralization, Oreana: Kerr, 2079.

Earthquake, Excelsior Mountains, January 30,1934 : Callaghan, 627.

Kelly Well, December 20, 1932: Wilson, 4542 .

Fault scarps of 1915, Pleasant Valley : Page, 2981.

Frazier Mountain overthrust, investigation by seismic methods; Buwalda, 60.1 .

Great Basin lake sediments: Shrock, 3700 .

Humboldt Range, central: Jenney, 1943.

Jurassic thrust faults, west-central Nevada: Ferguson, 1236.

Scheelite-leuchtenbergite vein, Paradise Range: Kerr, 2082.

Tonopah mining district: Nolan, 2907.

Tungsten, Silver Dyke: Kerr, 2086.

Tuscarora mining district, Elko County : Nolan, 2908.

Physiographic geology.

Boulder Reservoir floor: Longwell, 2445.

Underground water.

Newlands area, high water table: Scofield, 3602 .

New Brunswick.

Economic geology.

Grand Lake coal field, Queens and Sudbury Counties: Wright, 4630 .

Historical geology.

Chaleur Bay region: Alcock, 12 ; Canada G. S., 661 .

Grand Lake conl field, Queens and Sudbury Counties: Wright, 4630.

Grand Manan Island: Gesner, 1408.

\section{Paleontology.}

Agnostians, Cambrian: Howell, 1850.

Paradoxides matthewi, Cambrian : Howell, 1855.

Walchia, Permian : Darrah, 978.

Physical geology.

Chaleur Bay region: Alcock, 12.

Grand Manan Island: Gesner, 1408.

Physiographic geology.

Chaleur Bay region: Alcock, 12.

Grand Lake coal fleld, Queens and Sudbury Counties: Wright, 4630.

Grand Manan Island: Gesner, 1408.

New England.

Physiographio geology.

Glacial history, late : Bryan, 526.

Glacial stages: Flint, 1287.

Peneplain : 'Tarr, 4015.

\section{Newfoundland.}

Areas described.

Bay of Exploits area : Heyl, 1736.

Blow-Me-Down area, aerial photographic surveys: Snelgrove, $\mathbf{3 7 8 0}$
Newfoundland-Continued.

Economic geology.

Bay of Exploits area: Heyl, 1736.

Bay of Islands Igneous complex : Cooper, 869.

Gold deposits: Snelgrove, 3779.

Marble, Canada Bay and White Bay area: Bain, 139.

Mineral possibilities: Trioche, 4168.

Historical geology.

Bay of Exploits area : Heyl, 1736.

Bay of Islands igneous complex : Cooper, 869.

Bibliography: Betts, 306.

Gold deposits: Snelgrove, $\mathbf{3 7 7 9}$.

Laccoliths, layered, peridotitic, Trout River alea: Ingerson, 1906.

Silurian, Notre Dame Bay: Twenhofel, 4197.

Mineralogy.

Gold deposits: Snelgrove, $\mathbf{3 7 7 9}$.

Paleontology.

Mollusks, Pleistocene: Richards, 3282.

Petrology.

Bay of Exploits area: Heyl, 1736.

Bay of Islands igneous complex : Cooper, 869.

Laccoliths, layered periodtitic, Trout River area: Inger'son, 1906.

Physical geology.

Bay of Exploits aren: Heyl, 1736.

Bay of Islands igneous complex : Cooper, 869.

Laccoliths, layered peridotjtic, Trout River area: Ingerson, 1906.

New Hampshire.

Economic geology.

Garnet, Merrimack County : Conant, 830.

Historical geology.

Franconia quadrangle: Billings, 317.

Grand Monadnock: Chamberlain, 717.

Littleton and Moosilauke quadrangles: Billings, 318, 320 .

Metamorphic rocks, southeastern New York: Balk, 159.

\section{Mineralogy.}

Cordierite, positive, Stoddard, Cheshire County, Conant, 829.

Radioactive minerals, Grafton: Shortle, 3696.

White Mountain magma series: Chapman, 733 .

Paleontology.

Brachiopoda, Devonian, in mica schist, Mt. Clough : Billings, 319.

Petrology.

Concretions, Champlain formation : Tarr, 4017.

Garnet, Merrimack County, Conant, 830 .

Mica schist, Devonian, Mt. Clough : Billings, 319.

Phenacite, molphology and paragenesis : Pough, 3113. 
New Hampshire-Continued.

Petrology-Continued.

Ring-dike complex, Belknap Mountains : Modell, 2756.

Percy region: Chapman, 734 .

Syenite, Red Hill: Quinn, $\mathbf{3 1 5 7 .}$

White Mountain magma series: Chapman, 733 .

Physical geology.

Franconia quadrangle: Billings, 317.

Littleton and Moosilauke quadrangle: Billings, 318,320 .

Ring-dike complex, Belknap Mountains: Modell, 2756.

Percy region : Chapman, 734.

White Mountain magma series: Chapman, 733 .

Physiographic geology.

Concretions, manzanese : Kindle, 2196.

Franconia quadrangle: Billings, 317.

Glacial Lake Hitchcock: Lougee, 2456.

Grand Monadnock: Chamberlain, 717.

Ice readvance at Littleton : Lougee, $\mathbf{2 4 5 5}$.

Littleton and Moosilauke quadrangles: Billings, 318.

New Jersey.

Economio geology.

Franklin and Sterling Hill, Sussex County, minerals: Palache, 2985.

Mineral industry, 1933 : Johnson, 1976 ; 1934 : Johnson, 1977.

Mineral zoning, Triassic: Newhouse, 2861.

Historical geology.

Coastal Plain : Kümmel, 2279.

Ground-water supply: Critchlow, 914.

Miocene, Fairton: Richards, 3279.

Monmouth and Rancocas groups: Jennings, 1994.

Pensauken formation : Berry, 299.

Watchung Mountains: Moldenke, 2765.

Mineralogy.

Agates in trap rock quarry: Reamer, 3211.

Amphibole, Franklin Furnace: Foshag, 1312.

Bentonite, Upper Cretaceous: Stephenson, 3880 .

Calcite twins, North Plainfield: Hawkins, 1654.

Clays, Cretaceous, Middlesex County, heavy minerals: Hawkins, 1652.

Franklin and Sterling Hill, Sussex County, minerals : Newhouse, 2863 ; Palache, 2985.

Hematite balls, New Street quarry, Patterson: Casperson, 699.

Pectolite : Peacock, 3031.

Willemite, fluorescence: Gunnell, 1569.

Xonotlite, Franklin Furnace: Bauer, 238.

Paleontology.

Aturoidea, Eocene: Miller, 2712.

Breviarca haddonfieldensis for Trigonarca saffordi, Cretaceous: Stephenson, 3875.
New Jersey-Continued.

Paleontology-Continued.

Cladoxylon dawsoni, Devonian, Canan. daigua Lake: Read, 3206.

Flora, Pensauken formation : Berry, 299.

Foraminifera: Cushman, 942.

Microfauna, Monmouth and Rancocas groups: Jennings, 1944.

Pectinidae, Tertiary: Rowland, 3389 ; Tucker, 4178.

Xanthias lenolensis, Cretaceous: Rathbun, 3185 .

Xylomites cycadeoldeae, Cretaceous, Woodbridge : Chrysler, 751.

\section{Petrology.}

Palisades sill : Butler, 594.

Physical geology.

Bottom conditions, tidal lagoon, Barnegat Bay : Lucke, 2477.

Coast sinking: Richards, 3278 .

Dutchess County: Barth, 198.

Physiographic geology.

Coastal Plain: Küimmel, 2279.

Pleistocene, late, marine and glacial deposits: Macclintock, 2504.

Watchung Mountains: Moldenke, 2765.

Underground water.

Atlantic City region, ground-water supplies : Barksdale, 184.

Fluctuations, water level, Plainfleld: Critchlow, 915.

Ground-water supply : Critchlow, 914.

New Mexico.

Areas described.

Bayard area, central mining district: Lasky, 2344.

Doña Ana County: Dunham, 1094.

San Juan Basin: Sears, 3621.

Economic geology.

Bayard area, central mining district: Lasky, 2344.

Central mining district: Schmitt, 3566.

Coal, San Juan Basin: Sears, 3621.

Copper, Lordsburg district: Lasky, 2342.

Minor districts: Koschmann, 2251.

Santa Rita and Tyrone districts: Paige, 2982.

Hobbs field : Zavoica, 4645.

Kaolin, Doña Ana County: Richard, 3273.

Lithium ores: Chambers, 724 .

Magnetite, Doña Ana County: Taft 4006.

Mount Taylor coal field: Hunt, 1888.

Natural-gas fields : Rettger, 3254 ; Winchester, 4564.

Oil and gas map: Winchester, 4565.

Ore deposits: Schmitt, $\mathbf{3 5 6 5}$.

Organ Mountains and Doũa Ana County: Dunham, 1094.

Petroleum, Permian: Bentz, 282.

Potash: Anonymous, 4663; Mansfleld, 2569.

Salt in potash mines: Ageton, 9 .

Santa Rita mining area: Spencer, 3303. 
New Mexico-Continued.

Economic geology-Continued.

Silver ores, primary, Bullard's Peak: Krieger, 2262.

Virginia mining district: Lasky, 2343. Hydrothermal leaching: Lasky, 2845.

Historical geology.

Animas sandstone, age and synonymy: Keyes, 2166.

Basalt flows, age : Keyes, 2124.

Bayard area, central mining district: Lasky, 2344.

Ceja Glorieta sandstone: Keyes, 2127.

Central mining district: Schmitt, 3566 .

Chupadera, invalid: Keyes, 2130.

Clovis area: Stock, 3931.

Clovis lake clays, age: Antevs, 79.

Cretaceous succession: Keyes, 2123.

Delaware Basin, Permian: Lang, 2334.

Guadalupan series: Keyes, 2134.

Hobbs field: Zavoica, 4645.

Jurassic formations, correlation : Baker, 143.

Mesa Verde group : Keyes, 2098.

Mount Taylor coal field: Hunt, 1888.

Navajo sandstone: Keyes, 2152.

Organ Mountains and Dóña Ana County: Dunham, 1094.

Pediments and terraces, Rio Puerco: Bryan, 525.

Santa Rita and Tyrone copper districts: Paige, 2982.

Santa Rita mining area: Spencer, 3803.

Shinarump, eastward extension : Keyes, 2139.

Tertiary base, northwestern New Mexico : Keyes, 2164.

Mineralogy.

Aerolite, Roy : Nininger, 2887.

Agates, near Laguna: Ellermeier, 1166.

Bayard area, central mining district: Lasky, 2344.

Lordsburg district: Lasky, 2342.

Meteorite, Pasamonte: Nininger, 2896. Roy, Harding County: Heineman, 1690.

Salt in potash mines: Ageton, 9.

Silver ores, primary, Bullard's Peak : Krieger, 2262.

Thulite, Pilar post offec, Taos County : Northrop, 2917.

Xenoliths, Organ batholith: Dunbam, 1096.

\section{Paleontology.}

Clovis area: Stock, 3931.

Clovis lake clays, age: Antevs, 79.

Diatoms, Qunternary, lake beds, Clovis : Lohman, 2439.

F a u a, B u r n et cave, Pleistocene: Schultz, 3591 .

Clovis, Pleistocene fluvial deposits: Howard, 1816.

Devonian, Sacramento Mountains : Stainbrook, 3816.

Folsom points and extinct bison, Clovis and Carlsbad: Howard, 1870.

Insectivores, Paleocene: Reynolds, 3260.
New Mexico-Continued.

Paleontology-Continued.

Insects, borings in fossil wood: Brues, 508.

Mammalian fauna, local and continental, relationships: Simpson, 3723.

New World man, near Folsom: Figgins, 1256.

Ostreidae, Upper Cretaceous, Gulf region: Stephenson, 3877.

Puerco Mammalia, lower Paleocene : Simpson, 3722.

Reptilia, Kirtland formation: Gilmore, 1434.

Rodents, cricetid, Tertiary: Wood, 4576.

Vertebrata and turkey, Tertiary: Needham, 2844.

\section{Petrology.}

Organ Mountains and Doña Ana County: Dunbam, 1094.

Virginia mining district: Lasky, 2343.

Xenoliths, Organ batholith: Dunham, 1096.

Physical geology.

Bayard area, central mining district: Lasky, 2344.

Chupadera beds, folding: Talmadge, 4011.

Flow units in basalt: Nichols, 2873.

Ice, perpetual, under lava: MacClary, 2502.

Mount Taylor coal field : Hunt, 1888.

Organ Mountains and Doña Ana County : Dunham, 1094.

Santa Rita and Tyrone copper districts : Paige, 2982.

Santa Rita mining area: Spencer, 3803.

Virginia mining district, hydrothermal leaching: Lasky, 2345.

Volcanoes, Pliocene, Navajo-Hopi country: Williams, 4509.

\section{Physiographic geology.}

Canjilon Divide, Rio Arriba County, periglacial landslides: Smith, $\mathbf{3 7 7 5}$.

Glaciation, northern New Mexico : Ellis, 1170.

Hypsometric map: Northrop, 2916.

Meteoritic impact scars: Turley, 4186.

Pediments, formation, Granite Gap : Bryan, 524.

Pediments and terraces, Rio Puerco: Bryan, 525.

Underground water.

Artesian-water supply, control: Meinzer, 2631.

Ground water, southern High Plains: Theis, 4062 .

Resources, northwestern New Mexico: Waring, 4339.

Ogallala formation, Llano Estacado, affected by ground water: Tbeis, 4064 .

Roswell region: Brown, 487.

New York.

Black mud shałes, eastern New Ycrk, paleocology: Ruedemann, 3403. 
New York-Continued.

Areas described.

Berne quadrangle : Goldring, 1463.

Economio geology.

Emery deposits, Peekskill region: But. ler, 595.

Hammond, Antwerp, and Lowville quadrangles: Buddington, $\mathbf{5 4 3}$.

Limonites, Taconic, origin: Newland, 2867.

Mining and quarry industries, 1930-33 : Newland, 2868.

Natural gas: Newland, 2869 ; Torrey, 4146.

Oswegatchle quadrangle: Dale, 961.

Potsdam quadrangle, St. Lawrence County : Reed, 3217.

Watkins quadrangle, gas possibilities: Bradley, 425.

Zinc mine, Balmat: Brown, 484.

Historical geology.

Adirondacks, gravity stratification in intrusive igneous complexes: Buddington, 546.

Allegany State Park: Thwaites, 4125.

Allegheny cuesta : Dale, 960 .

Anorthosite, Adirondacks, mode of emplacement : Miller, 2727.

Berne quadrangle: Goldring, 1463.

Catskill name, history and value in geology : Chadwick, 715.

Chemung is Portage: Chadwick, 707.

Cherts, Ordovician, eastern New York: Ruedemann, 3416.

Radiolarian, Ordovician, eastern New York: Ruedemann, 3411.

Clinton formation, western New York: Sanford, 3491.

Clinton group: Sanford, 3495.

Correlations by graptolites, Lower Paleozoics : Decker, 1001.

Devonian, Upper: Chadwick, 706, 711, $712,714$.

Devonian and Silurian sections : Fettke, 1244.

Dutchess County: Balk, 162.

Emery deposits, Peekskill region: Butler, 595.

Excursion, geological : Marelli, 259.

Genesee River: Fairchild, 1212.

Genesee Valley: Fairchild, 1211.

Grenville, St. Lawrence County: Dale, 959.

Hamilton group, facies relationships : Cooper, 863.

Hammond, Antwerp, and Lowville quadrangles: Buddington, 543; Gilluly, 1431.

John Boyd Thacher State Park : Torrey, 4147.

Lowville quadrangle: Ruedemann, 3401.

Natural-gas fields : Torrey, 4146.

Ordovician, Adirondack foreland arch: Kay, 2034.

A!tered volcanic matcrials and related clays: Kay, 2031.

Oswegatchie quadrangle: Dale, 961 .
New York-Continued.

Historical geology-Continued.

Phosphatic nodules, Silurian, origin : Seiwell, 3644

Pleistocene, Long Island : Wells, 4388.

Potsdam quadrangle, St. Lawrence County : Reed, 3217.

Rensselaer grit problem: Ruedemann, 3414.

Russell quadrangle, St. Lawrence County : Dale, 958.

Shales, black, Ordovician, Mohawk Valley: Ruedemann, 3406.

Skaneateles quadrangle: Smith, 3746.

Thorold sandstone : Chadwick, 709 ; Sanford, 3493.

Tully formation: Cooper, 862 .

Watkins quadrangle: Bradley, 425.

Zinc mine, Balmat: Brown, 484.

Mineralogy.

Bertrandite and epistilbite, Bedford: Pough, 3112.

Celestite, Chittenango Falls: Thibault, 4066.

Origin, near Syracuse: Thibault, 4065.

Cyrtolite, analysis: Muench, 2817, 2819.

Dutchess County : Barth, 198.

Fluorescence, Herkimer quartz crystals : Bernheimer, 294.

Fluorescent and phosphorescent minerals, Bedford: Zodac, 4652.

Gore Mountain garnet: Rowley, 3392.

Ilmenite, Bedfold: Zodac, 4649.

Limonites, Taconic, origin : Newland, 2867.

Minerals : Brown, 495.

Schroeckingerite, Bedford : Armstrong, 85.

Selenite, phosphorescent, Hudson : Zodac, 4651.

Sulphur, black, Hillburn : Roedder, 3331.

Supergene sphalerite, galena, willemite, Balmat: Brown, 486.

Tourmaline, Buchanan : Zodac, 4650.

$U$-galena and uraninite in Bedford cyrtolite: Kerr, 2081.

Whiteface Mountain minerals : Newland, 2866.

Zinc mine, Balmat: Brown, 484.

Paleontology.

Annelid jaws, Hamilton, Ontario County : Eller, 1161.

Archaeopteris macilenta and A. sphenophyllifolia of Lesquereux: Arnold, 92.

Berne quadrangle: Goldring, 1463.

Blastoids, Middle Devonian: Reimann, 3240.

Brachiopods, Silurian, Triplesidae: Ulrich, 4214.

Calamopitys, Devonian, Taughannock Gorge: Thomas, 4083.

Cephalopods, Cherry Valley, Devonian: Flower, 1292.

Upper Devonian: Flower, 1291.

Coral, Portage: Chadwick, $\mathbf{7 1 3 .}$ 
New York-Continued.

Paleontology-Continued.

Crinoids, Devonian: Goldring, 1464, $1465,1466$.

Cyathospongia, new class of Porifera: Okulitch, 2945.

Devonian, Upper, faunal differentiation : Chadwick, 706.

Dipleura dekayi, Devonian, young stages: Cooper, 861.

Echinocaris, Upper Devonian, Alfred. Station: Eller, 1163.

Eurypterus (Stylonurus?) maccarthyi, Devonian : KJellesvig, 2225.

Fishes, Devonian : Bryant, 527.

Fraxinus nigra, Pleistocene, Orleans County : West, 4423.

Gilboa petrifled forest: Goldring, 1462.

Otarion halli, Hamilton group, Erie County: Wheeler, 4441.

Plants, Devonian : Arnold, 86.

Pseudohydnoceras erraticum, Devonian : Reimann, 3239.

Pterygotus, Devonian : Ruedemann, 3404.

Radiolarda, Ordovician cherts: Ruedemann, 3416.

Terataspis grandis, giant trilobite: Reimann, 3242.

Teredo lignite, Long Island: Fox, 1322.

Tully formation: Cooper, 862 .

\section{Petrology.}

Dutchess County: Balk, 162; Barth, 198.

Limonites, Taconic, origin : Newland, 2867.

Niagara Gorge sediments: Alling, 50.

Onondaga formation, Erie County, differentiation by heavy minerals : Alexander, 23.

Onondaga limestone, black concretions, composition : Schwartz, 3594.

Poundridge granite: Bell, 265.

Physical geology.

Adirondacks, gravity stratification in in. trusive igneous complexes: Buddington, 546.

Dutchess County: Balk, 162.

Faulting, Mohawk Valley: Megathlin, 2629.

Guns of Seneca Lake: DeVarigny, 1037.

Hudson gorge in the Highlands: Thompson, 4096.

Metamorphic rocks, southeastern New York: Balk, 159.

Metamorphism, granitic dike, Franklin : Milton, 2742

Ordovician, Adirondack foreland arch : Kay, 2034.

Oswegatchie quadrangle: Dale, 961.

Potsdam quadrangle, St. Lawrence County : Reed, 3217.

Sensitivity to tilt, seismographic: Delaney, 1014.

Tilt measurements, seismographic, Buffalo: Delaney, 1015.
New York-Continued.

Physical geology-Continued.

Waterfalls, protruding crest lines: Conant, 831.

Physiographic geology.

Berne quadrangle: Cook, 843 ; Goldring, 1463.

Boulder trains, Allegany County : Chadwick, 710.

Catskills, glacial geology : Rich, 3266.

Chittenango Falls State Park, glacial history : Holmes, 1785.

Genesee River: Fairchild, 1212.

Genesee Valley: Fairchild, 1211.

Glacial drift : Engeln, von, 1183.

Gotiglacial broadmapping: De Geer, 1004.

Hammond, Antwerp, and Lowville quadrangles: Buddington, 543.

Hudson gorge in the Highlands : Thompson, 4096.

Hudson River Valley: Morris, 2800.

Kaaterskill piracy, 1934 : Cressey, 896.

Long Island, central, glacial: Fleming, 1281.

Oswegatchie quadrangle: Dale, 961.

Pleistocene, late, marine and glaclal deposits : MacClintock, 2504.

Potsdam quadrangle, St. Lawrence County : Reed, 3227.

Skaneateles quadrangle: Smith, 3746.

Underground water.

Allegany State Park, ground-water: Thwaites, 4125.

Fluctuations in water level, Woodgate: Cullings, 927.

Genesee Valley: Fairchild, 1211.

Ground-water resources, Monroe County : Leggette, 2378.

Levels, ground-water, Long Island : Leggette, 2380.

Long Island ground-water supplies : Thompson, 4095 .

Rochester region, effect of preglacial topography on ground water: Leggette, 2377.

Nickel.

British Columbia, Fraser River-Harrison Lake region: Horwood, 1800.

Yale district: Horwood, 1799.

Development and use: Stanley, 3821.

Montana, Stillwater igneous complex: Howland, 1869.

Ontario, Pigeon River area: Tanton, 4014.

Sudbury nickel field: Burrows, 585; Collins, 812; Thomson, 4114; Walker, 4321.

Quebec, Abitibi area: Dresser, 1079.

Nitrocellulose sections, fossils and rocks: Fenton, 1234.

Nodules, Orcgon, opal or agate filled: Renton, 3248. 
Nomenclature.

Absorption and transpiration, terms defined: Lee, 2365.

Allogenotype, new term : Howell, 1859.

Animas sandstone, New Mexico: Keyes, 2166.

Argyrotheca gardnerae, new name : Cooke, 844.

Aubrey as terranal title: Keyes, 2179.

Barrancos and arroyos: Grant, 1496.

Benton formation, Montana: Keyes, 2172.

Brachyaspidion for Brachyaspis Miller : Miller, 2715.

Breviarca haddonfieldensis for Trigonarca saffordi: Stephenson, $\mathbf{3 8 7 5}$.

Bryozoa : Bassler, 231.

Cambrian, redefinition : Keyes, 2159.

Type formations revised, Montana and Yellowstone National Park: Deiss, 1012.

Upper Mississippi Valley: Raasch, 3161 ; Sardeson, 3511.

Canada, Canadian Shield pre-Cambrian : Brock, 461.

Carboniferous, proposed dismemberment: Keyes, 2186.

Cardium nixicollis for C. vaughani, preoccupied: Stephenson, 3879.

Carsioptychus for Plagioptychus Matthew : Simpson, 3725 .

Catskill name, history and value in geology : Chadwick, 715.

Chupadera formation: Keyes, 2140.

Clipfold : Mathews, 2617.

Comanche, terranal title: Keyes, 2118.

Corals, type species: Wells, 4391.

Cretaceous rocks, Texas: Thompson, 4102.

Crustaceans, decapod, name changes: Rathbun, 3186.

Crystal forms and form-names: Rogers, 3338 .

Crystallography : Boldyrev, 365.

Dakota sandstone: Keyes, 2178.

Diplotype, new term : Knight, 2234.

Flaws and tear faults: Gill, 1426.

Folds : Straley, 3962.

Foraminifera, subgeneric: Schenck, 3553.

Gastropoda, Carboniferous : Knight, 2235.

Glacial tills: Keyes, 2100.

Glyptostrobus in America: Brown, 493.

Grassy Creek shale, abandoned: Weller, 4384.

Ground-water classifications : Lee, 2366.

Group, use of term : Keyes, 2097.

Harttites for Harttia, preoccupied : Howell, 1857.

Heliocephalus for Malvernia Delo: Delo, 1021.

Homonyms and nomenclators: Oehser, 2939.

Igneous rock names, evaluation: Haff, 1596.
Nomenclature-Continued.

Jonesites, new name for ostracode genus Placentula : Coryell, 879.

Jurassic formations, Utah, Arizona, Colorado and New Mexico: Baker, 143.

Kaskaskia limestone title, validity: Keyes, 2184.

Lepidostrobus kentuckiensis for $\mathrm{L}$. fischeri : Scott, 3603 .

Madreporaria Hexacorolla check list, 1758-1935: Vaughan, 4277.

Mesa Verde group: Keyes, 2098.

Meteorites : Nininger, 2895.

Mineral associations, high-temperature, shallow: Butler, 591.

Mineraloids : Rogers, 3339.

Montezuma, marine Jurassic: Keyes, 2180.

Nanicella, for Endothyra gallowayi: Henbest, 1692.

Navajo sandstone in synonmy: Keyes, 2152.

Neotypes in zoological nomenclature: Frizzell, 1346.

Orthocera: Teichert, 4038.

Orthoceras: Teichert, 4038.

Orthoceratites: Teichert, 4038.

Orthoceros: Teichert, 4038.

Ostrea battensis for 0 . johnsoni, preoccupied: Stephenson, 3879.

Palmula Lea for Flabellina D'Orbigny: Howe, 1844.

Parendoceras for Saffordoceras Ulrich and Foerste: Ulrich, 4215.

Pectinidae, rectification of names: Hertlein, 1719.

Pennsylvania, Pocono formation: Ashley, 106.

Permian: Keyes, 2105.

Petrofabric analysis: Fairbairn, 1205.

Phenoclast: Erwin, 1187; Whitcomb, 4449.

Plains, rock, base, and depositional: Melton, 2658.

Pleistocene : Keyes, 2149.

Prairie du Chien title unnecessary: Keyes, 2137.

Pravognathus for Heterognathus Stauffer: Stauffer, 3841.

Priority vs. usage, geological terminology : Keyes, 2121.

Procedure in taxonomy: Schenk, 3554.

Rocky Mountains, terranal terminology: Keyes, 2169.

Rodents, for cusps of cheek teeth : Wood, 4578.

Sage Breaks shale substituted for Carlile shale, Wyoming: Thomas, 4056 .

Simmys, replacing Eumysops, preoccupied: Wilson, 4551.

Spirancilla for Ancilla buchinoides Lamarck: Vokes, 4295.

Sporadoceras milleri for Paralegoceras milleri : Miller, 2709. 
Nomenclature-Continued.

Stage as stratigraphic unit: Schenck, 3545 .

Stratigraphic terminology: Schencl, 3550.

Strobilopterus princetonii for Peterygotus princetonii: Ruedemann, 3407.

Supai as terranal title: Keyes, 2183.

Syngony, use of term : Rogers, 3336.

Terminology, coarse sediments: Wentworth, 4405.

Erosion cycle surface forms: Maxson, 2619.

Medium-grained sediments: Allen, 47.

Universal geological: Krystofovich, 2277.

Theriosynoecum for Morrisonia, preoccupied: Branson, 439.

Todilto limestone: Keyes, 2167.

Toxostoma redivivum, Plelstocene, California: Engels, 1184.

Tyente sandstone and Montezuma shales, Arizona : Keyes, 2165.

Upthrust, geologic term: Willis, 4523.

Valentine: Johnson, 1966.

Volcanism vs. vulcanism: Shepherd, 3686.

Wisconsin glacial tills : Keyes, 2103.

Yanktonian series for Benton shales, Iowa: Keyes, 2174.

North America: Baulig, 239.

North Carolina.

Economic geology.

Barite deposits : Stuckey, 3972.

Clay, for bleaching oils: Grove, 1559. Resources, Spruce Pine and Linville Falls quadrangles: Hunter, 1890.

Copper deposits, Ducktown type, southern Appalachians; Ross, 3364.

Cyanite: Stuckey, 3973.

Gold deposits: Bryson, 532; Pardee, 3004.

Southern Appalachians: Anonymous, 4692.

Lithium in spodumene pegmatites, Kings Mountain : Hess, 1720.

Pyropbyllite, pre-Cambrian, Randolph County : Burgess, 578.

Talc deposits: Stuckey, 3971.

Tin, Lincolnton area: St. Clair, 3474.

\section{Historical geology.}

Clay resources, Spruce Pine and Linville Falls quadrangles: Hunter, 1890.

Coastal Plain: Prouty, 3150.

Magnetic anomalies and geologic structures: MacCarthy, 2499.

Durham Triassic basin: Johnson, 1979.

Elizabeth City area: Lohman, 2441.

Monazite, Mars Hill, age : Marble, 2579.

Morgan Creek Dam area : Prouty, 3139.

Talladega series, pre-Cambrian: Crickmay, 909.

Southern Appalachians: Crickmay, 910.
North Carolina-Continued.

Mineralogy.

Alleghanyite, chemical formula and crystal system : Rogers, 3333.

Autunite, Mitchell County: Johnson, 1957.

General : Pratt, 3126.

Hiddenite, Stony Point: Colburn, 801.

Hyalite: Henderson, 1702.

Meteorite, Moore County: Henderson, 1698.

Pyroxamangite: Henderson, 1699.

\section{Paleontology.}

Aturia, Eocene: Stenzel, 3867.

Comatulids, Eocene : Gislén, 1439.

Eucrassatella mansfleldi, Pliocene: MacNeil, 2560.

Fauna, Pleistocene Pamlico, southern Atlantic Coastal Plain: Richards, 3284 .

Foraminifera, upper Eocene: Cushman, 941.

Mollusca, Pliocene Croatan sand : Mansfleld, 2574.

Nonion pizarrensis and Nonionella auris, Miocene: Kjellesvig, 2225.

Pectinidae, Tertiary: Rowland, 3389; Tucker, 4178.

Torreya antiqua, Cretaceous, Fayetteville: Boeshore, 364.

Whales, Miocene: Prouty, 3142.

Petrology.

Sands, variagated, eastern North Carolina: Cobb, 790.

Slates, probable sedimentation: Alexander, 22.

Physical geology.

Fulgurites, Cretaceous, Atlantic Coastal Flain: Petty, 3069.

Physiographic geology.

Carolina bays: MacCarthy, 2500; Prouty, 3148, 3151; Watson, 4362.

Coastal Plain: Prouty, 3150.

Triassic basin : MacCarthy, 2497.

Meteor craters: Prouty, 3140.

Meteor's and Carolina bays: MacCarthy, 2501.

Settlement influenced by physiography : Norburn, 2909.

Underground vater.

Elizabeth City area: Lohman, 2441.

Geology and water resources: Bryson, 531.

North Dakota.

Ecomomic geology.

Bentonite: Anonymous, 4673.

Geophysical exploration: Wilson, 4543.

Glaubrr salt, natural deposits: Lavine, 2353.

Gold: Anonymous, 4674.

Minot area: Andrews, 70.

Historical geology.

Glauber salt, natural deposits: Lavine, 2353.

Minot area : Andrews, 70. 
North Dakota-Continued.

Paleontology.

Conifers, Lower Cretaceous, near Mandan : Brown, 490.

Glyptostrobus in America: Brown, 493.

Polyporites stevensoni, Cretaceous, Wade : Brown, 494.

Rodents, cricetid, Teritary : Wood, $\mathbf{4 5 7 6 .}$

Physiographio geology.

Lake, Pleistocene, White River Valley: MacClintock, 2506.

Lake Souris, glacial: Andrews, 71.

Undergróund water.

Drought, 1934, effect, James and Cheyenne River basins: Sayre, 3525.

Water conservation: Anonymous, 4671.

Water conservation and utilization: Anonymous, 4670.

Water resources: Anonymous, 4671.

Northwest Territories.

Economio geology.

El Dorado ores, mineragraphy: Kidd, 2190.

Mineralization, Great Bear Lake district: Kidd, 2189.

Pitchblende, Beaverlodge and Hottah Lakes: Haycock, 1658.

La Bine Point, Great Bear Lake: Spence, 3801.

Rae to Great Bear Lake, Mackenzie district: Kidd, 2191.

Yellowknife River area: Jolliffe, 1988.

Historical geology.

Granite porphyries, Great Bear Lake: Riley, 3304.

Rae-Great Bear Lake area, Mackenzie District : Canada G. S., 668, 669, 670; Kidd, 2190, 2191.

Great Slave Lake, east arm: Stockwell. 3940.

Yellowknife River area: Jolliffe, 1988.

Mineralogy.

Great Bear Lake area: Kidd, 2190.

Quartz reins: Furnival, 1370.

Silver-urainite deposits, Great Bear Lake : Thomson, 4105.

Thorium from pitchblende, Great Bear Lake: Merkel, 2666.

Uraninite, Hottah Lake: Bruner, 511.

Paleontology.

Chaetetes akpatokensis, Ordovician: Oakley, 2928.

Petrology.

Granite porphyries, Great Bear Lake: Riley, 3304.

Pitchblende ore, Beaverlodge and Hottah Lakes: Haycock, 1658

\section{Physical geology.}

Granite porphyries, Great Bear Lake : Riley, 3304.

Great Bear Lake, large quartz veins: Furnival, 1370.

Rae to Great Bear Lake, Mackenzie district: Kidd, 2191.
Nova Scotia.

Economic geology.

Gold mineralization, zonal: Newhouse, 2865.

Lake Ainslie area, Inverness County: Norman, 2911.

Malayash salt deposit, gravimetric sur: vey : Miller, 2698.

Historical geology.

Goldenville-Halifax boundary, Fairview : King, 2209.

Halifax formation, pre-Cambrian, Point Pleasant Park : Belyea, 274.

Lake Ainslie area, Inverness County: Norman, 2921.

Malagash salt deposit, gravimetric survey : Miller, 2698.

Paleontology.

Corals, Carboniferous: Lewis, 2407.

Cretaceous fossils, Banquereau: Stephenson, 3878.

Physical geology.

Gold mineralization, zonal: Newhouse, 2865.

Physiographic geology.

Concretions, manganese : Kindle, 2196. Nuées ardentes, mechanics: Finch, 1262.

Numerical field tabulation, igneous rocks : Spearman, 3800 .

Oahu.

Historical geology.

Bibliography, annotated : Stearns, 3856.

General : Stearns, 3848 .

Ocean basins: Field, 1250, 1251, 1252, 1253. Oceans.

Bottom, geological mapping: Shepard, 3674 .

Origin : Keyes, 2182.

Ohio.

Eoonomio geology.

Gypsum deposits, Sandusky: Jones, 2009.

Kelley's Island: Ver Steeg, 4281.

Natural gas, central and eastern Ohio: Stout, 3949.

Lima-Indiana district: Ley, 2413

Petroleum and natural gas, source ma. terial: Stout, $\mathbf{3 9 5 0}$.

\section{Historical geology.}

Correlation by insoluble residues, Penn. sylvanian limestones; Mitchell, 2754.

Cromwell oil field: Rison, 3307.

General : Kans. Geol. Soc., 2020.

Gypsum deposits, Sandusky: Jones, 2009.

Hocking County State Parks : Ver Steeg, 4278.

Kelley's Island: Ver Steeg, 4281.

Mohlcan Forest Park: Ver Steeg, 4284.

Ohio River Valley: Meinzer, 2635.

Silurian formations, correlation: Foerste, 1298

Sylvania sandstone, Devonian, nortbwestern Obio: Carman, 680. 
Ohio-Continued.

Mineralogy.

Celestite and fluorite, origin, Clay Center : Morrison, 2802.

Conglomerate, glacial, fluorescent and phosphorescent: Wuestner, 4632.

Gems : Schiefer, 3557.

Paint Creek meteorite: Ver Steeg, 4279.

Sphalerite in ironstone concretions: Greene, 1515.

Paleontology.

Actinopterygian Jaws, Mississipplan: Cooper, 859.

Alethopteris grandifolia, Summit County : Arnold, 88.

Brachiopods, Silurian, Triplesiidae : Ulrich, 4214.

Casteroides ohioensis, distribution : Cabn, 623.

Charophyta, Paleozoic: Peck, 3040.

Crinoids, Silurian, Centreville: Foerste, 1303.

Fusulinids, Permian: Thompson, 4101.

Glacial and postglacial plant migrations : Braun, 450.

Ostracoda, Silica shale, devonian : Stewart, 3897 .

Pollen analysis, Mud Lake bog: Sears, 3623.

Tetrapods, Dunkard series: Burke, 579.

Trochiliscus, Sandusky, Devonian: Hacquaert, 1591.

Petrology.

Correlation by insoluble residues, Pennsylvanian limestones: Mitchell, 2754.

Physical geology.

Hocking County State parks: Ver Steeg, 4278.

Radio transmission survey : Hlggy, 1738.

Physiographic geology.

Erosion surfaces, eastern Ohio: Cole, 805.

Hocking County State parks: Ver Steeg, 4278.

Kelley's Island: Ver Steeg. 4281.

Mohican Forest Park : Ver 'Steeg, 4284.

Powell and Broadway end moraines: White, 4457.

Preglacial physiography, western Ohio: Ver Steeg, 4283.

Preglacial topography, western Ohio: Ver Steeg, 4285.

Relief, relative: Smith, 3751 .

Scioto glacial lobe: White, 4456.

Scioto Valley: Rich, 3267.

Underground water.

Ohio River Valley: Meinzer, 2635.

Oil. See Petroleum.

Oil and conl, effects of geophysical factors on: White, 4451.

Oil sands, correlation by fluorescence: Melhase, 2647.

Oil shale. See also Bltiuminous rocks; Petroleum.

General : Schreiter, 3577.
Oi: shali-Continued.

Petroleum, permeability measurements : Clough, 785.

Oklahoma.

Economic geology.

Ardmore district, petroleum: Tomlinson, 4143.

Caliche: Gould, 1484.

Comanche oil and gas field: Swigart, 3995.

Carbon ratios, Arkansas-Oklahoma coal field : Hendricks, 1708.

North of the Ouachitas: Fisher, 1270.

Coal flelds, Pennsylvanian: Hendricks, 1709.

Coal map, Howe district: U. S. G. S., 4230 .

Lehigh district: U. S. G. S., 4231.

McAlester district: U. S. G. S., 4232.

Stigler-Poteau district: U. S. G. S., 4233.

Wilburton district, Latimer County: U. S. G. S., 4234.

Coals, Pennsylvanian, Western Interior Province: Young, 4639.

Cromwell oil fleld: Rison, 3307.

Cushing oil field, Creek County: Wardwell, 4338.

Davenport oil field, Lincoln County : Brandentbaler, 436.

Deaner oil field, Okfuskee County : Kirwan, 2222.

Fitts oil pool: Dott, 1071 ; Hyatt, 1901.

Gravel deposits: Bloesch, 350.

Fematite, Reagan sandstone, Wichita and Arbuckle Mountains: Williams, 4504.

Lucien oil field: Zavoico, 4642.

- Mapping geological structure by reflection waves: Goldstone, 1468.

Midcontinent oil fields, regional investigations: Hiestand, 1737.

Shoestring oil fields: Bass, 222.

Migration of oil, Oklahoma City field: Brauchli, 448.

Muskogee County, Pennsylvanian oil and gas sands: Wilson, $\mathbf{4 5 3 0 .}$

Natural-gas flelds, Arkansas Basin, eastern Oklahoma: Colton, 820.

Southern Oklahoma: Tomlinson, 4142.

Naval Reserve oil fleld, Osage County: Vanderpool, 4260.

Oil, possibilities, Osage County: Bass, 221.

Oil fleld, Okmulgee County: Westby, 4426.

Ore deposits, Tri-State district : Fowler, 1319.

Osage County: Bass, 220.

Oil and gas fields: U. S. G. S., 4237, 4238.

Seminole oil pool, Seminole County: Swarts, 3987.

Slick oil field, Creek County : Schwarzenbeck, 3600 .

Tatums pool, Carter County: Grimes, 1551. 
Oklahoma-Continued.

Economic geolcgy-Continued.

Tri-State mining district, chertiflcation : Fowler, 1317.

Historical geology.

Arbuckle Mountains, structural history: Dott, 1072.

Arbuckle Mountains and Bucher's laws: Tomlinson, 4141.

Ardmore area: Floyd, 1293.

Bartlesville and Burbank sands: U. S. G. S., 4235, 4236.

Bigfork chert, origin, Radiolaria: Henbest, 1694 .

Bluejacket sandstone, correlation : Dane, 971.

Boone chert: Giles, 1422.

Cambrian-Ordovician boundary, Arbuckle limestone, Murray County: Bridge, 457.

Chattanooga shale, Osage County: Leatherock, 2363.

Coal fields, Pennsylvanian correlations : Hendricks, 1707, 1709.

Coal map, Howe district: U. S. G. S., 4230.

Lehigh district: U. S. G. S., 4231.

McAlester district: U. S. G. S., 4232.

Stigler-Poteau district: U. S. G. S., 4233.

Wilburton district, Latimer County: U. S. G. S., 4234 .

Comanche oil and gas field: Swigart, 3995.

Correlation, Bainbridge and Henryhouse formations: Ball, 170.

By graptolites: Decker, 1000, 1001.

By insoluble residues: Ireland, 1907.

Davenport oil field, Lincoln County : Brandenthaler, 436.

Deaner oil field, Okfuskee County : Kirwan, 2222.

Fitts pool, Pontotoc County: Hyatt, 1901.

General : Kansas Geol. Soc., 2020.

Gravel deposits : Bloesch, 350.

Lehigh district: Knechtel, 2228.

Lucien oil field: Zavoico, 4642.

Mayes-Boone, correlation : Brant, 447.

Midcontinent oil fields, regional investigations: Hiestand, 1737.

Muskogee County, Pennsylvanian, correlation: Wilson, 4530.

Natural-gas fields, southern Oklahoma: Tomlinson, 4142.

Naval Reserve oil field, Osage County: Vanderpool, 4260 .

Oil, possibilities, Osage County: Bass, 221.

Osage County: Bass, 220.

Oil and gas fields; U. S. G. S., 4237, 4238.

Ouachita boulder problem: Kramer, 2255 ; Van der Gracht, 4264.

Ouachita Mountains, Carboniferous, Bendian: Harlton, 1634.

Correlations: Fitts, 1276.

Structural history: Miser, 2748.
Oklahoma-Continued.

Historical geology-Continued.

Permian and Pennsylvanian: Green, 1511.

Quinton-Scipio district: Dane, 969.

Seminole oil pool, Seminoles County: Swarts, 3987.

Shinarump, eastward extension : Keyes, 2139.

Slick oil field, Creek County : Schwarzenbeck, 3600 .

Sylvan shale, Johns Valley: Decker, 998 ; Oklahoma Geol. Soc., 2943.

Talibina chert section, Atoka: Gardner, 1380.

Tatums pool, Carter County: Grimes, 1551.

Tectonics, Arbuckle and Ouachita Mountains : Gardner, 1381.

\section{Mineralogy.}

Dolomite, castellated, pseudomorphs, Major County: Merritt, 2677.

Enargite and plumbojarsite, Picher: Ransome, 3178

Gypsum crystals, Alfalfa County : Merritt, 2676.

Hematite, Reagan sandstone, Wichita and Arbuckle Mouptains: Williams, 4504.

Meteorite fall, central Oklahoma, August 17, 1936 : Monnig, 2768.

Mineral provinces: Evans, 1190.

\section{Paleontology.}

Actinopterygian jaws, Mississippian : Cooper, 859.

Allagecrinus strimplei, Pennsylvanian, Dewey : Kirk, 2219.

Asteriaform fossils, Francis formation : Jones, 1999.

Brachiopods, Silurian, Triplesiidae: U1rich, 4214.

Cephalopoda, Nowata shale: Miller, 2707.

Pennsylvanian : Newell, 2859.

Crustaceans, phyllocarid, S i l u r i a n : Ruedemann, 3409.

Fusulinids, $10 \mathrm{w}$ e $\mathbf{r}$ Pennsylvanian : Thompson, 4099.

Graptolites, Silurian : Decker, 997.

Simpson group : Decker, 996.

Sylvan shale: Decker, 998.

Viola limestone: Ruedemann, 3402.

Invertebrates, Pennsylvanian: Newell, 2856.

Ostracoda, Pennsylvanian, Ardmore basin: Bradfleld, 414.

Permian, Caddo County : Harris, 1642.

Peccary, Pleistocene, near Alva: Johnston, 1981.

Phacopinae, Devonian: Delo, 1020.

Staffella, Pennsylvanian: Thompson, 4098.

Symbos, Pleistocene, Chickasha : Stovall, 3955.

Ursus horribilis nelsoni, Dewey County : Stovall, 3954

Ursus horribilis oklahomaensis, Pleistocene: Stovall, 3951. 
Oklaboma-Continued.

Paleontology-Continued.

Vertebrates, Pliocene, Ogallala, Beaver County : Hesse, 1732.

\section{Petrology.}

Ardmore Basin, Pennsylvanian sandstones: Lucas, 2475.

Correlation by insoluble residues: Ireland, 1907.

Physical geology.

Earthquake, April 11, 1934: Sellards, 3640.

Faulting, Pennsylvanian: Cram, 889.

Fitts pool, Pontotoc County : Hyatt, 1901.

Ouachita Mountains, crustal movement: Inechtel, 2229.

Sedimentation, Lake Spavinaw : Kesler, 2088.

\section{Physiographic geology.}

Ripple marks, Carboniferous, Ardmore: De Bethune, 994.

Underground water.

Cushing oil field, Creek County, water invasion: Wardwell, 4338.

Ground water in southern High Plains: Theis, 4062.

Oklahoma and Kansas, oil fields, paleogeology: Hiestand, 1737.

Oligocene. See Tertiary.

Ontario.

Areas describcd.

Straw-Manitou Lakes area: Thomson, 4109.

Economic geology.

Anhydrite, hypogene, McIntyre mine, Porcupine district: Langford, 2336.

Aplites with cobalt-silver ores: Bastin, 234.

Canadian shield mining districts: Wright, 4627.

Clays, refractory, Mattagami River: Hilder, 1739.

Copper-nickel, Pigeon River area: Tanton, 4014 .

Gold, Afton-Scholes area: Moore, 2781.

Central Patricia mine, Kenora district: Cormie, $\mathbf{8 7 6 .}$

East of Lake Superior: Kindle, 2195.

Manitou Lake-Lake of the Woods: Thomson, 4111.

Hollinger: gold mine: Ringsleben, 3306 .

Lake Shore mine area: Robson, 3328.

Lake Superior region: Rama Rao, 3167 .

Little Long Lac-Jellicoe area: Bruce, 505.

Little Long Lac-Sturgeon River areas: Thomson, 4107.

Makwa-Churchill area: Laird, 2289.

Natural-gas fields: Harkness, 1633.

Natural gas in 1933: Harkness, 1631.

Patricia gold mine : Reid, 3238 .

Petroleum in 1933 : Harkness, 1632.

Porcupine area: Hurst, 1899.

Renfrew County mineral deposits : Freeman, 1336.

Rock wool: Goudge, 1483.
Ontario-Continued.

Economic yculogy-Continued.

Stocks, granitic, and auriferous velns, Goudreau: Emmons, 1178.

Straw-Manitou Lakes area: Thomson, 4109.

Sturgeon River area: Tanton, 4.013.

Sudbury nickel field: Burrows, 585; Collins, 812 ; Thomson, 4114:.

Swayze gold area: Rickaby, 3294.

Tashota-Sturgeon River district: Flaherty, 1278.

Telluride ores: Thomson, 4106, $\$ 108$.

Vein formation, Porcupine: Hurst, 1898 ; Reid, 3237.

Vipond gold mine, Porcupine district: Dougherty, 1073.

Historical geology.

Canadian Shield mining districts: Wright, 4627 .

Chert, Lockport and Onondaga formations: Laird, 2290.

East Bay, Minnitaki Lake, Kenora district: Pettijohn, 3067.

Gold, Afton-Scholes area: Moore, 2781. East of Lake Superior: Kindle, 2185. Manitou Lake-Lake of the Woods : Thomson, 4111.

Hamilton correlations: Warthin, 4351.

Hollinger gold mine: Ringsleben, 3306.

Lake Nipigon area: Canada G. S., 650.

Lake Shore mine area: Robson, 3328.

Lake Superior region: Leith, 2390.

Little Long Lac-Jellicoe area: Bruce, 505.

Makwa-Churchill area: Laird, 2289.

Mine Centre area, Rainy River district: Canada G. S., 666.

Natural-gas flelds: Harkness, 1633.

Papaonga River area, Patricia portion, Kenora district: Wright, 4:631.

Porcupine area: Hurst, 1899.

Pre-Cambrian, Lake Superior region: Rama Rao, 3167.

Renfrew County : Freeman, 1336.

Saganaga granite batholith: Grout, 1557.

Savant Lake area: Rittenhouse, 3308.

Straw-Manitou Lakes area: Thomson, 4109.

Sturgeon River area: Tanton, 4013.

Sudbury nickel fleld: Burrows, 585.

Sudbury nickel irruptive, geological environment: Collins, 815 .

Swayze gold area: Rickaby, 3294.

Syenites, Coldwell district: Thomson, 4110.

'Tasbota-Sturgeon River district: Flaherty, 1278.

Vermilion Township, Kenora district: Pettijohn, 3065.

Wilberforce uraninite, age: Aiter, 56.

Mineralogy.

Aplites with' cobalt-silver ores: Bastin, 234.

Calcite crystal, Godfrey : Parsons, 3020.

Cubanite, Sudbury: Peacock, 3037. 
Ontario-Continued.

Mineralogy-Continued.

Cyrtolite, analysis: Muench, 2819.

Feldspar twinning, differentiated sill: Chapman, 736.

Hackmanite, Bancroft, reversible photosensitivity : Lee, 2368.

Heavy minerals, Canadian shield granites: Bruce, 502.

Little Long Lac and Sturgeon River areas: Thomson, 4107.

Ore deposition, Cobalt area: Dadson, 949.

Porphyry and quartz diabase, metallogenetic relations: Burwash, 586.

Renfrew County mineral deposits : Freeman, 1336.

Telluride ores: Thomson, 4106, 4108.

Thomsonite, Lake Superior : Combs, 822.

Uraninite crystal, ratio variation: Alter, 57.

Vein formation, Porcupine : Hurst, 1898.

Paleontology.

Cephalopods, Silurian, Hudson Bay region: Foerste, 1303.

Fauna, Cataract formation: Johnson, 1967.

Homalophyllum thedfordensis, Devonian: Stewart, 3896.

Ostracoda, Devonian, Arkona: Coryell, 881.

Ordovician, in Hull and Decorah formations: Kay, 2028.

Wood, Devonian. Kettle Point, Lake Furon: Russell, 3427.

\section{Petrology.}

Chert, Lockport and Onondaga formations: Laird, 2290.

Claire River syncline, Tweed: Fairbairn, 1206.

Feldspar twinning, differentiated sill: Chapman, 736 .

Magnetic differentiation, Sudbury nickel intrusive: Walker, 4321.

Quartz, Okanagan district: Walker, 4322 .

Savant Lạke area : Rittenhouse, 3308.

Slate, varved, pre-Cambrian: Pettifohn, 3066 .

Sudburite, Sudbury: Thomson, 4115.

Sudbury nickel fleld: Buddington 545 ; Burrows, 585; Thomson, 4114, 4116.

Syenites, Coldwell district: Thomson, 4110.

Physical geology.

Anbydrite, hypogene, McIntyre mine, Porcupine district: Langford, 2336.

Canadian Shield mining districts: Wright, 4627.

Claire River syncline, Tweed: Fairbairn, 1206 .

Earthquake, November 1, 1936: Hodgson, 1770

East Bay, Minnitaki Lake, Kenora district: Pettijohn, 3067.
Ontario-Continued.

Physical geology-Continued.

Elongation in deformed rocks: Fairbairn, 1209.

Hollinger gold mine: Ringsleben, 3306 .

Porcupine area: Hurst, 1899.

Saganaga granite batholith: Grout, 1557.

Savant Lake area : Rittenhouse, 3308.

Stocks, granitic, and auriferous veins, Goudreau : Emmons, 1178.

Straw-Manitou Lakes area: Thomson, 4109.

Sturgeon River area: Tanton, 4013.

Sudbury nickel field: Burrows, 585; Collins, 812 ; Fenner, 1221: Reynolds, 3258, Thomson, 4114.

Tashota-Sturgeon River district: Flaherty, 1278.

Vein formation, Porcupine: Hurst, 1898 ; Reid, 3237.

Vermilion Township, Kenora district: Pettijohn, 3065.

Physiographic geology.

Algonquin beaches, Penetanguishene Peninsula, Georgian Bay: Stanley, 3820.

Frost circles and sballow rock structures: Williams, 4518.

Savant Lake area: Rittenhouse, 3308 .

Watercourses near French River, origin : Quirke, 3159.

Opal.

California, alteration of lavas around hot springs, Lassen Volcanic National Park: Anderson, 63.

Fluorescence: Dake, 955.

General: Randolph, 3184; Taliaferro, 4008.

Oregon, Opal Butte: Renton, 3247.

Utah, opalized spherules: Alexander, 24.

Ordovician. See also Paleontology, Ordovician.

Alaska, interior, volcanism: Mertie, 2680.

Ruby-Kuskokwim region: Mertie, 2681.

Antillean-Caribbean region: Schuchert, 3579.

Arizona, Paleozoic formations: Stoyanow, 3959.

Arkansas, northern: McKnight, 2552.

Polk Creek shale: Decker, 998.

Bentonite correlation, eastern North America : Rosenkrans, 3358.

Bentonites, possible volcanic sources: Whitcomb, 4448 .

California, Death Valley National Monument : Anonymous, 4664.

Canada, western: Goodman, 1473.

Chaleur Bay region, Quebec and New Brunswick : Alcock, 12

Clays, fire, distribution in U. S. : Chellkowsky, 743. 
Ordovician-Continued.

Colorado, Mosquito Range Paleozoic limestones: Johnson, 1970 ; Singewald, 3730 .

San Juan region: Cross, 925.

Yule Creek formations: Vanderwilt, 4261.

Decorah shale: Stauffer, 3840.

Galena dolomite, Upper Mississippi Valley : Kay, 2030.

Gaspe, southeastern : Kindle, 2193.

Greenland: Koch, 2244, 2245.

Northeast: Teichert, 4037.

Idaho, Casto quadrangle: Ross, 3369 .

Illinois, Fernvale formation: Greger, 1519.

Marion and Clay Counties: Weller, 4385.

I!linois Basin: Weller, 4386.

Iowa, St. Peter sandstone: Thiel, 4069.

Kansas, Central uplift: Koester, 2246.

Northeastern : Ockerman, 2933.

Kentucky, Rogers Gap and Fulton formation: McFarlan, 2520.

Maine: Ruedemann, 3410.

Appalachian Trail: Philbrick, 3071.

Manitoba, Elbow-Morton area: Stockwell, 3939.

Maquoketa shale, isopach map, upper Mississippi Valley: Ladd, 2285.

Maryland, bentonite beds, lower Chambersburg: : Whitcomb, 4450.

Frederick Valley limestones: Jonas, 1993.

Limestones of Frederick Valley : Stose, 3948 .

Michigan, central oil fields: Zavolca, 4644.

Natural-gas fields: Newcombe, 2853.

Minnesota, Minneapolis-St. Paul metropolitan area: Schwartz, 3597.

Minnesota River Valley : Couser, 885.

St. Croix River, Paleozoic: Clement, 774.

St. Peter sandstone: Thiel, 4069.

Southeastern: Powell, 3114:

Stillwater deep-well records: Stauffer, 3839.

Mississippi Valley, cross sections: Workman, 4618.

Upper: Kans. Geol. Soc., 2020; Kay, 2029.

Missouri, cross section, Forest City, Mo., to Du Bois, Nebr.: Condra, 833.

Insoluble residues, correlation: McQueen, 2561.

St. Louis County and City of St. Louis: Gleason, 1443.

Montana, Big Horn County and Crow Indian Reservation: Thom, 4074.

Nebraska, cross section, Du Bois, Nebr., to Forest City, Mo., Condra, 833.

Water-bearing formations: Condra, 835.

Newfoundland, Bay of Exploits area: Heyl, 1736.
Ordovician--Continued.

Newfoundland-Continued.

Bay of Islands igneous complex: Cooper, 869.

Gold deposits: Snelgrove, 3779.

Trout River area: Ingerson, 1906.

New Hampshire, Franconia quadrangle: Billings, 317.

Littleton and Moosilauke quadran. gles : Billings, 318.

Percy ring-dike complex: Chapman, 734.

New Mexico. Bayard area : Lasky, 2344.

Organ Mountains and Doña Ana County: Dunham, 1094.

Santa Rita mining area: Spencer, 3803.

New York, Adirondack foreland arch: Kay, 2034.

Altered volcanic materials and related clays: Kay, 2031.

Berne quadrangle: Goldring, 1463.

Black shales, Mohawk Valley : Ruedemann, 3406.

Dutchess County: Balk, 162.

Eastern, cherts : Ruedemann, 3416.

Hammond, Antwerp, and Lowville quadrangles: Buddington, 543.

John Boyd Thacher State Park: Torrey, 4147.

Lowville quadrangle: Ruedemann, 3401.

Natural-gas fields: Torrey, 4146.

Potsdam quadrangle, St. Lawrence County : Reed, 3217.

Northwest Territories, Yellowknife River area: Jolliffe, 1988.

Oklahoma, Cambrian-Ordovician boundary, Arbuckle limestone, Murray County: Bridge, 457.

Correlation by insoluble residues: Ireland, 1907.

Fitts pool, Pontotoc County: Hyatt, 1901.

Lucien field: Zavoico, 4642.

Sylvan shale: Decker, 998.

Pennsylvania, Bellefonte quadrargle: Butts, 598.

Bentonite beds, lower Chambersburg: Whitcomb, 4450.

Chester Valley : Mackin, 2544 ; Miller, 2718.

Eastern region: Miller, 2717.

Lebigh Valley Cambro-Ordovician limestones: Hills, 1742.

Soutbeastern, Appalachian structure: Jonas, 1991.

Post-Keweenawan, age by helium method: Urry, 4246.

Prairie du Chien formation: Powers, 3116.

Prairie du Chien group, isopach map, upper Mississippi Valley: Powers, 3115.

Upper Mississippi Valley: Fowers, 3117. 
Ordovician-Continued.

Quebec, Dartmoutn River area, Gaspe Peninsula: Jones, 2003.

Deschambault region, Portneuf County : Laverdière, 2352.

Lacolle conglomerate: Clark, 767.

Lac St.-Jean region, northwest part: Denis, 1030.

Marsoui area, Gaspe Peninsula : Jones, 2001.

Mount Megantic region: McGerrigle, 2525.

Natural-gas fields: Snider, 3781.

North-central Gaspe: Jones, 2002.

Témiscouata area : McGerrigle, 2524.

St. Peter formation, isopach map, upper Mississippi Valley: Lamar, 2293.

St. Peter sandstone, upper Mississippi Valley: Howell, 1865.

Southwestern U. S. : Effinger, 1144.

Stewartville and Dubuque formations: Kay, 2032.

Tennessee, Flynn Creek disturbance, Jackson County: Wilson, 4536.

Nashville dome: Wilson, 4531.

South-central: Theis, 4063.

Western : Born, 376.

Texas, trans-Pecos, unconformities: Arick, 84.

Utah, Gold Hill mining district: Nolan, 2905.

Virginia, altered volcanic materials and related clays: Kay, 2031.

Eagle Rock, Pulaski overthrust : Woodward, 4611.

Shenandoah Valley: Cady, 621.

West Virginia, eastern: Reeves, 3233.

Wisconsin, Baraboo area: Raasch, 3162. Mohawkian relations: Bays, 247.

St. Peter sandstone: Theil, 4069.

Wisconsin-Illinois lead-zinc district Behre, 255.

Ore-body zoning: Riley, $\mathbf{3 3 0 5}$.

Ore deposits, origin: Bastin, 233; Butler, 592 ; Fitzhugh, 1277. For ore deposits in general see Economic geology (general)

Alabama, Hog Mountain district: Park, 3007.

Arizona : Schmitt, 3565 . Copper districts: Tenney, 4040.

Arkansas, cinnabar deposits: Stearn, 3846.

Northern: McKnight, 2552.

Barite deposits, Virginia: Edmunson, 1136.

British Columbia, Barkerville gold belt : Hanson, 1627.

Bralorne mine area: Hedley, 1685 ; Joralemon, 2013.

Brittania mines: Ebbutt, 1118.

Cariboo district: Hanson, 1624.

Hidden Creek ore bodies: Nelson, 2845.

Ore depths in mines; Schofield, 3573.

Ymir-Nelson area: Cockfield, 796.
Ore deposits-Continued.

California, Mojave mining district: Scbroter, 3578.

Mother Lode and Sierra Nevada batholiths: Cloos, 781.

Santa Rita ol'e body: Henderson, 1706.

Canada, eastern, ore deposits: Wright, 4628.

Gold deposits, Canadian $\mathbf{S}$ h i eld : Bruce, 503 ; Dougherty, 1074.

Synclines : Bichan, 314.

Carbonates in veins, Charlewood, 739.

Celestite and fluorite by replacement: Morrison, 2802.

Colorado, Aspen district: Vanderwilt, 4262 .

Calumet iron mine, contact ore deposition: Behre, 262.

Climax, molybdenite: Coulter, 883.

Columbia and Dew Drop vein systems, Boulder County: Walker, 4318.

Continental Divide region: Behre, 257.

Copper-silver v ei n s, hydrothermal, northeastern plateau: Fischer, 1265.

Cripple Creek district: Loughlin, $2459,2460$.

Front Range area: Lovering, 2469.

Jamestown district; Goddard, 1457.

La Plata mining district : Eckel, 1126.

London fault: Singewald, 3731 .

Montezuma quadrangle: Buddington, 547 ; Lovering, 2466.

Ore deposition south of Ouray : Moehlman, 2760.

San Juan region: Cross, 925.

Tincup mining district, Gunnison County: Goddard, 1458.

Ward district ores: Wahlstrom, 4309.

Zoning, Mosquito Range and San Juan Mountains: Loughlin, 2462.

Contact ore deposits, southwestern U. S. : Raguin, 3165.

Copper deposits, Ducktown type, south ern Appalachians: Fenner, 1222 ; Ross, 3364.

Southern Appalachians : Ross, 3368 .

Eastern United States: Ross, 3363.

North America: Ransome, 3179.

Pyritic deposits, mesothermal type, origin : Kania, 2019.

Sedimentary deposits, Western States: Finch, 1259.

Differentiation in traps and ore deposition: Lane, 2324.

El Dorado ores, Northwest Territories : Kidd, 2190.

Enargite and plumbojarsite, Picher, Okla.: Ransome, 3178.

Epithermal precious-metal deposits: Nolan, 2904.

Fractures, ore bearing: Emmons, 1176.

Gogebic iron range, Michigan and Wisconsin: Atwater, 113. 
Ore deposits-Continued.

Georgia, Battle Branch gold mine: Park, 3010.

Gold, Ontario, Vipond mine: Dougherty, 1073.

Solubility and geologic application: Milner, 2741.

Idaho, Edwardsburg and Thunder Mountain area: Shenon, 3665.

Lead-zinc deposits, Tri-State district: Fowler, 1319 ; Sales, 3476.

Liquid inclusions: Yuster, 4641.

Manganese: Harper, 1637.

Solution, transportation and precipitation: Savage, 3516.

Magnetites, diagnostic possibilities: Davis, 984

Manitoba, God's Lake gold mine: Baker, 155.

Manitoba and Ontario mining districts : Wright, 4627.

Massachusetts, Taconic limonites: Newland, 2867.

Mechanics of metasomatism : Bain, 138.

Mexico: Schmitt, 3565.

Beryl and berillium: Santillan, 3497.

Colorado mine; Cananea: Kelley, 2049.

Copper, Campo Morado, State of Guerrero: Flores, 1290.

Mapimi, Coahuila Peninsula: Singewald, 3732.

Ore-body zoning, Sierra Mojada, Coahuila: Riley, 3305.

Pilares mine, Sonora: Tenny, 4041.

Primary silver ores, Batopilas: Krieger, 2262.

Sabinal silver district, Chibuahua: Krieger, 2261.

Tepezala, Aguascalientes, pyrometasomatic vein deposits: Wandke, 4328.

Michigan, copper deposits: Broderick, 465.

Keweenawan lavas, differentiation : Broderick, 464.

Lake Superior iron deposits: Royce, 3397.

Mineral associations, high-temperature, shallow: Butler, 591.

Shallow to moderate depths: Buddington, 544.

Mineral veins, origin: Behre, 258.

Mineral zoning, Triassic: Newhouse, 2861.

Minerals and superheated water: Crowley, 926.

Minnesota, Lake Superior iron deposits: Royce, 3397 .

Mississippi Valley: Graton, 1500.

Missouri, Cornwall copper mines: Rust, 3446.

Southeastern, lead deposits: Tarr, 4020.

Montana, Butte mining district: Hart, 1647.

Flathend mine: Shenon, 3661.

Hog Heaven mining district, Flathead County: Shenon, 3664.
Ore deposits-Continued.

Nevada, Contact mining district: Schrader, 3576

Dumortierite - andalusite mineralization, Oreana : Kerr, 2079.

Ely district: Bateman, 236.

Silver Dyke area: Kerr, 2086.

Tuscarora mining district, Elko, County : Nolan, 2908.

New Mexico : Schmitt, 3565.

Bayard area: Lasky; 2344.

Central mining district: Schmitt, 3566.

Organ Mountains and Doña Ana County : Dunbam, 1094.

Primary silver ores, Bullard's Peak : Krieger, 2262.

Santa Rita mining area: Spencer, 3803.

Virginia mining district, hydrothermal leaching: Lasky, 2345.

New York, supergene minerals at Balmat: Brown, 486.

Taconic limonites: Newland, 2867.

Zinc mine, Balmat: Brown, 484.

North Carolina, gold: Bryson, 532.

Northwest Territories, Rae to Great Bear Lake, Mackenzie district : Kidd, 2191.

Nova Scotia, gold zonal mineralization: Newhouse, 2865.

Oklahoma, hematite, Wichita and Arbuckle Mountains: Williams, 4504.

Ontario, aplites with cobalt-silver ores: Bastin, 234.

Central Patricia gold mine: Cormie, 876 ; Reid, 3238.

Cobalt area: Dadson, 949.

East of Lake Superior: Kindle, 2195.

Goudreau, granitic stocks, and veins: Emmons, 1178.

Hypogene anhydrite: Langford, 2336.

Lake Shore mine area: Robson, 3328.

Porcupine district, vein formation : Hurst, 1898 ; Reid, 3237.

Porphyry and quartz diabase, metallogenetic relations: Burwash, 586 .

Sudbury nickel field: Burrows, 585 ; Collins, 812.

Tashota-Sturgeon River district: Flaberty, 1278.

Ore, western United States: Anderson, 68.

Ore bodies, localization : Bruce, 504.

Ore shoots: Douglas, 1075, 1076.

Oregon: Hodge, 1762.

Gold-quartz veins, Cornucopia: Goodspeed, 1478.

Skamania mining district: Pratt, 3125.

Tellurides, Cornucopia: Goodspeed, 1475.

Outcrops: Eby, 1123.

Oxides, manganese, and ground-water circulation: Hewett, 1734 .

Porphyries and ore deposition, relations, Alma district, Colo.: Singewald, 3729 . 
Ore deposits-Continued.

Quebec, Horne mine, gabbro and sulphides, relations: Suffel, 3977 .

Lamaque mine, Bourlamaque Township : Bell, 267 ; Wilson, 4537.

Malartic gold mine area, Abitibi : O'Neill, 2954.

Noranda district, Amulet mine, rock alteration: Wllson, 4547 .

Siscoe gold mine area : Beckman, 128.

Western : Bell, 269.

Replacement, filled fissure veins : Shaub, 3652 .

Saskatchewan, Beaverlodge area : Cameron, 630 .

Serpentinization : Hess, 1721.

South Dakota, Black Hills, gold deposits : Wright, 4629.

Succession of minerals and temperatures of formation : Lindgren, 2421.

Tectonic position of Rocky Mountain ore districts: Billingsley, 322.

Tennessee, zinc deposits, southern Appalachians: Currier, 937.

Tri-State zinc and lead ores, genesis: Ridge, 3295.

Utah, Gold Hill mining district: Nolan, 2905.

Moscow silver mines: Johnson, 1964.

Vermont, Taconic limonites: Newland, 2867.

Virginia, Austinville mines, Wythe County, zoning of ores: Brown, 498.

Gold deposits, Piedmont region : Park, 3009.

Perthites, origin : Kearfott, 2036.

Southwestern, zinc and lead region: Currier, 936.

Zinc deposits, southern Appalachians : Currier, 937.

Waters, magmatic and meteoric: Lindgren, 2418.

Wisconsin-Illinois lead-zinc district: Behre, 255.

Wisconsin, Lake Superior iron deposits : Royce, 3397.

Wyoming, Black Hills, gold deposits : Wright, 4629.

Zoning, hypogene, in metalliferous lodes: Emmons, 1179.

Ore deposits of the Western States: Graton, 1502.

Ore zones : Butler, 592.

Oregon.

Bibliography of geology : Hodge, 1764.

Economio geology.

Bibliography, geology and mineral resources: Treasher, 4160.

Copper: Gilluly, 1428.

Diatomite: Lazell, 2361.

Diatomite and pumice, eastern Oregon : Moore, 2779.

Gold-quartz veins, Cornucopia: Goodspeed, 1478 .
Oregon-Continued.

Economic geology-Continued.

Iron, Columbia County: French, 1339.

Native, Klamath Falls: Melhase, 2645.

Mineral deposits, western Oregon : Pardee, 3002 .

Mineral survey: Anonymous, 4660.

Natural-gas fields: Kirkbam, 2220.

Nonmetallic mineral resources, eastern Oregon : Moore, 2777.

Ore deposits: Hodge, 1762.

Tellurides, Cornucopia : Goodspeed, 1475.

Historical geology.

Bibliography, geology and mineral resources: Treasher, 4160.

Cascade Mountains, North Santiam River district: Thayer, 4059, 4061.

Clarno formation, age: Chaney, 727.

Harney Basin : Piper, 3090.

Marine Eocene: Turner, 4188.

Natural-gas fields: Kirkham, 2220.

Oligccene, marine, northwestern Oregon : Packard, 2980.

Saddle Mountain State Park: Layfleld, 2358.

Skamania mining district: Pratt, 3125 .

Tertiary, western Washington and Oregon: Weaver, 4368, 4369.

Umpqua formation, basaltic rocks : Wells, 4389.

Wallowa Mountains, replacement of dikes and sills: Goodspeed, 1476.

Mineralogy.

Agates, drusy, Jefferson County : Southwick, 3702.

Polka - dot, Pon y B u t t e, Jefferson County : Forbes, 1306.

Bibliography, geology and mineral resources: Treasher, 4160.

Fluorescent minerals : Dake, 953.

Hyalite opal, Opal Butte: Renton, 3247.

Mineral deposits, western Oregon : Pardee, 3002 .

Mineral survey: Anonymous, 4660.

Nodules, opal or agate filled: Renton, 3248.

Obsidian, Glass Buttes : Randolph, 3175.

Zeolite locality: Melhase, 2648.

\section{Paleontology.}

Cedrela, Miocene, Sucker Creek: Arnold, 95.

Comstock flora, Eocene: Sanborn, 3481.

Cone, Mosier : Lazell, 2362.

Cophocetus oregonensis, Miocene, Otter Creek : Packard, 2979.

Crooked River basin, Tertiary: Anony. mous, 4708.

Dipoides stirtoni, Pliocene, Crooked Creek: Wilson, 4549.

Faunas, middle Eocene : Merriam, 2668.

Ferns, Roseberg: Wharton, 4438.

Flora, Miocene, Blue Mountains: Oliver, 2950.

Foraminifera, Eocene, western Oregon: Berthiaume, 304. 
Oregon-Continued.

Paleontology-Continued.

Forests, Jurassic, Cretaceous, Tertiary and Quaternary: Sanborn, 3482.

Glyptostrobus in America : Brown, 493.

Mabonia, Tertiary, Harney and Malheur Counties: Arnold, 93.

Mammals, Miocene, Sucker Creek : Scharf, 3535.

Miocene leaves, fruits, and seeds: Brown, 489.

Oligocene, marine, northwestern Oregon: Packard, 2980.

Petrified woods: Forbes, 1305.

Pleurotomarid, Eocene: Schenck, 3544.

Pseudotsuga taxifolioidea, Miocene: Arnold, 90.

Rodents, cricetid, Tertiary: Wood, $\mathbf{4 5 7 6}$.

Geomyid, Middle Tertiary: Wood, 4580.

Miocene, John Day Valley: Wood, 4574.

Teredo, borings in petrifled wood: Lazell, 2360; wharton, 4436.

Teredo wood, petrifled, Rosenburg: Wharton, 4437.

Tilia, Miocene: LaMotte, 2304.

Tritropidoceras packardi, Triassic : Schenk, 3555.

\section{Petrology.}

Cascade Range, intrusive and contact metamorphism: Buddington, 549.

Collapsed pumice: Fuller, 1360.

Gold-quartz veins, Cornucopia: Goodspeed, 1478.

Keratophyres, eastern Oregon, and the spilite problem: Gilluly, 1430.

Newberry volcano, central Oregon: Williams, 4507.

Quartz porphyroblasts in siliceous hornfels : Goodspeed, 1477.

Spherulites, Clarno acid lavas: Wilkinson, 4482 .

Umpqua formation, basaltic rocks : Wells, 4389.

Physical geology.

Cascade Mountains, North Santiam River district: Thayer, 4059, 4061.

Intrusires and contact metamorphism : Buddington, 549.

Crater Lake, dacitic flow structure: Allen, 40.

Fumaroles, Mount Hood: Phillips, 3076.

Great Basin lake sediments: Shrock. 3700.

Harney Basin: Piper, 3090.

Keratophyres, eastern Oregon, and the spilite problem: Gilluly, 1430.

Mount Mazama, Crater Lake National Park, glacial history: Atwood, 117.

Explosion vs. collapse: Smith, 3774.

Newberry volcano, central Oregon: Williams, 4507.

Saddle Mountain State Park: Layfleld, 2358.

Skamania mining district, Pratt, 3125 .

Stalagmites, ice, in Malheur Cave: Dake, 957
Oregon-Continued.

Physical gcology-Continued.

Volcanic and seismic history: Hodge, 1760.

Physiographic geology.

Columbia River, ancient: Randolph, 3176.

Crescent Lake and vicinity: Holdredge, 1778.

Forests, submerged, Columbia River gorge : Lawrence, 2354.

Glaciers from an airplane: Richards, 3275 .

Mount Hood: Phillips, 3077.

Harney Basin: Piper, 3090.

Mount Mazama, Crater Lake National Park, glacial history: Atwood, 117.

Pleistocene alluvial stages, northwest Oregon : Allison, 53.

Willamette Valley, fill: Felts, 1218. Glacial erratics: Allison, 51.

Underground water.

Butter Creek area, Umatilla County: Anonymous, 4689.

Harney Basin : Piper, 3088.

Thermal springs: Waring, 4341.

Orientation of minerals, autoliths: Pabst, 2977.

In rocks: Pabst, 2975.

Origin of the continents: Stille, 3901 .

Orogeny : Schuchert, 3587 ; Stille, 3904.

Antillean-Caribbean region: Schuchert, 3579 .

Appalachian drainage: Meyerhoff, 2689, 2692.

Appalachian geosyncline: Morris, 2801 ; Ver Wiebe, 4288.

Appalachians, southern structure : Boesch, 363.

Time location of: Holden, 1777.

Basin Range hypothesis: Keyes, 2116.

California : Stille, 3900, 3904.

Klamath Mountains: Hinds, 1746 , 1748.

Miocenc, Coast -Ranges: Reed, 3224

Northern Inyo Range: Anderson, 66 .

Southern: Reed, 3931.

Tick and Red Rcck canyons: Luce, 3466.

Canada, western : Goodman, 1473.

Chaleur Bay region, Quebec and New Brunswick: Alcock, 12.

Colorado, Front Range: Van Tuyl, 4260.

Rocky Mountain Nat. Park: Effinger, 1143.

South Park: Stark, 3836

Continents, motion, and mountain building: Gunn, 1566

Origin and motion: Gunn, 1567.

Stable platform areas: Moore, 2792.

Cordilleran systems, American, development: Stille, 3902.

Syncline-shifting: Stille, 3903 .

Cuba, Santa Clara Province, nortbern : Rutten, 3463.

Deformation of earth's crust, Paleozolc : Moore, 2787. 
Orogeny-Continued.

European and North American mountain systems: Suess, 3975.

Folded mountains, origin : Prouty, 3147.

Grand Canyon region, Colorado Pateaus : Keyes, 2160.

Greenland : Koch, 2244, 2245.

Christian X's Land, Caledonian: Wegmiann, 4377.

Franz Joseph region: Odell, 2936.

Mexico, Bay of Acapulco: Sânchez, 3484.

Coahuila Peninsula, mountains west of Laguna district: Kellum, 2058: Kelly, 2068.

Pachuca silver district: Wisser, 4567.

Sierra de Parras, Coabuila Peninsula: Imlay, 1905.

Midcontinent region: Keyes, 2181.

Mississippi River arch: Howell, 1866.

Mississippi Valley, upper: Kans. Geol. Soc., 2020.

Modern mountain ranges, origin: Andrews, 72

Montana, Glacier Park, mountains : Fenton, 1228.

Mountain arcs, types: Tokuda, 4135.

Mountain building, east and west coasts, North America: Seidl, 3633.

Phenomenon resembling: Broggi, 466.

Mountain chains, origin : Bruet, 509.

Mountains, North American continent: Brown, 483.

Oklahoma, Arbuckle and Ouachita Mountains : Gardner, 1381.

Ouachita Mountains: Fitts, 1276.

Oregon, Cascade Mountains, North Santiam River section: Thayer, 4061.

Overthrust, Reading, Pennsylvania: Stose, 3947.

Paleozoic, in North America: Van der Gracht, 4253.

Pennsylvania, Bellefonte quadrangle: Butts, 598

Periodicity: Keyes, 2115.

Epeirogenic movements: Born, 374.

Pre-Cambrian buried surface in U. $\mathbf{S}$. : Moss, 2811.

Puerto Rico: Meyerboff, 2685.

Quebec, Appalachians : Keith, 2041.

Rocky Mountains, geosyncline, Cretaceous: Keyes, 2096.

Southern: Keyes, 2148.

Sierra Nevada: Lawson, 2356.

Southwestern U. S. : Effinger, 1144.

Structural features, crossing North Atlantic: Baker, 153.

Tectonic relations, North America and Europe: Stille, 3901 ; Suess, 3976.

Texas, Arbuckle and Ouachita Mountains: Gardner, 1381.

East of Pecos River : Sellards, 3638.

Llano region: Stenzel, 3868.

Southern Permian basin: Kinkel, 2217.

Trans-Pecos: Baker, 145; structural features: King, 2211.
Orogeny-Continued.

Trinidad: Kugler, 2280 ; Lehner, 2381.

Utah, central : Spieker, 3806.

Virginia, Devonian fold, Botetourt County : Holden, 1776.

Structural pattern: Bevan, 312.

West Indies: Meyerhoff, 2685 ; Rutten, 3461.

Oscillation. See Changes of level.

Ostracoda. See also Crustacea.

Bairdia subdeltoidea, Oligocene, Alabama: Howe, 1834.

Black Hills, Jurassic, South Dakota : Harper, 1635.

Carboniferous, revision: Kellett, 2046.

Cavellina nebrascensis, Pennsylvanian, Nebraska : Lalicker, 2292.

Choctawhatchee Mi ocene, Florida: Howe, 1839

Chouteau formation, Missouri : Morey, 2798.

Cretaceous, Texas: Alexander, 26.

Cypridella and Cypridinella, KansasMissouri Pennsylvanian: Rogers, 3340 .

Cytheridea, shell structure, Tertiary: Stephenson, 3882.

Devonian, Silica shale, Obio: Stewart, 3897.

Eucythere, Tertiary, Mississippi : Howe, 1841.

Gulf Coastal Plain, Cretaceous, Arkansas: Israelsky, 1910.

Hull and Decorah formations, Ontario and Iowa: Kay, 2028.

Indiana, Flat Rock Creek, Silurian : Coryell, 880 .

Jackson Eocene, Louisiana : Howe, 1838.

Jonesites, new name for Placentula: Coryell, 879.

Louisiana, Vicksburg Oligocene: Howe, 1846.

Microfauna, Monmouth and Rancocas groups, New Jersey: Jennings, 1944.

Microfossils, Potamides matsoni zone, Louisiana: Stephenson, 3881.

Mississippian, Callaway County, Missouri: Morey, 2796.

Wyoming: Morey, 2797.

Missouri, St. Louis Pennsylvanian outlier: Kellett, 2046.

Nebraska, Big Blue series: Upson, 4241.

Missouri series: Johnson, 1978.

Oklahoma, Permian, Caddo County: Harris, 1642.

Ontario, Devonian, Arkona: Coryell, 881.

Pennsylvania and West Virginia, Nineveh limestone: Holland, 1779.

Pennsylvanian, lower, central Missouri: Bailey, 133.

Oklahoma : Bradfield, 414.

Pennsylvanian and Permian, Kansas: Kellett, 2045. 
Ostracoda-Continued.

Primitiidae and Beyrichiidae, revision, Devonian, Pennsylvania: Swartz, 3991.

Tennessee, western, Devonian: Wilson, 4532.

Texas, Cretaceous: Alexander, 27.

Theriosynoecum for Morrisonia, preoccupied : Branson, 439.

Overthrusts.

Alberta, foothills structures: Link, 2422.

Metamorphic terranes: Balk, 161; Knopf, 2240.

Virginia, southwestern, zinc and lead region: Currier, 936.

oxides, opaque, and sulphides, in common igneous rocks: Newhouse, 2862.

Ozarkian question: Kobayashi, 2241.

Paleobotany. See aiso I'aleontology: Lull, 2485 ; Wieland, 4475.

Alaska, Glacier Bay, interglacial forests: Cooper, 870, 871.

Tertiary: Follick, 1780.

Alethopteris grandifolia, Carboniferous, Ohio: Arnold, 88.

Algae as rock builders: Johnson, 1975.

Amber, Cedar Lake, Manitoba: Walker, 4323.

Mexican: Buddhue, 537.

Apostle Islands, Nipissing flora, Wisconsin: Wilson, 4544.

Archaeopteris, Devonian, Pennsylvania : Arnold, 89.

Archaeopteris macilenta and A. sphenophyllifolia of Lesquercux: Arnold, 92.

Berberis caplani, Miocene, Colorado: Cockerell, 793.

Blue Mountains, Miocene, Oregon : Oliver, 2950

Calamopitys, Devonian, New Yo:k: Thomas, 4083.

California, Mojave petrified forest: Stock, 3936.

Tertiary, Trinity County : MacGinitie, 2531.

Callixylon, Devonian, near Ada, Okla.: Miser, 2750.

Carboniferous floras, eastern U. S. and western Europe: Jongmans, 2011.

Forest, Mazon Creek, Ill. : Noé, 2900.

Cedarville Tertiary flora, Nevada and California : LaMotte, 2309.

Cedrela, Miocene, Sucker Creek, Oregon : Arnold, 95.

Cenozoic floras, succession and distribution, norther'n Pacific basin: Chaney, 728 .

Charophyta, Paleozoic: Peck, 3040.

Cladoxylon dawsoni, Devonian, New York : Read, 3206.

Coal flora: Bertrand, 305.

Coals, Cretaceous, Greenland: Miner, 2745.

Cretaceous, Tertiary, Montana : Miner, 2745 .
Paleobotany-Continued.

Coals-Continued.

Microscopic features, Alberta: Jones, 2005 ; Thiessen, 4072.

Colorado, Mosquito Range, Paleozoic folmations: Johnson, 1970.

Comstock flora, Eocene, Oregon: Sanborn, 3481.

Conifers, Lower Cretaceous, Maryland and North Dakota: Brown, 490.

Copper replacement minerals: Ward, 4335.

Cordaites missouriense, Carboniferous, Missouri : Cribbs, 898.

Correlations and provinces, floral, Carboniferous: Jongmans, 2012.

Corylus, Pleistocene, California : Mason, 2596.

Cretaceous, western Greenland: Seward, 3644.

Crinoid stems on fossil wood, Devonian, Indiana: Wickwire, 4472.

Cycadeoid investigations: Wieland, 4473.

Cycad forest, Black Hills, South Dakota: Anonymous, 4712.

Dadoxylon steidtmannii, Carboniferous, Illinois: Miner, 2746.

Devonian, Kentucky : Read, 3208.

New York: Arnold, 86.

Scaumenac Bay, Quebec: Arnold, 91.

Diicbnia kentuckiensis, Deronian, Kentucky : Read, 3207.

Ellensburg flora, Miocene, central Washington : LaMotte, 2306.

Etching of Illinois coals, chrome-sulphuric acid: McCabe, 2493.

Ferns, Roseburg, Oregon: Wharton, 4438.

Ficus aquiana, Eocene, Virginia : Berry, 302.

Flora in coal balls, Pennsylvanian, Illinois : Graham, 1491

Floras, Tertiary, distribution : Chaney, 729.

Forests, Oregon: Sanborn, 3482 .

Fossil forests as compass of the past: Krystofovich, 2276.

Fossils, Miocene lake, Colorado: Caplan, 675 .

Fraxinus nigra, Pleistocene, New York: West, 4423.

Gilbon petrified forest, New York: Goldring, 1462.

Ginkgo forests, Wahington : Beck, 249, 251, 254.

Glacial and postglacial vegetation : Sears, 3626 .

Glyptostrobus in America: Brown, 493.

Grasses, Kansas, Colorado, and $\mathrm{Ne}$ braska : Elias, 1155.

Greenland, east, Scoresby Sound: Harris, 1643 .

Moor : Iverson, 1913.

Plants from Kingigtok and Kagdlunguak: Seward, 3644.

Green River and Florissant floras, relation : Cockerell, 794. 
Paleobotany-Continued.

Gymnosperms, fossil: Wodehouse, 4570. Humus stratigraphy, Oklahoma: Sears, 3625 .

Idaho, Sucker Creek, Miocene: Brooks, 470.

Tertiary flora: Dorf, 1069.

Illinois, Volo bog, Lake County : Artist, 97.

Insects, borings in fossil woods : Brues, 508.

Iowa, pollen analysis, East McCulloch peat bed : Lane, 2332.

Kansas, late Paleozoic plants: Elias, 1156.

Laccopteris galleyi, Cretaceous, Kansas : Miner, 2744.

Lake, Cladophora, and coal balls: Kindle, 2200.

Lake Michigan region, postglacial vegetation: Fuller, 1359.

Land connection, Asia and North America, indicated by fossil trees: Berry, 298.

La Porte flora, Plumas County: Potbury, 3110.

Leaves, dicotyledonous, Cretaceous, Texas: Ball, 173.

Fruits, seeds, Miocene, Washington, Idaho, Oregon: Brown, 489.

Lepidocarpon sporangia, Carboniferous, Illinois : Reed, 3216.

Lepidostrobus gallowayi, Devonian, Pennsylvania: Arnold, 87.

Lepidostrobus kentuckiensis for L. fischeri: Scott, 3603.

Life, ancient, distribution around $\mathrm{Pa}$ cific Ocean: Williams, 4516.

Mahonia, Tertiary, Oregon : Arnold, 93.

Manitoba, Canadian amber with insects: Carpenter, 681.

Chemawinite, Canadian amber: Walker, 4319.

Marine plants and Pacific paleogeog. raphy: Setchell, 3642.

Miocene, Washington : LaMotte, 2308.

Maryland, Archaeomonadaceae: Deflandre, 1002.

Mesozoic plant food and mammallan evolution: Werner, 4411.

Michigan, pollen from bogs: Houdek 1805.

Montana, algal flora, pre-Cambrian : Fenton, 1233.

Nevada. flora, Miocene, from 49 Camp LaMotte, 2303.

Gold in petrified wood, Aspen District, Churchill County: Palmer, 2996. 2997.

Plants in Nothotherium dung, Gypsum Cave : Laudermilk, 2346.

New Jersey and New York, late Pleistocene marine and glacial: MacClintock, 2504.

New York, Skaneateles quadrangle: Smith, 3746.
Paleobotany-Continued.

Ohio, glacial and postglacial plant migrations: Braum, 450.

Mud Lake bog, pollen analysis: Sears, 3623.

Oldhamia, supposed, Kensse!aer grit: Ruedemann, 3414.

Oligocene florule, Vancouver Island, British Columbia: LaMotte, 2305.

Oregon, cone, Mosier: Lazell, 2362.

Croaked River basin: Anonymous, 4708.

Petrified woods : Forbes, 1305.

Teredo burrows in fossilized wood, Roseburg: Wharton, 4436.

Origin of the angiosperms: Cockerell, 792.

Ovate bodies on fossil ground sloth hair: Hausman, 1650.

Paleozoic fossils, Ordovician, Tennessee: Bassler, 227.

Paleozoic plants, Midcontinent region: Elias, 1158.

Paleozoic plants and environment: Arnold, 94.

Palms, fossil: Noé, 2902.

Passage Hills, east Greenland, Devonian : Säve-Söderbergh, 3468 .

Pennsylvania, coal flora, Wilkes-Barre and Pittsburgh region: Darrah, 975.

Pennsylvanian flora, Kansas: Moore, 2790.

Pennsylvanian, lower, central Missouri : Bailey, 133.

Pensauken formation, Pleistocene, New Jersey: Berry, 299.

Permian, early, flora of America : White, 4454.

Petrified forests: Wieland, 4474.

Petrified wood with teredo borings : Hughes, 1878.

Picea canadensis, Pleistocene, Missouri : Hansen, 1623.

Piceoxylon cf. laricinoldes, Jackson Island, east Greenland : Høeg, 1772.

Pinus collinsi, Miocene, Maryland : Berry, 303.

Plant distribution as guide to age determination: Chaney, 730 .

Pleistocene, Fairbanks, Alaska: Chaney, 731.

Pollen analysis, Hartford, Mich., bog: Osvald, 2970.

Indiana lake and bog sediments: Houdek, 1806.

Indicating postglacial climate: Sears, 3624.

Pollen profiles, type: Sears, 3627 .

Polyporites stevensoni, Cretaceous, North Dakota: Brown, 494.

Pre-Kansan Minnesota peat bog: Nielsen, 2884.

Prunus ca! vertensis, Miocene, Virginia : Berry, 303.

Pseudotsuga taxifolioidea, Miocene, Oregon: Arnold, 90. 
Paleobotany-Continued.

Quebec, Matamek River peat bog, pollen analysis: Bowman, 408.

Redwood, fossil, Nevada: Walker, 4317.

Sapindus oregonianus, Miocene, climatic implications : LaMotte, 2301.

Saskatchewan, Cretaceous, Berry, 300.

Schilderia adamanica, Triassic, Arizona: Daugherty, 981.

Seed ferns, Paleozoic, decline: Krick, 2259.

Selenium in Cretaceous vegetation, Wyoming: Beath, 248.

Sequoioxylon pearsallii, Miocene, Colorado: Andrews, 73.

South Dakota, Fossil Cycad National Monument, Black Hills: Anonymous, 4711.

Spores of Illinols coal No. 6: Schopf, 3575.

Spruce in western Miocene: Beck, 253.

Spruce cones, Grass Lake, Illinois: Anonymous, 4709 .

Systematic revisions, Miocene, 1934-36 : LaMotte, 2310.

Taeniopteris, Carboniferous, Pennsylvania: Darrah, 976.

Tempskya, fleld identification, Cretaceous fern: Brown, 492.

Teredo borings in petrifled wood; Ross Island, Oregon: Lazell, 2360.

Tertiary flora, southwestern Idaho: Dorf, 1070.

Tilia, Miocene, Oregon : LaMotte, 2304.

Torreya antiqua, Cretaceous, North Carolina: Boeshore, 364.

Trochiliscaceae, Devonian, Missourl : Peck, 3043.

Trochillscilds, Carboniferous and Devonian, North America: Hacquaert, 1593.

Trochiliscus, Devonian, Kentucky and Obio: Hacquaert, 1591.

Utah, fossil trees: Pulver, 3153.

Walchia, Permian, Pennsylvania and New Brunswick: Darrah, 978.

Washington, Ginkgo Petrifted Forest: Martín, 2591.

Upper Miocene florules: LaMotte, 2307.

Yakima basalts with fossils: Beck, 250.

West Virginfa, Alma bed coal, Spruce River no. 4 mine: Fieldner, 1255.

Wood, Devonian, Kettle Point, Lake Huron, Ontario: Russell, 3427.

Fossil. identification: Bailey, 129.

Tertiary, Washington: Anonymous, 4700.

Yellowstone National Park, petrified forest: Cbapman, 735.

Xylomites cycadeoideae, Cretaceous, New Jersey : Chrysler, 751.

Paleobiology, Jurassic mammais: Simpson, 3714.
Paleoclimatology. See also Geologic history.

Climatic implications, Sapindus oregonianus, Miocene : LaMotte, 2301.

Fauna, Pacific coast, evolution : Howell, 1848.

Gulf border salt deposits, origin: Russell, 3445 .

Humus stratigraphy, Oklahoma: Sears, 3625.

Peat deposits, correlation, time units and climatic changes: DachnowskiStokes, 847.

Fostglacial climate, eastern North America : Sears; 3624.

Paleoecology: Twenhofel, 4201.

Arthropoda: Raymond, 3205.

Black mud shales, eastern New York: Ruedemann, 3403.

Cedarville Tertiary flora, Nevada and California: LaMotte, 2309.

Effect on historical geolngy : Twenhofel, 4200.

Foraminifera, Paleozolc, relationships and ecology: Cushman, 943.

Illinois, Volo bog, Lake County : Artist, 97.

Marine biology : Fish, 1266.

New Jersey, tidal lagoon, bottom conditions; Barnegat Bay : Lucke, 2477.

Paleozoic plants and environment: Ar. nold, 94.

Midcontinent region: Elias, 1158.

Spongiae: deLaubenfels, 1016.

Trilobites, habits: Scheville, 3556.

Vertebrata: Case, 697.

Viewpoints and objects: Fenton, 1227.

Paleogeographic maps.

Arizona, Grand Canyon, Tonto group : Wheeler, 4446.

California, southern: Reed. 32:31.

Kansas, regional investigations in ofl fields: Hiestand, 1737.

Land and sea connections, Central America and West Indies: Rutten, 3460.

Mexico, Coabuila Peninsula: Kellum, 2057.

northwestern: Kellum, 2054.

New England, Taconle thrustings: Kay, 2033.

Oil flelds, distribution and continental spreading: Wade, 4300.

Oklahoma, regional Investlgations in oil flelds : Fiestand, 1737.

Ozarkian : Kobayashi, 2241.

South Carolina, Coastal Plain, Cooke, 847.

Paleogeography. See also Geologic history; Paleoclimatology; Paleogeographic maps.

Antillean-Caribbean region: Schuchert, 3579.

California, southern, Eocene: Reed, 3230 . 
Paleogeography-continued.

Land and sea connections, Central America and West Indies: Rutten, 3460 .

Land bridge, Siberia to Alaska: Berry, 298 ; Smith, 3763.

Life, ancient, distribution around Pacific Ocean: Williams, 4516.

Oklahoma and Kansas, oil fields: Hiestand, 1737.

Pacific Ocean: Setchell, 3642.

Permian sequences, correlation : Schuchert, 3580 .

Texas, Catahoula formation, Fayette County : Bowling, 407.

Wyoming, northwestern, Cambrian: Miller, 2714.

Palcometerology. See Paleoclimatology.

Paleontology : Hawkins, 1655 ; Lull, 2485. For areal sce names of States. See also the classes of animals and Invertebrates (general) ; Evolution; Paleobotany ; Problematic organisms; Restorations.

Acila, pelecypod, valid species: Schenck. 3540.

Algae as rock builders: Johnson, 1975.

Allogenotype, new term: Howell, 1859.

Biotic sequence by volcanic ash falls: Keyes, 2142.

Corals, nomenclature and type spectes: Wells, 4391.

Description, method of: Phleger, 3078.

Diplotype, new term: Knight, 2234.

Dipnoans, development of cranial roof: Romer, 3351.

Illustrations, Paleontologic, preparation: Reeside, 3232.

Invertebrate: Croneis, 921.

Text-books: Twenhofel, 4192.

Landscapes showing ancient life : Knight, 2233.

Life, ancient, distribution around $\mathrm{Pa}$ cific Ocean: Williams, 4516.

Mammalian fauna, local and continental, relationships: Simpson, 3723.

Mexico, Tampico Embayment: Barker, 182.

Mollusca, nonmarine: Henderson, 1703.

Paleoecology, effect on : Twenhofel, 4200.

Paleontologic researches: $M$ erriam, 2671.

Paleozoic corals Heliolites, Tetraduim and Chaetites: Okulitch, 2948.

Pelecypods, nuculid, classification : Schenck, 3537.

Pelvis, from fish to man: Gregory, 1527.

Photomicrography in oil industry : Sneigr, 3778 .

Pravognathus for Heterognathus Stauffer: Stauffer, 3841 .

Report on fossil echinoderms: Jackson, 1923.

Report on invertebrate paleontology: Raymond, 3194.

Report on vertebrate paleontology: Romer, 3345 .
Paleontology-Continued.

Type specimens, catalog, Univ. Cincinnati Mus.: Chappars, 737.

\section{Cambrian.}

Alabama, larval stages, trilobites, Cherokee County : Lalicker, 2291.

Alaska, brachiopods : Cooper, 865 .

Briscoia fauna: Kobayashi, 2242.

Alberta, Inglefieldia? birdsalli : Howell, 1863.

Brachiopods, Ozarkian and Canadian : Ulrich, 4216.

British Columbia, mid-Cambrian Arthropoda: Raymond, 3199.

California, Marble Mountains fauna: Mason, 2597.

Canada, northwestern, trilobites: Kobayashi, 2242.

Edrioasteroidea: Bassler, 232.

Faunas, northern hemisphere: Howell, 1862.

Greenland and Labrador, Foraminifera : Howell, 1852.

Labrador, Cyathospongia: Okulitch, 2945.

Massachusetts, Paradoxides fa u a : Howell, 1860.

Missouri, trilobitcs, Bonneterre dolomite: Lochman, 2431.

Montana, trilobites: Kobayasbi, 2242.

Montana and Wyoming, faunas: Howell, 1861.

Nevada, Cyathospongia: Okulitch, 2945.

Faunas, Goodsprings and Sheep Mountain : Mason, 2598.

Trilobites: Kobayashi, 2242.

New Brunswick, Agnostians: Howell, 1851.

Paradoxides matthewi: Howell, 1855.

Protaspides of trilobites: Raymond, 3200 .

St. Croixan, Upper Cambrian, faunas, type region: Raasch, 3163.

Trilobites, nomenclature: Resser, 3250, 3252.

. Vermont, Agnostian trilobites, St. Albans : Howell, 1850.

Faunas: Raymond, 3204 .

Wisconsin, Baraboo area : Raasch, 3162.

Wyoming, trilobites: Miller, 2713.

Carboniferous.

Arizona, Conularia kaibabensis, Permian : McKee, 2539.

Mississippian Burlington fauna : Keyes, 2110.

Paleozoic formations: Stoyanow, 3959.

Paradise formation, fauna: Hernon, 1714.

Arkansas, conodonts, Mississippian, Caddo Gap : Cooper, 857.

Griffithides conwayensis, Pennsylvanian, Conway County: Whceler, 4443.

British Columbia, anthracolithic corals, Permian, Similkameen district: Smith, 3770 . 
Paleontology-Continued.

Carboniferous-Continued.

British Columbia-Continued.

Cache Creek Permian series: Crockford, 916.

Cephalopods, Permian: Miller, 2706.

Permian, cephalopods : Miller, 2708.

Bryozoa : Bassler, 231.

Callfornia, trilobites, Shasta County: Wheeler, 4442.

Cephalopoda, Pennsylvanian, Kansas and Oklahoma: Newell, 2859.

Charophyta, Paleozoic: Peck, 3040.

Corals, Misissippian: Grove, 1558.

Colorado, footprints, red beds near Boulder : Toepelmann, 4134.

Mosquito Range, Paleozoic formations: Johnson, 1970.

Staffella, Pennsylvanian, McCoy: Thompson, 4098.

Faunal stratigraphy and goniatite phylogeny : Bisat, 326.

Flora of America, early Permian : White, 4454.

Gastropoda, Paleozoic: Knight, 2235.

Greenland, east, Godthaab Gulf, vertebrate beds : Nielsen, 2892.

Illinois, coal-ball flora, Pennsylvanian : Graham, 1491.

Dadoxylon steidtmannii : Miner, 2746.

Forest, Mazon Creek : Noe, 2900.

Lepidocarpon sporangia: Reed, 3216.

Siliceous sponge spicules, Pennsylvanian: Weller, 4382.

Indiana, coprolites in Salem limestone: Shrock, 3698 .

Ditomopyge, adolescent development : Weller, 4383.

Siliceous sponge spicules, Pennsylvanian : Weller, 4382.

Iowa, Chouteau limestone fauna: Keyes, 2122.

Rockford fauna from Arizona: Keyes, 2185.

Kansas, Artinskia whortani, Permian: Miller, 2710.

Ditomopyge, adolescent development: Weller, 4383.

Flora, Pennsylvanian : Moore, 2790.

Insects : Tillyard, 4121.

Ostracodes, Pennsylvanian and Permian : Kellett, 2045.

Pennsylvanian invertebrates: Newell, 2856.

Permian insects: Carpenter, 683.

Kentucky; Productella wayensis, Mill Springs: Brill, 459.

Lithostrotionella: Hayasaka, 1657.

Midcontinent region: Keyes, 2181.

Missouri, Allagecrinus americanus, Mississippian : Peck, 3041.

Central, lower Pensylvanian: Balley, 133.

Cordaites missouriense: Cribbs, 898.

Microcrinolds, Lower Mississippian : Peck, 3042.
Paleontologr-Continued.

Carboniferous-Continued.

Missourt-Continued.

Münsteroceras mitchelli, Burlington: Miller, 2703.

Ostracoda, Chouteau formation : Morey, 2798; Mississippian, Callaway County: Morey, 2796.

St. Louis Pennsylvanian outlier fauna : Kellett, 2046.

Strophalosia, Mississippian, St. Louis County : Hinchey, 1743.

Structure in Productus coloradoensis, Pennsylvanian : Girty, 1438.

Nebraska, Cavellina nebrascensis, Pennsylvanian : Lalicker, : 2292.

Ostracoda, Big Blue series: Upson, 4241; Missouri : series: Johnson, 1978.

Nova Scotia, corals : Lewis; 2407.

Ohio, Alethopteris grandifolia, Summit County : Arnold, 88.

Angustidontus gracilis, Mississippian : Cooper, 859.

Permian fusulinfds: Thompson, 4101.

Oklahoma, Allagecrinus strimplei, Pennsylvanian: Kirk, 2219.

Angustidontus seriatus, Mississippian : Cooper, 859.

Asteriaform fossils, Francis formation: Jones, 1999.

Fususlinids, 10 w.e r Pennsylvanian: Thompson, 4099.

Ostracoda, Pennsylvanian, Ardmore Basin : Bradfleld, 414; Permian, Caddo County : Harris, 1642.

Pennsylvanian invertebrates: Newell, 2856.

Staffella, Pennsylvanian, Coal County: Thompson, 4098.

Ostracoda : Kellett, 2046

Pedicellariae, Texas, Illinois, Missourt: Geis, 1401.

Pennsylvania, coal flora, Wilkes-Barre and Pittsburgh region : Darrah, 975.

Taeniopteris, Monongahela City : Darrah, 976.

Pennsylvania and New York, Archaeopteris macilenta and $A$. sphenophyll! folia of Lesquereux : Arnold, 92.

Schizoblastus, Osage group, Iowa and Missouri : Cline, 779.

South Dakota, fusulinids, Pennsylvanian, Black Hills: Thompson, 4100.

Tetrapods, Ohio, Pennsylvania and West Virginia : Burke, 579.

Texas, Eurylepidoides socialfs, Dundee: Case, 693.

Flying reptle, Permian, Castle Peak: Mathews, 2609.

Red beds, vertebrates: Romer, 3347 .

Rugose coral, lower Permian: Heritsch, 1713.

Trimerorhachis, Archer County : Case, 692.

$311-37-29$ 
Paleontology-Continitéd: ;: "

Carboniferous - Continued.

Texas-Continued."

Waagenophyllum, Permian: Heritsch, 1712.

Texas and Mexico, Parafusulina, dimorphism : Dunbar, 1091.

Trilobite genera: Weller, 4387.

Virginfa, Protocanites lyoni, Mississippian : Mifer, 2705.

Walchia, Pennsylvania and New Brumswick: Darrah, 978.

West Virginia, Alma bed coal, Spruce River no. 4 mine: Fieldner, 1255.

Wyjoming, Casper formation, Cephalopoda: Miller, 2712.

Cephalopods, Phosphoria formation, Permian : Miller, 2699.

Fusulinids, Pennsylvanian, B l a c k Hills: Thompson, 4100:

Ostracoda, Mississippian: Morey, 2797.

Punctospirifer pulchra, Permian: 'Thomas, 4085.

\section{Cretaceous.}

Alabama, Diploschiza molleni: Stephenson, 3876 .

Giant turtle and mososaur: Anonymous, 4676.

Greene County, reptiles : Renger, 3245 .

Alberta, dinosaurs: Parks, 3013.

Fauna Milk River beds: Russell, 3430.

Hooded hadrosaurs: Sternberg, 3884.

Lea Park shale fauna: Warren, 4348.

Arizona, faunas, Bisbee: Stoyanow, 3960.

Pleslosaur, Black Mesa: O'Connell, 2934.

Arkansas, Ostracoda, Gulf coastal plain : Israelsky, 1910.

California, diatoms, Panoche Hills: Hanna, 1615.

Dinosaur, Patterson : Hesse, 1730.

Canada, western, mammals: Russell, 3434.

Coals, microscopic features, Alberta: Jones, 2005.

Crustacea, Atlantic and Gulf Coastal Plain : Rathbun, 3184.

Cuba, Foraminifera, Santa Clara Province : Rutten, 3462.

Orbitoldes, Havanna Province: Gravell, 1505.

Rudistids, Santa Clara Providence: Rutten, 3464.

Georges Bank fossils : Stephenson, 3878.

Foraminifera : Cushman, 944.

Plethopora americana: Bassler, 230.

Greenland, coals, paleobotanic examination : Miner, 2745.

East: Bøgvad, 361; Frebold, 1332.

Koldewey Island : Frebold, 1333.

Western, plants : Seward, 3644.

Jamaica, corals: Wells, 4390.

Kansas, Cephalopoda: Morrow, 2803.

Hierosaurus coleii, Gove County: Mehl, 2630.
Paleontology-Continued.

Cretaceous-Continued.

Kansas-Continued:

$\therefore$ Laccopteris galleyi, Mankato : Miner, 2744.

Manitoba, amber, Cedar Lake, fauna: Walker, 4323.

Trinacromerum kirki : Russell, 3432.

Maryland, conifers, Northwest Branch : Brown, 490.

Mexico, Echinodermata, San Louis Potosi : Lambert, 2295.

Echinoids: Müllerried, 2812.

Mollusca, Lower California: Anderson, 65.

Mexico and Texas, Cephalopoda, Rio Grande : Renz, 3249.

Mississippi, Diploschiza melleni : Stephenson, 3876.

Montana, coals, paleobotanical examination: Miner, 2745.

Meniscoëssus, Ekalaka : Simpson, 3720.

Paleocene mammals : Simpson, 3715.

New Jersey, Breviarca haddonfieldensis for Trigonarca saffordi: Stephenson, 3875 .

Microfauna, Monmouth and Rancocas groups : Jennings, 1944.

Xanthias lenolensis: Rathbun, 3185.

Xylomites cycadeoideae, Woodbridge: Chrysler, 751.

New Mexico, Reptilia, Kirtland formation: Gilmore, 1434.

North Carolina, Torreya antiqua, Fayetteville: Boeshore, 364.

North Dakota, conifers, near Mandan: Brown, 490.

Polyporites stevensonl, Wade; Brown, 494.

Opossums, recent and fossil, classification: Simpson, 3717.

Oregon, forests: Sanborn, 34\$2.

Ostreidae, Gulf region: Stephenson, 3877.

Saskatchewan, floras, Whitemud and Ravenscrag formations: Berry, 300 .

Lea Park shale fauna : Warren, 4348.

South Carolina, Myrtle Beach, invertebrates: Prouty, 3138.

Tempskya, fleld identification, fern : Brown, 492.

Texas, dicotyledonous leaves, Erath County : Ball, 173.

Echinoids, trans-Pecos: Smiser, 3744.

Navarro-Taylor diagnostic Foraminifera: Plummer, 3099.

Ostracoda : Alexander, 26, 27.

Pteranodon : Gilmore, 1435.

Trinidad, Northern Range fauna: Trechmann, 4161.

Toco Bay, sponges and coral : Thomas, 4084.

Venericardia beaumonti : Rutsch, 3458.

Verneuilinidae, Valvulinidae and Virgulinidae: Cusbman, 945. 
Paleontology-Continued:

Oretaceous-Continued:

Wyoming, selenium in vegetation: Beath, 248.

Triceratops eurycephalus, Goshen County: Schlalkjer, 3558.

Devonian.

Alberta, fish, Triassic and Devonian, Canadian Rockies : Warren, 4849.

'Timanites occidentalis, Jasper Park: Miller, 2711.

Ammonoidea : Miller, 2704.

Arizona, Paleozolc formations: Stoyanow, 3959.

Catskill magnafacies, seaward phase: Caster, 703.

Charophyta, Paleozolc: Peck, 8040.

Colorado; flsh : Bryant, 530.

Devonian, Middle, mid-West: Cooper, 864.

Edrioasteroidea : Bassler, 232.

Greenland, east, Gauss Peninsula and Passage Hills: Săve-Söderbergh, 3468.

East, labyrinthodont stẹgocephalians and primitive Reptilla : Süve-Söderbergh, 3469 .

East, Placoderml; Stensio, 3885.

Indiana, crinold stems on fossil wood: Wickwive 4472.

Tabulate corals Falls of the Ohlo: Werner, 4420.

Iowa, ammonoids: Miller, 2701.

Athyris and Cyrtina: Fenton, 1226.

Atrypa : Fenton, 1232.

Crinolds, Cedar Valley formation: Laudon, 2350.

Phacopinae : Delo, 1020.

Kentucky, Dlichnia kentuckiensis : Read, 3207.

Flora: Read, 3208.

Tabulate corals, Falls of the Ohio: Werner, 4420.

Michigan, southeastern, Dundee limestone: Balley, 223.

Missouri, Gruenewaldtia : Greger, 1520. Trochiliscaceae : Peck, 3043.

Montana, Pterygotus: Ruedemann, 8404.

Nanicella, for Endothyi'a gallowayi: Henbest, 1692.

New Hampshire, Brachiopoda, in mica schist, Mount Clough: Billings, 819.

New Mexico, fauna, Sacramento Mountains : Stainbrook 3816.

New York, annelia Jaws, Hamllton, Ontario County : Eller, 1161.

Blastolds: Reimann, 3240.

Calamopitys, Taughannock Gorge: Thomas, 4083.

Cephalopods, Connewango : Flower 1291.

Cherry Valley cephalopods: Flower, 1292.

Cladoxylon dawsoni, Canadalgua Lake: Read, 8206.
Paleontology-Continued:

Devonian-Continued.

New York-Continued.

Crinoids : Goldring, 1464 ; 1465, 1466.

Dipleura dekayi, young stages: Cooper, 861.

Echinocaris, Alfred Station: Wller, 1163.

Eurypterus (Stylonurus?) maccarthyi : Kjellesvig, 3215.

Faunal differentiation: Chadwick, 706.

Fishes : Bryant, 527.

Gilboa petrifled forest: Goldring, 1482.

Otarion ball, Hamilton group, Erie. County : Wheeler, 4441.

Plants : Arnold, 86.

Pseudohydnoceras erraticum: ReImann, 3239.

Pterygotus: Ruedemann, $\mathbf{3 4 0 4 .}$

Terataspis grandis, giant trllobite : Reimann, 3242.

New York, Tully formation: Cooper. 862.

Ohio, Ostracoda, Silica shale: Stewart, 3897.

Oklahoma, Phacopinae: Delo, 1020.

Ontario, Homalophyllum thedfordensis: Stewart, 3896.

Ostracoda, Arkona : Coryell, 881.

Wood, Kettle Point, Lake Huron = Russell, 3427.

Pennsylvania, Archaeopteris, McKean County : Arnold, 89.

Cephalopods, Conewango: 'Flower, 1291.

Chemung tracks and trails: Willard, 4487.

Eurypterus arnoldi, McKean County : Eblers, 1147.

Hypothyridina venustula : Willard, 4488.

Lepidostrobus gallowayi, Port Allegany: Arnold, 87.

Onondaga faunas: Willard, 4501.

Ostracoda, revision Primitlidae and Beyrichlidae: Swartz, 3991.

Sauripterus taylori: Gregory, 1524.

Schizodiscus antecrenulus, Pery County : Cleaves, 771.

Spirifer divaricatus: Willard, 4498.

Sporadoceras milleri, Drie County: Miller, 2709.

Phacopid trilobites, revision: Delo, 1019.

Quebec, cephalaspids: Robertson, 3320.

Dipnoan skull roof: Romer, 3350 .

Plants, Scaumenac Bay: Arnold, 91.

Scaumenella mesacanthl: GrahamSmith, 1493.

Stromatoporoidea, systematic position : Parks, 3014, 3015.

Tennessee, western', Ostracoda, Birdsong shale: Wilson, 4532.

Trilobites, Lichadian, revision: Phleger, 3080. 
Paleontology-Continued.

Devonian-Continued.

Trochiliscus, ' Kentucky and Ohlo: Hacquaert, 1591.

Vertebrates, early, environment : Romer, 3346.

Wyoming, eurypterids, Beartooth Butte : Ruedemann, 3407.

Fishes, Beartooth Butte : Bryant, 528. surassic.

Arcidae, classification : Reinhart, 3243.

Arizona, dinosaur, bipedal : Camp, 631.

Greenland, Cape Leslie, Milne Land, invertebrates: Spath, 3798, 3799.

East, Scoresby Sound, plants : Harris, 1643.

Plesiosaur: von Huene, 1876.

Paleobiology, mammals : Simpson, 3714.

South Dakota, Ostracoda, Morrison formation, Black Hills: Harper, 1635.

Utah, Apatosaurus, osteology : Gilmore, 1437.

Wyoming: Crickmay, 901.

Invertebrates, Morrison : Branson, 438.

Sinclair dinosaur expedition, 1934: Brown, 474.

\section{Ordovician.}

Alberta, cephalopods: Ulrich, 4210.

Arizona, Paleozoic formations: Stoy. anow, 3959.

Arkansas, graptolites, Polk Creek shale : Decker, 998.

Batostoma to Fenestella: Sardeson, 3515.

Brachiopods, Ozarkian and Canadian: Ulrich, 4216.

Bryozoa, Leptotrypa to Fustulipora: Sardeson, 3514.

Calapoecia, revision: Cox, 886.

California, auluroid, Barrell Springs : Phleger, 3079.

Canada, northwestern, trilobites: Kobayashi, 2242.

Cephalopods, Ozarkian and Canadian: Ulrich, 4210.

Chazyan corals: Okulitch, 2947.

Colorado, Astraspis and Friptychius, Canon City: Bryant, 529.

Edrioasteroidea : Bassler, 232.

Fulton fauna: Shideler, 3689.

Greenland, north, actinoceroid Cephalopoda: Teichert, 4035.

Illinois, Fernvale formation, fauna : Greger, 1519.

Iowa, cephalopods, Maquoketa shale: Foerste, 1299.

Conodonts, Decorah shale: Stauffer, 3840.

Ostracoda in Hull and Decorah formations: Kay, 2028.

Labrador, fossils : Little, 2426.

Minnesotr, Batostoma and Hemiphragma: Sardeson, 3512.

Conodonts, Decorah shale: Stauffer, 3840; Glenwood beds: Stauffer, 3837 .

Paleontology-Continued.

Ordovioian-Continued.

Minnesota-Continued.

Dekayella praenuntia: S a rdes on, 3507.

Hallopora : Sardeson, 3508.

Homotrypa minnesotensis: Sardeson, 3506.

Monotrypa and Eridotrypa: Sardeson, 3513.

Monticulipora grandis and $\mathbf{M}$. arborea: Sardeson, 3504.

Prasopora simulatrix : Sardeson, 3503.

Missouri, cephalopods: Ulrich, 4210.

Inarticulate brachiopods, Grass y Creek shale, Pike County: Greger, 1516.

New York, Radiolaria in cherts : Ruedemann, 3416.

Northwest Territories, Chaetetes akpatokensis: Oakley, 2928.

Oklahoma graptolites, Simpson group : Decker, 996.

Sylvan shale: Decker, 998.

Viola limestone: Ruedemann, 3402.

Ontario, Ostracoda, in Hull and Decorah formations: Kay, 2028.

Phacopid trilobites, revision: Delo, 1019.

Quebec, cephalopods, Beatricea, Akpatok Island: Foerste, 1301.

Percé : Foerste, 1302.

Fauna Black River group: Okulitch, 2946.

Graptolites near Levis: Ruedemann, 3405.

Whitehead formation, Perce, brachiopods and trilobites: Cooper, 867.

South Dakota, fossils, upper Deadwood formation : Furnish, 1369.

Tennessee, cephalopods : Ulrich, 4210.

Oligorbynchia, Chazy: Cooper, 860.

Paleozoic fossils, Central Basin : Bassler, 227.

Tennessee and Quebec, graptolites: Ruedemann, $\mathbf{3 4 1 5}$.

Tetradium, revision: Okulitch, 2944.

Trilobites, Lichadian, revision : Phleger, 3080.

Utah, graptolites, Logan Canyon and Mount Pisgah : Clark, 764

Vermont, cephalopods : Ulrich, 4210.

Vertebrates, early, environment: Romer, 3346.

Wisconsin, monactellid, spouges : Howell, 1856.

Starfish : Jones, 2006.

Wyoming, Big Horn and related cephalopods : Foerste, 1295.

Pre-Cambrian.

Ancient life : Keyes, 2108, 2113.

Taconic Olenellus fauna, importance: Keyes, 2128.

Quaternary.

Alaská, Pleistocene flora, Fairbanks : Chaney, 731. 
Paleontology-Continued.

Quaternary-Continued.

Arcidae, classiflcation: Relnhart, 3243.

Arizona, egg flled with colemanite: Ward, 4334.

Atlantic Coastal Plain, soutbern Pleistocene fauna: Richards, 3284.

California, Anabernicula 'gracilenta, Pleistocene ; McKittrick : Ross, 3378.

Aves, Manix Lake beds, Mojave Desert: Compton, 824; Pleistocene, McKittrick: Miller, 2722; Rancho La Brea : Compton, 825; Howard, 1824.

Channel Island elephants: Stock, 3923, 3930.

Lateral change of fauna near Ventura : Bailey, 131.

Moris reyana, Pleistocene, Playa del Rey : Howard, 1825:

Mycteria wetmorel, Rancho La Brea, Pleistocene : Howard, 1823.

Parapavo californicus, Pleistocene, La Habra: Howard, 1826.

Peromyscus nesodytes, Pleistocene, Santa Rosa Island: Wilson, 4555.

Pinto Basin site, Pleistocene: Campbell, 635 .

San Pedro Hills, fossils from Pleistocene terraces: Woodring, 4601.

Toxostoma redivivum, Pleistocene, Rancho La Brea : Engels, 1184.

Canada, James Bay, Recent and Pleistocene marine shells: Richards, 3281.

Fost-Plestlocene fosstls, eastern Arctic regions: Nichols, 2871.

Clinocardium, new pelecypod genus: Keen, 2037.

Colorado, Helisoma ammon, Pleistocene : Henderson, 1705 .

Cuba, Mecoliotia bermudezi, Pleistocene: Clench, 778

Fauna, Pacific coast, evolution : Howell, 1848.

Georgia, mammoths and mastodonts, Savannah: Mitchell, 2753.

Glacial and postglacial vegetation : Sears, 3626

Hair, fossil ground sloth, and ovate bodies: Hausman, 1650.

Idaho, Erethizon bethygnathum; Grand View : Wilson, 4553.

Sloths, Pliocene and Pleistocene: Gazin, 1393.

Illinois, mastadon, avian, and other remains, Aurora : Smith, 3746 .

Molluscan fauna, Pleistocene, loess : Baker, 157.

Trumpeter swan, Pleistocene, Aurora: Wetmore; 4432.

Indiana, mammals, Pleistocene: Lyon, 2490.

Pollen, analysis, lake and bog sediments : Houdek, 1806.
Paleontolog 7 Continued.

Quaternary-Continued.

Iowa, Mastodon americanus tusk, Franklin County : Cable, 619.

Mexico, marine Plelstocene mollusks, Oaxaca : Palmer, 2995.

Michigan, Elephas primigenius americanus, Cass County: Case, 691.

Missouri, Picea canadensis, Pleistocene, Macon County : Hansen, 1623.

Mollusks, Pleistocene and recent : Shimek, 3690.

Nebraska, Casteroides, Pleistocene: Wood, 4582.

Nevada, Gypsum Cave, Las Vegas, Pleistocene : Harrington, 1641.

Spizaëtus willetti, Pleistocene, Smith Creek cave: Howard, 1822.

New Jersey, flora of Pensauken formation : Berry, 299.

New Mexif̧o, Burnet Cave, fauna, Guadalupe Mountains: Schultz, 3591.

Clovis area: Stock, 3931.

Clovis fauna, Pleistocene fluvial deposits: Howard, 1816.

Clovis lake clays, Plelstocene : Anters, 79.

Diatoms, Lake beds, Clovis : Lohman, 2439

Man, near Folsom : Figgins, 1256.

New York, Fraxinus nigra, Pleistocene, Orleans County: West, 4423.

Oklahoma, Pleistocene peccary, near Alva: Johnston, 1981.

Symbos, Pleistocene, Chickasha: Stovall, 3955 .

Ursus horribilis oklahomaensis, Pleistocene : Stovall, 3951.

Oregon, forests: Sanborn, 3482.

Yennsylvania, mollusks, Harmonsburg marl : Brooks, 471.

Pleistocene life: Walker, 4314.

Proboscidea, ancestral tree: Osborn, 2959.

Texas, birds, Pleistocene, Pliocene, Hemphill County: Compton, 823.

Pleistocene fauna, Williams Cave, Guadalupe Mts.: Ayre, 125.

West Indies, reef cora]s, Cenozoic, evolution: Gerth, 1407.

Wisconsin, Apostle Islands Nipissing flora: Wilson, 4544.

silurian.

Brachiopoda, Triplesiddae: Ulrich, 4214.

Illinols, Ceratiocaris leesi : Roy, $\mathbf{3 3 9 5}$.

Ceratiocaris markhami: Roy, 3393.

Conularia manni; Roy, 3394.

Indiana, Ostracoda, Waldron shale, Flat Rock Creek: Coryell, $\mathbf{8 8 0}$

Ohlo, crinolds: Foerste, 1303

Oklahoma, graptolites: Decker, 997.

Phyllocarid crustaceans, Carter County : Ruedemann, 3409.

Ontario, Hudson Bay region, cephalopods: Foerste, 1303. 
Paleontology-Continued. Silurian-Continued.

Phacopid trilobites, revision: Delo, 1019.

Quebec, Gaspe Peninsula, cephalopods: Foerste, 1300.

Stromatoporoidea, systematic position: Parks, 3014.

Trilobites, Lichadian, revision: Phleger, 3080 .

Vertebrates, early, environment : Romer, 3346.

Tertiary.

Alabama, Bairdia subdeltoidea, oligocene, Old Fort Stephens: Howe, 1834.

Discocyclina, Eocene, Salt Mountain : Vaughan, 4276.

Foraminifera, Gulf Coast: Hadley, 1594.

Invertebrates, Eocene : Aldrich, 19.

Nonionella cockfieldensis, Claiborne, Eocene : Garrett, 1387.

Venericardia planticosta, Eocene: Chavan, 74.

Zeugmatolepas americana, Eocene: Withers, 4568.

Alaska floras: Hollick, 1780.

Arcidae, classiflcation: Reinhart, 3243.

Arizona, Dipoides williamsi, Pliocene: Stirton, 3910.

Badlands, color records: Germann, 1405 .

Beavers: Stirton, 3907.

British Columbia, Oligocene florule, Vancouver Island: LaMotte, 2305.

Trogosus minor, Eocene: Russell, 3429.

Bryozoa : Bassler, 231.

California, Arctothere, Pliocene: Stock, 3935 .

Artiodactyla, Oligocene, Las Posas Fills : Stock, 3921.

Astrodapsis, Monterey County, Miocene : Richards, 3276.

Aturoidea, Eocene: Miller, 2702.

Aves, Miocene : Miller, '2721.

Cernictis hesperus, Pliocene, San Pablo Bay: Hall, 1606.

Coyrlus, Pleistocene, Montecito, Santa Barbara County : Mason, 2596.

Eohaplomys, Sespe Eocene: Stock, 3914.

Eumysops simplex, Sespe Hocene: Wilson, 4550 .

Foraminifera, Eocene, Ventura County : Cushman, 946.

Fresh-water mollusks, Pliocene, Kettleman Hills: Pilsbry, 3086.

Haliotis elsmerensis, Pliocene, Elsmere Canyon: Vokes, 4292.

Helicina vo kesi, Eocene, Fresno County : Hanna, 1618.

Heteromyid rodents, Pliocene and Miocene: Wood, 4581.

Insectivora, Sespe Eocene: Stock, 3916.

Paleontology-Continued.

Tertiary-Continued.

California-Continued.

Leptoreodon (Hesperomeryx) edwardsi, Sespe Eocene: Stock, 3928.

Merychippus zone fauna, Coalinga district: Bode, 355.

Miocene marine mammals, Bakersfield region: Wilson, 4546.

Moris vagabundis, Miocene, Granite Creek : Compton, 828.

Oligocene mammal-bearing beds, Death Valley: Stock, 3924.

Palos Verdes Hills: Woodring, 4603.

Peratherium callfornicum, Sespe Eocene : Stock, 3926.

Perissodactyla, Sespe Eocene: Stock, 3927.

Protitanops curryi, Oligocene, Titus Canyon formation: Stock, 3934.

Protohippus tehonensis, San Joaquia Valley: Stock, 3919.

Rodents, Oligocene, Las Posas Hills: Wilson, 4548.

Teeth, protohippine horses, Miocene, Coalinga district: Bode, 354.

Teleodus callfornicus, Sespe Eocene: Stock, 3920.

Velates, Eocene: Vokes, 4291.

Viverravus (Plesiomiacis) progressus, Sespe Eocene: Stock, 3915.

California and Oregon, middle Eocene faunas: Merriam, 2668.

Canada, western, mammals: Russell, 3434.

Carriacou, West Indies: Trechmann, 4162.

Cedarrille flora, Nevada and Calfornia: LaMotte, 2309.

Cenozolc floras, succession and distribution, northern Paciflc basin: Chaney, 728.

Clinocardium, new pelecypod genus : Keen, 2037.

Colorado, Berberis caplani, Miocene, Creede: Cockerell, 793.

Chrydopidae, Florissant and Creede : Carpenter, 682.

Grasses : Elias, 1155.

Ischyromys, Ollgocene, molars: Friant, 1340.

Miocene lake, fossils: Caplan, 675.

Nemestrinidae, Miocene, Florissant: Bequaert, 283.

Peratherium huntil, Mlocene, Florissant : Gazin, 1392.

Plesiadapis gidleyi, upper Paleocene: Simpson, 3718.

Sequoloxylon pearsallil, M l o cen $\theta$. Florissant : Andrews, 73.

Tiffany fauna, upper Paleocene: Simpson, 3716, 3719.

Titanoides: Patterson, 3022.

Composition, Tertiary faunas: Elllsor, 1173.

Crustacea, Atlantic and Gulf Coastal Plain : Rathbun, 3184. 
Paleontology-Continued.

Tertiary-Continued.

Cuba, Clypeaster pinarensis, oligocene : Lambert, 2294.

Foraminifera, Matanzas Bay region: Palmer, 2991; . Santa Clara Province : Rutten, 3462.

Manati, Oligocene: Duelo, 1087.

Mollusks, Plelstocene, Matanzas and Pinar del Rio provinces: Richards, 3280.

Cytheridea, shell structure: Stephenson, 3882 .

Faunas: Dunbar, 1093.

Florida, Crassatellites (Hybolophus?) leonensis, M loc e ne: Mansfeld, 2575.

Gastropods and schaphopods, Miocene, Alaqua Creek Valley: Mansfield, 2572.

Mollusca, Alum Bluff Miocene : Gard. ner, 1383.

Okeechobee district, Pliocene shells: Smith, 3761.

Ostracoda, Miocene: Howe, 1839.

Ovoviviparous reproduction, Miocene Turritellidae: Sutton, 3984.

Foraminifera, upper 'Eocene, south. eastern United States: Cashman, 941.

Geomyid rodents, western U. S. : Wood, 4580.

Georges Bank, Foraminifera: Cushman, 944.

Glyptostrobus in America: Brown, 493.

Green River and Florissant floras, relation : Cockerell, 794.

Heteromyid rodents, western North America: Wood, 4573.

Idaho, Ceratomeryx prenticel, Pliocene, Hagerman; Gazin, 1394.

Erethizon bethygnathum, Grand view : Wilson, 4553.

Miocene, leaves, fruits, and seeds: Brown, 489.

Plants, Sucker Creek, Miocene: Brooks, 470.

Pliocene horses: Gazin, 1397.

Sloths, Pliocene and Pleistocene: Gazin, 1393.

Snake Rirer Valley : Rice, 3264.

Southwestern, flora: Dorf, 1070.

Jamaica, Eocene corals: Wells, 4390.

Kansas, grasses: Elias, 1155.

Gnathabelodon thorpei, Pliocene, Trego County: Barbour, 176.

Kansasimys dublus, Pliocene, Edson: Wood, 4579.

Loulsiana, Claiborne tentative foraminiferal zonation: Israelsky, 1912.

Decapod crustaceans: Stenzel, 2866.

Foraminifera, larger, Jackson Eocene: Gravell, 1506.

Felícolepidina nortoni, Eocene, St. Landry Parish: Vaughan, 4275.

Jackson Eocene Ostracoda: Howe, 1838.
Paleontology-Continued.

Tertiary-Continued.

Louisiana-Continued.

Microfossils, Potrimides matsonl zone: Stephenson, 3881.

Ostracoda, Vicksburg Oligocene : Howe, 1846.

Mammalian fauna, local and continental, relationshigs: Simpson, 3723.

Mammals, continental Pliocene: Stirton, 3911.

Paleocene, census: Simpson, 3721.

Maryland, Mlocene pearl, Jones Wharf, St. Mary's county : Berry, 297.

Pinus collinsi, Calvert Miocene, Plum Foint: Berry, 303.

Turtles, Calvert County, Miocene : Collins, 809.

Mexico, Foraminifera: Thalmann, 4053 ; Eocene: Nuttall, 2923; Orbitiodal Eocene, Barker, 183.

Mexico and Antigua, Operculina and Operculinoides: Vaughan, 4273.

Mississippi, Bolivinella, Oligocene : Howe, 1832.

Decapod custaceans: Stenzel, 3866.

Eucy there: Howe, 1841.

Foraminifera, Gulf coast: Hadley, 1594.

Foraminifera, larger, Jackson Eocene : Gravell, 1506.

Vicksburg group at Vicksburg : Mornhinveg, 2799.

Mollusca, Venericardia planicosta group. Rutsch, $\mathbf{3 4 5 7 .}$

Montana, coals, paleobotanic examination : Miner, 2745.

Horatiomys montanus, Miocene: Wood, 4572.

Paleocene mammals: Simpson, 3715, 3724.

Pseudocylindrodon neglectus, Oligocene, Fipestone Springs : Burke, $\mathbf{5 8 0}$.

Nebraska, anserine blrd, Pliocene, Keith County: Compton, 828.

Craterogale simus, Dawes County: Gazin, 1398.

Cynodesmus, Pliocene : McGrew, 2532.

Grasses. Elias, 1155.

Mesocyon geringensis, Miocene, Morrill County: Barbour, 177.

Miocene and Pliocene mammals, Valentine: Stirton, 3906.

Miocene dogs: Loomis, 2450.

Miocene hawks: Wetmore, 4433.

Miocene mammals : Colbert, 799.

Ogallala, Pliocene mastodon, Hesse, 1724.

Pliocene antelopes, Cherry County: Furlong, 1366.

Prosthennops nlobrarensis, Brown County : Colbert, 800.

Scotts Bluff National Monument: EPflnger, 1141.

Sloux County, Ollgocene, Palaeolagus haydenl: Dice, 1039. 
Paleontology-Continued.

Tertiary-Continued.

Nebraska-Continued.

Vertebrate fauna, Feldt Ranch, Ogallala: Hesse, 1725.

Nevada, Cupidinus Pliocene, Willow Creek : Chaffee, 716.

Merycodonts, Tonopah, Miocene : Furlong, '1365.

Miocene camel, Eureka County. Cockerell, 791.

New Jersey, Aturoidea, Eocene: Miller, 2702.

Microfauna, Monmouth and Rancocas groups: Jennings, 1944.

New Mexico, insect borings in fossil wood : Brues, 508.

Puerco paleocene Mammalia: Simpson, 3722.

Vertebrata and turkey: Needham, 2844.

North Carolina, Aturia, Eocene : Stenzel, 3867.

Eocene comatulíds: Gíslén, 1439.

Eucrassatella mansfieldi, Pliocene. MacNeil, 2560.

Nonion pizarrensis and Nonion auris, Miocene: Kjellesvig, 2224.

Pliocene Mollusca, Croatan sand: Mansfield, 2574.

Whales, Miocene: Prouty, 3142.

Oklahoma, Pliocene vertebrates, Ogallala, Beaver County : Hesse, 1732.

Opossums, recent and fossil, classification: Simpson, 3717.

Oregon, Cedrela, Miocene, Sucker Creek: Arnold, 95.

Cophocetus oregonensis, Miocene, Otter Creek: Packard, 2979.

Crooked River basin: Anonymous, 4708.

Dipoides stirtoni, Pliocene, Crooked Creek: Wilson, 4549.

Forests: Sanborn, 3482 .

Mahonia, Harney and Malheur Counties: Arnold, 93.

Mammals, Miocene, Sucker Creek : Scharf, 3535 .

Miocene flora, Blue Mountains: Ollver, 2950 ; leaves, fruits, and seeds : Brown, 489.

Northwestern, Marine 01 ig o c e ne: Packard, 2980.

Pseudotsuga taxifolioidea, ' Miocene. Arnold, 90.

Rodents, Miocene John Day Valley: Wood, 4574.

Tilia, Miocene : LaMotte, 2304.

Palms, fossil : Noé, 2902.

Pectinidae, Atlantic and Gulf coast: Rowland, 3389 ; Tucker, 4178.

Index fossils, southeastern U. \$.: Mansfield, 2573.

Proboscidea : Osborn, 2961.

Ancestral tree: Osborn, 2959.

Raphidiodea, Neartic, revision. Carpenter, 684 .

\section{Paleontology-Continued.}

Tertiary-Continued.

Rodents, crecetid: Wood, 4576.

Sapindus oregonianus, Miocene, climatic implications: La Motte, 2301.

South Dakota, coprolite, Oligocene, White River bad lands: Stovall, 3952.

Dogs, Miocene : Lomis, 2450.

Schaubeumys grangeri; Miocene: Wood, 4572.

Sinclarirella, Apatemydiae, White River Oligocene: Jepsen, 1947.

Stylemys nebrascensis, Oligocene : Case, 698.

Vultures, Pliocene, Bennett County : Compton, 827.

White River Oligocene mammals: Scott, 3612.

Texas, Aturia, Eocene: Stenzel, 3867.

Aves; Pleistocene, Pliocene, Hamphill County: Compton, 823.

Borophagus diversidens, Pliocene : Vander Hoof, 4258.

Ceratobulimina, Eocene, structure: Plummer, 3100.

Claibọne tentative foraminiferal zonations: Israelsky, 1912.

Coastal Plain vertebrates: Wood, 4587.

Decapod crustaceans: Stenzel, 3866.

Foraminifera, Conroe oil field: Gravell, 1507.

Jackson group of formations, Foraminifera : Ellisor, 1171.

Larger Foraminifera, Jackson Eocene : Gravell, 1506.

Midway group: Gardner, 1382.

Mollusca, fresh-water, Miocene, Fayette County : McNeil, 2559.

Pediomeryx hemphillensis, Pliocene, Coffee Ranch: Stirton, 3912.

Trinidad, Acila schomburgki, Oligocene : Schenck, 3547.

Foraminifera: Geyn, van de, 1411.

Helicolepidina, Eocene, relationships : Barker, 181.

Ophioderma, Pliocene, Matura Bay : Berry, 295.

Utah, rodents, Uinta County Eocene: Burke, 581.

Valentine: Johnson, 1966.

Venericardia planicosta, variations : Chavan, 740.

Verneuilinidae, Valvulinidae and Virgulinidae: Cushman, 945.

Virginia Ficus aquiana, Belvedere Beach, Eocene: Berry, 302.

Peritresius virginianus, Miocene: Berry, 296.

Prunus calvertensis, Calvert Miocene, Nomini Cliffs : Berry, 303.

Washington, Chehalis Valley fossil wood: Anonymous, 4700.

Ginkgo, Miocene, Petrifled Forest : Beck, 251, 254. 
Paleontology-Continued.

Tertiary-Continued.

Washington-Continued.

Mlocene leaves, fruits, and seeds: Brown, 489.

Priscacara campi, Eocene, Kittitas County : Hesse, 1731.

Spruce in westeru Miocene: Beck, 253.

Wyoming, Ectoganus glliriformis, Eocene, Worland, Gazin, 1396.

Florentiamyinae, Miocene: "Wood, 4575.

Goshen Hole area, Oligocene and Miocene vertebrates: Schlaikjer, 3560 .

Oligocene mammals: Schlaikjer, 3559.

Lambdotherium popoagicum, Eocene, Tulsa : Bonillas, 366.

Miocene tapir, Goshen Hole: Schlaikjer, 3561 .

Yellowstone National Park, insect borTriassic. ings in fossil wood: Brues, 508.

Alberta, fish, Triassic and Devonian, Canadian Rockies : Warren, 4349 .

Arcidae, classification: Relnhart, 3243.

Arizona, Moenkopi sandstone: Brady, 429.

Theropod, Navajo sandstone: Brady, $430,432$.

Connecticut, Seminotus fultus: Thorpe, 4120.

Greenland, east, flshes: Nielsen, 2883.

Godthaab Gulf, vertebrate beds: Nielsen, 2882.

Invertebrates: Spath, $\mathbf{3 7 9 7}$.

Labyrinthodont Stegocephalians and primitive R e t ili a : Säve-Söderbergh, 3469 .

Nevada, coral reefs: Muller, 2825.

Oregon, Tritropidoceras packardi: Schenk, 3555.

Tèxas, Angistorihinus alticephalus : Stovall, 3953.

Utah, Semionotus cf: gigas, Zion Park : Hesse, 1727 .

Wyoming, Corosaurus alcovensis, Jackson Canyon: Case, 696.

\section{Undifferentiated.}

Appalachian uplift, eastern formations : Woodward, 4609.

British Columbia, Fraser River-Harrison Lake region: Horwood, 1800.

Similkameen and Lillooet districts : Cockfleld, 795.

Canadian Rockies: Kelly, 2067.

Classification by pulsation theory: Grabau, 1489, 1490.

Correlations, later Paleozolc, America and Europe: Noe, 2901.

Correlations by graptolites: Decker, 1001.

Deformation of earth's crust: Moore, 2787.
Paleontology-Continued.

Undifferentiated-Continued.

Dipnoans, development of cranial roof : Romer, 3351.

Eryops, ilio-sacral attachment: Olson, 2951.

Foraminifera, relntionships and ecology : Cushman, 943.

Heliolites, Tetradium and Chaetetes: Okulitch, 2948.

Lower Paleozoic, colrelations and classification of strata: Ulrich, 4211.

New Hampshire, garnet, Merrimack County : Conant, 830.

New Iork, Dutchess County: Barth, 198.

Orogeny, in North America: Van der Gricht, 4253.

Pegmatites, age and distribution: Landes, 2311.

Sedimentation cycles: Wanless, 4331.

Yukon. Carmacks district: Bostock, 379.

Palladium, Wyoming, Centennial district: Coulter, 884 .

Panama (including Canal Zone).

Mineralogy.

Agates, Canal Zone: Freehan, 1335.

Paleontology.

Pectinidae, Tertiary: Tucker, 4178.

Physical geology.

Earthquake, November 30, 1935 : Bodle, 357.

Scismic records: Kirkpatrick, 2221.

Paragenesis.

Arizona, pyritic copper deposits : Kania, 2017.

British Columbia, pyritic copper deposits : Kania, 2019.

Yale district: Horwood, 1799.

California, Crestmore: Daly, 962.

Colorado, Calumet iron mine, contact ore deposition; Behre, 262.

Cripple Creek area: Loughlin, 2460.

Ore deposition south of Ouray : Moehlman, 2760.

Sugar Loaf district, Lake Couniy, ore minerals: Sandberg, 3487.

Ward district ores: Wablstrom, 4309.

Copper sulphides, origin, Colorado mine, Cunanea, Mexico: Kelley, 2049.

Georgia, Battle Branch gold mine: Park, 3010.

Hawail, crystal cavities in lava: Dunham, 1095.

Manitoba, Flin Flon mine: Brownell, 499.

Mineral associations, cooling intrasions: Schnelderhöhn, 3569.

Missouri, southeastern, lead deposits : Tarr, 4020

Montana, Butte district ores: Hart, 1647. 
-Paragenesis-Contlnued.

Colorado-Continued.

Nevada, tungsten mineralization, Silver Dyke: Kerr, 2086.

Newfoundland, Bay of Exploits area : Heyl, 1736.

New Mexico, Bayard area : Lasky, 2344.

Lordsburg : district: Lasky, 2342.

Organ Mountains and Doña Ana County : Dunham, 1094.

Virginia mining district: Lasky, 2345.

New York, supergene minerals at Balmat: Brown, 486.

Nova Scotia, gold zonal mineralization: Newhouse, 2865.

Ontario, Central Patricia gold mine: Reid, 3238 ; Cormie, 876.

Gold, Manitou Lake-Lake of the Woods area : Thomson, 4111.

Hypogene anhydrite: Langford, 2336.

Ore deposit; succession of minerals: Lindgren, 2421.

Phenacite: Pough, 3113.

Tri-State zinc and lead ores: Ridge, 3295.

Utah, lead and silver ores, Park City : Bryan, 515.

Zinc and lead deposits, northern Arkansas: McKnight, 2552.

Peat.

Correlation by deposits: DachnowskiStokes, 947.

Pacific Coast States and water resources : Dachnowski-Stokes, 948.

Pre-Kansan Minnesota peat bog: Nielsen, 2884.

Pebbles.

Feldspar in sandstone: Williams, 4506.

Sphericity values, determination and calculation of : Pettijohn, 3068.

Transportation by ice : King, 2208.

Pediments.

Arizona, Ajo region : Gilluly, 1433.

Formation of: Bryan, 523.

New Mexico, Granjte Gap: Bryan, 524. Rio Puerco: Bryan, 525.

Pegmatites.

Age and distribution: Landes, 2311.

California, andalusite inclusions: Murdoch, 2833.

Lithium, Pala : Donnelly, 1067.

Colorado: Landes, 2312.

Connecticut, Collins Hill; Portland : Jenks, 1942.

Massachusetts, Fitchburg : Hitchin, 1751. Missouri, Sheahan quarry, Graniteville : Tolman, 4138.

Nevada, dike, Oreana : Kerr, 2078.

New Mexico, Organ Mountains and Doña Ana County : Dunham, 1094.

North Carolina, spodumene pegmatites, Kings Mountain: Hess, 1720.

Pennsylvania, Cambrian, Morgan Hill : Fraser, 1329.
Pegmatites-Continued.

Quebec, monazite, West Portland Township : Spence, 3802.

South - Dakota, morinite from Black Hills : Runner, 3424.

Succession of minerals and temperatures of formation: Lindgren, 2421.

Virginia, Amelia deposits: Glass, 1441.

Pelecypoda. See also Mollusca.

Acila, valid species: Schenck, 3540.

Acila schomburgki, Oligocene, Trinidad: Schenck, 3527.

Alberta, Milk River Cretaceous: Russell, 3430.

Anadara, Oligocene, arcid : Schenck, 3541.

Arcidae, classification: Reinhart, 3243. Incorrect assignments: Reinhart, 3244.

Arizona, Jurassic and Cretaceous : Stoyanow, 3960.

Breviarca haddonfieldensis, Cretaceous, New Jersey : Stephenson, 3875.

Cache Creek Permian, British Columbia : Crockford, 916.

California, San Pedro Hills, fossils from Pleistocene terraces: Woodring, 4601.

Cardild, revision : Keen, 2038.

Carriacou, West Indies: Trechmann, 4162.

Clinocardium, n. gen. : Keen, 2037.

Crassatella melina, Miocene, New Jersey : Richards, 3279.

Crassatellites (Hybolophus?) leonensis Miocene, Florida: Mansfield, 2575.

Diploschiza melleni, Cretaceous, Alabama, Mississippi: Stephenson, 3876.

Eucrassatella mansfieldi, Pliocene, North Carolina: MacNeil, 2560.

Evolution: Schenck, 3551.

Georges Bank and Banquereau, Nova Scotia, Cretaceous: Stephenson, 3878.

Glycymeris, - classification : Schenck, 3543.

Greenland, east, Cretaceous: Bøgvad, 361.

Guatemala B a r rettia: MacGillavry, 2530.

Inoceramus and Pteria, Cretaceous, Greenland: Frebold, 1332.

Key to genera of Puget Sound: Miller, 2725.

Lea Park shale fauna, Alberta : Warren, 4348.

Saskatchewan: Warren, 4348.

Mexico, Lower Callfornia, Cretaceous : Anderson, 65.

Nuculid, classification: Schenck, 3537.

- Revision : Schenck, 3552.

Oregon, teredo burrows in fossilized wood, Roseburg: Wharton, 4436.

Orthoceras: Teichert, 4038. 
Pelecypoda-Continued.

Ostrea Idriaensis, Eocene, Californla: Vokes, 4290.

Ostreidae, Gulf region, Upper Cretaceous : Stephenson, 3877.

Pearl, Miocene, Maryland : Berry, 297.

Pectinacea, upper Paleozoic, classiflcation : Newell, 2858.

Morphology : Newell, 2857.

Pectinidae, rectiflcation of names : Hertlein, 1719.

Tertlary, Atlantic and Gulf coast: Rowland, 3389 ; Tucker, 4178.

Protothaca, Miocene: Frizzell, 1344.

Pseudomonotis subcircularis, type species : Muller, 2823.

Quebec, Black River group: Okulitch, 2946.

Rudistids, Cretaceous, Cuba : Rutten, 3464.

Shell structure: Schenck, 3538.

Spirifer divaricatus, Devonlan, Pennsylvania : Willard, 4498.

Veneracea, classiflcation : Frizzell, 1345. Genera : Frizzell, 1348.

Venericardia planicosta, Eocene, Alabama: Chavan, 741.

Variations: Chavan, $\mathbf{7 4 0}$.

Veneridae, phylogeny : Frizzell, 1347.

Virginia, Yorktown : McGavock, 2523.

Wyoming, Jurassic : Crickmay, 901.

Peneplafns: Gabriel, 1371; Keyes, 2147, 2162,2175 ; R1ch, 3271; Ver steeg, 4282.

Allegheny Plateau, slope, and regional dip : Fridley, 1342.

Appalachian mountain sculpture: Ashley, 107.

Appalachians, southern: Wright, $\mathbf{1 6 2 5}$.

Colorado, Front Range: Van Tuyl, 4268.

Desert cliff recession, lateral regional planation : Glock, 1449.

Inland phases: Van Tuyl, 4270.

Iowa, peneplanation, driftless area : Keyes, 2161.

New England: Tarr, 4015.

Ohio, Kentucky and West Virginla : Cole, 805.

Pennsylvania, Bellefonte quadrangle: Butts, 598.

Philadelphia area: Watson, 4359.

Stages, developmental: Keres, 2143.

Vermont: Jacobs, 1925.

Wind gaps, water gaps, and erosion surfaces: Ver Steeg, 4280.

Wisconsin, cuesta vs. peneplane, driftless area : Martin, 2587.

Driftless area : Bates, 237.

Peneplain or peneplane: Johnison, 1959.

Peneplains and peneplanation:.Ver Steeg, 4282.

Pennsylvania.

Economio geology.

Bellefonte quadrangle: Butts, 598.
Pennsylvania-Continued.

Economic geology-Continued.

Butler and Zellenople quadrangles : Richardson, 3286.

Coal and oil, occurrence, Pittsburgh region : Linton, 2424.

Deep-sand oil and gas, possibility, northwestern Pennsylvania : Fettke, 1240.

Farmington gas fleld: Sanders, 3489.

Gas and ofl possibllities, northwest Pennsylvania : Fettke, 1241, 1242.

Gas, Tioga region: Ashley, 100.

Hebron gas fleld, Potter County : Reeves, 3234.

Mineral resources: Ashley, 101.

Mineral zoning, Triassic: Newhouse, 2861.

Natural-gas fields: Torrey, 4146.

Oil in Oriskany, Warren County : Ruggles, 3417.

Oriskany sand development: Cathcart, 705.

Petroleum, recovery by water-flooding pressure : Clapp, 753.

Possibility of deep oil and gas production: Fettke, 1243.

\section{Historical geology.}

Appalachian structure, southeastern Pennsylvania: Jonas, 1991.

Bellefonte quadrangle: Butts, 508.

Bentonite beds, lower Chambersburg : Whitcomb, 4450.

Bradfordian series, discontinued: Cas ter, 702.

Brallier shale and Chemung formation: Butts, 597.

Butler and Zelienople quadrangles: Richardson, 3286.

Coal and oil, occurrence, Pittsburgh region : Linton, 2424.

Correlation by insoluble residues, Cambro-Ordovician limestones, Lehigh Valley : Hills, 1742.

Deep-sand oil and gas, possibllity, northwestern Pennsylvania: Fettke, 1240.

Devonian and Shlurian sections: Fettke, 1244.

Devonian, continental: Willard, 4499.

Delta, Appalachian geosyncline: Burroughs, 584.

Southwestern Pennsylvania: WWllard, 4496.

Devonian-Mississippian boundary, western Pennsylvania : Caster, 704.

Eastern region: Miller, 2717.

General : Anonymous, 4697; Willard, 4489.

Glenarm series, Chester Valley : Mackin, 2544 ; Miller, 2718.

Hamilton group, Allegheny front: Willard, 4495.

Central Pennsylvania: Willard, 4490.

Hebron gas fleld, Potter County: Reeves, 3234 . 
Pennsylvania-Continued.

Historical geology-Continued.

Igneous rocks, pre-Cambrian: Bascom, 219.

Martic overthrust: Mackin, 2544 : Miller, 2718.

Martinsburg limestones, Ordovician : Miller, 2724.

Mauch Chunk formation, contains limestone: Stone, 3942.

Mississippian-Devonian boundary, western Pennsylvania: Caster, 704.

Natural-gas fields: Torrey, 4146.

Northwestern Pennsylvania: Fettke, 1242.

Onondaga formation, Deronian: Willard, 4501.

Oriskany sand development: Cathcart, 705.

Pegmatites, Cambrian, Morgan Hill : Fraser, 1329.

Philadelphia area: Watson, 4359.

Pleistocene sedimentation, Philadelphia area : Ehrenfeld, 1149.

Pocono: Ashley, 106; Chadwick, 708.

Pocono sandstone: Wagner, 4307.

Portage group: Willard, 4494.

Possibility of deep oil and gas production: Fettke, 1243.

Reading overthrust: Stose, 3947.

Sllurian : Swartz, 3989.

Rochester and McKenzie formations, relation: Swartz, 3990.

Tioga region: Ashley, 100.

Tully limestone and fauna: Willard, 4500.

Volcanic rocks, pre-Triassic, southern Appalachians: Jonas, 1992.

\section{Mineralogy.}

Aragonite in cares, Allentown: Faux, 1217.

Bellefonte quadrangle: Butts, 598.

Carnotite, Mauch Chunk : Myers, 2839.

Dickite, Schuylkill County: Honess, 1788.

Halotrichite, Jeddo mines, Freeland : Shrader, 3697.

Meteorites: Anonymous, 4701.

Minerals, Serpentine Range: Gehman, 1400.

Pegmatites, Cambrian, Morgan Hill : Fraser, 1320.

Sphalerite, mylonitic, Friedensville: Butler, 596.

Zinc ore, Friendensville: Fraser, 1327.

\section{Paleontology.}

Archaeopteris macilenta and $\mathbf{A}$. sphenophyllifolia of Lesquereux : Arnold, 92.

Archaeopteris with associated seedlike structures, Devonian: Arnold, 89.

Cephalopods, Upper Devonian : Flower, 1291.

Chemung tracks and tralls: Willard, 4487.

Coal flora, Wilkes-Barre and Pittsburgh region: Darrah, 975.
Pennsylvania-Continued.

Paleontology-Continued.

Eurypterus arnoldi, Devonian, McKean County : Ehlers, 1147.

General : Willard, 4502.

Hypothyridina venustula, Deronian : Willard, 4488.

Lepidostrobus gallowayi, Devonian, Port Allegany : Arnold, 87.

Mollusks, Harmonsburg marl: Brooks, 471.

Ostracoda, Nineveh limestone: Holland, 1779.

revision of Primitlidae and Beyrichildae, Devonian : Swartz, 3991.

Sauripterus taylori, Devonian: Gregory, 1524.

Schizodiscus antecrenulus, Devonian, Perry County : Cleaves, 771.

Spirifer divaricatus, Devonian : Willard, 4498.

Sporadoceras milleri, Devoniān, Erie County : Miller, 2709.

Taeniopteris, Carboniferous, Monongahela City : Darrah, 976.

Tetrapods, Dunkard series: Burke, 578.

Tully limestone and fauna: Willard, 4500.

Walchia, Permian: Darrah, 978.

Petrology.

Correlation by insoluble residues, Cam. bro-Ordovician limestones: Hills, 1742.

Gabbro, alteration, near Philadelphia: Watson, 4360 .

Pegmatites, Cambrian, Morgan Hill : Fraser, 1329.

Shales and noncalcareous under clays associated with Illinois coals : Grim, 1546.

Zinc ore, Friedensville : Fraser, 1327.

Physical geology.

Eastern region: Miller, 2717.

Farmington gas field, fault: Sanders, 3489.

Faulting, Conemaugh formation near Bakerstown Station: Ross, 3377.

Granite intrusions near Philadelphia : Watson, 4361.

Lehigh Valley, magnetic survey : Ewing, 1199.

Shearing, Durham and Reading Hills: Fraser, 1328.

Physiographio geology.

Bellefonte quadrangle: Butts, 598.

Devonian ice : Willard, 4491.

Eastern region : Miller, 2717.

Floods, March 1936: Anonymous, 4686.

General : Anonymous, 4695.

Philadelphia area : Watson, 4359.

Potter County drainage: Anonymous, 4705.

Underground water.

Bellefonte quadrangle: Butts, 598.

Springs flowing over 1,000 gallons a minute : Anonymous, 4714.

Pennsylvanian. See Carboniferous. 
Pennsylvanian-Permian boundary: Romer, Petroleum-Continued. 3347.

Pentremites, See Blastoldea.

Permeability, unconsolidated rocks: Tickell, 4128.

Permeability measurements without cores: Ryder, 3465.

Permian. See Carboniferous.

Permian red-beds vertebrates, Texas: King, 2214.

Permian, world problem : Keyes, 2132.

Perspective block diagrams: Secrist, 3628.

Petrifaction: Wieland, 4474.

Petrified forests.

Silicifleation : Randolph, 3172.

Petrofabrics.

Analysis and application: Fairbairn, $1205,1207$.

Autoliths, mineral orientation: Pabst, 2977.

Cleavage: of granites: Bell, 266 ; Osborne, 2968.

Elongation in deformed rocks: Falrbairn, 1209.

Greenland, crystallines, Liverpool Land : Sahlstein, 3472.

Quebec, mineral orientation, Shawinigan Falls area : Osborne, 2967.

Petrof 8 brics and orogenesis: Sander, $\mathbf{3 4 8 8}$.

Petrole ım. See also Bituminous rocks and sands; Oil shales; Fisher, 1.271, 1272; Melhase, 2650; Ver Wiebe, 4287.

Accumulation, stratigraphic vs. structural : Levorsen, 2404.

Aer al discovery: Maple, 2576.

Albr rta : Calder, 625.

A :habasca sands: Ball, 171.

Bittleview anticline, Wainwrigbt area, possibilities: Hume, 1886.

Firemost-Skiff area, possibilities : Eowells, 1867.

Mjlk River area: Russell, 3433.

Tu :ner Valley field : Spratt, 3811.

Tu :ner Valley gas and oil fleld: J Iume, 1883.

Arka] sas, Gulf Coastal Plain: Moody, 2773 ; Spooner, 3810.

Hel upstead County, shoreline possib lities: Easton, 1113.

Sme ckover field: Haury, 1649.

Snov Hill Permian fleld: Easton, 1.14.

Bartlei ville and Burbank sands, Oklahema and Kansas: U. S. G. S., 4235,4238 .

Bibliog aphy of recent sediments and solurce beds : Trask, $\mathbf{4 1 5 0}$

Biogent sis of: Thayer, 4058.

Califor ia, Buena Vista Hills oil field : Ho vard, 1828.

Coalisıga district, accumulation of oil : Gal loway. 1377

California-Continued.

Edison oil field: Carter, 688; Noble, 2899.

Geophysical prospecting: Anonymous, 4680.

Mountain View oil fleld: Gow, 1488

Mount Poso ofl field: Diepenbrock. 1.046.

Newhall fleld: Walling, 4325.

Oll conversion, Santa Fe Springs field : Trask, 4153.

Playa del Rey fleld: Hoots, 1790.

Recent discoveries and present supply : Hoots, 1793.

Reserves: Eaton, 1116.

Round Mountain field: Diepenbrock, 1047.

San Joaquin Valley : Mills, 2731.

Venice and Del Rey flelds, Miocene: Corey, 875 .

Canada, analyses : Rosewarne, 3361.

Western: Goodman, 1473.

Carbon-ratio theory, status in Illinols: Bell, 264.

Connate water in oil sands: Pyle, 3514, 3155.

Correlation by fluoresence: Melhase, 2647.

Deep-well drilling: Heald, 1663.

Degree of reduction and volatility, source beds : Trask, 4151.

Determination of saturation of oil sands : Hillis, 1741.

Development in America, history : Goodrich, 1474 ; Levorsen, 2406 ; White. 4452.

Domes: Balk, 160.

Electrical mapping,, oll structures: Jakosky, 1929.

Electrical prospecting: Swartz, 3992.

Erolution of, and geophysical factors : White, 4451.

Experimental studies, origin: Stadnichenko, 3812.

Hxploring down: Kelly, 2065.

Exploring with explosives: Heiland, 1686.

Fluid phenomena, porous strata : Boatright, 353 .

Fluorescence of oil sands, correlation aid : Melhase, 2647.

Foraminifera as guide fossils: Ellis, 1169 ; Nuttall, 2925.

Formation time: Van Tuyl, 4271.

Fuels, mineral, reserves, 0 . S. : Garfias, 1384.

Genesis: Van Tuyl, 4266.

Geophysical prospecting: Rosaire, 3353 : Umpleby, 4222.

Early history : De Golyer, 1006.

Gulf coast : Rosaire, 3355 ; in 1935 : De Golyer, 1008.

Geothermal gradient, United States: Van Orstrand, 4264.

Ground waters in oll flelds: Lahee, 2288. 
Petroleum-Continued.

Gulf coast deep oil reserve : Mills, 2740 .

Gulf coast district, geophysical prospecting: Mills, 2734.

Gulf coast exploration to 1936 : Rosaire, 3354.

Geosyncline, Texas and Louisiana: Barton, 203.

Louisiana and Texas: Logan, 2437.

Oil flelds: Barton, 209, 215; Texas and Louistana: Logan, 2436; Williams, 4521.

Oils, variation with age and depth: Barton, 204.

Salt deposits, origin: Russell, 3445. Salt domes : Ritz, 3309.

Gulf Coast States, gravity survey: Baker, 156.

Hydrocarbons, extraterrestrial, and petroleum genesis : Van Tuyl, 4267.

Hydrogenation and origin: Pratt, 3127.

Illinois, Eastern Interior Basin, possibllities : Sanders, 3490.

Marion and Clay Counties, possibilltles: Weller, 4385.

Illinols Basin, possibilities: Howard, 1831 ; Weller, 4386.

Iowa, deep wells, oil and gas possibillties : Lees, 2369.

Kansas, Barton arch oll fleld: Woodruff, 4605.

Central uplift: Koester, 2246.

Northeastern : Ockerman, 2933.

Regional investigations in oll flelds: Hiestand, 1737.

Shoestring oil sands : Patton, 3024.

Western structure and production: Thomas, 4082.

Kentucky, Fordsville and Cannelton quadrangles: Mayfleld, 2622.

Oil and gas possibilities: Hager, 1599.

Louisiana : Howe, 1842.

Belle Isle salt dome, St. Mary Parish : Barton, 207.

Cameron and Vermilion Parishes, salt domes: Howe, 1835.

Cotton Valley fleld: Tucker, 4179.

Gulf coast flelds: Woodruff, 4606.

Jennings salt dome, Acadia Parish: Halbouty, 1601.

Northeastern : Easton, 1112.

Northern, oil fields : Easton, 1111.

Rodessa oil fleld: Mills, 2733, 2736.

Selsmic exploration: Taylor, 4029.

Valentine (La Rose) dome, Lafourche Parish : Buchanan, 533.

Louisiana and Texas Gulf coast : Deussen, 1033 .

Marsh and water areas, prospecting: Flude, 1294.

Salt domes : Sawtelle, 3519.

Salt on domes, overhanging : Judson, 2015.

Metamorphism, organic sediments and derivea oils: White, 4453.
Petroleum-Continued.

Mexico: Ortega, 2958.

Limestone reservoir racks: Muir, 2822.

Northeastern : . Kane, 2017, 2018 ; Tatum, 4021.

Oaxaca, Puebla, Guerrero: Parades, 3000.

Tampico embayment region: Barker, 182 ; Kellum, 2059 ; Muir, 2821; Index fossils : Nuttall, 2924.

Michigan, central ofl flelds: Zavoica, 4644.

Crystal oil fleld: Eddy, 1133.

Hart oil field, Oceana County : Riggs, 3302.

Micromagnetic surveys: Jenny, 1946.

Midcontlnent shoestring oil flelds : Bass, $22 \dot{2}$.

Migration: Barton, 212 : Cheney, 749.

Missouri, 1933-34: Greene, 1513.

Savannab area, possibilities : Greene, 1512.

Montana, Big Horn County and Crow Indian Reservation: Thom, 4074.

Cut Bank oil fleld: Stewart, 3898.

Naphthene and methane oils, occurrence and origin : Hlauscheck, 1753.

Nebraska, possibilities: Kimball, 2192.

Nebraska and the Dakotas, geophysical prospecting: Wilson, 4543 .

New Mexico, Hobbs field: Zavoica, 4645. Permian : Bentz, 282.

Ohio, source material: Stout, 3950.

Oil production and petroleum engineering: Scott, 3611.

Oil sands, Gulf coast, characteristics: Halbouty, 1602.

Oil shales in the U. S. : Schreiter, 3577.

Oll wells, economic spacing: Cheney, 745.

Oklahoma, Ardmore district: Tomlinson, 4143.

Comanche fleld: Swigart, 3995.

Cromwell oil fleld: Rison, 3307.

Cushing fleld, Creek County: Wardwell, 4338.

Davenport fleld, Lincoln County : Brandenthaler, 436.

Deaner fleld, Okfuskee County : Kirwan, 2222.

Fitts pool: Dott, 1071 ; Hyatt, 1901.

Lucien fleld : Zavoico, 4642.

Migration of oll, Oklahoma City field : Brauchli, 448.

Muskogee County, Pennsylvanjan oil and gas sands: Wilson, 4530.

Naval Reserve fleld, Osage County: Vanderpool, 4260.

Okmulgee County oil field: Westby, 4426.

Osage County : Bass, 220, 221 ; U. $\mathbf{s}$. G. S., 4237, 4238.

Reginnal investigations in oil fields: Hlestand, 1737. 
Petroleum-Continued.

Oklahoma-Continued.

Seminole pool, Seminole County: Swarts, .3987.

Slick field: Schwarzenbeck, 3600.

Tatums pool, Carter County : Grimes, 1551.

Orjgin : Barton, 213 : Berl; ; 292 ; Brooks, 468; Harkness, 1632 ; Henderson, 1704 ; Hoots, 1790.

Chemical and geochemical aspects: Brooks, 469

Occurrence: Brauchli, 449.

Origin and accumulation: Clark, 760.

Paleogeology, showing possibilities: Levorsen, 2403.

Paleontology, importance in Gulf coast drilling: Mills, 2738.

Pennsylvanla, Butler.. and Zellenople quadrangles: Richardson, 3286.

Northwestern, deep sands, possibility : Fettke, 1240, 1241, 1242, 1243.

Oriskany, Warren County :: Ruggles, 3417.

Pittsburgh region: Linton, 2424.

Permeability, measurements without cores : Ryder, 3465.

unconsolidated rocks: Tickell, 4128.

Pool development: Lahee, 2287.

Porosity and permeability of rocks: Tickell, 4127.

Porosity and $\mathrm{s}$ at uration studies: Barnes, 187.

Pressure phenomena in ofl. flelds : Clark, 769.

Production practice: Wrather, 4620.

Recovery by water-flooding pressures: Clapp, 753.

Reserves: Pew, 3070.

Method of estimation: Huntington, 1892.

United States: Heroy, 1717.

Residues, insoluble, as guides: Burpee, 583.

Sabine uplift, Importance: Easton, 1115.

Salt domes, Gulf coast: Brown, 488.

Sands, compressibllity : Botset, 382.

Physical tests : Fancher, 1214.

Permeablilty measurements: Clough, 785.

Saskatchewan, Eagle Hills anticline, Battleford a r e a, possibilities : Hume, 1885.

Hudson Bay Junction area, possibilitles : McLearn, 2555.

Sediments, organic content: Trask, 4149.

Seismic exploration for: Gabriel, 1372.

Shoestring oil sands: Patton, 3024.

Shortage: Snider, 3782.

Source beds: Bayley, 244 ; Trask, 4152. means of recognition: Trask, 4157.

Tectonics and accumulation of : Broggi, 467.
Petroleum-Continued.

Tertiary and Paleozolc fields: Wade, 4300.

Tertiary faunas: Dunbar, 1093.

Texas: Deussen, 1035.

Brenham salt dome, Washington and Austin Counties: Burford, 576.

Buckeye fleld, Matagorda County : Brucks, 508.

Claiborne possibilities, Laredo area: Owens, 2974.

Clay Creek salt dome, Washington County : Ferguson, 1237.

Cole field, Webb County : Short, $\mathbf{3 6 9 5}$.

Conroe ofl field : Mtchaux, 2694; Williams, 4515, 4520; Zavolco, 4643.

Driscoll pool, Duval County : Sheldon, 3658 .

East Texas field: Ralston, 3166 ; Ruiz, 3418; Zavolco, 4646.

Esperson dome, Liberty County : Goldston, 1467.

Galreston Bay, geophysical explorations: Singleton, 3735.

Galveston County, geophysical prospecting: Singleton, 3734.

Geophysical prospecting in Gulf : Williams, 4522.

Government Wells ofl fleld, Duval County : Cooper, 868; Trenchard, 4166.

Greta oil fleld, Refugio County: Stamey, 3817.

Gulf coast fields: Woodruff, 4606.

Gulf coast salt-dome area: Mills, 2732.

Hardin dome, Liberty County : Brace, 413; Teas, 4034

High Island dome: Halbouty, 1603.

Hilbig oll field, Bastrop County : Blackburn : 329 ; Smiser, 3743.

Hoskins . Mound salt dome: Barton, 208; Marx, 2594.

Loulsiana Gulf coast, deep possibillties: Mills, 2735; Shore-line or shoestring posslbllitles: Weinzlerl, 4379.

McFaddin and other oll flelds: Getzendaner, 1410.

Mercedes fleld, Hidalgo County: Pírce, 3136.

Mexia-Talco fault zone: Smlth, $\mathbf{3 7 4 9}$.

Northeastern. Talco fleld: Olcott 2949 ; Fault line: Hager, 1598.

Nocona oll fleld, Montague County : Billings, 321.

Orange field: Deussen, 1036.

Palo Pinto County : Plummer, 3098.

Panhandle oll and gas fleld. Rugatz, 3332.

Pearsall fleld, Frio County: Champion, 725.

Placedo oil field, Vifctoria County: Hedley, 1684.

Plymouth fleld reserves: Corning. 877. 
Petroleum-Continued.

Texas-Continued.

Prospecting in Gulf of Mexico : Mills, 2737.

Raccoon Bend oil field, Austin County : Teas, 4032.

Rodessa field : Ivy, 1920 ; Mills, 2733, 2736.

Sarnosa oil field: Jones, 2007.

Saxet oil field: Anonymous, 4707.

Somerset field, Bexar and Atascosa Counties : Jones, 2008 .

Source beds shown by reduction of sediments, East Texas basin : Trask, 4154 .

South, ofl and gas fields: Post, 3108; Oil fields : Pinkley, 3087.

Sugarland oil field: McCarter, 2495.

Talco field: Wendlandt, 4395; Reserves: Mills, 2739.

Tomball oil field, Harris County : Eby, 1122

Variation and migration, crude oil, Spindletop, Jefferson County : Barton, 206.

West, Ordovician flelds: Kroenlein, 2265 ; Permlan : Bentz, 282.

Wheat oil pool: Adams, 4.

White Point ofl field: Anonymous, 4706 .

Texas and Louisiana Gulf coast : Deussen, 1033 .

Texas and Louisiana, overhanging salt on domes: Judson, 2015.

Rodessa field: Ivy, 1921.

Transformation in nature : Barton, 204.

Trinidad: Lehner, 2381.

Palo Seco oil fleld, Miocene : Halse, 1612.

United States: U. S. Nat. Res. Comn., 4239.

Utah, Great Salt Lake basin, possibillties : Eardley, 1107.

Origin of, near Thistle: Schneider, 3568.

Possibilities:-Bignel, 316.

Washington, western Whatcom County, possibilities: Glover, 1450.

West Virginia, Monongahela Valley: U. S. Com., 4224.

Oriskany and Corniferous sands: Martens, 2585.

Wyoming: Marxel, 2595.

Big Medicine Bow oil field, Carbon County : Shoenfelt, 3693.

Garland anticline, Big Horn and Park Counties: Dobbin, 1051.

Lance Creek field: Brainerd, 434.

Medicine Bow oil field: McCanne, 2494.

Osage ffeld: Dobbin, 1052.

Petroleum source beds: Bayley, 244 ; Trask, $4152,4157$.

Petrology (general): Frondel, 1349. For areal see names of States. See also Igneous and volcanic rocks; Sedimentary rocks; Technique.
Petrology (general)-Continued.

Adirondack rocks, metamorphism: v8. flowage: Buddington, 548.

Albite fayalite system : Bowen, 389

Autoliths, mineral orientation: Pabst, 2977.

Basalt, crystallization process: Barth, 197.

Clays, ceramic, mineral constitution: Grim, 1550.

Cleavage of granites: Bell, 266; Osborne, 2968

Coals : Theissen, 4072.

Densities, rocks, from chemical analyses: Daly, 966.

Dunite intrusion, and olivine: Bowen, 388.

Elongation in deformed rocks: Fairbairn, 1209 .

Feldspars: Parmelee, 8016.

Fluorescence, use of : Quinn, 3156

Galena in Cambrian limestone: Lochman, 2432 .

Georges Bank, continental margin bedrock:- Stetson, 3887.

Igneous rocks : Alling, 49 Classification : Shand, 3645 .

Relations: Hodge, 1765.

Iron ores of U. S.: Cooke, 854.

Lava, acidic, variation in alkaline content: Fuller, 1361.

Louisiana, salt-dome cap rock: Hanna, 1619.

Marble : Bain, 136.

Microscopic method to distinguish quartz and untwinned oligoclaseandesine : Dodge, 1053.

Mineral $f a c i e s$, interpretation, in metamorpric rocks: Turner, 4189.

Molding sands, durability: Casberg, 690.

Oil sands, Gulf coast, characteristics: Halbouty, 1602,

Petrofabrics and orogenesis:- Sander, 3488.

Petrographic methods, soil laboratories; Fry, 1356.

Phenoclast: Erwin, 1187; Whitcomb 4449.

Photomicography in oil industry: Sneigr, 3778.

Potash-rich rocks, origin: Tel'zaghi, 4043.

Pyroxene group: Winchell, 4561.

Quartz, particles, volume, shape and roundness: Wadel, 4303.

Quartz, smoky, spectrophotometric study : Mohler, 2764.

Quartz-cristobalite temperature of conversion: Cole, 804.

Rocks, classiflcation : Anonymous, 4713. Identification by reflected light: Wright, 4226.

Rosiwal method and modal determlnation of rocks : Larsen, 2338.

Rosiwal petrographic analysis and geographic mapping: Trefethen, 4165 . 
Petrology (general)-Continued.

Sediments, Continental Shelf, mid-Atlantic States: Shepard, 3675.

Sedimentary rocks: Anonymous, 4713.

System $\mathrm{MgO}-\mathrm{FeO}-\mathrm{SiO}_{2}$ : Bowen, 385 .

Terminology, medium-grained sediments : Allen, 47.

Texas, salt dome cap rock: Hanna, 1619.

Tourmaline: Kollida, 2249.

Spectrographic analysis: Warner, 4343.

Volume, shape, position, rock fragments in openwork gravel: Wadell, 4304.

Petrotectonics.

Ontario, Claire River syncline: Fairbairn, 1206.

Quebcc. minerals orientation. Shawinigan Falls area: Osborne, 2967.

Phenacite. morphology and paragenesis: Pough, 3113.

Phenoclast: Erwin, 1187 ; Whitcomb, 4449.

Phosphate.

Arizona, bermanite, with triplite: Hurlbut, 1896.

Montana, western: Pardee, 3005.

Phosphorescent minerals : Zodac, 4655.

Physical geology (general) : Fitzhugh, 1277 ; Mather, 2599. For areal see names of States.

Ablation of sllow, western mountains : Matthes, 2613.

Adirondack rocks, metamorphism vs. flowage: Buddington, 548 .

Antillean-Caribbean region: Schuchert, 3579.

Appalachian geosyncline, eastern : Morris, 2801.

Assiniboine great sedimentation cycle: Keyes, 2170.

Atlantic Coastal Plain, significance geophysical data: Miller, 2719.

Basin Range hypothesis: Keyes, 2116.

Structure, genesis: Giamella, 1414.

Clipfold: Mathews, 2607.

Continents and oceans, origin: Bowie, 399.

Continents, form, drift, and rhythm; Watts, 4364 .

Stratigraphic evidence on tectonics: Moore, 2792.

Cordilleran systems, Amcrican, development: Stille, 3902.

Cryptovolcanic structures, Midcontinent region: Bucher, 534 .

Deep-focus earthquakes, implication : Stechschulte, 3859.

Deformation of earth's crust, Paleozoic : Moore, 2787.

Desiccation features in humid climate: Krynine, 2273.

Domes, fracture systems: Balk, 160.

Earth, interior: Daly, 965.

Earthquakes, deep-focus: Gutenberg, 1588.

Earth strength: Leith, 2388.

Geological significance: Leith, 2389.
Physical geology (general)-Continued.

Elevation and depression, crustal, causes: De Lury, 1023.

Energy sources, crustal movements : Heim, 1688.

Eolian sands, rounding: MacCarthy, 24.98.

Evapolation, high altitudes and latitudes: Church, 752.

Exfoliation of rocks, fatigue factor: Griggs, 1545.

Fault movements, mechanics: Hulin, 1881.

Rate, Great Basin Province: Blackwelder, 333.

Faults, geosynclinal boundary: Ver Wiebe, 4288.

Flaws and tear faults: Gill, 1426.

Flow units in basalt : Nichols, 2873.

Force required to move particles on stream bed: Rubey, 3400 .

Geologic structures: Cloos, 782.

Geomorphology, Gulf const salt struc. tures: Ritz, 3309.

Mountainous deserts : Davis, 986.

Granitic rocks, derivations: Collins, 814.

Gravel channels, buried, location: Crampton, 892.

Gravity observations and basement structures: Thom, 4075.

Ice, agent of rock weathering: Grawe, 1508.

Inertia in low-angle thrust faulting : Stevens, 3893.

Insolation hypothesis of rock weathering: Blackwelder, 336.

Intrusions, mechanics of : LoewinsonLessing, 2434.

Knickpoints and valley-in-valley forms : Johnson, 1962.

Lake balls, formation: Allen, 39 ; Huutsman, 1893.

Lake, Cladophora, and coal balls: Kindle, 2200.

Landslides, analysis and control : Hennes, 1711.

Landslides and related phenomena : Sharpe, 3649 .

Landslips, subsidences, and rock-falls: Ladd, 2284.

Lime-secreting algae: Kindle, 2198.

Limestones, development of porosity: Howard, 1830.

Magma formation, locus: De Lury 1022.

Mississippi Valley, upper, KeweenawanUpper Cambrian unconformity : Atwater, 112.

Missouri, striated rock surfaces, st. Francis River Valley: Wentworth, 4403.

Motion, compressional phase, deep-focus earthquakes: Sharpe, 3650.

Nuess ardentes, mechanics: Finch, 1262.

Oceans, origin : Keyes, 2182.

$311-37-30$ 
Physical geology (general)-Continued.

Oil fields, distribution, and continental spreading: Wade, 4300.

Ore bodies, localization: Bruce, 504.

Overthrusts in metamorphic terranes: Balk, 161; Knopf, 2240.

Pedestal rocks, southern Appalachian Piedmont: Crickmay, 907.

Peneplains, formation : Rich, 3271.

Plains, rock, base, and depositional: Melton, 2658.

Plasticity of rocks under high pressure: Griggs, 1541.

Power to move continents: Munroe, $\dot{2} 829$.

Rift Valley types: Willis, 4524.

Rise of molten rock: Miller, 2726.

Rock expansion, spontaneous: Bain, 137.

Rock foliation, mechanics: Fairbairn, 1208.

Rocky Mountains, southern: Keyes, 2148.

Rocky Mountains and Great Plains, cycles: Lugn, 2481.

Salt marshes and coastal stability: Goldthwait, 1469

Sand structures, shallow-water : Kindle, 2203.

Sensitivity to tilt, seismographic : Delaney, 1014.

Shafts, vertical, in limestone caves: Pohl, 31.02.

Sierra Nevada: Lawson, 2356.

Soft-rock deformation : Rettger, 3253.

Strain ellipsoid theory of rupture: Griggs, 1542.

Strength of rocks under high pressure: Griggs, 1542.

System $\mathrm{CaO}-\mathrm{MgO}-\mathrm{SiO}_{2}$, reactions between solids: Taylor, 4030.

Tectonic relations, North America and Europe: Stille, 3901.

Thrust faults: Willis, 4527.

Thrusting of unfolded rocks: De Bethune, 993.

Upthrust, geologic term: Willis, 4523.

Volcanism, relation to geologic history: Whitney, 4467.

Zoning, bypogene, in metalliferous lodes: Emmons, 1179.

Phjsiographic geology (general) : Bretz, 453. For areal see names of States. See also Drainage changes; Glacial geology.

Ages, tentative, Plelstocene shore lines: Cooke, 845.

Antillean-Caribbean region: Schuchert, 3579.

Appalachian drainage: Meyerhoff, 2689, 2692.

Appalachian mountain sculpture: Ashley, 107.

Appalachians, southern: Boesch, 363; Wright, 4625 .

Arid regions during ice age: Pittelkow, 3095 .
Physlographic geology (general)-Continued.

Basin Range hypothesis : Keyes, 2116.

Bay-bar and shore-line processes : Brown, 480.

Changing sea level: Johnson, 1960.

Continents, form, drift, and rhythm : Watts, 4364.

Copper and lost stones in glacial till : Glock, 1448.

Correlation, European and American: Keyes, 2158.

Cryptovolcanic structures, Midcontinent region: Bucher, 534.

Desert cliff recession, lateral regional planation: Glock, 1449 .

Desert mountains, stream carved slopes and plains : Field, 1254.

Earth forms and military operations: Patton, 3026.

Erosion, cyclic and noncyclic aspects : Fenneman, 1219.

Fllnt flakes and artifacts, weathering: Smith, 3760.

Geologic structures: Cloos, 782.

Geomorphology, mountainous deserts : Davis, 986.

Georges Bank canyon, bedrock : Stetson, 3889 .

Glaciation, correlation, Northern and Soutbern Hemispheres: Coleman, 806.

Huron-Erie district, tilt-line variations : Leverett, 2401 .

Knickpoints and valley-in-valley forms : Johnson, 1962.

Lakes and mountain barriers theory: Furcrou, 1364.

Meteorite craters and cryptovolcanic structures: Boon, $\mathbf{3 7 0}$.

Mexico, physiographic provinces: Ordo. nez, 2956.

Native-copper masses in glacial tills: Glock, 1447.

New England, ground-water supply: Bryan, 522.

New England-Acadian shore line: Moore, 2776.

Newer Appalachians, south of New River: Wright, 4625.

Nomenclature: Rigdon, 3301.

North America regional exposition, history of : Joerg, 1953.

Oceans and seas, classifcation: Giles, 1423.

Ocean bottom, geological mapping : Shepard, 3674

Outlines : Longwell, 2442.

Patriclan center of glaciation: Tyrrell, 4203.

Patrician glaciation, strategic role: Keyes, 2095.

Patrician ice movements: Leverett, 2402.

Patrician 1ce sheet: Martin, 2586.

Pediments, formation: Bryan, 523. 
Physlographic geology (general)-Continued.| Fisces-Continued.

Peneplains: Keyes, 2143, 2147, 2162.

Formation: Rich, 3271.

Iuland phases: Van Tuyl, 4270.

Peneplanation concept and land forms : Gabriel, 1371.

Physiography, new presentation: Atwood, 119, 120.

Plains, rock, base, and depositional: Melton, 2658.

Pre-Cambrian buried surface in U. S.: Moss, 2811.

Reviews, geomorphologic papers : Bryan, $517,518$.

Rock fans and pediments, origin and evolution: Rich, 3268.

Rocky Mountains, southern end: Keyes, 2131.

Slumping and gully formation : Mitchell, 2755.

Streams, flood-plain: Melton, 2660.

Submarine canyons, from changes of sea level: Shepard, 3677, 3680.

Hudson Gorge to Chesapeake Bay, dredge samples: Stetson, 3892.

Origin: Daly, 968; Shepard, 3672, 3676,3682 .

Submarine valleys, age, central Atlantic coast: Stetson, 3891.

Submerged valleys on continental slopes, origin : Hess, 1723.

Talus slopes, Basin Range province: Blackwelder, 334 .

Terminology, erosion-cycle surface forms: Maxson, 2619.

Wind gaps, water gaps, and erosion surfaces: Ver Steeg, 4280.

Physiographic nomenclature: Rigdon, 3301. Pisces.

Alberta, Milk River Cretaceous : Russell, 3430.

Triassic and Devonian, Canadian Rockles: Warren, 4349.

Beartooth Butte, Devonian, Wyoming: Bryant, 528.

Cephalaspids, Devonian, Quebec: Robertson, 3320 .

Devonian, New York : Bryant, 527.

Upper, Colorado: Bryant, 530.

Dipnoans, Paleozoic, cranial roof: Romer, 3351.

Eurylepldoides socialis, Permo-Carboniferous, Texas: Case, 693.

Fish to man: Gregory, 1523.

Greenland, enst, Triassic : Nielsen, 2883.

Osteostrachi, sensory, canal system: Robertson, 3321.

Pelvis, from fish to man : Gregory, 1527.

Pennsylvanian, lower, central Missouri: Bailey, 133.

Placodermi, Devonian, east Greenland : Stensio, 3865.

Priscacara campl, Eocene, Washington: Hesse, 1731.

Sauripterus taylori, Devonian, Pennsylvania: Gregory, 1524.
Semionotus fultus, Trlassic, Connectlcut : Thorpe, 4120.

Semionotus cf. gigas, Triassic, Utah : Hesse, 1727.

Triassic fish faunas, western America: Hesse, 1728.

Trinidad, Northern Range: Trechmann, 4161.

Pitchblende.

Northwest Territories, Beaverlodge and Hottah Lakes : Haycock, 1658.

Great Bear Lake : Spence, 3801.

Mineralization, Great Bear Lake district: Kidd, 2189.

Rae to Great Bear Lake, Mackenzle district: Kidd, 2191.

Thorium, Great Bear Lake: Merkel, 2666.

Placers: Fitzhugh, 1277.

Alaska, Ruby-Kuskokwim region: Mertle, 2681.

Upper Copper and Tanana Rivers area : Mofft, 2763.

British Columbia, Cariboo district : Hanson, 1624.

Pre-Mississippian veins and deposits, Cariboo district: Lay, 2357.

California : Jenkins, 1936.

Colorado, Tincup mining district, Gunnison County : Goddard, 1458.

Gold prospecting: Jacy, 1927 ; Storms, 3945.

Gravel channels, buried, location : Crampton, 892.

Idaho, Edwardsburg and Thunder Mountain area: Shenon, 3665

Mexico, gold: Barrera, 193.

Bajada: Webber, 4375.

Nevada, gold: Vanderburg, 4252.

Tuscarora mining district, Elko County : Nolan, 2908.

New Mexico, Bayard area : Lasky, 2344.

Quebec, Mount Megantic region: McGerrigle, 2525.

Virginia, gold deposits, Piedmont region: Park, 3009.

Planktonic faunas, Paleozolc: Reed, 3223; Schuchert, 3581 .

Plant distribution as guide to age determination: Chaney, 730.

Plants, fossil. See Paleobotany.

Plasticity of rocks under high pressure: Griggs, 1541.

Platinum.

Mexico : Santillan, 3498.

Montana, Stillwater igneous complex: Howland, 1869.

Ontario, Renfrew County: Freeman, 1336.

Wyoming, Centennial district: Coulter, 884.

Pleistocene. See Glacial geology; Quaternary. 
Pleistocene glaciation, cause and result: Fairchild, 1213.

Pleistocene, term, in glacial geology : Keyes, 2149.

Pleochroic halos: Sparks, 3795.

Pliocene. : See :Tertiary.

Plotting maps from aerial photographs: Birdseye, 325.

Pollen analysis: Wodehouse, 4570.

Illinois, Volo bog, Lake County : Artist, 97.

Ohio, Mud Lake bog: Sears, 3623.

Peat bed, East McCulloch, Iowa : Lane, 2332.

Postglacial climate, eastern Nortl America : Sears, 3624.

Quebec, Matamek River peat bog: Bowman, 408.

Pollen profiles, types: Sears, 3627 .

Polyzoa. See Bryozoa.

Popular and elementary geology.

Along the hill : Fenton, 1225.

Crystallography : Lazell. 2359.

Fossils : Randolph, 3177.

Minerals: Vaughan, 4272.

Porifera. See Spongiae.

Porosity and permeability: Graton, 1501; Tickell, 4127.

Porphyries and ore deposition, relations, Alma district, Colo.: Singewald, 3729.

Postglacial vegetation, Lake Michigan region: Fuller, 1359.

Potash : Johnson, 1955.

Alunite Boulder Dam area, mineral occurrences : Lee, 2367.

Geologic age of deposits: Rutherford, 3455 .

Nevada, alunite, Sugarloaf Butte: Heineman, 1689.

New Mexico: Mansfield, 2569. Salt in potash mines: Ageton, 9.

Occurrence: Johnson, 1955.

Polyhalite: Ramsdell, 3170.

Rocks rich in potash: Terzaghi, 4043.

Texas: Mansfield, 2569.

Polyhalite: Cunningham, 934.

Utah, Salt Valley anticline area: Dane, 970.

Potash-rich rocks, origin: Terzaghi, 4043.

Power to move continents: Munroe, 2829.

Pravognathus for Hetelognathus Stauffer: Stauffer, 3841.

Pl'e-Cambrian. See also Paleontology, preCambtian : Keyes, 2135.

Alaska, interior, volcanism: Mertle, 2680.

Algonkian error : Lane, 2327.

Ancient life: Keyes, 2108; Raymond, 3196.

Antillean-Caribbean region: Schuchert, 3579 .
Pre-Cambrian-Continued.

Appalachians, southern, Talladega series: Crickmay, 910.

Arizona, Algonkian formations, Grand Canyon: Hinds, 1745.

Archean rocks at Grand Canyon: Campbell, 626.

Ep-Archean and Ep-Algonkian intervals: Hinds, 1749.

Eparchaean plain : Whitman, 4466.

Silver King area, Superior: Galbraith, 1373.

Arizona and Nevada, Boulder Reservolr floor : Longwell, 2445.

British Columbia, Barkerville gold belt : Hanson, 1627.

Cariboo district: Fanson, 1624.

Keithley Creek area, Cariboo district : Lang, 2333.

California, Death Valley National Monument: Anonymous, 4664.

Elizabeth Lake quadrangle: Simpson, 3713.

Cambrian and pre-Cambrian, upper Mississippi Valley : Atwater, 114.

Canada, Canadian Shield : Brock, 461.

Gold fields: Dougherty, 1074.

Eastern, ore deposits : Wright, 4628.

Killarney and Algoman granites, age differences : Chamberlin, 720 ; Lane, 2322 ; Lawson, 2355.

Sudbury series, Canadian Shield: Collins, 816.

Classifications and correlations: Chamberlin, 718 .

Clays, fire, distribution in U. S.: Chelikowsky, 743.

Colorado, batholiths, Front Range: Boos, 373.

Book Cliffs coal field : Erdmann, 1185.

Columbia and Dew Drop vein systems, Boulder County: Walker, 4318.

Correlation of granites by heary minerals: Stark, 3832.

Ciripple Creek district: Loughlin, 2459.

Front Range area: Lovering, 2469.

Golden area: Johnson, 1971.

Jamestown district: Goddard, 1457.

Migmatites, Sawatch Range: Stark, 3830 .

Montezuma quadrangle: Lovering, 2466.

Mosquito Range: Johnson, 1970.

Rocky Mountain National Park: Effinger, 1143.

San Juan region: Cross, 925.

Sawatch Range: Barnes, 186 ; Stark, 3829 .

Tincup mining district, Gunnison County : Goddard, 1458.

Yule Creek formations: Vanderwilt, 4261.

Continents, stable platform areas: Moore, 2792. 
Pre-Cambrian-Continued.

Ep-Archean and Ep-Algonkian intervals: Hinds, 1749 .

Gaspe, southeastern : Kindle, 2193.

Gogebic iron range, Michigan and Wisconsin : Atwater, 113.

Gold-producing areas: Danloux-Dumesnil, 974.

Greenland: Koch, 2244, 2245.

Christian X's Land: Wegmann, 4377. Northeast: Telchert, 4037.

Scoresby Bay area: Bentham, 281.

Ymer Island: Cleaves, 772.

Idaho, Casto quadrangle: Ross, 3369.

Edwardsburg and Thunder Mountain area: Shenon, 3665.

Illinois Basin: Weller, 4386.

Kansas, Central uplift : Koester, 2246.

Eastern: Kansas G. S., 2022.

Northeastern : Ockerman, 2933.

Keweenawan, age by helium method: Lane, 2323.

Lablador, Wapussakatoo Mountains : Gill, 1424.

Lake Superior and Barbaboo areas, upper Mississippi Valley: Leith, 2387.

Maine, geologic map: Keith, 2040.

Manitoba, Cross Lake area, pre-Keewatin (?) tonalite : Horwood, 1798.

Elbow-Morton area: Stockwell, 3939.

Flin Flon mine: Brownell, 499.

Missi series, Flinflon: Ambrose, 58, '59.

Northern, Seal River: Johnston, 1980.

Manitoba and Ontario mining districts: Wright, 4627.

Maryland, eastern, igneous rocks : Bascom, 219.

Mexico: Sanitallân, 3500, 3501.

State of Chiapas, pre-Tertiary : Müllerried, 2815.

Michigan, granitic sequence, southern complex: Dickey, 1044.

Keweenawan lavas: Broderick, 464.

Lake Superior iron deposits: Royce, 3397.

Lake Superior region: Leith, 2390; Rama Rao, 3167.

Negaunce iron formation, Marquette County : Adler, 6.

Palmer gneiss: Lames, 2300.

Minnesota, Lake Superior iron deposits : Royce, 3391.

Lake Superior region: Leith, 2390.

Minneapolis-St. Paul metropolitan area: Schwartz, 3597.

Minnesota River Valley: Couser, 885.

Mississippi Valley : Atwater, 114.

Ogishkemuncie Lake region: Sleight, 3740.

Mississippi Valley, upper: Atwater, 114 ; Kans. Geol. Soc., 2020.

Lake Superior and Baraboo areas: Leith, 2387.

Structural map: Howell, 1864.

Missouri, cross section, Forest City, Mo., to Du Bols, Nebr.: Condra, 833 .
Pre-Cambrian-Continued.

Montana, Big Horn County and Crow Indian Reservation : Thom, 4074.

Hog Heaven mining district, Flathead County : Shenon, 3664.

Idabo batholith, northeastern part: Langton, 2337.

Neihart mining district, Cascade County : Schafer, 3526.

Rocky Mountains: Keyes, 2117.

Western, unconformity: Deiss, 1009.

Nebraska, cross section, Du Bols, Nebr., to Forest City, Mo.: Condra, 833.

Water-bearing formations: Condra, 835.

Newfoundland, gold deposits. Snelgrove, 3779.

New Mexico, Bayard area: Lasky, 2344.

Organ Mountains and Doña Ana County : Dunham, 1094.

New York, Dutchess County: Balk, 162.

Grenville, St. Lawrence County : Dale, 959.

Hammond, Antwerp, and Lowville quadrangles: Buddington, 543.

Oswegatchie quadrangle : Dale, 961.

Potsdam quadrangle, St. Lawrence County : Reed, 3217.

Russell quadrangle: Dale, 958.

Zinc mine, Balmat: Brown, 484.

Nova Scotia, Hallfax formation, Point Pleasant Park : Belyea, 274.

Lake Ainslie area: Norman, 2911.

Northwest Territories, Great Bear Lake area : Kidd, 2190.

Granite porphyries. Riley, $\mathbf{3 3 0 4 .}$

Rae to Great Bear Lake, Mackenzie district: Kidd, 2191.

Yellowknife River area: Jolliffe, 1988.

Ontario, Afton-Scholes area: Moore, 2781.

East Bay, Minnitakl Lake, Kenora district: Pettijohn, 3067.

East of Lake Superior: Kindle, 2195.

Gold deposits belt, Manitou LakeLake of the Woods: Thomson, 4111.

Goudreau, granitic stocks, and veins: Emmons, 1178.

Hollinger gold mine. Ringsleben, 3306.

Lake Shore mine area: Robson, $\mathbf{3 3 2 8 .}$

Makwa-Churchill area: Laird, 2289.

Porcupine area: Hurst, 1899.

Renfrew County: Freeman, 1336.

Savant Lake area: Rittenhouse, 3308.

Straw-Manitou Lakes area : Thomson, 4109.

Sturgeon River area: Tanton, 4013. Sudbury nickel field. Burrows, 585.

Swayze gold area: Rickaby, 3294.

Syenites, Coldwell district: Thomson, 4110.

Varved slate: Pettijohn, 3066.

Vermilion Townshlp, Kenora district : Pettijohn, 3065. 
Pre-Cambrian-Continued.

Pegmatites, age and distribution : Landes, 2311.

Pennsylvania, Chester Valley : Mackin, 2544 ; Miller, 2718.

Eastern, igneous rocks : Bascom, 219.

Eastern region. Miller, 2717.

Philadelphia area: Watson, 4359.

Reading overthrust: Stose, 3917.

Southeastern, Appalachian structure : Jonas, 1991.

Quebec, Abitibi area : Dresser, 1079.

Cadillac belt, Pandora to Pan Canadian: Gunning, 1573.

Chibaugamau Lake area: Mawdsley, 2617.

Chibougamau-Opawica-map a rea : Norman, 2913.

Chibougamau-Waswanipi $d$ is t r i ct: Norman, 2915.

Deschambault region, Portneuf County : Laverdiere, 2352.

Despinassy area, Abitibi County : Faessler, 1204.

Duparquet Township : O'Neill, 2953.

Gatineau region: Retty, 3255.

Granite: Osborne, 2964.

Guillet (Mud) Lake area : Henderson, 1701.

Horne mine, Noranda: Price, 3132.

Intrusives, Laurentian complex: Osborne, 2969.

Lamaque mine, Bourlamaque Township : Wilson, 4537.

Lamaque-Sigma mines area: Bell, 267.

Lac St.-Jean region, northwest part: Denis, 1030.

Malartic gold mine area, Abitibl : O'Neill, 2954.

Natural-gas ffelds: Snider, 3781.

Noranda district, Amulet mine, rock alteration: Wilson, 4547.

Osisko Lake area : Conolly, 840.

Pusticamica Lake area, Abitibi district: MacKenzie, 2540.

Sabourin area, Témiscamingue Coun. ty : Denis, 1031.

St. Helen Island, Montreal: Osborne, 2966.

St. Lawrence, north shore, Manjgouagan to Godbout: Faessler, 1203.

Shawinigan Falls district: Osborne, 2965.

Siscoe gold mine area: Backman, 128.

Travers Lake area, Témiscamingue County : Retty, 3258.

Waswanipi map area: Norman, 2912.

Western : Bell, 269, 270.

Saskatchewan, Beaverlodge area : Cameron, 630 .

Lake Athabaska area: Alcock, 15.

Mudjatik-Haultain area: Alcock, 13. Northern, Goldfields area: Canada G. S., 664 .
Pre-Cambrian-Continued.

South Dakota, Black Hills: Wright, 4629.

Black Hills, granites: Taylor, 4024. Southwestern U. S.: Effinger, 1144.

Taconic Olenellus fauna, importance: Keyes, 2128.

Texas, Llano region, structure: Stenzel, 3868; Unconformities: S te nzel, 3870.

Trans-Pecos, Structural f e a t u res: King, 2211 ; Unconformitles : Baker, 148.

Unconformity, upper Mississippi Valley : Atwater, 112.

U. S., buried surface: Moss, 2811.

Utah: Blackwelder, 330.

Salt Valley anticline area : Dane, 970.

Vermont, Green Mountains: Jacobs, 1926.

Virginia, James River iron and marble belt: Furcron, 1362.

Shenandoah Valley: Cady, 621.

Southwestern, hypersthene granodiorite: Jonas, 1989.

Wisconsin, Baraboo area : Raasch, 3162 ; Thwaites, 4123.

Lake Superior iron deposits: Royce, 3397.

Lake Superior region: Leith, 2390.

Mississippi Valley, upper: $\Delta$ twater, 114.

Wyoming: Blackwelder, 330.

Black Hills: Wright, 4629.

Sherman peneplain, Laramie Mountains: Hares, 1629.

Yukon, Carmacks district: Bostock 379.

Precious stones: Rogers, 3337.

Canada, semi-precious and ornamental stones: Parsons, 3019.

Opal: Randolph, 3174.

Valuation and prices, history : Ball, 174.

Pre-Devonian structural zones, Scotland and eastern North America: Jonas, 1990.

Primary banding, basic plutonic rocks: Coats, 787.

Primates. See Mammalia.

Priority vs. usage, geologic terminology : Keyes, 2121.

Protaspides of trilobites: Raymond, 3200.

Protozoa. See Foraminifera; Invertebrates (general).

Pseudomorphs.

California, quartz fluorite: Murdoch, 2831.

Silica fllorite: Murdoch, 2832.

Dolomite, castellated: Merritt, 2677.

Mineral, in American Museum: Frondel, 1350.

Virginia, vein quartz, Fauquier County: Thiesmeyer, 4070 .

Puerto Rico.

Economic geology.

General: Meyerhoff, 2685. 
Puerto Rico-Continued.

Economic geology-Continued.

Manganese, origin: Harper, 1637.

Mineral resources: Eckel, 1127 ; Meyerhoff, 2684 ; Ray, 3188, 3189.

Historical geology.

General: Meyerhoff, 2685.

Mineralogy.

General: Ray, 3190.

Magnetite, Humacao: Colony, 817.

Petrology.

General: Ray, 3190, 3191.

Physical geology.

General: Meyerhoff, 2685.

Physiographic geology.

General: Meyerhoff, 2685.

Pulaski overthrust, Virginia: Woodward, 4611.

Pulsation theory: Grabau, 1489, 1490.

Pumice.

Oregon: Fuller, 1360.

Eastern : Moore, 2779.

Pyrite oxidation: Bain, 135.

Pyrophyllite, North Carolina, pre-Cambrian: Burgess, 578.

Quartz: Van Amringe, 4249.

British Columbia, pre-Cambrian, Vernon: Walker, 4324.

California, Rincon, spectrographic examination, smoky and ordinary quartz: Kennard, 2072.

Etching: Meen, 2627.

Northwest Territories, Great Bear Lake area : Furnival, 1370.

Ontario, Okanagan district: Walker, 4322.

Paramolphs after tridymite and cristobalite: Moehlman, 2757.

Smoky, spectrophotometric study: Mobler, 2764.

Temperature of formation: Meen, 2628.

Quaternary. See also Glacial geology; Paleontology, Quaternary.

Ages, tentative, Pleistocene shore lines: Cooke, 845 .

Alaska, Coast Range, glaciation: Kerr, 2076.

Antillean-Caribbean region: Schuchert, 3579.

Arizona, Bajada placers: Werber, 4419.

Arizona and Nevada, Boulder Reservoir floor: Longwell, 2445.

British Columbia, Coast Range, glaciation: Kerr, 2076.

California, Buena Vista Hills oil field: Howard, 1828.

Mesozolc and Cenozoic eruptive rocks, Klamath Mountains: Hinds, 1746.

Mount Diablo and Coalinga areas: Clark, 755.

Mount Poso oil field: Diepenbrock, 1046.

Natural-gas flelds: Hoots, 1792.

Pinnacles National Monument: Andrews, 74.
Quaternary-Continued.

Callfornia-Continued.

South coastal basin : Eckls, 1131.

Southern: Reed, 3231.

Ventura County: Conkling, 837.

Chaleur Bay region, Quebec and New Brunswick : Alcock, 12.

Colorado, Montezuma quadrangle: Lovering, 2466.

Rocky Mountain National Park: Deflnger, 1143.

South Park: Johnson, 1974.

Georges Bank, canyons: Stetson, 3890.

Hawaii, island of Oahu : Stearns, 3849.

Idaho, Casto quadrangle: Ross, 3369. natural-gas flelds: Kirkham, 2220.

Iowa, southern: Wood, 4591.

Louisiana, Jennings salt dome, Acadia Parish : Halbouty, 1601.

Post-Fleming coastal surface formations: Doering, 1054.

Maryland, southern, Coastal Plain : Dryden, 1084.

Mexico, Sierra de Parras, Coahulla Peninsula: Imlay, 1905.

Michigan, Cranbrook area: Stanley, 3819.

Minnesota, Minneapolis-St. Paul metropolitan area: Schwartz, 3597.

St. Croix River, Pleistocene: Sardson, 3510 .

Mississippi : Morse, 2805.

Mississippi Valley, cross sections : Workman, 4618.

Upper: Kans. Geol. Soc., 2020.

Montana, Hog Heaven mining district, Flathead County: Shenon, 3664.

Idaho batholith, northeastern part: Langton, 2337.

Richey-Lambert coal field: Parker, 3012.

Rosebud coal fleld: Pierce, 3084.

Nebraska, Pleistocene : Lugn, 2478.

New Mexico, Clovis lake clays, Pleistocene: Antevs, 79.

New York, Hammond, Antwerp, and Lowville quadrangles: Buddington, 543.

Long Island Pleistocene: Wells, 4388.

Oahu : Stearns, 3848.

Ontario, Vermilion Township, Kenora district: Pettijohn, 3065.

Pennsylvania, Bellefonte quadrangle: Butts, 598.

Philadelphia area : Watson, 4349.

Pleistocene, Europe and America: Wormington, 4619.

Post-Keweenawan, age by helium method: Urry, 4246.

Saskatchewan, southern, Regina area: Fraser, 1330.

South Carolina, Coastal Plain: Cooke, 847.

Santee-Cooper power project: Taber, 4002.

Tennessee, south-central : Theis, 4063. 
Quaternary-Continued.

Texas, Atascosa and Frio Counties: Lonsdale, 2446.

Buckeye field, Matagorda County : Brucks, 506.

Greta oil fields, Refugio County: Stamey, 3817.

Post-Fleming coastal surface formations: Doering, 1054.

Reynosa problem : Price, 3133 .

Trinity River, Dallas County : Shuler, 3704.

Uvalde and Medina Counties: Sayre, 3524.

Utah, Book Cliffs coal fleld: Fisher, 1269.

Virginia, Shenandoah Valley: Cady, 621.

Wasbington, natural-gas fields: Kirkham, 2220.

Wisconsin, Baraboo area: Raasch, 3162 .

Yukon, Carmacks district : Bostock, 379. Quebec.

Areas described.

Dartmouth River urea, Gaspe Pewinsula : Jones, 2003.

Marsoui: area; Gaspe Peninsula: Jones, 2001.

Economic geology.

Abitibi area: Dresser, 1079.

Asbestos, Thetford district: Cooke, 852.

Beattie gold mine, Duparquet Township : O'Neill, 2953.

Cadillac belt, Pandora to Pan Canadian : Gunning, 1573.

Chibougamau Lake area: Mawdsley, 2617.

Chibougamau-Opawica map area: Norman, 2913.

Chibougamau-Waswanipi district: Norman, 2915.

Gaspe, north-central : Jones, 2002.

Gold deposits, western Quebec: Bell, 268.

Granites : Osborne, 2962.

Pre-Cambrian, rift, grain, and hardway : Osborne, 2964.

Guillet (Mud) Lake area: Henderson, 1701.

Horne, mine, Noranda: Newhouse, 2860 ; Price, 3131, 3133.

Gabbro and sulphides, relations: Suffel, 3977 .

Ilmenite, Ivry, Terrebonne County: Keys, 2188.

Labelle-L'Annonciation area: Osborne, 2963.

Lamaque mine, Bourlamaque Township : Wilson, 4537.

Lamaque-Sigma mines area, Bourlamaque Township, Abitibi County : Bell, 267.

Limestones: Goudge, 1482.

Madeline Lake, Abitibi, gold: Mackenzie, 2541.

Malartic gold-mine area, Abltibi: O'Neill, 2954.
Quebec-Continued.

Economic geology-Continued.

Mining operations, 1934 : Dufresne, 1088.

Mount Megantic region gold placers: McGerrigle, 2525.

Natural gas: Snider, 3781.

Noranda district, Amulet mine, rock alteration: Wilson, $\mathbf{4 5 4 7}$

Prospecting, western Quebec: Bell, 270.

Roselake district: MacKenzie, 2542.

Siscoe gold mine area: Backman, 128.

Telluride ores, Eureka mine: Thomson, 4106.

Waswanipi map area: Norman, 2912.

Western Quebec: Bell, 269.

Historical geology.

Abitibi area: Dresser, 1079.

Amos sheet. Abitibi County: Canada G. S., (j43.

Appalachians, reconnaissance: Keith, 2041.

Asbestos, Thetford district: Cooke, 852.

Bolton igneous series, Silurian: Clark, 766.

Cadillac belt, Pandora to Pan Canadian : Gunning, 1573.

Cambrian, Lower, southern Quebec: Clark 768.

Chaleur Bay region: Alcock, 12 ; Canada G. S., 661 .

Chibougamau area, Abitibi County : Canada G. S., 647.

Chibougamau Lake area: Mawdsley, 2617.

Chibougamau-Opawica map area: Norman, 2913.

Chibougamau-Waswanipi district: Norman, 2915.

Dartmouth River area, Gaspé Peninsula: Jones, 2003.

Despinassy area, Abitibi County : Faessler, 1204.

Escuminac area, Bonaventure County: Canada G. S., 662.

Gaspé, north-central : Jones, 2002, 2004.

Gatineau region and vicinity: Retty, 3255.

Guillet (Mud) Lake area: Henderson, 1701.

Horne mine, Noranda: Price, 3132.

Intrusives, Laurentian complex: Osborne, 2969.

Kinojevis sheet, Témiscamingue and Abitibi Counties : Canada, G. S., 649.

Labelle-L'Annonciation area: Osborne, 2963.

L a c o l l e conglomerate, Ordovician : Clark, 767.

Lac St.-Jean region, northwest part: Denis, 1030.

Lake Memphremagog, Silurian : Clark, 765.

Lamaque mine, Bourlamaque Township : Wilson, 4537 .

Lamaque-Sigma mines area : Bell, 267. 
Quebec-Continued.

Historical geology-Continued.

Limestones: Goudge, 1482.

Ma lartic gold-mine area, Abitibi: O'Neill, 2954.

Monazite, analysis and age: Muench, 2818.

Mount Megantic region: McGerrigle, 2525.

Osisko Lake area: Conolly, 840.

Paleozoic, Deschambault region, Portneuf County : Laverdiere, 2352.

Petrotectonics, Shawinigan Falls area : Osborne, 2967.

Pre-Cambrian tectonic features, Chibougamau district: Norman, 2914.

Prospecting, western Quebec: Bell, 270.

Pusticamica Lake area. Abitibi district: MacKenzie, 2540.

Roselake district: MacKenzie, 2542.

Rouyn-Bell River area, geologic map: Canada G. S., 671.

Sabourin area, Temiscamingue County: Denis, 1031.

St. Lawrence, north shore, Manigouagan to Godbout: Faessler, 1203.

Shawinigan Falls district: Osborne, 2965.

Siscoe gold-mine' area: Backman, 128.

Témiscouata area: McGerrigle, 2524.

Travers Lake area, Témiscamingue County: Retty: 3256.

Waswanipi map area : Norman, 2912.

Western Quebec : Bell, 269.

Mineralogy.

Asbestos, Thetford district: Cooke, 851.

Chibougamau-Waswanipi district: Norman, 2915.

Garnet, trisoctahedral, West Thetford : Parsons, 3021.

Monazite, analysis and age: Muench, 2818.

West Portland Township: Spence, 3802.

Telluride ores, Eureka mine: Thomson. 4106.

Paleontology.

Brachiopods and trilobites, Whitehead formation, Upper Ordovician, Percé: Cooper, 867.

Cephalaspids, Devonian: Robertson, 3320.

Cephal opods, Beatricea, Akpatok Island: Foerste, 1301.

Silurian, Gaspe Peninsula: Foerste, 1300.

Upper Ordovician, Percé: Foerste, 1302.

Devonian plants, Scaumenac Bay: Arnold, 91.

Dipnoan skull roof, Devonian: Romer, 3350.

Fauna, Black River group: Okulitch, 2946.

Graptolites, Ordorician, Levis : Ruedemann, 3405 .

Perce : Ruedemann, $\mathbf{3 4 1 5}$
Quebec-Continued.

Paleontology-Contínued.

Pollen analysis, Matamek River peat bog: Bowman, 408.

Scaumanella mesacanthi, Devonian: Graham-Smith, 1493

\section{Petrology.}

L a c o l l e conglomerate, Ordorician: Clark, 767.

Mount Megantic region: McGerrigle, 2525.

Noranda district, Amulet mine, rock alteration: Wilson, 4547.

Petrotectonics, Shawinigan Falls area : Osborne, 2967.

Shawinigan Falls district: Osborne, 2965.

Physical geology.

Appalachians, reconnaissance: Keith, 2041.

Asbestos, Thetford district: Cooke, 852.

Breccia, St. Helen Island, Montreal: Osborne, 2966.

Cadillac belt, Pandora to Pan Canadian : Gunning, 1573.

Chaleur Bay region: Alcock, 12.

Chibougamau Lake area: Mawdsley, 2617.

Earthquake, Timiskaming, November 1 , 1935 : Anonymous, 4715 ; Hodgson, 1769.

Intrusives, Laurentian complex : O\&borne, 2969.

Labelle-L'Annonciation area: Osborne, 2963.

Lamaque-Sigma mines area, Bourlamaque Township, Abitibi County : Bell, 267.

Ma lartic gold-mine area, Abitibl: O'Neill, 2954.

Osisko Lake area : Conolly, 840.

Peridotites and pyroxenites, eastern townships: Cooke, 850.

Petrotectonics, Shawinigan Falls area : Osborne, 2967.

Pre-Cambrian tectonic features, Chibougamau district: Norman, 2424.

Siscoe gold-mine area: Backman, 128.

Physiographic geology.

Chaleur Bay region: Alcock, 1.2.

Gatineau region and vicinity: Retty, 3255.

Labelle-L'Annonciation area: Osborne, 2963.

Moraines, washboard, Opawica-Chibougamau area: Mawdsley, 26.18.

Mount Megantic region: McGerrigle, 2525.

St. Lawrence, north shore, Manigouagan to Godbout, Faessler, 1203.

Témiscouata area: McGerrigle, 2524.

Waswanipi map area: Norman, 2912.

Quicksilver.

Arizona, Chinle shales, Lees Ferry: Lausen, 2351.

Arkansas, cinnabar deposits: Stearn, 3846. 
Quicksilver-Continued.

Deposits near Little Missouri River: Hansell, 1622 ; Reed, 3218, 3219.

Southwestern : Reed, 3210.

British Columbia, Windemere district, schwatzlte: Warren, 4344.

California, Clear Lake area: Anderson, 64.

Monterey and Kings Counties: Franke, 1325.

Mexico, native mercury, San Luis Potosi : Franks, 1326.

Texas, rare chlorides, Terlingua: Ross, 3373.

Terlingua district: Ross, 3374.

Radiolaria.

Fauna in Ordovician cherts, New York : Ruedemann, 3416.

Novaculite and chert, origin: Henbest, 1694.

Radio transmission and geology: Spieker, 3808.

Radioactive elements, abundance, and related geologic problems: Wells, 4393.

Radloactivity.

Ages, astronomical and geological : Urry, 4242.

Arkansas, spring water, Hot Springs : Schlundt, 3564 .

Eartb, crust: Evans, 1194.

Geothermal gradients and radioactivity : De Lury, 1025.

Helium method, pre-Cambian: Urry, $4243,4245$.

Pitchblende, age, Great Bear Lake, Canada: Marble, 2578.

La Bine Point, Great Bear Lake : Spence, 3801.

New Hampshire, Grafton : Shortle, 3696.

Rocks and minerals: Kovarik, 2253. Radium.

California, content of lavas, Lassen Volcanic National Park: Evans, 1192.

Colorado, southwestern : Ives, 1919.

Northwest Territories, Great Bear Lake: Kidd, 2189; Thomson, 4105.

Pitchblende, La Bine Point, Great Bear Lake : Spence, 3801.

Refractive indices, determination by immersion method: Slawson, 3739.

Refugian stage, Pacific coast: Schenck, 3549.

Rellef maps.

Antillean-Caribbean region: Schuchert, 3579.

Arkansas, cinnabar deposits: Stearn, 3846.

California, Elizabeth Lake quadrangle: Simpson, 3713.

Colorado, San Juan region: Cross, 925.

Mexico, Bay of Acapulco: Sánchez, 3484.

Slerra de Parras, Coahulla Peninsula : Imlay, 1905.
Rellef maps-Continued.

Ohio: Smith, 3751.

Pennsylvania : Willard, 4489.

Reptilia.

Alabama, Cretaceous, Renger, 3245.

Alberta, Milk River Cretaceous: Russell, 3430 .

Ornithomimus edmonticus and Struthiomimus currelli, cospecific: Sternberg, 3883 .

Anchisauridae, theropod, Jurassic, Arlzona: Brady, 431.

Angistorhinus alticephalus, Triassic, Texas: Stovall, 3953.

Apatosaurus, jurassic, Utah: Gilmore, 1437.

Captorhinus, brain case: Price, 3128.

Ceratopsia, mnsculature and function: Russell, 3428.

Corosaurus alcovensis, Triassic, Wyoming: Case, 696.

Dinosaurs: Reed, 3232.

Bipedal, Jurassic, Arizona: Camp, 631.

Cretaceous, Alberta: Parks, 3013 ; California: Hesse, 1730 ; Montana and Wyoming. Gilmore, 1436.

Fort Peck, Mont. : Harbicht, 1628.

Sinclair expedition, 1934, Wyoming: Brown, 474.

Tracks : Sbuler, 3705.

Fauna, Burnet Cave, Pleistocene, New Mexico: Schultz, 3591.

Will:ams Cave, Guadalupe Mountains, Tex.: Ayre, 125.

Flying, Permian, Texas : Mathews, 2609.

Greenland, primitive : Romer, 3349.

Hadrosaurs, hooded, Upper Cretaceous, Alberta: Sternberg, 3884.

Hierosaurus coelil, Cretaceous, Kansas : Mehl, 2630.

Kirtland formation, New Mexico: Gilmore, 1434.

Nothosaur, Triassic, Wyoming: Case, 695.

Pelvis, from fish to man: Gregory, 1527.

Peritresius virginianus, Miocene, Virginia: Berry, 296.

Plesiosaur, Cretaceous, Arizona: O'Connell, 2934.

Jurassic, Greenland: von Huene, 1876.

Primitive Reptilla, east Greenland: Säve-Söderbergh, 3469 .

Pteranodon, Cretaceous, 'Texas: Gilmore, 1435.

Sinclair dinosaur book: Sinclair Refining Co., 3726.

Stylemys nebrascensis, Oligocene, South Dakota: Case, 698.

Theropod, Navafo sandstone, Arizona: Brady, 430, 432.

Trachodon, systematic position: Sternberg, 3885 .

Trachodont jaw, Laramie, Colorado: Toepelmann, 4132. 
Reptilia-Continued.

Triceratops eurycephalus, Cretaceous, Wyoming: Schlaikjer, 3558.

Trinacromerum kirki, Cretaceous, ManItoba: Russell, 3432.

Turtle, giant, and mososaur, Cretaceous, Alabama : Anonymous, 4676.

Mocene, Maryland : Collins, 809.

Residues, insoluble, obtained by acetic acid: St. Clair, 3473.

Restorations: Fititz, 1343. See also Paleontology.

Apatosnurus lousiae, Utah: Gilmore. 1437.

Baluchitherium : Granger, 1494; Gregory, 1526.

Carboniferous forest, Field Museum. Chicagro: Noe, 2900.

Chasmusaurus belli, musculature: Russell, 3428 .

Corosaurus alcovensis, Triassic, Wyo. ming: Case, 696.

Dinosaurs, Upper Cretaceous, Alberta : Russell, 3431.

Durylepidoides socialis, Permo-Carbonteerous, Texas: Case, 693.

Geologic landscapes: Reid, 3236.

Nebraska, Miocene mammals: Colbert, 799.

Sinclair dinosaur book: Sinclair Refining Co., 3726.

Trimerorhachis, Permo-Carboniferous, Texas: Case 692.

Rhode Island.

\section{Physical geology.}

Earthquake, November 3, 1913 : Brown, 479.

Ripple marks.

California, Laguna Beach, rhomboid ripple marks: Woodford, 4596.

Oklahoma, Carboniferous; De Bethune, 994.

Sand structures, shallow-water : Kindle, 2203.

Rivers.

California, river action, San Gabriel Mountains: Louderback, 2453.

Classification, flood-plain streams: Melton, 2660 .

Columbia River, ancient: Randolph, 3126.

Dynamics of streams: Straub, 3964, 3966.

Indlana, Wabash River valley floor : Fidler, 1246.

Meander-scroll and meander-bar plains : Melton, 2652.

Mississippi, upper : Flint, 1288.

Morphology, fluvial ; Shulits, 3707.

New York, Hudson River Valley: Morris, 2800.

Wyoming, stream capture, Blg Horn Basin, Absaroka Range: Mackin, 2543.

Greybull River: Mackin, 2545.
Road materials.

California, southern Peninsular Range: Miller, 2728.

Perris block : Dudley, 1085.

Geologic formations, relation to: Runner, 3419.

Montana, southeastern : Perry, 3059.

Oklahoma, caliche: Gould, 1484.

Rocks. See Igneous and volcanic rocks; Sedimentary rocks.

Rock fans and pediments, origin and evolution : Rich, 3268.

Rock temperature and depths: Spicer, 3805.

Rock temperatures in deep mines, Ontarlo: Cleland, 773.

Rock wool, Ontario : Goudge, 1483.

Rocky Mountain geosyncline, Cretaceous : Keyes, 2096.

Roselite, rule of highest pseudo-symmetry : Peacock, 3039.

St. Pierre.

Economio geology.

General: Aubert de la Rue, 122.

Historical geology.

Cambrian Langlade: Aubert de la Rue, 121.

General: Aubert de la Rue, 122.

St. Peter sandstone, sedimentary and petrographic analysis: Thiel, 4069. Sult.

Louisiana, Cameron and Vermilion Parishes, salt domes: Howe, 1835.

Jefferson Island salt dome, Iberia Parish : O'Donnell, 2938.

Michigan : Exworthy, 1201.

New Mexico, salt in potash mines: Ageton, 9.

Nova Scotia, Malagash sult deposit: Miller, 2698.

Texas: Young, 4640.

Hoskins Mound salt dome: Barton, 208; Marx, 2604.

Utah, Salt Valley anticline area: Dane, 970.

Salt domes.

Anhydrite cap rock, origin: Goldman, 1461.

Antllean-Caribbean region: Schuchert, 3579.

Cap rock, anbydrite, origin: Hanna, 1621.

Domes : Balk, 160.

Fluid mechanics: Nettleton, 2847.

Geophysics, relation to salt-dome struc ture : Barret, 194 ; Eby, 1120.

Gulf coast: Ritz, 3309 .

Exploration to 1936 : Rosaire, 3354.

Oll flelds: Barton, 215 ; Louisiana and Texas: Logan, 2437 ; Williams, 4511.

Louisiana, Belle Isle salt dome, St. Mary Parish : Barton, 207.

Cameron and Vermilion Parishes : Howe, 1835 ; McGuirt, 2534. 
Salt domes-Continued.

Louisiana-Continued.

Côte Blanche salt dome, St. Mary Parish : Barton, 211.

Jefferson Island salt dome, Iberia Parish : O'Donnell, 2938.

Jennings salt dome, Acadia Parish: Halbouty, 1601.

Mechanics: Barton, 201.

Northern, oil fields: Easton, 1111.

Valentine (La Rose), Lafourche Parish : Buchanan, 533.

Louisiana and Texas: Sawtelle, 3519.

Overhanging salt on domes: Judson, 2015.

Oil fields, Gulf coast: Woodruff, 4606.

Origin: Brown, 488; Clapp, 758.

Structure elements: Balk, 160 .

Texas: Deussen, 1035.

Brenham salt dome, Washington and Austin Counties : Burford, 576.

Carlos dome, Grimes County: Rolshausen, 3341 .

Clay Creek salt dome, Washington County: Ferguson, 1237.

Conroe fleld: Zavoica, 4643.

East of Pecos River: Sellards, 3638.

Esperson dome, Liberty County : Goldston, 1467.

High Island dome: Halbouty, 1603.

Hockley salt shaft, Harris County : Teas, 4031.

Hoskins Mound salt dome, Brazoria County: Marx, 2594.

Mechanics : Barton, 201.

Mount Sylvan : Wendlandt, 4394.

South, oil fields: Pinkley, 3087.

Sugarland oil fleld: McCarter, 2495.

Texas and Louisiana, overhanging salt on domes: Judson, 2015.

Tomball oil field, Harris County, Texas: Eby, 1122.

Sand. See also Silica.

Alberta. Edmonton district: Rutherford, 3456.

British Columbia, industrial and nonmetallic minerals: Richmond, 3287.

Canada, natural bonded molding sands: Freeman, 1337.

Eolian sands: MacCarthy, 2498.

Gulf coast, petrology and physical characteristics: Halbouty, 1602.

Iowa, southern, road and concrete materials: Wood, 4591.

Manitoba : Hutt, 1900.

Foundry sands: Stanley, 3822.

Pennsylvania, Bellefonte quadrangle: Butts, 598.

South Caroliua, Coastal Plain: Cooke, 847.

Texas, Palo Pinto County: Plummer, 3098.

Washington and Idaho, sands, quartz, washed from kaolins: Wilson, 4538.

West Virginia, upper Monongahela Valley : U. S. Com., 4224.
Sand craters, possible signiflcance: Macqueen, 2563.

Sandstone.

California, nonmetallic minerals : Bradley, 421.

Mississippi, Highland Churçh sandstone: Morse, 2808.

New York, Potsdam quadrangle, St. Lawrence County: Reed, 3217.

Pennsylvania, Bellefonte quadrangle: Butts, 598.

Weathering, Iowa State Capitol Building: Gwynne, 1590.

Sapphires.

Montana : Howard, 1827.

Utah, eastern Piute County: Crawford, 895.

Saskatchewan.

Economic geology.

Beaverlodge area: Cameron, 630.

Gold deposits, Lake Athabaska: Alcock, 15.

Hudson Bay Junction area: McLearn, 2555.

Regina area, southern Saskatchewan: Fraser, 1330.

Historical geology.

Amisk Lake area, geologic map: Canada, G. S., 642.

Beaverlodge area: Cameron, 630.

Eagle Eills anticline, Battleford area: Hume, 1885.

Fond-du-lac area: Canada G. S., 663.

Gold deposits, Lake Athabaska : Alcock, 15.

Goldfields area : Canada G. S., 664.

Hudson Bay Junction area: McLearn, 2555.

Lea Park shale, Cretaceous: Warren, 4348.

Mudjatik-Haultain area : Alcock, 13 ; Canada G. S., 651, 652, 653, 654.

Regina area, geologic map: Canada G. S., 656 .

Southern Saskatchewan: Fraser, 1330.

Sources of ground water: Wickenden, 4471.

Stony Rapids area, west half : Canada G. S., 672 .

Tazin Lake area: Canada G. S., 673.

Mineralogy.

Bruno meteorite: Nininger, 2894.

Paleontology.

Floras, Whitemud and Ravenscrag formations: Belry, 300.

Lea Park shale fauna, cretaceous: Warren, 4348.

Physical geology.

Beaverlodge area: Cameron, 630.

Physiographic geology.

Regina area, southern Saskatchewan: Fraser, 1330.

Underground water.

Sources of ground water: Wickenden, 4471. 
Scablands, Washington: Hodge, 1763.

Scaphopoda.

Florida, Alaqua Creek Valley, Miocene : Mansfleld, 2572.

Nova Scotia, Banquereau, Cretaceous : Stephenson, 3878.

Science in U. S. Coast and Geodetic Survey : Bowie, 400.

Scolecodonts.

Ordovician, South Dakota: Furnish, 1369.

Sedimentary rocks: Anonymous, 4713. See also Petrology.

Alaska, southern Alaska Range: Capps, 677.

Alaska and Yukon, shapes, glacial and ice-jam cobbles: Wentworth, 4412.

Anisotrophy, effect on apparent resistivity curves: Pirson, 3093.

Arkansas, Bloyd shale, stratigraphy and cyclical sedimentation. Henbest. 1693.

Arkose deposits in humid Tropics : Krynine, 2274.

Chart, color, for description of : Goldman, 1460.

Colloids, clay, cause of bedding : Keller, 2044.

Consolidation of sediments: Kindle, 2199.

Continental Shelf, mid-Atlantic States: Shepard, 3675 .

Continents, stratigraphic evidence on tectonics: Moore, 2792

Correlation by insoluble residues: McQueen, 2561 ; Shrock, 3699.

Paleozolc limestones: Singewald, 3730.

Pennsylvanian limestones: Mitchell, 2754.

Glauconite, genesis : Galliher, 1376

Heavy minerals, Paleozoic formations, Virginia: Johnson, 1969.

Virginia : Smith, 3771.

Manitoba, Missi series, Flinflon: Ambrose, 58.

Marine unconformities and conglomerates: Twenhofel, 4198.

Mexico, arkose deposits in humid Tropics: Krynine, 2272.

Mineralogy : Pettijohn, 3064.

Mississippi, Eocene : Grim, 1548.

North Carolina, slates: Alexander, 22.

Nora Scotia, Hallfax formation, Point Pleasant Park: Belyea, 274.

Oklahoma, Penusylvanian sandstones, Ardmore Basin : Lucas, 2475.

Ontario varved slate, pre-Cambrian: Pettijohn, 3066.

Origin and composition: Runner, 3421.

Pennsylvania, Pleistocene, Philadelphia area : Ehrenfeld, 1149.

Puerto Rico: Ray, 3191.

Quartz, particles, volume, shape and roundness : Wadell, 4303.
Sedimentary rocks-Continued.

Rocky Mountains and Great Plains, cycles : Lugn, 2481, 2482, 2483.

St. Peter sandstone, analysis: Thiel, 4069.

Submarine canyons, Fudson Gorge to Chesapeake Bay, dredge samples: Stetson, 3892.

Terminology, medium-grained sediments : Allen, 47.

Texas, Catahoula formation, Fayette County : Bowling, 407.

Natural glasses, Pennsylvanian limestones: Patton, 3028.

Wisconsin, glacial cobbles, shape: Wentworth, 4411.

Insoluble residues, correlation of dolomite : Burpee, 582 ; Drindak, 1081 ; Wilcox, 4477; Trempealeau formation : Hougen, 1807.

St. Peter sandstone : Tyler, 4202.

Sedimentation. See also Conglomerates; Erosion; Sedimentary rocks: Trask, 4155 ; 'Trowbridge, 4170.

Analysis, mechanical, of sediments : Krumbein, 2270.

Arkansas, Bloyd shale, stratigraphy and cyclical sedimentation: Henbest, 1693.

Arkose deposits in humid Tropics: Krynine, 2274.

Assiniboine great cycle : Keyes, 2170.

California, gravel cusps, tide relations: Shepard, 3673.

Great Basin lake sediments: Shrock, 3700 .

Monterey Bay, interstitial: Galliber, 1374.

Santa Monica Bay: Shepard, 3670.

Southern: Ashauer, 98.

Chemical papers on : Steiger, 3863 .

Clastic sediments, porosity and permeability : Fraser, 1331 ; Muskat, 2838.

Colloids, clay, cause of bedding: Keller, 2044.

Colorado Delta : Fox, 1321.

Continental Shelf, mid-Atlantic States: Shepard, 3675.

Continents and oceans, origin: Bowle, 399.

Cores from ocean bottom: Anonymous, 4716 ; Piggot, 3085.

Cycles, Paleozoic: Wanless, 4331.

Pennsylvanian and Permian rocks, midcontinent: Moore, 2783.

Earth, age : Louderback, 2454.

Ecology of sand areas: Twenhofel, 4193.

Florida and Bahamas, calcareous shallow-water marine deposits: Thorp, 4118.

Formulas, new : Wadell, 4302.

Georges Bank, continental margin bedrock: Stetson, 3887 .

Glacial sediments : Leighton, 2383. 
Sedimentation-Continued.

Hawail, Pearl and Hermes reef: Thorp, 4119.

Hydrologic and hydrographic investigations: Piper, 3089.

Kansas, Kansas River Valley, weath ered till: Hoover, 1795.

Kentucky, island formed in Mississippi River : Shull, 3708.

Lake Bennett, Ark. : Glymph, 1456.

Lake Booneville, Ark. : Glymph, 1454.

Lake Harris, Ala. : Eargle, 1109.

lake Mendota, mud deposits: Williams, 4505.

Lake Purdy, Ala.: Eargle, 1110.

Lake Sapulpa, Okla.: Glymph, 1455.

Lake Spavinaw, Okla, : Kesler, 2088.

Lake Taneycomo, Taney Counts. Mo.: Kesler, 2089.

Lime-secreting algae: Kindle, 2198.

Littoral drift: Hennebique, 1710.

Louisiana, southwestern coast: Howe, 1840.

Marine unconformities and conglomerates: Twenhofel, 4198.

Massachusetts, marine erosion, glacia deposits, Massachusetts Bay: Stetson, 3888.

Mexico, arkose deposits in humid Tropics: Krynine, 2272.

Michigan, Huron River, abandoned channels: Bay, 243.

Southern Lake Michigan botiom deposits: Hough, 1809.

Valley-train deposits, Iron County : Bergquist, 287.

Mississippi River sands, minerals, size distribution : Russell, 3438.

Nevada, Great Basin lake sediments: Shrock, 3700.

New River, Virginia and West Virginia : Brown, 477.

Niagara Gorge, N. Y. : Alling, 50.

North Carolina, slates: Alexander, 22.

Oregon, Great Basin lake sediments: Shrock, 3700 .

Periodicity in epeirogenic movements: Born, 374.

Porosity and permeability: Graton, 1501.

Rip currents: Shepard, 3683.

Rock fans and pediments, origin and evolution : Rich, 3268.

Rocky Mountains and Great Plains, cycles: Lugn, 2481, 2482, 2483.

Sediments, organic content: Trask, 4149.

Sillceous sediments, notes, 1934-35: Tarr, 4019.

Silt problem: Stevens, 3894.

Silting of reservoirs : Eakin, 1106

Size frequency distribution, calculations : Krumbein, 2269, 2271; Wentworth 4413.

Solids, settling velocity: Wadell, 4301.

Transportation by water in open channels : U. S. Bur. Reclamation, 4223.
Sedimentation-Continued.

Sorting of river sediments: Straub, 3965.

Stanford University studies: Blackwelder, 335 .

Structure and creep : Stearn, 3845.

Terminology, coarse sediments: Wentworth, 4405 .

Medium-grained sediments: Allen, 47.

Transportation of silt by streams: O'Brien, 2931.

Tropics, humid : Krynine, 2275.

Types of sediments: Twenhofel, 4195. Varved sediments, Pleistocene lake, $\mathrm{Ne}$ braska and North Dakota : MacClintock, 2506.

Volume, shape, position, rock fragments in openwork gravel: Wadell, 4304.

Sediments, Continental Shelf, mid-Atlantic States: Shepard, $\mathbf{3 6 7 5}$

Seismic prospecting by reflection: Pirson, 3092.

Seismology : Eickelberg, 1150; Heck, 1677 ; Macelwane, 2518: Seeburger, 3632. See also Earthquakes; Geophysical prospecting.

Alaska, microseisms, January 1, 1929_ December 31, 1931, Sitka: Bradford, 419.

Seismograph station near Fairbanks : Heck, 1680.

Anolysis, seismic profiles: Roman, 3344 .

California, Coast and Geodetic seismological program : Ulrich, 4218 .

Los Angeles Basin, seismic reflection profile: Gutenberg, 1580.

Program : Ulrich, 4220.

Southern: Wood, 4583.

Strong-motion program: Ulrich, 4217.

University : Byerly, 611.

Compressibility, rocks and glasses, high temperatures and pressures: Birch, 324.

Deductions from deep-focus earthquakes : De Lury, 1028.

Deep-focus seismograms, approximation : Sohon, 3787.

Earth crust, structure : Gutenberg, 1578, 1589 ; Macelwane, 2515.

Earth physics: Fleming, 1280.

Earthquake, belts, relation to submarine topography : Heck, 1681.

June 24, 1935 : Blum, 352.

Magnitude scale, instrumental: Richter, 3290 .

Origin, genetic system: Landsberg, 2316.

Earthquakes, April 1935-March 1936: Eickelberg, 1151.

Earthquakes, deep-focus: Gutenberg, 1588 ; Lynch, 2489.

And moon phases: Stetson, 3886.

Characteristics: Brunner, $\mathbf{5 1 3}$

Geologic significance; Iseith, 2389 ; Thom, 4081. 
Seismology-Continued.

Earthquakes, deep- and shallow focus, occurrence: Landsberg, 2314.

Earthquakes, Hawalian, travel times: Jones, 1996.

Earthquakes, recorded in artesian wells : Leggette, 2375.

Epicenter determination of deep earthquakes: Westland, 4430.

Epicenter work: Bodle, 358.

First-order leveling: Rappleye, 3183.

Formula for weathering correction : Rutherford, 3450 .

Geologico-seismological frontier, progress : Macelwane, 2517.

Ground motion, determination from seismograms: Blake, 342; Wenner, 4399.

Jesuit Seismological Association progress report: Macelwane, 2516.

Kilauea eruption, 1931-32 : Jones, 1995.

List of seismolegic stations of world : McComb, 2508.

Microseisms : Gutenberg, 1586.

And changing meteorologic conditions, relations: Bradford, 417.

Record of 24 weeks: Sohon, 3788.

Modern seismology : Scrase, 3614.

Moon, effect on earthquakes, southern California : Allen, 41.

Motion, compressional phase, deep-focus earthquakes: Sharpe, $\mathbf{3 6 5 0 .}$

New Ingland, present status: Leet, 2373.

Surface lavers, data : Leet, 2374.

Pacific region: Jeffreys, 1931.

Northeast, earthquake service: Heck, 1666.

Pauama Canal Zone, records: Kirkpatrick, 2221.

Progress, recent: Heck, 1679.

Report, 1934 : Heck, 1668.

U. S. Const and Geodetic Survey: Heck, 1671.

Propagation, elastic waves in limestone:Ewing, 1196.

Quarry blasting, observations: Ewing, 1195.

Recording strong earthquake motions: Heck, 1667.

Reduction of seismograms, shaking-table experiments : Dyk, 1102.

Reflection seismology : Hollister, 1781 ; Westby, 4424.

Report advisory committee: Day, 987, 988.

Seismic waves: Gutenberg, 1579.

Seismographs: McComb, 2510.

Electro-magnetic: Benioff, 276.

Linear strain: Benioff, 278.

Strong-motion, improvement: Gebbardt, 1399.

Selsmometer, tilt compensation: McComb, 2509.

With galvanometer registration: Wenner, 4397.
Seismology-Continued.

Seismometer and tiltmeter, tbree-component: Slichter, 3741.

Seismometers, different types: Irland, 1908.

Status, Canada: Hodgson, 1768.

North America: Heck, 1672.

Strong-motion measurements: Blake, 341.

Vibration work, problems : Heck, 1674.

Teleseismic recording in Iowa: Seeburger, 3631.

Velocity of elastic waves in rocks: Gutenberg, 1583.

Washington, Puget Sound basin, selsmic history: Bradford, 415.

Wave-transmission studies: Wenner, 4398.

Waves, long-period, in eplcentral areas: Neumann, 2849.

Well gage as seismograph: Blanchard, 344 ; Byerly, 606.

Work of Jesuits in U. S.: Macelwane, 2514.

Selenite, criterion of effective wind scour : Bryan, 519.

Selenium, Cretaceous in vegetation, Wyoming : Beath, 248.

Serpentine minerals, $X$-ray and optical investigations: Selfrłdge, $\mathbf{3 6 3 5}$.

Serpentinization: Hess, 1721.

Shale.

Compaction, gravitational : Hedberg, 1682.

Iowa, southern, road and concrete materials: Wood, 4591.

New York, eastern, black mud shales; ecology : Ruedemann, 3403.

Silicifleation, Mogul mine, S. Dak: Schwartz, 3596."

West Virginia, upper Monongahela Valley : U. S. Com., 4224.

Shearing phenomena at high pressure, experlments : Bridgman, 458.

Shore lines. See also Beaches; Changes of level; Glacial lakes; Terraces.

Bay bars: Brown, 480.

British Columbia, fiord-land: Peacock, 3035.

California, gravel cusps, tide relations: Shepard, 3673.

Greenland, submarine ridge, southeast coast: Taning, 4012.

Hawali, Oahu, shore benches: Stearns, 3850 .

Hawaii, Oahu, and Maui, Plelstocene: Stearns, 3851.

Louisiana, southwestern coast: Howe, 1840 .

Maine : Goldthwait, 1471.

Maryland, Round Bay, Severn River: Scheld, 3536.

Mexico, northwestern: Kellum, 2054. 
Shore lines-Continued.

New Jersey, coast sinking: Richards, 3278.

Tidal lagoon, bottom conditions, Barnegat Bay : Lucke, 2477

North Carolina, Coastal Plain: Prouty, 3150.

Ontario, Algonquin beaches, Penetanguishene Peninsula : Stanley, 3820.

Pleistocene, tentative ages: Cooke, 845.

Texas-Louisiana Gulf coast, oil-field possibilities: Weinzierl, 4379.

Siderite, Cárlos dome, Texas: Rolshausen, 3341.

silica. See also Quartz; Sand.

California, ceramic materials other than clays: Burchflel, 574.

Chert and flint: Gunnell, 1572.

South Dakota, Mogul mine, shale: Schwartz, 3596.

Sills; California, Pinnacles National Monument: Andrews, 74 .

Silt, transportation by streams: O'Brien, 2931.

Silurian. See also Paleontology, Silurian. For Lower Silurian see Ordovician.

Alaska, Ruby-Kuskokwim region : Merti, 2681.

Arkansas, northern: McKnight, 2552.

Canada, western : Goodman, 1473.

Chaleur Bay region, Quebec and New Brunswick : Alcock, 12.

Clays, fire, distribution in U. S.: Chelikowsky, 743 .

Gaspe, southeastern : Kindle, 2193.

Illinois, Marion and Clay Countles : WelIer, 4385.

Illinois Basin : Weller, 4386.

Indiana, southeastern, correlation: Foerste, 1298.

Kansas, Central uplift: Koester, 2246.

Hollow Pool area : Johnston, 1982.

Northeastern : Ockerman, 2933.

Kentucky, southeastern, correlation: Foerste, 1298.

Maine, Appalachian Trall : Philbrick, 3071.

Geologic map : Keith, 2040.

Maryland, Rochester and McKenzie formations, relation: Swartz, 3990.

Mexico: Santlllân, 3500, 3501.

Michigan, central oll flelds: Zavoica, 4644.

Natural-gas fields: Newcombe, 2853.

Mississippi Valley, cross sections: Workman, 4618.

Upper: Kans. Geol. Soc., 2020 ; Sutton, 3983 ; Workman, 4617.

Missouri, cross section, Forest City, Mo., to Du Bois, Nebr.: Condra, 833.

St. Louis County and City of St. Louis: Gleason, 1443.

Nebraska cross section, Du Bois, Nebr., to Forest City, Mo.: Condra, 833.

Water-bearing formations: Condra, 835.
Sllurian-Continued.

Newfoundland, Bay of Exploits area: Heyl, 1736.

Gold deposits : Snelgrove, 3779.

Notre Dame Bay: Twenhofel, 4197.

New Hampshire, Littleton and Moosilauke quadrangles: Billings, 318.

New Mexico, Bayard area: Lasky, 2344.

Organ Mountains and Doña Ana County : Dunham, 1094.

Santa Rita mining area: Spencer, 3803.

New York, Berne quadrangle: Goldring, 1463.

Clinton group: Sanford, 3495.

John Boyd Thacher State Park : Torrey, 4147.

Natural-gas fields: Torrey, 4146.

Skaneateles quadrangle: Smith, 3746.

Thorold sandstone: Chadwick 709; Sanford, 3493.

Western, Clinton formation: Sanford, 3491 .

Northwest Territories, Yellowknife River area : Jolliffe, 1988.

Ohio, Gypsum deposits, Sandusky: Jones, 2009.

Kelley's Island : Ver Steeg, 4281.

Sonthwestern, correlation: Foerste, 1298.

Oklahoma, correlation by insoluble residues : Ireland, 1907.

Fitts pool, Pontotoc County : Hyatt, 1901.

Ontario, Lockport and Onondaga formations : Laird, 2290.

Pennsylvania, Bellefonte quadrangle: Butts, 598.

Butler and Zelienople quadrangles: Richardson, 3286.

Eastern region: Miller, 2717.

North-central : Swartz, 3989.

Rochester and McKenzie formations, relation: Swartz, 3990.

Tioga region: Ashley, 100.

Post-Keweenawan, age by helium method : Urry, 4246.

Quebec, Dartmouth River area, Gaspe Peninsula : Jones, 2003.

Lake Memphremagog: Clark, 765.

North-central Gaspe: Jones, 2002.

Temiscouata area: McGerrigle, 2524.

Restorations, geologic landscapes : Reid, 3236.

Southwestern U. S.: Effinger, 1144.

Tennessee, eastern : Prouty, 3141, 3145. Nashville dome: Wilson, 4531.

South-central : Theis, 4063.

Western: Born, 376; Correlation : Foerste, 1298.

Texas, trans-Pecos, unconformities: Arick, 84.

Utah, Gold Hill mining district: Nolan, 2905.

Virginia, Eagle Rock, Pulaski overthrust: Woodward, 4611.

Shenandoah Valley: Cady, 621.

West Virginia, eastern: Reeves, 3233. 
Silurian-Continued.

Wisconsin : Shrock, 3701.

Dolomites, insoluble residues correlation: Burpee, 582.

Wisconsin-Illinois lead-zinc district : Behre, 255.

Silver.

Alaska, southern Alaska Range: Capps, 677.

Upper Copper and Tanana Rivers area : Moffit, 2763.

Arizona, Silver King area, Superior : Galbraith, 1373.

Boulder Dam area, mineral occurrences: Lee, 2367.

British Columbia, Nahatlatch region : Horwood, 1801.

Ore depth in mines: Schofield, 3573.

Portland Canal area: Hanson, 1626.

Slocan mining camp area: Cairnes, 624.

Windemere district, schwatzite: Warren, 4344

California, Cerro Gordo mining district: Webb, 4373.

Mojave mining district, Kern County : Schroter, 3578; 'Tucker, 4181.

Chalcocite - stromeyerite - argentite, relations: Schwartz, 3595 .

Colorado, batholith, Twin Lakes and Clear Creek districts: Chapman, 732.

Continental Divide region: Behre, 257.

Cripple Creek district: Loughlin, $2459,2460$.

Front Range area : Lovering,' 2469.

Hydrothermal veins, northeastern plateau : Fischer, 1265.

Jamestown district: Goddard, 1457. La Plata mining district: Eckel, 1126.

London fault: Singewald, 3731 .

Montezuma quadrangle: Lovering, 2466.

Ore deposition south of Ouray : Moehlman, 2760.

San Juan region: Cross, 925.

Sugar Loaf district, Lake County, ore minerals: Sandberg, 3487.

Tincup mining district, Gunnison County : Goddard, 1458.

Ward district ores: Wablstrom, 4309.

White Raven mine, Ward: Wahlstrom, 4308.

Distribution in base-metal ores: Lasky, 2341 ; Warren, 4345.

Epithermal precious-metal deposits: Nolan, 2904.

Idaho, Casto quadrangle: Ross, 3369.

Manitoba, Flin Flon mine: Brownell, 499.

Mexico, Cusibuiriachic, Chibuahua : Donald, 1057.

Ore-body zoning, Sierra Mojada, Coahuila, Riley, 3305 .

Pachuca district: Wisser, 4567.
Silver-Continued.

Mexico-Continued.

Primary ores, Batopilas: Krieger, 2262.

Sabinal district, Chihuahua : Kreiger, 2261.

Tepezala, Aguascalientes, pyrometasomatic vein deposits: Wandke, 4328.

Montana, first production: Gilbert, 1419.

Flathead mine: Shenon, 3661.

Hog Heaven mining district, Flathead County: Shenon, 3664.

Neihart mining district, Cascade County, Schafer, 3526.

Nevada, Chief district, Lincoln County: Callaghan, 629 .

Contact mining district: Schrader, 3576.

Humboldt Range: Jenney, 1943.

Tonopah mining district: Nolan, 2907

Tuscarora mining district, Elko County: Nolan, 2908.

New Mexico, Bayard area : Lasky, 2344.

Organ Mountains and Doña Ana County : Dunham, 1094.

Primary ores, Bullard's Peak : Krieger, 2262 .

Northwest Territories, Great Bear Lake district: Spence, 3801 ; Thomson, 4105 .

Mineralization : Kidd, 2189.

Kae to Great Bear Lake, Mackenzie district: Kidd, 2191.

Ontario, aplites with cobalt-silver ores: Bastin; 234.

Ore deposits: Butler, 592.

Oregon, gold-quartz veins, Cornucopia : Goodspeed, 1478.

Tellurides, Cornucopia: Goodspeed, 1475.

Quebec, Abitibl area. Dresser, 1079.

Chibougamau-Waswanipi dist $\mathrm{r}$ ic t: Norman, 2915.

Western: Bell, 269.

Stromeyerite: Schwartz, 3595.

Succession of minerals and temperatures of formation: Lindgren, 2421.

Texas, Shafter mining district: Ross, 3375.

Utah, Gold Hill mining district: Nolan, 2905.

Moscow mines: Johnson, 1964.

Park City ore deposits: Bryan, 515.

Wyoming, South Pass and Atlantic City district, Fremont County : Abbott, 1.

Sink holes.

Michigan, Indian Lake and other regions : Poindexter, 3105.

Tennessee, Montlake: Stockdale, 3937.

16th International Geological Congress, U. S 1933 : Schumacher, 3593. 
Size frequency distribution, calculations: Krumbein, 2269, 2271; Wentworth, 4413.

Slate.

California, nonmetallic minerals : Bradley, 421.

Maine, Appalachian Trail, Philbrick, 3071.

North Carolina: Alexander, 22.

Ontario, varved slate, pre-Cambrian: Pettijohn, 3066.

Slides. See Landslides.

Soapstone.

Virginia, James River iron and Marble belt: Furcron, 1362.

Washington: Wilson, 4539.

Societies. See Associations.

Soil materials, constitution and highway construction : Ekblaw, 1154.

Soils, varying properties: Ekblaw, 1154.

South Carolina.

Areas described.

Coastal Plain: Cooke, 847.

Economic geology.

Gold : Linneman, 2423 ; Pardee, 3004.

Southern Appalachians: Anonymous, 4692.

Granite, Columbia quadrangle: Kesler, 2087.

Historical geology

Coastal Plain: Cooke, 847.

Magnetic anomalies and geologic structures: MacCarthy, 2499.

Santee-Cooper power project: Taber, 4002.

\section{Mineralogy.}

Pyroxmangite: Henderson, 1699.

Paleontology.

Cretaceous invertebrates, Myrtle Beach : Prouty, 3138.

Eucrassatella mansfieldi, Pliocene: MacNeil, 2560.

Fauna, Pleistocene Pamlico, southern Atlantic Coastal Plain: Richards 3284.

Foraminifera, upper Eocene: Cushman, 941.

Pectinidae, Tertiary : Rowland, 3389; Tucker, 4178.

Physical geology.

Beach sands: Martens, 2584.

Fulgurites, Cretaceous, Atlantic Coastal Plain: Petty, 3069.

Granite, injection processes, Columbia quadrangle : Kesler, 2087.

Physiographic geology.

Carolina bays: Prouty, 3148, 3151; MacCarthy, 2500; Watson, 4362.

Coastal Plain: Cooke, 847. Magnetometer observations: MacCarthy, 2496.

Triassic basin: MacCarthy, 2497.

Dial Bays, origin : Prouty, 3144.

Meteors and Carolina bays: MacCarthy, 2501.
South Carolina-Continued.

Physical geology-Continued.

Meteor craters: Prouty, $\mathbf{3 1 4 0 .}$

Meteorite scars (?), origin: Johnson, 1963.

Sand craters, possible significance. Macqueen, 2563.

Underground water.

Coastal Plain: Cooke, 847.

South Dakota.

Biennial report of State geologist: Rothrock, 3379, 3382.

Silicification of shale, Mogul mine : Schwartz, 3596.

Economic geology.

Geophysical exploration: Wilson, 4543.

Gold deposition, Black Hills: Wright, 4629.

Lithium ores: Chambers, 724 .

Logs of deep wells, western South Dakota: Rotbrock, 3383.

Historical geology.

Artesian conditions, west-central : Roth. rock, 3384.

Badlands, color records : Germann, 1405.

Black Hills-Bighorn-Beartooth region, gravity anomalies : Chamberlin, $\mathbf{7 1 9}$.

Cedar Creek anticline, southern half: Dobbin, 1049.

Day County : Rothrock, 3381.

Fusulinids, Black Hills, Pennsylvanian : Thompson, 4100.

Gold deposition, Black Hills: Wright, 4629.

Mississippian-Pennsylvanian contact, western South Dakota: Meyerhoff, 2686.

Ordovician fossils, upper Deadwood formation: Furnish, 1369.

Pre-Cambrian granites, Black Hills : Taylor, 4024.

Mineralogy.

Bennet County meteorite: O'Harra, 2941 .

Black Hills, mineral localities: 'Overman, 2973.

Minerals : Ulke, 4205.

Cummingtonite, Black Hills: Wayland, 4365.

Morinite from Black Hills pegmatite : Runner, 3424.

Paleontology.

Coprolite, oligocene, White River badlands: Stovall, 3952.

Deadwood faunas, Cambrian : Meyerhort, 2690.

Faunal zones: Meyerhoff, 2687.

Dogs, Miocene, phylogeny : Loomis, 2450.

Fossil Cycad National Monument, Black Hills: Anonymous, 4711.

Fusulinids, Black Hills, Pennsylvanian : Thompson, 4100.

Geomyid rodents, Middle Tertiary: Wood, 4580.

Mammals, White River Oligocene : Scott, 3612 . 
South Dakota-Continued.

Paleontology-Continued.

Ordovician fossils, upper Deadwood formation : Furnish, 1369.

Ostracoda, Morrison' formation, Black Hills : Harper, 1635.

Schaubeumys grangeri, Miocene: Wood, 4572.

Sinclairella, Apatemyidae, White River Oligocene: Jepsen, 1947.

Stylemys nebrascensis, Oligocene: Case, 698.

Vultures, Pliocene, Bennett County: Compton, 827.

\section{Petrology.}

Pre-Cambrian granites, Black Hills: Taylor, 4024.

Physical geology.

Cycles of erosion, central Black Hills: Work, 4616.

Day County : Rothrock, 3381.

Underground water.

Artesian conditions, west-central: Robinson, 3327 ; Rothrock, 3384.

Artesian-head decline: Robinson, 3326.

Day County : Rothrock, 3381.

Drought, 1934, effect, James and Cheyenne River basins: Sayre, 3525.

Huron, water supply : Rothrock, 3380.

Thermal springs, southeastern Black Hills: Work, 4615.

Sphalerite, Missouri, Joplin region, fluid inclusions: Smitb, 3775.

Spherulites.

Oregon, Clarno acid lavas: Wilkinson, 4482 .

Spongiae.

Cyathospongia, Cambrian, Labrador, Nevada, New York: Okulitch, 2945.

Paleoecology : deLaubenfels, 1016.

Paleozofc, Carnegie Museum: Eller, 1162.

Pseudohydnoceras erraticum, New York, Devonian: Reimann, 3239.

Spicules, siliceous, Pennsylvanian, Illinois and Indiana: Weller, 4382.

Trinidad, Toco Bay, Oppèr Cretaceous: Thomas, 4084.

Wisconsin, monactellid, Ordovician : Howell, 1856.

Springs. See also Hot springs; Thermal waters; Underground waters.

Arizona, Indian Elot.Springs, Grabam County : Knechtel, 2230.

FIorida : Stringfield, 3969.

History of ideas on origin of : Baker, 154.

Idaho, Snake River springs and alcoves, origin : Stearns, 3853 .

Idaho and Oregon: Waring, 4341.

Michigan, Big Spring, Schoolcraft County : Poindexter, 3104.

New Mexico, Roswell region: Brown, 487.

Pennsylvanía, flowing over 1,000 galInns a minute: Anonymous, 4714 .
Springs-Continueâ.

West Virginia: Price, 3130.

Wyoming, Alcova Dam and reservoi* sites : Bradley, 423.

Yellowstone National Park : Behre, 261; Day, 991.

Stalactites and stalagmites.

Massachusetts, West Roxbury, in sewer : Quinn, 3158.

Oregon, Malheur Cave, ice stalagmites: Dake, 957.

Stocks, Colorado, Spanish Peaks region: Knopf, 2239.

Stone.

California, Elizabeth Lake quadiangle: Simpson, 3713.

Mississippi, Highland Church sandstone : Morse, 2808.

Resistivity exploration for: Kurtenacker, 2282.

Stratigraphic geology. See Historical geology.

Stratiglaphic terminology: Schenck, 3550.

Stream capture.

New York, Hudson gorge in Highlands = Thompson, 4096.

Kaaterskill piracy, 1934: Cressey. 896.

Tennessee, Gap Creek, subterrancan. and sulface: Cullison, 928.

Virginia, Natural Bridge and Naturalt Tunnel: Woodward. 4612.

Strength of the earth: Daly; 967 .

Strength of rocks under high pressure: Griggs, 1542 .

Strike and pitch, intersecting formations, formula: Weir, 4380 .

Stromeyerite: Schwartz, 3595.

Stromotoporoidea.

Devonian : Parks, 3015.

Kansas and Oklahoma, Pennsylvanlap invertebrates: Newell, 2856.

Systẹmatic position: Parks, 3014.

Strontium.

Arizona, western: Moole, 2778.

California, southeastern: Moore, 2778.

Structural bearings and time determina tions: Burwash, 588.

Structural features, crossing North Atlantie: Baker, 152, 153.

Structural geology. See Physical geoiogy.

Structural materials. See Building stone: Clay, etc.

Studies in paleogeology : Levorsen, 2403.

Studiy and teaching. See also Educational.

Geology, exhibits, Chicago Museum : Shepherd, 3684.

Historical introduction: Woodford, 4597.

Talking motion pictures in geology: Croneis, 920, : . . .

Why geology: Willard, 4503 . 
Stylolites.

'Tennessee and Texas, rare: Stockdale, 3938.

Submarine canyons and valleys.

Submarine canyons: Shepard, 3672.

California : Shepard, 3671, 3681, 3682. Origin : Daly, 968 ; Shepard, 3682.

Submarine canyons and changes of sea level: Shepard, 3680 .

Submerged valleys on continental slopes, origin: Hess, 1723.

Subsidence. See also Changes of level.

Louisiana, cheniers; Russell, 3442.

Salt marshes and coastal stability: Goldthwait, 1469.

Subterranean water. See Underground water.

Suggestions to authors: Lane, 2331 ; Snider, 3805.

Sulphur.

Boulder Dam area, mineral occulrences: Lee, 2367.

British Columbia, industrial and nonmetallic minerals : Richmond, 3287.

California, Clear Lake area: Anderson, 64.

Gossans, with native sulphur: Raymond, 3193 .

Louisiana, Jefferson Island salt dome, Iberia Parish: O'Donnell, 2938.

New York, black sulphur, Hillburn; Roedder, 3331.

Texas, Hoskins Mound salt dome: Barton, 208; Marx, 2594.

Washington, Mount Adams area : Fowler, 1316.

Surface and ground-water planning: Drane, 1078.

Surveys. See also History.

Activities, State Geological Surveys: Bevan, 310, 313

Alabama Geological Survey, history: Jones, 2010.

Alaska, aerial photography: Smith, 3764.

Alberta, Geological Survey Division, report, . 1932: Allan, 31; 1933: Allan, 32 ; 1934 ; Allan, 33 ; 1935 ; Allan, 34 .

California, State mineralogist, biennial report: Bradley, 422.

Canada : Sawa, 3518.

Report 1935: Collins, 810.

Education, geological and public surveys : Butler, 590; Short, 3694.

Florida, Geological Survey, administrative report: Gunter, $\mathbf{1 5 7 5}$

Functions of State surveys: Ashley, 102.

Geodetic surveys: Bowie, 394, 403.

Government surveys and mining industry: Sales, 3477.

Illinois, Geological Survey, research program: Leighton, 2384.
Surveys-Continued.

Louisiana, report, 1934-35: Moresi, 2793.

Mineral industry, development: Loughlin, 2458.

Mississippi, State geologist, report, 1932-33 : Lowe, 2474; 1934-35 : Morse, 2807.

Missouri, report of State geologist: Buehler, 551.

Montana Bureau of Mines and Geology : Anonymous, 4683.

Ohio, radio-transmission survey : Higgy, 1738.

Pennsylvania Geological Survey : Anonymous, 4694; Ashley, 108; Logue, 2438 ; Stone, 3943.

Establishment: Mendenhall, 2664.

Topographic and Geologic Survey, 1919-30: Ashley, 99.

Service: Bain, 134.

South Dakota, biennial report of State geologist: Rothrock, 3379, 3382.

State resource survey, model: Leighton, 2386.

Texas, Division of Natural Resources: Schoch, 3570.

United States Geological Survey, annual report, 1935: Mendenhall, 2661 ; 1936 : Mendenhall, 2665.

Value : Roberts, 3316.

Value to nonmining communities: Agar, 7.

Washington, Division of Geology, biennial reports: Culver, 929, 930, 931.

Wyoming, State geclogist, report: Marxel, 2595.

Surveying from air, scope and limits: Miller, 2723.

Syenite, New Hampshire, Red Hill : Quinn, 3157.

Tables of formations. See Geologic formations, tables.

Taconic Olenellus fauna, importance: Keyes, 2128.

Talc.

California, ceramic materials other than clays: Burchfiel, 574

Georgia : Crickmay, 912.

North Carolina: Stuckey, 3971.

Washington :. Merten, 2679; Wilson, 4539.

Talking motion pictures in geology: Croneis, 920.

Technique. See also Mineralogy; Paleontology; Petrology.

Acetic acid, used to obtain insoluble residues: St. Clair, 3473.

Aerial mapping, recent developments: Talley, 4009.

Aerial reconnaissance and contour mapping : Eliel, 1160. 
Technique-Continued.

Aerial photography, equipment, development: Meyer, 2683.

Pacific region: Patton, 3029.

Ammonium chloride sublimate apparatus: Cooper, 858.

Analysis, Mechanical, of sediments: Krumbein, 2270.

Bubbles, removal from old thin sections : Keller, 2043.

California, Rincon, spectrographic examination, smoky and ordinary quartz: Kennard, 2072.

Canada, aerial surveying: Peters, 3062.

Cell to determine refractive indices of crystal grains: Saylor, 3523.

Chalcocite types, identification by carbon arc: Stephens, 3873.

Contour method, mapping ore bodies: Conolly, 841.

Cores from ocean bottom, apparatus: Anonymous, 4716; Piggot, 3085.

Correlation by insoluble residues, Cambro-Ordovician limestones, Lebigh Valley : Hills, 1742.

Crystals, atomic arrangement models: Buerger, 557.

Determination, true dip, in pits, graphic method: Weisbord, 4381.

Graphically : Rich, 3272.

Determinations, quantitative, detrital quartz and feldspar: Russell, 3437.

Dielectric separation of mineral grains: Berg, 284.

Dip construction, John L. Rich, simplification: Woolnough, 4600.

Electrical prospecting, instruments : Bruckshaw, 507.

Etching and preserving metallic meteorites : Nininger, 2893.

Etching of Illinois coals, chrome-sulphuric acid : McCabe, 2493.

Explosives for geophysical prospecting: Loving, 2472.

Field photography for geologists : Thwaites, 4126.

Foraminifera, making prints of : Bakx. 157.

Recovery by flotation: Anonymous, 4684.

Gold prospecting: Jacy, 1927.

Gradiometer, magnetic: Roman, 3343 .

Gravity instruments, for rapid measurement: Peterson, 3063.

$\mathrm{R}$ e cent developments: Hoskinson, 1804.

Illuminator, critical microscopy: Uber, 4204.

Immersion liquids, high refractive index: West, 4422.

Alpha - monochlornaphthalene-methylene iodide series: Buerger, 563.

Maps, new mounting method: Mackin, 2546.

Methods, making thin sections of fossils: Murata, 2830.

Studying fluctuations: Wenzel, 4418.
Technique-Continued.

Microscope, inverted metallographic: O'Neill, 2955.

Universally movable tube: Sueno, 3974.

Method to distinguish quartz and untwinned oligoclase-andesine: Dodge, 1053.

Minerals determination by specific gravity balance: Kerr, 2083.

Powdered, separation: Rosenholtz, 3357.

Refractive indices determination by immersion method: Slawson, 3739.

Removal of iron oxide coatings : Drosdoff, 1082.

Multiple grinding, thin section chips: Wentworth, 4406.

Nitrocellulose sections, fossils and rocks: Fenton, 1234.

Nomogram for apparent dip: Johnson, 1958.

Oil sands, correlated by fluorescence: Melhase, 2647.

Gulf coast, characteristics : Halbouty, 1602.

Pebbles, sphericity, determination and calculation: Pettijohn, 3068.

Perspective block diagrams: Secrist, 3629.

Petrographic methods, soil laboratories: Fry, 1356.

Petroleum, permeability measurements: Clough, 785 .

Physiography, new presentation: Atwood, 119, 120.

Plagioclase determination: Ho, 1754.

Polaroid for photographing large thin sections: Shaub, 3655.

Porosity and saturation studies: Barnes, 187.

Preparation, paleontologic illustrations : Reeside, 3232.

Rocks and minerals: Reberholt, 3212.

Preservation of fragile specimens : Toothaker, 4144.

Reservoir-sedimentation surveys : Eakin, 1105.

Rock-slicing machine: Shaub, 3653.

Rock saw, improved Vanderwilt: Emigh, 1175.

Sampling heavy minerals: Cogen, 797.

Sections, polished, making, mounting and filing: Shaub, 3654 .

Oriented, small single crystals : Buerger, 561.

Sediments, argillaceous, investigations : Bray, 451.

Indurated, thin-section mechanical aralysis : Krumbein, 2267.

Seismograph : McComb, 2510.

New electro-magnetic: Benioff, 276.

Linear strain: Benioff, 278.

Strong-motion, improvement: Gebhardt, 1399.

Seismological Laboratory, Pasadena, instrument development: Benioff, 277. 
Tecinnique-Continued.

Seismometer, different types: Irland, 1908.

Tilt-compensation : McComb, 2509.

Tiltmeter, three-component: Slichter, 3741.

With galvanometer registration: Wenner, 4397.

Sensitivity to tilt, seismographic: DeIaney, 1014.

Shale, bituminous, carbon and hydrogen determination: Hoots, 1791.

Size frequency distribution, calculations : Krumbein, 2269, 2271; Wentworth, 4403.

Sorting of river sediments: Straub, 3965.

Staining minerals: Gaudin, 1389, 1390. Table for polishing ores: Hatton, 1648. Thin sections: Murray-Hughes, 2836.

Time cbart, pipette mechanical analysis : Krumbein, 2268.

X-ray, identiflcation of ore minerals: Waldo, 4312.

Method for estimating quartz: Clark, 761.

Method to distinguish space groups, hexagonal system: Barnes, 188.

Powder camera: Buerger, 556.

Tectonic relations, North America and Lurope: Stille, 3901.

Téleconnection, geochronology and historic time: De Geer, 1003.

Tennessee.

Economic geology.

Clay, bleaching and ceramic: Mansfield, 2570.

Industry: Whitlatch, 4464.

Origin and distribution: Eckel, 1130.

Under clays of commercial coals : Whitlatch, 4462.

Western Tennessee Valley: Spain, 3794.

Copper deposits, Ducktown type, southern Appalachians: Ross, 3364.

Marble : Oder, 2937.

Natural gas, Paleozoic horizons, Cincinnati arch region: Bailey, 132.

Tripoli deposits, western Tennessee Valley : Spain, 3793.

Zinc deposits, Cambrian, southern Appalachians: Currier, 937.

Historical geology.

Cretaceous, Upper, and Tertiary, western Tennessee : Born, 376.

Flynn Creek disturbance, J a cks on County: Wilson, 4536.

General : Kansas Geol. Soc., 2020.

Nashville dome, pre-Chattanooga development: Wilson, 4531.

Upper Paleozoic developments: Wilson, 4534.

Porters Creek formation, sand lenses: Whitlach, 4463.

Ridgetop shale, Mississippian, age: Wilson, 4533.
Tennessee-Continued.

Historical geology-Continued.

Silurian, eastern Tennessee: Prouty, $3141,3145$.

Formations, correlation: Foerste, 1298.

Talladega series, southern Appalachians : Crickmay, 910.

Tennessee, south-central: Theis, 4063.

Tripoli deposits, western Tennessee Valley : Spain, 3793.

Tuscaloosa formation, outliers: Born, 375.

Mineralogy.

Ducktown Basin minerals: Blakemore, 343.

Magnetite, Union County: Hall, 1607.

Mica peridotite, Union County: Hall, 1608.

Paleontology.

Brachlopods, Silurian, Tripleslidae: 0lrich, 4214.

Cephalopoda, Ozarkian and Canadian: Ulrich, 4210.

Graptolites, Ordovician, Knoxville: Ruedemann, 3415.

Oligorhynchia, Chazy: Cooper, 860.

Ostracoda, Birdsong shale, western Tennessee: Wilson, 4532.

Paleozoic fossils, Central Basin: Bassler, 227.

Verneuilinidae, Valvulinidae, and Virgulinidae: Cushman, 945.

Petrology.

Clay, origin and distribution: Eckel, 1130.

Tuscaloosa formation, outliers: Born, 375.

Physical geology.

Flynn Creek disturbance, Jackson County: Wilson, 4536.

Great Smoky thrust fault, Blount and Sevier Counties: Wilson, 4529.

Stream piracy, subterranean and surface, Gap Creek : Cullison, 928.

Stylolites, rare: Stockdale, 3938.

Physiographic geology.

Montlake, a sink hole: Stockdale, 3937.

Tennessee, south-central: Theis, 4063.

Unaerground vater.

Ground water, south-central Tennessee: Theis, 4063.

Terminology of coarse sediments: Wentworth, 4405.

Terraces. See also Beaches; Changes of level; Glacial lakes; Shore lines.

Ages, tentative, Pleistocene shore lines: Cooke, 845 .

Appalachians, southern: Wright, 4625.

Arizona and Nevada, Boulder Reservoir floor : Longwell, 2445.

British Columbia, white silt, Oakangan Valley : Flint, 1286. 
Terraces-Continued.

California coast: Buwalda, 603.

Salton volcanic domes, Salton Sea: Kelley, 2051.

San Nicolas Island: Kemnitzer, 2070.

South coastal basin: Eckls, 1131.

Canada, eastern Arctic regions : Nichols, 2871.

Colorado, Arkansas River valley and Royal Gorge: Powers, 3119.

Front Range: Van Tuyl, 4268.

Colorado River, upper, Pleistocene: Blackwelder, 331.

Correlation: Allison, 52.

Hawaii, Oahu, shore benches: Stearns, 3850 .

Idaho, Casto quadraingle: Ross, 3369.

Indiana, Wabash River Valley floor: Fidlar, 1246.

Kansas, Kansas River Valley, weathered till : Hoover, 1795.

Lake Michigan Basin, bathymetric studies: Evans, 11.89

Maryland: Cooke, 84.9.

Round Bay, Severn River: Scheid, 3536.

Southern Coastal Plain : Dryden, 1084

Montana, Rosebud coal field: Pierce, 3084.

Nêw Jersey, Coastal Plain: Kümmel, 2279.

New Mexico, upper Rio Puerco: Bryan, 525.

North Carolina, Coastal Plain: Prouty, 3150.

Oahu, marine benches: Wentworth, 4400 .

Oregon, Crescent Lake and vicinity: Holdredge, 1778.

Northwest, Pleistocene alluviai stages : Allison, 53.

South Carolina, Coastal Plain: Cooke, 847.

South Dakota, central Black Hills: Work, 4616.

Texas, Trinity River, Dallas County: Shuler, 3704 .

Marsalis terrace : Kelsey, 2069.

Thermal spring, extinct, South Park Colo.: Gould, 1486.

Tertiary. See also Paleontology, Tertiary.

Alabama, Vicksburg group: Cooke, 846.

Alaska, Ruby-Kuskokwim region : Mertie, 2681.

Southern Alaska Range: Capps, 677.

Antillean-Caribbean region: Schuchert, 3579 .

Arizona, Gila conglomerate, pliocene: Knechtel, 2231.

Navajo-Hopi country, Pliocene: Williams, 4509.

Arizona and Nevada, Boulder Reservoir floor : Longwell, 2445.

Arkansas, Gulf Coastal Plain: Spooner, 3810.

Midway group, Eocene: Alexander, 25. Badlands, color recolds: German, 1405.
Tertiary - Continued.

British Columbia, Keithley Creek area, Cariboo district: Lang, 2333.

Portland Canal area: Hanson, 1626.

Similkameen and Lillooet districts: Cockfleld, 795.

California, Buena Vista Fills oll fleld: Howard, 1828.

Death Valley National Monument: Anonymous, 4664 .

Diatomite, Lompoc: Mulryan, 2826.

Edison oil field: Carter, 688; Noble, 2899.

Elizabeth Lake quadrangle: Simpson, 3713.

Eocene, Santa Lucia Mountains : Herold, 1716.

Kreyenhagen shale, Oligocene, Cantua Creek-Panoche Creek district: Condit, 832.

Merced formation: Johnson, 1965.

Mesozoic and Cenozoic eruptive rocks, Klamath Mountains: Hinds, 1746.

Miocene : Kleinpell, 2226, 2227 ; Reed, 3227.

Mojave Desert: Hulin, 1880.

Mount Diablo and Coalinga areas: Clark, 755.

Mount Diablo and vicinity: Taff, 4005.

Mount Poso oil fleld: Diepenbrock, 1046.

Natural gas fields: Hoots, 1792.

Oligocene mammal-bearing beds, Death Valley : Stock, 3924.

Oligocene Tumey formation: Atwill, 116.

Ostrea idriaensis, Eocene: Vokes, 4290 .

Palos Verdes Hills: Woodring, 4603.

Perris block : Dudley, 1085.

Petaluma district: Morse, 2806.

Pinnacles National Monument: Andrews, 74.

Placers in river channels: Duling, 1089.

Playa del Rey field: Hoots, 1790.

Refugian stage, Paciflc coast: Schenck, 3549.

Riverside and Orange Counties, clays : Sutherland, 3981.

San Gabriel Mountains, Martinez : Clements, 775 .

San Nicolas Island: Kemnitzer, 2070.

Santa Monica Mountains : Soper, 3788.

Santa Rosa Island: Moody, 2774.

South Coastal basin : Eckis, 1131.

Southern: Reed, 3231.

Tehachapi region: Buwalda, 602.

Tick and Red Rock Canyons: Luce, 2476.

Vacaville-Rumsey Hills area : Kirby, 2218.

Vaqueros formation, Oligocene (?) : Schenck, 3539. 
Tertiary-Continued.

California-Continued.

Venice and Del Rey fields, Miocene: Corey, 875.

Ventura area : Fourmarier, 1314

Ventura County: Conkling, 837.

Carriacou, West Indies: Trechmann, 4162.

Clays, fire, distribution in U. S.: Chelikowsky, $\mathbf{7 4 3}$.

Colorado, anticlines between Hiawatha gas field and Baggs, Wyo. : Bradley, 424.

Batholith, Twin Lakes and Clear Creek districts : Chapman, 732.

Book Cliffs coal field: Erdman, 1185.

Cripple Creek district: Loughlin, 2459.

Dawson and Laramie formations, Denver Basin: Dane, 972.

Front Range: Lovering, 2469, 2471; Van Tuyl, 4268.

Golden area : Johnson, 1971.

Hiawatha gas fields: Nightingale, 2886.

La Plata mining district : Eckel, 1126.

Montezuma quadrangle: Lovering, 2466.

San Juan region: Burbank, 571; Cross, 925 ; Volcanic rocks : Larsen, 2340.

Sawatch Range: Stark, 3829.

Spanish Peaks region: Knopf, 2239.

South Park: Howland, 1868; Johnson, 1974.

Tincup mining district, Gunnison County: Goddard, 1458.

Cuba : Schürmann, 3589.

Provinces of Habana and Pinar del Río: Herrera y Fritot, 1718.

Santa Clara Province, northern : Rutten, 3463 .

Eocene sequence, western North America : Clark, 759.

Florida, faunal zones, Miocene Choctawhatchee formation: Mansfield, 2571.

Georges Bank, canyons: Stetson, 3890.

Greenland : Koch, 2244, 2245.

Kap Dalton region: Wager, 4306.

Northeast: 'Teichert, 4037.

Ymer Island: Cleares, $\mathbf{7 7 2}$.

Gulf coast oil fields: Barton, 215.

Hawaii, island of Oahu : Stearns, 3849 .

Idaho, Casto quadrangle: Ross, 3369.

Edwardsburg and Thunder Mountain area: Shenon, 3665 .

Natural-gas fields: Kirkham, 2220.

Yellow Pine district, Valley County: Currier, 938.

Illinois, Marion and Clay Counties: Weller, 4385.

Illinois Basin: Weller, 4386.

Jamaica. basal complex: Trechmann, 4163.

Lake Uinta, Eocene, Utah and Colorado: Bradley, 427.
Tertiary-Continued.

Louisiana: Howe, 1833, 1842.

Claiborne tentative foraminiferal zonation: Israelsky, 1912.

Gulf coast fields : Woodruff, 4606.

Jennings salt dome, Acadia Parish : Halbouty, 1601.

Midway group, Eocene: Alexander, 25.

Monroe gas field : Fergus, 1235.

Post-Fleming coastal surface formations: Doering, 1054.

Richland gas field: Gordon, 1480.

Louisiana and Texas Gulf coast: Deussen, 1033.

Maryland, Coastal Plain : Dryden, 1084 ; Monroe, 2770.

Mexico: Santillán, 3500, 3501.

Coahuila Peninsula; Kellum, 2057; Kelly, 2068.

Cusihuiriachic, Chihuahua: Donald, 1057.

Mapimi district: Singewald, 3728 .

Northeastern: Kane, 2016, 2017 ; Warner, 4342.

Pachuca silver district: Wisser, 4567.

Tampico region : Kellum, 2059; Muir, 2821 ; Thallmann, 4051.

Tuxpan and Papantla Miocene formations: Thallmann, 4052.

Minnesota, St. Croix River, Pleistocene : Sardeson, 3510.

Mississippi : Morse, 2805.

Covington County: George, 1402.

Eocene : Grim, 1548.

Vicksburg group: Cooke, 846 ; Morningveg, 2799.

Vicksburg National Military Park area: Morse, 2810.

Missouri, southeast: Farrar, 1215.

Montana, Big Horn County and Crow Indian Reservation: Thom, 4074.

Hog Heaven mining district, Flathead County: Shenon, 3664.

Idaho batholith, northeastern part: Langton, 2337.

Northeastern, Missouri and Milk Rivers: Perry, 3058.

Nye-Bowler lineament, Stillwater and Carbon Counties: Wilson, 4535.

Richey-Lambert coal field: Parker, 3012.

Rosebud coal field: Pierce, 3084.

Southeastern : Ferry, 3059.

Nebraska, Scotts Bluff Nat. Monument : Effinger, 1141.

Water-bearing formations: Condra, 835.

Nerada, Humboldt Range: Jenney, 1943.

Placers : Vanderburg, 4252.

Silver Dyke area: Kerr, 2086.

Tonopah mining district: Nolan, 2907. 
Tertiary-Continued.

New Jersey, Coastal Plain: Kümmel, 2279.

Miocene, Fairton: Richards, 3279.

New Mexico, Bayard area: Lasky, 2344.

Hobbs field: Zavoica, 4645.

Mount Taylor coal fleld : Hunt, 1888.

Navajo-Hopi country, Pliocene: Williams, 4509.

Northwestern : Keyes, 2164.

Organ Mountains and Dõ̃a Ana County: Dunham, 1094.

Santa Rita mining area: Spencer, 3803 .

New York, Genesee Valley: Fairchild, 1211.

North Carolina, Coastal Plain : Prouty, 3150.

North Dakota, Minot area: Andrews, 70.

Oahu: Stearns, 3848.

Oil flelds, distribution, and continental spreading: Wade, 4300.

Oil sands, Gulf coast, characteristics: Halbouty, 1602.

Oregon, Harney Basin: Piper, 3090.

Marine Eocene: Turner, 4188.

Saddle Mountain State Park: Layfield, 2358.

Umpqua formation : Wells, 4389.

Pectinidae, index fossils, southeastern U. S. : Mansfield, 2573.

Pennsylvania, Philadelphia area: Watson, 4359.

Post-Keweenawan, age by helium method: Urry, 4246.

Puerto Rico : Meyerhoff, 2685.

Quebec, Mount Megantic region: McGerrigle, 2525.

Restorations, geological landscapes: Reid, 3236.

Sabine uplift, importance : Easton, 1115.

Saskatchewan, southern, Regina area: Fraser, 1330.

South Carolina, Coastal Plain: Cooke, 847.

Santee-Cooper power project: Taber, 4002.

South Dakota, Black Hills: Wright, 4629.

Southwestern U. S. : Effinger, 1144.

Tennesseè, western : Born, 376; Whit. lach, 4463.

Texas, Atascosa and Frio Counties: Lonsdale, 2446.

Brenham salt dome, Washington and Austin Counties: Burford, 576.

Catahoula formation, Fayette County : Bowling, 407.

Claiborne tentative foraminiferal zonation: Isıaelsky, 1912.

Clay Creek salt dome, Washington County : Ferguson, 1237.

Conroe field: Michaux, 2694; Zavoica, 4643 .

Driscoll pool, Duval County : Sheldon, 3658.

East Texas oil field: Zavoico, 4646.
Tertiary-Continued.

Texas-Continued.

Eocene and Miocene formations, Walker and Gonzales Counties: Renick, 3246.

Government Wells oil field: Cooper, 868 ; Trenchard, 4166.

Greta oll field; Refugio County : Stamey, 3817.

Gulf coast fields: Woodruff, 4606.

Hilbig oil field, Bastrop County : Blackburn, 329 .

Rodessa field : Ivy, 1921.

McFaddin and other oil fields: Getzendaner, 1410.

Midway group: Gardner, 1382.

Mount Sylvan dome: TVendlandt, 4394.

Northeast embayment, natural gas fields : Ley, 2492.

Post-Fleming coastal surface formations: Doering, 1054.

Potamides matsoni zone: Ellisor, 1172.

Somerset oil field, Bexar and Atascosa Counties: Jones, 2008.

Stone City formation, Claiborne group : Stenzel, 3871.

Trans-Pecos, structural features: King, 2211.

Uvalde and Medina Counties: Sayre, 3524.

Texas and Louisiana, Gulf coast: Deussen, 1033

Trinidad : Kugler, 2280 ; Lehner, 2381.

Palo. Seco oil field, Miocene: Halse, 1612.

Utah : Spieker, 3807.

Book Cliffs coal field: Fisher, 1269.

Gold Hill mining district: Nolan, 2905.

Navajo-Hopi country, Pliocene: Williams, 4509.

Southeastern: Baker, 142.

Valentine: Johnson, 1966.

Washington, Cascade Mountains, Treasher, 4159; Warren, 4350.

Coals : Daniels, 973.

Columbia River course, Miocene: Chappell, 738.

Mount Rainier National Park: Coombs, 856.

Natural-gas flelds: Kirkham, 2320.

Olympic peninsula: Weaver, 4367.

West Indies: Rutten, 3461.

Wyoming: Nace, 2840.

Anticlines between Hiawatha gas field and Baggs, Wyo.: Bradley, 424.

Black Hills : Wright, 4629 .

Eocene, Wind River Basin: Wood, 4586.

Goshen Hole area: Schlaikjer, 3559, 3560 . 
Tertiary-Continued.

Wyoming-Continued.

Hiawatha gas fields: Nightingale, 2886.

Lance Creek field: Brainerd, 434.

Yukon, Carmacks district: Bostock, 379.

Tetradymite, Inyo Mountains, California: Webb, 4372.

Texas.

Areas described.

Atascosa and Frio Counties: Lonsdale, 2446.

Economic geology.

Amarillo district gas fields: Cotner, 882.

Barbers Hill area, mosaic map: Barton, 210.

Bend arch district, natural gas fields : Kendrick, 2071.

Bleaching clays: Phillips, 3075 .

Brenham salt dome, Washington and Austin Counties : Burford, 576.

Buckeye field, Matagorda County : Brucks, 506.

Chlorides, rare mercury, Terlingua: Ross, 3376.

Claiborne oil possibilities, Laredo area : Owens, 2974.

Clay Creek salt dome, Washington County : Ferguson, 1237.

Cole field, Webb County: Short, 3695 .

Conroe oil field: Michaux, 2694; Williams, 4515, 4520; Zavoica, 4643.

Correlations by Foraminifera: Nuttall, 2925.

Driscoll pool, Duval County: Sheldon, 3658.

East Texas district: Ralston, 3166 ; Zavoica, 4646 .

Esperson dome, Liberty County: Goldstone, 1467.

Fault line, northeast Texas: Hager, 1598.

Galveston Bay, geophysical explorations: Singleton, 3735.

Gas fields, northeast Texas embayment: Ley, 2412.

General : Sellards, 3637.

Geophysical prospecting, Galveston County: Singleton, 3734.

In Gulf: Williams, 4522.

Geophysics, relation to salt-dome structure: Eby, 1120, 1121.

Government Wells field: Cooper, 868; Trenchard, 4166; Whisenant, 4447.

Greta oil fleld, Refugio County : Stamey, 3817.

Gulf coast, deep onl possibilities : Mills, 2735.

Oil fields: Barton, 215; Logan, 2436, 2437 ; Williams, 4521.

Oil horizons : Deussen, 1033.

Salt-dome area, natural-gas fields, Teas, 4033; Petroleum reserve: Mills, 2732.

Texas-Continued.

Economic geology-Continued.

Halite : Young, 4640.

Hardin dome oil field, Liberty County : Brace, 413 ; Teas, 4034.

High Island dome: Halbouty, 1603.

Hilbig oil fleld, Bastrop County : Blackburn, 329 ; Smiser, 3743.

Hockley salt shaft, Harris County : Teas, 4031

Hoskins Mound salt dome: Barton, 208 ; Marx, 2594.

Iron ores, east Texas : Eckel, 1125.

Northeastern Texas: Eckel, 1124.

McFaddin and other oil fields: Getzendaner, 1410.

Mercedes oil and gas field, Hidalgo County : Price, 3136.

Mexia-Talco fault zone: Smith, 374y.

Mineral production, 1882-1933: Sellards, 3639.

Mineral resources: Baker, 146.

Minerals, metallic, nonmetallic, and ores: Baker, 147.

Mount Sylvan dome: Wendlandt, : 4394.

Natural-gas fields : Rettger, 3254.

Nocona oil field, Montague County : Billings, 321.

Oil fields, Gulf coast: Woodruff, 4606.

Oil and gas flelds, south Texas dis-

trict: Post, 2108.

Orange oll field: Deussen, 1036.

Ordovician oil production, west Texas: Kroenlein, 2265.

Palo Pinto County: Plummer, 3098.

Panhandle oil and gas field: Gould, 1485 ; Panhandle Geol. Soc., 2999 : Rogatz, 3332 .

Pearsall oil fleld, Frio County: Cham. pion, 725 .

Petroleum, East Texas : Ruiz, 3418.

Permian: Bentz, 282.

Prospecting in Gulf of Mexico: Mills, 2737.

Placedo oil fleld, Victoria County : Hed. ley, 1684.

Plymouth oll field, reserves: Corning, 877.

Polybalite: Cunningham, 934.

Possibilities, Texas-Louisiana, shoreline or shoestring oil fields: Weinzierl, 4379.

Potash: Anonymous, 4663; Mansfield, 2569.

Prospecting, Gulf coast marsh and water areas: Flude, 1294.

Raccoon Bend oil field, Austin County: Teas, 4032 .

Rodessa field: Ivy, 1920, 1921 ; Mills, 2736.

Salt domes : Sawtelle, 3519 .

East Texas: Sellards, 3638 .

Salt, overhanging, on salt domes: Judson, 2015.

Sarnosa ofl field: Jones, 2007.

Saxet oil field: Anonymous, 4707. 
Texas-Continued.

Economic geology-Continued.

Shafter mining district, Presidio County : Róss, 3375.

Siderite in cap rock, Carlos Dome, Grimes County: Rolshausen, 3341.

Somerset field, Bexar and Atascosa counties: Jones, 2008

Source beds shown by reduction of sediments, East Texas basin :

Trask, 4154 .

Structures, south, Texas ofl fields: Pinkley, 3087.

Sugarland oil field, Fort Bend County : McCarter, 2495.

Talco oil field, northeastern Texas: Olcott, 2949 ; Wendlandt, 4395.

Reserves: Mills, 2739.

Terlingua quicksilver district: Ross, 3374.

Thirty-five years of progress: Deussen, 1035.

Tomball oil field, Harris County : Eby, 1122.

Variation and migration, crude oil, Spindletop, Jefferson County : Barton, 206.

Wheat ofl pool : Adams, 4.

White Point oil fleld: Anonymous, 4706.

Historical geology.

Atascosa and Frio Counties: Lonsdale, 2446.

Bend arch district, natural gas fields: Kendrick, 2071.

Bisset conglomerate, age: King, 2212.

Brenham salt dome, Washington and Austin Counties: Burford, 576.

Buckeye field, Matagorda County: Brucks, 506.

Caballos novaculite, origin, Radiolaria : Henbest, 1694.

Catahoula formation, Fayette County: Bowling, 407.

Chittim anticline, Maverick County : Hess, 3097.

Claiborne, correlation in southwest and east: Stenzel, 3872.

Tentative foraminiferal zonation: Israelsky, 1912.

Clay Creek salt dome, Washington County : Ferguson, 1237.

Colorado River Valley: Bullard, 566.

Comanche, terranal title: Keyes, 2118.

Concho arch: Cheney, 744.

Conroe oil fleld, Montgomery County: Michaux, 2694 ; Zavoico, 4643.

Coral, rugose, lower Permian: Heritsch, 1713.

Corpus Christ1 Basin: Price, 3135.

Correlations by Foraminifera: Nuttall, 2925.

By graptolites, Lower Paleozoics : Decker, 1001.

East Texas: 'Thomas, 4089

Upper Cambirian: Bridge, 456.
Texas-Continued.

Historical geology-Continued.

County geological maps: Texas Univ., Bur. Econ. Geology., 4048.

Cretaceous section, Maverick County : Vanderpool, 4259.

Delaware Basin, Permian: Lang, 2334.

East Texas oil Feld : Zavoico, 4646.

Edwards limestone, water resources, San Antonio area: Livingston, 2429.

Eocene: Stenzel, 3867.

Eocene and Miocene formations, Walker and Gonzales Counties: Renick, 3246.

Fredericksburg group, Lower Cretaceous : 'Thompson, $410 \%$.

Gas flelds, northeast Texas embayment: Ley, 2412.

Greta oil field, Refugio 'County : Stamey, 3817.

Government Wells oil fleld, Duval County : Trenchard, 4166.

Guadalupe Mountains, Permian : King, 2215.

Gulf coast, geosyncline: Barton, 203. Oil horizons: 'Deussen, 1033.

High Island dome: Halbouty, 1603.

Hilbig oil field, Bastrop County :Blackburn, 329.

Hockley salt shaft, Harris County : Teas, 4031.

Hoskins Mound salt dome, Irazoria County : Marx, 2594.

Eueco limestone, synonyms: Keyes, 2138.

Jackson group of formations: Ellisor, 1171.

Kleberg County : Livingston, 2430.

Llano region, pre-Cambrian structure: Stenzel, 3868 .

Malone formation: Keyes, 2151.

Midway group: Gardner, 1382.

Mount Sylvan dome: Wendlandt, 4394.

Navarro-Taylor contact, microscopic evidence: Plummer, 3099.

Palo Pinto County: Plummer, 3098 .

Panhandle, major unconformities: Rusk, 3425.

Oil and gas field: Rogatz, 3332.

Pearsall oil field, Frio County: Cham. pion, 725 .

Permian basin, southern: Kinkel, 2217. West Texas basin: Adams, 3 .

Post-Fleming coastal surface formations: Doering, 1.054.

Potamides matsoni zone: Ellisor, 1172.

Pre-Cambrian unconformities, Llano region: Stenzel, 3870.

Trans-Pecos region: Baker, 148.

Raccoon Bend oil feld, Austin County: Teas, 4032

Red beds, Carboniferous: Romer, 3347.

Reynosa problem: Price, 3133.

Rodessa field: Ivy, 1921. 


\section{Texas-Continued.}

Historical geology-Continued.

Round Rock, Williamson County, Cretaceous: Sellards, 3636.

Salt domes, mechanics : Barton, 201.

Shafter mining district, Presidio County: Ross, 3375.

Shinarump, eastward extension: Keyes, 2139.

Somerset field, Bexar and Atascosa Counties: Jones, 2008.

Source beds shown by reduction of sediments, East Texas basin : Trask, 4154.

Stone City formation, Claiborne group: Stenzel, 3871.

Structural and economic geology: Sellards, 3637.

Structures, east of Pecos River: Sellards, 3638

South Texas oil flelds: Pinkley, 3087.

Sugarland oil field, Fort Bend County : McCarter, 2495.

Talco oil field, northeastern Texas: Olcott, 2949.

Tectonics, Arbuckle and Ouachita Mountains: Gardner, 1381.

Terlingua quicksilver district: Ross, 3374.

Thirty-five years of progress: Deussen, 1035.

Trans-Pecos : Baker, 145.

Early Paleozoic unconformities : Arick, 84.

Later Paleozoic unconformities: King, 2213.

Structural features: King, 2211.

Unconformities, late Paleozoic, northcentral Texas: Cheney, $\mathbf{7 4 8 .}$

Upper Cretaceous : Adkins, 5.

White and Baker well, Pecos County : Carsey, 687.

Uvalde and Medina Counties: Sayre, 3524.

Wichita Falls district, major unconformities: Kay, 2035.

Wolf Mountain phacolith, Llano: Stenzel, 3869 .

\section{Mineralogy.}

Kiamichi formation: Sidwell, 3709.

Meteorites, preliminary check list: Monnig, 2767.

Salt-dome cap-rock minerals: Hanna, 1619.

Wolf Mountain granite, accessory minerals: McAdams, 2491.

\section{Paleontology.}

Angistorhinus alticephalus, Triassic, Big Spring: Stovall, 3953.

Archidiskodon imperator tusk: Anonymous, 4669.

Aturia, Eocene : Stenzel, 3867.

Aves, Pleistocene, Pliocene, Hemphill County : Compton, 823.

Borophagus diversidens, upper Pliocene : Vander Hoof, 4258.
Texas-Continued.

Paleontology-Continued.

Cephalopoda, Pennsylvanian: Williams, 4512.

Upper Cretaceous, Rio Grande: Renz, 3249.

Ceratobulimina. structure, Eocene: Plummer, 3100.

Claiborne, tentative foraminiferal zonation: Israelsky, 1912.

Conrad's type fossil localities: Keyes, 2168.

Coral, rugose, lower Permian :'Heritsch, 1713.

Decapod crustaceans, middle Elocene and Oligocene: Stenzel, 3866.

Echinoids, Cretaceous, trans-Pecos : Smiser, 3744

Eurylepidoides socialis. Permo-Carboniferous, Dundee: Case, 693.

Fauna, Pleistocene, Williams Cave, Guadalupe Mts.: Ayre, 125.

Foraminifera: Cushman, 942.

Index fossils, Conroe oil field : Gravell, 1507.

Larger, Jackson Eocene: Gravell, 1506.

Upper Eocene : Cushman, 941.

Foraminifral analcite shale: Milton, 2743.

Leaves, dicotyledonous, C r e t a c e o u s, Erath County: Ball, 173.

Microfossils, index: Thomas, 4091.

Midway group: Gardner, 1382.

Mollusca, fresh-water, Miocene, Fayette County: McNeil, 2559.

Navarro-Taylor contact, microscopic evidence: Plummer, 3099.

Ostracoda, Cretaceous: Alexander, 26, 27.

Ostreidae, Upper Cretaceous, Gulf region: Stepenson, 3877.

Palo Pinto County : Plummer, 3098.

Parafusulina, Permian, dimorphism : Dunbar, 1091.

Pectinidae, Tertiary : Rowland, 3389.

Pedicellariae, Carboniferous : Geis, 1401.

Pediomeryx hemphillensis, Coffee Ranch, Pliocene: Stirton, 3912

Pteranodon, Upper Cretaceous : Gilmore, 1435.

Reptile, flying, Permian, Castle Peak: Mathews, 2609.

Trimerorhachis, Permo-Carboniferous, Archer County: Case, 692.

Verneuilinidae, Valvulinidae, and Virgulinidae: Cushman, 945.

Vertebrates, Permian red beds: King, 2214 ; Romer, 3347.

Tertiary, Coastal Plain: Wood, 4587.

Waagenopbyllum texanum, Permian: Heritsch, 1712.

petrology.

Catahoula formation, Fayette County: Bowling, 407. 
Texas-Continued.

Petrology-Continued.

Dolomite in Permian limestones, west Texas: Cunningham, 933.

Foraminiferal analcite shale: Milton, 2743.

Glasses, natural, Pennsylvanian limestones: Patton, 3028.

Hilbig oil field, Bastrop County : Smiser, 3743.

Wolf Mountain granite, accessory minerals : McAdams, 2491.

Physical geology.

Balcones faulting and folding zone: Sellards, 3638 .

Caliche, origin: Price, 3133.

Conroe oil field: Zavoica, 4643.

Corpus Christi area, diastrophism: Price, 3134.

Deformation east of Pecos River: Sellards, 3638.

Earthquake, April 11, 1934: Sellards, 3640 .

Fault line, northeast Texas: Hager, 1598.

Fracture systems, central Texas: Melton, 2655.

Fractures, surface: Barton, 202.

Government Wells district: Cooper, 868.

Gravity survey, Crosbyton: Hoskinson, 1803.

Llano region, pre-Cambrian structure: Stenzel, 3378.

Mexia-Talco fault zone: Smith, 3749.

Falo Pinto County : Plummer, 3098.

Fermian basin, southern Kinkel, 2217.

Recent movements, Balcones fault system : Bryan, 514.

Stylolites, rare: Stockdale, 3938.

Trans-Pecos: Baker, 145.

Uvalde and Medina Counties: Sayre, 3524.

Wolf Mountain phacolith, Llano: Stenzel, 3869 .

Physiographic geology.

Corpus Christi area : Price, 3134.

Drainage, southern Texas: Barton, 202.

Llano Estacado lakes: Patton, 3027.

Marsalls terrace, Trinity River: Kelsey, 2069.

Meteorite craters: Monnig, 2766, Spencer, 3804.

Mounds, soil, origin: Melton, 2654.

Mounds and soil mottlings, nortbeastern Texas: Rich, 3265.

Post-Fleming coastal surface formations : Doering, 1054.

Shore line, rivers and springs: Shuler, 3706.

Terraces, Trinity River, Dallas County : Shuler, 3704.

Trans-Pecos, .Baker, 145.

Underground water.

Atascosa and Frio Counties: Lonsdale, 2446.

Corpus Christi Basin : Price, 3135.
Texas-Continued.

Underground water-Continued.

Edwards limestone, water resources, San Antonio area : Livingston, 2429.

Ground water, Coastal Plain: Turner, 4190.

Southern High Plains: Theis, 4062.

Kleberg County: Anonymous, 4667; Livingston, 2430.

Ogallala formation, Llano Estacedo, affected by ground water: Theis, 4064.

Palo Pinto County: Plummer, 3098.

Shore line, rivers and springs: Shuler, 3706.

Structural and economic geology: Sellards, 3637.

Uvalde and Medina Counties: Sayre, 3524.

Water, conservation, relation of geology and engineering: Bartlett, 200.

Report on: White 4461.

Supplies : Baker, 146.

Wells, central Texas, that filled with water: Kramer, 2254.

Textbooks.

Coal petrography: Stadnichenko, 3813.

Crystallography : Kraus, 2258.

Down to earth: Bayely, 246; Mather, 2605 ; Snider, 3783.

The earth: Brown, 482.

Economic geology of mineral deposits : Bain, 141 ; Lilley, 2415.

Fossils : Lull, 2485.

Historical geology: Ver Wiebe, 4286.

Igneous rocks, interpretative petrology : Alling, 49.

Introduction to geology : Branson, 441; Croneis, 917 ; De Wolf, 1038.

Invertebrate paleontology ; Decker, 999 ; Twenhofel, 4192.

Laboratory exercises in geology: Wanless, 4329.

Laboratory manual : Bergquist, 286 ; Secrist, 3628.

Minerals and rocks: Walls, 4326.

Mineral classification: Seaman, 3619.

Mineralogy : Kraus, 2258.

Mineralogy and geology tables: Kelley, 2047.

Mineralogy, determinative, supplement : Lewis, 2408.

Manual : Rosevear, 3360.

Minerals : Hawkins, 1651.

Mining geology: Houk, 1811; Hunt, 1889.

Outlines of physical geology : Longwell, 2442.

Paleontology, invertebrate: Croneis, 921.

Synopsis of lectures: Chaney, 726 .

Principles of geology: Field, 1249.

Structural geology: Nevin, 2852 ; Snider, 3784

And economic deposits: Gilluly, 1432 ; Stark, 3835. 
Thermal expansion, typical rocks: Griffith, Triassic. See also Paleontology, Triassic. 1540.

Thermal waters.

Arkansas, spring water, Hot Springs: Schlundt, 3564 .

California, alteration of lavas around hot springs, .Lassen Volcanic $\mathrm{Na}$ tional Park: Anderson, 63.

Decomposition of carbonate minerals: Wells, 4392.

Idaho, Casto quadrangle: Ross, 3367.

South Dakota, southeastern Black Hills : Work, 4615.

Yellowstone National Park: Allen, 36, 37 ; Day, 991, 992.

Thomas Jefferson, paleontologist: Osborn, 2960.

Thorianite, Serpentine Range, Pennsylvania: Gchman, 1400.

Thorium, Northwest Territory, from pitchblende : Merkel, 2666.

Tilting of ground and tides, Chesapeake Bay : Merritt, 2678.

Tin.

California, Perris block: Dudley, 1085; Sampson, 3479.

Mineral pipes and.disseminations, ores: Weed, 4376.

North Carolina, Lincolnton area: St. Clair, 3474.

Puerto Rico: Meyerboff, 2685.

Succession of minerals and temperatures of formation : Lindgren, 2421.

Washington: Fernquist, 1238.

Titanium.

Arkansas, Magnet Cove : Brock, 460.

Virginia, mineralization: Ross, 3366.

Topographic mapping by means of aerial photographs: Banks, 175.

Tourmaline : Kollida, 2249.

Analysis spectrographic: Warner, 4343.

Crystallography space group: Barnes, 189.

Muscovite, with oriented inclusions of : Frondel, 1355.

Tracks and trails.

Arizona, vertebrate and invértebrate, Moenkopi sandstone : Brady, 429.

Footprints, Boulder, Colo. : Toepelmann, 4134.

Oldhamia, supposed, Rensselaer grit: Ruedemann, 3414.

Pennsylvania, Chemung: Willard, 4487.

Travertine.

Virginia, Lexington: Steidtmann, 3860 , 3862.

Yellowstone National Park : Allen, 37.

Trend of geology : Allan, 35.

Triangulation of North American continent: Bowie. 391.

Alaska, southern Alaska Range: Capps, 677.

Upper Copper and Tanana Rivers area : Mofft, 2763.

Antillean-Caribbean region: Schuchert, 3579.

Arizona, Grand Canyon rim: McKee, 2537.

Moencopi sandstone: Brady, 428.

British Columbia, Similkameen and Lil. looet districts: Cockfield, 795.

California, Elizabeth Lake quadrangle: Simpson, 3713.

Mesozoic and Cenozoic eruptive rocks, Klamath Mountains : Hinds, 1746.

Natural-gas felds: Hoots, $\mathbf{1 7 9 2 .}$

Southern, Perris block; Dudley, 1085.

Canada, western : Goodman, 1473.

Chaleur Bay region, Quebec and New Brunswick : Alcock, 12.

Clays, fire, distribution in U. S. : Chellkowsky, 743.

Colorado, Book Cliffs coal field: Erdmann, 1185.

La Plata mining district : Eckel, 1126.

San Juan region: Cross, 925.

Deformation of earth's crust, Paleozoic : Moore, 2787.

Greenland: Koch, 2244.

Northeast: Teichert, 4037.

Mexico: Santillán, 3501.

Tampico region : Muir, 2821.

Montana, Big Horn County and Crow Indian Reservation: Thom, 4074.

Nevada, Humboldt Range: Jenney, 1943.

West-central, formations: $M$ uller, 2824.

New Jersey, Watchung Mountains : Moldenke, 2765.

New Mexico, Ceja Glorieta sandstone: Keyes, 2127.

Hobbs fleld: Zavoica, 4645.

North Carolina, Durbam Basin: Johnson, 1979.

Pennsylvania, eastern region: Miller, 2717.

Philadelphia area: Watson, 4359.

Post-Keweenawan, age by helium method: Urry, 4246.

South Dakota, west-central : Rothrock, 3384.

Southwestern U. S. : Effinger, 1144.

Texas, Bisset conglomerate: King, 2212.

White and Baker well, Pecos County, unconformities : Carsey, 687.

Utah, Gold Hill mining district: Nolan, 2905.

Monument Valley-Navajo Mountain region: Baker, 144.

Salt Valley anticline area : Dane, 970.

Southeastern: Baker, 142.

Virginia, James River iron and marble belt: Furcron, 1362. 
Triassic-Continued.

Wyoming, Devil's Tower National Monument : Effinger, 1142.

Lance Creek field: Brainerd, 434.

Yukon, Carmacks district: Bostock, 379.

Trilobita. See also Crustacea.

Agnostia : Howell, 1853.

Agnostian, Cambrian, New Brunswick: Howell, 1850; Vermont: Howell, 1849.

Asaphus megistus, Virginia: Curfman, 935.

Brachyaspidion for Brachyaspis Miller : Miller, 2715.

California, Carboniferous: Wheeler, 4442.

Cambrian, nomenclature: Resser, 3250 , 3252.

Canada, northwestern, Cambrian and Ordovician: Kobayashi, 2242.

Carboniferous genera: Weller, 4387.

Dalmanites, nomenclature: Delo, 1018.

Dipleura dekayi, Devonian, New York: Cooper, 861.

Ditomopyge, Kansas and Indiana: Weller, 4383.

Griffithides conwayensis, Pennsylvaninn, Arkansas: Wheeler, 4443.

Habits : Delo, 1017 ; Scheville, 3576.

Heliocephalus for Malvernia Delo: Delo, 1021.

Inglefieldia? birdsalli, Cambrian, Alberta: Howell, 1863.

Larval stages, Cambrian, Alabama: Lalicker, 2291.

Locomotive habits : Delo, 1017.

Michigan, southeastern, Dundee limestone: Bailey, 233.

Missouri, Bonneterre dolomite: Lochman, 2431.

Montana and Nevada, Upper Cambrian : Kobayashi, 2242.

New York, Berne quadrangle: Goldring, 1463.

Ordovician, Labrador : Little, 2426.

Otarion halli, Hamilton group, New York: Wheeler, 4441.

Ozarkian faunas, southeastern Minnesota: Powell, 3114.

Paradoxides, Cambrian, Massachusetts : Howell, 1860.

Paradoxides matthewi, Cambrian, New Brunswick: Howell, 1855.

Phacopid trilobites, revision: Delo, 1019.

Phacopinae, Devonian, Oklaboma and Iowa: Delo, 1020.

Protaspides: Raymond, 3200.

Quebec, Perce, Upper Ordovician, Whitehead formation: Cooper, 867 .

Revision, Lichadian: Phleger, 3080.

Segmentation of trunks: Levereault, 2400.

$311-37-32$
Trilohita-Continued.

Terataspis grandis, Devonian, New York : Reimann, 3242.

Wyoming, Cambrian : Miller, 2713.

Trinidad.

Economic geology.

Correlations by Foraminifera: Nuttall, 2925.

General : Kugler, 2280 ; Lehner, 2381.

Palo Seco oil field: Halse, 1612.

Historical geology.

Correlations by Foraminifera: Nuttall, 2925.

General : Kugler, 2280 ; Lehner, 2381.

Northern Range: Trechmann, 4161.

Palo Seco oil fleld: Halse, 1612.

Paleontology.

Acila schonburgki, Oligocene: Schenck, 3547.

Fauna, Northern Range: Trechmann, 4161.

Foraminifera, Tertiary: Geyn, van de, 1411.

Helicolepidina, Eocene, relationships: Barker, 181.

Ophioderma, Pliocene, Matura Bay: Berry, 295.

Sponges and coral, Upper Cretaceous, 'oco Bay: Thomas, 4084.

Physical geology.

General: Kugler, 2280 ; Lehner, 2381.

Tri-State district, lead-zinc deposits: Sales, 3476.

Tungsten.

Boulder Dam area: Lee, 2367.

Colorado, Boulder area : Ives, 1916.

Front Range area: Lovering, 2469.

Tincup mining district, Gunnison County: Goddard, 1458.

Idaho, rare metals: Bell, 272.

Nevada, Humboldt Range: Jenney, 1943.

Scheelite-leuchtenbergite vein, Paradise Range: Kerr, 2082.

Silver Dyke area : Kerr, 2086.

Turquoise.

Genuine and imitation: Kollida, 2250.

Turtles. See Reptilla.

Type specimens, catalog, Cincinnati Univ. Mus. : Chappars, 737.

Unconformities.

Allegheny and Conemaugh formations, southwestern Pennsylvania: Sher. rill, 3687 .

California, Santa Ana Mountain footbills : Moody, 2775.

Cambrian-Algonkian, western North Amelica : Hinds, 1750.

Keweenawan-Upper Cambrian, upper Mississippi Valley : Atwater, 112.

Marine unconformities and conglomer. ates: Twenhofel, 4198.

Montana, western: Deiss, 1009. 
Unconformities-Continued.

New York, Dutchess County : Balk, 162 Texas, Llano region, pre-Cambrian: Stenzel, 3870 .

North-Central, late Paleozoic: Cheney, 748 .

Panhandle: Rusk, 3425 .

Pecos County: Carsey, 687.

Trans-Pecos, early Paleozoic: Arick, 84; Later Paleozoic: King, 2213 ; Pre-Cambian: Baker, 148.

Upper Cretaceous: Adkins, 5.

Wichïta Falls district: Kay, 2035.

Underground water (general): Imbeaux, 1904. For areal see names of States. See also Gejsers; Mineral water; Springs; Therman water.

Absorption and transpiration, report: Lee, $2365 ;$ 1935-36: Lee, 2366.

Artesian-water supply, control : Meinzer, 2631.

Coastal Plain: Meinzer, 2634.

Drought-area conditions: Meinzer, 2632.

Droughts of 1930-34, effect on: Hoyt, 1871.

Earthquakes, distant, effect on level in wells : Blanchard, $\mathbf{3 4 5}$.

Erosion, accelerated, effects: Lowdermilk, 2473.

Fluctuations of level : Thompson, 4094.

Ground water, Midwest drought area : Meinzer, 2633.

Oil fields: Lahee, 2288.

Ground water and contamination : Fiedler, 1247.

History of ideas on origin of : Baker, 154.

McGee, W. J., work on ground-water levels: Meinzer, 2638.

Magmatic and meteoric : Lindgren, 2418.

Manganese, solution, transportation and precipitation: Savage, 3516.

Maximum levels : Horton, 1796.

Methods of studying fluctuations: Wenzel, 4418.

Movements: Meinzer, 2640.

New England, ground-water supply: Bryan, 522.

Observation wells, need for: Meinzer, 2636.

Oxides, manganese, and ground-water circulation: Hewett, 1734.

Peat lands, Pacific Coast States, and water resources: DachnowskiStokes, 948.

Report of committee, 1934-35: Thompson, 4092; 1935-36: Thompson, 4093.

Seepage, by gravity : Muskat, 2837.

Effluent, channel-storage determination of: Meinzer, 2639.

Stream flow, relation to: Harrold, 1645 .

Storage, natural stream channel: Horton, 1797.

Surface and ground-water planning: Drane, 1078.
Underground water (general)-Continued.

United States: U. S. Nat. Res. Comm., 4239 ; 1935 : Meinzer, 2637.

Water index, underground, relation to run-off : Saville, 3517.

Wells, observation, manual of methods: Leggette, 2376.

Ungulata. See Mammalia.

United States.

General : Baulig, 240.

Physiographic geology.

Heights and ruggedness, Hawaii and U. S. : Palmer, 2992.

United States Bureau of Mines: Finch, 1260.

Upper Silurian, See Silurian.

Uranium. See also Carnotite. Cyrtolite, analysis: Muench, 2817.

New York, U-galena and uraninite in Bedford cyrtolite: Kerr, 2081.

Ontario, crystal ratio variation: Alter, 57.

Utah.

Geologic processes and human activities: Schneider, 3567.

Areas described.

Monument Valley-Navajo Mountain region: Baker, 144.

Salt Valley anticline area: Dane, 970.

Economic geology.

Book Cliffs coal field: Fisher, 1269.

Boulder Dam region, mineral resources: Hewett, 1735

Copper, Bingham: Boutwell, 383 .

Minor districts: Gilluly, 1429.

Tintic district: Park, 3006.

Gold Hill mining district: Nolan, 2905 ; Singewald, 3727

Lead and silver ores, Park City : Bryan, 515.

Monument Valley-Navajo Mountain region: Baker, 144.

Moscow silver mines: Johnson, 1964.

Natural-gas flelds: Kirkham, 2220; Winchester, 4564.

Oil and gas possibilities, Great Salt Lake Basin: Eardley, 1107.

Petroleum, origin, near Thistle : Schneider, 3568.

Possibilities: Bignel, 316.

Historical geology.

Archean (?) metaquartzites east of Bountiful : Crawford, 894.

Bingham district: Boutwell, 383 .

Book Cliffs coal field: Fisher, 1269.

Cambrian sections, west of Morgan : Redden, 3214.

Cretaceous, late and early Eocene: Spieker, 3807.

Gold Hill mining district: Nolan, 2905.

Grand and San Juan Counties: U. S. G. S., 4226 .

Great Salt Lake Basin: Eardley, 1107. Jurassic formations, correlation: Baker, 143.

Lake Uinta, Eocene: Bradley, 427. 
Utah-Continued.

Historical geology-Continued.

Mississippian-Pennsylvanian

Wasatch Mountains: Bissell, 327.

Monument Valley-Navajo Mountain region: Baker, 144 ; U. S. G. S., 4227.

Moscow, silver mines: Johnson, 1964.

Natural-gas flelds: Kirkham, 2220.

Pre-Cambrian rocks, summary: Blackwelder, 330.

Salt Valley anticline area: Dane, 970. Structure, southeastern Utah: Baker, 142.

Tintic district: Park, 3006.

:Uinta Mountains, north flank: Bradley, 426.

Structure : Forrester, 1309.

Mineralogy.

Adamite, Gold Hill, Tooele County: Staples, 3825 .

Austinite, Gold Hill : Staples, 3824.

Feldspars replacing fossils: Stringham, 3970.

iLead and silver oles, Park City : Bryan, 515.

Opalized spherules: Alexander, 24.

Pseudobrookite, Joy, Juab County: Palache, 2988.

Sapphires, eastern Piute County : Crawford, 895 .

Thomas Range: Montgomery, 2772.

\section{Paleontology.}

Apatosaurus, osteology: Gilmore, 1437.

Gold Hill mining district: Nolan, 2905.

Graptolites, Ordovician, Logan Canyon and Mount Pisgah: Clark, 764.

Rodents, Uinta County Eocene: Burke, 581.

Semionotus cf. gigas, Triassic, Zion Park: Hesse, 1727.

Trees, fossil : Pulver, 3153.

Physical geology.

Book Cliffs coal fleld: Fisher, 1269.

Earthquake, March 24, 1934: Shenon, 3662.

Erosion. epicycles, southern Utah: Bailey, 130.

Gold Hill mining district: Singewald, 3727.

Monument Valley-Navajo Mountain region : Baker, 144.

Orogeny, central Utah: Spicker, 3806.

Structure, southeastern Utah: Baker, 142.

Uinta Mountains, structure: Forrester, 1309.

Volcanoes, Pliocene, Navajo-Hopi country: Williams, 4509.

Physiographic geology.

Book Cliffs, rock fans and pediments: Rich, 3268.

Colorado River, upper, Pleistocene terraces: Blackwelder, 331.

Monument Valley-Navajo Mountain region: Baker, 144.

Rainbow Bridge: O'Connell, 2935.
Utah-Continued.

Physiographic geoliogy-Continued:

Uinta Mountains, north flank:: Bradley, 426.

Underground water.

Earthquakes, effect on ground-water lev. els : Taylor, 4026.

Fluctuations in levels: :Taylor, 4027.

Ground water relieves drought emergency : Taylor, 4025.

Ogden artesian-water supply: Leggette, 2379.

Recharge possibilities: Redden, 3215 .

Water from wells: Waring, 4340 .

Vanadium.

Colorado, steigerite, San Miguel County : Henderson, 1697 .

Varves.

Dating possibilities, fossil mammal-artifact localities: MacClintock, 2505 .

Pleistocene lake, White River Valley, Nebraska and North Dakota: MacClintock, 2506.

Veins.

Mexico, Alamo distriet, Lower California: Moehlman, 2758.

Northwest Territories, Great Bear Lake area, quartz: Furnlval, 1370.

Ontario, Porcupine district: Reid, 3237.

Ventffact localities in U. S.: Wentworth, 4402 .

Vermes. 'See also Invertebrates (general).

Coprolites, Mississippian, Indiana: Shrock, 3698.

Georges Bank and Banquereau, Nova Scotia, Cretaceous: Stephenson, 3878.

Teredo borings, in lignite, Long Island, N. Y. : Fox, 1322.

In petrified wood, Ross Island, Oregon : Lazell, 2360.

Teredo wood, petrified, Roseburg, Oreg. : Wharton, 4437.

Worm impression on Cambrian trilobite cheek : Ruedemann, 3413.

Vermiculite, Georgia : Prindle, 3147.

Vermont.

Economic geology.

Copper ores, Orange County: Buerger, 564.

Limonites, Taconic, origin: Newland, 2867.

Historical geology.

Cambrian and Ordovician stratigraphy and faunas: Schuchert, 3582 .

Green Mountains : Jacols, 1926.

Mineralogy.

Copper ores, Orange County: Buerger, 564.

Limonites, Taconic, origin: Newland, 2867.

Paleontology.

Agnostian trilobites, Cambrian, St. Albans: Howell, 1850. 
Vermont-Continued.

Paleontology-Continued.

Cambrian and Ordovician stratigraphy and faunas: Schuchert, 3582.

Cephalopods, Ozarkian and Canadian: Ulrich, 4210.

Champlain sea, Pleistocene, fauna: Howell, 1854.

Fauna, upper thrust block, Highgate Falis: Kindle, 2194.

Faunas, Upper Cambrian: Raymond, 3204.

Petrology.

Concretions, Champlain formation : Tarr, 4017.

Copper ores, Orange County : Buerger, 564.

Felsite dilses, devitrified, Ascutney Mountain : Balk, 163.

Limonites, Taconic, origin: Newland, 2867.

Serpentinization of ultrabasics: Bain, 140.

West Rutland crystalline limestone: Bain, 138.

Physical geology.

Serpentine and country rock contacts, metamorphic differentiation: Phillips, 3074.

Serpentinization of ultrabasics: Bain, 140.

Physiographic geology.

Peneplain : Jacobs, 1925.

Vertebrata (general). See also Amphibia, Aves, etc.

American Indian discoveries, vertebrate fossils : Kindle, 2197.

Arizona, Paradise formation: Hernon, 1714.

Astraspis and Eriptychius, Ordovician, Colorado: Bryant, 529.

California, Sespe beds, Simi Valley: Stock, 3918.

Clovis area, New Mexico: Stock, 3931.

Colorado, South Park: Stark, 3839.

Environment, early : Romer, 3346.

Godthaab Gulf, Permian and Triassic, east Greenland: Nielsen, 2882.

Nebraska, Ogallala, Tertiary: Hesse, 1725.

Oklahoma; Ogallala, Pliocene, Beaver County : Hesse, 1732.

Paleoecology: Case, 697.

Paleontology, vertebrate, report on : Romer, 3345, 3348.

Permian, New Mexico: Camp, 632; Texas : King, 2214.

Scaumenella mesacanthi, Devonian, Quebec: Graham-Smith, 1493.

Skulls, evolution: Gregory, 1525, 1528.

Tertiary, New Mexico: Needham, 2844.

Tetrapods, Carboniferous, Pennsylvania, Ohio and West Virginla: Burke, 579.

Texas, Carboniferous red beds: Romer, 3347.
Virginia.

Rogers, William Barton, first State geologist: Bevan, 308; Roberts, 3319.

Soil classification: Obenshain, 2929; Halifax County: Obenshain, 2930.

Areas described.

James River iron and marble belt: Furcron, 1362.

Economic geology.

Austinville mine, Wythe County, zoning of ores: Brown, 498.

Barite deposits : Edmunson, 1136.

Copper deposits, Ducktown type, southern Appalachians : Ross, 3364

Cyanite: Taber, 4003.

Gold, Piedmont region: Park, 3009.

Southern Appalachians: Anonymous, 4692.

Gold-belt operations : McGill, 2526.

Greenstone: Hughes, 1879.

History, mineral industry: Boyle, 411.

James River iron and marble belt: Furcron, 1362 .

Mineral resources: McGill, 2529.

Zoning, Triassic: Newhouse, 2861.

Sulphide deposits, southwestern Vir-ginia : Ross, 3362 .

Zinc deposits, Cambrian, southern Appalachians: Currier, 937.

Zinc and lead region, southwestern Virginia : Currier, 936.

Historical geology.

Algonkian formations, Blue RidgeMountains : Holden, 1775.

Allanite, Amherst County, age: Marble, 2577.

Brallier shale and Chemung formation : Butts, 597.

Gold deposits, Piedmont region : Park, 3009.

Granites, ages. Sutherland, 3982.

James River iron and marble belt: Furcron, 1362.

Lava flow, Cambrian : Furcron, 1363.

Ordovician altered volcanic materials and related clays: Kay, 2031.

Patuxent sandstone, northeastern Virginia: Roberts, 3318.

Pegmatites, age: Pegau, 3044.

Richmond area : Bevan, 309.

Salem area : Barlow, 185.

Shenandoah Valley: Cady, 621.

Structural pattern: Bevan, 312.

Volcanic rocks, pre-Triassic, southern Appalachians: Jonas, 1992.

Zinc and lead region, southwestern Virginia : Currier, 936.

\section{Mineralogy.}

Barite deposits : Edmundson, 1136.

Heavy minerals, Paleozoic formations: Johnson, 1969.

Shenandoah Valley: Smith, 3771.

Marble, Grayson County : Kessler, 2090.

Mineral contribution to Confederacy: Boyle, 412. 
Virginia-Continued.

Mineralogy-Continued.

Minerals : Ulke, 4206.

Mines and quarters near Washington: Ulke, 4207.

Pegmatite minerals, Amelia: Glass, 1441.

Phenacite, Amelia County : Pough, 3111.

Amelia Court House: Thibault, 4067. Morphology, Amelia: Hough, 1808.

Shell casts, Mlocene, fluorescent and phosphorescent: Barclay, 179.

Titanium deposits: Ross, 3366.

Vein-quartz pseudomorphs, Fauquier County: Thiesmeyer, 4070.

Zinnwaldite, Morefield mine, Amelia: Glass, 1440 .

Paleontology.

Asapbus megistus, trilobite near Lexington: Curfman, 935.

Fauna, Pleistocene Pamlico, southern Atlantic Coastal Plain: Richards, 3284.

Ficus aquiana, Belvedere $\mathrm{B}$ e a $\mathrm{ch}$, Eocene : Berry, 302.

Gastropoda, Yorktown formation: Twardy, 4191.

Pectinidae, Tertiary : Rowland, 3389 ; Tucker, 4178.

Peritresius viriginianus, $\mathrm{M}$ i o cene: Berry, 296.

Protocanites lyoni, Mississippian: Millèr, 2705.

Prunus calvertensis, Calvert Miocene, Nomini Cliffs : Berry, 303.

Reefs, Austinville: Resser, 3251.

Shell casts, Miocene, fluorescent and phosphorescent: Barclay, 179.

Yorktown pelecypods: McGavock, 2523.

Petrology.

Blue Ridge hematite: Sears, 3620.

Diabases, contained minerals: Pegau, 3045.

Hypersthene granodiorite, change to unakite and age: Jonas, 1989.

Marble, Grayson County: Kessler, 2090.

Perthites, origin : Kearfott, 2036.

Phenacite, morphology and paragenesis: Pough, 3113.

Physical geology.

Atlantic Coastal Plain: Ewing, 1198.

Caverns, Great Valley: McGill, 2527.

Devonian fold, Botetourt County : Holden, 1776.

Eagle Rock, Pulaski overthrust: Woodward, 4611 .

Landslide, Cherry Hill : Ladd, 2283.

Lava flow, Cambrian: Furcron, 1363.

Natural Bridge and Natural Tunnel: Woodward, 4612.

Salem b!ock, Pulaski overthrust: Woodward, 4610 .

Silicification, fault surface, Blacksburg: Holden, 1774.

Structural pattern: Bevan, 312.
Virginia-Continued.

Physical geology-Continued.

Travertine deposits near Lexington: Steidtmann, $3860,3862$.

Zinc and lead region, southwestern Virginia: Currier, 936.

Physiographic geology.

Natural Bridge, origin: Moore, 2780.

Natural Bridge and Natural Tunnel: Woodward, 4602 .

Zinc and lead region, southwestern Virginia: Currier, 936.

Underground water.

Honeycomb structure below river beds: Mathews, 2618.

Shenandoah Valley, ground-water resources: Cady, 621.

Spring, ebb and flow, near Fairfield : Stow, 3956 .

Waters and humidity, cavern near Lexington: Steidtmann, 3861.

Volcanic ash.

Ordivician, Appalachlan Valley: Kay, 2031.

Volcanism. See also Volcanoes: Burbank, 573.

Alaska, interior: Mertie, 2680.

Southern Alaska Range: Capps, 677.

Appalachians, southern, pre-Triassic volcanics: Jonas, 1992.

Arizona and Nevada, Boulder Reservoir floor: Longwell, 2445.

Boron, volcanologic compounds: Schaller, 3534 .

California, Pinnacles National Monument: Andrews, 74.

Colorado, Cripple Creek district : Loughlin, 2459.

Independence Pass district, fissure eruptions: Burbank, $\mathbf{5 7 2}$.

San Juan region : Cross, 925 ; Larsen, 2340.

Connecticut, spatter cone in trap sheet: Foye, 1323.

Geologic history, relation to: Whitney, 4467.

Geyser basins and igneous emanations: Allen, 38.

Hawaiian Islands: Doorninck, $\operatorname{van}$ 1068.

Idaho, lava floods, Soda Springs valley : Stearns, 3854.

Rifting and volcanic activity, Craters of the Moon: Shepherd, $\mathbf{3 6 8 5}$.

Southeastern, welded rhyolite tuffs: Mansfield, 2566.

Mexico, karst topography and lava caves: Wittich, $\mathbf{4 5 6 9 .}$

Pachuca silver district: Wisser, 4567.

Tepezala, Aguascalientes, pyrometasomatic, vein deposits: Wandke, 4328.

Missouri, post-Cambrian, explosive type: Rust, 3448.

Southeastern: Tolman, 4139; PostCambrian: Rust, 3447. 
Volcanism-Continued.

Montana, Highwood Mountains : Larsen, 2339.

Nevada, Silver Dyke area: Kerr, 2086.

New Mexico, Mount Taylor coal field: Hunt, 1888.

Organ Mountains and Doña Ana County : Dunham, 1094.

Oregon, Cascade Mountains, North Santiam River section: Thayer, 4061.

Crater Lake, dacitic flow structure: Allen, 40.

Harney Basin : Piper, 3090.

Quebec, Cadillac belt, Pandora to Pan Canadian: Gunning, 1573.

Chibougamau - Waswanipi district : Norman, 2915.

-Washington, Mount Adams area: Fowler, 1316.

Mount Rainier National Park: Coombs, 856.

Southern Cascades: Treasher, 4159.

Wyoming, Absaroka volcanics: Rouse, 3396, 3397, 3398.

Yellowstone National Park: Allen, 37. Lava cliffs: Brouwer, 472.

Rhyolite structure: Brouwer, 473.

Yukon, Carmacks district : Bostock, 379.

Volcanism vs. vulcanism : Shepherd, 3686.

Volcanoes. See also Volcanism : Leet, 2370.

Active volcanoes and volcanic peaks: McGavock, 2522.

Alaska, Akutan volcano, Aleutian Islands : Finch, 1263.

Shishaldin volcano, 1932 eruption: Finch, 1261.

Bogoslof volcano: Lukens, 2484.

California, Clear Lake area: Anderson, 64.

Lassen Peak, eruptions: Holmes, 1783.

Central America: Sorre, 3789.

Guatemala, Fuego, Atitlan and Santa Maria, 1934: Reck, 3213.

Hawaii, Kilauea eruptions, 1931-32: Jones, 1995 ; 1934 : Jones, 1997.

Kilauea Volcano, ground surface movements: Wilson, 4556.

Mauna Loa eruption, November 21, 1935 : Jaggar, 1928; Lava flows, Hodgkins, 1766.

Oahu: Stearns, 3855.

Martinique, Mont Pelee eruption, 192932: Arsandaux, 96 ; Perret, 3055 ; Romer, 3362 .

Mexico : Sorre, 3789.

Pinacates region: Ives, 1975.

Oregon: Hodge, 1760.

Fumaroles, Mount Hood: Phillips, 3076.

Trinidad: Lehner, 2381.

Washington, Mount Adams area : Fowler, 1316.

West Indies, Guadeloupe, Martinique: Barrabe, 192.
Volcanoes, active, and volcanic peaks: McGavock, 2522.

Volcanoes, extinct.

Antillean-Caribbean region: Schuchert, 3579.

Arizona, Zuni volcanic crater: Keyes, 2144.

California, Clear Lake area: Anderson, 64.

Mono Craters, southern extension : Mayo, 2626.

Salton domes: Kelley, 2051; Rogers, 3335 .

Canada: Hanson, 1625.

Colorado, Cripple Creek district: Kohanowski, 2247 ; Loughlin, 2459.

Hawaii, island of Kauai : Clark, 770.

Louisiana, nortbeastern: Easton, 1112.

Mexico: Coleman, 807.

Oregon, Mount Mazama, explosion vs. collapse: Smith, 3774; Glacial history: Atwood, 117.

Newbery volcano: Williams; 4507.

Tennessee, Flynn Creek disturbance, Jackson County: Wilson, 4536.

Trinidad : Lehner, 2381.

Washington, Mount Rainier National Park: Coombs, $\$ 56$.

Washington.

Division of geology, third biennial report: Culver, 929 ; fourth biennial report: Culver, 930 ; biennial report: Culver, 931.

Geology and geography, interrelations: Freeman, 1338.

Topographic mapping, status: Glover, 1451.

Areas described.

Mount Rainier National Park: Coombs, 856.

Economic geology.

Coal : Daniels, 973.

Copper: Pardee, 3003.

Mineral resources: Anonymous, 4677; Glover, 1452.

Mount Adams area: Fowler, 1316.

Natural-gas fields : Kirkham, 2220.

Oil and gas possibilities, Whatcom County: Glover, 1450.

Sands, quartz, washed from kaolins: Wilson, 4538.

Talc deposits: Merten, 2679.

Talc and soapstone: Wilson, 4539.

Tin, Spokane: Fernquist, 1238.

Historical geology.

Cascade Mountains, Mount Aix quad. rangle: Warren, 4350.

Replacement of dikes and sills : Goodspeed, 1476 .

Southern: Treasher, 4159.

Geology and geography, interrelations: Freeman, 1338.

Ginkgo Miocene forests: Beck, 251.

Gries Ranch horizon and faunas, Tertiary : Effinger, 1145. 
Washington-Continued.

Historical geology-Continued.

Hammar Bluff formation: Glover, 1453.

Keechelus andesites, Mount Rainier: Coombs, 855.

Mount Adams area : Fowler, 1316.

Mount Rainier National Park: Coombs, 856.

Natural-gas fields: Kirkham, 2220.

Olympic Peninsula: Weaver, 4367.

Pleistocene correlations, Pacific Coast: Allison, 54.

St. Helens mining district: Houghland, 1810.

Seattle area, Eocene: LaMotte, 2302.

Tertiary, western Washington and Oregon : Weaver, 4368, 4369.

Wahluke PJeistocene sediments: Beck, 252 .

Willamette Valley, relation to Cascade Mountains : Thayer, 4060.

\section{Mineralogy.}

Agates, blue: Clinesmith, 780 .

Fluorescent minerals: Dake, 953.

Meteorite, Willamette, 1902: Wimmer, 4559 .

\section{Paleontology.}

Eastern Washingon: Anonymous, 4696.

Florules, upper Miocene: LaMotte, 2307.

Ginkgo: Beck, 249.

Miocene forests: Beck, 251, 254; Martin, 2591.

Gries Ranch horizon and faunas, Tertiary : Effinger, 1145.

Lumbricaria holothuroid casting: Fenton, 1224.

Miocene leaves, fruits, and seeds: Brown, 489.

Priscacara campl, Eocene, Kittitas County : Hesse; 1731.

Spruce in western Miocene: Beck, 253.

Wood, Chehalis Valley, Tertiary : Anonymous, 4700 .

Yakima basalts with fossils: Beck, 250.

Petrology.

Migmatites, Kettle Range: Campbell, 634.

Mount Rainier National Park: Coombs, 856.

Physical geology.

Columbia River course, Miocene: Chappell, 738 .

Geology and geography, interrelations: Freeman, 1338.

Mount Adams area: Fowler, 1316.

Mount Rainier National Park: Coombs, 856.

Seismic history, Puget Sound Basin: Bradford, 415.

Transverse folding, Cascade Range: Waters, 4358.

Willamette valley, relation to Cascade Mountains: Thayer, 4060.
Washington-Continued,

Physiographic geologu.

Canyons, soil, and summer-fallow cultivation: Thomson, 4113.

Cascades, southern: Treasher, 4159.

Columbia River, ancient: Randolph, 3176 .

Course, Miocene: Chappell, 738.

Drift, stratifled, and deglaciation, eastern Washington: Flint, 1289.

Forests, submerged, Columbia Rivergorge : Lawrence, 2354.

Geology and geography, interrelations: Freeman, 1338.

Glacial till: Field, 1248.

Glaciers from an airplane: Richards,3275.

Grand Coulee: Fernquist, 1239.

Glacial origin : Keyes, 2102.

Ground subsidence, Bellingham: Frederickson, 1334

Mounds, soil, origin: Melton, 2654.

Mount Rainier National Park: Coombs,. 856.

Okanogan region, southern, glaciation: Flint, 1284.

Palouse topography and stream history: Thomson, 4112.

Scablands, origin: Hodge, 1763.

Yakima region, central Washington: Buwalda, 599.

Water gaps.

Pennsylvania : Meyerhoff, 2688.

Water table.

Nevada, Newlands area: Scofield, 3602.

South Dakota, west-central, artesian. conditions: Robinson, 3327.

Water, underground. See Underground water.

Waters, magmatic and meteoric: Lindgren, 2418 .

Weathering.

Clay shales: Hind, 1744.

Exfoliation of rocks, fatigue factor: Griggs, 1545.

Flint flakes and artifacts: Smith, 3760.

Formula for correction: Ruthorford, 3450.

Ice, agent of : Grawe, 1508.

Insolation hypothesis of rock weathering: Blackwelder, 336 .

New York, waterfalls, protruding crest Iines: Conant, 831 .

Pedestal rocks, southern Appalachian Piedmont: Crickmay, 907.

Rock foliation, mechanics: Fairbairn, 1208.

Sandstone, Iowa State Capitol build.. ing: Gwynne, 1590.

Well records. See Borings.

West Indies (general) : Meyerhoff, 2685 ; Sor-re, 3789. Sce also names of 1slands.

Marlne geology : Hacquaert, 1522. 
West Indies (general)-Continued.

Economic geology.

Copper : Ross, 3371.

\section{Historical Geology.}

Antilles, structure: Rutten, 3461.

Carriacou: Trechmann, 4152.

Caribbean Sea, shores, structure : Rutten, 3461 .

Guadeloupe, Martinique: Barrabe, 192.

Land and sea connections with Central America: Rutten, 3460.

\section{Paleontology.}

Carriacou: Trechmann, 4162.

Pectinidae, Tertiary, Rowland, 3389.

Reef corals, Cenozoic, evolution : Gerth, 1407.

Physical geology.

Antilles, structure : Rutten, 3461.

Gravity anomalies: Bowie, 395.

Guadeloupe, Martinique: Barrabé. 192.

Physiographic geology.

Guadeloupe, Martinique: Barrabe, 192.

West Virginia.

Economic geology.

Alma coal bed, Spruce River No. 4 mine : Fieldner, 1255.

Deep-well records : Tucker, 4180.

Iron: McKinley, 2551.

Manganese: Reeves, 3233.

Monongahela Valley, upper: U. S. Com., 4224, 4225.

Natural gas: Sisler, 3736.

Oriskany and Corniferous sands: Martens, 2585.

Historical geology.

Deep-well records: Tucker, 4180.

Eastern West Virginia : Reeves, 3233.

Paleontology.

Alma coal bed, Spruce River No. 4 mine : Fieldner, 1255.

Ostracodes, Nineveh limestone: Holland, 1779.

Tetrapods, Dunkard series : Burke, 579.

Petrology.

Oriskany and Corniferous sands: Martens, 2585.

Physiographic geology.

Erosion surfaces, western West Virginia : Cole, 805 .

Underground water.

Springs: Price, 3130.

Wind gaps.

Pennsylvania : Meyerhoff, 2688.

Wind gaps, water gaps, and erosion surfaces: Ver Steeg, 4280.

Wind- and water-gap systems in Pennsylvania: Meyerhoff, 2688.

Wind work.

Abrasion: Powers, 3122.

Arizona, bajada placers: Werber, 4409. Canyons, headward elongation: Melton, $2656,2659$.
Wind work-Continued.

Dune sands, wind-blown soils, Mississippi Basin : Cobb, 789.

Dunes, parabolic, wind-rift and longitudinal: Melton, 2657.

Dust-bowl area : Anonymous, 4704.

Dust storms: Throckmorton, 4121.

Alabama, November 13, 1933 : Poor, 3106.

Great Plains: Keyes, 2114.

June 1936: Kohler, 2248.

November 1933-May 1934: Mattice, 2616.

Southwest : Boon; 368.

Southwestern plains area: Choun, 750 .

U. S., April 1936 : Martin, 2588 ; May 1936 : Martin, 2589.

Michigan, Grand Sable dunes, Lake Superior, Alger County: Bergquist, 288.

Ripple marks, eolian, antidune phase: Willard, 4497.

Selenite, criterion of effective wind scour: Bryan, 519 .

Ventifact localities: Wentworth, 4402. New Mexico: Needham, 2843.

Wisconsin.

Economic geology.

Gogebic iron range: Atwater, 113.

Greensands, Cambrian: Twenhofle, 4199.

Lake Superlor iron deposits: Royce. 3397.

Lake Sunerior region: Leith, 2390.

Lead-zinc district, Wisconsin-Illinois: Behre, 255.

Historical geology.

Baraboo area: Raasch, 3162 ; Thwaites, 4123.

Cambrian: Twenhofel, 4196.

Formation names in upper Mississippi region: Sardeson, 3511.

Correlations by graptolites, Lower Paleozoics : Decker, 1001.

Devonian: Raasch, 3160.

Upper Mississippi Valley : Stainbrook, 3815.

Galena dolomite, Upper Mississippi Valley: Kay, 2030.

General: Kansas Geol. Soc., 2020 ; Trowbridge, 4174.

Gogebic iron range: Atwater, 113.

Isopach map, Galena, Decorah, and Platteville formations: Ball, 166.

'Trempealeau, Dresbach and Franconia formations: Edwards, 1140.

Lake Superior iron deposits: Royce, 3397.

Lake Superior region: Leith, 2390.

Lead-zinc district, Wisconsin-Illinois : Behre, 255.

Magnesian limestone, lower: Keyes, 2101. 
Wisconsin-Continued.

Historical geology-Continued.

Mississippl Valley cross sections : Workman, 4618.

Upper : Atwater, 114.

Mohawkian relations: Bays, 247.

Norwalk-Jordan-Madison sandstone question: Ulrich, 4212.

Ordovician, upper Mississippl Valley: Kay, 2029.

Prairie du Chien beds, Upper Mississipp: Valley: Powers, 3116, 3117.

St. Croix River, Paleozoic: Clement, $\mathbf{7 7 4}$.

Silurian: Shrock, 3701.

Upper Mississippi Valley: Sutton, 3983.

Mineralogy.

Heavy minerals, St. Peter sandstone: Tyler, 4202.

Zircon crystals in pegmatite, Mellen: Wilcox, 4478.

Paleontology.

Apostle Island, Nipissing flora: Wilson, 4544 .

Baraboo area, Paleozolc: Raasch, 3162.

Gastropods, dwarfed, Guttenberg beds : Ball, 169.

Mollusca, sequence in loess deposits: Baker, 150.

Postglacial vegetation, Lake Michigan region : Fuller, 1359.

'Sponges, monactellid, Ordovician: Howell, 1856.

Starfish, Ordovician : Jones, 2006.

Petrology.

Heavy minerals, St. Peter sandstone: Tyler, 4202.

Residues, insoluble, correlation of Silurian dolomites: Burpee, 582.

Mendota dolomite: Wilcox, 4477.

Oneota dolomite: Drindak, 1081.

Sedimentary rocks : Shrock, 3699 .

Trempealeau formation: Hougen, 1807.

St. Peter sandstone, sedimentary and petrographic analysis: Thiel, 4069.

Shape, glacial cobbles: Wentworth, 4411.

Zircon, crystals in pegmatite, Mellen : Wilcox, 4488.

\section{Pliysical geology.}

Abrasion, wind: Powers, 3122.

Lake Mendota, mud deposits: Williams, 4505.

Physiographic geology.

Baraboo district: Thwaites, 4123.

Correlation, erosion surfaces: Johnson, 1961.

Cuesta vs. peneplain, Driftless Area: Martin, 2587.

Peneplanation, Driftless Area: Bates, 237.

Shape, glacial cobbles: Wentworth, 4411.

Two Creeks forest bed, Manitowoc County: Wilson, 4545.
Wisconsin-Continued.

Underground water.

Zones of mineralization: Thwaites, 4124.

Woolastonite, Kern County, Calif.: Melhase, 2649.

Wyoming.

State geologist report: Marxel, 2595.

Economic geology.

Anticlines between Hiawatha gas fleld and Baggs, Wyo.: Bradley, 424.

Baxter Basin gas fields, Sweetwater County : Nightingale, 2885.

Big Horn Basin, natural gas flelds: Emery, 1174.

Big Medicine Bow oil flela, Carbon County: Shoentelt, 3693.

Billy Creek gas field, Johnson County: Boyer, 410.

Garland anticline, Big Horn and Park Counties: Dobbin, 1051.

Gold deposition, Black Hills: Wright, 4629.

Hiawatha gas fields: Nightingale, 2886.

Lance Creek oil and gas fleld: Brainerd, 434 .

Lost Soldier district gas fields: Tillot. son. 4129.

Medicine Bow oil field, Carbon County : McCanne, 2494.

Osage oll field, Weston County: Dobbin, 1052.

Platinum group, Centennial district: Coulter, 884.

South Pass and Atlantic City district, Fremont County: Abbott, 1.

Historical geology.

Absaroka volcanics, origin : Rouse, 3387 .

Alcova Dam and reservotr sites, North Platte River, Natrona County: Bradley, 423.

Anticlines between Hiawatha gas field and Baggs, Wyo.: Bradley, 424.

Badlands, color records : Germann, 1405.

Baxter Basin gas fields, Sweetwater County: Nightingale, 2885.

Beartooth Mountain uplift: Thom, 4076.

Big Horn Basin, natural-gas flelds: Emery, 1174.

Black Hills-Bighorn-Beartooth region, gravity anomalies: Chamberlin, 719.

Cambrian, northwest Wyoming: Miller, 2714.

Carboniferous: Branson, 440.

Casper formation, Cephalopoda : Miller, 2712.

Cretaceous, late and early Teritary: Nace, 2840.

Devils Tower National Monument: Effinger, 1142.

Eocene, Wind River Basin: Wood, 4586.

Frontier-Niobrara contact, $\mathrm{L}$ a $\mathrm{r} \mathrm{am}$ i e basin: Thomas, 4086 . 
Wyoming-Continued.

Historical geology-Continued.

Fusulinids, Black Hills, Pennsylvanian : Thompson, 4100.

Garland anticline, Big Horn and Park Counties: Dobbin, 1051.

Gold deposition, Black Hills: Wright, 4629 .

Goshen Hole area, Oligocene and early Miocene: Schlaikjer, 3560.

Yoder Oligocene. Schlaikjer, 3559.

Hiawatha gas fields: Nightingale, 2886.

Jurassic : Crickmay, 901.

Lance Creek oil and gas field: Brainerd, 434 .

Lost Soldier district gas fields: Tillotson, 4129

Osage oil field, Weston County : Dobbin, 1052

Permo-Pennsylvanian section, Hartville area: Condra, 834.

Popo Agie and Jelm Jurassic formations: Branson, 442.

Pre-Cambrian rocks, summary: Blackwelder, 330.

Quadrant formation, basal Pennsylvanian: Scott, 3608 .

Sherman peneplain, pre-Cambrian, Laramie Mountains : Hares, 1629.

Snake River Valley above Idabo Falls: Debler, 995.

Tensleep formation, Pennsylvanian: Branson, 437

Torrington member, Lance formation: Schlaikjer, 3558 .

Trout Creek Canyon, Park County: Sheets, 3657.

\section{Mineralogy.}

Concretions, Red Desert: Cassinet, 700.

Dahllite, spherulitic concretions, Ishawooa : McConnell, 2511.

Moss agates, Sweetwater River area: Ellermeier, 1167.

South Pass and Atlantic City district, Fremont County : Abbott, 1.

Paleontology.

Casper formation, Cephalopoda: Miller 2712 .

Cephalopods, Big Horn, and related: Foerste, 1295.

Phosphoria formation, Permian: Miller, 2699.

Corosarus alcovensis, Triassic, Jackson Canyon: Case, 696

Deadwood faunas, Cambrian : Myerhoff, 2690 .

Dinosaurs, Cretaceous: Gilmore. 1436.

Ectoganus gliritormis, Eocene, Worland : Gazin, 1396

Eohippus tooth compared to Byracotherium tooth: Friant, 1341.

Eurypterids, Devonian, Beartooth Butte : Ruedemann, 3407 .
Wyoming-Continued.

Paleontology-Continued.

Faunas, Upper Cambrian : Howell, 1861.

Fishes, Devonian, Beartooth Butte: Bryant, 528.

Florentiamyinae, Miocene: Wood, 4575.

Fusulinids, Black Hills, Pennsylvanian : Thompson, 4100.

Geomyid rodents, Middle Tertiary: Wood, 4580 .

Goshen Fole area, Oligocene mammals : Schlaikjer, 3559 .

Invertebrates, Morrison: Branson, 438.

Jurassic: Crickmay, 901.

Lambdotherium, Eocene, Tulsa: Bonillas, 367.

Lambdotherium popoagicum, Eocene, Tulsa: Bonillas, 366 .

Nothosaur, Triassic: Case, 695.

Ostracoda, Mississippian: Morey, 2797.

Protomeryx, Miocene: Loomis, 2449.

Punctospirifer pulchra, Permia $n$ : Thomas, 4085.

Selenium in vegetation, Cretaceous: Beath, 248.

Sinclair dinosaur expedition, 1934 : Brown, 474

Tapir, Miocene, Goshen Hole: 'SchlaikJer, 3561 .

Triceratops eurycephalus, Cretaceous, Goshen County: Schlaikjer. 3568.

Trilobites, Cambrian: Miller. 2i13.

Vertebrates, Miocene, Goshen Hole area : Schlaikjer, 3560

\section{Petrology.}

Dabllite, spherulitic concretions, Ishawooa: McConnell, 2511.

Heavy minerals, Front Range granites: Boos, 371.

Plysical geology.

Absaroka voicanics: Rouse, 3386, 3387, 3388.

Beartooth overthrust, investigation by seismic methods: Buwalda, 601.

Devils Tower National Monument: Eftinger, 1142 .

Folding, Shoshone River area near Cody: Bucher, 535.

Jointing of the Devils Tower: Dutton, 1101.

Permo-Pennsylvanian section, Hartville area: Condra, 834.

Physiographio geology.

Glaciers, Grand Teton National Park: Fryxell, 1358.

Greybull River, stream c a p ture : Mackin, 2545 .

Sherman peneplain, pre-Cambrian, Laramie Mountains: Hares, 1629.

Stream capture, Big Horn Basin; Absaroka Range. Mackin, 2543.

Greybull River: Mackin, 2545.

Teton Mountains: Fryxell, 1357.

Wind River Range, erosional history: Atwood, 118. 
Wyoming-Continued.

Underground water.

Alcova Dam and reservolr sites, North Platte River, Natrona County. Bradley, 423.

Snake River Valley above Idaho Falls: Debler, 995.

Xenoliths, Organ batholith, New Mexico: Duuham, 1096.

$\mathrm{X}$-ray.

X-ray identification, antlerite and brochantite: Waldo, 4313

Ore minerals: Waldo, 4312.

$X$-ray method for estimating quartz: Clark, 761 .

X-ray powder camera: Buerger, 556.

Yellowstone National Park.

Historical geology.

Cambrian type formations, revision: Deiss, 1012.

Grand Canyon of the Yellowstone: Howard, 1813.

Mineralogy.

Bore-hole investigations: Fenner, 1223.

Paleontology.

Insects, borings in fossil wocd: Brues, 508.

Petrified forest: Chapman, 735.

Petrology.

Bore-hole investigations: Fenner, 1223.

Lava cliffs: Brouwer, 472.

Rhyolites, structure: Brouwer, 473.

Physical geology.

Hot springs: Allen, 37 ; Behre, 261; Day 992.

Lava cliffs: Bruwer, 472.

Rhyolites, contact effects upon basalt, Gardiner River: Fenner, 1220.

Structure: Brouwer, 473.

Physiographic geology:

Hayden Valley lacustrine deposits: Howard, 1812.

Underground water.

Bore-hole investigations: Fenner, 1223.

Geyser basins and igneous emanations: Allen, 38.

Hot springs: Allen, 36 ; Behre, 261 ; Day, 991, 992.

Young's modulus of rocks, determination: Ide, 1902.

Yukon.

Economic geology.

Mining industry, 1934: Bostock, 378; 1935: Bostock, 380.

Teslin-Quiet Lake-Big Salmon area, prospecting possibilities:-Bostock, 381.

Historical geology.

Carmacks district: Bostock, 379 ; Canada G. S., 660.

Laberge area: Canada G. S., 665.

Ogilvie area: Canada G. S., 667.

Teslin-Quiet Lake area: Canada G. S., 674.
Yukon-Continued.

Historical geology-Continued.

Teslin-Quiet Lake-Big Salmon area, prospecting possibilities: Bostock, 381.

Physical geology.

Carmacks district: Bostock, 379.

Physiographic geology.

Carmacks district: Bostock, 379.

Glaciers: Washburn, 4354.

Shapes, glacial and ice-jam cobbles: Wentworth, 4412.

Zinc.

Arkansas, northern : McKnight, 2552 ; Miser, 2749.

Boulder Dam area, mineral occurrences : Lee, 2367.

British Columbia, Portland Canal area : Hanson, 1626.

Slocan mining camp area: Cairnes, 624.

California, Cerro Gordo mining district: Webb, 4373.

Canada, Cordilleran region: Alcock, 10.

Colorado, batholith, I'win Lakes and Clear Creek districts: Chapman, 732.

Cripple Creek district: Loughlln, $2459,2460$.

Montezuma quadrangle: Lovering, 2466.

San Juan region: Cross, 925 .

Hydrothermal experiments with min. erals: Kristofferson, 2264.

Manitoba, Flin Flon mine: Brownell, 499.

Mexico, Cusihuirfachic, Chiluahua : Donald, 1057.

Mississippi Valley type ores: Graton, 1500.

Missouri, southeastern: Tarr, 4020.

Montana, Neihart mining district, Cascade County: Schafer, 3526.

New Jersey, minerals, Franklin and Sterling Fill, Sussex County : Palache, 2985.

New Mexico, Bayard area: Lasky, 2344. Organ Mountains and Doña Ana County : Dunham, 1094.

Santa Rita mining area: Spencer. 3803.

New York, Balmat mine: Brown, 484.

Ontario, Renfrew County: Freeman. 1336.

Ore deposits, Butler, 592.

Pebble and ruby jack, Joplin district, formation temperature: Smlth, 3776 .

Pennsylvania, Friedensville: Fraser, 1327 ; Butler, 596.

Quebec, north-central Gaspe: Jones, 2002.

Western: Bell, 269.

Saskatchewan, Beaverlodge area : Cameron, 630. 
504 BIBLIOGRAPHY OF NORTH AMERICAN GEOLOGY, 1935 AND 1936.

Zinc-Continued

Tennessee, southern Appalachians: Currier, 937.

Tri-State mining district: Fowler, 1317, 1319 ; Rama Rao, 3167.

Tri-State ores, genesis : Ridge, 3295.

Utah, adamite, Gold Hill, Tooele County : Staples, 3825 .

Gold Hill mining district: Nolan, 2905.

Zinc-Continued.

Virginia, southern Appalachians: Currier, 937.

Southwestern : Currier, 936.

Western United States, reșources: Loughlin, 2457.

Wisconsin-Illinols lead-zinc district: Behre, 255.

Zircon, crystals in pegmatite, Wisconsin: Wilcox, 4478. 
The use of the subjoined mailing label to return this report will be official business, and no postage stamps will be required

\section{UNITED STATES DEPARTMENT OF THE INTERIOR \\ GEOLOGICAL SURVEY \\ OFFICIAL BUSINESS}

This label can be used only for returning official publications. The address must not be changed.
PENALTY FOR PRIVATE USE TO AVOID PAYMENT OF POSTAGE, $\$ 300$

\title{
U. S. GEOLOGICAL SURVEY,
}

\author{
WASHINGTON, D. C.
}

